La Dusica en la

atedral de Cordoba.

a través del 1 lagisterio

de Jaime Balius y Cila

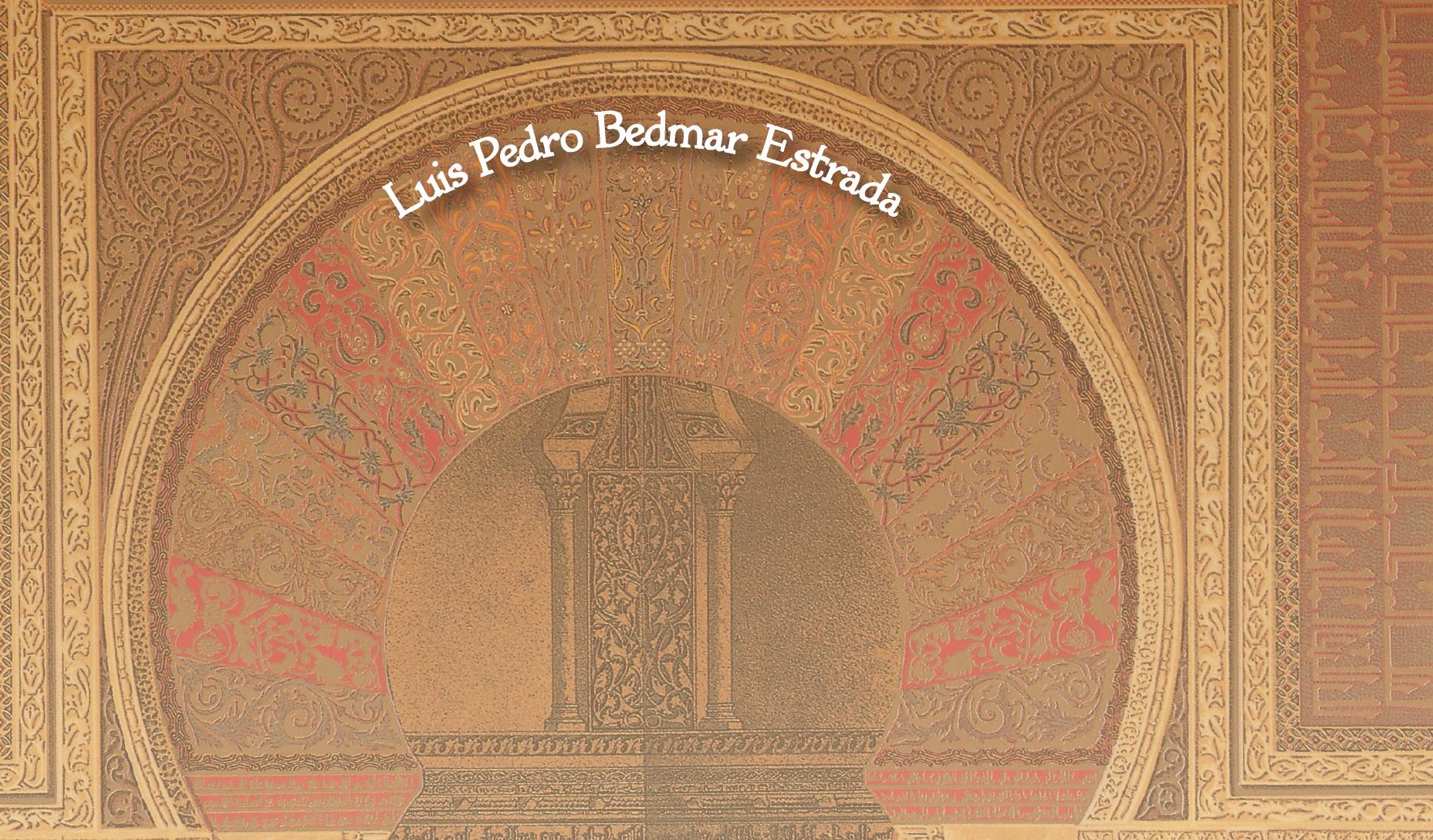

1

JUNTA DE ANDALUCIA

CONSEJERÍA DE CULTURA 


La húsica en la

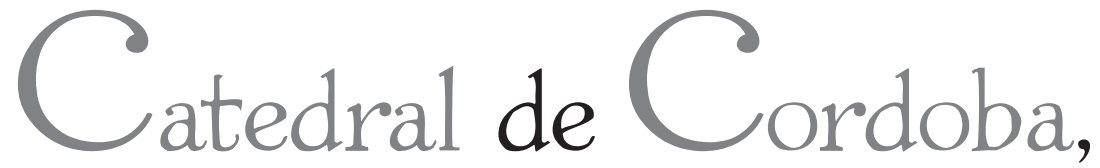

a través del $\bigcap_{\text {abjisterio }}$

de Jaime $B_{\text {alius y }} \widetilde{C}_{\text {ila }}$

$$
(1785-1822)
$$

Luis Pedro Bedmar Estrada

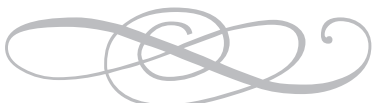


Esta obra obtuvo una ayuda de la Consejería de Cultura de la Junta de Andalucía a Proyectos de investigación Musical

Edita:

JUNTA DE ANDALUCÍA. Consejería de Cultura

Coordina:

Centro de Documentación Musical de Andalucía

(c) de la edición: JUNTA DE ANDALUCÍA. Consejería de Cultura

(C) Luis Pedro Bedmar Estrada

ISBN: 978-84-8266-907-6

Depósito Legal: CO. 915/2009

Imprenta San Pablo, S. L. - Córdoba

Sór Ángela de la Cruz, 12 - TIf. 957283306

www.imprentasanpablo.com 


\section{$\mathscr{A} \mathscr{M}$ OStedad,}

mi esposa, mi amiga, mi compañera,

sin cuya infinita paciencia y apayo,

hubiese sida imposible la realización de este trabajo. 



\section{ÍNDICE}

\section{VOLUMEN I. TEXTOS.}

PÁG.

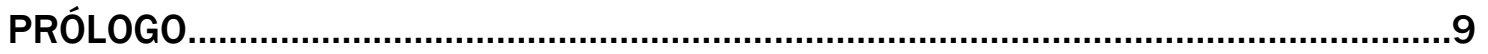

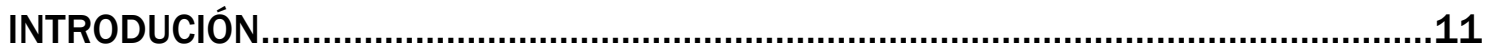

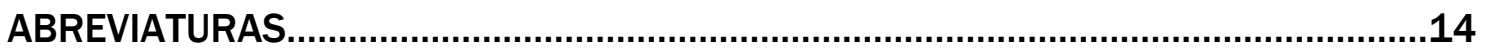

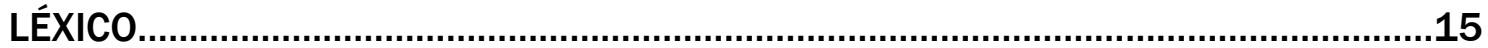

CAPÍTULO 1. EL ESTADO DE LA CUESTIÓN...................................................19

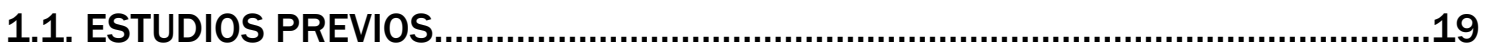

1.2. NUESTRO PROPÓSITO....................................................................................22

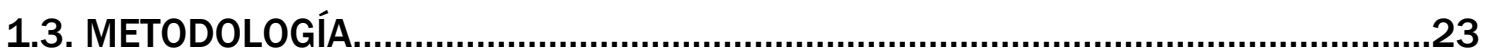

CAPÍTULO 2. ASPECTOS MUSICALES DE FINALES DEL SIGLO XVIII Y PRINCIPIOS DEL XIX. SU CONTEXTO POLÍTICO-SOCIO-CULTURAL..........25

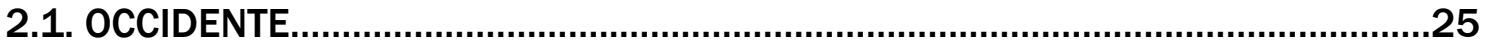

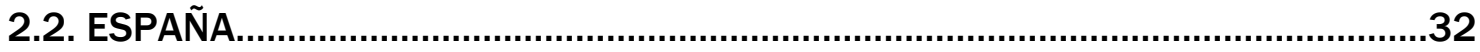

2.1.1. LA INVASIÓN NAPOLEÓNICA (1808)..........................................................33

2.1.2. ASPECTOS MUSICALES............................................................................34

CAPÍTULO 3. LA CÓRDOBA DE LA ÉPOCA .....................................................37

3.1. ASPECTOS DEMOGRÁFICOS, SOCIOECONÓMICOS, EDUCATIVOS, CULTURALES

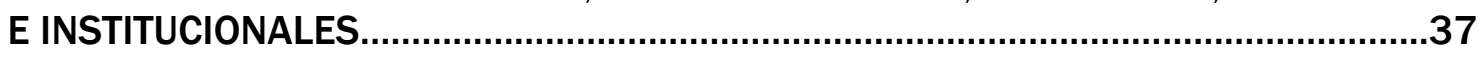

3.2. LA IMAGEN URBANA DE CÓRDOBA EN EL CAMBIO DE SIGLO..........................45

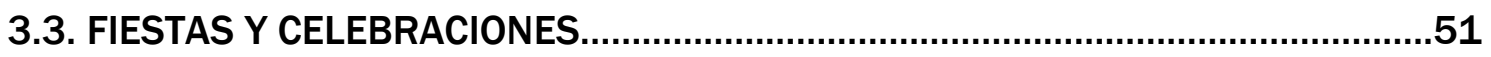

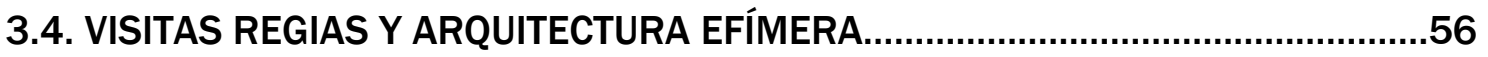

3.5. CÓRDOBA DURANTE LA GUERRA DE LA INDEPENDENCIA...............................59

CAPÍTULO 4. LA MEZQUITA-CATEDRAL DE CÓRDOBA .................................69

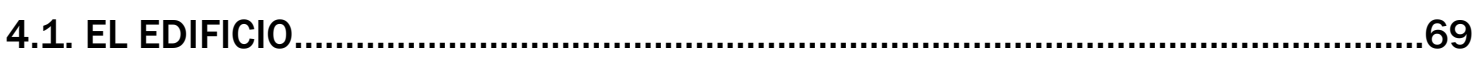

4.1.1. DE TEMPLO CRISTIANO A MEZQUITA........................................................69

4.1.2. DE MEZQUITA A CATEDRAL........................................................................73

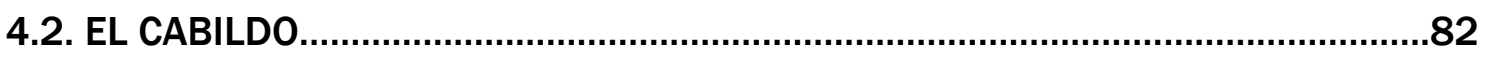




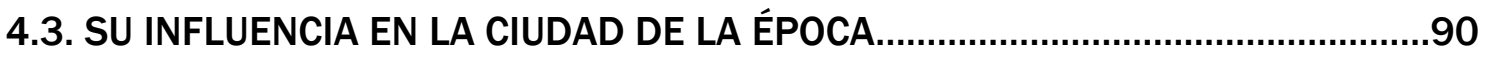

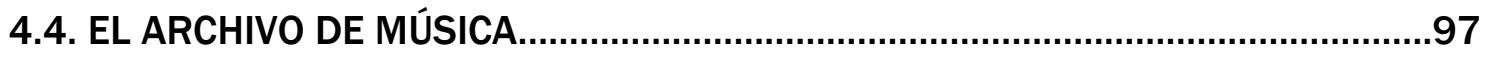

CAPÍTULO 5. LA ORGANIZACIÓN MUSICAL DE LA CATEDRAL. SU ESTRUCTURA Y ELEMENTOS QUE LA INTEGRAN. LA CAPILLA DE MÚSICA. .111

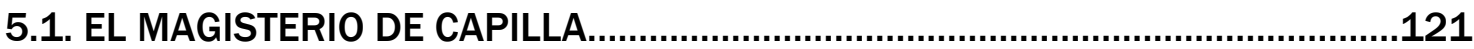

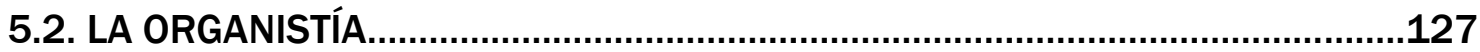

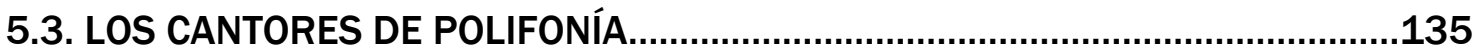

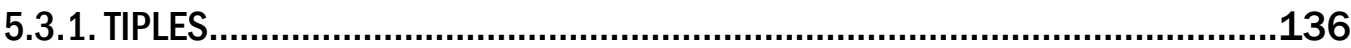

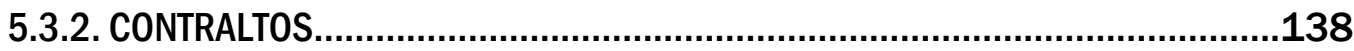

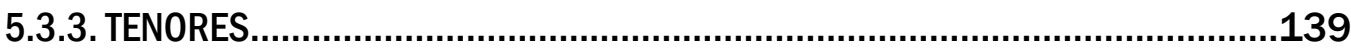

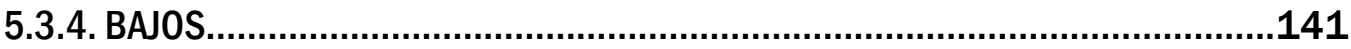

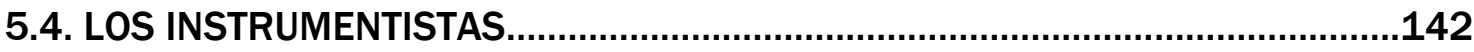

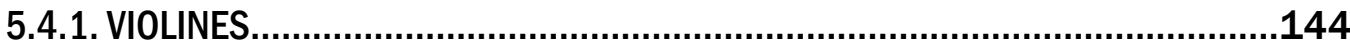

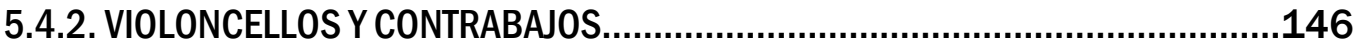

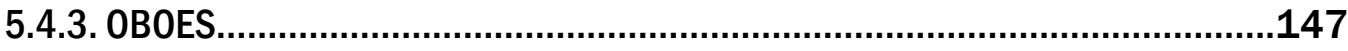

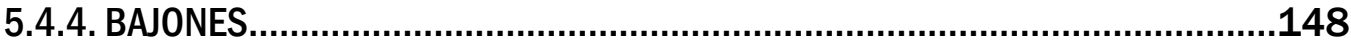

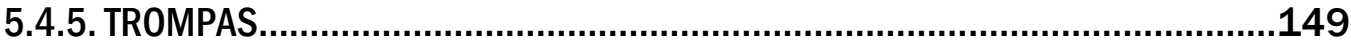

5.5. LOS NIÑOS DE CORO Y EL COLEGIO DE INFANTES.......................................151

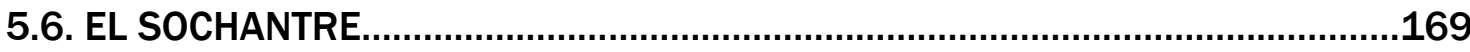

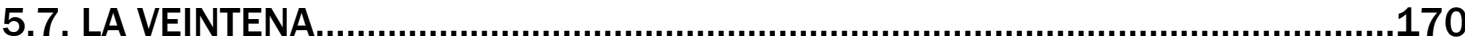

5.8. ESTATUTOS Y NORMAS DE FUNCIONAMIENTO DE LA CAPILLA DE

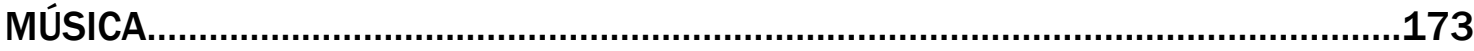

5.9. VACIADO CRONOLÓGICO DE NOTICIAS MUSICALES (1785-1822).................177

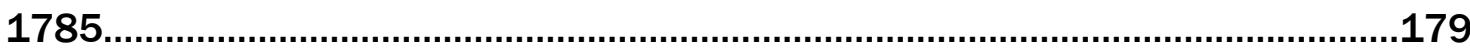

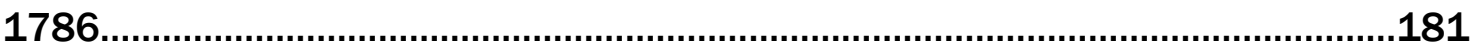

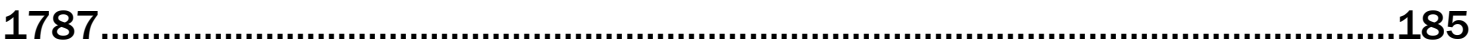

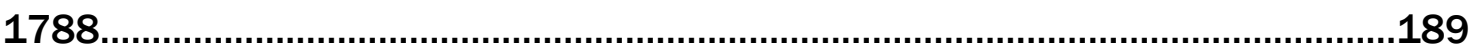

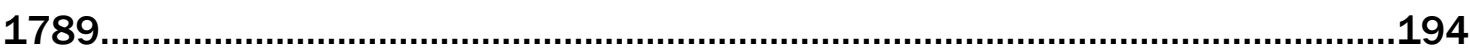

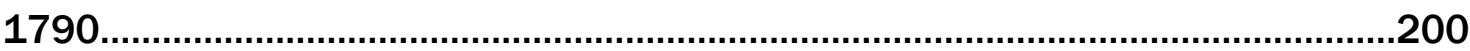

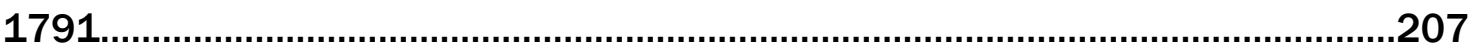

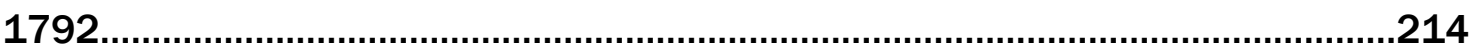

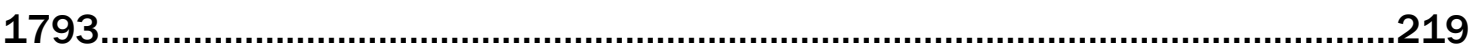

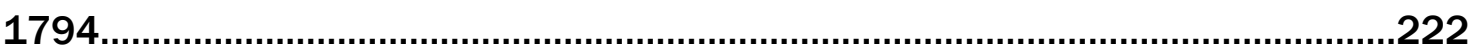




1796

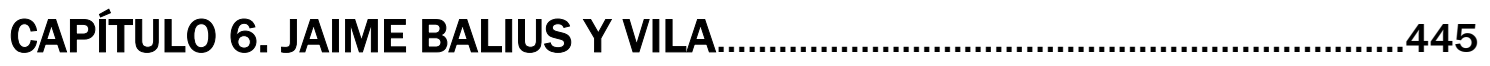

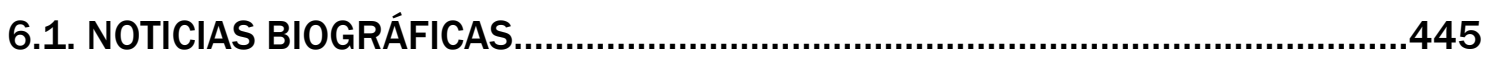

6.1.1. ANTES DE SU LLEGADA A CÓRDOBA. 1750-1785....................................446

6.1.2. SU PRIMERA ETAPA EN CÓRDOBA. 1785-1787 .........................................454

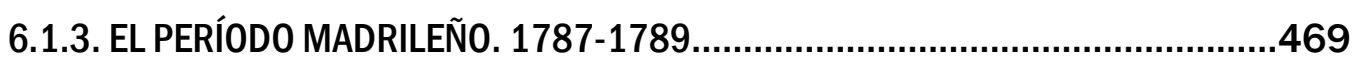


6.1.4. SU REGRESO DEFINITIVO A CÓRDOBA. 1789-1822 ....................................472

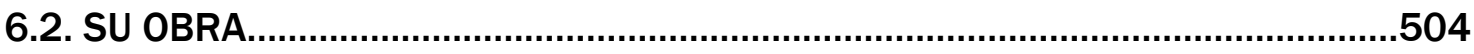

6.2.1. CARACTERÍSTICAS PRINCIPALES..........................................................506

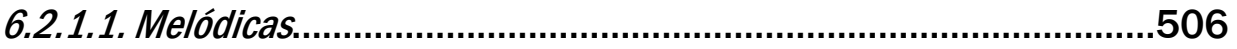

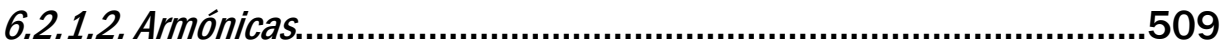

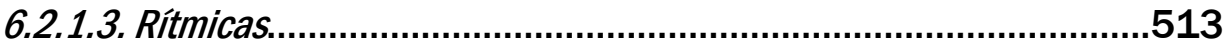

6.2.1.4. Agógicas y Dinámicas..................................................................517

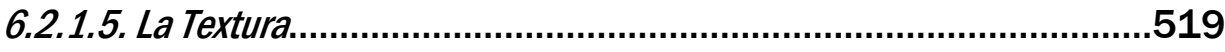

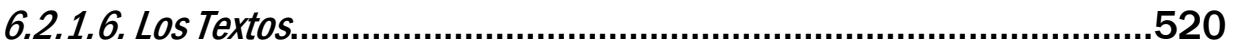

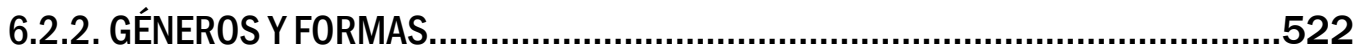

6.2.2.1. Cánticos..................................................................................523

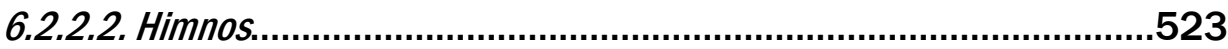

6.2.2.3. Lamentaciones......................................................................524

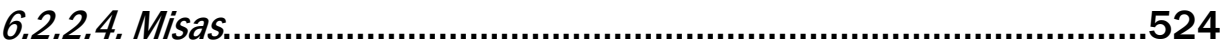

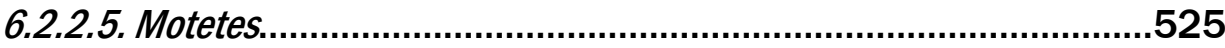

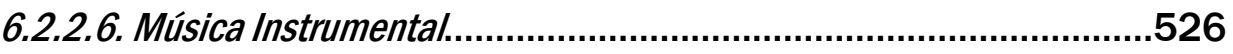

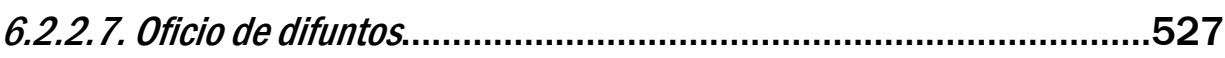

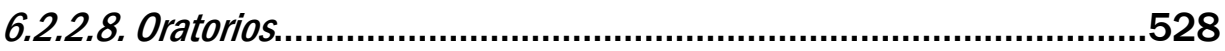

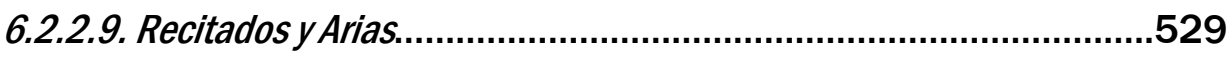

6.2.2.10. Responsorios y Secuencias....................................................530

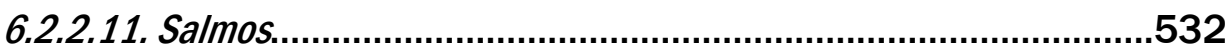

6.2.2.12. Varia en castellano...............................................................532

6.2.2.13. Varia en latín...........................................................................535

6.2.2.14. Villancicos y Kalendas..........................................................535

6.2.3. PLANTILLA INSTRUMENTAL....................................................................540

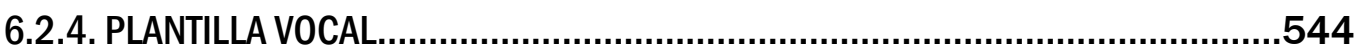

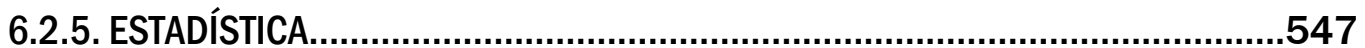

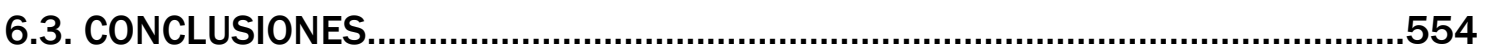

CAPÍTULO 7. FUENTES Y BIBLIOGRAFÍA...................................................559

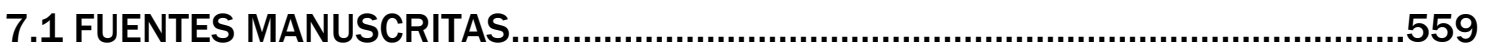

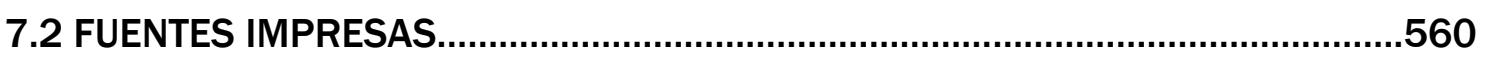

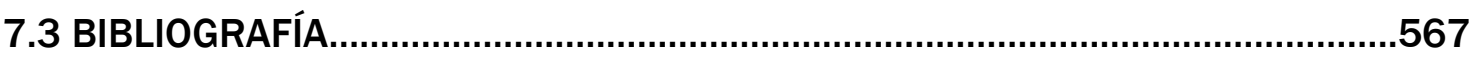


DOCUMENTO N¹. Sobre la visita de Carlos IV a Córdoba en 1796. (extracto).....585

DOCUMENTO No2. Ceremonial y manual de las preces, antífonas, himnos, salmos y oraciones que deben decirse en esta Santa Iglesia Catedral de Córdoba. (1805).

(extracto).

DOCUMENTO $\mathrm{N}^{\circ} 3$. Sobre los abusos que se producen en el canto durante las procesiones. .595

DOCUMENTO N4. El Colegio de Infantes de Córdoba...........................................598

A) Constituciones del Colegio de Infantes. 598

B) Cabildo sobre la supresión del Colegio de Infantes y la reorganización de los Niños de Coro y Acólitos. 609

C) Decreto de supresión del Colegio de Infantes. .611

D) Valoración del edificio y los muebles del Colegio de Infantes. 614

E) Diligencias de venta del Colegio de Infantes .615

F) Destino de los muebles e instrumentos musicales del Colegio de Infantes.....616 DOCUMENTO N5. La Santa Escuela de Cristo. 618

DOCUMENTO $\mathrm{N}^{\circ} 6$. Cabildo sobre la dotación de la veintena y los músicos. 619 DOCUMENTO N$^{\circ} 7$. Cabildo para tratar sobre rebajas en los sueldos de los músicos (I).

DOCUMENTO N8. Cabildo para tratar sobre rebajas en los sueldo de los músicos. (II).

DOCUMENTO N9. Cabildo sobre el pago de un impuesto al General Gobernador de Córdoba. 629

DOCUMENTO N¹0. Celebración del Regimiento de Caballería de Santiago........630 DOCUMENTO $\mathrm{N}^{\circ} 11$. Solemnidad conmemorativa del nacimiento de Nuestro Señor Jesucristo en la Santa Iglesia Catedral de Córdoba..............................................634

DOCUMENTO No 12. La Tertulia Patriótica de Córdoba...........................................636

DOCUMENTO No 13. Testamento de Jaime Balius y Vila (1)...............................638

DOCUMENTO $\mathrm{N}^{\circ}$ 14. Testamento de Jaime Balius y Vila (2).................................641

DOCUMENTO N 15. Juán Lucas del Pozo y Cáceres...............................................643

LÁMINAS. 


\section{VOLUMEN II. [EN CD.ROM] CATÁLOGO DE LAS OBRAS.}

\section{CAPÍTULO 8. CATÁLOGO DE OBRAS DE JAIME BALIUS Y VILA}

EXISTENTES EN EL A.C.C

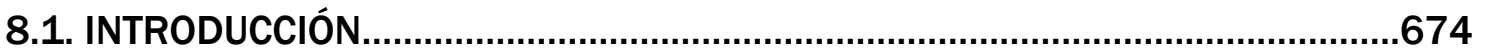

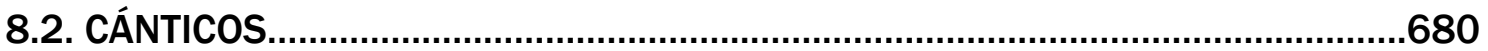

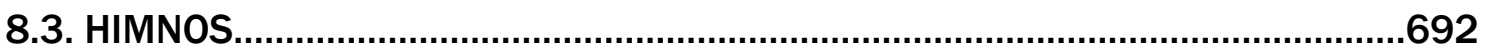

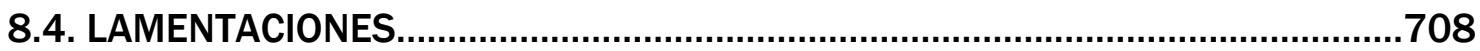

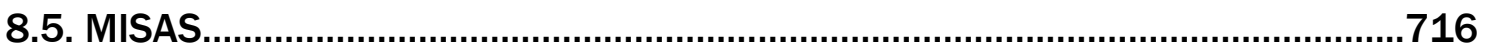

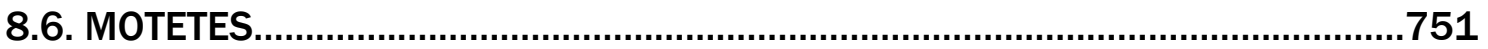

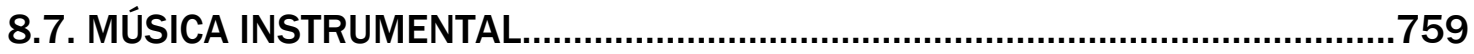

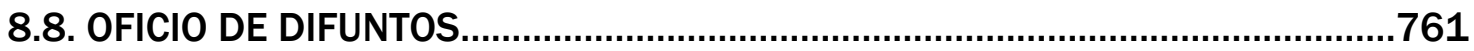

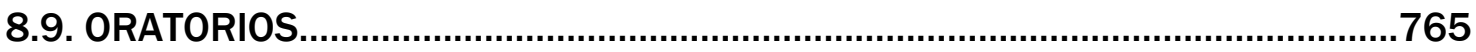

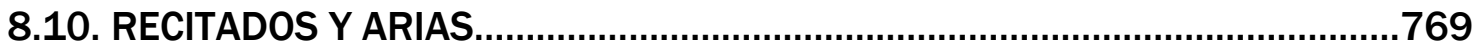

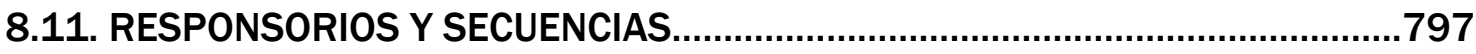

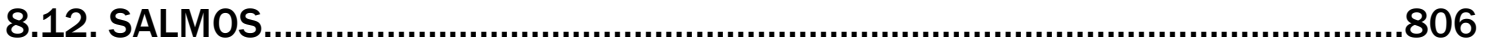

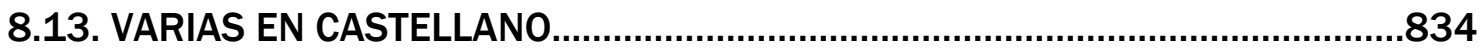

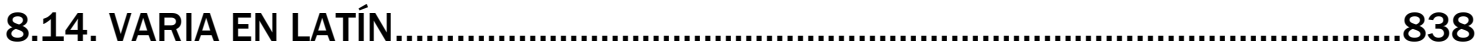

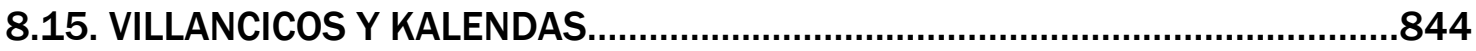

CAPÍTULO 9. LA MÚSICA DE JAIME BALIUS EN OTRAS CATEDRALES, MONASTERIOS, BIBLIOTECAS Y ARCHIVOS DIVERSOS...........................1072

9.1. EN EL ARCHIVO DE LA IGLESIA DE SANTA MARÍA LA GELTRÚ.....................1074

9.2. EN EL ARCHIVO DE PRESBÍTEROS DE VILLAFRANCA DEL PENEDÉS (MUSEO DE VILLAFRANCA). 1074

9.3. EN EL ARCHIVO EPISCOPAL DE LA SEU D'URGELL....................................1074

9.4. EN EL ARCHIVO HISTÓRICO COMARCAL DE CERVERA..................................1075

9.5. EN EL ARCHIVO MUSICAL DE LA IGLESIA PARROQUIAL CANET DE MAR....1075

9.6. EN EL ARCHIVO MUSICAL DE LA IGLESIA DE SAN ESTEVE DE OLOT.............1075

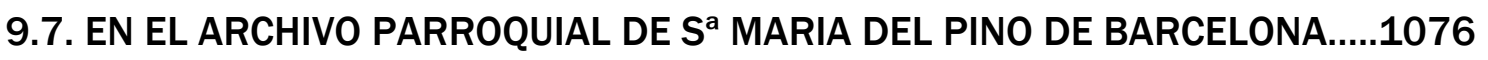

9.8. EN EL ARCHIVO HISTÓRICO MUNICIPAL DE ANTEQUERA...............................1077

9.9. EN LA BIBLIOTECA DE CATALUÑA (BARCELONA)........................................1078

9.10. EN LA BIBLIOTECA MUNICIPAL DE GERONA............................................1078

9.11. EN LA BIBLIOTECA NACIONAL...............................................................1080 
9.12. EN LA CATEDRAL DE ALBARRACÍN........................................................1080

9.13. EN LA CATEDRAL DE CÁDIZ.......................................................................1081

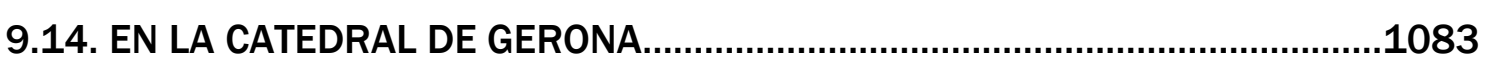

9.15. EN LA CATEDRAL DE GRANADA.........................................................1087

9.16. EN LA CAPILLA REAL DE LA CATEDRAL DE GRANADA..............................1091

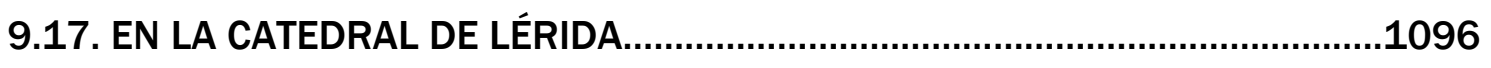

9.18. EN LA CATEDRAL DE MÁLAGA................................................................1097

9.19. EN LA CATEDRAL DE OVIEDO ...............................................................1125

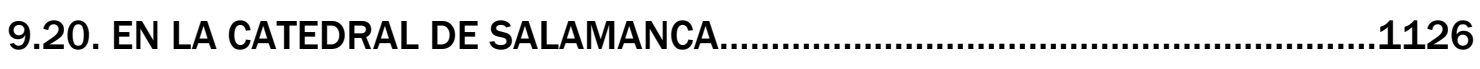

9.21. EN LA CATEDRAL DE SANTIAGO DE COMPOSTELA.....................................1126

9.22. EN LA CATEDRAL DE SEVILLA..............................................................1127

9.23. EN LA CATEDRAL DE TORTOSA.........................................................1127

9.24. EN LA CATEDRAL DE VALENCIA.........................................................1127

9.25. EN LA CATEDRAL DE VALLADOLID...........................................................1128

9.26. EN LA COLEGIATA DE LA SEU DE MANRESA..............................................1128

9.27. EN EL MONASTERIO DEL ESCORIAL.........................................................1129

9.28. EN EL MONASTERIO DE GUADALUPE (CÁCERES).....................................1129

9.29. EN EL MONASTERIO DE MONTSERRAT.....................................................1130

\section{VOLUMEN III. [EN CD.ROM] TRANSCRIPCIONES Y DOCUMENTO SONORO.}

DE LA ANTIGUA SERPIENTE. Recitado y Aria con Violines, Oboes y Trompas. De Tiple. (2/12).

DE VILLAVICIOSA VIENEN. Villancico a 7 voces [a 4] con Violines, Oboes, Trompas y Acompañamiento.

$(62 / 426)$ 1245

DOMINE y DIXIT DOMINUS. A 8 Voces, con Violines, Oboes, Trompas y Bajo.

$(8 / 68)$. 
HOC CORPUS. Motete para el Monumento. A 4 voces, con Violines y acompañamiento. (118/1079)

MAGNÍFICAT. A 5 voces, con Violines, Oboes, Trompas y Bajo.1791.(2/14)......1540

MISA LLANA. A 4 voces y órgano. (14/107). 1682

SALUTIS HUMANAE. Himno para las segundas vísperas de la Ascensión. A 4 voces con acompañamiento y bajón. (127/1221). 1817

CD DE AUDIO 1850 


\section{PRÓLOGO.}

Es para mí un honor y una satisfacción poder redactar unas pocas líneas de presentación a este buen trabajo del profesor D. Luis Pedro Bedmar, que va a enriquecer, sin duda, el conocimiento de la catedral y ciudad de Córdoba en un tramo cronológico de no pequeñas perturbaciones y cambios. La vida y obra de un Maestro de Capilla en el siglo XVIII, y hasta no hace tanto tiempo, trasciende los límites de la catedral y marca su huella en el desarrollo cultural de la sociedad.

Bien sabido es, que la Iglesia ha sido un eslabón básico en el devenir de la Música a lo largo de su historia, como lo fue de la filosofía, del arte y de cualquier otro campo de nuestra cultura occidental. Su larga trayectoria, enraizada en la teoría y la práctica del substrato griego y mediooriental, atemperándose a la sensibilidad de cada nuevo asentamiento cristiano, daría frutos como el Canto Mozárabe español, el Ambrosiano, el Galicano y tantos otros Cantos Autóctonos que desembocarían en el gran río del Canto Gregoriano, la Polifonía y el Contrapunto después... Su legado, después de tantos siglos, sigue siendo un organismo vivo, sujeto como tal a crecimiento, transformaciones, momentos de exaltación y de depresión y aun de enfermedades y continúa presente en el torrente sanguíneo de nuestra producción musical contemporánea.

Concretamente, las catedrales y monasterios, por el procedimiento pedagógico perfectamente eficaz de la “inmersión” en la música, de la "vivencia” a través de su práctica constante, han sido el principal vivero musical de España. Quedaríamos asombrados, si elaboráramos una lista (inmensa) de grandes músicos, directores de orquesta, compositores, instrumentistas, musicólogos..., que tienen una deuda de diverso calibre con el seminario, el noviciado, la catedral o cualquier otra institución eclesial. Otro tanto cabría decir de la temática y motivación de sus obras tanto de música práctica, como científica. Efectivamente, una buena parte de la gran historia de la música española se realiza y conserva en los archivos catedralicios.

Los centros civiles de formación musical, los Conservatorios por ejemplo, son instituciones relativamente recientes. Todavía en los años 70 (1970) no eran más de seis los dependientes del Estado en toda España. Fue la Iglesia la que suplió secularmente esta carencia de infraestructura académica y la que tuteló con sus buenos profesionales 
sus primeros pasos, como había hecho con la universidades medievales en su momento. No hace mucho tiempo, la figura del Maestro de Capilla de la catedral era un punto de referencia en la vida musical de cada ciudad por su prestigio y trascendencia.

La práctica constante de la música en la liturgia de nuestras catedrales, con varios actos al día, no sólo propiciaba una educación permanente en su ámbito social, sino también una necesidad de incrementar el repertorio de acuerdo con una demanda tan exigente y continuada.

Ello explica el acervo inmenso de obras que pueblan nuestros archivos catedralicios. La Iglesia, la catedral de Córdoba concretamente, ha cumplido su misión de creación, primero, y de conservación y custodia de tan preciado legado, después. A otros corresponde la misión de estudiar y divulgar tanta riqueza documental acumulada.

En esta dirección van trabajos de investigación como el que presentamos. Si además, el autor, Luis Pedro Bedmar, centra su análisis sobre una figura tan relevante como Jaime Balius, el Maestro de Capilla más prolífico, sin duda, pero también más representativo de la historia musical de Córdoba y figura muy destacada del acontecer musical español entre los siglos XVIII y XIX, el interés crece exponencialmente.

El Maestro Balius debe relamerse de gusto, dicho sea con todos los respetos, al verse de nuevo protagonista de una trayectoria que nunca debió olvidarse. Todo ello gracias al trabajo concienzudo, escrupuloso, exhaustivo... del Dr. Luis Pedro Bedmar, quien así pasa a engrosar la lista de grandes estudiosos y fervientes admiradores de Córdoba y su Catedral.

Málaga, Junio del 2009.

Dr. Adalberto Martínez Solaesa Profesor Emérito de la Universidad de Málaga

Organista Titular de la Catedral. 


\section{INTRODUCCIÓN.}

Las catedrales y monasterios son una fuente valiosísima de información para conocer el desarrollo que a través de los siglos ha tenido la vida musical en España y en el mundo. Durante mucho tiempo fueron casi la única fuente de transmisión de la música culta, convirtiéndose en verdaderos antecedentes de los conservatorios actuales, ya que en los citados centros religiosos se enseñaban los fundamentos teóricos y prácticos de la música, y se interpretaba un amplio repertorio de piezas musicales, tanto monódicas como polifónicas, a capella o con acompañamiento instrumental. ${ }^{1}$

El patrimonio musical que contienen dichas catedrales y monasterios, además de colegiatas o iglesias de cierta relevancia, es muy importante por el gran número de obras que se conserva, así como por su variedad formal, estilística y por la calidad de sus composiciones. Esta calidad venía dada por la sólida formación musical que tenían los Maestros de Capilla. Sus conocimientos y habilidades incluían la técnica de interpretación del canto gregoriano, el dominio de uno o varios instrumentos, entre ellos el órgano, la técnica vocal, la armonía, el contrapunto, la composición y en definitiva, todos aquellos recursos necesarios para dirigir la compleja y abundantísima actividad de las catedrales.

El repertorio que se conserva es en su mayoría religioso, muy de acuerdo con la consideración de la música como “ancilla Liturgiae”, y lógicamente cubre todo el espectro amplísimo exigido por esta dedicación y que podríamos concretar dos frentes:

Litúrgico: La Misa, con sus partes fijas u Ordinario (Kyrie, Gloria, Credo, Sanctus y Agnus) y variables o Propio (Introito, Gradual, Secuencia y Alleluya, Ofertorio, Comunión). El Oficio (antífonas, responsorios, secuencias, salmos, cánticos, himnos, lamentaciones, oratorios, villancicos, kalendas, recitados y arias, etc.).

Paralitúrgico: Procesiones, rogativas, triduos, novenas, exposición del Santísimo Sacramento... (salmos, antífonas, himnos, gozos, etc.).

\footnotetext{
${ }^{1}$ Todo ello comprendido dentro del ordo cathedralis o dentro del ordo monasticus entendiendo éstos como el conjunto de cantos, oraciones y celebraciones que componían el Oficio en las catedrales o en los monasterios. Cf. FERNÁNDEZ DE LA CUESTA, Ismael. Historia de la música española. Desde los orígenes hasta el ars nova. Madrid, Alianza Editorial, 1983, págs. 123-144.
} 
También suele haber en las catedrales una pequeña representación de música profana, ya sea vocal, instrumental o mixta. En ocasiones este repertorio profano permite comprobar la implicación del Maestro de Capilla en la vida cultural de la ciudad. ${ }^{2}$ Todo el repertorio citado refleja la práctica diaria de la música en catedrales y monasterios en sus diversos grados de solemnidad.

Lo dicho hasta ahora es de aplicación general para los grandes templos religiosos de España y de la cristiandad. En el caso que nos ocupa, la Catedral de Córdoba, gran parte de su repertorio es aún desconocido, aunque ya están en marcha varios proyectos como el presente que se ocupan de distintos autores y que en un futuro próximo verán la luz.

Por nuestra parte pretendemos contribuir a este esclarecimiento ocupándonos de una época muy interesante a todos los niveles, como es el final del siglo XVIII y principios del XIX, una de las época que ha dejado mayor huella en nuestros archivos catedralicios, y a pesar de ello, de las más desconocidas de nuestra Historia de la Música española. Ello justifica la aparición de un trabajo como el que presentamos. Concretamente, hemos acotado las fechas entre 1785 y 1822, ya que durante este período, y salvo una pequeña interrupción, ejerció su Magisterio en Córdoba uno de los más prestigiosos Maestros de Capilla que ha tenido España. Este es Jaime Balius y Vila. Al hilo de su vida y su obra como guión conductor, atenderemos también otros aspectos de la vida musical de la Catedral cordobesa, como la composición de la Capilla de Música, los Estatutos que regían sus actividades y en suma, los elementos que componían la actividad musical de la época y su repercusión en la sociedad cordobesa.

La importancia que concedemos a Jaime Balius y Vila radica tanto en las cualidades de su obra como en el papel que ésta representa en el contexto de todo el archivo musical de la Catedral de Córdoba. En el primer caso, hay que destacar su calidad musical, fundamentalmente basada en un dominio absoluto de las técnicas compositivas, en una gran inspiración melódica y en una gran variedad formal, todo ello

\footnotetext{
${ }^{2}$ Efectivamente podemos ver cómo algunos Maestros componen obras profanas que tienen que ver con algún asunto de relevancia sucedido en la ciudad. Por ejemplo, Jaime Balius escribió la Canción Patriótica Nobles Andaluces durante la invasión francesa, o más tarde Cordobeses Ilustres para celebrar la visita a Córdoba de Isabel de Braganza.
} 
inmerso dentro de un lenguaje estilístico puramente clásico, aunque con reminiscencias del barroco, como la utilización del bajo contínuo y la policoralidad.

En cuanto a la valoración de su obra dentro del cómputo general del archivo catedralicio, es indudable que destaca no sólo por estar cualitativamente a la altura de la realizada por cualquier otro Maestro de Capilla, sino sobre todo por su cantidad. En este sentido, hay que tener en cuenta que el total de las obras musicales controladas hasta el momento en el Archivo de la Catedral de Córdoba rebasa las 3000. Pues bien, de ellas, 720 están compuestas por Jaime Balius, es decir, casi una cuarta parte. De estas 720, 44 son atribuidas a Jaime Balius por el autor de este trabajo, una vez revisados todos los anónimos del archivo. En cualquier caso, podemos afirmar que es el autor más prolífico de toda la historia musical de la Catedral de Córdoba, y desde luego, si extrapolamos su obra a la Historia de la Música, estaría también en un puesto destacado entre los autores con mayor producción musical.

Esta valoración muy positiva que nosotros hacemos de su obra es compartida por firmas ilustres y queda reflejada en documentos tan importantes como el Diccionario de la Música Española e Hispanoamericana, de Emilio Casares. Allí, en el apartado dedicado a Balius, nos dice Civil y Castellví: “...Balius fue uno de los Maestros más distinguidos de su tiempo. Su himno Deus tuorum militum, a cuatro voces de estilo riguroso, compuesto para las oposiciones a la magistratura de Córdoba, conserva aún su celebridad, y el soberbio "Hoc Corpus", a cuatro voces con acompañamiento a viento (fagotes y oboes) para ser cantado el Jueves Santo ante el Monumento, puede ser considerado como una verdadera obra de arte." 3

Pretendemos por tanto con este trabajo y mediante un estudio sistemático y exhaustivo aportar nuestra colaboración para sacar a la luz una parte importante de la historia musical de la Catedral de Córdoba y más concretamente de un compositor como Jaime Balius y Vila, que indudablemente merece un mayor reconocimiento a nivel histórico y social ya que nos dejó un legado digno de figurar con letras de oro dentro del patrimonio musical de nuestro país.

\footnotetext{
${ }^{3}$ Citado por Garbayo, Javier: “Balius Vila, Jaime”, en: Casares, E. y otros: Diccionario de la Música Española e Hispanoamericana. Madrid, Sociedad General de Autores, 1999, V.II. pág.112.
} 


\section{ABREVIATURAS.}

A.C.C. Archivo de la Catedral de Córdoba.

pág.: página.

págs.: páginas.

Cf.: confróntese.

$\mathrm{T}$ : Tomo

fol: folio.

s/f: sin foliar.

r: recto.

v: vuelto.

Mrs: maravedíes.

Ms: manuscrito.

Rs: reales.

Fan: fanega.

S: Soprano.

A: Alto. En algún caso también aparece como C: Contralto

$\mathrm{T}$ : Tenor.

B. Bajo.

Ob: Oboe.

Tpa. Trompa.

Vl: Violín.

Vla: Viola.

Vc: Violoncello.

Cb: Contrabajo.

Acmpto: Acompañamiento.

$\mathrm{N}^{\circ} \mathrm{X} / \mathrm{N}^{\circ} \mathrm{X}$. Cuando aparecen dos números separados por una barra inclinada nos referimos a la caja y a la carpeta en que se encuentra la obra a que hacemos referencia, dentro del Archivo de la Catedral de Córdoba. 


\section{LÉXICO. ${ }^{4}$}

Aspa: En la organización de la Capilla de Música de la Catedral de Córdoba, en los cuadrantes que recogían la asistencia de los músicos, se reflejaba la ausencia de alguno de ellos con un aspa en su correspondiente casilla. Las aspas son por tanto, en la época y contexto de este trabajo, las faltas de asistencia, que además llevaban consigo la correspondiente sustracción del sueldo de ese día, salvo que se contara con la autorización del Cabildo para no asistir.

Beca: La plaza o prebenda de colegial; y así se dice: fulano entra en la beca de fulano. ${ }^{5}$

Cédula: Pedazo de papel o pergamino escrito, o para escribir en él alguna cosa. ${ }^{6}$

Colación: El acto de colar o conferir canónicamente los beneficios eclesiásticos. ${ }^{7}$

Congrua: La renta eclesiástica señalada por el sínodo para la manutención del que se ha de ordenar in sacris. ${ }^{8}$ Renta anual que debía acreditar un eclesiástico antes de recibir Ordenes Sagradas para garantizar su honesta sustentación. Podía basarse en una pensión (capellanía o beneficio) o en bienes patrimoniales. ${ }^{9}$

Costa: La cantidad de que se da o se paga por alguna cosa. ${ }^{10}$ Con frecuencia, los músicos solicitaban algún complemento económico o ayuda de costa, para poder hacer frente a sus necesidades.

Deán: Dignidad eclesiástica que después del Obispo o Arzobispo preside y gobierna los cabildos de las mas iglesias catedrales. ${ }^{11}$

Dotaciones: Fundaciones Pías. Patronatos. Conjunto de bienes (muebles o inmuebles, en metálico o en especie) asignados como “dote” para sustentar las cargas de una fundación, como la celebración cte determinado número de misas o la asistencia a determinadas funciones religiosas durante el año. ${ }^{12}$

\footnotetext{
${ }^{4}$ Recogemos aquí algunos términos frecuentemente utilizados en la documentación catedralicia durante la época que nos ocupa, finales del siglo XVIII y principios del XIX. Algunos siguen utilizandose hoy día, otros han caído en desuso.

${ }^{5}$ Diccionario de la Real Academia Española (1783), pag.151.

${ }^{6}$ Ibid. pág.225.

${ }^{7}$ Ibid. pág.254.

${ }^{8}$ Ibid. pág.273.

${ }^{9}$ DÍEZ MARTÍNEZ, Marcelino. La Música en Cádiz. La Catedral y su proyección urbana durante el siglo XVIII. Cádiz, Servicio de publicaciones de la Universidad de Cádiz, 2004, pág. 23.

${ }^{10}$ Diccionario de la R.A.E. (1783), pág.300.

${ }^{11}$ Ibid. pág.324.

${ }^{12}$ DÍEZ MARTíNEZ, Marcelino. La Música en Cádiz. La Catedral y su proyección urbana durante el siglo XVIII. Cádiz, Servicio de publicaciones de la Universidad de Cádiz, 2004, pág. 23.
} 
Fábrica: Fondo o patrimonio propio de una catedral o iglesia para atender a su conservación y a los gastos del personal y del culto. Era administrado por un oficial o Mayordomo de Fábrica, bajo la autoridad del señor Obrero. ${ }^{13}$

Jabardo: En las Constituciones del Colegio del Santo Ángel de Niños de Coro de Córdoba, figura este término refiriéndose al grupo musical que formaban los niños para “cantar y tocar instrumentos en público”. ${ }^{14}$ En el Diccionario de la Real Academia de 1783, este término tenía, entre otras, la siguiente acepción: “La junta de gente de baxa esfera o mala vida". 15

Obrero: El responsable de todo lo relativo a la conservación de la iglesia y administración de su patrimonio o Fábrica. ${ }^{16}$

Orden: Cualquiera de los grados de este sacramento, que se van recibiendo sucesivamente y constituyen ministros de la Iglesia; como ostiario, lector, exorcista y acólito (los quales se llaman órdenes menores) y el subdiaconato, diaconato, y sacerdocio, que se llaman mayores. ${ }^{17}$

Patitur: Licencia o permiso por enfermedad. ${ }^{18}$ Patitur abierto, cuando se permitía salir de la ciudad, y patitur cerrado cuando era dentro de ella.

Pertiguero: Ministro secular en las iglesias catedrales, que asistía acompañando a los que ofician en el altar, coro, púlpito y otros ministerios. Viste ropas rozagantes, y en la mano lleva por insignia de este oficio una vara, ó pértiga guarecida de plata. ${ }^{19}$

Prebendado: El dignidad, canónigo o racionero de las iglesias catedrales y colegiales. $^{20}$

Ración: Prebenda o porción diaria que percibía un prebendado o beneficiado de una iglesia para su sustento. ${ }^{21}$

\footnotetext{
${ }^{13}$ Ibid.

${ }^{14}$ A.C.C.Constituciones del Colegio del Ángel de la Guarda, que para la manutención, cristiana educación y útil enseñanza de los Infantes que sirven al Coro de la Santa Iglesia Catedral de Córdoba, ha fundado el Ilmo. Señor Deán y Cabildo de ella. Córdoba, 1771, pág. 10. Al hacerse estas interpretaciones (que eran sobre todo villancicos) fuera del Colegio, tenían que ir acompañados del Maestro de Capilla o del Rector del Colegio.

${ }^{15}$ Diccionario de la R.A.E. (1783), pag.576.

${ }^{16}$ DÍEZ MARTíNEZ, Marcelino. La Música en Cádiz. La Catedral y su proyección urbana durante el siglo XVIII. Cádiz, Servicio de publicaciones de la Universidad de Cádiz, 2004, pág. 23.

${ }^{17}$ Diccionario de la R.A.E. (1783), pág.600.

${ }^{18}$ DÍEZ MARTINEZ, Marcelino. La Música en Cádiz. La Catedral y su proyección urbana durante el siglo XVIII. Cádiz, Servicio de publicaciones de la Universidad de Cádiz, 2004, pág. 23.

${ }^{19}$ Diccionario de la R.A.E. (1783), pag.730.

${ }^{20}$ Ibid. pág. 756.
} 
Racionero: El prebendado que tiene ración en alguna iglesia catedral o colegial. ${ }^{22}$

Recle: Tiempo en que se permite a los prebendados no asistir a coro, para su descanso y recreación. ${ }^{23}$

Sínodo: Junta de personas legítimamente congregadas, doctas y graduadas, que concurren de diversas partes para la controversia, consejo y establecimientos eclesiásticos. $^{24}$

Situar: Asignar o determinar fondo para que alguno cobre alguna cosa. ${ }^{25}$

\footnotetext{
${ }^{21}$ DÍEZ MARTINEZ, Marcelino. La Música en Cádiz. La Catedral y su proyección urbana durante el siglo XVIII. Cádiz, Servicio de publicaciones de la Universidad de Cádiz, 2004, pág. 23.

${ }^{22}$ Diccionario de la R.A.E. (1783), pag.787.

${ }^{23}$ Ibid. pág.796.

${ }^{24}$ Ibid. pág.858.

${ }^{25}$ Ibid. pág.859.
} 


\section{CAPÍTULO 1. EL ESTADO DE LA CUESTIÓN.}

\subsection{ESTUDIOS PREVIOS.}

Existen diversos trabajos publicados que se han ocupado de las actividades musicales en la Catedral de Córdoba, como los realizados por D. Manuel Nieto Cumplido, D. Rafael Vázquez Lesmes y D. Francisco Javier Lara Lara. ${ }^{26}$ Estos magníficos trabajos son un referente obligado para comprender la organización de la Capilla Musical desde los primeros tiempos. Todos ellos se centran en épocas anteriores al siglo XIX. Por consiguiente se detienen a las puertas del ámbito cronológico que nosotros pretendemos recorrer, aprovechando la figura del Maestro de Capilla Jaime Balius y Vila. Tampoco hay trabajos monográficos en profundidad sobre este personaje, salvo referencias puntuales en tratados de historia, diccionarios, catálogos de otras catedrales, etc., como veremos inmediatamente. Sin embargo creemos que su estudio es del máximo interés porque marca una cumbre en la Historia de la Música cordobesa y es un punto obligado de referencia para lanzar luz sobre un período de la Historia de la Música española, entre el Clasicismo y el Romanticismo, muy necesitado aún de datos y estudio.

La gran producción musical que realizó Jaime Balius, su paso por diversos lugares del norte, centro y sur de la península (aunque fuera para presentarse a una oposición) y la gran notoriedad de que disfrutó en su época, como prueba la presencia de sus obras en la mayoría de las catedrales, monasterios o iglesias importantes de nuestro país, justifican su elección como punta de lanza de este estudio.

Cabe recordar que estuvo de Maestro de Capilla en La Seo de Urgel, en Gerona, en el Monasterio de la Encarnación de Madrid y en Córdoba. Pero también se presentó a oposiciones en Oviedo, El Burgo de Osma y Toledo. Si a esto sumamos su presencia como jurado en oposiciones de diversas ciudades, y el conocimiento que amigos y

\footnotetext{
${ }^{26}$ NIETO CUMPLIDO, Manuel. "La música en la Catedral de Córdoba (1236-1577)”, en AA.VV. El Patrimonio Histórico-Musical de Córdoba. Córdoba, Ayuntamiento de Córdoba, 2004. VÁZQUEZ LESMES, Rafael: "La Capilla de Música de la Catedral de Córdoba: Apuntes para su historia”. Córdoba, Boletín de la Real Academia de Córdoba, 110 (1986), págs. 113-141. LARA LARA, Francisco Javier. El canto llano en la Catedral de Córdoba. Los libros corales de la misa. Granada, Universidad de Granada, 2004.
} 
alumnos suyos tuvieron de su música, hace pensar que al menos en los centros musicales de cierta relevancia se pueda encontrar alguna o algunas de sus obras. Así pues, vamos a enumerar los datos que, de momento, tenemos al respecto.

Las referencias más completas que hemos encontrado sobre Balius se deben a la musicóloga catalana Gloria Ballus Casoliva; al historiador, erudito investigador y canónigo-archivero de la Catedral de Córdoba, Manuel Nieto Cumplido y al también musicólogo Javier Garbayo.

Gloria Ballus, en su tesis doctoral La música a la Colegiata Basílica de Santa María de la Seu de Manresa, se ocupa del aspecto biográfico y da una nutrida relación de obras. ${ }^{27}$

Por su parte Manuel Nieto Cumplido nos aporta valiosa información de su llegada a Córdoba y de su labor como Maestro de Capilla en el artículo “Maestros de Capilla de la Catedral de Córdoba”. ${ }^{28}$

Importante también es la información existente en el Diccionario de la Música Española e Hispanoamericana que dirige Emilio Casares. Allí vemos un artículo de Javier Garbayo en el que desgrana los hitos principales de la vida del Maestro. También recoge algunas aportaciones de Pedrell, de Pena y Anglés y de Civil y Castellví. Al final del artículo figura un listado de obras, que aunque incompleto da una idea de la producción del músico. ${ }^{29}$

Antonio Martín Moreno se ocupa de nuestro autor en su Historia de la Música Española del siglo XVIII, donde traza una línea biográfica y de distribución de obras. ${ }^{30}$ También se ocupa de él Carlos Gómez Amat en su Historia de la Música Española del siglo XIX, aunque de una forma más pasajera. ${ }^{31}$ En el Diccionario de la música y los músicos de Mariano Pérez encontramos una entrada breve y concisa de nuestro autor. ${ }^{32}$

\footnotetext{
${ }^{27}$ Cf. BALLUS CASOLIVA, Gloria: La música a la Colegiata Basílica de Santa María de la Seu de Manresa: 1714-1808. Tesis Doctoral. Universidad Autónoma de Barcelona, 2004.

${ }^{28}$ NIETO CUMPLIDO, Manuel. "Maestros de Capilla de la Catedral de Córdoba”. A.A.V.V.: Boletín de la Confederación Andaluza de Coros de 1995. Córdoba, Ed. CO.AN.CO., 1995, págs. 11-12.

${ }^{29}$ GARBAYO, Javier: "Balius Vila, Jaime”, en: CASARES, E. y otros: Diccionario de la Música Española e Hispanoamericana. Madrid, Sociedad General de Autores, 1999, Vol. 2, Págs. 111 y 112.

${ }^{30}$ MARTín MORENO, Antonio. Historia de la música española. Madrid, Alianza Editorial, colección Alianza Música, 1985, volumen IV, pág. 201.

${ }^{31}$ GOMEZ AMAT, Carlos. Historia de la música española. Madrid, Alianza Editorial, colección Alianza Música, 1984, volumen V, pág. 271.

${ }^{32}$ PEREZ, Mariano: Diccionario de la Música y los Músicos. Madrid, Ediciones Istmo, 1985, pág. 123.
} 
Fundamental es la aportación de Jordi Roig, ya que gracias a su trabajo Presencia musical en la Catedral de la Seu d'Urgell en la segunda mitad del siglo XVIII a través de sus actas capitulares, hemos conocido la fecha exacta de la llegada de Balius a la citada ciudad catalana. ${ }^{33}$

Francesc Civil Castellví en su artículo "La Capilla de música de la Catedral de Gerona, siglo XVIII”, incluye datos de la estancia allí de Balius. ${ }^{34}$ El mismo Civil Castellví le dedica unas líneas en su libro El fet musical a les comarques Gironines en el lapse de temps 1800-1936. ${ }^{35}$

Muy interesante es también el trabajo de María Galdón i Arrue La música a la Catedral de Girona durant la primera meitat del segle XIX, porque entre otras cosas nos revela el nombre de varios alumnos de Balius en Gerona. ${ }^{36}$

En La Música en el Monasterio de la Encarnación, Siglo XVIII, de Paulino Capdepón, se reproducen obras de los Maestros de Capilla de este convento, entre los que se encuentra Balius. ${ }^{37}$

También los encontramos en el libro Villancicos Barrocos en la Capilla Real de Granada, donde Germán Tejerizo le dedica una breve semblanza, y transcribe su villancico "Ahora llegan dos pastores". ${ }^{38}$

En alguna ocasión, podemos encontrar alguna de sus obras incluso en lugares que no son grandes ciudades o centros musicales de primer nivel. De hecho en el boletín n 3 del Instituto de Estudios "Pedro Suárez", de Guadix, Año 1990, el investigador Gonzalo Pulido Castillo, nos habla de los villancicos que se interpretaban en Huescar (Granada):

\footnotetext{
${ }^{33}$ ROIG I CAPDEVILA, Jordi. "Presencia musical en la Catedral de la Seu d'Urgell en la segunda mitad del siglo XVIII a través de sus actas capitulares”. Anuario Musical, 59. Barcelona, Consejo Superior de Investigaciones Científicas, Institución "Milá i Fontanals”, Departamento de Musicología, 2004.

${ }^{34}$ CIVIL CASTELLVÍ, Francesc: "La Capilla de Música de la Catedral de Gerona, siglo XVIII”. Anales del Instituto de Estudios Gerundenses, Volumen XIX. Gerona, 1968, págs. 131-188.

${ }^{35}$ CIVIL CASTELLVÍ, Francesc: El fet musical a les comarques Gironines en el lapse de temps 18001936. Gerona, Caja de Pensiones, 1970, págs. 11-12.

${ }^{36}$ GALDON I ARRUE, María Montiel. La música a la Catedral de Girona durant la primera meitat del segle XIX. Tesis Doctoral.Universidad Autónoma de Barcelona, 2003.

${ }^{37}$ CAPDEPÓN VERDÚ, Paulino. La música en el Monasterio de la Encarnación, siglo XVIII. Madrid, Alpuerto, 1997.

38 TEJERIZO ROBLES, Germán. Villancicos Barrocos de la Capilla Real de Granada. Sevilla, Junta de Andalucía, Consejería de Cultura, Editoriales Andaluzas Unidas, 1989, Vol. II, Págs. 80 y 193-219.
} 
"Naturalmente, y como era costumbre en todas las Capillas musicales, muchas de las partituras interpretadas no eran originales del Maestro titular, sino que procedían de préstamos o intercambios de otros Maestros de Capilla. También existían compositores, algunos oscenses, cuyas obras eran interpretadas esporádicamente por la Capilla parroquial. Citemos algunos: Antonio José Jaén (un poco mayor que Carmona), Simón Arroyal (que luego sustituyó a Carmona, tras su muerte o jubilación), Alfonso de Mora (natural de Totana), José García Zamora (de Caravaca), fray Vicente Valencia (de Granada), Monzón, Tornel, Osete, Moreno, Luís Escudero, Soler, José Samaranch y Ramoneda, y Jaime Balius y Vila, el excelente Maestro de la Catedral de Córdoba”. 39

Por su parte, el profesor Luís Bedmar Encinas compositor y director de la antigua Orquesta Municipal de Córdoba, realiza transcripciones de diversas obras de Jaime Balius y Vila, algunas de las cuales, como los himnos a San Rafael y a San Juan Bautista, ${ }^{40}$ son publicadas en el Boletín de la Confederación Andaluza de Coros del año 2000, y otras, como la canción patriótica Nobles Andaluces, son interpretadas por la propia Orquesta Municipal y el Coro de la Cátedra Ramón Medina. Posteriormente, la Orquesta de Córdoba bajo la dirección de Leo Brower interpretó la transcripción para Orquesta de Cuerdas del Cuarteto $n^{\circ} 3$.

\subsection{NUESTRO PROPÓSITO.}

Hasta aquí los precedentes que conocemos. Son todos ellos muy interesantes aunque son trabajos parciales que se ocupan en la mayoría de los casos de realizar una semblanza biográfica. La dificultad en conocer la amplia obra de Balius ha hecho que ninguno de los artículos precedentes haya dado un número siquiera aproximado de sus obras, que como veremos es mucho más elevado que lo dicho hasta ahora. Como hemos adelantado en el prólogo, lo que nos proponemos en este trabajo es tener una visión mucho más profunda de este gran músico rellenando vacíos de sus notas biográficas,

\footnotetext{
${ }^{39}$ PULIDO CASTILLO, Gonzalo. “Los Villancicos de Huescar”, en Boletín $n^{\circ} 3$. Guadix, Instituto de Estudios “Pedro Suárez”, 1990.

${ }^{40}$ Ver transcripción de BEDMAR ENCINAS, Luis. "Himno a San Rafael”, "Himno a San Juan Bautista”, en A.A.V.V.: Boletín de la Confederación Andaluza de Coros de 2000. Córdoba, Ed. CO.AN.CO., 2000.
} 
estableciendo un catálogo completo de sus obras conservadas en la Catedral de Córdoba y las referencias a todas las conocidas hasta ahora como existentes en otros archivos, estudiando su personalidad artística a través de las características de su obra, analizando una muestra representativa de su música, transcribiendo varias de sus composiciones, etc. Con ello pretendemos aportar nuestro granito de arena al conocimiento de una época hasta ahora poco conocida de nuestra historia.

\subsection{METODOLOGÍA.}

La metodología de trabajo ha pasado por la observación directa, el análisis y la transcripción de fuentes primarias, desde actas capitulares, cuentas de fábrica, correspondencia, expedientes, certificados de aspas, hasta partituras musicales. Las pocas fuentes secundarias existentes, también han sido de utilidad para, sobre todo, corroborar datos biográficos.

Las dificultades en algunos casos han sido notables, bien a la hora de transcribir determinadas actas capitulares que tenían una caligrafía ilegible o algunas partituras que el paso del tiempo había deteriorado hasta el extremo de no apreciarse las notas musicales. En estos casos el análisis armónico comparado nos ha deparado la solución. 


\section{CAPÍTULO 2. ASPECTOS MUSICALES DE FINALES DEL SIGLO XVIII Y PRINCIPIOS DEL XIX. SU CONTEXTO POLÍTICO-SOCIO-CULTURAL. ${ }^{41}$}

\subsection{OCCIDENTE.}

Como veremos en el apartado de Notas Biográficas, el Maestro de Capilla objeto de nuestro estudio, Jaime Balius (1750-1822), desarrolla la mayor parte de su labor durante la segunda mitad del siglo XVIII y los primeros años del XIX. Vivió, por tanto, una época histórica de indudables transformaciones a todos los niveles.

Venimos de lo que se ha dado en llamar "El siglo de las luces”, vinculado a la Ilustración y el Enciclopedismo, que marca las tendencias de pensamiento en Europa y América durante el siglo XVIII, previas a la Revolución Francesa. Es la exaltación de la razón y el empirismo. Descartes sostenía que si el ingenio humano aplicaba correctamente el método, no había verdad que no pudiera ser alcanzada. Un nuevo espíritu, racional y crítico, renueva el pensamiento europeo. Sus efectos se extienden sobre la filosofía, la política, el arte, la ciencia. La Ilustración es el movimiento que recoge todas esas innovaciones renovadoras. Se desarrolla -con intensidad y tiempos diferentes- en buena parte de Europa y sus colonias americanas.

Sin embargo, a nivel político, los estados más importantes de Europa eran, con la excepción de Gran Bretaña, monarquías absolutas al margen del carácter más o menos ilustrado de sus monarcas. El resentimiento contra este absolutismo, la propagación de las nuevas ideas ilustradas (gracias entre otros a Voltaire, Rousseau o Montesquieu), el poder creciente de la burguesía y en definitiva el deseo de acabar con un Antiguo Régimen lleno de desigualdad social, fueron algunas razones que llevaron a la Revolución Francesa en 1789.

La convulsión social que produjo esta revolución fue evidente; sus ideas de libertad, igualdad y fraternidad marcaron sin duda el futuro, generando sin embargo,

\footnotetext{
${ }^{41}$ Pretendemos en este capítulo dar una visión global del entorno histórico de la época, pero resaltando especialmente los aspectos musicales. También intentamos crear un paralelismo temporal entre los acontecimientos socio-políticos-culturales más importantes y algunos hitos musicales relevantes, buscando una breve historia comparada en la que incluimos también referencias a Jaime Balius y Vila.
} 
una gran desconfianza en unos estados europeos recelosos de los nuevos planteamientos socio-políticos franceses.

Igualmente asistimos a otra revolución, esta vez industrial, que partiendo de Inglaterra afectará progresivamente a toda Europa, y que por un lado mina algunas cosas, como el artesanado, la pequeña empresa familiar, e influye en la demografía de los pueblos, las fuentes de subsistencia, etc., y por otro lado aporta grandes avances en la mecanización. ${ }^{42}$

Por lo que se refiere a la música, los últimos años del siglo XVIII y primeros del XIX coinciden plenamente con el Clasicismo musical y con los primeros tiempos del Romanticismo. "El Clasicismo aspira [...] a una música supranacional con elementos europeos como lenguaje universal de la humanidad (fundamentalmente instrumental). Los ideales del Clasicismo son la sencillez y la claridad”. ${ }^{43}$ Austria, Alemania e Italia seguirán siendo consideradas como los tres focos con más peso específico en el terreno musical.

Se asientan los recursos armónicos de la tonalidad clásica, y los polos de atracción de la Tónica, Dominante y Subdominante imponen su ley. La forma "sonata” (preclásica y clásica) es la novedad entre las formas musicales. Hay un predominio absoluto de la melodía sobre los demás elementos musicales. Estas melodías debían ser cantables, fruto de la naturalidad, bellas, y fácilmente reconocibles por el público. Para facilitar esta identificación se tiende a la regularidad, a la simetría, características también definitorias de la arquitectura neoclásica. Las frases suelen ser de ocho compases, divididos en dos semifrases de 4 , o de seis, subdivididas en dos semifrases de 3.

Pero una de las mayores aportaciones del Clasicismo fue la configuración de la Orquesta Clásica. Tuvo sus precedentes en la llamada Escuela de Mannheim, con la contratación en 1742, por parte del Duque del Palatinado, de Joaquín Stamitz (1717-57), violinista checo, como Kapellmeister. Él fue el encargado de buscar en toda Europa una serie de músicos de alto nivel, que pudieran constituir la Orquesta de Mannheim. "Bajo su dirección, la orquesta de esta ciudad conquistó renombre a través de toda Europa por su virtuosismo, por su extensión dinámica, hasta entonces desconocida, que iba

\footnotetext{
${ }^{42}$ Cf. PALMER, R. y COLTON, J.: Historia Contemporánea. Madrid, Akal., 1980.

${ }^{43}$ ULRICH MICHAEL, Atlas de Música. Alianza Editorial, Madrid 1998, Volumen II, pág.367.
} 
desde el pianísimo más suave hasta el fortísimo más intenso y por el estremecedor sonido de sus crescendos", ${ }^{4}$

La consolidación del clasicismo vino de la mano de Haydn, Mozart y Beethoven, este último ya abriendo la puerta a un nuevo período. A principios del período clásico, la orquesta estaba compuesta normalmente por dos oboes, dos trompas y el grupo de cuerdas. En otras ocasiones se fueron incorporando otros instrumentos de viento, como las flautas traveseras, los fagotes y las trompetas. Como elemento de precisión rítmica se hizo uso de los timbales. Los trombones, en cambio, no tuvieron cabida en la orquesta; su utilización quedó relegada a la música sacra -en la que doblaban las partes de contralto, tenor y bajo- y a la ópera. El fagot, que no siempre estaba escrito en la partitura fue utilizado regularmente y adquirió a finales del clasicismo, cierta autonomía, alejándose así de la simple función de duplicar la línea del bajo que se le había encomendado en un principio. Las trompas y las trompetas pasaron a ocupar el papel de "pedales de la orquesta”, normalmente en asociación con los timbales.

En cuanto a los compositores contemporáneos de Balius, además de Haydn (1732-1809), Mozart (1756-1791) y Beethoven (1770-1827), podemos citar a Schubert (1797-1828), Weber (1786-1826), etc. Es decir, que compartió época con varios de los más grandes compositores de todos los tiempos.

La orquesta que utilizaba Balius era muy cercana a la “Orquesta Clásica”, con cuerda, oboes, trompas, fagotes, y ocasionalmente flautas y clarines, teniendo en cuenta no obstante los altibajos que podía sufrir esta plantilla debido a las cambiantes situaciones económicas de la Catedral.

Sin embargo podía existir alguna diferencia, dada la tendencia de Balius a prescindir de las violas. El hecho de prescindir de las violas era habitual en las Capillas Musicales de la época. En cuanto a sus técnicas compositivas (y aunque las analizaremos más detenidamente en el capítulo 6), podemos decir que combinaba una

\footnotetext{
${ }^{44}$ GROUT, Donald y PALISCA, Claude. Historia de la Música Occidental, II. Madrid, Alianza Editorial, 2001, colección Alianza Música, nº16, pág.624.
} 
armonía tonal, con una configuración melodico-rítmica muy variada, todo ello sobre el soporte del bajo contínuo.

Quiso el destino que el mismo año en que muere uno de los mayores genios de la música, J.S.Bach (Julio de 1750), naciera Jaime Balius y Vila (Noviembre 1750). También pocos años más tarde (1759), cuando Balius ya se encuentra probablemente aprendiendo música en la Escolanía de Montserrat, muere la otra gran figura del Barroco, G.F.Haëndel. Sin embargo, como hemos dicho, Balius fue en gran parte coetáneo de los tres principales compositores de lo que se ha dado en llamar como “periodo clásico”, a saber, F. J. Haydn (1732-1809), Mozart (1756-1791) y Beethoven (1770-1827).

En la segunda mitad del siglo XVIII se dan también acontecimientos sociopolíticos y artísticos de relevancia. En 1774 muere Luís XV, rey de Francia y asciende al trono Luís XVI. En 1776 tiene lugar la Independencia de los Estados Unidos, comenzándose desde ese año a utilizar el término "United States of América”, 45

Diez años más tarde, y encontrándose Jaime Balius casi recién llegado a Córdoba en su primer periodo como Maestro de Capilla de la Catedral, se estrena en Viena una de las óperas más famosas de todos los tiempos: Las Bodas de Fígaro, de W.A. Mozart (1 de Mayo de 1786).

En 1789 George Washington es elegido primer presidente de los EE.UU (Febrero). En ese mismo año, en Europa se avecinan tiempos de cambio con el inicio de la Revolución Francesa. En el marco de ésta, se aprueba la famosa "Declaración los Derechos del Hombre y del Ciudadano” (Agosto). Un poco antes, en el mes de Junio, Jaime Balius llega a Córdoba para comenzar su segundo periodo como Maestro de Capilla de la Catedral, cargo que ostentaría hasta su muerte.

El inicio de 1790 nos trae el estreno de “Cosi fan tutte” de Mozart (2 de Enero), ópera en la que destaca una perfecta combinación entre la poesía y el humor, acompañadas de una música magistral. Pero en Francia están ocupados con otros temas

\footnotetext{
${ }^{45}$ Cf. ANDERSON, M.S. La Europa del siglo XVIII. Madrid, Ed. Aguilar, 1964.
} 
bien distintos, como la declaración de la Asamblea Francesa en la que proclama la igualdad de todos los ciudadanos ante la ley. En nuestro país se firma el Tratado del Escorial, por el que España renuncia a favor de Inglaterra a sus derechos sobre la costa occidental de América del Norte. Al año siguiente (1791), y poco tiempo después de estrenar su ópera “La Flauta Mágica” (30 de Septiembre), muere Mozart.

Los años 1792 y 1793 son años especialmente activos en el desarrollo de la Revolución Francesa. Una nueva canción, “La Marsellesa”, se convierte en símbolo de la Revolución. En Agosto fuerzas populares toman el Palacio de las Tullerías en París y la familia real es encarcelada. Se establece la República en Francia (Septiembre).

Ya en 1793, la Convención francesa decide por un solo voto de diferencia (361 a favor y 360 en contra) la pena de muerte del rey Luís XVI. Igualmente, la Convención Nacional francesa declara la guerra a España y la Confederación Alemana declara la guerra a Francia. (Marzo). Como contrapeso cultural a tanta agitación, se inaugura el Museo del Louvre en París (Agosto).

En 1797 nace Franz Schubert, y Franz Haydn estrena su "Himno a Austria" en el $5^{\circ}$ cumpleaños del Emperador Francisco II (12 de febrero).

El comienzo del siglo XIX nos trae un gran acontecimiento musical, como es el estreno el día 2 de abril de 1800, de la Sinfonía № 1 de Beethoven en Viena. Por su influencia en los tiempos posteriores, sobre todo en lo que se refiere a procedimientos compositivos y utilización de la orquesta, esta obra podría ser considerada como un hito en la Historia de la Música. Pocos días después, concretamente el 24 de Abril, se funda la Biblioteca del Congreso de los EE.UU., la más grande del mundo.

Mientras tanto, aquí en Córdoba, Jaime Balius sigue trabajando por conseguir estabilizar su plantilla orquestal, y así, el 26 de Abril, lo encontramos dirimiendo entre dos opositores de trompa que quieren entrar en su Capilla musical y sometiendo al 
Cabildo la solicitud de un violinista que pretende entrar a formar parte de dicha Capilla. $^{46}$

En 1801 se estrena una obra musical importante en la Historia de la Música como es el oratorio "Las Estaciones” de Joseph Haydn (24 de Abril). En España se firma el tratado de paz entre España y Portugal, llamado de Badajoz, que pone fin a la denominada “Guerra de las naranjas” (6 de Junio).

El 5 de abril de 1803 se estrena la Sinfonía $N^{\circ} 2$ de Beethoven en Viena y el 11 de Diciembre nace el compositor francés Louis Hector Berlioz. Al año siguiente, tuvo lugar un suceso histórico de gran trascendencia en la historia de Europa, con evidentes influencias en la vida española. Napoleón es proclamado Emperador de Francia el 18 de Mayo de 1804. Posteriormente, es consagrado emperador por el Papa Pío VII en la Catedral de París (2 de diciembre). La Sinfonía $N^{0} 3$ de Beethoven se estrena el 7 de abril de 1805 y la Sinfonía $N^{0} 4$ se estrena el 7 de marzo de 1807 en el Palacio Lobkowitz de Viena. Este mismo año, el 27 de octubre, a nivel político, se firma el Tratado hispano-francés de Fontainebleau, por el que Napoleón consigue su pretensión de introducir sus tropas en territorio español.

1808 y los años siguientes, son decisivos en lo que nos atañe, ya que acontecieron sucesos muy importantes como La Guerra de la Independencia y otros. Merece por tanto ser estudiado un poco más en profundidad en el siguiente apartado, que hace referencia más concreta a lo sucedido en España durante la vida de Balius. Tan solo de forma esquemática para continuar este apartado daremos algunos datos relevantes. En Marzo de 1808, Carlos IV abdica la corona de España en su hijo Fernando VII. El 2 de Mayo, se produce en Madrid la insurrección popular contra el Ejército de ocupación francés. En Junio, José Bonaparte es coronado rey de España. A final de 1808 (22 de Diciembre) y quizás como reflejo musical de la convulsión social y política que vive Europa se estrena la $5^{\mathrm{a}}$ Sinfonía de Beethoven, quizás la obra más famosa de toda la música clásica. Algunos comentarios que esta obra mereció fueron: “El final era una explosión tempestuosa de tan poderosa fantasía como difícilmente se

\footnotetext{
${ }^{46}$ A.C.C. Actas Capitulares. Sábado 26 de Abril de 1800, T.95.
} 
encontraría algo parecido". ${ }^{47}$ (Allgemenie musikalische Zeeitung). O bien esta otra opinión de Hoffmann: "El imperio de lo colosal, de lo inmenso, descubierto por el genio de Beethoven". ${ }^{48}$ Lamentablemente esta obra tardará aún en conocerse en otros países. En Rusia, se ejecutó por primera vez en 1859, en Italia en 1887 y en España en $1888 .{ }^{49}$ En el mismo concierto se estrenó también la Sinfonía $\mathrm{N}^{\circ} 6$. Al año siguiente, en 1809, muere Haydn en Viena (31 de mayo).

Ya en el año 1812, las Cortes de Cádiz juran la primera Constitución española (Marzo), y Napoleón inicia la campaña de Rusia (Junio).

En Enero de 1813 las Cortes de Cádiz suprimen el Tribunal de la Inquisición, y en Marzo, El rey José Bonaparte abandona Madrid tras la derrota de las tropas francesas. El día 8 de Diciembre se estrena la Sinfonía No 7 de Beethoven en el Aula Magna de la Universidad de Viena. Pocos meses después, en Febrero de 1814, se estrena la $8^{\text {a }}$ Sinfonía de Beethoven. Mientras tanto en España, Fernando VII vuelve al poder y restablece la Inquisición.

En 1815 Napoleón Bonaparte huye de la isla de Elba, reorganiza su Ejército e inicia el llamado "Período de los Cien Días". En Marzo, Napoleón entra en París proveniente de Elba, pero en Junio, en la Batalla de Waterloo, Napoleón es derrotado definitivamente por los aliados. En Octubre, llega a la isla de Santa Elena, lugar de su destierro hasta su muerte. Como consecuencia, en Enero del año siguiente (1816), toda la familia Bonaparte es desterrada de Francia por una ley del Gobierno francés. En Febrero se estrena en Roma "El Barbero de Sevilla", de Rossini.

Otra de las obras musicales más populares de la historia, en este caso el villancico "Noche de Paz", se interpreta por primera vez en 1818, concretamente el día 24 de Diciembre, en un pueblecito de Salzburgo, llamado Oberndorf.

\footnotetext{
${ }^{47}$ DE LA GUARDIA, Ernesto. Las Sinfonías de Beethoven. Ricordi Americana. Buenos Aires, 1927, pag. 163.

${ }^{48}$ Ibid. Págs.. 165-166.

${ }^{49}$ Ibid. pag. 165.
} 
La muerte de Carlos IV se produce al año siguiente, en 1819 (Enero). Será un importante año para el arte español con la inauguración del Museo del Prado en Madrid (Noviembre).

1820 nos trae la muerte de Jorge III, rey de Inglaterra y 1821 la muerte de Napoleón además de la Independencia de México. Por último en 1822, además de producirse la muerte de Jaime Balius, concurren otros sucesos relevantes como que América Central anuncia la incorporación del Imperio Mexicano, o que comienzan las obras del primer ferrocarril público del mundo (Stockton-Darlington) en Inglaterra. La Orquesta Filarmónica de Berlín, fundada también en 1822, se considera la orquesta más importante de Alemania y, tal vez, del mundo entero. Dos años más tarde de la muerte de Balius, en 1824, se estrena la Sinfonía No 9 y la Misa en Re de Beethoven en el Kärtnertortheater de Viena. Poco después, en 1827, fallece Ludwig van Beethoven, y un año más tarde, en 1828, muere el pintor y grabador español Francisco José de Goya y Lucientes.

\subsection{ESPAÑA.}

Durante la vida de Jaime Balius reinaron en España Fernando VI, Carlos III, Carlos IV, Fernando VII, José Bonaparte y de nuevo Fernando VII.

Fernando VI ocupó el trono desde 1746 a 1759, era normalmente aceptado como culto e inteligente, y murió sin descendencia, subiendo al trono su hermanastro Carlos III, hijo de Felipe V e Isabel de Farnesio (su segunda mujer). Este ocupó el trono desde 1759 hasta 1788. Su reinado fue uno de los más importantes y fructíferos de la historia de España, siendo llamado “El mejor alcalde de Madrid”, por la cantidad de mejoras que acometió en esa ciudad. Lo sucedería su hijo Carlos IV desde 1788 a 1808. Con él surge una grave crisis interna, desencadenada por un amplio conjunto de factores, que marcan el tránsito entre el siglo XVIII y XIX, destacando entre todos el impacto que en España produce la Revolución Francesa y la Guerra de la Independencia. 
El final de esa guerra, con la salida de España de José Bonaparte, trajo a Fernando VII, “El deseado”, que al final acabó siendo claramente rechazado por la sociedad y cuyo reinado es valorado muy negativamente por los historiadores. ${ }^{50}$

\subsubsection{LA INVASIÓN NAPOLEÓNICA (1808):}

La historia de España a partir de 1808 y durante un periodo de 5 años está manifiestamente influida por la lucha contra los franceses, los cuales aprovecharon su paso hacia Portugal para invadir la Península. Las luchas palaciegas propician que Carlos IV abdique en Fernando VII, a su vez desplazado por José Bonaparte. La reacción de los madrileños contra esta invasión, concretada en el famoso "Dos de Mayo”, fue una clara expresión de rechazo contra los planes de Napoleón para anexionarse España, y supuso el inicio de la contienda. ${ }^{51}$ Podríamos destacar dos etapas especialmente significativas en la guerra:

La primera contempla un desarrollo muy favorable para los intereses franceses, estando a punto de conquistar toda España, salvo parte de Andalucía, (facilitando esto último una reorganización de las fuerzas nacionales).

La segunda tiene lugar cuando los franceses no consiguen hacerse con Portugal y será desde allí desde donde Wellington comenzará a retomar España. El hecho de que en 1812 Napoleón decidiese desplazar sus intereses y parte de sus tropas a otros lugares fue también determinante para que Wellington pudiese vencer definitivamente en Vitoria en junio de 1813. En diciembre fue liberado Fernando VII, con lo que la situación volvía a la existente en 1808, pero con unos 200.000 franceses y aproximadamente unos 400.000 españoles muertos. ${ }^{52}$ Terminada la Guerra de la Independencia, se prepara el regreso de Fernando VII, cuyo reinado podríamos dividir en tres periodos (teniendo en cuenta que anteriormente al primero ya está establecida la Constitución de Cádiz de 1812):

\footnotetext{
${ }^{50}$ Cf. CROCE, Benedetto. Historia de Europa en el siglo XIX. Ed. Ariel, Barcelona, 1996 y GONZALEZ DURO, E. Fernando VII, El Rey Felón. Editorial Oberón, 2006.

${ }^{51}$ Cf. DEL MORAL, Cristina. La Guerra de la Independencia. Anaya, Madrid, 1990.

${ }^{52}$ Cf. AYMES, J.R. La Guerra de la Independencia en España (1808-1814). Ed. Siglo XXI, Madrid, 1974.
} 
- $\quad 1814$ a 1820: Reacción Absolutista. Se suprime la Constitución y en Europa se organiza la Santa Alianza para defender el tradicionalismo monárquico. Es la época en que muchos guerrilleros se lanzan al campo, destacando entre ellos Espoz, Mina y "El Empecinado”. Riego se subleva y finalmente Fernando VII, asustado, jura la Constitución de Cádiz.

- 1820-1823: Es el trienio constitucionalista. Comienza el gobierno liberal. Regresan los exiliados. La actividad política se agota en discursos parlamentarios mientras aumenta el déficit del Estado. En Seu d’Urgell, (casualmente el mismo lugar donde Jaime Balius había sido Maestro de Capilla en 1780), se organiza una "Regencia" considerando al rey como prisionero de los liberales. Por fin, tras un ultimátum de Rusia, Prusia, Francia y Austria (La Santa Alianza), a petición del rey español, un ejército francés, "Los cien mil hijos de San Luís” atraviesa España, sin encontrar resistencia hasta Cádiz. Fernando VII restaura de nuevo el absolutismo.

- 1823-1833: Es la década absolutista. Balius ya ha muerto, y en España se desata una ola de persecuciones contra los exaltados. El exilio es masivo hacia Francia y sobre todo hacia Inglaterra. ${ }^{53}$

\subsubsection{ASPECTOS MUSICALES.}

Parece admitido que el atraso musical que en algunos aspectos vive España durante buena parte del XIX, se debe a diversos factores entre los que podemos destacar “el continuo estado de guerra, desde la invasión napoleónica al desastre del 98, pasando por toda una serie de feroces luchas civiles". ${ }^{54}$ También influye el aislamiento

\footnotetext{
${ }^{53}$ Cf. LOVETT, Gabriel. La Guerra de la Independencia y el Nacimiento de la España Contemporánea. Ed. Península, Barcelona, 1975.

${ }^{54}$ GOMEZ AMAT, Carlos. Historia de la música española. Siglo XIX. Alianza Editorial, colección Alianza Música, no 5, Madrid 1984, pág. 14.
} 
con respecto a Europa y el consiguiente colonialismo musical sobre todo por parte de Italia.

Resultan igualmente negativas las sucesivas desamortizaciones de las que más adelante daremos cuenta, y que llevan consigo una gran mengua de los recursos económicos de la Iglesia, que es quien mayoritariamente cultiva la música, al igual que períodos políticos de crisis, como el reinado de Fernando VII. A pesar de todo ello, la producción musical de autores españoles sigue funcionando sobre todo dentro de las Capillas musicales, donde sus Maestros siguen infatigables componiendo toda clase de música religiosa, y en algunos casos también música profana, bien sea teatral o puramente instrumental. Figuras como Francisco Queralt, Francisco Juncá, Domingo Arquimbau, Josep Pons, Pérez Gaya, Plácido García, Aranaz o Doyagüe, fueron los Maestros de catedrales como Barcelona, Toledo, Sevilla, Valencia, Ávila, Burgos, Cuenca y Salamanca. Todos ellos y otros muchos constituyeron, junto a Balius, la plana mayor de creadores de música religiosa en España.

También fuera de las catedrales, monasterios e iglesias se hacía música, aunque evidentemente de carácter y finalidad muy diferentes.

A este respecto, Gómez Amat nos describe perfectamente el panorama musical de la época, reflejando un acercamiento del público más a la ópera que a la propia música sinfónica. ${ }^{55}$

Habría que centrarse además en la zarzuela, para encontrar una verdadera música española, “donde los músicos no tratan de imitar ejemplos extraños sino de transitar por un camino propio y de mayor porvenir". ${ }^{56}$ No obstante, la mayoría de los compositores más afamados de zarzuelas, serían posteriores a la muerte de Jaime Balius, por lo que nos limitamos a citar brevemente algunos de los compositores de

\footnotetext{
55 "El reinado de la ópera y de lo italiano es absolutamente natural, puesto que la aristocracia de la sangre, y también la del dinero, eran operófilas e italianizantes. Algún monarca reina en Italia antes que en España, y otras personas reales vienen de allí con la ópera en la sangre. La comunicación entre las dos penínsulas era constante. Seríamos aficionados a la ópera como lo fuimos a la pintura, por influencia de la Corona. Mientras en el centro de Europa, los salones de la nobleza, y luego de la burguesía, servían de hogar a la música sinfónica y camerística, como claro precedente de los conciertos públicos, en los salones españoles se cantaba en italiano. Rossini era recibido en triunfo, mientras Beethoven resultaba un perfecto desconocido para el público y una especie de fantasma para los "enterados". Si esto podía ocurrir de alguna manera en otros lugares de Europa donde conocían a Beethoven, con mayor razón sucedería en España”. GOMEZ AMAT, Carlos. Historia de la música española. Siglo XIX. Alianza Editorial, colección Alianza Música, nº 5, Madrid 1984, pág. 17.

${ }^{56}$ Ibid., pág. 17.
} 
música profana que coincidieron con él en el tiempo y en nuestro país, cuales fueron Arriaga, Boccherini, Carnicer y Sor.

- $\quad$ Arriaga (1806-1826), fue un niño prodigio que lamentablemente no vivió lo suficiente para desarrollar todo su potencial artístico. Suele llamársele el Mozart español. Entre sus obras destacan "Los esclavos felices” o su "Sinfonía en re menor". "Su estética fluctuó entre el neoclasicismo y el romanticismo". ${ }^{57}$ No obstante, son muchos los que ven en su música influencias mozartianas.

- Boccherini (1743-1805), fue un gran violonchelista italo-español, y un experimentado compositor. Desde 1786 vivió en Madrid, y aunque de 1787 a 1797 vivió en la Corte de Federico II de Prusia, regresó a Madrid donde murió en la mayor pobreza. Escribió 20 sinfonías y numerosa música de cámara, además de su conocido Concierto de violoncello. Su estilo está más cercano al de Haydn. $^{58}$

- $\quad$ Carnicer (1789-1855) hizo una gran labor al introducir en sus óperas, tonadillas típicas españolas. Formado en la Seo de Urgel y Barcelona, fue director de ópera y profesor del Conservatorio de Música de Madrid. Compuso tanto música para la escena como de carácter religioso. ${ }^{59}$

- $\quad$ Sor (1778-1839) fue un gran guitarrista y también dedicó parte de su tiempo a la composición. Pedagógicamente, además de su Método para la guitarra, escribió un Tratado de armonía aplicado a la guitarra. Su estilo es el lazo de unión entre lo clásico y lo romántico, con influencias de Mozart, Haydn y Beethoven. ${ }^{60}$

\footnotetext{
${ }^{57}$ PÉREZ, Mariano. Diccionario de la Música y los Músicos. Ediciones Istmo, Madrid 1985, Vol. I, pág. 86.

${ }^{58}$ Cf. Ibid., pág. 180 .

${ }^{59}$ Cf. Ibid., pág.245.

${ }^{60}$ Cf. Ibid., Vol. III, pág. 215.
} 


\section{CAPÍTULO 3. LA CÓRDOBA DE LA ÉPOCA.}

\subsection{ASPECTOS DEMOGRÁFICOS, SOCIOECONÓMICOS, EDUCATIVOS, CULTURALES E INSTITUCIONALES.}

Cuando Balius llega a Córdoba en 1785, encuentra una ciudad en franca decadencia demográfica. Los 46.136 habitantes que tenía la ciudad empiezan a disminuir. ${ }^{61}$ "La crisis demográfica se manifiesta de forma clara a raíz de la mortífera epidemia de tercianas que padece la ciudad en 1785-86”. ${ }^{2}$

Si nos atenemos al número de habitantes que según el censo de Floridablanca había en 1787, y que son 34.684, podemos deducir que las citadas epidemias produjeron alrededor de 12.000 muertos. Además, “la situación demográfica se agrava en las décadas posteriores y hasta bien entrado el siglo XIX, la ciudad no recupera los niveles alcanzados en los años centrales de la centuria del Setecientos”. ${ }^{3}$

A pesar de estas calamidades, el carácter de los cordobeses es según Ramírez de las Casas Deza, alegre y positivo. Veamos una imagen descriptiva de los cordobeses de entonces: "Los cordobeses son bien formados, de color trigueño o moreno por lo general, gallardos y buenos jinetes, y, disfrutando de un cielo despejado, de un clima meridional apacible y risueño y de un suelo feracísimo y ameno, son vivos, alegres, ingeniosos, de imaginación ardiente, ponderativos, amantes del lujo y de la vida libre y aventurera, frugales, presuntuosos, poco dados al trabajo, enemigos de la profesión militar". ${ }^{64}$

Según Ortí Belmonte, "Los cordobeses, acostumbrados a una existencia plácida, pero monótona, respetuosos con la autoridad y el clero, que era dueño de hermosas fincas en el término de la población y ejercía gran ascendencia en las almas,

\footnotetext{
${ }^{61}$ Cf. ARANDA DONCEL, Juan: Historia de Córdoba. La época moderna. Córdoba, Publicaciones del Monte de Piedad y Caja de Ahorros de Córdoba, 1984, pág. 205.

62 Ibid. pág. 205.

63 Ibid. Pág. 206.

64 RAMÍREZ DE LAS CASAS DEZA, L.M. Indicador Cordobés, León, $1^{\text {a }}$ Edición 1856 (3ª Edición 1976) págs. 88-89.
} 
conservaban sus costumbres sencillas, y celebraban las fiestas religiosas tradicionales...”. ${ }^{65}$

En cuanto a la situación económica, sabemos por el Obispo don Agustín de Ayestarán y Landa (1796-1805), que no había un comercio fuerte que hiciera circular el dinero, que la industria era escasa y que la poca riqueza existente estaba repartida entre pocas manos. ${ }^{66}$

No obstante, Nieto Cumplido, que a su vez cita a Ortiz Juárez, hace alusión a que entre 1784 y 1800, se hallaban trabajando en Córdoba “por lo menos ciento noventa y cinco orfebres aprobados por el concejo en un franco proceso de industrialización...”. ${ }^{67}$ Recordemos que ya desde 1503, los plateros cordobeses toman conciencia de grupo creando la Cofradía de San Eloy, celebrando las reuniones y Cabildos en el Hospital del mismo nombre en la collación de San Pedro. Esta Cofradía o Congregación tuvo al principio funciones asistenciales y benéficas. ${ }^{68}$ También desde finales del siglo XV existía en Córdoba otro gremio que aún perdura a finales del

${ }^{65}$ ORTí BELMONTE, Miguel Ángel. Córdoba durante la guerra de la Independencia 1808-1813. Córdoba, Imprenta “La Comercial”, 1930, pág.1.

66 "La población de esta ciudad no es tanto como la de la capital del Reino, ni de otras ciudades como Cádiz, Barcelona, Sevilla, Zaragoza y Valencia. La concurrencia de los extranjeros es ninguna o rara. Tampoco mantiene tropas acuarteladas sino solamente algunas partidas que no aumentan el número de ciertas gentes a que por su ociosidad sea menester proporcionar distracciones, porque solamente las Milicias Provinciales concurren a su tiempo. Tampoco hay un comercio que ocupe a muchas personas y haga girar mucho dinero. La industria es bien escasa. Faltan también Tribunales Supremos, y, por consiguiente, pleiteantes, pretendientes y curiales. Su población, pues, se reduce a diferentes hacendados y mayorazgos con muchas tierras y haciendas. Los menestrales necesarios al número de sus pobladores. Pocos comerciantes, muchos jornaleros y peones. Mercaderes y varios labradores. Como el número de propietarios no es proporcionado a su término y a las campiñas que le rodean, Vuestra Magestad juzgará que no es pueblo por lo general en que sus vecinos estén sobrados de tiempo y dinero. Esta ciudad, tan grande y célebre en otros tiempos, no se halla en aquel estado de población y riqueza en que produciría alguna ventaja un teatro. No faltan riquezas de alguna consideración pero en pocas manos y por esta razón en ellas deberían buscarse medios de ocupar a más gentes y personas y no proporcionar distracción a las ocupadas". NIETO CUMPLIDO, Manuel y otros. Historia del Monte de Piedad y Caja de Ahorros de Córdoba. Córdoba, Monte de Piedad, 1979, págs. 55-56. A su vez, en dicho libro se notifica que estos datos proceden de la Memoria de Licenciatura de D. Luis Enrique Sánchez García, titulada Don Agustín de Ayestarán y Landa, Obispo de Córdoba, 1796-1805, con permiso del autor. ${ }^{67}$ Ibid. pág.57.

${ }^{68}$ Cf. VALVERDE CANDIL, M. y RODRÍGUEZ LÓPEZ, M. J., Platería Cordobesa. Córdoba, Ayuntamiento, 1994. 
XVIII, como es el de los colmeneros, cuyo correcto funcionamiento regulan las ordenanzas municipales al menos hasta $1790{ }^{69}$

Antonio Ponz nos remite a la realidad que él contempla cuando nos informa de que en la última década del siglo XVIII, “Córdoba es pueblo de muchos mendigos que no debía haberlos en una ciudad como ésta". ${ }^{70}$

Esta situación se agrava con la entrada de los franceses. A partir de 1808 se somete a los pueblos a impuestos o contribuciones elevadas. Aún así, "el problema financiero es el más grave que tiene José Napoleón durante los cincos años de su reinado, pues el Estado español tenía sus finanzas en la más absoluta ruina”. ${ }^{71}$

Ciertamente no es que esta situación fuera exclusiva de Córdoba, sino que el resto de ciudades andaluzas también sufrían en mayor o menor grado sus dificultades económicas, todo ello a pesar de que "La Andalucía de la bisagra del XVIII al XIX era quizás, en todos los campos, la porción peninsular dotada de mayor riqueza, tanto potencial como operativamente, y desde luego, en posesión de las mayores reservas de cualquier tipo". ${ }^{72}$

En cuanto a los centros de enseñanza de la ciudad, podemos citar cinco colegios principales: “Colegio de la Piedad, Colegio de la Purísima Concepción, Colegio de Santa Victoria, Sociedad Económica de Amigos del País y Colegio del Ángel de la Guarda, proliferando, además, con carácter particular cierto número de escuelas privadas". ${ }^{73}$ El Citado Colegio del Ángel de la Guarda, que hacía las funciones de Colegio de Infantes, será objeto de un estudio más detenido cuando hablemos de la Capilla Musical y más concretamente de los Niños de Coro.

Además de los citados, hay que nombrar a otro pequeño establecimiento: “ $L a$ Santa Escuela de Cristo”. Era como una Hermandad "para unos curas del Sagrario de la Santa Iglesia Catedral, para que con más comodidad pudieran asistir a los ejercicios

69 Cf. HIDALGO NUCHERA, Patricio y PADILLA ÁLVAREZ, Francisco. Las Ordenanzas de Colmeneros del Concejo de Córdoba (siglos XV-XVIII). Ediciones La Posada, Ayuntamiento, Córdoba 1998.

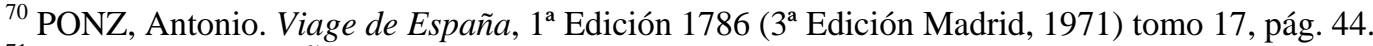

71 PALACIOS BAÑUELOS, Luis: Historia de Córdoba. La etapa contemporánea. Córdoba, Publicaciones del Monte de Piedad y Caja de Ahorros de Córdoba, 1990, pág. 72.

72 CUENCA TORIBIO, José Manuel. Andalucía, una introducción histórica. Monte de Piedad y Caja de ahorros de Córdoba. Córdoba, 1980, pág. 87.

${ }^{73}$ NIETO CUMPLIDO, Manuel y otros. Historia del Monte de Piedad y Caja de Ahorros de Córdoba. Córdoba, 1979, pág. 60. 
los Eclesiásticos y personas seglares de esta parroquia [...] Estos hermanos de la Convalecencia tenían al año dos o tres días de Jubileo de las cuarenta horas y el último día había procesión fuera de la Capilla por el patio con el Santísimo bajo de palio y los Colegiales cantando el himno Tantum Ergo a cuatro". ${ }^{74}$ Esta humilde escuela, tenía en 1816 su sede en la Iglesia del Colegio de Infantes. ${ }^{75}$

En lo referente al mundo del arte a finales del XVIII, "prevalece intensamente el barroco, mereciendo especial mención la presencia del rococó por el asentamiento en la ciudad de algunos arquitectos y escultores franceses, y se constatan los inicios del neoclasicismo". ${ }^{76}$

Entre los arquitectos destacan Diego de los Reyes, Luís Aguilar Arriaza (que restauró la torre de la Catedral), Ignacio de Thomas (que nos ha dejado la torre de la iglesia de Santa María Magdalena y el informe para la ejecución del murallón de la Ribera), Francisco Eulogio Vázquez, Baltasar Drevetón (autor de la Capilla de Santa Inés y del arreglo del antiguo Mihrab) y Juan Miguel Verdigueir (autor de la imagen de Santa Inés) -ambos franceses-, Ventura Rodríguez, etc.

Como escultores y retablistas de especial renombre pueden citarse Alonso Gómez de Sandoval, Juan Prieto, Francisco Javier Pedrajas, además de los italianos Domingo García Palmerani, y Jerónimo Buti, pasando por Joaquín Arali (autor de la imagen de la Virgen de los Dolores de la Capilla de Nuestra Señora del Mayor Dolor), Manuel Sánchez Sandoval, Teodosio Sánchez Cañadas, hasta llegar quizás al más conocido por el gran público como es Pedro Duque Cornejo, "que lega a la ciudad una de las mejores joyas del barroco, el coro de la Catedral". ${ }^{77}$ En esta obra se empleó “caoba de las Antillas, invirtiéndose en su ejecución 900.000 reales. [...] El resultado

\footnotetext{
${ }^{74}$ LUCAS DEL POZO Y CÁCERES, Juan. Rasgos biográficos y fisonómicos [de cordobeses]. Córdoba, 1863. Biblioteca Municipal de Córdoba. s/f.

${ }^{75}$ A.C.C. Obras Pías. Caja 523. Expediente de Venta del Colegio de Infantes. Córdoba 1816. Para más información ver en Apéndice Documental La Santa Escuela de Cristo.

${ }^{76}$ NIETO CUMPLIDO, Manuel y otros. Historia del Monte de Piedad y Caja de Ahorros de Córdoba. Córdoba, 1979. pág. 65.

${ }^{77}$ Ibid., pág. 66.
} 
final fue una obra de excepcional calidad, considerada como la última de las grandes sillería barrocas de nuestro país". ${ }^{78}$

En la pintura destacan Agustín Grande, Fray Jerónimo Espinosa, Álvarez Torrado y José Pérez Ruano. ${ }^{79}$

Por lo que toca a la orfebrería, destaca como figura estelar Damián de Castro (autor de tres urnas eucarísticas de la Catedral) en cuya obra puede apreciarse la evolución artística operada en las artes en la segunda mitad del siglo XVIII, y junto a él merecen un recuerdo Bartolomé y Pedro de Aranda, Leiva, Antonio Ruiz, Santa Cruz, Repiso y Cristóbal Sánchez Soto. ${ }^{80}$

De esta época, y personaje a destacar es también Ángel de Saavedra (17911865), poeta y dramaturgo español romántico, más conocido por el Duque de Rivas. ${ }^{81}$

En cuanto a la Música, casi toda ella se produce dentro de la Catedral y de algunas iglesias y conventos que podían permitirse tener algunos músicos, como por ejemplo San Hipólito. Y como compositor de más relevancia, está sin duda Jaime Balius y Vila, Maestro de Capilla de la Catedral y objeto de este trabajo. Las intervenciones musicales de la Capilla de Música tienen gran aceptación entre el público, que acude a verlas con gran interés sobre todo en las fechas más señaladas como Navidad, Semana Santa, día del Corpus, etc. También es muy importante el papel institucional desempeñado por estos músicos, ya que participan habitualmente en todas aquellas recepciones a autoridades importantes que visitan la ciudad o en celebraciones diversas por algún suceso importante como la coronación de un nuevo Rey, acabando

78 DABRIO GONZALEZ, M ${ }^{a}$ Teresa y RAYA RAYA, M ${ }^{a}$ Ángeles. "Las obras del setecientos”, en: VILLAR MOVELlÁn, Alberto y otros. Córdoba, Arte. Caja Provincial de Ahorros de Córdoba. Córdoba 1994, pág. 85.

${ }^{79}$ Cf. JAÉN MORENTE, Antonio. Historia de la ciudad de Córdoba. León, 1917, pág. 286.

${ }^{80}$ Cf. ORTIZ JUÁREZ, Dionisio. Catálogo de la Exposición de Orfebrería Cordobesa. Córdoba 1973.

${ }^{81}$ Pertenecía a una familia aristócrata cordobesa. Realizó sus estudios en el Seminario de Nobles de Madrid y después ingresó en el Ejército. A pesar de su juventud se distinguió en la guerra de Independencia contra los franceses en 1808. Su amistad con Manuel José Quintana le orientó hacia las artes y la participación política liberal. Fue condenado a muerte por Fernando VII pero pudo huir. Marchó a Londres donde conoció la obra de Shakespeare, Walter Scott y lord Byron; después estuvo en Francia, Italia y Malta. En 1834 regresó a España, tras la muerte del rey y participó de lleno en la vida política; fue embajador en Francia, presidente del Consejo de Estado (1863) y director de la Real Academia Española, desde 1862 hasta su muerte. Ángel de Saavedra fue poeta, pero sobre todo dramaturgo; su drama "Don Álvaro o la fuerza del sino” (1835) sigue siendo la obra romántica por excelencia del teatro español. La obra tuvo repercusión internacional y años más tarde el compositor italiano Giuseppe Verdi la usó como libreto de su ópera "La forza del destino". Cf. AGRAMONTE, Francisco. Diccionario Biográfico Cronológico. Aguilar, Madrid, 1945, pág. 661. 
casi siempre estos actos con el canto de un Te Deum. De todo ello hablaremos con más detenimiento en el apartado de Fiestas y Celebraciones.

En el ámbito civil, fue a partir de 1800 cuando comienzan a proliferar otros centros de producción musical o teatral, como el Teatro Cómico, en la calle Ambrosio de Morales (restaurado y reinaugurado en Abril de 2002), o posteriormente el Teatro del Recreo, el Teatro Moratín y ya a finales de siglo, en 1873, el Gran Teatro. ${ }^{82}$ No podemos dejar de nombrar igualmente el nacimiento en 1810 de la Academia de Ciencias, Bellas Letras y Nobles Artes. ${ }^{83}$ Esta Academia fue fundada concretamente el día 11 de Noviembre, “desgajándose de la sección de Letras de la Sociedad Patriótica o Económica de Amigos del País". ${ }^{44}$ Fue su fundador y primer director el canónigo penitenciario de la Catedral cordobesa doctor don Manuel $\mathrm{M}^{\mathrm{a}}$ de Arjona y Cubas. Aunque comenzó llamándose Academia General de Ciencias, Bellas Letras y Nobles Artes, en julio de 1915 Alfonso XIII le concede el título de Real.

A partir de 1820 se creó la Tertulia Patriótica, que durante tres años agrupó a diversos personajes de la ciudad con el objeto de comentar y discutir acerca de la Constitución de Cádiz. De sus componentes, lugares de celebración y otros particulares tenemos una descripción completa en el Apéndice Documental.

Completan el panorama general de Córdoba en ésta época, instituciones como el Ayuntamiento, la Inquisición y la Iglesia. Evidentemente el papel del Ayuntamiento en la ciudad era notorio, así como la influencia que ejercían todos los cargos importantes del municipio, bien fuera el Corregidor, miembros de los "veinticuatro”, Alcaldes mayores primeros, Alcaldes mayores segundos etc. Mientras que el Corregidor era el máximo representante del Municipio, los Alcaldes, eran por entonces verdaderos jueces que entendían de causas civiles y criminales, estando con anterioridad separadas ambas “varas”, y unidas en la época que nos ocupa. Pero además, los Alcaldes constituyen en

\footnotetext{
${ }^{82}$ Cf. RAMÍREZ DE ARELLANO, R. El Teatro en Córdoba. Tip. del Hospicio Provincial, Ciudad Real, 1912.

${ }^{83}$ Cf. CUENCA TORIBIO, José Manuel. Historia de Córdoba. Librería Luque, Córdoba 1993, pág. 154.

${ }^{84}$ CRIADO COSTA, Joaquín y PORRO HERRERA M ${ }^{\mathrm{a}}$ José. Anuario de la Real Academia de Córdoba, de Ciencias, Bellas Letras y Nobles Artes. Córdoba, Real Academia, 2003, pág.3.
} 
cierto modo una correa de transmisión del Rey, siendo nombrados por éste a propuesta de la Cámara. ${ }^{85}$ Para más datos sobre el Municipio de Córdoba y su provincia, su organización y funcionamiento en esta época, podemos acudir a los diversos trabajos que sobre esta materia tiene publicados el Catedrático de la Universidad de Córdoba, D. José Manuel de Bernardo Ares. ${ }^{86}$ También podemos encontrar un retrato de las cualidades y obligaciones que debían tener los integrantes del Ayuntamiento de entonces en una obra que escribió D. Joséf de Eguiluz (Corregidor de Córdoba) en 1796, y que lleva por título Breve Demostración de las principales obligaciones del Magistrado Político y de los individuos que componen el Ayuntamiento. ${ }^{87}$

En cuanto a la Inquisición, durante muchos años ejerció su oficio con determinación en Córdoba, generando gran número de expedientes de los que nos da cuenta Ramírez de las Casas Deza en su Colección de los autos generales y particulares de la fe celebrados por la Inquisición en Córdoba. Estos autos de fe provocaban una gran expectación entre la población, como sucedió en 1799, cuando se condenó a una mujer por hechicera y supersticiosa: “El deseo de presenciar un auto, por no haberse celebrado ninguno en mucho tiempo, hizo que el concurso fuese tan numeroso que no bastando las guardias a contener la gente hubo peligro de que algunas personas se sofocasen". ${ }^{88}$ En Abril de ese mismo año, la Inquisición pide la actuación de la Capilla Musical de la Catedral para una celebración de la Iglesia de San Pablo. ${ }^{89}$ Se le consulta

\footnotetext{
85 “a partir de 1750 el monarca, a propuesta de la Cámara, nombra directamente a estos magistrados, poniendo fin a la inveterada costumbre de ser elegidos por los corregidores. Al asumir esta tarea el rey a mediados del siglo XVIII, no sólo se constata una mayor intervención de la administración central en los gobiernos locales como consecuencia lógica del absorbente absolutismo, sino que además se realza la propia institución de los alcaldes mayores cxigiéndoles una serie de requisitos imprescindibles para correcto ejercicio de su importante misión en la gobernación de los pueblos, al mismo tiempo que se les libraba de las posibles veleidades de corregidores poco escrupulosos”. BERNARDO ARES, José Manuel. Los Alcaldes Mayores de Córdoba (1750-1833). Córdoba, Publicaciones del Monte de Piedad y Caja de Ahorros de Córdoba, 1978. Pág. 10.

${ }^{86}$ Cf. BERNARDO ARES, José Manuel de. "Hacienda Municipal, Oficios y jurisdicciones enajenadas. El Municipio de Córdoba a mediados del siglo XVIII". Revista Omeya, Córdoba 1979, y "Municipios cordobeses en 1815: análisis económico-administrativo de los gobiernos locales de 29 pueblos de señorío y realengo". Boletín de la Real Academia de Córdoba. Córdoba, 1977.

${ }^{87}$ Cf. EGUILUZ, Josef. Breve demostración de las principales obligaciones del Magistrado Político y de los individuos que componen el Ayuntamiento. Córdoba, Imprenta de Juan Rodríguez de la Torre, 1796.

${ }^{88}$ RAMÍREZ DE LAS CASA DEZA, L.M. Colección de los autos generales y particulares de la Fe celebrados por el Tribunal de la Inquisición de Córdoba. Córdoba, 1836, págs. 273-292.

${ }^{89}$ En dicho lugar ya se habían realizado autos de fe anteriormente. En su Colección de los autos... , Ramírez de las Casas Deza nos cuenta como el 5 de Diciembre de 1745, tuvo lugar un auto de fe en la iglesia del convento de San Pablo, donde dos personas fueron condenadas por judaizantes, un gitano por blasfemo público y cinco personas más por hechicería y superstición.(págs. 273-292).
} 
al Maestro de Capilla D. Jaime Balius si es posible destinar parte de los músicos de su Capilla a tal celebración. Naturalmente responde en sentido afirmativo.

En 1819 todavía se juzgaban causas diversas. Así lo confirma Rafael Gracia Boix: "Carta de remisión de relación de las causas de fe, pendientes en el Tribunal de Córdoba en 1819”. “En 7 foxas útiles, remitimos a V.A. la relación de las causas de fee pendientes en este Tribunal, que há formado y puesto en él, para el efecto, muestro colega en Ynquisidor Fiscal, a virtud de lo resuelto por V.A. en 25 de Septiembre anterior...". 90

Para finalizar este apartado contextualizador, y en un intento de resumir la situación de la Iglesia, podemos decir que los eclesiásticos conservan numerosos bienes de diversos tipos, "acrecentados con las voluminosas rentas que percibe la Iglesia como institución”. ${ }^{91}$ Estas rentas son fundamentalmente los diezmos. Además la Iglesia tiene numerosas posesiones en propiedad que bien utiliza o bien alquila a terceros. Al menos hasta la llegada de las desamortizaciones, la Iglesia mantiene un buen poder económico. Pero también le llegó el momento de contribuir a las arcas reales. “ $L a$ riqueza de la iglesia cordobesa ayudó a paliar el lastimoso estado de la hacienda real en la época de Carlos IV mediante sustanciosas contribuciones económicas y el patrimonio sufriría amputaciones de cierta entidad con la llamada desamortización de Godoy". ${ }^{92}$ Otra buena parte del dinero se utiliza en reparación y construcción de templos, fundación de obras pías y limosnas a los pobres. En cuanto a su línea de pensamiento y resumiendo en pocas líneas el sentir de la Iglesia cordobesa de aquel momento, nos atendremos a las palabras de Nieto Cumplido cuando dice que "la inmensa mayoría del clero, condicionada por una formación seminarística o colegial anclada en la más pura tradición escolástica, [...] respira un ambiente conservador e

\footnotetext{
90 GRACIA BOIX, Rafael. Colección de Documentos para la Historia de la Inquisición en Córdoba. Córdoba, Publicaciones del Monte de Piedad y Caja de Ahorros de Córdoba, 1982, pág. 294. A su vez, Gracia Boix extrae esta información del Archivo Histórico Nacional, Sección Inquisición, legajo 2478. Las causas a que se hace referencia sumaban un total de 52, y en ellas se juzgaban delitos varios, como hechicería, curandería, hechos sacrílegos e irreligiosos, etc. Llama la atención que entre los encausados, además de gente del pueblo, hubiera numerosos sacerdotes, e incluso un marqués, concretamente el Marqués de la Vega de Armijo.

91 ARANDA DONCEL, Juan. Historia de Córdoba. La Época Moderna (1517-1808). Córdoba, Publicaciones del Monte de Piedad y Caja de Ahorros de Córdoba, 1984, pág.217.

92 Ibid. Pág. 218.
} 
integrista”. ${ }^{93}$ En cualquier caso, y a pesar de las complicaciones que comienzan a presentarse y que se verán aumentadas durante la primera mitad del siglo XIX, la Iglesia como institución, todavía sigue aglutinando en torno a sí un poder económico cierto, además de una influencia social evidente en todos los aspectos de la Cultura.

En el ámbito cronológico de nuestro trabajo, ocuparán la sede episcopal Don Baltasar de Yusta Navarro (1777-1787), Don Antonio Caballero y Góngora (17901796), Don Agustín de Ayestarán y Landa (1796-1805) y Don Pedro Antonio de Trevilla (1805-1832).

\subsection{LA IMAGEN URBANA DE CÓRDOBA EN EL CAMBIO DE SIGLO.}

A finales del siglo XVIII podemos observar una vista general de Córdoba casi totalmente encerrada en el interior de sus antiguas murallas, salvo el Campo de la Verdad y otros reducidos núcleos. La ciudad todavía se articula en torno a las respectivas parroquias, y entre algunas de ellas, en los últimos años del siglo se producen fusiones. “Así, en 1782, el prelado Yusta Navarro decide fusionar las parroquias de San Salvador y Santo Domingo de Silos, [...]. Años más tarde, en Febrero de 1799, el obispo D. Agustín de Ayestarán y Landa realiza la misma operación con las de San Juan de los Caballeros y Omnium Sanctorum ". ${ }^{94}$

Para ilustrar la época que estamos trabajando, finales del XVIII y principio del XIX, vamos a utilizar tan solo algún ejemplo de los muchos que componen el magnífico libro de D. Francisco Cosano Moyano “Iconografía de Córdoba”, comenzando por un grabado de Juan Fernando Palomino. Este, presenta en 1781 una copia prácticamente igual a la imagen que de Córdoba presenta Hoefnagle en el siglo XVI. ${ }^{95}$ Como decimos,

\footnotetext{
${ }^{93}$ NIETO CUMPLIDO, Manuel y otros. Historia del Monte de Piedad y Caja de Ahorros de Córdoba. Córdoba, 1979, pág. 69.

94 ARANDA DONCEL, Juan. Historia de Córdoba. La Época Moderna (1517-1808). Córdoba, Publicaciones del Monte de Piedad y Caja de Ahorros de Córdoba, 1984, pág.206.

${ }^{95}$ El belga Hoefnagle (1542-1601), fue un gran artista que dominaba varias especialidades. Además de hacer magníficas imágenes de las ciudades que visitaba en sus viajes a Inglaterra, Francia y España, escribía poesía y también tocaba diversos instrumentos musicales.
} 
el autor del grabado es Juan Fernando Palomino, hijo de Juan Bernabé -primer director de la sección de grabado de la Real Academia de San Fernando-, quien ejecuta la copia con unos criterios muy esquemáticos, basados en un dibujo simplista, pero de indudable interés histórico. ${ }^{96}$

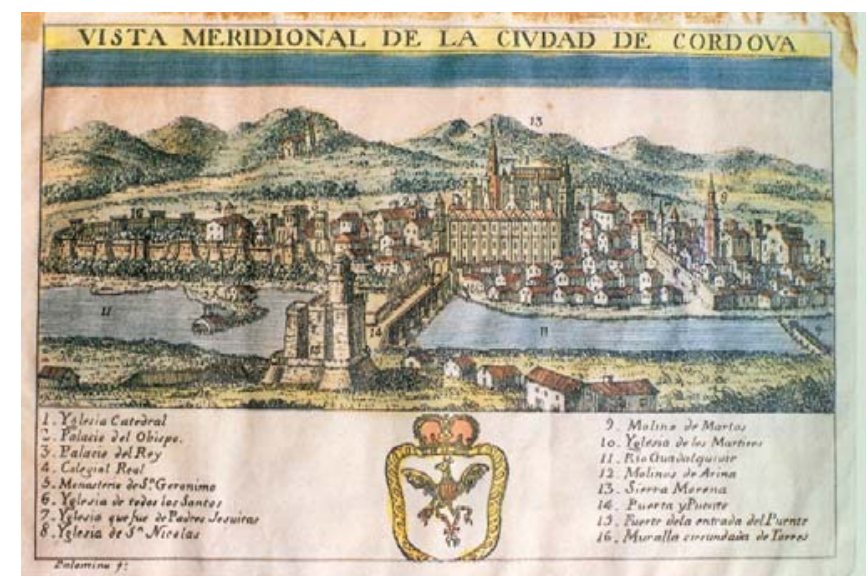

Juan Fernando Palomino. Vista meridional de la Ciudad de Córdoba. Siglo XVIII.

También es fundamental para tener una idea de cómo era Córdoba a principios del siglo XIX, el testimonio de Mackenzie, el cual nos sumerge en una Córdoba de abundante vegetación, donde la palmera destaca en las numerosas huertas y jardines existentes, y donde las casas blancas se adornan con flores variadas, sobre todo rosas, claveles y narcisos. ${ }^{97}$

\footnotetext{
${ }^{96}$ Cf. COSANO MOYANO, Francisco. Iconografía Cordobesa. Córdoba, Cajasur, 1999, págs. 60-61.

${ }^{97}$ "La extensión de Córdoba es la misma ahora que en la época de su mayor prosperidad, aunque sólo tiene poco más de treinta mil habitantes. Las murallas son las mismas y las casas han disminuido y se han distribuido más cómodamente de forma que la mayor parte de ellas tienen una parcela libre, que es utilizada como huerta. Aquí se encuentran frutos y flores tropicales que florecen sin protección al aire libre y que viven en compañía y armonía con las producciones de los climas templados. El melocotonero, peral y manzano, el naranjo, limonero, higuera e incluso el platanero, todos ellos alcanzan una igual perfección. Pero el rasgo más singular de los huertos de Córdoba es la elevada palmera que desde lejos se ve coronando árboles, paredes y tejados. La palmera es, realmente, de las primeras cosas que el viajero descubre cuando se aproxima a Córdoba, y por un momento él se imagina que va a entrar en una ciudad africana o asiática". [Sigue una extensa descripción sobre los caracteres botánicos, cultivo, etc., de la palmera datilera y el naranjo]. "Las calles de Córdoba son casi todas cortas, estrechas y muy ruinosas, como es el caso de todas las ciudades donde estuvieron establecidos los Árabes durante un largo período; como ellos no usaban vehículos de ruedas, y procediendo de un clima suave, construyeron sus calles estrechas, ya que los aleros de los tejados, podían con eficiencia protegerlas de los rayos del sol. Ellas, no obstante, se mantienen completamente limpias y las casas se enjabelgan primorosamente de blanco, cada una de ellas con ventanas enrejadas y sus zaguanes, y encima un balcón saliente, adornado con narcisos, claveles y rosas, y de vez en cuando un pequeño limonero, entre cuyo follaje con frecuencia se pueden vislumbrar los ojos negros y las mejillas morenas de una beldad, tan excelsa como la fruta madura que pende de él”. MACKENZIE, A.S.: A year in Spain by a young American, Boston, Hilliard, Gray, Little and Wilkins, 1829, págs. 262-4.
} 
Del siglo XIX destacaremos igualmente la panorámica de Guesdón. Tomada a vista de pájaro, posiblemente desde un globo, Alfred Guesdón nos muestra una perspectiva de la ciudad de Córdoba. Dotada de un gran valor testimonial en cuanto a la rigurosidad de su trama urbanística, realiza un estudio topográfico perfecto de la ciudad bordeada aún por su muralla medieval y atravesada por el eje de separación de su Medina y Ajerquía. Realizada el año 1860, en ella podemos ver nítidamente una imagen captada con precisión fotográfica desde lo alto del Guadalquivir, por encima de la actual barriada del Sector Sur. ${ }^{98}$

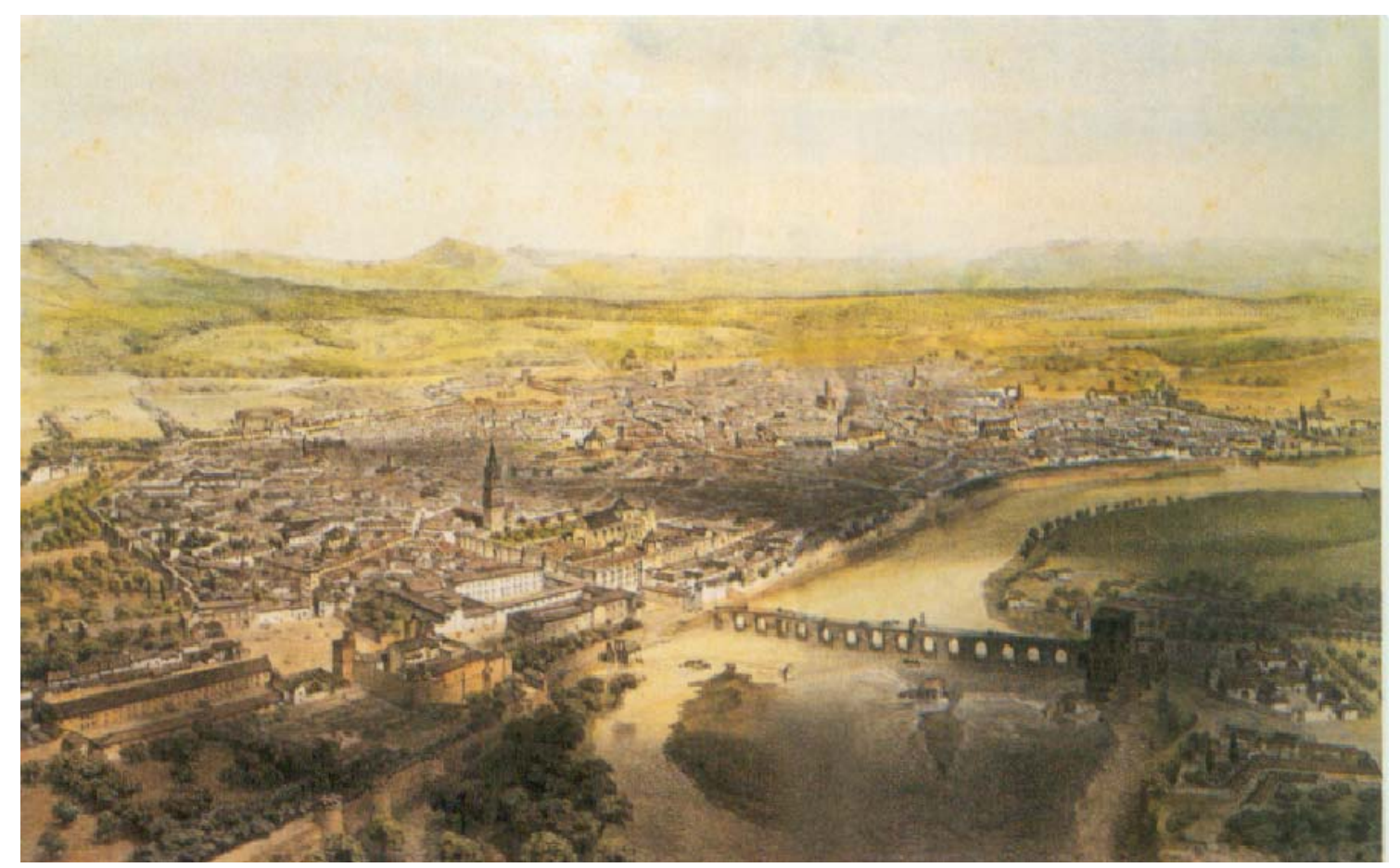

Guesdón. Córdoba. Vista tomada desde encima del Guadalquivir. Siglo XIX. 1860.

Queremos asimismo ofrecer algunas de las imágenes legadas por Parcerisa, que ayudan a comprender esta breve imagen de la ciudad de Córdoba. Francisco Javier Parcerisa fue pintor y litógrafo barcelonés de principios del XIX, que ilustró la obra de Pedro de Madrazo Recuerdos y Bellezas de España. Sus múltiples estampas de las ciudades españolas son un valioso testimonio gráfico para observar aspectos arquitectónicos, urbanos y costumbristas de la España del XIX. También queremos hacer referencia a David Roberts otro de los grandes viajeros románticos, nacido en Escocia finales del XVIII. Aunque empezó su carrera como pintor de decorados de

\footnotetext{
${ }^{98}$ COSANO MOYANO, Francisco. Iconografía Cordobesa. Córdoba, Cajasur, 1999, págs. 68-69.
} 
escena en su país, pronto exhibió las primeras pinturas de caballete en la Institución de Bellas Artes en Edimburgo. Posteriormente se trasladó a Londres, perfeccionando su técnica y exhibiendo sus obras en galerías de prestigio. En 1832 emprendió un viaje de dos años a través de España. "Roberts, como buen viajero romántico que es, destaca los edificios monumentales, idealizando sus dibujos y dando importancia a todo lo decadente -así, por ejemplo, dibuja los molinos en su estado ruinoso-; además, al buscar el protagonismo arquitectónico en la escena, los estiliza elevando su módulo sobremanera...”.99
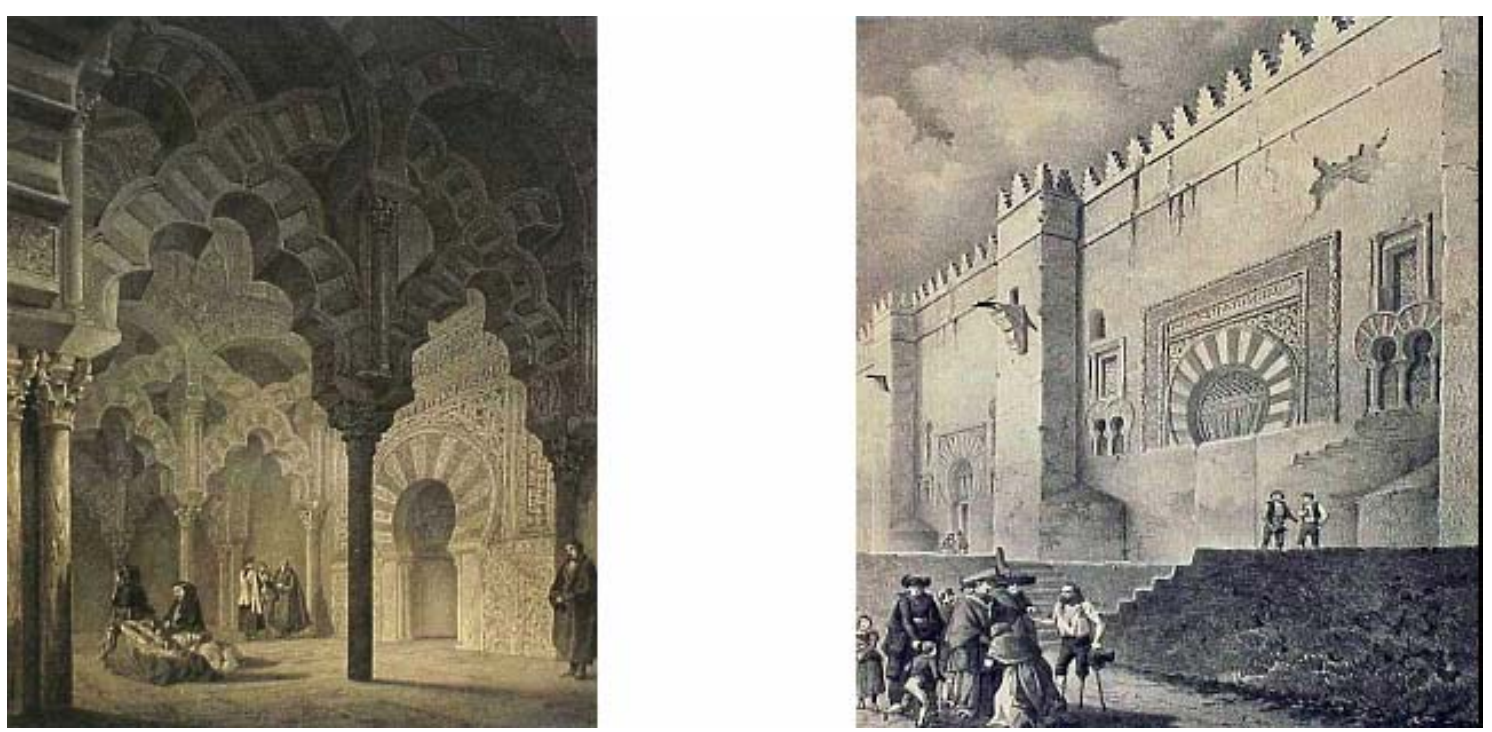

Capilla del Mirhab y Exterior de la Catedral. Parcerisa.

${ }^{99}$ Ibid. Pág. 76. 

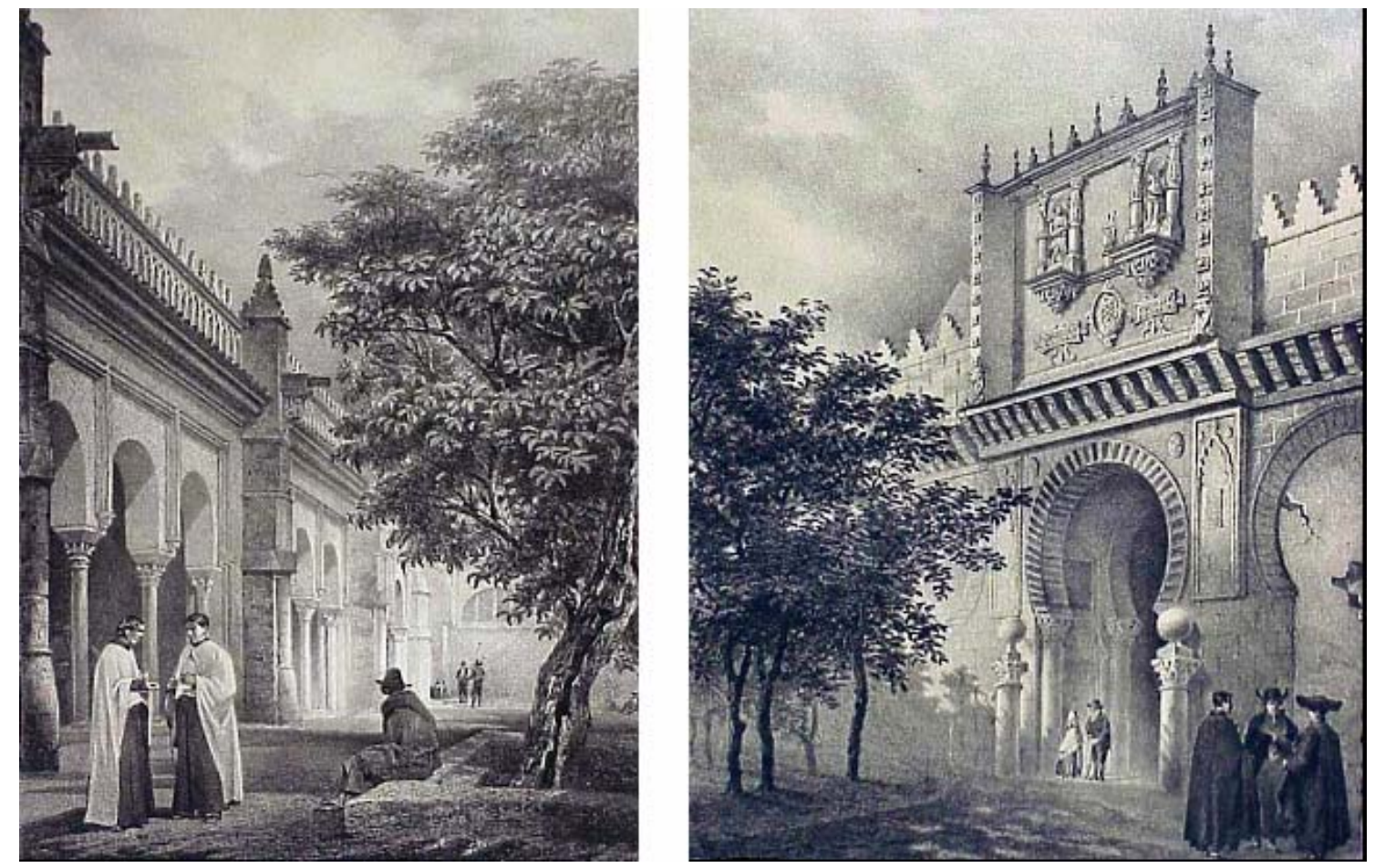

Patio de la Catedral y Puerta de las Palmas. Parcerisa.

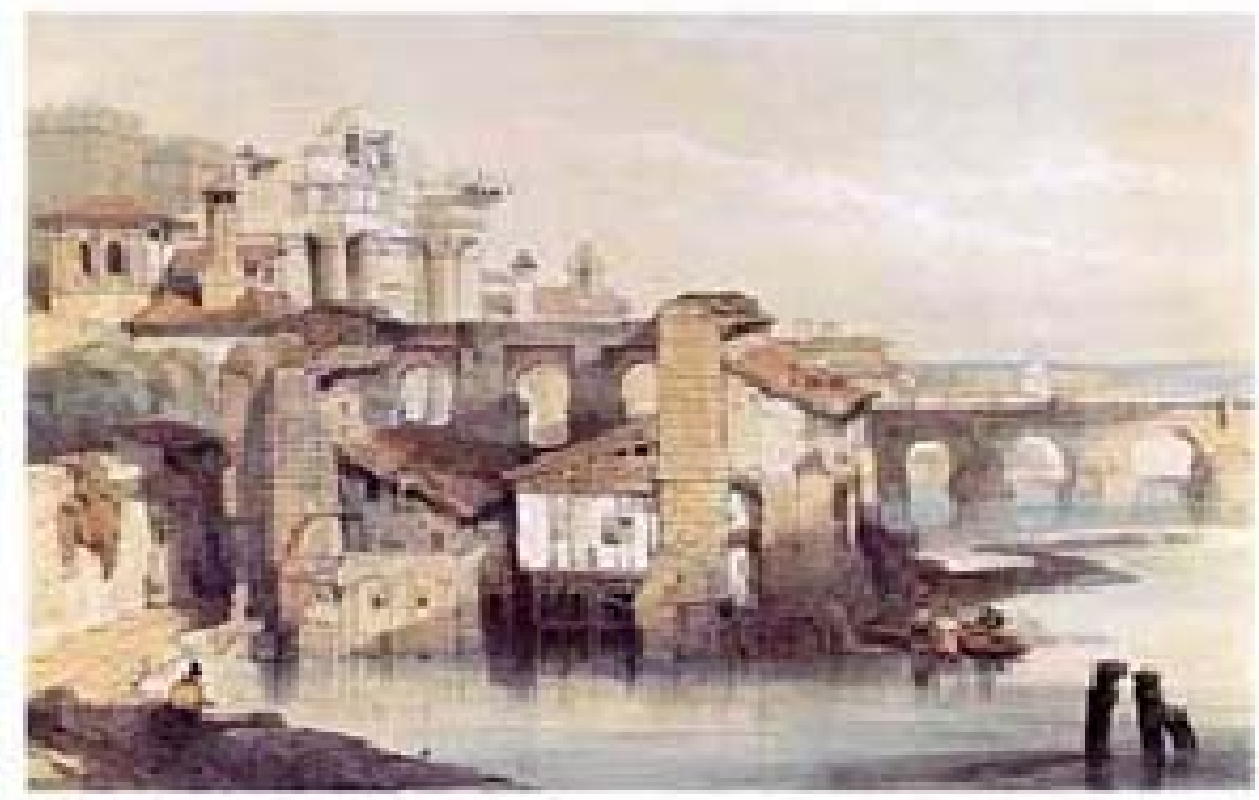

Molino de la Albolafia. Roberts. 


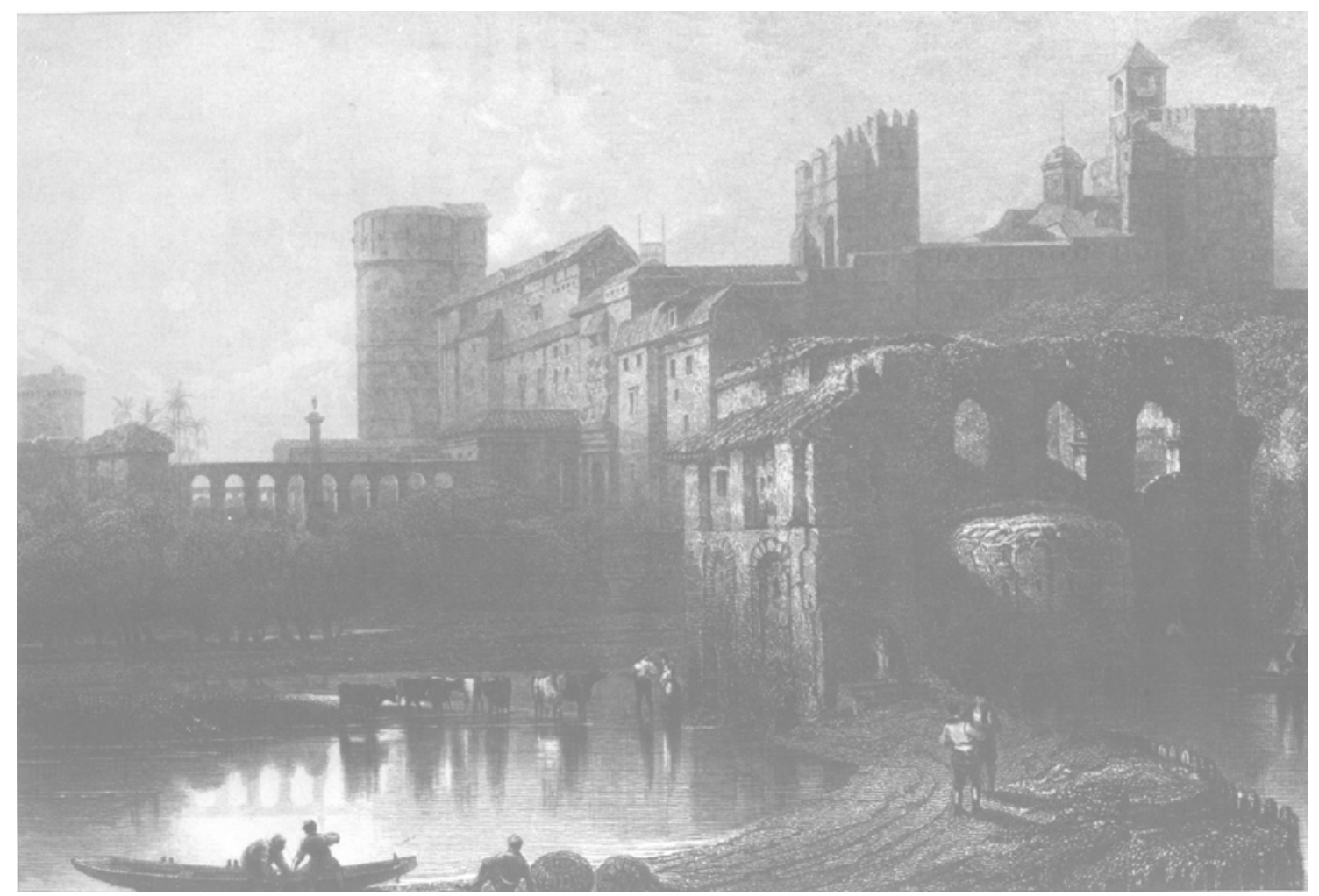

Otra perspectiva del Molino de la Albolafia, en este caso con el Alcázar de los Reyes Cristianos al fondo. Roberts.

No son estos lo únicos autores que se han ocupado de la Córdoba romántica. Otros muchos como Taylor, Vivian o Chapuy han reflejado en sus imágenes distintas escenas de la ciudad. Abundante y explícita representación de ellos la tenemos en el libro anteriormente citado Iconografía de Córdoba.

A veces, la imagen urbana de la ciudad podía verse alterada de forma más o menos definitiva con motivo de alguna celebración especial o de una visita que hiciera a Córdoba un personaje de relieve. Se construían calles ficticias, pórticos, tablados, escenarios teatrales y estatuas colosales, en lo que se conoce como arquitectura efímera. De estas fiestas hablaremos en el apartado siguiente. 


\subsection{FIESTAS Y CELEBRACIONES.}

Las fiestas de finales del XVIII y principios del XIX mantienen una gran similitud con las de tiempos anteriores. Las corridas de toros siguen teniendo gran aceptación. Allí se congregan diversas capas sociales, que vitorean a los toreros, aplauden y se divierten con el colorido de la fiesta. El lugar elegido habitualmente es la plaza de la Corredera. ${ }^{100}$

La asistencia a las comedias es otra distracción, al menos durante el tiempo en que no estuvieron prohibidas. A finales del siglo XVIII se produce un enfrentamiento entre partidarios y detractores de las mismas.

El Obispo Yusta Navarro presiona para que aquellas representaciones sean suprimidas. "Al final, las presiones cosechan los frutos deseados, ya que una real orden dada en 1784 prohíbe cualquier tipo de representaciones". ${ }^{101}$ No obstante, a los pocos años, en 1799, una solicitud hecha por Casimiro Montero al Municipio para volver a representar comedias tiene distinto final, puesto que a pesar de la oposición de gran parte de los capitulares y del nuevo obispo don Agustín Ayestarán y Landa, se aprueba que el mencionado empresario establezca un teatro en la capital.

Esta decisión de Carlos IV, despertará protestas de diversos capitulares y miembros del clero, posiblemente los mismos que aplaudieran y reverenciaran al monarca tres años antes cuando visitó Córdoba, evento del que daremos cuenta enseguida. No duró mucho esta época de representación de comedias, ya que " $a$ principios de Octubre de 1801 queda clausurado el teatro". ${ }^{102}$

Otra distracción de los cordobeses era caminar junto a la ribera del río, divertirse con un paseo en barca, o reunirse en tertulia junto a algún recodo fluvial como el que

\footnotetext{
100 "Las exhibiciones taurinas tienen lugar durante la mayor parte de los días feriados. Asimismo, las autoridades municipales organizan siempre lucidos festejos para celebrar diversos acontecimientos relevantes y para obsequiar a los visitantes ilustres. Tampoco faltan en determinadas fiestas señaladas del calendario litúrgico y, a veces, se programan para conseguir fondos destinados a un fin concreto. Normalmente, la grandiosa plaza de la Corredera sirve de marco, aderezándose con múltiples adornos y colgaduras en los balcones. Con carácter excepcional se habilitan otros espacios del casco urbano”. ARANDA DONCEL, Juan. Historia de Córdoba. La Época Moderna (1517-1808). Córdoba, Publicaciones del Monte de Piedad y Caja de Ahorros de Córdoba, 1984, pág.274.

${ }^{101}$ Ibid. Pág. 277.

${ }^{102}$ Ibid. Pág. 278.
} 
nos muestra el grabado de Roberts, que vemos a continuación. En él aparecen, en amigable compañía, un grupo de cordobeses, hombres y mujeres. Unos pescan, otros charlan, y todos disfrutan de la magnífica panorámica del puente romano y la Catedral al fondo.

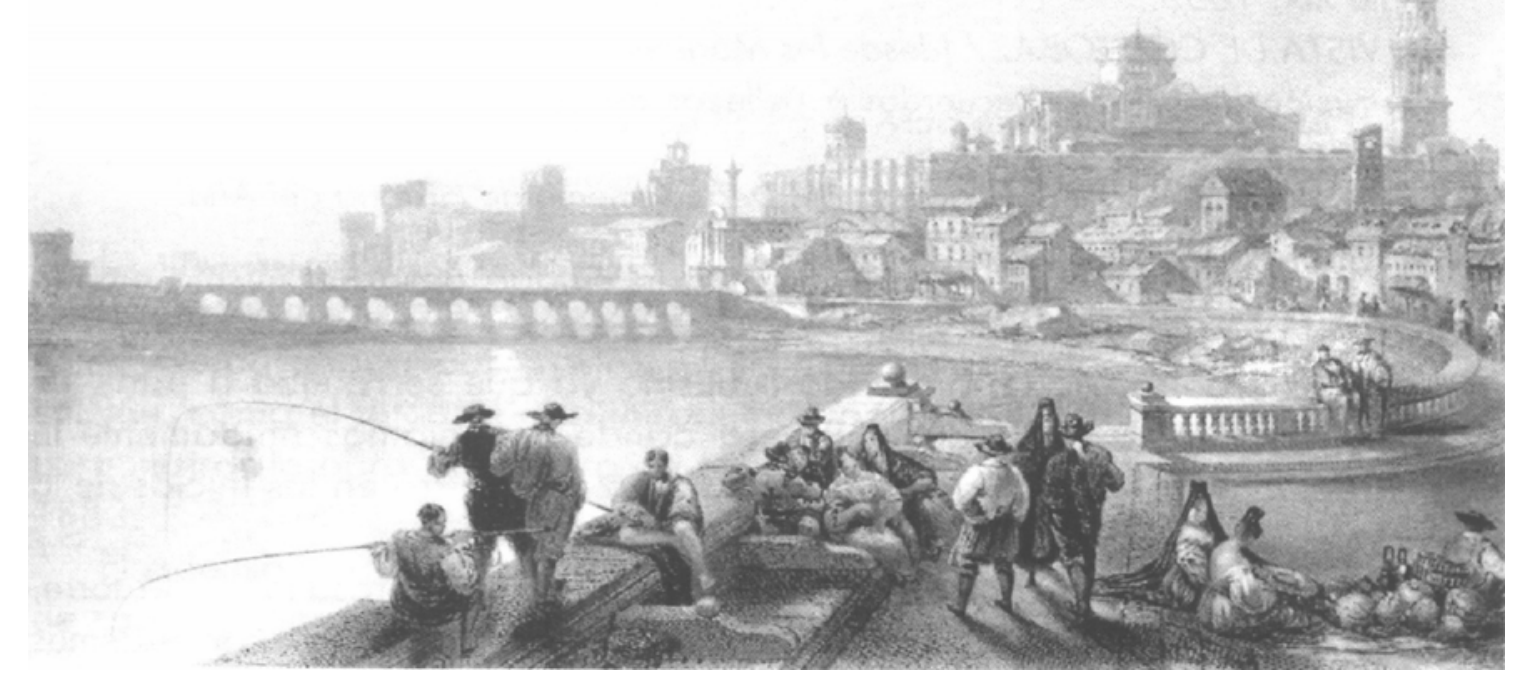

Córdoba. Vista desde el Gualdalquivir. Roberts. 1835.

Las ferias que los cordobeses celebran a lo largo del año son también motivo de alegría, ya que además de divertirse, aprovechan para transacciones comerciales diversas, sobre todo de alimentos, ganados y gran variedad de caballos. Respecto a su duración, las más importantes son las que "coinciden con las que se celebran en la actualidad en honor de la Virgen de la Salud y Nuestra Sra. De la Fuensanta respectivamente”. ${ }^{103}$ Es decir, finales de Mayo y principios de Septiembre.

Si las ferias son las fiestas profanas por excelencia, no podemos dejar de referirnos a las fiestas religiosas. En ellas se integra plenamente el pueblo, que las vive de forma intensa. Entre dichas celebraciones resaltaremos el día de San Rafael, la Semana Santa, y el día del Corpus. Sobre la celebración de San Rafael hay numerosos

\footnotetext{
${ }^{103}$ Ibid. Pág. 279.
} 
testimonios del reconocimiento popular que se le manifiesta y de la gran afluencia de público a las fiestas en su honor. "La tradición hace remontar a principios del XIV la aparición del Arcángel San Rafael al mercedario fray Simón de Souza. La piadosa leyenda cobra de nuevo actualidad en la persona del sacerdote Andrés de Roelas en 1578. Sin embargo, hasta mediados de la centuria siguiente, con ocasión de la peste de 1649, la figura de San Rafael no cobra un protagonismo singular". ${ }^{104}$

En 1795, el escultor cordobés D. Alonso Gómez de Sandoval reformó la escultura de San Rafael que previamente él mismo había hecho. Después de llevarla al palacio del Obispo, y ser bendecida por el mismo, se organizaron diversos actos que culminaron con una solemne procesión y el canto de villancicos y del habitual Te Deum. ${ }^{105}$ Para saber en qué se basa esa devoción absoluta de los cordobeses al Arcángel San Rafael, nada mejor que leer la Centuria Histórica donde se expresan los motivos de la confianza de los cordobeses en la protección del Arcángel Señor San Rafael, escrita por Manuel Antonio Ramírez y Góngora. ${ }^{106}$ En cualquier caso, todavía se mantiene hoy día esa devoción popular hacia San Rafael, custodio de Córdoba y según la tradición, autor de numerosos milagros como protector de la ciudad frente a desastres diversos.

También debemos citar a San Acisclo y Santa Victoria como patronos de la ciudad, y a la Virgen del Socorro, cuya ermita se encuentra junto a la plaza de la Corredera, centro de reunión habitual de los cordobeses. Aunque la devoción hacia esta Virgen comienza según Aranda Doncel a finales del siglo XVI, a principios del siglo XIX la cofradía de Nuestra Señora del Socorro experimenta una gran afiliación de hermanos, gracias a las indulgencias concedidas por Pio VII. ${ }^{107}$

\footnotetext{
${ }^{104}$ Ibid. Pág. 107.

105 "Hízose un gran convite para la procesión que había de celebrarse por la tarde y tuvo efecto, formándola dos batidores á caballo, detrás el señor Conde de Villanueva de Cárdenas, llevando el pendón, á seguida la Cruz, y después de esta el convite, interpolados todos los individuos de la nobleza, gremios, comunidades, ermitaños y cuanto notable había en Córdoba; tras estos el clero secular, la congregación de San Pedro, la imagen, y cerrando la Universidad de Sres. Beneficiados, á los que seguían el Ayuntamiento y la tropa. Emprendieron su marcha por las calles del Paraíso, Tendillas, Plata, Liceo, entrando el Ángel en los conventos de las Capuchinas, Nieves y Espíritu Santo, siguió por el Salvador, San Pablo, entrando también en Santa Marta, San Andrés, Realejo á Santa María de Gracia, donde estuvo un rato en altar preparado, y desde allí á su iglesia, terminando con villancicos y Tedeum”. RAMIREZ DE ARELLANO, Teodomiro. Paseos por Córdoba. León, Everest, 1976, pág. 75.

${ }^{106}$ Cf. RAMIREZ Y GÓNGORA, Manuel Antonio. Centuria Histórica donde se expresan los motivos de la confianza de los cordobeses en la protección del Arcángel Señor San Rafael. Córdoba, Imprenta de Juan Rodríguez de la Torre, 179?.

107 "La hermandad de Nuestra Señora del Socorro logra en 1801 la concesión de indulgencias por Pío VII. A través de cinco rescriptos, fechados en la Ciudad Eterna el 21 de febrero y 4 y 5 de mayo del citado año, el Pontífice otorga distintas gracias espirituales a las personas que visiten la ermita el día de
} 
Respecto a la Semana Santa, a finales del siglo XVIII y principios del XIX ya existían en Córdoba numerosas Hermandades que hacían acto de penitencia por las calles de Córdoba. Las procesiones se vivían con una gran participación popular. ${ }^{108}$

No podemos olvidar el día del Corpus ${ }^{109}$, cuya fiesta se celebra desde época medieval, y que se manifiesta en Córdoba con gran vistosidad y majestuoso ceremonial. Hay que destacar en este caso la Custodia Procesional de Enrique de Arfe, pieza de gran valor artístico. ${ }^{110}$

Igualmente lucidas eran las paradas militares, que se celebraban para conmemorar algún evento relacionado con la vida castrense o para acompañar un acto político. Un ejemplo lo tenemos en las funciones celebradas por el Regimiento de Caballería de Santiago, II $^{\circ}$ de Línea, en el día 21 de Julio de 1820. Este acto se hizo para celebrar la reciente instauración de las Cortes y el juramento que el rey Fernando VII

la fiesta de la titular y a los miembros de ambos sexos de la cofradía, incentivando el ingreso en la misma mediante indulgencias plenarias. [...] El hermano mayor de la cofradía Francisco Montes Calatrava solicita licencia para la publicación de las indulgencias concedidas por Pío VII al obispo de la diócesis Agustín de Ayestarán y Landa, quien expide el permiso correspondiente el 23 de septiembre de 1801. [...] La publicación de las indulgencias dadas por Pío VII surte los efectos deseados, puesto que en los años siguientes numerosas personas ingresan en la cofradía de Nuestra Señora del Socorro. La avalancha de solicitudes llega a tal extremo que la hermandad multiplica en 1803 los efectivos humanos que tenía a finales del siglo XVIII”. ARANDA DONCEL, Juan. La devoción a la Virgen del Socorro en Córdoba durante los siglos XVII al XX. Córdoba, Cajasur, 1998, págs.191-192.

${ }^{108}$ Una amplia descripción de las Hermandades Procesionales y de todas las circunstancias sociales y religiosas que acontecieron en la Semana Santa de entonces, las podemos encontrar en el libro que nos está sirviendo de base en este apartado: ARANDA DONCEL, Juan. Historia de Córdoba. La Época Moderna (1517-1808). Córdoba, Publicaciones del Monte de Piedad y Caja de Ahorros de Córdoba, 1984, págs. 257-269.

${ }^{109}$ Corpus Christi: (Cuerpo de Cristo) Nombre común con el que se conoce la solemnidad litúrgica del Santísimo Cuerpo y Sangre de Cristo. Establecida en 1264 por Urbano IV para celebrar la presencia real y, al mismo tiempo, sacramental de Cristo en la Eucaristía. Es común en este día que se realicen procesiones llevando por las calles el Santísimo Sacramento.

${ }_{110}$ "La custodia de Córdoba, como la de Sahagún — con la que guarda gran semejanza, especialmente en su parte superior- es una obra plenamente gótica en su arquitectura, que se forma por tres cuerpos decrecientes, rematados por una forma bulbosa, sobre la que se asienta el Resucitado. Su estructura se compone de pilares que sostienen las cubiertas de cada cuerpo, y arbotantes que refuerzan la estructura principal, como si trataran de contrarrestar los empujes de las bóvedas como en la gran arquitectura. Sus pilares son, sin embargo, mucho más robustos y elevados que los de Sahagún por lo que la apariencia de la custodia es menos traslúcida y más elevada. Con respecto al diseño de las plantas de cada uno de los cuerpos, Arfe utiliza los núcleos hexagonales y octogonales alternantes, lo mismo que en Sahagún, y así mismo el desarrollo de las tracerías es similar pues utiliza arcos conopiales, entrelazados, mixtilíneos e incluso de medio punto, que unen pilares y chapiteles, determinando los aéreos espacios propios de su estilo. Sin embargo, la altura de la custodia resulta excesiva, ya que en determinado momento se alargaron sus pilares y se le añadió un nuevo friso rompiendo las proporciones iniciales. También hay que anotar que la iconografía de la custodia de Córdoba es mucho más rica que la de Sahagún, dadas sus mayores dimensiones y seguramente las más ambiciosas pretensiones del cabildo cordobés”. SANZ, M ${ }^{\mathrm{a}}$ Jesús. La Custodia Procesional. Enrique de Arfe y su escuela. Córdoba, Publicaciones Obra Social y Cultural Cajasur, 2000, pág. 39. 
hizo de la Constitución, dentro del recién estrenado Trienio Liberal. Si nos atenemos a la descripción que el autor (que por cierto solo firma con sus iniciales, J.M.) hace de los acontecimientos, parece que fue una gran fiesta en la que participaron todas las instituciones oficiales, desde el Ayuntamiento, la Iglesia, etc., además de una multitudinaria representación popular. Podemos decir que hubo tiempo para todo, desde la Santa Misa a una comida de hermandad, un desfile militar, un baile, etc. En alguno de estos actos participó la Capilla de Música de la Catedral, que además es citada expresamente alabando su actuación. ${ }^{111}$

Importantes eran también las aglomeraciones de gente que se producían en torno a algún orador de prestigio bien de la ciudad o de fuera. Así sucede con las predicaciones de fray Diego José de Cádiz, quien en 1786 congrega a una gran multitud tanto en la Catedral como en la plaza de la Corredera. ${ }^{112}$

\footnotetext{
111 "A las nueve de la mañana estando ya reunido el numeroso convite de todas las Autoridades, Cabildos, Comunidades Religiosas, Militares, empleados civiles y demás personas, el Sr. Maestre-Scuela Dignidad de esta Catedral acompañado de dos Señores Canónigos de la misma dio principio á la Misa, que le fue oficiada por Capilla de Música de dicha Santa Iglesia. Después del Evangelio el Sr. D. José Garrido, Canónigo Magistral, pronunció un elocuente discurso probando, por el origen de las sociedades y de las leyes, el gran beneficio ó favor que Dios ha hecho á España con la instalación del Soberano Congreso y juramento de nuestro amado Monarca el Sr. D. FERNANDO VII, según y como antiguamente lo prestaban nuestros Reyes de Aragón y Castilla. Concluida la Misa, el Ilmo. Sr. Obispo entonó el acostumbrado cántico de acción de gracias; y la orquesta desempeñó su parte con la misma perfección y aplausos que los demás". Noticia de las funciones celebradas por el Regimiento de Caballería de Santiago, II ${ }^{\circ}$ de Línea, en el día 21 de Julio de 1820. Córdoba, Imprenta Nacional, 1820, pág. 4. Como hemos dicho, del autor solo conocemos las iniciales, J.M. Este opúsculo se encuentra en la Biblioteca Municipal de Córdoba. Además, por su interés tanto desde el aspecto socio-cultural como desde el puramente musical, al que se refiere en varias ocasiones, lo hemos incluido completo en el Apéndice Documental.

112 "La presencia del famoso capuchino en 1786 constituye un verdadero acontecimiento y congrega una muchedumbre, ansiosa de escucharle, en los sermones que tienen por escenario el crucero de la Mezquita-Catedral y la plaza de la Corredera. Un exponente de la calurosísima acogida serán los agasajos y distinciones que recibe. Los Cabildos municipal y eclesiástico le nombran caballero veinticuatro y canónigo honorario respectivamente y el titular de la mitra teólogo de Cámara y Examinador sinodal. Con la misma aureola popular misiona en un buen número de localidades cordobesas, entre ellas Cabra, Priego, Montoro, Castro del Río y Baena". ARANDA DONCEL, Juan. Historia de Córdoba. La Época Moderna (1517-1808). Córdoba, Publicaciones del Monte de Piedad y Caja de Ahorros de Córdoba, 1984, pág.271.
} 


\subsection{VISITAS REGIAS Y ARQUITECTURA EFÍMERA.}

Mención aparte merecen las fiestas y celebraciones especiales que se realizan con motivo del nombramiento de un nuevo Rey o de la visita a Córdoba de algún personaje importante, sobre todo de miembros de la realeza. Del primer caso podemos citar los festejos para celebrar la proclamación de Carlos IV, durante los cuales se hizo en Córdoba una gran mascarada con la participación de múltiples gremios que se adhirieron al acto. ${ }^{113}$ Mucha razón tiene Ramírez de Arellano cuando nos habla de una extensa resonancia impresa de dicha mascarada. Efectivamente, podemos encontrar en la Biblioteca Municipal de Córdoba el Prospecto o diseño simbólico de la máscara que con motivo de la Real Proclamación de nuestro Rey y Señor D. Carlos Cuarto (que Dios guarde) y que va a executar esta M.N. y M.L. ciudad de Córdoba, tienen dispuesto hacer los individuos de las Artes de Albañilería y Carpintería, con los ramos de Hortelanos, Silleros, y otros asociados a ella. El autor es Manuel Antonio Ramírez y Góngora, y en él se describe con profusión la composición de dicha máscara, su lugar en el cortejo, el acompañamiento que llevará etc. ${ }^{114}$ Pero no es el único trabajo hecho para esta celebración. Si acabamos de ver al gremio de albañiles, carpinteros, etc., colaborando para este diseño, los confiteros no quieren ser menos y hacen su propia composición. De ella tenemos noticia en la Métrica descripción de la Máscara que los honrados gremios de Confitería ó Chocolatería unidos, Especería, Panadería y Zapatería, darán a el público en esta M.N. y M.L. ciudad de Córdoba, como especial signo de amoroso júbilo, por la proclamada exaltación de los reyes nuestros señores $D$. Carlos Cuarto y $D^{a}$ Luisa de Borbón, siendo su autor Francisco José de Segovia y

113 “En 1789, desearon proclamar a Carlos IV con mas solemnidad que se había hecho á otros monarcas, y entre los festejos figuró una gran mascarada, de los gremios de confitería, chocolatería, especería, panadería y zapatería, de la cual hay una extensa descripción impresa: allí se simbolizaron las puertas de la ciudad, la campiña, la sierra, la mitología, el sol, el agua y cuanto puede uno pensar, por su puesto en la forma ampulosa de aquellos tiempos, aunque ya acercándose un tanto a los nuestros. Esta gran mascarada, que en pasar por un punto tardaba mucho tiempo, había de hacerlo por debajo de un gigante de veinte varas de alto, colocado mas arriba de la iglesia de San Francisco, con un pié en cada una de las aceras de la calle, figurando el coloso de Rodas, según los grabados hechos entonces y del que conservamos un ejemplar”. RAMIREZ DE ARELLANO, Teodomiro. Paseos por Córdoba. León, Everest, 1976, pág. 297.

${ }^{114}$ Cf. RAMIREZ Y GÓNGORA, Manuel Antonio. Prospecto o diseño simbólico de la máscara que con motivo de la Real Proclamación de nuestro Rey y Señor D. Carlos Cuarto (que Dios guarde) y que va a executar esta M.N. y M.L. ciudad de Córdoba, tienen dispuesto hacer los individuos de las Artes de Albañilería y Carpintería, con los ramos de Hortelanos, Silleros, y otros asociados a ella. Córdoba, Imprenta de Juan Rodríguez de la Torre, 1789. 
Valenzuela. ${ }^{115}$ Otra visión de los actos de dicha proclamación la tenemos en el Gozo y lealtad con que orla Córdoba la corona de su triunfo en la Real Proclamación del Rey y Señor D. Carlos Cuarto, de Ramírez y Góngora. ${ }^{116}$

En lo referido a visitas reales, podemos decir que eran el culmen en cuanto a actividad, representaciones y fiestas. Asimismo tenían una consecuencia inmediata, y era la mejora en el aspecto urbano de la ciudad. Cronológicamente vamos a destacar dos: la primera se refiere a la visita de Carlos IV a Córdoba, en Marzo de 1796. Como consecuencia se organizan toda clase de festejos, se mejoran aspectos urbanísticos de la ciudad, se arreglan y engalanan las calles con adornos diversos, se instala una iluminación multicolor y se construyen decoraciones de arquitectura efímera. ${ }^{117}$ La música tuvo un papel importante en los actos, ya que "había cinco orquestas de Música: la primera frente del Palacio Episcopal: la segunda en la Plaza Mayor: la tercera en las Casas Capitulares: la quarta en la Plazuela de S. Hypolito; y la quinta en el balcón de la Inquisición”. ${ }^{118}$ También participó la Capilla de Música de la Catedral cantando el habitual Te Deum.

\footnotetext{
${ }^{115}$ Cf. SEgOVIA Y VALEnZUELA, Francisco José de. Métrica descripción de la Máscara que los honrados gremios de Confitería ó Chocolatería unidos, Especería, Panadería y Zapatería, darán a el público en esta M.N. y M.L. ciudad de Córdoba, como especial signo de amoroso júbilo, por la proclamada exaltación de los reyes nuestros señores D. Carlos Cuarto y $D^{a}$ Luisa de Borbón. Córdoba, Imprenta de Juan Rodríguez de la Torre, 1789.

${ }^{116}$ Cf. RAMIREZ Y GÓNGORA, Manuel Antonio. Gozo y lealtad con que orla Córdoba la corona de su triunfo en la Real Proclamación del Rey y Señor D. Carlos Cuarto. Córdoba, Imprenta de Juan Rodríguez de la Torre, 1789.

${ }_{117}$ Uno de estos ejemplos de arquitectura efímera se hizo en la Cruz del Rastro, al final de la Calle de la Feria: "En la Cruz del Rastro se figuraba un monte en cuya cima había una graciosa cúpula sostenida de varias columnas. En medio se representaba Mercurio sobre mi montón de vanderas, y de otros trofeos”. LEAL, Rafael. OBSEQUIOS DE CÓRDOBA A SUS REYES, o descripción de las demostraciones públicas de amor y lealtad que Córdoba tributó a nuestros Católicos Monarcas en los días 11, 12 y 13 de Marzo de 1796, en que la honraron con su augusta presencia. Córdoba, Imprenta de Juan Rodríguez de la Torre, 1796, pág.32. En esa misma calle, se llevarán a cabo obras de reforma. El Corregidor de la ciudad le pide al Cabildo catedralicio que se implique en dichas mejoras. "El Señor Presidente dixo: que había mandado juntar al Cabildo para leer un oficio del Caballero Corregidor de esta ciudad, dirigido al Señor Deán, para que hiciera presente al Cabildo, que habiendo determinado allanar la calle de la Feria con el motivo de la venida del Rey a esta ciudad, y habiendo en ella muchas casas propias de la mesa capitular, le pedía concurriese por su parte para dicha obra, y todo lo concerniente al decoro y hermosura de la expresada calle”. A.C.C. Actas Capitulares. Lunes 11 de Enero de 1796. T. 94, fol. 230 $\mathrm{v}$.

${ }^{118}$ LEAL, Rafael. OBSEQUIOS DE CÓRDOBA A SUS REYES, o descripción de las demostraciones públicas de amor y lealtad que Córdoba tributó a nuestros Católicos Monarcas en los días 11, 12 y 13 de Marzo de 1796, en que la honraron con su augusta presencia. Córdoba, Imprenta de Juan Rodríguez de la Torre, 1796, pág.44.
} 
De todo ello tenemos conocimiento gracias a Fray Rafael Leal, Regente de Estudios del Convento de San Agustín de Córdoba. Este nos describe en sus Obsequios de Córdoba a sus Reyes..., cómo fue la visita real. Lo hace en un lenguaje poético acompañado de frecuentes citas a pie de página en donde glosa o explica con detalle aquellas circunstancias más importantes. De estas notas al pie hemos extractado aquellos pasajes más interesantes para este trabajo y los hemos incluido en Apéndice Documental.

Por último haremos referencia a la visita efectuada por Isabel de Braganza. El 18 de Septiembre de 1816 a las seis de la tarde, llegó a Córdoba la Reina Isabel de Braganza, segunda mujer de Fernando VII, y su hermana la Infanta Francisca, que habiendo desembarcado en Cádiz, se dirigían hacia Madrid. Se alojaron en el Palacio Episcopal. A su paso por Córdoba, fueron agasajadas por la ciudad, la cual se engalanó con decoraciones efímeras, mejorando además su aspecto urbano con la pavimentación del itinerario que iba a seguir la comitiva. ${ }^{119}$

El día 19 por la noche, “se repitieron todos los festejos del anterior, admitiendo S.M. y A. al Besamano á varios Particulares y á la Nobleza de ambos sexos: y se añadió el espectáculo de un gracioso Castillo de fuegos artificiales que se colocó en el Campo Santo delante del Palacio, desde cuyos balcones se dignaron S.M. y A. presenciar este obsequio, dando miles muestras de su complacencia, y con la misma

\footnotetext{
119 “En 1816, Córdoba había recibido a la reina Isabel de Braganza, segunda mujer de Fernando VII. La entrada de Isabel de Braganza en Córdoba la conocemos por el Expediente de Gastos ocurridos con motivo del tránsito por esta Ciudad de S.M. e Ynfanta conservado en el Archivo Municipal. Por las cuentas que presenta, don Nicolás Vázquez, mayordomo tesorero de propios y arbitrios, sabemos que se pagaron al Maestro mayor de la ciudad, Pedro de Lara, treinta y dos mil reales por el empedrado de las calles de la carrera oficial que debía seguir la comitiva regia, veintitrés mil ciento treinta por el arreglo del arrecife del río y otros cuarenta y nueve mil doscientos cincuenta y seis reales para otras obras públicas. [...]. Las decoraciones efímeras, probablemente por utilizar otras anteriores y por ser menos numerosas que las previstas para entradas de monarcas, resultaron más económicas. Ascendió su costo a trece mil cuatrocientos setenta y nueve reales, siendo la partida más alta los diez mil ciento treinta y seis reales utilizados por Pedro de Lara para algunos arreglos de la Posada del Puente, la fuente de San Salvador y el adorno de la plaza de toros. [...] El Campo de los Mártires se iluminó y en él se erigió un tablado para la música por José Cruz, que cobró mil trescientos reales, aunque la partida más elevada por este concepto fue de tres mil novecientos ochenta reales pagados a don Juan Valdelomar $<<$ para la música de Lucena>>. No faltó en esta entrada la presencia de fuegos artificiales, realizados por el Maestro polvorista José Roldán, ni las tradicionales iluminaciones de la Corredera y Casas Capitulares". MORENO CUADRO, Fernando. Arte Efímero Andaluz. Servicio de Publicaciones de la Universidad de Córdoba. Córdoba 1997, pág. 141.
} 
oyeron en su retrete una Letrilla que puso en Música Don Jayme Baliús, Maestro de Capilla de esta Santa Iglesia, y cantaron los profesores de ella". ${ }^{120}$

Efectivamente para aquella ocasión, Balius compuso la obra Cordobeses ilustres y nobles, que tiene el siguiente texto: Estribillo: Cordobeses Ilustres y Nobles, decid en alta voz, que viva nuestra Reina en pacífica unión. Copla: Ya la España se Alegra pues su suelo pisó, su gran Reina y su Infanta para dar esplendor. Regocijo sin fin Córdoba la mostró, pues de amor a sus Reyes dio la prueba mayor.

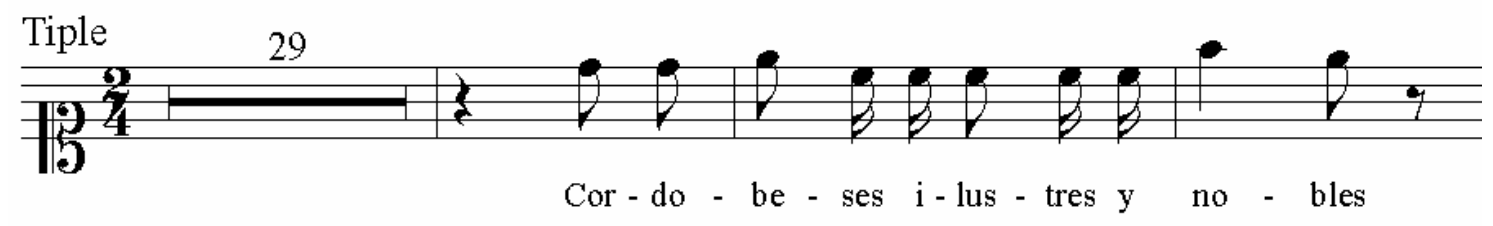

Esta obra tiene la signatura 84/669-3, en el Archivo de la Catedral de Córdoba.

\subsection{CÓRDOBA DURANTE LA GUERRA DE LA INDEPENDENCIA.}

Corría el mes de Abril de 1808 cuando Fernando VII, parece que augurando los sucesos que se avecinaban, envió una carta al Cabildo de la Catedral de Córdoba -como seguramente lo hizo a otros- pidiendo que se hicieran rogativas por él:

"Como el acierto que deseo conseguir en el gobierno de estos reynos, que Dios se ha servido poner a mi cuidado por renuncia de mi Augusto Padre, pende de la Divina asistencia principalmente: he resuelto que se implore esta por medio de fervorosas y devotas rogativas, de que he tenido a bien avisaros, para que como os lo

\footnotetext{
${ }^{120}$ Cf. ANÓNIMO. Noticia Breve de los Obsequios Tributados por la Ciudad de Córdoba a la Reyna Nuestra Señora $D^{a}$ María Isabel de Braganza y a la Serenísima Señora $D^{a}$ María Francisca de Braganza. Córdoba, Imprenta de D. Luis Ramos y Coria, 1816, pág. 5. A lo largo de sus 18 páginas, este opúsculo refleja con toda precisión los momentos de la estancia de Isabel de Braganza en Córdoba durante los días 18, 19 y 20 de Septiembre de 1816.
} 
mando y encargo, dispongan se hagan en esa Iglesia las que en similares casos se acostumbran, ve que me daré por servido". ${ }^{121}$

A principios de Mayo de 1808, la previsible llegada de los franceses a Córdoba causa entre sus habitantes gran preocupación, a pesar de que el entonces Corregidor Agustín Guajardo y Fajardo intenta tranquilizar a la población con palabras de ánimo en la seguridad de que Córdoba luchará contra el invasor. Para transmitir esa calma se constituye una Junta de la Tranquilidad, integrada por las principales autoridades. Pero no fue la única, puesto que a fin de coordinar esfuerzos...

“se constituyó una Junta de Gobierno, dependiente de la de Sevilla, compuesta por el comandante Echavarri —vasco de origen que se encontraba en Andalucía encargado de la persecución de bandidos y contrabandistas-; el corregidor Guaxardo por el Ayuntamiento; los marqueses de la Puebla de los Infantes y de Lendinez; representando a la nobleza el marqués de Benamejí y por el pueblo el diputado del Común de vecinos Alonso Tauste, así como el síndico Antonio Bartolomé Tassara”. ${ }^{122}$

Dicha Junta de Gobierno empezó a tomar decisiones inmediatamente, nombrando al citado Echavarri como general al mando de las tropas que debían enfrentarse a los franceses. Éste, también de inmediato, comenzó a formar un ejército que reunía tanto a tropas regulares como a civiles. "Contando con los voluntarios alistados se llegó a formar un ejército integrado por 3.000 de tropas de línea; 90 batallones integrados por los paisanos, con un contingente aproximado de 20.000 hombres y 3.000 jinetes". ${ }^{123}$ Sin embargo, y a pesar del heroico comportamiento de las tropas no pudo detener el avance francés hacia Córdoba en la Batalla de Alcolea, que tuvo lugar el día 7 de Junio de $1808 .^{124}$

\footnotetext{
${ }^{121}$ A.C.C. Actas Capitulares. Martes 12 de Abril de 1808, T.99.

122 PALACIOS BAÑUELOS, Luis. Historia de Córdoba. La Etapa Contemporánea. Córdoba, Publicaciones del Monte de Piedad y Caja de Ahorros de Córdoba, 1990, pág. 44.

${ }^{123}$ Ibid. Pág. 47.

124 “...confiados en que nadie había de oponerse á su paso, los cordobeses concibieron hacerles resistencia, y llamando a sus compatriotas de los pueblos, juntáronse unos cincuenta mil hombres, sin armas apropósito y sin instrucción alguna en el arte de la guerra: puesto al frente de aquel desordenado ejército el Comandante General de esta Provincia D.Pedro Agustín Chavarri y poniendo por intercesoras á la Virgen de Linares, que ya hemos dicho trajeron a la parroquia de San Pedro, y a la de la Fuensanta, que el entusiasmo y la devoción popular puso la banda de Generala, se aprestaron a la
} 
Con la llegada de los franceses a la ciudad, se produce lo esperado; saqueos, asesinatos, etc. La sorpresa paraliza el funcionamiento de muchas actividades, incluso se cierra la Catedral durante unos días. ${ }^{125}$ Afortunadamente no duró mucho esta primera estancia ya que teniendo noticias de que un ejército español al mando del general Castaños se dirige a su encuentro, el general francés Dupont, ordena reagruparse hacia el norte, primero en dirección a Andujar y después a Bailén donde el día 19 de Julio tiene lugar la famosa batalla y en la cual los franceses son derrotados.

Córdoba vive envuelta en sentimientos contrapuestos: Por un lado, la lógica alegría por la derrota del enemigo, con celebraciones donde se ensalza el fervor patriótico, misas conmemorativas, etc. Por otro, la preocupación de que el invasor

defensa de esta ciudad, situándose en el puente de Alcolea, sin mas fuerza disciplinada que una escasa compañía y una batería mal provista de municiones que llegó de Sevilla en la tarde del seis de junio: á el amanecer del siete, ya estaba situada ésta donde está la casa de la hacienda de Pendolillas, propia del señor Marqués de Benamejí, algunos certeros tiradores frente á los vados, y los pocos soldados de infantería con todos los paisanos en el puente, si bien puede asegurarse que la mayoría de estos solo servía para hacer bulto, pues en su mayor parte solo tenían para la defensa malas escopetas y multitud de picas, con lo que, aunque superiores en número á los franceses, mal podían hacer resistencia á éstos que eran unos quince mil, bien armados y experimentados en cien combates. Sin embargo, la lucha se sostuvo tres horas, durante las cuales los tiradores les hicieron bastantes bajas y la artillería barrió las primeras fuerzas que intentaron pasar el puente, pero la falta de municiones adelantaron el éxito de la acción, y la caballería enemiga se echó sobre aquel improvisado ejército, que salió á la desbandada, llevando el pánico, no solo á esta ciudad, sino también á otros pueblos, á donde llegaron en su precipitada huida. Dueño Dupont del puente, empezó el avance de sus tropas hacia Córdoba, con grandes precauciones, temeroso de más resistencia, hasta dar frente á la puerta Nueva que permanecía cerrada: sin abandonar aquel punto, destacó tropas por la ronda, y algunas que llegaron al santuario de la Fuensanta fueron las que, como en su lugar dijimos, arrojaron esta venerada imagen desde el camarín á la iglesia; las otras fueron hostilizadas desde los terrados del convento de los PP. de Gracia y otros puntos, sin conseguirse con esto mas que aumentar el deseo de avasallar á los cordobeses. La puerta Nueva fue abierta á cañonazos, después de arrojar algunas bombas sobre la población, sufriendo mas que todos el barrio de la Magdalena, si bien llegaron dos o tres de aquellas á la calle de la Candelaria y otros puntos; de las balas arrojadas en dicho día hemos podido recoger dos, de las que una hemos regalado al Museo provincial, como recuerdo de tan memorable hecho de armas.

Aún se conservan en la puerta Nueva, hoy de Alfonso XII, los agujeros hechos por las balas; en este sitio contamos lo ocurrido en la casa que hace esquina á la calle del Pozo, que escusamos repetir. El General Dupont hizo tocar á degüello y permitió á los soldados el saqueo de la población, órdenes que se retiraron, gracias al Marqués de la Puebla, Alférez mayor de la ciudad, que cerca de San Pedro se presentó á Dupont declarando que Córdoba se daba por rendida y que le suplicaba se apiadase de sus desconsolados habitantes". RAMÍREZ DE ARELLANO, Teodomiro: Paseos por Córdoba. Ed Everest, León 1976, págs.509-510.

125 "Se leyó un llamamiento dado por los Señores Puntadores de Horas Canónicas, sobre que el Cavildo, oído su informe, declaró el modo de llenar las casillas de los cuadrantes desde el día que ocuparon la ciudad las tropas francesas hasta que se abrió la Iglesia: en su virtud se acordó que en los cinco días que estuvo cerrada y sin uso alguno sagrado la Iglesia, no haya ganancia alguna, ni puntuación tanto para los Señores Capitulares, como para los Ministros. Y asimismo que se dé comisión a los expresados Señores afectos, para que informen con la brevedad posible, si abierta la Iglesia, los Señores ausentes con motivo de la irrupción del exército francés, tienen o no, derecho a gozar licencia; extendiéndose este informe también a los Ministros que se ausentaron con igual motivo" A.C.C. Actas Capitulares. Miércoles 6 de Julio de 1808. T. 99, fol, 68r. 
pueda volver, como así fue el 23 de Enero de 1810, y la preparación de nuevos ejércitos para hacerle frente.

Como hemos dicho, desde Enero de 1810, Córdoba está de nuevo ocupada por las tropas de Napoleón. Ahora la ocupación sí será larga, puesto que estarán hasta el 4 de Septiembre de 1812. Ese día, "las tropas españolas reconquistaban la ciudad y el día 11 llegaba el comandante general Pedro Agustín de Echávarri. La normalidad volvía a Andalucía y a Córdoba”.126

Ya hemos visto que antes de la primera llegada de los franceses, e incluso durante la misma, el papel del pueblo es activo en la preparación de su defensa y en el rechazo al invasor. En esa postura influyó mucho la Iglesia, que ya desde el principio promovió "una campaña de mentalización e invitación a todo el pueblo para que tomara las armas contra el francés”. ${ }^{127}$ Esta campaña se hacía a través de los púlpitos, desde donde se predicaban encendidos discursos, y también incluyendo en los catecismos pasajes con alegatos en contra de la invasión. Veamos uno de estos fragmentos:

“-¿Quién es el enemigo de nuestra felicidad?

- El emperador de los franceses.

- ¿Quién es este hombre?

- Un malvado, un ambicioso, principio de todos los males, fin de todos los bienes y compuesto y depósito de todos los vicios.

- ¿Cuántas naturalezas tiene?

- Dos: una diabólica y otra humana”. ${ }^{28}$

En algún caso los curas no solo hicieron sermones antifranceses sino que llegaron a tomar las armas y participaron en la lucha. En otros casos bajaban de los púlpitos y salían a las calles, en una especie de procesiones propagandísticas contra Napoleón. Así sucedió en un pueblo de Córdoba, Puente Genil, donde los frailes “con un crucifijo en la mano y arrastrando largas y ruidosas cadenas por las calles, no

126 PALACIOS BAÑUELOS, Luis. Historia de Córdoba. La Etapa Contemporánea. Córdoba, Publicaciones del Monte de Piedad y Caja de Ahorros de Córdoba, 1990, pág. 78.

${ }^{127}$ Ibid. Pág. 45.

128 Ibid. 
cesaron de predicar guerra y exterminio al extranjero, usando en sus discursos de todos los tonos, excitando el entusiasmo con fogosas peroraciones, o haciendo caer el ridículo sobre los invasores, de los que decían, entre otras cosas peregrinas, que valían menos que mujeres preñadas". 129

En las actas capitulares del Cabildo cordobés, hay abundantes referencias a todas las circunstancias que rodean la invasión. Las noticias reflejadas en dichas actas, insisten en el saqueo de las arcas y en los destrozos realizados por las tropas francesas en posesiones de la iglesia. ${ }^{130}$ Asimismo dan fe de los procesos seguidos por las autoridades francesas contra miembros del clero, y tratan todos aquellos asuntos que de una forma u otra implicaban la actuación del Cabildo. Estos destrozos, forman parte de una larga lista de asaltos que los franceses realizaron dentro y fuera de la iglesia durante su estancia en Córdoba. ${ }^{131}$

Hay que decir sin embargo, que algunos aspectos del comportamiento de la población y el clero cambiaron durante la segunda estancia de los franceses en Córdoba. Este es un período más largo, de casi tres años, durante el cual los invasores tienen oportunidad de ejercer más control y más presión sobre la población, con arrestos e incluso fusilamientos de aquellos que notoriamente les hacían frente, lo que lleva a cierta parte de la ciudadanía y a las autoridades a plantearse un cambio de postura. En ello también influye la atracción por algunas ideas y costumbres nuevas que traen los franceses. Los políticos locales no tienen más remedio que pedir al pueblo que colabore con los invasores como mal menor. Se hacen nombramientos importantes sobre personas adictas al nuevo régimen, y en definitiva se van estableciendo dos bandos bien

\footnotetext{
${ }^{129}$ Ibid. Pag. 46. A su vez, Palacios recoge esta cita de: PEREZ DE SILES Y PRADO, A. y AGUILAR Y CANO, A. Apuntes históricos de la Villa de Puente Genil. Córdoba, 1984, p.143.

130 "El Señor Doctoral dio cuenta de que los franceses habían saqueado el Erario de Cabeza de Rentas, y se dio comisión para que con la parte de Su Ilustrísima informen los Diputados de dicha oficina sobre lo que se les ofreciese y pareciese con respecto a los varios ramos de que se compone dicho erario. Igualmente los Señores Diputados de Obras Pías dieron cuenta que por los mismos franceses se habían saqueado los caudales que en el mencionado Erario existían de aquélla oficina, y se les dio comisión para que informen con llamamiento sobre la situación de dichas Obras Pías; y medios que juzguen oportunos para ponerlas de algún modo corrientes. El Señor Roncali, como Diputado de la Fuensanta, expuso que saqueada dicha ermita por los Franceses, hecha pedazos la imagen de Nuestra Señora y destruida la Sacristía, se había ofrecido un devoto a componer la imagen y poner otra vez corriente la expresada ermita, y le acordó admitir con gratitud la propuesta, y que el Señor Diputado intervenga en todo como corresponde”. A.C.C. Actas Capitulares. Martes 28 de Junio de 1808. T. 99, fol, 65r.

${ }^{131}$ Para más información al respecto, ver: MORENO VALERO, Manuel. "Saqueo de las tropas francesas en Córdoba”, en Boletín de la Real Academia de Córdoba, $n^{\circ} 138$ (Enero-Junio 2000). Real Academia, Córdoba, 2000, págs. 215-226.
} 
diferenciados: Los adictos al régimen o afrancesados y los que de una manera u otra, aunque sea con una resistencia pasiva, se atreven a rechazarlo. Así transcurren los casi tres años hasta que Córdoba vuelve a ser libre en Septiembre de 1812.

En el aspecto musical, hay que destacar la activa participación de la Capilla de Música de la Catedral, que frecuentemente interpreta un Te Deum cada vez que se celebra alguna victoria de los españoles sobre los franceses. Posteriormente, y en la segunda entrada de los franceses, José Napoleón visita Córdoba el día 26 de Enero de 1810. En esta visita, tanto el pueblo como las autoridades intentan dar la imagen de una aceptación de lo inevitable, de forma que el recibimiento al "intruso" se procura que sea lo más amable posible. “Este buen recibimiento incluía Te Deum en la Catedral”. ${ }^{132}$

Importante es también la aportación del Maestro de Capilla, Jaime Balius y Vila, que compone Nobles Andaluces, una canción patriótica de rechazo al invasor que, como analizaremos en su momento, bien pudiera ser considerada como un primer Himno de Andalucía.

Pero la música participa de estos acontecimientos no solo a estos niveles, sino que también el pueblo y las tropas españolas se suman a esta forma de expresión con canciones que ridiculizan al invasor y exaltan al Rey Fernando VII, a la Patria, etc.

Del magnífico trabajo que sobre la guerra de la independencia en Córdoba tiene Ortí Belmonte, entresacamos el texto de una de estas canciones:

\section{TIPO DE LAS CANCIONES MARCIALES QUE SE CANTABAN POR EL PUEBLO Y LA TROPA DE CÓRDOBA:}

España de la guerra, tremóla su pendón contra el poder infame del gran Napoleón.

Sus crímenes oíd escuchad su traición

132 PALACIOS BAÑUELOS, Luis. Historia de Córdoba. La Etapa Contemporánea. Córdoba, Publicaciones del Monte de Piedad y Caja de Ahorros de Córdoba, 1990, pag. 60. 
con que ha la faz del mundo

se ha cubierto de honor.

Coro:

A la guerra,

a la guerra españoles.

Muera Napoleón

y viva el Rey Fernando

la Patria y Religión.

En Alianza estrecha

de amistad socolor

ejércitos armados

a ocuparla mandó.

La plaza y los fuertes

con ellos guareció

y Murat los reales

en Madrid asentó.

Coro:

A la guerra,

a la guerra españoles.

Muera Napoleón

y viva el Rey Fernando

la Patria y Religión.

Con perfidia inaudita

a Bayona llamó

a nuestro Rey Fernando

de España nuevo Sol.

A sus padres $y$ hermanos 
también los convocó

y presa hace de todos

cual sangriento león.

Coro:

A la guerra,

a la guerra españoles.

Muera Napoleón

y viva el Rey Fernando

la Patria y Religión.

[....]

De todas las riquezas

Murat se apoderó

y con segura escolta

a Francia las mandó.

Esparce mil papeles

de terrible seducción

$y$ hace ver con descaro

de su amo la traición.

Coro:

A la guerra,

a la guerra españoles.

Muera Napoleón

y viva el Rey Fernando

la Patria y Religión.

Así del gran Fernando

a la España privó

y hacerla su esclava

para siempre pensó. 
Mas no lo logrará,

que armada de valor

en masa se levanta

por vengar la traición.

Coro:

A la guerra,

a la guerra españoles.

Muera Napoleón

y viva el Rey Fernando

la Patria y Religión.

Perecerán las glorias

de toda su nación

al denodado impulso

del esfuerzo español.

$Y$ él mismo entre pesares

angustias y aflicción

será víctima triste

de su ciega ambición.

Coro:

A la guerra,

a la guerra españoles.

Muera Napoleón

y viva el Rey Fernando

la Patria y Religión.

Recuerdo de Sagunto

excitan nuestro ardor

y cual ella perezca

todo buen español.

A Numancia imitad

renuévese su horror

y antes de ser esclavos 
muramos con honor.

Coro:

A la guerra,

a la guerra españoles.

Muera Napoleón

y viva el Rey Fernando

la Patria y Religión. ${ }^{133}$

Esta resistencia de algunos ciudadanos, que tan explícitamente reflejan las anteriores estrofas, tenía sin embargo terribles consecuencias en caso de ser apresados, y una buena parte de la sociedad cordobesa sufría en silencio el ajusticiamiento de patriotas. Por el contrario, el pueblo "mostraba su satisfacción cuando corrían de boca en boca los audaces golpes de mano de partidas guerrilleras como las de Juan Lorenzo Rey y Mariano Rodríguez; verdaderos héroes populares que tuvieron la provincia de Córdoba como escenario y que en sus correrías llegaron a colmar la paciencia de los militares franceses al atreverse a entrar en la propia capital". ${ }^{134}$

Por tanto, y como resumen de este apartado, podemos decir que a pesar del aparente esfuerzo para dar una imagen de normalidad ante el invasor, la vida de los cordobeses fue realmente dura, en un ambiente de desconfianza y miedo por las posibles represalias de los franceses ante cualquier atisbo de oposición. ${ }^{135}$

\footnotetext{
133 ORTÍ BELMONTE, Miguel Ángel. Córdoba durante la Guerra de la Independencia, 1808-1813. Córdoba, Imprenta “La Comercial”, 1930, pág. 237-238.

${ }^{134}$ AGUILAR GAVILÁN, Enrique. Historia de Córdoba. Madrid, Silex, 1995, pág.63.

135 "no resulta extraño que la desconfianza entre los ciudadanos, el miedo a la delación por la existencia de agentes dedicados a estos menesteres, los arbitrarios encarcelamientos de vecinos sospechosos de ayudar a la guerrilla y los no menos frecuentes ajusticiamientos de patriotas en la Corredera y en los muros exteriores de la Puerta del Rincón fueran verdaderamente las realidades que enmarcaron la vida diaria de los cordobeses de aquel tiempo”. AGUILAR GAVILÁN, Enrique. Historia de Córdoba. Madrid, Silex, 1995, pág.63.
} 


\section{CAPÍTULO 4. LA MEZQUITA-CATEDRAL DE CÓRDOBA. ${ }^{136}$}

\subsection{EL EDIFICIO.}

“Tratar de dar una imagen de la Mezquita mediante una descripción, sería algo así como intentar encerrar un universo de formas en un puño. La Mezquita no se describe o se escribe, solo se ve y se siente. El cálculo de sus dimensiones, la disposición y variedad de sus columnas, etc., no pueden dar una idea de las formas que huyen, que se esfuman en múltiples horizontes". ${ }^{137}$ Intentaremos sin embargo, aportar una cronología básica de sus cambios o modificaciones sustanciales a lo largo del tiempo, y de los autores de esas obras.

\subsubsection{DE TEMPLO CRISTIANO A MEZQUITA.}

La Mezquita de Córdoba, “obra cumbre de la arquitectura hispanoárabe”, ${ }^{138}$ se comenzó a construir alrededor del año 786 sobre un templo cristiano visigodo, la Iglesia de San Vicente, bajo el auspicio del emir Abd al-Rahman I. Esta mezquita tenía planta casi cuadrada (79,021 x 78,88 m) y se encontraba dividida interiormente en dos mitades casi exactas, al norte el patio y al sur el oratorio, este último formando un gran espacio cubierto de planta basilical con once naves perpendiculares al muro de alquibla. Vemos en la imagen adjunta una realización de la planta de la Mezquita hecha por L. Torres Balbás.

\footnotetext{
${ }^{136}$ No se pretende en este capítulo realizar un estudio artístico pormenorizado de esta formidable construcción, objetivo que queda fuera del ámbito de este trabajo y que además está plenamente cubierto con la existencia de libros especializados, sino aportar una resumida visión histórica del espacio donde desarrolló su trabajo Jaime Balius y Vila.

137 SÁNCHEZ MÁRMOL, Fernando. Andalucía Monumental. Granada, Biblioteca de la Cultura Andaluza, 1985, pág. 34.

${ }^{138}$ ANGULO IÑIGUEZ, Diego. Historia del Arte. Madrid, 1978. Vol. 1, pág. 332.
} 

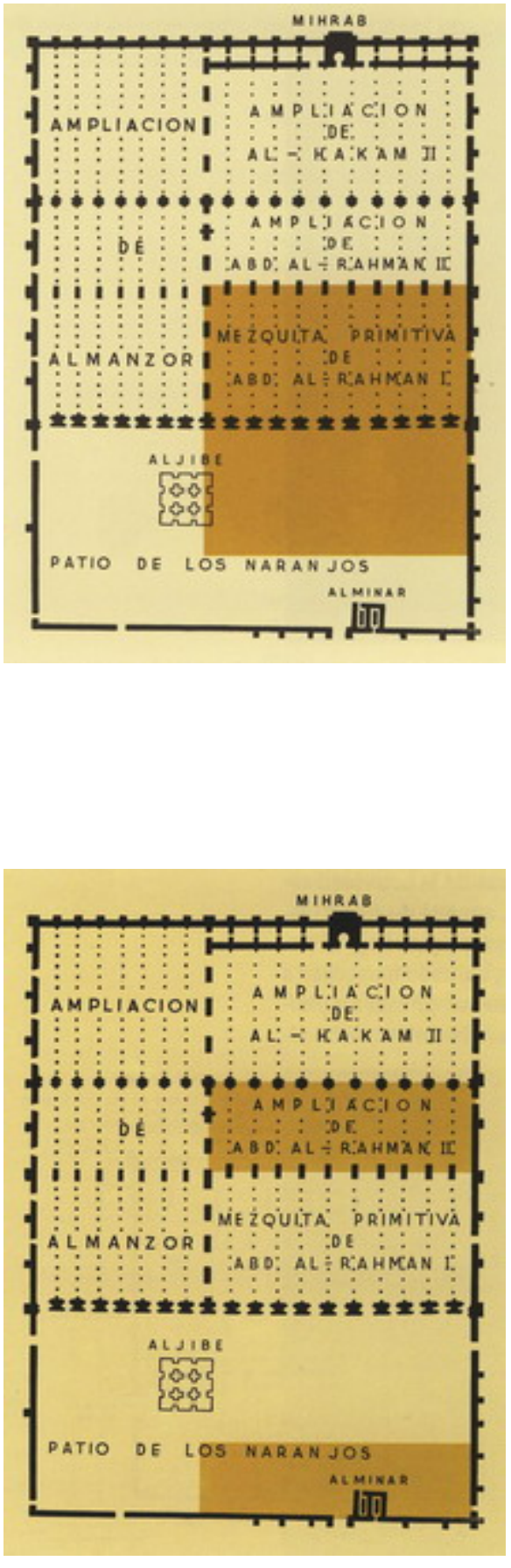

Posteriormente, el hijo de Abd al-Rahman I, el emir Hisam I (788-796) dota a la mezquita de lavatorio y alminar, documentados ambos en excavaciones realizadas en la década de los años 30 del siglo XX. Ese primer alminar está localizado en el actual patio, algunos metros al sur de la torre actual. ${ }^{139}$ En la edificación de esta Mezquita primitiva, se utilizó material de acarreo, es decir procedente de edificaciones de los siglos anteriores (I-VII), tanto romanas como hispanovisigodas.

La primera ampliación importante es acometida entre los años 840 y 848 por el emir Abd al-Rahman II (822-852), quien prolonga las naves 64 metros hacia el sur desde la quibla anterior. En las nuevas arquerías destaca la ausencia de basas en las columnas y la presencia de los primeros capiteles islámicos. El hijo de Abd al-Rahman II, Muhammad I, fue el encargado de rematar el proyecto de su padre, finalizó la decoración y restauró partes de la mezquita antigua, y en especial la famosa Puerta de San Esteban, de los Visires o de San Sebastián, como también es conocida. ${ }^{140}$

\footnotetext{
${ }^{139}$ Cf. NIETO CUMPLIDO, Manuel. La Catedral de Córdoba. Córdoba, Publicaciones de la Obra Social y Cultural de Cajasur, 1998.

${ }^{140}$ Ibid.
} 


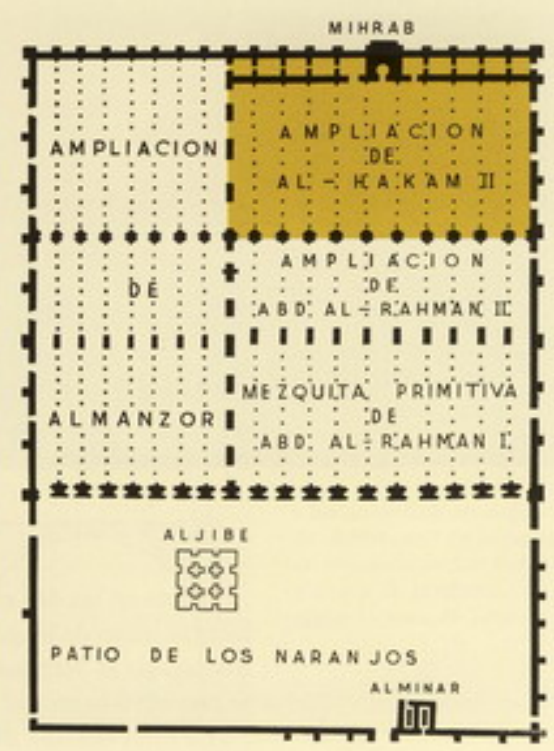

Al-Hakam II (961-976), hijo y sucesor de Abd al-Rahman III, dentro de un ambicioso proyecto iniciado ya por su padre, amplía nuevamente hacia el sur en 47 metros la sala del oratorio. $^{141}$ Parece evidente la intención de convertir el edificio en el emblema oficial del Califato. Se completa la decoración y exterior de las fachadas y al interior se construye una cúpula en la nave central sobre el lugar ocupado por el anterior mihrab de Abd al-Rahman II y el inicio de la parte nueva de la mezquita, que continuando por dicha nave desemboca en las tres cúpulas situadas delante del nuevo mihrab. ${ }^{142}$

La última ampliación de la mezquita de Córdoba es obra de Almanzor, primer ministro del anulado califa Hisam II. La gran población que alcanzó la ciudad de Córdoba a finales del siglo X hizo necesario que se iniciase una nueva ampliación del edificio, a pesar de que las obras de al-Hakam II se habían realizado pocas décadas antes. Si hasta ahora lo normal fue derribar siempre el muro de alquibla para ampliar las once naves del templo hacia el sur, esta fórmula ya no era posible ante el desnivel del terreno y la cercanía del lecho del río Guadalquivir, por lo que fue necesario buscar otra solución. Hacia el lado occidental no podía crecer el edificio pues junto a la vía pública se hallaba el palacio califal y en su parte norte se encontraba el patio, por lo que finalmente sólo quedó la opción de aumentar el edificio hacia el este, a pesar de encontrarse allí casas y calles. Las obras de ampliación tuvieron lugar a lo largo de la última década del siglo $\mathrm{X}$ y consistieron en añadir ocho naves al este de la sala de oración, en toda su longitud, así como en aumentar en igual anchura el patio. 143 "Quedó así completada la grandiosa planta de la Aljama, 179 metros de largo por 128 metros

\footnotetext{
${ }^{141}$ Nieto Cumplido distingue una fase independiente para describir las mejoras de Abd al-Rahman III. Cf. NIETO CUMPLIDO, Manuel y RECIO MATEO, Luis. La Mezquita Catedral de Córdoba, Patrimonio de la Humanidad. Córdoba, Edilux, 2006, pag. 15.

${ }^{142}$ Cf. NIETO CUMPLIDO, Manuel. La Catedral de Córdoba. Córdoba, Publicaciones de la Obra Social y Cultural de Cajasur, 1998.

${ }^{143} \mathrm{Cf}$. http://crc.cervantes.es/ACTCULT/mezquita_cordoba/indice.htm.
} 
de ancho; casi 23.000 metros cuadrados de superficie construida. Las columnas de toda esta fábrica superaban con creces el número de mil". 144

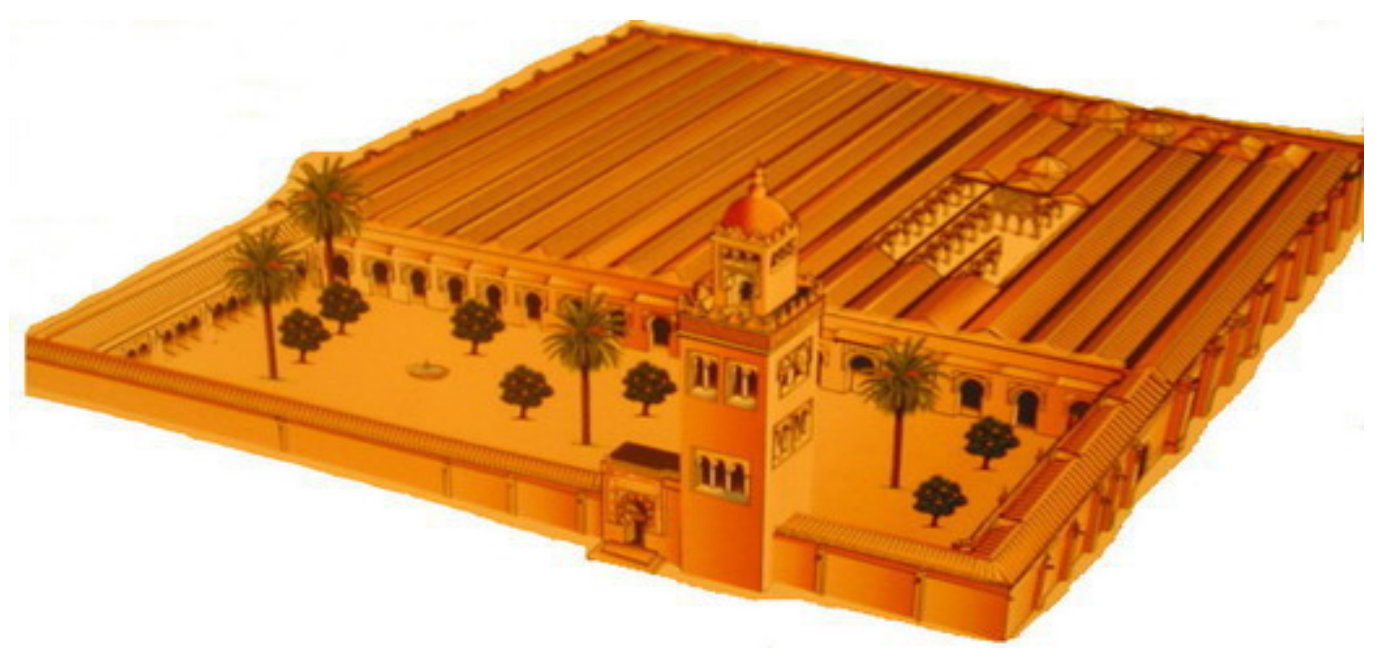

Recreación Infográfica de la Mezquita Califal basada en los dibujos de D. Félix Hernández. ${ }^{145}$

Visto el desarrollo de estas fases podemos encontrar un paralelismo musical, muy oportuno en el contexto de este trabajo, recordando las palabras del doctor Villar, cuando dice que "Ia Gran Mezquita de Córdoba se desarrolló en modo semejante a una sinfonía en cuatro movimientos: Abderramán I, Andante; Abderramán II Presto-adagio molto; Aljáquime, Allegro vivace e con brio, molto maestoso; Almanzor, Allegro ma non troppo". 146

\footnotetext{
${ }^{144}$ SCHOMMER, Alberto Y VILLAR MOVELLÁN, Alberto. La búsqueda: la Mezquita de Córdoba. Córdoba: Caja Provincial de Ahorros de Córdoba, D.L. 1993, pág. 20.

145 Extraído de: NIETO CUMPLIDO, Manuel y RECIO MATEO, Luis. La Mezquita Catedral de Córdoba, Patrimonio de la Humanidad. Córdoba, Edilux, 2006, pag. 15.

${ }^{146}$ VILLAR MOVELLÁN, Alberto. La Catedral de Córdoba. Sevilla, Caja San Fernando, D.L., 2002, pág. 31.
} 


\subsubsection{DE MEZQUITA A CATEDRAL. ${ }^{147}$}

Tras la reconquista de la ciudad por Fernando III el Santo, el 29 de Junio de 1236, el obispo de Osma consagró la aljama, convirtiéndola en templo cristiano bajo la advocación de Santa María Madre de Dios. "Como sello y rúbrica del gran acontecimiento, según costumbre de la Iglesia, los clérigos y obispos entonaron el Te Deum". ${ }^{148}$ A partir de ahí, se siguen realizando actuaciones de importancia hasta que a finales del siglo XV, el Cabildo opta por la realización de una reforma del espacio islámico que según palabras de la profesora Laguna Paúl, reconvierte el recinto islámico en cristiano, cerrado y sagrado. ${ }^{149}$

En esta reforma total, desarrollada en el siglo XVI, juegan un papel fundamental los Hernán Ruiz. Se trata de una familia de reputados arquitectos originarios de Córdoba, que durante el siglo XVI y principio del XVII desarrollaron gran cantidad de obras arquitectónicas y de ingeniería tanto en su ciudad como en otras ciudades de España, adquiriendo por su labor fama nacional.

Hernán Ruiz “El Viejo” (hacia 1475-1547), nace en Córdoba, en una fecha incierta aunque establecida en torno a 1.475. Sus padres eran Gonzalo Rodríguez y Maria Ruiz, aunque toma el apellido de la madre. Junto con su familia vive primero en el barrio de San Lorenzo y después en el barrio de San Pedro. Fruto de sus segundas nupcias con Catalina Simonez, tuvo siete hijos, de los cuales el mayor, Hernán Ruiz II, llegaría a ser al mayor arquitecto de Andalucía. En 1.502 se estrena como maestro mayor de la Catedral y desde esa fecha es arquitecto de la Catedral y del Obispado de Córdoba. Durante cincuenta años desarrolla una gran actividad que lo lleva a adquirir gran prestigio en toda España.

\footnotetext{
${ }^{147}$ La información contenida en este subapartado referente a la familia Hernán Ruiz, está basada en el material que en su día obtuvimos durante la asistencia a los cursos de doctorado que, sobre este tema, impartió en la Universidad de Córdoba el Catedrático-Doctor D. Alberto Villar Movellan y en los diversos artículos que el mismo Villar y las doctoras $\mathrm{M}^{\mathrm{a}}$ Teresa Dabrio y $\mathrm{M}^{\mathrm{a}}$ Ángeles Raya tienen en el volumen 2, "Arte" de la colección Córdoba, editada por la Caja Provincial de Ahorros de Córdoba en 1994.

${ }^{148}$ NIETO CUMPLIDO, Manuel. La Catedral de Córdoba. Córdoba, Publicaciones de la Obra Social y Cultural de Cajasur, 1998, pág. 333.

${ }^{149}$ Cf. LAGUNA PAÚL, Teresa. “Córdoba. la Mezquita y el Casco Histórico”. Ciudades y Monumentos de España Patrimonio de la Humanidad. Madrid, Ferrovial, 2001.
} 
Las reformas de la Catedral de Córdoba durante la primera mitad del XVI son dirigidas por el maestro mayor de las obras catedralicias, Hernán Ruiz I. Estas reformas pueden dividirse en tres fases:

\section{$1^{\text {a }}$ Fase. (1505 a 1514).}

En la época del obispo Juan Daza, las reformas afectaron fundamentalmente al exterior, y se centraron en la modificación de las galerías del Patio de los Naranjos y en la decoración de las puertas situadas en el muro occidental. De hecho, el escudo de este obispo está en la puerta de S. Miguel. No olvidemos que esta zona comunica directamente con el Palacio Episcopal. Bajo el episcopado de Martín Fernández de Angulo, el maestro Ruiz el Viejo procedió a redistribuir el espacio circundante del patio. Emplea módulos tripartitos formados por tres arcos peraltados sobre columnas y encuadrados por alfiz, separándolos entre sí por machones góticos. Por lo que se refiere a las puertas del oeste, fronteras al palacio episcopal, se verán revestidas por molduras y motivos ornamentales del gótico humanista. Así, a la Puerta de la Paloma se le añaden alfices y un arco conopial entre baquetones. Por último, en el Postigo de la Leche se construye un arco conopial rebajado surmontado por un arco ciego cuyo intradós destaca por la complicada labor que lo adorna. Como veremos posteriormente, el grupo de los tres arcos lo utilizará en diversas reformas incluso del interior.

$2^{\mathrm{a}}$ Fase. (1514 a 1523).

Hacia 1514 se inician las reformas en el interior, que afectan al ángulo sureste del edificio. Aumenta considerablemente la dotación de capillas funerarias y, en especial, se construyen la Librería y la Sala Capitular. Para emplazar la Librería se aprovechó lo que había sido Capilla de Santiago, trabajando en ella Ruiz desde 1516. El espacio de tres naves se cerró con muros y se practicaron tres puertas adinteladas decoradas con baquetones. La cubierta se hizo de bóveda de nervios diagonales y terceletes decorados con claves. Para sacristía se usó la Capilla de los Santos Acisclo y Victoria, cuya cubierta sirvió al maestro de ensayo para las que poco después emplearía en las naves del crucero.

Entre 1516 y 1518 se remodela la antigua Sala Capitular, también con tres naves, utilizando para techar bóveda de nervios combados formando cuadrifolias en la 
central y terceletes con claves en las laterales, con los nervios descansando en ménsulas ornadas con torsos de personajes y ángeles. Pero además de las obras encargadas por el Cabildo, Hernán Ruiz I, por su condición de maestro mayor de fábrica, controlaba todo lo que se hacía en el recinto, dando en muchos casos las trazas de las obras. En torno a 1520 se construyen la capilla de la Encarnación y la capilla de los Recaudos, cubiertas ambas con bóveda de crucería estrellada.

\section{$3^{\mathrm{a}}$ Fase. (A partir de 1523).}

"Sin embargo, la decisión de acometer obras de mayor enjundia se debió al obispo Alonso Manrique. El 22 de julio de 1521 el prelado comunicó al Cabildo Catedral su deseo de construir una nueva capilla mayor y coro, cuyos trabajos, después de las oportunas consultas técnicas, se emprendieron el 7 de septiembre de 1523 bajo la dirección de Hernán Ruiz el Viejo”. 150

La decisión contó en principio con la oposición del Ayuntamiento y de algunos canónigos. Esta polémica, nunca debe entenderse como una polémica de carácter artístico, sino que las protestas estaban más relacionadas con el hecho de que algunos concejales tenían previsto su sitio de enterramiento en ese lugar. Sin embargo, después de los primeros momentos, el propio Ayuntamiento contribuyó aportando fondos para su construcción.

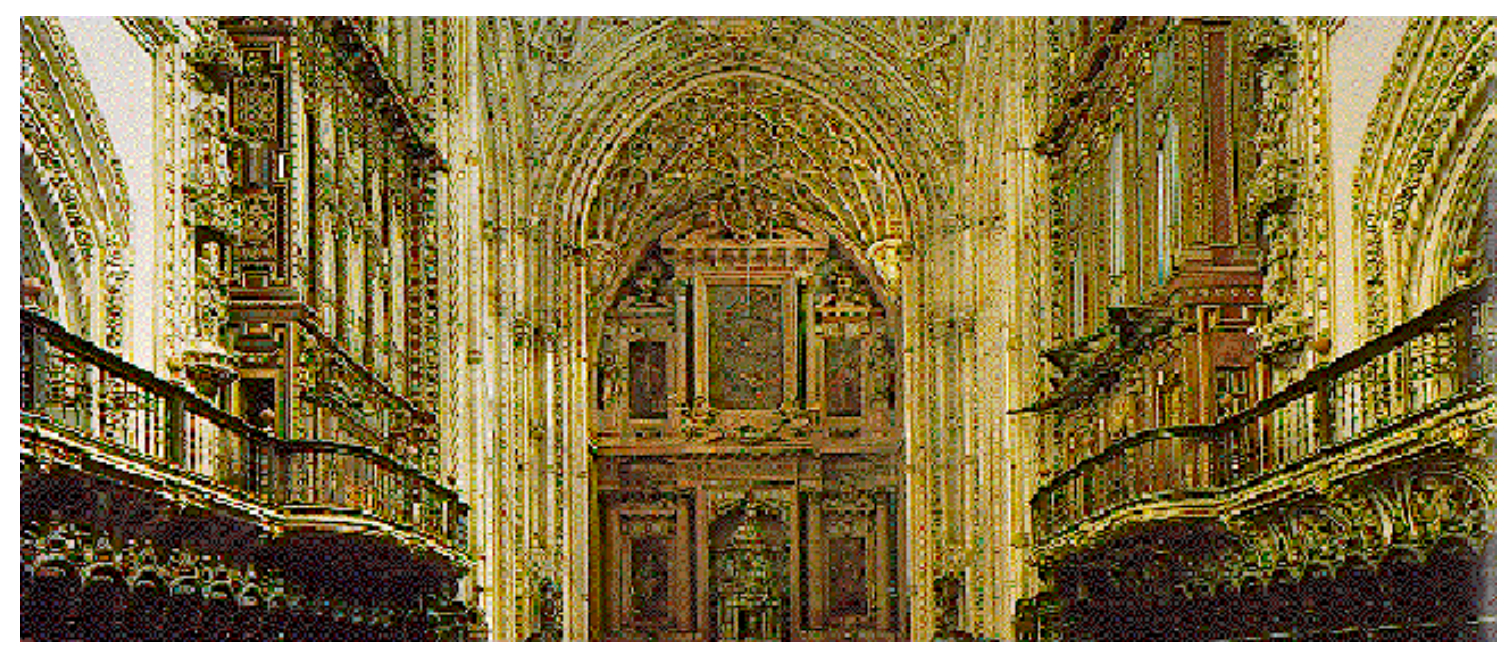

150 DABRIO GONZALEZ, M ${ }^{\mathrm{a}}$ Teresa y RAYA RAYA, M ${ }^{\mathrm{a}}$ Ángeles. “El arrebato humanista”, en: VILLAR MOVELlÁn, Alberto y otros. Córdoba, Arte. Caja Provincial de Ahorros de Córdoba. Córdoba 1994, pag.44. 
En 1523, el Obispo don Alonso Manrique planteó la construcción de una gran catedral en el centro del edificio, para trasladar la Capilla Mayor que se había realizado en el lado occidental de la Mezquita: en contra de la opinión del corregidor y del consejo de la ciudad fueron aprobadas las obras por el Emperador Carlos V, iniciándose la construcción gótica bajo la supervisión de Hernán Ruiz I.

"Ese mismo año de 1523, Alonso Manrique fue promovido a la sede de Sevilla, y para ocupar su lugar llega a Córdoba fray Juan Álvarez de Toledo (15231537), lo que significó no sólo la continuación de las obras a buen ritmo, sino también la plena aceptación del lenguaje formal del Renacimiento, que terminará por anular los modernos esquemas goticistas. Aprovechando la disposición ortogonal de la construcción islámica y utilizando el espacio de once naves y doce tramos, Hernán Ruiz organizó una auténtica iglesia de planta de cruz latina inscrita en un rectángulo, con tres naves, nártex a los pies y transepto en la cabecera”. ${ }^{151}$

“Así mismo, en 1533, mandó reformar la entrada principal de la Catedral, la puerta de las Palmas, añadiéndole un remate con la escena de la anunciación: la constante preocupación por cristianizar los puntos clave del edificio". ${ }^{152}$

Continuador de la obra de Hernán Ruiz I “El Viejo” en la Catedral, es su hijo Hernán Ruiz II “El Joven” (1508-1569). Nació en Córdoba, ciudad donde aprendió el oficio de arquitecto con su padre. Fue un extraordinario maestro, ejemplo de humanista e iniciador y alma del bajorrenacentismo andaluz del Quinientos. En sus obras se extiende la interpretación estética desde el plateresco final hasta el manierismo de finales del siglo XVI, convirtiéndose en un perfecto ensamblador de su nueva arquitectura con la precedente en un mismo edificio.

Ejerció la profesión como Maestro Mayor desde 1530, aunque antes colaboró con su padre en las obras del Coro de la Catedral. En 1547, tras la muerte de su progenitor, recibe el nombramiento de Maestro Mayor del Cabildo catedralicio.

\footnotetext{
151 Ibid.

152 SCHOMMER, Alberto Y VILLAR MOVELLÁN, Alberto. La búsqueda: la Mezquita de Córdoba. Córdoba: Caja Provincial de Ahorros de Córdoba, D.L. 1993, pág. 26.
} 
Se trata, sin duda alguna, de uno de los mayores arquitectos nacidos en Andalucía, con una obra parangonable a la de cualquier profesional del Renacimiento italiano de primera fila; realizó obras civiles y religiosas, públicas y privadas, trabajos de planificación urbana, comunicaciones e hidráulicas, mobiliario y arquitectura efímera, ingenios, escritos y dibujos y ejerció la docencia, todo ello en las actuales provincias de Badajoz, Cádiz, Córdoba, Huelva, Jaén, Málaga y Sevilla.

Pero veamos con más detenimiento su aportación a la Catedral de Córdoba, a través del libro Hernán Ruiz “EL Joven”, de Alfredo J. Morales:

"A la impaciencia del obispo don Leopoldo de Austria por el retraso de la obra catedralicia, se ha atribuido la incorporación de Hernán Ruiz II a las mismas en 1545, como colaborador de su padre. Bajo la dirección de éste el templo que se alzaba en medio de la antigua mezquita, había alcanzado las cornisas, por lo que a su fallecimiento, el hijo se centró en la elevación de los muros del crucero y capilla mayor obras que debió complementar a partir de 1564 con el reforzamiento de los muros del crucero, sector que resultó regentado durante el proceso constructivo. De su intervención son prueba la remodelación de los arcos inferiores y los escudos del obispo don Cristóbal de Rojas”. ${ }^{153}$

Tuvo también participación en determinados encargos de particulares en la catedral cordobesa localizados en el flanco oriental. Es el caso de la capilla de la Asunción, fundación del canónigo Pedro Fernández de Valenzuela, que trazó en torno a 1552. Tan interesante como el tratamiento de los muros laterales, sin orden arquitectónico y con remates en forma de espejos, es el retablo que preside el recinto, con el que se establece el modelo de mayor éxito y consecuencias de la retablística cordobesa del quinientos.

Otra obra extraarquitectónica de Ruiz el Joven en la catedral cordobesa fue el diseño de la reja de la capilla del canónigo Juan de Castro, concertada en febrero de 1559 con el rejero sevillano Pedro Delgado.

\footnotetext{
${ }^{153}$ MORALES, Alfredo J. Hernán Ruiz “El Joven”. Madrid, Akal Ediciones, 1996, pág. 12.
} 
Hernán Ruiz II desempeñó un papel decisivo en la construcción de la Capilla del Espíritu Santo o de los Simancas, como popularmente se conoce la última creación de Ruiz el Joven para la catedral cordobesa. La obra fue contratada en 1568, un año antes de fallecer. El recinto, resuelto en claro sentido ascensional, es de un efectismo extraordinario.

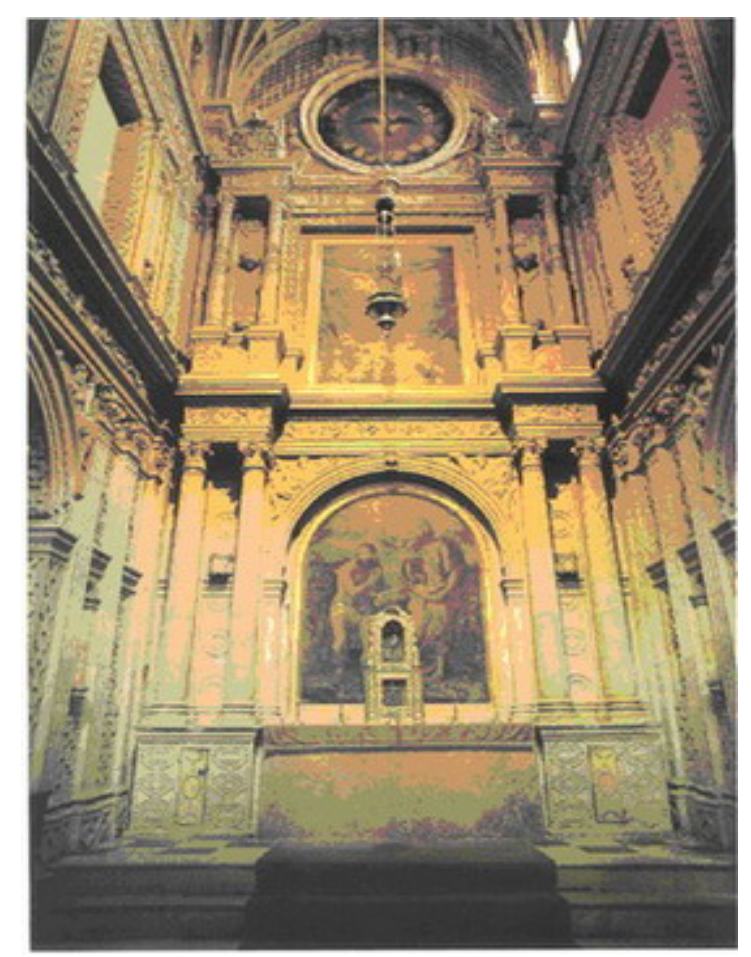

Córdoba. Catedral. Capilla del Espíritu Santo o de los Simancas.

Hernán Ruiz III (hacia 1534-1606) fue el último arquitecto de importancia de la dinastía cordobesa de los Ruiz. Hijo primogénito del genial Hernán Ruiz el Joven, con él aprendería el oficio aunque sin llegar a su altura estilística. Casó con Andrea de Toro en 1561 y tuvo dos hijos arquitectos. En el seno familiar tuvo problemas por su relación con su sirvienta negra Sebastiana. Como persona, vemos a un Hernán Ruiz III bastante inestable, hasta tal punto que en algún momento, concretamente en 1567 ingresa en la cárcel por incumplimiento de contrato relacionado con el puente de Andujar, ciudad en la que instala su residencia en 1560, con el encargo de repararlo. En Córdoba, tuvo como gran oponente a Juan de Ochoa, preferido normalmente por el Ayuntamiento. En los documentos aparecía como Juan de Oliva, ya que una mala lectura ocultó el verdadero nombre de Juan de Ochoa. Podemos decir que en períodos de sede vacante, el 
Cabildo prefiere llamar a Hernán Ruiz III, mientras que en sede plena los obispos se inclinan por Juan de Ochoa.

Su obra es reconocida por servir de transición hacia el Barroco. Ejemplo de ello es la Capilla de la Asunción de la Catedral cordobesa, trazada por su padre y ejecutada por él en el año 1552. Con veinticinco años llegó a ser Maestro Mayor de Córdoba, tras la marcha de su padre a la capital hispalense. Su personalidad le acarreó diversos conflictos con las autoridades, y su carácter inquieto le llevó a recorrer numerosos pueblos y ciudades andaluzas, así como a visitar la Corte. Pronto iría a Sevilla en busca de los cargos vacantes por muerte de su padre, volviendo a su ciudad natal con las manos vacías. Eso sí, conseguiría algunos trabajos de la Iglesia en el territorio de la diócesis hispalense, que alternaría con otros ecijanos como las Carnicerías Reales de 1572.

A partir de 1572 se le encarga en Córdoba una gran actuación como es la Puerta del Puente, de la que podemos decir que es la obra civil más monumental del último cuarto de siglo. Era entonces, la puerta de entrada a la ciudad.

En Montilla, realizaría en 1576 la desaparecida torre de Santiago. En 1577 se le encarga el diseño del monumento para guardar la custodia del Jueves Santo. Este intenso trajín de obras fue el motivo que le llevó a perder el cargo de Maestro Mayor de la Catedral en 1580, fecha en la que iniciaría la capilla mayor de Villanueva de Córdoba y la inconclusa sacristía del convento cordobés de San Pablo, obra esta patrocinada por Fray Martín de Córdoba y Mendoza. También en 1583 ejecutó la desaparecida Capilla de los Mártires en la iglesia de San Pedro y la traída y arca real del agua en Ecija. Ya en la década de 1590 y en sede vacante, estaría ocupado en la construcción del cuerpo de campanas de la Catedral de Córdoba y de la portada de ingreso al coro nuevo, cuyo diseño revela la huella de Sebastián Serlio. Ya anciano, fallecería de forma accidental en Arcos de la Frontera en 1606.

Permítasenos una breve incursión al ambiente musical que vivieron los Hernán Ruiz. Durante los momentos en que trabajaron dentro de la Catedral, ejecutando sus actuaciones arquitectónicas, compartieron espacio con los Maestros de Capilla de la época, y no es difícil aventurar que oyeran las composiciones musicales de éstos. 
Igualmente dichos Maestros debieron presenciar las grandes obras que estaban realizando los arquitectos. La relación entre ellos y su posible influencia sería motivo de otro trabajo. En cualquier caso queremos dejar constancia del nombre de los Maestros de Capilla coetáneos con los Hernán Ruiz: Martín de la Fuente (1505-1522), Luís de Can de Roa (1523), Pedro de Vega (1523-1524), Álvaro de Cervantes (1525-1531), Alonso de Vieras (1531-1532), ¿Cristóbal? de Morales (1532-1533), Alonso de Vieras (1534-1557), Rodrigo de Ceballos (1556-1561), Diego Ximénez (1561-1562), Alonso de Vieras (1562-1563), Andrés de Villalar (1563-1566). Jerónimo Durán de la Cueva $(1567-1614){ }^{154}$

Nos hemos referido anteriormente a Juan de Ochoa (1554-1606). El coro y el crucero fueron concluidos por él, siendo obispo de Córdoba Reinoso Daza:

"Entre sus actuaciones destaca la ejecución del cimborrio o bóveda oval y las cubiertas mayores del templo, así como la bóveda del coro. Juan de Ochoa muestra en su obra la influencia italiana y de la familia de los Hernán Ruiz, dando como resultado un estilo manierista que se deja llevar hacia el barroquismo. El trascoro también es obra de Ochoa, y se dispone en esquema triangular, estando rematado por San Pedro en su cátedra”. 155

Una inscripción conmemorativa recorre los arcos del lado sur del crucero para recordar la conclusión de los trabajos de construcción del templo en el año 1607. Hay objetos muebles de importancia en la catedral como es el caso del Retablo Mayor, obra de Alonso Matías, realizado entre los años 1618 y 1652, o la lámpara realizada en 1629 por Martín Sánchez. El Retablo Mayor: El obispo Diego de Mardones lo encargó tras

\footnotetext{
${ }^{154}$ Las fechas entre paréntesis corresponden al período en el que ejercieron el Magisterio de Capilla. Como se puede comprobar, Álvaro de Vieras repite en tres ocasiones y Cristóbal de Morales figura entre interrogación puesto que no está comprobado al cien por cien que fuera el Maestro de Capilla de esos años. El hecho de que aparezca en los documentos solo su apellido, Morales, dificulta esa certeza. Sin embargo, en la biografía de Cristóbal de Morales no queda claramente delimitado dónde estuvo desde 1531, año en que abandona el Magisterio de Plasencia y 1535, en que ingresa en la Capilla Sixtina de Roma, por lo que bien podría haber pasado parte de ese tiempo en Córdoba. Así lo dice Nieto Cumplido en su trabajo sobre los Maestros de Capilla de Córdoba. NIETO CUMPLIDO, Manuel. "Maestros de Capilla de la Catedral de Córdoba”. A.A.V.V.: Boletín de la Confederación Andaluza de Coros de 1995. Córdoba, Ed. CO.AN.CO., 1995, pág.5.

${ }^{155}$ MARFIL, Pedro. "La Catedral”, en AA.VV. Córdoba, Patrimonio de la Humanidad. Córdoba, Diario Córdoba, 2002, pág.358.
} 
concluir las obras del crucero. Se eligió un proyecto de Alonso Matías (1580-1629) el cual muestra en sus obras un fuerte influjo manierista. Alonso Matías es un autor granadino, con formación sevillana. Se traslada a Córdoba en 1611, donde realiza su obra principal, este Retablo de la catedral. El diseño estableció como materiales para su ejecución el mármol y el bronce, realizando una obra de decoración arquitectónica alejada del típico retablo de arte mueble, y que por sus subdivisiones lo acercan más al renacimiento que al barroco. El retablo se decora con pinturas al lienzo de Acisclo Antonio Palomino (1655-1726). Las esculturas fueron realizadas por Sebastián Vidal (+1678), artista con experiencia en retablos que trabajó en Córdoba y provincia, siendo su obra principal el tabernáculo de la Catedral del año 1653.

La Sillería del Coro: Uno de los elementos artísticos de mayor importancia de la Catedral cordobesa es sin duda la sillería del coro, obra de Pedro Duque Cornejo concluida en 1757. Está tallada en madera de caoba, y presenta dos filas de asientos, la superior destinada a los canónigos es la más profusamente decorada, presentando escenas de la vida de Jesús y de la Virgen. La fila inferior presenta escenas del Antiguo Testamento y de los mártires cordobeses. Preside el conjunto la cátedra episcopal, que como un trono se estructura a modo de retablo, con escenas alusivas a los apóstoles y coronado por la Ascensión de Cristo. El conjunto está rematado por un San Rafael central y las alegorías de la Prudencia y la Templanza.

Las esculturas de los evangelistas talladas en los púlpitos son obras del escultor neoclásico Michel de Verdiguier. Los relieves de los tornavoces son atribuidos al escultor cordobés Alonso Gómez de Sandoval quien siguió aquí la estética de la obra de Duque Cornejo. A partir de entonces la Catedral tendrá ocasionales reformas, mejoras o adiciones de obras artísticas. Posteriormente, en el siglo XIX, las tendencias románticas influyeron en las restauraciones que se llevaron a cabo, pasándose de la conservación tradicional a la restauración como recuperación de los elementos medievales del edificio. 
Desde 1785 y hasta 1822, el Maestro de Capilla Jaime Balius y Vila es testigo de diversas actuaciones como restauraciones de lienzos, ${ }^{156}$ realización de la mesa del altar mayor, ${ }^{157}$ reparación de órganos, ${ }^{158}$ etc.

A partir del 1860, el obispo Juan Alfonso de Alburquerque promueve obras de limpieza de enlucidos. En 1862, ante la venida de la Reina Isabel II se limpió y pintó la Catedral, eliminándose el encalado del oratorio.

La Mezquita-Catedral fue declarada monumento nacional el 21 de noviembre de 1882, pasando a la tutela del Estado el edificio en cuanto a su conservación y restauraciones. Ricardo Velázquez Bosco asume el puesto de arquitecto conservador y lleva a cabo importantes obras en puntos tales como la Puerta de San Sebastián, la fachada occidental y sus portadas, la Capilla de Villaviciosa, la Maqsura y el Mihrab, etc.

En los años treinta del siglo XX el arquitecto Félix Hernández emprendió importantes excavaciones arqueológicas, y desarrolló decisivas obras de restauración y consolidación del monumento hasta su muerte en 1975. Destacan sus intervenciones arquitectónicas en las cubiertas y en la torre.

En los últimos 20 años destaca la importante restauración llevada a cabo por los arquitectos Gabriel Ruiz Cabrero y Gabriel Rebollo Puig, por iniciativa de la Junta de Andalucía y del Cabildo Catedralicio.

\subsection{EL CABILDO.}

Los Estatutos de Fresneda de 1577 establecían el número de 58 beneficiados en la Santa Iglesia Catedral de Córdoba, repartidos conforme a la siguiente estructura:

\footnotetext{
${ }^{156}$ El lienzo de la Asunción fue restaurado en 1799 por Antonio Álvarez Torrado.

${ }^{157}$ Realizada en 1818 por Manuel de la Peña Padura, Arquitecto Mayor de Madrid.

158 "En acta capitular de 23 de Abril de 1798 consta una petición del tesorero don Cayetano Carrascal en la que indica < < que en el órgano antiguo havía de de hacer alguna obra, según se había reconocido, y era necesario desmontar parte de él >>. NIETO CUMPLIDO, Manuel. La Catedral de Córdoba. Córdoba, Publicaciones de la Obra Social y Cultural de Cajasur, 1998, pág. 563.
} 
“Deanazgo, Arcedianazgo de Córdoba, Maestrescolía, Chantría, Arcedianazgo de Castro, Arcedianazgo de Pedroche, Thesoreria, Priorato. Los quales beneficios se nombran dignidades y los que las poseyeren se podrán poner don por prominencia. Ay veynte Canonicatos en la dicha Yglesia, de los cuales uno está supreso en el Santo oficio de la Inquisición, ay diez raciones y veynte medias raciones”. 159

Vázquez Lesmes nos dice que en 1735 se mantenía esta composición y además describe con precisión el resto de Ministros de la Catedral:

“El capellán perpetuo don Tomás Moreno, en su descripción de la catedral de Córdoba, fechada en 1735, expone que en esta fecha la citada Iglesia tenía ocho dignidades, 20 canonicatos, 30 racioneros-se entienden diez racioneros y veinte medios racioneros-, 76 ministros o capellanes de coro, 30 músicos entre organistas, bajones, bajoncillos, chirimías, oboes, violines, violones, arpas, peregrinas, claves y flautas dulces, 12 niños de coro, 6 acólitos, un pertiguero, dos alcaides del silencio, llamado uno de ellos enterrador mayor; dos sacristanes, mayor y menor, dos celadores. Y fuera del coro muchos ministros y contadores, administradores, fieles y ministros de las carnicerías, etc., lo que resulta difícil de contabilizar. Agrega que existen 58 capillas, contando la del cardenal Salazar por dos; la fundada por el cardenal y la de San Lorenzo. En medio de la Iglesia hay 20 altares y dentro de las capillas, 74”. ${ }^{160}$

Poco varía esta composición en la época de D. Jaime Balius, perdurando, como ahora veremos, los cargos tradicionales. Nos sirve de guía en este ejemplo un Repartimiento de Casillas de finales de Junio de 1785, por el que conocemos además, los apellidos del resto de Canónigos, Racioneros y Medio Racioneros. ${ }^{161}$

\footnotetext{
${ }^{159}$ FRESNEDA, Fray Bernardo de. Estatutos de la Sancta Iglesia Catedral de Córdoba. Antequera, 1577. Pág. 1.

${ }^{160}$ VÁZQUEZ LESMES, Rafael. Córdoba y su Cabildo Catedralicio. Córdoba, Cajasur, 1987. Pág. 23.

${ }^{161}$ A.C.C. Cuentas de Casillas del año 1785. T.2155, s/f.
} 


\begin{tabular}{|l|l|}
\hline SEÑORES & MARAVEDÍES \\
\hline Deán (Canónigo). D. Francisco Ramírez Fernández & 2965 \\
\hline Maestre escuela (Racionero) & 2910 \\
\hline Arcediano de Córdoba (Canónigo) & 1935 \\
\hline $\begin{array}{l}\text { Arcediano de Pedroche (Canónigo). D. Joseph } \\
\text { Medina. }\end{array}$ & 2770 \\
\hline Arcediano de Castro (Canónigo) & 3870 \\
\hline Prior (Canónigo) & 1260 \\
\hline Tesorero (Canónigo) & 2820 \\
\hline Santo Oficio & 1935 \\
\hline Chantre & 1308 \\
\hline Amestoi (Racionero) & 1935 \\
\hline Pedro Albarez (Racionero) & 1208 \\
\hline Yusta & 1665 \\
\hline Ferrer & 1790 \\
\hline Romualdo Mon y Velarde & 1440 \\
\hline Villodres & 1913 \\
\hline Garnica & 1428 \\
\hline Samaniego (Racionero) & 1548 \\
\hline Rojano & 1935 \\
\hline Alfaro & 1350 \\
\hline Ximenez & 1935 \\
\hline Manuel García Serrano & 710 \\
\hline Juan de Benjumea & 911 \\
\hline Córdoba & 835 \\
\hline Manuel Zangotita & 891 \\
\hline Francisco Díaz Brabo & 792 \\
\hline Avalle & 901 \\
\hline Ramón Riera (Medio Racionero) & 465 \\
\hline López-Saez & \\
\hline Clemente Cerbent y Arenillas & \\
\hline
\end{tabular}




\begin{tabular}{|l|l|}
\hline Torres & 821 \\
\hline Castillejo & 1845 \\
\hline Barcia (Canónigo) & 1435 \\
\hline Chabes & 1455 \\
\hline Carrasquilla & 1742 \\
\hline Juan Gómez (Canónigo secretario) & 1492 \\
\hline Raimundo García del Olmo (Canónigo) & 1742 \\
\hline Pedro Antonio León (Racionero) & 1533 \\
\hline Pedro Carrascal (Racionero) & 1375 \\
\hline Eduardo Carol (Racionero) & 1363 \\
\hline Franco Alarcón & 1477 \\
\hline Nicolás Moyano & 210 \\
\hline Francisco Nieto & 861 \\
\hline Areco & 691 \\
\hline Baena & 816 \\
\hline Trespalacios & 680 \\
\hline Guajardo & 739 \\
\hline Escanero & 735 \\
\hline Andrés de Morales (Medio Racionero) & 627 \\
\hline González & 875 \\
\hline Nadales & 946 \\
\hline Aguilar & 875 \\
\hline & \\
\hline
\end{tabular}

No figura aún en esta lista D. Juan Antonio del Peral, Medio Racionero que entra el día 5 de Julio de $1785 .{ }^{162}$ Esta estructura no siempre se mantiene inalterable ya que, como veremos posteriormente cuando hablemos de la Capilla de Música, también los miembros del Cabildo se ven afectados por la penuria económica que afecta a todos los estamentos sobre todo a partir del siglo XIX. En una relación de miembros del Cabildo de 1806, comprobamos que ha descendido su número, ya que de los 51 que

${ }^{162}$ A.C.C. Actas Capitulares. 5 de Julio de 1785. T.90, fol. 144r. 
acabamos de ver en la lista anterior, sólo quedan 29 (14 Canónigos y 15 Racioneros enteros y medios) en la siguiente relación:

\section{COMPONENTES DEL CABILDO DE LA CATEDRAL DE CÓRDOBA EN ENERO DE 1806: ${ }^{163}$}

\section{CANÓNIGOS}

Doct. Don Felipe Ventura González, Deán:

Doct. Don Lorenzo Irisarri, Maestre Escuela.

Doct. Don Antonio Venero y Texada, Chantre:

Lic. Don Juan Ramón de Ubillos, Arcediano de Pedroche y Canónigo:

Don Baltasar de Yusta Lamparero, Prior y Canónigo:

Don Pedro Segovia:

Don Diego Ugalde:

Doct. Don Juan de Santa Cruz y Pedraxas:

Doct. Don Agustín de los Arcos:

Doct. Don Miguel García de Pisa, Lectoral:

Doct. Don Gregorio Marcos Merlo, Magistral:

Doct. Don Manuel Maria de Arjona, Penitenciario:

Doct. Don Ramón Riera:

Doct. Don Luís de Albarracín y Quero,

\section{RACIONEROS ENTEROS Y MEDIOS}

Don Juan Benito Samaniego:

Don Rafael Guajardo Faxardo

Don Josef Roncali

Don Manuel Serrano

Don Felipe Escanero

Don Manuel Rodríguez Nadales

Don Pedro Ángel López

Don Andrés Xaramillo

${ }^{163}$ Extraído de: Nuevo Estatuto sobre el modo de cumplir lo días de oficios. Córdoba, 1806, pag.1. 


\section{Don Francisco Muñoz}

Don Bernardo García Cañete

Don Cipriano Gálvez

Don Pedro García

Doct. Don Josef Garrido y Portilla

Don Josef Mazuelo

Doct. Don Felipe Villaescusa y Villarreal.

Además, las dificultades económicas se hacen notar en las retribuciones de los capitulares. Así nos lo corrobora García-Cuevas cuando nos habla de las rebajas en los sueldos e incluso de las dificultades de dicho Cabildo para pagar las asignaciones íntegras de sus ministros:

“Si en los inicios del ochocientos, la dotación del deanato ascendía a 53.314 rs. 4 mrs., a fines de 1807, había descendido a 50.271 rs. 21 mrs. Por si fuera poco, la valuación del quinquenio 1809-1813, coincidente con el período bélico, arroja los siguientes resultados: Deanato, 30.379 rs. 27 mrs. Canonicato, 12.507 rs. 26 mrs. R. entera, 15.803 rs. 5 mrs. En efecto, la dificultad para hacer expedita la cobranza de las rentas durante la guerra de la Independencia, empeoró la situación de la mayoría de los capitulares. Sus perniciosos efectos se dejaron sentir, con toda su crudeza, a la altura de 1811; para paliarlos, se realizaron distribuciones reintegrables a las prebendas enteras. La preocupación por el futuro inmediato era muy grande. El Cabildo se veía incapaz, además, para satisfacer el sueldo íntegro de sus ministros”. ${ }^{164}$

En conclusión, podemos decir que la estructura del Cabildo se mantiene casi idéntica a la existente ya en el siglo XVI, descrita en los Estatutos de Fresneda, y que esta estructura se modifica parcialmente a principios del siglo XIX debido sobre todo a la escasez en los recursos económicos.

\footnotetext{
${ }^{164}$ GARCÍA-CUEVAS VENTURA, José. El Cabildo Catedralicio cordobés desde la Revolución hasta la Restauración (1788-1882). Córdoba, Servicio de Publicaciones de la Universidad, 1996. Pág. 101.
} 
Finalizamos este apartado con un listado de Prebendados que se incorporaron entre 1788 y $1823 .{ }^{165}$

\section{PREBENDADOS DE 1788 A 1822}

Francisco Castillejo y Velasco ................................................................1788

Pedro de Campos de Orellana .................................................................1788

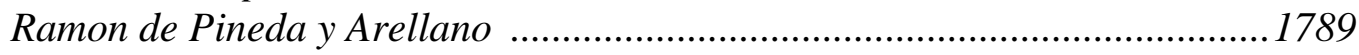

Bartolomé Muñoz Colmena .........................................................................1789

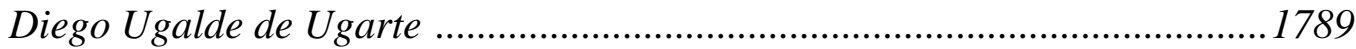

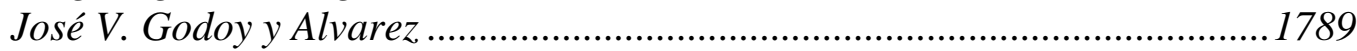

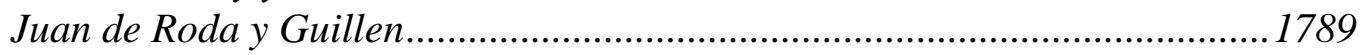

Andrés Xaramillo de León........................................................................1790

Francisco Muñoz Colmena.........................................................................1790

Nicolas Amat Cortes ...................................................................................1791

Diego A. Navarro Martin de Villodres ......................................................1792

Cristobal Álvarez de Sotomayor y Aragones .................................................1792

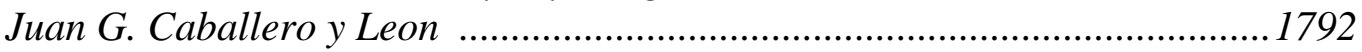

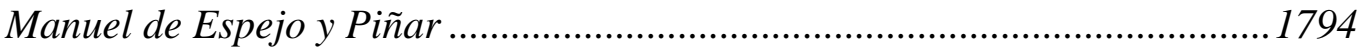

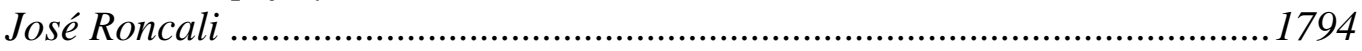

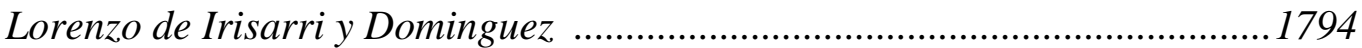

Francisco A. de Goyena y Cañedo ..............................................................1794

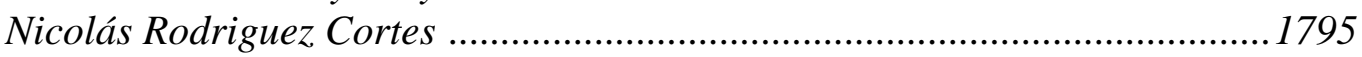

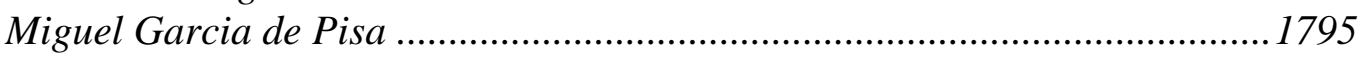

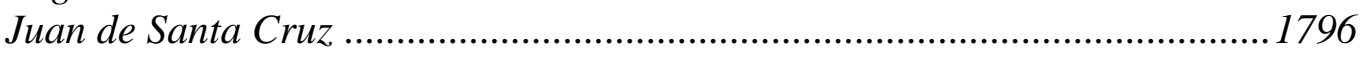

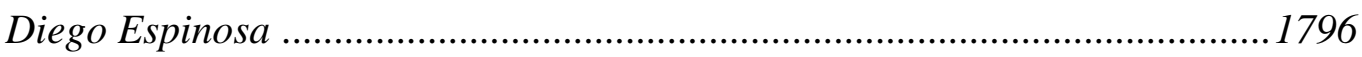

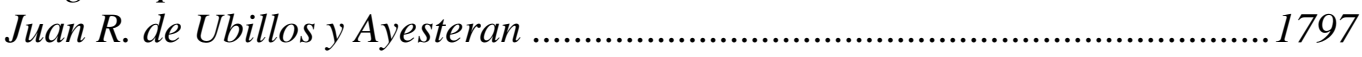

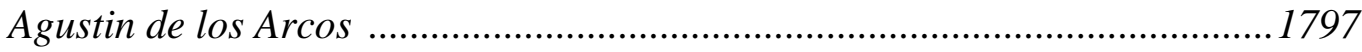

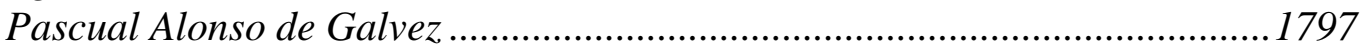

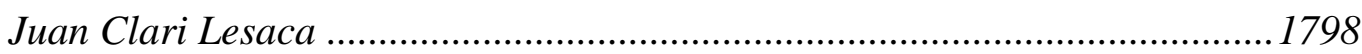

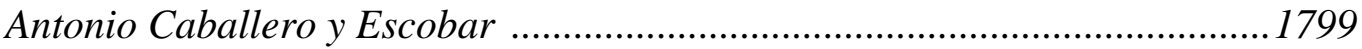

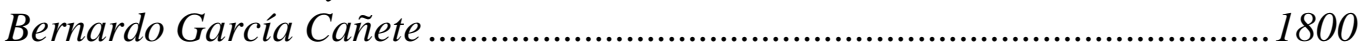

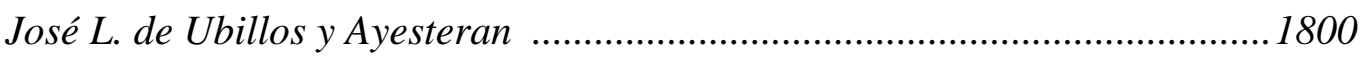

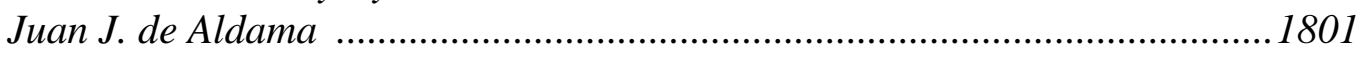

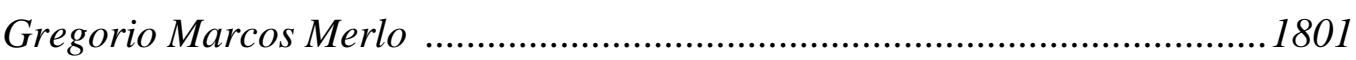

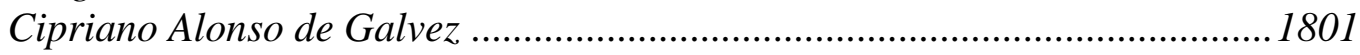

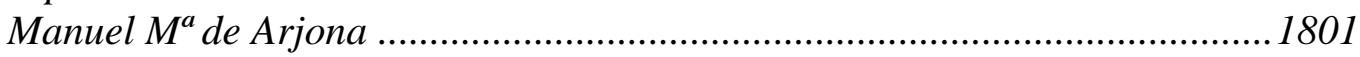

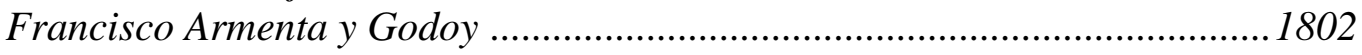

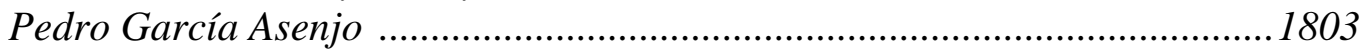

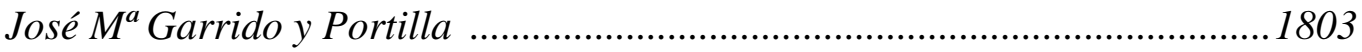

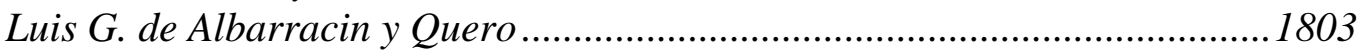

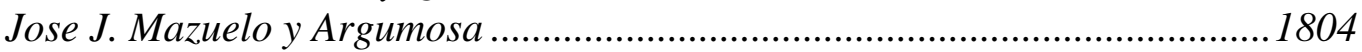

Diego Millán López de Gordoa .......................................................................1804

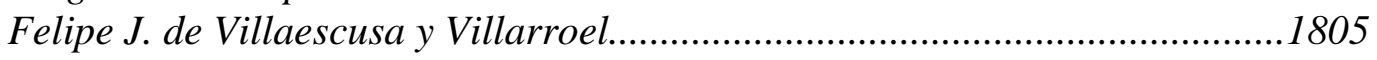

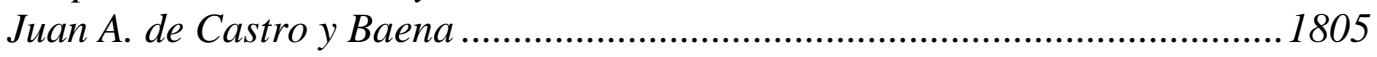

${ }^{165}$ Ibid. pág. 241. 


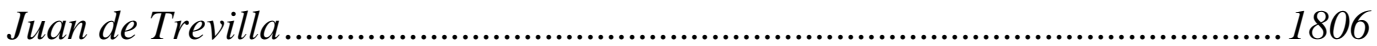

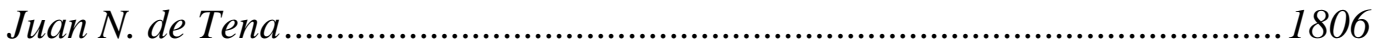

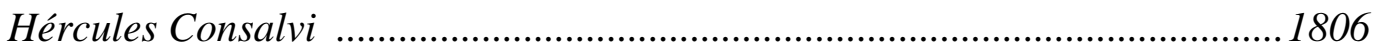

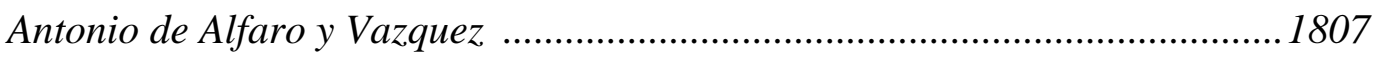

Miguel de Tosta y Montaño ...........................................................................1807

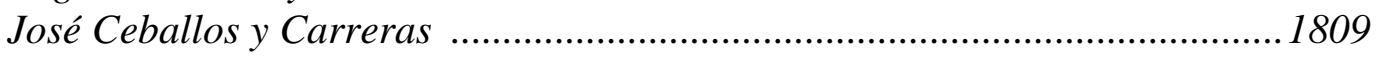

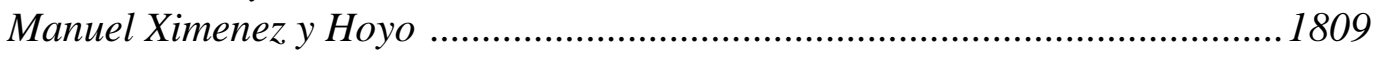

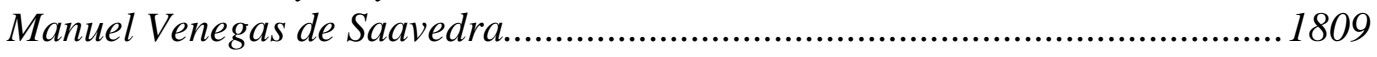

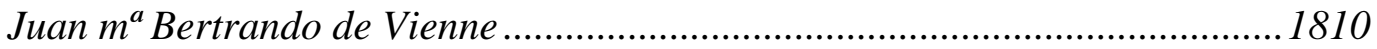

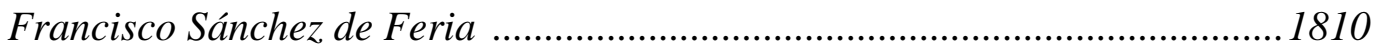

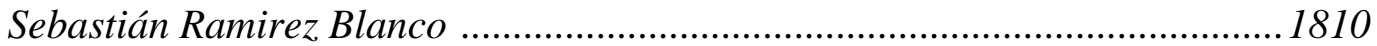

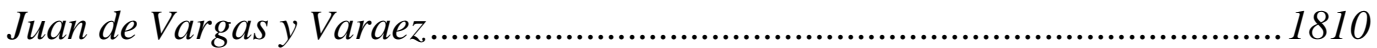

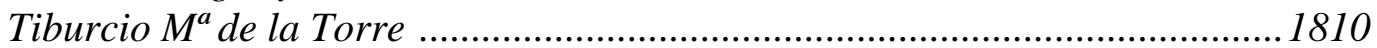

Francisco Castillejo y Camacho ................................................................1810

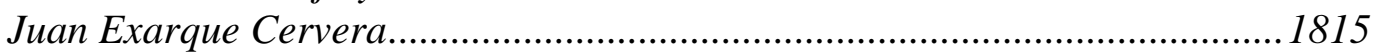

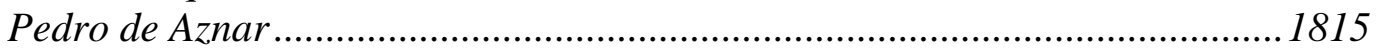

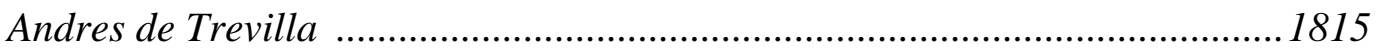

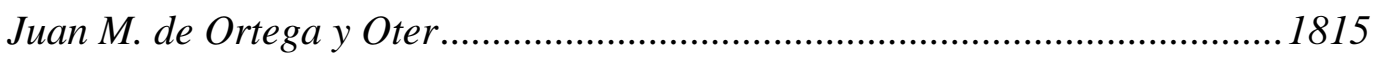

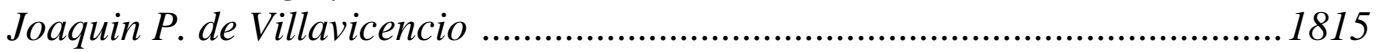

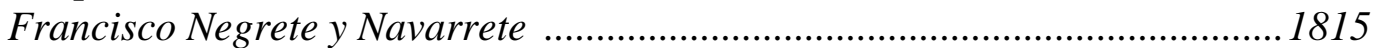

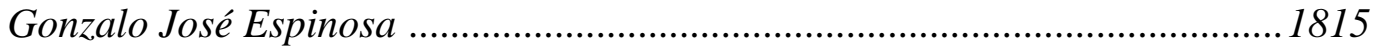

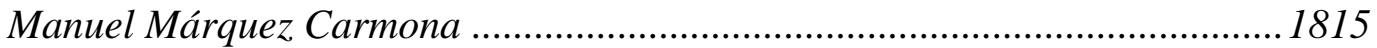

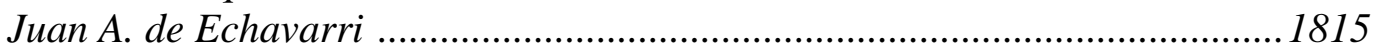

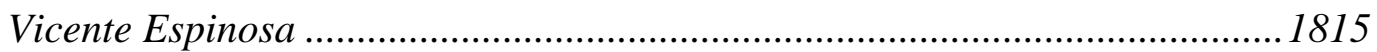

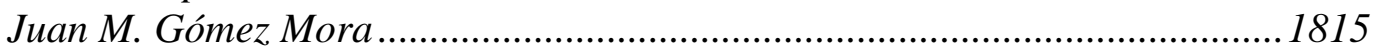

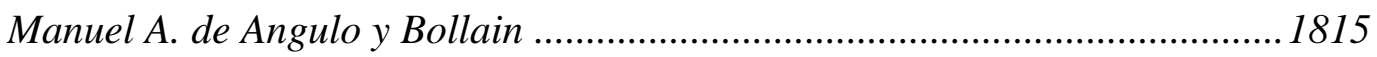

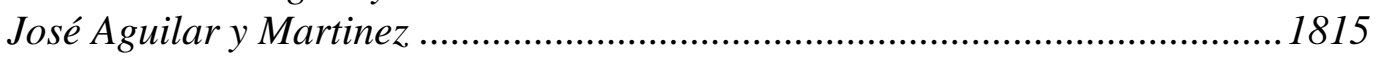

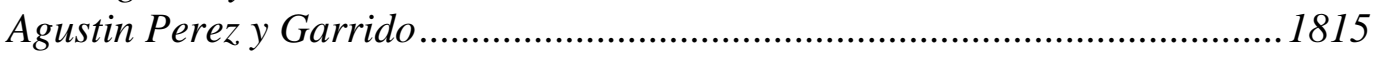

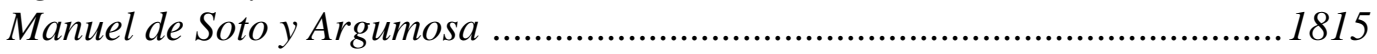

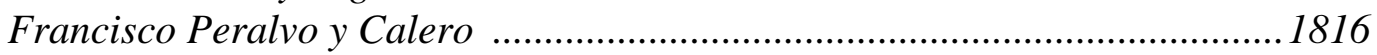

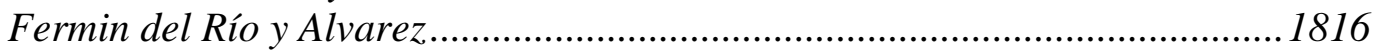

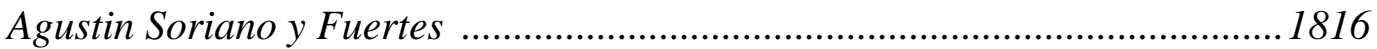

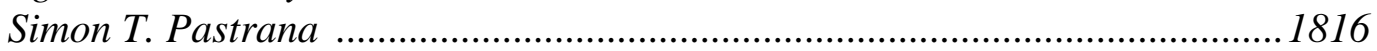

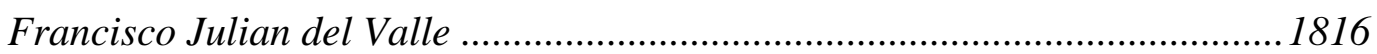

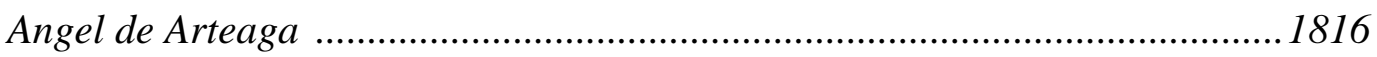

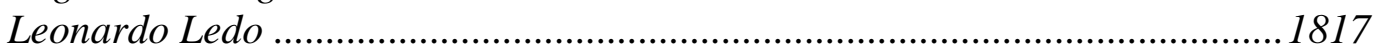

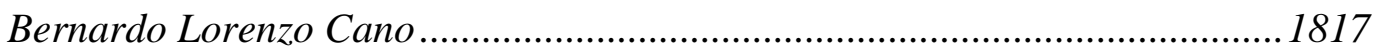

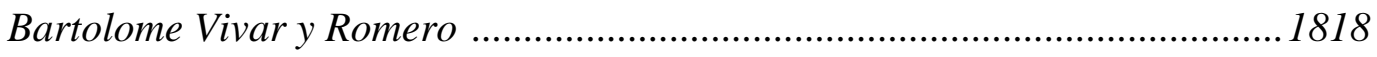

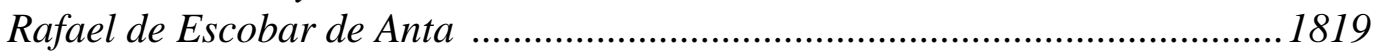

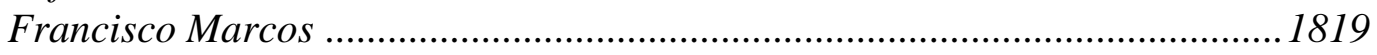

Antonio Sanchez del Villar ..........................................................................1820

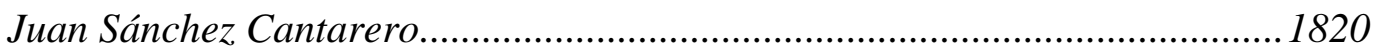

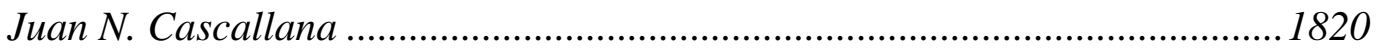

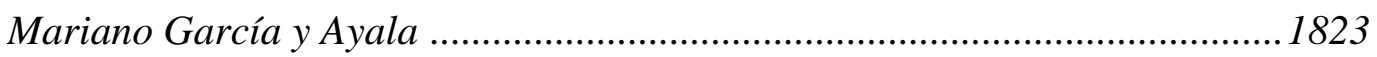

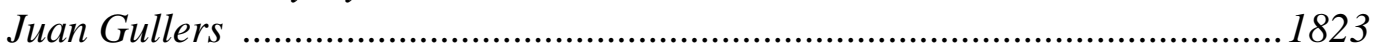

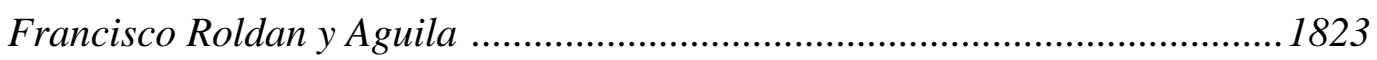




\subsection{SU INFLUENCIA EN LA CIUDAD DE LA ÉPOCA.}

Sin duda la influencia que desempeña la Catedral de Córdoba y los miembros que componen su estructura en la vida económica, social y cultural de la ciudad es muy importante a lo largo de toda su trayectoria multisecular. Aquí nos limitamos a contemplarla en este período de entre siglos, trazando sólo las líneas generales pero acompañadas de algunos interesantes ejemplos.

Como ya dijimos en el Capítulo 3, La Córdoba de la Época, la Catedral es un gran centro de poder económico, con numerosas posesiones que le rinden amplias rentas. Estas rentas se utilizan para muy diversas cuestiones, desde el pago de los sueldos de sus empleados, la adquisición de obras de arte, el mantenimiento y reforma del edificio, una amplia obra social, etc. También se dio la circunstancia de tener que contribuir con sus fondos a paliar la mala situación económica que en su momento vivió la Hacienda Pública:

"La caótica situación hacendística padecida durante la crisis del Antiguo Régimen, como es harto sabido, obligó al Estado a aumentar la presión tributaria sobre las rentas eclesiales, salvaguardadas hasta entonces por privilegios y exenciones. El intervencionismo iba a poner en entredicho, una vez más, el auténtico cariz de la restauración religiosa. En el mes de febrero de 1815, el Cabildo realizaba el anticipo correspondiente al empréstito de tres millones, sin disimular su orgullo por haber sido el primero en afrontarlo, «dando exemplos de amor y fidelidad aun á las mas ilustres, y opulentas Yglesias de la Nación»”.166

En cuanto a la obra social, podemos destacar su participación en la construcción de Hospitales, Colegios, además de diversas obras de caridad, como las limosnas diarias para los más necesitados. Vázquez Lesmes resalta la tradición de la Iglesia en la realización de multitud de Obras Pías. ${ }^{167}$ Nos informa además, de la gran cantidad de

\footnotetext{
${ }^{166}$ GARCÍA-CUEVAS VENTURA, José. El Cabildo Catedralicio cordobés desde la Revolución hasta la Restauración (1788-1882). Córdoba, Servicio de Publicaciones de la Universidad, 1996. Pág. 127.

167 "La Iglesia siempre ha tratado de predicar entre sus fieles el ejercicio de la caridad como eje primigenio y básico representativo de la doctrina de Cristo. Y ésta ha sido una de las premisas que han pilotado su lema de amor y entrega al prójimo plasmada a través de las instituciones creadas y fundadas con la finalidad de repartir sus beneficios entre los más abandonados de la sociedad cuando al Estado
} 
Obras Pías realizadas por la Catedral de Córdoba y cuya documentación se conserva en el A.C.C.: "Conforman un conjunto bastante voluminoso cuya documentación ha sido debidamente inventariada. Se trata de, aproximadamente, de un centenar de obras pías que dan lugar a una acumulación documental compuesta por unas mil cajas conteniendo numerosísimos legajos en donde se vierten todos los detalles de las diferentes fundaciones...". 168

La Catedral, como lugar de prestigio y autoridad en todos los frentes, es un recinto imprescindible para la celebración de actos que reflejen cualquier circunstancia social importante o extraordinaria que afecte a la ciudad, desde visitas reales, proclamación de la constitución, rogativas por alguna necesidad, etc. En la mayoría de los casos se incluye la interpretación de un Te Deum a cargo de la Capilla de Música, además de procesiones introductorias o de despedida. Veamos algunos ejemplos:

En Marzo de 1796 la familia real, a su paso por Córdoba, visita la Catedral con toda la pompa y circunstancia acostumbradas:

"En la tarde del mismo día doce pasaron SS. MM. á visitar la Catedral: Templo, cuya grandiosidad y magnificencia prueban, que la Arquitectura Arábiga no era tan mezquina y grosera como comúnmente se piensa. En la Puerta llamada del Perdón recibió á SS. MM. el Excmo. é Ilmo. Señor Obispo con su Cabildo y Clero, según previene el Ceremonial en semejantes casos. La Música cantó el Te Deum

aún no se le vislumbraba siquiera el inicio de ningún tipo de políticas sociales. Pues bien, en esta línea y siguiendo el consejo evangélico, se crean un conjunto de fundaciones por parte de fieles creyentes, imbuidos del espíritu de entrega a los demás, de servicio a Dios y con la firme convicción, también, de ser un mérito que añadir al logro de la salvación eterna. La fundación de hospitales, asilos, casas de expósitos, hermandades, becas de ayudas para el estudió, sufragios a favor de los difuntos, enfocadas en el orden asistencial, de culto, docentes, sociales..., asentadas generalmente mediante cláusulas testamentarias a favor de personas e instituciones o corporaciones eclesiásticas con el objeto de llevar a buen puerto los fines deseados e impulsados por la iglesia, es una constante encontrada a partir de la época bajomedieval y con mayor incidencia en la plenitud de la moderna. Se trata de lo que entonces y hoy conocemos por fundaciones u obras pías que como cesiones de capitales o de bienes muebles $e$ inmuebles hechas por particulares a personas o corporaciones generalmente religiosas, tienen el objeto de hacer cumplir las condiciones contenidas en las cláusulas testamentarias”. VÁZQUEZ LESMES, Rafael. "El Colegio de Niños de Coro de la catedral de Córdoba: antecedentes, fundación y constituciones". AA.VV. La Iglesia Española y las Instituciones de Caridad. El Escorial, Actas del Simposium, 2006, pág.1.

${ }^{168}$ Ibid. pág.2. Vázquez Lesmes hace un estudio mucho más profundo de las Obras Pías de la Catedral en su libro Córdoba y su Cabildo Catedralicio en la modernidad. Córdoba, Cajasur, 1987. Capítulo IV: "Un Patrimonio del Cabildo: las obras Pías”. 
Laudamus y debaxo del Palio fueron conducidas SS. MM. procesionalmente hasta el Altar mayor; y hecha oración al Santísimo, examinaron atentamente el Templo, y quanto hay en él digno de verse". 169

Los gastos derivados de esta visita real fueron grandes para la ciudad de Córdoba, que se engalanó profusamente. Pero dos años después, el Cabildo vuelve a requerir el apoyo de los cordobeses para ayudar económicamente a la Corona. Así, el obispo Agustín de Ayestarán y Landa (1796-1805) dirige una carta pastoral a sus diocesanos para que se esfuercen en contribuir con un donativo a la defensa de la Nación:

"Todos sabemos por una desgraciada experiencia, que unas largas y continuadas guerras, casi sin interrupción, han afligido á nuestra Nación desde principios de este Siglo, y que su pesado yugo ha oprimido sin distinción á todas sus Provincias y Reynos: las muertes, las desgracias, las pérdidas, la carestía y necesidades se han sucedido con tanta constancia, que no sin dolor podremos leer la Historia de esta Época: y las Ciudades, Villas y Lugares nos darán en ella las reliquias y señales de su decadencia y atraso. En vano nos hemos prometido los Españoles algún descanso y consuelo en los días de paz y serenidad; porque pasando estos con rapidez, hemos vuelto á llorar de nuevo los estragos de la guerra, y este terrible azote del género humano se ha hecho sentir en todo. [...] Estos verdaderos sentimientos, que deben penetraros, y la feliz experiencia que tenemos de vuestro amor y fidelidad al Soberano, como también de vuestra docilidad á nuestras instrucciones, nos hace concebir la dulce esperanza de que sensibles a vuestros intereses personales y espirituales, contribuiréis al Rey en la presente ocasión, ó por Donativo, ó por Préstamo, ó de ambos modos, según vuestras respectivas facultades. [...] Y haciéndolo así, vivid seguros de que habréis cumplido las altas y sagradas obligaciones de conciencia y de justicia, que nos estrechan á la defensa de la Religión y de la Patria: las de reconocimiento y gratitud á bondad y dignación de nuestro Augusto Soberano, que nos pide esta defensa de un modo, tanto mas obligante, quanto mas honroso: y las de la imitación que debemos al ejemplo con que nos edifica; y habremos llenado al fin

${ }^{169}$ LEAL, Rafael. OBSEQUIOS DE CÓRDOBA A SUS REYES, o descripción de las demostraciones públicas de amor y lealtad que Córdoba tributó a nuestros Católicos Monarcas en los días 11, 12 y 13 de Marzo de 1796, en que la honraron con su augusta presencia. Córdoba, Imprenta de Juan Rodríguez de la Torre, 1796. Pág. 48. 
todos los deberes de un fiel Vasallo Español, que en suma se reducen á servir a Dios y al Rey: <<Reddite quae sunt Caesaris: \& quae sunt Dei, Deo>>. Dada en nuestro Palacio Episcopal de Córdoba, firmada de nuestra mano, y refrendada de nuestro infrascripto Vice-Secretario de Cámara á doce días del mes de Agosto del año de mil setecientos noventa y ocho.

Firmado: Agustín, Obispo de Córdoba.

Firmado: Por mandato de S.S.I. el Obispo mi Señor: Josef Fernández Soler” ${ }^{170}$

También son dignos de mencionar los actos celebrados dentro de la Catedral con motivo de la publicación de la Constitución de 1812:

"Los actos programados con motivo de la publicación de la Constitución tuvieron especial magnificencia. A pesar de su nulo entusiasmo, el Cabildo colaboró en el realce de los mismos, mostrando una completa docilidad a los dictados de los munícipes. El día 16 se oficiaba en la iglesia catedral una misa en honor del Santísimo Sacramento y de la Virgen de Linares, con la asistencia de las primeras autoridades; en el desarrollo de la función, los capitulares juraron la Carta Magna”. 171

Como hemos visto, la ceremonia religiosa se mezcla con la civil, que se incrusta en forma de juramento de la Carta Magna. No es el único caso de utilización del templo catedralicio para fines civiles:

"En el templo matriz también se conmemoraron, a iniciativa del poder civil, algunos episodios estelares en la fase postrera de la lucha contra la Francia napoleónica. En 1813 se reanudó con esplendidez la memoria por las víctimas del dos de mayo; similar lucimiento tuvieron la festividad de San Fernando y el aniversario por los caídos. El Cabildo accedió, además, a que la sala del Cardenal se convirtiera en el escenario para el nombramiento de los electores de partido; en la capilla mayor se

\footnotetext{
${ }^{170}$ AYESTARÁN Y LANDA, Agustín. Carta Pastoral de Ilustrísimo Señor D. Agustín de Ayestarán y Landa, Obispo de Córdoba, dirigida á todos sus súbditos y diocesanos, á fin de que se esfuercen á contribuir y suscribir á un Donativo ó Préstamo, ó a ambos, voluntarios, para la defensa de la Nación. Córdoba 1798. En Biblioteca Municipal. Págs. 1-5.

${ }^{171}$ GARCÍA-CUEVAS VENTURA, José. El Cabildo Catedralicio cordobés desde la Revolución hasta la Restauración (1788-1882). Córdoba, Servicio de Publicaciones de la Universidad, 1996. Pág. 124.
} 
oficiaron los actos religiosos de apertura y clausura. Idéntico ceremonial se empleó en la elección de los diputados a Cortes". 172

Pero la actuación del Cabildo no se detenía en acoger celebraciones civiles, sino que también podía actuar como autoridad competente para emitir documentos acerca del comportamiento político de distinguidos ciudadanos, ajenos incluso al cuerpo clerical. Es el caso de lo sucedido años más tarde, y en circunstancias políticas bien distintas, en las que era conveniente demostrar la adhesión a la causa monárquica:

"El Cabildo siguió expidiendo durante este período documentos acreditativos de la conducta política de algunos personajes públicos, solicitados por los propios interesados, en cumplimiento de las exigencias marcadas por la real orden de 30 julio de 1814. Entre ellos se contaron el alcalde mayor Ruiz Morguecho y el antiguo administrador de Bienes Nacionales, Lorenzo Basabrú”. 173

La Catedral es el primer centro cultural de la ciudad, además de religioso. Concretamente en música, es el centro que la produce, consume y enseña. Aquí vienen músicos de diferentes lugares de España y algunos extranjeros, sobre todo italianos, que encuentran en la Capilla de Música su puesto de trabajo. Muchos de estos músicos ejercen además como profesores de los Niños de Coro, tanto en la enseñanza de canto como de instrumentos. Sus muros albergan verdaderas joyas artísticas en todas las facetas; pintura, arquitectura, escultura, rejería, platería, libros antiguos, partituras, etc. Como hemos dicho, es lugar de celebración de verdaderos eventos musicales, unas veces unidos al culto, otras como actividades paralitúrgicas, pero que en cualquier caso atraían la atención de un público ávido de escuchar los populares villancicos, deleitarse con las voces de los últimos cantores llegados de tierras lejanas, o disfrutar con la parafernalia de alguna conmemoración.

Así ocurrió cuando se hizo en Córdoba un acto que celebraba la aceptación de la Constitución por Fernando VII. Este acto, auspiciado por el Regimiento de Caballería de Santiago (y al que nos hemos referido en apartado de Fiestas y Celebraciones),

\footnotetext{
172 Ibid.

${ }^{173}$ Ibid. Pág. 128.
} 
convocó en la Catedral a muchos cordobeses que querían disfrutar de las especiales circunstancias, el boato propio de la ocasión y la intervención religiosa y musical. Estas intervenciones fueron aplaudidas por el gran gentío allí convocado:

"Concluida la Misa, el Ilmo. Sr. Obispo entonó el acostumbrado cántico de acción de gracias; y la orquesta desempeñó su parte con la misma perfección y aplausos que los demás. El Templo preparado para esta oblación, aunque por su estructura es grande y majestuoso, había adquirido para esta ocasión una belleza en sus adornos, que podía servir de geroglífico á la festividad del día. No se puede figurar un aparato religioso más imponente que el de aquella Iglesia enteramente ocupada en todo su pavimento, y lo mismo en su atrio y ángulos que la son contiguos. La variedad de gentes, en clases, estados, sexos y fortunas y su humilde postración ante el Tabernáculo presentaba en pequeño una imagen de la Iglesia Católica interesada en los respetos que se merecen las instituciones civiles. Allí se veían las armas anudadas con las letras, demostrando que la Religión del Cordero es su más firme apoyo, y que la Constitución de la Monarquía es en ambas la base de su prosperidad. Allí no se echaba de menos persona alguna visible, toda Córdoba parece que se había convocado á dar pruebas autenticas de que una es su voluntad y una su opinión”. ${ }^{174}$

La Catedral es punto de referencia también a nivel provincial. Por ejemplo, en 1762, el Maestro de Capilla de la Iglesia Parroquial de Nuestra Señora de la Asunción y Ángeles, de Cabra, escribe al Maestro de Capilla de Córdoba, Juan Manuel Gaitán, para que le diga cómo soluciona el eterno problema de la salida de los músicos a tocar en funciones ajenas a la Catedral, dentro y fuera de la ciudad, cómo divide a los músicos cuando hay que atender dos eventos al mismo tiempo, etc. Al parecer, Gaitán le contesta que en Córdoba se remiten a las normas establecidas en sus Constituciones. ${ }^{175}$ No obstante, Gaitán, “sabedor de que no todos aprueban estas normas, confía en la

\footnotetext{
${ }^{174}$ Noticia de las funciones celebradas por el Regimiento de Caballería de Santiago, II de Línea, en el día 21 de Julio de 1820. Córdoba, Imprenta Nacional, 1820, págs. 4-5. Ver completo en Apéndice Documental.

${ }^{175} \mathrm{Al}$ parecer, se refiere a las Constituciones y Arreglamento que deben observar el Maestro de Capilla, Músicos y cantores de la Sancta Yglesia de Córdova. 1601. A.C.C. Obras Pías, caja 816, nº 9.
} 
autoridad de Castro y Burgos [vicario egabrense] para que pueda darle a la Capilla de Música de Cabra <<el alma que le falta >>,${ }^{176}$

Si hasta aquí hemos hablado de la relevancia de la Catedral como institución, no lo es menos el papel individual que juegan algunos de sus miembros. ${ }^{177}$ Papel especialmente importante, si tenemos en cuenta las diversas líneas de pensamiento político que enarbolaban públicamente diferentes componentes del Cabildo, así como las consecuencias que en algunos casos podían depararles. Así sucedió con el penitenciario Arjona, al cual se le formó “una causa de purificación por su presunta adhesión al gobierno francés. En la consecución de la sentencia absolutoria -7 de agosto de 1815- no debieron resultar inoperantes las generosas exculpaciones aducidas por sus mismos compañeros”. ${ }^{178}$ Otros capitulares, sin embargo, tuvieron que emigrar durante la dominación francesa. "Los capitulares emigrados durante la dominación enemiga fueron Agustín de los Arcos, Juan de Roda, Pedro Ángel López y Miguel de Tosta”. ${ }^{179}$ Las posturas de los distintos capitulares, tanto en los períodos monárquicos como constitucionales, así como las persecuciones que sufrieron por hacerlas públicas quedan bien reflejadas en el libro que venimos citando, El Cabildo Catedralicio cordobés desde la Revolución hasta la Restauración (1788-1882), de José GarcíaCuevas.

Para el estudio mucho más en profundidad de todo lo referente al papel de la Catedral de Córdoba en los ámbitos ya comentados; económico, social, cultural, y otros; sus relaciones con los distintos estamentos locales como el Ayuntamiento, el Ejército, o con distintas instituciones como la Corona, la Santa Sede, etc., son imprescindibles al

\footnotetext{
${ }^{176}$ PÉREZ MORAL, Lourdes. "La Capilla de Música de la Iglesia Parroquial de Nuestra Señora de la Asunción y Ángeles de Cabra”, en El Egabrense, decenario independiente, $n^{\circ}$ 968. 2000. págs. 5-6. Aprovechamos esta cita para resaltar la existencia de un rico archivo musical en la referida Iglesia de Cabra, así como la presencia de una Capilla Musical desde muy antiguo.

177 En algunos casos esta relevancia traspasa los límites de la ciudad, saltando a puestos de responsabilidad a nivel nacional: "A lo largo del reinado de Carlos IV, algunos prebendados cordobeses adquirieron un singular crédito. Sin duda, el más significado fue el del lectoral Ramón José de Arce. En 1791, el monarca le designaba para ocupar una plaza del Consejo de Hacienda. Su imparable ascenso culminaría con el nombramiento de inquisidor general y arzobispo de Burgos". GARCÍA-CUEVAS VENTURA, José. El Cabildo Catedralicio cordobés desde la Revolución hasta la Restauración (17881882). Córdoba, Servicio de Publicaciones de la Universidad, 1996. Pág. 119.

${ }^{178}$ Ibid. Pág. 128.

${ }^{179}$ Ibid. Pág. 124.
} 
menos, el libro de Vázquez Lesmes Córdoba y su Cabildo Catedralicio, ${ }^{180}$ y el citado de García-Cuevas. ${ }^{181}$

\subsection{EL ARCHIVO DE MÚSICA. ${ }^{182}$}

La sección de música del Archivo de la Catedral de Córdoba conserva una muy valiosa colección de obras repartida entre Libros Corales y partituras. Buena parte de este material es manuscrito, aunque también hay partituras impresas. Los citados Libros Corales son verdaderas joyas tanto por la música que contienen como por la encuadernación, las miniaturas policromadas, etc. Estas miniaturas son descritas con precisión en el libro La miniatura en la Catedral de Córdoba, de D. Manuel Nieto Cumplido $^{183}$.

Entre los Libros Corales hay varios de 1502, que constituyen la música más antigua conservada, en lo referente al repertorio monódico. Asimismo, en cuanto a polifonía, lo más antiguo es un libro de Jerónimo Durán de la Cueva, que fue Maestro de Capilla entre 1567 y 1614. A partir de ahí, una notable colección de obras nutre la sección de música del A.C.C. Estas obras, como detallaremos más adelante, tienen distinta procedencia. En ocasiones, la lejanía en el tiempo ha hecho que no se conserve la producción de algunos Maestros de Capilla. En otras, esos Maestros al marcharse se han llevado sus obras. A este respecto, el mismo D. Manuel Nieto nos informa en conversación personal que “a pesar de componer por encargo del Cabildo, había ocasiones en que los Maestros de Capilla consideraban las obras compuestas como propiedad personal. No obstante, y gracias a las positivas gestiones que realiza el Cabildo, siempre que es posible esa música permanece en el archivo. Es el caso de Jacinto de Mesa, cuya familia dona sus obras”.

En 1988, un Convenio de cooperación firmado entre la Consejería de Cultura de la Junta de Andalucía y los Obispos del Sur, impulsó la catalogación de los fondos musicales de los archivos catedralicios de Andalucía. Además de ello, en el A.C.C.,

\footnotetext{
${ }^{180}$ VÁZQUEZ LESMES, Rafael. Córdoba y su Cabildo Catedralicio en la modernidad. Córdoba, Cajasur, 1987.

${ }^{181}$ GARCÍA-CUEVAS VENTURA, José. El Cabildo Catedralicio cordobés desde la Revolución hasta la Restauración (1788-1882). Córdoba, Servicio de Publicaciones de la Universidad, 1996.

${ }^{182}$ A estos fondos que vamos a detallar, habría que añadir algunas partituras del repertorio habitual utilizado en la Catedral de Córdoba durante buena parte del siglo XX, y que todavía hoy estarían en uso.

${ }^{183}$ NIETO CUMPLIDO, Manuel. La miniatura en la Catedral de Córdoba. Córdoba, Monte de Piedad y Caja de Ahorros de Córdoba, 1973.
} 
para situar cronológicamente a los compositores fue necesario realizar un estudio de las actas capitulares, los expedientes de limpieza de sangre o de ingreso, estatutos y constituciones de Capillas, estatutos del Cabildo, estatutos de la música, etc. Como resultado, D. Manuel Nieto publica un trabajo con los datos biográficos principales de los Maestros de Capilla de la Catedral cordobesa. ${ }^{184}$ De ese trabajo hemos extractado tan solo los nombres y las fechas de sus Magisterios.

1. MARTÍN DE LA FUENTE. (1505-1522). No se conserva música.

2. LUIS DE CAN DE ROA. (1523). No se conserva música.

3. PEDRO DE VEGA (1523-1524). No se conserva música.

4. ÁLVARO DE CERVANTES (1525-1531). No se conserva música.

5. ALONSO DE VIERAS (1531-1532). No se conserva música.

6. CRISTÓBAL DE MORALES? (1532-1533). No se conserva música.

7. ALONSO DE VIERAS (1534-1557). No se conserva música.

8. RODRIGO DE CEVALLOS (1556-1561). No se conserva música.

9. DIEGO DE XIMÉNEZ (1561-1562). No se conserva música.

10. ALONSO DE VIERAS (1562-1563). No se conserva música.

11. ANDRES DE VILLALAR (1563-1566). No se conserva música.

12. JERÓNIMO DURAN DE LA CUEVA (1567-1614) (47 años).

Es el Maestro de Capilla de más larga duración y el primero del que se conserva música. 13. NUÑO GONZÁLEZ DE ACEVEDO (1615-1616). No se conserva música.

14. JUAN DE RISCOS (1616-1618). No se conserva música.

15. NUÑO GONZÁLEZ DE ACEVEDO (1618-1621). No se conserva música.

16. JUAN DE MONTIEL (1618-1651). No se conserva música.

17. GABRIEL DÍAZ. (1621-1637). No se conserva música.

18. FRANCISCO DE HUMANES ALDANA (1637-1663). Sí se conserva música.

19. JACINTO ANTONIO DE MESA (1656-1683). Sí se conserva música.

20. JUAN PACHECO MONTIÓN (1684-1706). Sí se conserva música.

21. AGUSTÍN CONTRERAS (1706-1751). Sí se conserva música.

22. JUAN MANUEL GAITAN Y ARTEAGA (1752-1780). Sí se conserva música.

23. JAIME BALIUS Y VILA (1785-1787 y 1789-1822). Sí se conserva música.

24. JUAN CUEVAS (1827-1833). No se conserva música.

25. SALVADOR SERRANO (1852-1868). No se conserva música.

26. ANDRÉS FERNÁNDEZ DE ENTRE-RÍOS Y LIDÓN. (1868-1876). No se conserva música.

27. JUAN ANTONIO GÓMEZ NAVARRO (1877-1916). Sí se conserva música.

28. FRANCISCO BLANCO NÁJERA (1916-1919). Sí se conserva música.

29. RAFAEL VICH BENNASAR (1921-1931). Sí se conserva música.

30. JOSÉ MANRIQUE VICENTE (1950-). No se conserva música.

${ }^{184}$ NIETO CUMPLIDO, Manuel. "Maestros de Capilla de la Catedral de Córdoba". Boletín de la Confederación Andaluza de Coros de 1995. Ed. CO.AN.CO. Córdoba, 1995. 
Pero además de ellos, otros músicos han dejado su obra o parte de ella en el archivo. Podemos diferenciar según la procedencia de dichas composiciones, las siguientes modalidades:

1) Obras compuestas por músicos pertenecientes a la Capilla de Música de la Catedral.

2) Arreglos, transcripciones e instrumentaciones realizadas por músicos de dicha Capilla sobre originales pertenecientes a otros compositores.

3) Obras adquiridas por el Cabildo o bien donadas, de autores ajenos a la Capilla de Música.

4) Obras anónimas.

Igualmente podemos hacer la distinción ya anteriormente enunciada en cuanto al formato en que se conserva la música del A.C.C.

1) Libros Corales. Se conservan 147, de los cuales del 1 al 132 contienen música monódica y los numerados del 133 al 147, polifonía. El número de las obras monódicas está por determinar. Las obras polifónicas suman 188.

2) Partituras y/o particellas. En este formato son 1426, las obras de diversos autores y épocas conservadas.

3) Colección Sánchez Centeno: La componen 1218 obras musicales de diversos estilos (aunque mayoritariamente religiosas), tanto impresas como manuscritas. Sus autores son igualmente muy variados y de diversas épocas y están ampliamente representados los compositores habituales del repertorio sacro que se interpretaba durante el siglo XX (Eslava, Perosi, Otaño, Almandoz, Ruiz Aznar, etc.). Esta colección fue recopilada por el sacerdote D. Carlos Sánchez Centeno, y forma parte de los fondos del A.C.C. gracias a las gestiones de D. Manuel Nieto Cumplido.

Sánchez Centeno realizó sus estudios en el Seminario de San Pelagio de Córdoba, y por su partida de bautismo sabemos que era natural de Almonaster la 
Real (Huelva). ${ }^{185}$ Posteriormente fue párroco en las localidades de Los Blázquez

y Palma del Río. Por último fue canónigo de la Catedral de Córdoba.

Por tanto, y sumando todos los parciales anteriores, serían 2832 las obras musicales censadas en el A.C.C., a falta de determinar el número de obras que componen los libros corales de monodia, con lo que sumarían entonces alrededor de 3000.

\section{1) LIBROS CORALES.}

Los autores que tienen música en los Libros Corales de polifonía son los siguientes: ${ }^{186}$

\begin{tabular}{|l|l|}
\hline AUTOR & $\boldsymbol{N}^{\boldsymbol{o}}$ DE OBRAS \\
\hline ANÓNIMO & 61 \\
\hline CHERCHEN, GAUDERICI DE & 1 \\
\hline DURÁN DE LA CUEVA, JERÓNIMO & 18 \\
\hline GAITÁN Y ARTIAGA, JUAN MANUEL & 3 \\
\hline GUERRERO, FRANCISCO & 17 \\
\hline HIDALGO, ANTONIO & 1 \\
\hline LOBO DE BORJA, ALFONSO & 12 \\
\hline LUPI, EDUARDO & 15 \\
\hline MESA, JACINTO ANTONIO DE & 9 \\
\hline PACHECHO MONTIÓN, JUAN & 1 \\
\hline ROGIER, PHILIPPE & 5 \\
\hline RUIZ, MATÍAS & 2 \\
\hline SORIANO, FRANCISCO & 1 \\
\hline VICTORIA, TOMÁS LUIS DE & 42 \\
\hline
\end{tabular}

${ }^{185}$ Infrascrito Cura propio de la Iglesia de San Martín de esta villa Certifica: que al folio séptimo del libro treinta y cuatro de bautismos se halla la siguiente:

Partida: En la Villa de Almonaster la Real, Diócesis de Sevilla, provincia de Huelva, el día 3 de Octubre de mil novecientos nueve: Yo D. Nicolás Ruiz Góngora, Cura propio de su Iglesia Parroquial del Sr. San Martín, bauticé solemnemente en ella á un niño que se le puso por nombre Carlos, y que nació el día treinta del último Julio á las diez de la noche en la Mina Cueva de la Mora perteneciente á esta feligresía; hijo legítimo de Ángel Sánchez Cabeza y de Piedad Centeno Navas, ambos naturales y casados según dijeron en Azuaga provincia de Badajoz el año de mil novecientos seis; siendo sus abuelos paternos, José Sánchez Solano y Rosario Cabeza Pila; y los maternos Antonio Centeno Hidalgo y Josefa Navas Murier, todos naturales de Azuaga; fueron sus padrinos Carlos Mesa Carmona y Cándida Diegue Arias, consortes y vecinos de ésta, a los que advertí el parentesco espiritual y obligaciones que contrajeron; siendo testigos D. Antonio Ramos Marín y Francisco Sánchez, ministros de esta iglesia, y para que conste lo anoto y firmo fecha ut supra: Firmado: Nicolás Ruiz

Concuerda con su original. Almonaster la Real cuatro de Mayo de mil novecientos veinte y nueve. Firmado: Francisco Rodríguez. A.C.C. Colección Sanchez Centeno. Expediente Personal.

${ }^{186}$ Cf. BEDMAR ENCINAS, Luis. "El archivo musical de la Catedral de córdoba en su conjunto y sus principales protagonistas”, en AA.VV. Actas de las I1 ${ }^{a}$ Jornadas de Patrimonio Histórico-Musical de Córdoba. Córdoba, Ayuntamiento de Córdoba, 2004, pág. 117. 


\section{2) PARTITURAS Y/O PARTICELLAS.}

Los autores de la música en formato de partituras y/o particellas son los siguientes:

\begin{tabular}{|l|l|}
\hline AUTOR & $\boldsymbol{N}^{\boldsymbol{o}}$ DE OBRAS \\
\hline ALAPONT, VICENTE & 1 \\
\hline ÁLVAREZ, MANUEL & 1 \\
\hline ANGUITA, NICOLÁS & 17 \\
\hline ANÓNIMO & 103 \\
\hline ARELLANO & 1 \\
\hline AUSTRIA, JUAN DE & 1 \\
\hline AYALA, FRANCISCO & 15 \\
\hline AZCONA, FRANCISCO & 1 \\
\hline BALIUS Y VILA, JAIME & 720 \\
\hline BALIUS, FRANCISCO & 17 \\
\hline BARZENAS & 3 \\
\hline BAS, GIULIO & 4 \\
\hline BERMEJA, JUAN DE LA & 1 \\
\hline BERNIA, MATEO & 1 \\
\hline BLANCO NAJERA, FRANCISCO & 2 \\
\hline BORDERIA, AGUSTÍN & 1 \\
\hline BUENO, JUAN & 5 \\
\hline COMES & 1 \\
\hline CONTRERAS, AGUSTÍN DE & 62 \\
\hline DES PRES, J. & 1 \\
\hline DURÁN DE LA CUEVA, JERÓNIMO & 2 \\
\hline ENRIQUEZ, ANDRÉS & 2 \\
\hline FERRERAS & 1 \\
\hline FOSCHINI, GAETANO F. & 2 \\
\hline FRANCÉS IRIBARREN, JUAN & 1 \\
\hline GAITÁN Y ARTEAGA, JUAN MANUEL & 74 \\
\hline GALÁN & 1 \\
\hline GARCÍA GUERRERO, BARTOLOMÉ & 30 \\
\hline GARĆA PACHECO, FABIÁN & 4 \\
\hline GIL, JOSÉ & 1 \\
\hline GIROWEZ & 1 \\
\hline GOICOECHEA, V. & 2 \\
\hline GÓMEZ NAVARRO, JUAN ANTONIO & 18 \\
\hline GUERRERO, VICENTE & 1 \\
\hline GUINER, LUIS & 1 \\
\hline GUTIÉRREZ RAVÉ Y NAVARRO, M. M. & 1 \\
\hline HALLER, MICH & 2 \\
\hline HAYDN, JOSEPH & 1 \\
\hline HERNÁNDEZ, PABLO & 1 \\
\hline & \\
\hline
\end{tabular}




\begin{tabular}{|l|l|}
\hline HICIECES, TOMÁS & 1 \\
\hline HUMANES ALDANA, FRANCISCO DE & 10 \\
\hline JUKLIR & 1 \\
\hline JUNCÁ, FRANCISCO & 1 \\
\hline LASA MENDIENTE, VICTOR & 1 \\
\hline MARRACO, SANCHO & 1 \\
\hline MARTÍNEZ RÜCKER, CIPRIANO & 1 \\
\hline MEDINA Y CORPA, BERNARDO & 9 \\
\hline MENCIA, MANUEL & 3 \\
\hline MESA, JACINTO ANTONIO DE & 169 \\
\hline MIR & 1 \\
\hline MITTERER, IGNACIO & 1 \\
\hline MOLINA, BRUNO & 2 \\
\hline MOYANO, JOSÉ MARIA & 1 \\
\hline PACHECO MONTIÓN, JUAN & 32 \\
\hline PADILLA, JUAN DE & 10 \\
\hline PALACIO RACIONERO, RAMÓN & 2 \\
\hline PALESTRINA & 1 \\
\hline PAQUERAS & 8 \\
\hline PATIÑO & 2 \\
\hline PERGOLESI, G. B. & 1 \\
\hline PERIS, J. M. & 1 \\
\hline PEROSI, L. & 1 \\
\hline PICANOL, JOSÉ & 1 \\
\hline PLEYEL, IGNACIO & 6 \\
\hline PONS, JOSÉ & 2 \\
\hline PUGNANI, GAETANO & 1 \\
\hline QUERALT, FRANCISCO & 7 \\
\hline QUESSADA, LOANNES & 1 \\
\hline RAVANELLO, ORESTE & 2 \\
\hline REYES, MANUEL & 1 \\
\hline ROBINEAU & 1 \\
\hline RODRÍGUEZ DE HITA & 2 \\
\hline ROLDÁN & 3 \\
\hline ROMEO, SEBASTIÁN & 1 \\
\hline ROMERO, MATEO & 2 \\
\hline ROXAS Y MONTES, DIEGO DE & 1 \\
\hline RUIZ SAMENTEGO, FRANCISCO & 1 \\
\hline SANTIAGO, FRANCISCO & 1 \\
\hline SANZ, DOMINGO & 1 \\
\hline SERRA, LUIS & 1 \\
\hline SERRACANT Y MAS & 1 \\
\hline SOLER, FRANCISCO & 1 \\
\hline SORIANO FUERTES, INDALECIO & 8 \\
\hline TEIXIDÓ BARCELÓ, JOSÉ & 4 \\
\hline TORRES, EDUARDO & 1 \\
\hline VALDÉS, JULIO & 1 \\
\hline VICH, RAFAEL & 4 \\
\hline VICTORIA, TOMÁS LUIS DE & 1 \\
\hline VIDAL, JUAN DOMINGO & 4 \\
\hline & \\
\hline
\end{tabular}




\begin{tabular}{|l|l|}
\hline VIÑAS, MARIANO & 1 \\
\hline ZAMEZA, JOSÉ & 1 \\
\hline
\end{tabular}

Un rápido análisis del anterior listado nos hace ver un reparto significativo de las obras:

A) La mayoría de autores nos ha dejado de una a veinte obras. Es lo habitual.

B) Después encontramos un pequeño número de ellos que se mueve entre 30 y 75 composiciones. Serían Bartolomé García Guerrero (30), Juan Pacheco Montión (32), Tomás Luís de Victoria (42), Agustín de Contreras (62) y Juan Manuel Gaitán y Arteaga (74).

C) Un tercer nivel lo ocuparía Jacinto de Mesa con 162 composiciones, un número ya muy respetable y que se sale de lo común.

D) Por último nos encontramos con Jaime Balius y Vila con 720 obras. Ya este número es asombroso en sí mismo, pero lo es más si consideramos, que en la mayoría de los casos se trata de obras de cierta extensión, que incorporan una plantilla orquestal y un formato con pretensiones más amplias de lo habitual en las catedrales españolas.

\section{3) COLECCIÓN SÁNCHEZ CENTENO. ${ }^{187}$}

Los autores que forman parte de esta colección son los siguientes:

\begin{tabular}{|l|l|}
\hline AUTOR & $\boldsymbol{N}^{\boldsymbol{o}}$ DE OBRAS \\
\hline AGUAYO, CÁNDIDO. & 1 \\
\hline AGUILAR, JUAN ANTONIO. & 1 \\
\hline AGUILERA, FLAVIO. & 4 \\
\hline AICÚA, JOSÉ JAIME & 1 \\
\hline AIZPURUA, PEDRO. & 3 \\
\hline ALBERDI, A. & 3 \\
\hline ALCACER, JOSÉ MARÍA. & 10 \\
\hline ALCÁNTARA, FELIPE. & 3 \\
\hline ALDAGA & 1 \\
\hline ALMANDOZ, NORBERTO. & 11 \\
\hline
\end{tabular}

${ }^{187}$ Nuestro agradecimiento a D. Santiago Tofée, habitual colaborador del A.C.C. por su inestimable ayuda en la confección de este punto. 


\begin{tabular}{|l|l|}
\hline ANDREU, FRANCISCO & 1 \\
\hline ANIANO, RICARDO. & 1 \\
\hline ANÓNIMO & 177 \\
\hline ANTEQUERA, P. AGUSTÍN DE & 2 \\
\hline ARAGÚE, TOMÁS & 3 \\
\hline ARAMBURU, LUIS DE. & 6 \\
\hline ARANAZ Y VIDES, PEDRO. & 1 \\
\hline ARANDA, LUIS DE. & 2 \\
\hline ARANGUREN & 1 \\
\hline ARAUZQUIN, JOSE ANTONIO DE & 4 \\
\hline ARABAOLAZA, GASPAR DE. & 2 \\
\hline ARCINIEGA, GREGORIO & 14 \\
\hline ARENAL, GONZALO. & 6 \\
\hline ARRUE, GUILLERMO. & 1 \\
\hline ARTEAGA (ARMONIZACIÓN) & 8 \\
\hline BABILONI MONTAÑES, MIGUEL. & 1 \\
\hline BACH. & 1 \\
\hline BALDELLÓ, FRANCISCO. & 1 \\
\hline BAYLOS ALBENIZ, MIGUEL & 17 \\
\hline BELTRÁN, JOSÉ & 1 \\
\hline BENEYTO, PATRICIO. & 3 \\
\hline BENITO, COSME DE. & 4 \\
\hline BENITO, JOSÉ DE & 2 \\
\hline BEOBIDE, JOSÉ MARÍA & 7 \\
\hline BERTINI, E. & 1 \\
\hline BILBAO, PEDRO DE. & 10 \\
\hline BLASCO, JULIO. & 1 \\
\hline BOADA, PEDRO. & 1 \\
\hline BONILLA, CONRADO. & 1 \\
\hline BORDÁS FLAQUER, JOSÉ. & 1 \\
\hline BORDESE, L. & 7 \\
\hline BOROBIA, RAMÓN. & 1 \\
\hline BORTNIASWKY & 1 \\
\hline BOTAZZO, ALOYSIUS & 1 \\
\hline BOTAZZO, LUIGI. & 4 \\
\hline BOTI, S. & 1 \\
\hline BROTO, JOAQUÍN. & 10 \\
\hline BURUTAIN, H. & 1 \\
\hline CALAHORRA, REMIGIO. & 10 \\
\hline CALLEJA, R. & 1 \\
\hline CALVO, JULIÁN. & 2 \\
\hline CAMPRODÓN, SANTIAGO. & 4 \\
\hline CAMPS ARNAU, JUAN. & 1 \\
\hline CANDI, CÁNDIDO. & 2 \\
\hline CAÑOTO CHACÓN, H. & 1 \\
\hline CARDOSO, E. & 3 \\
\hline & \\
\hline
\end{tabular}




\begin{tabular}{|l|l|}
\hline CARMONA, A. & 1 \\
\hline CASTELLANO, JESÚS. & 5 \\
\hline CASTRO, M.R. & 1 \\
\hline CEBALLOS & 1 \\
\hline CEGONAL, ESTEBAN. & 1 \\
\hline CELAYA, LEONARDO. & 1 \\
\hline CHARRICHENA, LUIS. & 3 \\
\hline CHOPIN & 1 \\
\hline CIRIA, EVARISTO. & 3 \\
\hline CLAVÉ. & 1 \\
\hline CLEMENTI, MUZIO. & 1 \\
\hline CODINACH, C. & 2 \\
\hline COMES, J.B. & 1 \\
\hline CUMELLAS RIBÓ, J. & 1 \\
\hline DEISS, LUCIEN. & 3 \\
\hline DI LASSO, ORLANDO. & 2 \\
\hline DISEP, RAFAEL. & 1 \\
\hline DOMINGO, JOSÉ. & 1 \\
\hline DONOSTIA, P. JOSE A. DE & 22 \\
\hline ECHARRI, B. & 36 \\
\hline EGUINO, JOSÉ. & 1 \\
\hline ENCINA, JUAN DEL & 3 \\
\hline ERARDO, P. & 1 \\
\hline ERENCHUM, JUAN. & 2 \\
\hline ERNICAS, FELIPE. & 1 \\
\hline ERVITI, JOSÉ. & 1 \\
\hline ESLAVA, HILARIÓN. & 4 \\
\hline ESPADA, MANUEL H. & 5 \\
\hline ESPINÓS, VICTOR. & 1 \\
\hline ESPINOSA, JUAN ANTONIO. & 1 \\
\hline ESTELLA, FRAY HILARIO DE & 3 \\
\hline ESTEVE, F. & 2 \\
\hline ESTEVE, RAMÓN. & 1 \\
\hline FERNANDEZ CABALLERO, MANUEL & 1 \\
\hline FERRARI, JOSÉ. & 1 \\
\hline FLORES, MARIIA. & 1 \\
\hline FONT DE ANTA & 1 \\
\hline FRANCK, CESAR & 2 \\
\hline GANNE, LOUIS. & 1 \\
\hline GARCÍA ROMANO, JESÚS & 34 \\
\hline GARCÍA, JAVIER. & 1 \\
\hline GARCÍA, JUAN ALFONSO. & 5 \\
\hline GARCÍA, M. & 2 \\
\hline GARRIDO, A. & 2 \\
\hline GENARO RENTRO, M. & 1 \\
\hline GESSA LOAYSA, A. & 3 \\
\hline & \\
\hline
\end{tabular}




\begin{tabular}{|l|l|}
\hline GIL, LUIS. & 1 \\
\hline GILABERT, SERAF́́N. & 1 \\
\hline GIMENEZ, GERÓNIMO. & 2 \\
\hline GINÉS PEREZ, J. & 1 \\
\hline GIORGINI, JOSÉ & 2 \\
\hline GIOVANETTI, E. & 3 \\
\hline GOMEZ (MAESTRO). & 1 \\
\hline GOMEZ NAVARRO, JUAN ANTONIO & 8 \\
\hline GOMIS, R. & 4 \\
\hline GONZALEZ, NICOLÁS. & 1 \\
\hline GOROSARRI, E. & 1 \\
\hline GOROSTIDI, M. & 2 \\
\hline GOUNOD & 1 \\
\hline GRANADOS (MAESTRO). & 1 \\
\hline GREGORIANO & 3 \\
\hline GRUBER & 1 \\
\hline GUERRERO, FRANCISCO. & 7 \\
\hline GUERRERO, JACINTO. & 1 \\
\hline GUERRERO, JUAN JOSÉ. & 1 \\
\hline GUILLÉN PEDAMONTI, E. & 1 \\
\hline GURIDI, JESÚS & 4 \\
\hline GURIDI, LUCAS. & 3 \\
\hline GURUCHARRI, F. & 2 \\
\hline HALLER, M. & 1 \\
\hline HERNANDEZ MURILLAS & 1 \\
\hline HERNANDEZ, R. & 1 \\
\hline HERZ & 1 \\
\hline HUERGA, EMILIANO DE. & 1 \\
\hline ICETA & 1 \\
\hline IGNACIO PRIETO, J. & 2 \\
\hline IÑIGUEZ, BUENAVENTURA & 1 \\
\hline IRAIZOZ, B. & 11 \\
\hline IRIGARAY, FERMÍN. & 3 \\
\hline IRUARRIZAGA, GERVASIO & 13 \\
\hline IRUARRIZAGA, JUAN & 4 \\
\hline IRUARRIZAGA, LUIS. & 12 \\
\hline IRUARRIZAGA, RUPERTO. & 25 \\
\hline ISAAC, ENRIQUE. & 1 \\
\hline ISIGARAY & 1 \\
\hline JESÚS, ESTANISLAO DE. & 1 \\
\hline JESÚS, JOSÉ DE. & 1 \\
\hline JORGE, FABIÁN. & 1 \\
\hline JOSE LUIS, P. & 1 \\
\hline JUARISTI. & 2 \\
\hline JUARRANZ, E. & 1 \\
\hline LAMANIÉ, JUAN. & 1 \\
\hline & \\
\hline
\end{tabular}




\begin{tabular}{|l|l|}
\hline LAMBERT. & 1 \\
\hline LARROCA, A. & 3 \\
\hline LÁZARO SECO, P. & 1 \\
\hline LAZCANO, FRANCISCO DE & 2 \\
\hline LEGARDA, P. SATURNINO. DE & 18 \\
\hline LEÓN, PEDRO DE. & 1 \\
\hline LIMIDO, ESTEBAN. & 1 \\
\hline LIZARRAGA, PEDRO. & 1 \\
\hline LLOBET, RAMÓN. & 1 \\
\hline LLONGUERAS, JOAN. & 2 \\
\hline LOBO, ALFONSO & 1 \\
\hline LOPE DE BAENA. & 1 \\
\hline LÓPEZ AHIJADO & 1 \\
\hline LÓPEZ ALMAGRO. & 4 \\
\hline LÓPEZ ESCUDERO, JULIÁN. & 2 \\
\hline LÓPEZ JUARRANZ & 1 \\
\hline LUNA, E. & 1 \\
\hline MANZANO, MIGUEL. & 1 \\
\hline MANZÁRRAGA (ARMONIZACIÓN) & 2 \\
\hline MANZÁRRAGA, TOMÁS DE. & 13 \\
\hline MARTÍ ESTELLÉS. & 1 \\
\hline MARTÍ́N GOROSTIDI. & 1 \\
\hline MARTÍN RODRIGUEZ. & 4 \\
\hline MARTINEZ CHACÓN, A. & 1 \\
\hline MARTINEZ DE CHONON. & 4 \\
\hline MARTINEZ RAMIREZ. & 1 \\
\hline MARTINEZ, CLAUDIO. & 1 \\
\hline MARTÍNEZ, S. & 1 \\
\hline MARTORELL, P.A. & 9 \\
\hline MAS Y SERRACANT. & 2 \\
\hline MATEO PEREDA. & 1 \\
\hline MATEU, VICENTE. & 1 \\
\hline MENDIVIL, JULIO. & 1 \\
\hline MIGUEL, FELICISIMO. & 1 \\
\hline MILAGROS, C. & 2 \\
\hline MILLÁN (MAESTRO). & 1 \\
\hline MILLET, L. & 1 \\
\hline MINGOTE, ÁNGEL & 12 \\
\hline MOCOROA, EDUARDO. & 2 \\
\hline MOCOROA, IGNACIO. & 6 \\
\hline MOLA, MANUEL. & 5 \\
\hline MOLERA, R. & 1 \\
\hline MORALES, C. & 3 \\
\hline MORENO, JESÚS. & 1 \\
\hline MORERE & 1 \\
\hline MOZART, W.A. & 1 \\
\hline & \\
\hline
\end{tabular}




\begin{tabular}{|l|l|}
\hline MUÑOZ, L. & 1 \\
\hline MUÑOZ, R. & 1 \\
\hline MUSET, FEDERICO. & 2 \\
\hline NANINI. & 1 \\
\hline NICOLAU, A. & 1 \\
\hline NOGALES, ALFREDO & 5 \\
\hline ONRUBIA, ALEJANDRO & 2 \\
\hline OTAÑO, NEMESIO. & 11 \\
\hline PACHECO, JOSÉ & 1 \\
\hline PAGELLA, GIOVANNI. & 1 \\
\hline PALACÍN, CÁNDIDO. & 2 \\
\hline PALAU, PEDRO. & 2 \\
\hline PANEDAS, C. & 1 \\
\hline PANTIÓN Y DÍAZ. & 1 \\
\hline PARDOS ARRUE, ILDEFONSO. & 13 \\
\hline PARIÑO, CARLOS. & 1 \\
\hline PASTOR, JOSÉ MARÍA. & 1 \\
\hline PASTOR, JUAN B. & 3 \\
\hline PEÑALBA & 1 \\
\hline PEÑAS ECHEVERRÍA, S. & 6 \\
\hline PÉPREZ GUTIERREZ, M. & 1 \\
\hline PERAL, M. & 1 \\
\hline PÉREZ JORGE, V. & 7 \\
\hline PEREZ MILLÁN, J. & 1 \\
\hline PÉREZ, JUAN FRANCISCO. & 6 \\
\hline PERIS, JOSÉ MARÍA. & 5 \\
\hline PEROSI, LAURENTIO. & 22 \\
\hline PILDAIN, J. & 4 \\
\hline PINARES (MAESTRO). & 2 \\
\hline PINILLA & 1 \\
\hline PLE, S. & 1 \\
\hline PRADO, J.R. DE & 2 \\
\hline PRIETO, JOSÉ IGNACIO & 7 \\
\hline PUJADAS, TOMÁS LUIS. & 22 \\
\hline RIAL, C. & 1 \\
\hline RIBALTA, PEDRO. & 2 \\
\hline ROBERTS, C. & 3 \\
\hline ROCAMORA, TOMÁS. & 5 \\
\hline ROMÁN GIMENO & 1 \\
\hline ROMEO, LUIS. & 1 \\
\hline RONQUILLO, JOAQUÍN & 1 \\
\hline ROQUES, LEÓN. & 1 \\
\hline RUBIO, SAMUEL. & 1 \\
\hline RUIZ AZNAR, VALENTÍN & 29 \\
\hline SAENZ, VICTOR. & 1 \\
\hline SAEZ DE ADANA, RAMÓN. & 3 \\
\hline & \\
\hline
\end{tabular}




\begin{tabular}{|l|l|}
\hline SAGASTIZABAL, B. & 3 \\
\hline SAINZ Y NOGUERA, E. & 2 \\
\hline SAN JOSÉ, JAVIER. & 9 \\
\hline SANCHEZ FRAILE, A. & 3 \\
\hline SANCHO MARRACO, J. & 2 \\
\hline SANGÜESA, S. & 1 \\
\hline SANTIESTEBAN & 1 \\
\hline SANTOS DE ALISEDA & 1 \\
\hline SCHUBERT, FRANZ. & 3 \\
\hline SCHUMANN & 1 \\
\hline SEBASTIÁN, J.A. DE & 4 \\
\hline SECANILLA & 1 \\
\hline SEMINARIO DE LOGROÑO & 5 \\
\hline SERRANO, JOSÉ. & 2 \\
\hline SIERRA, MANUEL. & 1 \\
\hline SILESIUS, J. & 1 \\
\hline SOLER, M. & 1 \\
\hline SOLÍS. & 1 \\
\hline SOLSONA, ENRIQUE. & 1 \\
\hline SORIA, M. & 1 \\
\hline STRAUSS, JOHANN & 1 \\
\hline SUQUIA, J. & 1 \\
\hline TABOADA, R. & 1 \\
\hline TERESA, DOMINGO DE. & 3 \\
\hline TESORO SACRO-MUSICAL (VV.AA.) & 25 \\
\hline THOMAS, JUAN M ${ }^{\text {. }}$ & 3 \\
\hline TOMADINI, J. & 1 \\
\hline TORRES, JUAN DE. & 1 \\
\hline UGARTE, ALFONSO & 1 \\
\hline UGARTE, JUAN MARÍA DE. & 1 \\
\hline URBANO DE VARGAS & 1 \\
\hline URGOECHEA & 1 \\
\hline URMENETA, A. & 2 \\
\hline URQUÍA, P. & 5 \\
\hline URTEAGA, LUIS. & 93 \\
\hline VALDÉS & 1 \\
\hline VALERA SILVARI. & 1 \\
\hline VARGAS (MAESTRO) & 1 \\
\hline VARIOS & 4 \\
\hline VAZQUEZ, M. & 1 \\
\hline VEIGA, PASCUAL. & 1 \\
\hline VELA, CASILDA & 1 \\
\hline VELASCO, LUIS. & 1 \\
\hline VERGUILLA, E. & 2 \\
\hline VICENS, A. & 1 \\
\hline VICTORIA, TOMÁS LUIS DE. & 4 \\
\hline & \\
\hline
\end{tabular}




\begin{tabular}{|l|l|}
\hline VIDAL URRA & 2 \\
\hline VIDAURRETA, A. & 1 \\
\hline VILA DE FORNS, CELESTINO & 3 \\
\hline VILLALBA MUÑOZ, ENRIQUE. & 1 \\
\hline VILLALBA, LUIS. & 1 \\
\hline VILLANI, F. & 4 \\
\hline VIÑAS, M. & 1 \\
\hline VIVANCO, S. & 1 \\
\hline VIVES, L. & 1 \\
\hline VIVO RUIZ, ELISA. & 1 \\
\hline VIVÓ, E. & 5 \\
\hline WARMONS, P. & 1 \\
\hline YAROFF, SERGE. & 1 \\
\hline ZANINETTI, J. & 2 \\
\hline ZINGARELLI & 1 \\
\hline ZUBIAGA, PABLO. & 1 \\
\hline ZUBIZARRETA, VICTOR DE. & 1 \\
\hline TOTAL DE OBRAS & $\mathbf{1 2 1 8}$ \\
\hline &
\end{tabular}

Así pues, un vasto número de composiciones y compositores integran los fondos musicales de este archivo, siendo en muchos casos autores de una gran formación musical, que nos ofrecen piezas de una calidad sobresaliente. 


\section{CAPÍTULO 5. LA ORGANIZACIÓN MUSICAL DE LA CATEDRAL. SU ESTRUCTURA Y ELEMENTOS QUE LA INTEGRAN. LA CAPILLA DE MÚSICA.}

La Capilla de Música es la institución a través de la cual se articula la mayor parte de la actividad musical de la catedral, sobre todo en lo referente a la interpretación de la polifonía (con o sin instrumentos). Asimismo el Sochantre y la Veintena se encargan del canto llano.

Según nos dice Samuel Rubio, refiriéndose a la época del Renacimiento, la Capilla Musical es un grupo de intérpretes vocales e instrumentales que ponen su música al servicio del culto divino. ${ }^{188}$

Igualmente nos dice que si bien el término “capilla” se refería a aquel espacio o aula del templo, generalmente vecinos al claustro, en el que tenían lugar los ensayos, por extensión se nombró así "al conjunto de músicos encargados de cantar o tocar, con todo el relativo acompañamiento de libros corales, instrumentos, vestimenta, distintivos, al servicio de una iglesia o corte”. ${ }^{189}$. Estas definiciones, que se hacen para una época anterior, mantienen su vigencia a finales del XVIII y principios del XIX.

La mayoría de las catedrales y monasterios o iglesias de cierta importancia contarían con una de estas “Capillas Musicales” para “contribuir con sus voces y sones al mayor esplendor de la celebración litúrgica". ${ }^{190}$ También las tenían los reyes y nobles.

El número de integrantes de estas Capillas podía variar dependiendo de diversos factores como los recursos económicos de sus sustentadores, la función a la cual estuvieran destinadas, la época o el lugar de creación. Sin embargo y centrándonos en el ámbito religioso se procuraba un mínimo de cantores y músicos que conformaran una

\footnotetext{
188 "la capilla es un grupo de cantores, más bien pequeño, compuesto de niños y adultos, más o menos especializados en el canto, que bajo la dirección y las enseñanzas de un $<<$ maestro $>>$ tiene la misión de interpretar la música polifónica vocal en los actos litúrgicos del culto divino. De ella formaron parte, desde tiempos remotos, uno o más organistas, y en época más reciente otra suerte de instrumentistas”. RUBIO, Samuel. Historia de la música española desde el ars nova hasta 1600. Madrid, Alianza Editorial, Alianza Música, 1983, págs. 14 y 15.

${ }^{189}$ Ibid.

${ }^{190}$ Ibid.
} 
base musical sólida. Esta base la componía el cuarteto vocal, tiple, alto, tenor y bajo, (o cantus-superius, altus, tenor, bassus) a ser posible con acompañamiento de órgano. Partiendo de esta pequeña célula podemos encontrar gran diversidad de plantillas. Pero de la observación de gran número de plantillas de diversas catedrales podemos deducir que la organización musical de éstas contaría por término medio con las siguientes figuras: Un Sochantre ${ }^{191}$, Capellanes de Veintena, Cantores, Ministriles, Mozos de Coro, uno o dos Organistas y el Maestro de Capilla. Estos músicos podían ocupar plazas dotadas, o bien ser contratados temporalmente. En ocasiones, y dependiendo de los avatares económicos, las plazas ocupadas en propiedad eran muy escasas, y la constitución de la Capilla variaba con contrataciones ocasionales en función de las necesidades de cada momento. ${ }^{192}$

Los músicos, bien porque los despidieran o bien por propia iniciativa en la búsqueda de un mejor puesto de trabajo, estaban en muchos casos moviéndose de un sitio a otro, opositando a una plaza mejor remunerada. Si esto no les era posible, buscaban alguna actividad complementaria que les sirviera de ayuda económica, aun cuando esta actividad estuviera fuera del entorno catedralicio y aun habiéndoselo prohibido el Cabildo previamente: “Dan la impresión estos cantores de gente de alegre vivir; van una y otra vez sin licencia a cantar aquí y allá, con los más diversos motivos: entierros, misas nuevas, procesiones, fiestas, como ávidos de ganar algunos dineros". 193

La forma de ingreso de estos músicos puede variar sensiblemente. En unas ocasiones las vacantes se anunciaban con suficiente antelación, se formaba un tribunal y se hacía la correspondiente oposición. En otras, una simple recomendación de otra catedral o de alguna persona reconocida bastaba para que se aceptara su incorporación a

\footnotetext{
${ }^{191}$ Hubo una época en la que el Chantre también tuvo que ver con la vida musical. "Antiguamente era el encargado en las catedrales de entonar y sostener el canto litúrgico. Tal cargo fue perdiendo contenido hasta quedar reducido a un canónigo dignidad, supervisor teórico del coro, no necesariamente músico". PÉREZ, Mariano. Diccionario de la Música y los Músicos. Madrid, Ediciones Istmo, 1985, vol. 1, pag. 268.

192 "Un dato que llama la atención es que las plazas que ocupaban gran parte de los músicos no eran fijas; en otros términos, no estaban dotadas de antemano -salvo los que se señalan en las Constitucionessino que, según las necesidades del culto, se iban contratando -o despidiendo- a aquellos músicos que acudían al Cabildo para pasar a formar parte -o irse- de dicha Capilla de Música”. ALÉN, Ma Pilar. "La Capilla de Música de la Real e Insigne Colegiata de Sta. María del Campo de La Coruña. (17501825)”, en Revista de Musicología, XXVII, 2. Madrid, Sociedad Española de Musicología, 2004, pág. 938.

${ }^{193}$ RUBIO, Samuel. Historia de la música española desde el ars nova hasta 1600. Madrid, Alianza Editorial, Alianza Música, 1983, pág. 31.
} 
la Capilla. Si fuera necesario, el Cabildo facultaba al Maestro de Capilla o a algún canónigo para que fuese a buscar un cantor o músico a otras ciudades. En cualquier caso (al menos en la Catedral de Córdoba), era condición indispensable la presentación de un expediente de limpieza de sangre, mediante el cual demostraban su descendencia de cristianos viejos. Este requisito podía ser obviado solamente si ya se había presentado con anterioridad en otra catedral durante un antiguo empleo y había sido aceptado. También se tenía en cuenta que un hermano del solicitante ya formara parte de la Capilla y por tanto se hubiera hecho las citadas pruebas.

Lo anteriormente dicho, lo podemos resumir siguiendo la terminología empleada por el doctor Martínez Solaesa, cuando nos habla de los diversos bloques en que se dividían los músicos en la mayoría de las catedrales:

"Bloque de Canto llano o Gregoriano, en el que destacan Salmistas y Sochantres. Eran los técnicos de la materia. No solían cantar con la Capilla.

Bloque de Capilla de Voz. Incluía los “Niños de Coro”. Estos, además de su participación con la Capilla polifónica, cantaban algunos fragmentos gregorianos, principalmente responsorios, y servían al Altar y al Coro. También integraban este bloque los Prebendados Tiple, Contralto, Tenor y Bajo, secundados por un mayor o menor número de <<músicos de voz >>, asalariados y seglares muchas veces.

Bloque de Capilla instrumental, de muy diversa composición y número, según la época y según los recursos económicos. [...] Estos puestos solían ser desempeñados por seglares, que unas veces pertenecían a la Plantilla y otras, eran contratados "ad casum”. La mayoría dominaba y compaginaba más de un instrumento.

Organista $1^{\circ}$ (normalmente clérigo pero no siempre), Organista $2^{\circ}$, y aún $3^{\circ}$, en muchos casos, con atribuciones muy bien delimitadas.

Maestro de Capilla, suprema autoridad ejecutiva, con misiones de enseñanza, composición y conservación del Archivo musical”. ${ }^{194}$

A todos los citados le dedicaremos un apartado independiente para conocer mejor sus peculiaridades.

\footnotetext{
${ }^{194}$ MARTíNEZ SOLAESA, Adalberto. Catedral de Málaga. Órganos y Música en su entorno. Málaga, Servicio de Publicaciones de la Universidad, 1996, pág. 55.
} 
Podemos encontrar numerosos tratados que nos hablan de las Capillas Musicales o de alguno de sus aspectos. Vamos a citar aquí algunos que creemos básicos:

Para obtener un conocimiento global de la creación, composición y funcionamiento de las Capillas Musicales en España son fundamentales los libros de Historia de la Música Española de Alianza Editorial, volúmenes 2, 3 y 4, respectivamente de Samuel Rubio, José López-Calo y Antonio Martín Moreno, así como La música en las catedrales españolas del Siglo de Oro, de Robert Stevenson, Historia de la Música Religiosa en España, de Andrés Araiz, o "Las Capillas Musicales catedralicias desde Carlos III hasta Fernando VII”, España en la Música de Occidente, de $\mathrm{M}^{\mathrm{a}}$ Pilar Alén, todos ellos citados en el capítulo de Bibliografía.

Para obtener un conocimiento particular y concreto de muchas de las Capillas Musicales españolas hay un numerosísimo abanico de trabajos que igualmente hemos reflejado en el capítulo de Bibliografía.

Es de agradecer la labor de difusión que sobre este tema está haciendo la Sociedad Española de Musicología a través de su Revista de Musicología, en la que en muchas ocasiones incluyen artículos sobre las Capillas Musicales de diversas ciudades, o referencias a tesis doctorales al respecto.

Igualmente positivo es el compromiso adquirido sobre el asunto por diversas instituciones oficiales, como Universidades, Diputaciones, Ayuntamientos y Gobiernos Regionales. Es de justicia resaltar en este caso la puesta en valor que la Junta de Andalucía está realizando sobre el Patrimonio Musical de las Catedrales Andaluzas, a través de un convenio con los Obispados de Andalucía mediante el cual se incentiva a los investigadores para sacar a la luz distintos aspectos de la organización y funcionamiento de la música en nuestras Catedrales, Monasterios o Colegiatas. Importantísimo es también, el papel que está desempeñando al respecto el Centro de Documentación Musical de Andalucía.

La reconquista de Córdoba por Fernando III el Santo en 1236, hizo que de inmediato empezara a interpretarse en Córdoba el Canto Gregoriano, “singular expresión del vínculo que se adquiría en aquel momento entre la ciudad y la cultura 
musical europea”. ${ }^{195}$. Las figuras del Chantre (en 1246) y posteriormente del Sochantre (en 1362), como responsables de la interpretación musical, hacen su aparición. Completan esta organización musical los Capellanes de la Veintena y los Mozos de Coro. Más tarde, en 1294, ya consta en el inventario de la Catedral la primera relación de libros litúrgicos musicalizados. ${ }^{196}$ Así pues ya tenemos a un primer grupo de personas encargadas de la música en la Catedral de Córdoba.

Sin embargo, habrá que esperar hasta 1505 para tener noticias del primer Maestro de Capilla. Este es Martín Rodríguez de la Fuente (llamado con frecuencia Martín de la Fuente). ${ }^{197}$

Pero quizás el momento clave para la fijación de la estructura básica de la Capilla de Música fue en 1563, tal como nos dice Vázquez Lesmes:

"La catedral de Córdoba, a partir de los inicios de la centuria del XVI, va a incrementar sus posibilidades corales en torno a la formación de una capilla de música como elemento indispensable para el desarrollo y brillantez de los cultos celebrados en ella, al contar, paralelamente, con fondos suficientes para su financiación. El primer paso en firme data de 1563, cuando el prelado Rojas y Sandoval, junto con el Cabildo, ordena por estatuto el acrecentamiento de los excusados con la exclusiva finalidad de cargar en ellos los salarios de los músicos, lo que equivale a su institucionalización como cuerpo profesional, enmarcada dentro de los organismos auxiliares componentes de la institución capitular. Consecuentemente a esta resolución de aspecto económico, se regula mediante normativa al efecto las obligaciones asignadas a cada uno de los miembros de la incipiente capilla, con especificación de las penas impuestas por la contravención de aquéllas. Entre los deberes impuestos al maestro de capilla, además de la enseñanza de los niños cantores y la preparación de todas las funciones litúrgicas con participación del coro, destaca la obligatoriedad de componer la música a interpretar en las festividades del Corpus y Navidad, ampliada posteriormente a toda la necesaria para el ceremonial del culto. Dos maestros de canto llano y canto de órgano, respectivamente, junto con dos organistas semaneros, tiples, contraltos, tenores, contrabajos, un sochantre y varios ministriles, conformaban la nómina de la capilla y

195 NIETO CUMPLIDO, Manuel. “La música en la Catedral de Córdoba (1236-1577)”, en AA.VV. El Patrimonio Histórico-Musical de Córdoba. Córdoba, Ayuntamiento de Córdoba, 2004, pág. 1.

${ }^{196}$ Cf. NIETO CUMPLIDO, Manuel. "La música en la Catedral de Córdoba (1236-1577)”, en AA.VV. El Patrimonio Histórico-Musical de Córdoba. Córdoba, Ayuntamiento de Córdoba, 2004, págs. 5-7.

197 Ibid. Pág. 11. 
se les reglamentaban sus conductas y actuaciones, tanto dentro como fuera del templo. Estas plazas, creadas por un estatuto del obispo Rojas y Sandoval, conforman la estructura básica de la capilla, pues tanto las voces como los instrumentos componen los elementos necesarios para su funcionamiento, posteriormente incrementados en el número de cantores y ministriles a fin de conseguir un mayor esplendor en los actos litúrgicos”. 198

A partir de ahí la historia de la Capilla Musical de la Catedral de Córdoba se va haciendo cada vez más densa, con progresivas ampliaciones en el número de cantores y músicos, con el establecimiento de diversos Estatutos que mejoran su funcionamiento, y con la presencia sucesiva de grandes Maestros de Capilla que componen excelentes obras musicales.

Todo ello queda perfectamente recogido en dos magníficos documentos, fundamentales para comprender este tema. Uno es La Música en la Catedral de Córdoba 1236-1577, de D. Manuel Nieto Cumplido (cuya referencia acabamos de ver en nota a pie de página), y otro es La Capilla de Música de la Catedral de Córdoba, de D. Rafael Vázquez Lesmes. ${ }^{199}$ El primero, como queda de manifiesto en el título, llega en su análisis hasta 1577. El segundo nos ofrece datos de la Capilla hasta casi el final del siglo XVIII. A partir de ahí pretendemos documentar la organización y funcionamiento de esta Capilla de Música, concretamente de 1785 a 1822, que coincide con el Magisterio de Jaime Balius y Vila. Esto lo haremos por apartados, en los que trataremos cada uno de sus estamentos, desde el Maestro de Capilla hasta los Niños de Coro.

No obstante, queremos aprovechar esta introducción para dar una visión general. Y ésta nos muestra una Capilla consolidada, que viene de ser dirigida por D. Juan Manuel Gaitán y Arteaga (desde 1752 a 1780). ${ }^{200}$

198 VÁZQUEZ LESMES, Rafael. Córdoba y su Cabildo Catedralicio en la modernidad. Córdoba, Cajasur, 1987, págs. 156-157.

${ }^{199}$ VÁZQUEZ LESMES, Rafael. "La Capilla de Música de la Catedral de Córdoba: apuntes para su historia. Córdoba, Boletín de la Real Academia de Córdoba., 110 (1986).

200 "De dos modos suele apellidarse a este maestro: Juan Manuel González Gaitán, tal como aparece en el acta capitular de 22 de diciembre de 1751 cuando se le nombra en el Magisterio cordobés, y Juan Manuel Gaitán y Artíaga, apellidos con los que imprime las letras de sus villancicos. En la misma sesión capitular en que Contreras ve aceptada su jubilación es propuesto Gaitán por su mérito y mucha habilidad en la composición. Era entonces Maestro de Capilla de Segovia”. NIETO CUMPLIDO, 
Pronto alcanzó fama Gaitán y también cobró prestigio la Capilla de Música. ${ }^{201}$ Por tanto, cuando llega Balius, la Capilla se encontraba en buena situación artística y todavía no habían empezado los problemas económicos más serios. ${ }^{202}$ De forma que pudo contar con una plantilla más o menos equilibrada para realizar su cometido. Esta plantilla incluía, -como se reitera en varios puntos de este trabajo- 2 oboes, 2 trompas, 1 o 2 bajones (fagotes), además de un número variable de violines, entre 4 y 6, más violoncello, contrabajo y acompañamiento. Ocasionalmente podemos encontrar flautas, y muy raramente violas. Además de estos músicos instrumentistas, se contaba con un pequeño coro, de número también variable, pero que oscilaba entre un mínimo indispensable de 4 voces (Tiple, Alto, Tenor y Bajo) y un máximo de 14 o 15.

Pero esta plantilla sufría constantes alteraciones. Como veremos en el Vaciado cronológico de noticias musicales, estas alteraciones se debían a las entradas o salidas de músicos de la Capilla por muy diversas razones, desde opositar a otros lugares, viajar a sus tierras de origen, hasta las bajas habituales por enfermedad. Estas bajas se podían suplir con contrataciones eventuales, o con el cambio de puesto de un músico, siempre que éste tocara varios instrumentos.

Estas frecuentes variaciones en la plantilla, pero sobre todo las constantes peticiones de aumento de sueldo de los músicos, motivaron que en 1796 se comenzara a pensar en una regulación de la plantilla, fijando sus componentes y los sueldos que debían percibir. El Martes 19 de Septiembre de 1797 el Cabildo acuerda, previo informe del Maestro de Capilla, que dicha plantilla quede establecida como sigue: “Quatro tiples, con la renta el que más, de once mil reales, quatro contraaltos con la de seis mil, cinco tenores con la de seis mil y seiscientos, dos bajos con la de siete mil y setecientos, seis violines con cinco mil y quinientos, dos trompas con tres mil y trescientos, un acompañamiento con tres mil y trescientos, y un bajón con la misma renta”. ${ }^{203}$

\footnotetext{
Manuel: "Maestros de Capilla de la Catedral de Córdoba”. Boletín de la Confederación Andaluza de Coros de 1995. Ed. CO.AN.CO. Córdoba, 1995, pág. 10.

201 "Con este prohombre de la música religiosa de la Catedral de Córdoba, juntamente con don Jaime Balius, que ocupó el mismo puesto, aquella [la Capilla] alcanzará sus más altas cimas y sus composiciones destacarán sobre las de sus antecesores". VÁZQUEZ LESMES, Rafael. "La Capilla de Música de la Catedral de Córdoba: apuntes para su historia. Córdoba, Boletín de la Real Academia de Córdoba., 110 (1986), pág. 139.

${ }^{202}$ Esto no es óbice para que con frecuencia veamos en las actas capitulares peticiones de aumento de sueldo o ayudas de costa por parte de los músicos.

${ }^{203}$ A.C.C. Actas Capitulares. Martes 19 de Septiembre de 1797. T.95, fol. 180v.
} 
Llama la atención que no se cite en esta lista algún instrumento como el oboe, aunque por las actas capitulares sabemos que sí había instrumentistas de esta especialidad, y además las obras de Balius casi siempre lo incluían. En cualquier caso, esta disposición pone un cierto orden, y aclara que no se podrán pedir aumentos de salario, aunque sí se podrán solicitar ayudas de costa para cubrir gastos eventuales: " $Y$ que a los músicos que bajo este nuevo plan se admitan, no se les de aumento de renta anual [...] Y que por lo tanto dichos músicos, fuera de la respectiva renta señalada, no tengan otra expectativa que la de pedir, cada vez con memorial en forma, alguna ayuda de costa". 204

Por tanto, esta regulación ayuda a consolidar la Capilla y su funcionamiento, que incluía participar en las actividades litúrgicas y paralitúrgicas que se celebraban en la Catedral, con especial protagonismo en las fechas más señaladas como Semana Santa, Día del Corpus, Día de la Asunción o Navidad. Precisamente para celebrar esta última festividad, se realizaba una ceremonia especial revestida de todo el boato propio de la fecha. Del desarrollo de esta ceremonia tenemos noticia gracias a Juan Lucas del Pozo. $^{205}$ Por su indudable interés la hemos incluido íntegra en el Apéndice Documental. ${ }^{206}$

Volviendo a los problemas económicos de la Capilla, que pronto se incrementarán, estos no se dieron sólo en Córdoba, sino en muchas otras ciudades, y coincidieron en buena parte con alguno de los procesos “desamortizadores” de la época.

\footnotetext{
${ }^{204}$ Ibid.

${ }^{205}$ Del Pozo, ingresó en 1806, cuando tenía 8 años, en el Colegio de Infantes de Coro. Posteriormente fue Vicerrector de dicho Colegio y músico de la Capilla en 1823. Además de músico tenía una gran vocación literaria, que plasmaba en numerosas crónicas acerca de multitud de asuntos y personajes de la ciudad. "Su voz ocupa el vacío que hay entre el contralto y el tiple, y tan lánguida y desabrida que no me gusta un pelo. Es de mala condición y muy soberbio. El falsete se lo dejó en los otros calzones; nadie lo saca de su paso y le aconsejo a Vd. que lo trate con cuidado porque a la mejor ocasión se le vendrá a las barbas. No obstante sabe muchas jaculatorias, tiene estampas y libros devotos, y es el Maestro segundo de educación de los Niños de Coro. Hay algo de haber caído de pies”. POZO, Juan Lucas del: Caricaturas de los Músicos de la Santa Iglesia Catedral de Córdoba. Córdoba, 1827, mecanografiado, pág. 332.

${ }^{206}$ En esta crónica hace una descripción precisa del ceremonial que se practicaba el día de Navidad, detallando los momentos de actuación de la Capilla de Música, el repertorio que interpretaba, etc. Cf. LUCAS DEL POZO Y CÁCERES, Juan. "Solemnidad del nacimiento de Nuestro Señor Jesucristo en la Santa Iglesia Catedral de Córdoba”. En Rasgos biográficos y fisonómicos [de cordobeses]. Córdoba, 1863. Biblioteca Municipal. s/f. A pesar del título del libro, éste contiene no solo rasgos biográficos de algunos cordobeses sino diversas crónicas descriptivas de momentos relevantes de la historia de nuestra ciudad.
} 
El comienzo de estos problemas y su gran influencia en el funcionamiento de las Capillas Musicales, están bien reflejados en multitud de noticias de actas capitulares, donde nos cuentan las grandes dificultades que tenían los músicos, que constantemente tenían que pedir “ayudas de costa” para sufragar cualquier gasto extraordinario, ya que su sueldo habitual era muy escaso.

Pero veamos cuales fueron las leyes que provocaron este cambio importante en el panorama general de las posesiones y riquezas de la Iglesia, con las consecuentes repercusiones en la actividad musical. Esta legislación desamortizadora reproduce los avatares de la revolución liberal, pues su vigencia y derogación están mediatizadas por la coyuntura política (avances liberales y reacciones absolutistas):

Una primera etapa (1766-1798) comprendió la venta de bienes de los jesuitas y la denominada desamortización de Manuel Godoy (bienes raíces pertenecientes a hospitales, hospicios, casas de misericordia o cofradías).

La segunda fase (1808-1823) correspondió a la desamortización impulsada durante la guerra de la Independencia por la administración de José I Bonaparte y por los legisladores reunidos en las Cortes de Cádiz (bienes de la Inquisición y reducción a un tercio del número de monasterios y conventos), así como a la obra del Trienio Liberal (prohibición de nuevas amortizaciones y supresión de los monasterios de órdenes monacales y de los conventos de órdenes militares).

En la tercera etapa (1834-1854), conocida como desamortización de Juan Álvarez Mendizábal y Baldomero Fernández Espartero, se procedió al sistemático despojo patrimonial de la Iglesia, y a la desaparición de monasterios y conventos.

La cuarta fase (1855-1924) se inauguró con la Ley General de 1 de mayo de 1855 (cuyo principal impulsor fue el ministro de Hacienda Pascual Madoz, razón por la cual es también conocida como Ley Madoz) y fue por duración y volumen de ventas la más importante. ${ }^{207}$

Aunque después hablaremos de Córdoba, vamos a ver un ejemplo concreto de recesión económica extrema dentro de otra Capilla. Para esto recurrimos a López Calo, quien nos cuenta cómo afectó esta escasez al sueldo del Maestro de Capilla de la Catedral de Granada, que era en 1826 D. Vicente Palacios: “El 16-11-1826 el Cabildo acordó, en vista de la gravísima situación de la economía de la Catedral, asignar a

\footnotetext{
${ }^{207}$ Cf. SIMÓN SEGURA, F. La desamortización española del siglo XIX. Madrid, 1973.
} 
Palacios solamente 9 reales diarios, en vez de los 20 que tenía hasta ese día”. A pesar de que Palacios dijo al Cabildo que esa cantidad no bastaba "para portarse con el decoro y decencia que exige su estado”, el Cabildo no pudo atender su justa reivindicación, y el sueldo de Palacios continuó siempre siendo muy exiguo. ${ }^{208}$

Como vemos, estas circunstancias afectaron al desarrollo de las Capillas Musicales, ${ }^{209}$ y no sólo de manera colectiva sino también individualmente a sus miembros. $^{210}$

En el caso de la Capilla Musical de la Catedral de Córdoba, se mantuvo una relativa estabilidad económica hasta la invasión napoleónica, siendo concretamente a partir de 1810, cuando se iniciará un declive progresivo de las dotaciones económicas para la música. A pesar de ello, podemos decir que gracias al esfuerzo de los componentes de su Capilla, ésta conservó su prestigio, al menos durante el tiempo en que fue Maestro de Capilla Jaime Balius y Vila. ${ }^{211}$

${ }^{208}$ LÓPEZ CALO, José. Catálogo del Archivo de Música de la Catedral de Granada. Centro de Documentación Musical de Andalucía (Junta de Andalucía), Granada 1991, Tomo I, pág. 151.

${ }^{209}$ Para tener una información más amplia al respecto, consultar: MYERS BROWN, Sandra. "Las Desamortizaciones Eclesiásticas del siglo XIX en España y sus consecuencias sobre la música (Madrid y Toledo)”, en Revista de Musicología Vol. XXVIII. Madrid, Sociedad Española de Musicología, 2005, pág. 310.

210 "Pedro Sans en 1834 estaba de monje organista en el Monasterio de Poblet, con motivo de la exclaustración marchó a Barcelona, donde tocaba el piano en un café para procurarse la subsistencia. A Don Modesto Berben, organista de la Real Capilla, se le vio pidiendo limosna en la Iglesia de San Luis de Madrid. En 1837 el Cabildo de Lérida suprime la Capilla Musical, en donde ejercía Juan Sariols y Porta como Maestro de Capilla. Durante un año se dedicó a tocar el contrabajo en funciones a las que era llamado, marcha a Reus, su ciudad natal, en donde colabora en una banda para, en 1841 pasar a Barcelona a tocar en un café". MARTÍN MARTÍN, Teodoro. "Aproximación a los efectos de la desamortización sobre las Capillas Musicales”. Letras de Deusto, vol. 35, nº 109. Octubre-Diciembre 2005, pág. 68. A su vez Martín extrae la cita del Diccionario biográfico-bibliográfico de efemérides de músicos españoles de Saldoni.

${ }^{211}$ En Diciembre de 1810 se celebran diversos Cabildos en los que se aprueban sustanciales rebajas en el sueldo de los músicos: "En este mismo día los S.S. Diputados y Canónicos, in sacris constituidos, juntos y congregados en la Capilla del Exmo. Sr. Salazar, donde por aora acostumbran celebrar sus Cabildos, citados ante diem por su Pertiguero acordaron lo siguiente. A virtud del llamamiento para tratar los puntos de economía y ahorros, indicados en el Cabildos anterior, se leyó el informe de los S.S. Diputados de Arcas de S. Acacio con la Pte. de S.Y. el qual decía a la letra lo que sigue = En consequencia de lo acordado por V.S. en 22 del presente sobre la necesidad en que se halla de moderar las rentas de los empleados en la Capilla de Música, y pagados por los fondos de las Arcas de San Acacio, y que para llevar a cabo esta moderación, presentamos las correspondientes listas con expresión de sus salarios, lo hacemos en la nota adjunta, formada por el Notario Secretario con presencia de los libros y asientos, V.S. arreglará este punto como le parezca; pero debemos prevenirle, que importará, que VS. acuerde al mismo tiempo, siguiendo los principios establecidos; Que estas moderaciones ó rebajas son puramente interinas, y mientras subsisten las causas, que han disminuido, y disminuyen tan considerablemente el ingreso de sus rentas. Que durante las mismas circunstancias no se provea plaza ninguna de Capellán, Músico, Sacristán, ni Servidero, y que continúen las vacantes, que hayan ocurrido y ocurran para aliviar los fondos y sus obligaciones. Córdoba, 24 de Diciembre de 1810= Juan de Trevilla= Juan Ramón de Ubillos = Oído 
García-Cuevas también valora la influencia positiva de Jaime Balius y plantea una visión algo más optimista de la Capilla cuando nos dice que durante esta época se atendió de forma competente la remuneración de los músicos. No obstante hemos visto que las rebajas fueron notables, y que al final acabaron por propiciar la desaparición de la Capilla de Música. ${ }^{212}$

\subsection{EL MAGISTERIO DE CAPILLA. ${ }^{213}$}

El Magisterio de Capilla es el puesto clave de la música catedralicia. Entre sus funciones, que después desarrollaremos, están las de director, compositor, educador, gestor, etc. Persona eminente, a la que se le exigen muchas cualidades, es la figura más importante del grupo de cantores e instrumentistas de la catedral. Su formación es muy completa y comenzaba a menudo desde los escalafones más bajos, como "seise”. Sus conocimientos iban desde el dominio de uno o más instrumentos, sobre todo el órgano, pasando por la armonía y el contrapunto, hasta la composición e instrumentación. Además debía conocer las formas musicales sacras y tener conocimiento del latín. “Obtenida la suficiente competencia y en el supuesto de que reuniera la edad y otros requisitos, como ser sacerdote o estar en vías de serlo próximamente, si así los exigían las bulas apostólicas, podía opositar a un Magisterio". ${ }^{214}$

este informe, acordó el Cabildo conformarse, y se conformó con él en todas sus partes y para proceder al señalamiento de la cuota respectiva, que a cada ministro ha de disminuirse en su consignación, se conferencio separadamente el punto, y el Cabildo acordó, que se hagan las rebajas, que resultan de las siguiente lista, en que van anotados los respectivos Músicos y Ministros con sus dotaciones anteriores, y las que les quedan líquidas, en la forma y modo que se aprobó por acuerdos o votaciones individuales, teniendo presente la nota indicada en el informe”. A.C.C. Actas Capitulares. Lunes 24 de Diciembre de 1810. T.100, s/f. En el Apéndice Documental se detallan estas rebajas en los sueldos.

212 “En el cruce de una a otra centuria, subsistía el auge de los tiempos modernos, acrecido, tal vez, gracias al talento creador del maestro Jaime Balius. Desde luego, en los inicios del Diecinueve, sin arredrarse ante las estrecheces, se atendió de forma competente la remuneración de músicos y cantantes; la escasez de voces, empero, fue un temprano indicio de descomposición. Desde los comedios de los años treinta, fue ya manifiesto el declive del cuerpo, tanto en su parte vocal como instrumental, circunstancias que, adicionadas a las necesarias economías, aconsejaron la suspensión de algunos ritos. Dentro de un amplio recorte presupuestario, la real orden de 5 de noviembre de 1842 dispuso, finalmente, la supresión de la capilla”. GARCÍA-CUEVAS VENTURA, José. El Cabildo catedralicio cordobés desde la Revolución hasta la Restauración (1788-1882). Córdoba, Servicio de Publicaciones de la Universidad, 1996, pág. 46.

${ }^{213}$ Nos ocupamos aquí de las funciones generales del Magisterio de Capilla. De Jaime Balius y Vila nos ocuparemos en capítulo aparte, por ser el protagonista de este trabajo.

214 RUBIO, Samuel. Historia de la música española desde el ars nova hasta 1600. Madrid, Alianza Editorial, Alianza Música, 1983, pág. 17. 
Según nos dice Samuel Rubio, antes del siglo XVI, podía recibir también el nombre de "Cantor", "término que siempre solía ir acompañado de algún aditivo o circunstancia que lo hacía inconfundible con el resto de los cantores”. ${ }^{215}$ Así podemos encontrarnos con un "Cantor Maestro del Canto” o un “Cantor Maestro de Capilla”, hasta que al final se le conoce sólo como "Maestro de Capilla”.

La plaza se proveía normalmente por oposición, aunque a veces también se hace por libre designación. Previamente se publicaba el edicto de convocatoria, el cual era llevado por un emisario a las ciudades que determinase el Cabildo. El tribunal al efecto estaba compuesto por los músicos de mejor formación, y si en la ciudad no los hubiere, se traían de fuera. Podía suceder que si el Maestro de Capilla anterior hubiese dejado el puesto por jubilación, fuera propuesto para formar parte del jurado. Así sucedió con la oposición en Córdoba de Jaime Balius y Vila, estando en su tribunal Juan Manuel Gaitán, anterior Maestro de Capilla ya jubilado, además de D. Francisco Ayala, organista primero y D. Mateo Bernia, músico de la Capilla de Santa Inés. Posteriormente, los ejercicios se remitieron al Maestro Ripa, de Sevilla para que pusiera su censura. ${ }^{216}$

Las pruebas de oposición eran realmente duras y podían incluir la realización de ejercicios contrapuntísticos, de interpretación al órgano, de dirección y sobre todo de composición. De las obras que hizo Balius para su oposición daremos cuenta en el capítulo siguiente.

Pasamos ahora a las funciones y obligaciones del Maestro de Capilla. Atendiendo a lo que nos dice Samuel Rubio, en el siglo XVI, las funciones de este en las diversas catedrales eran muy similares. No obstante nos pone como ejemplo las establecidas en la Catedral de León, por estar muy pormenorizadas, aunque en las mismas se hace también referencia a otras como Badajoz o Sevilla:

“1. Debe tener capilla, es decir, lugar de ensayos y clases, con su llave, en la catedral, capilla que le señalarán el deán y el cabildo de la misma.

\footnotetext{
${ }^{215}$ Ibid.

${ }^{216}$ Cf. A.C.C. Actas Capitulares. 9 de Mayo de 1785. T.90, folio 120r.
} 
$2^{0}$. Deberá estar en ella, por la mañana, desde la hora de prima hasta una hora después de concluidas las restantes horas menores, todo el año, a excepción de la cuaresma; por la tarde, desde la una hasta una hora después de vísperas durante los meses de octubre a mayo; desde las dos, desde el primero de mayo hasta el primero de octubre. Dos horas a la mañana y otras dos de tarde, puntualizan las actas de Badajoz.

$3^{o}$. Impartirá lecciones, durante ese tiempo, de Canto Llano, canto de órgano, contrapunto y composición a las dignidades y canónigos que lo quieran aprender.

$4^{\circ}$. Iguales enseñanzas, no cita la composición, impartirá a los «seis mozos», así en la capilla como en casa, con que sean diestros para cantar todas las obras y canto que sean necesarios.

$5^{\circ}$. Reitera esta obligación para con «los mozos de coro y acólitos», «y todo lo demás de que fueren capaces para el servicio del coro y aprovechamiento de ellos». Algunas catedrales determinan expresamente que esta enseñanza debe ser gratuita; la de Burgos prohíbe al maestro dar «lecciones a otras gentes extravagantes» durante este tiempo, dejándole libertad, sin embargo, para impartir clases particulares durante las horas libres «a quien tuviere por bien y se lo pague».

$6^{\circ}$. A cargo del maestro corre el deber «de buscar los seis mozos de coro», que han de tener «buenas voces», y cuando reclutare alguno nuevo debe presentarlo ante el cabildo a fin de que oyéndole cantar «lo reciba si le parece bien, y si no se vaya».

$7^{\mathbf{0}}$. Cuando se produce alguna vacante tiene quince días de plazo para cubrirla, no descontándole mientras tanto nada de la cuota que le dan por cada niño para su manutención y vestido; a partir del décimo quinto día le suspenden la asignación correspondiente.

$\mathbf{8}^{\circ}$. Debe enseñarles, «mostrar» dicen las actas, todas las obras que se han de cantar, y pasarlas a los cantores para que no hagan falta en el coro, es decir, ensayarlas a fin de evitar los fallos y equivocaciones.

$9^{\circ}$. «Item, que el dicho maestro de capilla sea obligado a hacer música de las fiestas de Navidad y Corpus Christi y otras fiestas que el cabildo mandare, dándole el administrador de la fábrica la letra o letras que para la dicha fiesta fuere menester.»

Finalmente, era obligación suya la de tener en su casa a los «seises mozos de coro», cuidando de su alimentación y vestido, de su buena educación y comportamiento, enseñándoles a leer y a escribir, todo lo cual podía ser inspeccionado 
de cerca por un delegado del cabildo, según se estipula expresamente en los «Estatutos» de la catedral hispalense». ${ }^{217}$

En esencia estas obligaciones se mantendrán en lo sucesivo, salvo algunas cuestiones discrecionales, como la obligación de que los “seises” vivan con el Maestro de Capilla. La existencia en algunas ciudades del Colegio Niños de Coro, evitarán al Maestro dicha obligación.

En Córdoba, a principios del siglo XVII también se establecieron unas normas que afectaban entre otros al Maestro de Capilla. Son las "Constituciones y Arreglamento que deben observar el Maestro de Capilla, Músicos y cantores de la Sancta Yglesia de Córdova, echo en 17 de Febrero de 1601". ${ }^{218}$ Entre otros puntos dice lo siguiente:

- El Maestro de Capilla tendrá quenta de que no siempre se canten unas mismas cosas sino diferentes misas y vísperas y motetes, diferenciando conforme a las fiestas, la música de diversos autores y letras, y que sean conforme al oficio del día, y que las misas y vísperas sean largas o breves, teniendo respeto a la Solemnidad de las fiestas y ocasiones, guardando esto con toda discreción, la disposición del tiempo y cosas que suelen ocurrir.

- El dicho Maestro tendrá cuidado de hazer buen trato a los cantores, y cuando los dichos cantores en esto o en otras cosas se tubieren por agrabiados, los dichos Obispo, Deán, y Cavildo lo remediarán como más convenga multando y executando las penas pecuniarias que les pareciese.

- El Maestro de Capilla á de ser obligado todos los días del año que no sean fiesta o no tenga obligación de asistir en el facistor de música en el Coro, á dar lección de canto de órgano y contrapunto, una ora por la mañana ó por la tarde, como más a cuento le viniese...

- El dicho Maestro á de ser obligado a componer chanzonetas y Villancicos para las fiestas de Navidad y Corpus Chistri y otras fiestas en que la Yglesia suele y acostumbra hacer semejante solemnidad, y prevenir y proveér los que las uvieren de decir. $Y$ asimismo compondrá y prevendrá los cantores en todas las

\footnotetext{
${ }^{217}$ RUBIO, Samuel. Historia de la música española desde el ars nova hasta 1600. Madrid, Alianza Editorial, Alianza Música, 1983, pág. 19-20.

${ }^{218}$ A.C.C. Obras Pías, Caja 816, nº 9.
} 
cosas particulares que los dichos Obispo, Deán y Cavildo le mandaren componer y prevenir para las fiestas y solemnidades extraordinarias que se pueden ofrecer, y todas estas cosas las tendrá vistas y prevenidas con los cantores antes de entrar en el Coro, porque comenzada tercia o visperas no han de tener licencia para poder salir de él, so pena de perder las horas; $y$ asimismo no podrán faltar de las procesiones y bocaciones a que so la misma pena todos los días han de asistir, como arriba se dispone.

- El dicho Maestro será obligado a tener en su casa doctrina, y enseñar á cantar los muchachos seizes, que en adelante, conforma a la dicha Bulla Apostólica se han de sustentar de cierta cantidad de renta de los Capellanes de la Capilla de Santa Inés, y los demás que nos, el Cavildo pleno ordenaremos y mandaremos que tengan, dándoles sustento competente en cumplimiento de los que se dispone por el estatuto de los excusados, lo cual todo hará y cumplirá el dicho Maestro, según y conforme a las Constituciones y Ordenaciones, que fueren hechas por nos los dichos Obispo, Deán y Cavildo...

Estas normas estarán vigentes casi dos siglos, aunque con motivo de la llegada de Juan Manuel Gaitán al Magisterio de Córdoba en 1752, se reforma la redacción de algunas de ellas, quedando como sigue:

"El Maestro de Capilla habría de hacer todas las composiciones necesarias; sus obras deberían quedar archivadas en la Catedral, previa ordenación de todo el archivo musical; deberá asistir a Coro en los días de Música; repartir los papeles sin guardar antigüedad a los músicos; ensayar en su casa una vez por semana con «los músicos instrumentistas que tocan los conciertos los domingos y jueves», así como con los cantores cuando se hubiere de cantar una obra nueva, aparte de mantener las pruebas públicas que son de costumbre de esta Catedral, y deberá interpretar alguna obra de calidad de maestro foráneo con tal que fuera de buen gusto, «dispensando en esta ocasión de la precisión que le va impuesta de que sean suyas las composiciones»". 219

${ }^{219}$ NIETO CUMPLIDO, Manuel: "Maestros de Capilla de la Catedral de Córdoba". Boletín de la Confederación Andaluza de Coros de 1995. Ed. CO.AN.CO. Córdoba, 1995, pág. 10. 
El Maestro de Capilla tenía normalmente la condición sacerdotal, -tal como hemos visto al principio de este subapartado- es más, estaba obligado a serlo para poder optar a la plaza. Pero también nos encontramos con alguna excepción, como la que se dio en la Iglesia Colegial de Antequera, con el Maestro José Zameza en 1761.

Según nos dice la doctora García Mohedo, Zameza presenta al Cabildo un memorial solicitando que le eximan de tal obligación:

"Memorial del Maestro de Capilla exponiendo se halla inquieto con su conciencia sobre elección de estado; por verse ligado en fuerza de la condición, con que fue admitido y expresaba la convocatoria de que había de vacar dicho Magisterio siempre y cuando su poseedor se colocase en matrimonio y pidiendo, se alce la dicha condición, para en libertad elegir el que más le convenga”. 220

Aunque pasan dos años hasta que contesta, El Cabildo finalmente acaba cediendo:

"Al haber acreditado la experiencia en el servicio de tres años, que lleva dicho D. José. La buen conducta de este sujeto es un todo, así en las prendas Morales como en la habilidad especial en su Ministerio, y que de solicitar ascenso en otra iglesia se priva al Cabildo de un Maestro tan completo, y por consiguiente seguirse mayor utilidad de condescender a su súplica”. 221

Por último y volviendo a Córdoba, este puesto fundamental está cubierto en este período de 1785-1822 (salvo una breve interrupción) por D. Jaime Balius y Vila, del que nos ocuparemos con todo detenimiento en el capítulo siguiente.

\footnotetext{
${ }^{220}$ DÍAZ MOHEDO, M ${ }^{a}$ Teresa. "La Iglesia Colegial de Antequera y su Capilla de Música, S.XVIII”, en Revista de Musicología Vol. XXVIII. Madrid, Sociedad Española de Musicología, 2005, pág. 286. A su vez toma dicho texto del Cabildo celebrado el 11 de Abril de 1761.

${ }^{221}$ Ibid. Cabildo celebrado el 5 de Febrero de 1763.
} 


\subsection{LA ORGANISTIIA.}

El organista ocupa el segundo puesto en importancia tras el Maestro de Capilla. Su formación musical es muy completa y además de dominar el instrumento, con frecuencia compone obras para la Capilla. Su presencia es contínua en la Liturgia y Paraliturgia diaria, más inclusive que la del Maestro. Actúa como solista, como acompañante de voces e instrumentos, es improvisador habitual y llegado el momento puede enseñar música a los Niños de Coro. Esta actividad constante, hace que sea necesario contar con más de un organista, normalmente dos y hasta tres en algunas catedrales y circunstancias.

Según Nieto Cumplido, el organista más antiguo del que se tiene noticia en la Catedral de Córdoba es Juan Rodríguez “El Viejo” que ejerció hasta 1459, y al que le sigue su hijo Juan Rodríguez “El Mozo”. 222 También nos habla de los primeros órganos:

"La catedral contaba con unos órganos en 1365, pero esto no quiere decir que no los tuviera desde antiguo. Sólo a partir de ese año tenemos documentación que certifique su presencia y uso. De 13 de octubre de 1365 es el acuerdo de celebrar una procesión solemne y otros oficios religiosos el día de Santa María de Marzo, $<<$ tañiendo los órganos $>>$, órganos que estaban colocados en la antigua Capilla Mayor (Capilla de Villaviciosa) en alto y al lado del Evangelio". 223

Igualmente, Nieto nos describe las primeras normas por las que ha de regirse el oficio de organista:

"Ha de ser obligado el organista a tañer en el choro el órgano a misa y vísperas todos los domingos y fiestas de seis y quatro capas que tengan vocación y procesión o sola vocación o procesión, y las misas de los sábados de la Quaresma y

\footnotetext{
${ }^{222}$ NIETO CUMPLIDO, Manuel. “La música en la Catedral de Córdoba (1236-1577)”, en AA.VV. El Patrimonio Histórico-Musical de Córdoba. Córdoba, Ayuntamiento de Córdoba, 2004, pág. 75.

${ }^{223}$ Ibid.
} 
Maytines y octavas solemnes y los días de procesiones generales donde el cabildo fuere y las vísperas primeras de las dichas fiestas, $y$ ha de tener mozo que le entone”. 224

Desde estos primeros tiempos, muchos y buenos organistas pasan por la Catedral de Córdoba, estando por lo general, muy bien considerados: “Los organistas, desde al menos 1459, mantuvieron una gran estabilidad en su oficio, bien distinta a la fugacidad de los Maestros de Capilla, y, en general, siempre recibieron elogios de su ejercicio, gozando de la ayuda de un auxiliar. Su oficio era de singular brillantez a la par que era uno de los pilares básicos de la Capilla”.225

Otro testimonio nos lo da Pérez Linde: “El organista, estaba considerado como el más importante dentro de los demás tañedores, pues era el instrumento que podía doblar más de una voz cuando éstas faltaban”. 226

Cuando Jaime Balius llega a Córdoba en 1785, era organista $1^{\circ} \mathrm{D}$. Francisco Ayala, que formó parte del tribunal de oposición de Balius y que gozaba de alta reputación como organista y como compositor, dejando en el A.C.C. quince obras de diferentes estilos. ${ }^{227}$

Además de Ayala, en la Catedral de Córdoba había un organista $2^{\circ}$, D. Joseph Benito Bach (que había ganado la plaza por oposición el día 16 de Noviembre de 1770). Entre los dos se repartían las numerosas obligaciones, turnándose habitualmente por semanas. Con ambos colaboran Joseph Gómez como entonador de órganos y Patricio Furriel y Crespo como afinador de órganos. Así consta en las Cuentas de Fábrica. ${ }^{228}$

\footnotetext{
${ }^{224}$ NIETO CUMPLIDO, Manuel. “La música en la Catedral de Córdoba (1236-1577)”, en AA.VV. El Patrimonio Histórico-Musical de Córdoba. Córdoba, Ayuntamiento de Córdoba, 2004, pág. 77. A su vez Nieto Cumplido cita la siguiente acta capitular: A.C.C. Actas Capitulares, 18, ff. 85v-90v.

225 Ibid.

226 PÉREZ LINDE, Manuel. Segunda mitad del siglo XVII: Música en la Catedral de Córdoba a través de Bartolomé García Guerrero. Córdoba, 2002, pág. 25. Tesina. Se conserva en el A.C.C.

${ }^{227}$ Sus composiciones conservadas en el A.C.C. son las siguientes: Almas a la Lid, villancico a 3 voces (110/966). Al convite venid, villancico a 4 voces (110/965). Beatus Vir a 7 voces (124/1171). Celebren, villancico a 4 voces (109/961). Credidi a 7 voces (124/1170). Dixit Dóminus a 7 voces (59/396). El día, la noche, villancico a 4 voces (109/962). Enigma prodigioso, villancico a 4 voces (110/963), Lauda Jerusalen a 7 voces (59/395). Laudate Dóminus a 7 voces (124/1172). Letatus sum a 7 voces (59/397), Magnificat a 7 voces (62/434), Maná misterioso, villancico a 4 voces (110/964), Venid, comed. Villancico a 4 voces (SSAT) con acmpto. (109/959), Ay, ay que amor. Villancico a 4 voces (SSAT) con acompto. (109/960).

${ }^{228}$ A.C.C. Cuentas de Fábrica de los años 1787-1789. T. 4042, s/f.
} 
Furriel mantuvo el cargo de organero durante todo el tiempo en que Balius fue Maestro de Capilla. ${ }^{229}$ Tuvo varios ayudantes ocasionales:

“En acta capitular de 23 de Abril de 1798 consta una petición del tesorero don Cayetano Carrascal en la que indica $<<$ que en el órgano antiguo havía de de hacer alguna obra, según se había reconocido, y era necesario desmontar parte de él >>. Para esta reparación se contó con Patricio Furriel [...], quien en 19 de mayo de 1798 procedió a su $<<$ composición $>>$. Se trata, sin duda, del órgano del lado del Evangelio. Con él trabajan un ensamblador y un oficial organero, aunque su equipo se ampliará con el tiempo hasta incluir en él a cinco oficiales. Pareció a sus contemporáneos que su trabajo se eternizaba, pues en ello empleó al menos quince años, a pesar de sus promesas escrituradas en 1801 y 1808 de concluirlo en plazos fijados. Por esto, el órgano ostenta sobre las puertas laterales los escudos de los obispos don Agustín de Ayestarán (1796-1805) y don Pedro Antonio de Trevilla (18051832). Una vez concluida la reparación de éste, Patricio Furriel la emprendió con el de la Epístola”.230

Si en el acta anterior hemos leído que al parecer el trabajo de Furriel como organero se demoraba excesivamente, ahora tenemos otra opinión también desfavorable de su labor, a pesar de “su mucho gusto y conocimiento de las Bellas Artes”:

"Don Patricio Furriel fue Jurado del Ayuntamiento de esta ciudad, cuando el Gobierno Absoluto. Era sujeto de mucho gusto y conocedor de las Bellas Artes. A él se debe la reparación de la Mezquita de la Santa Iglesia Catedral de esta Ciudad y otras obras que hizo con mucho acierto. Tenía título de organero y templador de los órganos de la Catedral, gasto toda su vida haciendo un gasto de muchos miles de duros a la fábrica de la Santa Iglesia y por remate de todo después de unos gastos tan grandes fue necesario dejarlos con muchos defectos, que con las sumas que se habían invertido en la composición de ellos sobraba para haber hecho uno tan bueno como el que tiene tan

\footnotetext{
${ }^{229}$ En 1821 todavía aparece en el Padrón Municipal con ese cargo. Allí consta además de su oficio, su domicilio, en la calle del Hilete $\mathrm{n}^{\circ} 3$, junto a la Parroquia de San Salvador y Santo Domingo de Silos. Estaba casado con $\mathrm{D}^{\mathrm{a}}$ María Muñoz y tenía un hijo de 18 años que era oficial de boticario. Archivo Municipal de Córdoba. Padrón de 1821.

${ }^{230}$ NIETO CUMPLIDO, Manuel. La Catedral de Córdoba. Córdoba, Publicaciones de la Obra Social y Cultural de Cajasur, 1998, pág. 563.
} 
celebrado la Catedral de la Ciudad de Sevilla. Y este sujeto murió desacreditado por los gastos que le hizo a la Catedral y a la fábrica tantas pérdidas que por su causa sufrió.

“El Padre Maestro Fr. José de Jesús Muñoz Capilla y Vega de la orden de San Agustín tuvo la culpa que el Furriel no cumpliera ningún plazo para la conclusión de los órganos por ser este Padre cuñado suyo, y por esta causa embrollándolo todo con el influjo que tenía con el Obispo y Canónigos y el fin era que al Furriel no le faltase trabajo con toda comodidad en esta Ciudad y el bienestar de la familia como era regular que así lo hiciese por amparar la hermana que era mujer del Furriel y a los hijos de éste que eran sus sobrinos". 231

Volviendo a los organistas, en 1787 sabemos que la plaza de $1^{\circ}$ se halla vacante por fallecimiento de Ayala. ${ }^{232}$ Le sucede Andrés Lidón. ${ }^{233}$ Pero hasta que llega Lidón, hay diversos aspirantes que se presentan para cubrir la plaza de organista $1^{\mathrm{o}}$ y que por diversas razones no se quedan, unas veces, porque no aprueban la oposición y otras, porque aun aprobándola no se incorporan a su destino.

En Julio de 1788 las actas capitulares reflejan diversas noticias conducentes a proveer la plaza: "El Señor Barcia dixo estaba en esta ciudad el Organista del tardon nombrado para examinar a los opositores a la plaza de $1^{\circ}$ organista de esta Santa

\footnotetext{
${ }^{231}$ POZO Y CÁCERES, Juan Lucas del. Rasgos biográficos y fisonómicos [de cordobeses]. Córdoba, 1863. Biblioteca Municipal de Córdoba. s/f.

${ }^{232}$ A.C.C. Cuentas de Fábrica de los años 1787-1789. T. 4042, s/f.

${ }^{233}$ Sabemos algo de la personalidad de Andrés Lidón gracias a la descripción que de él hace Lucas del Pozo, otro músico de la Capilla. Del Pozo escribió en 1827 unas narraciones acerca del carácter de los músicos, a fin de que el nuevo Maestro de Capilla, Juan Cuevas, los conociera mejor. Ciertamente estas narraciones tienen un humor pintoresco y algo brusco en ocasiones, pero nos sirven para hacernos una idea de alguno de los rasgos que conformaban la personalidad de los músicos. A pesar de estar hechas en fecha posterior a la muerte de Balius, describen a músicos que ejercieron bajo su mandato, como es el caso de Lidón. De él dice lo siguiente: "Es el primero de la Catedral de Córdoba y uno de los últimos de España. Es juicioso y hombre de bien, algo de amor propio y aconsejo a Vd. dos cosas. $1^{a}$, que la semana que toque no venga usted al Coro, porque no queremos verlo de mal humor, y la $2^{a}$ que echa usted algún pajarito de seda, sea fuera del Barrio, donde los gusanos no oigan el órgano de Lidón, porque sino se pierden. Y si usted lo encuentra en la calle y no lo saluda, no lo eche usted de ver, que es corto de vista". POZO, Juan Lucas del: Caricaturas de los Músicos de la Santa Iglesia Catedral de Córdoba. Córdoba, 1827, mecanografiado, pág. 336. "El 24 de Enero de 1857 falleció D. Andrés Lidón, el organista, hombre afortunado y de poco mérito en el órgano". POZO CÁCERES, Juan Lucas del. "Músicos fallecidos desde 1826”. En Colección de Obras. Córdoba, 1863. Ms., pág. 395.
} 
Iglesia, que son el de Calahorra, a quien se sigue perjuicio en la detención y el de Plasencia”. Y se acordó fijar en breve el día de los exámenes. ${ }^{234}$

Ese día se fijó para el 27 de Julio, Domingo: “...que se examinen los dos opositores que han venido desde Calahorra y Plasencia, desde el Domingo 27 del presente por la tarde acabado el Coro. Y concluidos los exámenes y presentada por el examinador la censura por escrito, el Cabildo determinará lo que tenga por más conveniente". 235

Una vez realizada la oposición para cubrir la plaza de organista $1^{\circ}$, el examinador emite juicio negativo sobre los dos aspirantes y el Cabildo acuerda "que ninguno de los dos se admita”, destinando una ayuda de costa para cada uno por los gastos de viaje: “Al de Calahorra se le den de ayuda costa para el viage tres mil reales de vellón y al de Plasencia mil quinientos". Y se dio comisión a los Diputados de Música para que sigan buscando un organista "de las calidades que se desea y que corresponde a esta Santa Iglesia”. 236

Si en el caso anterior, los opositores no fueron del agrado del Cabildo, en el caso siguiente sí se acepta a un organista venido de Sevilla.

Así sucede con Pedro Bodul de Santamant, organista $2^{\circ}$ de Sevilla: “Acordó el Cavildo elegir y en efecto eligió por primero organista de esta Santa Iglesia a dicho Santamant con salario de doce mil reales anuales". ${ }^{237}$ A pesar de ello, parece que no llegó a incorporarse a su plaza puesto que a principio de 1790 se leyó un memorial de José Ferrer y Beltrán, presbítero, organista de la Catedral de Oviedo “en el que expone ha llegado a su noticia, se halla vacante la plaza de primero de esta Santa Iglesia; por lo que suplica al Cavildo se sirva tenerlo presente en ella y con la misma renta que fue nombrado Santamant”. ${ }^{238}$

En Febrero de 1790 se presentan otros dos nuevos aspirantes a la plaza de primer organista: "Se leyeron dos memoriales, uno de Juan Andrés Lambida, Capellán Real

\footnotetext{
${ }^{234}$ Ibid. Miércoles 23 de Julio de 1788. T.91, fol. 443.

${ }^{235}$ Ibid. Jueves 24 de Julio de 1788. T.91, fol. 444.

${ }^{236}$ Ibid. Jueves 31 de Julio de 1788. T.91, fol. 452.

${ }^{237}$ A.C.C. Actas Capitulares. Miércoles 4 de Noviembre de 1789. T.92, fol.89r.

${ }^{238}$ A.C.C. Actas Capitulares. Jueves 14 de Enero de 1790. T.92, fol. 106r.
} 
afecto al órgano del Monasterio de la Encarnación y otro de Antonio Saborit, clérigo, en los que suplican y pretenden la plaza de organista vacante en esta Santa Iglesia”. 239 No obstante la plaza no se cubrirá y será posteriormente adjudicada a Andrés Lidón.

La plaza de $2^{\circ}$ organista también estará vacante muchos años después. En 1815 Francisco Balius ${ }^{240}$ escribe al Cabildo solicitando el puesto. "Se leyó un memorial de Francisco Balius, organista de la Real Colegiata de San Hipólito, pretendiendo la plaza de segundo vacante en esta Santa Iglesia”. ${ }^{241}$ Sin embargo, algo no le gustaba al Cabildo o al Maestro de Capilla, puesto que dicha solicitud no se aceptó de forma inmediata. Esto lo comprobamos al año siguiente, en Septiembre de 1816, cuando el Cabildo vuelve a tratar "acerca del modo de proveer la Segunda Plaza de Organista”.242

Vuelve a insistir Francisco Balius en ocupar la plaza, y esta vez sí consigue que lo examinen, y el Cabildo acuerda "que el martes 28 del corriente por la mañana se haga el examen (de $2^{\circ}$ organista) en forma del único opositor D. Francisco Balius; que para él se nombran por examinadores a el organista D. Andrés Lidón, a D. Josef Moyano, pbro. individuo de la Capilla de Música y a D. Miguel Reynaldi, primer violinista de ella”. ${ }^{243}$ Como podemos comprobar, no está en el tribunal el Maestro de Capilla, lo que por otra parte puede ser lógico teniendo en cuenta su supuesta relación de parentesco. Por fin, el viernes 31 de Enero de 1817, el Cabildo acuerda, una vez oídos los informes de los examinadores, nombrar como $2^{\circ}$ organista de la Catedral de Córdoba a Francisco Balius: "En virtud de llamamiento se oyeron las censuras de los examinadores para la plaza de $2^{\circ}$ organista, y el informe de los Señores Diputados de arcas de San Acacio con la parte de S.I. y con vista de todo el Cabildo por todos votos secretos: Acordó conceder a D. Francisco Balius la plaza de segundo organista”.244

\footnotetext{
${ }^{239}$ A.C.C. Actas Capitulares. Miércoles 3 de Febrero de 1790. T.92, fol. 124v.

${ }^{240}$ Suponemos que este Francisco Balius es el sobrino de Jaime Balius, que vino con él a Córdoba cuando era muy joven, tal como veremos cuando hablemos de la primera etapa del Maestro en nuestra ciudad. Parecería lógico pensar que su tío intercediera por él y que obtuviera la plaza sin mayores problemas, sin embargo no fue así, sino que tuvo que insistir repetidamente para ser oído.

${ }^{241}$ A.C.C. Actas Capitulares. Miércoles 23 de Agosto de 1815, T.103.

${ }^{242}$ A.C.C. Actas Capitulares. Lunes 23 de Septiembre de 1816, T.104.

243 Ibid. Sábado 25 de Enero de 1817, T.104.

${ }^{244}$ Ibid. Viernes, 31 de Enero de 1817, T.104, fol 100v.
} 
Según Lucas del Pozo, agradaba oírle tocar el órgano, aunque tiene otros defectos muy acusados. $^{245}$

Al igual que ocurrió con Ayala, Francisco Balius también compone obras de diversos estilos, conservándose 17 de ellas en el Archivo de la Catedral de Córdoba. ${ }^{246}$

Pero, ¿Quién era este Francisco Balius? Parece lógico pensar que fuera el sobrino que vivía con Jaime Balius cuando éste llegó a Córdoba, y que aparece como tal sobrino en el censo de aquella época, con la edad de 13 años. Por eso resulta extraño que su solicitud para entrar en la plaza de organista $2^{\circ}$ no fuera aceptada en primera instancia, y que tuvieran que pasar dos años. Esta circunstancia y el hecho de que Jaime Balius no dejara nada a su sobrino en su primer testamento nos hace pensar que las relaciones entre ambos no fueran demasiado buenas.

Sin embargo, ¿Es este Francisco Balius el mismo que participa en las oposiciones a Maestro de Capilla de Lérida en $1793 ?^{247}$ ¿Es el mismo que aparece en 1794 como organista de Solsona y que pasó algún tiempo en la cárcel del Obispo? ${ }^{248}$ ¿Es el que se presentó en 1796 a Maestro de Capilla de la Catedral de Granada? ${ }^{249}$ ¿Es

\footnotetext{
245 "Es tan músico como feo, da mucho gusto en el órgano, como Vd. verá: todos le toman parecer menos yo porque aunque es voto, tiene, tiene. Pregunta: ¿Qué tiene? Respuesta: Tiene que en untándole los labios con el bálsamo de Noé habla lo que quiere el untador, es decir, que aunque Vd. ha entrado con general aplauso, podrá tener acaso algún émulo, y si cuando Vd. saque al público su primera obra, todos le tomaran parecer a Balius, y si ya ha hecho con él la operación indicada y dice que no vale nada, voto a san, que aunque sea la mejor del mundo no se ha de festejar. Método curativo de esta enfermedad. Llama Vd. al consabido a su casa, y le da la siguiente receta. Por la mañana aguardiente, dos cuartillos, que mezclará con doce alfajores de las Dueñas, y en ayunas lo tomará el paciente; lo deja Vd. reposar hasta las once, en cuya hora repetirá otra receta de la botica que tiene el Cabildo junto a San Juan y en cantidad de media cuartilla le dará a beber en pequeñas porciones; esta operación durará hasta la una. Lo deja Vd. reposar y a la oración se repite la misma receta, pero el doble de cantidad y si con esto no basta se continuará. Es especifico acreditado en la naturaleza de este individuo". POZO, Juan Lucas del: Caricaturas de los Músicos de la Santa Iglesia Catedral de Córdoba. Córdoba, 1827, mecanografiado, pág. 337.

${ }^{246}$ Las obras de Francisco Balius conservadas en el A.C.C. son las siguientes: Aunque yo ya no canto, villancico, recitado y aria de tenor (103/864). Ave Maris Stella a 4 y 8 voces (62/432). Beatus Vir a 8 voces (32/222). Cuando volvían los pastores, villancico $3^{\circ}$ de pastorela a 6 voces $(105 / 888)$. Dómine a 8 voces (58/386). Dixit Dóminus a 4 y 8 voces (7/66). El Sansón Divino, villancico a 8 voces (109/948). Himno a la Santísima Trinidad a 4 voces (72/546). Invitatorio de difuntos a 4 voces (60/413). Laudate Dóminum a 4 y 8 voces (58/388). Lauda Jerusalén a 4 y 8 voces (27/195). Lauda Jerusalén a 4 y 8 voces (58/389). Magnificat a 4 y 8 voces (62/433). Misa de facistol a 4 voces (111/986). Laetatus Sum a 4 y 8 voces (SATB) con violines, trompas, oboes, viola y acompañamiento (58/385). Triste la tierra, dúo de contralto y bajo (61/423). Villancico a San Pedro a 8 voces (72/547).

${ }^{247}$ Cf. BALLUS CASOLIVA, Gloria: La música a la Colegiata Basílica de Santa María de la Seu de Manresa: 1714-1808. Tesis Doctoral. Universidad Autónoma de Barcelona, 2004. Vol. II, pág 3. ${ }^{248}$ Ibid.pág 2.

249 LÓPEZ CALO, José. Catálogo del Archivo de Música de la Catedral de Granada. Centro de Documentación Musical de Andalucía (Junta de Andalucía), Granada 1991, Tomo I. Pag.146.
} 
el mismo que se presentó en 1807 a la plaza de Maestro de Capilla de Málaga y que no obtuvo ningún voto siendo uno de los censores Pons? ${ }^{250}$

Según la doctora Gloria Ballus, el Francisco Balius que vemos en estos lugares es hermano de Jaime. ${ }^{251}$ Bien, pues en ello estamos, tratando de encontrar una certeza sobre si se trata de la misma persona, o de distintas, hermano y sobrino de Jaime Balius. Después de la muerte de Jaime Balius y Vila, Francisco Balius y Andrés Lidón formarán parte del tribunal examinador del siguiente Maestro de Capilla, Juan Cuevas, quien toma posesión por poderes el 5 de Febrero de $1827 .{ }^{252}$

${ }^{250}$ MARTÍNEZ SOLAESA, Adalberto. Catedral de Málaga. Órganos y Música en su entorno. Málaga, Servicio de Publicaciones de la Universidad, 1996, pág. 289. Recordemos que Pons había sido compañero de Francisco Balius en Córdoba, cuando ambos vivían en la misma casa, y había sido alumno preferido de Jaime Balius y Vila.

${ }^{251}$ Cf. BALLUS CASOLIVA, Gloria: La música a la Colegiata Basílica de Santa María de la Seu de Manresa: 1714-1808. Tesis Doctoral. Universidad Autónoma de Barcelona, 2004. Vol. II, pág 3.

252 "Desde la muerte de Jaime Balíus, había ejercido como Maestro de Capilla interino Antonio Gil Hurtado, capellán de San Acacio, en una interinidad que se vería prolongada por los graves asuntos políticos nacionales. De la época de su magisterio es la ordenación del archivo musical realizada por don José Moyano, capellán de San Acacio y contralto († 1825). Aún antes de la convocatoria de la oposición, en 28 de julio de 1824, Juan Cuevas, maestro de Capilla de la iglesia colegial de San Felipe, de Játiva, se ofreció al cabildo para cubrir la vacante, pero no obtuvo respuesta. No mucho después, en 3 de noviembre del mismo año, comienzan los capitulares a estudiar la provisión del magisterio, hecho confirmado por un acta capitular posterior al referir que se ha presentado un solo opositor, don Ramón Palacio, racionero y maestro de Capilla de Zamora, quien tuvo por jueces de sus ejercicios a don José Moyano, don Antonio Gíl, Nicolás de Anguíta, capellán de San Acacio y contralto, Andrés Lidón Pérez y Francisco Balíus, organistas primero y segundo respectivamente. Por apreciar disconformidad entre los pareceres de los jueces, en 15 de julio de 1825 se determina que las composiciones de Palacio se envíen a un maestro, cuyo nombre no se cita, para escuchar su veredicto, mientras el opositor permanece a la espera en Córdoba inútilmente hasta septiembre del mismo año. Será en 20 de junio del año siguiente cuando el Cabildo tome la determinación de no cubrir la vacante del magisterio. En 30 de agosto de 1826 los capitulares encomiendan a los diputados de la Música la provisión sin previas oposiciones, y en 16 de Diciembre acuerdan nombrar como maestro de Capilla a don Juan Cuevas, ahora racionero y maestro de Capilla de Toledo. Durante el último año, por promoción de don Antonio Gil a una medía ración, había ejercido de maestro interino Nicolás de Anguíta. El maestro Cuevas recibe la colación de una capellanía de Santa Inés y toma posesión por poderes en 5 de febrero de 1827". NIETO CUMPLIDO, Manuel. "Maestros de Capilla de la Catedral de Córdoba”. A.A.V.V.: Boletín de la Confederación Andaluza de Coros de 1995. Córdoba, Ed. CO.AN.CO., 1995, pág. 12. 


\begin{tabular}{|c|c|c|c|c|c|c|c|c|c|c|c|c|c|c|c|c|c|c|c|c|c|c|c|c|c|c|c|c|}
\hline \multicolumn{29}{|c|}{ ORGANISTAS } \\
\hline & 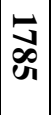 & $\stackrel{5}{\circ}$ & & & ज્ञ & ک઼ & స్తి & & 해 & Сુ & : & 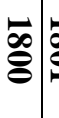 & & के & 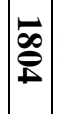 & 空 & : & 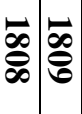 & $\overrightarrow{0}$ & & 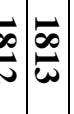 & & 离 & $\stackrel{\infty}{\infty}_{\infty}^{\infty}$ & $\overrightarrow{0}$ & 总 & 㤐 & 承 \\
\hline $\begin{array}{l}\text { FRANCISCO } \\
\text { AYALA. } \\
\text { ORGANISTA 1 } 1^{\circ}\end{array}$ & $\mathbf{X}$ & $\mathbf{X} \mid \boldsymbol{Y}$ & & & & & & & & & & & & & & & & & & & & & & & & & & \\
\hline $\begin{array}{l}\text { JOSÉ BENITO } \\
\text { BACH. } \\
\text { ORGANISTA 2 }{ }^{\circ} .\end{array}$ & $\mathbf{X}$ & $\mathbf{X} \mid \mathbf{I}$ & $\mathbf{x} \mid \boldsymbol{Y}$ & $|X|$ & $\mathbf{X}$ & $\mathbf{X} \mathbf{X}$ & $\mathbf{X}$ & $\mathbf{X} \mid \mathbf{X}$ & $\mathbf{X} \mid Y$ & $\mathbf{X} \mid \mathbf{X}$ & $X$ & $\mathbf{X}$ & $\mathbf{X}$ & $\mathbf{X} \mathbf{X}$ & $\mathbf{X}$ & $\mathbf{X} \mathbf{X}$ & $\mathbf{X}$ & $\mathbf{X} \mathbf{X}$ & $\mathbf{X} \mathbf{X} \mid$ & $\mathbf{X} \mid \mathbf{X}$ & $\mathbf{X} \mathbf{X}$ & & & & & & & \\
\hline $\begin{array}{c}\text { ANDRÉS } \\
\text { LIDÓN. } \\
\text { ORGANISTA }{ }^{\circ} \text {. }\end{array}$ & & & & & & $\mathbf{X} \mathbf{X}$ & $\mathbf{X}$ & $\mathbf{X} \mid \mathbf{X}$ & $|x|$ & $\mathbf{X} \mathbf{X}$ & $\mathbf{X}$ & $\mathbf{X}$ & & $\mathbf{X} \mathbf{X}$ & $\mathbf{X}$ & $\mathbf{X} \mathbf{X}$ & $\mathbf{X}$ & $\mathbf{X} \mathbf{X}$ & $\mathbf{X} \mathbf{X} \mid$ & $\mathbf{X} \mid \mathbf{X}$ & $\mathbf{X} \mathbf{X}$ & $\mathbf{X} \mid$ & $\mathbf{X} \mathbf{X}$ & $\mathbf{X}$ & $\mathbf{X}|\mathbf{X}|$ & $\mathbf{X}$ & & $\mathbf{X}$ \\
\hline $\begin{array}{l}\text { FRANCISCO } \\
\text { BALIUS. } \\
\text { ORGANISTA 20. }\end{array}$ & & & & & & & & & & & & & & & & & & & & & & & & $\mathbf{X} \mathbf{X}$ & $\mathbf{X} \mathbf{X}$ & $\mathbf{X}$ & $\mathbf{X}$ & $\mathbf{X}$ \\
\hline
\end{tabular}

\subsection{LOS CANTORES DE POLIFONÍA.}

La presencia de una plantilla vocal para el canto de órgano de forma independiente de los Capellanes de Veintena, que preferentemente atendían el Canto Gregoriano, queda recogida en las actas capitulares a partir de 1455: “Los capellanes de la Veintena, aparte de su participación en el canto gregoriano, cosa que les venía de antiguo y era su oficio principal, comienzan a figurar como cantores. [...] Se pasa después a institucionalizar el cuerpo de cantores con el soporte económico del fondo destinado a los capellanes de la Veintena”. 253

Ya en la época de Balius, las actas capitulares siguen refiriéndose a ellos con frecuencia. Su papel era fundamental, y tenían que abordar obras de muy diversa índole. Desde el tradicional repertorio religioso en latín, hasta los villancicos, pasando por los recitados y arias, que en muchas ocasiones tenían una dificultad notable. Por ello el

\footnotetext{
${ }^{253}$ Cf. NIETO CUMPLIDO, Manuel. “La música en la Catedral de Córdoba (1236-1577)”, en AA.VV. El Patrimonio Histórico-Musical de Córdoba. Córdoba, Ayuntamiento de Córdoba, 2004, pág. 73.
} 
Cabildo se esmera en su búsqueda, y cuando los encuentra les asigna normalmente buenos sueldos. $^{254}$

Los cantores de los que tenemos constancia durante la época que nos ocupa son los siguientes: ${ }^{255}$

\subsubsection{TIPLES.}

D. Dionisio de la Mata, tiple. ${ }^{256}$

D. Mateo Bernia, tiple. ${ }^{257}$

D. Juan Bueno, tiple. ${ }^{258}$

D. Alfonso Martín, tiple. ${ }^{259}$

D. Mariano Especiali, tiple. ${ }^{260}$

D. José María Moyano, tiple y contralto. ${ }^{261}$

D. Antonio Ordoñez, tiple. $^{262}$

${ }^{254}$ Por ejemplo en 1810, después del Maestro de Capilla, los sueldos más altos corresponden a algunos cantores. Cf. A.C.C. Actas Capitulares. Lunes 24 de Diciembre de 1810, tomo 100.

${ }^{255}$ No es fácil en muchas ocasiones, precisar la entrada o salida exacta de algunos músicos en la Capilla. Las cuentas de fábrica de algunos años no se conservan, o no incluyen las nóminas de los músicos. En otras ocasiones, los músicos son contratados temporalmente, por poco tiempo, y es difícil seguirles el rastro, por lo que estas tablas se ha confeccionado acudiendo a otros comprobantes, como las actas capitulares, los certificados de aspas, etc. Con todo ello se ha intentado reconstruir lo más fielmente posible la presencia de los músicos en la Capilla de Jaime Balius.

${ }^{256}$ Estaba en la Capilla desde antes de 1785. De hecho, en 1781, cuando se jubiló el anterior Maestro de Capilla (Gaitán), Dionisio de la Mata ejerció interinamente el cargo hasta la llegada de Balius. También lo ejerció entre 1787 y 1789 cuando Balius marchó a Madrid.

${ }^{257}$ Ya estaba en la Capilla de Música cuando llegó Balius. De hecho formó parte de su tribunal examinador.

${ }^{258}$ Ya está en la Capilla de Música en 1785.

${ }^{259}$ Es uno de los tiples más estables de la Capilla, en la que aparece ya en 1785, permaneciendo en ella hasta 1809.

${ }^{260}$ Aparece en actas capitulares desde 1785. Fue uno de los tres implicados en la insubordinación y enfrentamiento al Maestro de Capilla en 1787, lo que influyó en la marcha de Balius a Madrid, según veremos en el capítulo siguiente.

261 "Don José María Moyano Presbítero Capellán de San Acasio y músico de voz de la Santa Iglesia Catedral. Fue este Señor natural de la Ciudad de Lucena de esta Provincia y un sacerdote muy honrado y cristiano en su facultad que era voz de contralto fue lo más singular que he conocido, por tener una voz tan hermosa de tanta extensión y que la unía al falsete con tal primor que daba mucho gusto oírlo cantar y él se prestaba a ello y no escusaba el trabajo, y así es que el Maestro Don Jaime Balius todas sus composiciones las hizo siempre obligado en la cuerda que desempeñaba Moyano más que ninguna otra. Cantó y trabajó en la Catedral cual no otro toda su vida, y aunque gozaba 13 reales los ganaba cual ninguno, en tales términos que al fin de sus días enfermó del pecho arrojando sangre por la boca y de esta enfermedad murió. Fue de lo más singular que se ha conocido porque su voz era admirable. Cantaba papeles de Tiple con mucho desahogo y estoy al decir que en toda España quizás no se habrá conocido otro que le iguale. En fin la voz que he oído toda mi vida con más gusto y que no se encontrará otra que la iguale”. Cf. LUCAS DEL POZO Y CÁCERES, Juan. “D. José María Moyano”. En Rasgos biográficos y fisonómicos [de cordobeses]. Córdoba, 1863. Biblioteca Municipal. s/f. Moyano está en la Capilla durante todo el tiempo en que Jaime Balius ocupa el puesto de Maestro. 

D. Rafael Gallardo, tiple. ${ }^{263}$
D. José Molina, tiple. ${ }^{264}$

Veamos ahora una tabla comparativa con los nombres y las fechas en que dichos músicos prestaron sus servicios en la Capilla de Música de la Catedral de Córdoba. ${ }^{265}$

\begin{tabular}{|c|c|c|c|c|c|c|c|c|c|c|c|c|c|c|c|c|c|c|c|c|c|c|c|c|c|c|c|c|c|c|}
\hline \multicolumn{31}{|c|}{ TIPLES } \\
\hline & $\mid \begin{array}{c}\vec{v} \\
\infty \\
\infty \\
i\end{array}$ & $\underbrace{\infty}_{\infty}$ & :̦ & : & $\mid \overrightarrow{\mathrm{g}}$ & & & & & & & & & & & bे & & & के & & 总 & & 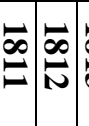 & $\vec{\infty} \mid \vec{\omega}$ & & $\mid \vec{\infty}$ & \begin{tabular}{|c|c|}
$\infty$ \\
\end{tabular} \mid & & & 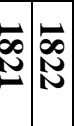 \\
\hline $\begin{array}{c}\text { DIONISIO } \\
\text { DE LA } \\
\text { MATA. }\end{array}$ & $\mathbf{X}$ & $\mathbf{X} \mid>$ & $\mathbf{X} \mid \mathbf{X}$ & $X$ & $\mathbf{X}$ & $\mathbf{X} \mid \mathrm{Y}$ & $\mathbf{X} \mid \boldsymbol{Y}$ & $\mathbf{X} \mid X$ & & & & & & & & & & & & & & & & & & & & & & \\
\hline $\begin{array}{l}\text { MATEO } \\
\text { BERNIA. }\end{array}$ & $\mathbf{X}$ & $\mathbf{X} \mid$ & $\mathbf{X} \mid \mathbf{X}$ & $\mathbf{X}$ & $\mathbf{X}$ & & $\mathbf{X} \mid \mathbf{Y}$ & $\mathbf{X} X$ & $\mathbf{X}$ & $X$ & & & & & & $\mathbf{X}$ & $\mathbf{X}$ & $\mathbf{X}$ & $\mathbf{X} X$ & & & & & & & & & & & \\
\hline $\begin{array}{c}\text { JUAN } \\
\text { BUENO. }\end{array}$ & $\mathbf{X}$ & $x \mid>$ & $\mathbf{X} \mathbf{X}$ & $\mathbf{X}$ & $\mathbf{X}$ & $\mathbf{X}$ & $\mathbf{X} \mid \mathbf{X}$ & $x \mid X$ & $X$ & $X$ & $\mathbf{X}$ & $\mathbf{X}$ & $\mathbf{X}$ & & & $\mathbf{X} X$ & $\mathbf{X}$ & $\mathbf{X}$ & $\mathbf{X} X$ & $\mathbf{X} \mathbf{X}$ & & & & & & & & & & \\
\hline $\begin{array}{l}\text { ALFONSO } \\
\text { MARTÍN. }\end{array}$ & $\mathbf{X}$ & $\mathbf{X} \mid \mathrm{X}$ & $\mathbf{X} \mid \mathbf{X}$ & $\mathbf{X}$ & $\mathbf{X}$ & $\mathbf{X}$ & $\mathbf{X} \mid \mathbf{X}$ & $\mathbf{X} \mid X$ & $\mathbf{x} \mid X$ & $X$ & $|\mathbf{X}|$ & $\mathbf{X}$ & $\mathbf{X}$ & & $\mathbf{X} \mid Y$ & $\mathbf{X} \mathbf{X}$ & $\mathbf{X}$ & $\mathbf{X}$ & $\mathbf{X} X$ & $\mathbf{X} \mathbf{X}$ & $X$ & & & & & & & & & \\
\hline $\begin{array}{l}\text { MARIANO } \\
\text { ESPECIALI. }\end{array}$ & $\mathbf{X}$ & $X \mid Y$ & $\mathbf{X} \mid \mathbf{X}$ & $X$ & $\mathbf{X}$ & $\mathbf{X}$ & $\mathbf{X} \mid \mathbf{Y}$ & $\mathbf{X} \mid X$ & $X$ & $X$ & $\mathbf{X}$ & $\mathbf{X}$ & $\mathbf{X}$ & & $\mathbf{X} \mid$ & $\mathbf{X} \mathbf{X}$ & $\mathbf{X}$ & $\mathbf{X}$ & $\mathbf{X} \mathbf{X}$ & & $X$ & $\mathbf{X}$ & $\mathbf{X} \mathbf{X}$ & $\mathbf{X}$ & $\mathbf{X} \mathbf{X}$ & & & & & \\
\hline $\begin{array}{c}\text { JOSÉ } \\
\text { MOYANO. }\end{array}$ & & & $\mathbf{X} \mid \mathbf{X}$ & $\mathbf{X}$ & $\mathbf{X}$ & $\mathbf{X} \mid Y$ & $\mathbf{X} \mid \mathbf{Y}$ & $\mathbf{X} X$ & $X$ & $\mathbf{X}$ & $\mathbf{X}$ & & $\mathbf{X} \mid$ & & $\mathbf{X} \mid>$ & $\mathbf{X}$ & $\mathbf{X}$ & $\mathbf{X}$ & $\mathbf{X} \mathbf{X}$ & & $X$ & $\mathbf{X}$ & $\mathbf{X} \mathbf{X}$ & $\mathbf{X} X$ & $\mathbf{X} \mathbf{X}$ & $\mathbf{X} \mathbf{X}$ & $\mathbf{X} \mathbf{X}$ & & & $\mathbf{X} \mid \mathbf{X}$ \\
\hline $\begin{array}{l}\text { ANTONIO } \\
\text { ORDÓÑEZ. }\end{array}$ & & & & & & & & & & & & & & & & & & & & & $X$ & $\mathbf{X}$ & $\mathbf{X} \mathbf{X}$ & $\mathbf{X} X$ & $\mathbf{X}$ & & & & & \\
\hline $\begin{array}{c}\text { RAFAEL } \\
\text { GALLARDO }\end{array}$ & & & & & & & & & & & & & & & & & & & & & $X$ & $\mathbf{X}$ & & $\mathbf{X} X$ & & $\mathbf{X} X$ & $\mathbf{X}|\mathbf{X}|$ & & & $\mathbf{X} \mathbf{X}$ \\
\hline $\begin{array}{c}\text { JOSÉ } \\
\text { MOLINA. }\end{array}$ & & & & & & & & & & & & & & & & & & & & & & & & & & & & & & $\mathbf{X} \mid \mathbf{X}$ \\
\hline
\end{tabular}

\footnotetext{
${ }^{262}$ Ingesa en la Capilla en 1807, en la que permanece hasta 1814, en que es expulsado por sus reiteradas faltas de asistencia.

${ }^{263}$ Ingresa en la Capilla en 1807.

${ }^{264}$ Ingresa en la Capilla en 1820.

${ }^{265}$ Además de los citados, hay dos referencias a otros tiples que aparecen una sola vez en las actas, por lo que deducimos que estuvieron de paso, o a prueba por un corto espacio de tiempo. Son, Cascagni en 1794 y Longanini en 1803.
} 


\title{
5.3.2. CONTRALTOS.
}

\author{
D. José de los Ríos, contralto. ${ }^{266}$ \\ D. Rafael García, contralto y tenor. ${ }^{267}$ \\ D. Juan García, contralto. ${ }^{268}$ \\ D. Josef Cheist, contralto. ${ }^{269}$ \\ D. Nicolás Anguita, contralto. ${ }^{270}$ \\ D. Fermín Espinosa, contralto. ${ }^{271}$ \\ D. José Luis de los Heros, contralto. ${ }^{272}$
}

\footnotetext{
${ }^{266}$ Ya está en la Capilla en 1785, y en ella permanece hasta su muerte en 1803.

267 Aunque cuando llegó Balius en 1785, ejercía de tenor, al poco tiempo aparece en las actas como contralto. Fue uno de los insubordinados que provocaron la marcha de Balius a Madrid. "Es de estatura regular, grueso, y no mal agestado, bonito, hombre de bastantes palabras, y no muy [¿?]. Se suprimió esta Capellanía, cuando se le colocó a este Señor y lo esta mas de cincuenta años porque aunque sus principios fueron de Contrabajo, y lo tocó tan mal, después fue Tenor y lo hizo peor y ha cantado de tanto gusto, y con tanta gana, que ni en el primero coro, ni en el segundo coro jamás ha hecho nada. Algún aspergillo y algunas pasiones, pues para esto le dio el naipe, es el producto que ha dado en la Santa Iglesia. Pero óigale usted (es hablando con el Maestro de Capilla Don Juan Cuevas que estaba recién venido a la Catedral), obtuvo dispensa para ser músico porque lo necesitaba, es decir, le suplieron el no saber música”. POZO, Juan Lucas del: Caricaturas de los Músicos de la Santa Iglesia Catedral de Córdoba. Córdoba, 1827, mecanografiado, pág. 329.

${ }^{268}$ Sabemos de él que en 1790 está durante la Semana Santa cantando con la Capilla. Está a prueba, su voz no disgusta, pero parece que el ser manco le trae alguna dificultad para desarrollar otras tareas. El resultado es que no vuelve a aparecer en las actas.

${ }^{269}$ Ingresa en la Capilla de Música en Enero de 1795. Pero en 1797 se marcha por "hallarse sirviendo otra Capilla de Música nombrada del Príncipe Pío, en la Villa y Corte de Madrid”. A.C.C. Actas Capitulares. Martes 19 de Septiembre de 1797. T. 95, fol. 181 v.

${ }^{270}$ En 1800 ingresa en la Capilla. "Aseadito, bonito, no mal Cleriguillo se le resbaló un pie en la Sierra de Jaén y vino rodando a Córdoba y no se mató porque cayó de pies, que sino...y aunque contra la voluntad de Dios quiso ser músico, porque si S.M. lo hubiera criado para el caso le hubiera dado voz, él dice que es contralto pero yo no he oído a ninguno por inteligente que sea, que le haya dado nombre: puede que Vd. Sr. Maestro se lo encuentre pero lo dificulto. Trata de compositor; y es aplicado, aunque no tenía gusto en que Vd. viniera, por eso no se enfade Vd., que es buen muchacho". POZO, Juan Lucas del: Caricaturas de los Músicos de la Santa Iglesia Catedral de Córdoba. Córdoba, 1827, mecanografiado, pág. 330. "Murió el día 6 de Enero de 1847 en esta Ciudad, D. Nicolás Anguita y Moya, Capellán músico de la Capilla de San Acacio, de la Santa Iglesia de Córdoba”. POZO CÁCERES, Juan Lucas del. “Músicos fallecidos desde 1826”. En Colección de Obras. Córdoba, 1863. Ms., pág. 393.

${ }^{271}$ Fue examinado y aprobado para entrar en la Capilla en 1802. Pero en 1804 es nombrado Racionero Medio de la Catedral de Salamanca, por lo que renuncia a su plaza.

${ }^{272}$ Ingresa en la Capilla de Música en Octubre de 1803. Además de músico, se hizo conocido por sus intervenciones en la Tertulia Patriótica establecida en Córdoba en 1820.
} 


\section{CONTRALTOS}

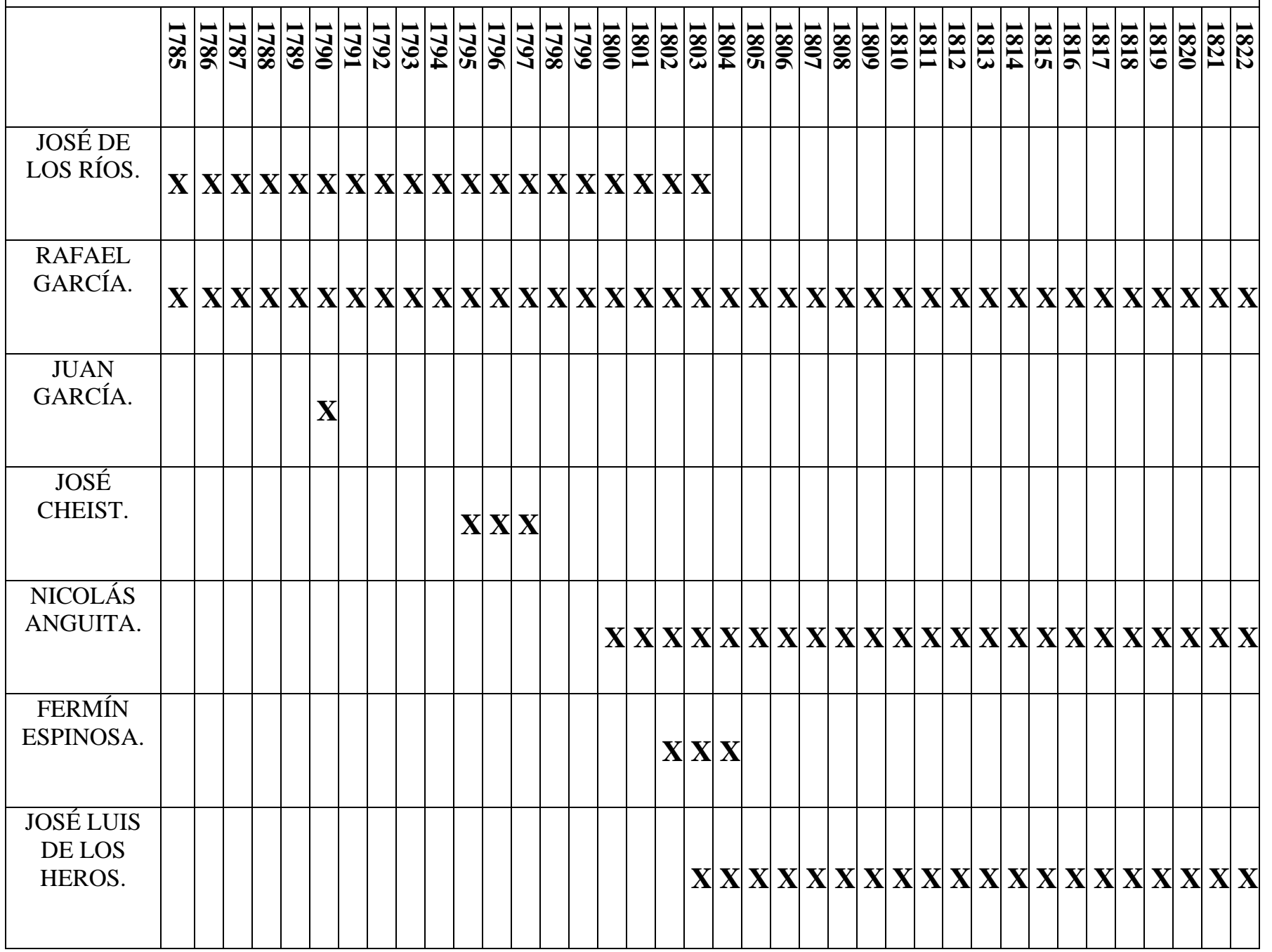

\subsubsection{TENORES.}

D. José Cabrera, tenor. ${ }^{273}$

D. Ignacio Casado, tenor. ${ }^{274}$

D. Pedro Marciag, tenor. ${ }^{275}$

D. Juan Franco, tenor. ${ }^{276}$

D. Sebastián Cabezón, tenor. ${ }^{277}$

\footnotetext{
${ }^{273}$ Sólo coincidió cuatro años con Balius. De 1785 a 1788.

${ }^{274}$ Éste tenor estuvo en la Capilla de Jaime Balius desde 1785 hasta 1790.

${ }^{275}$ En 1785 ya figura como miembro de la Capilla; en 1797 solicita al Cabildo su jubilación y éste accede.

${ }^{276}$ Está en la Capilla desde 1785 a 1798 en que fallece.
} 
D. Antonio Gil, tenor. ${ }^{278}$

D. Ángel Arteaga, tenor. ${ }^{279}$

D. Manuel Gutierrez Ravé, tenor. ${ }^{280}$

D. Ángel Moreno, tenor. ${ }^{281}$

D. José Ruiz, tenor. ${ }^{282}$

${ }^{277}$ Aparece en las actas en 1790. Al año siguiente, también aparece muy brevemente en las actas un tenor procedente de Madrid, Tadeo Mintegui. No vuelve a aparecer su nombre en adelante, por lo que probablemente estuvo poco tiempo, utilizando esta Capilla como lugar de paso hacia otro destino.

${ }^{278}$ Ingresa en la Capilla en 1792. Será uno de los personajes más nombrados en las actas capitulares, con constantes peticiones de ayuda de costa y otros asuntos. Desde la muerte de Balius en 1822 y hasta la llegada de Juan Cuevas como nuevo Maestro en 1827, Gil tendrá a su cargo de forma interina la dirección de la Capilla de Música.

${ }^{279}$ Ingresa en 1798. Vino a Córdoba traído por el Maestro de Capilla Jaime Balius y Vila, que fue a buscarlo expresamente a Santo Domingo de la Calzada. En Octubre de 1822 fue acusado de conspiración y rebelión contra el sistema constitucional, comunicándole el Cabildo la sentencia pronunciada contra él por la audiencia territorial de Castilla La Vieja y León. Dicha sentencia lo condenó a ocho años de confinamiento en una de las Islas Baleares, bajo la vigilancia de las autoridades civiles y militares. Cf. A.C.C. Actas Capitulares. Lunes 14 de Octubre de 1822. T. 106, fol. 246r.

${ }^{280}$ Ingresa en la Capilla de Música en 1803. "El 3 de Febrero de 1849, Sábado a las 3 en punto de la tarde falleció en esta ciudad el señor Racionero Medio D. Manuel Gutierrez Ravé. Haviendo obtenido este señor una Capellanía de músico tenor de la Capilla de San Antonino de esta Santa Iglesia, después pasó a Málaga donde obtuvo una capa de coro de músico tenor de aquella Santa Iglesia Catedral y después fue agraciado por S.M. con la media ración de esta Santa Iglesia Catedral de Córdoba, la que disfrutó hasta su fallecimiento. En la noche del 3 fue depositado en el panteón de la Salud donde se mantuvo insepulto hasta el Domingo siguiente 4 por la tarde que a las cuatro de ella se le dio sepultura. El Cabildo le hizo su funeral el Lunes 5 por la mañana después de Nona. Testó ante D. Rafael Fernandez Cañete y Grande Escribano público y del número de esta ciudad. Murió en una casa en la plazuela de D. Jerónimo Páez, donde vivía. La muerte del señor Gutierrez Ravé la ocasionó el atropello que recibió de un carro en una de las calles de esta ciudad hayándose de paseo. Así fue que Domingo 4 siendo reconocido su cadáver por los facultativos nombrados judicialmente cuyo auto duró desde las 7 hasta las diez de su mañana, abriendo el cráneo del difunto declararon que no había otro motivo de su muerte más que dicho atropello del carro. Por lo cual se siguió expediente contra el agresor”. POZO CÁCERES, Juan Lucas del. "Noticia del fallecimiento de algunos canónigos de Córdoba”. En Colección de Obras. Córdoba, 1863. Ms., pág. 360.

281 "Como miente tanto no podemos estar a su dicho, no se sabe su origen. Lo cierto es que vino a Córdoba de Canoche del mercat. ¿Vd. lo entiende Sr. Maestro?. Entró en Coro con condición pero antes del año se le dio una Culebra, y salio de él y al cabo de veinte años volvió casado y con hijos, y lo tiene Vd. a sus órdenes. No se fíe Vd. de él; su voz está cansada, sabe su obligación. Y aunque verdad o mentira ha sido Capa”. POZO, Juan Lucas del: Caricaturas de los Músicos de la Santa Iglesia Catedral de Córdoba. Córdoba, 1827, mecanografiado, pág. 331. "En el día 17 de Agosto de 1849 a las diez y cuarto de su mañana falleció en el Hospital General de esta Ciudad D. Ángel Moreno, músico tenor de la Santa Iglesia Catedral, al que se le dio sepultura la mañana del día siguiente sin hacerle ninguna clase de funeral”. POZO CÁCERES, Juan Lucas del. "Músicos fallecidos desde 1826”. En Colección de Obras. Córdoba, 1863. Ms., pág. 393.

${ }^{282}$ Ingresa en la Capilla de Música en 1816. 


\section{TENORES}

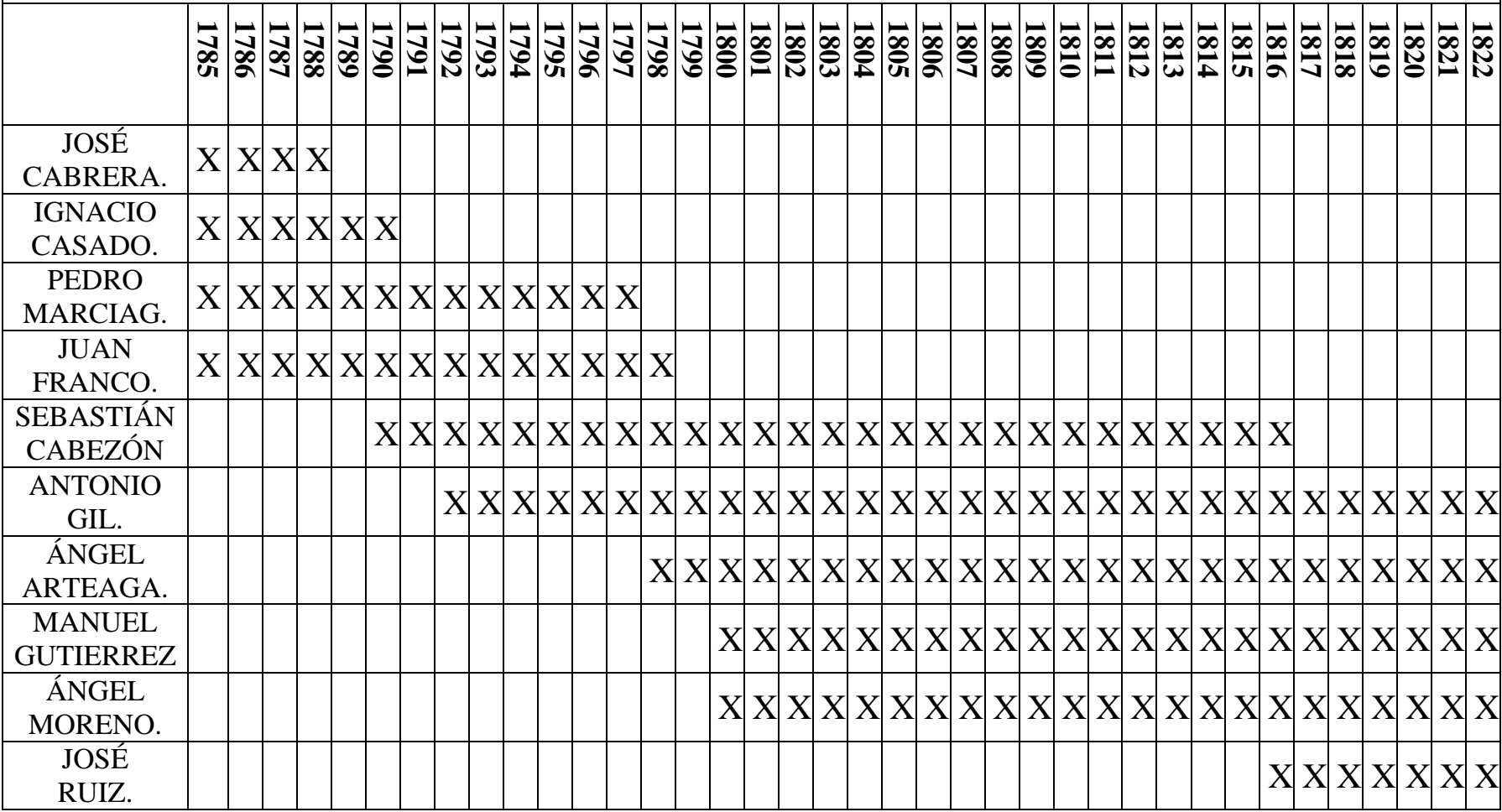

\subsubsection{BAJOS.}

D. Manuel Álvarez, bajo. ${ }^{283}$

D. Benito Torrellas, bajo. ${ }^{284}$

D. Salvador Serrano, bajo. ${ }^{285}$

D. Gregorio Muñoz Villareal, bajo. ${ }^{286}$

\footnotetext{
${ }^{283}$ Desempeña el papel de Bajo en la Capilla de Música desde 1790 a 1808 en que se marcha a Cartagena. ${ }^{284}$ Ingresa en la Capilla de Música en 1804. En ella permanece hasta 1816, en que se marcha por "haberlo hecho Su Majestad, músico de Cámara y de su Capilla”. A.C.C. Actas Capitulares. Miércoles 26 de Junio de 1816. T. 103, fol. $346 \mathrm{v}$.

${ }^{285}$ Ingresa en 1805. "A cualquier cosa se llaman bajo. Se han empeñado en que ha de ser músico y yo en que no. Y Vd. se empeñará en lo mismo que digo. Su voz parda y fingida, su gesto, y su escuela descuella hoy entre la Capilla; tiene su poquito y algo más de amor propio, y aunque algo feo y nada hábil es el mejor ecijano que ha salido de esta tierra". POZO, Juan Lucas del: Caricaturas de los Músicos de la Santa Iglesia Catedral de Córdoba. Córdoba, 1827, mecanografiado, pág. 331.

${ }^{286}$ Ingresa en 1816. "Su voz está mohosa de no usarla, debe ser grande, pero como no hemos oído más que una cuarta parte no le puedo hablar a Vd. Ha principiado a aprender música a la edad de cincuenta años, con que sáquele Vd. púa al trompo". POZO, Juan Lucas del: Caricaturas de los Músicos de la Santa Iglesia Catedral de Córdoba. Córdoba, 1827, mecanografiado, pág. 331. "Murió a lo que creo la noche del 15 de Noviembre de 1846 en esta Ciudad D. Gregorio Villareal, Capellán de San Pedro de la Santa Iglesia Catedral de Córdoba". POZO CÁCERES, Juan Lucas del. "Músicos fallecidos desde 1826”. En Colección de Obras. Córdoba, 1863. Ms., pág. 393.
} 


\begin{tabular}{|c|c|c|c|c|c|c|c|c|c|c|c|c|c|c|c|c|c|c|c|c|c|c|c|c|c|c|c|c|c|}
\hline \multicolumn{30}{|c|}{ BAJOS } \\
\hline & 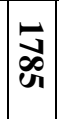 & $\vec{s}$ & $\vec{~}$ & 놈 & $\overrightarrow{0}$ & & bे & & bु & बे & ज্ & & & & & $\vec{b}$ & $\mid \begin{array}{l}\vec{\infty} \\
\ddot{\phi} \\
\end{array}$ & & $\vec{b}$ & & 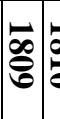 & & $\overrightarrow{\mathbf{e}}$ & $\vec{\omega} \underset{\vec{\omega}}{\vec{\Phi}}$ & \begin{tabular}{l|l}
$\vec{\infty}$ & $\vec{\infty}$ \\
$\vec{v}$
\end{tabular} & $\vec{\sigma} \underset{⿱ 亠 凶}{\vec{\sigma}}$ & $\mid \begin{array}{ll}\infty \\
\infty\end{array}$ & 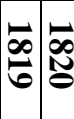 & : \\
\hline $\begin{array}{l}\text { MANUEL } \\
\text { ÁLVAREZ. }\end{array}$ & & & & & $\mathbf{X}$ & & $\mathbf{X} \mid \mathbf{Y}$ & $\mathbf{X} \mid X$ & $\mathbf{x}$ & $X$ & & & & & & $\mathbf{X} \mathbf{X}$ & $\mathbf{X}$ & & $\mathbf{X} \mathbf{X}$ & $X$ & & & & & & & & & \\
\hline $\begin{array}{c}\text { BENITO } \\
\text { TORRELLAS }\end{array}$ & & & & & & & & & & & & & & & & & $\mathbf{X}$ & $\mathbf{X}$ & & $X$ & $\mathbf{X}$ & & $\mathbf{X} \mathbf{X}$ & $\mathbf{X}$ & & $X$ & & & \\
\hline $\begin{array}{l}\text { SALVADOR } \\
\text { SERRANO. }\end{array}$ & & & & & & & & & & & & & & & & & & $\mathbf{X}$ & & & $\mathbf{X}$ & $\mathbf{X} \mathbf{X}$ & $\mathbf{X} \mathbf{X}$ & $\mathbf{X}$ & & $\mathbf{X} X$ & $\mathbf{x} \mid \mathbf{X}$ & $\mathbf{X}$ & $\mathbf{x} X \mathbf{X}$ \\
\hline $\begin{array}{l}\text { GREGORIO } \\
\text { MUÑOZ. }\end{array}$ & & & & & & & & & & & & & & & & & & & & & & & & & & $\mathbf{X} \mathbf{X}$ & $\mathbf{x} \mid \mathbf{X}$ & $\mathbf{X} X$ & $\mathbf{X}|\mathbf{X}| \mathbf{X}$ \\
\hline
\end{tabular}

\subsection{LOS INSTRUMENTISTAS.}

La entrada de los instrumentos en la Capilla de Música está fechada algo más tarde que la de los cantores. "Los ministriles con instrumentos de viento -flautas, chirimías, sacabuches, bajones y cornetas- se incorporan a la capilla de Música en torno al 4 de enero de 1528 ". ${ }^{287}$ Sin embargo, al cabo de un año y tres meses, y debido a su comportamiento, fueron despedidos. "El comportamiento de los ministriles no fue del agrado del cabildo por desacato. [...] El obispo don Francisco Álvarez de Toledo (1523-1537) y todos los canónigos fueron unánimes en despedirlos el 7 de abril de 1529”. ${ }^{288}$ En los años sucesivos su contratación es intermitente hasta que progresivamente se va regularizando. También era muy habitual que los instrumentistas supieran tocar más de un instrumento. En el siglo XVII, y según Pérez Linde, su situación era la siguiente:

“En el siglo XVII, el concepto de ministril era el de un músico instrumentista, que generalmente sabía tocar más de un instrumento y que acompañaba a los coros doblando al unísono o a la octava alguna de las líneas importantes de la polifonía. Los instrumentistas eran de viento y en algunas ocasiones también de cuerda. Los más

\footnotetext{
${ }^{287}$ Cf. NIETO CUMPLIDO, Manuel. “La música en la Catedral de Córdoba (1236-1577)”, en AA.VV. El Patrimonio Histórico-Musical de Córdoba. Córdoba, Ayuntamiento de Córdoba, 2004, pág. 77.

${ }^{288}$ Ibid.
} 
característicos eran: flautas, trompas, fagotes, bajón dulce, chirimías, cornetillas y contrabajos. El arpa se empleó durante todo el siglo como instrumento acompañante de cuerda". 289

Sus obligaciones incluían además de tocar en el Coro, asistir a procesiones: “< $<$ Han de ser obligados los ministriles a tañer en el dicho choro a misa y primeras y segundas vísperas y en las procesiones en todas las fiestas de guardar y las que tuvieren solennidad de seis capas aunque no sean de guardar, y en las procesiones generales donde el cabildo fuere y en los maytines de Navidad $>>$ ". ${ }^{900}$

Como veremos en el apartado referente a la plantilla instrumental, en la época de Balius estos instrumentistas eran fundamentalmente: oboes, trompas, bajones, violines, violoncellos y contrabajos. En menor medida estaban presentes flautas y clarines. Y muy escasamente, la viola. También y como sucedía en épocas anteriores, estos músicos solían tocar más de un instrumento, y en ocasiones tres o más. Esto dificulta a veces su asignación concreta a uno o a otro, ya que en las actas capitulares pueden venir citados sus nombres asociados a distintos instrumentos según el momento o la circunstancia. Por ejemplo, si por causa de la edad perdían la dentadura, los instrumentistas de viento solían pasar a tocar alguno de cuerda o a cumplir otra función dentro de la Capilla. O si había alguna vacante de algún instrumento solista, el Maestro podía pedirle a otro músico de la Capilla que la ocupara temporalmente.

No hemos encontrado constancia de que Balius utilizara el arpa, al menos escribiendo una particella con tal nombre. Sin embargo es probable que el papel de acompañamiento sí pudiera hacerlo en alguna ocasión dicho instrumento. Nos lleva a pensar esto el hecho de que en las Cuentas de Fábrica se haga referencia ocasional a un arpista, Nicolás Hinestrosa. ${ }^{291}$

\footnotetext{
${ }^{289}$ PÉREZ LINDE, Manuel. Segunda mitad del siglo XVII: Música en la Catedral de Córdoba a través de Bartolomé García Guerrero. Córdoba, 2002, pág. 25. Tesina. Se conserva en el A.C.C.

${ }^{290}$ NIETO CUMPLIDO, Manuel. "La música en la Catedral de Córdoba (1236-1577)", en AA.VV. El Patrimonio Histórico-Musical de Córdoba. Córdoba, Ayuntamiento de Córdoba, 2004, pág. 79. A su vez cita: A.C.C. Actas Capitulares, 18, ff. 85v.-90v.

${ }^{291}$ A.C.C. Cuentas de Fábrica de los años 1787-1789. T. 4042, s/f. En otras Capillas sí está más contrastada la presencia de arpistas, como sucede en la Capilla Real de Granada. Allí, el día 13 de Abril de 1791, y tras una oposición en la que debió enfrentarse a otros aspirantes, toma posesión de su plaza Braulio Ugena. Cf. LÓPEZ CALO, José. Documentario Musical de la Capilla Real de Granada. Granada, Centro de Documentación Musical de Andalucía (Junta de Andalucía), 2005, pág. 421.
} 
Además de los músicos que citaremos a continuación, otros muchos, tanto cantantes como instrumentistas, pasaron por la Catedral de Córdoba durante el período que estamos estudiando (1785-1822). La mayoría de ellos vinieron a hacer oposiciones que finalmente no ganaron, con lo que se tenían que conformar con las ayudas de costa que les daba el Cabildo para volver a sus lugares de origen. Algunos se quedaron a prueba durante un tiempo, sobre todo si coincidía con alguna baja temporal o definitiva de algún músico de la Capilla, aunque al final (y una vez abonados sus servicios) siguieran el camino de los anteriores, regresando a sus ciudades. Los menos, aprobaron su oposición, pero inmediatamente siguieron presentándose a otras plazas con mejores condiciones en diferentes catedrales o monasterios, y al poco tiempo se marcharon. Curiosamente, estos últimos solían ser extranjeros. Nombres como Cascagni, Longanini y otros, pasan fugazmente por Córdoba para dirigirse a tierras más lejanas.

La relación cronológica de los instrumentistas que ejercieron su labor en algún momento, durante el tiempo en que Jaime Balius fue Maestro de Capilla es la que vemos a continuación.

\subsubsection{VIOLINES.}

D. Juan José de la Peña, violín. ${ }^{292}$

D. Juan Busquets, violín. ${ }^{293}$

D. Mathias Redel, primer violín. ${ }^{294}$

D. Pascual Redel, violín. ${ }^{295}$

D. Rafael del Río, violín y contralto. ${ }^{296}$

\footnotetext{
292 Aparece en las actas capitulares de 1788. Sin embargo en 1793 ya se habla de su muerte en dichas actas.

293 Está en la Capilla desde los primeros tiempos de Jaime Balius. Fue uno de los responsables de las desavenencias con el Maestro de Capilla que al parecer provocaron la marcha de éste a Madrid en 1787.

${ }^{294}$ Desde 1785 nos lo encontramos en las actas. Muere en 1804. Fue durante todo este tiempo el primer violín de la Capilla de Música.

295 También es nombrado en las actas en 1785. "No cuente Vd. con él porque no hace más que encomendarse a Dios, y pedir ayudas de costas”. POZO, Juan Lucas del: Caricaturas de los Músicos de la Santa Iglesia Catedral de Córdoba. Córdoba, 1827, mecanografiado, pág. 333.

${ }^{296}$ En 1790 ya consta en las actas. Además de violinista era contralto. "Alumno del Colegio de Infantes de Coro del Santo Ángel de la Guarda y basta, fue capa de Coro en Origuela (ique bueno nadaría el negocio!) y después nos vino a Córdoba y su Capellanía se hizo Beneficio simple en esta Sr. porque aunque algún tiempo tocó de mala gana el Violín, para excusarse de este trabajo se fingió loco y no hizo lo que todos sino la mitad porque un loco hace ciento y este no ha hecho mas que a cincuenta que es el número de capitulares que lo toleran. Es rubio, delgado, y de su voz no hablemos porque no tendrá Vd. el
} 

D. Lope de Mora, violín. ${ }^{297}$
D. Josef Las, violín, flauta, oboe y fagot. ${ }^{298}$
D. Josef Vasconcelos, violín. ${ }^{299}$
D. Miguel Reinaldi, primer violín. ${ }^{300}$
D. Juan de Mora, violín. ${ }^{301}$
D. José Talavera, violín. ${ }^{302}$

\begin{tabular}{|c|c|c|c|c|c|c|c|c|c|c|c|c|c|c|c|c|c|c|c|c|c|c|c|c|c|c|c|c|c|c|c|c|c|c|c|}
\hline \multicolumn{36}{|c|}{ VIOLINES } \\
\hline & : & : & 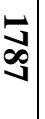 & & & 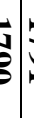 & & & & & & t) & & 동 & & 冚 & & : & 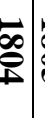 & & & & & & & & & & 电 & & & $\left(\begin{array}{l}\infty \\
\infty \\
\infty\end{array}\right)$ & & & b \\
\hline $\begin{array}{l}\text { JUAN DE LA } \\
\text { PEÑA. }\end{array}$ & $\mathbf{X}$ & $\mathbf{X}$ & $\mathbf{X}$ & & & & $\mathbf{X}$ & & & & & & & & & & & & & & & & & & & & & & & & & & & & \\
\hline $\begin{array}{c}\text { JUAN } \\
\text { BUSQUETS. }\end{array}$ & $\mathbf{X}$ & $\mathbf{X}$ & $\mathbf{X}$ & $\mathbf{X} \mid$ & $\mathbf{X}$ & $\mathbf{X}$ & $\mathbf{X}$ & & & $\mathbf{X} \mid Y$ & & $X$ & $\mathbf{X}$ & $\mathbf{X}$ & & & & & & & & & & & & & & & & & & & & & \\
\hline $\begin{array}{l}\text { MATIAS } \\
\text { REDEL. }\end{array}$ & $\mathbf{X}$ & $\mathbf{X}$ & $\mathbf{X}$ & $\mathbf{X}$ & $\mathbf{X}$ & $\mathbf{X}$ & $\mathbf{X}$ & $\mathbf{X} \mathbf{2}^{2}$ & $\mathbf{X} \mid \mathbf{2}$ & $\mathbf{X} \mid Y$ & $\mathbf{X}$ & $\mathbf{X}$ & $\mathbf{X}$ & $\mathbf{X}$ & $\mathbf{X}$ & $\mathbf{X}$ & $\mathbf{X}$ & & $\mathbf{X}$ & & & & & & & & & & & & & & & & \\
\hline $\begin{array}{l}\text { PASCUAL } \\
\text { REDEL. }\end{array}$ & $\mathbf{X}$ & $\mathbf{X}$ & $\mathbf{X}$ & $\mathbf{X}$ & $\mathbf{X}$ & $\mathbf{X}$ & $\mathbf{X}$ & $\left.\mathbf{X}\right|^{2}$ & $\mathbf{X} \mid$ & $\mathbf{X} \mid 2$ & 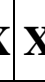 & $X$ & $\mathbf{X}$ & $\mathbf{X}$ & $\mathbf{X}$ & $\mathbf{X}$ & $\mathbf{X}$ & $\mathbf{X}$ & $\mathbf{X}$ & $\mathbf{X}$ & $\mathbf{X}$ & $\mathbf{x}$ & $\mathbf{X} \mid \mathbf{2}$ & $\mathbf{X} \mid>$ & $\mathbf{X} \mid$ & $\mathbf{X}$ & & & $x$ & & $X$ & $\mathbf{X}$ & $\mathbf{X}$ & & $\mathbf{X}$ \\
\hline $\begin{array}{l}\text { RAFAEL } \\
\text { DEL RÍO. }\end{array}$ & & & & & & $\mathbf{X}$ & $\mathbf{X}$ & $\mathbf{X}$ & $\mathbf{X} \mid 2$ & $\mathbf{X} \mid 2$ & $X$ & $\mathbf{X}$ & $\mathbf{X}$ & $\mathbf{X}$ & $\mathbf{X}$ & $\mathbf{X}$ & $\mathbf{X}$ & $\mathbf{X}$ & $\mathbf{X}$ & $\mathbf{X}$ & $\mathbf{X}$ & $\mathbf{X}$ & $\mathbf{X}$ & $\mathbf{X}$ & $\mathbf{X} \mid \boldsymbol{Z}$ & $\mathbf{X} X$ & $\mathbf{X}$ & $X$ & $\mathrm{X}$ & $X$ & & $\mathbf{X}$ & $\mathbf{X}$ & $\mathbf{X} \mid \mathbf{X}$ & $\mathbf{X} \mathbf{X}$ \\
\hline $\begin{array}{l}\text { LOPE DE } \\
\text { MORA. }\end{array}$ & & & & & & & & & & $\mathbf{X} \mid Y$ & $X$ & $X$ & $\mathbf{X}$ & $\mathbf{X}$ & $\mathbf{X}$ & $\mathbf{X}$ & $\mathbf{X}$ & $\mathbf{X}$ & $\mathbf{X}$ & $\mathbf{X}$ & $\mathbf{X}$ & $\mathbf{x}$ & & & $\mathbf{X} \mid$ & & & & $X$ & & $X$ & $\mathbf{X}$ & $\mathbf{X}$ & & \\
\hline $\begin{array}{l}\text { JOSÉ } \\
\text { LAS. }\end{array}$ & & & & & & & & & & $Y$ & & $X$ & $\mathbf{X}$ & $\mathbf{X}$ & $\mathbf{X}$ & $\mathbf{X}$ & $\mathbf{X}$ & $\mathbf{X}$ & $\mathbf{X}$ & $\mathbf{X}$ & & $\mathbf{X}$ & & & $\mathbf{X} \mid Y$ & & & & & & & & & & \\
\hline $\begin{array}{c}\text { JOSÉ } \\
\text { VASCONCE- } \\
\text { LOS }\end{array}$ & & & & & & & & & & & & & & & $\mathbf{X}$ & $\mathbf{X}$ & $\mathbf{X}$ & & $\mathbf{X}$ & $\mathbf{X}$ & & $\mathbf{X}$ & & & & & & & & & & & & & \\
\hline $\begin{array}{c}\text { MIGUEL } \\
\text { REINALDI. }\end{array}$ & & & & & & & & & & & & & & & & & & & & & $\mathbf{X}$ & $\mathbf{x}$ & $\mathbf{X} \mid z$ & $\mathbf{X} \mid Y$ & $\mathbf{X} \mid$ & $\mathbf{X} X$ & $\mathbf{X} \mid \mathrm{X}$ & $X$ & $x$ & & & $x$ & & $\mathbf{X} \mid \mathbf{X}$ & $\mathbf{X} \mathbf{X}$ \\
\hline
\end{tabular}

gusto de oírlo”. POZO, Juan Lucas del: Caricaturas de los Músicos de la Santa Iglesia Catedral de Córdoba. Córdoba, 1827, mecanografiado, pág. 329.

${ }^{297}$ Fue Niño de Coro, después Acólito y en 1794 pasa a ocupar plaza de violinista. Estuvo casado con Josefa Bach, hija del organista $2^{\circ}$ de la Capilla, José Benito Bach.

298 Balius recomienda especialmente la contratación de este músico en 1795, ya que tocaba excepcionalmente varios instrumentos.

${ }^{299}$ Aparece en las actas en 1803. También se le nombra como “el portugués”.

${ }^{300}$ Sucede a Mathias Redel cuando este muere, y en 1805 pasa a ocupar el puesto de primer violín de la Capilla. También en 1805, se cita fugazmente a Fructuoso Gómez, un violinista que, procedente de Sevilla, entra en la Capilla. Sin embargo, no volvemos a tener noticias de él.

${ }^{301}$ Hermano de Lope de Mora, sigue como él todos los escalafones, desde Niño de Coro, Acólito, hasta ingresar en la Capilla de Música en 1806.

${ }^{302}$ Ingresa en la Capilla de Música en 1816. "Parece un puchinela, y en tiempo de antaño también quiso peer en botija; pero arrepentidos quiere Dios, y el Cabildo lo mismo. Es un violincito que puede suplir”. POZO, Juan Lucas del: Caricaturas de los Músicos de la Santa Iglesia Catedral de Córdoba. Córdoba, 1827, mecanografiado, pág. 337. “A los cinco días de ser atendido de pulmonía falleció en esta Ciudad en la noche del 10 de Febrero de 1863 D. José Talavera y Blo., violinista que fue de la Catedral y compañero mío del Colegio”. POZO CÁCERES, Juan Lucas del. “Músicos fallecidos desde 1826”. En Colección de Obras. Córdoba, 1863. Ms., pág. 397. 


\begin{tabular}{|c|c|c|c|c|c|c|c|c|c|c|c|c|c|c|c|c|c|c|c|c|c|c|c|c|c|c|c|c|c|c|c|}
\hline $\begin{array}{c}\text { JUAN DE } \\
\text { MORA. }\end{array}$ & & & & & & & & & & & & & & & $\mathbf{X}$ & $\mathbf{X}$ & $\mathbf{X}$ & $\mathbf{X}$ & $\mathbf{X}$ & $\mathbf{X}$ & $\mathbf{X}$ & $\mathbf{X}$ & $\mathbf{X}$ & $\mathbf{X}$ & $\mathbf{X}$ & $\mathbf{X}$ & $\mathbf{X}$ & $\mathbf{X}$ & $\mathbf{X}$ & $\mathbf{X}$ & $\mathbf{X}$ \\
\hline $\begin{array}{c}\text { JOSÉ } \\
\text { TALAVERA. }\end{array}$ & & & & & & & & & & & & & & & & & & & & & & & $\mathbf{X}$ & $\mathbf{X}$ & $\mathbf{X}$ & $\mathbf{X}$ & $\mathbf{X}$ & $\mathbf{X}$ & $\mathbf{X}$ \\
\hline
\end{tabular}

\subsubsection{VIOLONCELLOS Y CONTRABAJOS.}
D. Vicente Marín, violoncello. ${ }^{303}$
D. Rafael Marín, violoncello. ${ }^{304}$
D. Juan Galvez, contrabajo. ${ }^{305}$
D. Francisco Cascante, contrabajo. ${ }^{306}$
D. Francisco de Paula López, contrabajo. ${ }^{307}$

\begin{tabular}{|c|c|c|c|c|c|c|c|c|c|c|c|c|c|c|c|c|c|c|c|c|c|c|c|c|c|c|c|}
\hline \multicolumn{28}{|c|}{ VIOLONCELLOS Y CONTRABAJOS } \\
\hline & 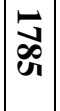 & & $\vec{\bullet}$ & & 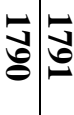 & : & 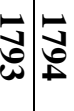 & 悹 & & $\mid \begin{array}{l}\mid \\
0\end{array}$ & $\overrightarrow{0}$ & $\vec{s}$ & 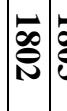 & & : & के & \begin{tabular}{c|c|}
$\overrightarrow{0}$ \\
$\overrightarrow{0}$
\end{tabular} & 包 & $\stackrel{\infty}{=}$ & $\stackrel{a}{a}$ & \begin{tabular}{l|l}
$\vec{\omega}$ & $\vec{\omega}$ \\
$\vec{\omega}$ &
\end{tabular} & $\begin{array}{l}\vec{b} \\
\vec{s} \\
\vec{v}\end{array}$ & 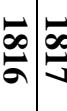 & $\overrightarrow{0}$ & & 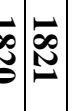 & \\
\hline $\begin{array}{c}\text { VICENTE } \\
\text { MARÍN. } \\
\text { VIOLONCELO. }\end{array}$ & $\mathbf{X}$ & $\mathbf{X} \mid \mathbf{X}$ & $\mathbf{X} \mathbf{X}$ & $\mathbf{X}$ & $\mathbf{X} \mathbf{X}$ & $\mid \mathbf{X}$ & $\mathbf{X} \mathbf{X}$ & $\mathbf{X}$ & $\mathbf{X} \mid \mathbf{X}$ & $\mathbf{x} \mid \mathbf{X}$ & $|\mathbf{X}|>$ & $\mathbf{X} \mid \mathbf{X}$ & $\mathbf{X}$ & & $\mathbf{X}|\mathbf{X}|$ & $\mathbf{X}$ & $\mathbf{X} \mid \mathbf{X}$ & $\mathbf{X} \mid \mathbf{X}$ & $\mathbf{X}|\mathbf{X}|$ & $|X| Y$ & \begin{tabular}{l|l}
$\mathbf{X}$ & $\mathbf{X}$
\end{tabular} & $\mathbf{X}|\mathbf{X}|$ & $\mathbf{X} \mid \mathbf{X}$ & $\mathbf{X}|\mathbf{X}|$ & & & \\
\hline $\begin{array}{c}\text { RAFAEL } \\
\text { MARÍN. } \\
\text { VIOLONCELO. }\end{array}$ & & & & & & & & & & & & & & & $\mathbf{X}$ & $\mathbf{X} \mid \mathbf{X}$ & $\mathbf{X} \mid \mathbf{X}$ & $\mathbf{X} \mid \mathbf{X}$ & $\mathbf{X} \mid \mathbf{X}$ & $\mathbf{X}$ & $\mathbf{X} \mid \mathbf{X}$ & $\mathbf{X}|\mathbf{X}|$ & $\mathbf{X} \mid \mathbf{X}$ & $\mathbf{X} \mid \mathbf{X}$ & & $\mathbf{X} \mathbf{X}$ & $X$ \\
\hline $\begin{array}{c}\text { JULIÁN } \\
\text { GALVEZ. } \\
\text { CONTRABAJO. }\end{array}$ & $\mathbf{X}$ & $\mathbf{X} \mid \mathbf{X}$ & $\mathbf{X} \mathbf{X}$ & $\mathbf{X}$ & $\mathbf{X} \mathbf{X}$ & $\mathbf{X} \mid \mathbf{X}$ & $\mathbf{X} \mathbf{X}$ & $\mathbf{X}$ & $\mathbf{X} \mid \mathbf{X}$ & $\mathbf{X} \mathbf{X}$ & $|\mathbf{X}| Y$ & $\mathbf{X}|\mathbf{X}|$ & $\mathbf{X}$ & $\mathbf{X} \mid \mathbf{X}$ & $\mathbf{Y} \mid \mathbf{X}$ & $\mathbf{X} \mid \mathbf{X}$ & $\mathbf{X} \mid \mathbf{X}$ & $\mathbf{X} \mid \mathbf{X}$ & $\mathbf{X}|\mathbf{X}|$ & $\mathbf{X}$ & $\mathbf{X} \mid \mathbf{X}$ & $\mathbf{X} \mid \mathbf{X}$ & $\mathbf{X} \mid \mathbf{X}$ & $\mathbf{X} \mid \mathbf{X}$ & $\mathbf{X} \mathbf{X}$ & $\mathbf{X}$ & \\
\hline $\begin{array}{l}\text { FRANCISCO } \\
\text { CASCANTE. } \\
\text { CONTRABAJO. }\end{array}$ & & & & & & & & & & $\mathbf{X} \mathbf{X}$ & $\left.\mathbf{X}\right|^{2}$ & $\mathbf{X} \mid \mathbf{X}$ & $\mathbf{X}$ & & $\mathbf{X}|\mathbf{X}|$ & $\mathbf{X} \mid \mathbf{X}$ & $\mathbf{X} \mathbf{X}$ & $\mathbf{X} \mid \mathbf{X}$ & & $\mathbf{X}$ & $\mathbf{X} \mid \mathbf{X}$ & $\mathbf{X} \mid \mathbf{X}$ & $\mathbf{X} \mid \mathbf{X}$ & & & & \\
\hline $\begin{array}{l}\text { FRANCISCO DE } \\
\text { PAULA. } \\
\text { CONTRABAJO. }\end{array}$ & & & & & & & & & & & & & & & & & & & & & & & & & & $\mathbf{x} \mathbf{X}$ & \\
\hline
\end{tabular}

\footnotetext{
${ }^{303}$ Está en la Capilla desde antes que llegara Balius. En 1805 aduce una enfermedad que le impide tocar el violoncello y pasa desde esa fecha a tocar el violín.

${ }^{304}$ Hijo de Vicente Marín, también violoncello. En 1805 entra en la Capilla sin sueldo, solo con ayudas de costa, para sustituir a su padre en la plaza de violoncello, ya que aquel había pasado a tocar el violín. Durante muchos años se mantiene esta situación de provisionalidad, hasta que en 1816, y tras una oposición, Rafael Marín es admitido formalmente con un sueldo fijo.

${ }^{305}$ Ya está en la Capilla en 1785.

${ }^{306}$ Ingresa en la Capilla de Música en Diciembre de 1797.

${ }^{307}$ Al morir Julián Galvez en 1820, Francisco de Paula López, que anteriormente había sido un díscolo Niño de Coro y ahora era acólito, solicita al Cabildo pasar a tocar el contrabajo y éste se lo concede.
} 


\subsubsection{OBOES.}
D. Pablo Bárcena, oboe. ${ }^{308}$
D. Manuel Valls, oboe y flauta y violín. ${ }^{309}$
D. Cristóbal Bendicho, oboe. ${ }^{310}$
D. Rafael Arroyo, oboe. ${ }^{311}$

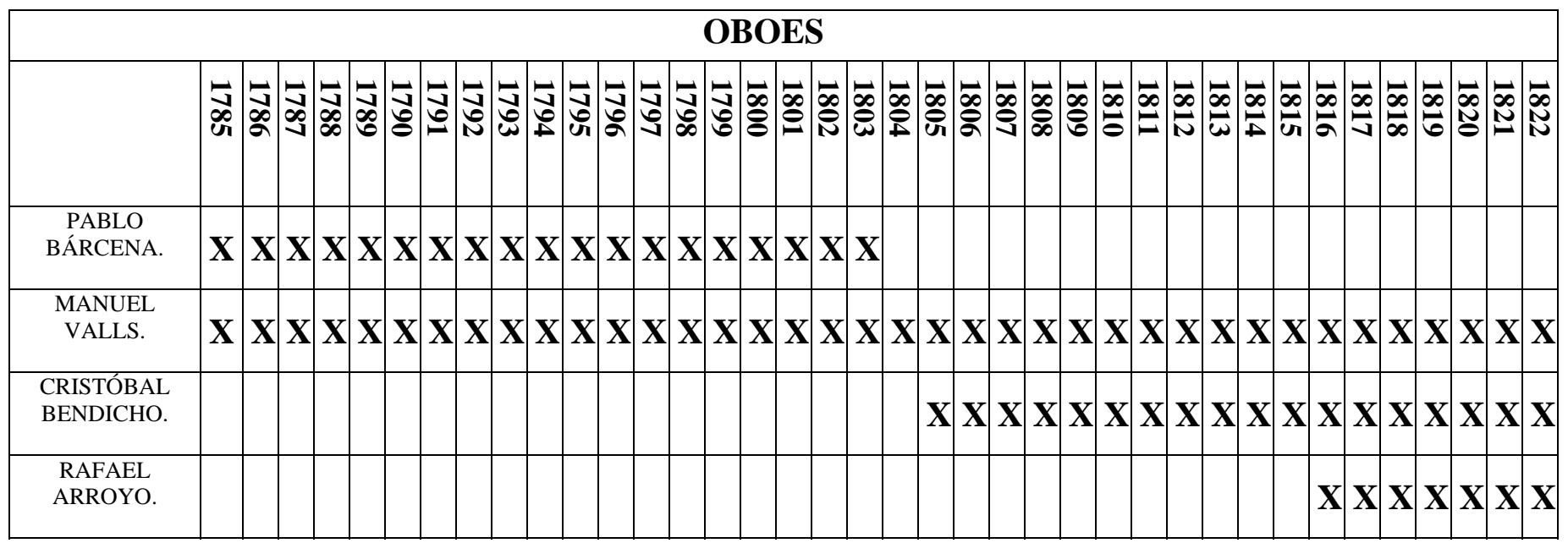

\footnotetext{
${ }^{308}$ Además de oboe también fue Maestro de Canto de Órgano de los Niños de Coro. En 1785 ya aparece en nómina.

${ }^{309}$ Es de los más antiguos de la Capilla, ya que está desde que llegó Balius en 1785, y en el Padrón Municipal de 1822 aparece todavía, con 63 años, viudo. "Buen catalán: mientras viva no faltara quien lo alabe. Es un cuarterón de violín pero fue una arroba de oboe y flauta. Ya no quiere tocar estos instrumentos porque le falta la dentadura, pero todavía las masca”. POZO, Juan Lucas del: Caricaturas de los Músicos de la Santa Iglesia Catedral de Córdoba. Córdoba, 1827, mecanografiado, pág. 333.

${ }^{310}$ Fue Niño de Coro y Acólito. En 1805 ingresa en la Capilla. "Como unos caen de pies este cayó en esta Santa Iglesia de cabeza, y porque alguna vez se ha caído de cara y es el más pobre de la orquesta y Capilla, hace muy poco papel; pero más es el ruido que las nueces, y aunque toca muy mal, porque ha sido Niño de Coro, es muy puntual en su obligación, servicial, humilde y aunque de su lengua escapen muy pocos, tiene buena reata, y esta en el caso de disimulársele todo, con que mírele Vd. con consideración”. POZO, Juan Lucas del: Caricaturas de los Músicos de la Santa Iglesia Catedral de Córdoba. Córdoba, 1827, mecanografiado, pág. 336.

${ }^{311}$ Ingresa en la Capilla de Música en 1816. "El 6 de Mayo falleció D. Rafael Arroyo y Franco, músico espulso de la Catedral. Fue compañero mío de Colegio. En el mismo año que Lidón fue su muerte, esto es en 1857”. POZO CÁCERES, Juan Lucas del. "Músicos fallecidos desde 1826”. En Colección de Obras. Córdoba, 1863. Ms., pág. 395.
} 


\title{
5.4.4. BAJONES.
}

\author{
D. Vicente Espinosa, bajón. ${ }^{312}$ \\ D. Antonio Hidalgo, bajón. ${ }^{313}$ \\ D. Mariano Ortega, bajón. ${ }^{314}$ \\ D. Mateo Tascón, bajón. ${ }^{315}$ \\ D. Juan Nepomuceno Puig, bajón. ${ }^{316}$ \\ D. Francisco de Lara, bajón, flauta y contrabajo. ${ }^{317}$ \\ D. José Mejias, bajón. ${ }^{318}$ \\ D. José Arjona, bajón. ${ }^{319}$
}

\footnotetext{
${ }^{312}$ Ya está en la Capilla en 1785, aunque tanto él como Antonio Hidalgo están mayores y enfermos. El mismo Espinosa pide en 1786 "una ayuda de costa en atención a sus enfermedades y notorias necesidades", y el Cabildo reconoce la urgencia de "nutrir la Iglesia de bajonistas mediante a ser notoria la necesidad, por hallarse imposibilitados el suplicante y D. Antonio Hidalgo”.A.C.C. Actas Capitulares. Jueves 13 de Julio de 1786. T 91. fol. 35 r.

${ }^{313}$ Como hemos dicho, en 1785 ya está en la Capilla, aunque con achaques que le imposibilitan su función.

${ }^{314}$ Es otro de los bajones que hay en 1785 en la Capilla, y aunque también padece enfermedades, las supera y perdura durante buena parte del período de Balius, concretamente hasta 1816. A pesar de todos los años que sirve a la Capilla, muere "en la mayor miseria". A.C.C. Actas Capitulares. Sábado 31 de Agosto de 1816. T. 104, fol. 3 r.

${ }^{315}$ Ingresa en la Capilla de Música en 1786 y permanece en ella hasta 1815.

${ }^{316}$ Es el bajón que más tiempo permanece en la Capilla de Balius, desde su ingreso en 1786.

${ }^{317}$ En 1816 gana las oposiciones para cubrir una plaza vacante de bajón en la Capilla. "Es una orquesta ambulante que si pudiera tocar de una vez los instrumentos que posee, no necesitaba usted más músicos que Lara, pero a pesar de esta habilidad y su honradez, isi viera Vd. que trabajo ha costado que vuelva al Coro!”. POZO, Juan Lucas del: Caricaturas de los Músicos de la Santa Iglesia Catedral de Córdoba. Córdoba, 1827, mecanografiado, pág. 339. "El día 5 de Junio de 1862 falleció en esta Ciudad D. Francisco de Lara, bajonista de la Capilla de Música de la Catedral de Córdoba, uno de los pocos afortunados que gozó mejor suerte que sus compañeros”. POZO CÁCERES, Juan Lucas del. "Músicos fallecidos desde 1826”. En Colección de Obras. Córdoba, 1863. Ms., pág. 397. Ingresa en la Capilla en 1816.

${ }^{318}$ Entró como Niño de Coro en 1801. En el Colegio de Infantes comenzó a tocar el bajón. Sustituye ocasionalmente a algún bajón de la Capilla cuando está enfermo o ausente por cualquier razón. iii Qué Bajón ha pegado aquí este bajón !!! Es mendigo de lecciones de bajón, y ha suplido una porción de tiempo de bajón. Don Manuel Vals le ha dado lecciones de bajón, sea por amor de Dios. En el Colegio comenzó a aprender bajón. S.M. le dé lo que más convenga”. POZO, Juan Lucas del: Caricaturas de los Músicos de la Santa Iglesia Catedral de Córdoba. Córdoba, 1827, mecanografiado, pág. 337.

${ }^{319} \mathrm{Al}$ igual que su compañero Mejias, José Arjona también actúa ocasionalmente con la Capilla, bien para sustituir o bien para reforzar en algún momento especial. "Aun todavía baja más este bajón. ¡Qué bajón! ¡Qué bajón! ¡Qué bajón!”. POZO, Juan Lucas del: Caricaturas de los Músicos de la Santa Iglesia Catedral de Córdoba. Córdoba, 1827, mecanografiado, pág. 338. "En 22 de Junio de 1858 falleció en el Hospital de la Misericordia de esta Ciudad D. José de Arjona, bajonista temporero de la Santa Iglesia Catedral”. POZO CÁCERES, Juan Lucas del. “Músicos fallecidos desde 1826”. En Colección de Obras. Córdoba, 1863. Ms., pág. 396
} 


\begin{tabular}{|c|c|c|c|c|c|c|c|c|c|c|c|c|c|c|c|c|c|c|c|c|c|c|c|c|c|c|c|c|c|c|c|c|c|}
\hline \multicolumn{34}{|c|}{ BAJONES } \\
\hline & : & $\overrightarrow{:}$ & 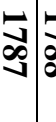 & & & 5 & & & $\vec{D}$ & & ठ্ & & ডે & 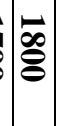 & $\mid \vec{\infty}$ & $\begin{array}{l}\overrightarrow{0} \\
\stackrel{\vec{v}}{\mathrm{v}}\end{array}$ & & & & 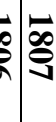 & & 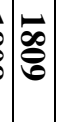 & & & $\stackrel{\infty}{\vec{\omega}}$ & 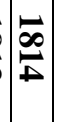 & & & $\vec{\infty}$ & & & 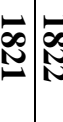 & \\
\hline $\begin{array}{c}\text { VICENTE } \\
\text { ESPINOSA. }\end{array}$ & $\mathbf{X}$ & $\mathbf{X}$ & $\mathbf{X}$ & & $\mathbf{X} \mid \boldsymbol{X}$ & $\mathbf{X}$ & & & & & & & & & & & & & & & & & & & & & & & & & & & \\
\hline $\begin{array}{l}\text { ANTONIO } \\
\text { HIDALGO. }\end{array}$ & $\mathbf{X}$ & $\mathbf{X}$ & $\mathbf{X}$ & & & $\mathbf{X} X$ & & & & & & & & & & & & & & & & & & & & & & & & & & & \\
\hline $\begin{array}{l}\text { MARIANO } \\
\text { ORTEGA. }\end{array}$ & $\mathbf{X}$ & $\mathbf{X}$ & $\mathbf{X}$ & $\mathbf{X}$ & & $\mathbf{X} X$ & $\begin{array}{r}X \\
X\end{array}$ & $\mathbf{X}$ & $X$ & $\mathbf{X}$ & $\mathbf{X}$ & $\mathbf{X}$ & $\mathbf{X} \mid \mathbf{X}$ & $\mathbf{X}$ & $\mathbf{X}$ & $\mathbf{X} \mid>$ & $\mathbf{X} \mid \boldsymbol{X}$ & $\mathbf{X} \mid \boldsymbol{X}$ & $\mathbf{X} \mid \mathbf{X}$ & $\mathbf{X} \mid \mathbf{X}$ & $X$ & $\mathbf{X}$ & $\mathbf{X}$ & $\mathbf{X} \mathbf{X}$ & $\mathbf{X} \mid \mathbf{X}$ & $\mathbf{X}$ & $X$ & $\mathbf{X}$ & & & & & \\
\hline $\begin{array}{l}\text { MATEO } \\
\text { TASCÓN. }\end{array}$ & & $\mathbf{X}$ & $\mathbf{X}$ & $\mathbf{X}$ & & $\mathbf{X} X$ & & $X$ & $X$ & $\mathbf{X}$ & $\mathbf{X}$ & $\mathbf{X} \mid \boldsymbol{Y}$ & $\begin{array}{l}\mathbf{X} \\
\mathbf{X}\end{array}$ & $\mathbf{X}$ & $\mathbf{X}$ & $\mathbf{X} \mid$ & $\mathbf{X} \mid \mathbf{X}$ & $\mathbf{X} \mid X$ & $\mathbf{X} \mid \mathbf{X}$ & $\mathbf{X} \mid \mathbf{X}$ & $X$ & $\mathbf{X}$ & $\mathbf{X}$ & $\mathbf{X} X$ & $\mathbf{X} \mathbf{X}$ & $\mathbf{X}$ & $X$ & & & & & & \\
\hline JUAN PUIG. & & $\mathbf{X}$ & $\mathbf{X}$ & $\mathbf{X} Y$ & & $\mathbf{X} X$ & $\mathbf{X} \mid X$ & $X$ & $X$ & $\mathbf{X}$ & $\mathbf{X}$ & $\mathbf{X}$ & $\mathbf{X} \mid \mathbf{X}$ & $\mathbf{X}$ & $\mathbf{X}$ & $\mathbf{X}$ & $\mathbf{X} \mid X$ & $\mathbf{X} \mid \mathbf{X}$ & $\mathbf{X} \mid \mathbf{X}$ & $\mathbf{X} \mid \mathbf{X}$ & $X$ & $\mathbf{X}$ & $\mathbf{X} \mid$ & $\mathbf{X} \mathbf{X}$ & $\mathbf{X} \mathbf{X}$ & $\mathbf{X}$ & $\mathbf{X}$ & $\mathbf{X} \mid Y$ & $\mathbf{X} \mid \mathbf{X}$ & $\mathbf{X}$ & $\mathbf{x}$ & $\mathbf{X}$ & \\
\hline $\begin{array}{l}\text { FRANCISCO } \\
\text { LARA. }\end{array}$ & & & & & & & & & & & & & & & & & & & & & & & & & & & & & $\mathbf{X} \mathbf{X}$ & & & $\mathbf{X}$ & \\
\hline $\begin{array}{c}\text { JOSÉ } \\
\text { MEJÍAS. }\end{array}$ & & & & & & & & & & & & & & & & & & & & & & & & & & & & & $\mathbf{X} \mathbf{X}$ & & $x$ & $\mathbf{X}$ & $\mathbf{X}$ \\
\hline $\begin{array}{c}\text { JOSÉ } \\
\text { ARJONA. }\end{array}$ & & & & & & & & & & & & & & & & & & & & & & & & & & & & & & & $\mathbf{X}$ & $\mathbf{X} \mid$ & \\
\hline
\end{tabular}

\subsubsection{TROMPAS.}
D. Federico Cudoire, trompa. ${ }^{320}$
D. Antonio García, trompa. ${ }^{321}$
D. Juan de Borja, trompa, viola y violín. ${ }^{322}$
D. Francisco Ferrer, trompa y guitarra. ${ }^{323}$

\footnotetext{
${ }^{320}$ Está en la Capilla de Música desde antes de 1785. Aunque oficialmente sigue conservando su plaza, es sustituido casi constantemente por Juan de Borja.

${ }^{321}$ Tras la muerte de Cudoire, pasa a ocupar oficialmente el puesto de primer trompa en 1796.

${ }^{322}$ Fue Niño de Coro. Ingresa en la Capilla en 1787 y aunque su instrumento principal es la trompa, también toca la viola. "Muy poca falta hace en la Capilla, y mucho menos en la orquesta. Tiene a menos el ser el músico y la música con él lo sea, y por eso ni él ha saludado a la música, ni esta lo ha saludado a él. Ha sido Niño de Coro en el del Santo Ángel”. POZO, Juan Lucas del: Caricaturas de los Músicos de la Santa Iglesia Catedral de Córdoba. Córdoba, 1827, mecanografiado, pág. 334.

${ }^{323}$ Es también un veterano de la Capilla de Música y ya en 1802 aparece en las actas. Estuvo hasta después de 1822. "Dios ponga tiento en mis labios ¿por donde te agarraré Ferrer? Creo que no tiene agarradera. Si hubiera sido Blanquillo, hubiera sido el mejor soldado de Bandera que se hubiese presentado en las Plazas a hacer reclutas. Si hubiera sido Pachón, hubiera sido el de mejor nariz que se hubiera hallado en el orbe. Si Donado de un Convento, hubiera acarreado él solo a su comunidad más
} 

D. Mariano Ferrer, trompa. ${ }^{324}$
D. Juan de la Cruz y Roxas, trompa, bajón y violín. ${ }^{325}$

\begin{tabular}{|c|c|c|c|c|c|c|c|c|c|c|c|c|c|c|c|c|c|c|c|c|c|c|c|c|c|c|c|c|c|c|c|c|c|}
\hline & & & & & & & & & & & & TR & $\mathbf{O M}$ & $\mathbf{P A}$ & & & & & & & & & & & & & & & & & & & \\
\hline & ড্ & ڤ্ & 灾 & : & & है & $\begin{array}{c}\overrightarrow{0} \\
0\end{array}$ & & & & $\vec{s}$ & ڤ్ర & : & & & 胥 & 密 & & $\stackrel{8}{0}$ & : & ) & & & & & $\stackrel{\infty}{\omega}$ & 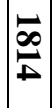 & & & $\stackrel{\infty}{\infty}$ & 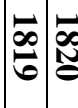 & & : \\
\hline $\begin{array}{l}\text { FEDERICO } \\
\text { CUDOIRE. }\end{array}$ & $\mathbf{X}$ & $\mathbf{X}$ & $\mathbf{X}$ & $\mathbf{X}$ & $\mathbf{X}$ & $\mathbf{X}$ & $\mathbf{X}$ & $\mathbf{X}$ & $\mathbf{X} \mid$ & & & & & & & & & & & & & & & & & & & & & & & & \\
\hline $\begin{array}{l}\text { ANTONIO } \\
\text { GARCÍA. }\end{array}$ & $X$ & $\mathbf{X}$ & $\mathbf{X}$ & $\mathbf{X}$ & $\mathbf{X}$ & $\mathbf{X}$ & $\mathbf{X}$ & $\mathbf{X}$ & $\mathbf{X} \mid$ & & $\mathbf{Y} X$ & $X$ & $\mathbf{X}$ & & & & & & & & & & & & & & & & & & & & \\
\hline $\begin{array}{l}\text { JUAN DE } \\
\text { BORJA. }\end{array}$ & $X$ & $\mathbf{X}$ & $\mathbf{X}$ & $\mathbf{X}$ & $\mathbf{X}$ & $\mathbf{X}$ & $\mathbf{X}$ & $\mathbf{X}$ & $\mathbf{X} \mid \mathbf{X}$ & & $\mathbf{X} X$ & $\mathbf{X}$ & $\mathbf{X} \mathbf{X}$ & $X$ & $\mathbf{X}$ & $X$ & $\mathbf{X}$ & $\mathbf{X}$ & $\mathbf{X} X$ & $\mathbf{X} \mid \mathbf{X}$ & $\mathbf{x} \mid \mathbf{X}$ & $\mathbf{X} X$ & $X$ & $X$ & & $\mathbf{X}$ & $\mathbf{X}$ & $\mathbf{X} \boldsymbol{X}$ & $\mathbf{X} \mid \mathbf{X}$ & $\mathbf{X}$ & & & \\
\hline $\begin{array}{c}\text { FRANCISCO } \\
\text { FERRER. }\end{array}$ & & & & & & & & & & & & & & & $X$ & $X$ & $\mathbf{X}$ & $\mathbf{X}$ & $\mathbf{X} X$ & $\mathbf{X} \mid \mathbf{X}$ & $\mathbf{x} \mid \mathbf{X}$ & $\mathbf{Y} X$ & $x$ & $X$ & & $X$ & $\mathbf{X}$ & $\mathbf{X} X$ & $\mathbf{X} \mid \mathbf{X}$ & $\mathbf{X} \mid \mathbf{X}$ & $\mathbf{X} \mathbf{X}$ & $\mathbf{X} \mid \mathbf{X}$ & $\mathbf{X} \mid \mathbf{X}$ \\
\hline $\begin{array}{l}\text { MARIANO } \\
\text { FERRER. }\end{array}$ & & & & & & & & & & & & & & & & & & $\mathbf{X}$ & $\mathbf{X}$ & $\begin{array}{l}\mathbf{X} \\
\mathbf{X}\end{array}$ & $\mathbf{x} \mid \mathbf{X}$ & $X X$ & $X$ & $X$ & & $\mathbf{X}$ & $\mathbf{X}$ & $\mathbf{X} X$ & $\mathbf{X} \mid \mathbf{X}$ & $\mathbf{X} \mid \mathbf{X}$ & $\mathbf{X} X$ & $\mathbf{X} \mid \mathbf{X}$ & $\mathbf{X} \mid \mathbf{X}$ \\
\hline $\begin{array}{l}\text { JUAN DE LA } \\
\text { CRUZ Y } \\
\text { ROXAS. }\end{array}$ & & & & & & & & & & & & & & & & & & & & & & & & & & & & & & & $\mathbf{X} X$ & & $\mathbf{X} \mid \mathbf{X}$ \\
\hline
\end{tabular}

Incluyendo los organistas, fueron en total 68 músicos, los que formaron parte de forma más o menos estable de la Capilla de Música durante el tiempo que la dirigió Jaime Balius y Vila. Evidentemente no estuvieron todos de forma simultánea, pero analizando estas tablas, podemos ver cómo, salvo períodos excepcionales, se mantuvo

que otros cientos muy diestros. Si fuera Calés javelara la mejor may, para jonjavar, que el mejor perdiz de su foro. Tiene una guitarrilla, sabe muchas canciones y a esta habilidad le debe muchos favores, ella le proporciona, le dan las once y algunos amigos, y todavía el jueves que mas descuidados estemos lo hallamos en la Plaza cantando coplas a son de su guitarra para ganar algunos cuartitos, como hacen los ciegos de su tierra. Sabe quien tiene en su casa el mejor vino de Jerez, Málaga y Valdepeñas y como no le cuesta nada el pedirlo, disfruta siempre de estos beneficios y todo lo debe a su [¿?]. Es un buen Trompa y podía ejecutar muy bien su papel, pero cuando toca, unas veces es ad libitum otras quita y pone puntos, y a un mismo tiempo toca, hace el ejercicio, baila, representa, riñe y canta". POZO, Juan Lucas del: Caricaturas de los Músicos de la Santa Iglesia Catedral de Córdoba. Córdoba, 1827, mecanografiado, pág. 339.

${ }^{324}$ Hermano de Francisco Ferrer. Desde 1804 lo vemos en la Capilla, aunque con un sueldo de tan solo cuatro reales diarios, lo que podría sugerir que su papel era más de refuerzo o sustitución de su hermano, en los frecuentes permisos que éste pedía. Su dotación era tan escasa, que en 1808, el Cabildo le concede 2000 reales de ayuda de costa. Cf. A.C.C. Actas Capitulares. Viernes 15 de Enero de 1808. T. 99, fol. 21 $\mathrm{V}$.

${ }^{325}$ Ingresa en la Capilla en 1819. 
de media la siguiente plantilla: 4-5 tiples, 2-3 contraltos, 4-5 tenores, 2 bajos, 4-6 violines, 1 violoncello, 1-2 contrabajos, 2 oboes, 3-4 bajones, 2 trompas y 2 organistas, que sumarían 34 músicos. Esto sin contar que para las ocasiones especiales, se pudieran contratar algunos refuerzos. ${ }^{326}$

\subsection{LOS NIÑOS DE CORO Y EL COLEGIO DE INFANTES.}

Tras la Reconquista, aquellas ciudades que pasan a manos cristianas y van implantando su liturgia, comienzan a tener un grupo de cantores del que forman parte frecuentemente los niños. Por tanto, la figura de estos Niños de Coro la podemos encontrar en las catedrales españolas desde muy antiguo, tanto con ese nombre como con otros muy diversos como Infantes de Coro, Mozos de Coro, Cantorcicos, Seises, etc. $^{327}$

Dependiendo de la época o del lugar, sus funciones podían variar, pero básicamente coincidían en su labor de acólitos, el canto e incluso la danza. También variaba su número, en función de las necesidades del culto y la situación económica del cabildo correspondiente. ${ }^{328}$

En los cabildos catedralicios pronto se vio la gran ayuda que estos niños podían suponer para la realización de múltiples actividades. Por otra parte, para las familias también constituía una ventaja que sus hijos entraran en ese círculo, ya que se les instruía en muy diversas materias y, si la situación económica del Cabildo lo permitía, recibían un pequeño sueldo, o al menos gratificaciones puntuales.

\footnotetext{
${ }^{326}$ Vistas estas cifras, podemos afirmar que la Capilla de Música de la Catedral de Córdoba estuvo, al menos en cuanto al número de componentes, a la altura de otras grandes catedrales: "La Catedral de Salamanca tenía en 1808 un total de 41 individuos adscritos a su Capilla Musical, distribuidos así: 10 racioneros músicos, 12 instrumentistas, 7 cantores, 10 niños de coro y 2 organistas. Muy cercana en número se hallaba la correspondiente Capilla de Santiago de Compostela, compuesta por 33 músicos: 13 cantores, 18 instrumentistas y 2 organistas”. MARTÍN MARTÍN, Teodoro. "Aproximación a los efectos de la desamortización sobre las Capillas Musicales". Letras de Deusto, vol. 35, n 109 . OctubreDiciembre 2005, pág. 51.

${ }^{327}$ Incluso se les puede designar con el término “coloradillos”, en alusión al color de su vestimenta. En MARTÍNEZ SOLAESA, Adalberto. Catedral de Málaga. Órganos y Música en su entorno. Málaga, Servicio de Publicaciones de la Universidad, 1996, p. 55. También se les puede llamar "infantillos". En MONTAGUT, Marian Rosa. "Una aproximación a la Capilla de Música de la Catedral de Tortosa (Tarragona): 1700-1750”. Anuario Musical nº 61. Barcelona, 2006, p. 156.

${ }^{328}$ Cf. RUBIO, Samuel. Historia de la Música Española. Desde el "ars nova” hasta 1600. Madrid, Alianza Editorial, 1983, pp. 34-39.
} 
Los niños podían vivir con sus padres, pero pronto se comenzó a utilizar otra fórmula y era que vivieran en casa del Maestro de Coro o del Maestro de Capilla. "Los <<seises>> vivían con el Maestro, aunque en esto se dieron muchas alternanzas, quien tenía que preocuparse de su alimentación, vestido, disciplina y buena crianza”. ${ }^{329}$

El siguiente paso fue la creación de colegios específicamente destinados a la manutención y formación de los mozos de coro. ${ }^{330}$ De esta forma comienzan a proliferar a partir del siglo XVI numerosos centros en las principales ciudades españolas destinados al efecto. Uno de estos fue el Colegio del Santo Ángel de la Guarda de Córdoba, al que nos referiremos en breve.

En la Catedral de Córdoba, los Mozos de Coro comienzan la realización de actividades en época muy temprana, y con el tiempo, estas actividades que en principio eran de ayuda en el altar y en las procesiones, va complementándose con tareas musicales. ${ }^{331}$ En el siglo XV, concretamente en 1430, “el deán, D. Fernando Pérez Contreras reunió en un volumen los principales estatutos y ordenanzas que desde el principio del establecimiento de esta Santa Iglesia habían hecho los obispos y el Cabildo, tanto para el gobierno de la institución capitular como del coro. Es aquí donde nos encontramos las primeras referencias a la asistencia de estos mozos al coro". 332

\footnotetext{
${ }^{329}$ Ibid. p. 35.

330 "Catedrales hubo, andando el tiempo, que para obviar todos los inconvenientes que la vida y situación de estos niños llevaban consigo, decidieron crear colegios propios. En Sevilla se fundó el llamado <<Colegio del Cardenal >> bajo la advocación de San Isidoro; el cardenal Silíceo erigió, en 1546, el de Toledo, <<con muchos niños>>, al decir de F. Rubio Piqueras; el de San José, con capacidad para diez niños cuando más, cuyo rectorado correspondía al propio Maestro de Capilla, se creó en León el año de 1650”. RUBIO. Historia de la Música Española..., p. 37.

331 "Los mozos de coro o cantorcicos se encuentran citados con estos nombres y para este período por primera vez en 1282 con un total de ocho, sólo ejerciendo el oficio de portadores de ciriales y de incensarios -menesteres de altar y procesiones-, pero no será hasta fines del siglo XIV cuando se hable de ellos como cantores formados en la escuela catedralicia. Representan el estamento inferior de las capillas, por edad y estatura, que no por la tesitura de las voces. [...] A mitad del siglo XV se les adiestra ya en el canto de órgano. [...] La enseñanza se ejercía bien en una de las cámaras (costado sur de la catedral), bien en una de las capillas". NIETO CUMPLIDO, Manuel. "La música en la Catedral de Córdoba (1236-1577)”. En El Patrimonio Histórico-Musical de Córdoba. Córdoba, Ayuntamiento de Córdoba, 2004, p. 71.

${ }^{332}$ VÁZQUEZ LESMES, Rafael. "El Colegio de Niños de Coro de la catedral de Córdoba: antecedentes, fundación y constituciones”. En La Iglesia Española y las Instituciones de Caridad. Actas del Simposium organizado por el Instituto Escurialense de Investigaciones Históricas y Artísticas. El Escorial, Ediciones Escurialenses, 2006, p. 6.
} 
Dichos mozos quedan a partir del siglo XVI bajo la tutela del Maestro de los Mozos o del propio Maestro de Capilla. ${ }^{333}$

En años sucesivos se implantarán nuevos Estatutos que regularán de una forma más completa la organización de la Capilla de Música y por ende de los Mozos de Coro. Un ejemplo son los Estatutos de la Sancta Yglesia Cathedral de Córdova. ${ }^{334}$ Son conocidos también como Estatutos de Rojas y Sandoval o Estatutos de Fresneda, por ser Cristóbal de Rojas y Sandoval (obispo de Córdoba entre 1562-1571) quien los inició y Bernardo de Fresneda (obispo de Córdoba entre 1571-1577) quien finalmente los culminó. Fueron editados en Antequera en 1577. Dichos Estatutos especifican con detalle los principales aspectos referidos a la organización y funcionamiento de la música en la Catedral, tanto en lo referido al Canto Llano como a la propia Capilla de Música. Nos hablan del Chantre, del Sochantre, Capellanes de Veintena, Maestro de Capilla, Organista, Cantores, Músicos Instrumentistas y Mozos de Coro. Recogen la experiencia acumulada a lo largo de más de tres siglos, durante los cuales se hizo música con medios diversos. Desde la primera redacción en 1563 hasta su publicación en 1577, experimentaron sucesivas adiciones o modificaciones, en función de la experiencia acumulada a lo largo de esos primeros años de rodaje. ${ }^{335}$ En estos Estatutos se contempla un apartado específico dedicado a los Mozos de Coro:

\footnotetext{
333 "A partir de la presencia de Martín Rodríguez de la Fuente, primero como cantor y Maestro de los Mozos (1505) y después como Maestro de Capilla (1515), estos mozos quedarán paulatinamente bajo la dependencia y magisterio de éste". NIETO CUMPLIDO, M. "La música en la Catedral de Córdoba..." p.72.

${ }_{334}^{\mathrm{p}} \cdot 72$. Cf. A.C.C. Estatutos de la Sancta Yglesia Cathedral de Córdova. Antequera, 1577.

335 "Lo primero que disponen y ordenan el obispo don Cristóbal de Rojas y Sandoval (1562-1571) y el Cabildo es la base económica que sustentará todo el cuerpo musical, sobre todo el de sochantre, cantores y músicos. Para ello se aumentan los escusados procedentes de los diezmos en favor de la Fábrica de la Catedral. Una vez que ajustaron cuentas y crearon un excelente soporte económico, se pasó a establecer el número de músicos: un Maestro de Capilla, obligado a componer chanzonetas y villancicos para la Navidad y el Corpus Christi, dos muchachos de buenas voces, un tiple, un contralto, un tenor, un contrabajo, un organista y cuatro ministriles. Se señala el salario del sochantre, figura que no sólo no se pierde, se consolida en virtud de su importancia en la ordenación de la música coral como antes se ha dicho. El número de mozos de coro, doce, y su Maestro. A esta estructura, consolidada por estatuto, se le añaden las obligaciones de cada persona o de cada grupo que interviene en la música, es decir, el reglamento -extremadamente minucioso- de las funciones de cada interviniente. Se ultiman con la disposición de celebrar oposiciones con edictos de convocatoria para los oficios vacantes que se fijarán en las puertas de las Catedrales de Sevilla, Granada, Toledo y Jaén, así como en cualquier otro lugar que interese. En virtud de estas disposiciones, a partir de la promulgación de los estatutos, se parte de cero y todos los oficios músicos salen a oposición. [...]". NIETO CUMPLIDO. "La música en la Catedral de Córdoba...” pp. 88-89.
} 


\section{Estatuto de los moços de choro y de su maestro.}

"Los mochachos que llaman moços de choro son tan necesarios que sin ellos avría gran falta en muchas cosas del servicio de la yglesia, y ansí ordenamos que aya siempre doce moços de choro como al presente los ay que sirvan de todas aquellas cosas contenidas en diversos lugares del Ceremonial. Los quales y qualquiera de ellos antes de ser rescebido se presentará en cabildo y siendo qual conviene para la yglesia como abaxo se dirá, el cabildo diputará uno o dos beneficiados que hagan la información de su limpieza, la qual después de acabada se leerá en cabildo, y paresciendo ayer satisfecho al estatuto de la limpieza que esta yglesia tiene será rescebido y en otra manera no.

Item, los dichos moços de choro han de andar vestidos de opas y bonetes de color colorado y sobrepellizes de lienzo a costa de la mesa capitular.

Item, los dichos moços de coro ternán un maestro señalado por el cabildo que los tenga a cargo y los lleve y traiga dende su casa a la yglesia, seis a un lado y seis a otro, y les enseñará a leer latín y cantar canto llano, dándoles mañana y tarde los días de entre semana lectión de lo uno y de lo otro, y principalmente los ha de instruir en aquellas cosas que han de cantar en el choro.

Item, el dicho maestro enseñará buenas costumbres a los dichos moços y dará orden cómo en sus casas estén corregidos y recogidos.

Item, quando el número de los doze moços de choro no esté cumplido, el maestro terná cuidado de buscar por la ciudad los que faltaren, que sean buenas vozes y edad, y buenos gestos y bien acostumbrados, y presentarlos ha al cabildo para que con su licencia se reciban, y al dicho maestro y a cada uno de los moços se les dará salario competente a costa de la mesa capitular". 336

Sirvan los ejemplos anteriores para ver las primeras citas que se hacen en la Catedral de Córdoba de los Mozos de Coro. A lo largo del tiempo, y en los sucesivos estatutos que conformaron la actividad catedralicia se sigue haciendo referencia a ellos. Queda comprobada la necesidad de su existencia para el buen funcionamiento de la Capilla de Música y la importancia que le conceden los sucesivos obispos. De esta forma llegamos al primer intento de dotar de un Colegio a los Mozos de Coro, que vemos a continuación.

${ }^{336}$ A.C.C. Estatutos de la Sancta Yglesia Cathedral de Córdova. Antequera, 1577, fol. 52v.-53r. 


\section{El Colegio de Infantes de Coro Santo Ángel de la Guarda. ${ }^{337}$}

\section{La $1^{\text {a }}$ Etapa. De 1771 a 1811:}

Encontramos un antecedente de este colegio en el proyecto que en su día hizo el Cardenal Obispo de Córdoba D. Pedro de Salazar. Este notable Prelado, concibió a finales del siglo XVII la idea de "establecer un colegio donde se acogiesen a niños pobres, enseñándolos á cantar y á tocar los instrumentos apropósito para dotar la Catedral de una excelente Capilla de música”. ${ }^{338}$

El edificio destinado en principio a tal efecto y construido en la plaza de la Iglesia de San Pedro Alcántara, acabó convirtiéndose en Hospital Provincial de Agudos, por petición que el Ayuntamiento de la ciudad, el Cabildo eclesiástico y el V.Fr. Francisco de Posadas (después beatificado), hicieron al Cardenal Salazar. ${ }^{339}$ Así pues, el proyecto no llegó a realizarse.

Habrá que esperar casi un siglo para que el Cabildo retome la idea, esta vez con éxito. Y así, en 1771 comienza a funcionar el Colegio de Infantes, que estaba destinado a mantener y darles cristiana educación y enseñanza a los infantes que servían en el Coro de la Santa Iglesia Catedral de Córdoba. En él, doce niños no sólo aprendían a leer y escribir sino que, a la vez, recibían enseñanza de canto llano, canto de órgano, composición musical, instrumentos y latín. La fundación de este colegio fue aprobada

\footnotetext{
${ }^{337}$ En la Catedral de Córdoba podemos encontrar un retablo dedicado precisamente al Ángel de la Guarda hecho en 1750 y citado posteriormente en las Constituciones del Colegio de 1771: "Siempre dedicaron estos Niños sus cultos à su Ángel Protector de la Guarda en el altar que tiene en esta Santa Iglesia, haviendole hecho Retablo dorado, Lámpara de plata, y Ornamentos; y celebrándole en èl muchas Misas Rezadas, y la fiesta annua con Misa Cantada, Sermòn, y Música el DIA dos de Octubre; y del mismo modo continuarà devoción tan laudable, dirigiéndola el Rector”. En A.C.C. Obras Pías. Caja 534. Constituciones del Colegio del Ángel de la Guarda, que para la manutención, cristiana educación y útil enseñanza de los Infantes que sirven al Coro de la Santa Iglesia Catedral de Córdoba, ha fundado el Ilmo. Señor Deán y Cabildo de ella. Córdoba, 1771, folio 6. También nos habla de este retablo Nieto Cumplido: "Se compone de banco, un cuerpo con tres calles enmarcado con dos columnas salomónicas y dos estípites y ático. En el registro central hornacina con la escultura del Angel de la Guarda, posiblemente de Alonso Gómez de Sandoval. En las calles laterales del cuerpo, dos pequeños lienzos, uno de Santo Domingo del Val y otro de San Antonio de Padua, representados como niños de coro. Ambos llevan inscripción. En el ático, cuerpo central, óleo sobre lienzo con un religioso ¿agustino? Ante una mesa acompañado del Angel de la Guarda, que lleva un cesto de frutas. En las calles laterales, dos pequeños óleos con las figuras del santo Niño de la Guardia y los santos Justo y Pastor también con sus inscripciones”. NIETO CUMPLIDO, Manuel. La Catedral de Córdoba. $2^{\mathrm{a}}$ Edición. Cajasur. Córdoba, 2008, p. 481.

${ }^{338}$ RAMÍREZ DE ARELLANO, Teodomiro: Paseos por Córdoba. León, Ed. Everest, 1976, p. 571.

${ }^{339}$ Ibid.
} 
en el Cabildo del día 17 de Abril de 1769 con el título del Santo Ángel de la Guarda. Sus aulas se instalaron en el Hospital de Convalecientes. ${ }^{340}$

Para poder realizar la instalación en este lugar se efectuó una escritura de venta “...de parte del Hospital de San Francisco de Asís de pobres conbalecientes para la construcción del Colegio de Niños de Choro". ${ }^{341}$ Esta escritura se hizo "en favor del Ilmo. Sr. Deán y Cavildo Pleno como Patrono de dicho Colegio, ante D. Juan Ignacio del Pino escribano del Rey [...] en 28 de Noviembre de 1769”. ${ }^{342}$ En la primera página de dicha escritura, también figura una nota escrita posteriormente y que dice: "Por escritura en Córdoba, en 9 de Noviembre de 1773 ante D. Juan Ignacio del Pino que se hallará al $n^{\circ} 6$ del legajo 16 de títulos de agua del Hospital de San Sebastián consta que dicho Hospital vendió á este Colegio una $4^{a}$ parte de paja de agua principal”. 343

Desde el citado año de 1769 en que se aprobó su fundación hasta el año 1771, se fueron resolviendo todas las cuestiones referentes no solo al edificio, sino a los fondos que lo sustentarían, a su composición y funcionamiento, etc. De la procedencia de esos fondos nos habla Vázquez Lesmes en su magnífico artículo sobre el Colegio de Infantes de Coro:

"Figuran en primer lugar, la Mesa Capitular, la cual, hasta entonces, se había encargado de costear su educación y vestuario; después, los excusados de la música, y una relación de las obras pías de cuyos fondos, una vez realizadas las oportunas

\footnotetext{
${ }^{340}$ Cf. NIETO CUMPLIDO, Manuel. Historia del Monte de Piedad y Caja de Ahorros de Córdoba. Obra Cultural del Monte de Piedad. Córdoba, 1979, p. 61. El edificio estaba en la calle de la Convalecencia, que toma el nombre del Hospital de los Convalecientes. Actualmente es la calle Medina y Corella. También es interesante lo que al respecto nos dice Ramirez de Arellano: "La calle de la Convalecencia es travesía entre las de los Manriques y Torrijos ó Palacio, y tiene á su mediación una plazuela con el mismo título; este lo tomó del edificio que fue Hospital de Convalecientes, después Colegio del Ángel para niños del Coro de la Catedral, y en el día está incorporado á la Casa central de expósitos. Como repetidas veces hemos anotado, muchos eran los hospitales existentes en Córdoba, pero casi en totalidad de corto número de camas y de escasísimos recursos: esto era causa de que en todos ellos diesen de alta á los enfermos en cuanto siquiera podían sostenerse, resultando volver á pocos días ó arrastrar una convalecencia larga, por no contar con el alimento necesario á reponerlos y tener que mendigarlo; semejante falta era lamentada por todos, y al fin movió á compasión á D. Francisco de las Infantas y Aguayo, del hábito de Calatrava y Veinticuatro de Córdoba, quien por su testamento, fecha 23 de Diciembre de 1616, fundó el Hospital de San Francisco de Asís, para la asistencia de los convalecientes, dejando el patronato del mismo al Cabildo eclesiástico, si bien no se realizó hasta muchos años después, 1664, en que Doña Leonor Galindo, su viuda, reiteró la fundación, escitando el celo de aquella respetable corporación, la cual adquirió local y abrió el establecimiento á la asistencia de los convalecientes". RAMÍREZ DE ARELLANO. Paseos por Córdoba...p. 575.

${ }^{341}$ A.C.C. Obras Pías. Caja 523. Expediente del Colegio de Infantes de Coro.

${ }^{342}$ Ibid.

${ }^{343}$ Ibid.
} 
consultas se podían detraer legalmente sumas dinerarias para esta finalidad. Estas son: la Octava de la Concepción, Obispo Mardones, Chantre Aguayo, fábrica de la Capilla de San Pedro y la de Santa Inés, la última tan relacionada con la música. Por fin, son las propias dignidades y los canónigos quienes aportan 50.000 rs. de vellón para la reparación del edificio, además de la provisión de ropas, menaje, utensilios, ornamentos sagrados, pinturas y otras cosas útiles. El líquido total de dinero que se aporta para el mantenimiento del Colegio se eleva a la cantidad de 124.624,25 rs., cantidad considerada como suficiente para su manutención anual”. 344

Por fin, el día 2 de Octubre de 1771, “día tan propio, como ser el Titular de la Casa, mandó el Cabildo, que en él se vistiesen las Becas à los Infantes, y se empezase en toda formalidad el régimen de este Colegio, y observancia de sus Constituciones”. ${ }^{345}$

Queda fijada perfectamente la organización y funcionamiento del Colegio gracias a dichas Constituciones. Por ellas sabemos que además del Rector del Colegio y los doce Infantes, se previó la existencia de "un Portero, un Mandadero, y un Cocinero". 346

Para la instrucción de los niños, se determina que tendrán profesores de diversas especialidades, como canto llano, canto de órgano, instrumentos, latín, etc. De hecho sabemos que el primer Maestro de Canto de Órgano fue D. Vicente Zabala: "Por decreto de 7 de Diciembre de 1770 se nombró en la maestría de Canto de Órgano de Acólitos y Niños de Coro a D. Vicente Zabala [...], acordando darle habitación en la misma Casa de los Niños, con comida, barba y ropa limpia, pero con la obligación de suplir al Maestro de Canto Llano en sus ausencias y enfermedades, no solo para la enseñanza del Canto Llano, sino también para traerlos y llevarlos al Choro". ${ }^{347}$

También queda bien establecida la jornada diaria, en la que el mandadero los levanta muy temprano "con el toque de una campanilla de mano". ${ }^{348}$ Una vez vestidos y aseados, "iràn inmediatamente à la Capilla à la Misa, que oirán de rodillas, y muy

\footnotetext{
${ }^{344}$ VÁZQUEZ LESMES, Rafael. "El Colegio de Niños de Coro de la catedral de Córdoba: antecedentes, fundación y constituciones”. AA.VV. La Iglesia Española y las Instituciones de Caridad. Actas del Simposium organizado por el Instituto Escurialense de Investigaciones Históricas y Artísticas. El Escorial, Ediciones Escurialenses, 2006, p. 160.

${ }^{345}$ A.C.C. Obras Pías. Caja 534. Constituciones del Colegio del Ángel de la Guarda... fol. 4.

${ }^{346}$ Ibid. fol. 5.

${ }^{347}$ A.C.C. Cuentas de Fábrica. Año de 1770. Tomo 4034, s/f.

${ }^{348}$ A.C.C. Obras Pías. Caja 534. Constituciones del Colegio del Ángel de la Guarda...fol. 7.
} 
devotamente” ${ }^{349}$ Concluida ésta, desayunarán e inmediatamente comenzarán el estudio de sus materias. Después, el Rector los conducirá a la Catedral para cumplir allí con sus obligaciones. Para ello, “se pondrán los mantos, y sobrepellices, y tomaran los vonetes, y puestos en orden los llevará el Rector à la Catedral ante sí de dos en dos, y del mismo modo volverán. Quando lleguen al Coro, hincados de rodillas rezarán una Estación al Santísimo, y luego preparará cada uno las cosas de su ministerio”. 350

Ya de vuelta en el Colegio, “y à las doce menos quarto al toque de Campana se labaràn las manos, y entrarán à comer al Refectorio”. ${ }^{351}$ La comida solía constar habitualmente de ensalada, patatas y huevos. ${ }^{352}$ Después de la comida, tendrán un rato de descanso. Por la tarde, de nuevo combinarán sus estudios con sus funciones dentro de la Catedral. Concluidas estas obligaciones, volverán al Colegio para cenar y dormir. Si esa era su rutina diaria habitual, ésta se modificaba los días de fiesta, quedando entonces a merced de las necesidades especiales del culto.

Las pruebas para entrar en el Colegio eran supervisadas normalmente por el Rector del mismo y por el Maestro de Capilla de la Catedral. ${ }^{353}$ Un ejemplo lo tenemos en las que se celebraron en Julio de 1785 para cubrir dos vacantes. El día 6 de ese mes, reunido el Cabildo en la Capilla de San Clemente, acontece lo que sigue:

\footnotetext{
${ }^{349}$ Ibid. fol. 8.

${ }^{350}$ Ibid.

${ }^{351}$ Ibid.

352 Por ejemplo, de los días 1 al 7 de Marzo de 1780, sus alimentos consistieron en lo siguiente: Domingo día 1: Pan, ensalada, papas y huevos. Lunes día 2: Pan, escarola, papas y huevos. Martes día 3 y Miércoles día 4 comieron igualmente pan, ensalada, papas y huevos. El Jueves día 5: Pan, ensalada, papas, sevollas y huevos. El Viernes 6: Pan, ensalada, papas y huevos. Y el Sábado 7: Pan, ensalada, papas, huevos y carne. Cf. A.C.C. Obras Pías. Caja 523. Expediente del Colegio de Infantes.

${ }_{353}$ Durante este primer período en que estuvo abierto el Colegio de Infantes de Coro fueron Maestros de Capilla sucesivamente Juan Manuel Gaitán y Jaime Balius y Vila. De este último se conservan en la Catedral de Córdoba 720 obras, entre las que encontramos una serie de villancicos dedicados a los Niños de Coro. Son los siguientes: 1) Desde que oyeron los niños. "Villancico $9^{\circ}$ para los niños". A 3 voces, con Violines, Oboes y Trompas. 129/1251. 2) Luego que aquellos pastores. "Villancico $9^{\circ}$ para los Niños de Coro con Violines, Oboes y Trompas. Año 1804. Balius”. A 4 voces. 88/720. 3) Vamos, vamos. "Villancico Noveno, de los Niños de Coro con Violines, Oboeses y Trompas. Balius". A 3 voces. 89/737. 4) Vino Jesús Rey. "Villancico último. Para lo Niños de Coro. Con Violines y Trompas. De Navidad. Maestro D. Jaÿme Balius. Año 1789". A 4 voces. 92/763. 5) Para que de todos modos. "Villancico $9^{\circ}$. Para los Niños. Con Violines y Acompañamiento. Maestro Balius. 1790”. A 4 voces. 92/766. 6) Los niños que ya han salido. "Nocturno Tercero. Villancico $9^{\circ}$ y último con Violines, Trompas. Año 1798. De los Niños de Coro. Balius". A 4 voces. 103/870. 7) Los niños que siempre. "Villancico último a 4. Para los Niños. Con Violines, Trompas y Acompañamiento. Para la Navidad del Señor. Maestro Jayme Balius Pbro. Año de 1786". 87/710. 8) Los Niños del Coro. "Nocturno $3^{\circ}$. Villancico Nono. Para los Niños de Coro. Año 1792. Balius”. A 4 voces, con Violines y Trompas. 95/799-3. 9) Los muchachos aunque tarde. "Villancico a 4 y a 8 con Seguidilla.Villancico para los Niños de Coro. A 4. Balius". Con Violines, Oboes y Trompas. 88/721. 10) Los niños que en la pasada Navidad. "Villancico Noveno y Tercero Nocturno. Para los Niños de Coro. Con Violines y Trompas. Balius. Año 1801”. A 4 voces. 79/601. 11) Para hacer una merienda. "Villancico a 4. Con Violines y Trompas. De Navidad. De los niños. Balius". 104/878.
} 
"En virtud del llamamiento para oír el informe de los señores Diputados del Colegio del Santo Ángel de la Guarda, a fin de proveer las dos vecas vacantes, o darse aquellas providencias conbenientes; en efecto informaron dichos señores con respeto a proveerlas; de las diligencias más exactas practicadas a este intento; y de estar lo niños pretendientes esperando para ser examinados; en cuya atención se mandó entrar al Rector de dicho Colegio, el que informó de todas las circunstancias que concurren en los opositores, é hizo saber su juicio comparativo; y habiéndose retirado se oyó otro informe del Maestro de Capilla; y concluido se dio principio á el examen de leer, escribir y cantar, en los que concurrieron y exercitaron, que fueron Antonio Díaz, natural de Zafra, de edad de 9 años y 9 meses: Rafael de León, natural de Córdoba, de 9 años y 3 meses: Mariano Ruiz Madueño, natural de Córdoba, de 8 años y 6 meses: Pedro de Luque Clavijo, natural de esta ciudad, de 9 años y 1 mes y Josef García, de la misma naturaleza de 9 años y 8 meses: y concluido el exercicio se pasó a la votación por cedulas, y quedaron nombrados Antonio Díaz y Rafael de León, que fueron los primeros en los referidos informes y censuras". 354

De esta forma, y durante muchos años, el Colegio cumplió con sus objetivos de dar cobijo y enseñanza a los Niños de Coro, además de surtir convenientemente a la Capilla de Música de jóvenes aprendices que sin duda fueron parte importante en la interpretación del repertorio habitual.

Sin embargo, con la llegada del nuevo siglo, el Colegio de Infantes se vio afectado progresivamente de problemas económicos, al igual que el resto de los sectores catedralicios. Ciertamente en Córdoba la invasión de los franceses supuso una ruina total para la economía de la ciudad y por supuesto de la Catedral. El expolio que hicieron las tropas napoleónicas dejó sin fondos a la sección Obras Pías y como consecuencia sin recursos para sostener el Colegio de Infantes de Coro. ${ }^{355}$ Ante la gravedad de la situación, la Diputación de Obras Pías le escribe al Obispo de la ciudad, D. Pedro Antonio de Trevilla, rogándole que las rentas de la Obra Pía fundada por el racionero D. Tomás Gonzalez de Tebar se utilizaran para la subsistencia del Colegio,

\footnotetext{
${ }^{354}$ A.C.C. Actas Capitulares. 6 de Julio de 1785. T.90, fol. 144r.

355 “....Habiendo faltado por la invasión de los franceses en esta ciudad, todos los fondos de Obras Pías, que suplían y adelantaban para todos los gastos del citado Colegio [de Infantes], no se encuentran en el día medios para su manutención". Informe de la Diputación de Infantes de Coro de 6 de Octubre de 1808. En A.C.C. Obras Pías. Caja 533.
} 
“mientras llega el caso de que se apliquen al Hospicio, luego que esté en exercicio, en los términos que tiene acordados el Cabildo". 356

Por su parte el Obispo contesta con la siguiente misiva:

"Muy señores míos: Queda en mi poder la atenta carta de VV.SS. su fecha 24 del corriente con la copia de la escritura de fundación para la enseñanza de la doctrina cristiana de los niños, y un exemplar del establecimiento del Colegio de Mozos de Coro; tomaré conocimiento de este asunto y avisaré lo que me parezca conveniente sobre la solicitud, asegurando a VV.SS. que haré quanto pueda en su obsequio. 29 de Noviembre de 1808. Firmado: Pedro Antonio Obispo de Córdoba”. ${ }^{357}$

No tenemos constancia de la decisión final tomada por el Obispo Trevilla, aunque todo hace suponer que alguna solución temporal se debió arbitrar bien por su parte o por parte del Cabildo (además de reducir el sueldo de los músicos drásticamente), ya que, aunque a duras penas, se mantuvo abierto el Colegio dos años más.

Sería a finales de 1810, cuando la situación ya se hizo del todo insostenible. El 19 de Diciembre de ese año se celebra un Cabildo para tratar sobre la supresión del Colegio de Infantes. En dicho Cabildo, se presenta un informe que dice textualmente que "el Colegio no puede subsistir por falta de Rentas; el Colegio no sirve ya para la enseñanza de música de los niños; el colegio pues debe suprimirse...”. 358

Haciendo un paréntesis en este caso particular, hay que decir que el cierre de un colegio de niños de coro a causa de las dificultades derivadas de la invasión de los franceses, no fue un caso exclusivo de Córdoba, sino que también ocurrió en otros colegios de España, por ejemplo en el Colegio de niños músicos de la Purísima Concepción de Valladolid. Dicho colegio funcionó de forma continuada desde 1627 hasta 1809. "En ese momento, las dificultades de la guerra contra el francés impiden el

\footnotetext{
${ }^{356}$ A.C.C. Obras Pías. Caja 533. Carta de 24 de Noviembre de la Diputación de Obras Pías (señores Ubillos, Ugalde, Nadales y Garrido) al Obispo de Córdoba.

${ }^{357}$ A.C.C. Obras Pías. Caja 533. Carta de 29 de Noviembre del Obispo de Córdoba a la Diputación de Obras Pías.

${ }^{358}$ A.C.C. Actas Capitulares. Miércoles 19 de Diciembre de 1810. T.100, fol. 193r.
} 
mantenimiento de la institución”. ${ }^{359}$ Según la musicóloga Victoria Cavia Naya, el nuevo régimen del citado colegio que se deriva a raíz de la Guerra de la Independencia "se concreta en que el niño de coro vive con su familia y acude a la catedral donde aprende música a la vez que se le entrega una pequeña retribución económica...”. ${ }^{360}$ Esta circunstancia y otras son muy similares a las que ocurrieron en el Colegio de Infantes de Coro de Córdoba, al que volvemos ahora para ver las circunstancias de su cierre.

El día 31 de Diciembre de 1810, el Cabildo toma la decisión de cerrarlo de inmediato, en los primeros días de Enero de 1811, para lo cual dicta un articulado que regula su desaparición. Bastan los dos primeros artículos para apreciar la contundencia con que se quiere abordar su clausura:

“Artículo 1": Desde el día primero del año próximo se cortan las respectivas cuentas de los fondos de la Mesa Capitular y demás, que estaban aplicados a la subsistencia de este establecimiento.

Artículo $2^{\circ}$ : Desde el mismo día podrán los padres, tíos, tutores, o encargados de los Niños, recogerlos á su respectivas casas, para cuidar de su educación, manutención y destino". 361

También aprueba una pequeña compensación económica para los niños y el personal de servicio: “en cuanto a las limosnas que se apuntan por vía de despedida para el Portero y Cocinera de la casa, y para los mismos Niños, acordó igualmente el Cabildo fijarlas para los primeros en la cantidad de cien reales, y para los segundos en la de cuarenta reales a cada uno, todas pagaderas por una sola vez y de los fondos de Obras Pías", 362

Y así fue como una fría mañana de Enero de 1811, en plenas navidades, los Niños de Coro de la Catedral de Córdoba fueron abandonando el que durante un tiempo fue su hogar, y en el que, a pesar de vivir con una gran disciplina, tenían garantizado el cobijo y la comida diaria. Concluían de esta forma casi 40 años de funcionamiento de esta institución.

${ }^{359}$ CAVIA NAYA, Victoria. "El Colegio de niños músicos de la Purísima Concepción de Valladolid en el siglo XIX: trayectoria y alternativas a la institución”, en Campos Interdisciplinares de la Musicología. Madrid, Sociedad Española de Musicología, 2002, volumen 2, p. 949.

${ }^{360}$ Ibid. p. 950.

${ }^{361}$ A.C.C. Actas Capitulares. Lunes 31 de Diciembre de 1810. T.100, fol. 220v.

${ }^{362}$ Ibid. fol. 222r. 


\section{La Transición. De 1811 a 1825:}

El cierre del Colegio no significa la desaparición de los Infantes de Coro de la actividad catedralicia, ya que se les permite seguir asistiendo a sus obligaciones, aunque residan en sus domicilios particulares, por lo que (aunque reducidos en número) todavía seguirán participando en la Capilla de Música. ${ }^{363}$

En el Colegio había una serie de instrumentos musicales, como violín, oboe, etc., que se les asignan a los niños para que puedan seguir estudiando. También hay un pianoforte cuyo destino queda a expensas de lo que diga el Cabildo. ${ }^{364}$

Tras unos años en que el Colegio permanece cerrado y, al parecer, sin un destino claro, en 1816 se realiza la tasación de algunos muebles y enseres que quedaban. También se realiza la tasación del edificio y todo ello se vende a la oficina de Cabeza de Rentas. ${ }^{365}$

No había pasado ni un año de esta venta, cuando el Cabildo se vuelve a plantear la reapertura del Colegio. De hecho encarga a Fernando López, maestro albañil y a Andrés Sánchez, maestro carpintero, un presupuesto de lo que costaría reabrir el edificio y dotarlo de los muebles necesarios. El presupuesto asciende a 11.766 reales de vellón, y tiene fecha de 18 de Septiembre de $1817 .^{366}$

En 1821 se produce una circunstancia que consideramos decisiva para que el Cabildo se plantee seriamente la reapertura del Colegio. Esta circunstancia es el conflicto disciplinario que se entabla con los Niños de Coro. Efectivamente, en la reunión del Cabildo del 16 de Enero de 1821, el señor Vivar, encargado interinamente del punto de Horas Canónicas, expone lo siguiente:

\footnotetext{
${ }^{363}$ Para la nueva situación de los Infantes de Coro, se hace un informe que se aprueba en Cabildo del miércoles 4 de Diciembre de 1811 y que dice lo siguiente: “....Los niños estarán obligados a todos lo cargos, oficios y asistencias como lo estaban anteriormente. Asistirán a todas las horas del Coro sean diurnas o nocturnas, sin dispensación ni excepciones. Toda su dotación queda reducida a los tres reales diarios, dejando a favor de sus fondos de dotación en Obras Pías todos los emolumentos que por costumbre o práctica le correspondía en el Punto y en las Capillas según el servicio que hagan. [...] No gozarán ni en octavas, ni en procesiones, ni entierros de Capitulares, ni en funciones ordinarias ni extraordinarias de V.S. ni de manual ni de gratificaciones de otra consignación, ni de Mesa Capitular ni de otros fondos aplicados a V.S. [...] Los Niños de Coro deberán estar sujetos y se sujetarán desde luego a rigurosa puntación en su cuadrante respectivo: todos por mañana y tarde con la pena o aspa de un real por cada falta en que incurran: la cual igualmente sufrirán en maitines los dos que estén de turno, si faltasen...”. A.C.C. Obras Pías. Caja 533. Informe sobre los Niños de Coro. Año de 1811.

${ }^{364}$ Cf. A.C.C. Actas Capitulares. Lunes 31 de Diciembre de 1810. T.100, fol. 222r.

${ }^{365}$ A.C.C. Obras Pías. Caja n ${ }^{\circ}$ 523. Expediente de venta del Colegio de Infantes de Coro.

${ }^{366}$ Cf. A.C.C. Obras Pías. Caja no 533.
} 
"Que el Niño de Coro Francisco de Paula López, a quien havia puesto una aspa por haver faltado al Coro y su destino, cometió en el día de ayer el exceso, no solo de preguntarle y aun reconvenirle sobre la expresada aspa, sino que advirtió, la havia quitado de los quadernos o quadrantes, de su autoridad propia: También refirió [el señor Vivar] que así el susodicho López, como los demás Niños de Coro y aun lo Acólitos cometían continuamente graves faltas de respeto y devoción en el Coro, sin que haian sido vastante para su corrección y enmienda, las advertencias y reprensiones de los señores Presidentes y Puntadores...”. 367

El Cabildo acuerda suspender temporalmente de todas sus funciones al Niño de Coro Francisco de Paula. ${ }^{368}$ El problema de indisciplina, no sólo de este niño, sino en general de todo el estamento de los infantes, provoca que durante los meses y años siguientes se debatan fórmulas para su solución, aunque en la mente de los capitulares estaba la que acabaría tomándose, cual fue la reapertura del Colegio, para que los niños recibieran allí una educación adecuada. De la lectura de las actas que hacen referencia al problema se desprenden varias circunstancias. En primer lugar vemos cómo en su día se tuvo que cerrar el Colegio por los problemas económicos. A raíz de aquello, los niños, aunque seguían cumpliendo con sus funciones en el Coro, vivían en sus casas. En segundo lugar, esto deparaba, según el Cabildo, que a los niños no se les pudiera instruir correctamente acerca de sus obligaciones y la forma de comportarse. Sin embargo no se podía prescindir de ellos porque todas las funciones que cumplían los infantes en la vida diaria de la Catedral los hacían casi imprescindibles. Estaba claro por tanto que la reapertura del Colegio era lo mejor, por lo que en 1825 se volvió a abrir, también por pocos años, ya que se cerró en 1848. Así nos lo dice García-Cuevas, ${ }^{369}$ y nos lo

\footnotetext{
${ }^{367}$ A.C.C. Obras Pías. Caja n 533.

${ }^{368}$ Ibid.

${ }^{369}$ Según García-Cuevas, en 1825 se vuelve a abrir el Colegio, aunque sin demasiado éxito: "En 1824 se dictaban unas bases en las que, como novedad de mayor alcance, se disponía la reunión de acólitos e infantes. Finalmente, un año más tarde, se abrió el Colegio del Ángel, con la admisión de porcionistas, evidenciándose muy pronto su incapacidad, para superar la decadencia, dada su cortedad de rentas, falta de personal docente y descuido en la enseñanza. Sin duda, para conjurar estos males, en la nueva preceptiva de 1833, se dispuso el término de la referida anexión”. GARCÍA-CUEVAS VENTURA, José. El Cabildo catedralicio cordobés desde la Revolución hasta la Restauración (1788-1882). Córdoba, Servicio de Publicaciones de la Universidad, 1996, p. 46.
} 
corrobora Juan Lucas del Pozo. ${ }^{370}$ Se inicia así una segunda etapa de la que vamos a tratar a continuación. ${ }^{371}$

\section{La $2^{\text {a }}$ Etapa. De 1825 a 1848:}

En reunión del Cabildo del día 25 de Mayo de 1825 se aprueba la reapertura del Colegio. $^{372}$ Esta reapertura presenta alguna novedad, como el reagrupamiento en un solo cuerpo de los Acólitos y los Niños de Coro. La sede permanece en el mismo edificio que en la primera etapa, es decir en el antiguo Hospital de Convalecientes, al que se le han hecho algunas obras de mejora. ${ }^{373}$ Se mantienen en esencia las Constituciones que se fijaron en 1771, pero se complementan con algunas otras normas recogidas en el siguiente reglamento:

“ $\left.1^{\circ}\right)$ Los Acólitos e Infantes de Coro deverán reunirse a formar un solo cuerpo Colegial de Mozos de Coro como los llaman nuestros estatutos los cuales todos indistintamente exercerán los oficios y funciones respectivos a ambas clases, desempeñando cada cual los que atendida su edad, fuerzas, instrucción y demás circunstancias le fuesen designadas.

$\left.2^{\circ}\right)$ El número de nuebos colegiales o Mozos de Coro será en el reestablecimiento del Colegio según lo fue a su erección el de doce, como conforme a nuestros estatutos y a los particulares de su constitución, no pasándose jamás de este número, para evitar así los enormes atrasos ocasionados en su anterior época, por el número excesivo en los fondos de sus rentas; mas no obstante si estas por algún medio o agregación se aumentasen en términos de poder sostener otros dos individuos más,

370 “El día 30 de Mayo de 1825 se instaló por segunda vez el Colegio de Ynfantes de Coro del Santo Ángel de la Guarda de esta Ciudad y el 1 de Mayo de 1848 se cerró”. POZO CÁCERES, Juan Lucas del. "Lista de algunos Maestros de Capilla de la Catedral de Córdoba”. En Colección de Obras. Córdoba, 184?. Ms., p. 391.

${ }^{371}$ Durante esta segunda etapa que estuvo abierto el colegio fueron Maestros de Capilla sucesivamente D. Juan Cuevas y D. Nicolás Anguita, haciendo este último las veces de Maestro de Capilla interino, ya que la plaza estaba oficialmente sin cubrir.

372 “...En virtud de llamamiento, los señores Diputados de Infantes de Coro y Acólitos, informaron de palabra al Cabildo, manifestándole que estando ya evacuadas todas las diligencia previas y dispuesto lo necesario para la apertura del Colegio del Santo Ángel, en cumplimiento de los acuerdos capitulares relativos a su reestablecimiento, sólo restaba que el Cabildo designase el día de su apertura. [...] El Cabildo enterado de cuanto dijeron los señores Diputados y conformándose con su informe acordó que se reestablezca el Colegio del Santo Ángel, bajo la denominación de Colegio reunido de Infantes de Coro y Acólitos, y que su apertura se unifique en el día de la Santísima Trinidad...”. A.C.C. Actas Capitulares. Jueves 26 de Mayo de 1825. T.100, fol. 353r.

${ }^{373}$ Como hemos dicho en anteriores páginas, el Colegio se cerró en 1811. En 1816 se vendió a la oficina de Cabezas de Rentas. A su vez esta lo alquilo a unos particulares. Y ahora, tras una reforma vuelve a utilizarse como Colegio de Infantes de Coro. 
estos podrán ser los muchachos destinados al canto bajo la dirección y enseñanza del Maestro de Capilla de que hablan nuestros estatutos en el de las obligaciones de él.

$\left.3^{\circ}\right)$ La dicha agregación o reunión de los Acólitos a los Infantes de Coro para formar el Colegio se irá haciendo progresivamente y a proporción que bayan vacando plazas de los primeros, se irán nombrando en igual número nuebos individuos del establecimiento. En cuyo caso al agregarse dichas plazas de Acólitos al Colegio se agregarán igualmente los asignados que hoy disfrutan, importe de sus opas y sobrepellices y demás emolumentos que le pertenecen al fondo de las rentas del mismo establecimiento, de cuyo estado y contribuyentes se han presentado al Cabildo con informes listas circunstanciadas.

$\left.4^{\circ}\right)$ Los que hayan ser nombrados bajo el nuevo plan de colegiales lo serán de la edad de 7 años a 10, y cumplirán en la de 16, según los recientes acuerdos del Cabildo. Mas al verificarse esto, los que por su buena conducta y aprovechamiento prometan esperanzas de ser útiles para la Iglesia o para el público se continuarán en el Colegio por otros 4 más; en cuyo tiempo al paso que se perfeccionan en el ramo de instrucción que hayan sobresalido, ofrecerán proporción para ser ocupados en los oficios de Acólitos y ejercer la funciones que exigen mayores fuerzas, como de mayor edad y corpulencia.

$\left.5^{\circ}\right)$ El sistema de instrucción y plan guvernativo y económico del Colegio será por ahora el mismo que regía en él antes de la supresión y está comprendido en sus constituciones impresas y aditamentos manuscritos mandados agregar a ellas como parte suya por acuerdo del Cabildo en el celebrado en 7 de Agosto de 1795 como deberá hacer con el presente reglamento por ser el principal o fundamental que ha de regir en el establecimiento.

$\left.6^{\circ}\right)$ Y último. Dicho establecimiento será colocado en la casa colegio del Ángel hecha para él desde un principio y en que permaneció hasta ser suprimido. Mas perteneciendo al presente su propiedad al Erario de Cabeza de Rentas, por enajenación hecha en su favor por el Cabildo, se tratará a nombre de él acerca de su arrendamiento y el valor de este será satisfecho por el mismo de los fondos de su mesa...

3 de Agosto de 1824. Firmado: Diputaciones de Acólitos e Infantes y Obras Pías". 374

Y con estos parámetros se inicia la $2^{\mathrm{a}}$ etapa del Colegio. Al poco tiempo vemos cómo de nuevo aparecen en las Actas Capitulares asuntos relacionados con el mismo.

${ }^{374}$ A.C.C. Obras Pías. Caja no 533. Reglamento para el Colegio de Infantes. 
Así, el día 12 de Julio de 1825, se aprueba la contratación de D. José Santillana como Tiple de la Capilla de Música, con la obligación de dar clase en el Colegio de Infantes. Igualmente, la madre del infante Mariano Zurbano pide una ayuda económica para paliar la penosa situación en que se encuentra su familia. Todo ello, mientras se discute la solicitud de D. Ramón Palacio, Racionero de la Catedral de Zamora para ocupar el puesto de Maestro de Capilla. ${ }^{375}$

También se intenta ir cubriendo las vacantes existentes en el Colegio, y a principios de Octubre se reciben varias solicitudes de niños que quieren cubrir una plaza, acordando el Cabildo que se les examine oportunamente a todos y que se comuniquen los resultados. ${ }^{376} \mathrm{El}$ día 14 de ese mes se procede al examen, al que se presentan los niños Antonio Izquierdo, Juan Antonio Cívico, José Fernandez y Mariano de Mora, quedando finalmente elegido Antonio Izquierdo, ordenando el Cabildo que se le practicaran las pruebas de limpieza de sangre. ${ }^{377}$

Tal era, sin embargo, el interés de los padres para que sus hijos entraran en el Colegio, que a los pocos días se recibe una carta de Antonio Cívico, padre del niño Juan Antonio Cívico, que a la sazón había quedado segundo en las puntuaciones del examen, en la que solicita al Cabildo que admita a su hijo como Infante de Coro, debido al excelente examen que hizo, a la buena voz que tenía y a sus probados conocimientos de lectura y escritura, con el compromiso de asumir su mantenimiento hasta que se produjera una nueva vacante. El Cabildo pasó dicha solicitud a la Diputación de Infantes de Coro para que informara al respecto. ${ }^{378}$

Como era previsible, a los pocos días se recibe una carta de Bartolomé Fernández, padre de José Fernández, tercero en la puntuación del examen, en la que solicita exactamente lo mismo, es decir, que su hijo sea admitido en el Colegio mientras se produce vacante, e igualmente su solicitud queda a expensas del informe de la Diputación de Infantes de Coro. ${ }^{379}$

\footnotetext{
${ }^{375}$ Cf. A.C.C. Actas Capitulares. Martes 12 de Julio de 1825. T.100, fol. 368v y 369r.

${ }^{376}$ Cf. A.C.C. Actas Capitulares. Martes 11 de Octubre de 1825. T.100, fol. 399r.

${ }^{377}$ Cf. A.C.C. Actas Capitulares. Viernes 14 de Octubre de 1825. T.100, fol. 402r.

${ }^{378}$ Cf. A.C.C. Actas Capitulares. Martes 25 de Octubre de 1825. T.100, fol. 405r.

${ }^{379}$ Cf. A.C.C. Actas Capitulares. Jueves 31 de Octubre de 1825. T.100, fol. 407r.
} 
Por si fuera poco se recibe una carta de Diego de Estrella, padre de Antonio José Estrella, en la que solicita lo mismo que los anteriores aunque su hijo no se había presentado al examen. ${ }^{380}$

Mientras tanto, ya se habían hecho las pruebas de limpieza de sangre a Antonio Izquierdo, y una vez presentadas ante el Cabildo éste da su consentimiento y dictamina que el citado niño "podía entrar en el Colegio y vestir el manto y la sobrepelliz para asistir al Coro". 381

Pero volviendo al anterior litigio, la insistencia de los padres tuvo éxito, y el día 18 de Noviembre el Cabildo aprobó admitir en el Colegio de Infantes a Juan Antonio Cívico, José Fernández y Antonio Estrella, eso sí, en calidad de porcionistas, es decir, con una serie de condiciones, como la obligación de proveerse ellos mismos del manto, la beca, el bonete y sobrepelliz, contribuir al Colegio con cuatro reales diarios, etc. Deberán hacerse las correspondientes pruebas de limpieza de sangre y superar un examen de admisión, que en este caso sólo tendría que realizar Antonio Estrella, puesto que los demás ya se habían examinado. ${ }^{382}$

En reuniones del Cabildo posteriores vemos que se admiten las pruebas de limpieza de sangre de los niños, que Antonio Estrella aprueba su examen de ingreso y que, en definitiva, se va completando esta primera promoción de la nueva etapa del Colegio de Infantes de Coro, la cual como hemos dicho anteriormente, tendrá un recorrido relativamente corto.

El día 12 de Abril de 1848, el Cabildo, vistas las dificultades económicas insalvables que de nuevo afectan al Colegio, decide lo siguiente:

“ $1^{\circ}$ ) Que en el último día del corriente mes de Abril se cierre el Colegio de Infantes de Coro.

$\left.2^{\circ}\right)$ Que de los cinco niños que hay en el día, uno de ellos que es ya Acólito quede segregado de este número, y los otros continúen asistiendo al Coro desde sus casas en los mismos términos y a las mismas horas que lo hacen ahora desde el Colegio.

\footnotetext{
${ }^{380}$ Cf. A.C.C. Actas Capitulares. Jueves 3 de Noviembre de 1825. T.100, fol. 408v.

${ }^{381}$ A.C.C. Actas Capitulares. Sábado 5 de Noviembre de 1825. T.100, fol. 409v.

${ }^{382}$ Cf. A.C.C. Actas Capitulares. Viernes 18 de Noviembre de 1825. T.100, fol. 414r.
} 
$\left.3^{\circ}\right)$ Que de las rentas propias que todavía conserva el Colegio se señalen dos reales diarios a cada uno con sujeción a aspas, a cuyo efecto se les anotará en los cuadrantes como a los veinteneros, por tener también como estos asistencia a Maitines.

$\left.4^{\circ}\right)$ Se abrirá un turno para que asistan semanalmente dos a la Capilla de Villaviciosa a las hora que según lo acordado por el Cabildo debe abrirse la expresada Capilla.

$\left.5^{\circ}\right)$ De las mismas rentas del Colegio se dotará un Maestro de Canto Llano con tres duros mensuales, los cuales se pagarán a un Maestro de Órgano cuando estén suficientemente instruidos en el primer ramo, cesando ya de un todo la enseñanza de la música por no ofrecerles ventaja alguna para el porvenir en el actual estado de cosas.

$\left.6^{\circ}\right)$ Se les señalarán un Dependiente de Coro que cuide de ellos y de su enseñanza, destinándoseles local por la Diputación para que concurran en él a aprender la Calenda, las Ceremonias del Coro y la lección de canto o de órgano.

$\left.7^{\circ}\right)$ Queda autorizada la Diputación de Infantes de Coro para proceder a la enajenación de los enseres del Colegio con el objeto de atender con su importe a cubrir la parte que se pueda de los gastos causados y que se causen desde Enero del presente año hasta fin del presente mes...”. 383

La información obtenida de este acta pone de manifiesto el agónico final de este Colegio, que en sus últimos días sólo tenía cuatro Niños de Coro y un Acólito, deudas contraídas y en definitiva unas circunstancias que inevitablemente propiciaron su desaparición.

No descartamos sin embargo, que en fechas posteriores pudiera haber existido una tercera etapa del Colegio, si no en los mismos términos del anterior, sí en otros parecidos. Nos induce a pensar esto el punto sexto del acta anterior donde se contempla la posibilidad de habilitar un local para que los niños pudieran recibir clases. Otro dato que apoya esta hipótesis es un documento del año 1852 encontrado en el Expediente del Colegio de Infantes de Coro, en el que se hace referencia a una casa situada en la calle Pedregosa (actualmente Blanco Belmonte), que el Cabildo habría habilitado para los Niños de Coro. ${ }^{384}$ Queda pues abierto el camino para una próxima investigación.

\footnotetext{
${ }^{383}$ A.C.C. Actas Capitulares. Miércoles 12 de Abril de 1848. T. 114, fol.187v y 188r.

${ }^{384}$ Cf. A.C.C. Obras Pías. Caja no 534.
} 


\subsection{EL SOCHANTRE.}

El sochantre tiene la función de guiar el canto llano en los oficios litúrgicos de las Catedrales, "teniendo a su cargo el canto de las antífonas gregorianas y la entonación de los salmos, himnos... y de otras partes gregorianas”. 385

Los Estatutos de la Sancta Yglesia Cathedral de Córdova dicen que "el oficio del Chantre era antiguamente el que haze ahora el Sochantre, y ansi esta dignidad se proueya en personas de buenas vozes y muy diestros en el canto, y como esto ha cessado, el Sochantre haze el officio en lugar del Chantre, al qual le quede todavía obligación de tener cuydado que el Sochantre como su lugarteniente haga el officio como conuiene en la entonación de las antíphonas, hymnos, psalmos y de los demás que es a su cargo". 386

La figura del sochantre aparece documentada por primera vez en la Catedral de Córdoba el 15 de marzo de 1362. El oficio estará vinculado durante la segunda mitad del siglo XIV indistintamente a una ración entera o a una media ración. ${ }^{387} \mathrm{La}$ importancia que para el Cabildo tiene esta figura, queda recogida en el siglo XVI: “El oficio de sochantre es tan necesario en todos los coros de las yglesias catedrales que sin él no se podría pasar sin desórdenes en las entonaciones y en todo el canto de él”. 388

Por si todas estas normas no fueran suficientes, a principio del siglo XIX, se vuelven a regular las obligaciones del Sochantre y de su Teniente, con el cual se alternaba en las labores propias del cargo. Así, el Sábado 27 de Junio de 1807, el Cabildo acuerda redactar dichas normas. En ellas se especifica que: "El Sochantre y su Teniente, en sus respectivos días darán las entonaciones en los Salmos, las Antífonas, Misas, Preces, Responsorios, y demás que se acostumbra en el Coro, Procesiones, Rogaciones, y otros actos, según se observa en la práctica del día”. 389

\footnotetext{
385 PEREZ, Mariano: Diccionario de la Música y los Músicos. Madrid, Ediciones Istmo, 1985, vol. 3, pág. 205.

${ }^{386}$ FRESNEDA, Fray Bernardo de. Estatutos de la Sancta Iglesia Catedral de Córdoba. Antequera, 1577. Fol. 2.

${ }^{387}$ NIETO CUMPLIDO, Manuel. "La música en la Catedral de Córdoba (1236-1577)”, en AA.VV. El Patrimonio Histórico-Musical de Córdoba. Córdoba, Ayuntamiento de Córdoba, 2004, pág. 69.

${ }^{388}$ Ibid. A su vez, éste cita: A.C.C. Actas Capitulares, 18, 85v.-90v.

${ }^{389}$ A.C.C. Actas Capitulares. Sábado 27 de Junio de 1807. T. 98, fol.254r.
} 
Tan importante se consideraba su función que se les prohibía salir de la ciudad de manera simultánea: “El Sochantre y Teniente no podrán a un tiempo ausentarse de la ciudad".390

La necesidad de contar con dos personas para hacer este trabajo estaba plenamente justificada, ya que supuestamente tenían que desarrollar su oficio todos los día del año: "El Sochantre de esta Santa Iglesia ará su ofto. en las oras diurnas de todos los días del año, ya fuesen de primera clase desde las primeras vísperas hasta las segundas”. 391

A lo largo de 37 puntos, se desarrollan estas y otras cuestiones. Después se abre un apartado especial sólo para el Teniente de Sochantre, en el que entre otras cosas dice que: "será de su cargo cantar y regir el Coro todos lo días y oras que no están señalados y referidos al Sochantre”. ${ }^{392}$

Por tanto, podemos concluir que el Sochantre es una figura imprescindible en la actividad musical de la Catedral, y que al igual que el Maestro de Capilla es el máximo responsable en el apartado de la polifonía, el Sochantre lo es igualmente en todas las piezas del canto llano que se interpretan en la misa y los oficios.

\subsection{LA VEINTENA.}

Según Samuel Rubio, durante el Renacimiento, “A la interpretación de la música polifónica prestaban su concurso otros componentes del clero catedralicio, como capellanes de veintena, así llamados por ser veinte, cuya misión principal, también remunerada, era la ejecución del canto llano". ${ }^{393}$ Este era en efecto su cometido principal, aunque no siempre fueran veinte, como nos dice Nieto Cumplido: "Entre los participantes en el canto del oficio divino contaron los 12 Capellanes de la

\footnotetext{
390 Ibid.

${ }^{391}$ Ibid. pág. 255.

392 Ibid. pág. 257.

393 RUBIO, Samuel. Historia de la música española desde el ars nova hasta 1600. Madrid, Alianza Editorial, Alianza Música, 1983, pág. 33.
} 
Veintena. [...] La denominación de Capellanes de la Veintena queda documentada [en la Catedral de Córdoba] desde el 5 de Marzo de 1462" ${ }^{394}$

Ya durante la época de Balius, la veintena, además de cumplir su función principal como intérpretes del canto llano, participaba activamente con la Capilla de Música, tanto en los actos que se celebraban dentro de la Catedral como en las procesiones, aunque en ocasiones se produjera cierta descoordinación:

"Otro abuso se ha introducido en el canto del Te Deum, que se dice en las mismas procesiones y es no cantarse nada por la Capilla ni por nadie, quando toca el verso de la música: los instrumentos solos son los que suplen, y el citado himno por consiguiente se dice ó canta a medias. Esto es tan claramente deparable y defectuoso, que no es necesario detenerse á demostrarlo. Es verdad, que quando se canta el Te Deum en el coro en el órgano, no se canta el $2^{\circ}$, que tocar éste; pero hay una voz, que lo dice en alto, y suple por el coro. En las Procesiones dichas no hay este arbitrio, ni conviene adoptarlo. Un medio sencillo y fácil es el que debe ponerse en execución; y es, que el Maestro de Capilla componga una música sencilla para los versos del Te Deum que corresponden a la Capilla en su alternación con la veintena, y que ésta música sea proporcionada y respectiva al Canto Llano, en que está apuntado el otro himno en los nuevos libretes, destinados al efecto; repartiendo los competentes papeles a los músicos y llevando el compás en otras ocasiones, como lo lleva, y ha llevado en otras equivalentes o semejantes". 395

También en 1810 tenemos referencia de que la veintena sigue integrada por doce miembros, tal como decía Nieto Cumplido que se hacía durante el Renacimiento:

"La veintena, compuesta de ordinario de doce individuos cantores, una ó dos más ó menos, sostenida hasta ahora por la Mesa Capitular, le ha costado y cuesta en cada año poco más de mil ducados en maravedies, y quinientas cuarenta fanegas de trigo, que valoradas al precio de 40 reales cada una importan "21.600” reales, $y$ unidos a los maravedies componen un anual de "33.130" reales". 396

\footnotetext{
${ }^{394}$ NIETO CUMPLIDO, Manuel. "La música en la Catedral de Córdoba (1236-1577)”, en AA.VV. El Patrimonio Histórico-Musical de Córdoba. Córdoba, Ayuntamiento de Córdoba, 2004, pag. 70.

${ }^{395}$ A.C.C. Actas Capitulares. 1 de Diciembre de 1810. T.100.

${ }^{396}$ A.C.C. Actas Capitulares. Miércoles 19 de Diciembre de 1810.
} 
Pero además de ilustrarnos sobre el número de componentes, este pasaje nos adelanta algo del problema que en esos momentos afectaba a todos los estamentos de la Catedral de Córdoba, como era la recesión económica. Esto hizo que la veintena también entrara en observación por si se podía reducir su asignación.

"pasaron ya aquellos días felices, en que la economía prudente podía mirarse como mezquindad, los ahorros por debilidad de espíritu y la previsión de las desgracias como una mala preparación de los ánimos. Vivimos ya en tiempos más ruinosos, y en proporción de la cortedad de medios, en que nos hallamos, de las desgracias que hemos padecido y de las desventuras que pueden sobrevenir, conviene buscar los remedios oportunos para que ni el culto público y solemne falte, y V.S. por su moderada congrua pueda atender exclusivamente á la celebración de los oficios, á la observancia de los ritos, y al canto de loor de la Divinidad. V.S. ha oído ya algunos medios practicables para economizar gastos, pero quedan aún otros, debiendo ser uno de los principales el pensamiento de evitar a V.S. los fondos y frutos, que se consumen en la manutención de la Veintena”. 397

Como no podía ser de otra manera, la recomendación es limitar los gastos, para así poder hacer frente a los años de carestía que se vivían entonces.

"Preparémonos para esta época, y con la sola aplicación, que desde luego se vaya haciendo de los fondos de música para los ministros del canto y rito, no pueden faltar a V.S. los fondos necesarios. Este punto propuesto por V.S. a los demás Cabildos, lo arreglarán y dispondrán en términos, que sin perjudicar a sus usos y exclusivos derechos en aquellos fondos establecerán plazas y dotaciones para el salméo, como lo hicieron para la música. V.S. logrará con este establecimiento una economía inmensa en los gastos que hoy hace para su manutención y resultará por otra parte una ventaja, que es digna de considerarse para las miras de V.S.”. 398

\footnotetext{
397 Ibid.

398 Ibid.
} 
Ya hemos visto que los Capellanes de Veintena, además de sus funciones naturales de apoyo al canto llano, se ocupaban también, si así fuese necesario, de apoyar a la Capilla de Música. Que su número no tenía que ser veinte, sino que en nuestra ciudad oscilaban alrededor de doce, y que al igual que otros estamentos, ellos también se vieron afectados por los recortes en los momentos de recesión económica. En cualquier caso fueron otro pilar importante en la organización musical de la Catedral de Córdoba.

\subsection{ESTATUTOS Y NORMAS DE FUNCIONAMIENTO DE LA CAPILLA DE MÚSICA.}

Según Vázquez Lesmes, hay que remontarse a la primera mitad del siglo XV para encontrar los primeros estatutos que regulan algunos aspectos relacionados con la música en la Catedral de Córdoba. Se trata de los llamados Estatutos de Pérez Contreras, Deán del Cabildo en $1430 .^{399}$ En ellos se fijan normas para la elección del sochantre, sus obligaciones o cómo enseñar Canto Llano a los Mozos de Coro, si bien la formalización de la Capilla de Música parece lógico establecerla con la llegada del primer Maestro en 1505: Martín Rodríguez de la Fuente (llamado con frecuencia Martín de la Fuente). ${ }^{400}$ Le siguieron Luís Can de Roa en 1523, Pedro de Vega en 1524 y así una larga lista de Maestros, hasta llegar en 1785 a Jaime Balius y Vila.

No obstante, parece que los primeros estatutos que afectan de una forma más completa a la organización de la Capilla de Música son los Estatutos de la Sancta Iglesia Catedral de Córdoba. ${ }^{401}$ Son conocidos también como Estatutos de Rojas y Sandoval o Estatutos de Fresneda, por ser Cristóbal de Rojas y Sandoval (obispo de Córdoba entre 1562-1571) quien los inició y Bernardo de Fresneda (obispo de Córdoba entre 1571-1577) quien finalmente los recopiló. Fueron editados en 1577. Dichos Estatutos sí que especifican con todo lujo de detalles los principales aspectos referidos a

\footnotetext{
${ }^{399}$ Cf. VÁZQUEZ LESMES, Rafael. "La Capilla de Música de la Catedral cordobesa”. Boletín de la Real Academia de Córdoba nº 110. Córdoba, 1986, pág. 115.

${ }^{400}$ NIETO CUMPLIDO, Manuel. "La música en la Catedral de Córdoba (1236-1577)", en AA.VV. El Patrimonio Histórico-Musical de Córdoba. Córdoba, Ayuntamiento de Córdoba, 2004, pag. 79.

${ }^{401}$ FRESNEDA, Fray Bernardo de. Estatutos de la Sancta Iglesia Catedral de Córdoba. Antequera, 1577.
} 
la organización y funcionamiento de la música en la Catedral, tanto en lo referido al Canto Llano como a la propia Capilla de Música. Nos hablan del Chantre, del Sochantre, Capellanes de Veintena, Maestro de Capilla, Organista, Cantores, Músicos Instrumentistas y Mozos de Coro. Recogen la experiencia acumulada a lo largo de más de tres siglos, durante los cuales se hizo música con medios diversos.

Estos Estatutos sientan la base de la posterior organización musical en la Catedral de Córdoba, por lo que hemos querido hacer una breve referencia a ellos.

Nos servimos del artículo de D. Manuel Nieto Cumplido "La música en la Catedral de Córdoba (1236-1577)”, para una primera vista de conjunto:

"Lo primero que disponen y ordenan el obispo don Cristóbal de Rojas y Sandoval (1562-1571) y el Cabildo es la base económica que sustentará todo el cuerpo musical, sobre todo el de sochantre, cantores y músicos. Para ello se aumentan los escusados procedentes de los diezmos en favor de la Fábrica de la Catedral. Una vez que ajustaron cuentas y crearon un excelente soporte económico, se pasó a establecer el número de músicos: un Maestro de Capilla, obligado a componer chanzonetas y villancicos para la Navidad y el Corpus Christi, dos muchachos de buenas voces, un tiple, un contralto, un tenor, un contrabajo, un organista y cuatro ministriles. Se señala el salario del sochantre, figura que no sólo no se pierde, se consolida en virtud de su importancia en la ordenación de la música coral como antes se ha dicho. El número de mozos de coro, doce, y su Maestro. A esta estructura, consolidada por estatuto, se le añaden las obligaciones de cada persona o de cada grupo que interviene en la música, es decir, el reglamento -extremadamente minucioso- de las funciones de cada interviniente. Se ultiman con la disposición de celebrar oposiciones con edictos de convocatoria para los oficios vacantes que se fijarán en las puertas de las Catedrales de Sevilla, Granada, Toledo y Jaén, así como en cualquier otro lugar que interese. En virtud de estas disposiciones, a partir de la promulgación de los estatutos, se parte de cero y todos los oficios músicos salen a oposición". 402

\footnotetext{
${ }^{402}$ Ibid. pág. 88.
} 
Desde la primera redacción en 1563 hasta su publicación en 1577, experimentaron sucesivas adiciones o modificaciones, en función de la experiencia acumulada a lo largo de esos primeros años de rodaje.

El siguiente paso en lo referente a Estatutos o normas que afectan a la música lo encontramos en 1601, cuando se promulgan las "Constituciones y Arreglamento que deben observar el Maestro de Capilla, Músicos y cantores de la Sancta Yglesia de Córdova, echo en 17 de Febrero de 1601", 403 y que forman un corpus doctrinal que regirá durante más de dos siglos, con algunas modificaciones puntuales. Una de estas modificaciones se hizo en 1753, y es recogida por Vázquez Lesmes en su artículo sobre la Capilla de Música de la Catedral de Córdoba. ${ }^{404}$

Paralelamente a estas normativas para la Capilla de Música de la Catedral, existen unas Constituciones y Estatutos que su Magestad Cathólica Felipe IV, nuestro Señor, mandó hacer para el buen govierno, y servicio de su Capilla Real, sita en la Santa Iglesia Catedral de Córdova. Estas constituciones, (fechadas el 30 de Marzo de 1704) regulan el funcionamiento de dicha Capilla en todos los aspectos, desde el nombramiento del Capellán, y el protocolo en las ceremonias, hasta las cualidades que deben adornar al Sochantre o a los Mozos de Coro:

"Ha de aver en la dicha Capilla dos Acólitos, ó mozos de Choro, que sepan leer, y escribir, y tengan vastantes voces para servir en el Choro, para los quales tenga la Fábrica de la Capilla ropas de paño negro y sobrepellizes, porque con este avito han de estar siempre en ella: y ponersele y quitarsele en la Sacristía donde se les ha de guardar. Y los dichos dos Acólitos han de ayudar las Misas, que se dixeren en la Capilla, y servir en el Altar, y Choro en lo que les mandaren, con todo cuydado,

\footnotetext{
${ }^{403}$ A.C.C. Obras Pías, caja 816, no 9.

404 “... al tener en cuenta que muchas de las disposiciones contenidas en estas constituciones, por el transcurso del tiempo, no habían sido puestas en práctica y con la finalidad de hacerlas observables, se tomó el acuerdo de reformar ocho de ellas, dándole dicho encargo al Deán y a un Canónigo, quienes, una vez redactadas, las presentaron al Cabildo, siendo aprobadas en el primer mes del año siguiente. Mediante su lectura detenida, se llega a la conclusión más de reafirmar y recordar obligaciones incumplidas que de nuevas aportaciones y cambios. Detalles sobre puntualidad, conducta y ceremonial, junto con el levantamiento del deber del ensayo diario cambiado por el de un día a la semana, constituyen las principales aportaciones añadidas". VÁZQUEZ LESMES, Rafael. "La Capilla de Música de la Catedral cordobesa”. Boletín de la Real Academia de Córdoba, nº 110. Córdoba, 1986, pág 122.
} 
diligencia, y humildad. Y la elección de los quales, y nombramiento será del Capellan mayor, y así mismo el despedir el que de ellos fuere díscolo, o por otros respectos no conviene para el servicio de la Capilla”. 405

Volviendo a los estatutos que afectan a la Capilla de Música de la Catedral, vemos cómo se sigue añadiendo cláusulas a las normativas anteriores. Estando ya Jaime Balius en Córdoba, concretamente en 1790, se añade otra que prohíbe “cantar pasiones en otras iglesias, excepto en el Monasterio de Religiosas de la Encarnación, por ser patronato del Cabildo". ${ }^{406}$ Era frecuente, y no solo en Córdoba, que los cabildos prohibieran a sus músicos actuar fuera de la Catedral. Así sucedía en Málaga, en cuya Catedral hay normativa al respecto: "Que ningún compañero pueda concurrir en función eclesiástica dentro ni fuera de Iglesias, siendo avisado por el Mayordomo y el que delinquiese sea multado en lo mismo que haya ganado. Y si hubiese concurrido de gracia, sea multado en diez reales por cada vez". ${ }^{407}$

De esta forma enlazamos con el nuevo siglo, al principio del cual se instituye el Ceremonial y manual de las preces, antífonas, himnos, salmos y oraciones que deben decirse en esta Santa Iglesia Catedral de Córdoba ${ }^{408}$. Fechado en 1805, su autor, el doctor D. Manuel Ximenez y Hoyo, Maestro de Ceremonias de dicha Catedral, nos detalla cómo debe celebrarse el citado ceremonial "en las rogativas, procesiones y demás funciones que se celebran y pueden ocurrir, con arreglo al ritual romano, y loables costumbres de dicha Santa Iglesia". 409

La precisión y detalle de este manual son extremos, describiendo con exactitud qué debe cantarse, en qué momento, quién debe encargarse de la interpretación, (la

\footnotetext{
${ }^{405}$ Constituciones y Estatutos que su Magestad Cathólica Felipe IV, nuestro Señor, mandó hacer para el buen govierno, y servicio de su Capilla Real, sita en la Santa Iglesia Catedral de Córdova. Córdoba, 1704, pág. 9. En Biblioteca Municipal.

${ }^{406}$ VÁZQUEZ LESMES, Rafael. "La Capilla de Música de la Catedral cordobesa”. Boletín de la Real Academia de Córdoba, nº 110. Córdoba, 1986, pág 122.

${ }^{407}$ TORRE MOLINA, Ma José de la. "Las constituciones de 1766 de la Capilla de Música de la Catedral de Málaga”, en Revista de Musicología Vol. XXVIII. Madrid, Sociedad Española de Musicología, 2005, pág. 303. A su vez, Torre Molina cita el Libro de las Constituciones y Acuerdos de la Capilla de Música de la Santa Iglesia Catedral de Málaga, f. 15r. (Junta de Capilla de 25/09/1814).

${ }^{408}$ XIMENEZ Y HOYO, Manuel. Ceremonial y manual de las preces, antífonas, himnos, salmos y oraciones que deben decirse en esta Santa Iglesia Catedral de Córdoba. Córdoba, 1805.

${ }^{409}$ Ibid. Pág.1.
} 
Capilla de Música, los Seises, los Veinteneros, etc.), con qué ropajes deben ir vestidos los "Ministros", y así sucesivamente con cada uno de los participantes en las ceremonias.

Toda esta minuciosidad es aplicada caso por caso, describiendo todas y cada una de dichas ceremonias, bien sean litúrgicas o paralitúrgicas: Rogativas, misas, recepciones de nuevos obispos, celebraciones por la subida al trono de un nuevo rey, procesiones, etc. ${ }^{410}$

En 1806, encontramos un Nuevo Estatuto sobre el modo de cumplir los días de Oficios (fechado el día 24 de Enero). En él se habla en algún momento del aspecto musical, especificando qué oración hay que cantar en cada estación de cada día. ${ }^{411}$

Por último, en 1810, se formulan una serie de normas para corregir defectos en el comportamiento de la Capilla de Música y los Veinteneros durante las procesiones. Estos defectos estriban principalmente en las grandes pausas en el canto, las conversaciones que mantienen los músicos durante la procesión, y en definitiva la falta de formalidad y solemnidad con que se actúa en estas funciones. ${ }^{412}$

\subsection{VACIADO CRONOLÓGICO DE NOTICIAS MUSICALES (1785-1822). ${ }^{413}$}

En la vida diaria de la Capilla Musical, muchas son las cuestiones que los músicos plantean al Cabildo. Pueden estar directamente relacionadas con la música o afectar a cuestiones de funcionamiento. Las reuniones del Cabildo se celebraban normalmente en la Capilla de San Clemente, hasta 1807 en que pasaron a celebrarse en la Capilla del Cardenal Salazar. Allí se trataban las cuestiones de interés, se hacían las

\footnotetext{
${ }^{410}$ Se pueden ver las 25 primeras normas en el Apéndice Documental.

411 Nuevo Estatuto sobre el modo de cumplir los días de Oficios. Córdoba, 1806. En Biblioteca Municipal.

${ }^{412}$ Se pueden ver completas dichas leyes en el Apéndice Documental.

413 Se ha organizado este apartado por años, haciendo referencia a la fecha concreta de cada noticia en nota a pie de página, en donde también se refleja el Tomo o Libro de Actas Capitulares de procedencia. Estas noticias no se han numerado correlativamente, ya que se han extraído de aquí algunas de ellas para ilustrar los apartados del Maestro de Capilla y de los organistas.
} 
tomas de posesión de los nuevos músicos, incluso se llegaba a examinar en alguna ocasión a los Niños de Coro.

Como hemos dicho, las noticias musicales de este periodo hacen referencia a muy variadas temáticas. Una de las más habituales era la petición de permiso para ausentarse. Estos permisos podían ser por enfermedad. En este caso era normal ir a recuperarse a algún sitio determinado, que podía ser la tierra de origen de cada uno, o algún sitio que le fuera beneficioso para su curación. ${ }^{414}$

También era común la petición de permiso para poder opositar a alguna vacante de músico de otra ciudad. ${ }^{415}$

Son igualmente muy frecuentes las noticias en que se hace referencia a peticiones de ayuda económica o aumentos de sueldo. Estas peticiones podían deberse a gastos derivados de alguna contingencia ocasional como viajes, gastos por enfermedad, etc. En estos casos, el interesado somete un breve memorial al Cabildo en el que le expone las razones que llevan a pedir dicha "ayuda de costa". Si son ayudas menores y/o el Cabildo encuentra justificadas las razones, suelen concederse. ${ }^{416}$

Otras noticias que encuentran cierta resonancia en las actas capitulares hacen referencia al funcionamiento de las actividades musicales en el Colegio del Santo Ángel de la Guarda, donde recibían educación los infantes que servían en el Coro de la Santa Iglesia Catedral de Córdoba. De los procedimientos para entrar a formar parte de él tenemos abundante información, así como de su vida diaria, donde los infantes o sus familiares solicitan (igual que lo hacen los músicos de la Capilla), toda clase de ayudas, permisos, etc., para atender muy diversas necesidades. ${ }^{417}$

\footnotetext{
${ }^{414}$ D. Antonio Gil, Capellán de San Acacio, y músico tenor de esta Santa Iglesia, pide permiso "para pasar a su tierra a tomar los aires patrios como medicina de la enfermedad que padece...”. A.C.C. Actas Capitulares. Lunes 27 de Junio de 1803, T.96.

${ }^{415}$ El Acólito Miguel López "solicita licencia para ir a la oposición de una plaza de Contraalto de la Colegial de Antequera, y se le concede por un mes". A.C.C. Actas Capitulares. Jueves 4 de Marzo de 1802, T.96.

${ }^{416}$ D. Miguel Reinaldi, que dos días antes ha conseguido la plaza de primer violín de la Capilla de música, solicita licencia "para pasar a Madrid por su familia y además una ayuda de costa". El Cavildo acuerda concederle "mes y medio de licencia a D. Miguel Reynaldi para que pase a Madrid, igualmente el Cavildo le concedió por votos secretos dos mil reales de ayuda de costa por una vez". A.C.C. Actas Capitulares. Viernes 27 de Septiembre de 1805, T.98.

${ }^{417}$ El Cabildo pide informes a los Diputados de Niños de Coro sobre el aspirante Mariano González, exigiendo que en dichos informes conste que dicho aspirante "no es de raza de moros, antes sí hijo de padres cristianos viejos y limpios, y de lexitimo matrimonio". A.C.C. Actas Capitulares. Martes 20 de Noviembre de 1821. T.106.
} 
También nos encontramos en alguna ocasión alguna referencia a la compra o arreglo de instrumentos, normalmente por estar muy deteriorados los existentes, y por supuesto son muy habituales las noticias que hacen referencia a oposiciones diversas de músicos asalariados tanto de voz como de instrumento, así como oposiciones a Capellanías. ${ }^{418}$ Nos podemos encontrar incluso referencias al ingreso de algún músico en la Cárcel Episcopal. ${ }^{419}$

Ya hemos visto algunos ejemplos de la gran variedad de noticias que tratan las actas capitulares. Ahora las veremos detalladas cronológicamente desde el momento en que Balius llega a Córdoba, en 1785 hasta 1822:

\section{5}

Petición de aumento de sueldo de D. Juan de la Peña, músico instrumentista, a quien el Cabildo "acordó concederle cincuenta reales y seis fanegas de trigo de aumento de salario". 420

Los Diputados del Colegio de Infantes dieron cuenta de haber dos opas vacantes en dicho colegio y el Cabildo acordó se dé llamamiento para oír los pretendientes y proveerlas. $^{421}$

“En virtud del llamamiento para oír el informe de los Señores Diputados del Colegio del Santo Ángel de la Guarda, a fin de proveer las dos vecas vacantes o darse aquellas providencias convenientes; en efecto informaron dichos Señores con respecto a proveerlas; de las diligencias más exactas practicadas a este intento; y de éstos los dichos pretendientes esperando para ser examinados; en cuya atención se mandó entrar a el rector de dicho colegio el que informó de todas las circunstancias que

\footnotetext{
418 "Se leió un memorial de Francisco Guentos violinista pidiendo licencia para hacer oposición a la plaza de primer violín de esta Santa Iglesia, y se acordó se le oiga el miércoles 8 del corriente después de completas, y a su tiempo informe el Maestro de Capilla". A.C.C. Actas Capitulares. Lunes 6 de Mayo de 1805, T.97.

${ }^{419}$ En el acta de este día se relata el hecho de "haber puesto preso a D. Manuel Valls músico de esta St ${ }^{a}$ Iglesia en la Carcel Episcopal para su debida corrección...", aunque no especifica los motivos que le llevaron a tal situación. A.C.C. Actas Capitulares. Martes 21 de Julio de 1804, T.97.

${ }^{420}$ A.C.C. Actas Capitulares. Miércoles 15 de Junio de 1785. T.90, f.134v.

${ }^{421}$ A.C.C. Actas Capitulares. Jueves 23 de Junio de 1785. Las opas vacantes eran las plazas del Colegio de Niños de Coro que había que cubrir por estar desiertas.
} 
concurren en los opositores, e hizo su juicio comparativo; y habiéndose retirado, se leyó otro informe del Maestro de Capilla; y concluido se dio principio a el examen de leer, escribir y cantar". Finalmente quedaron nombrados Antonio Díaz y Rafael de León. ${ }^{422}$

Se presenta memoria de genealogía de Joseph de Posadas: "Se mandó entrar al notario secretario secular con testigos quien leyó el memorial de genealogía de Joseph de Posadas, nombrado en media Capellanía de Veintena”. 423

El Cabildo concede a D. Mateo Bernia, tiple de la Capilla, patitur abierto hasta el día 4 de Octubre del presente año debido a su quebrada salud. También concedió a José López, Infante de Coro, [¿?] días de licencia para ir a tomar las aguas. ${ }^{424}$

Se leyeron dos memoriales uno de D. Pascual Redel y otro de D. Mariano Ortega solicitando ayuda de costa. ${ }^{425}$

“Los Diputados de la Capilla de la Sangre, expusieron que los dos tiples Bernia y Especiali, se hallaban actualmente malos, y aún se aseguraba que a lo menos el uno quedase inútil y que hacía una gran falta en la capilla un tiple, en virtud de lo que se dio colisión a dichos Señores para que propongan medios de cubrirse esta falta. Se propuso lo mismo por los diputados de Santa Inés, respecto de la falta de tiple primero para la capilla". 426

D. Antonio Hidalgo bajonista, pide ayuda de costa: "El Cavildo tuvo a bien en virtud del citado informe concederle 50 pesos". 427

Mariano Ortega músico instrumentista pide aumento de salario: “Celebrado en virtud de votación secreta hecha primera y segunda vez, todo aumento de salario al que

\footnotetext{
${ }^{422}$ Ibid. Miércoles 6 de Julio de 1785. T. 90, fol. 144 v.

${ }^{423}$ Ibid. Miércoles 20 de Julio de 1785. T.90.

${ }^{424}$ Ibid. Jueves 28 de Julio de 1785. T.90.

${ }^{425}$ Ibid. Sábado 27 de Agosto de 1785.

${ }^{426}$ Ibid. Martes 7 de Septiembre de 1785.

${ }^{427}$ Ibid. Martes 7 de Septiembre de 1785.
} 
hoy goza dicho Ortega que es de 150 ducados de vellón. Después, por gracia, se le concedió de ayuda de costa y por una sola vez la cantidad de 1000 reales de vellón”. 428 En el mismo día, el músico tiple Juan Bueno pide recibir las órdenes sagradas y el Cabildo acuerda que así se haga. ${ }^{429}$

“Sobre la pretensión de D. Pascual Redel músico instrumentista, se leyó el informe y en virtud de él acordó el Cabildo concederle quatrocientos cincuenta reales de ayuda de costa." 430

El Cabildo discute sobre la pretensión de D. Pablo de Bárcena, instrumentista de la Capilla de Música de esta Santa Iglesia, “que solicita una aiuda de costa” para sus necesidades. Se acuerda concederle seiscientos reales de vellón. ${ }^{431}$

\section{6}

“Haviéndose leído un memorial de D. Rafael García, músico de este Santa Iglesia, solicitando aumento de salario, se dio comisión a los señores Diputados del arca de vacantes de San Acacio" para que informen. ${ }^{432}$

Se leyó informe de los Diputados del colegio del Santo Ángel de la Guarda "Sobre la pretensión de Josef Triguillos, colegial de él, para que se le concediese licencia para hace oposición a una plaza de música de la ciudad de Lucena y que se le diese para el viage aiuda de costa”. El Cabildo acordó concederle un mes de permiso y negarle la ayuda de costa. ${ }^{433}$

“Habiéndose leydo un memorial de D. Juan Busquets, profesor de música de la Capilla de esta Santa Iglesia en que pretende que por la grave enfermedad que padece

\footnotetext{
${ }^{428}$ Ibid. Martes 7 de Septiembre de 1785.

${ }^{429}$ Ibid. Martes 7 de Septiembre de 1785.

430 Ibid. Miércoles 14 de Octubre de 1785. T. 90, fol. 185 r.

431 Ibid. Viernes 16 de Diciembre de 1785. T. 90.

432 Ibid. Jueves 16 de Marzo de 1786. T. 90.

433 Ibid. Sábado 1 de Abril de 1786. T. 90. fol. 222 v.
} 
y urgencias en que se halla se le conceda alguna aiuda de costa de las arcas de vacantes de la Capilla de Santa Inés”. 434

El Cabildo acuerda conceder mil quinientos reales de vellón como ayuda de costa al anteriormente citado D. Juan Busquets. ${ }^{435}$

El músico D. Rafael García solicita aumento de salario, “y habiéndose pasado a votar se le consignaron cien ducados anuales de aumento de salario". 436

"Se leyó un memorial de D. Mariano Ortega, bajonista con salario en las Arcas de San Acacio, pidiendo aumento de salario” y se dio comisión a los Diputados para que informasen. ${ }^{437}$ El Cabildo concede a D. Mariano Ortega, un aumento en su salario anual de "cincuenta ducados y un caíz de trigo". 438

“El Señor Arcediano de Pedroches hizo presente la necesidad de dar providencia para que el Maestro de Capilla y demás músicos, cumpliesen exactamente, con la obligación de enseñar a los niños y mozos de Coro". ${ }^{439}$

Se leyó un memorial de D. Vicente Espinosa (bajonista), por el que solicita “una ayuda de costa en atención a sus enfermedades y notorias necesidades”. El Cabildo da comisión a los Diputados de Música para que informen al respecto, y así mismo informen sobre la necesidad de "nutrir la Iglesia de bajonistas mediante a ser notoria la necesidad, por hallarse imposibilitados el suplicante y D. Antonio Hidalgo". 440

\footnotetext{
434 Ibid. Sábado 1 de Abril de 1786. T. 90. fol. 223 r.

435 Ibid. Lunes 3 de Abril de 1786. T. 90. fol. 226 r.

${ }^{436}$ Ibid. Miércoles 5 de Abril de 1786. T. 90. fol. 227 v.

${ }^{437}$ Ibid. Miércoles 5 de Julio de 1786. T. 91. fol. 24 v.

${ }^{438}$ Ibid. Jueves 13 de Julio de 1786. T 91. fol. 35 r.

${ }^{439}$ Ibid.

${ }^{440}$ Ibid.
} 
D. Pascual Redel músico instrumentista solicita ayuda de costa "por estar días há gravemente enfermo y muy falto de medios para su curación y alimento”. El Cabildo le concede quinientos reales de ayuda de costa. ${ }^{441}$

"Se mandó leer un memorial de D. Manuel Montesa, difunto, músico tenor que fue de esta Santa Yglesia, el qual memorial, por no haver avido Cabildo no se ha presentado hasta oy. Con el que solicita una ayuda de costa para subvenir a los crecidos gastos en su enfermedad o para su entierro, pues se hallaba en aquella ocasión casi desgraciado”. Se dio comisión a los Diputados de Santa Ynés para que informasen. $^{442}$

“Se leyó una carta de D. Joseph Cordón y Ayala, músico instrumentista de la Santa Iglesia de Málaga, que noticioso de la falta que hay en esta Santa Iglesia de bajonista, y hallándose con instrucción en este y otros instrumentos, solicita el permiso del Cabildo para venir a ser oído, y teniéndose presente la necesidad de bajón, y lo acordado en 17 de julio próximo pasado, se acordó renovar la comisión que en dicho día se dio a los señores Diputados de Escusados de Fábrica para que informasen con llamamiento sobre el mejor y más breve modo de remediar la expresada necesidad de bajonista”. ${ }^{443}$

Sobre la anterior solicitud hecha por D. Manuel Montesa, el Cabildo acordó "que de los caudales de arcas vacantes de Santa Inés se libren mil reales para pagar la casa que havitaba el difunto, y para socorro de su familia que subministraran los señores Diputados en el modo que les parezca más oportuno”. ${ }^{444}$

Se concede a D. Vicente Espinosa "mil reales de ayuda de costa por una vez de los caudales de escusados". 445

\footnotetext{
441 Ibid. Sábado 12 de Agosto de 1786. T. 91. fol. 48 v.

442 Ibid. Martes 12 de Septiembre de 1786. T. 91. fol. 57r.

443 Ibid. Sábado 16 de Septiembre de 1786. T. 91. fol. 58r.

${ }^{444}$ Ibid. Sábado 16 de Septiembre de 1786. T. 91. fol. 58.

${ }^{445}$ Ibid. Lunes 25 de Septiembre de 1786. T. 91. fol. 71.
} 
"Sobre la necesidad que havía de bajonista para celebrar los Oficios divinos, con la solemnidad debida, en atención a hallarse imposibilitados dos de tres que havía en la iglesia, y leído el informe de los señores Diputados conformándose el Cabildo con él, y en atención a hacer sobrante en los caudales de escusados, se acordó que se pongan edictos para término de 44 días, que cumplirán el 8 de Noviembre próximo, para que concurran los pretendientes, señalando de salario annual 350 ducados para el que sea nombrado, visto el mérito de los pretendientes". 446

D. Julián Gálvez, solicita aumento en su salario de 25 ducados anuales y un caíz de trigo. Se le niega lo primero y se le concede lo segundo. ${ }^{447}$

“En virtud del llamamiento para oír el informe de los Diputados de excusados de música sobre el aumento de salario que solicita Don Vicente Marín músico instrumentista de esta Santa Iglesia, leído el informe de los expresados señores se pasó a votar secretamente sobre si se le habían de aumentar cien ducados anualmente y resultó concedido dicho aumento", 448

D. Mariano Ortega, músico instrumentista, "solicita una ayuda de costa en atención a la pobreza en que le han puesto las continuas enfermedades que ha padecido”. El Cabildo acordó dar comisión a los Diputados de la Sangre para que informen al respecto. ${ }^{449}$

Se celebra Cabildo para tratar sobre la provisión de la plaza de bajonista. El día 8 de Noviembre se había cumplido el plazo dado por el Cabildo para presentarse a dicha plaza, ahora las actas reflejan que: "Havían firmado 5 opositores, a saber, D. Mateo Tascón, D. Joseph Berner, D. Andrés Muñoz, D. Juan Puig y D. Joseph Cordón”. Al final de este proceso quedarán nombrados D. Mateo Tascón y D. Juan Puig. ${ }^{450}$

\footnotetext{
446 Ibid.

${ }^{447}$ Ibid. Miércoles 27 de Septiembre de 1786. T. 91. fol. 73.

${ }^{448}$ Ibid. Viernes 6 de Octubre de 1786. T.91.

${ }^{449}$ Ibid. Viernes 10 de Noviembre de 1786. T. 91. fol. 97.

${ }^{450}$ Ibid. Martes14 de Noviembre de 1786. T. 91. fol. 98.
} 
Se lee informe de los Diputados de la Capilla de la Sangre "sobre aumentar el salario annual a D. Manuel Tromperi, músico instrumentista de esta Santa Yglesia. Leído el informe, se pasó a votar secretamente sobre si se le havía de conceder el aumento de 50 ducados y 6 fanegas de trigo y resultó concedido". ${ }^{451}$

\section{7}

“En virtud del llamamiento para oír el informe del Maestro de Capilla sobre el mérito y habilidad de los opositores a la capellanía de San Acacio, vacante por muerte de Don Miguel de Hinestrosa, entró el dicho Maestro y dijo, que de todos los opositores el que resultó más apto es Don Joseph María Moyano, presbítero, y en su vista se procedió a la elección por votos secretos y de ella resultó elegido por todos votos el dicho Don Joseph María Moyano”. Se le asignó sueldo de seiscientos ducados con la precisa condición de que enseñara en el Colegio del Ángel de la Guarda a los que tengan voz de contralto. El Cabildo acordó también despedir a los restantes opositores con una ayuda de costa de seiscientos reales de vellón. ${ }^{452}$

Se lee memorial presentado por Don Alfonso Alfaro, presbítero, Rector del Colegio del Santo Ángel en el que pide se le releve de sus funciones. ${ }^{453}$

Se acuerda la "provisión de la Capellanía de San Antonio, vacante por muerte de Don Francisco Ayala”. 454

“En virtud del llamamiento por el informe del Maestro de Capilla acerca de la suficiencia y habilidad de Juan de Borja en el instrumento de trompa”, se acuerda aceptarlo como miembro de la capilla. ${ }^{455}$

“En virtud del llamamiento para oír el informe de los señores Diputados de excusados de música sobre la plaza vacante de organista, leído el informe se acordó se

\footnotetext{
${ }^{451}$ Ibid. Miércoles 29 de Noviembre de 1786. T. 91. fol. 107.

${ }^{452}$ Ibid. Lunes 29 de Enero de 1787. T.91.

${ }^{453}$ Ibid. Martes 27 de Febrero 1787. T.91.

${ }^{454}$ Ibid. Martes 27 de Febrero 1787. T.91.

${ }^{455}$ Ibid. Martes 27 de Febrero 1787. T.91.
} 
fijen edictos convocando un organista con el salario de ochocientos ducados anuales". 456

Ese mismo día el Cabildo acuerda a propósito de la convocatoria de la plaza de organista por muerte de Don Francisco Ayala, que "se fijen edictos contando sesenta días que empezaran a correr desde el jueves próximo 8 del presente”. 457

"Se leyó un memorial de Don Alonso Martín, músico tiple de esta Santa Iglesia por el que solicita aumento de salario en atención a no poder subsistir por la carestía de los tiempos”. Se acordó dar misión a los señores Diputados de las arcas de San Acacio para que informen sobre esta pretensión. ${ }^{458}$

“En virtud del llamamiento para oír el informe y censura que tenga tomada el Maestro de Capilla nombrado examinador de los opositores a la plaza de organista, se mandó entrar a dicho Maestro de Capilla, quien con la claridad correspondiente dijo había examinado a todos los opositores con la exactitud posible, y que tenía formado juicio de que ninguno de los opositores era capaz de desempeñar la plaza de Organista Mayor de esta Santa Iglesia. Se acordó habiéndose votado de palabra y de secreto, se suspenda la provisión de la plaza de órgano, hasta que se presenten sujetos capaces de desempeñar dicho empleo, y continúen los edictos para que puedan concursar otros opositores y que sean examinados por el mismo Maestro de Capilla, y hecho el examen informe él mismo con separación y gradación del mérito y habilidad de cada uno por escrito". 459

“En virtud del llamamiento para oír la relación sobre la posición de los edictos a la Capellanía de San Antonio vacante por muerte de Don Francisco Ayala y opositores que han concurrido, se mandó entrar al notario secretario, quien dijo, se habían fijado por dos veces edictos, que ha concurrido un solo opositor, el que,

\footnotetext{
${ }^{456}$ Ibid. Sábado 3 de Marzo 1787. T.91.

${ }^{457}$ Ibid. Sábado 3 de Marzo 1787. T.91.

${ }^{458}$ Ibid. Sábado 3 de Marzo 1787. T.91.

${ }^{459}$ Ibid. Miércoles 2 de Mayo de1787. T.91
} 
examinado por el Maestro de Capilla y oído su informe no fue de la aprobación del Cabildo". 460

"Se leyeron dos cartas de dos pretendientes del magisterio de capilla con noticia que tenían de la retirada del Maestro actual; y se acordó se entreguen a los Señores Diputados de Santa Inés para que a tiempo oportuno informen con llamamiento, así de los referidos, como de cualesquiera otros que puedan ser aptos para dicho empleo". 461

"Que dichos Señores Diputados reconozcan el inventario de papeles de música y manden añadir los que se hubieren hecho posteriormente, o manden hacer otro nuevo, que incluya todas las obras propias de dicho archivo, procurando sea esto antes de la retirada del actual Maestro asalariado por este Cabildo”. ${ }^{462}$

"Habiéndose dado la noticia que en el anterior Cabildo de los que excesos de varios músicos cuya recepción y salario penden de éste, y han sido causa de la retirada de dicho Maestro; para tomar de ello conocimiento y, según el proceder a lo que se considere oportuno, se dio comisión a dichos Señores Diputados de arcas vacantes de Santa Inés, para que con asistencia de la parte del Señor Obispo informen con llamamiento de todo lo que consideren conducente a la corrección de los músicos que resulten culpados y sirva de escarmiento y se les de a entender la subordinación que deben tener al Maestro". 463

“El Señor Arcediano de Pedroche hizo presente que el Maestro de Capilla Don Jaime Balius está ya entregando para inventario los papeles y obras de música que ha compuesto el tiempo que ha estado en esta Santa Iglesia. Que es cierto ha dicho que el despedirse del empleo ha provenido de varias disputas y desazones que le habían dado algunos músicos, a quienes sabido quienes son es correspondiente corregir; y a su consecuencia se acordó dar comisión a los mismos Señores Diputados de vacantes de

\footnotetext{
${ }^{460}$ Ibid. Lunes 9 de Julio de 1787. T.91.

${ }^{461}$ Ibid. Martes 31 de Julio de 1787. T.91, fol. 249r.

462 Ibid. Martes 31 de Julio de 1787. T.91, fol. 249r.

${ }^{463}$ Ibid. Martes 31 de Julio de 1787. T.91, fol. 250r.
} 
Santa Inés con la parte del Ilustrísimo Señor Obispo nuestro prelado, digan al Maestro de Capilla, está admitida su despedida; y en cuanto a los excesos de los músicos que se dé igualmente comisión a los dichos Señores Diputados con la parte, informen con llamamiento para el viernes 17 del corriente de todo lo que sepan en orden a este asunto y lo que juzguen conducente para que a los músicos que se hallen culpados se les dé el castigo que merecen y sirva de precaución para lo venidero". 464

El antiguo Maestro de Capilla Don Juan Manuel Gaitán pide permiso para ausentarse de la ciudad. "Le fue concedido patitur abierto para la ciudad y sus arrabales desde hoy hasta el 7 de Mayo inclusive del año próximo venidero de 1788 " ${ }^{465}$

“Se leyó memorial de Don Mateo Tascón, bajonista de esta Santa Iglesia por el que pide una ayuda de costa, y se mandó dar comisión a los Señores Diputados de excusados para que informen con llamamiento sobre el contenido de este memorial". 466

“En orden a la pretensión de Don Mateo Tascón bajonista de ésta Santa Iglesia, leído que fue dicho informe, y lo que de palabra añadieron los referidos Señores Diputados, se acordó por votos secretos que al mencionado Don Mateo Tascón se den por una vez seiscientos reales del caudal de excusados". ${ }^{467}$

"Sobre la pretensión de Juan Puig bajonista de esta Santa Iglesia, leído que fue dicho informe, se acordó por votos secretos que al mencionado Don Juan Puig se le den de ayuda de costa por una vez cuatrocientos reales del caudal de excusados". 468

“Se leyó una carta de Don [ं?] pretendiente de la plaza de primer organista de esta Santa Iglesia y se mandó dar comisión a los Señores Diputados de excusados con

\footnotetext{
464 Ibid. Lunes 13 de Agosto 1787. T.91, fol, 256r.

465 Ibid. 23 de Octubre de 1787. T.91, fol. 259. Aunque no ejerce ya como Maestro de Capilla, Gaitán sigue asistiendo al Coro. Como veremos más adelante, pide frecuentes permisos por enfermedad, a pesar de lo cual se mantiene en contacto con la vida catedralicia hasta su muerte en 1804.

${ }^{466}$ Ibid. Lunes 5 de Noviembre de 1787. T.91, fol. 297r.

${ }^{467}$ Ibid. Jueves 7 de Noviembre de 1787. T.91, fol. 298r.

${ }^{468}$ Ibid.
} 
la parte de su Ilustrísima, informen con llamamiento a su tiempo sobre éste y los demás pretendientes". 469

“Siguiendo el llamamiento para oír las pruebas de limpieza de sangre de Rafael Galiano, nombrado niño de coro, se mandó entrar al notario secretario Don Fernando Aragoneses que leyó la partida de bautismo del dicho Rafael, por la que consta es hermano entero de Joseph Galiano, actual niño de coro”. El Cabildo aprobó las pruebas de limpieza de sangre de Rafael Galiano, y también las de Joseph Pavón, que las había presentado ese mismo día. ${ }^{470}$

\section{8}

Don Félix Vasallo acólito de esta Santa Iglesia pide una ayuda de costa para comprar un bajón. "Se resuelve que se le den de ayuda de costa por una vez, doscientos reales". 471

Joseph Pavón, niño de coro de esta Santa Iglesia pide alguna ayuda de costa para sufragar los crecidos gastos de las pruebas que se le han hecho para entrar en el Colegio del Santo Ángel. ${ }^{472}$

Se leyó memorial de D. Matheo Tascón, bajonista de la Capilla de Música, en el que manifiesta que "para su convalecencia está en Sevilla con licencia del Cabildo en que pide se le prorrogue ésta por más tiempo”. Se da comisión a los Diputados de escusados de Música para que informen. ${ }^{473}$

\footnotetext{
469 Ibid.

${ }^{470}$ Ibid. Lunes 17 de Diciembre de 1787. T.91, fol. 319.

${ }^{471}$ Ibid. Martes 19 de Febrero de 1788. T.91.

${ }^{472}$ Ibid. Martes 19 de Febrero de 1788. T. 91.

${ }^{473}$ Ibid. Viernes 2 de Mayo de 1788. T.91, fol. 382.
} 
Se leyó memorial presentado por D. Juan Franco, presbítero músico, en el que pide permiso para ir a su tierra. El Cabildo acuerda “darle licencia para ir a su tierra hasta el 4 de Octubre exclusibe del presente año". ${ }^{474}$

Se leyó un memorial de D. Vicente Espinosa, "ministril de esta Santa Iglesia, pidiendo una ayuda de costa”. Se dio comisión a los Diputados de excusados de Música. ${ }^{475}$

Vista su anterior petición, el Cabildo le concede a D. Vicente Espinosa, 800 reales de ayuda de costa. Igualmente se conceden a D. Matheo Tascón, bajonista, mil cien reales por el mismo concepto. ${ }^{476}$

“En virtud del llamamiento para oír el informe de los Señores Puntadores de las horas canónicas con la parte de la Dignidad Episcopal sobre el patitur abierto o licencia que pretende D. Vicente Espinosa, músico instrumentista y ministril de esta Santa Iglesia, oído dicho informe se acordó por votos secretos se le conceda para no asistir al Coro desde oi hasta fin de Junio del año que viene de 89 ". 477

El señor Chantre dijo que era preciso tratar sobre la Capellanía vacante de San Antonino, y se acordó dar llamamiento a los Diputados de San Acacio "para que informen si se han cumplido el término de los últimos edictos mandados fixar para la oposición a la referida Capellanía en la referida voz de contraalto. Y si en caso de no haverse cumplido dicho término y haverse de fixar otros edictos, por no haver concurrido opositores, será conveniente se llamen para otra voz que en la Capilla de Música sea más necesaria que la de contraalto”. 478

“El Señor Barcia dixo estaba en esta ciudad el Organista del tardon nombrado para examinar a los opositores a la plaza de $1^{\circ}$ organista de esta Santa Iglesia, que son

\footnotetext{
${ }^{474}$ Ibid. Martes 20 de Mayo de 1788. T.91, fol. 389.

475 Ibid. Martes 10 de Junio de 1788. T. 91, fol. 405.

${ }^{476}$ Ibid. Sábado 5 de Julio de 1788. T. 91, fol. 425.

${ }^{477}$ Ibid. Lunes 21 de Julio de 1788. T.91, fol. 439.

${ }^{478}$ Ibid. Lunes 21 de Julio de 1788. T.91, fol. 440.
} 
el de Calahorra, a quien se sigue perjuicio en la detención y el de plasencia”. Y se acordó fijar en breve el día de los exámenes. ${ }^{479}$

Juan de la Peña, músico instrumentista, pide ayuda de costa. Se da comisión a los Diputados de San Acacio para que informen. ${ }^{480}$

Respecto a las oposiciones para cubrir la plaza de organista $1^{\circ}$, el Cabildo acuerda "que se examinen los dos opositores que han venido desde Calahorra y Plasencia desde el Domingo 27 del presente por la tarde acabado el Coro. Y concluidos los exámenes y presentada por el examinador la censura por escrito, el Cabildo determinará lo que tenga por más conveniente”. 481

Se concede a D. Juan de la Peña "una ayuda de costa por una vez de novecientos reales de vellón". 482

Una vez más el Cabildo trata el tema de la Capellanía vacante de San Antonio y acuerda que por no haberse presentado opositor alguno, "se fixen nuevos edictos para voz de bajete o contraalto por término de 60 días que han de comenzar el día 3 del próximo mes de Agosto". 483

El Señor Arcediano, comunica al Cabildo que ha hecho varias gestiones para buscar Maestro de Capilla "y no se ha hallado alguno de las calidades que se requieren y corresponde a esta Santa Iglesia”, por lo que se acordó dar comisión a los Diputados de Santa Inés para que sigan buscando una persona apropiada. ${ }^{484}$

Una vez realizadas las oposiciones para cubrir la plaza de organista $1^{\circ}$, el examinador emite juicio negativo sobre los dos aspirantes y el Cabildo acuerda "que ninguno de los dos se admita”, destinando una ayuda de costa para cada uno por los

\footnotetext{
479 Ibid. Miércoles 23 de Julio de 1788. T.91, fol. 443.

${ }^{480}$ Ibid. Miércoles 23 de Julio de 1788. T.91, fol. 444.

${ }^{481}$ Ibid. Jueves 24 de Julio de 1788. T.91, fol. 444.

${ }^{482}$ Ibid. Lunes 28 de Julio de 1788. T.91, fol. 446.

${ }^{483}$ Ibid. Miércoles 30 de Julio de 1788. T.91, fol. 449.

${ }^{484}$ Ibid. Miércoles 30 de Julio de 1788. T.91, fol. 450.
} 
gastos de viaje: “Al de Calahorra se le den de ayuda costa para el viage tres mil reales de vellón y al de Plasencia mil quinientos”. Y se dio comisión a los Diputados de Música para que sigan buscando un organista "de las calidades que se desea y que corresponde a esta Santa Iglesia”. ${ }^{485}$

“Se leyó un memorial de D. Joseph María Moyano, Capellán de San Acacio por el que pide un aumento de renta en atención a la crecida familia que tiene a su cargo". Se dio comisión a los Diputados de San Acacio para que informasen. ${ }^{486}$

El Cabildo acuerda aumentarle doscientos ducados en el sueldo a D. Joseph Moyano “en atención a su especial habilidad y estar mui cargado de familia”. ${ }^{487}$

"Se leyó memorial de D. Pablo Bárcena, músico instrumentista de esta Santa Iglesia, por el que solicita se le de una ayuda de costa”. Y se dio comisión a los Diputados de excusados de música para que informasen. ${ }^{488}$

Se concede a D. Joseph de los Ríos una ayuda de costa de dos mil reales de vellón "y para que se inviertan en la manutención y asistencia del mencionado Capellán gravemente enfermo, que se le suministren por mano de los Señores Diputados". 489

Se leyeron dos memoriales de aspirantes a cubrir una Capellanía vacante en la Capilla de San Antonio [no se citan sus nombres]. Sin embargo, uno de ellos es militar, por lo que el Cabildo le pide al Notario Secretario que "escriba al músico del regimiento instruyéndolo de las Cláusulas de la fundación de la Capellanías de San Antonio y de la obligación de ordenarse de presbítero intra annum para si enterado de ello determina hacer la oposición”. ${ }^{490}$

\footnotetext{
${ }^{485}$ Ibid. Jueves 31 de Julio de 1788. T.91, fol. 452.

${ }^{486}$ Ibid. Sábado 30 de Agosto de 1788. T.91, fol. 458.

${ }^{487}$ Ibid. Martes 26 de Septiembre de 1788. T.91, fol. 463.

${ }^{488}$ Ibid. Miércoles 22 de Octubre de 1788. T.91, fol. 493.

${ }^{489}$ Ibid. Miércoles 22 de Octubre de 1788. T.91, fol. 495.

${ }^{490}$ Ibid. Miércoles 22 de Octubre de 1788. T.91, fol. 495.
} 
D. Juan Franco, músico de la Capilla de Santa Inés solicita permiso "para estar más tiempo en su tierra por hallarse gravemente enfermo”. El Cabildo se lo concede ya que al suplicante "le han repetido tres veces las tercianas", como justifica con certificado médico. ${ }^{491}$

Se leyó memorial de D. Joseph Benito Bach “organista de esta Santa Iglesia, por el que pide aumento de salario o ayuda de costa”. Se da comisión a los Diputados de excusados de música para que informen. ${ }^{492}$

Sobre la anterior petición de D. Joseph Benito Bach, el Cabildo decide que dada la necesidad del solicitante, "el tiempo que sirve y su exactitud en el cumplimiento de su obligación junto con su buena conducta", se le concedan dos mil doscientos reales de ayuda de costa. ${ }^{493}$

D. Josef Cabrera y D. Josef de Los Ríos, Capellanes de San Acacio piden licencia para no asistir a al Coro, "a fin de conbalecer de la grave enfermedad que han padecido”. El Cabildo le concede licencia al D. Josef Cabrera “hasta el Sábado de Ramos inclusive del próximo año venidero de 1789, no estando antes apto para residir”. Y a D. Josef de los Ríos “licencia por dos meses contados desde hoy en la misma forma que la antecedente". ${ }^{494}$

Se leyó memorial de D. Pedro Marciag, músico tenor de esta Santa Iglesia en que pide una ayuda de costa. Y el Cabildo da comisión a los Diputados de San Acacio para que informen "primeramente sobre lo que anteriormente está acordado de que este y otros músicos se ordenen para cantar las Passiones; y evaquado este punto informen después sobre el contenido del memorial que ahora se presenta". 495

\footnotetext{
${ }^{491}$ Ibid. Miércoles 29 de Octubre de 1788. T.91, fol. 499.

492 Ibid. Jueves 6 de Noviembre de 1788. T.91, fol. 500.

${ }^{493}$ Ibid. Jueves 13 de Noviembre de 1788. T.91, fol. 505.

${ }^{494}$ Ibid. Martes 2 de Diciembre de 1788. T.91, fol. 512.

${ }^{495}$ Ibid. Martes 16 de Diciembre de 1788. T.91, fol. 517.
} 
Se conceden a D. Pascual Redel 600 reales de ayuda de costa. ${ }^{496}$

\section{9}

El Lunes día 5 de Enero de 1789, el Cabildo lee una carta recibida del Rey en la que se solicitan “devotas rogativas” por el éxito en sus funciones. ${ }^{497}$ Dos días mas tarde, el Miércoles día 7, se vuelve a reunir el Cabildo y toma una larga serie de acuerdos al respecto, de entre los que sacamos aquellos que afectan a la Capilla de Música: “...Concluida la $2^{a}$ estación de la Procesión Claustral, se diriga esta á la Capilla del Sagrario en la que presente el Santísimo Sacramento se dirán las preces pro Rege, y acabadas cantará la música el motete $O$ vere Deus, y desde allí cantando el himno Ave Maris Stella se irá el Choro y Música á la Capilla de Nuestra Señora de Villaviciosa donde cantará la música el Subtuum presidium, con la oración correspondiente, y de allí se restituirá la procesión al Choro cantando las [¿ं?] a los Santos Apóstoles Santiago y Santos Patronos y dichas las oraciones seguirá la misa conventual...". 498

"Se leyó un memorial de D. Mathias Redel, músico instrumentista de esta Santa Iglesia, en el que pide al Cabildo se sirva mandarle librar una ayuda de costa para subvenir a sus atrasos”. Y se dio comisión a los Diputados de Santa Inés para que informasen. $^{499}$

"Se leyó un memorial de Juan de Borja, acólito de esta Santa Iglesia, por el que pide se le nombre en una plaza de trompa mediante el examen a que también suplica sea admitido, y haber estado cinco años supliendo esta plaza y exercitándose en este instrumento”. Se comisiona a los Diputados de Santa Inés para que informen. ${ }^{500}$

\footnotetext{
${ }^{496}$ Ibid. Viernes 16 de Diciembre de 1788. T.91, fol. 519.

${ }^{497}$ Ibid. Lunes 5 de Enero de 1789. T.91, fol. 527.

${ }^{498}$ Ibid. Miércoles 7 de Enero de 1789. T.91, fol. 528.

${ }^{499}$ Ibid. Lunes 9 de Marzo de 1789. T.91, fol 552.

${ }^{500}$ Ibid. Martes 17 de Marzo de 1789. T.91, fol. 555.
} 
Se lee un memorial de los Diputados de Santa Inés acerca de la necesidad de encontrar nuevo Maestro de Capilla. "Oído que fue dicho informe se acordó dar comisión a los referidos señores Diputados para que practiquen las diligencias sobre este asunto en la forma que se les ha comunicado en este Cabildo y de sus resultas informen con llamamiento". ${ }^{501}$

Respecto a la ayuda de costa que pedía D. Mathias Redel, el Cabildo acordó “se le den de ayuda de costa un mil reales de vellón por una vez". 502

“Sobre la pretensión de Juan de Borja, Acólito de esta Santa Iglesia, oído dicho informe, se acordó que al suplicante se le consignen 150 ducados annuales y que sirva la plaza de trompa de D. Federico [Cudoire]; lo que ha de ser durante la vida de este, y en vacando esta plaza tratará el Cabildo de proveerla o en el dicho Borja o en otro que sea más acreedor”. ${ }^{503}$

“El Sr. Magistral dixo havía admitido algunos memoriales de pretendientes a las opas de Niños de Coro con más edad que está acordada, con respecto a que pueda haverlos proporcionados para acólitos, si vacasen algunas plazas de estos”. El Cabildo acordó oír a los aspirantes en los días siguientes. ${ }^{504}$

"Se leyó un memorial de D. Juan Gaytán, Maestro de Capilla jubilado y Capellán de San Acacio pidiendo patitur abierto acompañando certificado de médico, y se cometió todo a los Señores Diputados de Arcas de Vacantes de San Acacio con la parte de nuestro Excmo. Prelado, para que informen sobre su contenido con llamamiento". 505

Se celebraron las pruebas para cubrir algunas vacantes existentes en el Colegio de Infantes de Coro del Santo Ángel. Una vez terminadas dichas pruebas y oído el

\footnotetext{
${ }^{501}$ Ibid. Jueves 26 de Marzo de 1789. T.92, fol. 2r.

${ }^{502}$ Ibid. Jueves 26 de Marzo de 1789. T.92, fol. 2r.

${ }^{503}$ Ibid. Jueves 26 de Marzo de 1789. T.92, fol. 2r.

${ }^{504}$ Ibid. Martes 26 de Mayo de 1789. T.92, fol. 18v.

${ }^{505}$ Ibid. Martes 26 de Mayo de 1789. T.92, fol. 20r.
} 
informe del Rector del colegio, "se pasó a votar por votos secretos y salieron electos por maior parte los tres siguientes: $1^{\circ}$ Matheo Merino, $2^{\circ}$ Francisco Ruiz Bendejo y $3^{\circ}$ Francisco López Ahumada”. 506

Además de las anteriores vacantes del Colegio de Infantes, se cubren otras dos más que recaen sobre Mariano Díaz e Isidro Bach. ${ }^{507}$ En este día se presenta detalladamente el memorial de genealogía de ambos. Igualmente "se leyó un memorial del referido Isidro Bach pidiendo al Cabildo que para satisfacer al estatuto de limpieza de esta Santa Iglesia le mande dar un testimonio de las pruevas que para el mismo fin se hicieron a su hermano Joaquín Bach, y se cometió a los Señores Diputados del Colegio de Infantes para que se le de el certificado que pide y se ha de dar". ${ }^{508}$

Se leyó un memorial de D. Vicente Espinosa “pidiendo patitur abierto y ayuda de costa, y se cometió a los Señores Diputados de Escusados de Música con la parte de su Excelencia nuestro Prelado para que informen sobre su contenido con llamamiento”. 509

Respecto a la solicitud que en su día hizo D. Juan Manuel González Gaitán, para no asistir al Coro, el Cabildo acordó “concederle licencia para poder salir a horas cómodas sin asistir a Coro (a menos que se pusiese bueno) hasta el día de Reyes del año próximo futuro del año de 1790”. 510

"Se dio comisión a los Señores Diputados referidos para que informen con llamamiento sobre el arreglo de músicos, con vista de sus obligaciones $y$ constituciones". 511

\footnotetext{
${ }^{506}$ Ibid. Viernes 29 de Mayo de 1789. T.92, fol. 24r.

${ }^{507}$ El padre de Isidro Bach, era Joseph Benito Bach, organista $2^{\circ}$ de la Catedral, natural de Madrid. Su abuelo también se llamaba Joseph Bach y era natural de Olot (Gerona).

${ }^{508}$ Ibid. Miércoles 10 de Junio de 1789. T.92, fol. 25r.

${ }^{509}$ Ibid. Miércoles 10 de Junio de 1789. T.92, fol. 26r.

${ }^{510}$ Ibid. Miércoles 10 de Junio de 1789. T.92, fol. 27r.

${ }^{511}$ Ibid. Miércoles 10 de Junio de 1789. T.92, fol. 28r.
} 
Se presentan detalladamente los memoriales de genealogía de los tres Infantes de Coro que en fechas anteriores resultaron elegidos por el Cabildo: Matheo Merino, Francisco Ruiz Bendejo y Francisco López Ahumada. ${ }^{512}$

"Se leyó un memorial de Francisco Montijano, organista de la Santa Iglesia de Baeza pidiendo certificación de la oposición que hizo a la plaza de Organista $1^{\circ}$ de esta Santa Iglesia y no haviendo en ésta práctica de dar certificaciones para semejantes oposiciones acordó el Cabildo no haber lugar a la solicitud de dicho Montijano”. 513

“Sobre el patitur abierto que solicita D. Vicente Espinosa, músico, oído dicho informe acordó el Cavildo atendida la notoria imposibilidad de dicho ministro para exercer su ministerio que también acredita la certificación jurada del médico, concederle y le concedió votando por votos secretos patitur abierto hasta fin de Junio del año próximo de mil setecientos noventa”. 514

"Sobre la ayuda de costa que pretende D. Vicente Espinosa, músico instrumentista de la Capilla, acordó el Cabildo por votos secretos concederle y le concedió quinientos reales por una vez de ayuda de costa de los caudales de escusados de música”. 515

“Se leyó un memorial de D. Bartolomé Gálvez, sochantre de esta Santa Iglesia pidiendo una aiuda de costa, con motivo de la carestía de los tiempos”. Y se dio comisión a los Diputados para que informaran. ${ }^{516}$

Se leen y aprueban, por considerar el Cabildo que estaban bien realizadas, las pruebas de limpieza de sangre de Mateo Merino y Francisco Ruiz Berdejo. ${ }^{517}$

\footnotetext{
512 Ibid. Miércoles 10 de Junio de 1789. T.92, fol. 28r.

${ }^{513}$ Ibid. Lunes 22 de Junio de 1789. T.92, fol. 29v.

${ }^{514}$ Ibid. Martes 23 de Junio de 1789. T.92, fol. 30v.

${ }^{515}$ Ibid. Jueves 25 de Junio 1789. T. 92, fol. 31r.

${ }^{516}$ Ibid. Lunes 13 de Julio de 1789. T.92, fol. 41r.

${ }^{517}$ Ibid. Miércoles 29 de Julio de 1789. T.92, fol. 48r.
} 
Se leen y aprueban, por considerar el Cabildo que estaban bien realizadas, las pruebas de limpieza de sangre de Isidro Bach. ${ }^{518}$

Se leen y aprueban, por considerar el Cabildo que estaban bien realizadas, las pruebas de limpieza de sangre de Francisco López Ahumada. ${ }^{519}$

“Se leyó una carta firmada de D. José Ponce de León, músico en la ciudad de Sevilla en que manifiesta sus deseos de acomodarse en la Capilla de esta Santa Iglesia, expresando en ella las calidades de su voz”. Y se dio comisión a los Diputados de la Capilla de San Acacio para que informasen. ${ }^{520}$

"Se leió un memorial de Mateo Merino, Infante de Coro y del Colegio del Ángel, en que suplica se le consigne alguna aiuda de costa para sufragar á los gastos de las pruebas de limpieza que ha hecho para lograr colocarse en dicho Colegio por criado del Cavildo". Y se dio comisión a los Diputados del Colegio para que informasen. $^{521}$

El Cabido concede trescientos reales de ayuda de costa a Mateo Merino, para sufragar los gastos de su expediente de limpieza de sangre. ${ }^{522}$

Los Diputados de Música presentan al Cabildo una lista de organistas por si alguno de ellos fuera adecuado para cubrir la vacante de organista $1^{\circ}$. El Cabildo acuerda que "en suposición de estar el Maestro de Capilla en la Corte, y ser su venida á esta mui pronta, se espere se restituia á esta Ciudad”, para que pueda participar en la elección del organista. ${ }^{523}$

\footnotetext{
518 Ibid. Lunes 3 de Agosto de 1789. T.92, fol. 50r.

${ }^{519}$ Ibid. Martes 4 de Agosto de 1789. T.92, fol. 52r.

${ }^{520}$ Ibid. Martes 25 de Agosto de 1789. T.92, fol. 58r.

${ }^{521}$ Ibid. Lunes 31 de Agosto de 1789. T. 92, fol. 61r.

${ }^{522}$ Ibid. Viernes 4 de Septiembre de 1789. T.92, fol. 66v.

${ }^{523}$ Ibid. Martes 20 de Octubre de 1789. T. 92, fol. 76v.
} 
El Niño de Coro y Colegial del Santo Ángel Francisco Ahumada, solicita una ayuda de costa. El Cabildo dio comisión a los Diputados de Santa Inés para que informasen. $^{524}$

Aunque anteriormente vimos que el Cabildo decidía esperar la vuelta de Jaime Balius de Madrid, para proveer la plaza de primer organista, en el día de la fecha se aprueba la contratación de Pedro Bodul de Santamant, organista de Sevilla, “con salario de doze mil reales anuales con las condiciones y cargas que han sufrido todos sus antecesores”. En esta acta no consta ningún informe o censura del Maestro de Capilla, como era habitual. ${ }^{525}$

“Se leio un memorial de D. Pedro Marciag, músico de esta Santa Iglesia, en el que solicita una ayuda de costa por los atrasos que experimenta con la carestía de los víveres y gastos que sufrió en el dilatado viaxe a Francia su País”. Se dio comisión a los Diputados de la Capilla de la Sangre para que informasen. ${ }^{526}$

“Sobre la licencia y ayuda de costa que solicita Ignacio Casado, músico de voz de esta Santa Iglesia, oído que fue y enterado el Cabildo de su contenido se acordó darle por razón de su enfermedad, licencia hasta el día de Domingo de Ramos, y por lo que respeta á la ayuda de costa, aviendose votado por pelotas se le concedió por una vez mil y quinientos reales de vellón”. 527

“Sobre la pretensión de Francisco Ahumada, Mozo de Coro, y colegial del Colegio del Santo Ángel sobre una ayuda de costa para subvenir los gastos hechos en las pruebas de limpieza para colocarse en esta Santa Iglesia”, el Cabildo acordó concederle trescientos reales de vellón. ${ }^{528}$

\footnotetext{
${ }^{524}$ Ibid. Sábado 31 de Octubre de 1789. T.92, fol. 80v.

${ }^{525}$ Ibid. Miércoles 4 de Noviembre de 1789. T.92, fol. 82 r.

${ }^{526}$ Ibid. Martes 10 de Noviembre de 1789. T.92, fol. 86v.

${ }^{527}$ Ibid. Martes 10 de Noviembre de 1789. T.92, fol. 87r.

${ }^{528}$ Ibid. Martes 10 de Noviembre de 1789. T.92, fol. 87r.
} 
“Acordó el Cavildo conceder y concedió por pluralidad de votos tres mil y trescientos reales de vellón por una vez de ayuda de costa al dicho D. Pedro Marciag”. 529

"Se leio un memorial de D. Juan Busquets músico violinista de la Capilla de esta Santa Iglesia en el que suplica al Cavildo se digne concederle una ayuda de costa para subvenir á su indigencia, y el Cavildo acordó cometer y cometió dicho memorial a los Diputados de la Capilla de Santa Inés para que informen con llamamiento”. 530

“Sobre la pretensión de ayuda de costa que solicita D. Juan Busquets, músico violín de esta Santa Iglesia: oído que fue y aviendo votado por pelotas acordó el Cavildo conceder y concedió a dicho Busquets por una vez la cantidad de mil y quinientos reales de ayuda de costa”. 531

\section{0}

Se leyó un memorial de D. Juan Manuel Gonzalez Gaytan, Maestro de Capilla jubilado, en el que solicita al Cabildo que le renueve la licencia que venía disfrutando debido a sus problemas de salud, y a su avanzada edad (74 años). El Cabildo dio comisión a los Diputados de San Acacio para que informasen. ${ }^{532}$

“Acordó el Cabildo conceder y concedió licencia al dicho D. Juan Manuel [Gaytán] por espacio y tiempo de un año, para que pueda no asistir al Coro”. 533

“Se leio otro memorial de D. Pascual Redel, músico violín de la Capilla de esta Santa Iglesia en el que suplica al Cavildo se digne aumentarle el corto salario de doscientos ducados que goza, o alguna ayuda de costa para subvenir á la grave

\footnotetext{
${ }^{529}$ Ibid. Jueves 19 de Noviembre de 1789. T.92, fol. 91r.

${ }^{530}$ Ibid. Viernes 4 de Diciembre de 1789. T.92, fol. 100r.

${ }^{531}$ Ibid. Sábado 19 de Diciembre de 1789. T.92, fol. 102v.

${ }^{532}$ Ibid. Martes 19 de Enero de 1790. T.92, fol. 109v.

${ }^{533}$ Ibid. Viernes 22 de Enero de 1790. T.92, fol. 111r.
} 
necesidad que el suplicante padece mediante la estrechez de los tiempos y carestía de víveres, y en su vista acordó el Cavildo cometer dicho memorial a los señores Diputados de la Capilla de San Acacio". ${ }^{534}$

"Se leyó un memorial de D. José Benito Bach, organista de esta Santa Iglesia en el que suplica se le conceda una ayuda de costa para socorrer en la gran necesidad que padece a causa de la carestía de víveres y demás; y el Cavildo acordó cometer y cometió dicho memorial a los Diputados de Escusados de Música”. 535

“Habiendo hecho presente el Sr. Arcediano de Pedroches y Canónigo, que el Maestro de Capilla le havía propuesto, que si se le relebase de hazer el Miserere nuevo que se acostumbra para la Semana Santa de este año, podría mexorar algunos himnos y salmos que ai inútiles y servirían en varias funciones; y en su vista acordó el Cavildo que se hiziere así por este año". 536

"Se leio un memorial de D. Juan Puig, bajonista de la Capilla de esta Santa Iglesia en el que hace presente hallarse sumamente empeñado á causa de estar cargado de familia y la carestía de víveres, por lo que suplica con todo respeto se digne este Cavildo librarle una ayuda de costa para subllevar su miseria; y se acordó cometerlo a los Señores Diputados de Escusados de Música para que informen”. 537

Sobre la pretensión de ayuda de costa que solicitó D. José Benito Bach, organista $2^{\circ}$, el Cabildo acuerda librar "por una vez y á favor de dicho D. José, la cantidad de doscientos ducados”. ${ }^{538}$

“El Señor Deán hizo presente el perjuicio que se seguía a esta Santa Iglesia de salir así los músicos como los Capellanes de San Pedro á cantar Pasiones a otras Iglesias, pues de ello resultaba el inutilizarse para cumplir en esta; y acordó el

\footnotetext{
${ }^{534}$ Ibid. Viernes 22 de Enero de 1790. T.92, fol. 111r.

535 Ibid. Viernes 22 de Enero de 1790. T.92, fol. 111v.

${ }^{536}$ Ibid. Martes 26 de Enero de 1790. T.92, fol. 113r.

${ }^{537}$ Ibid. Sábado 13 de Febrero de 1790. T.92, fol. 115r.

${ }^{538}$ Ibid. Sábado 20 de Febrero de 1790. T.92, fol. 116v.
} 
Cavildo, se de llamamiento con la parte para determinar sobre la pena y demás que convenga”. 539

El Cabildo trata el tema de la provisión de una Capellanía vacante en la Capilla de San Antonino: “Aviéndose puesto seis vezes edictos para esta Capellanía vacante por muerte de D. Francisco Ayala organista primero de esta Santa Iglesia desde Febrero de 1787 en todo este tiempo no havia parecido sugeto a propósito cual se necesita. [...] Y que mediante a que D. José Cabrera [Capellán de San Acacio] tenía adquirido derecho por aver firmado en tiempo la oposición en clase de contralto devía oirse y nombrarse para ello examinador a disposición de este Cavildo: Oído el informe se mandó entrar al Secretario y se acordó que el Lunes próximo primero de Marzo haga su oposición dicho D. José Cabrera después del Coro por la mañana, para lo que se nombró examinador a nuestro Maestro de Capilla, D. Jaime Valius”. 540

“Después a consecuencia de lo dicho informaron los Señores Diputados de San Antonino como D. Juán de Dios Merinero, Presbítero Capellán de las Descalzas Reales de Madrid deseaba hacer oposición en clase de tenor, bien a esta Capellanía, si quedose por proveer o a sus resultas; y que el Maestro de Capilla informaba hacia falta, un tenor presbítero para las próximas Pasiones, y demás funciones de Semana Santa, por hallarse D. Ignacio Casado y D. Sebastián Cabezón incapaces de trabajar por sus achaques, y el Cavildo suspendió en esta parte la determinación hasta ver las resultas de la actual oposición, y que ha de hacer D. José Cabrera”. 541

Sobre el asunto, tratado en anteriores Cabildos, de la salida de músicos a cantar Pasiones fuera de la Catedral y lo perjudicial que ello se consideraba para el buen funcionamiento de la Capilla de Música, el Cabildo acuerda: “que cualesquiera de los dichos [músicos] que salga a cantar las dichas Pasiones incurra en la pena de la tercera parte de su renta de cuatro meses”. Se exceptúa de esta norma al Monasterio de Religiosas de la Encarnación, que era Patronato del Cabildo. ${ }^{542}$

\footnotetext{
${ }^{539}$ Ibid. Sábado 27 de Febrero de 1790. T.92, fol. 118v.

${ }^{540}$ Ibid. Sábado 27 de Febrero de 1790. T.92, fol. 119r.

${ }^{541}$ Ibid. Sábado 27 de Febrero de 1790. T.92, fol. 119v.

${ }^{542}$ Ibid. Martes 2 de Marzo de 1790. T.92, fol. 120v.
} 
Acerca de la oposición para proveer una Capellanía vacante de San Antonino, a la que se presenta D. José Cabrera, una vez celebrada, el Maestro de Capilla informa al Cabildo: "Por lo que se le mandó entrar a dicho Maestro D. Jaime Valius y dixo que por el examen que había hecho a D. José Cabrera, Capellán de San Acacio, opositor a la de San Antonio, hacía juicio que el expresado D. José, no obstante aver cumplido a satisfacción en el examen, no era a propósito para un primer contraalto, que es lo que en día se necesita y busca para esta Capilla; pero sí mui al caso para la clase de segundo, que es la que en el día puede exercer, y que efectivamente efectúa con destreza; y asimismo aseguró que era un Ministro pronto y dispuesto á quanto se le mandaba, y que desempeñaba con esmero su obligación; aunque según su entender no estaba suficientemente dotado, y parecía acreedor a que el Cabildo se sirviese atenderlo”. Visto lo cual el Cabildo acordó fijar nuevos edictos para cubrir la Capellanía de San Antonio. No obstante y atendiendo al positivo informe del Maestro de Capilla sobre el buen comportamiento de Cabrera, se le aumentó el sueldo en cien ducados anuales. ${ }^{543}$

“Los Señores Diputados de la Capilla de Santa Inés expusieron tenían noticias del Maestro de Música de esta Santa Iglesia, cómo los músicos del primer coro estaban en bastante decadencia en sus vozes, bien por razón de sus edades, como por sus achaques en la salud". Lo que se puso en conocimiento de los señores capitulares para que decidieran lo más conveniente al respecto. ${ }^{544}$

En cuanto a la Capellanía vacante de San Antonio, "se mandó entrar al notario secretario, quien dixo que habiéndose cumplido el término de los edictos fixados para la insinuada Capellanía, no había parecido ni firmado opositor alguno”, por lo que el Cabildo acordó fijar nuevos edictos. ${ }^{545}$

A pesar de la anterior noticia, acto seguido se informa de la presentación de un opositor que pretendía la Capilla de San Antonio: “Los Señores Diputados dieron

\footnotetext{
543 Ibid. Martes 2 de Marzo de 1790. T. 92, fol. 121r.

${ }^{544}$ Ibid. Sábado 6 de Marzo de 1790. T. 92, fol. 123v.

${ }^{545}$ Ibid. Sábado 27 de Marzo de 1790. T. 92, fol. 129v.
} 
quenta de que se había presentado D. Juan García, músico, con ánimo de firmar la oposición á la Capellanía referida, pero que parecía incapaz de ella por ser manco, que no obstante había cantado, y en las circunstancias en que se halla oy la Capilla de Música tan falta de contraltos podría servir a lo menos esta Semana Santa y que el Maestro de Capilla informaría de su suficiencia, y haviendo mandado entrar al Maestro de Capilla y oído su informe acordó el Cavildo que el D. Juan García referido aiude y asista los días de música toda la Semana Santa y Pascua”. Además se aprobó darle una ayuda de costa de 600 reales. $^{546}$

“El Señor tesorero hizo presente cómo D. Pablo de Bárcena, obue de la Capilla de Música, parecía estaba imposibilitado de seguir en su empleo a causa de diversos achaques y padeceres; que el Cabildo se sirviese tomar los medios que tuviese por convenientes para declararlo por tal; o que se le compela á que cumpla con sus deveres; pues la falta de dicho instrumento es ocasión de no salir las obras compuestas por el presente Maestro de Capilla con la sonora armonía que ellas exigen”. 547

Se da cuenta de la presentación de tres opositores a la Capellanía de San Antonio, D. Manuel Álvarez Roldán, presbítero natural de la villa de Priego, de 36 años de edad; D. Joaquín Ruiz, de 26 años, natural de Alcalá de los Ganzules, y D. Fernando Ruiz y Fuentes, de 22 años, músico de la Santa Iglesia Real y Colegial de Antequera. Y acordó el Cabildo "se de principio a la oposición el día 15 del presente mes por la mañana después del Coro, para lo que se nombró por examinador al Maestro de la Capilla de Música de esta Santa Iglesia”. 548

Una vez celebrada la oposición para cubrir la Capellanía de San Antonino, y oído el informe del Maestro de Capilla, salió nombrado para ella D. Manuel Álvarez Roldán, a quien se asignó un sueldo de 800 ducados anuales. ${ }^{549}$

\footnotetext{
${ }^{546}$ Ibid. Sábado 27 de Marzo de 1790. T. 92, fol. 130r.

${ }^{547}$ Ibid. Viernes 14 de Mayo de 1790. T. 92, fol. 138r.

548 Ibid. Viernes 14 de Mayo de 1790. T. 92, fol. 138v.

${ }^{549}$ Ibid. Lunes 17 de Mayo de 1790. T. 92, fol. 139v.
} 
“En virtud del llamamiento para dar la colación y posesión de la Capellanía de San Antonino a D. Manuel Álvarez, presbítero, provisto en ella, entró el Señor Notario y testigos, con el referido D. Manuel Álvarez, y puesto este de rodillas ante el Sr. Presidente le dio la colación de la citada Capellanía, por imposición de un bonete, e inmediatamente hizo el juramento de guardar los estatutos de esta Santa Iglesia”. Asimismo se concede a D. Joaquín Ruiz, otro de los opositores, 450 reales de ayuda de costa "para volverse a su destino". 550

“Se leyó un memorial de D. Vicente Valíer, de nación Napolitano, á quien el Cavildo se dignó admitir para oír su voz de la clase de contralto, á quien después de oído se le manifestó no acomodar al Coro de esta Santa Iglesia”. Se le concedió no obstante una ayuda de costa de 300 reales de vellón. ${ }^{551}$

“El Señor Deán hizo presente al Cavildo, solían venir a esta Iglesia algunos músicos, los que movidos de lograr alguna gratificación emprendían y solicitaban el ser oídos, aunque fuesen de inferior voz y habilidad, lo que cedía en gravamen de las rentas de esta Santa Iglesia; y antiguamente se observaba que dicho Señor Deán siempre que se presentaba algún músico, y quería ser oído, dicho Señor lo remitía al Maestro de Capilla para que lo oiese y tantease, y si era apto para servir en el Coro se daba cuenta y si era insuficiente se excluía por el Señor Deán y no se admitía para ser oído, en cuia atención acordó el Cavildo en los sucesivo se observe como ha expuesto el Señor Deán”. 552

D. Vicente Espinosa solicita una ayuda de costa "a causa de sus graves y continuados accidentes, y asimismo que se le continúe el patitur”. Se dio comisión a los Diputados de Escusados de Música para que informen. ${ }^{553}$

El Cabildo concede a D. Pascual Redel 1200 reales de vellón de ayuda de costa. $^{554}$

\footnotetext{
${ }^{550}$ Ibid. Miércoles 19 de Mayo de 1790. T. 92, fol. 140v.

${ }^{551}$ Ibid. Sábado 19 de Junio de 1790. T. 92, fol. 152r.

${ }^{552}$ Ibid. Sábado 19 de Junio de 1790. T. 92, fol. 152r.

${ }^{553}$ Ibid. Martes 22 de Junio de 1790. T. 92, fol. 153v.
} 
Se conceden a D. Vicente Espinosa, bajonista de la Capilla de Música, 500 reales de ayuda de costa. ${ }^{555}$

“Sobre la pretensión de D. Juan Puig, también bajonista de dicha Capilla, aviendose leído y pasado a votar por pelotas por dos vezes fue negada la ayuda de costa que solicitaba el dicho Puig”. 556

“El Señor Deán hizo presente cómo en esta [ciudad] se hallaba un músico tenor de la ciudad de Granada [D. Luis Gonzalez], y que según havía entendido era diestro en su facultad, y de especial habilidad”. Y se acordó que el Domingo siguiente día 8 fuera oído. ${ }^{557}$

Una vez oído D. Luis González, tenor de Granada, el Cabildo acordó comunicarle que de momento volviera a su ciudad, en espera de que el Maestro de Capilla regresara a Córdoba para oír su parecer. Asimismo se le concedió una ayuda de costa de 600 reales de vellón. ${ }^{558}$

“Se leyó un memorial de D. Joseph de los Rios, presbítero, Capellán de San Antonino, por el que solicita algún aumento o ayuda de costa”. Y el Cabildo dio comisión a los Diputados de San Acacio y San Antonino para que informasen. ${ }^{559}$

“Se leyó memorial de D. Mateo Blanco, Capellán de San Pedro, en el que solicita se le perdonen las aspas que se le han echado en la música durante su enfermedad y se acordó cometerlo a los Señores Diputados de Arcas del Punto" 560

“Sobre la Capellanía de la Capilla de Santa Inés, vacante por muerte de D. Ignacio Casado, oído que fue dicho informe, y los que dichos Señores Diputados han

\footnotetext{
${ }^{554}$ Ibid. Martes 22 de Junio de 1790. T. 92, fol. 154r.

555 Ibid. Miércoles 28 de Julio de 1790. T. 92, fol. 165v.

${ }^{556}$ Ibid. Miércoles 28 de Julio de 1790. T. 92, fol. 165v.

${ }^{557}$ Ibid. Sábado 7 de Agosto de 1790. T. 92, fol. 170r.

${ }^{558}$ Ibid. Jueves 12 de Agosto de 1790. T. 92, fol. 172r.

${ }^{559}$ Ibid. Jueves 14 de Septiembre de 1790. T. 92, fol. 189r.

${ }^{560}$ Ibid, Sábado 13 de Noviembre de 1790. T. 92, fol. 196v.
} 
tomado del Maestro de Capilla, acordó el Cavildo se pongan edictos para la expresada Capellanía por el término de sesenta días que se contarán desde oi. Y que estos sean para tenores, por hacer falta en la Capilla". ${ }^{561}$

"Se leyó un memorial de D. Josef Benito Bach, organista de esta Santa Iglesia por el que solicita algún aumento o alluda de costa en atención a estar supliendo de primer organista y de hallarse con una dilatada familia". 562

El Cabildo concede a D. José Benito Bach 1.500 reales de ayuda de costa. ${ }^{563}$

\section{1}

D. Juan Manuel Gonzalez Gaitán pide que se le prorrogue el permiso para no asistir al Coro, debido a que continúan sus problemas de salud. El Cabildo dio comisión a los Diputados de la Sangre para que informasen. ${ }^{564}$

Se leyó un memorial de $\mathrm{D}^{\mathrm{a}}$ Inés Valenciano, madre del difunto D. José Cabrera por el que solicita una ayuda de costa "respecto a los muchos atrasos que ha dejado su hijo”. Y se cometió a los Diputados de la Sangre para que informasen con llamamiento. ${ }^{565}$

"Se leyó un memorial de D. Juan Puig, bajonista de esta Santa Iglesia por el que solicita una ayuda de costa. Y el Cavildo acordó cometerlo a los Señores Diputados de Escusados de Música con la parte de Su Ilustrísima para que informen con llamamiento". 566

\footnotetext{
${ }^{561}$ Ibid. Sábado 13 de Noviembre de 1790. T. 92, fol. 197r.

${ }^{562}$ Ibid. Jueves 25 de Noviembre de 1790. T. 92, fol. 197v.

${ }^{563}$ Ibid. Jueves 16 de Diciembre de 1790. T. 92, fol. 201v.

${ }^{564}$ Ibid. Sábado 15 de Enero de 1791. T. 92, fol. 212r.

${ }^{565}$ Ibid. Sábado 15 de Enero de 1791. T. 92, fol. 212r.

${ }^{566}$ Ibid. Miércoles 26 de Enero de 1791. T. 92, fol. 213r.
} 
“El Señor Chantre hizo presente lo ocurrido con los músicos y Capellanes en las vísperas de la conversión de San Pablo y lo ocurrido con D. Dionisio de la Mata y D. Bartolomé de Gálvez en la vocación de dicho [¿...?] y las providencias que había tomado mandándolos retirar a sus respectivas casas, lo que aprobó el Cavildo. Y además les mandó aspar desde las vísperas hasta que vuelvan reprehendidos al Coro, para lo que nombró a los Señores Prior, Magistral, Lectoral, Trespalacios y González, a quienes encargó el Cavildo, hicieran ver a los referidos, lo sensible que había sido el escándalo causado en dicha vocación”. 567

"Se leyó un memorial de D. Pedro Marciag, músico de esta Santa Iglesia, en que solicita ayuda de costa, y en su vista acordó el Cavildo remitirlo a los Señores Diputados de Arcas de San Acacio con la parte de S.E. para que informen con llamamiento". 568

Sobre la solicitud de D. Juan Manuel Gaitán, “acordó el Cavildo concederle licencia por un año atendiendo a la conserbación de un Ministro que tan bien le ha servido". 569

“Sobre la solicitud de $D^{a}$ Inés Balenciano, madre del difunto señor D. Joseph Cabrera, oído que fue dicho informe acordó el Cavildo librarle y le libró por una vez de ayuda de costa á la referida, tres mil reales de vellón, los que mandó entregar al señor D. Antonio Castillejo para que después de pagar las deudas que dejó el difunto Cabrera entregue lo restante a dicha $D^{a}$ Inés, su madre". ${ }^{570}$

Se le aumenta el sueldo a D. Pedro Marciag: “Acordó el Cavildo aumentarle y aumentó doscientos ducados annuales sobre los quinientos que goza, por la exactitud con que ha cumplido los doce años que está sirviendo al Cavildo”. ${ }^{571}$

\footnotetext{
${ }^{567}$ Ibid. Miércoles 26 de Enero de 1791. T. 92, fol. 213r.

${ }^{568}$ Ibid. Miércoles 26 de Enero de 1791. T. 92, fol. 213v.

${ }^{569}$ Ibid. Jueves 27 de Enero de 1791. T. 92, fol. 214r.

${ }^{570}$ Ibid. Jueves 27 de Enero de 1791. T. 92, fol. 214v.

${ }^{571}$ Ibid. Sábado 5 de Febrero de 1791. T. 92, fol. 214v.
} 
"Sobre la solicitud de D. Juan Puig, bajonista de esta Santa Iglesia, oído que fue dicho informe y la necesidad en que se halla constituido por la larga y contagiosa enfermedad que padeció su difunta mujer, acordó el Cavildo librarle y le libró de ayuda de costa 200 ducados de vellón por una vez contra los excusados de música”. 572

Se leyó un memorial de D. Juan José de la Peña, músico, en el que solicitaba una ayuda de costa, y se dio comisión a los Diputados de San Acacio para que informasen. ${ }^{573}$

“El Señor Chantre, como Diputado de las Arcas de San Acacio, hizo presente al Cabildo la muerte de D. Joseph Cabrera, Capellán de la Capilla de la Sangre”. ${ }^{574}$

"Sobre la solicitud de ayuda de costa de D. Juan José de la Peña, músico instrumentista de esta Santa Iglesia, oído que fue dicho informe acordó el Cavildo, por votos secretos librarle y le libró doscientos ducados de ayuda de costa por una vez". ${ }^{775}$

“El Sr. Deán hizo presente se había presentado en el día, un Soldado de Guardia Españolas, a quien se había oído dos veces en Coro y había asegurado el Maestro de Capilla: Podía se muy útil tanto para el canto llano, como para acompañar en la Capilla”, y en vista de este informe acordó el Cabildo, dar y dio comisión a los señores Diputados de Arcas de San Acacio, para que informaran de los fondos disponibles para la contratación de este músico. ${ }^{576}$

“El Sr. Arcediano de Pedroche, como Diputado de las Arcas de vacantes de San Acacio, hizo presente había llegado el músico de Madrid que había informado el Maestro de Capilla, y en su vista acordó el Cavildo que se oiga mañana en la tarde 25 de Marzo e informen los Señores Diputados de dichas Arcas con llamamiento". 577

\footnotetext{
572 Ibid. Lunes 14 de Febrero de 1791. T. 92, fol 215v.

${ }^{573}$ Ibid. Sábado 5 de Marzo de 1791. T. 92, fol. 221r.

${ }^{574}$ Ibid. Sábado 5 de Marzo de 1791. T.92, fol. 221r.

575 Ibid. Lunes 17 de Marzo de 1791. T. 92. fol. 222v.

${ }^{576}$ Ibid. Lunes 17 de Marzo de 1791. T. 92, fol. 223r.

${ }^{577}$ Ibid. Jueves 24 de Marzo de 1791. T. 92, fol. 224v.
} 
“Hizo presente el Señor Arcediano, se habían cumplido los edictos de la Capellanía de San Antonino, y en su vista acordó el Cavildo se pongan nuevos edictos". 578

"Se leyó un memorial de D. Félix Basallo en el que participa haber logrado una plaza de bajonista en la Ciudad de Lucena, por que suplica licencia para ir a servir dicha plaza, y una ayuda de costa, y en su vista acordó el Cabildo cometer dicho memorial a los Señores Diputados de Acólitos para que informen sobre las ayudas de costa y dio comisión a los Señores Diputados del Colegio de Infantes para que informen con llamamiento a quien corresponde entrar a servir la plaza de Acólito que resulta vacante". 579

Sobre la provisión de una plaza vacante en la Capilla de Santa Inés por muerte de D. Ignacio Casado, se trata lo siguiente: "respecto á haver declarado del Maestro de Capilla no ser suficiente ninguno de los opositores para dicha Capellanía, se ponga esta declaración en los autos y se pongan nuevos edictos, reservándose por ahora el Cavildo, el término que han de correr dichos edictos, y las voces que se han de llamar". 580

Igualmente, para proveer una plaza vacante en la Capilla de San Acacio por muerte de D. José Cabrera, “acordó el Cavildo se pongan edictos para contralto de primera cuerda por el término de sesenta días, expresando en ellos, se le consignará más de los cuatro mil reales que vale dicha Capellanía, aquello que se juzgue según su habilidad, y que ha de ser sacerdote o ha de tener la correspondiente edad para ordenarse dentro del año". ${ }^{581}$

“Sobre la solicitud de D. Mariano Villuendas, soldado del reximiento de Guardias Españoles, oído que fue el informe y lo que el Maestro de Capilla expuso verbalmente sobre la buena voz que tiene el dicho Villuendas para ser un Ministro útil

\footnotetext{
${ }^{578}$ Ibid. Jueves 24 de Marzo de 1791. T. 92, fol. 224v.

${ }^{579}$ Ibid. Sábado 26 de Marzo de 1791. T. 92, fol. 226v.

${ }^{580}$ Ibid. Sábado 26 de Marzo de 1791. T. 92, fol. 226v.

${ }^{581}$ Ibid. Martes 29 de Marzo de 1791. T.92, fol. 228v.
} 
acordó el Cavildo admitirle y le admitió siempre que haga constar la respectiva licencia de su Capitán y le señaló cuatrocientos ducado por ahora, en calidad de ayuda de sochantre, lo que empezará a ganar desde el día que se presente en el Coro, en el que tendrá obligación de asistir a todas las oras diurnas, maitines de las octavas, y demás que asistan los sochantres, y le concedió el Cabildo treinta días de recles al año, y le señaló a D. Bartolomé de Gálvez por maestro". 582

Sobre los edictos para la provisión de la Capellanía vacante en Santa Inés, el Cabildo acuerda se pongan dichos edictos "por el término de sesenta días, los que se han de contar desde el veintiséis de Marzo en que acordó el Cavildo se fijaran dichos edictos y que en ellos se convoque o se expresen sean para las voces de tenor, tiple o contralto".583

“El Señor Arcediano hizo presente que respecto á haverse oído al músico tenor de Madrid se le podrá despachar vien admitiéndolo si se le contemplara útil o dándole una ayuda de costa para que retirara, y en su vista acordó el Cavildo dar comisión a los Señores Diputados de arcas de vacantes de Santa Inés, para que con presencia del Maestro de Capilla informen de su utilidad y abilidad y que renta se le ha de consignar". 584

“Sobre la pretensión de D. Tadeo Mintegui, músico tenor, oído que fue dicho informe, y lo que expuso verbalmente el Maestro de Capilla, acordó el Cavildo admitirle y le admitió en su Capilla de Música con el salario de quatrocientos ducados anuales, desde el día que entre á servir y con la obligación que ha de tomar Capellanía en teniendo edad para ordenarse sacerdote; asimismo encargó el Cavildo al Maestro de Capilla cuidara el que estudiara dicho Mintegui, a quien concedió el Cavildo dos mil reales de ayuda de costa". 585

\footnotetext{
582 Ibid. Martes 29 de Marzo de 1791. T.92, fol.228v.

${ }^{583}$ Ibid. Martes 29 de Marzo de 1791. T. 92, fol. 229v.

${ }^{584}$ Ibid. Martes 29 de Marzo de 1791. T. 92, fol. 229v.

${ }^{585}$ Ibid. Viernes 1 de Abril de 1791. T. 92, fol. 231v.
} 
D. Julián Gálvez, músico instrumentista, solicita una ayuda de costa, "respecto al poco salario que goza”. Y se dio comisión a los Diputados de Escusados de Música para que informasen. ${ }^{586}$

Sobre la provisión de la plaza vacante de Acólito, por haberse marchado Feliz Basallo, el Cabildo acuerda nombrar en su puesto a Lope de Mora. ${ }^{587}$

“Sobre la pretensión de ayuda de costa de D. Julián Gálvez, músico instrumentista de esta Santa Iglesia, oído que fue dicho informe se pasó a votar por votos secretos y salió negada”. 588

“El Señor Deán hizo presente havía entendido que havían retirado de esta ciudad al Sr. Villuendas, soldado del regimiento de Guardias Españoles y admitido por el Cavildo con el título de ayuda de Sochantre, y en su vista acordó el Cavildo dar y dio comisión a los Señores Diputados de la Capilla de la Sangre para que á nombre del Cavildo escriban al Señor Patriarca recomendando este punto". 589

“Se leyó un memorial de Tadeo Mintegi, músico pidiendo licencia para sacar a la Corte de Madrid, a traer parte de su familia y el Cavildo acordó concederle y le concedió lizencia para dicho fin hasta el día 15 del mes de Junio próximo pasado futuro". 590

El Cabildo concede a Lope de Mora, Acólito, trescientos reales de vellón de ayuda de costa. ${ }^{591}$

El Cabildo concede a D. Dionisio de la Mata tres mil reales de vellón de ayuda de costa. ${ }^{592}$

\footnotetext{
${ }^{586}$ Ibid. Jueves 7 de Abril de 1791. T. 92, fol. 235r.

${ }^{587}$ Ibid. Martes 12 de Abril de 1791. T. 92, fol. 236v.

${ }^{588}$ Ibid. Sábado 16 de Abril de 1791. T. 92, fol. 237v.

${ }^{589}$ Ibid. Sábado 16 de Abril de 1791. T. 92, fol. 239r.

${ }^{590}$ Ibid. Miércoles 27 de Abril de 1791. T. 92, fol. 241r.

${ }^{591}$ Ibid. Jueves 12 de Mayo de 1791. T. 92, fol. 243v.

${ }^{592}$ Ibid. Lunes 23 de Mayo de 1791. T. 92, fol. 247v.
} 
“El señor Presidente dixo que se cumplían en el día los edictos a la Capellanía de Santa Inés, y parece se habían presentado opositores, y haviendo mandado entrar al Notario Secretario, hizo relación de que havía firmado la oposición a la Capellanía referida [espacio en blanco], natural de Cádiz, de 23 años cumplidos, que aunque no havía presentado su partida de baptismo havía ofrecido traérsela, a cuyo fin havía escrito a Cádiz, en cuya vista acordó el Cavildo que el citado opositor y los demás que huviesen firmado en el Domingo próximo por la mañana después de Coro se examinen por el Maestro de Capilla y este informe al Cavildo de su suficiencia e idoneidad". 593

"Se leyó un memorial de Antonio Díaz, Infante de Coro, pidiendo licencia para pasar a Zafra su tierra a visitar a sus Padres, y el Cavildo se la concedió hasta el día de la Natividad de Nuestra Señora". 594

D. José de los Ríos, Capellán perpetuo de San Antonino solicita licencia para no asistir al Coro por encontrarse enfermo. ${ }^{595}$

D. Tadeo Mintegui solicita una ayuda de costa para ayudarle a sufragar los gastos ocasionados por el traslado de su familia a Córdoba. El Cabildo dio comisión a los Diputados de Arcas vacantes de Santa Inés para que informasen. ${ }^{596}$

El Cabildo concede a D. José de los Ríos licencia para no asistir al Coro “hasta el día de la Concepción próximo futuro". 597

D. Tadeo Mintegui solicita que se le perdonen las faltas que ha tenido por su viaje y su correspondiente descuento económico. El Cabildo acuerda que se satisfagan al interesado "216 reales de vellón que importan dichas aspas”. 598

\footnotetext{
${ }^{593}$ Ibid. Viernes 27 de Mayo de 1791. T. 92, fol. 255v.

${ }^{594}$ Ibid. Lunes 11 de Julio de 1791. T. 92, fol. 261v.

595 Ibid. Lunes 8 de Agosto de 1791. T. 92, fol. 271r.

${ }^{596}$ Ibid. Lunes 8 de Agosto de 1791. T. 92, fol. 271v.

${ }^{597}$ Ibid. Jueves 29 de Agosto de 1791. T. 92, fol. 276v.

${ }^{598}$ Ibid. Jueves 1 de Septiembre de 1791. T.92, fol. 282v.
} 
Don Dionisio de la Mata pide permiso al Cabildo para salir fuera de Córdoba a restablecerse de su enfermedad. ${ }^{599}$

“El Cabildo acuerda dar licencia a dicho Capellán [D. Dionisio de la Mata] para que pueda salir fuera de la ciudad para lograr su completo restablecimiento, dispensándolo para asistir al coro hasta el día miércoles de ceniza próximo siguiente y no más". 600

El Cabildo fija los edictos para la provisión de una Capellanía vacante en la Capilla de Santa Inés, por muerte de D. Ignacio Casado. ${ }^{601}$

Para proveer una Capellanía vacante por muerte de D. José Cabrera, “acordó el Cavildo se fijen edictos por término de 60 días en la forma ordinaria y principiaran a contarse desde el día de oi para tiple o contraalto. Y que se pase decreto al Notario Secretario D. Fernando Aragonés para que no admita a esta oposición á alguno de los Capellanes músicos de esta Iglesia sin que primero y ante todo haya expresado renuncia de cualquiera Capellanía y salario que goce en ella", ${ }^{602}$

“Se leyó un informe de D. Manuel Valls, músico, pidiendo un aumento de salario y el Cavildo acordó cometerlo a los Señores Diputados de Escusados de Música”. 603

\section{2}

Se presentó un memorial de Don José Bach, organista segundo, solicitando una ayuda de costa, en atención a que hace algún tiempo está “supliendo por el primero sin otro salario que el propio que se le consignó por el Cabildo". 604

\footnotetext{
${ }^{599}$ Ibid. Viernes 30 de Septiembre de 1791. T.93.

${ }^{600}$ Ibid. Jueves 13 de Octubre de 1791. T. 93. fol. 18 v.

${ }^{601}$ Ibid. Jueves 10 de Noviembre de 1791. T. 93, fol. 39r.

${ }^{602}$ Ibid. Viernes 25 de Noviembre de 1791. T. 93, fol. 44v.

${ }^{603}$ Ibid. Martes 6 de Diciembre de 1791. T. 93, fol. 50v.

${ }^{604}$ Ibid. Jueves 12 de Enero de 1792. T. 93. fol. 53 r.
} 
“Se leyó un memorial de Don Juan Manuel Gaitán, Maestro de Capilla jubilado y Capellán de la Capilla de San Acacio suplicando licencia para no asistir al coro por su notoria imposibilidad, que igualmente se acredita por certificado médico que acompaña”. El Cabildo acordó que los Diputados de San Acacio informen al respecto. $^{605}$

Habiéndose leído solicitud de Don Manuel Valls, músico instrumentista que solicitaba aumento de sueldo, el Cabildo acuerda “aumentarle la consignación que actualmente goza, cincuenta ducados anuales". 606

El Cabildo trata la anterior petición de Don Juan Manuel Gaitán, Maestro de Capilla jubilado y acuerda: "Se le conceda licencia y dispensación de la asistencia al choro por sus notorios achaques y enfermedades; y se le concedió dicha licencia para un año que debe contarse desde este día”. ${ }^{607}$

Respecto a la anterior petición de Don José Benito Bach en la que solicitaba aumento de sueldo el Cabildo acuerda: "concederle y se le concedió ciento y cincuenta ducados de aumento sobre los trescientos ducados y el caíz de trigo que tiene. $Y$ habiéndose después seguido el votar la ayuda de costa que solicitaba, se votó igualmente por pelotas y se le concedió cien ducados de ayuda de costa por una vez". 608

Se leyó una carta de Don José Valls, Presbítero, organista de la Capilla de Nuestra Señora de la Victoria del Palacio de la Condesa, por la que solicita la plaza de primer organista de la Catedral. El Cabildo dio comisión a los Señores Diputados de música para que informasen. ${ }^{609}$

\footnotetext{
${ }^{605}$ Ibid. Jueves 19 de Enero de 1792. T. 93. fol. 64 r.

${ }^{606}$ Ibid. Martes 24 de Enero de 1792. T. 93. fol. 67 v.

${ }^{607}$ Ibid. Martes 24 de Enero de 1792. T. 93, fol. $68 \mathrm{v}$.

${ }^{608}$ Ibid. Lunes 13 de Febrero de 1792. T. 93, fol. 73 r.

${ }^{609}$ Ibid. Viernes 9 de Marzo de 1792. T. 93, fol. 80 v.
} 
“Se leyó un memorial de Don Dionisio de la Mata, músico de esta Santa Iglesia por el que solicita una ayuda de costa, para subvenir con ella al desfalco que por razón de aspas de música se le ha formado”. El Cabildo dio comisión a los Señores Diputados de San Acacio para que informasen. ${ }^{610}$

El Cabildo acuerda proveer unas plazas vacantes para el Colegio de Infantes de Coro, y también acuerda: “dar permiso a Don José Benito Bach organista segundo de esta Santa Iglesia para que pueda extraer de dicho colegio a su hijo Joaquín, para los fines que en su memorial expresó”. 611

"Se leyó memorial de Don Andrés Lidón, organista primero de esta Santa Iglesia, suplicando se le conceda alguna ayuda de costa por razón de gastos ocurridos en su dilatado viaje”. El Cabildo acuerda concederle mil quinientos reales de ayuda de costa. En el mismo Cabildo se trata la solicitud de Don Juan José de la Peña, músico instrumentista de la Catedral en el que suplica "se le conceda alguna ayuda de costa para subvenir sus necesidades y urgencias”. El Cabildo acordó dar comisión a los Diputados de música par que informen. ${ }^{612}$

En Septiembre de ese año de 1792 se realizan unas pruebas para cubrir vacantes en el Colegio de Infantes de Coro. Se hacen dichas pruebas en dos turnos. En el primer turno resulta elegido el niño Joseph Serrano. A continuación se abre un segundo turno para seguir examinando. En este caso el Cabildo "en virtud del llamamiento para oír el examen de los pretendientes a las opas vacantes del Colegio de Infantes, y en su lista y del informe del examinador nombrado para hacer su provisión, se mandó entrar al rector del mismo colegio quien expuso dicho informe con individual expresión de todos los pretendientes. Y enseguida se mandó entrar a cada uno separadamente, examinándolos en leer, escribir y canto. Y finalizada dicha diligencia se mandaron retirar. Y el Cabildo acordó pasar a evacuar la elección por votos secretos en la forma ordinaria, y de todo resultó quedar electos Joseph Jaén, Juan de Mora, y Rafael de

\footnotetext{
${ }^{610}$ Ibid. Viernes 9 de Marzo de 1792. T. 93, fol. 81 r.

${ }^{611}$ Ibid. Martes 4 de Septiembre de 1792. T. 93, fol. $139 \mathrm{v}$.

${ }^{612}$ Ibid. Viernes 7 de Septiembre de 1792. T. 93. fol. $141 \mathrm{r}$.
} 
León” ${ }^{613}$ "Se leyó el memorial genealógico de Joseph Serrano, admitido a la plaza vacante en el Colegio de Infantes y se acordó dar comisión a los Señores Diputados de dicho colegio para que hagan las pruebas de limpieza de sangre a dicho Serrano conforme al estatuto". 614

"Primeramente se mandó entrar al secretario secular y dio cuenta de haber firmado la oposición a la Capellanía vacante de San Acacio Don Joseph González y Don Antonio Hernández, y de estar cumplido el término de los edictos, y se acordó señalar el día 18 del corriente para que hagan la oposición, y con informe del Maestro de Capilla”. ${ }^{615}$

"Se vio un memorial de Don Antonio Gil, músico tenor en la Capilla de Antequera, en que suplica al Cabildo, que hallándose en exercicios para ordenarse en las próximas témporas, y siendo éste justamente el tiempo en que se hacen las oposiciones a la Capellanía vacante, a que desea concurrir, se sirva el Cabildo no cerrar el concurso, y suspender la elección hasta que sea oído: y se acordó concederle esta gracia", ${ }^{616}$

En el Cabildo de este día se leyeron los memoriales genealógicos de Rafael de León, Joseph Jaén, y Juan de Mora, admitidos para las plazas del Colegio de Infantes de esta Santa Iglesia; y se acordó que los diputados de dicho colegido hagan las informaciones de limpieza de sangre conforme al estatuto. No obstante en el caso de Juan de Mora, "mediante a que según exponía es hermano de Lope de Mora, que ha sido colegial en el mismo colegio y para su entrada se le hicieron y aprobaron los informes según estatuto”, se resolvió que esto acreditaba su limpieza de sangre. ${ }^{617}$

"Se vio un memorial de Don Rafael del Río músico contralto de esta Capilla en que pide licencia al Cabildo para ir a Sevilla a recibir el orden de Diácono en las

\footnotetext{
${ }^{613}$ Ibid. Sábado 15 de Septiembre de 1792. T. 93. fol. 144 v.

${ }^{614}$ Ibid. Sábado 15 de Septiembre de 1792. T. 93. fol. 144 v.

${ }^{615}$ Ibid. Lunes 17 de Septiembre de1792. T. 93. fol. 145 v.

${ }^{616}$ Ibid. Lunes 17 de Septiembre de 1792. T. 93. fol. 145 v.

${ }^{617}$ Ibid. Lunes 17 de Septiembre de 1792. T. 93. fol. 146 r.
} 
próximas témporas, y se le concedió por diez días contados desde hoy el que salga de ésta ciudad". 618

"Se vio el informe de los Señores Diputados de excusados de música, sobre la pretensión de Don Joseph de la Peña, músico instrumentista de la Capilla de esta Santa Iglesia, y habiendo votado por pelotas en la forma ordinaria, se acordó librarle por una vez, cien ducados de vellón sobre el fondo de dichos excusados". ${ }^{619}$

"Se mandó entrar al Maestro de Capilla, el que informó al Cabildo que los tres opositores que habían concurrido a la oposición de la Capilla de San Acacio, habían desempeñado los exercicios de la oposición, y que a todos los tres les consideraba beneméritos y acreedores a dicha Capellanía, por lo que (habiéndose retirado) el Cabildo acordó proveerla en Don Antonio Gil”, 620

En el Cabildo de este día se vuelve a tratar el tema de Don Antonio Gil. Después de unas discusiones previas se acuerda asignarle una renta anual de seis mil reales. Asimismo, "se dio licencia al expresado Don Antonio Gil para que pase a la ciudad de Antequera o a donde le convenga para practicar las diligencias conducentes a sus órdenes, pruebas de limpieza de sangre, y su establecimiento en esta ciudad, hasta el día último de este mes”. ${ }^{621}$

Se oyeron las pruebas de Don Joseph Jaén nombrado para Infante del Colegio del Santo Ángel de la Guarda, las cuales fueron aprobadas, "y se acordó que había cumplido con el estatuto de limpieza, y en su consecuencia que podía tomar la opa en dicho colegio, y entrar con sobrepelliz en el coro". 622

\footnotetext{
${ }^{618}$ Ibid. Lunes 17 de Septiembre de 1792. T. 93. fol. 146 r.

${ }^{619}$ Ibid. Jueves 20 de Septiembre de 1792. T. 93. fol. 146 v.

${ }^{620}$ Ibid. Miércoles 3 de Octubre de 1792. T. 93. fol. 150 v.

${ }^{621}$ Ibid. Sábado 6 de Octubre de 1792. T. 93. fol. 153 v.

${ }^{622}$ Ibid. Martes 16 de Octubre de 1792. T 93. fol. 154 r.
} 
$\mathrm{Al}$ igual que hemos visto anteriormente como se aprueba la limpieza de sangre de Joseph Jaén, ahora el Cabildo aprueba igualmente los informes de limpieza de sangre de José Serrano y Rafael de León. ${ }^{623}$

En el día de la fecha se lee el memorial de genealogía de Don Antonio Gil. En el se dice que Don Antonio Gil es natural de la ciudad de Orihuela. Sus padres son Don Carlos Gil y Doña Ana Hurtado naturales de dicha ciudad. Sus abuelos paternos son Cristóbal Gil, natural de Cartagena, y María Ventura Ruiz, natural de Murcia. Sus abuelos maternos son Don Juan Hurtado, y Doña Josefa Sanz de Martínez naturales de Orihuela. $^{624}$

\section{3}

El Cabildo discute acerca de la pretensión de Don Bartolomé de Gálvez, ayuda de sochantre, que pedía una ayuda económica. "Habiendo votado secretamente en la forma acostumbrada, se acordó darle doscientos ducados por una vez". ${ }^{2} 5$

"Se leyó una carta del Eminentísimo Cardenal Patriarca, en que recuerda al Cabildo la oferta que le había hecho de aumentar el salario del primer organista Don [Andrés] Lidón, conforme fueran vacando otros que tenían algunos individuos de la Capilla de Música, de los que había [una vez] muerto Don Joseph de la Peña. Y se acordó dar comisión a los Señores Diputados de excusados de música para que informen con llamamiento sobre el salario vacante por muerte de dicho Peña, y se sirva responder al Eminentísimo Señor Patriarca”. ${ }^{626}$

“En virtud del llamamiento para oír el informe de los Señores Diputados de excusados de música con la parte de su excelencia, sobre la pretensión de ayuda de costa de la viuda de Don Juan Joseph de la Peña, músico instrumentista de la Capilla

\footnotetext{
${ }^{623}$ Ibid. Lunes 22 de Octubre de 1792. T. 93. fol. 156 r.

${ }^{624}$ Ibid. Martes 6 de Noviembre de 1792. T. 93. fol. $160 \mathrm{v}$.

${ }^{625}$ Ibid. Sábado 26 de Enero de 1793. T. 93, fol.180 v.

${ }^{626}$ Ibid. Sábado 26 de Enero de 1793. T. 93, fol. 182 v.
} 
de esta Santa Iglesia, oído que fue dicho informe: se acordó librarla por una vez seiscientos reales de vellón”. 627

“En virtud del llamamiento para oír el informe de los Señores Diputados de acólitos, y niños de coros, sobre la pretensión de ayuda de costa de Cristóbal Bendicho, acólito de esta Santa Iglesia: oído que fue dicho informe se acordó librarle por una vez doscientos reales". ${ }^{628}$

"Se leyó un memorial de Don Juan Manuel Gaitán, Maestro de Capilla jubilado de esta Santa Iglesia, pidiendo patitur abierto, en atención a su notoria enfermedad y privación de vista. Y se acordó concedérselo por un año”. ${ }^{629}$

"Se reúne el Cabildo para oír el informe de los Señores Diputados de excusados de música con la parte de su Ilustrísima, sobre el salario vacante por muerte de Don Juan Joseph de la Peña. Oído que fue con lo demás que verbalmente expusieron, acordó el Cabildo: que al organista primero de esta Santa Iglesia se le consignen, como consignaron, los cien ducados de vellón que el referido gozaba con más las doce fanegas de trigo que igualmente tenía”. El salario total que le queda al organista es de 10.260 reales de vellón. ${ }^{630}$

"Se leyó un memorial de Don Antonio Gil, Capellán de San Acacio pidiendo licencia para pasar a la ciudad de Málaga a ordenarse de Subdiácono. Y se acordó dar sólo hasta la víspera del viernes de dolores”. 631

"Se leyó un memorial de Don Mateo Tascón, músico instrumentista de esta Capilla, pidiendo una ayuda de costa y que se le perdonen las aspas que se le pusieron

\footnotetext{
${ }^{627}$ Ibid. Miércoles 30 de Enero de 1793. T. 93, fol. 183 r.

${ }^{628}$ Ibid. Miércoles 30 de Enero de 1793. T. 93, fol. 183 v.

${ }^{629}$ Ibid. Miércoles 30 de Enero de 1793. T. 93, fol. 184 r.

${ }^{630}$ Ibid. Viernes 15 de Febrero de 1793. T. 93, fol. 186 r.

${ }^{631}$ Ibid. Martes 12 de Marzo de 1793. T. 93.
} 
durante su ausencia”. Se acordó dar comisión a los Señores Diputados de excusados de música para que informen". 632

Se da cuenta de la muerte de Don Bartolomé de Gálvez. Asimismo, “se leyó un memorial de Don Julián de Gálvez, músico instrumentista de la Capilla de esta Santa Iglesia, por el que pide se le aumente el salario que goza, en atención a no bastarle para mantener la dilatada familia que ha quedado a su cargo por muerte de dicho Don Bartolomé, su padre. Y se acordó dar comisión a los Señores Diputados de excusados de música para que informen con llamamiento". 633

“Se leyó un memorial de Don Andrés Lidón, primer organista de esta Santa Iglesia, en que pide se le complete hasta la cantidad de doce mil reales que se le ofrecieron al admitirlo en dicha plaza, mediante a que por el fallecimiento de Don Bartolomé de Gálvez, resultaba fondo en la fábrica par dicho efecto”. Se dio comisión a los Señores Diputados de excusados de música para que informaran al respecto. Asimismo se les pidió que informaran sobre la obligación que contrajo el Cabildo en la admisión de dicho organista, y en que términos se respondió a la carta de recomendación a su favor que escribió el Cardenal Patriarca al Cabildo. ${ }^{634}$

En virtud del llamamiento para oír los informes de los Diputados de música sobre las pretensiones de Don Andrés Lidón, organista primero de la Catedral, de Don Julián Gálvez y de Don Mateo Tascón, ambos músicos instrumentistas, el Cabildo acuerda lo siguiente: a Don Andrés Lidón, se le aumenta el sueldo hasta once mil reales y se acuerda escribir una carta al Cardenal Patriarca de las Indias, que lo había recomendado, haciéndole saber dicha subida. A Don Julián Gálvez se le conceden mil cien reales de ayuda de costa. Y a Don Mateo Tascón, igualmente cuatrocientos reales de ayuda de costa. Asimismo se pide a los Señores Diputados de excusados de música que informen sobre la situación en que quedan los sobrantes de dichos caudales. ${ }^{635}$

\footnotetext{
632 Ibid. Martes 23 de Abril de 1793. T. 93, fol. 199 v.

${ }^{633}$ Ibid. Lunes 13 de Mayo de 1793. T. 93, fol. 202 v.

${ }^{634}$ Ibid. Lunes 13 de Mayo de 1793. T. 93, fol. 202 v.

${ }^{635}$ Ibid. Miércoles 4 de Septiembre de 1793. T. 93, fol. 246v.
} 
"Se leyó un memorial de Don Antonio Gil pidiendo licencia para pasar a la ciudad de Málaga ir a otra donde se hagan órdenes generales en las próximas témporas de San Mateo, y recibir el de presbítero, deteniéndose después en Antequera a celebrar su primera misa el día de la Virgen del Rosario. Y el Cabildo acordó concederle dicha licencia hasta el día 15 del próximo mes de octubre”. 636

"El Señor Ugalde dixo: que en el archivo general de esta Santa Iglesia había algunos exemplares de una obra de música, los que convendrían vender, reservando uno par colocarlo en la librería del Cabildo, la que estaba arreglando como comisionado juntamente con el señor Riera: y se acordó dar, y dio comisión a dichos señores para que reconozcan los citados exemplares e informen con llamamiento". ${ }^{637}$

Los Señores Diputados de arcas de Santa Inés informan que Don Federico Cudoire ha solicitado una ayuda de costa. ${ }^{638}$

\section{4}

Se da cuenta de los opositores presentados para cubrir la Capellanía vacante de San Pedro, y se cita al Maestro de Capilla como juez examinador. ${ }^{639}$

“En virtud del llamamiento para oír el informe de los Señores Diputados de Arcas vacantes de San Acacio, sobre la solicitud de Doña Francisca Almoguera, viuda de Don Bartolomé Gálvez, sochantre que fue de esta Santa Iglesia: oído que fue dicho informe se acordó librar a dicha viuda mil y quinientos reales en recompensa del trabajo que tuvo su marido en la instrucción en canto llano de Don Mariano Villuendas, ayuda de sochantre, en que le encargó el Cabildo, ofreciéndole el correspondiente premio que no había recibido". ${ }^{640}$

\footnotetext{
${ }^{636}$ Ibid. Lunes 16 de Septiembre de 1793. T. 93, fol. 257 v.

${ }^{637}$ Ibid. Lunes 14 de Octubre de 1793. T. 94, fol. 3 r.

${ }^{638}$ Ibid. Lunes 23 de Diciembre de 1793. T. 94.

${ }^{639}$ Ibid. Miércoles 22 de Enero de 1794. T.94, fol. 37 v.

${ }^{640}$ Ibid. Viernes 24 de Enero de 1794. T.94, fol. 39 r.
} 
“En continuación del mismo llamamiento para dar cuenta de haberse cumplido los edictos de la Capellanía de la Sangre, vacante por muerte de Don Dionisio de la Mata y en atención a no haber parecido opositor alguno, al parecer por ser muy raras las voces de tiple que pedían dichos edictos: Se acordó que se fixen de nuevo con término de sesenta días contados desde el día de su fixación en esta ciudad, y que en ellos se convoque para oponerse a dicha Capellanía a todas clases de voces para la Capellanía, y elegir la que sea más conveniente”. ${ }^{641}$

"Se leyó un memorial de Don Juan Manuel Gaitán, Maestro de Capilla jubilado, pidiendo licencia para no asistir al coro mediante su notoria privación de vista: Y se acordó dar, y dio comisión a los Señores Diputados de Arcas vacantes, para que informen con llamamiento". ${ }^{642}$

"Se leyó otro memorial de Don Pascual Redel, violinista de la Capilla de Música de esta Santa Iglesia pidiendo aumento de salario: y se acordó dar y dio comisión a dichos Señores Diputados para que informen con llamamiento sobre esta pretensión". 643

“En virtud para oír el llamamiento del informe de los Señores Diputados de Arcas de vacantes de San Acacio con la parte de nuestro Excelentísimo Prelado sobre la licencia que pide [Gaitán] para no residir en el coro por causa de su notoria privación de vista. Y oído que fue dicho informe se acordó concederle otra licencia por el término de un año". ${ }^{444}$

“En continuación del llamamiento para oír el informe de los mismos Señores Diputados sobre la pretensión de Don Phelipe Van-Acken: se acordó admitir a dicho Don Phelipe para que entre en el coro en la clase de psalmista y con la obligación de cantar en la Capilla de Música cuando el Maestro le necesite y le llame, y con la de suplir las ausencias y enfermedades de los organistas, gozando de los mismos días de

\footnotetext{
${ }^{641}$ Ibid. Viernes 24 de Enero de 1794. T.94, fol. 39 v.

${ }^{642}$ Ibid. Viernes 24 de Enero de 1794. T.94, fol. 39 v.

${ }^{643}$ Ibid. Viernes 24 de Enero de 1794. T.94, fol. 39 v.

${ }^{644}$ Ibid. Jueves 30 de Enero de 1794. T.94, fol. 41 v.
} 
recles que se concedieron a Don Mariano Villuendas, y con trescientos ducados cada año de dichas arcas". 645

Se concede el aumento de salario que pedía a Don Pascual Redel músico instrumentista de la Capilla. ${ }^{646}$

"Se leyó memorial de Don Andrés Lidón organista primero de esta Santa Iglesia en que pide licencia para acompañar a su madre en el viaje a su país: y se acordó dar y dio comisión a los Señores Diputados de Excusados de Música para que informen con llamamiento”. ${ }^{647}$

"En virtud del llamamiento para oír el informe de los Señores Diputados de Excusados de Música con la parte de su Excelentísima sobre la licencia que solicitaba Don Andrés Lidón, primer organista de esta Santa Iglesia, para ir a llevar y acompañar a su madre a su país: oído que fue dicho informe se votó por pelotas en la forma acostumbrada, y se acordó denegarle la expresada licencia”. 648

"Se leyó un memorial de Lope de Mora, Acólito de esta Santa Iglesia en el que pide se sirva el Cabildo colocarle en la plaza vacante de violinista por muerte de Don Joseph de la Peña, en atención a su mérito y habilidad para tocar dicho instrumento y se acordó dar y dio comisión a los Señores Diputados de Arcas vacantes con la parte de su Excelentísima para que informen con llamamiento y el parecer del Maestro de Capilla sobre dicha solicitud". 649

Don Andrés Lidón vuelve a pedir un permiso para ausentarse de la ciudad [en este caso para contraer matrimonio]. El Cabildo acuerda estudiar esta nueva petición. ${ }^{650}$

\footnotetext{
${ }^{645}$ Ibid. Jueves 30 de Enero de 1794. T.94, fol. 41 v.

${ }^{646}$ Ibid. Jueves 30 de Enero de 1794. T.94, fol. 41 v.

${ }^{647}$ Ibid. Viernes 23 de Febrero de 1794. T.94, fol. 47 v.

${ }^{648}$ Ibid. Sábado 15 de Marzo de 1794. T.94, fol. 48 r.

${ }^{649}$ Ibid. Sábado 15 de Marzo de 1794. T.94, fol. 48 v.

${ }^{650}$ Ibid. Lunes 17 de Marzo de 1794. T.94, fol. 50 r.
} 
“En virtud del llamamiento para oír el informe de los Señores Diputados de Excusados de Música con la parte de su Excelentísima sobre la licencia que de nuevo solicitaba Don Andrés Lidón, organista primero de esta Santa Iglesia, para pasar a su país: oído que fue dicho informe, y atendiendo a la nueva causa que exponía, de tener que tomar el estado de matrimonio en dicho su país: se acordó concederle la licencia por el término de dos meses, que deberán contarse desde el día en que salga de esta ciudad". 651

“Que se informe por el notario secretario a los músicos y capellanes, el silencio y circunspección que deben guardar en todas las procesiones, y vocaciones dentro y fuera de la iglesia". ${ }^{652}$

"Se leyó informe sobre la pretensión de Lope de Mora, acólito de esta Santa Iglesia para que se le consignase alguna renta de dichas arcas de San Acacio: oído dicho informe y el de el Maestro de Capilla acordó el Cabildo consignar y consignó al referido Lope de Mora cuatro reales de vellón diarios en calidad de músico instrumentista [violinista] sujetos a aspas y demás obligaciones correspondientes a músicos, conservándose en la plaza de acólito y sin concurrir al Jabardo, y estando subordinado en todo a la dirección del Maestro de Capilla”. 653

Se leyó un memorial de Don Alfonso Martín músico y Capellán de San Acacio, pidiendo aumento de renta, y el Cabildo comisionó a los Señores Diputados de Arcas vacantes de dicha capilla para que informen. ${ }^{654}$

“En virtud del llamamiento para oír el informe de los Señores Diputados de Arcas vacantes de Santa Inés, con la presente sobre la ayuda de costa que pretende Don Antonio García, músico; oído dicho informe acordó el Cabildo concederle y le

\footnotetext{
${ }^{651}$ Ibid. Lunes 17 de Marzo de 1794. T.94, fol. 51 r.

652 Ibid. Martes 1 de Abril de 1794. T.94, fol. 55 v.

${ }^{653}$ Ibid. Martes 1 de Abril de 1794. T.94, fol. 56 r.

${ }^{654}$ Ibid. Martes 1 de Abril de 1794. T. 94, fol. 56 r.
} 
concedió doscientos ducados de ayuda de costa por una vez que libró contra dichas arcas". 655

“Habiéndose zelado sobre los músicos dependientes de este Cabildo, varias relajaciones y abusos que se notan en ellos, en el Coro, y sus tribunas, en el facistolillo y asimismo en las rogativas y procesiones, dentro y fuera de la iglesia, se acordó se les informen por el notario secretario que han de tener una total subordinación al Maestro de Capilla y sus disposiciones, y que aunque se hallen malos, estando en el Coro, o en procesiones, o acto de música, deben salir al medio con los demás músicos, so pena de ser aspados por el mismo hecho de estar en sus sillas, o fuera del sitio de la música, ahora sean músicos de voz, o de instrumento. Que en las tribunas se guarde silencio y compostura por todos los músicos citados, y no se templen los instrumentos durante el salmeo, canto del coro, o misa, en que se nota mucho abuso". 656

El Maestro de Capilla solicita al Cabildo que se quede el opositor a la Capellanía vacante de Don Dionisio de la Mata, para que cantase la Pasión y demás que se ofreciese, para poder formar un juicio de sus cualidades. El Cabildo acepta dicha petición. ${ }^{657}$

Se leyó un memorial de Don Joseph Cascagni, músico tiple pidiendo ser admitido en la Catedral de Córdoba. El Cabildo acuerda que los Diputados de San Acacio informen el próximo jueves. ${ }^{658}$

El Cabildo acuerda que los Diputados de San Acacio informen sobre la suficiencia de Don Joseph Cheist de Fernández, opositor a la Capilla vacante de San Acacio, previamente consultado el Maestro de Capilla. ${ }^{659}$

\footnotetext{
${ }^{655}$ Ibid. Martes 1 de Abril de 1794. T. 94, fol. 56 v.

${ }^{656}$ Ibid. Sábado 5 de Abril de 1794. T.94, fol. 59 r.

${ }^{657}$ Ibid. Miércoles 9 de Abril de 1794. T.94, fol. 61 r.

658 Ibid. Miércoles 23 de Abril de 1794. T.94, fol. 64 r.

${ }^{659}$ Ibid. Miércoles 23 de Abril de 1794. T.94, fol. 64 r.
} 
“En virtud del llamamiento para oír el informe del Maestro de Capilla Don Jaime Valius sobre la suficiencia de Don Joseph Cheist de Fernández, Clérigo Diácono, opositor a la capilla vacante de San Acacio se mandó entrar a dicho Maestro de Capilla y presentó al Cabildo una certificación en que manifestaba su dictamen sobre la suficiencia de dicho opositor, y habiéndose retirado y reconocido por el Cabildo que el referido Don Joseph es útil para el servicio de el Choro de esta Santa Iglesia y desempeño de la Capellanía vacante, mandó que dicha certificación pase al notario secretario, Don Francisco Beltrán, para que la una a los autos posesorios de dicha Capellanía”. 660

“En continuación del llamamiento para ver el informe de los mismos Señores sobre la ayuda de costa que solicita Don Joseph Cascagni músico tiple, oído dicho informe y votándose por votos secretos acordó el Cabildo conceder y concedió a dicho Cascagni dos mil reales de vellón de ayuda de costa por una vez y de los caudales de arcas de vacantes de San Acacio”. 661

Don Pedro Marciag, músico de la Capilla, pide licencia hasta el día del Corpus para ir a la villa y corte de Madrid. Se da comisión a los Diputados de Arcas vacantes para que informen. ${ }^{662}$

"Se leyeron memoriales el uno de Don Matías Redel, y el otro de Don Juan Busquet, músicos de la Capilla de esta Santa Iglesia, en que pedían ayuda de costa para socorrer sus necesidades: y se acordó dar y dio comisión a los Señores Diputados de Arcas vacantes de Santa Inés para que informen con llamamiento", 663

Se concede licencia a Don Pedro Marciag para que pase a la villa y corte de Madrid desde el día después de la octava del Corpus hasta el día de la Asunción de Nuestra Señora del presente año. ${ }^{664}$

\footnotetext{
${ }^{660}$ Ibid. Miércoles 23 de Abril de 1794. T.94, fol. 64 v.

${ }^{661}$ Ibid. Miércoles 23 de Abril de 1794. T.94, fol. 65 r.

${ }^{662}$ Ibid. Martes 20 de Mayo de 1794. T.94, fol. 69 v.

${ }^{663}$ Ibid. Lunes 2 Junio de 1794. T.94, fol. $70 \mathrm{v}$.

${ }^{664}$ Ibid. Martes 3 de Junio de 1794. T.94, fol. 73 v.
} 
El Cabildo trata las anteriores peticiones de ayuda de costa de Don Matías Redel y Don Juan Busquet. A uno y a otro se le conceden mil reales de ayuda. ${ }^{665}$

El Maestro de Capilla informa que ninguno de los opositores a la Capellanía de San Pedro es apto para cubrir el puesto, por lo que el Cabildo acuerda que se vuelvan a fijar los edictos. ${ }^{666}$

Don Vicente Marín, músico violón de la Capilla, pide licencia para ausentarse, y el Cabildo acuerda concedérsela hasta la víspera de Nuestra Señora de la Concepción. ${ }^{667}$

Se leyó un memorial de Don Antonio Gil, Capellán de San Acacio, por el que solicita se le perdonen las aspas que ha tenido por estar ausente de esta ciudad. Se dio comisión a los Señores Diputados de San Acacio para que informen. ${ }^{668}$

El Señor Chantre hace saber al Cabildo que el Maestro de Capilla dice que hace mucha falta un bajo para la Capilla de Música y que sabía que en Murcia había un músico de especial habilidad para tocar el violón. Se acordó dar comisión a los Señores Diputados de Música, para que informen con llamamiento, de los fondos que hay para dotar dicha plaza. ${ }^{669}$

Con motivo de la muerte de Don Federico Cudoire, Don Juan de Borja, músico instrumentista solicita algún aumento de salario, por haber estado supliendo al citado Cudoire durante mucho tiempo. ${ }^{670}$

Se concede a Don Juan de Borja un aumento de ciento cincuenta ducados anuales. ${ }^{671}$

\footnotetext{
${ }^{665}$ Ibid. Viernes 6 de Junio de 1794. T.94, fol. 75 v.

${ }^{666}$ Ibid. Sábado 26 de Septiembre de 1794. T.94, fol. 114 v.

${ }^{667}$ Ibid. Sábado 26 de Septiembre de 1794. T.94, fol. 115 r.

${ }^{668}$ Ibid. Jueves 13 de Noviembre de 1794. T.94, fol. 141 r.

${ }^{669}$ Ibid. Jueves 13 de Noviembre de 1794. T.94, fol. 141 r.

${ }^{670}$ Ibid. Viernes 9 de Diciembre de 1794. T.94, fol. 148 r.

${ }^{671}$ Ibid. Martes 16 de Diciembre de 1794. T.94, fol. 153 v.
} 
“El Señor Riera dio zelo sobre que se notaba en algunas ocasiones que el Coro respondía tan bajo a los Señores que capitulaban, y cantaban la música, que ocasionaba una disonancia muy reparable, y digna de corregirse, y habiendo corrido el voto, acordó el Cabildo que por el Señor Presidente se amoneste a todos los Capellanes, y se abstengan en lo sucesivo de semejante desentono", ${ }^{672}$

\section{5}

"Se leyó un memorial de D. Antonio Gil, en que pedía mandara el Cabildo darle un testimonio de las pruebas que se le hicieron para obtener la Capellanía de san Acacio". 673

"Se leyó un memorial de D. Juan Gaytán en que pedía licencia de patitur abierto: Y se acordó dar y dio comisión a los Señores Diputados de Arcas de vacantes para que informen con llamamiento". ${ }^{674}$

El Cabildo acuerda fijar el comienzo de las oposiciones a la Capellanía de San Pedro el día 23 de ese mismo mes, haciendo constar a los opositores la obligación de ejercer el oficio de Sochantre. Se nombró examinador al Maestro de Capilla de esta Santa Yglesia. ${ }^{675}$

Se presenta el memorial de genealogía de D. Joseph María Cheist de Fernández.

Pretendiente.

D. Joseph María Cheist de Fernández, natural de la ciudad de Zeuta, bautizado en la parroquia de Santa María de los Remedios, extramuros de ella, en el día 10 de Noviembre de 1770.

\section{Padres.}

D. Francisco Xavier Cheist de Fernández y $D^{a}$ María Catalina Marcelo, de la misma naturaleza.

\footnotetext{
${ }^{672}$ Ibid. Lunes 22 de Diciembre de 1794. T.94, fol. 154 r.

${ }^{673}$ Ibid. Miércoles 14 de Enero de 1795. T. 94.

674 Ibid.

${ }^{675}$ Ibid. Viernes 16 de Enero de 1795. T. 94, fol. 163r.
} 


\section{Abuelos Paternos.}

D. Manuel Cheist de Fernández y $D^{a}$ Juana Galca, naturales de dicha ciudad.

\section{Abuelos Maternos.}

D. Francisco Marcelo y $D^{a}$ María Guerrero, naturales también de dicha ciudad.

"Y puesto de rodillas delante del señor Presidente, y la mano sobre el libro de los Sagrados Evangelios, juró por Dios nuestro Señor, según su estado, que el referido memorial de su genealogía era cierto y verdadero", ${ }^{676}$

El Cabildo acuerda que en los postigos del Coro, en los días de fiesta y de mucha concurrencia, se pongan dos niños del Colegio de Infantes, para que impidan la entrada a cualquier seglar. ${ }^{677}$

Se leyó memorial de Don Vicente Marín: el Cabildo acuerda consignarle quinientos reales de ayuda de costa, por una vez sobre los caudales de excusados de música. ${ }^{678}$

“Se leyó un memorial de Don Joseph Las, músico instrumentista y se acordó en su vista, suspender su administración, y con este motivo se dio comisión a los Señores Diputados de las Arcas, para que informen al Cabildo sobre los fondos de estos caudales, y con dictamen del Maestro de Capilla, si convendrá admitir instrumentista o músico de voz, según lo que haga más falta para el servicio de la Capilla”. ${ }^{679}$

"Se leyó un memorial de Don Joseph Serrano, suplicando se volviese a admitir a su hijo en el Colegio de Infantes: y en su vista acordó el Cabildo, no a lugar, previniendo que en lo sucesivo no se vuelva a admitir memoriales de infantes". 680

\footnotetext{
${ }^{676}$ Ibid. Viernes 30 de Enero de 1795. T. 94, fol. 167v.

${ }^{677}$ Ibid. Sábado 21 de Marzo de 1795. T. 94, fol. 183 r.

${ }^{678}$ Ibid. Lunes 20 de Abril de 1795. T. 94, fol. 185 v.

${ }^{679}$ Ibid. Viernes 6 de Junio de 1795. T. 94, fol. 193 r.

${ }^{680}$ Ibid. Lunes 7 de Septiembre de 1795. T. 94, fol. 211 r.
} 
“En virtud del llamamiento para oír el informe de los Señores Diputados de la Capilla de Santa Inés, con la parte de nuestro Excelentísimo Prelado sobre la pretensión de Don Joseph Las: oído que fue dicho informe: se mandó entrar al Maestro de Capilla, el que expuso que el pretendiente tocaba excelentemente varios instrumentos, como la flauta, oboe, fagot, y violín, del que había mucha necesidad en la Capilla: y habiéndose retirado se pasó a votar secretamente y executado, se acordó admitir y se admitió al expresado Don Joseph Las para que toque en la Capilla de esta Santa Iglesia, los instrumentos que sabe tocar, en la forma y lugar que disponga el Maestro de Capilla, según le parezca más conveniente: y se le asignaron trescientos ducados anuales de salario, y además cincuenta ducados con la obligación de enseñar a cualquiera de los niños de Coro, que quiera aprender algún instrumento de los que toca”. 681

"Se acordó que los Señores Diputados del Colegio de Infantes informen con llamamiento sobre los pretendientes a las plazas vacantes, para oír el parecer del Maestro de Capilla, y en su vista acordar lo que convenga". 682

Se leyeron dos memoriales: uno de Lope de Mora, músico instrumentista y otro de Don Pedro Turón, primer sochantre. El primero pedía aumento de salario y el segundo una ayuda de costa. Se dio comisión a los Diputados de San Acacio para que informasen. $^{683}$

El Cabildo se reúne en la Capilla de San Clemente para tratar lo siguiente: “en virtud del llamamiento para oír a los niños pretendientes de las plazas vacantes en el Colegio de Infantes de Coro, y el informe del Maestro de Capilla sobre la suficiencia de cada uno: se mandó entrar a éste con dichos niños, que los fueron Joseph de Aguilar, Joseph Villalba, Rafael Ayllón, Miguel López, Manuel Navarro, Joseph Baena, Francisco García, Francisco Angulo, Rafael Roma Santa, Miguel Cueva, Juan de Luque, Francisco Escalona, Andrés de Heredia, y Juan Ximénez, y habiendo sido examinados: y oído el parecer del Maestro de Capilla: se acordó suspender por ahora

\footnotetext{
${ }^{681}$ Ibid. Miércoles 14 de Octubre de 1795. T. 94, fol. 219 r.

${ }^{682}$ Ibid. Jueves 19 de Noviembre de 1795. T. 94, fol. 223 v.

${ }^{683}$ Ibid. Jueves 19 de Noviembre de 1795. T. 94, fol. 224 r.
} 
el nombramiento y se dio comisión a los Señores Diputados de dicho Colegio para que informen con llamamiento sobre las becas que hay vacantes correspondientes a este Cabildo, supuesto el decreto en que se reducen a doce todas las que deben estar provistas, y que el Maestro de Capilla ponga su informe por escrito en que gradúe el mérito de los pretendientes, para en su vista hacer el nombramiento". 684

De nuevo, el Cabildo se reúne dos días más tarde en la Capilla de San Clemente, para resolver el tema de los Niños de Coro: "en virtud del llamamiento para oír el informe de los Señores Diputados de Infantes de Coro, sobre las becas vacantes, que corresponde proveer a este Cabildo, y el parecer del Maestro de Capilla sobre el mérito de los niños pretendientes, que habían sido examinados: oído que fue dicho informe se leyó el parecer del Maestro de Capilla, que fue del tenor siguiente:”. [Se reproduce a continuación íntegro el informe de Jaime Balius].

Ilustrísimo Señor. De mandato de N.S.J. hice el examen a los catorce pretendientes que se presentaron delante de N.S.J. el día 3 del presente mes, para cumplir hasta el número de doce niños de Coro: Para este efecto propongo los más idóneos por su graduación como sigue:

1. Miguel López, edad ocho años, su voz natural, fina, agradable y de buena entonación.

2. Joseph Villalba, edad de siete años, su voz bastante dilatada y de buena entonación.

3. Francisco García, edad muy cerca de los nueve años, tiene su voz bastante agradable y afina bien lo que canta.

4. Joseph Aguilar, edad siete años y medio, su voz tiene buenos altos, los bajos y medios desagradables.

5. Andrés de Heredia, edad siete años, voz muy agradable, pero muy endeble.

6. Francisco Escalona, edad de siete años, saca la voz con mucha violencia.

7. Marcos de Luna, edad 7 años, saca la voz con mucha violencia.

8. Rafael Roma Santa, edad de siete años, al natural su voz no es desagradable pero tiene mala afinación.

${ }^{684}$ Ibid. Jueves 3 de Diciembre de 1795. T. 40, fol. 225 v 
Los demás no los pongo porque no considero circunstancias apetecibles en ellos.

Éste es mi sentir y V.S.I. como dueño, dispondrá lo que sea de su mayor agrado: Córdoba 4 de Diciembre de 1795. B.L.M. de V.S.I. su rendido servidor y Capellán, Jayme Balius.

Tras este informe, se procede a la votación para elegir a los que el Cabildo considera apropiados: "Y enseguida habiendo parado a votar secretamente, en la forma ordinaria, fueron nombrados Miguel López, Francisco García y Rafael Ayllón y se dio comisión a los Señores Diputados de Infantes de Coro para examinar la edad de Rafael Aillón y teniendo más edad de diez años que den cuenta al Cabildo para nombrar otro en su lugar: pero que teniendo menor de diez años quede desde luego admitido. El Señor Doctoral contradixo esta determinación en cuanto al nombramiento de Rafael Ayllón”. ${ }^{685}$ Como se puede apreciar, se respeta el criterio del Maestro de Capilla sólo en parte.

El Cabildo oye los memoriales de genealogía de los niños anteriormente aprobados para el Colegio de Infantes. ${ }^{686}$

\section{6}

"Se leyó un memorial de Lope de Mora, en que despedía la opa de acólito por estar admitido de violinista de la Capilla de esta Santa Iglesia: y se acordó admitir dicha despedida, y que en su lugar entrara de acólito el Niño de Coro más antiguo: y también se dio comisión a los Señores Diputados de Acólitos para que informen con llamamiento, si convendrá que salga del Colegio de Infantes el niño Pavón, a ocupar la plaza de acólito que tenía Juan de Feria, difunto", ${ }^{687}$

\footnotetext{
${ }^{685}$ Ibid. Sábado 5 de Diciembre de 1795. T. 94, fol. 227 r.

${ }^{686}$ Ibid. Jueves 16 de Diciembre de 1795. T. 94, fol. 227 v.

${ }^{687}$ Ibid. Jueves 14 de Enero de 1796. T. 94, fol. 232 r.
} 
"Se leyó un memorial de Don Mateo Tascón, bajonista de esta Santa Iglesia, en que pedía licencia para ir a la ciudad de Sevilla”. Y el Cabildo acordó dar comisión a los Señores Diputados de Música para que informasen. ${ }^{688}$

"Se leyó un memorial de Joseph de Gálvez, acólito más antiguo por el que solicitaba la Capellanía vacante por muerte de Juan de Feria. Y se acordó y dio comisión a los Señores Diputados de Opas Pías para que informen con llamamiento”. 689

“El Señor Chantre hizo presente: que el niño López, admitido en el Colegio de Infantes tenía más de trece años según constaba de su partida de baptismo: y se acordó dar, y dio comisión a los Señores Diputados del Colegio de Infantes para que informen con llamamiento sobre si ha de llevarse a debido efecto su admisión en dicho Colegio". 690

Se leyó informe de los Diputados de San Acacio sobre la licencia que pedía el Maestro de Capilla jubilado Don Juan Manuel Gaitán. El Cabildo acordó concederle dicha licencia por el término de un año contado desde el día de la fecha. ${ }^{691}$

El Cabildo acuerda aceptar la pretensión de Don Joseph de Gálvez para ocupar la plaza vacante existente por muerte de Don Juan de Feria. ${ }^{692}$

“En continuación del llamamiento para oír el informe de los mismos Señores [de Acólitos] sobre el Niño de Coro que ha de ocupar la plaza vacante de acólito: oído que fue dicho informe se acordó suspender por ahora la provisión de dicha plaza, supliendo el Niño de Coro más antiguo cuando haya falta de acólitos: y que a la mayor brevedad se traiga la comisión dada”. ${ }^{693}$

\footnotetext{
${ }^{688}$ Ibid. Jueves 14 de Enero de 1796. T. 94, fol. 232 r.

${ }^{689}$ Ibid. Viernes 22 de Enero de 1796. T. 94, fol. 234 r.

${ }^{690}$ Ibid. Viernes 22 de Enero de 1796. T. 94, fol. 234 v.

${ }^{691}$ Ibid. Viernes 22 de Enero de 1796. T. 94, fol. 235 r.

${ }^{692}$ Ibid. Sábado 30 de Enero de 1796. T. 94, fol. 236 v.

${ }^{693}$ Ibid. Sábado 30 de Enero de 1796.T. 94, fol. 236 v.
} 
Se presenta el memorial de genealogía de Miguel López, agraciado para Infante de Coro de esta Santa Iglesia. ${ }^{694}$

"Se leyó un memorial de Joseph Gómez, acólito de esta Santa Iglesia, en que pedía licencia para pasar a Baza a hacer oposición a una plaza de organista: y se acordó dar, y dio comisión a los Señores Diputados de Acólitos para que informen con llamamiento". 695

“En continuación del mismo llamamiento para oír el informe de dichos Señores Diputados sobre la pretensión de Don Antonio Gil, Capellán de la misma Capilla: en su vista y habiendo votado secretamente en la forma ordinaria, se acordó concederle doscientos ducados de aumento de renta anual, con la obligación de enseñar a cantar a los niños de Choro, que tengan buena voz, y disposición para aprender un buen estilo, so pena de que no cumpliendo con esta obligación se le privará de este aumento que ahora se le da". 696

“El Señor Doctoral dixo: que convendría determinar el número de músicos, tanto de voz como de instrumento para la Capilla de esta Santa Iglesia, y fixar la renta que había de tener cada uno, sin que en ningún caso se le pudiese dar aumento de renta anual, y sólo sí una ayuda de costa, manifestando la necesidad, para lo que se debería hacer un estatuto, o constitución, la que sirviera de regla al Cabildo, y en ningún tiempo se alterase el dicho establecimiento”. Y se acordó que los Señores Diputados de San Acacio y Santa Inés informasen. ${ }^{697}$

“En virtud del llamamiento para oír el informe de los Señores Diputados de las Arcas de San Acacio, sobre la licencia que solicita Don Antonio Gil, habiéndose votado se la concedió el Cabildo, hasta la víspera del Corpus de este presente año". ${ }^{698}$

\footnotetext{
${ }^{694}$ Ibid. Miércoles 2 de Marzo de 1796. T. 94, fol. 243 v.

${ }^{695}$ Ibid. Miércoles 2 de Marzo de 1796. T. 94, fol. 243 v.

${ }^{696}$ Ibid. Miércoles 2 de Marzo de 1796. T. 94, fol. 244 r.

${ }^{697}$ Ibid. Miércoles 2 Marzo de 1796. T. 94, fol. 244 r.

${ }^{698}$ Ibid. Sábado 2 de Abril de 1796. T. 95, fol. 2 r.
} 
Juan Puig, músico instrumentista, solicita una ayuda de costa. El Cabildo le concede seiscientos reales por una vez sobre el caudal de excusados de música. ${ }^{699}$

Se leen las pruebas de limpieza de sangre de Miguel López, anteriormente admitido para Infante de Coro. Se acuerda que dichas pruebas están bien hechas y son por lo tanto aceptadas. ${ }^{700}$

Se leyó un memorial de Don Pedro Marciag, músico tenor de la Catedral, en que pedía una ayuda de costa. Se acordó dar comisión a los Señores Diputados de San Acacio para que informasen con llamamiento. ${ }^{701}$

“Se leyó un memorial de Don Pascual Redel, músico instrumentista de esta Santa Iglesia, en que pedía una ayuda de costa, por tenerle embargado su salario los Señores Diputados de la Mesa Capitular para pago de los alquileres de la casa en que vive. Y en su vista acordó el Cabildo dar y dio comisión a los Señores Diputados del Arca de vacantes de San Acacio, para que informen con Ilamamiento", ${ }^{702}$

Se leyó un memorial de Don Antonio García, primer trompa de la Capilla de Música en que pide una ayuda de costa. ${ }^{703}$

Don Antonio Gil, pide al Cabildo una ayuda de costa para sufragar los gastos que ha tenido en su reciente viaje a Madrid y por encontrarse en una situación de estrechez económica. ${ }^{704}$

“Se leyó un memorial de Don Joseph Moyano, Presbítero Capellán de San Acacio de esta Santa Iglesia, en que con respecto a los años que ha que sirve, a la familia que mantiene de madre y hermanos, y la carestía de los tiempos presentes, pide aumento de salario. Y en su vista se dio comisión a los Señores Diputados de Arcas de

\footnotetext{
${ }^{699}$ Ibid. Martes 10 de Mayo de 1796. T. 95, fol. 10 r.

${ }^{700}$ Ibid. Lunes 23 de Mayo de 1796. T. 95, fol. 14 r.

${ }^{701}$ Ibid. Lunes 23 de Mayo de 1796. T. 95, fol. 14 v.

${ }^{702}$ Ibid. Jueves 21 de Julio de 1796. T. 95, fol. 32 v.

${ }^{703}$ Ibid. Lunes 5 de Septiembre de 1796. T. 95.

${ }^{704}$ Ibid. Viernes 16 de Septiembre de 1796. T. 95.
} 
vacantes de dicha Capilla, para que con la parte de la Dignidad Episcopal informen sobre ello con llamamiento", 705

El notario secretario Don Francisco Beltrán, da cuenta al Cabildo de que se ha presentado un nuevo opositor a la Capilla de San Antonino, vacante por muerte de Don Joseph de los Ríos. Dicho opositor era Don Cristóbal Ximénez, músico tenor de la Capilla de la Soledad de Madrid de 36 años de edad. El Cabildo acuerda que como estaba aún abierto el concurso, se admita a dicho opositor. Se señala el examen el lunes siguiente por la mañana, y a los dos examinadores nombrados, ordena que se agregue el Maestro de Capilla, "respecto a estar ya en esta ciudad". ${ }^{706}$

El Cabildo acuerda aumentar el salario de Don Joseph Moyano, en doscientos ducados anuales sobre el salario que ya gozaba. ${ }^{707}$

El Cabildo trata sobre la ausencia de Don Joseph Cheist. Dicho músico se había ausentado de Córdoba para ordenarse Presbítero en su ciudad. Eso tuvo lugar en el día de la Trinidad del año anterior, para lo cual se le concedieron dos meses de licencia. Al parecer en el día de la fecha se encontraba en Madrid, sin ánimo de regresar, por lo que se acordó enviarle un requisitorio a través del Vicario madrileño, para que se presentara de inmediato, so pena de suprimirle su plaza. ${ }^{708}$

Anteriormente, Don Antonio Gil había pedido una ayuda de costa para sufragar su viaje a Madrid. El importe de esa ayuda solicitada era igual al que le habían descontado de su sueldo por cada día que había faltado. Ahora, el Cabildo acuerda concederle dicha ayuda de costa. ${ }^{709}$

Se leyó un memorial de Don Manuel Valls, primer oboe de la Capilla de Música, en el que pide "algún socorro por haber tenido que satisfacer el funeral de su difunto

\footnotetext{
${ }^{705}$ Ibid. Viernes 23 de Septiembre de 1796. T. 95, fol. 59 r.

${ }^{706}$ Ibid. Sábado 22 de Octubre de 1796. T. 95.

${ }^{707}$ Ibid. Sábado 22 de Octubre de 1796. T. 95.

${ }^{708}$ Ibid. Sábado 22 de Octubre de 1796. T. 95.

${ }^{709}$ Ibid. Martes 6 de Diciembre de 1796. T. 95, fol. 81 v.
} 
padre, y hacerse traer un oboe y flauta para el desempeño de su obligación”. El Cabildo acordó suspender toda determinación al respecto, hasta tener más informes sobre este asunto y sobre el próximo arreglo de la Capilla de Música. ${ }^{710}$

\section{7}

"Se leyó memorial de Don Juan Manuel González Gaitán, Maestro de Capilla jubilado de esta Santa Iglesia pidiendo licencia para no asistir al Coro, mediante su mucha edad, y notoria privación de vista. Se dio comisión a los Señores Diputados de Arcas de Vacantes de San Acacio, para que informen con llamamiento". 711

Vista la anterior petición de Gaitán, el Cabildo acuerda lo siguiente: "por su crecida edad de más de ochenta años, los achaques que padece, junto con la notoria ceguedad de vista: oído todo, y votado según costumbre, se acordó continuarle dicha licencia y patitur abierto, por el tiempo de un año contado desde esta fecha, en los mismos términos que hasta ahora se le ha concedido en los anteriores". 712

"Se leyó un memorial de Don Joseph Benito Bach, Organista segundo de esta Santa Iglesia, pidiendo una ayuda de costa por las causas que expone. Y se dio comisión a los Señores Diputados de Excusados de Música con la parte, para que informen con llamamiento". ${ }^{713}$

Se reúne el Cabildo para ver las pruebas de limpieza de sangre de Joseph Villalba, Infante de Coro admitido en el Colegio del Santo Ángel de la Guarda. Vistas las pruebas, se declararon bien hechas y por tanto correctamente admitido a Joseph Villalba. $^{714}$

\footnotetext{
${ }^{710}$ Ibid. Martes 6 de Diciembre de 1796. T. 95, fol. 81 r.

${ }^{711}$ Ibid. Lunes 16 de Enero de 1797. T. 95, fol. 89 r.

${ }^{712}$ Ibid. Martes 24 de Enero de 1797. T. 95, fol. 91 v.

${ }^{713}$ Ibid. Viernes 17 de Marzo de 1797. T. 95.

${ }^{714}$ Ibid. Lunes 7 de Agosto de 1797. T. 95, fol. 159 v.
} 
“El Señor Chantre como Diputado del Colegio del Santo Ángel hizo presente al Cabildo, que habiendo mandado al músico Don Vicente Marín asistiese a dicho Colegio para enseñar a los Niños de Coro, se había excusado, alegando no tener esta obligación, y que sólo se ofrecía a enseñarles yendo los discípulos a su casa: y para determinar se acordó dar comisión a los expresados señores Diputados a fin de que informen con llamamiento sobre las obligaciones de este músico, y condiciones con que fue admitido". 715

El Cabildo decreta la suspensión del aumento de salario de que gozaba el músico instrumentista D. Vicente Marín por negarse a ir a dar clase (de violoncello) al Colegio de Infantes, “alegando no tener tal obligación”, aún después de haber sido requerido para ello. ${ }^{716}$ En acta de 19 de Octubre de 1797 se confirma que el aludido y los demás músicos, deben enseñar música a los niños del colegio. ${ }^{717}$

El Cabildo aprueba que la Capilla de Música cante al día siguiente, la Antífona Tota Pulchra, durante la procesión que se iba a celebrar dentro de la Catedral para el traslado de una imagen. ${ }^{718}$

El Cabildo acuerda proveer de nuevo la Capellanía de San Acacio, declarada vacante por abandono de Don Joseph María Fernández Cheist. Éste ha informado al Cabildo "hallarse sirviendo otra Capilla de Música nombrada del Príncipe Pío, en la Villa y Corte de Madrid". Por tanto el Cabildo acuerda que se publiquen edictos durante sesenta días, convocando a los que teniendo voz de tiple, contralto, o tenor, quieran venir a opositar. ${ }^{719}$

Don Pedro Marciag, músico tenor de la Capilla de Música, pide que se le jubile, “con el salario que se tuviese por conveniente, en atención a que la quebrancía que padece le inutiliza a cumplir con su obligación, como corresponde se les dio comisión,

\footnotetext{
${ }^{715}$ Ibid. Lunes 14 de Agosto de 1797. T 95.

${ }^{716}$ Ibid. Lunes 4 de Septiembre de 1797, T.95.

${ }^{717}$ Ibid. Jueves 19 de Octubre de 1797. T.95.

${ }^{718}$ Ibid. Jueves 7 de Septiembre de 1797. T. 95.

${ }^{719}$ Ibid. Martes 19 de Septiembre de 1797. T. 95, fol. 181 v.
} 
para que, con la misma parte, y oyendo también al Maestro de Capilla informen con llamamiento en qué términos siendo hacedero, convendrá acceder a su solicitud", 720

"Se leyó un memorial de Matheo Merino, Infante de Coro de esta Santa Iglesia, de los que corresponde su nombramiento a éste Cabildo, pidiendo una ayuda de costa, y licencia para ir a mudar de ayres, a causa de enfermedad de efusión de sangre, que acredita con certificación jurada de médico. Y se dio comisión a los Señores Diputados de Arcas de Santa Inés, para que sobre ello informen con llamamiento con la parte”. 721

El 19 de Septiembre de 1797 el Cabildo aprueba una regulación de la plantilla de la Capilla de Música, fijando las plazas y los sueldos de los músicos, previo informe de Jaime Balius. El resultado es el siguiente: “Quatro tiples, con la renta el que más, de once mil reales, quatro contraaltos con la de seis mil, cinco tenores con la de seis mil y seiscientos, dos bajos con la de siete mil y setecientos, seis violines con cinco mil y quinientos, dos trompas con tres mil y trescientos, un acompañamiento con tres mil y trescientos, y un bajón con la misma renta”. ${ }^{722}$ Además, se aclara que no se podrán pedir aumentos de salario, aunque sí se podrán solicitar ayudas de costa para cubrir gastos eventuales: "Y que a los músicos que bajo este nuevo plan se admitan, no se les de aumento de renta anual [...] Y que por lo tanto dichos músicos, fuera de la respectiva renta señalada, no tengan otra expectativa que la de pedir, cada vez con memorial en forma, alguna ayuda de costa". ${ }^{723}$

Si estas medidas se toman con carácter general, también se pone de manifiesto que hace falta cubrir con urgencia ciertas plazas para el correcto funcionamiento de la Capilla: “Es preciso remediar la falta de voces que en el día se advierte para la correspondiente decencia del culto Divino a que se aspira, a causa de estar inutilizadas la mayor parte de ellas; y ser las que mayor falta hacen, según se informa, un tiple, un contraalto, dos tenores, y un bajo, y además un violín, y un acompañamiento, para cuia dotación parecer haver sobrante en los caudales de ambas capillas", ${ }^{724}$

\footnotetext{
${ }^{720}$ Ibid. Martes 19 de Septiembre de 1797. T. 95, fol. 182 r.

${ }^{721}$ Ibid. Martes 19 de Septiembre de 1797. T. 95, fol. $182 \mathrm{v}$.

${ }^{722}$ Ibid. Martes 19 de Septiembre de 1797. T.95, fol. 180v.

${ }^{723}$ Ibid.

${ }^{724}$ Ibid.
} 
Para buscar a los músicos que cubran estas plazas se faculta al Maestro de Capilla: “Acordó el Cabildo dar comisión al Maestro de Capilla, para que de acuerdo de dichos Señores Diputados escriva desde aquí cartas adonde quiera que sepa haver dichos músicos, proponiéndoles vengan a ser oídos". ${ }^{725}$ En el caso de que con esta forma no se provean las plazas, se le autoriza a buscarlos personalmente: “Acordó el Cabildo que solo en el caso de no poderse conseguir de este modo el llenar dichas plazas, se determinará con previo llamamiento sobre el medio propuesto por dichos Señores Diputados, que el mismo Maestro de Capilla vaya en persona a buscarlos, concertarlos y traerlos", 726

En referencia a la anterior ayuda de costa que solicitaba Matheo Merino, Colegial del Santo Ángel de la Guarda, el Cabildo acuerda lo siguiente: “concederle dicha licencia hasta Navidad, y que la pida de nuevo si necesitase más tiempo para su curación, y en cuanto a la ayuda de costa, en atención a ser dicho colegial huérfano de padre y madre, y absolutamente pobre, y constar que en iguales circunstancias se dio a Miguel de Herrera la cantidad de seiscientos reales en dos ocasiones, 300 en cada una de los caudales del Colegio, se acordó concederle por una sobre los mismos caudales igual cantidad de 300 reales". 727

En este acta hay un informe exhaustivo sobre instrucciones para el "govierno de la campana”, especificándose las horas en que tiene que sonar según el mes del año o las festividades importantes como la Navidad o Semana Santa. ${ }^{728}$

Se presenta un memorial de Don Manuel Valls, primer oboe de la Capilla de Música de la Catedral "en que por los motivos de haber tenido que satisfacer como buen hijo los costos del funeral de su padre y madre, hacer traer un oboe y flauta para el desempeño de su obligación, y estar cumpliendo con la de enseñar a los Niños de Coro por espacio de quince a dieciséis años, y con respecto a la carestía de los tiempos, pide se le alivie con el socorro que sea del agrado del Cabildo. Y se dio

\footnotetext{
${ }^{725}$ Ibid.

${ }^{726}$ Ibid.

${ }^{727}$ Ibid. Viernes 22 de Septiembre de 1797. T. 95, fol. 184 v.

${ }^{728}$ Ibid. Lunes 2 de Octubre de 1797, T.95.
} 
comisión a los Señores Diputados de Excusados de Música con la parte, para que informen con llamamiento". ${ }^{729}$

Se presenta ante el Cabildo un músico llamado Francisco Cascante, profesor de contrabajo, que solicita ser oído. Se acuerda oírlo al día siguiente, con la concurrencia del Maestro de Capilla y los demás músicos. ${ }^{730}$ Posteriormente en acta de 4 de Diciembre de 1797, vemos cómo es "admitido con el salario de trescientos ducados anuales, y la obligación de asistir a todas las funciones, actos y horas para las que dentro y fuera del Coro sea citado por el Maestro de Capilla...". 731

"Se acordó dar y dio comisión a los mismos Señores Diputados de Santa Inés con la parte, para que oyendo al Maestro de Capilla, informen con llamamiento sobre los pretendientes a la plaza vacante del Colegio del Santo Ángel, correspondiente a este Cabildo, y en su vista pasar a su provisión". ${ }^{732}$

El Cabildo trata acerca de la provisión de una plaza vacante del Colegio del Santo Ángel. Una vez realizados los exámenes por el Maestro de Capilla, éste entrega su informe, "y habiéndose mandado leer dicho informe, y teniéndose por suficiente, se pasó a votar por cédulas dicha plaza, y resultó competir Joseph Escalona con Andrés de Heredia que fueron los dos mejores según el informe del Maestro, y volviéndose a votar por votos secretos, por el mayor número de ellos salió nombrado Joseph Escalona”. ${ }^{733}$

“En este día los Señores Deán y Canónigos, enterados por el Maestro de Capilla de que para las tercias solemnes de bajones, hace falta un contrabajo en cada coro, y siendo éste uno de los actos a que dicho Maestro debe citar al nuevo [músico

\footnotetext{
${ }^{729}$ Ibid. Miércoles 22 de Noviembre de 1797. T. 95, fol. 202 v.

${ }^{730}$ Ibid. Lunes 27 de Noviembre de 1797, T.95, fol 212r.

${ }^{731}$ Ibid. Lunes 4 de Diciembre de 1797, T.95, fol.216r.

${ }^{732}$ Ibid. Miércoles 29 de Noviembre de 1797. T. 95, fol. 213 v.

${ }^{733}$ Ibid. Miércoles 29 de Noviembre de 1797. T. 95, fol. 212 v.
} 
contrabajo] recibido por el anterior Cabildo, acordaron se cite igualmente para él a Don Julián Gálvez", 734

El Cabildo trata acerca de la ayuda de costa solicitada por el oboe Don Manuel Valls. Acuerda concederle quinientos reales de ayuda de costa. ${ }^{735}$

Se presenta el memorial de la genealogía de Francisco Escalona, detallando todos sus inmediatos parientes. Se da comisión a los Señores Diputados del Colegio del Santo Ángel para que revisen la información. ${ }^{736}$

"Se leyó un memorial de Joseph Gómez, Acólito de esta Santa Iglesia, solicitando ayuda de costa, y se sometió a informe de los Señores Diputados de Acólitos". 737

“En virtud del llamamiento para oír el informe de los Señores Diputados de Acólitos sobre la ayuda de costa solicitada por Joseph Gómez y habiéndose votado en la forma acostumbrada, se le concedieron trescientos reales por una vez". ${ }^{738}$

\section{8}

Se trata la petición del Infante de Coro Mateo Merino en el que pide socorro o ayuda a costa para atender a su curación y subsistencia "por no haver logrado alivio con la licencia que se dio para ir a tomar los ayres de su pays”. ${ }^{739}$

Se leyó un memorial de Don Juan Manuel Gaitán, Presbítero Maestro de Capilla jubilado, "en que pide la continuación del patitur abierto por las causas y achaques que antes de ahora a manifestado muchas veces". 740

\footnotetext{
${ }^{734}$ Ibid. Lunes 4 de Diciembre de 1797. T. 95, fol. 216 v.

${ }^{735}$ Ibid. Sábado 16 de Diciembre de 1797. T. 95, fol. 217 r.

${ }^{736}$ Ibid. Sábado 16 de Diciembre de 1797. T. 95, fol. 217 v.

${ }^{737}$ Ibid. Sábado 16 de Diciembre de 1797. T. 95, fol. 218 r.

${ }^{738}$ Ibid. Miércoles 20 de Diciembre de 1797. T. 95, fol. 219 r.

${ }^{739}$ Ibid. Lunes 22 de Enero de 1798, T.95.
} 
El Cabildo trata acerca del permiso solicitado anteriormente por el Maestro de Capilla jubilado Don Juan Manuel Gaitán: “en su vista, y habiéndose votado por pelotas, se acordó continuarle dicho patitur por otro año contado desde que expiró el anterior, y en los mismos términos que hasta ahora se le ha concedido dicha gracia". ${ }^{74}$

Los Diputados de Arcas Vacantes de Santa Inés, hicieron presente que por la muerte del Presbítero Don Juan Franco, ocurrida en el mes de Enero próximo pasado, “había vacado una Capellanía afecta a música de la Capilla dicha de Santa Inés. Y en su vista se les dio comisión, con la parte de su Ilustrísima para que informen con llamamiento las diligencias que deban practicarse para su provisión en esta vacante". 742

Se lee memorial de Don Cayetano María Pichini, napolitano, primer violín “que dice haber sido ms. en la Santa Iglesia de Santiago, y dejado de serlo por no probarle bien aquel temperamento, pidiendo ser admitido en la vacante que ha entendido haber en esta Santa Iglesia, a cuyo fin se sujeta antes, o al examen de los profesores de la Real Capilla de Su Majestad, o a venir en persona a ser oído, siempre que se le suplan los gastos del viaje”. Se dio comisión a los Diputados de San Acacio para que informen. $^{743}$

"Se leyó un memorial de Francisco Villegas, haciendo presente que la asistencia y cuidado en la enfermedad de su sobrino Matheo Merino, Infante de Coro que fue de esta Santa Iglesia, le han ocasionado crecidos gastos, además de lo que tiene aún que pagar al médico y boticario y no lo ha hecho por la cortedad de sus medios, y pidiendo para ello una ayuda de costa”. Se dio comisión a los Diputados de Santa Inés para que informen. ${ }^{744}$

\footnotetext{
${ }^{740}$ Ibid. Miércoles 24 de Enero de 1798. T. 95, fol. 226 v.

${ }^{741}$ Ibid. Jueves 1 de Febrero de 1798. T. 95, fol. 231 v.

${ }^{742}$ Ibid. Lunes 26 de Febrero de 1798. T. 95, fol. 241 r.

${ }^{743}$ Ibid. Lunes 26 de Febrero de 1798. T. 95, fol. $243 \mathrm{r}$.

${ }^{744}$ Ibid. Lunes 26 de Febrero de 1798. T. 95, fol. 243 v.
} 
Se leen las pruebas de limpieza de sangre de Francisco Escalona, recientemente admitido como Infante de Coro. Se acuerda que dichas pruebas están correctamente realizadas. $^{745}$

Se presenta un memorial de Francisco Escalona, Infante de Coro, solicitando ayuda de costa para sus pruebas, y se dio comisión a los Diputados del Colegio del Santo Ángel para que informen. ${ }^{746}$

En relación a la ayuda de costa solicitada por Francisco Villegas como tío de Matheo Merino, Infante de Coro que fue de la Catedral, el Cabildo acuerda lo siguiente: “en su vista, y habiéndose votado se acordó concederle por una vez doscientos reales de vellón del caudal de Arcas”. ${ }^{747}$

Respecto al procedimiento que se sigue para cubrir una vacante de la Capilla de Santa Inés, por muerte de Don Juan Franco, el Cabildo acordó: “se fixen edictos por término de sesenta días que empiecen a correr desde el día veinte del corriente, convocando a concurso a los que tengan voz de tiple, por ser de la que hay mayor necesidad según informe del Maestro de Capilla", ${ }^{748}$

El Cabildo resuelve la provisión de dos becas vacantes del Colegio del Santo Ángel. Estas becas recaen sobre Joseph Raphael Carrasco y Francisco Diego Bonilla. ${ }^{749}$

“Se leyó memorial de Don Vicente Marín, músico de violonchelo, de esta Santa Iglesia pidiendo una ayuda de costa por los motivos que expresa”. Se dio comisión a los Señores Diputados de Excusados de Música para que informen. ${ }^{750}$

\footnotetext{
745 Ibid. Martes 27 de Febrero de 1798. T. 95, fol. 250 v.

${ }^{746}$ Ibid. Martes 13 de Marzo de 1798. T. 95, fol. 251 v.

${ }^{747}$ Ibid. Viernes 16 de Marzo de 1798. T. 95, fol. 254 r.

${ }^{748}$ Ibid. Sábado 17 de Marzo de 1798. T. 95, fol. 254 v.

${ }^{749}$ Ibid. Viernes 16 de Marzo de 1798. T. 95, fol. 254 v.

${ }^{750}$ Ibid. Sábado 17 de Marzo de 1798. T. 95, fol. 256 v.
} 
Se presentaron los memoriales de genealogía de Joseph Raphael Carrasco, y Francisco Bonilla, admitidos recientemente para las dos plazas vacantes del Colegio del Santo Ángel. 751

En este día se da la noticia del arreglo del órgano antiguo. ${ }^{752}$

En este Cabildo se oyen las pruebas de limpieza de sangre echas anteriormente a Francisco Bonilla, Infante de Coro, y se acuerda aprobarlas por estar bien realizadas. ${ }^{753}$

El Cabildo oye las pruebas echas a Joseph Carrasco, recientemente admitido como Colegial e Infante de Coro. Vistas las cuales acuerda que están bien realizadas y son por tanto aprobadas. ${ }^{754}$

Respecto a una plaza vacante que había en la Capilla de San Acacio, el notario da fe de que se había presentado a firmar la oposición, Don Gabriel de Ugarte, “Clérigo que dijo ser de menores, empleado con voz de tiple en la Colegiata del Salvador de Sevilla, natural de Puente La Reina, Obispado de Pamplona, y de edad de veinticinco años y medio, y que dicha oposición la hacía con voz de contralto”. Se acordó admitir a dicho opositor y nombrar para su examen esa misma tarde al Maestro de Capilla Don Jayme Balius. $^{755}$

Se oye el informe del Maestro de Capilla sobre el opositor a la Capilla vacante de San Acacio, que se examinó el sábado pasado por la tarde después completas: “se mandó entrar a dicho Maestro, quien leyó el informe que traía escrito y jurado en forma, reducido en sustancia, a que dicho opositor tenía tal cual inteligencia en la música, voz de contralto, pero tan corta que se oye poco aún cantando de solo y mucho

\footnotetext{
${ }^{751}$ Ibid. Miércoles 28 de Marzo de 1798. T. 95, fol. 260 v.

752 Ibid. Lunes 23 de Abril de 1798. T.95.

${ }^{753}$ Ibid. Miércoles 23 de Mayo de 1798. T. 95, fol. 277 v.

${ }^{754}$ Ibid. Lunes 4 de Junio de 1798. T. 95, fol. 279 v.

${ }^{755}$ Ibid. Lunes 4 de Junio de 1798. T. 95, fol. 280 v.
} 
menos o nada acompañando a la Capilla; por lo que y no tener estilo moderno, le contemplaba inútil para esta Iglesia”, ${ }^{756}$

Se oye un informe verbal de los Señores Diputados de San Acacio, sobre el nulo efecto que han producido las cartas que ha escrito el Maestro de Capilla solicitando músicos para cubrir las Capellanías vacantes de San Acacio y San Antonino, o bien no siendo idóneos ni suficientes los que se han presentado. Por tanto el Cabildo acuerda “declarar por necesaria e indispensable la salida de dicho Maestro de Capilla a buscar los expresados músicos”. Se acuerda también que emprenda el viaje en el tiempo que menos falta haga en la Iglesia. ${ }^{757}$

Se oye el informe de los Señores Diputados del Colegio del Santo Ángel, sobre la solicitud de ayuda de costa pedida por el niño Francisco Escalona: "en su vista, y habiéndose votado por pelotas, se acordó concederle por una vez la de trescientos reales de vellón”. ${ }^{758}$

Se lee memorial de Don Gabriel de Ugarte, opositor a la Capilla de San Acacio, que habiendo sido examinado no ha sido aceptado. Por lo que, “pide una ayuda de costa, para subvenir a los gastos e incomodidades del camino, ya que no merezca el honor de ser contado por uno de los ministros de este Cabildo". Se acordó dar comisión a los Diputados de San Acacio para que informen. ${ }^{759}$

Don Joseph Carrasco y Don Diego Bonilla, Colegiales del Santo Ángel, e Infantes de Coro, solicitan una ayuda al Cabildo para sufragar los gastos ocasionados en sus respectivas pruebas, “a que no alcanzan las facultades de sus padres”. El Cabildo le concede a cada uno trescientos reales de vellón. ${ }^{760}$

\footnotetext{
${ }^{756}$ Ibid. Lunes 18 de Junio de 1798. T. 95, fol. 283 r.

${ }^{757}$ Ibid. Lunes 18 de Junio de 1798. T. 95, fol. 283 v.

${ }^{758}$ Ibid. Jueves 28 de Junio de 1798. T. 95, fol. 285 v.

${ }^{759}$ Ibid. Jueves 28 de Junio de 1798. T. 95, fol. 286 v.

${ }^{760}$ Ibid. Jueves 28 de Junio de 1798. T. 95, fol. 286 v.
} 
“En virtud de celo que dio el Señor Arcediano de que siendo ya inútiles, por cansadas, las voces de tiple de la Capilla, y haber poca esperanza de que se encuentren cuales se desean aún mediante la diligencia que va a hacer el Maestro, según lo acordado el dieciocho del presente, podían suplir su falta algunos de los Colegiales del Santo Ángel, Infantes de Coro de esta Santa Iglesia, de mejor voz y disposición para ello, destinándoseles entre los mismos músicos un Maestro que les adiestrase en el buen estilo de cantar: en su vista, teniéndolo el Cabildo por muy conveniente, y siendo una de las obligaciones de dichos músicos el enseñar, siempre que se les mande, a dichos colegiales, acordó y mandó que Don Mariano Especiali vaya precisamente a dicho Colegio en las horas y días que se le ordenen por los Señores Diputados, a dar lección del buen estilo del canto y música a aquellos colegiales que según el juicio y elección del dicho Maestro de Capilla, tengan destreza y voz más a propósito para cantar en la cuerda de tiples, para que sean útiles a la Capilla, zelando dichos Señores de que así lo cumpla puntualmente y dando cuenta de lo contrario para la providencia que convenga". ${ }^{761}$

Se leyó un memorial de Mariano Díaz, Infante de Coro, por el que pide al Cabildo su permiso "para pasar a servir una plaza de instrumento en la Ciudad de Lora, y asimismo solicita una ayuda de costa”. El Cabildo le concede dicho permiso y da comisión a los Diputados del Colegio de Infantes para que informen sobre la ayuda de costa que solicita. ${ }^{762}$

En relación con las gestiones relativas a la comisión pendiente para buscar músicos para la Capilla de Música de la Catedral, el Cabildo acordó admitir para la Capilla de San Antonino a Don Ángel Arteaga, “con cuatrocientos ducados anuales, los que se le han de pagar en calidad de salario de Arcas de Vacantes de San Acacio, con condición de asistir en el Colegio del Ángel a enseñar a sus Colegiales, siempre que el Cabildo se lo mande. [...] En vista de lo que se expuso en este Cabildo sobre los gastos causados por el Maestro de Capilla en el viaje que este hizo para buscar

\footnotetext{
${ }^{761}$ Ibid. Jueves 28 de Junio de 1798. T. 95, fol. 287r.

762 Ibid. Sábado 28 de Julio de 1798. T. 95, fol. 295v.
} 
músicos para esta Santa Iglesia, se acordó que el dicho Maestro presente la cuenta de los gastos para en su vista determinar el Cabildo lo que tenga por conveniente". ${ }^{763}$

En este Cabildo se presenta la cuenta de gastos que ha tenido el Maestro de Capilla en su viaje para buscar músicos que hacían falta para la Capilla de Música: "se pasaron a leer dichas cuentas, de las que resulta, haber gastado dicho Maestro en los viajes que ha hecho, conducción del tenor que ha traído y manutención, la cantidad de seis mil setecientos ochenta y dos reales los que se le mandaron abonar entre estas Arcas [San Acacio] y las de Santa Inés, y además le concedió el Cabildo por ayuda de costa, la cantidad de tres mil reales, y que se le perdonen las aspas que ha causado en su viaje, respecto a la economía y exactitud, con que ha desempeñado la comisión que se le confió: y asimismo acordó el Cabildo que al tenor que ha traído, se le dé por ayuda de costa, la cantidad de mil setecientos treinta y ocho reales". ${ }^{764}$

“Habiendo hecho presente los referidos Señores Diputados algunos desordenes que se notaron en algunos músicos, acordó el Cabildo, dar comisión a los expresados Señores Diputados para que informen de los desordenes y abusos que se notan en los individuos de la Capilla de Música, con presencia de lo acordado en este particular y providencias que se han tomado para que los dichos cumplan con su obligación expresando al mismo tiempo los aumentos que tienen y si convendría jubilar a algunos para reformar la Capilla”. ${ }^{765}$

"Se leyó un memorial de Juan Busquet por el que solicita una ayuda de costa, y en su vista, se dio comisión a los referidos Señores Diputados, para que con la parte informen con llamamiento". ${ }^{766}$

En este Cabildo se informa sobre los opositores que se han presentado a las dos medias Capellanías vacantes, y se nombra al Maestro de Capilla como examinador. ${ }^{767}$

\footnotetext{
763 Ibid. Sábado 27 de Octubre de 1798. T. 95, fol. 318 r.

${ }^{764}$ Ibid. Miércoles 7 de Noviembre de 1798. T. 95, fol. 325 v.

${ }^{765}$ Ibid. Miércoles 7 de Noviembre de 1798. T. 95, fol. 325 v.

${ }^{766}$ Ibid. Miércoles 7 de Noviembre de 1798. T. 95, fol. 326 r.

${ }^{767}$ Ibid. Martes 13 de Noviembre de 1798. T. 95, fol. 328 r.
} 
“En virtud del llamamiento para oír los opositores a las dos medias Capellanías de veintena vacantes, se mandó entrar al notario secretario Don Francisco Beltrán quien dio cuenta de haberse presentado otro opositor a las dos medias Capellanías vacantes. Y enseguida, se mandó entrar al Maestro de Capilla y opositores, y se procedió a hacer el examen como es costumbre, y después se le dixo al Maestro de Capilla diese su dictamen y enseguida se procedió a la votación, y salió nombrado en la primera media Capellanía Don Joseph González y en la segunda Don Joseph Bázquez”. 768

\section{9}

El Cabildo concede a Don Pascual Redel una ayuda de costa de mil reales de vellón. Asimismo se leyó un memorial de Don Lope de Mora, violinista, solicitando ayuda de costa. Se da comisión a los Diputados de San Acacio para que informen. Se leyó otro memorial de Don Mariano Fernández de Mesa, vecino de Córdoba, que expone que hace días firmó una oposición a una Capellanía vacante de música, y que no pudo concurrir el día del examen por encontrarse fuera de la ciudad. Por lo que "suplica al Cabildo se digne asignarle día para executar y cantar lo que se le mande, a fin de ver si puede lograr dicha Capellanía. Y en cuyo supuesto, se acordó que cante el lunes dieciocho de febrero, después de completas: y señaló el Cabildo por juez de este acto al Maestro de Capilla, encargándole a éste cite la música para lo que ocurra en dicha oposición de dicho Don Mariano, o de otro cualquiera que se presente”. 769

“En virtud del llamamiento para oír la censura del Maestro de Capilla, acerca de la habilidad y suficiencia de los opositores que se han presentado a las Capillas de San Acacio y San Antonino, oído que fue dicho informe, acordó el Cabildo se una dicha censura a los autos, y en atención a no tener la aptitud necesaria los opositores que han manifestado, que se fixen nuevos edictos por el término de sesenta días". "Y asimismo dio el Cabildo su comisión a los mismos Señores Diputados para que informen con

\footnotetext{
${ }^{768}$ Ibid. Martes 20 de Noviembre de 1798. T. 95, fol. 331 r.

${ }^{769}$ Ibid. Viernes 15 de Febrero de 1799. T. 95, fol. 369 r.
} 
llamamiento sobre la queja dada por el Maestro de Capilla, acerca del aumento que se ha hecho en las ausencias que hace la Capilla a las funciones que le convidan fuera de esta Santa Iglesia”, ${ }^{770}$

Se leyó el informe de los Señores Diputados de Acólitos sobre la solicitud de ayuda de costa de Cristóbal Bendicho: "se pasó a votar por pelotas, y resultó que el Cabildo le concedió trescientos reales por una vez en calidad de ayuda de costa". ${ }^{771}$

"Se leyó un memorial de Don Juan Busquets, músico instrumentista de la Capilla de Música de esta Santa Iglesia, por el que solicita se digne el Cabildo facilitar el camino que sea de su mayor agrado, respecto a su avanzada edad, falta de vista, y treinta y cuatro años que lleva de servicio”. Se dio comisión a los Diputados de Santa Inés para que informasen. ${ }^{772}$

Se presenta un nuevo opositor a la Capellanía de San Antonino. Este opositor, de apellido Fuentes, es músico contralto de la Catedral de Granada, y manifiesta "no haber estudiado latinidad. $Y$ en su vista acordó el Cabildo dar comisión a los Señores Diputados de las Arcas de San Acacio, para que le hagan ver, la imposibilidad que tiene para obtener dicha Capellanía”. 773

El Cabildo trata "sobre el cumplimiento de la oposición a la plaza de violín segundo primero en esta Iglesia y ayuda de costa que se podría dar a sus opositores”. Se dio comisión a los Diputados de San Acacio para que informasen. ${ }^{774}$

Los Diputados de San Acacio presentan al Cabildo un informe de palabra "sobre haber concluido su oposición a la plaza de $2^{\circ}$ violín primero Don Joseph Murachs y a

\footnotetext{
${ }^{770}$ Ibid. Viernes 19 de Abril de 1799. T. 95, fol. 383 v.

${ }^{771}$ Ibid. Viernes 28 de Junio de 1799. T. 95, fol. $404 \mathrm{v}$.

${ }^{772}$ Ibid. Miércoles 24 de Julio de 1799. T. 95, fol. 416 v.

773 Ibid. Lunes 29 de Julio de 1799. T. 95, fol. 419 r.

${ }^{774}$ Ibid. Jueves 8 de Agosto de 1799. T. 95, fol. 422.
} 
la Capellanía de San Antonino Don Juan de Fuentes, acordaron que en dichas actas se libraran mil reales de ayuda de costa, quinientos a cada uno de estos dos sujetos", 775

“Habiendo hecho presente el Señor Chantre la insubordinación de los músicos al Maestro de Capilla y demás superiores, y especialmente la ausencia que al principio de la octava en la titular había hecho sin decir nada ni pedir permiso alguno el tenor Don Antonio Gil, se acordó que los Diputados de San Acacio informen sobre el particular". ${ }^{776}$

“El Señor Chantre, como Diputado del Colegio de Infantes, hizo presente al Cabildo que en la noche del jueves 19 del corriente, Rafael de Ayllón, uno de los colegiales de dicho Colegio, había herido a Francisco Bonilla su compañero con un cuchillo en un muslo, que en la misma hora, se había llamado al cirujano, quien lo curó, y sigue asistiéndole, sin haber resultado al parecer accidente grave”. Asimismo el Chantre recuerda que dicho colegial Ayllón, ha tenido siempre una mala conducta y gran falta de aplicación, además de poco respeto con sus superiores. Por todo ello el Cabildo acordó su expulsión, y facultó a los Diputados del Colegio para que "revisen el comportamiento de colegiales y acólitos", ${ }^{777}$

El Maestro de Capilla presenta el informe sobre la oposición que habían hecho cuatro aspirantes a la plaza vacante de violín que había en la Capilla de Música. A continuación se pasó a la votación, "la cual recayó en Don Joseph de Vasconcelos y Melo”. Se le asignó un sueldo de cuatrocientos ducados de renta anual. ${ }^{778}$

Se leyó un memorial de Don Joseph Las en el que solicita licencia para viajar a Barcelona, “a evacuar ciertos negocios que le interesan”. Se da comisión a los Diputados de Santa Inés para que informen. ${ }^{779}$

\footnotetext{
775 Ibid. Viernes 9 de Agosto de 1799. T. 95, fol. 423.

${ }^{776}$ Ibid. Martes 27 de Agosto de 1799. T. 95, fol. 427.

${ }^{777}$ Ibid. Lunes 23 de Septiembre de 1799. T. 95, fol. 435 v.

${ }^{778}$ Ibid. Lunes 7 de Octubre de 1799. T. 95, fol. 439 v.

${ }^{779}$ Ibid. Lunes 7 de Octubre de 1799. T. 95, fol. 439 v.
} 
"Se leyó un memorial del violinista Don Joseph Vasconcelos, solicitando licencia para ir a su patria, Badajoz, a levantar su casa y una ayuda de costa para esto”. Otro violinista, Don Lope de Mora, también solicita una ayuda de costa. Se da comisión a los Diputados de San Acacio para que informen. ${ }^{780}$

En cuanto a la anterior petición de Don Joseph Las para ir a Barcelona a tratar unos negocios, el Cabildo acordó darle el correspondiente permiso, "con tal de que haya vuelto y se presente en la calenda de víspera de Navidad de este año". ${ }^{781}$

El Cabildo manda fijar edictos durante cuarenta días, para anunciar la plaza vacante de trompa que hay en la Capilla de Música, insistiendo en que dichos edictos contengan el sueldo con que está dotada dicha plaza. ${ }^{782}$

\section{0}

“Habiéndose leído la despedida que en su plaza de Acólito hace Luis de León, por haber obtenido la de primer violín en la Iglesia de Baza, se mandó que saliese a ser acólito el Niño de Coro Mora”. ${ }^{783}$

El bajonista Matheo Tascón solicita una ayuda de costa. Se da comisión a los Diputados para que informen. ${ }^{784}$

El Cabildo acuerda concederle a Juan de Mora una ayuda de costa de doscientos reales por una vez. ${ }^{785}$

“Se leyó un memorial de Don Joseph Las, músico instrumentista, por el que solicita se le perdonen las aspas que ha causado en el viaje que con licencia del

\footnotetext{
${ }^{780}$ Ibid. Jueves 15 de Octubre de 1799. T. 95, fol. 441 v.

${ }^{781}$ Ibid. Jueves 15 de Octubre de 1799. T. 95, fol. 441 v.

${ }^{782}$ Ibid. Jueves 15 de Octubre de 1799. T. 95, fol. 441 v.

${ }^{783}$ Ibid. Martes 14 de Enero de 1800. T. 95, fol. 458 r.

${ }^{784}$ Ibid. Martes 14 de Enero de 1800. T. 95, fol. 458 r.

${ }^{785}$ Ibid. Jueves 30 de Enero de 1800. T. 95, fol. 461 v.
} 
Cabildo realizó”. Y se dio comisión a los Diputados de Santa Inés para que informasen. $^{786}$

"Se leyó un memorial de Don Joaquín Martínez de Castro opositor a la primer plaza de trompa, por el que solicita una ayuda de costa”. Igualmente se dio comisión a los Señores Diputados para que informasen. ${ }^{787}$

"Se leyó un memorial de Don Ángel Arteaga, tenor de la Capilla de Música, solicitando aumento de salario, por las razones expresadas en dicho memorial, y se cometió a los mismos Señores Diputados para que informen". 788

“Acordó el Cabildo admitir y admitió a Don Nicolás Anguita, Clérigo de Menores, con el salario de trescientos ducados anuales". 789

“Sobre la solicitud de Don Ángel Arteaga, tenor de la Capilla de Música, y en vista de dicho informe, y de la oferta que se le hizo al expresado, acordó el Cabildo concederle, el que entre en una de las plazas de tenor que se establecieron en el plan que se formó de acuerdo del Cabildo con su respectiva dotación de seiscientos ducados". 790

Sobre la contratación de otro músico para la Capilla, el Cabildo “admitió a Don Manuel Gutiérrez Ravé, clérigo de cuatro grados, para tenor de la Capilla de Música, con la dotación de cuatrocientos ducados anuales, los que se le han de satisfacer de las Arcas de Santa Inés". 791

“Don Joaquín Obiols solicita entrar de violín en esta Santa Iglesia aunque sea en calidad de super numerario". ${ }^{792}$

\footnotetext{
${ }^{786}$ Ibid. Jueves 30 de Enero de 1800. T. 95, fol. 462 v.

${ }^{787}$ Ibid. Jueves 30 de Enero de 1800. T. 95, fol. 462 v.

${ }^{788}$ Ibid. Jueves 20 de Febrero de 1800. T. 95, fol. 470 v.

${ }^{789}$ Ibid. Jueves 13 de Marzo de 1800. T. 95, fol. 476 r.

${ }^{790}$ Ibid. Jueves 13 de Marzo de 1800. T. 95, fol. 476 r.

${ }^{791}$ Ibid. Jueves 13 de Marzo de 1800. T. 95, fol. 476 r.

${ }^{792}$ Ibid. Sábado 26 de Abril de 1800. T. 95, fol. 486 v.
} 
Don Manuel Gutiérrez Ravé solicita una ayuda de costa. Se da comisión a los Señores Diputados de Santa Inés para que informen. ${ }^{793}$

“Los Diputados del Colegio de Infantes, hicieron presente al Cabildo, se habían visto en la precisión de suspender al Maestro de Música de dicho Colegio, Don Pablo Bárcena, en atención a haberle mandado hacer otro método para la enseñanza de dichos Infantes, y no haberlo querido executar; y en vista de los expuesto, acordó el Cabildo siga la referida suspensión y el nombramiento hecho por los Señores Diputados en Don Vicente Marín, y que se le contribuya a éste con el salario que gozaba Bárcena". 794

En vista del informe que dieron los Señores Diputados del Colegio de Infantes sobre las plazas que estaban próximas a quedar vacantes, “acordó el Cabildo darles su comisión para que sobre dichas vacantes informen con llamamiento”. 795

“Acordó el Cabildo renovar la comisión que tiene dada a los Señores Diputados de obras pías, sobre los vestidos que usan los Infantes de Choro, en las octavas del Corpus y Concepción”, ${ }^{796}$

“Don Pablo Bárcena solicita se le reponga en la plaza de Maestro de Música de dicho Colegio que ha servido hasta aquí”. Se refiere al Colegio de Infantes. ${ }^{797}$

Los tres opositores que han hecho las pruebas a la plaza de trompa primero, Don Francisco Jardín, Don Joaquín Martínez de Castro y Don Francisco Ferrer, solicitan una ayuda de costa. El Cabildo acordó “concederles a los referidos mil reales de vellón a cada uno de ayuda de costa, por una vez de los caudales de las Arcas de Santa Inés, y

\footnotetext{
793 Ibid. Martes 29 de Abril de 1800. T. 95, fol. 487 r.

${ }^{794}$ Ibid. Viernes 2 de Mayo de 1800. T. 95, fol. 487 v.

${ }^{795}$ Ibid. Viernes 2 de Mayo de 1800. T.95, fol. 487 v.

${ }^{796}$ Ibid. Viernes 2 de Mayo de 1800. T. 95, fol. $487 \mathrm{v}$.

${ }^{797}$ Ibid. Sábado 21 de Junio de 1800. T. 95, fol. 497 v.
} 
asimismo acordó concederle al dicho Ferrer licencia para que pase a su tierra hasta el día de la Natividad de Nuestra Señora". 798

El Cabildo le concede a Manuel Gutiérrez Ravé, músico tenor de la Capilla de Música, quinientos reales de ayuda de costa. ${ }^{799}$

El Cabildo le concede a Miguel López, Niño de Coro, trescientos reales de ayuda de costa. ${ }^{800}$

"Se presentó un memorial del músico voz de esta Santa Iglesia Don Ángel Arteaga, solicitando licencia para pasar a Burgos su patria, a traerse su madre, concediéndole dicha licencia hasta el día de la festividad de la Concepción de Nuestra Señora en este presente año", ${ }^{801}$

"Oído el informe del Maestro de Capilla sobre la idoneidad y demás circunstancias de los pretendientes a las becas vacantes en el Colegio de Niños de Coro y excluidos los que no llegaban a la edad de siete años y pasaban de la de diez, se votó secretamente si se había de admitir al niño Joseph Talavera dispensándole la edad de ocho meses que le faltaban para los siete años en atención a ser, según el informe del Maestro de Capilla, el mejor de los pretendientes y habiendo acordado que se admitiera el nombramiento, se pasó a hacer éste por votos secretos y recayó en el referido Joseph Talavera cuya elección contradixo el Señor Serrano, por no haberse examinado los muchachos a presencia del Cabildo como otras veces”. Se dio comisión a los Diputados del Colegio para que se practicaran las diligencias previas al ingreso de los nombrados para dicho Colegio. ${ }^{802}$

El Señor Don Lope de Mora, violinista, pide ayuda de costa. ${ }^{803}$

\footnotetext{
${ }^{798}$ Ibid. Viernes 27 de Junio de 1800. T. 95, fol. 503 r.

${ }^{799}$ Ibid.Viernes 27 de Junio de 1800. T. 95, fol. 503 r.

${ }^{800}$ Ibid. Martes 12 de Agosto de 1800. T. 95, fol. 516 v.

${ }^{801}$ Ibid.Lunes 6 de Septiembre de 1800. T. 95, fol. 538 v.

${ }^{802}$ Ibid.Viernes 17 de Octubre de 1800. T. 95, fol. 546 r.

${ }^{803}$ Ibid.Viernes 17 de Octubre de 1800. T. 95, fol. 546 r.
} 
“Mandaron entrar en virtud del llamamiento al notario secretario y testigos, y leído el memorial de genealogía presentado por Joseph Talavera, electo colegial del Santo Ángel, acordaron dar comisión a los Señores Diputados de Acólitos y Niños de Coro, para que conforme a estatuto reciban la información de limpieza de sangre que ofrece el referido Joseph Talavera”. 804

"Habiendo oído el informe de los Señores Diputados de Arcas vacantes de Santa Inés, sobre la admisión de un Infante de Coro, e igualmente habiendo oído a los Infantes opositores a esta plaza, y el informe del Maestro de Capilla, procedieron a votar, y resultó electo Vallejo”, ${ }^{805}$

Don Rafael del Río pide licencia para ir fuera de Córdoba, “a cambiar de aires, a causa de enfermedad que acreditó con relación jurada de médico. Se le concedió la licencia que pide desde esta fecha hasta el día de la Concepción de este año". ${ }^{806}$

Se presenta el memorial de genealogía de Mariano Vallejo, admitido para Colegial del Santo Ángel. ${ }^{807}$

El Cabildo aprueba el expediente de limpieza de sangre del Niño de Coro Joseph Talavera. $^{808}$

Se presentan dos memoriales solicitando ayudas de costa. Uno del músico contrabajo Julián Gálvez y otro del Acólito Francisco García. Se da comisión para que informen a los Diputados de Acólitos. ${ }^{809}$

El Cabildo aprueba el expediente de limpieza de sangre del Niño de Coro Joseph Vallejo. $^{810}$

\footnotetext{
${ }^{804}$ Ibid. Miércoles 22 de Octubre de 1800. T. 95, fol. 548 r.

${ }^{805}$ Ibid. Lunes 24 de Noviembre de 1800. T. 95, fol. 564 r.

${ }^{806}$ Ibid. Lunes 24 de Noviembre de 1800. T. 95, fol. 564 r.

${ }^{807}$ Ibid. Jueves 27 de Noviembre de 1800. T. 95, fol. 566 v.

${ }^{808}$ Ibid. Jueves 4 de Diciembre de 1800. T. 96, fol. 2 v.

${ }^{809}$ Ibid. Jueves 4 de Diciembre de 1800. T. 96, fol. 3 r.

${ }^{810}$ Ibid. Jueves 4 de Diciembre de 1800 . T. 96, fol. 3 v.
} 


\section{1}

Se presenta memorial de Don Mateo Bernia, músico Capellán de Santa Inés, “en que pide patitur abierto a causa de la enfermedad que padece, y se acredita de la certificación jurada del médico que lo asiste que presentó”. Se dio comisión a los Diputados de Santa Inés para que informasen. ${ }^{811}$

Se leyó un memorial de Don Vicente Marín, Profesor de Música, en la que solicita una ayuda de costa. Se dio comisión a los Diputados de Excusados de Fábrica. $^{812}$

“Leído el informe sobre la ayuda de costa que solicitaba el músico Francisco Cascante, y procedido a votar por pelotas le concedieron de ayuda de costa por una vez seiscientos reales de vellón”, ${ }^{813}$

“Se leyó un memorial de Don Antonio Gil, Presbítero, músico tenor Capellán de San Acacio, en que solicita una ayuda de costa”. Se dio comisión a los Diputados de San Acacio para que informasen. ${ }^{814}$

Respecto a la licencia solicitada por Don Mateo Bernia, músico Presbítero, Capellán de Santa Inés, el Cabildo resuelve “concederle la licencia de patitur abierto que solicita hasta el último día de Junio inclusive de este presente año encargándole que si sus achaques lo permiten haga por asistir los días solemnes al Coro sin que por esto pierda la licencia de patitur que queda expresada". 815

“Habiendo el Señor Deán hecho presente haber una beca vacante en el Colegio del Santo Ángel perteneciente a este Cabildo, y que hacía falta su pronta provisión por la escasez de niños que sirven en el Coro, se acordó dar comisión a los Señores

\footnotetext{
${ }^{811}$ Ibid. Sábado 10 de Enero de 1801. T. 96, fol. 13 r.

${ }^{812}$ Ibid. Sábado 10 de Enero de 1801. T. 96, fol. 14 v.

${ }^{813}$ Ibid. Jueves 15 de Enero de 1801. T. 96, fol. $16 \mathrm{v}$.

${ }^{814}$ Ibid. Jueves 15 de Enero de 1801. T. 96, fol. 16 v.

${ }^{815}$ Ibid. Jueves 15 de Enero de 1801. T. 96, fol. 17 r.
} 
Diputados de Arcas de Vacantes de Santa Inés, con la parte de Nuestro Ilustrísimo Prelado para que dispongan lo conveniente a la provisión de la expresada beca". ${ }^{816}$

El Cabildo concede a Don Vicente Marín, músico, seiscientos reales de vellón de ayuda de costa por una vez. ${ }^{817}$

Don Juan Puig solicita una ayuda de costa. El Cabildo le concede seiscientos reales de vellón de ayuda de costa por una vez. ${ }^{818}$

“Habiéndose leído los llamamientos e informes de los Señores Diputados de Arcas de Vacantes de Santa Inés, sobre las ayudas de costa que solicitan Don Joseph Las, y Don Juan de Borja, acordaron negarle al Las la ayuda de costa, y librarle al Borja mil y quinientos reales de vellón por una vez de dichas Arcas, lo cual se votó por pelotas". 819

Nicolás Anguita, músico contralto, pide licencia para ir a Sevilla a hacer oposición a una media ración de contralto. El Cabildo acuerda “darle licencia por el tiempo que dure la oposición, encargándole que concluida deberá inmediatamente regresar". 820

“Leído el llamamiento y oído el informe de los Señores Diputados del Colegio de Infantes sobre la provisión de la veca vacante, se mandó entrar al Maestro de Capilla, y a los Infantes pretendientes, que fueron probados de voz y lectura, y habiendo el Maestro de Capilla dado su censura sobre ellos, y retirándose, se procedió por el Cabildo a la votación por cédulas y resultó nombrado Infante de Coro Francisco de Paula Ruiz”. ${ }^{821}$

\footnotetext{
${ }^{816}$ Ibid. Lunes 26 de Enero de 1801. T. 96, fol. 21 v.

${ }^{817}$ Ibid. Lunes 26 de Enero de 1801. T. 96, fol. 22 v.

${ }^{818}$ Ibid. Miércoles 25 de Febrero de 1801. T. 96, fol. 32 v.

${ }^{819}$ Ibid. Miércoles 4 de Marzo de 1801. T. 96, fol. 38 r.

${ }^{820}$ Ibid. Jueves 5 de Marzo de 1801. T. 96, fol. 40 r.

${ }^{821}$ Ibid. Lunes 16 de Marzo de 1801. T. 96, fol. 41 r.
} 
"Se leyó un memorial del músico Joseph Las en que pide licencia para ir a hacer oposición a una plaza de oboe de la Santa Iglesia de Sevilla, y se le concedió hasta la Semana Santa exclusive”, ${ }^{822}$

"Leído el llamamiento sobre la provisión de la veca vacante en el Colegio del Santo Ángel, se le mandó entrar al Maestro de Capilla, y a los Infantes opositores, y examinados éstos de voz y lectura, se les mandó retirar, y se mandó al Maestro de Capilla que diese su censura, lo que efectuó por escrito, y se le mandó retirar, y enseguida oído el informe de los Diputados de Arcas Vacantes de Santa Inés con la parte de Su Ilustrísima, se procedió a la elección por cédulas, y resultó nombrado para Colegial del Santo Ángel el Infante de Coro Miguel Colmenero”, ${ }^{823}$

Se presenta detalladamente el memorial de genealogía de Francisco de Paula Ruiz. ${ }^{824}$

"Oído el informe de los Señores Diputados de Niños de Coro y del Maestro de Capilla acerca de los pretendientes a la vacante del Colegio del Santo Ángel se nombró para ella por votos secretos a Joseph Megía”, 825

Se presenta detalladamente el memorial de genealogía del Niño de Coro recientemente aceptado, Joseph Megía. ${ }^{826}$

Don Pablo de Bárcena, solicita ayuda de costa. Se da comisión a los Diputados de Excusados de Fábrica para que informen. ${ }^{827}$

Se presentan las pruebas de limpieza de sangre del Niño electo Colegial del Santo Ángel, Francisco Colmenero, y se dan por bien realizadas. ${ }^{828}$

\footnotetext{
${ }^{822}$ Ibid. Lunes 16 de Marzo de 1801. T. 96, fol. 42 v.

${ }^{823}$ Ibid. Lunes 16 de Marzo de 1801. T. 96, fol. $42 \mathrm{v}$.

${ }^{824}$ Ibid. Martes 24 de Marzo de 1801. T. 96, fol. 49 v.

${ }^{825}$ Ibid. Jueves 26 de Marzo de 1801. T. 96, fol. 56 v.

${ }^{826}$ Ibid. Lunes 13 de Abril de 1801. T. 96, fol. 54 r.

${ }^{827}$ Ibid. Lunes 13 de Abril de 1801. T. 96, fol. 55 r.
} 
"Sobre la ayuda de costa solicitada por el músico Don Pablo Bárcena, se concedió por una vez y por votos secretos de los fondos de los mismos Excusados [de música] cien ducados". ${ }^{829}$

"Sobre la solicitud de ayuda de costa hecha por Francisco Colmenero, Colegial del Santo Ángel y Francisco Ferrer músico trompa, concedieron por una vez y por votos secretos cuatrocientos reales al primero y quinientos al segundo". 830

Se vieron las pruebas de limpieza de sangre del Infante de Coro Francisco Ruiz, y el Cabildo las aprobó por considerarlas bien realizadas. ${ }^{831}$

“Oído el informe de los Señores Diputados de Vacantes de Santa Inés, con la parte, sobre la solicitud del tenor Manuel Ravé le concedieron por una vez por votos secretos cien ducados de ayuda de costa y se dio comisión a los mismos Señores Diputados si para las Capellanías que hay vacantes será menester poner nuevos edictos". ${ }^{832}$

Se leyó un memorial del Maestro de Capilla jubilado Don Juan Manuel Gaitán, en el que pide licencia y continuación de la dispensa que le está concedida para no asistir al Coro. ${ }^{833}$

"Se leyó un memorial del músico Don Nicolás Anguita, en solicitud de que se le perdonen las aspas que ha contraído a causa de una ausencia que ha hecho con motivo de una oposición y se cometió a informe de los Señores Diputados de Arcas de Vacantes de San Acacio". 834

\footnotetext{
${ }^{828}$ Ibid. Lunes 13 de Abril de 1801. T. 96, fol. 58 v. En esta nota aparece como Francisco Colmenero, estando tachado el nombre de Miguel en el acta original y superpuesto el de Francisco.

${ }^{829}$ Ibid. Miércoles 22 de Abril de 1801. T. 96, fol. 61 v.

${ }^{830}$ Ibid. Miércoles 22 de Abril de 1801. T. 96, fol. 62 r.

${ }^{831}$ Ibid. Martes 12 de Mayo de 1801. T. 96, fol. 81 r.

${ }^{832}$ Ibid. Viernes 19 de Junio de 1801. T. 96, fol. 109 r.

${ }^{833}$ Ibid. Sábado 27 de Junio de 1801. T. 96, fol. 111 v.

${ }^{834}$ Ibid. Viernes 3 de Julio de 1801. T. 96, fol. 114 v.
} 
“El Señor Maestre Escuela zelo sobre haber muchos Capellanes con obligación de residir en el Coro de esta Santa Iglesia y no lo hacían y que otros muchos obtenían otros beneficios incompatibles con las Capellanías que disfrutaban servideras en esta Santa Iglesia y el Cabildo acordó dar y dio comisión a los Señores Chantre y para que a la mayor brevedad posible informen con llamamiento". 835

El Cabildo concede a Don Juan Manuel Gaitán Maestro de Capilla jubilado “licencia de patitur abierto hasta el próximo San Juan, y al músico Nicolás Anguita que se le de por vía de ayuda de costa el importe de las aspas que ha contraído el tiempo que ha estado ausente con motivo de la oposición que dixo que fue a hacer a Sevilla, a cuyo fin se le concedió la respectiva licencia”, ${ }^{836}$

El Cabildo le concede al Infante de Coro Francisco Ruiz, una ayuda de costa de doscientos reales de vellón. ${ }^{837}$

Se celebran oposiciones para cubrir vacantes de diversas Capellanías. Una vez examinados los opositores por el examinador Don Juan de Ortíz, Capellán de San Pedro resultan elegidos Don Antonio González y Don Rafael Lucena. ${ }^{838}$

El Acólito Cristóbal Bendicho, solicita una ayuda de costa. Se da comisión a los Diputados de Acólitos para que informen. ${ }^{839}$

"Se leyó un memorial del músico D. Joséf Las en que solicitaba una ayuda de costa, y se cometió a informe con llamamiento de los Diputados de Arcas vacantes de San Acacio con la parte de Su Ilustrísima”, ${ }^{840}$

"Sobre las ayudas de costa que solicitan los músicos Don Francisco Cascante, y Don Lope de Mora, se le concedieron por votación secreta según estatuto, al primero

\footnotetext{
${ }^{835}$ Ibid. Viernes 3 de Julio de 1801. T. 96, fol. 114 v.

${ }^{836}$ Ibid. Viernes 24 de Julio de 1801. T. 96, fol. 120 r.

${ }^{837}$ Ibid. Martes 28 de Julio de 1801. T. 96, fol. 121 r.

${ }^{838}$ Ibid. Viernes 7 de Agosto de 1801. T. 96, fol. 126 r.

${ }^{839}$ Ibid. Viernes 7 de Agosto de 1801. T. 96, fol. $126 \mathrm{v}$.

${ }^{840}$ Ibid. Martes 10 de Noviembre de 1801. T. 96, fol. 181r.
} 
seiscientos reales de vellón y al segundo mil reales de vellón, todo por una vez, y sobre el patitur que pedía el bajonista Don Mariano Ortega, se le concedió hasta pasada la Semana Santa”. 841

\section{2}

Se leyeron las pruebas de sangre del Infante de Coro Josef Cristóbal Mexías, vistas las cuales se aprobaron por estar correctamente realizadas. Asimismo se leyó un memorial del Acólito Miguel López en el que solicitaba una ayuda de costa, y se dio comisión a los Diputados de Acólitos para que informaran. ${ }^{842}$

El organista segundo Josef Benito Bach pide se le prorrogue la “licencia de patitur abierto que tiene concluida”, ${ }^{843}$

En este Cabildo "se leyó un memorial del Acólito Bendicho en el que pide licencia para ir a oponerse a una plaza de bioloncelo de la Catedral de Guadix, y el Cavildo acordó darle licencia por un mes”. También “se leyó otro memorial del Acólito Gómez en el que da cuenta haver logrado la plaza de organista en la Colegiata de Ronda, y por consiguiente se despide del Cavildo". 844

"Se leyó un memorial de Don Nicolás Anguita, músico de la Capilla de esta Santa Iglesia, en el que solicita que del salario que goza, se le haga renta colativa, para ascender a las sagradas órdenes. Y el Cabildo dio comisión a los Señores Diputados de Arcas Vacantes de San Acacio para que informen sobre esta solicitud". 845

"Se leyó memorial del Acólito Cristóbal Bendicho en que despide su plaza por haberse acomodado en otra de oboe en la Santa Iglesia de Guadix". También "se vio

\footnotetext{
${ }^{841}$ Ibid. Sábado 9 de Diciembre de 1801. T. 96, fol. 209 r.

${ }^{842}$ Ibid. Martes 19 de Enero de 1802. T. 96, fol. 220 v.

${ }^{843}$ Ibid. Sábado 30 de Enero de 1802, T.96. El patitur se refiere a la licencia por enfermedad. Podía ser cerrado si era dentro de la ciudad y abierto si el individuo debía salir de la misma para buscar un lugar adecuado donde curarse.

${ }^{844}$ Ibid. Miércoles 10 de Febrero de 1802, T.96.

${ }^{845}$ Ibid. Lunes 15 de Febrero de 1802. T. 96, fol. 229 r.
} 
un memorial del Acólito Miguel López en que solicita licencia para ir a la oposición de una plaza de Contraalto de la Colegial de Antequera, y se le concede por un mes”. Por último, y procedente del Colegio del Santo Ángel, se leyó “un memorial del Infante de Coro Josef Mejias, que solicita una ayuda de costa para sufragar los gastos de entrada en el Colegio". 846

“Se leyó un memorial de Don Mateo Tascón, músico bajonista en la Capilla de esta Santa Iglesia, en el que solicita una ayuda de costa, y se mandó pasar a los Señores Diputados del Excusado de Fábrica con la parte de Su Ilustrísima para que informen". 847

"Leído el llamamiento para oír el informe de los Señores Diputados de la Capilla de Santa Inés, sobre la solicitud de Don Rafael del Río, Presbítero, acordó el Cabildo conformándose con el informe, que el Don Rafael del Río, supuesta la imposibilidad que manifiesta para cantar, cumpla su primera obligación de tocar el violín en el lugar que le señale el Maestro de Capilla, pero si pudiere cantar y el Maestro lo necesita, lo hará del mismo modo, pues de lo contrario el Cabildo tomará las providencias que tenga por conveniente". ${ }^{848}$

Se lee un informe del Maestro de Capilla “en razón del músico contralto que se ha presentado, Don Fermín Espinosa, y acordó el Cabildo oído el informe del Maestro se admita dicho músico señalándole por salario de las Arcas de Vacantes de Santa Inés, quinientos ducados en cada año, advirtiéndole al Maestro que en cumplimiento de su obligación, le instruya para el mejor desempeño y arreglo en la Capilla". ${ }^{449}$

En relación a los opositores que se han presentado a la Capellanía de San Pedro, vacante por fallecimiento de Don Antonio Villalba, "se mandó entrar al Maestro, el cual leyó su informe que juró, proponiendo en el primer lugar como más adecuado para el desempeño de las obligaciones de dicha Capellanía a Don Manuel Alvarez,

\footnotetext{
${ }^{846}$ Ibid. Jueves 4 de Marzo de 1802, T.96.

${ }^{847}$ Ibid. Jueves 1 de Abril de 1802. T. 96, fol. 244 r.

${ }^{848}$ Ibid. Viernes 2 de Abril de 1802. T. 96, fol. 245 r.

${ }^{849}$ Ibid. Viernes 2 de Abril de 1802. T. 96, fol. 245 v.
} 
Presbítero, en segundo lugar a Don Marcos Díaz, Presbítero y segundo Sochantre de la Santa Iglesia de Sevilla, y en tercer lugar a Don Josef González, Presbítero y Don Manuel Váquez, Clérigo de Menores, y los dos, Capellanes de la Veintena de esta Santa Iglesia, y oído el informe acordó el Cabildo, se haga la consulta a S.M. en los términos que el Maestro propone, y con arreglo a las reales órdenes". 850

“Los Señores Diputados del Colegio del Santo Ángel, hicieron presente la necesidad de proveer la veca vacante en dicho Colegio, que corresponde al Cabildo pleno, y el Cabildo señaló el día siguiente martes 27 para oír a los niños pretendientes, nombrando para examinarlos y que informase a Don Francisco Bono, Presbítero, Capellán de San Pedro en esta Santa Iglesia, y Rector de dicho Colegio”. 851

"Sobre la solicitud de Lope de Mora para la Sacristía de la Capellanía de Santo Tomás de esta Santa Iglesia, se mandó entrar a el notario secretario, el que hizo relación de la fundación e informe, y oído todo se adjudicó dicha Sacristía a el expresado Lope de Mora, y así se hizo saber al notario secretario y testigos". 852

Don Nicolás Anguita, solicita algún aumento del salario que goza de trescientos ducados. Se dio comisión a los Diputados de San Acacio para que informen. ${ }^{853}$

Sobre el patitur abierto que solicitaba Don Josef Bach, organista segundo de esta Santa Iglesia, “acordó el Cabildo concederle dicho patitur hasta fin de mayo, reintegrándole de las aspas causadas desde la fecha del informe que es 5 de marzo de este año". ${ }^{854}$

\footnotetext{
${ }^{850}$ Ibid. Miércoles 7 de Abril de 1802. T. 96, fol. 246 r.

${ }^{851}$ Ibid. Lunes 26 de Abril de 1802. T. 96, fol. $248 \mathrm{v}$.

${ }^{852}$ Ibid. Lunes 26 de Abril de 1802. T. 96, fol. $248 \mathrm{v}$.

${ }^{853}$ Ibid. Lunes 26 de Abril de 1802. T. 96, fol. 249 r.

${ }^{854}$ Ibid. Martes 27 de Abril de 1802. T. 96, fol. 249 v.
} 
"Se leyó el informe sobre la ayuda de costa que solicita Don Mateo Tascón, músico instrumentista de esta Santa Iglesia, y el Cabildo le concedió cincuenta pesos de ayuda de costa por una vez". 855

"Se leyó el llamamiento para oír el examen de los niños pretendientes a la beca vacante en el Colegio del Santo Ángel, y en su vista pasar al nombramiento de ella; se mandó entrar a Don Francisco Bono, nombrado para examinar a dichos niños, los que igualmente se mandaron entrar y cantaron a presencia del Cabildo, y oído el informe del dicho Don Francisco Bono, fue nombrado para la dicha beca vacante, Rafael de Doblas”. 856

Se leyó el memorial de genealogía de Rafael de Ledesma y Doblas, recientemente elegido Colegial del Santo Ángel, "y el Cabildo dio comisión a los Señores Diputados del Colegio del Santo Ángel para que evacuen las demás diligencias de pruebas". 857

Se tratan los casos de D. Fermín María Espinosa, músico de la Capilla de esta Santa Iglesia y de D. Francisco Ferrer, instrumentista de la misma Capilla, a los cuales le fueron concedidos como ayuda de costa por una vez, "a el primero dos mil reales de vellón. Y al segundo mil reales de vellón”. Asimismo "se leió un memorial de D. Matias Redel primer Biolinista de la Capilla de esta Santa Iglesia en el que solicita una ayuda de costa...". ${ }^{858}$

Vista la anterior solicitud de D. Matias Redel “...primer Biolinista de la Capilla de Música de esta Santa Iglesia se acordó por votación secreta concederle del fondo nuestras arcas, tres mil reales de vellón por una vez de ayuda de costa”. ${ }^{859}$

\footnotetext{
${ }^{855}$ Ibid. Martes 27 de Abril de 1802. T. 96, fol. 249 v.

${ }^{856}$ Ibid. Martes 27 de Abril de 1802. T. 96, fol. 249 v.

${ }^{857}$ Ibid. Jueves 6 de Mayo de 1802. T. 96, fol. 251 r.

${ }^{858}$ Ibid. Martes 1 de Junio de 1802, T.96.

${ }^{859}$ Ibid. Viernes 4 de Junio de 1802, T.96.
} 
“Francisco Ferrer, músico trompista de la Capilla de esta Capilla, solicita licencia del Cavildo para tomar los aires patrios a fin de reestablecer su salud...". 860

El Cabildo concede a Don Juan de Mora doscientos reales de ayuda de costa por una vez. ${ }^{861}$

"Se leyó un memorial de Don Juan Nepomuceno Puig, músico bajonista de la Capilla de esta Santa Iglesia, solicitando una ayuda de costa, y se dio comisión a los Señores Diputados de Excusados de Fábrica, con la parte de Su Ilustrísima para que informen sobre esta solicitud". ${ }^{862}$

“Sobre la solicitud de Don Francisco Ferrer, músico de la Capilla de esta Santa Iglesia, se acordó por votación secreta, concederle la licencia que solicita para tomar los aires patrios, y restablecer su salud, hasta el día de Todos los Santos”. ${ }^{863}$

Se leyó un memorial del Maestro de Capilla Gaitán, en el que solicita "se le continúe la licencia que el Cabildo le tiene concedida", ${ }^{864}$

"Se leyó un memorial de Josef de Doblas, padre de Rafael de Doblas, Niño de Coro de esta Santa Iglesia, en el que expone que habiendo sido muchos los gastos causados en las pruebas de su hijo, suplica a V.S. se digne librar alguna ayuda de costa para subvenir a estos crecidos gastos; el Cabildo acordó se de comisión a los Señores Diputados del Colegio de Niños de Coro para que informen sobre esta solicitud". ${ }^{865}$

“Sobre el patitur que solicita Don Juan Manuel Gaitán, Presbítero, Capellán perpetuo en la de San Acacio; el Cabildo acordó que se conforma en todo y por todo con dicho informe, y así se le concedió a el dicho Don Juan Gaitán licencia hasta fin de

\footnotetext{
${ }^{860}$ Ibid. Lunes 28 de Junio de 1802, T.96.

${ }^{861}$ Ibid. Lunes 5 de Julio de 1802. T. 96, fol. 270 r.

${ }^{862}$ Ibid. Lunes 5 de Julio de 1802. T. 96, fol. 270 v.

${ }^{863}$ Ibid. Lunes 5 de Julio de 1802. T. 96, fol. 271 r.

${ }^{864}$ Ibid. Lunes 5 de Julio de 1802. T. 96, fol. 271 v.

${ }^{865}$ Ibid. Sábado 24 de Julio de 1802. T. 96, fol. 276 r.
} 
junio de 1803, en cuyo día deberá prorrogar la dicha licencia, y que dicho acuerdo pase a los Diputados de Horas Canónicas, para su inteligencia”, 866

“Se leyó el memorial de Don Nicolás de Anguita, músico en esta Santa Iglesia, en el que pide una ayuda de costa para socorrer a sus padres, e igualmente expone que deseando servir mejor a la Iglesia, adelantando en su facultad, solicita de V.S. licencia por el tiempo de un año para pasar a Madrid a conseguirlo; el Cabildo acordó se diese comisión a los Señores Diputados de la Capilla de San Acacio para que informen sobre esta solicitud". ${ }^{867}$

"Se leyeron otros dos memoriales uno de Don Antonio Gil, Presbítero, y otro de Don Alonso Martín, Presbítero, ambos músicos de voz en los que exponen a V.S. el corto salario que gozan, y las cargas y obligaciones que tiene la Capilla de San Acacio, cuyas Capellanías gozan, suplican a V.S. se digne por un efecto de su notoria caridad, aumentarles el salario, y el Cabildo acordó dar y dio comisión a los Señores Diputados de Arcas de San Acacio para que con la parte de Su Ilustrísima informen con llamamiento sobre esta solicitud". 868

“El Señor Presidente expuso al cabildo, que con motivo de ir la Música a las Vísperas de San Francisco el domingo 3 de Octubre día en que se celebra Nuestra Señora del Rosario y ser las segundas Vísperas de dicha festividad de Música, si le parecía al Cabildo que dichas segundas Vísperas fuesen a canto llano; el Cabildo acordó se conformaba con lo expuesto por el Señor Presidente”. 869

“Se tubo presente un memorial de D. Andrés Lidón, organista primero de esta Iglesia en que solicita se le aumente mil....., de los once mil que goza". 870

\footnotetext{
${ }^{866}$ Ibid. Sábado 24 de Julio de 1802. T. 96, fol. 277 v.

${ }^{867}$ Ibid. Jueves 29 de Julio de 1802. T. 96, fol. 280 v.

${ }^{868}$ Ibid. Lunes 27 de Septiembre de 1802. T. 96, fol. 293 v.

${ }^{869}$ Ibid. Viernes 1 de Octubre de 1802. T. 96, fol. 295 r.

${ }^{870}$ Ibid. Lunes 11 de Octubre de 1802 T.96.
} 
“Los señores diputados de Sagradas ceremonias expusieron en su informe por escrito y de palabra que lo hecho por este cavildo en celebridad de el casamiento del serenísimo Príncipe de Asturias, nuestro actual Soverano, que Dios guarde, el Señor D, Carlos quarto, celebrado en el año pasado de ¿? fue: tres noches de repique con iluminación en la torre, y en el último de estos tres días después de completas se cantó el himno Te Deum. Y que lo convendría hacer en obsequio y celebridad de el casamiento del Serenísimo Príncipe de Asturias D. Fernando, con la Serenísima Princesa de Nápoles Da María Antonia”. ${ }^{871}$

“Habiéndose leído un memorial del músico Josef Ferrer [se refiere a Francisco Ferrer, trompa] al que acompañaba una certificación jurada de el médico que lo asiste, en el que expone estar para cumplirse la licencia que el Cabildo le dio para recuperar su salud fuera del Obispado, y no habiéndolo conseguido hasta la presente como lo acredita la certificación dicha, suplica al Cabildo se digne prorrogarle la expresada licencia, y el Cabildo acordó dar y dio comisión a los Señores Diputados de Arcas de Santa Inés con la parte de Nuestro Prelado, para que informen con llamamiento sobre esta solicitud". ${ }^{872}$

“Se leyó un memorial de Don Lope de Mora, músico violinista de esta Santa Iglesia, en que solicita una ayuda de costa, y se cometió a informe con llamamiento de los Señores Diputados de Arcas de Vacantes de San Acacio con la parte de Su Ilustrísima Nuestro Prelado". 873

“Acordó el Cabildo prorrogar, y prorrogó la licencia de patitur abierto a Francisco Ferrer, músico trompa de la Capilla de esta Santa Iglesia, desde el día en que concluye el que antes tenía, hasta el próximo Miércoles de Ceniza exclusive del año que viene de 1803 ". 874

\footnotetext{
${ }^{871}$ Ibid. Viernes 22 de Octubre de 1802, T.96.

${ }^{872}$ Ibid. Sábado 29 de Octubre de 1802. T. 96. fol. 318 r.

${ }^{873}$ Ibid. Lunes 11 de Noviembre de 1802. T. 96, fol. 323 r.

${ }^{874}$ Ibid. Martes 16 de Noviembre de 1802. T. 96, fol. 325 r.
} 
"Se leyeron dos memoriales, uno de Don Mateo Bernia, músico tiple en esta Santa Iglesia, en que solicita licencia de patitur abierto, y otro de Don Manuel Ravé, en que pide una ayuda de costa y ambos se sometieron a informe de los Señores Diputados de Arcas Vacantes de Santa Inés, con la parte de Su Ilustrísima, Nuestro Prelado". 875

El Cabildo le concede a Don Lope de Mora una ayuda de costa de mil quinientos reales de vellón. ${ }^{876}$

"El Cabildo acordó conceder y concedió licencia de patitur abierto a Don Mateo Bernia, músico tiple de la Capilla de esta Santa Iglesia, hasta la próxima Semana Santa" ${ }^{877}$

Se conceden diversas ayudas de costa a D. Andrés Lidón, organista primero y a D. Juan Puig, bajonista. "Al primero en atención al doble trabajo que está dando en suplir por el segundo organista que está enfermo. Y al segundo en atención al buen desempeño de su obligación, a estar enseñando a los niños de coro y a la indigencia que sufre por la carestía de los tiempos". ${ }^{878}$

Algunos Diputados de Arcas Vacantes de San Acacio solicitan al Cabildo se haga un "Plan comprehensivo del número de plazas que ha de tener la Capilla de Música, con asignación de un salario fijo para cada plaza, sin que este pueda aumentarse en lo sucesivo...". El Cabildo contesta que tiene "plena libertad para aumentar los salarios a los músicos...”. 879

\section{3}

\footnotetext{
${ }^{875}$ Ibid. Martes 16 de Noviembre de 1802. T. 96, fol. 325 v.

${ }^{876}$ Ibid. Viernes 19 de Noviembre de 1802. T. 96, fol. 327 r.

${ }^{877}$ Ibid. Sábado 20 de Noviembre de 1802. T. 96, fol. 327 v.

${ }^{878}$ Ibid. Jueves 2 de Diciembre de 1802, T.96.

${ }^{879}$ Ibid. Sábado 4 de Diciembre de 1802. T.96.
} 
“Sobre la ayuda de costa que solicita Don Pascual Redel, músico de esta Santa Iglesia, el Cabildo por votación secreta le concedió 2000 reales de vellón por una vez. $Y$ enseguida se leyó otro memorial de Don Francisco Cascante en el que solicita una ayuda de costa, el Cabildo dio comisión a los Señores Diputados de Arcas de Vacantes para que con la parte de Nuestro Prelado, informen al Cabildo sobre esta solicitud". 880

"Se mandó leer un memorial de Juan Bueno, músico tiple de la Capilla de esta Santa Iglesia en que solicita una ayuda de costa a causa de su enfermedad, y carestía de los tiempos, y no haber pedido otra alguna en los muchos años que lleva de servicio”. Y el Cabildo dio comisión a los Diputados de Santa Inés para que informasen sobre esta solicitud. ${ }^{881}$

El músico violinista Joseph Vasconcelos pide una ayuda de costa. ${ }^{882}$

“El Señor Presidente dixo que Don Ángel Moreno músico tenor de esta Santa Iglesia presentaba un memorial al Cabildo pidiendo una ayuda de costa, y el Cabildo acordó dar y dio comisión a los Señores Diputados de Arcas de Vacantes para que informen con llamamiento sobre esta solicitud". 883

"Leído el llamamiento para oír el informe de los Señores Diputados de Arcas Vacantes con la parte de Nuestro Ilustrísimo Prelado, sobre la ayuda de costa que solicita Don Ángel Moreno, músico tenor de esta Santa Iglesia, y leído que fue, el Cabildo acordó conceder y concedió por una vez cincuenta pesos al dicho Don Ángel de ayuda de costa", 884

“Continuando el Cabildo antecedente de Señores Canónicos, y a virtud de la palabra del Señor Segovia, Diputado de la Capilla de Santa Inés de esta Santa Iglesia,

\footnotetext{
${ }^{880}$ Ibid. Lunes 31 de Enero de 1803. T. 96.

${ }^{881}$ Ibid. Martes 8 de Febrero de 1803. T. 96, fol. 349 v.

${ }^{882}$ Ibid. Lunes 14 de Febrero de 1803 T.96.

${ }^{883} \mathrm{Ibid}$. Miércoles 16 de Marzo de 1803. T. 96, fol. 366 r.

${ }^{884}$ Ibid. Lunes 28 de Marzo de 1803. T. 96, fol. 367 v.
} 
sobre la Capellanía vacante en dicha Capilla, el Cabildo acordó se pongan edictos llamando a toda clase de voz para la oposición de dicha Capellanía de Música”. 885

"Se leyó un memorial de Don Antonio Gil, músico tenor por el que solicita licencia para pasar a Madrid enseguida de un pleito de su hermano, y para recobro de su salud, y el Cabildo acordó dar y dio comisión a los Diputados de Arcas de Vacantes de San Acacio con la parte de Su Ilustrísima para que informen con llamamiento sobre esta solicitud". 886

“El Cabildo acordó por votos secretos librar y libró un mil reales de vellón, de ayuda de costa por una vez a favor de Don Juan de Borja, músico instrumentista de esta Santa Iglesia”. ${ }^{887}$

“Se leyó un memorial de Don Josef Las, músico instrumentista de la Capilla de esta Santa Iglesia en el que solicita algún aumento de salario, en atención a desempeñar cuando se ofrece en la Capilla, algunos otros instrumentos además de aquél para que fue admitido, y el Cabildo acordó dar y dio comisión a los Señores Diputados de Arcas de Vacantes de Santa Inés, con la parte de Su Ilustrísima para que informen al Cabildo con llamamiento sobre esta solicitud”. 888

"Sobre la solicitud de Don Sebastián Cabezón Capellán de San Antonino, y músico instrumentista de Nuestra Santa Iglesia en razón de que se le de una ayuda de costa para resarcirse en la extrema necesidad a que está reducido, el Cabildo acordó por votos secretos concederle y le concedió tres mil reales de vellón de ayuda de costa por una vez del caudal perteneciente a la Capilla de San Antonino”. 889

Se leen memoriales de D. Juan Manuel Gaitán, Maestro de Capilla jubilado y de Capellán de San Acacio [en excedencia], en la que "solicita prórroga de la licencia de

\footnotetext{
${ }^{885}$ Ibid. Lunes 28 de Marzo de 1803. T. 96, fol. 368 v.

${ }^{886}$ Ibid. Viernes 22 de Abril de 1803. T. 96, fol. 373 v.

${ }^{887}$ Ibid. Viernes 22 de Abril de 1803. T. 96, fol. 374 r.

${ }^{888}$ Ibid. Viernes 22 de Abril de 1803. T. 96, fol. 374 r.

${ }^{889}$ Ibid. Martes 7 de Junio de 1803. T. 96, fol. 405 v.
} 
patitur que goza, por continuar sus padeceres”, y de D. Antonio Gil, Capellán de San Acacio, y músico tenor de esta Santa Iglesia, "en que pide prórroga de la licencia que se le dio para Madrid, para pasar a su tierra a tomar los aires patrios como medicina de la enfermedad que padece...". 890

En acta posterior tenemos noticia de que a Gaitán se le concede su petición, pero a Gil se le deniega. ${ }^{891}$

“Se leyó un memorial de Don Andrés Lidón, organista primero, solicitando se le aumente su salario hasta doce mil reales de vellón, y se cometió por el Cabildo a los Señores de Excusados de Música con la parte de Nuestro Ilustrísimo Prelado para que informen sobre su contenido con llamamiento". 892

Los Diputados de San Acacio expusieron que los días pasados cantó en el Coro un tiple venido de Sevilla, el cual manifestó "no encontrarse muy a gusto en aquella Catedral, y se ofreció a venir a ésta, siempre que el Cabildo le diera facilidades para ello". ${ }^{893}$

Sobre la admisión en la Capilla de Música del tiple Señor Longanini, el Cabildo da comisión a los Diputados de San Acacio para que "puedan ofrecer y ofrezcan a dicho tiple hasta veinticuatro mil reales anuales, sujetos a jubilación de doce mil, si por su decadencia de voz el Cabildo determinase concedérsela, ofreciéndole al mismo tiempo dieciocho mil reales anuales sin sujección a jubilación, para que eliga de estos parecidos el que le acomode, y informen dichos Señores las resultas con llamamiento". 894

En este día se oye el informe del Maestro de Capilla acerca del opositor que se había presentado para cubrir una plaza vacante en la Capilla de Santa Inés. Esta plaza

\footnotetext{
${ }^{890}$ Ibid. Lunes 27 de Junio de 1803. T.96.

${ }^{891}$ Ibid. Jueves 21 de Julio de 1803. T.96.

${ }^{892}$ Ibid. Jueves 28 de Julio de 1803. T. 96, fol. 447 r.

${ }^{893}$ Ibid. Jueves 28 de Julio de 1803. T. 96, fol. 448 r.

${ }^{894}$ Ibid. Viernes 29 de Julio de1803. T. 96, fol. 450 v.
} 
quedó vacante como consecuencia de la muerte de Don Juan Franco, ocurrida el día 25 de Enero de 1798. El opositor presentado se llama Don Fermín Espinosa, y según el informe “tiene suficiencia en el canto de órgano y calidad de voz”. El Cabildo acuerda admitirlo. ${ }^{895}$

"Se leyó un memorial de Don Nicolás de Anguita, músico, pidiendo aumento de salario, y el Cabildo lo cometió a los Señores Diputados de Arcas de Vacantes de San Acacio para que con la parte de Su Ilustrísima Nuestro Prelado informen sobre su contenido con llamamiento". 896

“Don Ángel Arteaga y Don Juan de Borja, músicos, piden licencia para ausentarse a negocios respectivamente propios. El Cabildo concedió licencia a Don Ángel Arteaga hasta Todos los Santos, a no ser que antes tenga concluidos sus asuntos en Salamanca, y a Don Juan de Borja se le concedió un mes de licencia contado desde el día 19 de Julio próximo pasado”. ${ }^{897}$

“En virtud del llamamiento para oír el informe de los Señores Diputados de Excusados de Música con la parte de Nuestro Ilustrísimo Prelado sobre la pretensión de aumento de sueldo que ha hecho Don Andrés Lidón, organista primero, oído dicho informe y habiéndose votado por votos secretos, acordó el Cabildo aumentar hasta doce mil reales anuales el sueldo que hoy goza de once mil, dicho Don Andrés Lidón”. 898

“En continuación del llamamiento para oír el informe de los mismos Señores y parte sobre la pretensión de ayuda de costa que solicita Don Joseph Bach, organista segundo de esta Santa Iglesia, oído dicho informe acordó el Cabildo por votos secretos conceder por una vez y concedió al Don Joseph Bach mil reales de vellón de ayuda de costa del caudal de Excusados”. 899

\footnotetext{
${ }^{895}$ Ibid. Viernes 26 de Agosto de 1803. T. 96, fol. 459 v.

${ }^{896}$ Ibid. Viernes 26 de Agosto de 1803. T. 96, fol. 459 v.

${ }^{897}$ Ibid. Viernes 26 de Agosto de 1803. T. 96, fol. $460 \mathrm{v}$.

${ }^{898}$ Ibid. Miércoles 31 de Agosto de 1803. T. 96, fol. 464 r.

${ }^{899}$ Ibid. Lunes 5 de Septiembre de 1803. T. 96, fol. 464 v.
} 
“Sobre la ayuda de costa que pretende Doña Paula de Bárcena, hija del difunto Don Pablo de Bárcena, músico que fue de esta Santa Iglesia, y para pago de su enfermedad y entierro, oído el informe y habiéndose votado por votos secretos, acordó el Cabildo conceder a Doña Paula de Bárcena para el expresado fin y le concedió por una vez, quinientos reales de vellón, de ayuda de costa de las Arcas de Excusados de Música”.900

"Se mandó entrar al notario secretario, quien dio cuenta de que habían firmado la oposición a la Capellanía vacante por muerte de Don Joseph de los Ríos, Presbítero, Don Manuel Gutiérrez Ravé, y a la vacante por haber obtenido otra incompatible, Don Manuel Álvarez, Don Nicolás Anguita y Don Joseph Luis de los Heros, y el Cabildo los admitió por opositores a las respectivas Capellanías, por examinador de los opositores a don Jaime Valius, Maestro de Capilla, mandó que el examen empiece esta tarde después de Vísperas y continúe en las demás tardes hasta concluirse, y concluidos informen los Señores Diputados de Arcas de Vacantes de San Acacio a su tiempo, y con la parte de Su Ilustrísima, trayendo también el Maestro su censura, para en su vista determinar lo que convenga", 901

“El Señor Segovia dixo se hallaba vacante una plaza de Niño de Coro, y el Cabildo mandó que los Señores Diputados de Arcas de Vacantes de Santa Inés con la parte de Su Ilustrísima reciban memoriales e informen de los pretendientes que se presenten". 902

“El Señor Deán dixo: que para descargo de su conciencien no podía menos que exponer al Cabildo que había algún músico tan olvidado de su obligación y del respeto debido y subordinación a este cuerpo, que no sólo se mantenía fuera y ausente, si no que lo hacía con descaro y habiéndosele negado la licencia que solicitaba, lo que podría traer algunos inconvenientes graves y malas consecuencias, y el Cabildo mandó

\footnotetext{
${ }^{900}$ Ibid. Lunes 5 de Septiembre de 1803. T. 96, fol. 464 v.

${ }^{901}$ Ibid. Lunes 19 de Septiembre de 1803. T. 97, fol. 4 r.

902 Ibid. Lunes 19 de Septiembre de 1803. T. 97, fol. 4 v.
} 
se dé llamamiento para tratar y resolver sobre este particular propuesto por el Señor Deán”.903

Se reúne el Cabildo para oír el informe del Maestro de Capilla acerca de los opositores a una de las Capellanías de San Antonino, vacante por fallecimiento de Don Joseph de los Ríos, el día 17 de mayo de 1796. "Y habiendo el Cabildo mandado entrar a el Maestro de Capilla Don Jaime Valius, presenta la certificación jurada que con fecha de 11 de octubre de 1803 había entendido, manifestando su sentir en orden a la habilidad y suficiencia de Don Manuel Gutiérrez Ravé, músico tenor de la Capilla de esta Santa Iglesia, y único opositor a dicha Capellanía vacante, y habiéndose retirado el referido Maestro, acordó el Cabildo que desde luego se proponga a S.M. (Dios le honre) el dicho Don Manuel Gutiérrez Ravé”. 904

Se celebra la oposición para cubrir una Capellanía vacante de San Acacio, por la dimisión de Don Joseph María Cheist. Se presenta a esta oposición Joseph Luis de los Heros, “y habiendo sido éste examinado por el Maestro de Capilla, se consideró por dicho Maestro como apto para el puesto, por lo que el Cabildo lo nombró de inmediato". 905

"Se leyó un memorial de Don Nicolás Anguita, pidiendo aumento de salario, y lo cometió el Cabildo a los Señores Diputados de Arcas de Vacantes con la parte para que informen con llamamiento". ${ }^{906}$

“En virtud del llamamiento para oír el examen de los pretendientes a la beca vacante en el Colegio de Niños de Coro, habiéndose examinado todos según práctica a presencia del Cabildo, y dado su censura el Maestro de Capilla que había sido nombrado examinador de aquéllos, acordó el Cabildo proveer dicha beca entre los pretendientes, y habiendo votado por cédulas salió electo Rafael Arroyo". 907

\footnotetext{
${ }^{903}$ Ibid. Lunes 19 de Septiembre de 1803. T. 97, fol. 4 v.

${ }^{904}$ Ibid. Martes 11 de Octubre de 1803. T. 97, fol. 7 v.

${ }^{905}$ Ibid. Jueves 13 de Octubre de 1803. T. 97, fol. 8 v.

${ }^{906}$ Ibid. Jueves 13 de Octubre de 1803. T. 97, fol. 8 r.

${ }^{907}$ Ibid. Lunes 17 de Octubre de 1803. T. 97, fol. 10 r.
} 
"En virtud del llamamiento para cubrir la beca vacante en el Colegio de Infantes de Coro el Cabildo mandó entrar al Maestro de Capilla y habiendo dado su censura se retiró y el Cabildo pasó a hacer elección de dicha beca por votos secretos y cédulas y salió electo por mayor número Joseph Lucena, natural de esta ciudad", 908

"Sobre la pretensión de aumento de salario hecha por Don Nicolás Anguita, músico de esta Santa Iglesia, leído el informe y habiendo corrido el voto, acordó el Cabildo conceder a dicho Anguita cien ducados de aumento anuales”. 909

"Se leyó un memorial de Lope de Mora, músico, pidiendo una ayuda de costa, que se cometió a los Señores Diputados de Arcas de Vacantes de San Acacio, por la parte de Su Ilustrísima, para que informen sobre su contenido con Ilamamiento”. 910

Se presenta el memorial de genealogía de Joseph Lucena, Niño de Coro recientemente electo. ${ }^{911}$

"Don Pedro de Segovia, expuso que los instrumentos de trompas y clarines estaban muy malos, y el Cabildo dio comisión a los Señores Diputados de Arcas de Vacantes de Santa Inés para que compren o manden hacer nuevos y buenos dichos instrumentos que se costearán del fondo de las expresadas Arcas”. 912

"Se leió un memorial de D. Rafael de Soto, pbro, haciendo dimisión de el servicio de una Capellanía de San Antonino...". 913

Se presenta con detalle el memorial de genealogía de José Luis de los Heros, recientemente aprobado para una Capellanía de San Acacio. ${ }^{914}$

\footnotetext{
${ }^{908}$ Ibid. Lunes 17 de Octubre de 1803. T. 97, fol. 11 r.

${ }^{909}$ Ibid. Jueves 20 de Octubre de 1803. T. 97, fol. 11 v.

${ }^{910}$ Ibid. Viernes 4 de Noviembre de 1803. T. 97, fol. 15 v.

${ }^{911}$ Ibid. Viernes 4 de Noviembre de 1803. T. 97, fol. 16 r.

${ }^{912}$ Ibid. Viernes 4 de Noviembre de 1803. T. 97, fol. 16 r.

913 Ibid. Lunes 7 de Noviembre de 1803. T.97.

${ }^{914}$ Ibid. Lunes 14 de Noviembre de 1803. T. 97, fol. 20 r.
} 
“Acordó el Cabildo conceder y concedió a Lope de Mora, violinista, mil y quinientos reales de ayuda de costa por una vez que libró en los fondos de Arcas de Vacantes de San Acacio". 915

"Se leyó un memorial de Francisco Cascante, músico contrabajo de la Capilla, pidiendo una ayuda de costa y el Cabildo lo cometió a los Señores Diputados de Arcas de Vacantes de San Acacio para que informen". 916

"Se leyó una carta de Don Francisco Viñals, contralto en la Santa Iglesia de Plasencia, solicitando venir a hacer oposición a la Capellanía de San Antonino, y el Cabildo cometió a los Señores Diputados de Arcas de Vacantes de San Acacio para que informen". 917

"Leído el llamamiento para oír el informe de los Señores Diputados del Colegio del Santo Ángel acerca de las pruebas de Rafael de Arroyo, nombrado Infante de Coro, se mandó entrar al notario secretario, el cual hizo relación de ellas, y mandado retirar el Cabildo las aprobó, por votación secreta, y declaró que estaban bien hechas y concluidas con arreglo a nuestros estatutos”. 918

Don José Luis de los Heros y Don Manuel Gutiérrez Ravé solicitan respectivas ayudas de costa. Al primero se le conceden dos mil seiscientos reales, pero al segundo se le niega dicha ayuda de costa. ${ }^{919}$

“Leído el llamamiento para oír el informe sobre la lexitimidad y limpieza de sangre de Joseph de Lucena, nombrado Infante de Coro, se mandó entrar al notario secretario, el cual hizo relación de ellas, y mandado retirar se acordó por votación

\footnotetext{
915 Ibid. Martes 15 de Noviembre de 1803. T. 97, fol. 22 r.

${ }^{916}$ Ibid. Martes 15 de Noviembre de 1803. T. 97, fol. 22 r.

${ }^{917}$ Ibid. Martes 15 de Noviembre de 1803. T. 97, fol. 22 r.

${ }^{918}$ Ibid. Sábado 3 de Diciembre de 1803. T. 97, fol. 27 r.

${ }^{919}$ Ibid. Lunes 5 de Diciembre de 1803. T. 97, fol. 27 v.
} 
secreta estar bien hechas las pruebas, y habiéndose vuelto a votar se declaró haber cumplido con lo mandado por nuestros estatutos". 920

El Cabildo concede a Rafael Arroyo, Colegial del Santo Ángel, una ayuda de costa de doscientos reales de vellón. ${ }^{921}$

El Señor Presidente dixo “que en la puerta se hallaba esperando Don Manuel Gutiérrez Ravé, agraciado por el Rey (que Dios guarde) en una Capellanía de la Capilla de San Antonino y habiéndole mandado entrar con el notario secretario, hizo presentación de la real cédula de provisión de dicha Capellanía”. ${ }^{222}$

"Sobre la solicitud de Don Pascual Redel y Don Francisco Cascante, músicos instrumentistas, oído dicho informe acordó el Cabildo por votos secretos conceder y concedió de los fondos de las Arcas de Vacantes de San Acacio mil y quinientos reales de vellón de ayuda de costa por una vez, a Don Pascual Redel, y mil reales del mismo fondo también por una vez a Don Francisco Cascante”. 923

En este día Don Manuel Gutiérrez Ravé recoge la Capellanía que le había sido concedida. "Y esperando el interesado en la puerta de la sala capitular se mandó entrar y entró con el notario secretario y testigos, y puesto de rodillas delante del Señor Presidente se le hizo la colación de la citada Capellanía en la forma acostumbrada. Después de lo cual el mismo agraciado presentó su memorial de genealogía”.924

"Se leyó un memorial de Don Joseph Luis de los Heros, pidiendo ayuda de costa y el Cabildo lo cometió a los Señores Diputados de Arcas de San Acacio para que informen". 925

Se presenta detalladamente el memorial de genealogía de Fermín Espinosa. ${ }^{926}$

\footnotetext{
${ }^{920}$ Ibid. Lunes 5 de Diciembre de 1803. T. 97, fol. 28 r.

${ }^{921}$ Ibid. Viernes 16 de Diciembre de 1803. T. 97, fol. $30 \mathrm{v}$.

${ }^{922}$ Ibid. Martes 20 de Diciembre de 1803. T. 97, fol. 32 v.

${ }^{923}$ Ibid. Viernes 23 de Diciembre de 1803. T. 97, fol. 34 r.

${ }^{924}$ Ibid. Viernes 23 de Diciembre de 1803. T. 97, fol. 34 r.

${ }^{925}$ Ibid. Viernes 23 de Diciembre de 1803. T. 97, fol. 34 v.
} 


\section{4}

Se leyó un memorial de Don Mateo Tascón, bajonista, en que pide una ayuda de costa, y se dio comisión a los Señores de Excusados de Fábrica para que informen. ${ }^{927}$

El Cabildo concede a Don Joseph Luis de los Heros dos mil reales de vellón de ayuda de costa por una vez, que libró sobre los fondos de Arcas de Vacantes de San Acacio. ${ }^{928}$

El Cabildo concede a Joseph Lucena, cuatrocientos reales de vellón de ayuda de costa, por una vez, que se le satisfacieron del caudal de Arcas de Vacantes de Santa Inés. ${ }^{929}$

“Sobre la solicitud de Don Manuel Gutiérrez Ravé, provisto en una Capellanía de San Antonino, para que las pruebas de limpieza de su padre, siendo originario de esta ciudad, y nacido por una casualidad pura, en la de Andúxar, se le hagan en ésta de Córdoba, y que por semejante razón habiendo salido su abuela materna Doña María de Arias Roldán de el Arahal, donde había nacido, de edad de cuatro o cinco años, y pasado a la ciudad de Málaga donde se crió, vivió, y murió, se le hagan la información de limpieza en dicha ciudad de Málaga, y no en el Arahal, donde nada habrá que pueda deponer de conocimiento; y oído dicho informe acordó el Cavildo conformarse con él”. 930

“El Señor Presidente dixo que en la puerta esperaba Don Fermín de Espinosa, músico, que tenía que manifestar al Cavildo una Cédula Real y habiéndole mandado entrar con el notario secretario, hizo presente la Real Cédula de S.M., de provisión de la Capellanía de Santa Inés vacante por muerte de Don Juan Franco, en que se había dignado agraciarle, y habiéndose retirado, el Cavildo la cometió a los Señores

\footnotetext{
${ }^{926}$ Ibid. Viernes 23 de Diciembre de 1803. T. 97, fol. 35 v.

${ }^{927}$ Ibid. Sábado 14 de Enero de 1804. T. 97, fol. 39 r.

${ }^{928}$ Ibid. Sábado 14 de Enero de 1804. T. 97, fol. 39 v.

${ }^{929}$ Ibid. Sábado 14 de Enero de 1804. T. 97, fol. 40 r.

${ }^{930}$ Ibid. Jueves 26 de Enero de 1804. T. 97, fol. 42 r.
} 
Diputados de Arcas de Vacantes de Santa Inés con la parte de Su Ilustrísima, para que informen sobre su contenido con llamamiento". 931

Sobre los documentos presentados por Don Fermín de Espinosa, músico, provisto de una Capellanía de Santa Inés, “acordó el Cavildo dar la colación de dicha Capellanía al expresado Don Fermín, y igualmente la posesión de ella luego que hubiese cumplido con el estatuto de limpieza de esta Santa Iglesia”. Una vez tomada esta resolución, el Cabildo mandó entrar a Don Fermín, “y puesto de rodillas delante del Señor Presidente se le hizo la colación de la referida Capellanía en la forma acostumbrada”. 932

“Acordó el Cavildo nombrar a Don Manuel Álvarez, Capellán de San Pedro, ayudante de Sochantre interino, con la obligación de cumplir su ministerio, y el de hacer de baxo de Capilla en la de música”. Asimismo se le asignó un sueldo de cuatrocientos ducados anuales, y se dio comisión a los Diputados de San Acacio "para que busquen persona, o personas en quien proveer la Sochantría o su ayuda en propiedad". 933

“Se leyó un memorial de Juan de Mora, Acólito, solicitando una ayuda de costa, y el Cavildo lo cometió a los Señores Diputados de Acólitos y Colegio de Infantes, para que informen sobre su contexto con llamamiento". 934

"Se leyó el memorial en que Don Fermín Espinosa, solicita que el Cavildo le mande dar testimonio de hallarse provisto en una de las Capellanías de Santa Inés, de haber recibido colación de ella, y de la renta que tiene a fin de hacerlos constar al Ilustrísimo Señor Obispo de su origen, para poderse ordenar, y el Cavildo acordó que los Señores Diputados de Arcas de Santa Inés, con la parte de su Ilustrísima, dispongan que el notario secretario dé el testimonio". ${ }^{935}$

\footnotetext{
${ }^{931}$ Ibid. Miércoles 1 de Febrero de 1804. T. 97, fol. 43 r.

932 Ibid. Viernes 10 de Febrero de 1804. T. 97, fol. 46 v.

933 Ibid. Sábado 11 de Febrero de 1804. T. 97, fol. 47 r.

${ }^{934}$ Ibid. Jueves 23 de Febrero de 1804. T. 97, fol. 49 r.

${ }^{935}$ Ibid. Martes 28 de Febrero de 1804. T. 97, fol. 51 r.
} 
“Se leyó un memorial de Don Ángel Arteaga, solicitando perdón de aspas, y que se le determine renta para congrua y se cometió a los mismos Señores Diputados con la parte, para que informen sobre su contenido con llamamiento", 936

Vista la solicitud de Don Mateo Tascón, músico, el Cabildo acordó “conceder y concedió al Don Mateo Tascón, setecientos cincuenta reales de vellón, de ayuda de costa por una vez, que libró sobre los fondos de Excusados de Fábrica”, 937

"Se leyó un memorial de Don Manuel Gutiérrez Ravé, provisto en una de las Capellanías de San Antonino, en que solicita se le dé testimonio de la Real Cédula de Su Majestad, presentándole para dicha Capellanía, a fin de remitirla al Ilustrísimo Señor Obispo de Málaga, para formalizar su solicitud de órdenes”.Y el Cabildo ordenó al notario secretario que así lo hiciese. ${ }^{938}$

“Se leyó un memorial de Don Matías Redel, pidiendo algún alivio en su trabajo en la música, respecto de los numerosos años que sirve, y ayuda de costa, y el Cavildo lo cometió a los Señores Diputados de Arcas de Santa Inés con la parte de Su Ilustrísima para que informen”. 939

"Se leyó un memorial de Don Joseph Vasconcelos, músico violinista, que cometió el Cavildo a los Señores Diputados de Arcas de Vacantes de San Acacio con la parte, para que informen de su contenido con llamamiento". No especifica en que consistía dicho memorial. ${ }^{940}$

“Sobre la solicitud de Don Ángel Arteaga, Presbítero y músico, oído el informe acordó el Cavildo, hacer y hizo perpetuos y colativos tres mil y trescientos reales de vellón de los quince mil que goza de salario Don Ángel Arteaga para que le sirvan de congrua, y pueda a consecuencia servir la prebenda, que obtiene en la Santa Iglesia de

\footnotetext{
${ }^{936}$ Ibid. Martes 28 de Febrero de 1804. T. 97, fol. 51 r.

${ }^{937}$ Ibid. Miércoles 29 de Febrero de 1804. T. 97, fol. 51 v.

${ }^{938}$ Ibid. Miércoles 29 de Febrero de 1804. T. 97, fol 51 v.

${ }^{939}$ Ibid. Viernes 2 de Marzo de 1804. T. 97, fol. 52 v.

${ }^{940}$ Ibid. Martes 13 de Marzo de 1804. T. 97, fol. 56 r.
} 
Salamanca, y a este fin se le da por el presente secretario el testimonio o certificado correspondiente. Asimismo habiéndole negado al Don Ángel el perdón de aspas que solicita, le concedió por votos secretos dos mil reales de vellón de ayuda de costa por una vez".941

Se leen las pruebas de limpieza de sangre de Don Manuel Gutiérrez Ravé. El Cabildo acuerda que dichas pruebas son satisfactorias y están correctamente realizadas, “y todo se hizo saber al notario secretario y testigos, y se mandó entrar al mismo Don Manuel Gutiérrez Ravé e hizo el juramento según costumbre”. ${ }^{942}$

“Se leyó un memorial de Don Manuel Álvarez Roldán, Presbítero y Capellán de una de las del Señor San Pedro en esta Santa Iglesia, en el que solicita una ayuda de costa, y se dio comisión a los Señores Diputados de Arcas de Vacantes de San Acacio con la parte de Su Ilustrísima para que informen con llamamiento". ${ }^{943}$

"Se leyó otro memorial de Don Benito Torrellas, profesor de música con voz de bajo, en el que solicita ser admitido por uno de los individuos de la Capilla de música de esta Santa Iglesia, con el salario que sea del agrado del Cavildo", ${ }^{944}$

Respecto a las pruebas para cubrir una Capellanía vacante en la Capilla de San Pedro, se informa de que "se ha presentado para hacer la oposición a ella Don Josef García, Presbítero y vecino de Zeuta, el cual en vista de los acordado por el Cavildo para no causarle más perjuicios en la detención se había ya exercitado y cantado en el coro; y habiéndose retirado el notario secretario y oído lo que informaron los Señores Diputados, acordó el Cavildo continúe abierto el término para si se presenta algún otro opositor, y que a la mayor brevedad se informe al Cavildo por los mismos Señores, con la censura de los examinadores, acerca del que se ha presentado". 945

\footnotetext{
${ }^{941}$ Ibid. Viernes 16 de Marzo de 1804. T. 97, fol. 57 r.

${ }^{942}$ Ibid. Miércoles 11 de Abril de 1804. T. 97, fol. 61 v.

943 Ibid. Miércoles 11 de Abril de 1804. T. 97, fol. 61 v.

${ }^{944}$ Ibid. Miércoles 11 de Abril de 1804. T. 97, fol. 61 v.

${ }^{945}$ Ibid. Viernes 13 Abril de 1804. T. 97, fol. 62 r.
} 
“Sobre la solicitud de Don Benito Torrellas, músico con voz de bajo, se mandó entrar al Maestro de Capilla y oído su informe con el de los Señores, se acordó admitir en calidad de bajo de la Capilla de Música de esta Santa Iglesia a el dicho Don Benito Torrellas señalándole de salario mil ducados de vellón, con la precisa condición de asistir a la enseñanza de los Infantes de Coro, o de alguno otro que el Cavildo le comisione, y enseguida se dio comisión a los mismos Señores para que informen acerca del músico Don Ángel Moreno a la mayor brevedad". 946

"Se leyó un memorial de Don Josef María Moyano, Presbítero y Capellán de una de las de San Antonino, y músico contralto en el que solicita algún aumento de renta, y se dio comisión a los Señores Diputados de Arcas de Vacantes de San Acacio y San Antonino con la parte de Su Ilustrísima para que informen sobre esta solicitud”. ${ }^{947}$

"En virtud del llamamiento para oír la censura de los examinadores de los opositores a la Capellanía de San Pedro, vacante por muerte de Don Vicente Alverola, se mandó entrar al notario secretario, quien leyó la censura, que con separación han dado Don Juan Ortiz Guerra, Presbítero, y Don Manuel Álvarez, sobre la suficiencia y aptitud de Don Pedro García Delgado, opositor a dicha Capellanía a quien habían examinado y ambos examinadores convienen en que el citado Don Pedro García no tiene la aptitud, y su voz, no llena las cualidades que se requieren para el desempeño de la Capellanía”.El Cabildo acuerda aceptar la resolución de los examinadores. ${ }^{948}$

“En virtud del llamamiento para oír el informe de los Señores Diputados de Arcas de Vacantes de San Acacio con la parte de Su Ilustrísima Nuestro Prelado, en razón de haberse cumplido el término porque fue admitido Don Ángel Moreno en la Capilla de Música, oído dicho informe acordó el Cavildo que desde el día de mañana inclusive, cese el situado de trescientos ducados que por un año señaló a dicho Don Ángel Moreno que podrán retirarse donde le acomoden y habiéndose votado por votos secretos si se le daría alguna ayuda de costa, le concedió el Cavildo setecientos

\footnotetext{
${ }^{946}$ Ibid. Viernes 13 de Abril de 1804. T. 97, fol. 62 r.

${ }^{947}$ Ibid. Viernes 13 de Abril de 1804. T. 97, fol. 62 v.

948 Ibid. Miércoles 18 de Abril de 1804. T. 97, fol. 63 r.
} 
cincuenta reales de ayuda de costa por una vez, que libró sobre el fondo de Arcas de San Acacio". 949

"Sobre la solicitud de Josef Vasconcelos, músico violinista segundo, oído el informe le concedió el Cavildo por votos secretos, cincuenta pesos, o setecientos cincuenta reales de vellón de ayuda de costa por una vez, que libró contra el fondo de las Arcas de Vacantes de San Acacio”. 950

Muere Mathias Redel, primer violín de la Capilla de Música y que ha sido citado en las actas capitulares en multitud de ocasiones. "El Sr. Segovia dio quenta de la muerte de Mathias Redel, primer violín de la Capilla de Música de esta Santa Iglesia...".951

"Se leyó una carta de el Excelentísimo Señor Gobernador de el Consejo pidiendo se permitiese a Benito Torrellas, músico de esta Santa Iglesia, permanecer en Madrid por algunos meses, y el Cavildo la cometió a los Señores Diputados de Arcas de Vacantes de San Acacio, con la parte de Su Ilustrísima, para que informen sobre su contenido con llamamiento". 952

“El Señor Segovia, dio cuenta de la muerte de Don Matías Redel, primer violín de la Capilla de Música de esta Santa Iglesia. Y el Cavildo dio comisión a los Señores Diputados de Arcas de Vacantes de Santa Inés, con la parte de Su Ilustrísima, para que informen con llamamiento sobre la provisión de esta plaza". 953

“En virtud de el llamamiento para oír el informe de los Señores Comisionados con la parte de Su Ilustrísima y asistencia del Señor Diputado de la Capilla de San Pedro, sobre los medios de facilitar la provisión de las dos Capellanías Vacantes en dicha Capilla, se mandó entrar al notario secretario quien leyó el informe, y habiéndose retirado, expusieron de palabra los Señores Comisionados lo que pensaron

\footnotetext{
${ }^{949}$ Ibid. Miércoles 18 de Abril de 1804. T. 97, fol. 64 v.

${ }^{950}$ Ibid. Miércoles 18 de Abril de 1804. T. 97, fol. 64 v.

${ }^{951}$ Ibid. Jueves 17 de Mayo de 1804, T.97.

${ }^{952}$ Ibid. Lunes 28 de Mayo de 1804. T. 97, fol. 78 v.

${ }^{953}$ Ibid. Lunes 28 de Mayo de 1804. T. 97, fol. 78 v.
} 
por conveniente, y habiendo corrido el voto, acordó el Cavildo adoptar el segundo medio que se propone en el informe, y que se pida a la Real Cámara provenga para la provisión de la segunda Capellanía vacante por muerte de Don Joseph Alverola sin perjuicio de proveerla en el tiempo que falta para cumplir los seis meses de vacante, $y$ que a los pretendientes que han solicitado ayuda de costa para venir, tomen los Señores Comisionados extensión de las circunstancias de su voz, y teniendo informes de que habiéndose alguno o algunos será suficiente para el desempeño de la Capellanía, podrán exigirles que vengan a ser oídos, y que se les dará la ayuda de costa que los mismos Señores comisionados estimen débense dar, (en caso de que no obtengan la Capellanía) a su prudente arbitrio, y atendidas las distancias de los pretendientes, y habiéndose mandado entrar de nuevo al notario secretario, el Señor Presiente le manifestó la resolución y acuerdo de el Cavildo".954

"Sobre la carta de el Excelentísimo Señor Governador de el Consejo, oído dicho informe acordó el Cavildo esperar al músico Torrellas por el tiempo que significa su Excelencia, y conservarle su plaza, conservando a su regreso la voz con que fue admitido a ella".955

“En virtud del llamamiento para oír las pruebas de Don Fermín Espinosa músico provisto en una Capellanía de Santa Inés, se mandó entrar al notario secretario, quien leyó dichas pruebas, y habiéndose retirado, acordó el Cavildo por votos secretos, que están bien hechas”. Por lo tanto se admitió a Don Fermín Espinosa al cual se le mandó entrar al Cavildo, "y puesto de rodillas delante del Señor Presidente, hizo el juramento acostumbrado", 956

Se lee una carta de Don Benito Torrellas, músico, dando gracias al Cabildo por haberle concedio cinco meses de permiso para prolongar su estancia en Madrid. ${ }^{957}$

\footnotetext{
954 Ibid. Martes 29 de Mayo de 1804. T. 97, fol. 79 r.

${ }^{955}$ Ibid. Martes 29 de Mayo de 1804. T. 97, fol. 80 v.

${ }^{956}$ Ibid. Martes 29 de Mayo de 1804. T. 97, fol. $80 \mathrm{v}$.

${ }^{957}$ Ibid. Viernes 8 de Junio de 1804. T. 97, fol. 82 r.
} 
Sobre la ayuda de costa que solicitó Don Juan Nepomuceno Puig, el Cabildo acuerda concederle quinientos reales de vellón de ayuda de costa por una vez. ${ }^{958}$

“Se leyó un memorial de Don Andrés Castilla, Diácono y Segundo Sochantre de la Santa Iglesia de Sevilla, de cuyo Cavildo había obtenido licencia para venir a la oposición de las Capellanías vacantes de San Pedro”. El Cabildo acordó que se le realizara el examen el sábado día 30 de ese mes, los Diputados correspondientes informen una vez terminados los examinadores. ${ }^{959}$

“El Señor Navarro dixo, que era preciso tratar de la provisión de la plaza de obue que servía Don Pablo Bárcena, porque Don Joseph Las, que suplía por el difunto, hacía mucha falta en el desempeño de la plaza de violín para la que se le había admitido en esta Capilla, y el Cavildo acordó dar comisión a los mismos Señores Diputados de Excusados, con la parte de su Ilustrísima, para que en vista de los fondos que tienen en el día los Excusados, se resuelvan los términos en que pueda proveerse la plaza que servía Bárcena”. ${ }^{960}$

Se da cuenta de la muerte de D. Juan Manuel Gaitán, que había sido Maestro de Capilla y actualmente era capellán de San Acacio. “El secretario expuso que D. Juan Gaitan Capellan de San Acacio haviendo fallecido...”. ${ }^{961}$ Gaitán había sido un respetado Maestro de Capilla de la Catedral, y había sido requerido en alguna ocasión para formar parte del tribunal de oposición al Magisterio de Capilla de otras Catedrales. Valga el ejemplo que nos pone López Calo, a raíz de las oposiciones para cubrir la plaza de Maestro de Capilla en la Catedral de Granada en 1775, tras la muerte del anterior Maestro D. Manuel Osete. Estas oposiciones contaron con los Maestros de Toledo y Zaragoza para supervisar los ejercicios, pero también “...se buscó el parecer de un tercer Maestro, el de Córdoba, que era Juan Manuel Gaitán y Arteaga”. 962

\footnotetext{
958 Ibid. Jueves 28 de Junio de 1804. T. 97, fol. 86 r.

${ }^{959}$ Ibid. Jueves 28 de Junio de 1804. T. 97, fol. $86 \mathrm{v}$.

${ }^{960}$ Ibid. Jueves 28 de Junio de 1804. T. 97, fol. 86 v.

${ }^{961}$ Ibid. Jueves 12 de Julio de 1804, T.97.

962 LÓPEZ CALO, José. Catálogo del Archivo de Música de la Catedral de Granada. Centro de Documentación Musical de Andalucía (Junta de Andalucía), Granada 1991, Tomo I. Pag.116.
} 
En el acta de este día se relata el hecho de "haber puesto preso a D. Manuel Valls músico de esta St Iglesia en la Cárcel Episcopal para su debida corrección...”, aunque no especifica los motivos que le llevaron a tal situación. ${ }^{963}$

“A consecuencia de la lectura de un memorial presentado por Don Manuel María Gutiérrez Ravé, músico tenor de esta Santa Iglesia, y Capellán de San Antonino; en que hace presente los crecidos gastos que le ocasiona la gracia de esta Capellanía, siendo tan considerables que no puede atender a ellos, respecto a no haber gozado otro salario que el de cuatrocientos ducados hasta ahora; y solicita que o bien se le haga algún aumento o bien se le dé alguna ayuda de costa”. El Cabildo acordó que informasen al respecto los Diputados de San Antonino y Santa Inés. ${ }^{964}$

Por muerte de Don Juan Manuel Gaitán, que ocupaba una Capellanía de San Acacio, “acordó el Cavildo por votos secretos que quedase admitido por tal servidor el Presbítero Don Gil Moscoso, residente en esta ciudad lo que certifico”. 965

“En continuación del llamamiento dado para que los Señores Diputados de Excusados de música informasen sobre las resultas de la diligencia mandada practicar con Don Manuel Bals, lo executaron expresando el modo, y forma en que lo habían hecho y quedó el Cavildo enterado”. ${ }^{966}$

Don Gil Mosocos, Presbítero, provisto servidero en la Capellanía vacante por muerte de Don Juan Gaitán en la Capilla de San Acacio presta juramento; “con la mano puesta sobre el libro de los Santos Evangelios, con asistencia del notario secretario capitular, y competente número de testigos". ${ }^{967}$

"En virtud del llamamiento para oír el informe de los Señores Diputados de Arcas de Vacantes de San Acacio sobre las pruebas de Don Josef de los Heros, electo

\footnotetext{
963 A.C.C. Actas Capitulares. Martes 21 de Julio de 1804, T.97.

${ }^{964}$ Ibid. Viernes 3 de Agosto de 1804. T. 97, fol. 100 v.

965 Ibid. Sábado 4 de Agosto de 1804. T. 97, fol. 102 r.

${ }^{966}$ Ibid. Miércoles 8 de Agosto de 1804. T. 97, fol. 102 v.

${ }^{967}$ Ibid. Miércoles 8 de Agosto de 1804. T. 97, fol. 103 r.
} 
Capellán de la misma Capilla de San Acacio, agregado a la música en clase de tenor y habiéndose mandado entrar al notario secretario, leyó el informe de los citados Señores, y las declaraciones de los testigos”. El Cabildo dio por bien realizadas dichas pruebas de limpieza de sangre. ${ }^{968}$

"Se leyó un memorial de Don Nicolás Anguita, pidiendo licencia para pasar a Madrid por el tiempo que se le concediese, y el Cavildo acordó darle dos meses perentorios para los fines que propone”. ${ }^{969}$

"Se leyó un memorial presentado por Don Fermín Espinosa y Martínez, Capellán Perpetuo de Santa Inés, solicitando licencia para pasar a su país”. El Cavildo dio comisión a los Diputados de Santa Inés para que informen. ${ }^{970}$

"Se leyó un memorial de Don Vicente Marín, músico de instrumento de la Capilla de esta Santa Iglesia, en que solicita que se le conceda una ayuda de costa en atención al buen desempeño de la Maestría de los Niños de Coro”. Y el Cabildo dio comisión a los Diputados de Excusados de Música para que informasen. ${ }^{971}$

Se leyó un memorial de Don Manuel Álvarez Roldán, actual Sochantre y bajo de Capilla, en el que expone que ha padecido una enfermedad, para cuya convalecencia necesita tomar algún permiso en horas convenientes. El Cabildo da comisión a los Diputados de San Acacio para que informen. ${ }^{972}$

El Cabildo acuerda que para sustituir a Don Manuel Álvarez Roldán que temporalmente se encuentra enfermo, se nombre para las labores de Sochantre a Don Francisco Bono, Capellán de San Pedro. ${ }^{973}$

\footnotetext{
${ }^{968}$ Ibid. Lunes 13 de Agosto de 1804. T. 97, fol. 104 v.

${ }^{969}$ Ibid. Lunes 13 de Agosto de 1804. T. 97, fol. 105 v.

${ }^{970}$ Ibid. Lunes 13 de Agosto de 1804. T. 97, fol. 105 v.

${ }^{971}$ Ibid. Lunes 27 de Agosto de 1804. T. 97, fol. 106 r.

${ }^{972}$ Ibid. Lunes 27 de Agosto de 1804. T. 97, fol. 106 v.

${ }^{973}$ Ibid. Viernes 31 de Agosto de 1804. T. 97, fol. 107 v.
} 
"Se leyó un memorial del bajonista Don Mariano Ortega, pidiendo una ayuda de costa; y se acordó que los Señores Diputados de Música informen con llamamiento lo que se les ofrezca". 974

"Leído el llamamiento para oír el informe de los Señores Diputados de Arcas Vacantes de San Acacio sobre la ayuda de costa que solicita Don Mariano Ortega, en vista de lo que dichos Señores expusieron en su informe, se acordó por votos secretos concederle cincuenta pesos de ayuda de costa del fondo de dichas Arcas". 975

Se leyó un memorial de Don Juan Guerra Ortiz, dando gracias a este Cabildo por haberle nombrado Sochantre interino. ${ }^{976}$

"Se leyó un memorial de Don Joseph Luis de los Heros, Capellán de San Acacio, exponiendo que con motivo de los gastos hechos para sus pruebas, había expedido más de dos mil y cuatrocientos reales y suplica se le conceda una ayuda de costa”. El Cabildo acordó dar comisión a los Diputados de San Acacio para que informen. $^{977}$

“Leído el llamamiento para oír el informe de los Señores Diputados de Arcas de Santa Inés, sobre la solicitud de Don Fermín Espinosa y Martínez, que solicita licencia por dos meses para pasar a Salamanca a hacer oposición, acordó el Cavildo oído dicho informe, se le concedan dichos dos meses". 978

“Se leyó un memorial de Don Benito Torrellas, bajo de la Capilla, en el que expone las circunstancias y atrasos que tiene contraídos para su subsistencia, y no pudiendo salir de esta capital para ir a cumplir los días que le faltan para cumplir en Madrid, y que por otra parte, está para expirar el término de su licencia, remedie su

\footnotetext{
974 Ibid. Viernes 31 de Agosto de 1804. T. 97, fol. 107 v.

975 Ibid. Viernes 7 de Septiembre de 1804. T. 97, fol. 112 v.

${ }^{976}$ Ibid. Viernes 7 de Septiembre de 1804. T. 97, fol. 112 v.

${ }^{977}$ Ibid. Viernes 7 de Septiembre de 1804. T. 97, fol. 112 v.

${ }^{978}$ Ibid. Viernes 7 de Septiembre de 1804. T. 97, fol. 112v.
} 
necesidad e indigencia; y se acordó cometerle a informe de los Señores Diputados de Arcas de Vacantes de San Acacio con la parte de Nuestro Ilustrísimo Prelado". ${ }^{979}$

“Sobre la pretensión del músico instrumento Don Vicente Marín; se acordó, que por una vez se le den cincuenta pesos por vía de ayuda de costa". 980

"Se leyó el llamamiento dado por los Señores Diputados de Arcas de San Acacio, para oír el informe sobre las pretensiones de Don Manuel Álvarez, acerca de su licencia de patitur abierto, y remisión de aspas, y recles, y ayuda de costa; en su virtud acordó el Cavildo que sin el menor retardo, se pase a la Diputación del punto de horas canónicas el decreto en que fue nombrado Sochantre interino, a fin de que el Señor Diputado del Mes, disponga el correspondiente cuadrante en que se le punten las faltas como tal Sochantre interino, y debiendo éstas señalasse con aspas, perderá por ahora la parte que a prorrata le quepa en cada día por el salario total; igualmente le concedía y concedió el Cavildo licencia de patitur abierto desde el veinte de Septiembre último hasta fin de Noviembre, dejando a su arbitrio y conciencia el uso de esta gracia sin tocar el punto de aspas, un recles; y que de los fondos de las mismas Arcas se le den por una vez y por vía de ayuda de costa mil reales de vellón”. 981

“Acerca de las pretensiones de Don Benito Torrellas, bajo de Capilla, acordó el Cavildo que por ahora no se admita a cantar a este Ministro en el Coro, ni fuera de él, respecto a no estar habilitado con la anuencia del Excelentísimo Señor Gobernador del Consejo, y que en atención a no tener medios eficaces para solicitar su libertad, se dé comisión a los mismos Señores, a fin de que representen a dicho Señor para que le conceda esta gracia, la cual obtenida, deberá probarse su voz nuevamente para ver si subsiste o á decaído; y en consideración a las actuales circunstancias y a su indigencia el Cavildo le consignó por una vez mil y quinientos reales por vía de ayuda de costa". ${ }^{982}$

\footnotetext{
${ }^{979}$ Ibid. Miércoles 3 de Octubre de 1804. T. 97, fol. 126 r.

${ }^{980}$ Ibid. Miércoles 17 de Octubre de 1804. T. 97, fol. 127 r.

${ }^{981}$ Ibid. Miércoles 17 de Octubre de 1804. T. 97, fol. 128 r.

${ }^{982}$ Ibid. Miércoles 17 de Octubre de 1804. T. 97, fol. 128 r.
} 
"Se leyó un memorial del músico instrumentista Don Francisco Ferrer, solicitando aumento de sueldo; y el Cavildo lo cometió a informe de los Señores Diputados de Arcas de Vacantes de Santa Inés". 983

"Se leyó un memorial de Don Mateo Bernia, músico de voz, solicitando licencia de patitur abierto en atención a sus males habituales; y se acordó cometerlo a informe de los Señores Diputados de Arcas de Vacantes de Santa Inés”. 984

"Se leyó previo el correspondiente llamamiento, el informe de los Señores Diputados de Arcas de Vacantes de Santa Inés, con la parte de su Ilustrísima, sobre la licencia de patitur abierto que solicita el músico Don Mateo Bernia; y en su vista acordó el Cavildo en atención a su edad, achaques habituales y servicios prestados en el espacio de treinta y ocho años, concederle y le concedió la licencia por tiempo de un año, dejando a su prudencia y conciencia la asistencia al Coro, cuando aquellas causas se lo permitan". 985

Los Diputados del Colegio del Santo Ángel, de Niños de Coro, informan al Cabildo de que algunos Infantes de Coro han estado enfermos de alguna enfermedad contagiosa, que habían sido trasladados al hospital a fin de evitar que el contagio se propagara. El Cabildo acordó que una vez regresen al colegio éste sea desinfectado y los niños estén allí resguardados sin salir a la calle hasta que el Cabildo dé su autorización. ${ }^{986}$

“Leído el llamamiento para oír el informe de los Señores Diputados de Arcas de Vacantes de Santa Inés, sobre la solicitud de Don Francisco Ferrer músico instrumentista, se procedió igualmente a la lectura de dicho informe, y por votos secretos se acordó darle cien pesos de ayuda de costa del fondo de dichas Arcas, y del mismo señalar otros cien pesos anuales a su hermano Don Mariano, mediante su singular habilidad en la trompa, con la obligación de asistir a la capilla de Música,

\footnotetext{
983 Ibid. Miércoles 17 de Octubre de 1804. T. 97, fol. 128 v.

${ }^{984}$ Ibid. Martes 23 de Octubre de 1804. T. 97, fol. 129 v.

985 Ibid. Viernes 26 de Octubre de 1804. T. 97, fol. 130 v.

${ }^{986}$ Ibid. Lunes 29 de Octubre de 1804. T. 97, fol. 131 v.
} 
como su hermano, y perfeccionarse cada día más en su profesión”. Asimismo se presentó un memorial de Don Nicolás Anguita “pidiendo prórroga de la licencia que le está concedida, y se cometió a informe de los Señores Diputados de Arcas de San Acacio con la parte de Su Ilustrísima”, ${ }^{987}$

"Se leyó un memorial de Don Joseph Bach, segundo organista y Don Julián Gálvez, músico instrumentista, pidiendo se les pague en especie el grano, que les corresponde por el tercio cumplido en fin de octubre". 988

Se presenta el músico Don Fructuoso Gómez, violinista supernumerario de la Catedral de Sevilla, que iba de viaje hacia Valladolid, a hacer una oposición. Dicho violinista solicita al Cabildo ser oído, y este acuerda que efectivamente lo sea advirtiéndole no obstante que no podrá reclamar ayuda de costa ni otra solicitud por el momento. ${ }^{989}$

"Se presenta un memorial de Don Antonio Gil, Capellán de San Acacio, solicitando se le disimule la tardanza en venir a esta ciudad a cumplir con su obligación mediante las circunstancias actuales y medidas tomadas por la Junta de Sanidad, y mediante a que dicho Capellán se ausentó sin licencia”. El Cabildo acordó pasarle esta información a los Diputados de San Acacio, pidiéndoles asimismo que tengan en cuenta "el modo que a tenido dicho Capellán de ausentarse y los acuerdos que han motivado las facilidades con que deja su obligación cuando le parece, sin pedir a nadie licencia”. 990

“El Señor Penitenciario hizo presente que el músico Don Vicente Marín tiene un hijo capaz de tocar muy bien el violoncelo, y siendo su padre acreedor a que se le atienda como a otros, proponía al Cavildo se le diese plaza como a Don Mariano

\footnotetext{
${ }^{987}$ Ibid. Lunes 5 de Noviembre de 1804. T. 97, fol. 133 v.

${ }^{988}$ Ibid. Miércoles 7 de Noviembre de 1804. T. 97, fol. 134 v.

${ }^{989}$ Ibid. Jueves 8 de Noviembre de 1804. T. 97, fol. 136 r.

${ }^{990}$ Ibid. Sábado 10 de Noviembre de 1804. T. 97, fol. 136 v.
} 
Ferrer; el Cavildo dio comisión a los Señores Diputados de Arcas de San Acacio con la parte de Su Ilustrísima para que informen con Ilamamiento". 991

"Se leyó un memorial de Don José Las, músico instrumentista solicitando se le quiten las aspas que se le han puesto en los cuadrantes; se cometió a informe de los Señores Diputados de Arcas Vacantes de Santa Inés con la parte de su Ilustrísima”. 992

Se leyó un memorial de Don Juan Nepomuceno Puig, bajonista, aunque no se especifica qué solicitaba dicho músico. ${ }^{993}$

“Relativo a las solicitudes de Don Antonio Gil y Don Nicolás Anguita, mediante no encontrarse mérito para conceder gracia alguna al Don Antonio Gil, porque se ausentó sin causa, ni licencia y debe sufrir la pena de su trasgresión, hasta que se restituya a su residencia: ni tampoco hallase causa para conceder igual gracia de ausencia al señor Don Nicolás Anguita por motivo de la Salud Pública, se acordó conformarse con dicho informe, y que por los Señores Puntadores se aspe al Don Antonio Gil con arreglo a la constitución de la Capilla y a Don Nicolás Anguita se le cuente lo mismo en los días que falte al cumplimiento de su obligación”. 994

“Se leyó una carta del Excelentísimo Señor Conde de Montarco, Gobernador del Consejo, contestando a la pregunta que se hizo a Su Excelentísima en 21 del pasado octubre sobre el músico Don Benito Torrellas, que dicho músico puede servir libremente la plaza de bajo de la Capilla de esta Iglesia, mediante haber concluido el término de cinco meses, que se pactó para desempeñar la parte de cantado, que le cupo en el teatro de Los Caños del Peral”. 995

"Se leyó un memorial de Don Fermín Espinosa Martínez, acompañado de un testimonio con que acredita haber sido nombrado para una media ración de contralto

\footnotetext{
991 Ibid. Sábado 10 de Noviembre de 1804. T. 97, fol. 136 v.

992 Ibid. Martes 13 de Noviembre de 1804. T. 97, fol. 138 v.

993 Ibid. Sábado 24 de Noviembre de 1804. T. 97, fol. 139 v.

${ }^{994}$ Ibid. Sábado 24 de Noviembre de 1804. T. 97, fol. 140 v.

${ }^{995}$ Ibid. Sábado 24 de Noviembre de 1804. T. 97, fol. 140 v.
} 
en la iglesia de Salamanca, por cuya causa queda vacante la Capellanía de Santa Inés, que obtenía en nuestra Santa Iglesia”. 996

Sobre la incorporación nuevamente a la Capilla de Música de Don Benito Torrellas, el Cabildo decide aceptarla. ${ }^{997}$

“Habiéndose presentado un memorial por Don Pascual Redel, violinista de la Capilla de Música de esta Iglesia, exponiendo sus servicios, solicita en él, que en atención a ellos se le conceda una ayuda de costa; y en su vista acordó el Cavildo cometerle y cometió a informe de los Señores Diputados de Arcas Vacantes de San Acacio". 998

Sobre las pretensiones del músico instrumentista Don Joseph Las el Cabildo acordó concederle licencia de patitur abierto por tiempo de un mes, asimismo le concedió una ayuda de costa de cien ducados. ${ }^{999}$

El Cabildo concede al músico tenor Don Manuel Gutiérrez Ravé una ayuda de costa de tres mil reales de vellón. Asimismo concede al músico violinista Don Lope de Mora otra ayuda de costa por valor dos mil reales de vellón. ${ }^{1000}$

"Se leyó un llamamiento dado por los Señores Diputados de Excusados con la parte de Nuestro Ilustrísimo Prelado, sobre la solicitud del segundo organista (Josef Bach) y el músico instrumentista Don Julián Gálvez, respecto a que se les pague en especie de trigo el tercio vencido a fin de octubre último; y oído el informe de dichos Señores, acordó el Cabildo que el receptor de este ramo pague en especie de trigo a estos Ministros el expresado tercio a fin de octubre”. ${ }^{1001}$

\footnotetext{
${ }^{996}$ Ibid. Sábado 24 de Noviembre de 1804. T. 97, fol. 141 r.

${ }^{997}$ Cf. Ibid. Martes 27 de Noviembre de 1804. T. 97, fol. 143 r.

${ }^{998}$ Ibid. Lunes 3 de Diciembre de 1804. T. 97, fol. 145 v.

${ }^{999}$ Ibid. Miércoles 9 de Diciembre de 1804. T. 97, fol. 146 r.

${ }^{1000}$ Ibid. Miércoles 19 de Diciembre de 1804. T. 97, fol. 149 r.

${ }^{1001}$ Ibid. Sábado 22 de Diciembre de 1804. T. 97, fol. 149 r.
} 
El Cabildo concede al bajonista Don Juan Puig, una ayuda de costa por valor de mil reales de vellón. Asimismo "el Señor Deán dixo que hallándose vacante una plaza de oboe en esta Santa Iglesia, y debiéndose proveer para el complemento de la Capilla de Música, en dictamen del Maestro de ella, no estando asegurado de que en los fondos de Excusados hubiese lo suficiente para su dotación, pidió que se diese la correspondiente comisión para el efecto; y en su vista acordó el Cabildo que los Señores Diputados de Excusados con la parte de Nuestro Ilustrísimo Prelado, informen si en el fondo de Excusados hay disposición para dotar competentemente la plaza de oboe vacante". 1002

“Acordó el Cavildo aumentar con doscientos ducados anuales la renta del músico tenor Don Josef Moyano”. Asimismo el Señor Segovia pidió que la comisión formada para evaluar los posibles cambios en los sueldos de la Capilla traiga sus resoluciones el segundo día de oficios del mes de febrero próximo. Por último el Cavildo concedió al violinista Don Lope de Mora una ayuda de costa de dos mil reales de vellón. ${ }^{1003}$

El Cabildo concede al músico Don Josef de los Heros 2633 reales de vellón de ayuda de costa, en consideración a los gastos de sus pruebas de limpieza de sangre. Asimismo se leyó un memorial de Don Francisco Cascante solicitando ayuda de costa, por el que el Cabildo cometió a informe de los Señores Diputados de Arcas Vacantes de Santa Inés, dicha petición. ${ }^{1004}$

\section{5}

“Se leyó un memorial de Don Mateo Tascón, bajonista, pidiendo una ayuda de costa, y se cometió a informe de los Señores Diputados de Excusados de Música con la parte de Su Ilustrísima para que informen con llamamiento”. ${ }^{1005}$

\footnotetext{
1002 Ibid. Sábado 22 de Diciembre de 1804. T. 97, fol. 149 v.

1003 Ibid. Sábado 22 de Diciembre de 1804. T. 97, fol. 150 v.

${ }^{1004}$ Ibid. Sábado 22 de Diciembre de 1804. T. 97, fol. 151 r.

${ }^{1005}$ Ibid. Lunes 14 de Enero de 1805. T. 97, fol. 152 r.
} 
"Se leyó un memorial de Don Mariano Ortega, bajonista, pidiendo una ayuda de costa, y se mandó pasar a los Señores Diputados de Arcas de San Acacio para que con la parte, informen con llamamiento". ${ }^{1006}$

"Se presentó un memorial de Don Joseph Las, músico instrumentista, pidiendo patitur abierto, y se cometió a informe con llamamiento de los Señores Diputados de Arcas Vacantes de Santa Inés.

Item. En virtud del llamamiento para oír el informe de los Señores Diputados de las mismas Arcas sobre la dimisión hecha por Don Fermín Espinosa, provisto de una media ración en Salamanca se acordó admitir la dimisión de la Capellanía de Santa Inés, que gozaba, declarada por vacante, y que se fijen edictos para su provisión con término de sesenta días”. ${ }^{1007}$

El Cabildo concede a don Mateo Tascón una ayuda de costa de cien ducados, del fondo de Excusados de Música. ${ }^{1008}$

El Cabildo concede a Don José Las, "patitur abierto desde el día en que concluyó la anterior concesión, hasta el sábado de Ramos inclusive”. ${ }^{1009}$

El Cabildo concede a Don Pascual Redel, una ayuda de costa de dos mil reales de vellón de los fondos de Arcas de San Acacio. ${ }^{1010}$

"Se leyó un memorial de Fructuoso Gómez, músico violinista, pidiendo se le viese ejercitar en su instrumento, y se cometió a informe de los Señores Diputados de Arcas de Santa Inés, con la parte de Su Ilustrísima, para que lo hagan con llamamiento". 1011

\footnotetext{
${ }^{1006}$ Ibid. Miércoles 16 de Enero de 1805. T. 97, fol. 153 v.

${ }^{1007}$ Ibid. Miércoles 16 de Enero de 1805. T. 97, fol. 154 r.

${ }^{1008}$ Ibid. Martes 22 de Enero de 1805. T. 97, fol. 155 r.

${ }^{1009}$ Ibid. Martes 22 de Enero de 1805. T. 97, fol. 155 v.

${ }^{1010}$ Ibid. Jueves 24 de Enero de 1805. T. 97, fol. 157 r.

${ }^{1011}$ Ibid. Jueves 24 de Enero de 1805. T. 97, fol. 157 r.
} 
"Se leyó un memorial de Juan de Mora, Acólito, pidiendo una ayuda de costa por los ocho meses que ha hecho de pertiguero y se mandó pasar a los Señores Diputados de Acólitos, para que informen con llamamiento". ${ }^{1012}$

"Se dio cuenta del memorial presentado por el Capellán de Santa Inés Don Rafael del Río, en que solicita se le conceda una ayuda de costa en atención a las circunstancias de los tiempos, y en su vista acordó el Cavildo cometerle a informe con llamamiento de los Señores Diputados de Arcas de Santa Inés con la parte de Nuestro Ilustrísimo Prelado". ${ }^{1013}$

“En continuación zeló el Señor Prior que hallándose vacantes dos plazas en la música instrumental, a saber la de primer violín, y otra de las inferiores de esta misma clase, pedía con todas las formalidades legales, que de ninguna suerte se procediese a dar paso alguno respectivo a su provisión ni aún por vía de interín, sin que preceda la fixación de edictos, según y como se hacía para las demás plazas de voz y de instrumento, practicándose en su consecuencia la oposición correspondiente entre los que se presentaran a virtud de la convocatoria por edictos: en su vista el Cavildo acordó dar comisión a los Señores Diputados de Arcas de la Capilla de Santa Inés para que respecto a haber cesado la epidemia procedan con la parte de Nuestro Prelado a disponer los edictos y demás que convenga”. 1014

"Se leyó un memorial del violinista Don Joseph de Vasconcelos y Melo, vulgo El Portugués, en solicitud de que se le conceda una ayuda de costa en atención a las actuales circunstancias de escasez y carestía de víveres de primera necesidad, y en su vista acordó el Cavildo cometerle a informe de los Señores Diputados de Arcas de San Acacio". 1015

“El Señor Escanero, zeló que los Niños de Coro usaban muchas veces unas sobrepellices indecentes por sucias, o rasgadas y rotas, y que gastaban o usaban de la

\footnotetext{
${ }^{1012}$ Ibid. Sábado 26 de Enero de 1805. T. 97, fol. 158r.

${ }^{1013}$ Ibid. Martes 5 de Febrero de 1805. T. 97, fol. 162 r.

${ }^{1014}$ Ibid. Martes 5 de Febrero de 1805. T. 97, fol. 162 r.

${ }^{1015}$ Ibid. Martes 9 de Febrero de 1805. T. 97, fol. 161 v.
} 
moda en el corte de pelo; en su consecuencia acordó el Cavildo que dándose la necesaria inteligencia a los Señores Diputados dispongan que se reformen desde luego en punto a el pelo encargando y previniendo al Rector este cuidado y el de las sobrepellices de suerte que siempre salgan al público con la posible limpieza, aseo y decencia”. 1016

“Leyose un memorial del tiple Don Alfonso Martín, Presbítero, en el que expone sus méritos y servicios de treinta y nueve años en el Coro, y solicita se le aumente su salario en su vista acordó el Cavildo que informen con llamamiento los Señores Diputados de Arcas de Vacantes de San Acacio lo que se les ofrezca previo Ilamamiento". 1017

"Se leyó el llamamiento para oír el informe de los Señores Diputados de Arcas de Santa Inés con la parte de Nuestro Ilustrísimo Prelado, sobre la solicitud de Don Fructuoso Gómez, violinista, y en su vista conformándose el Maestro con dicho informe acordó que se le oiga en la tarde de mañana jueves catorce del corriente, y que en su virtud informe el Maestro de Capilla lo que resulte; sin más suceso por ahora”. "Item se continuó el llamamiento que leyó el dado por los mismos Señores Diputados de Arcas de Santa Inés, sobre el modo de proveer la sirvientía de la Capellanía Vacante por la promoción de Don Fermín Espinosa; y habiéndose conferenciado lo conveniente acerca de este punto, se acordó por votos secretos, que se sortease entre los señores presentes; y habiendo entrado el notario secretario capitular con las cédulas, se certificó la suerte en el Señor Don Ramón Riera, y vuelto a entrar el notario secretario se le hizo así entender por el Señor Presidente, de que certificó”. ${ }^{1018}$

El Cabildo le concede a Don Francisco Cascante, una ayuda de costa de veinticinco doblones, con la condición de que pague al Cabildo lo que debe por el arrendamiento de la casa en que vive. ${ }^{1019}$

\footnotetext{
1016 Ibid. Miércoles 13 de Febrero de 1805. T. 97, fol. 162 v.

${ }^{1017}$ Ibid. Miércoles 13 de Febrero de 1805. T. 97, fol. 164 r.

1018 Ibid. Miércoles 13 de Febrero de 1805. T. 97, fol. 164 v.

1019 Ibid. Viernes 15 de Febrero de 1805. T. 97, fol. 165v.
} 
“Leyose el llamamiento dado por los Señores Diputados de Arcas de Vacantes de Santa Inés, para oír la censura del Maestro de Capilla sobre la suficiencia del violinista Fructuoso Gómez, en su consecuencia precedido el toque de campanilla, se mandó entrar a el expresado Maestro de Capilla, y leyó la censura que había dispuesto; retirado, se trató largamente acerca de la admisión de este sujeto; y por el Cavildo acordó por uniformidad de votos, que se aprueben los exercicios a Gómez, teniendo presente su suficiencia para lo hubiere en las oposiciones acordadas para las plazas de violín, y sus resultas; y en atención a haber servido algunos días incorporado por la Capilla de Música, acordó concederle, y le concedió una ayuda de costa de mil reales de vellón, que certifico". 1020

"Sobre la solicitud del oboe Don Manuel Valls y Carlien, y en su vista, habiéndose conferenciado acerca de si debía hacerse aumento de sueldo a este Ministro, o había de concedérsele una ayuda de costa; se acordó por pelotas, que fuese lo segundo; y repartidas nuevamente, resultó que se le concedieron por una vez sobre los fondos de Excusados, cien ducados de vellón, y así quedó acordado”. ${ }^{1021}$

"Se leyó un memorial del trompa Don Mariano Ferrer, sobre que se conceda una ayuda de costa a su hermano Don Francisco, en atención a la escasez y carestía de los víveres; y se acordó cometerle a informe de los Señores Diputados de Arcas de Santa Inés con la parte de Su Ilustrísima, de que certifico”. ${ }^{1022}$

El Cabildo concede a Don José Vasconcelos y Melo, una ayuda de costa de cien ducados del fondo de Arcas de San Acacio. ${ }^{1023}$

“Se leyó un memorial de Don Antonio Gil, Capellán de San Acacio, solicitando condonación de las aspas en que incurrió por su ausencia, y una ayuda de costa, y se mandó pasar a los Señores Diputados de Arcas de San Acacio con la parte para que informen con llamamiento. Igualmente se dio parte de la solicitud del contralto Don

\footnotetext{
${ }^{1020}$ Ibid. Miércoles 20 de Febrero de 1805. T. 97, fol. 166 v.

${ }^{1021}$ Ibid. Jueves 21 de Febrero de 1805. T. 97, fol. 167 r.

1022 Ibid. Jueves 21 de Febrero de 1805. T. 97, fol. 167 v.

${ }^{1023}$ Ibid. Jueves 14 de Marzo de 1805. T. 97, fol. 172 v.
} 
Nicolás Anguita sobre el mismo asunto, y se cometió a informe de los Señores Diputados con la parte”. ${ }^{1024}$

El Cabildo ratifica el sueldo de Don Juan Guerra, Capellán de San Pedro, en cuatrocientos ducados. Asimismo el Cabildo solicita a los Señores Diputados de Arcas de Vacantes de San Acacio un informe "sobre si hay algún acuerdo relativo a el señalamiento de salario hecho a Álvarez [se refiere a Don Manuel Álvarez, Sochantre] como bajo de Capilla, o debe hacerlo como Capellán de San Pedro". ${ }^{1025}$

“Se leyó un llamamiento dado por los Señores Diputados del Colegio del Santo Ángel para oír su informe sobre los medios de entablar en él mejor régimen; en su consecuencia se trató y conferenció este punto con la detención que exige la materia, corriendo el voto por todos los Señores que se hallaron presentes, y resultando ser diferentes los dictámenes, se acordó renovar la comisión en favor de los mismos Señores Diputados con facultades amplias a fin de que puedan tratar y traten con los demás Cavildos sobre el desempeño actual, y dotación sucesiva que deberá tener este Colegio, informando con llamamiento sobre los puntos de reforma del mismo en lo económico, y moral con lo demás que dichos Señores estimasen”. 1026

El Cabildo le concede a Don Francisco Ferrer, músico trompa, una ayuda de costa de veinticinco doblones. ${ }^{1027}$

El Cabildo concede a Don Rafael del Río y Don Francisco de Borja, músicos, respectivas ayudas de costa por la cantidad de cien ducados a cada uno de ellos. Asimismo el músico Don Joseph Las pidió que se amplíe por más tiempo la licencia de patitur abierto que disfruta, y el Cabildo cometió dicha solicitud a los Diputados de Arcas de Santa Inés. Por último el Señor Segovia presentó la cuenta de gastos que le

\footnotetext{
${ }^{1024}$ Ibid. Jueves 14 de Marzo de 1805. T. 97, fol. 172 v.

1025 Ibid. Martes 2 de Abril de 1805. T. 97, fol. 184 v.

${ }^{1026}$ Ibid. Lunes 22 de Abril de 1805. T. 97, fol. $186 \mathrm{v}$.

${ }^{1027}$ Ibid. Viernes 26 de Abril de 1805. T. 97, fol. 188 v.
} 
había entregado el músico Don Francisco Ferrer, por un viaje a Cádiz para comprar trompas y clarines, decidiendo el Cabildo que se le abonaran. ${ }^{1028}$

"Se leyó un memorial de Don Vicente Marín, pidiendo una ayuda de costa en atención a su actual enfermedad, y se acordó cometerla a informe de los Señores Diputados de Excusados de Fábrica con la parte de la dignidad Episcopal. Últimamente se leyó otro memorial de los Acólitos en que repiten su pretensión de aumento de salario, y se acordó que los Señores Diputados informen con llamamiento y con la parte”. ${ }^{1029}$

El Cabildo concede a Don Vicente Marín, músico instrumentista una ayuda de costa de cien ducados de vellón sobre los fondos de Excusados de Fábrica. ${ }^{1030}$

“Se leyó un memorial de Don Francisco Güentos, violinista, pidiendo licencia para hacer oposición a la plaza de primer violín de esta Santa Iglesia, y se acordó se le oiga el miércoles 8 del corriente después de Completas, y a su tiempo informe el Maestro de Capilla de su mérito". 1031

"Se acordó por votos secretos conceder a Don Antonio Gil una ayuda de costa por una vez de mil quinientos reales del fondo de dichas Arcas [de San Acacio]: a Don Nicolás Anguita mil reales en los mismos tiempos y a Don Alfonso Martín en atención a sus largos y buenos servicios, arreglada conducta y corta dotación que ha obtenido hasta aquí, trescientos ducados”. ${ }^{1032}$

"Se dio cuenta de un memorial de Don Manuel Álvarez, Sochantre interino pidiendo una ayuda de costa y se acordó pase a los Señores Diputados de Arcas de San Acacio y que informen con llamamiento". ${ }^{1033}$

\footnotetext{
${ }^{1028}$ Ibid. Sábado 27 de Abril de 1805. T. 97, fol. 190 r.

1029 Ibid. Sábado 27 de Abril de 1805. T. 97, fol. 190 r.

${ }^{1030}$ Ibid. Jueves 2 de Mayo de 1805. T. 97, fol. 192 r.

1031 Ibid. Lunes 6 de Mayo de 1805. T. 97, fol. 194 r.

1032 Ibid. Lunes 13 de Mayo de 1805. T. 97, fol. 200 r.

1033 Ibid. Sábado 25 de Mayo de 1805. T. 97, fol. 202 v.
} 
“Se leyó un memorial de Don Mateo Bernia, Capellán de Santa Inés pidiendo aumento de renta o ayuda de costa y se mandó pasar a los Señores Diputados de Arcas de Santa Inés con la parte de la Dignidad Episcopal para que informen con llamamiento". 1034

El Cabildo le concede a don Mariano Ortega, bajonista, una ayuda de costa de mil quinientos reales por una vez del fondo de Arcas de San Acacio. ${ }^{1035}$

"Se leyó un memorial del violinista Lope de Mora, pidiendo aumento de salario y se cometió a informe de los Señores Diputados de Arcas Vacantes de San Acacio con la parte de la Dignidad Episcopal para que lo verifiquen con Ilamamiento". ${ }^{1036}$

“Sobre la solicitud de continuación de patitur de Don Joseph Las, leído el expresado informe y manifestado los Señores Diputados haberse informado del médico que le ha asistido de que estaba capaz de desempeñar su obligación, se acordó que desde el sábado 1 de junio de este año de presente a cumplir con su plaza, y en atención a los muchos gastos, que le han seguido por sus males, se determinó por votos secretos darle cuarenta ducados de ayuda de costa". ${ }^{1037}$

"Sobre la asignación de salario al primer violín de la Capilla, expusieron verbalmente los Señores Comisionados cuanto tuvieron por conveniente, y corrido el voto se acordó señalar ochocientos ducados de salario al primer violín”. Asimismo el Cabildo acordó fijar los edictos para cubrir dicha plaza por término de sesenta días. Igualmente el Señor Deán expuso la necesidad que había de cubrir una plaza de tiple en la Capilla de Música, por lo que se renovó la comisión de los Diputados correspondientes para que realicen las diligencias al efecto. ${ }^{1038}$

\footnotetext{
${ }^{1034}$ Ibid. Sábado 25 de Mayo de 1805. T. 97, fol. 202 v.

1035 Ibid. Martes 28 de Mayo de 1805. T. 97, fol. 204 r.

1036 Ibid. Martes 28 de Mayo de 1805. T. 97, fol. 204 r.

1037 Ibid. Miércoles 29 de Mayo de 1805. T. 97, fol. 206 r.

1038 Ibid. Miércoles 29 de Mayo de 1805. T. 97, fol. 206 r.
} 
"Se dio cuenta de un memorial de Don Julián Gálvez, músico instrumentista, pidiendo ayuda de costa, y se mandó pasar a informe de los Señores Diputados de Excusados de Música con la parte de la dignidad Episcopal para que informen con llamamiento". 1039

“Sobre las solicitudes de Don Manuel Álvarez y Don Lope de Mora, se pasó a votar secretamente leído dicho informe sobre una y otra, y salió negada la ayuda de costa que pretendía Don Manuel Álvarez, y a Don Lope de Mora se le concedieron ciento cincuenta ducados de aumento de sueldo". ${ }^{1040}$

“Se leyó un memorial de Don Nicolás Anguita pidiendo licencia para pasar a ordenarse de Subdiácono a Jaén, y se acordó darle la expresada licencia quedando sujeto a las aspas en que incurra según costumbre”. ${ }^{1041}$

"Se presentó un memorial de Don Francisco Ferrer, primer trompa de la Capilla de Música, pidiendo aumento de salario, y se acordó pase a los Señores Diputados de Arcas Vacantes de Santa Inés con la parte de la Dignidad Episcopal para que informen con llamamiento". ${ }^{1042}$

"Sobre el aumento de sueldo que tiene solicitado el músico trompa Don Francisco Ferrer, y después de haberse conferenciado largamente sobre si había o no de determinarse por la comisión que está pendiente relativa a los sueldos de los músicos, o se debería suspender hasta evacuarla, se acordó que por ahora no se admita solicitud de esta clase, y que la citada comisión se traiga al primer día de oficios; y todo sea y se entienda sin perjuicio de cien ducados de aumento a favor de Ferrer, que deberán corresponderle desde esta fecha”. ${ }^{1043}$

\footnotetext{
${ }^{1039}$ Ibid. Lunes 10 de Junio de 1805. T. 97, fol. 209 r.

${ }^{1040}$ Ibid. Lunes 10 de Junio de 1805. T. 97, fol. 209 v.

${ }^{1041}$ Ibid. Lunes 10 de Junio de 1805. T. 97, fol. 210 r.

1042 Ibid. Lunes 10 de Junio de 1805. T. 97, fol. 210 r.

1043 Ibid. Sábado 22 de Junio de 1805. T. 97, fol. 213 v.
} 
El Cabildo le concede a Don Julián Gálvez, una ayuda de costa de cincuenta ducados de vellón. ${ }^{1044}$

“Sobre la licencia de patitur abierto que pretende Don Manuel Álvarez Roldán, se acordó concederle esta gracia en atención a sus enfermedades hasta la Asunción de Nuestra Señora, 19 de Agosto venidero". 1045

“Se leyó una carta de Joseph Álvarez, primer violín de la Catedral de Plasencia, por el que suplica a V.S. que atendiendo a la rigurosa estación del tiempo, se digne tenerle presente si no se proveiese al fin del concurso la plaza de primer violín de esta Santa Iglesia. El Cavildo acordó dar y dio comisión a los Señores Diputados de Arcas Vacantes de Santa Inés para que con la parte de la Dignidad Episcopal, informen con llamamiento sobre esta solicitud". ${ }^{1046}$

“Se leyó un memorial de Don Miguel Reynaldi, primer violín en la Capilla de la Encarnación de Madrid, en el que suplica a V.S. se sirva mandar se le avise de todo, y siempre que se abonen los gastos del viaje vendrá a que V.S. lo oiga. El Cavildo acordó dar y dio comisión a los Señores Diputados de Arcas Vacantes de Santa Inés para que con la parte de la Dignidad Episcopal informen con llamamiento”. ${ }^{047}$

Se leyó un memorial de Don Benito Torrellas, bajo de la Capilla de Música, en el que solicita una ayuda de costa. Se dio comisión a los Diputados correspondientes para que informasen. ${ }^{1048}$

El Cabildo concede al Acólito Joseph Villalba una ayuda de costa de doscientos reales de vellón. ${ }^{1049}$

\footnotetext{
1044 Ibid. Miércoles 26 de Junio de 1805. T. 97, fol. 214 r.

1045 Ibid. Viernes 5 de Julio de 1805. T. 97, fol. 217 v.

${ }^{1046}$ Ibid. Miércoles 17 de Julio de 1805. T. 97, fol. 222 r.

${ }^{1047}$ Ibid. Miércoles 24 de Julio de 1805. T. 97, fol. 234 v.

1048 Ibid. Lunes 29 de Julio de 1805. T. 97, fol. 227 v.

1049 Ibid. Miércoles 31 de Julio de 1805. T. 97, fol. 228 r.
} 
El Acólito Francisco Ahumada solicita que se le perdonen las aspas causadas en un viaje que hizo a Granada para hacer una oposición. El Cabildo dio comisión a los Diputados de San Acacio para que informasen con llamamiento. ${ }^{1050}$

"Sobre la solicitud del Acólito Francisco Ahumada relativa a que no se le recibiesen en cuenta las aspas causadas en un viaje que hizo para hacer oposición a una plaza de música en la Catedral de Granada, el Cavildo siguiendo su laudable costumbre en este punto, acordó no haber lugar a el descuento y remisión de dichas aspas; pero usando de su acostumbrada benignidad, en continuación de el mismo dato, decidió por votos secretos concederle por una vez cien reales de ayuda de costa para que pudiese resarcir la quiebra que resultase de las ya mencionadas aspas”. ${ }^{1051}$

"Se leyó un memorial de Don Manuel Valls, músico obue en la Capilla de esta Santa Iglesia, en el que suplica a V.S. se sirva aumentarle la renta, mandando sea de las Arcas de Santa Inés, el Cavildo conferenciado este punto acordó no dar lugar la solicitud del dicho Don Manuel Valls”. ${ }^{1052}$

"Sobre la ayuda de costa que solicita Joseph Jaén, Acólito de esta Santa Iglesia, oído que fue dicho informe se procedió a votar por votos secretos, y el Cavildo le concedió doscientos reales de ayuda de costa por una vez al dicho Joseph Jaén”. ${ }^{053}$

"Se leyó un informe de los Diputados de San Acacio sobre la ayuda de costa que solicita Don Benito Torrellas, bajo de esta Capilla, y habiéndose votado por votos secretos el Cavildo le concedió por una vez cincuenta ducados”. ${ }^{1054}$

"Se leyó el llamamiento para oír la censura del Maestro de Capilla acerca de los opositores a la plaza de primer violín de esta Santa Iglesia. Y oídas que fueron se

\footnotetext{
1050 Ibid. Sábado 3 de Agosto de 1805. T. 97, fol. 237 r.

1051 Ibid. Lunes 12 de Agosto de 1805. T. 97, fol. 237 v.

1052 Ibid. Lunes 5 de Septiembre de 1805. T. 98, fol. 4 v.

${ }^{1053}$ Ibid. Miércoles 7 de Septiembre de 1805. T. 98, fol. 5 r.

${ }^{1054}$ Ibid. Miércoles 7 de Septiembre de 1805. T. 98, fol. 6 r.
} 
procedió a la votación por cédulas, y salió provisto por todos votos en la plaza de primer violín de esta Santa Iglesia Don Miguel Reynaldi”. ${ }^{1055}$

"Sobre la ayuda de costa que solicita Rafael Morales, Acólito de esta Santa Iglesia, y leído que fue el informe, el Cavildo por votos secretos le concedió 200 reales de ayuda de costa por una vez". ${ }^{1056}$

Una vez elegido Don Miguel Reynaldi como primer violín de la Capilla de Música, los otros tres opositores a dicha plaza solicitan una ayuda de costa. Dichos opositores fueron Don Cecilio Castaño, Don Joaquín Obich y Soler, y Don Francisco de Paula. El Cabildo dio comisión a los Señores Comisionados para que informasen sobre esta solicitud. $^{1057}$

D. Miguel Reinaldi, que dos días antes había conseguido la plaza de primer violín de la Capilla de música, solicita licencia "para pasar a Madrid por su familia y además una ayuda de costa”. El Cabildo acuerda concederle "mes y medio de licencia a D. Miguel Reynaldi para que pase a Madrid, igualmente el Cavildo le concedió por votos secretos dos mil reales de ayuda de costa por una vez". ${ }^{1058}$

“Don Pascual Redel, músico violinista, presentó en este Cavildo un memorial exponiendo su situación miserable y pidiendo se le ayude con lo necesario para su subsistencia, y la de su dilatada familia; el Cavildo acordó dar y dio en efecto comisión a los Señores Diputados de Arcas Vacantes de San Acacio con la parte de Nuestro Ilustrísimo Prelado para que informen con llamamiento sobre esta solicitud". ${ }^{1059}$

“Se leyó un memorial de Don Joseph Las, músico instrumentista acompañado de una certificación jurada de el médico Don Joseph Liado en que suplica se le conceda licencia para ausentarse por algún tiempo de esta ciudad, y mudar de aires,

\footnotetext{
1055 Ibid. Miércoles 25 de Septiembre de 1805. T. 98, fol. 13 r.

${ }^{1056}$ Ibid. Viernes 27 de Septiembre de 1805. T. 98, fol. 14 r.

${ }^{1057}$ Ibid. Viernes 27 de Septiembre de 1805. T. 98, fol. 15 v.

1058 Ibid. Viernes 27 de Septiembre de 1805, T.98.

1059 Ibid. Viernes 11 de Octubre de 1805. T. 98, fol. 22 v.
} 
para recuperar su salud perdida; y el Cavildo dio comisión a los Señores Diputados de Arcas Vacantes de Santa Inés con la parte de Nuestro Ilustrísimo Prelado para que informen con llamamiento sobre esta pretensión”. ${ }^{1060}$

El Cabildo concede 400 reales de vellón de ayuda de costa al Acólito Francisco Ahumada. ${ }^{1061}$

"Se leyó un llamamiento para oír el informe de los Señores Diputados de Arcas Vacantes de San Acacio sobre la solicitud de aumento de salario del músico instrumentista Don Pascual Redel; y el Cavildo a consecuencia de este informen en que se demuestra y acredita el mérito singular de este ministro, decidió conceder y en efecto concedió por votos secretos el aumento de doscientos ducados anuales, consignados a la persona por sus particulares circunstancias y cualidades, y de ningún modo a la plaza que goza, que deberá reducirse a su antiguo estado verificada que sea por cualquier motivo su vacante”. ${ }^{1062}$

Se leyó un memorial de Don Antonio Gil, Presbítero, Capellán de la Capilla de San Acacio solicitando aumento de renta. El Cabildo dio comisión a los Diputados de San Acacio para que informasen. ${ }^{1063}$

El músico instrumentista Don Francisco Cascante solicita aumento de salario. El Cabildo cometió a los Diputados de San Acacio para que informasen. ${ }^{1064}$

"Se leyó un memorial de Don Miguel Reynaldi, primer violinista de esta Santa Iglesia solicitando aumento de sueldo sobre el de ochocientos ducados a que fue llamado en virtud de edictos, y que con efecto fue agraciado y más una ayuda de costa para hacer su regreso de Madrid a ésta, y para proporcionar ciertas sinfonías y

\footnotetext{
${ }^{1060}$ Ibid. Viernes 11 de Octubre de 1805. T. 98, fol. 22 v.

1061 Ibid. Viernes 11 de Octubre de 1805. T. 98, fol. 23 r.

1062 Ibid. Jueves 31 de Octubre de 1805. T. 98, fol. 28r.

1063 Ibid. Jueves 31 de Octubre de 1805. T. 98, fol. 28 r.

${ }^{1064}$ Ibid. Jueves 31 de Octubre de 1805. T. 98, fol. 28 r.
} 
cuartetos consecuentes para el arreglo de la orquesta; el Cavildo decidió no haber lugar ni a una ni a otra solicitud”. ${ }^{1065}$

El Cabildo concede a Don Joseph Las licencia para ausentarse de Córdoba, por motivos de salud, hasta la víspera de Navidad. ${ }^{1066}$

"Sobre la solicitud que tenía hecha Don Antonio Gil, tenor en la Capilla de Música de esta Santa Iglesia, cerca de que se le aumente la renta; oído que fue dicho informe el Cavildo acordó conceder y concedió por votación secreta aumentar y aumentó a dicho ministro hasta novecientos ducados de renta sobre la que goza el referido Don Antonio Gil”. ${ }^{1067}$

"Se leió un memorial de D. Josef Bach organista $2^{\circ}$ de esta Santa Iglesia en el que suplica a v.s. se digne concederle la ayuda de costa que le dicte su gran piedad para remediar sus graves vigencias”. 1068

"Se presentó un memorial de Don Antonio González Colloto, Sacristán de la Capilla de San Acacio, en el que hace presente a V.S. los atrasos y necesidades urgentísimas en el día a causa de lo calamitoso de los tiempos y su renta cortísima; se digne por un efecto de su bondad darle una ayuda de costa”. El Cabildo dio comisión a los Diputados de San Acacio para que informasen. ${ }^{1069}$

"Se leyó un memorial de Don Mateo Bernia Capellán de Santa Inés en esta Santa Iglesia en el que expone a V.S. que hallándose con las piernas hinchadas y con úlceras en del cirujano que le asiste, suplica a V.S. se digne concederle patitur abierto para su salud”. El Cabildo cometió a los Señores Diputados de Santa Inés para que informasen. ${ }^{1070}$

\footnotetext{
1065 Ibid. Jueves 31 de Octubre de 1805. T. 98, fol. 28 v.

${ }^{1066}$ Ibid. Miércoles 13 de Noviembre de 1805. T. 98, fol. 32 r.

${ }^{1067}$ Ibid. Viernes 15 de Noviembre de 1805. T. 98, fol. 34 r.

1068 Ibid. Viernes 15 de Noviembre de 1805, T.98.

1069 Ibid. Miércoles 20 de Noviembre de 1805. T. 98. fol. 35 v.

${ }^{1070}$ Ibid. Miércoles 20 de Noviembre de 1805. T. 98, fol. 35 v.
} 
El Cabildo concede a Don Mateo Bernia, “licencia por el término de un año para que cuide de su salud libertándole de la residencia a Coro, encargándole como le encarga que en los días más solemnes que su salud le permita asistir a la música por la falta que hay en el día de su cuerda”. ${ }^{1071}$

No debió encontrarse muy a gusto el antes citado violinista Miguel Reinaldi, o quizás tuvo algún tipo de problema, porque tan solo dos meses después de conseguir su plaza de primer violín, renuncia a ella. El acta capitular dice que presenta su renuncia "por los motivos que acompaña”, pero no sabemos cuales son esos motivos. ${ }^{1072}$ Curiosamente al poco tiempo cambia de opinión, y el Viernes 7 de Febrero de 1806, solicita volver a formar parte de la Capilla y recuperar su puesto “desengañado de los motivos que lo havian inducido a renunciar la plaza de primer violín”. 1073

"Se leyeron dos memoriales de los Acólitos Rafael de Morales y Fausto de Soto, solicitando uno y otro ayuda de costa”. El Cabildo cometió a los Diputados de el Colegio de Infantes y Acólitos para que informen. ${ }^{1074}$

En cuanto a la solicitud hecha por Don Francisco Cascante, músico instrumentista en la que solicitaba se le aumentara el sueldo o en su defecto una ayuda de costa, el Cabildo acuerda lo siguiente: "se le den por una vez a este ministro en calidad de ayuda de costa mil reales de vellón”. ${ }^{1075}$

"Se leyó un memorial de Don Juan Bueno músico tiple de esta Santa Iglesia, en que solicita aumento de salario”. El Cabildo dio comisión a los Diputados de Santa Inés para que informasen. ${ }^{1076}$

\footnotetext{
${ }^{1071}$ Ibid. Miércoles 27 de Noviembre de 1805. T. 98, fol. 35 v.

1072 Ibid. Miércoles 27 de Noviembre de 1805 T.98, fol.33v.

1073 Ibid. Viernes 7 de Febrero de 1806, T.98.

1074 Ibid. Lunes 2 de Diciembre de 1805. T. 98, fol. 35 v.

1075 Ibid. Martes 3 de Diciembre de 1805. T. 98, fol. 39 v.

${ }^{1076}$ Ibid. Martes 3 de Diciembre de 1805. T. 98, fol. 40 r.
} 
"Se leyó un memorial del músico instrumentista Don Juan de Borja en solicitud de aumento de sueldo”. El Cabildo dio comisión a los Diputados de Santa Inés para que informasen. ${ }^{1077}$

El Cabildo concede doscientos reales de vellón, de ayuda de costa, al Acólito Fausto de Soto. Sin embargo, niega la ayuda de costa solicitada por el otro Acólito, Rafael Morales. ${ }^{1078}$

“Sobre la solicitud de ayuda de costa de Don Joseph Bach, segundo organista, y Don Juan Nepomuceno Puig, músico bajonista de esta Santa Iglesia; y habiéndose procedido a determinar por votos secretos sobre estas dos pretensiones, en primera votación se concedieron cincuenta pesos de ayuda de costa por una vez a el segundo organista Don Joseph Bach, y en segunda se acordó dar igual cantidad a el músico instrumentista Don Juan Nepomuceno Puig”. ${ }^{1079}$

El Cabildo acuerda conceder a Don Antonio González Poyoto, la cantidad de seiscientos reales de vellón como ayuda de costa. ${ }^{1080}$

“Se leyó un memorial de Don Joseph Luis de los Heros, Subdiácono y Capellán de la Capilla de San Acacio, solicitando se le haga presente en el Coro todo el tiempo invertido en los exercicios y en la recepción de sus órdenes, y acreditando el número de días que fue exercitado por una certificación de el Reverendo Padre Guardián de el Convento de San Francisco de la Observancia; y el Cavildo en vista de esta solicitud y en virtud de el certificado adjunto concedió como lo acostumbra se haga presente en el Coro como lo pide este Capellán”. ${ }^{1081}$

\footnotetext{
1077 Ibid. Lunes 16 de Diciembre de 1805. T. 98, fol. 43 v.

1078 Ibid. Jueves 19 de Diciembre de 1805. T. 98, fol. 44 r.

${ }^{1079}$ Ibid. Lunes 23 de Diciembre de 1805. T. 98, fol. 46 v.

${ }^{1080}$ Ibid. Lunes 23 de Diciembre de 1805. T. 98, fol. 48 r.

${ }^{1081}$ Ibid. Lunes 23 de Diciembre de 1805. T. 98, fol. 48 v.
} 


\section{6}

Sobre la petición de aumento de sueldo que solicita Don Juan de Borja, el Cabildo le concedió cien ducados de aumento sobre el salario que gozaba. ${ }^{1082}$

“Se leyó un memorial de Don Nicolás Anguita, músico de voz en la Capilla de esta Santa Iglesia en el que solicita aumento del salario que goza; el Cavildo acordó dar y dio comisión a los Señores Diputados de Arcas Vacantes de San Acacio para que con la parte de Nuestro Prelado informen a el Cavildo sobre esta pretensión”.

"Se leyó otro memorial de Don Manuel Valls y Carliez, primer obue de esta Santa Iglesia en el que suplica a V.S. tenga a bien pasarle la renta a las Arcas Vacantes de San Acacio, aumentándoselas según la voluntad de V.S.”. El Cabildo dio comisión a los Diputados de San Acacio para que informasen. ${ }^{1083}$

Sobre la solicitud de ayuda de costa que pide Don Juan Bueno, músico tiple de esta Santa Iglesia, el Cabildo le concedió cien ducados de ayuda de costa por una vez. $^{1084}$

"Se leyó un memorial de Don Miguel Reynaldi, en que después de exponer al Cavildo que por siniestros informes que lo habían exasperado había hecho dimisión de la plaza de primer violín de esta Santa Iglesia, y después de manifestar su arrepentimiento en esta parte, suplica humildemente se le vuelva a admitir”. El Cabildo dio comisión a los Diputados de Santa Inés para que informasen. ${ }^{1085}$

Sobre la solicitud de Don Miguel Reynaldi, en que pide su reingreso a la Capilla de Música, “el Cavildo procediendo a determinar sobre este punto acordó se admita de nuevo en la mencionada plaza de primer violín a el expresado Reynaldi con el sueldo

\footnotetext{
1082 Ibid. Miércoles 15 de Enero de 1806. T. 98, fol. 53 r.

1083 Ibid. Miércoles 22 de Enero de 1806. T. 98, fol. 54 v.

${ }^{1084}$ Ibid. Miércoles 22 de Enero de 1806. T. 98, fol. 54 v.

1085 Ibid. Martes 4 de Febrero de 1806. T. 98, fol. 58 v.
} 
de ochocientos ducados anuales que fue la dotación ofrecida en los edictos de convocatoria para la oposición”. ${ }^{1086}$

"Se leyó un memorial del músico instrumentista Don Joseph Las, en solicitud de aumento de sueldo; y el Cavildo decidió dar y dio en efecto admisión a los Señores Diputados de Arcas Vacantes de Santa Inés, con la parte de Nuestro Ilustrísimo Prelado para que informen con llamamiento sobre esta solicitud". ${ }^{1087}$

Los Señores Don Vicente Marín y Don Mateo Tascón, solicitan ayuda de costa. El Cabildo le concede veinticinco doblones a cada uno de ellos. ${ }^{1088}$

"Se leyó un memorial de Don Josep Luis de los Heros, Capellán de la Capilla de San Acacio en solicitud de que se le haga presente en el Coro los días que de orden de Nuestro Ilustrísimo Prelado, ha estado haciendo exercicios para órdenes en el Oratorio de San Felipe Neri, y acreditando la verdad de este relato con certificado de el Prepósito de el Oratorio, el Cavildo en virtud y a consecuencia de este documento acordó que se llenen las casillas del cuadrante de este Capellán, haciéndolo presente en el Coro los días gastados en exercicios anotados en el certificado". Idéntico memorial presenta Don Nicolás Anguita músico contralto, e idéntica respuesta recibe del Cabildo. ${ }^{1089}$

"Se leyó una carta de Don Miguel Reynaldi, violinista primero de la Capilla de esta Santa Iglesia, dando las más rendidas y expresivas gracias a este Cavildo por la bondad y benignidad con que ha atendido sus repetidas pretensiones, y ofreciendo venir en el tiempo que se le ha señalado a cumplir su obligación con honradez y puntualidad; el Cavildo acordó que se conservase este escrito para los efectos convenientes en lo sucesivo". 1090

\footnotetext{
${ }^{1086}$ Ibid. Lunes 10 de Febrero de 1806. T. 98, fol. 61 v.

${ }^{1087}$ Ibid. Lunes 10 de Febrero de 1806. T. 98, fol. 62 r.

1088 Ibid. Sábado 15 de Febrero de 1806. T. 98, fol. 63 r.

${ }^{1089}$ Ibid. Jueves 27 de Febrero de 1806. T. 98, fol. 67 v.

${ }^{1090}$ Ibid. Sábado 1 de Marzo de 1806. T. 98, fol. 68 r.
} 
“Sobre la solicitud de Don Manuel Valls, primer oboe de la Capilla de Música de esta Santa Iglesia, acerca de que se le pase su renta con algún aumento a las citadas Arcas (de San Acacio); oído que fue dicho informe se procedió a la votación por votos secretos y salió admitido el pase de su renta a las referidas Arcas Vacantes de San Acacio, y en esta virtud se procedió a la segunda votación sobre el aumento de renta que solicita el suplicante, y habiéndose votado por votos secretos, el Cavildo le concedió cien ducados más de renta sobre los cuatrocientos y cincuenta ducados que gozaba dicho Ministro”. ${ }^{1091}$

Don Benito Torrellas solicita permiso para viajar a la ciudad de Cádiz. “El Cavildo acordó conceder y concedió al referido Don Benito Torrellas, la licencia que solicita, cuya licencia se le concede hasta la semana de Dolores exclusive”. ${ }^{1092}$

Se leyó un memorial del Acólito Joseph Villalba por el que solicita una ayuda de costa. "El Cavildo dio comisión a los Señores Diputados de Acólitos para que informen con llamamiento sobre esta solicitud".

"Item se leyó otro memorial de Don Manuel Vals y Carlier, primer oboe de la Capilla de Música de esta Santa Iglesia, en que hace presente a V.S. que habiendo pasado su renta que gozaba de los fondos de Excusados a las Arcas de San Acacio con el aumento de cien ducados más sobre los que gozaba de dichos Excusados, lo noticiaba a V.S. para su gobierno, viviendo siempre agradecido por los favores que V.S. le ha dispensado; el Cavildo acordó pase este memorial a los Señores Diputados de Excusados de Fábrica para su inteligencia, y gobierno, y al mismo tiempo se dio comisión a los mismos Señores Diputados para que con la parte de Nuestro Ilustrísimo Prelado informen al Cavildo acerca de la segunda plaza de oboe de la Capilla de Música de esta Santa Iglesia que está vacante”. 1093

"Se le mandó entrar al Maestro de Capilla que estaba a la puerta de la Sala Capitular para que informase al Cavildo acerca del contralto de Antequera a quien se

\footnotetext{
${ }^{1091}$ Ibid. Sábado 1 de Marzo de 1806. T. 98, fol. 69 r.

1092 Ibid. Jueves 6 de Marzo de 1806. T. 98, fol. 70 v.

1093 Ibid. Sábado 8 de Marzo de 1806. T. 98, fol. 71 v.
} 
le había oído, y habiendo informado el Maestro de Capilla al Cavildo que el referido contralto no llenaba las intenciones del Cavildo, el Cavildo en virtud de este informe acordó despedir y despidió al referido contralto". ${ }^{1094}$

Se leyó un memorial de Don Joseph Vasconcelos y Melo, segundo violín de la Capilla de Música, en el que suplica aumento de salario. El Cavildo dio comisión a los Diputados de San Acacio para que informasen. Igualmente se leyó otro memorial de Juan de Mora, Acólito, en el que hace presente, "que habiendo hecho oposición a la plaza de primer violín de esta Santa Iglesia, su aplicación a este instrumento, suplica a V.S. se digne conceder la asignación diaria que estime conveniente, y el Cavildo acordó dar y dio comisión a los mismos Señores para que con la parte de Nuestro Ilustrísimo Prelado informen al Cavildo con llamamiento sobre esta solicitud". ${ }^{1095}$

Se leyeron dos memoriales, uno de Don Juan Bueno, músico tiple de la Capilla de Música y otro de Don Mariano Ferrer músico instrumentista. En ambos casos se solicita una ayuda de costa. El Cabildo dio comisión a los Diputados de Santa Inés para que informasen.

“Ítem se leyó otro memorial de Don Joseph María de León, beneficiado músico contralto de la Colegiata de Antequera, en el que hace presente a V.S., que habiendo tenido la satisfacción y complacencia de haber sido oído por V.S. y siendo los gastos que ha causado en la venida y estancia en esta ciudad muchos, suplica a V.S. se digne concederle alguna ayuda de costa; el Cavildo acordó dar y dio comisión a los mismos Señores para que con la parte de Nuestro Ilustrísimo se informe al Cavildo con llamamiento sobre esta solicitud". 1096

Respecto a la anterior ayuda de costa que solicitaron Don Juan Bueno y Don Mariano Ferrer, el Cabildo acuerda concederles a ambos cien pesos de ayuda de costa por una vez. Respecto a la solicitud de Don Juan Antonio León, contralto de Antequera,

\footnotetext{
${ }^{1094}$ Ibid. Sábado 8 de Marzo de 1806. T. 98, fol. 72 r.

1095 Ibid. Sábado 15 de Marzo de 1806. T. 98, fol. 76 r.

${ }^{1096}$ Ibid. Sábado 15 de Marzo de 1806. T. 98, fol. 76 v.
} 
que también solicitaba una ayuda de costa para cubrir sus gastos de viaje, el Cabildo le concedió doscientos cincuenta reales de vellón. ${ }^{1097}$

"Se presentó un memorial de Don Juan Nepomuceno Puig, en solicitud de que a su hijo Don Joaquín, se le agracie, precediendo el debido examen e informe del Maestro de Capilla, con la plaza de segundo oboe vacante, pensionándolo con la obligación de tocar también bajón y flauto siempre que se juzgue necesario; y el Cavildo acordó dar y dio en efecto comisión a los Señores Diputados de Excusados de Fábrica con la parte de Nuestro Ilustrísimo Prelado para que informen con llamamiento sobre esta pretensión”. 1098

"Se presentó un memorial de Don Manuel Gutiérrez Ravé, en solicitud de licencia para pasar a Málaga a hacer oposición a una media ración de aquella Santa Iglesia afecta a su facultad, y el Cavildo acordó dar y dio en efecto comisión a los Señores Diputados de Arcas Vacantes de San Acacio, con la parte de Nuestro Ilustrísimo Prelado para que informen con llamamiento sobre esta solicitud". ${ }^{1099}$

Sobre la petición de aumento de sueldo de Don Joseph Las, músico instrumentista, el Cabildo "le concedió cien ducados de aumento anuales, y dio comisión a los mismos Señores Diputados para que encarguen de parte del Cavildo el mexor y más exacto cumplimiento de sus obligaciones apercibiéndolo con privación de su empleo en el caso de reincidencia en sus pasadas faltas”. 1100

El Sr. D. Pedro Segovia [encargado de asuntos musicales], dice “que se havian copiado doce oberturas para el uso de la Capilla de música de esta Santa Iglesia, las cuales se habian [en el acta se escribe havian y poco después habian] hallado destrozadas, rotas e incapaces de servir”. Se acuerda estudiar el coste de dicha copia. $^{1101}$

\footnotetext{
${ }^{1097}$ Ibid. Sábado 29 de Marzo de 1806. T. 98, fol. 84 r.

${ }^{1098}$ Ibid. Miércoles 2 de Abril de 1806. T. 98, fol. 86 v.

${ }^{1099}$ Ibid. Miércoles 2 de Abril de 1806. T. 98, fol. 87 v.

${ }^{1100}$ Ibid. Jueves 17 de Abril de 1806. T. 98, fol. 88 v.

${ }^{1101}$ Ibid. Lunes 28 de Abril de 1806, T.98, fol. 94v.
} 
El Cabildo concede a Don Manuel Álvarez, Sochantre interino, mil seiscientos reales de ayuda de costa por una vez.

“Item se leyó otro informe de los mismos Señores Diputados de San Acacio sobre la pretensión del Acólito Juan de Mora y oído que fue dicho informe el Cavildo acordó admitir y admitió al referido Juan de Mora de violinista Supernumerario de la Capilla de esta Santa Iglesia con el sueldo de ciento cincuenta ducados anuales dexando la plaza de Acólito que obtenía”. “Item se leyó un memorial de Don Josep Luis de los Heros Capellán de San Acacio en el que hace presente a V.S. que con el motivo de haber recibido todas sus órdenes sin intermisión se le han originado unos gastos extraordinarios por lo que suplica a V.S. se sirva aumentarle la renta. El Cavildo acordó dar y dio comisión a los Señores Diputados de Arcas de San Acacio para que con la parte de Nuestro Ilustrísimo Prelado informen al Cavildo con llamamiento sobre esta solicitud". 1102

“En virtud y a consecuencia de una palabra del Señor Segovia se dio comisión a los Señores Diputados de Arcas Vacantes de San Acacio con la parte de Nuestro Ilustrísimo Prelado, para que informen con llamamiento sobre el modo de habilitar a Don Joseph García para que entre con sobrepelliz en el coro para que pueda alternar con los dos Sochantres interinos haciendo el oficio y otra comisión para que igualmente informen con llamamiento". 1103

"Se leyó un memorial de Juan de Mora, haciendo dimisión de la plaza de Acólito que obtenía en virtud de haber sido nombrado por el Cavildo de Señores Dignidades y Canónigos, violinista Supernumerario de la Capilla de Música de esta Santa Iglesia, y el Cavildo admitió la expresada dimisión y en el mismo acto nombró al Niño de Coro Francisco Escalona para ocupar la plaza dimitida”. ${ }^{1104}$

"Se leyó un memorial de Don Julián de Gálvez, músico instrumentista de esta Santa Iglesia por el que pide a V.S. una ayuda de de costa, el Cavildo acordó dar y dio

\footnotetext{
1102 Ibid. Sábado 10 de Mayo de 1806. T. 98, fol. 99 r.

1103 Ibid. Sábado 10 de Mayo de 1806. T. 98, fol. 99 r.

${ }^{1104}$ Ibid. Viernes 16 de Mayo de 1806. T. 98, fol. 100 v.
} 
en efecto comisión a los Señores Diputados de Excusados de Música para que con la parte de Nuestro Prelado informen con llamamiento sobre esta solicitud". ${ }^{1105}$

“Sobre las solicitudes de Don Julián de Gálvez, músico contralto de la Capilla de esta Santa Iglesia, y Don Juan Nepomuceno Puig, bajonista en la misma, y habiéndose oído el informe relativo a la solicitud del mencionado Gálvez, procediendo el Cavildo a determinar por votos secretos acordó concederle y le concedió en efecto cincuenta ducados de ayuda de costa por una vez. El Don Juan Nepomuceno Puig solicitaba que a su hijo Don Joaquín se le nombrase segundo oboe de la Capilla de Música, y oído el informe de los Señores Comisionados sobre esta pretensión el Cabildo acordó dar y dio en efecto comisión a los Señores Diputados de Excusados de Música con la parte de Nuestro Ilustrísimo Prelado para que con arreglo a estatuto fixen edictos convocando para oposiciones a la plaza de segundo oboe con la renta que gozaba el que obtenía anteriormente y prefixando en dichos edictos el término que estimen conveniente para poder en virtud de el resultado de estas oposiciones, y de los exámenes que en ellas se hagan, atender el mérito del Don Juan Nepomuceno Puig, y de su hijo". 1106

"Sobre la licencia pedida por Don Mariano Ferrer, músico instrumentista de la Capilla de esta Santa Iglesia; y el Cavildo oído que fue este informe, usando de su acostumbrada benignidad y conociendo que la ida de este Ministro a la Corte podría ser más por lograr otro establecimiento más interesante que por perfeccionarse en su facultad, acordó concederle y en efecto le concedió tres meses de licencia.

En seguida se leyó un memorial de Don Miguel Reynaldi, primer violín de la Capilla de esta Santa Iglesia, en solicitud de licencia para pasar a la Corte a diligencias propias suyas, que debían evacuarse el presente; y el Cavildo dio comisión a los Señores Diputados de Arcas Vacantes de Santa Inés, para que con la parte de Nuestro Ilustrísimo Prelado, informen con llamamiento sobre esta pretensión”. ${ }^{1107}$

\footnotetext{
${ }^{1105}$ Ibid. Viernes 23 de Mayo de 1806. T. 98, fol. 105 r.

${ }^{1106}$ Ibid. Miércoles 4 de Junio de 1806. T. 98, fol. 105 r.

${ }^{1107}$ Ibid. Miércoles 4 de Junio de 1806. T. 98, fol. 105 v.
} 
El Cabildo concede a Don Miguel Reynaldi, primer violín de la Capilla, permiso para viajar a Madrid a fin de resolver negocios personales, por un espacio de dos meses a contar desde el día de la fecha. ${ }^{1108}$

El notario secretario informa al Cabildo que respecto a la oposición para cubrir plaza de oboe segundo, solo había firmado dicha oposición y se había presentado, Don Joaquín Puig; “mas los Señores Diputados expusieron de palabra haberse presentado en el día de ayer por segundas personas otros dos opositores, los que no hacían personalmente por estar enfermos, y suplicaban al Cavildo los esperase unos días hasta que pudieran presentarse”. El Cabildo acordó dilatar el día de la oposición hasta que estos músicos se pudieran presentar. ${ }^{1109}$

"Se leyó un memorial de Don Francisco Ferrer, músico instrumentista de esta Santa Iglesia, solicitando una ayuda de costa a causa de sus atrasos y alimentos que dispensa a su hermano por el que poco salario que goza; y el Cavildo acordó que los Señores Diputados de Arcas de Santa Inés informen sobre él, con la parte de Nuestro Ilustrísimo Prelado”. ${ }^{1110}$

El Señor Magistral pide al Cabildo que determine el día del examen para la provisión de la plaza de oboe segundo de la Capilla. El Cabildo acuerda que los opositores fueran examinados por el Maestro de Capilla el día siguiente martes por la tarde. ${ }^{1111}$

“En virtud del llamamiento para oír el informe del Maestro de Capilla sobre los exercicios de los opositores a la plaza de $2^{\circ}$ oboe vacante en esta Santa Iglesia, entró en esta Sala Capitular el referido Maestro: e informó in voce al Cavildo, lo que se le ofreció y pareció: y retirado de ella, procedió el Cavildo a su votación por cédulas; y salió nombrado Don Cristóbal Bendicho". ${ }^{1112}$

\footnotetext{
1108 Ibid. Sábado 28 de Junio de 1806. T. 98, fol. 112 v.

1109 Ibid. Jueves 7 de Agosto de 1806. T. 98, fol. 128 r.

${ }^{1110}$ Ibid. Miércoles 13 de Agosto de 1806. T. 98, fol. 137 r.

${ }^{1111}$ Ibid. Lunes 25 de Agosto de 1806. T. 98, fol. 137 v.

1112 Ibid. Miércoles 27 de Agosto de 1806. T. 98, fol. 139 r.
} 
“En virtud del llamamiento para oír el informe de los Señores Diputados de Arcas Vacantes de Santa Inés, sobre la licencia que solicita Don Miguel Reynaldi, violín primero de esta Santa Iglesia, para permanecer en Madrid hasta restablecerse de la enfermedad hemorroidal que dice está padeciendo; oído que fue dicho informe, acordó el Cavildo que por el notario secretario se le escriba a dicho Don Miguel Reynaldi, que el Cavildo sólo le concede licencia hasta el día de San Miguel próximo, en cuyo día deberá estar en esta ciudad, y que no verificándolo, el Cavildo tomará las providencias que juzgue oportunas, tenga por conveniente y a las que él se ha hecho acreedor". 1113

"En virtud del llamamiento para oír el informe de los Señores Diputados de Arcas Vacantes de San Acacio con la parte de Nuestro Ilustrísimo Prelado sobre el aumento de renta que pretende Don Nicolás Anguita, oído que fue el informe, y cuanto se dixo de palabra, acordó el Cavildo dar nueva comisión a dichos Señores Diputados para que a la mayor brevedad informen al Cavildo con llamamiento si hay en ese Cavildo alguna Capilla vacante con que premiar a este Ministro, y caso que la haya cómo podrá proveerse; si será necesario fijar edictos o no". "Item se leyó el informe de los mismos Señores sobre la solicitud de Don Vicente Marín, acerca de que se le dé plaza en la Capilla a su hijo Rafael, y el Cavildo en vista del informe, de cuanto se expuso de palabra, y teniendo presente la comisión que está pendiente sobre el plan y nuevo arreglo de plazas de músicos, acordó renovar dicha comisión y que ésta se traiga en todo el mes de octubre, con vista del plan que manifestó el Señor Argote, se formó cuando entró el Maestro de Capilla Gaitán, y en atención al mérito del Don Vicente Marín, y a la habilidad particular y rara de su hijo Rafael en el violonchelo, y haber desempeñado varias veces la plaza de su padre en la Capilla de Música de esta Santa Iglesia, acordó el Cavildo por votos secretos se le diesen cien ducados de ayuda de costa que libró sobre las Arcas de San Acacio”. 1114

\footnotetext{
1113 Ibid. Jueves 4 de Septiembre de 1806. T. 98, fol. 145 r.

${ }^{1114}$ Ibid. Viernes 5 de Septiembre de 1806. T. 98, fol. 146 r.
} 
En el día de la fecha, se presenta el memorial de genealogía de Juan Lucas del Pozo, recién elegido Infante de Coro y Colegial del Santo Ángel. ${ }^{1115}$

El Cabildo concede a Rafael de Morales, Acólito, una ayuda de costa de trescientos reales de vellón. Igualmente el Cabildo concede a Don Francisco Ferrer, músico trompa de la Capilla, una ayuda de costa de mil cien reales de vellón. ${ }^{1116}$

Don Miguel Reynaldi envía un nuevo memorial al Cabildo, haciendo presente que siempre cumplió con su obligación y que si está retrasando su vuelta de Madrid es por motivo de enfermedad, tal como prueba en certificado médico que acompaña. Por lo tanto pide al Cabildo permanecer en Madrid hasta curarse de su dolencia. El Cabildo le responde reafirmándose en su anterior acuerdo del día 4 de Septiembre pasado. ${ }^{1117}$

"Se leyeron dos memoriales: el primero de Don José Vasconcelos, violinista de la Capilla de Música de esta Santa Iglesia, solicitando una ayuda de costa para subvenir a los gastos de una grave enfermedad que padece: y el segundo de Don José García, Salmista de este Coro en el que suplica se le adelanten cuatrocientos ducados de su salario”. El Cabildo dio comisión a los Diputados de San Acacio para que informasen sobre ambas pretensiones. ${ }^{1118}$

El Cabildo concede a Don José Vasconcelos una ayuda de costa de mil quinientos reales. Asimismo concede a Don José García el adelanto de cuatrocientos ducados sobre su sueldo. ${ }^{1119}$

"Se leyeron dos memoriales, uno del Acólito Fausto de Soto y otro del Infante de Coro Juan del Pozo: pidiendo ambos una ayuda de costa: y el Cavildo acordó dar y

\footnotetext{
1115 Ibid. Sábado 20 de Septiembre de 1806. T. 98, fol. 148 v.

${ }^{1116}$ Ibid. Martes 23 de Septiembre de 1806. T. 98, fol. 148 v.

${ }^{1117}$ Ibid. Martes 23 de Septiembre de 1806. T. 98, fol. 150 r.

${ }^{1118}$ Ibid. Viernes 3 de Octubre de 1806. T. 98, fol. 154 r.

${ }^{1119}$ Ibid. Sábado 4 de Octubre de 1806. T. 98, fol. 155 v.
} 
dio comisión a los Señores Diputados de Acólitos y de Infantes para que con llamamiento informen lo que tengan por conveniente". ${ }^{1120}$

"Se leyó un memorial de Don Cristóbal Bendicho, $2^{\circ}$ oboe en esta Capilla de Música: solicitando una ayuda de costa para subvenir a las necesidades en que le ha puesto una grave enfermedad que padece, y el Cavildo acordó dar y dio comisión a los Señores Diputados de Excusados de Fábrica con la parte, para que informen con llamamiento lo que se les ofrezca y parezca”. ${ }^{1121}$

El Cabildo concede a Don Cristóbal Bendicho, oboe $2^{\circ}$ de la Capilla, cien ducados de ayuda de costa por una vez. Igualmente concede a Fausto de Soto, Acólito una ayuda de costa de trescientos reales. ${ }^{1122}$

El Cabildo concede a Juan Lucas del Pozo, Infante de Coro, una ayuda de costa de trescientos cincuenta reales.

“Item se leyó otro memorial de Don Joseph Arbiol, Maestro de Capilla en la de San Clemente pretendiendo entrar en la de esta Santa Iglesia, en plaza de tenor, y el Cavildo acordó se tenga presente para cuando haya plaza vacante”. ${ }^{1123}$

"Se leyó un memorial de Francisco Bonilla, Acólito de esta Santa Iglesia en que pide al Cavildo se sirva concederle una ayuda de costa en atención a hallarse sin la decente ropa para hacer su Ministerio de Acólito ni sus padres podérsela hacer por sus cortas facultades, y el Cavildo acordó dar comisión a los Señores Diputados de Acólitos para que informen con llamamiento.

Item se leyó otro memorial de Don Pedro Joseph de Arroyo, padre de Rafael, Colegial en el Santo Ángel, en que manifiesta al Cavildo la larga y penosa enfermedad que dicho su hijo pasó en su casa y los gastos que por ella se le originaron, sin que el Colegio haya sufragado con cosa alguna; por lo que y en atención a la falta de medios del suplicante, espera de la notoria caridad del Cavildo, se sirva mandar se le satisfaga la

\footnotetext{
${ }^{1120}$ Ibid. Miércoles 22 de Octubre de 1806. T. 98, fol. 161 r.

${ }^{1121}$ Ibid. Sábado 25 de Octubre de 1806. T. 98, fol. 162 r.

1122 Ibid. Viernes 7 de Noviembre de 1806. T. 98, fol. 171 r.

${ }^{1123}$ Ibid. Lunes 10 de Noviembre de 1806. T. 98, fol. 172 v.
} 
cantidad que invirtió en el médico cirujano y botica”. El Cabildo dio comisión a los Diputados de Infantes para que informasen con llamamiento. ${ }^{1124}$

"En virtud del llamamiento para oír el informe de los Señores Diputados de Arcas de San Acacio con la parte de Nuestro Ilustrísimo Prelado, sobre el número de Capillas vacantes en la misma, y resultando entre otras cosas que en el año de 1803, vacó una de San Antonino por ascenso de Don Manuel Álvarez, se opusieron a ella Don Nicolás Anguita y Don Joseph Heros, y no habiéndose provisto después de repetidos edictos acordó el Cavildo nombrar y nombró para esta Capilla a Don Nicolás Anguita en atención a los adelantamientos que ha hecho y adquirido en la música, a su buena conducta y estado sacerdotal, a la importancia del cumplimiento de las obligaciones anexas, y a lo raro de voces de contralto, debiendo resultar vacante a su debido tiempo la renta que en la actualidad goza.

Item se leyó el informe de dichos Señores Diputados con la parte de Nuestro Ilustrísimo Prelado sobre la pretensión de Don Joseph de los Heros y el Cavildo en su vista acordó por votos secretos dar y dio al expresado Don Joseph de los Heros, 200 ducados de ayuda de costa por una vez.

Item se leyó un memorial de Don Miguel Reynaldi, primer violín de esta Santa Iglesia, en que suplica al Cavildo se sirva mandar se le quiten las aspas puestas en el cuadrante durante su ausencia, mediante a los muchos gastos que le ocasionó la enfermedad que le imposibilitó presentarse en esta Santa Iglesia a su debido tiempo para el cumplimiento de su obligación, y el Cavildo en su vista acordó dar y dio comisión a los Señores Diputados de Arcas Vacantes de Santa Inés para que con la parte, informen con llamamiento sobre el contenido de este memorial”. ${ }^{1125}$

"Se leyeron dos memoriales: uno del Acólito Jaén, y otro de Don Juan Puig: ambos solicitando una ayuda de costa de la Piedad del Cavildo; y éste acordó dar comisión a los Señores Diputados de Acólitos para que informen con llamamiento

\footnotetext{
${ }^{1124}$ Ibid. Jueves 20 de Noviembre de 1806. T. 98, fol. 177 v.

1125 Ibid. Jueves 20 de Noviembre de 1806. T. 98, fol. 178 r.
} 
sobre el primero: y a los Señores Diputados de Excusados de Fábrica con la parte sobre el segundo". 1126

"Se leyeron dos memoriales: el uno de Don Mariano Repiso, Sacristán de la Capilla de San Acacio: y el otro de Don José Vasconcelos, segundo violín de la Capilla de Música de esta Santa Iglesia, ambos solicitando patitur abierto en atención a las enfermedades que padecen: y el Cavildo acordó dar y dio comisión a los Señores Diputados de Arcas de San Acacio para que informen sobre el primero. Y sobre el segundo a los Señores Espejo y Riera ambos con llamamiento.

Asimismo se leyó otro memorial de Don Francisco Cascante, contrabajo de la Capilla de Música de esta Santa Iglesia, en que expone su indigencia y necesidad, y pide en su socorro una ayuda de costa: y el Cavildo acordó dar y dio comisión a los Señores Diputados de Arcas de San Acacio para que informen con llamamiento lo que se les ofreciese y pareciese". 1127

"Se leyó un memorial de Don Mateo Bernia, Capellán de una de las de Santa Inés, en el que expone se le concluyó el patitur abierto que por tiempo de un año tenía; y siguiendo sus males actuales y vicisitudes pide: se le conceda por el tiempo que fuere del agrado del Cavildo patitur abierto”. Y el Cabildo dio comisión a los Señeros Espejo y Riera para que informasen. ${ }^{1128}$

"Sobre la solicitud de Don Miguel Reynaldi, primer violín en la Capilla de Música de esta Santa Iglesia, pidiendo se le quitaran sesenta y dos aspas en que ha incurrido en su ausencia y enfermedad, y habiendo oído el referido informe, acordó el Cavildo darle por una vez y en razón de ayuda de costa setecientos reales.

Enseguida se leyó otro llamamiento de los Señores Comisionados para oír el informe sobre el patitur abierto que solicita Don Mateo Bernia Capellán de una de las de Santa Inés; y en su virtud el Cavildo acordó concederle patitur abierto a Don Mateo Bernia por el tiempo de un año, perseverando sus achaques y padeceres en el curso de él". ${ }^{1129}$

\footnotetext{
${ }^{1126}$ Ibid. Lunes 1 de Diciembre de 1806. T. 98, fol. 179 v.

${ }^{1127}$ Ibid. Lunes 1 de Diciembre de 1806. T. 98, fol. 180 v.

${ }^{1128}$ Ibid. Lunes 1 de Diciembre de 1806. T. 98, fol. $181 \mathrm{r}$.

${ }^{1129}$ Ibid. Jueves 4 de Diciembre de 1806. T. 98, fol. 182 v.
} 
El Cabildo le concede a Don Francisco Cascante una ayuda de costa de mil reales. Asimismo el Cabildo concede a Don José Vasconcelos permiso (patitur abierto) hasta la víspera del Corpus del año entrante. ${ }^{1130}$

El Cabildo concede a Don Juan Nepomuceno Puig una ayuda de costa de cien ducados. $^{1131}$

\section{7}

"Se leyó un informe de los Señores Diputados de Acólitos relativo a las plazas de Acólito que pretenden Antonio Ayllón y Antonio María Jurado, y el Cavildo en su vista y lo que de palabra expusieron los Señores Diputados acordó nombrar y nombró a Antonio Ayllón en la vacante y a Antonio María Jurado para que sirva la plaza de Escalona.

Item se leyó otro informe de los mismos Señores sobre la ayuda de costa que solicita el padre de Fausto de Soto, Acólito que fue de esta Santa Iglesia. El Cavildo en vista de lo que dichos Señores expusieron de palabra, acordó por votos secretos dar y dio por una vez cuatrocientos reales de ayuda de costa al dicho padre de Fausto de Soto". ${ }^{1132}$

"Se leyó un memorial de Miguel Colmenero, Infante de Coro en el Colegio del Santo Ángel en el que pide al Cavildo se sirva tenerle presente en la plaza vacante de Acólito, y el Cavildo en atención a haberla ya provisto cuando se leyó esta representación acordó se tenga presente para la primera vacante”. 1133

El Maestro de Capilla de cuenta al Cabildo de la falta de respeto que había observado durante una procesión claustral en D. Francisco Ferrer, quien fue multado por el Deán con cuatro aspas. ${ }^{1134}$

\footnotetext{
${ }^{1130}$ Ibid. Sábado 6 de Diciembre de 1806. T. 98, fol. 184 v.

${ }^{1131}$ Ibid. Viernes 19 de Diciembre de 1806. T. 98, fol. 186 v.

1132 Ibid. Jueves 15 de Enero de 1807. T. 98, fol. 190 v.

${ }^{1133}$ Ibid. Jueves 15 de Enero de 1807. T. 98, fol. $191 \mathrm{v}$.

${ }^{1134}$ Ibid. Jueves 15 de Enero de 1807. T. 98, fol. 192 r.
} 
“Se leyó un memorial de Don Mateo Tascón, músico bajonista de la Capilla de esta Santa Iglesia, en que suplica al Cavildo se sirva darle una ayuda de costa en atención al desempeño de su obligación en la plaza de primer bajón, y en haber sido nombrado diferentes veces y en la actualidad por los Señores Diputados del Colegio de Niños, para la enseñanza de éstos, y el corto salario que goza: y el Cavildo acordó dar y dio comisión a los Señores Diputados de Excusados con la parte para que informen con llamamiento". 1135

“Se leyó memorial de D. Vicente Marín, músico instrumentista de esta Santa Iglesia y Maestro de música del Colegio de Infantes de Coro, en el que hace presente al Cavildo que hace 28 años que le esta sirviendo, y que siéndole forzoso servir en las necesidades de su familia, ha contraído por ese motivo algunas deudas que no puede satisfacer si el Cavildo no tiene la bondad de darle aquella ayuda de costa que sea de su agrado...". ${ }^{1136}$

"Se leyó un memorial de Joseph Villalba, Acólito de esta Santa Iglesia en el que hace presente al Cavilo la crecida familia de su casa, y las ningunas proporciones de sus padres, por lo que se haya constituido en una verdadera indigencia, la que suplica al Cavildo se sirva remediarla mediante la ayuda de costa que sea de su agrado, y el Cavildo acordó dar y dio comisión a los Señores Diputados de Acólitos para que informen con llamamiento". ${ }^{1137}$

El Cabildo concede al Acólito Villalba, doscientos reales de vellón de ayuda de costa. $^{1138}$

"Se leyó un memorial de Francisco Escalona, Acólito que fue de esta Santa Iglesia e Infante de Coro, en el que hace presente al Cavildo haberse retirado por haberle tocado la suerte de miliciano, y hallándose en la mayor indigencia, suplica al

\footnotetext{
${ }^{1135}$ Ibid. Jueves 22 de Enero de 1807. T. 98, fol. 193 v.

${ }^{1136}$ Ibid. Jueves 22 de Enero de 1807, T.98.

${ }^{1137}$ Ibid. Jueves 22 de Enero de 1807. T. 98, fol. 194 r.

${ }^{1138}$ Ibid. Jueves 29 de Enero de 1807. T. 98, fol. 197 v.
} 
Cavildo que teniendo presente el tiempo que ha servido a esta Santa Iglesia, se sirva concederle aquella ayuda de costa o socorro que sea de su agrado, y el Cavildo en su vista acordó dar y dio comisión a los Señores Diputados de Acólitos para que informen con llamamiento". 1139

El Cabildo acuerda conceder las ayudas de costa anteriormente solicitadas por D. Vicente Marín y D. Mateo Tascón: “...acordó dar y dio por una vez en razón de ayuda de costa y a cada uno cinquenta pesos”. ${ }^{1140}$

Se leyó un memorial de Don Manuel Gutiérrez Ravé, recientemente agraciado con una media ración en la Catedral de Málaga, en que suplica al Cabildo se le dé un testimonio de las pruebas que hizo en la Catedral de Córdoba. El Cabildo ordena que se le dé testimonio de dichas pruebas. ${ }^{1141}$

"Se leyeron dos memoriales, uno de Don Salvador Serrano, Capellán de Veintena de esta Santa Iglesia; y otro de Don Julián de Gálvez, músico instrumentista de ella: y el Cavildo acordó: al primero dar comisión para que con llamamiento informen los Señores Diputados de Veintena: y al otro en la misma forma para que lo hagan los Señores Diputados de Excusados de Música con la parte”. ${ }^{1142}$

“Se leyó un memorial de Don Manuel Álvarez de Roldán, Capellán Perpetuo de la del Señor San Pedro de esta Santa Iglesia, en el que expresa al Cavildo las razones que le asisten para desde el día de la fecha de dicho memorial hacer la renuncia en manos del Cavildo del salario de 400 ducados que goza, por los oficios de Sochantre y músico, cuyos oficios igualmente renuncia para que el Cavildo los provea en quien fuese de su agrado, pues el dicho Don Manuel Álvarez desde dicha fecha quedaba sólo con su Capellanía de San Pedro, y el Cavildo en su vista acordó dar y dio comisión a

\footnotetext{
${ }^{1139}$ Ibid. Jueves 12 de Febrero de 1807. T. 98, fol. 202 r.

${ }^{1140}$ Ibid. Martes 17 de Febrero de 1807, T.98.

${ }^{1141}$ Ibid. Martes 17 de Febrero de 1807. T. 98, fol. 205 r.

1142 Ibid. Sábado 28 de Febrero de 1807. T. 98, fol. 213 v.
} 
los Señores Diputados de Arcas de San Acacio con la parte para que informen con llamamiento". 1143

"Se leyó un memorial de Don Joseph Las, músico instrumentista de esta Santa Iglesia en el que pide al Cavildo se sirva dispensarle aquella ayuda de costa que sea de su agrado en atención a los atrasos que padece por causa de su largo padecer, y que en la actualidad se haya amenazado judicialmente para el pago del alquiler de la casa sin tener arbitrios para pagarlo; y el Cavildo en su vista acordó dar y dio comisión a los Señores Diputados de Arcas de Santa Inés con la parte para que informen con llamamiento". 1144

El Señor Arcediano de Pedroche comunicó al Cabildo que Don Manuel Gutiérrez Ravé, había sido recientemente agraciado con una media ración en la Catedral de Málaga. Pero que sin embargo antes de marcharse debía cumplir con una serie de misas correspondientes a su cargo y que aún no había realizado. El Cabildo decidió comunicar al Señor Gutiérrez Ravé que debía decir dichas misas antes de ausentarse. ${ }^{1145}$

El Cabildo concede a Don Julián de Gálvez, músico instrumentista una ayuda de costa de cincuenta ducados. ${ }^{1146}$

El Arcediano de Pedroche presentó al Cabildo a Don Rafael Gallardo, como sustituto de Don Mateo Bernia, recientemente fallecido para cubrir una Capellanía de Santa Inés. "Igualmente hizo presente al Cavildo dicho Señor Arcediano que habiendo resultado vacante por la salida de Bonilla del Colegio de los Infantes de Coro una beca propia del Patronato de ese Cavildo, se sirva determinar lo que convenga; y el Cavildo acordó dar y dio comisión a los Señores Diputados del expresado Colegio para que admitan memoriales de los pretendientes que se presenten, e informase de lo que resulte, e informen con llamamiento.

\footnotetext{
${ }^{1143}$ Ibid. Martes 3 de Marzo de 1807. T. 98, fol. 215 r.

1144 Ibid. Martes 3 de Marzo de 1807. T. 98, fol. 215 v.

1145 Ibid. Jueves 5 de Marzo de 1807. T. 98, fol. 217 r.

${ }^{1146}$ Ibid. Sábado 14 de Marzo de 1807. T. 98, fol. 219 v.
} 
Item se leyó un memorial de Don Mariano Ferrer, músico instrumentista de la Capilla de esta Santa Iglesia, solicitando de el Cavildo una ayuda de costa en atención a la dotación de mil quinientos reales que goza y que apenas le alcanza para el preciso alimento". El Cabildo dio comisión a los Diputados de Santa Inés para que informasen. $^{1147}$

"Se leyó un informe de los Señores Diputados de Acólitos, sobre el socorro que solicitaba Francisco Escalona, Acólito que fue de esta Santa Iglesia, el cual fue denegado por votos secretos". 1148

Se presentan las pruebas de limpieza de sangre de Antonio Jurado, Acólito recién elegido por el Cabildo. Una vez vistas dichas pruebas se acuerda darlas por bien hechas y por lo tanto el Cabildo acepta al mencionado Antonio Jurado. ${ }^{1149}$

En el día de la fecha, el Cabildo acepta por fin la renuncia de Don Manuel Álvarez, anterior Sochantre, y que se había despedido para marchar a cubrir una media ración en la Catedral de Málaga. Asimismo el Cabildo acuerda iniciar los trámites para proveer a la mayor brevedad posible la plaza de Sochantre y Teniente de Sochantre de la Catedral. ${ }^{1150}$

"Se leyó un memorial de Antonio Jurado, Acólito de esta Santa Iglesia, en el que suplica una ayuda de costa con el motivo de los gastos que le han ocasionado las pruebas; y el Cavildo acordó dar y dio comisión a los Señores Diputados de Acólitos, para que con llamamiento informen sobre él". ${ }^{1151}$

Los Niños de Coro José Jaén, Rafael Morales, José Villalba y Francisco Bonilla, solicitan una ayuda de costa y el Cabildo les concede doscientos reales a cada uno de ellos. También se leyó un memorial de José Gómez, Organista de la Catedral de

\footnotetext{
${ }^{1147}$ Ibid. Sábado 14 de Marzo de 1807. T. 98, fol. 221 v.

${ }^{1148}$ Ibid. Martes 17 de Marzo de 1807. T. 98, fol. 223 r.

1149 Ibid. Miércoles 19 de Abril de 1807. T. 98, fol. 228 r.

${ }^{1150}$ Ibid. Miércoles 29 de Abril de 1807. T. 98, fol. 232 v.

${ }^{1151}$ Ibid. Sábado 2 de Mayo de 1807. T. 98. fol. 232 v.
} 
Guadix, solicitando un testimonio de las pruebas de limpieza de sangre que tenía hechas en esta Catedral como Niño de Coro. El Cabildo acordó facilitarle dicho testimonio. ${ }^{1152}$

Se leen las pruebas de Antonio Ayllón nombrado Acólito. El Cabildo vistas dichas pruebas acuerda darlas por satisfactorias y acepta a dicho Antonio Ayllón. Igualmente se leyó un informe de los Diputados de Acólitos sobre la ayuda de costa que solicitaba el también Acólito Antonio María Jurado. El Cabildo acordó concederle trescientos reales de vellón por una vez. ${ }^{1153}$

Los Señores Diputados de Arcas de San Acacio leen un informe al Cabildo con las propuestas para cubrir las plazas de Sochantre y Teniente de Sochantre. Una vez oídas estas propuestas el Cabildo da comisión a los dichos Señores Diputados de San Acacio para que a la mayor brevedad posible resuelvan el tema de la provisión de Sochantre y Teniente de Sochantre y que asimismo presenten un plan completo y detallado con las obligaciones de cada uno de ellos. ${ }^{1154}$

El Señor Arcediano de Pedroche comunica al Cabildo que se han presentado varios memoriales para cubrir la plaza vacante de Infante de Coro. El Cabildo acuerda que el Maestro de Capilla vaya a examinar a dichos niños en el Colegio del Santo Ángel y que una vez examinados traiga al Cabildo sus resoluciones. ${ }^{1155}$

"Se leyó un llamamiento para oír el informe y la censura del Maestro de Capilla sobre los pretendientes a la beca vacante en aquél [se refiere al Colegio de Infantes] y con atención a todo lo expuesto, el Cavildo nombró para la mencionada beca a José de Arroyo". 1156

Los Señores Diputados de Arcas Vacantes de San Acacio informan al Cabildo de sus propuestas para cubrir las plazas de Sochantre y Teniente de Sochantre: " $Y$

\footnotetext{
1152 Ibid. Lunes 11 de Mayo de 1807. T. 98, fol. 232 r.

1153 Ibid. Martes 26 de Mayo de 1807. T. 98, fol. 241 r.

1154 Ibid. Martes 26 de Mayo de 1807. T. 98, fol. 241 v.

1155 Ibid. Miércoles 27 de Mayo de 1807. T. 98, fol. 243 r.

${ }^{1156}$ Ibid. Miércoles 17 de Junio de 1807. T. 98, fol. 249 r.
} 
conformándose el Cavildo con lo expuesto, acordó proceder y procedió a nombrar por votos secretos y nombró por Sochantre a Don Juan Ortíz, Presbítero Capellán de San Pedro: y Sochantre interino: y al Presbítero Don José González, Veintenero, Subteniente". 1157

Se leyó un memorial de Don Juan de Mora, violinista, solicitando una ayuda de costa. El Cabildo le concedió por una vez mil quinientos reales de vellón. ${ }^{1158}$

Interesantísima noticia es la que figura en el acta del 27 de Junio y que refleja a través de 45 normas muy concretas las funciones, obligaciones, permisos, etc., del Sochantre y su teniente. ${ }^{1159}$

"Se leyó un memorial de Don Miguel Reynaldi, primer violinista de la Capilla de Música de esta Santa Iglesia pidiendo a V.S. una ayuda de costa por estar enseñando el instrumento del violín a varios niños del Colegio de Infantes de orden de los Señores Diputados de él; y el Cavildo acordó dar y dio comisión para que con llamamiento informen sobre esta solicitud a los Señores Diputados de Arcas Vacantes de Santa Inés con la parte de Nuestro Señor Prelado”. 1160

Acerca de la forma más idónea de proveer definitivamente una plaza vacante en la Capilla de San Antonino, el Cavildo acuerda que "era necesario que Don Nicolás de Anguita, músico contralto de la Capilla de esta Santa Iglesia se presentase a nuevo examen, en que acreditase sus adelantamientos en la música, y su idoneidad para poder ser presentado a dicha Capellanía e instruir con el certificado de su examen dicho expediente que hasta ahora había carecido de esta formalidad, determinando: que el referido, si quería ser agraciado en ella, se presentase a referido examen. Y para que lo probasen y examinasen nombró el Cavildo a Don Jaime Balius, Maestro de Capilla de

\footnotetext{
${ }^{1157}$ Ibid. Sábado 27 de Junio de 1807. T. 98, fol. 253 v.

1158 Ibid. Sábado 27 de Junio de 1807. T. 98, fol. 256 v.

1159 Ibid. Sabado 27 de Junio de 1807, T.98.

${ }^{1160}$ Ibid. Sábado 4 de Julio de 1807. T. 98, fol. 260 r.
} 
Música de esta Santa Iglesia, Don Alfonso Martín y Don Joseph Moyano músicos de la misma, que deberán certificar en forma su juicio y parecer". ${ }^{1161}$

En este día se presenta al Cabildo el memorial de genealogía detallado de Joseph María de Arroyo, recientemente elegido Colegial del Santo Ángel. ${ }^{1162}$

"Se leyó un memorial de Don Mariano Ortega, músico instrumentista de la Capilla de esta Santa Iglesia, en que pide una ayuda de costa, y el Cavildo dio comisión a los Señores Diputados de Excusados de Música con la parte de Nuestro Ilustrísimo Prelado para que informen con llamamiento". 1163

"Se leyó un memorial de Don Juan Puig, bajonista de la Capilla de Música de esta Santa Iglesia en el que pide licencia para ir a su tierra, y se dio comisión a los Señores Diputados de Excusados de Música con la parte de Nuestro Ilustrísimo Prelado para que informen con llamamiento.

Item se leyó un memorial del Acólito Antonio Ayllón en el que pide una ayuda de costa en atención a los empeños que ha contraído por una larga enfermedad y el costo de las pruebas, y el Cavildo dio comisión a los Señores Diputados de Acólitos para que informen con llamamiento". 1164

"Se leyó un llamamiento para oír el informe de los Señores Diputados de Excusados de Música con la parte de Nuestro Ilustrísimo Prelado sobre las solicitudes de Don Andrés Lidón y Don Juan Puig, y oído dicho informe y cuanto de palabra expusieron dichos Señores Diputados, se acordó conceder cuarenta días de licencia contados desde el día que salga de esta ciudad a Don Andrés Lidón con sujeción a aspas, para que pueda conducir a Madrid a su hijo, agraciado por decreto con una plaza de Niño Cantor de la Real Capilla: que entretanto sirva el órgano el segundo organista, y caso de imposibilitarse por enfermedad, u otra causa lo sirva Don José Waluir, por el tiempo que permanezca en esta ciudad según ha ofrecido y manifiestan

\footnotetext{
${ }^{1161}$ Ibid. Sábado 11 de Julio de 1807. T. 98, fol. 263 r.

1162 Ibid. Viernes 17 de Julio de 1807. T. 98, fol. 265 v.

1163 Ibid. Viernes 24 de Julio de 1807. T. 98, fol. 268 r.

1164 Ibid. Lunes 28 de Julio de 1807. T. 98, fol. 268 v.
} 
en su informe los expresados Señores Diputados mediante ser Organista de la Catedral de Solsona, y práctico en el manejo del órgano.

Y a Don Juan Puig un mes de licencia contando desde el día que salga de esta ciudad para ir a ver a su Madrid, con sujeción a aspas.

Enseguida se leyó un llamamiento para oír el informe de los Señores Diputados de Acólitos sobre la ayuda de costa que solicita Don Antonio de Ayllón, y oído dicho informe con cuanto verbalmente expusieron los expresados Señores Diputados se acordó por votos secretos concederle trescientos reales de vellón de ayuda de costa por una vez". 1165

En este día el Cabildo discute acerca de si mantener o no mantener las pruebas de limpieza de sangre en los términos que hasta ahora se venían realizando, debido al alto coste que tienen para los interesados. ${ }^{1166}$

Los Señores Diputados de Arcas Vacantes de Santa Inés, informan que Don Miguel Reynaldi primer violín de la Capilla, está realizando su trabajo como profesor de violín de los Niños de Coro con gran puntualidad y esmero. En consecuencia el Cabildo le concede tres mil reales de ayuda de costa.

“Enseguida se leyó el llamamiento para oír el informe de los mismos Señores con la parte, sobre haber evacuado las diligencias de estilo en torno a las pruebas de José María de Arroyo nombrado Infante de Coro: y oído dicho informe que leyó el notario secretario, mandado entrar a éste llegó a manifestar ser hermano de padre y madre de Rafael Arroyo, agraciado anteriormente con la beca de Niño de Coro”. El Cabildo aceptó dichas pruebas. ${ }^{1167}$

"Se dio cuenta de un memorial de Don José Vicente García, Presbítero y Salmista de esta Santa Iglesia, pidiendo una ayuda de costa, que se cometió a informe con llamamiento de los Señores Diputados de Arcas Vacantes de San Acacio, con la

\footnotetext{
1165 Ibid. Lunes 3 de Agosto de 1807. T. 98, fol. 273 v.

${ }^{1166}$ Ibid. Sábado 8 de Agosto de 1807. T. 98, fol. 276 v.

${ }^{1167}$ Ibid. Jueves 13 de Agosto de 1807. T. 98, fol. 280 r.
} 
parte, y lo mismo se verificó con el memorial de Lope de Mora, músico instrumentista que solicita igual ayuda de costa que también se leyó en Cavildo”. ${ }^{1168}$

"Se leyó el informe de los Señores Diputados de Acólitos sobre la ayuda de costa que solicitaba Francisco Bonilla, y por votación secreta le fueron concedidos doscientos reales de vellón por una vez”. 1169

"Se leyó un memorial de Don Andrés Lidón, pidiendo prórroga de la licencia que se le concedió para pasar a Madrid, y se acordó pase a informe de los Diputados de Excusados de Música con la parte de Su Ilustrísima para que informen con llamamiento". 1170

"En virtud del llamamiento para oír el informe de los Señores Diputados de Acólitos sobre la ayuda de costa que solicita Miguel Colmenero, leído el expresado informe se procedió a la votación secreta por la que salió negada dicha solicitud”. ${ }^{1171}$

“En virtud del llamamiento para oír el informe de los Señores Diputados de Arcas Vacantes de San Acacio sobre la solicitud de Don José Vicente García, leído dicho informe se procedió a la votación secreta y por ella se le concedieron mil y quinientos reales de ayuda de costa por una vez del fondo de dichas Arcas encargándole estrictamente se aplique a la música, asistiendo a las lecciones diarias que le dé Don Benito Torrellas, quien ha de dar cuenta a el Cavildo al cabo de un año de sus adelantamientos.

Continuando el mismo llamamiento para oír el informe de los mismos Señores sobre la ayuda de costa que solicita Don Benito Torrellas, se determinó por votación secreta darle una ayuda de costa por una vez de doscientos ducados del fondo de dichas Arcas, y por vía también de ayuda de costa, cien ducados anuales desde el día de la fecha para que enseñe música a Don José Vicente García, dando cuenta al Cavildo a fin de un año de sus adelantamientos.

\footnotetext{
${ }^{1168}$ Ibid. Viernes 4 de Septiembre de 1807. T. 98, fol. 287 v.

${ }^{1169}$ Ibid. Viernes 18 de Septiembre de 1807. T. 98, fol. $290 \mathrm{r}$.

1170 Ibid. Miércoles 23 de Septiembre de 1807. T. 98, fol. 291 v.

${ }^{1171}$ Ibid. Viernes 25 de Septiembre de 1807. T. 98, fol. 292 v.
} 
Y enseguida del expresado llamamiento, para oír el informe de los mismos Señores sobre la ayuda de costa que solicita Don Lope de Mora, se acordó por votos secretos concederle del fondo de dichas Arcas mil reales por una vez". ${ }^{1172}$

"Sobre la solicitud de Don Andrés Lidón, organista primero de esta Santa Iglesia, leído dicho informe redundó a que en virtud de las causas que exponían, podía el Cavildo concederle la prórroga de licencia que gustase, corrido el voto, se acordó prorrogarle dicha licencia hasta fin del presente mes de octubre”. ${ }^{1173}$

"Se presentó un memorial de D. Juan Nepomuceno Puig, Bajonista de esta Santa Iglesia, pidiendo una ayuda de costa". ${ }^{1174}$

"Se leyó un memorial de Don Antonio Gil, Capellán de San Acacio, pidiendo una ayuda de costa, y se cometió a informe de los Señores Diputados de dicha Capilla por la parte de Su Ilustrísima.

Se dio cuenta de otro memorial de Don Francisco Cascante, músico contrabajo, que se cometió a informe de los mismos Señores Diputados de San Acacio con la parte”. ${ }^{1175}$

"Se leyó un memorial de Don Antonio Ordóñez, Presbítero músico tiple de la Catedral de Cádiz, solicitando que el Cavildo le señalase día y hora para cantar en el coro y pudiesen de este modo oírle los Señores que no le hubiesen oído cuando cantó la primera vez, y se acordó que mañana por la tarde miércoles 28 del corriente, después de coro, cantase, avisando el notario secretario al Maestro de Capilla y al interesado para dicho efecto.

Se dio cuenta de otro memorial de Don Pedro de Arroyo Ruiz, solicitando una ayuda de costa por los gastos que se le habían ofrecido para equipar a su hijo José María en el ingreso de plaza de Niño de Coro, y se cometió a informe a los Señores Diputados de Arcas de Santa Inés con la parte de Su Ilustrísima”. 1176

\footnotetext{
1172 Ibid. Jueves 1 de Octubre de 1807. T. 98, fol. 301 r.

1173 Ibid. Jueves 8 de Octubre de 1807. T. 98, fol. 311 v.

1174 Ibid. Miércoles 14 de Octubre de 1807, T.98.

1175 Ibid. Jueves 22 de Octubre de 1807. T. 99, fol. 2 r.

${ }^{1176}$ Ibid. Martes 27 de Octubre de 1807. T. 99, fol. 4 r.
} 
“Se leyó un memorial de Don José Benito Bach, organista de esta Santa Iglesia, solicitando una ayuda de costa, y se cometió a informe de los Señores Excusados de Música con la parte de Su Ilustrísima.

También se dio cuenta de otro memorial de Don Francisco Ximénez Delgado, Presbítero, Sochantre en Granada solicitando sea oída su voz, y se acordó que se avise al Maestro de Capilla y a Don Juan Ortiz para que en la tarde de este día después de Completas se le pruebe al expresado Ximénez en canto llano y música, para informar al Cavildo de su calidad, voz, pericia e inteligencia”. 1177

Para resolver la solicitud de Don Antonio Ordóñez que pretendía ser oído por este Cabildo, se lleva a cabo dicha prueba que está supervisada por el Maestro de Capilla. Una vez realizada el Cabildo llama a dicho Maestro: “Enseguida se mandó entrar a Don Jaime Balius, Maestro de Capilla quien informó de la calidad de voz y demás circunstancias del referido Padre Ordóñez, y habiéndose retirado se acordó por votos secretos conceder seiscientos ducados de salario con las dos siguientes condiciones: primera que dichos seiscientos ducados no han de empezar a correrle hasta que presente en debida forma los papeles correspondientes de su habilitación. Segunda: que verificada dicha habilitación le correrá dicho salario por dos años en cuyo tiempo deberá instruirse bien en la música”. 1178

“El Señor Prior dijo que hacía mucho tiempo se hallaban vacantes algunas capellanías de esta Capilla afectas a Música, y que no habiéndose procedido a la fijación de edictos llamando opositores, y proceder a su provisión, se diese comisión para que a la mayor brevedad informen los Señores Diputados de esta Capilla sobre dicho punto, y se acordó dar la expresada comisión para que con la parte de Su Ilustrísima se efectúe a la mayor brevedad”. ${ }^{1179}$

\footnotetext{
${ }^{1177}$ Ibid. Sábado 31 de Octubre de 1807. T. 99, fol. 5 v.

${ }^{1178}$ Ibid. Sábado 31 de Octubre de 1807. T. 99, fol. 6 r.

${ }^{1179}$ Ibid. Sábado 31 de Octubre de 1807. T. 99, fol. 6 r.
} 
“Se leyó un memorial de Don Manuel Álvarez y Roldán, Capellán de San Pedro, pidiendo licencia para pasar a Santiago a hacer oposición a la plaza de Sochantre o baxo de Capilla de aquella Santa Iglesia y corrido el voto se le concedió dicha licencia con sujeción a aspas por tres meses empezados a contar desde este día de la fecha”. ${ }^{1180}$

"Se leyó un memorial de Don Ángel Arteaga, músico tenor de esta Santa Iglesia, exponiendo se hallaba con una carta del Deán de Santiago, llamándole a ser oído, y pidiendo licencia para verificarlo, y se mandó entrar a los Señores Diputados de Arcas Vacantes de Santa Inés, con la parte de Su Ilustrísima para que informen con llamamiento.

A los mismos Señores igualmente con la parte de Su Ilustrísima se cometió para que informasen otro memorial de el Padre Antonio Ordóñez, músico tiple de la Catedral de Cádiz, solicitando un testimonio de lo acordado sobre su admisión en la Capilla de esta Santa Iglesia, para hacerlo presente a sus superiores". ${ }^{1181}$

El Cabildo acuerda facilitar a Don Antonio Ordóñez el documento acreditativo que este pedía, de haber realizado las pruebas en la Catedral de Córdoba y haber obtenido plaza. ${ }^{1182}$

"Sobre la ayuda de costa que solicitan Don José Bach, organista, y Don Juan Puig, bajonista de esta Santa Iglesia, leídos dichos informes, se acordó dar al primero mil y quinientos reales de ayuda de costa por una vez, del fondo de dichos Excusados de Música, y al segundo mil reales decidiendo esta y otra consignación por votos secretos”. Igualmente se leyó un memorial de Don José García salmista de la Catedral presentándose para obtener la Capellanía vacante de San Pedro. ${ }^{1183}$

El Cabildo concede a Don Francisco Cascante una ayuda de costa de mil quinientos reales de vellón como ayuda de costa. ${ }^{1184}$

\footnotetext{
${ }^{1180}$ Ibid. Miércoles 4 de Noviembre de 1807. T. 99, fol. 6 v.

${ }^{1181}$ Ibid. Miércoles 4 de Noviembre de 1807. T. 99, fol. 6 v.

1182 Ibid. Viernes 6 de Noviembre de 1807. T. 99, fol. 7 v.

1183 Ibid. Viernes 13 de Noviembre de 1807. T. 99.

${ }^{1184}$ Ibid. Viernes 13 de Noviembre de 1807. T. 99, fol. 10 v.
} 
"Se leyó un memorial de Don Vicente Marín, músico instrumentista de esta Santa Iglesia, pidiendo una ayuda de costa, y se cometió a informe de los Señores Diputados de Excusados de Música con la parte de su Ilustrísima”. ${ }^{1185}$

El Cabildo concede a José María de Arroyo, Infante de Coro una ayuda de costa de trescientos reales, para contribuir a los gastos que tuvo en su entrada al Colegio de Infantes. $^{1186}$

El Cabildo concede a Don Antonio Gil una ayuda de costa de mil quinientos reales. ${ }^{1187}$

"Se leyeron dos memoriales de Don Juan Bueno tiple y Don Mariano Ferrer músico instrumentista, solicitando ambos una ayuda de costa, y se mandaron pasar a los Señores Diputados de Arcas de Santa Inés para que con la parte de Su Ilustrísima informen con llamamiento sobre su contenido". ${ }^{1188}$

El Cabildo concede a Don Vicente Marín, músico instrumentista una ayuda de costa de cien ducados, por una vez del fondo de Excusados de Música. ${ }^{1189}$

\section{8}

El Cabildo concede a Don Juan Bueno, una ayuda de costa de mil quinientos reales de vellón, del fondo de Arcas Vacantes de Santa Inés. ${ }^{1190}$

“Se leyó un memorial de Don Antonio Ordóñez, con el que incluía las licencias de su religión, para fijar su establecimiento en la Capilla de Música de esta Santa

\footnotetext{
${ }^{1185}$ Ibid. Jueves 3 de Diciembre de 1807. T. 99, fol. 14 v.

${ }^{1186}$ Ibid. Viernes 4 de Diciembre de 1807. T. 99, fol. 15 r.

${ }^{1187}$ Ibid. Viernes 4 de Diciembre de 1807. T. 99, fol. 15 r.

1188 Ibid. Miércoles 16 de Diciembre de 1807. T. 99, fol. 17 v.

1189 Ibid. Jueves 17 de Diciembre de 1807. T. 99, fol. 18 r.

${ }^{1190}$ Ibid. Jueves 14 de Enero de 1808. T. 99, fol. 20 v.
} 
Iglesia, y se cometió a informe de los Señores Diputados de Arcas Vacantes de Santa Inés con la parte de Su Ilustrísima”. 1191

“Sobre la solicitud de Don Mariano Ferrer, músico trompa, leído dicho informe redundo a manifestar la indigencia de este Ministro con la corta dotación de cuatro reales diarios, su aplicación, y conducta, se acordó por votos secretos concederle dos mil reales de ayuda de costa por una vez". 1192

"Se dio cuenta de un memorial de Don Mateo Tascón, solicitando aumento de renta, y se mandó pasar a los Señores Diputados de Excusados de Música para que, con la parte de Su Ilustrísima informen con llamamiento.

Se presentó un memorial del Acólito José de Villalba pidiendo ayuda de costa, y se cometió a informe de los Señores Diputados de Acólitos”. 1193

Se hizo relación de un memorial de Don Manuel Álvarez Roldán, que pedía licencia para ir a Cartagena a hacer oposición a la plaza de Sochantre. ${ }^{1194}$

"Se leyeron dos memoriales, el uno de Don Mariano Especiali solicitando patitur abierto, y el otro de Don Francisco Cascante, con igual solicitud y además la de una ayuda de costa, y se mandaron pasar a los Señores Diputados de Arcas Vacantes de San Acacio, para que con la parte de Su Ilustrísima informen con Ilamamiento". 1195

“En virtud del llamamiento para oír el informe de los Señores Diputados de Arcas Vacantes de San Acacio con la parte de Su Ilustrísima, sobre la solicitud de Don Mariano Especiali, músico tiple de esta Santa Iglesia, leído dicho informe, redundó a manifestar la larga y penosa enfermedad que ha padecido este Ministro, las reliquias y que de resultas de ella, le han quedado, la edad de sesenta y dos años que tiene, la intemperie de la iglesia y rigor de la estación que se experimenta, contrarias a su

\footnotetext{
${ }^{1191}$ Ibid. Jueves 14 de Enero de 1808. T. 99, fol. 21 v.

1192 Ibid. Viernes 15 de Enero de 1808. T. 99, fol. 21 v.

1193 Ibid. Viernes 22 de Enero de 1808. T. 99, fol. 22 r.

${ }^{1194}$ Ibid. Viernes 22 de Enero de 1808. T. 99, fol. 22 r.

1195 Ibid. Viernes 22 de Enero de 1808. T. 99, fol. 22 v.
} 
padecer, según lo acredita la certificación jurada del médico Don Antonio Muñoz y Criado, se acordó concederle patitur abierto por votos secretos hasta fin de junio de este año.

En continuación del mismo llamamiento para oír el informe de los expresados Señores sobre igual patitur y ayuda de costa que solicita Don Francisco Cascante, músico contrabajo de esta Santa Iglesia, se procedió a la lectura de dicho informe, redundó a exponer la debilidad con que ha quedado este Ministro, de resultas de la larga y peligrosa enfermedad que ha padecido, según lo expresa la certificación jurada del médico Don José Criado y su indigencia por la corta dotación de trescientos ducados, numerosa familia que mantener, y carestía de todas las cosas en los actuales tiempos: en su vista acordó el Cabildo por votos secretos concederle patitur abierto hasta fin de mayo, y mil y quinientos reales de ayuda de costa del fondo de dichas Arcas de San Acacio". 1196

El Cabildo acuerda concederle a Don Manuel Álvarez, dos meses de licencia con sujeción a aspas, para que se presente a una oposición en Cartagena, a la plaza de Sochantre. ${ }^{1197}$

El Cabildo concede a Don José Villalba, Acólito, una ayuda de costa de doscientos reales por una vez. ${ }^{1198}$

"Se hizo presente un memorial del Acólito José Jaén, pidiendo una ayuda de costa, y se mandó pasar a informe de los Señores Diputados de Acólitos para que lo verifiquen con llamamiento". 1199

El Cabildo acepta al soldado Don Antonio Ordóñez para que pase a formar parte del coro. En este mismo día se presenta un memorial del violinista Don José Las, pidiendo una ayuda de costa, y una carta de Don Ángel Arteaga "solicitando no se

\footnotetext{
${ }^{1196}$ Ibid. Martes 26 de Enero de 1808. T. 99, fol. 23 v.

${ }^{1197}$ Ibid. Sábado 30 de Enero de 1808. T. 99, fol. 26 r.

1198 Ibid. Sábado 30 de Enero de 1808. T. 99, fol. 26 v.

${ }^{1199}$ Ibid. Sábado 13 de Febrero de 1808. T. 99, fol. 28 v.
} 
provea su plaza, hasta que se acabe de verificar su colocación en la Iglesia de Santiago". 1200

“En virtud del llamamiento para oír el informe de los Señores Diputados de Excusados de Música con la parte de Su Ilustrísima sobre la solicitud de Don Mateo Tascón, músico instrumentista, se procedió a la lectura de dicho informe, reducido a manifestar la necesidad de este Ministro, su corta dotación de trescientos cincuenta ducados, su habilidad, exactitud, puntual asistencia a enseñar en el Colegio del Santo Ángel, circunstancias que le hacían acreedor a la piedad de el Cabildo quien por votos secretos le concedió cien ducados de aumento de salario del fondo de dichos Excusados de Fábrica.

Enseguida del mismo llamamiento para dar la colación de la Capellanía de San Pedro a Don José Vicente García, se mandó entrar al notario secretario y testigos, y puesto de rodillas el referido Don José Vicente García, delante de la parte de Su Ilustrísima y del Señor Deán, se le hizo la colación de la expresada Capellanía que se hallaba vacante, por la imposición de un bonete sobre su cabeza en la forma acostumbrada.

Se dio cuenta de un memorial de Don Cristóbal Bendicho, pidiendo una ayuda de costa, y se cometió a informe de los Señores Diputados de Excusados de Música con la parte”. ${ }^{1201}$

"Se leyeron dos memoriales, uno de Don Sebastián Cabezón, Capellán Perpetuo de San Antonino, solicitando patitur abierto, y otro de Don Juan de Mora, violinista, pidiendo una ayuda de costa, y se acordó pasar uno y otro a los Señores Diputados de Arcas Vacantes de San Acacio para que con la parte de Su Ilustrísima informen con llamamiento". 1202

El Cabildo concede a Don Cristóbal Bendicho, una ayuda de costa de cincuenta ducados. Asimismo concede a José Jaén, Acólito, una ayuda de costa de doscientos reales. $^{1203}$

\footnotetext{
${ }^{1200}$ Ibid. Sábado 13 de Febrero de 1808. T. 99, fol. 29 v.

${ }^{1201}$ Ibid. Miércoles 17 de Febrero de 1808. T. 99, fol. 30 v.

${ }^{1202}$ Ibid. Martes 23 de Febrero de 1808. T. 99, fol. 32 r.

${ }^{1203}$ Ibid. Viernes 26 de Febrero de 1808. T. 99, fol. 32 v.
} 
El Cabildo concede a Don José Las, cien ducados de ayuda de costa, por una vez del fondo de Arcas Vacantes de Santa Inés. ${ }^{1204}$

"Se leyó un memorial de Don Manuel Álvarez., Capellán de San Pedro, expresando haber obtenido la Sochantría Mayor de la Iglesia de Cartagena, y pidiendo no se dé por vacante la Capellanía de San Pedro, hasta que se cumpla el término prevenido por derecho, por si acaso no le probase aquel clima, y se acordó nombrar a los Señores Espejo y Villaescusa con la parte de Su Ilustrísima para que informen con llamamiento y asistencia del Señor Deán”. ${ }^{1205}$

“El Cavildo concede a Don Sebastián Cabezón Capellán de San Antonino, patitur abierto hasta el Sábado Santo inclusive del presente año”. ${ }^{1206}$

Sobre la solicitud de Don Manuel Álvarez, que había obtenido la Sochantría de la Catedral de Cartagena, y solicitaba al Cabildo de Córdoba que no ofertara de nuevo su plaza hasta ver si el nuevo clima le iba bien el Cavildo cordobés acuerda que en el momento que el Cabildo de Cartagena nombre firmemente a Don Manuel Álvarez como Sochantre y le comience a pagar, su plaza aquí en Córdoba debe salir a oposición. ${ }^{1207}$

“En virtud del llamamiento para oír el informe de los Señores Diputados de Arcas Vacantes de San Acacio con la parte de Su Ilustrísima sobre la ayuda de costa que solicita Juan de Mora, se leyó dicho informe, reducido a exponer que aún y cuando en el año anterior se le concedió una ayuda de costa de mil y quinientos reales, a dicho Mora, era tan corta su dotación de ciento y cincuenta ducados para mantener a sus padres y cuatro hermanas, que en esta atención la de su buena conducta, y desempeño de su obligación, era acreedor a la piedad del Cavildo, y por votos secretos se le

\footnotetext{
${ }^{1204}$ Ibid. Sábado 5 de Marzo de 1808. T. 99, fol. 35 r.

1205 Ibid. Martes 22 de Marzo de 1808. T. 99, fol. 39 v.

${ }^{1206}$ Ibid. Sábado 26 de Marzo de 1808. T. 99, fol. 43 v.

${ }^{1207}$ Ibid. Jueves 31 de Marzo de 1808. T. 99, fol. 45 v.
} 
concedieron mil y quinientos reales de ayuda de costa por una vez del fondo de dichas Arcas”. ${ }^{1208}$

"Se dio cuenta de un memorial del Acólito Francisco Bonilla, y se acordó pase a los Señores Diputados de Acólitos para que informen sobre la ayuda de costa que solicita”. 1209

"Se dio cuenta de un memorial de Don José Luis de los Heros, Capellán de San Acacio, solicitando un testimonio de las pruebas que hizo para entrar a servir su Capellanía, y se acordó que con asistencia de los Señores Diputados de dicha Capilla se le dé por el notario secretario, testimonio de lo que convenga y deba dar fe". ${ }^{210}$

"Se dio cuenta de un memorial del Acólito Miguel Colmenero, pidiendo una ayuda de costa, y se cometió a informe de los Señores Diputados de Acólitos”. ${ }^{1211}$

"En virtud del llamamiento para oír el informe de los Diputados de Arcas Vacantes de San Acacio con la parte de Su Ilustrísima sobre el Reglamento General para la Capilla de Música de esta Santa Iglesia, se procedió a la lectura de dicho informe que original se mandó coger a este acuerdo, y se determinó aprobar el expresado Reglamento, como Reglamento, que pase a los demás Cavildos para su aprobación, y para este efecto se dio comisión al Señor Presidente para que en ellos lo proponga". 1212

Don Antonio Ordóñez, músico tiple de la Capilla solicita una ayuda de costa en atención a la renta tan corta que tiene asignada. ${ }^{1213}$

"En virtud del llamamiento para oír el informe de los Señores Diputados de Acólitos sobre las ayudas de costa, que solicitan Francisco Bonilla y Miguel

\footnotetext{
${ }^{1208}$ Ibid. Jueves 7 de Abril de 1808. T. 99, fol 51 v.

1209 Ibid. Sábado 30 de Abril de 1808. T. 99, fol. 56 r.

${ }^{1210}$ Ibid. Sábado 30 de Abril de 1808. T. 99, fol. 56 v.

${ }^{1211}$ Ibid. Jueves 12 de Mayo de 1808. T. 99, fol. 59 r.

1212 Ibid. Jueves 12 de Mayo de 1808. T. 99, fol. 59 v.

1213 Ibid. Jueves 12 de Mayo de 1808. T. 99, fol. 59 v.
} 
Colmenero, leído dicho informe en que se manifestaba ser ciertas las necesidades que exponían, se acordó por votos secretos conceder a cada uno de ellos doscientos reales de ayuda de costa por una vez". ${ }^{1214}$

"Se leyó un memorial del Acólito Miguel Colmenero, despidiéndose de su destino por haber ido a servir al ejército, y se nombró en su lugar al Niño de Coro José Mexía”.1215

"En virtud del llamamiento para oír el informe de los Señores Diputados de Excusados de Música con la parte de Nuestro Ilustrísimo Prelado, se procedió a su lectura y decía así: Señor: en virtud del anterior Decreto de V.S. de 27 de mayo último hemos visto el Reglamento de la Capilla de Música de esta Santa Iglesia, y enterados de todo su contenido decimos, que nos conformamos con él en la parte que nos toca, y nada tenemos que añadir o corregir en un plan también meditado y formado con tanto pulso. V. S. en su vista podrá proveer como juzgue más conveniente”. 1216

"Se leyó un memorial del violinista Juan de Mora, solicitando patitur abierto, y ayuda de costa, y se cometió a informe de los Diputados de Arcas Vacantes de San Acacio con la parte de Su Ilustrísima”. ${ }^{1217}$

"Se leyó un memorial del Acólito Joseph Mexías, solicitando una ayuda de costa, y se acordó pase a los Señores Diputados de Acólitos para que informen”. ${ }^{1218}$

“El Señor Deán dijo había suplicado a los individuos de este Cavildo se juntaran para hacer presente que habiéndose ausentado de esta ciudad el Padre Antonio Ordóñez, tiple agregado a la Capilla de Música desde el día 7 de junio de este año, no se había presentado hasta ahora, en cuya vista el Cavildo acordaría si se le debía admitir o no y se dio comisión a los Señores Diputados de Arcas Vacantes de

\footnotetext{
1214 Ibid. Viernes 20 de Mayo de 1808. T. 99, fol. 60 v.

1215 Ibid. Martes 28 de Junio de 1808. T. 99, fol. 65 r.

${ }^{1216}$ Ibid. Miércoles 3 de Agosto de 1808. T. 99, fol.86 r.

${ }^{1217}$ Ibid. Viernes 16 de Septiembre de 1808. T. 99, fol. 99 v.

${ }^{1218}$ Ibid. Viernes 23 de Septiembre de 1808. T. 99, fol. 102 r.
} 
Santa Inés con la parte de Su Ilustrísima para que informen con llamamiento sobre esta palabra”. 1219

En este día se presenta un informe sobre las cuentas del Colegio de Infantes, y el Estado en que han quedado tras el saqueo de los franceses de los fondos de Obras Pías. Concluye el informe poniendo de manifiesto la gran dificultad para seguir manteniendo dicho Colegio. ${ }^{1220}$

Se presenta un informe detallado del memorial de genealogía de Don José García, salmista y capellán de San Pedro. ${ }^{1221}$

"En virtud del llamamiento para presentar por segunda vez el nuevo Reglamento de la Capilla de Música, se leyó el informe dado anteriormente por los Señores Diputados de Excusados de Música, en 2 de agosto de este año, reducido a que bien visto y examinado el Plan, o Reglamento de la Capilla de Música, se conformaban con él en la parte que les tocaba y nada tenían que añadir o corregir pues estaba dicho Plan perfectamente motivado y formado con el mayor pulso; en su vista, corrido el voto se acordó que en cuanto a el Plan, o Arreglo de Músicos, se tenga éste por primer tratado. Y por lo que toca al arreglo de Música se dio comisión a los Señores Diputados de Excusados de Música con agregación del Señor Arcediano, y Penitenciario, para que lo traigan por partes, o como mejor les parezca”. ${ }^{1222}$

"Se leyó un memorial de Don Miguel Reynaldi, primer violín de la Capilla de esta Santa Iglesia, pidiendo una ayuda de costa, y se cometió a informe de los Señores Diputados de Santa Inés con la parte”. ${ }^{1223}$

"Sobre la solicitud del violinista Juan de Mora, leído dicho informe, reducido a que siendo su pretensión la de patitur abierto por una parte, y la de una ayuda de costa,

\footnotetext{
${ }^{1219}$ Ibid. Viernes 30 de Septiembre de 1808. T. 99, fol. 124 v.

${ }^{1220}$ Ibid. Viernes 7 de Octubre de 1808. T. 99, fol. 127 r.

${ }^{1221}$ Ibid. Viernes 14 de Octubre de 1808. T. 99, fol. $130 \mathrm{v}$.

1222 Ibid. Jueves 20 de Octubre de 1808. T. 99, fol. 134 r.

${ }^{1223}$ Ibid. Jueves 20 de Octubre de 1808. T. 99, fol. 134 v.
} 
en atención a los grandes gastos que le ha originado su prolongada enfermedad, siendo cierto cuanto expone, le juzgaban acreedor a la piedad del Cavildo, quien en su vista acordó negar el patitur abierto, que solicita, y concederle setecientos cincuenta reales de ayuda de costa por una vez, del fondo de dichas Arcas.

Se leyó un memorial de Don Francisco Cascante, músico instrumentista, pidiendo una ayuda de costa y se cometió a informe de los Señores Diputados de San Acacio con la parte.

Se leyó un memorial de Don Ángel Arteaga, pidiendo razón de su sueldo, que tenía en esta Iglesia, y se cometió a informe de los Señores Diputados de Arcas de Santa Inés con la parte". ${ }^{1224}$

"Se leyó un memorial de Don Antonio Gil, Presbítero Capellán Perpetuo de esta Santa Iglesia, pidiendo un testimonio de las pruebas que hizo al ingreso en su Capellanía, y se acordó que con asistencia de los Señores Diputados de San Acacio, se le dé por el notario secretario testimonio de lo que considere y sea de dar. Igualmente se dio cuenta de un memorial de Don José González, Teniente de Sochantre, pidiendo una ayuda de costa, y se cometió a informe de los Señores Diputados de Arcas Vacantes de San Acacio con la parte”. ${ }^{1225}$

El Cabildo trata el tema del Padre Antonio Ordóñez, músico tiple. Éste, había huido de Córdoba el día 7 de junio por la entrada de los franceses, refugiándose en Cádiz. Vuelve a Córdoba a mitad de septiembre y solicita al Cabildo volver a ser admitido. El Cabildo considera que estuvo excesivo tiempo fuera de Córdoba sin ninguna clase de permiso, pero considerando las razones de su huída recomienda volver a admitirlo.

Asimismo el Cabildo trata una solicitud de Don Miguel Reynaldi. Éste expone, que lleva dieciséis meses dando clase de violín a los Niños de Coro, y que por esta razón y por haber padecido recientemente una enfermedad, suplica se le recompense en los términos que sean del agrado del Cabildo, el cual acordó por ahora suspender la

\footnotetext{
${ }^{1224}$ Ibid. Miércoles 26 de Octubre de 1808. T. 99, fol. 138 v.

1225 Ibid. Lunes 31 de Octubre de 1808. T. 99, fol. 141 v.
} 
resolución sobre la solicitud de Don Miguel Reynaldi, y dio comisión a los Diputados de Santa Inés para que informasen. ${ }^{1226}$

"Se leyó el llamamiento para celebrar el Segundo Tratado sobre el Nuevo Plan o Reglamento de la Capilla de Música, y con efecto se dio principio a la discusión leyendo un extracto del Nuevo Reglamento que habían trabajado los Señores Diputados para la más cómoda inteligencia del Reglamento a causa de la disfunción de éste, y oído por el Cavildo se acordó conformándose con dicho Reglamento se tenga éste por Segundo Tratado, de los tres que han de preceder para el Nuevo Estatuto reforma del antiguo que trata de la música. Y además se leyó otro papel que contiene 9 proposiciones sobre varios puntos de reformar en la música sobre lo cual estando ya anteriormente dada comisión para esta reforma se acordó unir a aquélla comisión y que todo se informe al Cavildo.

Se leyó un memorial de Joseph Villalba, Acólito de esta Santa Iglesia en el que pide una ayuda de costa, y se dio comisión a los Señores Diputados de Infantes y Acólitos, para que informen con llamamiento". ${ }^{1227}$

“Primeramente se leyó un llamamiento para celebrar el Tercer Tratado sobre el Reglamento Nuevo de la Capilla de Música; se conferenció lo suficiente acerca de este punto y corrido el voto por todos los Señores que se hallaron presentes, acordó el Cavildo; que en efecto se tuviese por el Tercer Tratado; y en consecuencia fue aprobado el referido plan por votación secreta; y se dio comisión a los mismos Señores que la han tenido, para su formación, para que soliciten la correspondiente aprobación a Nuestro Ilustrísimo Prelado en forma debida, trayéndolo previo llamamiento para que el Cavildo haga el juramento a su tiempo oportuno: de que certifico”. ${ }^{1228}$

“El Acólito Joseph Jaén presentó un memorial que se leyó, pidiendo que se le conceda una ayuda de costa; el cual se remitió a informe de los Señores Diputados de Acólitos e Infantes trayéndolo con llamamiento”. 1229

\footnotetext{
${ }^{1226}$ Ibid. Viernes 4 de Noviembre de 1808. T. 99, fol. 142 v.

${ }^{1227}$ Ibid. Martes 8 de Noviembre de 1808. T. 99, fol. $143 \mathrm{v}$.

${ }^{1228}$ Ibid. Jueves 10 de Noviembre de 1808. T. 99, fol. 145 r.

${ }^{1229}$ Ibid. Martes 15 de Noviembre de 1808. T. 99, fol. 146 v.
} 
El Cabildo acuerda elevar el Estatuto o Nuevo Reglamento de Música, a la consideración del Señor Obispo para que este dé igualmente su aprobación. Igualmente se dispone que dicho Reglamento se imprima y reparta entre todos Señores Capitulares. $^{1230}$

El Cabildo acuerda concederle a Don Vicente Marín, músico instrumentista una ayuda de costa de cincuenta pesos. También le concede al Acólito Joseph Jaén una ayuda de costa de ciento cincuenta reales, o diez pesos. Por último le concede al músico instrumentista Francisco Cascante una ayuda de costa de cien ducados. ${ }^{1231}$

El Cabildo trata acerca de los abusos que se dan en la formación de las procesiones, en las cuales al parecer no se mantiene un buen orden ni la compostura requerida. Se da comisión a los Señores Diputados de Ceremonias para que informen sobre el asunto.

Igualmente se leyó un memorial del Acólito Antonio Ayllón, en el que solicita una ayuda de costa en atención a su pobreza. Se dio comisión a los Diputados de Acólitos e Infantes para que informasen con llamamiento. ${ }^{1232}$

"Se leyó el informe de los Señores Diputados de Arcas de Vacantes de San Acacio con la parte de Nuestro Ilustrísimo Prelado, sobre la pretensión que tenía hecha Don Joseph González, Teniente de Sochantre; y enterado el Cavildo de su contenido, acordó consignarle y le consignó por una vez la cantidad de cien ducados por vía de ayuda de costa por votación secreta, con lo que se concluyó este acto”. ${ }^{1233}$

"Se leyó un informe de los Señores Diputados de Acólitos e Infantes sobre la ayuda de costa solicitada por el Acólito Antonio Ayllón, a quien por votos secretos

\footnotetext{
${ }^{1230}$ Ibid. Miércoles 16 de Noviembre de 1808. T. 99, fol. 147 v.

${ }^{1231}$ Ibid. Jueves 24 de Noviembre de 1808. T. 99, fol. 153 v.

1232 Ibid. Jueves 1 de Diciembre de 1808. T. 99, fol. 153 v.

${ }^{1233}$ Ibid. Viernes 2 de Diciembre de 1808. T. 99, fol. 156 v.
} 
acordó el Cavildo darle por una vez doscientos reales de vellón, con lo que se concluyó este acta". 1234

El Cabildo, “con consideración a las actuales aflictivas calamidades, determinó por uniformidad de votos que se suspenda la música de la calenda y villancicos que de inmemorial tiempo se ha acostumbrado el día víspera del Nacimiento de Nuestro Buen Jesús, extendiéndose este acuerdo a la Nochebuena en la propia forma así como en los días de Pascua, y demás que ha sido estilo cantar villancico; que se cierren todas las Capillas de la Iglesia para que sea la única misa en la citada noche la del Gallo, respecto a deber ser más temprano que en otros años, haciéndose saber a todos los Sacristanes por el notario secretario capitular, cuidando de su execución el infrascrito: que la Prima se cante a las siete en punto, y enseguida la Misa de Aurora, o de Luz, quedando así encargado de cantarla el Señor Tesorero, el Señor Ugalde el Evangelio, y la Epístola el Señor Magistral: y por último se dio comisión a los mismos Señores Diputados de Ceremonias para que informen los días en que podrán hacerse dos, tres o más sermones, exponiendo su dictamen con respecto al modo y forma en que deberá concurrir en su caso el Cavildo". 1235

\section{9}

"Se leyó un memorial de Don Mariano Ferrer, músico instrumentista, solicitando una ayuda de costa; y se acordó pasarle a informe de los Señores Diputados de Arcas de Santa Inés, con la parte de Su Ilustrísima para que le evacuen con llamamiento.

Asimismo se dio cuenta de otro memorial de Don Manuel de Cava, músico de voz de la Encarnación de Madrid, solicitando que se le admitiese a examen para que por sus resultas se le asignase alguna dotación; y el Cavildo acordó no tener cavimiento esta pretensión por ahora; con lo que quedó concluido este acto”. 1236

\footnotetext{
${ }^{1234}$ Ibid. Martes 6 de Diciembre de 1808. T. 99, fol. 159 r.

1235 Ibid. Martes 20 de Diciembre de 1808. T. 99, fol. 160 v.

${ }^{1236}$ Ibid. Sábado 14 de Enero de 1809. T. 99, fol. 165 r.
} 
"Se leyó una carta de Nuestro Ilustrísimo Prelado, que a la letra dice así: Ilustrísimos Muy Señores Míos: aunque la Real Orden que aplica al hospicio las Obras Pías, parece que las aplica no sólo para su dotación, sino para su manutención, sin embargo, como mis deseos son de cooperar en todo lo posible a que tengan efecto los de vuestras Ilustrísimas: convengo gustoso en aplicar por tres años las rentas de la Obra Pía de Niños de Doctrina al Colegio de Niños”. ${ }^{1237}$

"Leyóse un llamamiento dado por los Señores Diputados con la parte de Nuestro Ilustrísimo Prelado, para leer el Nuevo Estatuto sobre arreglo de la Capilla de Música en su consecuencia acordó el Cavildo estar conforme con todo lo en él contenido". ${ }^{1238}$

"Se leyó un llamamiento dado por los Señores Comisionados de Arcas de Vacantes de Santa Inés con la parte de Nuestro Ilustrísimo Prelado para leer el informe relativo a la solicitud de Don Miguel Reynaldi; en su virtud se procedió a votar por pelotas, y resultó que se le concedieron cincuenta doblones de ayuda de costa por una vez sobre los fondos de las Arcas de Santa Inés. El Señor Argote contradijo este acuerdo, y pidió que se diese llamamiento para tratar de aumento de sueldo a favor de este sujeto, persuadido a que así se le premiaba mejor su trabajo en la constante asistencia y enseñanza de los Niños de Coro con lo que quedó concluido este acto”. ${ }^{1239}$

"Se dio cuenta de la pretensión para ayuda de costa presentada por el Acólito Bonilla, y se cometió a informe de los Señores Diputados de Acólitos e Infantes para que lo traigan con llamamiento". ${ }^{1240}$

Se leyeron dos informes relativos a la pretensión de los Acólitos Bonilla y Jurado que pedían ayuda de costa. El Cabildo concede a Bonilla doscientos reales de vellón y a Jurado ciento cincuenta. Asimismo se dio cuenta de un memorial presentado por Don Julián Gálvez, músico instrumentista, solicitando una ayuda de costa. Y se dio

\footnotetext{
${ }^{1237}$ Ibid. Jueves 26 de Enero de 1809. T. 99, fol. 167 r.

1238 Ibid. Martes 7 de Febrero de 1809. T. 99, fol. 170 v.

1239 Ibid. Miércoles 8 de Febrero de 1809. T. 99, fol. 172 r.

${ }^{1240}$ Ibid. Jueves 23 de Febrero de 1809. T. 99, fol. 178 v.
} 
comisión a los Diputados de Excusados de Fábrica para que informasen con llamamiento. $^{1241}$

"Se leyó un memorial presentado por Don Joseph Luis de los Heros, Capellán de San Acacio, solicitando licencia para pasar a la ciudad de Cádiz a negocios propios; en su vista acordó el Cavildo cometerlo y lo cometió a informe de los Señores Diputados de Arcas de Vacantes de San Acacio con la parte de Nuestro Ilustrísimo Prelado.

Finalmente se leyó otro memorial de Don Manuel Valls, primer oboe de la Capilla de Música, pretendiendo una ayuda de costa; el cual se remitió a informe de los Señores Diputados de San Acacio con la parte de Nuestro Ilustrísimo Prelado, y evacuado lo traiga con llamamiento". ${ }^{1242}$

"Se dio cuenta de un memorial presentado por Don Alonso Martín, como albacea de Don Juan Bueno, músico de voz de esta Santa Iglesia, que falleció el día 3 del presente mes de Abril, solicitando que por la infelicidad en que se hallaba, y deudas que tenía, se le conceda una ayuda de costa o limosna para poder atender al pago de sus deudas; en su consecuencia acordó el Cavildo cometerle a informe de los Señores Diputados de Arcas de Santa Inés, evacuando lo que traigan con llamamiento”. ${ }^{243}$

El Cabildo concede a Don Julián Gálvez, músico instrumentista, la cantidad de cien ducados de vellón como ayuda de costa. ${ }^{1244}$

Se presentó un memorial por el músico instrumentista Don Juan Nepomuceno Puig, solicitando ayuda de costa. Se cometió a informe de los Señores Diputados de Excusados de Fábrica. El Acólito Joseph Mejías presentó otro memorial pidiendo una ayuda de costa para poderse presentar con mayor decencia en el vestido. Se cometió a informe de los Diputados de Infantes y Acólitos. ${ }^{1245}$

\footnotetext{
${ }^{1241}$ Ibid. Martes 14 de Marzo de 1809. T. 99, fol. 185 v.

1242 Ibid. Martes 11 de Abril de 1809. T. 99, fol. 191 v.

1243 Ibid. Martes 11 de Abril de 1809. T. 99, fol. 192 r.

${ }^{1244}$ Ibid. Miércoles 19 de Abril de 1809. T. 99, fol. 195 r.

1245 Ibid. Jueves 20 de Abril de 1809. T. 99, fol. 196 r.
} 
"Se dio cuenta del informe de los Señores Diputados de Arcas de Vacantes de San Acacio, con la parte, relativo a la licencia que tenía solicitada el músico de voz Don Joseph Luis de los Heros, para ausentarse a la ciudad de Cádiz; y en su virtud acordó el Cavildo concederle y le concedió el término de dos meses, contados desde el día en que salió de Córdoba con sujeción a aspas.

Dióse cuenta de un memorial presentado por parte del músico Don Joseph Las, solicitando una ayuda de costa; el cual se cometió a informe de los Señores Diputados de Arcas de Vacantes de Santa Inés, para que con la parte de Nuestro Ilustrísimo Prelado informen con llamamiento.

Últimamente se leyó un memorial del Acólito Joseph Jaén, en que solicita la agregación a la Capilla de Música en clase de violín o viola, el cual se cometió a informe de los Señores Diputados de Arcas Vacantes de Santa Inés, con la parte de Nuestro Ilustrísimo Prelado trayéndolo con llamamiento”. ${ }^{1246}$

El Cabildo concede a Joseph Mejías la cantidad de doscientos reales de vellón como ayuda de costa. Asimismo el Cabildo concede a Don Manuel Valls una ayuda de costa de dos mil reales de vellón. ${ }^{1247}$

"Dióse cuenta del informe evacuado por los Señores Diputados de Arcas Vacantes de Santa Inés, relativo al patitur abierto que ha solicitado el músico instrumentista Don Joseph Las, con la intervención de la parte de Nuestro Ilustrísimo Prelado; en su vista y de lo resultante de la certificación médica que acompaña, acordó el Cavildo concederle esta licencia de patitur abierto hasta la víspera del Corpus exclusive.

Se celó por un señor que el trompa Borja, asiste mucho tiempo ha, y no toca porque parece que se lo impide la falta de un diente, y en su virtud acordó el Cavildo dar y dio comisión a los expresados Señores Diputados de Arcas de Vacantes de Santa Inés, para que informen con llamamiento, tomando previamente los convenientes conocimientos el Maestro de Capilla asociando con la parte de Su Ilustrísima, si puede o no continuar

\footnotetext{
${ }^{1246}$ Ibid. Miércoles 26 de Abril de 1809. T. 99, fol. 198 v.

${ }^{1247}$ Ibid. Viernes 5 de Mayo de 1809. T. 99, fol. 202 r.
} 
tocando la trompa, y si en su defecto podrá aplicársele a otro instrumento o jubilarle”. 1248

El Cabildo concede a Don Alfonso Martín, albacea de Don Juan Bueno tiple recientemente difunto, una ayuda de costa de mil reales de vellón, para pagar diversos gastos tanto de su enfermedad como de su funeral. También concede el Cabildo una ayuda de costa de mil quinientos reales de vellón al Padre Don Antonio Ordóñez.

"Últimamente zeló un señor cuán conveniente sería instruir bien en la música a el referido Padre Ordóñez, y prevenir a Especiali por el medio que pareciese más decoroso, que se abstuviese de cantar; enterado el Cavildo acordó dar y dio comisión a los mismos Señores Diputados de Arcas de Vacantes de Santa Inés, con la parte de Nuestro Ilustrísimo Prelado para que informen sobre este zelo, y si en su caso será Especiali a propósito para enseñarle, consulta el punto con el Maestro de Capilla”. 1249

“Leyóse un informe de los Señores Diputados de Arcas Vacantes de San Acacio relativo a la pretensión del Acólito Joseph Jaén, reducido a incorporarse en la Capilla de Música en clase de violinista, y en su vista acordó el Cavildo que se siga el Plan presentado anteriormente, y aprobado por Su Ilustrísima, y que se tenga presente en tiempo oportuno". 1250

El Cabildo acuerda que Don Juan de Borja, músico trompa, pase a tocar la viola en atención al defecto que presenta en su dentadura. Asimismo se concede a Don Mariano Ferrer una ayuda de costa de doscientos ducados de vellón. ${ }^{1251}$

Se presenta un memorial de Don Joseph Luis de los Heros, músico de voz, en que pretende nueva licencia para continuar ausente. Igualmente se dio cuenta de otro memorial presentado por Don Nicolás de Anguita, en que solicita una ayuda de costa. En ambos casos se dio comisión a los Diputados de San Acacio para que informasen. ${ }^{1252}$

\footnotetext{
1248 Ibid. Viernes 5 de Mayo de 1809. T. 99, fol. 202 v.

1249 Ibid. Viernes 12 de Mayo de 1809. T. 99, fol. 203 r.

${ }^{1250}$ Ibid. Viernes 19 de Mayo de 1809. T. 99, fol. 206 r.

${ }^{1251}$ Ibid. Viernes 19 de Mayo de 1809. T. 99, fol. 206 v.

${ }^{1252}$ Ibid. Viernes 23 de Junio de 1809. T. 99, fol. 219 v.
} 
"Dióse cuenta de un memorial del músico de voz Don Benito Torrellas, en que solicita una ayuda de costa, el cual se cometió a informe de los Señores Diputados de Arcas de Vacantes de San Acacio, para que evacuado lo traigan con Ilamamiento". ${ }^{1253}$

"Se leyó un memorial de Francisco Bonilla, Acólito, despidiéndose con motivo de hallarse nombrado por Su Ilustrísima Nuestro Prelado, Sacristán Mayor de la Parroquia de Villafranca, y el Cavildo acordó tenerlo por despedido". ${ }^{1254}$

"El Señor Deán dijo, que habiéndose experimentado el Infante de Coro Mariano Vallejo, según lo mandó el Cavildo, parece puede desempeñar el Ministerio de Acólito, y el Cavildo, acordó pase a servir la plaza de Acólito en lugar de Francisco Bonilla". ${ }^{1255}$

El Cabildo concede a Don Nicolás Anguita, mil reales de vellón de ayuda de costa. Igualmente se leyó un memorial de Don Francisco Cascante, músico instrumentista solicitando una ayuda de costa y el Cabildo lo cometió a los Diputados de Arcas Vacantes de San Acacio. ${ }^{1256}$

Se lee un informe acerca de Don Juan Nepomuceno Puig. Este músico bajonista, expone que habiendo entrado a formar parte de la Capilla de Música al mismo tiempo que Mateo Tascón, aquél cobra más sueldo que él. Y dándose la circunstancia de que el mencionado Puig cumple puntualmente con su obligación y toca todos los papeles encomendados por el Maestro de Capilla, solicita un aumento de sueldo. El Cabildo le concede cincuenta ducados anuales más de sueldo.

Igualmente el Cabildo concede a Don Mateo Tascón cincuenta ducados de ayuda de costa. $^{1257}$

\footnotetext{
${ }^{1253}$ Ibid. Miércoles 5 de Julio de 1809. T. 99, fol. 225 v.

${ }^{1254}$ Ibid. Lunes 11 de Julio de 1809. T. 99, fol. 229 r.

1255 Ibid. Lunes 24 de Julio de 1809. T. 99, fol.236r.

${ }^{1256}$ Ibid. Martes 1 de Agosto de 1809. T. 99, fol. 238 r.

${ }^{1257}$ Ibid.Viernes 4 de Agosto de 1809. T. 99, fol. 239 v.
} 
El Cabildo acuerda, previo informe positivo del Maestro de Capilla, designar a Mariano Especiali para que instruya en la música y en la técnica de la voz al Padre Don Antonio Ordóñez. A este fin se le exime a Especiali de asistir a Coro con la condición de que enseñe también a cualquier otro músico que lo necesite. ${ }^{1258}$

“El Señor Penitenciario expuso, que se había copiado el Reglamento de Música, o sea de la Capilla de Música, sin que hasta ahora se hubiese gratificado con cosa alguna a la persona que lo executó; y tratándose este punto se acordó que se le gratifique con media onza de los fondos que corresponda”. ${ }^{1259}$

“Los Señores Diputados del Colegio de Infantes expusieron la necesidad que había de nombrar algunas plazas, y el Cavildo acordó informen sobre esto con llamamiento". 1260

El Cabildo concede a Don Francisco Cascante, músico instrumentista, la cantidad de mil reales de vellón de ayuda de costa. ${ }^{1261}$

Una vez sometido al Señor Obispo el Nuevo Estatuto sobre el arreglo de la Capilla de Música, éste da su aprobación y el Cabildo lo corrobora. El Obispo, Don Pedro Antonio de Revilla manda que se cumpla en todos sus extremos, por estar perfectamente realizado. ${ }^{1262}$

“Se leyó un memorial del Padre Antonio Ordóñez, músico tiple solicitando se le asigne para congrua parte de su situado y conceda algún aumento de éste, y el Cavildo lo cometió a los Señores Diputados de Arcas de Vacantes de Santa Inés con la parte de Su Ilustrísima para que informen con llamamiento.

\footnotetext{
1258 Ibid.Viernes 4 de Agosto de 1809. T. 99, fol. 240 v.

1259 Ibid. Jueves 31 de Agosto de 1809. T. 99, fol. 245 v.

1260 Ibid. Martes 5 de Septiembre de 1809. T. 99, fol. 248 v.

1261 Ibid. Sábado 16 de Septiembre de 1809. T. 99, fol. 252 v.

1262 Ibid. Miércoles 20 de Septiembre de 1809. T. 99, fol. 253 r.
} 
Item se leyó otro memorial del músico instrumentista Don Joseph Las, solicitando alguna ayuda de costa y el Cavildo lo cometió a los mismos Señores para que con la parte de Su Ilustrísima informen con Ilamamiento sobre su contenido”. 1263

"Dióse cuenta de un memorial presentado por el Acólito Joseph Jaén, despidiéndose del Cavildo con motivo de haberse colocado en clase de músico en la Iglesia de la ciudad Lora, y solicitando una ayuda de costa para sus urgencias; y el Cavildo acordó cometerlo a informe de los Señores Diputados de Acólitos e Infantes, para que evacuado lo traigan con llamamiento". ${ }^{1264}$

El Cabildo concede a Don Vicente Marín una ayuda de costa de cien ducados. También concede a Joseph Jaén una ayuda de costa de ciento cincuenta reales. Asimismo el Cabildo nombra nuevo acólito al Niño de Coro Lucena, en lugar de Joseph Jaén, y acuerda se mantengan en ocho el número de Niños de Coro. Dándose la circunstancia de que existían algunas plazas por cubrir, se acuerda que se admitan memoriales de pretendientes a las plazas vacantes de Niño de Coro. ${ }^{1265}$

Se presentan tres memoriales. Uno del Presbítero músico Don Antonio Gil, otro del Presbítero músico Don Joseph Luis de los Heros, y otro de don Mariano Ortega, músico bajonista. Todos ellos solicitan una ayuda de costa, para lo cual se da comisión a los Señores Diputados de Arcas Vacantes de San Acacio para que informen con llamamiento. $^{1266}$

“El Acólito Joseph Lucena, solicita por un memorial que se le conceda una ayuda de costa; enterado el Cavildo de esta pretensión la cometió a informe con llamamiento de los Señores Diputados de Acólitos”. ${ }^{1267}$

\footnotetext{
1263 Ibid. Miércoles 20 de Septiembre de 1809. T. 99, fol. 254 v.

${ }^{1264}$ Ibid. Viernes 6 de Octubre de 1809. T. 99, fol. 262 v.

1265 Ibid. Miércoles 11 de Octubre de 1809. T. 99, fol. 264 r.

${ }^{1266}$ Ibid. Miércoles 11 de Octubre de 1809. T. 99, fol. 264 v.

${ }^{1267}$ Ibid. Martes 17 de Octubre de 1809. T. 99, fol. 266 v.
} 
El Cabildo le concede al Acólito Lucena doscientos reales de vellón de ayuda de costa.

“Asimismo se leyó otro informe de los Señores Diputados de Infantes, que a la letra dice así: Señor: en virtud de la determinación de V.S. del año último, quedaron reducidas a ocho plazas por ahora, y hasta nueva determinación las doce de que se componía la Comunidad del Colegio del Santo Ángel de la Guarda. De estas doce plazas nombraba V.S. seis, y el Cavildo de Señores Canónigos las otras seis. Parece muy arreglado a esta práctica o convenio entre los dos Cavildos, que quedando reducidas hoy las plazas a ocho, cuatro sean del nombramiento de V.S. y cuatro del de Señores Canónigos. Entre los que existen hoy en el Colegio, que son cinco, cuatro han sido nombrados por V.S.: Joseph Talavera, en dos de diciembre de 1802, Rafael Ledesma en cuatro de junio de 1802, Rafael de Arroyo en cinco de diciembre de 1803, Juan Lucas del Pozo en trece de octubre de 1806. Es pues necesario que para que se verifique la igualdad convenida entre los dos Cavildos nombre el de Señores Canónigos las tres plazas que han de nombrarse ahora, y que V.S. pase para este fin los oficios correspondientes para que no se retarde el nombramiento de estas tres plazas que hacen hoy mucha falta". 1268

El Acólito Joseph Villalba solicita una ayuda de costa, y el Cabildo lo cometió a los Diputados de Acólitos e Infantes para que informen con llamamiento. También solicita una ayuda de costa Don Joseph Luis de los Heros. En este caso el Cabildo acordó suspender la resolución hasta que los Señores Diputados de San Acacio evacuen la comisión que tienen relativa a la aplicación del Nuevo Estatuto de los músicos. ${ }^{1269}$

El Cabildo acuerda que se admitan memoriales de pretendientes para cubrir tres plazas vacantes de Infantes de Coro. ${ }^{1270}$

El Cabildo concede a Joseph Villalba, Acólito, doscientos reales de vellón de ayuda de costa.

\footnotetext{
${ }^{1268}$ Ibid. Martes 31 de Octubre de 1809. T. 99, fol. 271 v.

1269 Ibid. Martes 7 de Noviembre de 1809. T. 99, fol. 273 r.

${ }^{1270}$ Ibid. Miércoles 8 de Noviembre de 1809. T. 99, fol. 273 v.
} 
“Ítem el Señor Ximénez expuso la necesidad de dotar mejor que lo están los Acólitos de esta Santa Iglesia, y habiendo sobre este punto comisión pendiente acordó el Cavildo que los Señores que la tienen a su cargo la evacuen con la brevedad posible”. ${ }^{1271}$

Se leyó un memorial de Don Pascual Redel músico instrumentista en que solicitaba una ayuda de costa debido a su enfermedad. Igualmente se leyó otro memorial del músico Juan de Mora en el que también solicitaba una ayuda de costa. Se cometieron ambas solicitudes a informe de los Diputados de San Acacio. ${ }^{1272}$

"Se leyó un memorial del Acólito Antonio de Ayllón y el Cavildo mandó pase a los Señores Diputados de Acólitos para que informen sobre su concepto con llamamiento". 1273

El Cabildo concede al Acólito Ayllón, una ayuda de costa de doscientos reales de vellón.

“Se leyó una carta dirigida por la Junta de Fortificación de esta ciudad, que copiada dice así: Ilustrísimo Señor: continuando esta Junta en complacer a V.I. accediendo a sus justas pretensiones; ha acordado queden rebajados del servicio de milicianos honrados, los músicos de esa Santa Iglesia en las presentes rogativas, y en aquellas otras festividades de primera clase en que su asistencia dé toda aquella dignidad que corresponde a tan solemnes días: habiendo pasado con esta fecha el correspondiente aviso al Sargento Mayor del Cuerpo para que lo tenga entendido y haga cumplir a su debido tiempo". 1274

"Primeramente se leyó un llamamiento para oír a los pretendientes que se han presentado a las Becas vacantes en el Colegio del Santo Ángel y la censura del Maestro de Capilla; en su consecuencia se mandó que entrasen los pretendientes uno a uno para ser oídos por el Cavildo con asistencia del Maestro de Capilla; con efecto lo executaron sucesivamente Francisco Garrido, Antonio Arroyo, Rafael Caballero, Juan

\footnotetext{
${ }^{1271}$ Ibid. Jueves 16 de Noviembre de 1809. T. 99, fol. 277 r.

1272 Ibid. Martes 21 de Noviembre de 1809. T. 99, fol. 277 v.

${ }^{1273}$ Ibid. Lunes 27 de Noviembre de 1809. T. 99, fol. 282 v.

${ }^{1274}$ Ibid. Miércoles 6 de Diciembre de 1809. T. 99, fol. 283 v.
} 
Fernández, Joseph Vergel, Pedro Rivera, Diego Pérez, Joseph María Rojo, Rafael de Luque, Manuel Vergel, Antonio Bermudo. Se oyeron e hicieron respectivamente su prueba en leer y escribir. Se retiraron y en su consecuencia informó el Maestro de Capilla lo que juzgó en dicho examen de que se acordó el Cavildo. Retirado, se procedió a la elección de tres plazas, quedando nombrados en ellas Francisco Garrido, Pedro Rivera, y Rafael de Luque, acordando, como acordó el Cavildo comisionar a los Señores Segovia y Lectoral para que entiendan en las pruebas de estos tres agraciados”.

En este Cabildo también se trató la solicitud de ayuda de costa que hace el músico instrumentista Don Francisco Ferrer, y se sometió a informe de los Diputados de Santa Inés. $^{1275}$

\section{0}

"Se zeló que aún antes de entrarse al Coro se hacían reparables los corrillos que se formaban en el trascoro y también las salidas largas que se hacían del Coro, en que se gastaba demasiado tiempo y se mandó guardar lo que previenen nuestros estatutos.

Ítem se zeló la poca uniformidad que se guardaba a menudo en continuar el rito con que se empezaba el oficio, y debía continuar respectivamente acelerándose particularmente muchos días en los Kiries de la misa y en el canto de Magnificat de Vísperas y el Cavildo dio comisión a los Señores Diputados de Ceremonias para que informen con llamamiento sobre este zelo, y modo de reformar el abuso que se había introducido". 1276

"Sobre el patitur abierto que solicita Don Pedro García, racionero entero de esta Santa Iglesia, habiéndose leído dicho informe y lo que a boca dixeron los mismos Señores, pasó el Cavildo a votar por votos secretos, y por estos acordó conceder y concedió al Señor Don Pedro García cuarenta días de patitur abierto para dentro y fuera de Córdoba contados los días desde el de la fecha y encargándole la conciencia

\footnotetext{
1275 Ibid. Miércoles 6 de Diciembre de 1809. T. 99, fol. 284 v.

${ }^{1276}$ Ibid. Sábado 31 de Marzo de 1810. T. 99, fol. 311 r.
} 
para presentarse en el Coro si antes de dichos cuarenta días se pusiese en estado de recobrada su salud para verificarlo.

Ítem en continuación del llamamiento para oír el informe de los Señores Diputados de Acólitos, y Infantes de Coro sobre la pretensión de ayuda de costa echa por el Acólito Jospeh Mexías, se leyó el citado informe y oído por el Cavildo, concedió votando por votos secretos al Acólito Joseph Mexías doscientos reales de vellón de ayuda de costa por una vez, que libró sobre su mesa capitular y en la casilla correspondiente.

Ítem se leyó un memorial de Mariano Especiali, en que manifestaba al Cavildo que el Padre Don Antonio Ordóñez parece se había ausentado de Córdoba con las actuales ocurrencias, o a lo menos no había parecido muchos días ha, a continuar en su instrucción como el Cavildo había mandado y aunque éste con dicho motivo había tenido a bien exonerar a Especiali de la asistencia a Coro, suplicaba le continuase la licencia para no asistir a Coro por tener precisión de ponerse en cura de los achaques que padecía y enterado el Cavildo mandó que Don Mariano Especiali se presente al Coro en los días que deba como músico y que presente otro memorial en la forma correspondiente para solicitar el patitur abierto o licencia que expresa”. ${ }^{1277}$

El Cabildo concede a Mariano Especiali, patitur abierto hasta fin del mes de mayo próximo, con la obligación de presentarse en Coro los días que debe, si antes de dicha época se restableciese perfectamente. ${ }^{1278}$

“Dióse cuenta de un memorial presentado por Don Miguel Reynaldi, primer violín de la Capilla de Música, solicitando que se le reintegren ciertos gastos que tiene hechos en papeles e instrumentos para la mejor educación de los Niños de Coro; en su consecuencia se remitió a informe de los Señores Diputados de Arcas de Vacantes de Santa Inés con la parte, para lo evacuen en tiempo oportuno y con atención a el Plan. Se leyó otro de Don Mariano Ferrer, músico instrumentista solicitando una ayuda de costa y se cometió a informe de los Señores Diputados de Arcas de Santa Inés con la parte, para que le evacuen en tiempo oportuno y con atención al Plan de música.

\footnotetext{
1277 Ibid. Martes 3 de Abril de 1810. T. 99, fol. 312 r.

${ }^{1278}$ Ibid. Sábado 14 de Abril de 1810. T. 99, fol. 320 r.
} 
Últimamente, se leyó otro de Don Sebastián Ordóñez, padre de Don Antonio, músico tiple de esta Santa Iglesia, solicitando que no le causase perjuicio alguno la ausencia que tiene hecha con motivo de la entrada del exército francés, pero que ignoraba su paradero; y el Cavildo acordó que luego que entienda su paradero, lo avise para tomar las disposiciones convenientes”. ${ }^{1279}$

“El Señor Deán dijo había suplicado al Cavildo se juntase para leer un memorial de Don Joseph Las, músico instrumentista, en el cual solicita dos cosas; la primera una ayuda de costa en atención a los muchos atrasos y empeños que ha contraído por sus enfermedades: la segunda que se le dispense o exonere de la obligación de tocar el oboe, por serle muy perjudicial a su salud, según lo acredita la certificación que acompaña, de Don Fernando de Gálvez, médico y de Don Antonio de Ramos, cirujano de esta ciudad: y enterado el Cavildo de estas solicitudes, acordó no haber lugar en cuanto ha la primera; y dio comisión a los Señores Diputados de las Arcas de Santa Inés, con la parte de nuestro Ilustrísimo Prelado, para que informen con llamamiento sobre la segunda, exponiendo al Cavildo si el suplicante tiene causa verdadera y bastante para ser exonerado de tocar dicho instrumento". ${ }^{280}$

El Cabildo acuerda que Don Joseph Las deje de tocar el oboe debido a su enfermedad, y pase a tocar el violín como él mismo ha propuesto. Asimismo acuerda que se intenten cubrir las dos plazas de oboes que actualmente están vacantes bien por ausencia o por enfermedad a la mayor brevedad posible. ${ }^{1281}$

"Se leyó un memorial del Acólito Mariano Vallejo, en que solicita una ayuda de costa para subvenir a sus necesidades. Y el Cavildo acordó dar y dio comisión a los Señores Diputados de Acólitos para que informen con llamamiento sobre esta solicitud". 1282

\footnotetext{
1279 Ibid. Domingo 27 de Mayo de 1810. T. 99, fol. 328 r.

${ }^{1280}$ Ibid. Lunes 27 de Agosto de 1810. T. 99, fol. 378 r.

${ }^{1281}$ Ibid. Viernes 7 de Septiembre de 1810. T. 100, fol. 4 r.

1282 Ibid. Miércoles 3 de Octubre de 1810. T. 100, fol. 49 r.
} 
El Cabildo concede al Acólito Mariano Vallejo doscientos reales de ayuda de costa por una vez.

“Ítem, se leyó un memorial de los músicos Don Nicolás Anguita, Don Juan Puig, Don Julián de Gálvez y Don Mariano de Ortega, en que reclaman el abuso que dicen introducido en la Capilla de Música, reducido a desmembrarse o separarse algunos de sus individuos de los demás, formando otra Capilla pequeña que asiste a varias funciones particulares del pueblo, en perjuicio de los excluidos, como son los suplicantes y otros; y el Cavildo acordó dar y dio comisión a los Señores Diputados de Excusados de Música con la parte de Su Ilustrísima para que informen con llamamiento sobre este punto".

Igualmente se leyó otro memorial del Acólito Joseph Lucena en que solicita una ayuda de costa para subvenir a sus necesidades. Y el Cabildo dio comisión a los Diputados de Acólitos para que informasen con llamamiento. ${ }^{1283}$

El Cabildo concede al Acólito Joseph Lucena una ayuda de costa de doscientos reales de vellón por una vez. ${ }^{1284}$

El Acólito Antonio Jurado solicita una ayuda de costa a causa de su corto salario. Y el Cabildo dio comisión a los Diputados de Acólitos para que informen con llamamiento sobre esta solicitud. ${ }^{1285}$

“A virtud del llamamiento para tratar de reformación espiritual, se leyó el estatuto sobre el modo de asistir al Coro los beneficiados; y a su consecuencia se propusieron para su corrección por varios señores algunos abusos que se notan en el Coro y altar, pidiendo que se reformasen a saber: primero que los acólitos en la incensación del Coro van precipitadamente y de carrera, haciendo un ruido artificioso y por juego con los incensarios, y sin guardar las ceremonias prescritas para este acto, como son las inclinaciones respectivas de cabeza a cada uno de los incensados, el número de golpes o turificaciones que les corresponde, y la circunspección y gravedad que al dicho acto son tan propias. Segundo que al empezar el Gloria Patri de los

\footnotetext{
${ }^{1283}$ Ibid. Miércoles 17 de Octubre de 1810. T. 100, fol. 64 r.

1284 Ibid. Sábado 20 de Octubre de 1810. T. 100, fol. 66 v.

1285 Ibid. Miércoles 24 de Octubre de 1810. T. 100, fol. 69 v.
} 
salmos no se ponen todos de pie, y muchos se sientan antes que se acabe el Amén del segundo verso. Tercero que al entrar el Preste en el Coro para capitular Vísperas no se levantan todos, quedándose algunos sentados hasta que aquél pasa o llega al sitio respectivo de cada uno. Cuarto que no se vigila por el Maestro de Ceremonias, ni se registran con anticipación el Cáliz, Batena, y Vinagreras, para que no halla faltas en la Hostia y Vino, como las suele haber muchas veces y muy reparable en medio de la Misa. Quinto que los ciriales salen apagados algunos días de la Sacristía, cuando se bajan al Coro para Vísperas, a causa del descuido y atropellamiento de los Acólitos, y de no zelar sobre esto el Maestro de Ceremonias. En cuya virtud, y siendo tan dignos de reforma estos abusos, acordó el Cavildo que por el Señor Presidente se corrijan con arreglo a Estatuto, valiéndose de los medios que le dicte su prudencia, y aún imponiendo multas o aspas según el mérito de las transgresiones, y de la reincidencia con que se cometan.

Ítem, se propuso otro defecto que se nota en las procesiones que salen a la calle, en las cuales no se guarda la moderación, silencio, y ceremonia que se debe, y que exige el buen ejemplo de los eclesiásticos en las funciones o actos públicos de la religión: siendo parte de causa, que influye en esto, las grandes pausas que se hacen voluntariamente en el canto de los himnos y salmos entre verso y verso, en las que se ocasiona la dicha falta de silencio en muchos, y aún hacen que se equivoquen y olviden los siguientes versos; agregándose además en el canto del Tedeum, que mientras tocan los instrumentos nadie canta el verso que corresponde a la Capilla por cuyo motivo se aumenta la ocasión de hablar y equivocarse, y los músicos de voz, no estando ocupados están más expuestos a incurrir en el defecto dicho. A cuya propuesta acordó el Cavildo que por lo respectivo al primer punto se guarde lo acordado ya en otro Cavildo, en que se previno que el Señor Presidente vigilase y corrigiese estos defectos, ayudándole a ello el Señor Puntador en caso necesario puesto que la distancia de muchos individuos en dichas procesiones suele ser un impedimento o inconveniente para el cumplimiento de éste su deber y encargo. Y por lo tocante a los dos siguientes puntos dio el Cavildo comisión a los Diputados de Ceremonias para que informen con llamamiento sobe ellos; exponiendo si será conveniente que el Sochantre en dichos himnos y salmos entone el un verso a continuación del otro, cantado por la música; y ésta respectivamente el suyo a continuación del cantado por la Veintena, sin más 
interrupción que la que se acostumbra en el Coro en los días de primera clase: y que el Maestro de Capilla componga una música para los versos del Tedeum, que tocan a la Capilla, correspondiente al canto llano, en que está apuntado el dicho himno para la Veintena en los libretes destinados a este fin". ${ }^{1286}$

El Cabildo concede al Acólito Antonio Jurado una ayuda de costa de doscientos reales de vellón. Asimismo el Acólito Antonio de Ayllón solicita una ayuda de costa y el Cabildo da comisión a los Diputados de Acólitos para que informen. ${ }^{1287}$

El Cabildo concede al Acólito Antonio de Ayllón trescientos reales de ayuda de costa. $^{1288}$

El Cabildo concede al Acólito Joseph Villalba doscientos reales de ayuda de costa. $^{1289}$

En este Cabildo se aprueba un reglamento o normativa para corregir los abusos en el canto, sobre todo en las procesiones. Se desarrolla completa dicha normativa en apéndice documental. ${ }^{1290}$

“A virtud del llamamiento para oír el informe de los Señores Diputados de Excusados de Música con la parte de Su Ilustrísima sobre la solicitud que tienen hecha algunos individuos de la Capilla, se leyó dicho informe, reducido en substancia a manifestar la imposibilidad que hay, atentas las circunstancias actuales de muchos músicos, de que se realice el plan de división de medias capillas, que sean respectivamente suficientes a llenar los justos deseos de los que pagan las funciones particulares, a que asisten ahora algunos de los dichos músicos: que no se han encontrado los acuerdos del Cavildo que se citan, sobre la prohibición de esta práctica, que se reclama por los exponentes: y que en virtud de esto, de las circunstancias del día, que no permiten los convites de la Capilla entera y amenazan a la subsistencia de

\footnotetext{
${ }^{1286}$ Ibid. Martes 6 de Noviembre de 1810. T. 100, fol. 92 v.

1287 Ibid. Sábado 10 de Noviembre de 1810. T. 100, fol. 115 r.

${ }^{1288}$ Ibid. Viernes 16 de Noviembre de 1810. T. 100, fol. 121 v.

${ }^{1289}$ Ibid. Jueves 29 de Noviembre de 1810. T. 100, fol. 149 r.

1290 Ibid. Sábado 1 de Diciembre de 1810. T. 100, fol. 149 v.
} 
ella, y de otras razones, que ofrecían los Señores Comisionados añadir de palabra, no debía el Cavildo tomar sobre el punto una resolución decidida, si no esperar a mejores tiempos para decidir. Oído este informe se discutió el punto, y no convenidos los pareceres a causa de los acuerdos del Cavildo sobre el particular, en cuya existencia se afirmaban varios señores; acordó por último el Cavildo repetir la comisión a los mismos Señores con agregación de los Señores Riera y Morales, para que examinen diligentemente los libros de acuerdos, con relación a este asunto, y en su vista informen con llamamiento sobre la providencia que deberá tomarse en orden a la querella o solicitud que antes se ha dicho". ${ }^{1291}$

En este Cabildo se trata acerca de las dificultades económicas del Colegio de Infantes de Coro, aconsejándose al final su supresión. Por la importancia de esta normativa, se refleja íntegramente en apéndice documental. ${ }^{1292}$

En este Cabildo se trata la reducción en los sueldos de los músicos, debido al mal momento por el que atraviesa la economía del Cabildo. Se detalla íntegramente en apéndice documental. ${ }^{1293}$

En este Cabildo se detalla la liquidación del Colegio de Infantes, una vez decidido en anterior Cabildo su supresión. Ahora se aprueba el destino de los enseres de dicho Colegio así como la forma de despedir al personal. Se presenta íntegramente en apéndice documental. ${ }^{1294}$

\section{1}

"Se leyó un memorial de María Antonia Pizarro, viuda de Don Gaspar Anguita, Colegial que fue en el del Santo Ángel, solicitando un testimonio de las pruebas que a

\footnotetext{
${ }^{1291}$ Ibid. Jueves 6 de Diciembre de 1810. T. 100, fol. 159 v.

1292 Ibid. Miércoles 19 de Diciembre de 1810. T. 100, fol. 192 r.

1293 Ibid. Lunes 24 de Diciembre de 1810. T. 100, fol. $215 \mathrm{v}$.

${ }^{1294}$ Ibid. Lunes 31 de Diciembre de 1810. T. 100, fol. 220 v.
} 
éste se hicieron para su admisión en el Colegio dicho. Y el Cavildo acordó que se dé este testimonio de lo que conste y fuere de dar". 1295

“El Señor Deán dijo había suplicado al Cavildo se juntase con motivo de un aviso que ha pasado a Su Ilustrísima, dando cuenta al Cavildo del encargo verbal, que le ha hecho el Señor General, Varón de Godinet, sobre que se cante en el domingo próximo un solemne Tedeum, con el mismo aparato que se puso para la fiesta de San Joseph, en acción de gracias por el feliz parto de la Emperatriz de los franceses. En cuya virtud acordó el Cavildo que se lleven a efecto los deseos del Señor General, que para el dicho acto del Tedeum se cite la hora de las once y media de la mañana; y que se haga saber así a Su Ilustrísima para que lo ponga en noticia del dicho Señor General; encargándole y suplicándole que se sirva si lo tiene a bien, inclinar al mismo Señor al efecto de que no envíe la tropa hasta las once, por impedir las distracciones y ruido, que ocasiona, y que podrán turvar los solemnes oficios de aquél día; para lo cual se dio comisión a los Señores Diputados de Ceremonias, como asimismo para que dispongan con el Señor Obrero el aparato que corresponda”. 1296

“A virtud del llamamiento para oír el informe de los Señores Diputados de Acólitos e Infantes sobre el inventario de las ropas, instrumentos, y muebles del Colegio y su destino, se leyó dicho informe, que a la letra decía así: presentamos a V.S. la lista de los bienes muebles, que existen en el Colegio Del Santo Ángel, y son los mismos que servían a los Infantes de Coro cuando se hallaban reunidos en él, para que V.S. determine sobre su uso o destino, que ha de darse a su valor, en caso de venderse, que será lo más acertado, excepto alguno que podrá dársele por V.S. aplicación en alguna de las casas u oficinas de su cargo. Entre dichos muebles se hallan un piano bueno, un bajón útil; y los demás instrumentos, de que habla el inventario, son todos inútiles, y están inservibles. Los que juzgamos podrían darse a los Infantes de Coro, que en la actualidad aprenden por ellos, para que los compusiesen, y ahorrasen así la compra de otros nuevos, para lo que tienen fondo. Del carbón se han vendido sesenta a. y concluida su venta podrán juntarse unos seiscientos reales, con los que se podrá comprar el paño suficiente para hacer cinco opas a los cinco Infantes que sirven en el

\footnotetext{
${ }^{1295}$ Ibid. Sábado 9 de Marzo de 1811. T. 100, fol. 285 r.

${ }^{1296}$ Ibid. Viernes 5 de Abril de 1811. T. 101, fol. 28 v.
} 
Coro, en lugar de las que usan y que están indecentes. Si ha V.S. le parece podrán ser de paño azul, como las de los Acólitos para un formarlos con arreglo a lo que V.S. tiene determinado en la aprobación del Plan de Reformas. Y sobre todo V.S. acordará lo más conveniente. Oído este informe, y leído el dicho inventario, acordó el Cavildo conformarse y se conformó con él, y dio comisión a los mismos Señores, para que dispongan la venta de todos los muebles útiles, de cuyo importe dispondrá el Cavildo, sin perjuicio de que procedan desde luego a la provisión de opas en la forma y modo que expresan en su dicho informe”. ${ }^{1297}$

"Se leyó un memorial de Don Juan de Mora, músico instrumentista, en que solicita patitur abierto a causa de su indisposición, certificada por el médico Don Fernando de Gálvez. Y el Cavildo acordó dar y dio comisión a los Señores Diputados de Arcas Vacantes de San Acacio, para que informen con llamamiento sobre esta solicitud.

Ítem se leyó un memorial de Don Rafael del Río, músico instrumentista, en que reclama la cantidad de seis reales en que se le aspa, y ha aspado contra lo dispuesto en la Fundación de su Capellanía, en los aniversarios de música, en que no ha tenido, ni tiene distribución; y pide que se le rebajen dichas aspas hasta la debida y prescrita cuota de tres reales, y que se le abonen los perjuicios, que se le han causado. Y el Cavildo acordó dar y dio comisión a los Señores Diputados de Arcas Vacantes de Santa Inés, para que de acuerdo con los Señores Puntadores de Horas Canónicas informen con llamamiento sobre esta solicitud". ${ }^{1298}$

“A virtud del llamamiento para oír el informe de los Señores Diputados del Colegio del Ángel sobre el oficio del Señor Comisario de Guerra, Don Juan Rodríguez Cayro, recibido y leído en el águila el día 10 del corriente después de maitines se volvió a leer este oficio, que a la letra decía así: Ilustrísimo Señor: la salud pública exige que una porción de individuos de varios sexos, que se hallan atacados de males venéreos en esta capital, se pongan en cura para evitar su propagación; y al tomar medidas para reunirlos en el hospital de Antón Cabrera, destinado a la curación de este género de dolencias, se ha tocado en el inconveniente, de que no estando en uso esta casa de dos

${ }^{1297}$ Ibid. Viernes 10 de Mayo de 1811. T. 101, fol. 40 v.
${ }^{1298}$ Ibid. Viernes 10 de Mayo de 1811. T. 101, fol. 41 v. 
a tres años a esta parte, su habilitación y servicio originaría un gasto a que no es fácil ocurrir hoy, y que podría evitarse por otros medios. A V.S.I. pertenecen las casas colegio de Niños de Coro, contiguo al hospital civil de San Sebastián, una comunicación que se dé a este hospital con el colegio, facilita la asistencia que este mismo hospital puede dar a los enfermos, que deban ocupar una parte del colegio, sin perjudicar a su estado, ni a su destino; más como no es justo disponer sin anuencia de V.S.I. del uso de un edificio que es de su propiedad he creído deber poner en noticia de V.S.I. la urgencia en que se halla el gobierno de servirse de él interinamente, muy confiado en que V.S.I. se prestará gustosamente a contribuir a este servicio público. Dios guarde a V.S.I. muchos años. Córdoba 10 de Mayo de 1811. Ilustrísimo Señor el Comisario de Guerra, haciendo funciones de Subprefecto: Juan Rodríguez Cayro: Ilustrísimo Señor Deán y Cavildo de la Santa Iglesia Catedral de esta ciudad de Córdoba.

Sobre este oficio acordó el Cavildo en dicho día dar y dio comisión a los referidos Señores Diputados del Colegio, para que con la posible brevedad informen con llamamiento sobre su contenido y contestación que deba darse. En cuya virtud y del llamamiento antes dicho, se leyó el indicado informe que a la letra decía así: El Colegio del Santo Ángel está hoy desierto, porque V.S. por justas causas ha determinado vivan en sus casas los Infantes de Coro, que se educaban y mantenían en él: en mucha parte de su edificio está muy deteriorado, y en alguna ruinoso; porque no habiendo alcanzado a mantener a los referidos Infantes de Coro las rentas, que V.S. había destinado a este fin, y empeñándose cada día más esta casa, hasta una suma que no puede pagar en muchos años, V.S. no le hizo a su tiempo las obras que necesitaba. En este estado podrá V.S. cederlo, o parte de él interinamente al gobierno, para el fin que propone; pero antes debería V.S. pasar oficio al Señor Comisario de Guerra, haciendo veces de Subprefecto Don Juan Rodríguez Cayro, para que lo haga registrar en la parte que ha de destinarse, y vea si acomoda al fin propuesto; y en caso de acomodar decretar su cesión interina. V.S. determinará lo que juzgue más conveniente: 13 de Mayo de 1811: Juan Ramón de Ubillos: Joseph Garrido y Portilla: Oído este informe acordó el Cavildo conformarse y se conformó con el; y dio comisión a los 
mismos Señores para que remitan el oficio contextación, que expresan en dicho informe". 1299

“A virtud del llamamiento para oír el informe de los Señores Diputados de Arcas de San Acacio con la parte de Su Ilustrísima sobre el patitur abierto, que solicita el violinista Don Juan de Mora, se leyó dicho informe, en cuya virtud y del estado casi desesperado de sanidad de este dependiente, acordó el Cavildo concederle y le concedió el patitur abierto por espacio de un año; y que se pase el competente decreto a los Señores Puntadores de Coro para su inteligencia y gobierno”. ${ }^{1300}$

"Se leyó un memorial de los Infantes de Coro, en que solicitan el pago de su salario por el tercio vencido a fin de abril, en atención a su necesidad, y demás que exponen. Y el Cavildo acordó dar y dio comisión a los Señores Diputados de Hacienda para que informen con llamamiento sobre esta solicitud". ${ }^{1301}$

“Se leyó un memorial de Don Juan Puig, bajonista de esta Santa Iglesia, en que solicita se deshaga una equivocación que parece hubo sobre el cuánto de su antigua renta, y que podrá influir en que se le tenga alguna consideración sobre la rebaja de su renta, acordada en el Cavildo de 24 de diciembre último, y que pide, si ha lugar, y sin oponerse al dicho acuerdo, en atención al estado y obligaciones de su familia. Y el Cavildo acordó dar y dio comisión a los Señores Diputados de Hacienda con la parte de Su Ilustrísima para que informen con llamamiento sobre esta solicitud". 1302

“A virtud de una palabra de los Señores Diputados de Ceremonias y considerando el Cavildo los varios motivos de irreverencias, que podrán ocasionarse al Santísimo Sacramento, si saliese esta tarde a la calle en procesión, a causa de las circunstancias particulares, que en la actualidad ocurren en el Triunfo y demás, acordó que por este año no se haga la dicha procesión por la estación acostumbrada, si no solamente por el patio, saliendo por la puerta del Arco de Bendiciones, y entrando por

\footnotetext{
${ }^{1299}$ Ibid. Lunes 13 de Mayo de 1811. T. 101, fol. 42 r.

1300 Ibid. Lunes 13 de Mayo de 1811. T. 101, fol. 44 r.

${ }^{1301}$ Ibid. Viernes 31 de Mayo 1811. T. 101, fol. 52 v.

${ }^{1302}$ Ibid. Lunes 10 de Junio de 1811. T. 101, fol. 55 r.
} 
la del Sagrario con dirección a éste; llevando la Custodia por toda esta estación los mismos Señores que fueron nombrados para el día del Corpus". ${ }^{303}$

El Señor Deán dijo que había suplicado al Cabildo que se reuniera para leer un memorial de Don Pascual Redel, músico instrumentista en que solicita patitur abierto a causa de sus achaques. Se dio comisión a los Diputados de San Acacio para que informasen. $^{1304}$

El Cabildo acuerda conceder a Don Pascual Redel dos meses de patitur abierto en atención a la enfermedad que le aqueja, y teniendo en cuenta la puntualidad y el mérito con que ha desempeñado su oficio y profesión. ${ }^{1305}$

En el Cabildo de este día se leyó una carta del Excmo. Sr. Gobernador General dirigida al Sr. Deán, en la que pedía que se diera permiso a algunos músicos para tocar en el teatro:

“Señor Deán y muy Sr. Mío: el Excmo. Sr. Governador General habiendo consentido en que se executen algunos conciertos vocales e instrumentales en la casa de teatro en lugar de comedias durante el mes en que estamos, ruego a V.S. tenga la bondad de permitir vengan algunos músicos de la Catedral, los que asisten ya ordinariamente a la Orquesta del Teatro, y particularmente el Sr. Torrella, a quien se desea de oír en la parte de canto, que como concierto académico cree S.E. no habrá dificultad, se le conceda este permiso". ${ }^{1306}$

Firma la carta Luís Fleuny, Gobernador General. El Cabildo aprobó tal petición.

“El Señor Deán dijo había suplicado al Cavildo se juntase para leer los memoriales de Don Vicente Marín, y de Joseph Talavera, en que solicitan la plaza de violín, vacante por muerte de Don Joseph Las. Y el Cavildo acordó que pasen a los

\footnotetext{
${ }^{1303}$ Ibid. Jueves 20 de Junio de 1811. T. 101, fol. 58 v.

${ }^{1304}$ Ibid. Martes 13 de Agosto de 1811. T. 101, fol. 97 v.

${ }^{1305}$ Ibid. Miércoles 14 de Agosto de 1811. T. 101, fol. 102 v.

${ }^{1306}$ Ibid. Sábado 31 de Agosto de 1811, T.101.
} 
Señores Diputados de Arcas Vacantes de Santa Inés, con la parte de Su Ilustrísima, para que informen con llamamiento sobre estas solicitudes, y si en las circunstancias actuales estamos en el caso de proveer esta plaza, y en éste, cómo se deberá executar, teniendo presente el Plan de Música acordado por el Cavildo”. ${ }^{1307}$

En este Cabildo se trata de la dotación económica para el sustento de los Niños de Coro:

"Su dotación [de los Niños de Coro] antes de la supresión del Colegio dependía de fondos propios no solamente de la Mesa Capitular, sino de la Fábrica y de todos los demás Cavildos que hay en esta Santa Iglesia. La Mesa Capitular contribuía con trigo y maravedíes, la Fábrica igualmente, aunque con pequeñas porciones que no bastaban para los gastos del Colegio. La Capilla de Santa Inés con trescientos ducados fijos, la de San Acacio con setecientos reales, y lo principal de las demás rentas, fuera de algunos cortísimos artículos, consistía en agregaciones de ciertas obras pías, que por analogía y destinos parecían a nuestros antecesores aplicables a la formación y constitución del Colegio. Todo este cúmulo de agregados no bastaba en los últimos tiempos para este establecimiento; muchos años había que no alcanzaba aún después de varias medidas que V.S. se sirvió tomar suprimiendo la mitad de las plazas: su empeño cada día era mayor, y su manutención una carga insoportable para los fondos de Obras Pías, que por otra parte habían llegado a un estado increíble de decadencia. V.S. por su Mesa Capitular no se hallaba capaz de hacer suplementos, ni de añadir obligaciones, que no podía desempeñar. Por esto se suprimió el establecimiento a los principios de este año, y aunque por este solo renglón se han economizado muchos gastos es indispensable continuar aquellos, que basten para la conservación por ahora de los cinco niños, que están sujetos a la disposición de V.S. para hacer el servicio del altar y coro en todos aquellos ministerios que por costumbre los practican ellos, y no otros. No es de nuestro propósito entrar a examinar en el día de la cuestión de la necesidad de estos niños para el servicio del Coro, suponiéndose que es imposible suplir por otros los destinos y cargos que hoy están señalados a esta clase de Ministros. ¿Quién que medite la naturaleza de su Ministerio podrá persuadirse de aquella

${ }^{1307}$ Ibid. Miércoles 6 de Noviembre de 1811. T. 101, fol. 171 v. 
necesidad, y de esta imposibilidad? Toda su ocupación en el altar y coro está reducida a cantar los versos, las calendas, preparar los libros para la procesión y Preste, los asientos de los facistoles para los Señores Caperos, los bancos para los sermones, traer y llevar los papeles y libros de Música, disponer los incensarios, asistir en la Sacristía para los lavatorios, presenciar y acudir en el punto a se cuanto ordene por los Señores Diputados, y servir de intérpretes generales en el Coro para todas las ocurrencias que la necesidad y la obligación del Señor Presidente exige para el servicio del Coro, y para todo lo demás, que la oportunidad, precisión, o caprichos de los Señores Residentes y Ministros del Coro y Música los emplea. ¿Quién deberá dudar siquiera que estas ocupaciones pueden ser exactamente desempeñadas por otras personas $y$ manos? Las partes del canto lo serían con mucha más gravedad y conocimiento por los Veinteneros, Ministros Principales destinados a este ramo, y todo lo demás, que es pura ocupación material por los Acólitos. Pero gastaríamos inútilmente el tiempo en proponer a V.S. el método con que podrían ser executados estos cargos por otros, porque al fin hallándose los niños con cierto derecho adquirido para que no sean despedidos en el estado actual, y obligado V.S. por otra parte a recompensar de alguna manera los servicios, en que se emplean, nada haríamos con presentar planes, que por ahora no tendrían observancia; puesto que hay educados estos jóvenes en este ramo, y que pueden desempeñarlo. Dejemos pues este pensamiento para otro tiempo, cuando faltando manos que puedan acudir a estos Ministerios, la necesidad obligue a tomar otras medidas con los medios que nos ofrezca para la dotación de Acólitos y otros Ministros la idea y pensamiento aprobado por el Cavildo y Nuestro Ilustrísimo Prelado sobre reunión de Capellanías, servicios, Sacristías, y demás arbitrios, pensamiento que luego que se concluyan algunos otros trabajos, se pondrán en execución, y se adelantará con empeño, como uno de los arbitrios que restan a V.S. para descargar a la Mesa Capitular del grave peso de la manutención de los Ministros. Entretanto continuaran los niños su servicio, y V.S. lo recompensarán con la consignación que resolverán por los antecedentes indicados, porque aunque no todos los fondos destinados en otros tiempos a su manutención sean ciertos y seguros por la decadencia de los tiempos, ni otros puedan realizarse por las necesidades ocurridas en el ramo decimal hay sin embargo algunos en que por ahora puede todavía asegurarse en el día la subsistencia de este salario moderado, que podrá señalarse. No estamos en tiempos 
de hacer planes perpetuos, ni por mucho tiempo. En cada año hay novedades grandes, que pueden obligar a variarlos, y la decadencia general, hace temer la necesidad de acomodarlos frecuentemente a las circunstancias de los tiempos, a que al fin se sujetan todos los establecimientos humanos. Según las actuales, la Mesa Capitular, rodeada de tantas y tan urgentes obligaciones de los individuos de V.S., y de sus Ministros y dependientes, oprimida con las contribuciones mensuales, de la capital, y de Castro del Río, que al cabo del año van a ascender tal vez al total importe de sus rentas, la lentitud y tardanza de los pagos, las bajas de todas las rentas de las posesiones de campo, que son las que hasta ahora más han sufrido, y la falta de mil recursos, que le eran propios o estaban expeditos en otro tiempo, le eximen seguramente de continuar con aquella porción de granos y maravedíes con que contribuía para la manutención de los niños. La Fábrica recargada igualmente con mil obligaciones amenazada de la cuota mensual que arregle la Junta de Repartimiento, privada de la mayor parte de los diezmos que era su principal ingreso y escasa de otros arbitrios que los tiempos y las desgracias le han cercenado, no podrá tal vez acudir con la parte íntegra de ayuda de costa, con que acostumbraba socorrer a los niños. Pero sin entrarnos a disponer de estos arbitrios, nos contentamos con excitar el zelo del Señor Obrero Mayor de cuya inclinación y amor ha V.S. no dudamos, que aplicará todos sus esfuerzos para que no se disminuya, si puede ser, la cuota antigua, esperando que las consideraciones anteriores y esta invitación son sobrados estímulos para que no perdone medio de acudir a la común urgencia. [...] La misma Diputación se haya igualmente pronta a hacer los pagos por meses o tercios a estos Ministros [se refiere a los Niños de Coro] según las reglas que V.S. tenga por conveniente fijar par su gobierno. Parece puede arreglarse la dotación diaria de cada niño por la de tres reales, y siendo cinco en el día los que han quedado, la cantidad de sesenta reales sobra para su salario anual. Esta dotación ciertamente no es excesiva pero tampoco es tan menguada que no se considere bastante para la ocupación, edad y salarios que suelen ganar los niños de esta clase. Esta dotación así señalada por punto general la cobrarán más o menos íntegra según su asistencia y la puntualidad con que desempeñen los cargos de su Ministerio. No es nuestro ánimo sujetarlos a una puntuación rigurosa, porque nos parece dar demasiada importancia a su edad, igualándola con la de los demás Ministros, que deben merecer otra atención y consideración pero sin estar sujeta a las aspas debe estarlo a la 
inspección de los Señores Presidente y Diputados del Punto, que podrán según los méritos de cada uno disminuir y cercenar el salario por los días del mes al tiempo de formar la certificación del Punto, en que conste la asistencia del niño o niños, en cuya virtud, y con su presentación en la oficina de Obras Pías, y con el decreto o visto bueno de los últimos se satisfará el salario. Más como ni los Señores Diputados del Punto, ni mucho menos el Señor Presidente puedan seguir todos los pasos de los niños en sus diferentes Ministerios, en el Coro y fuera de él, ni tampoco puedan observar en la práctica de todas sus ocupaciones la puntualidad, docilidad, modestia y desempeño exacto de su conducta importará escoger entre los Ministros Veinteneros, y nombrar uno que sea el jefe inmediato que esté a la mira de lo que practique cada niño en su Ministerio, que prevenga a todos y cada uno de sus respectivos cargos, que estén sujetos a sus avisos y amonestaciones, y que sepa y entienda por los mismos, los pasos, ocupaciones y encargos que les permitan salir del Coro. Todo el encargo de este Comisionado será enseñarles lo que deben hacer y cantar, prevenirles y amonestarles para su enmienda, y cuando lo exijan sus faltas, y el castigo queda reservado al tiempo de hacer la certificación o libranza para el pago del salario, porque entonces los Señores Diputados del Punto, previos los informes del Rector, y según las resoluciones tomadas por el Señor Presidente, arreglarán la dotación o disminución del salario mensual, según los méritos cualificados de cada niño. [...] Éstos Señores (Deán o Presidente) quedan autorizados para consentir o disminuir la parte que les parezca del salario si las faltas o defectos del niño o niños, diesen lugar a este castigo; podrán amonestarlos según lo exija la edad, imprecisión e indocilidad de cada uno; podrán suspenderlos y aún privarlos de su destino sin otra condición que la de dar cuenta a V.S. de lo acordado y executado; zelarán como encargados únicos en este ramo sin dependencia de V.S. en las medidas, correcciones y castigos, que su prudencia les dicte atendiendo sobre la edad y falta de conocimiento y previsión de dichos niños. Desde luego pueden executar su autoridad desde el primer paso, que ha de ser el de disponer se satisfaga el salario de cada uno desde la fecha de 26 de abril último, en que tomaron la última gratificación. [...] Concluyamos de una vez. Los niños estarán obligados a todos los cargos, oficios y asistencias, como lo estaban anteriormente. Asistirán a todas las horas del Coro, sean diurnos o nocturnas, sin dispensaciones ni excepciones: toda su dotación queda reducida a los tres reales diarios, dejando a favor de sus fondos de 
dotación en Obras Pías todos los emolumentos que por coste o práctica le correspondían en el Punto y en las Capillas, según el servicio hagan. Todas las ganancias peculiares de los del Punto y de la Música, en cuanto pueda ser, tendrán el mismo destino y siéndoles segura la dotación de los tres reales por ahora, y en cuanto se les asista, no gozarán ni en Octavas ni en procesiones, ni en entierros de Capitulares, ni en funciones ordinarias ni extraordinarias de V.S., ni de manual, ni de gratificación ni de otra consignación de Mesa Capitular, ni otros fondos aplicados a V.S. Sobre todo V.S. acordará lo que le parezca justo. Córdoba 4 de diciembre de 1811: éste informe no vino firmado porque aún estaba en borrador cuando se leyó: Oído este informe, acordó el Cavildo conformarse y se conformó con él en todas sus partes; añadiendo solamente y declarando que los Niños de Coro deberán estar sujetos y se sujetarán desde luego a rigurosa puntuación en su cuadrante respectivo; todos por mañana y tarde con la pena de aspa de un real por cada falta, en que incurran: la cual igualmente sufrirán en Maitines los dos que estén de turno, sin faltasen; quedando en lo relativo a patitur, y demás a la prudencia de los Señores Diputados las resoluciones y providencias convenientes con arreglo a las facultades y reglas que se les dan, y prescribe el dicho informe. Y por lo respectivo al Señor Obrero Mayor y a los demás Cavildos, acordó Éste invitarlos y los invitó al efecto o efectos, que en el mismo se proponen; dando al mismo tiempo a los Señores Presidente y Diputados del Punto todas las comisiones y autoridad correspondientes para executar todo lo en él expuesto, y en la forma que se expresa”. ${ }^{1308}$

\section{2}

“El Señor Deán dijo, había suplicado al Cavildo se juntase para exponerle, que hallándose comisionado por el Cavildo pleno de 4 de diciembre último, para invitar a éste Cavildo a contribuir a la dotación de los Niños de Coro, lo executaba así, esperando, que resolviese sobre este asunto. Y el Cavildo en su virtud acordó dar y dio comisión a los Señores Diputados de Arcas Vacantes de San Acacio con la parte de Su Ilustrísima, o sin ella respectivamente, según la cualidad de los fondos aplicables, para

\footnotetext{
${ }^{1308}$ Ibid. Miércoles 4 de Diciembre de 1811. T. 101, fol. 182 r.
} 
que informen con llamamiento si han de continuar las mismas consignaciones que estaban destinadas para el mismo objeto antes de la extinción del Colegio de los Infantes". 1309

“A continuación del llamamiento para oír el informe de los mismos Señores (Diputados de Arcas Vacantes de San Acacio) sobre la consignación de dichas Arcas en favor de los Niños de Coro, se oyó el dicho informe verbal, y en su virtud acordó el Cavildo que continúe la misma consignación o dotación con que contribuían estas Arcas al sustento de los dichos Niños, antes de la extinción del Colegio; y que esta consignación se destine y pague por tercios en la oficina de Obras Pías a beneficio del fondo designado para este objeto, y mientras corra a su cargo el pago de los salarios de estos Ministros". 1310

"Se leyó un memorial de Don Bernardino Martínez de León en que solicita graciosamente la casa que fue Colegio de los Infantes de Coro para vivirla y cuidar de mayor conservación. Y el Cavildo acordó que pase a los Señores Diputados de Obras Pías para que cuidando de esta casa y viendo las utilidades que pueden sacarse de ella, informen con llamamiento lo que les parezca sobre el derecho de su propiedad y destino que pueda dársele”. ${ }^{1311}$

"Se leyó un memorial de de Don Juan Puig, bajonista segundo, en que pide espera para el pago de la renta de su casa, propiedad de la Mesa Capitular, en atención a la escasez de su sueldo, multitud de familia y circunstancias del tiempo. Y el Cavildo acordó que pase a los Señores Diputados de Hacienda, para que en vista de lo que expone este interesado, procedan sobre esta solicitud, según les parezca conveniente". ${ }^{1312}$

"Se leyó un memorial de Don Vicente Marín, en que pide la casa Colegio, que fue de los Niños de Coro, para habilitarla graciosamente en atención a la disminución

\footnotetext{
${ }^{1309}$ Ibid. Miércoles 15 de Enero de 1812. T. 101, fol. 197 v.

${ }^{1310}$ Ibid. Jueves 20 de Febrero de 1812. T. 101, fol. 213 v.

${ }^{1311}$ Ibid. Jueves 27 de Febrero de 1812. T. 101, fol. 215 v.

${ }^{1312}$ Ibid. Lunes 9 de Marzo de 1812. T. 101, fol. 220 r.
} 
de su renta. Y el Cavildo acordó que pase a los Señores Diputados de Obras Pías, para que se reúna a la Comisión dada sobre el destino de la citada casa”. ${ }^{1313}$

"Se leyó un memorial de los Niños de Coro, en que exponiendo su indigencia, solicitan que se les pague el salario acordado por el Cavildo, que en gran parte se les está debiendo por su servicio del año pasado, y del corriente. Y el Cavildo acordó dar y dio comisión a los Señores Diputados de Obras Pías para que informasen con llamamiento”. 1314

“A continuación del llamamiento para oír el informe de los Señores Diputados de Obras Pías sobre la solicitud de los Niños de Coro, se leyó dicho informe, y en su vista acordó el Cavildo que se pague inmediatamente a dichos Niños todo su adeudo hasta el día, continuando corrientes sus pagos mensuales, según está anteriormente acordado; y dio facultades a los mismos Señores para que busquen fondos de donde puedan tomar y tomen con calidad de reintegro las cantidades necesarias a dicho efecto". ${ }^{1315}$

“El Señor Presidente dijo había suplicado al Cavildo se juntase, para oír un memorial que parecía urgente; y fue el de Don Juan de Mora, músico instrumentista de esta Iglesia, en que solicita patitur abierto, a causa de su enfermedad, que acredita con la certificación jurada del médico Don Fernando de Gálvez. Y el Cavildo acordó que pase a los Señores Diputados de Arcas Vacantes de San Acacio, para que informen con llamamiento sobre esta solicitud". 1316

El Cabildo concede a Don Juan de Mora patitur abierto por espacio de un año, contando desde el día de la fecha. ${ }^{1317}$

\footnotetext{
${ }^{1313}$ Ibid. Sábado 21 de Marzo de 1812. T. 101, fol. 228 r.

${ }^{1314}$ Ibid. Miércoles 22 de Abril de 1812. T. 101, fol. 236 r.

1315 Ibid. Miércoles 29 de Abril de 1812. T. 101, fol. 241 v.

${ }^{1316}$ Ibid. Miércoles 10 de Junio de 1812. T. 101, fol. $256 \mathrm{v}$.

${ }^{1317}$ Ibid. Sábado 20 de Junio de 1812. T. 101, fol. 264 r.
} 
En el Cabildo de hoy, se trata sobre el uso que se le va a dar a la casa del antiguo Colegio de Infantes. Después de oír un largo informe sobre los costes que tuvo la casa en el momento de su compra, así como lo que costaría hoy día arreglarla, el Cabildo decide cederla al Prefecto de la ciudad, que la había solicitado para convertirla de nuevo en un hospital. A este respecto se acuerda que dicha casa quede unida al hospital de San Sebastián mediante un pasaje al efecto ${ }^{1318}$.

Los Señores Puntadores exponen que el Niño de Coro Arroyo no asiste a pesar de las aspas que se le imponen; y que habían entendido que estaba ya ocupado o iba a ocuparse en otro destino, por lo que el Cabildo dio comisión a dichos Señores para que informasen sobre la forma mejor de solucionar este tema. ${ }^{1319}$

“A continuación del llamamiento para oír el informe de los Señores Puntadores sobre la asistencia del Niño Arroyo, se leyó dicho informe, y en su virtud y de las faltas frecuentes en que incurren los dos Niños, Arroyo, acordó el Cavildo que se despidan; y dio comisión a los mismos Señores con agregación del Señor Ugalde, para que informen con llamamiento sobre los medios que podrán adoptarse para suplir la falta de estos dos Ministros, teniendo presentes los oficios, que con arreglo a estatuto, práctica, deben desempeñar”. ${ }^{1320}$

"Habiéndose leído un memorial de Don Sebastián Cabezón, en que pide licencia para no asistir al Coro durante su convalecencia se dudó por el Cavildo sobre la pertenencia del conocimiento de este asunto, y dio comisión a los Señores Segovia y Ugalde, para que informen a qué Cavildo toca el tratar de su contenido”. 1321

“A virtud del llamamiento para oír el informe de los Señores Diputados de Arcas de San Acacio con la parte de Su Ilustrísima sobre el patitur abierto que solicita Don Sebastián Cabezón se leyó dicho informe, y en su virtud acordó el Cavildo

\footnotetext{
1318 Ibid. Martes 23 de Junio de 1812. T. 101, fol. 264 r.

${ }^{1319}$ Ibid. Jueves 1 de Octubre de 1812. T. 102, fol. 23 r.

${ }^{1320}$ Ibid. Martes 6 de Octubre de 1812. T. 102, fol. 27 v.

${ }^{1321}$ Ibid. Miércoles 7 de Octubre de 1812. T. 102, fol. 32 r.
} 
conceder y concedió al suplicante el patitur abierto que pide, hasta el último día de Carnestolendas próximas inclusive; y mandó que se pase al punto del Coro el competente decreto para inteligencia y gobierno de aquella Diputación”. ${ }^{1322}$

Seguidamente, vemos cómo un músico tiple trae una carta de recomendación nada menos que del General Echavarri. ${ }^{1323}$ Este músico es el Padre D. Antonio Ordóñez, del cual "se leyó dicho informe, y el Cabildo en su conformidad acordó que al referido Ordóñez se le admita al exercicio de su antigua plaza de tiple con el mismo salario de 600 ducados anuales, sujetos á aspas y en los mismos términos que anteriormente se le concedió, todo por ahora, y sin perjuicio del plan acordado sobre reformas y economías, al qual habrá de sugetarse en su caso y tiempo, sin que esta gracia sirva de exemplar para nuevas admisiones de músicos, ni para hacer novedad en las reglas acordadas del salario de los demás ministros, ni menos para que el referido Ordóñez pueda solicitar, ni se le concede cantidad alguna por lo respectivo á todo el tiempo, que ha estado ausente no solo por vía de salario, sino ni aún por gratificación ó ayuda de costa". ${ }^{1324}$

“A virtud del llamamiento de los Señores Diputados de Sagradas Ceremonias sobre si deberá continuar en este presente año la antigua costumbre que se observaba en la kalenda y maitines de Nochebuena y demás festividades de Pascua; leído el informe de dichos Señores, acordó el Cavildo que siga en la misma forma que estos últimos años”. 1325

\section{3}

“A virtud del llamamiento para oír el informe y plan de los Señores Comisionados sobre el aumento y arreglo de los Niños de Coro y provisión de la plaza

\footnotetext{
${ }^{1322}$ Ibid. Sábado 24 de Octubre de 1812. T. 102, fol. 41 r.

${ }^{1323}$ Aunque ya hemos hablado de él en la introducción histórica, recordemos que estuvo al frente de las tropas cordobesas cuando llegaron los franceses en 1808.

${ }^{1324}$ Ibid. Miércoles 1 de Noviembre de 1812, T.102, fol. 44r.

1325 Ibid. Miércoles 16 de Diciembre de 1812. T. 102, fol. 63 r.
} 
vacante de Acólito acordaron lo siguiente: Primeramente se aprobó el dicho llamamiento en todas sus partes a excepción del punto de la cera, que deberán traer desde la casa de los Señores Capitulares. [...] Se determinó el número de seis niños por lo cual deberán admitirse los memoriales para las cuatro plazas vacantes, siendo de provisión de sus respectivos Cavildos. Se nombró para la vacante de Acólito en lugar de Jurado al Niño de Coro más antiguo, Talavera, según costumbre, previniendo que este deberá permanecer en el punto de horas canónicas con la obligación y hasta tanto que enseña a los niños que nuevamente se admitan”. ${ }^{1326}$

“Se leyó un memorial de Don Mariano Especiali con certificación del médico que lo asiste, y pide en virtud de sus padeceres se le conceda patitur abierto por el tiempo que el Cavildo le pareciere justo". ${ }^{1327}$

El Cabildo concede a Don Mariano Especiali patitur abierto hasta el último día de junio inclusive, y se mandó pasar al punto de horas canónicas el correspondiente decreto. $^{1328}$

“Se leyó un memorial del Padre Don Antonio Ordóñez por el que pide licencia al Cavildo para ir a Cádiz por su padre: y el Cavildo acordó pase a los Señores Diputados de Arcas de Santa Inés para que informen”. 1329

“A virtud del llamamiento para presenciar el examen de los niños que pretenden entrar en el Coro y si hubiese alguno apto pasar a la elección de uno que corresponde su nombramiento a este Cavildo. Habiendo tocado la campanilla se mandó entrar al Maestro de Capilla y niños que estaban a la puerta, y siguiéndose el examen de voz de leer y escribir y oído el informe del Maestro se pasó a la votación y salió nombrado por pluralidad de votos el niño Francisco de Mora”. ${ }^{330}$

\footnotetext{
${ }^{1326}$ Ibid. Lunes 11 de Enero de 1813. T. 102, fol. $68 \mathrm{v}$.

${ }^{1327}$ Ibid. Viernes 12 de Febrero de 1813. T. 102, fol. 79 r.

${ }^{1328}$ Ibid. Sábado 20 de Febrero de 1813. T. 102, fol. 82 r.

${ }^{1329}$ Ibid. Sábado 20 de Febrero de 1813. T. 102, fol. 82 r.

${ }^{1330}$ Ibid. Martes 23 de Febrero de 1813. T. 102, fol. 82 v.
} 
"A virtud del llamamiento para elegir otro niño de los que ya han salido examinados en el Cavildo pleno anterior e igualmente reconocer a los dos que están anteriormente admitidos, y si aún están hábiles ratificar su nombramiento. Enseguida se pasó a la votación y salió nombrado el niño Rafael Vázquez, después se examinaron los dos niños anteriormente admitidos y estando aún aptos se ratificó su nombramiento". 1331

En el día de hoy se presenta el memorial de genealogía de Francisco de Mora, nombrado recientemente para Niño de Coro por el Cabildo. ${ }^{1332}$

Se presenta el memorial de genealogía de Rafael Vázquez, recientemente elegido Niño de Coro. Y se dio comisión a los Diputados de Arcas de Santa Inés para hacer las pruebas de este y de los otros dos pretendientes nombrados hace tres años, cuya elección fue confirmada por este Cabildo en el día 23 de febrero último. ${ }^{1333}$

"Se acordó que para los Niños de Coro, se suministren desde luego los vestuarios por la Mesa Capitular por vía de empréstito, y que después la Mesa cobre de los fondos sobre que deba recaer esta carga, informando si fuere preciso con llamamiento los Señores Diputados de Hacienda". ${ }^{1334}$

El Cabildo aprueba las informaciones de limpieza de sangre de los siguientes Niños de Coro: Rafael de Luque y Lucena, Pedro Rivera, y Rafael Vázquez. ${ }^{1335}$

“A continuación del llamamiento sobre la solicitud del Acólito Mexías, se leyó un informe de los Señores Comisionados, y en su virtud acordó el Cavildo que se guarde y observe lo acordado anteriormente sobre denegación de ayudas de costa; y que no se admitan por ahora memoriales con estas solicitudes”. 1336

\footnotetext{
${ }^{1331}$ Ibid. Martes 23 de Febrero de 1813. T. 102, fol. 83 v.

1332 Ibid. Jueves 4 de Marzo de 1813. T. 102, fol. 85 r.

1333 Ibid. Jueves 4 de Marzo de 1813. T. 102, fol. 85 v.

1334 Ibid. Lunes 29 de Marzo de 1813. T. 102, fol. 93 r.

1335 Ibid. Lunes 29 de Marzo de 1813. T. 102, fol. 93 v.

${ }^{1336}$ Ibid. Jueves 13 de Mayo de 1813. T. 102, fol. 107 v.
} 
El Cabildo nombra a Don Francisco Carmona para cubrir la plaza vacante de Acólito. Dicho Carmona era en esa fecha Acólito de la Colegiata de San Hipólito. ${ }^{1337}$

El Cabildo aprueba las pruebas de limpieza de sangre del Acólito Francisco Carmona por considerarlas bien hechas. ${ }^{1338}$

"Se leyó otro memorial de los Acólitos de esta Iglesia, en que piden aumento de sueldo en consideración a las circunstancias de los tiempos. Y el Cavildo acordó que pase a los Señores Diputados de Acólitos y de Hacienda para que informen con llamamiento sobre esta solicitud". 1339

"Se leyó otro memorial del Acólito Vallejo, en que pide que se le levanten las aspas, en que ha incurrido durante su enfermedad, que acredita con certificación de médico. Y el Cavildo acordó que pase a los Señores Puntadores de Horas Canónicas para que informen con llamamiento sobre este punto". 1340

“A continuación del llamamiento se leyó otro informe de los Señores Diputados de Acólitos y Hacienda sobre la solicitud del aumento de su renta, y en su conformidad acordó el Cavildo que se asigne por dotación fija a los Acólitos de esta Iglesia la cantidad de seis reales diarios, y que este gravamen recaiga sobre la Mesa Capitular por ahora y en el interin se buscan otros arbitrios para este objeto, sobre el cual dio el Cavildo comisión a los mismos Señores, como asimismo para que arreglen el nuevo método aspas que en los sucesivo conviene adoptar sirviendo entre tanto el reglamento formado para los Niños”. ${ }^{1341}$

El Cabildo acuerda acceder a la solicitud del Acólito Vallejo, determinando que se le levanten las aspas que se le han impuesto durante su enfermedad. ${ }^{1342}$

\footnotetext{
${ }^{1337}$ Ibid. Sábado 29 de Mayo de 1813. T. 102, fol. 111 r.

${ }^{1338}$ Ibid. Lunes 14 de Junio de 1813. T. 102, fol. 116 r.

${ }^{1339}$ Ibid. Jueves 12 de Agosto de 1813. T. 102, fol. 135 r.

${ }^{1340}$ Ibid. Miércoles 25 de Agosto de 1813. T. 102, fol. 141 r.

${ }^{1341}$ Ibid. Martes 7 de Septiembre de 1813. T. 102, fol. 145 r.

1342 Ibid. Jueves 16 de Septiembre de 1813. T. 102, fol. 147 r.
} 
El tiple Antonio Ordóñez solicita licencia para pasar a Cádiz a resolver varios negocios que le interesan. Y el Cabildo acordó que informen con llamamiento sobre esta solicitud los Diputados de Santa Inés. ${ }^{1343}$

“A propuesta del Señor Maestre Escuela, dio el Cavildo comisión a los Señores Diputados de Infantes, del Colegio de San Pelagio y al Señor Ugalde para que informen con llamamiento sobre si convendrá reformar el estatuto o costumbre actual sobre las pruebas para todos los individuos de la Iglesia que asisten al Coro". ${ }^{1344}$

“En virtud de llamamiento se leyó un informe de los Señores Diputados de Arcas Vacantes de Santa Inés con la parte de Su Ilustrísima sobre la ausencia que sin licencia del Cavildo ha hecho el Capellán Don Rafael del Río; y se acordó que descontándose al dicho Capellán el importe de las cargas de su Capellanía y las aspas en que haya incurrido, le reprendan los Señores Diputados a nombre del Cavildo, y le entreguen la renta sobrante de su Capellanía, en cuyo pleno goce continuará desde el día.

Ítem a virtud del mismo llamamiento y leído otro informe de los mismos Señores, se acordó que se entregue el importe de las aspas del Capellán Río, al Acólito Joseph de Talavera que ha suplido por él”. 1345

Se leyó un memorial de Don Sebastián Cabezón, que acompaña de certificado médico, pidiendo en atención a su edad y achaques licencia de patitur abierto. Y el Cabildo dio comisión a los Diputados de Arcas de San Acacio para que informasen. ${ }^{1346}$

“Se leyó un memorial del Acólito Joseph Lucena, despidiéndose de su plaza por no haber podido eximirse de la suerte de soldado, que le ha tocado. El Cavildo acordó que por vía de gratificación se le perdonen las aspas que expresó el dicho Acólito en su memorial.

\footnotetext{
${ }^{1343}$ Ibid. Jueves 16 de Septiembre de 1813. T. 102, fol. $147 \mathrm{v}$.

${ }^{1344}$ Ibid. Viernes 12 de Noviembre de 1813. T. 102, fol. $166 \mathrm{r}$.

${ }^{1345}$ Ibid. Martes 16 de Noviembre de 1813. T. 102, fol. 168 r.

${ }^{1346}$ Ibid. Martes 7 de Diciembre de 1813. T. 102, fol. 172 v.
} 
Se leyó también un memorial de Don Manuel de Doblas y Zapata, pretendiendo la dicha plaza de Acólito vacante. El Cavildo atendiendo a que según costumbre correspondía nombrar en dicha plaza al Niño de Coro más antiguo, que en el día es Rafael de Doblas, el cual por su débil salud y pequeño cuerpo no puede exercer las funciones de Acólito, y conmovido de varias desgracias domésticas de esta familia, nombró por Acólito al citado Manuel de Doblas y acordó que los Señores Diputados de Acólitos informen con llamamiento sobre el modo de hacerle las informaciones”. ${ }^{347}$

El Cabildo acordó conceder a Don Sebastián de Cabezón el patitur abierto que solicitaba, hasta el día del Corpus. ${ }^{1348}$

"En virtud de llamamiento se leyó un informe de los Señores Diputados de Hacienda con los de Acólitos con los fondos que puedan contribuir al aumento de seis reales de sueldo diario acordado a favor de los Acólitos. En su vista acordó el Cavildo que las aspas de los Capellanes de Coro propias de los Señores Puntadores y cedidas a los Niños de Coro, se apliquen a la dotación de Acólitos, a cuyo fin se entregarán los recibos de aspas para su cobranza a la Diputación de Hacienda.

Ítem que las aspas de un Acólito por día sea de cuatro reales y sólo queden dos al que falte.

Ítem que sobre la agregación de los setenta reales que pagaban las Obras Pías al Colegio de Niños de Coro sobre igual agregación del sobrante de las Obras Pías de los Señores Mardones y Salizanes, informen los Diputados de Obras Pías con agregación de los de Acólitos.

Ítem que sobre la agregación del sobrante de la Obra Pía del Señor Millán informen los Señores Diputados de ella con agregación de los de Obras Pías y Acólitos. Y finalmente que sobre igual agregación de los sobrantes de la Obra Pía del Señor Chantre Aguayo a la misma dotación informen los Señores Diputados de Obras Pías y Acólitos con agregación de los de dicha Obra Pía a Aguayo, que con previo llamamiento deberán nombrarse en el primer Cavildo de enero.

Siguiendo el mismo el mismo llamamiento de los Señores Diputados de Acólitos sobre las pruebas que debe hacer el Acólito nombrado Manuel Doblas, se acordó y declaró

\footnotetext{
${ }^{1347}$ Ibid. Jueves 16 de Diciembre de 1813. T. 102, fol. 174 r.

1348 Ibid. Jueves 16 de Diciembre de 1813. T. 102, fol. 175 r.
} 
que éste a cumplido con la fe de bautismo presentada por el mismo, con que acredita ser hermano entero del Niño de Coro Rafael de Doblas; y que en su consecuencia desde esta tarde pueda el nuevo nombrado entrar en el Coro con sobrepelliz". ${ }^{1349}$

"Se acordó también que vengan todos los días un Niño de Coro y un Acólito a ayudar en la Capilla de Villaviciosa las misas rezadas de los Señores Capitulares una hora antes de empezar la campana. Y que sobre la reforma total necesaria para que los Señores Capitulares digan con el debido decoro las misas rezadas, informen los Señores Diputados de Ceremonias con llamamiento, con lo que se concluyó”. ${ }^{1350}$

“En virtud de llamamiento y oído el informe de los Señores Diputados de Arcas de Santa Inés con la parte de Su Ilustrísima, se acordó que se conceda licencia para ausentarse al Padre Don Antonio Ordóñez hasta la mitad de Enero, y que se le avise que si para dicho tiempo no ha vuelto a su destino o se ausenta otra vez sin la debida previa licencia, tomará el Cavildo las providencias que corresponde”. ${ }^{1351}$

\section{4}

“Don Andrés Lidón presentó un memorial en que se ofrece a desempeñar las dos plazas de organista de esta Santa Iglesia con tal que se le pague por entero su dotación de primero. Se acordó que los Señores Diputados de Excusados de Fábrica informen sobre él con llamamiento.

Leído un memorial de Don Antonio Gil, en que presentando certificación jurada de médico, pide licencia de patitur abierto, se acordó que los Señores Diputados de San Acacio con la parte informen sobre él con llamamiento.

Un memorial en que Don Antonio Ordóñez pide prórroga de la licencia que se le concedió, y mandó pasar a los Señores Diputados de Santa Inés con la parte de Su Ilustrísima para que informen con llamamiento". 1352

\footnotetext{
${ }^{1349}$ Ibid. Lunes 20 de Diciembre de 1813. T. 102, fol. 175 v.

1350 Ibid. Lunes 20 de Diciembre de 1813. T. 102, fol. 176 r.

1351 Ibid. Lunes 20 de Diciembre de 1813. T. 102, fol. 176 r.

1352 Ibid. Viernes 14 de Enero de 1814. T. 102, fol. 182 r.
} 
“En virtud de llamamiento y oído el informe de los Señores Diputados de la Capilla de San Acacio con la parte de Su Ilustrísima sobre la solicitud de Don Antonio Gil, se concedió a éste la licencia de patitur abierto hasta la Dominica in Pasione”. ${ }^{1353}$

"Se acordó que un informe presentado por los Señores Diputados de Excusados de Fábrica, vuelva otra vez a la misma comisión para que venga como debe con la parte; y entonces se acordará sobre la solicitud de Don Andrés Lidón, que es el objeto de dicho informe.

Se leyó un memorial de Don Francisco Balius, solicitando la plaza vacante de segundo organista, el que se mandó pasar a los Señores Diputados de Excusados con la parte para que en vista de los antecedentes y uniéndolos todos informen con llamamiento". 1354

“Oído un informe de los Señores Diputados de Excusados de Fábrica con la parte de Su Ilustrísima sobre la solicitud de Don Andrés Lidón, fue aprobado dicho informe por votación secreta, y mandado insertar a la letra en el presente acuerdo, como se executa: informe: Don Andrés Lidón primero y único organista en la actualidad de esta Santa Iglesia solicita que la baxa de cinco mil cuatrocientos reales que se le hizo de su sueldo en diciembre de 1810 se le compense por V.S. con el que ha vacado por la muerte de Don Joseph Bach, obligándose a servir ambas plazas como lo ha hecho no sólo desde la vacante si no también en todo el tiempo de su dilatada enfermedad. Para inclinar la piedad de V.S. a su solicitud le recuerda su puntual y constante servicio sin haber incurrido en nota alguna, y representa que siendo antes su sueldo de doce mil reales, y habiéndolo dexado reducido a seiscientos ducados, le tiene esta renta tan escasa para el sustento de su persona y el de su dilatada familia, que se ha vista en la triste necesidad de contraer tantas deudas que lo reducen en el día a un estado de verdadera indigencia, y lo tienen sin arbitrio para poder dar carrera a sus hijos varones que ya lo exigen por su edad.

Esto es sustancialmente lo que Lidón expone a V.S. y sobre lo que nos manda informar, y en cumplimiento de su decreto decimos que toda la exposición del suplicante es

\footnotetext{
${ }^{1353}$ Ibid. Miércoles 19 de Enero de 1814. T. 102, fol. 183 v.

${ }^{1354}$ Ibid. Miércoles 16 de Marzo de 1814. T. 102, fol. 196 r.
} 
cierta, y al mismo tiempo notoria haciéndolo acreedor a la gracia que pide sin que en su concesión se contravenga al Reglamento que V.S. tiene aprobado en orden a las consignaciones y sueldo de todos sus Ministros, porque habiéndose verificado la muerte del segundo organista después de la aprobación de dicho Reglamento, V.S. está expedito para consignarle al primero la renta que gozaba el difunto en atención a que en nada se grava el fondo de donde se deducen estas consignaciones, y ha que estando desempeñando las dos plazas de de organista sin que se trate por ahora de la provisión de la segunda, parece que está en el orden de justicia, que V.S. conceda a este Ministro laborioso por el servicio que está haciendo lo que tenía asignado cuando solo cumplía las obligaciones de primer organista. Tampoco se opone a la concesión de esta gracia el artículo en que V.S. convino de suprimir las plazas de música que fueron vacando para que la Fábrica se compensase de los gastos de cera, aceite y demás a que se obligó, con los sueldos que fuesen vacando y se fuesen suprimiendo porque siendo el órgano un instrumento de absoluta necesidad para el culto, cuando se trata de supresión de plazas no puede extenderse a ésta. Sobre todo V.S. acordará lo que más convenga. Córdoba Diputados, 15 de Marzo de 1814: Juan de Trevilla, Gregorio Marcos Merlo y Jospeh Garrido”. 1355

“A propuesta de los Diputados de Obras Pías se acordó que el Colegio de Niños de Coro se habilite en forma de casas para darse en arrendamiento, y para la execución de la obra y execución de este acuerdo se dio comisión a los mismos Señores Diputados". 1356

“En virtud de llamamiento se leyó un informe de los Señores Diputados de Arcas de Santa Inés con la parte sobre la solicitud del Padre Don Antonio Ordóñez, tiple de nuestra Capilla de Música, y se acordó que si el dicho no está en esta ciudad para la tarde del Miércoles Santo, se declarase vacante su plaza; y si en lo sucesivo se nota descuido en la asistencia de este Ministro, informarán los mismos Señores

\footnotetext{
1355 Ibid. Jueves 17 de Marzo de 1814. T. 102, fol. 196 v.

${ }^{1356}$ Ibid. Jueves 17 de Marzo de 1814. T. 102, fol. 197 v.
} 
Comisionados si convendrá ponerle para mayor estímulo toda la renta en distribuciones conforme al Reglamento aprobado para la Capilla de Música”. ${ }^{1357}$

En virtud de llamamiento se leyó el informe de lo Señores Diputados de Arcas de San Acacio con la parte de nuestro Ilustrísimo Prelado sobre el aumento de sueldo que solicitan los Capellanes de San Acacio y en atención á lo que expone la Diputación se acordó que en uso de las Facultades del Cabildo, la dotación de estas Capellanías que hasta aquí ha sido de quatro mil, sea desde hoy de ocho mil reales de vellón annuales; y que si llega el caso de dar á los Capellanes los salarios que antes de la rebaja gozaban además de las Capellanías, se entiendan dichos salarios y aumentos como cantidades añadidas á la antigua base de quatro mil reales annuales y no á la de ocho mil que hoy se ha acordado: Y supuesto el estado de las arcas, los Señores Diputados hagan las diligencias posibles para reintegrarlas, dando cuenta al Cabildo y llamamiento quando les parezca oportuno". 1358

"Se leyó un memorial de varios músicos instrumentistas de esta Iglesia en que piden que en atención a haber variado las circunstancias se le reintegre en el total de su dotación; disminuida por acuerdo del Cavildo en el año 1810. Y el Cavildo acordó que pase a los Señores Diputados de Excusados de Fábrica con la parte de Su Ilustrísima para que informen sobre esta solicitud". 1359

"Se leyó un memorial de Don Pedro Heredia, Capitán retirado en que pide al Cavildo que se sirva mandar que ninguno de los músicos asistan a la función pública de música baja, anunciada por carteles. Y se acordó que pase a los Señores Diputados de Ceremonias con agregación del Señor Ugalde, para que con presencia de los acuerdos y práctica asidua del Cavildo informen lo que les parezca con relación a este punto, y otros de esta naturaleza con la posible brevedad y habilitando para esto cualquier día”. 1360

\footnotetext{
${ }^{1357}$ Ibid. Miércoles 23 de Marzo de 1814. T. 102, fol. 224 v.

${ }^{1358}$ Ibid. Sábado 23 de Abril de 1814. T. 102, fol.223r.

1359 Ibid. Sábado 21 de Mayo de 1814. T. 102, fol. 234 v.

${ }^{1360}$ Ibid. Viernes 3 de Junio de 1814. T. 102, fol. 239 r.
} 
"Se leyó un memorial del Acólito Talavera en que pide que se le perdonen las aspas en que ha incurrido durante su larga enfermedad. Y se acordó que pase a los Señores Diputados de Acólitos para que informen". ${ }^{1361}$

"A virtud de llamamiento se leyó un informe de los Señores Diputados de Acólitos sobre la solicitud de José Talavera, y en su virtud acordó el Cavildo que se levanten las aspas en que ha incurrido por su enfermedad”. ${ }^{1362}$

"En virtud de llamamiento y oído el informe de los Señores Diputados de Excusados de Fábrica, firmado también por la parte de S.I. se acordó aprobar en todo dicho informe, y que a su consecuencia los músicos instrumentistas Don Vicente Marín, Don Juan Nepomuceno Puig, Don Mateo Tascón, y Don Cristóbal Bendicho, gocen el sueldo que les estaba asignado íntegramente y sin disminución alguna desde el presente día.

Leído un memorial de Don Antonio Ordóñez pidiendo licencia para ir a Marid, se acordó que no se le dé curso". 1363

“Se leyó un memorial de Don Antonio Gil, Presbítero Capellán de San Acacio, solicitando la competente licencia para ausentarse a su país por una temporada; y se acordó que los Señores Diputados de Arcas de San Acacio informen con llamamiento cuánto se les ofrezca en razón de esta solicitud”. ${ }^{1364}$

“Dióse cuenta de un memorial de Doña Joaquina de Almeida, casada con Don Miguel Reynaldi, primer violín de esta Santa Iglesia, en que solicita se la continúen sus alimentos sobre el sueldo de su marido para no perecer, y se le cometió a informe de los Señores Diputados de Arcas de Vacantes de Santa Inés para que digan cuánto se les ofrezca y parezca.

Ítem se leyó otro memorial de Don Francisco Ferrer, músico instrumentista, en que pretende que su perjuicio de lo que resulta en la representación que con los demás sus

\footnotetext{
1361 Ibid. Viernes 17 de Junio de 1814. T. 102, fol. 239 v.

1362 Ibid. Martes 21 de Junio de 1814. T. 102, fol. 240 r.

1363 Ibid. Martes 2 de Agosto de 1814. T. 102, fol. 254 r.

${ }^{1364}$ Ibid. Martes 9 de Agosto de 1814. T. 102, fol. 258 v.
} 
compañeros tiene hecho, se le adelanten los ochocientos veinte reales que debe a la Mesa Capitular a cuenta de lo que por ella tenga a bien concedérsele. Y se cometió a informe de los Señores Diputados de Arcas de Vacantes de Santa Inés, para que expongan cuánto se les ofrezca y parezca”. ${ }^{1365}$

"Don Miguel Reynaldi, primer violinista, presentó un memorial pidiendo licencia para pasar a Sevilla: se acordó que los Señores Diputados de Arcas de Santa Inés con la parte de Su Ilustrísima informen sobre el asunto con llamamiento”. ${ }^{1366}$

"Se llamó a dicho Señor [Trevilla] nombrado parte de Su Ilustrísima y no estando en el sitio acostumbrado, se procedió en virtud de llamamiento a oír el informe de los Señores Diputados de Arcas de Santa Inés sobre la licencia que para pasar a Sevilla solicita Don Miguel Reynaldi, a quien se concedió dicha gracia hasta el día de Todos los Santos". 1367

"Un memorial, en que el bajonista Don Mariano Ortega se quexa de que a petición de la Diputación de Hacienda, se le ha embargado toda su renta, pasó a informe con llamamiento de los Señores Diputados de San Acacio con la parte de Su Ilustrísima". 1368

“En virtud de llamamiento se leyó el informe de los Señores Diputados de Arcas de San Acacio con la parte de Su Ilustrísima, sobre el reintegro que los Ministros dotados con las rentas de dicha Capilla han pedido de sus asignaciones, y se acordó: Primero que desde el principio del tercio corriente todos los que están dotados por dichas Arcas gocen de su última asignación completa.

Segundo que si los fondos de la dicha Capilla no alcanzaran para pagar por entero a todos, se dé cuenta al Cavildo para tomar las medidas convenientes.

Tercero que los aumentos concedidos a los Capellanes se entiendan en el modo y forma acordados en 23 de abril del presente año.

\footnotetext{
1365 Ibid. Martes 30 de Agosto de 1814. T. 102, fol. 264 r.

1366 Ibid. Miércoles 7 de Septiembre de 1814. T. 102, fol. 268 r.

1367 Ibid. Viernes 16 de Septiembre de 1814. T. 102, fol. 270 r.

1368 Ibid. Viernes 23 de Septiembre de 1814. T. 102, fol. 272 v.
} 
Cuarto que no se provean por ahora plaza ninguna de Capellán ni de músico ni de Sacristán.

Quinto que para cumplir los cargos de las fundaciones se provean las sirventías de capellanías para lo cual los Señores Diputados de Arcas, informarán de las que estén vacantes". 1369

“En virtud de llamamiento se leyó el informe de los Señores Diputados de Arcas de Santa Inés con la parte de Nuestro Ilustrísimo Prelado sobre el reintegro de los músicos y demás dotados por dichas Arcas, y se acordó en todo y por todo lo mismo que en el Cavildo precedente de Señores, Dignidades y Canónigos se acaba de acordar en cuanto a las Arcas de San Acacio, menos en el artículo 3 por no haberse aumentado por este Cavildo la dotación de las Capellanías de Santa Inés.

En virtud de una palabra del Señor Magistral se acordó que los Señores Diputados de Arcas de Santa Inés vistos los acuerdos anteriores, informen para el día 7 del mes futuro sobre la despedida que parece merecer Don Antonio Ordóñez por haberse ausentado sin licencia del Cavildo". 1370

“El Señor García dixo que en la primera Navidad después de la irrupción de los franceses se acordó que los maitines de Nochebuena fuesen a canto llano, y que no hubiese villancicos ni en ellos, ni en la misa; que concluida ésta y los laudes se cerrase la iglesia, y se entrase a prima a las seis; pero que como las circunstancias han variado y vuelto las cosas a su antiguo estado, pedía al Cavildo que se celebrase acuerdo decisivo sobre esta materia: se acordó que los señores Diputados de Ceremonias informen sobre este asunto con llamamiento". ${ }^{1371}$

El Cabildo, vistos los antecedentes reiterados de faltas en su asistencia de Don Antonio Ordóñez, acordó por mayoría de votos la expulsión de dicho músico. ${ }^{1372}$

\footnotetext{
1369 Ibid. Martes 27 de Septiembre de 1814. T. 102, fol. 274 r.

1370 Ibid. Martes 27 de Septiembre de 1814. T. 102, fol. 274 v.

1371 Ibid. Viernes 7 de Octubre de 1814. T. 102, fol, 276 r.

1372 Ibid. Viernes 7 de Octubre de 1814. T. 102, fol. 276 v.
} 
“Se acordó renovar la comisión dada a los Señores Diputados de Obras Pías sobre el destino que conviene dar al Colegio de Niños de Coro, ampliándola a la renta de dicho Colegio, y modo de venderlo, teniendo presente el destino y propiedad de la Iglesia". 1373

\section{5}

El Cabildo trata sobre una Real Orden por la que se invita al Cabildo a considerar el pase de las prebendas que disfrutaba Don Ángel Arteaga al músico Antonio Ordóñez. El Cabildo da comisión a los Señores Diputados de Santa Inés para que informen. $^{1374}$

"Se leyó un memorial de Don Nicolás Anguita, músico de voz de esta Santa Iglesia, en que solicita una de las Capellanías de San Acacio u otra; y se acordó que pase a informe de los Señores Diputados de Arcas de la propia Capilla y la traigan con llamamiento". 1375

"Se leyó un memorial del Acólito Joseph Talavera, en que se despide con motivo de haber sido provisto en la Sacristía de la Parroquial en la villa de Castro del Río, y pide que se le tenga presente en alguna de las plazas de violín que hay vacantes; y se acordó, que con suspensión de la despedida se pase esta solicitud al Cavildo de Señores, Dignidades y Canónigos para los fines convenientes”. ${ }^{1376}$

"Se leyó un memorial de Don Benito Torrellas, músico de voz en que solicita licencia para pasar a Sevilla a evacuar asuntos propios y se acordó que los Señores Diputados de Arcas de San Acacio con la parte de Nuestro Ilustrísimo Prelado informen con llamamiento". ${ }^{1377}$

\footnotetext{
1373 Ibid. Martes 29 de Noviembre de 1814. T. 102, fol. 288 r.

1374 Ibid. Jueves 5 de Enero de 1815. T. 102, fol. 298 r.

1375 Ibid. Jueves 12 de Enero de 1815. T. 102, fol. 299 r.

${ }^{1376}$ Ibid. Sábado 14 de Enero de 1815. T. 102, fol. 299 v.

${ }^{1377}$ Ibid. Sábado 14 de Enero de 1815. T. 102, fol. 300 r.
} 
“Se leyó una carta del músico tiple Ordóñez, dirigida desde Madrid con fecha 17 de enero último; y en su vista se acordó que se conteste a ella por el notario secretario capitular, con expresión de lo acordado en Cavildo de 7 de octubre del año inmediato pasado; añadiendo que le ha sido al Cavildo de satisfacción su nueva colocación en la Capilla Real”. 1378

“Don Mariano Especiali, solicita que se le conceda el patitur que el Cavildo tenga por conveniente; y se acordó que los Señores Diputados del Punto de Horas Canónicas informen con llamamiento". 1379

"Se leyó un memorial de Don Manuel Valls músico instrumentista, quien por la debilidad de su dentadura por efecto de las fluxiones, solicita que se le exonere de tocar en el Facistol, sirviendo sólo en la música instrumental, y caso de no poder cumplir aún con este alivio, que se tenga presente que sabe tocar el violín; y el Cavildo acordó, que pase a informe con llamamiento de los Señores Diputados de Arcas de San Acacio con la parte de Nuestro Prelado". ${ }^{1380}$

"Se leyó un llamamiento de los Señores Diputados de Arcas de San Acacio sobre las licencias de patitur abierto que solicitan Don Sebastián Cabezón, y Don Mariano Especiali, ambos músicos de voz, oído ambos informes acordó el Cavildo concederles y les concedió dicha licencia de patitur abierto hasta el Jueves Santo del año siguiente de 1816.

Ítem para oír el informe de los mismos Señores sobre la solicitud del Presbítero músico contralto, Don Nicolás de Anguita, en el que se expresan con prudente extensión las cualidades, conductas y circunstancias de este sujeto, y por último se le hace acreedor al goce de la Capellanía de San Acacio, vacante por muerte de Don Pedro Tuñón. En su consecuencia, se procedió a la votación por cédulas, y en ellas resultó quedar nombrado el citado Capellán, en la mencionada Capellanía, lo cual se hizo entender,

\footnotetext{
${ }^{1378}$ Ibid. Sábado 4 de Febrero de 1815. T. 102, fol. 309 v.

${ }^{1379}$ Ibid. Miércoles 15 Febrero de 1815. T. 102, fol. 317 r.

${ }^{1380}$ Ibid. Miércoles 1 de Marzo de 1815. T. 102, fol. 329 r.
} 
previo toque de campana, al notario secretario en presencia de competente número de testigos, y en presencia de los mismos, se hizo colación y canónica institución por imposición de un bonete en su cabeza, quedando así nombrado y reservando la posesión a cuando se habilite con arreglo a estatuto". ${ }^{1381}$

“Joseph María Villalba, actual Sacristán de la Parroquia de la villa de Rute, pide que V.S. le perdone sus faltas en los diecinueve años que le ha servido de Niño de Coro y Acólito, despidiéndose de este destino, y que por un efecto de equidad le remita las aspas en que ha incurrido desde su ausencia. A su virtud acordó el Cavildo remitirle y condonarle las aspas que indica, y admitirle la despedida que hace de su destino de Acólito, nombrando en su lugar, como en efecto nombró a Rafael de Doblas, Niño de Coro más antiguo". ${ }^{1382}$

"Doña María Antonia Ilarduy, viuda de Don Joseph López, expone su indigencia, y trabajos con que vive, y noticiosa de la vacante que ha ocurrido de Niño de Coro, suplica a V.S. admita a su hijo Francisco de Paula y se acordó que con los demás que se han presentado, pase a los Señores Diputados de Acólitos y Niños de Coro para los fines convenientes". 1383

Don Manuel Valls presenta un extenso memorial en el que solicita dejar de tocar el oboe, por ser éste perjudicial para su dentadura. El Cabildo no toma una resolución en este día al respecto. ${ }^{1384}$

“El Señor Segovia, como Diputado de Acólitos y Niños de Coro, dio cuenta de la vacante que había ocurrido entre los mismos, por el ascenso de Rafael Doblas, y de la necesidad que había de proveerse; enterado el Cavildo acordó que se reciban memoriales, dando cuenta a su tiempo la Diputación para oírlos y proceder a su provisión.

\footnotetext{
${ }^{1381}$ Ibid. Sábado 18 de Marzo de 1815. T. 102, fol. 373 v.

${ }^{1382}$ Ibid. Martes 18 de Abril de 1815. T. 102, fol. 388 r.

1383 Ibid. Miércoles 19 de Abril de 1815. T. 102, fol. 388 v.

${ }^{1384}$ Ibid. Miércoles 26 de Abril de 1815. T. 103, fol. 15 v.
} 
Con este motivo el infrascrito secretario, hizo presente que convendría aumentar un Niño, porque sobre experimentarse muchas faltas, podría enfermar alguno de los actuales, como sucede con harta frecuencia, y se acordó que este zelo se agregue a la comisión". 1385

"Se leyó un memorial del bajo de Capilla Don Benito Torrellas, en que solicita que se le auxilie con alguna cantidad para salir de sus empeños, y apuros; a su vista se acordó cometerle a informe de los Señores Diputados de Arcas Vacantes de San Acacio, evacuándole con llamamiento”. 1386

El Cabildo acuerda que Don Manuel Valls, deje de tocar el oboe en la música de Facistol, de acuerdo con dos certificados médicos que avalan esta conveniencia. ${ }^{1387}$

“Don Miguel Reynaldi, primer violín de la Capilla de Música, presenta un memorial desde Málaga solicitando licencia para mantenerse ausente”. ${ }^{1388}$

“El Acólito Antonio Ayllón, presentó un memorial exponiendo los servicios de pertiguero que estaba haciendo por la ausencia del propietario, y que habiendo acudido a percibir las propinas que creía corresponderle, se le contestó por el notario secretario que no le tocaban, porque la ausencia del propietario la había hecho con licencia legítima del Cavildo; en su vista se acordó que informen con llamamiento los Diputados de Arcas Vacantes de San Acacio y Santa Inés cuánto se les ofrezca y parezca en el asunto". 1389

"Se leyó un memorial del Acólito Mariano Vallejo, en que solicita que se le remitan y condonen unas aspas que se le han impuesto por las faltas que ha tenido en días que supone haber estado enfermo, y se cometió a informe de los Señores Puntadores de Horas Canónicas con llamamiento”. 1390

\footnotetext{
${ }^{1385}$ Ibid. Miércoles 10 de Mayo de 1815. T. 103, fol. 26 v.

1386 Ibid. Miércoles 10 de Mayo de 1815. T. 103, fol. 33 v.

${ }^{1387}$ Ibid. Jueves 8 de Junio de 1815. T. 103, fol. 104 v.

${ }^{1388}$ Ibid. Jueves 8 de Junio de 1815. T. 103, fol. $104 \mathrm{v}$.

1389 Ibid. Martes 20 de Junio de 1815. T. 103, fol. 140 r.

1390 Ibid. Martes 4 de Julio de 1815. T. 103, fol. 173 r.
} 
"Don Lope de Mora pretende por un memorial entrar en una de las plazas de violín vacantes, o que se le aumente la dotación de la que obtiene, y se cometió a informe de los Señores Diputados de Arcas Vacantes de San Acacio con llamamiento: y Don Francisco Cascante solicita por otro memorial, que se le aumente su sueldo, o se le libre una ayuda de costa para salir de sus apuros, el cual se cometió a informe de los mismos Señores". 1391

"Se leyó un llamamiento para oír el informe de los Señores Diputados sobre los memoriales presentados por los pretendientes a la plaza de Infante de Coro vacante, oír su examen y proceder en su vista a su provisión. Los dichos Señores Diputados informaron a los pretendientes que había de los cuales sólo tres comparecieron, a saber Miguel de Mora, Miguel López y Calero, y Francisco López Ilartuy, y en el acto se presentó Joseph Criado, los cuales fueron examinados por el Maestro de Capilla; fenecido este acto, preguntó el mismo Maestro de Capilla, si había algún otro pretendiente desde la puerta de esta Sala Capitular, y acudieron Francisco González y Joseph Fernández, que también fueron examinados, y retirándose de este lugar, expuso su dictamen el citado Maestro de Capilla, executándolo verbalmente y resultando ser el mejor y más del caso el referido Francisco de Paula López Ilarduy, y quedó elegido por uniformidad de votos, dándose comisión a los mismos Señores Diputados, para que intervengan en sus pruebas, presentándolas a su tiempo con el correspondiente informe, previo llamamiento". ${ }^{1392}$

“A virtud de llamamiento se leyó un informe de los Señores Diputados de Arcas Vacantes de San Acacio, sobre la solicitud de Don Manuel Valls, y se acordó, que las asistencias se entiendan con arreglo al propio informe, añadiéndose la de la procesión del día del Corpus; y la de la su Octava.

Ítem se leyó otro informe de los mismos Señores sobre la pretensión de Don Benito Torrellas; en su vista acordó el Cavildo que se suspenda hacer consignación alguna

\footnotetext{
${ }^{1391}$ Ibid. Martes 4 de Julio de 1815. T. 103, fol. 175 r.

1392 Ibid. Lunes 10 de Julio de 1815. T. 103, fol. 199 r.
} 
hasta que los Señores Diputados presenten el estado de fondos que tuvieren estas Arcas a fin de proceder con todo conocimiento y a su tiempo informen con llamamiento". ${ }^{1393}$

El Cabildo acordó perdonar las aspas que tenía el Acólito Mariano Vallejo, en atención a las causas expresadas de su enfermedad. ${ }^{1394}$

El Cabildo acepta las pruebas de limpieza de sangre aportadas por Francisco López, recién nombrado Infante de Coro. ${ }^{1395}$

“A virtud de llamamiento para ver y cometer los documentos de Don Ángel Arteaga, provisto en la media ración vacante por muerte de Don Felipe Villaescusa, habiéndose tocado la campanilla, entró el notario secretario, quien paso a leer la Cédula Real y poder otorgado en favor de Don Jaime Balius, Maestro de Capilla de esta Santa Iglesia para la toma de posesión y demás necesario en estos casos, y habiendo dado lugar el mencionado secretario, se procedió a la votación por pelotas y resultó ser suficiente el poder y la Cédula Real con todos sus registros y tomas de razón, por lo que quedaron vistos estos documentos y se dio comisión a los Señores Magistral y Don Juan de Exarque para su revisión y que a su tiempo los traigan a Cavildo previo llamamiento”. ${ }^{1396}$

Se presenta detalladamente el memorial de genealogía de Don Ángel Arteaga. Y el Cabildo acepta todo lo contenido en él. ${ }^{1397}$

“Se leyó un memorial de Don Francisco Balius, organista de la Real Colegiata de San Hipólito, pretendiendo la plaza de segundo vacante en esta Santa Iglesia; y se acordó que los Señores Diputados de Arcas de San Acacio y Santa Inés con la parte de

\footnotetext{
${ }^{1393}$ Ibid. Lunes 10 de Julio de 1815. T. 103, fol. 203 r.

1394 Ibid. Miércoles 12 de Julio de 1815. T. 103, fol. 208 r.

1395 Ibid. Sábado 5 de Agosto de 1815. T. 103, fol. 229 v.

${ }^{1396}$ Ibid. Sábado 5 de Agosto de 1815. T. 103, fol. 229 v.

${ }^{1397}$ Ibid. Miércoles 9 de Agosto de 1815. T. 103, fol. 231 v.
} 
Su Ilustrísima informen con llamamiento sobre la provisión de dicha plaza, y modo de hacerla con lo demás que tengan por conveniente”. ${ }^{1398}$

“A propuesta del Señor Armenta, se acordó que los mismos Señores Diputados (de Santa Inés) activen su informe sobre la ausencia del primer violinista (Miguel Reynaldi) con lo que se concluyó”. 1399

"Se leyó un memorial de los hijos y herederos de Don Mateo Tascón, músico bajonista de esta Santa Iglesia, pidiendo una ayuda de costa, y se acordó que el Señor Garrido nombrado Diputado de Excusados de Fábrica en julio de 1814 acompañado de la parte de Su Ilustrísima informe sobre dicho memorial con llamamiento”. ${ }^{400}$

“Se leyó el informe del Señor Garrido, como último Diputado de Excusados, con la parte de Su Ilustrísima, y se acordó que no se resuelva nada sobre la ayuda de costa que solicitan los hijos de Don Mateo Tascón, hasta que el Señor Arcediano y el Peniteniciario evacuen el informe que sobre Excusados de Fábrica se le encargó en el Cavildo de 17 del corriente”. ${ }^{1401}$

"En virtud de llamamiento se leyeron las censuras de los tres examinadores nombrados en el Cavildo de 27 del presente para la plaza de Veintena vacante, y resultó electo por votación canónica para la dicha Capellanía de Veintena, Don Antonio de Ayllón, Acólito de esta Santa Iglesia.

Y quedando vacante una plaza de Acólito por dicha elección, se acordó que según la práctica observada más frecuentemente, pase a Acólito el Niño más antiguo de Coro, Juan Lucas del Pozo”. 1402

"Se leyó un memorial de Don Francisco Martínez, escrito en Madrid a 24 del corriente, solicitando la plaza de tiple vacante; y se acordó que los Señores Diputados

\footnotetext{
1398 Ibid. Miércoles 23 de Agosto de 1815. T. 103, fol. 234 v.

${ }^{1399}$ Ibid. Jueves 7 de Septiembre de 1815. T. 103, fol. 241 r.

1400 Ibid. Viernes 6 de Octubre de 1815. T. 103, fol. 254 v.

${ }^{1401}$ Ibid. Miércoles 25 de Octubre de 1815. T. 103, fol. 260 v.

1402 Ibid. Martes 31 de Octubre de 1815. T. 103, fol. 261 v.
} 
de Arcas de Santa Inés con la parte, informen sobre dicho memorial con llamamiento". 1403

“Los Señores Diputados de Acólitos y Niños de Coro dieron cuenta de estar vacante una plaza de Niño de Coro por salida a Acólito de Juan Lucas, y se acordó que dichos Señores admitan memoriales y los traigan a Cavildo para proveer en la forma acostumbrada dando llamamiento”. ${ }^{404}$

\section{6}

"Se leyó un memorial de Don Joseph Ruiz, pidiendo un salario de músico, como tenor, en la Capilla de esta Santa Iglesia y se acordó que los Señores Diputados de Arcas de San Acacio con la parte de Su Ilustrísima informen sobre esta solicitud con Ilamamiento". 1405

“A propuesta del Señor Ceballos se acordó que los Señores Diputados de Hacienda, tratando el asunto con los de Cabeza de Rentas y con los de Obras Pías, informen con llamamiento sobre el destino que pueda darse a la Casa Colegio de Niños de Coro". 1406

"Oído el informe de la Diputación de Hacienda se acordó que el Señor Diputado de Hospitales informe con llamamiento sobre todos los puntos tocados en dicho informe de la Diputación de Hacienda, añadiendo lo conveniente sobre el arrendamiento del Colegio [de Niños de Coro], y frutos vendidos y gastados, o invertidos en el hospital". ${ }^{407}$

\footnotetext{
1403 Ibid. Martes 31 de Octubre de 1815. T. 103, fol. 262 v.

${ }^{1404}$ Ibid. Lunes 27 de Noviembre de 1815. T. 103, fol. 271 r.

${ }^{1405}$ Ibid. Viernes 19 de Enero de 1816. T. 103, fol. 288r.

${ }^{1406}$ Ibid. Viernes 26 de Enero de 1816. T. 103, fol. 291 v.

${ }^{1407}$ Ibid. Martes 13 de Febrero de 1816. T. 103, fol. 295 v.
} 
“En virtud del llamamiento y oído el informe de los Señores Diputados de Hacienda sobre la disposición que puede tomarse sobre la Casa Colegio de Niños de Coro, en que exponían dichos Señores que Cabeza de Rentas estaba en resolución de comprarla para ampliar sus tercias, se acordó que sobre esta propuesta informen las dos Diputaciones de Hacienda y Cabeza de Rentas con la parte de Su Ilustrísima”. ${ }^{408}$

"Se leyó un memorial de Don Joseph Moyano, pidiendo licencia de patitur abierto, acompañado de certificación jurada de facultativo, se mandó pasar a informe con llamamiento de los Señores Diputados de Arcas de San Acacio con la parte”. ${ }^{4409}$

“En virtud de llamamiento y oído el informe del Señor Diputado de Hospitales sobre la renta de frutos y aprovechamiento de la Casa Colegio de Niños de Coro, fue aprobada y recomendada la conducta de dicho Señor Diputado, y se acordó que su informe se una al expediente que sobre esta materia obra en la oficina de Obras Pías, para que den llamamiento para determinar los Señores Diputados de ellas”. 1410

“El Señor Maestre Escuela propuso por una palabra escrita que se renueven las providencias que tomó el Cavildo en 7 de diciembre de 1768 sobre la mejor educación posible de los Niños de Coro, y se acordó que sobre dicha propuesta informen con Ilamamiento los Señores Diputados de Acólitos e Infantes de Coro”. 1411

El Cabildo concede a Don Joseph Moyano la licencia de patitur abierto que éste había solicitado. ${ }^{1412}$

El Cabildo concede a Don Sebastián Cabezón, Capellán de San Antonino, licencia de patitur abierto por un año.

\footnotetext{
1408 Ibid. Martes 20 de Febrero de 1816. T. 103, fol. 298 v.

${ }^{1409}$ Ibid. Martes 20 de Febrero de 1816. T. 103, fol. 300 r.

${ }^{1410}$ Ibid. Miércoles 21 de Febrero de 1816. T. 103, fol. 301 r.

${ }^{1411}$ Ibid. Viernes 23 de Febrero de 1816. T. 103, fol. 302 r.

1412 Ibid. Sábado 2 de Marzo de 1816. T. 103, fol. 305 r.
} 
Igualmente Don Mariano Especiali solicita que se le amplíe la licencia de patitur atendiendo a las circunstancias de su mal, y el Cabildo acuerda que los Diputados de Arcas de San Acacio informen con llamamiento. ${ }^{1413}$

“A la Diputación de Acólitos y Niños de Coro se dio comisión para informar con llamamiento sobre el arreglo de ellos en general y personalmente.

En virtud de llamamiento y oído el informe de los Señores Diputados de Arcas de San Acacio con la parte de Su Ilustrísima, se concedió a Don Mariano Especiali prórroga por un año de la licencia de patitur abierto que le era concedida". ${ }^{1414}$

Don Benito Torrellas, pide licencia de patitur abierto para ir a Madrid. Se cometió a los Diputados de San Acacio para que informasen. ${ }^{1415}$

Don Antonio Gil pide licencia de patitur abierto, presentando la correspondiente certificación médica. Se acordó que los Diputados de San Acacio informen con llamamiento. $^{1416}$

"En virtud de Ilamamiento, se concedió a Don Benito Torrellas licencia para ausentarse por mes y medio y a Don Antonio Gil la de patitur abierto por dos meses; todo conforme a lo que en su informe expusieron los Señores Diputados de Arcas de San Acacio con la parte". ${ }^{1417}$

El Señor Deán presenta un muy extenso informe sobre la solicitud que hace el Maestro de Capilla de arreglar el tema del poco número de voces con que cuenta para realizar apropiadamente los cantos. El Cabildo acuerda encomendar al mismo Deán la solución provisional en al distribución de estas voces, para que se dé el mejor efecto posible.

\footnotetext{
${ }^{1413}$ Ibid. Miércoles 27 de Marzo de 1816. T. 103, fol. 317.

1414 Ibid. Martes 2 de Abril de 1816. T. 103, fol. 321 r.

1415 Ibid. Martes 2 de Abril de 1816. T. 103, fol. 325 v.

${ }^{1416}$ Ibid. Martes 23 de Abril de 1816. T. 103, fol. 326 r.

${ }^{1417}$ Ibid. Viernes 26 de Abril de 1816. T. 103, fol. 326 v.
} 
También el Señor Deán presenta un informe muy detallado sobre la actitud de Don Miguel Reynaldi, que se niega a comulgar los días de festividades importantes, como es costumbre para todos los Ministros y miembros del Coro. Además, Reynaldi manda una carta al Cabildo, defendiendo su posición y [según el Cabildo] menospreciando el Sacramento de la Comunión. Ante esto se acuerda asparle en los días que falte a tal obligación. ${ }^{1418}$

“En virtud de llamamiento y oído el informe de los Señores Diputados de Arcas de Santa Inés con la parte de Su Ilustrísima, se concedieron a Don Francisco Ferrer cien ducados de aumento de renta, por votación secreta, mientras que esté de único trompa como en el día". 1419

"Se leyó un informe de los Señores Diputados de ceremonias sobre la comisión relativa al primer violín Don Miguel Reynaldi y oído que fue se acordó nombrar una comisión compuesta de los Señores Deán, Lectoral, Ximénez Hoyo y Caballero para que en presencia del notario secretario reprendan fuertemente al dicho Reynaldi y en cuanto a aspas continuarán hasta que el Cavildo disponga se levanten uniendo la carta dirigida últimamente al Señor Deán por el Reynadli a los demás documentos que deben pasar según acuerdo al Cavildo de Señores Deán y Canónigos, informando los Señores lo que les parezca, y lo mismo respecto al tiempo que deben durar las aspas”. ${ }^{1420}$

“El Señor Deán dixo: que reunía al Cavildo para dar cuenta de un memorial de Don Benito Torrellas, bajo que fue de esta Santa Iglesia y en el día da cuenta al Cavildo haberlo hecho Su Majestad, músico de Cámara y de su Capilla, cuyas plazas ponía a la disposición del Cavildo y pedía que hallándose sumamente atrasado con poner casa y mudar su familia que le era forzoso, esperaba que el Cavildo le abonase el todo o parte de los atrasos del tiempo de los franceses, y se acordó pase este memorial a los Señores Diputados de San Acacio para que informen con llamamiento.

\footnotetext{
${ }^{1418}$ Ibid. Lunes 10 de Junio de 1816. T. 103, fol. 337 r.

1419 Ibid. Miércoles 12 de Junio de 1816. T. 103, fol. 340 r.

${ }^{1420}$ Ibid. Sábado 15 de Junio de 1816. T. 103, fol. 342 r.
} 
Otro memorial de Don Antonio Gil, que pide continuación del patitur abierto y se acordó pase a los Señores Diputados de San Acacio para que informen”. ${ }^{1421}$

“Se leyó el informe de los Señores Comisionados sobre el asunto de Don Miguel Reynaldi, relativo a la insubordinación y falta de respeto que ha observado con el Cavildo y el Señor Deán, y no había llenado sus obligaciones y deberes con exactitud, según resulta del expediente que sobre ello se ha formado; enterado el Cavildo de todo, y de la humillación y respeto con que había recibido la reprensión y cargos que se le habían hecho por los Señores Comisionados por este efecto, con las protestas que consta haber hecho de cumplir en adelante con sus deberes y de sumisión y reverencia al Cavildo, acordó éste aprobar y conformarse con el informe en todo, y que la pena con que le multó el día 10 de junio, suspendiéndolo de todas las ganancias de su cuadrante desde dicho día, sea extensiva y dure solamente hasta el último del corriente julio con lo que se concluyó este auto”. ${ }^{1422}$

"En virtud de llamamiento se leyó un informe de los Señores Diputados de Arcas de San Acacio con la parte de Su Ilustrísima relativo a la solicitud de Don José Ruiz, para que se le admita en la plaza de tenor para la Capilla de esta Iglesia, y enterado el Cabildo, e igualmente de la certificación del Maestro de Capilla Don Jaime Balius y Vila, acerca de la instrucción y suficiencia de aquél, acordó por medio de votos secretos; que Don José Ruiz, vecino de esta ciudad sea admitido en la plaza de tenor de la Capilla de esta Santa Iglesia, y se le consignase cuatrocientos ducados de salario". 1423

“Acordó el Cavildo a la palabra del Señor Don Pascual Gálvez concerniente del arreglo de la Música de la Capilla; que cuando se traigan a Cavildo las cuentas de Arcas de San Acacio, se tendrá presente el Plan de Música, que está acordado anteriormente.

\footnotetext{
${ }^{1421}$ Ibid. Miércoles 26 de Junio de 1816. T. 103, fol. 346 v.

1422 Ibid. Lunes 15 de Julio de 1816. T. 103, fol. 358 v.

${ }^{1423}$ Ibid. Lunes 29 de Julio de 1816. T. 103, fol. 375 r.
} 
Se leyó un memorial de Don Miguel Reynaldi, en que reclama las aspas y pena impuesta por el Cavildo en su cuadrante; y pide asimismo licencia para pasar a la Corte a aprender; y se acordó: que los Diputados de Arcas con presencia del expediente formado a este interesado, informen con llamamiento y la parte de Su Ilustrísima extensivo a la licencia que pide". ${ }^{1424}$

“En virtud de llamamiento y habiéndose mandado entrar el notario secretario, procedió éste a la lectura de la justificación y pruebas de Don Ángel Arteaga, provisto racionero medio de esta Santa Iglesia; y enterado el Cavildo aprobó en debida forma por votos secretos las expresadas pruebas, y declaró haber satisfecho a los Estatutos, pudiendo en su consecuencia vestir el manto capitular, y residir su prebenda, de la que esta tarde a completas se dará la posesión en su nombre a Baltasar de Yusta”. ${ }^{1425}$

“En virtud de llamamiento el Señor Don José Garrido dio la posesión en el Coro, ante el notario secretario y testigos, a Don Jaime Balius y Vila, a nombre y como apoderado de Don Ángel Arteaga de la ración media, en que Su Majestad lo ha nombrado, y ante los mismos hizo en el Cabildo el juramento acostumbrado de observar los Estatutos, y loables costumbres de esta Santa Iglesia, guardar el secreto de lo acordado en los Cabildos, y defender la Concepción Inmaculada de María Santísima; con lo que se concluyó este acto”. ${ }^{1426}$

El Cabildo concede a Don Antonio Gil, prórroga de la licencia de patitur abierto que disfruta, durante sesenta días más para que pueda tomar los baños minerales que solicita con certificación jurada del médico. ${ }^{1427}$

"En virtud de llamamiento se procedió a oír los pretendientes presentados para la provisión de la plaza de Infante de Coro vacante que corresponde a este Cavildo; y

\footnotetext{
${ }^{1424}$ Ibid. Lunes 29 de Julio de 1816. T. 103, fol. 375 r.

1425 Ibid. Lunes 29 de Julio de 1816. T. 103, fol. 376 r.

${ }^{1426}$ Ibid. Lunes 29 de Julio de 1816. T. 103, fol. 376 r.

${ }^{1427}$ Ibid. Martes 30 de Julio de 1816. T. 103, fol. 378 v.
} 
después de ello procediendo a votar la dicha plaza recayó el nombramiento en Francisco Duarte por votos secretos". ${ }^{1428}$

Don Miguel Reynaldi vuelve a escribir un memorial al Cabildo solicitando de nuevo que se le perdonen las aspas que le habían sido impuestas y se le dé licencia para ir a Madrid. Todo esto lo hace mediante un larguísimo escrito en que razona cada uno de los puntos.

Igualmente en este Cabildo se nombra a Gabriel de Mora para cubrir una plaza de Infante de Coro vacante y se solicita que se le exonere de la obligación de hacer las habituales pruebas, por tener un hermano Infante de Coro (Francisco de Mora), que ya anteriormente las había presentado y le habían sido aprobadas. ${ }^{1429}$

“En este Cavildo se dio cuenta de cierta instancia que le dirige Don Rafael Marín, exponiendo en ella, que con el permiso correspondiente desde el año de 1805 hasta el día, estaba sirviendo la plaza de violoncelo que tiene su padre, quien desempeña al mismo tiempo una de violín en la Capilla, habiendo entrado en ella el Don Rafael en la ocasión de una enfermedad aguda que dicho señor padecía, y en que era mucha su falta; que en 1806 solicitó se dignase el Cavildo admitirlo con algún sueldo, habiéndosele librado cien ducados por una vez; que ha continuado después con muy cortas interrupciones con la esperanza de lograr algún día su colocación; a cuya atención suplicaba se le concediese el salario que necesita, para su socorro; el Cavildo en su vista acordó pase esta representación a los Señores Diputados de Arcas de San Acacio con la parte de Su Ilustrísima para que informen con Ilamamiento”. ${ }^{1430}$

“Acerca de la solicitud de Luis de Mora, padre de Gabriel, agraciado en la plaza de Niño o Infante de Coro, y procediendo a votos secretos se declaró tener este satisfecho a los Estatutos de esta Santa Iglesia, habiendo acreditado ser hermano entero de Francisco de Mora, que está sirviendo para igual plaza, y notoriado así en la

\footnotetext{
${ }^{1428}$ Ibid. Viernes 9 de Agosto de 1816. T. 103, fol. 385 v.

${ }^{1429}$ Ibid. Viernes 9 de Agosto de 1816. T. 103, fol. 387 r.

${ }^{1430}$ Ibid. Martes 13 de Agosto de 1816. T. 103, fol. 391 v.
} 
forma acostumbrada al notario secretario, el Cavildo acordó igualmente que entrase el Gabriel desde luego a servir su destino". ${ }^{1431}$

En este Cabildo se presenta de forma detallada el memorial de genealogía de Francisco Duarte, recién elegido Niño de Coro. ${ }^{1432}$

"En virtud de llamamiento se leyó el informe de los Señores Diputados de Hacienda sobre el destino que deberá darse a los retablos y demás enseres del Colegio que fue de Infantes, en cuyo informe proponía que no teniendo uso ni destino en poder del Cavildo los muebles de la iglesia se vendan a beneficio de la Mesa, luego que haya comprador, comisionándose a la Diputación, más los demás muebles, que puedan servir a los Niños de Coro, bajo el plan que se adopte para su reforma, según resulte de la comisión dada sobre este punto, deben recogerse por la oficina de hacienda, y conservarse hasta que se acuerde el dicho plan, en cuyo caso se dará cuenta al Cavildo para que determine sobre ellos lo conveniente. El Cabildo aprobó este informe en todo, dando la comisión oportuna a los Señores Diputados de Hacienda”. ${ }^{143}$

“En este Cavildo se dio cuenta de cierta solicitud de Nicolás Torrellas a nombre de su padre Don Benito, en la que implora la piedad del Cavildo en la ocasión de habérsele detenido en la Mesa la gratificación de dos mil reales concedida por el Cavildo de Señores, Dignidades y Canónigos”. ${ }^{1434}$

El Cabildo, una vez revisadas todas las circunstancias que afectan a la petición de Nicolás Torrellas, hijo de Benito Torrellas acuerda que no hay lugar para conceder dicha solicitud. ${ }^{1435}$

"En virtud de llamamiento se leyó un informe de los Señores Diputados de Arcas de San Acacio, con la parte de Su Ilustrísima sobre la solicitud de Rafael Marín a la plaza de violoncello, que actualmente y muchos años hace sirve a mérito, o otra de la

\footnotetext{
${ }^{1431}$ Ibid. Martes 13 de Agosto de 1816. T. 103, fol. 392 r.

${ }^{1432}$ Ibid. Miércoles 14 de Agosto de 1816. T. 103, fol. 392 v.

1433 Ibid. Viernes 23 de Agosto de 1816. T. 103, fol. 393 v.

${ }^{1434}$ Ibid. Viernes 23 de Agosto de 1816. T. 103, fol. 395 r.

${ }^{1435}$ Ibid. Sábado 31 de Agosto de 1816. T. 104, fol. 3 r.
} 
Capilla, con el sueldo que el Cavildo tenga a bien concederle; y enterado éste acordó: que este pretendiente sea examinado por el Maestro de Capilla el lunes próximo 2 de septiembre por la mañana después de Coro; dando comisión a los mismos Señores Diputados para el efecto, y con su informe y previo llamamiento se acordara lo conveniente.

En virtud del mismo llamamiento se leyó un informe de los Señores Diputados de Arcas de San Acacio, relativo a la solicitud de Rafael Arroyo de una plaza de músico en la Capilla de esta Iglesia; y enterado el Cavildo acordó: que este pretendiente sea examinado por el Maestro de Capilla el lunes próximo 2 de septiembre por la mañana después de Coro; dando comisión a los mismos Señores Diputados para el efecto, y con su informe y previo llamamiento se acordara lo conveniente.

Don Lope de Mora, segundo violín de esta Santa Iglesia, presenta memorial solicitando aumento de su salario, y el Cavildo acordó; pase a los Señores Diputados de Arcas de San Acacio para que con la parte de Su Ilustrísima informen sobre esta pretensión con llamamiento.

Don Cristóbal Bendicho, músico instrumentista de esta Santa Iglesia presentó memorial, suplicando del Cavildo se sirviese librarle doscientos noventa y dos reales y treinta y dos maravedíes para costear el entierro de su compañero Don Mariano Ortega, que falleció en la mayor miseria; y enterado el Cavildo acordó, que los Señores Diputados de Arcas de San Acacio, informen con llamamiento y la parte de Su Ilustrísima sobre este asunto lo que se les ofrezca.

Don Francisco Cascante, individuo de la Capilla de Música de esta Santa Iglesia presentó memorial, con la solicitud de que se le aumente el salario que disfruta, en atención a las causas que expresa, y enterado el Cavildo acordó: que los Señores Diputados de Arcas de San Acacio, con la parte de Su Ilustrísima informen con llamamiento sobre esta solicitud.

El Señor Prior manifestó; que en las Vísperas de San Bartolomé y vocación a su Capilla, faltó el músico Valls, que acompaña con el instrumento de oboe cuya plaza obtiene en la Capilla de Música, siendo de su obligación; habiéndose seguido escándalo por defecto de esta acostumbrada y precisa solemnidad; todo lo cual hacía presente, para que averiguada la causa, se consignase y obligase al dicho Valls, al cumplimiento y asistencia que es de su cargo; y se acordó que los Señores Diputados de 
Arcas de San Acacio informen sobre este asunto con llamamiento, teniendo a la vista el acuerdo del Cavildo sobre la media jubilación del mencionado Valls.

El Señor Penitenciario manifestó hallarse vacante la plaza de bajón de esta Capilla, por muerte de Don Mariano Ortega; y se acordó dar comisión a los Señores Diputados de ambas Arcas con la parte de Su Ilustrísima para informar con llamamiento”. 1436

"En virtud de llamamiento se leyó un informe de los Señores Diputados de Arcas de San Acacio, con la parte de Su Ilustrísima y una certificación del Maestro de Capilla Don Jaime Balius, que comprende los exercicios, examen y censura de Don Rafael Marín, pretendiente a la plaza de violoncelo de la Capilla de esta Iglesia [desde 1805 estaba en esta plaza de forma interina], y enterado el Cavildo de cuanto en aquél se expresa, mérito y circunstancias que concurren en el pretendiente, acordó por votos secretos: que admitía y admitió para la plaza de violoncelo de la Capilla de esta Santa Iglesia, a Don Rafael Marín, conforme al nombramiento y le consignó anualmente el sueldo de cuatrocientos ducados, siendo condición que ha tener obligación de dar lecciones a los Niños y Acólitos de Coro.

En virtud del mismo llamamiento se leyó un informe de los Señores Diputados de Arcas de San Acacio, con la parte de Su Ilustrísima, y una certificación del Maestro de Capilla Don Jaime Balius, comprensiva de los exercicios, examen y censura de Don Rafael Arroyo, pretendiente a la plaza de oboe en la Capilla de Música de esta Santa Iglesia, y enterado el Cavildo de cuanto en aquél se expresa, y del mérito y circunstancias del pretendiente, acordó por votos secretos; que admitía y admitió para la plaza de oboe, en la Capilla de Música de esta Santa Iglesia, con formal nombramiento a Don Rafael Arroyo, y le consignó anualmente el sueldo de trescientos ducados; siendo expresa condición, que ha de continuar tomando lecciones, y perfeccionándose con su maestro Don Manuel Valls, a lo menos tres días a la semana; y asimismo ha de ser de su obligación el dar lecciones y enseñar a los Acólitos y Niños de Coro". ${ }^{1437}$

\footnotetext{
${ }^{1436}$ Ibid. Sábado 31 de Agosto de 1816. T. 104, fol. 3 r.

${ }^{1437}$ Ibid. Miércoles 4 de Septiembre de 1816. T. 104, fol. 7 v.
} 
El Cabildo concede cien ducados de ayuda de costa, a Don Antonio Colloto, “Presbítero Capellán septuagenario y cuya pobreza causa compasión”. ${ }^{1438}$

“Se leyó un informe de los Señores Diputados de Acólitos y Niños de Coro, acerca de las palabras de los de Obras Pías, relativa a los que hayan de tener las Achas en el presbiterio, con arreglo a la fundación del Señor Don Pedro de Cabrera, y enterado el Cavildo acordó: que los Infantes de Coro saquen las Achas a el presbiterio, alumbrando desde el fin del prefacio hasta consumir, en los días establecidos y que se señalan en la fundación a la Obra Pía fundada por el Señor Don Pedro Cabrera; y en las ocasiones que falten Infantes de Coro para este servicio, suplirán los Acólitos, quedando los Señores Puntadores autorizados para la elección y nombramiento”. ${ }^{1439}$

“En virtud de llamamiento se leyó un informe de los Señores Diputados de Arcas de Vacantes de Santa Inés, y San Acacio, acerca del modo de proveer la segunda plaza de organista, y conformándose el Cavildo con dicho informe, acordó; que esta plaza sea dotada con seiscientos ducados, y se da comisión a los mismos Señores para que informen los edictos, e informes en tiempo con llamamiento". 1440

“Se leyó un informe de los Señores Diputados de Arcas Vacantes de Santa Inés, con la parte de Su Ilustrísima Nuestro Prelado, acerca del modo de proveer la plaza de bajón, vacante por muerte de Don Mariano Ortega y el Cavildo acordó que se conformaba y conformó con el informe; y que la dotación de quinientos ducados que tiene esta plaza, se satisfagan y paguen solamente de los fondos del Arca de Vacantes de Santa Inés. Y se da comisión a los mismos Señores para que formen los edictos e informen a su tiempo con llamamiento.

Se leyó un memorial de Rafael Luque, Niño de Coro que ha sido de esta Santa Iglesia, en el que hace presente que ha tomado plaza de soldado en el regimiento de [ं?] españoles y no pudiendo por esta causa continuar en su destino, se despide del Cavildo;

\footnotetext{
${ }^{1438}$ Ibid. Viernes 6 de Septiembre de 1816. T. 104, fol. $10 \mathrm{v}$.

1439 Ibid. Sábado 7 de Septiembre de 1816. T. 104, fol. 14 r. Las hachas de viento, eran según el diccionario de la Real Academia de 1783, "cierto género de hacha formada de varias resinas y cera, que resisten al viento por grande que sea sin apagarse”.

${ }^{1440}$ Ibid. Miércoles 25 de Septiembre de 1816. T. 104, fol. 26 v.
} 
y se acordó que mediante la vacante que resulta, se da comisión a los Señores Diputados de Arcas de Santa Inés para que informen con llamamiento y traigan las censuras anteriores para cuya provisión se designa el sábado próximo 28 del corriente mes.

Se leyó un memorial de Don José Talavera músico Acólito de esta Santa Iglesia empleado con instrumento de violín, y solicita se le consigne el salario correspondiente a su mérito y servicios, por los motivos que expresa, según sea del agrado del Cavildo, y se acordó que los Señores Diputados de Santa Inés, con la parte de Su Ilustrísima, informen con llamamiento sobre esta solicitud". 1441

Don Miguel Reynaldi presenta una solicitud de licencia para pasar a la Corte. Se cometió a los Diputados de Santa Inés para que informasen. ${ }^{1442}$

“En virtud del llamamiento presentado por los Señores Diputados de Santa Inés [está tachado Diputados de Niños de Coro], las últimas censuras y habiendo concurrido los interesados y pretendientes, se procedió al examen de todos [los Niños] por el Maestro de Capilla, y concluido, y oído su parecer e informe, se practicó la votación secreta para la provisión de la vacante, y resultó y recayó el nombramiento en Francisco Sáez; en cuya virtud se dio comisión a los Señores Diputados de Arcas de Santa Inés para proceder a las pruebas correspondientes según costumbre”. ${ }^{1443}$

Don Lope de Mora, segundo violín de la Capilla, solicita aumento de sueldo. El Cabildo acuerda que se le aumenten cincuenta ducados anuales.

Don Cristóbal Bendicho, manifiesta que habiendo muerto su compañero Don Mariano Ortega, bajonista de la Capilla, el Cabildo le ayude a sufragar los gastos de su entierro y un adelanto que las Arcas de San Acacio habían hecho al difunto. Y el Cabildo acordó que se abone al administrador de la Capilla de San Acacio lo que había adelantado a Don Mariano Ortega, y su entierro se satisfaga por la Diputación. ${ }^{1444}$

\footnotetext{
${ }^{1441}$ Ibid. Miércoles 25 de Septiembre de 1816. T. 104, fol. 27 v.

1442 Ibid. Miércoles 25 de Septiembre de 1816. T. 104, fol. 28 v.

1443 Ibid. Sábado 28 de Septiembre de 1816. T. 104, fol. 33 r.

${ }^{1444}$ Ibid. Miércoles 2 de Octubre de 1816. T. 104, fol. 34 v.
} 
“En virtud del llamamiento se leyó un informe de los Señores Diputados de Arcas Vacantes de Santa Inés y San Acacio con la parte de Nuestro Prelado, sobre la solicitud de Don José Talavera, Acólito de esta Santa Iglesia, y músico con instrumento de violín y enterado el Cavildo nombró por examinadores del expresado Don José Talavera, al Maestro de Capilla y primer violín, y señaló el martes próximo quince del corriente después del Coro, para un concierto en el sitio acostumbrado; los cuales clasificarán la idoneidad y mérito del pretendiente, y en su vista se acordará lo conveniente". ${ }^{1445}$

Una vez realizado el examen de Don José Talavera, Acólito y músico de la Capilla en la especialidad de violín, se leyeron el informe y la censura de los examinadores. El Cabildo acordó que se le paguen cuatrocientos ducados de sueldo aprobando por tanto que ocupe dicha plaza. ${ }^{1446}$

"Se leyó un memorial de Don Gregorio Muñoz Villareal, salmista de la Santa Iglesia Catedral de Málaga, en que expresando que habiendo sido oído cantar en examen público por Don Jaime Balius, Maestro de Capilla y Don Juan Ortíz Sochantre, con aprobación del Cavildo, es conveniente el que se mande traer la censura, para que conste el grado de mérito que resulte, y que se le tenga presente en virtud de él, en las provisiones que ocurran; y se acordó se traiga la censura por los Comisionados, para los efectos que expresa el interesado". ${ }^{1447}$

“A propuesta del Señor Deán, se nombró para la plaza de Acólito que está vacante, a Rafael Vázquez”. 1448

Se presentó una censura firmada por el Maestro de Capilla Don Jaime Balius y por el Sochantre, Don Juan Guerra Ortíz, en virtud del examen de voz y canto llano que

\footnotetext{
1445 Ibid. Viernes 11 de Octubre de 1816. T. 104, fol. 44 v.

${ }^{1446}$ Ibid. Martes 22 de Octubre de 1816. T. 104, fol. 53 v.

${ }^{1447}$ Ibid. Miércoles 30 de Octubre de 1816. T. 104, 58 r.

1448 Ibid. Miércoles 30 de Octubre de 1816. T. 104, fol. 59 v.
} 
habían hecho a Don Gregorio Muñoz Villarreal. Visto lo positivo del informe, el Cabildo acordó que se busque dotación para aceptarlo en esta Catedral. ${ }^{1449}$

Una vez terminado el plazo para presentar aspirantes a la plaza de segundo organista, se informa de que únicamente se había presentado Don Francisco Balius. Enterado el Cabildo acordó que se dé comisión a los Diputados de Santa Inés para que informen con llamamiento.

Asimismo se leyó una exposición de Don Benito Torrellas, profesor de música y bajo que ha sido de esta Santa Iglesia y actualmente de la Real Capilla, por el que reclama la cantidad que resulta de la rebaja y retención de su salario que se le hizo por el Cabildo durante la estancia de los franceses. El Cabildo dio comisión a los Diputados de San Acacio para que informen. ${ }^{1450}$

Se presentan dos opositores a la plaza de bajón vacante. Son Don Francisco de Lara vecino de Sevilla y Don Francisco Navarro bajón de la Capilla Real de Granada. El Cabildo acordó que los Diputados de Santa Inés informen al respecto con llamamiento. ${ }^{1451}$

Se leyó un memorial de Don Francisco Navarro, músico de bajón de la Capilla Real de Granada, solicitando se prorrogue la fecha de las oposiciones a bajón en esta Catedral, por encontrarse su mujer enferma. El Cabildo cometió a la comisión encargada para que informe con llamamiento.

Igualmente se leyó otro memorial de Rafael López, en que manifiesta tener una voz nada vulgar, y deseando ejercitarla e instruirse para algún día obtener plaza en el Coro de esta Santa Iglesia, solicita se le admita en clase de pretendiente. El Cabildo cometió dicho memorial a la Diputación de San Acacio para que informe con llamamiento. ${ }^{1452}$

\footnotetext{
1449 Ibid. Sábado 9 de Noviembre de 1816. T. 104, fol. 65 r.

${ }^{1450}$ Ibid. Sábado 9 de Noviembre de 1816. T. 104, fol. 66 r.

1451 Ibid. Sábado 9 de Noviembre de 1816. T. 104, fol. 66 v.

1452 Ibid. Miércoles 20 de Noviembre de 1816. T. 104, fol. 72 r.
} 
El Cabildo acuerda examinar a Don Rafael López, aspirante para entrar en el Coro, designando al Maestro de Capilla y al Sochantre como examinadores. ${ }^{1453}$

El Cabildo acuerda examinar de bajón a Don Francisco de Lara, sin perjuicio de que en su día, cuando pudiera venir, se examine igualmente a Don Francisco Navarro. De momento y para el examen de Lara se nombran como examinadores al Maestro de Capilla Don Jaime Balius, a Don Miguel Reynaldi, primer violín, y a Don Manuel Valls primer oboe. Asimismo Don Francisco de Lara presenta un memorial solicitando alguna ayuda económica, por los días que lleva esperando el examen. Se da comisión a los Diputados de Santa Inés para que informen sobre esta solicitud. ${ }^{1454}$

Don Francisco Cascante, músico contrabajo, solicita patitur abierto en atención a la enfermedad que padece. El Cabildo dio comisión a los Diputados de San Acacio para que informen. ${ }^{1455}$

El Cabildo acuerda indemnizar económicamente a Don Francisco de Lara, por los días que lleva esperando a que se realice la oposición de bajón. Asimismo acuerda que las oposiciones comiencen en la mañana del día siguiente al de la fecha. ${ }^{1456}$

Se leen las pruebas de Francisco Duarte, nombrado recientemente Infante de Coro. El Cabildo acuerda aceptar dichas pruebas de limpieza de sangre, por estar correctamente realizadas. Y autoriza a Duarte a entrar en el Coro con sobrepelliz. ${ }^{1457}$

“En virtud de llamamiento se procedió a la provisión de la plaza de bajón vacante, y recayó en Don Francisco de Lara.

En este Cavildo se dio cuenta de un memorial de Don Miguel Reynaldi en que exponiendo los buenos servicios que había hecho en los cuatro años que fue maestro del Colegio de Niños de Coro y que sólo había recibido la gratificación de cien

\footnotetext{
1453 Ibid. Miércoles 27 de Noviembre de 1816. T. 104, fol. 74 v.

1454 Ibid. Miércoles 27 de Noviembre de 1816. T. 104, fol. 75 r.

1455 Ibid. Martes 3 de Diciembre de 1816. T. 104, fol. 80 r.

${ }^{1456}$ Ibid. Martes 3 de Diciembre de 1816. T. 104, fol. $80 \mathrm{v}$.

${ }^{1457}$ Ibid. Miércoles 4 de Diciembre de 1816. T. 104, fol. 80 v.
} 
doblones por los dos años primeros, suplicaba que el Cavildo le remunerase con lo que fuese de su agrado: el Cavildo dio comisión a los Señores Diputados de Arcas de Santa Inés para que informen con llamamiento". ${ }^{1458}$

Se presentó un memorial de Don Juan Nepomuceno Puig, músico bajonista de esta Santa Iglesia, en que solicita un aumento de sueldo. El Cabildo dio comisión a los Diputados de Santa Inés, para que informen con llamamiento.

Enseguida se leyó otro memorial de Don Francisco Navarro, músico bajonista de la Real Capilla de Granada, en que expone que ya se encuentra en esta ciudad, y solicita ser examinado. El Cabildo dio comisión a los Diputados de Santa Inés para que informasen. $^{1459}$

El Cabildo acuerda que en el día de mañana, se examine a Don Francisco Navarro, bajonista de la Real Capilla de Granada, nombrando por examinadores a Don Jaime Balius, Don Miguel Reynaldi y Don Manuel Valls. ${ }^{1460}$

“En virtud de llamamiento se leyó el informe de los Señores Diputados de Arcas de San Acacio con la parte de Su Ilustrísima sobre la solicitud de licencia de patitur abierto del músico Don Francisco Cascante; el Cavildo en su consecuencia acordó conceder a Don Francisco Cascante la licencia de patitur abierto hasta Pascua de Resurrección próxima venidera exclusive”. ${ }^{1461}$

\section{7}

Don Francisco Cascante, músico de la Capilla presenta un memorial en el que dice encontrarse gravemente enfermo y pide una ayuda de costa. El Cabildo dio comisión a los Diputados de San Acacio para que informasen.

\footnotetext{
1458 Ibid. Miércoles 4 de Diciembre de 1816. T. 104, fol. 81 v.

1459 Ibid. Lunes 16 de Diciembre de 1816. T. 104, fol. 85 v.

1460 Ibid. Jueves 19 de Diciembre de 1816. T. 104, fol. 88 r.

1461 Ibid. Lunes 23 de Diciembre de 1816. T. 104, fol, 91 r.
} 
También se leyó otro memorial de Don Francisco Balius, organista de la Colegiata de San Hipólito, que expone haber firmado la oposición a la plaza de segundo organista: “Se leyó memorial de D. Francisco Balius, organista de la Real Colegiata de san Hipólito, que expuso haber firmado la oposición a la plaza de $2^{\circ}$ organista de esta Santa Iglesia en 23 de Octubre último...”, solicitando por tanto que se le examine. ${ }^{1462}$

Don Francisco de Lara, músico de bajón, solicita licencia para pasar a Sevilla y otros pueblos a arreglar los intereses que dejó pendientes para venir a Córdoba. El Cabildo da comisión a los Diputados de Santa Inés para que informen. ${ }^{1463}$

El Cabildo acuerda dar a la hija única de Don Francisco Cascante la cantidad de cien ducados como ayuda de costa. ${ }^{1464}$

El Cabildo concede a Don Francisco Navarro, opositor venido de Granada para la plaza de bajón, una ayuda de costa de doscientos ducados. ${ }^{1465}$

Respecto a la plaza de segundo organista el Cabildo acuerda lo siguiente: que la dotación de seiscientos ducados que se señalan a la plaza de segundo organista se pague de las Arcas de San Acacio; que no se prorroguen los edictos para dicha plaza; que en el martes 28 del corriente por la mañana se haga el examen en forma del único opositor Don Francisco Balius; que para él se nombren por examinadores a Don Andrés Lidón, Don Joseph Moyano y Don Miguel Reynaldi. ${ }^{1466}$

Los Diputados de Arcas de San Acacio manifestaron al Cabildo que nada se había acordado acerca de si el examen de segundo organista debía de incluir la vertiente compositiva teórica práctica como era costumbre. El Cabildo acordó que así se hiciera. ${ }^{1467}$

\footnotetext{
1462 Ibid. Martes 14 de Enero de 1817. T. 104, fol. 93 v.

1463 Ibid. Jueves 16 de Enero de 1817. T. 104, fol. 95 r.

1464 Ibid. Miércoles 22 de Enero de 1817. T. 104, fol. 97 r.

1465 Ibid. Miércoles 22 de Enero de 1817. T. 104, fol. 97 v.

1466 Ibid. Sábado 25 de Enero de 1817. T. 104, fol. 98 v.

${ }^{1467}$ Ibid. Martes 28 de Enero de 1817. T. 104, fol. 100 r.
} 
Una vez realizado el examen a la plaza de segundo organista, y habiéndose oído las censuras de los examinadores, el Cabildo acordó conceder a Don Francisco Balius la plaza de segundo organista.

En cuanto a la solicitud de Don Francisco de Lara, el Cabildo acordó concederle licencia para ausentarse desde el día 27 del corriente hasta la Semana de Pasión exclusive. $^{1468}$

Don Andrés Lidón, organista primero de esta Santa Iglesia, solicita un aumento de su remuneración. El Cabildo dio comisión a los Diputados de Excusados de Fábrica para que informen. ${ }^{1469}$

Se leyó un memorial de Diego Barriga, vecino de esta ciudad en que solicita que su hijo Antonio Barriga de diez años, entre a servir de Niño de Coro. El Cabildo acordó que pase a los Diputados de Niños de Coro para que informen. ${ }^{1470}$

“Se leyó un memorial de Doña Mónica Cascante, vecina de esta ciudad, hija del difunto Don Francisco Cascante, músico instrumental que fue de esta Santa Iglesia, por el que solicita que el instrumento de contrabajo que ha dejado su padre, quede para el uso de la Capilla de Música por no ser de los comunes, y que se le dé la cantidad que el Cavildo considere justa, para poder subvenir a las necesidades que le ocurren. Y el Cavildo acordó; pase a los Señores Diputados de Arcas Vacantes de Santa Inés para que informen con llamamiento sobre esta solicitud". ${ }^{1471}$

Don Andrés Lidón, pide que se le compense económicamente, por los muchos años que ha pasado atendiendo a las dos plazas de organista. El Cabildo dio comisión a los Diputados de Excusados de Fábrica para que informen. ${ }^{1472}$

\footnotetext{
${ }^{1468}$ Ibid. Viernes 31 de Enero de 1817. T. 104, fol. 100 v.

1469 Ibid. Martes 25 de Febrero de 1817. T. 104, fol. 106 r.

${ }^{1470}$ Ibid. Martes 4 de Marzo de 1817. T. 104, fol. 110 v.

${ }^{1471}$ Ibid. Miércoles 5 de Marzo de 1817. T. 104, fol. 113 v.

1472 Ibid. Jueves 13 de Marzo de 1817. T. 104, fol. 117 r.
} 
El Cabildo discute acerca de la posibilidad de volver a abrir un colegio "para la reunión, educación y enseñanza de los Infantes de Coro”. Para lo cual solicitan un informe de los Diputados de Infantes de Coro con agregación del Señor Penitenciario. $^{1473}$

“Se leyó un memorial de Don Antonio Gil, Presbítero Capellán de San Acacio de esta Santa Iglesia, pidiendo aumento de renta, y se acordó que los Señores Diputados de Arcas de San Acacio con la parte de Su Ilustrísima informen con llamamiento". 1474

Don Miguel Reynaldi, primer violín de la Capilla, pide que se le conceda una gratificación por los dos años últimos que tuvo a su cargo el Magisterio del Colegio de los Niños de Coro. También pide licencia para pasar a hacer oposiciones en otras catedrales. El Cabildo cometió a los Diputados de Santa Inés para que informen. ${ }^{1475}$

Francisco de Mora, Infante de Coro, solicita una ayuda de costa. El Cabildo dio comisión a los Diputados de Hacienda para que informen. ${ }^{1476}$

Sobre la solicitud de Don Antonio Gil en que pide aumento de salario, el Cabildo acordó que se suspenda la resolución de esta pretensión hasta que los Señores Diputados de San Acacio hayan evacuado el informe acordado y pueda procederse con conocimiento de su estado de fondos.

Asimismo, el Cabildo acuerda que se examine a Don Rafael López de latín, voz, y canto llano, señalándose el jueves próximo 29 del corriente y designando como sus jueces al Sochantre y al Maestro de Capilla. ${ }^{1477}$

El Cabildo concede a Don José Ruiz, músico tenor, licencia durante dos meses para ir a Granada. ${ }^{1478}$

\footnotetext{
1473 Ibid. Sábado 15 de Marzo de 1817. T. 104, fol. 118 r.

${ }^{1474}$ Ibid. Jueves 27 de Marzo de 1817. T. 104, fol. 122 v.

1475 Ibid. Viernes 9 de Mayo de 1817. T. 104, fol. 139 v.

${ }^{1476}$ Ibid. Martes 20 de Mayo de 1817. T. 104, fol. 144 r.

${ }^{1477}$ Ibid. Viernes 23 de Mayo de 1817. T. 104, fol. 147 r.
} 
Sobre la solicitud de ayuda de costa que tiene hecha Francisco de Mora, Infante de Coro, el Cabildo acordó denegarla. ${ }^{1479}$

El Cabildo acuerda gratificar a Don Miguel Reynaldi con dos mil reales de vellón por los dos últimos años que estuvo de maestro de los Niños de Coro.

Asimismo el Cabildo concede a Don Juan Puig, bajonista un aumento de sueldo de cien ducados de vellón. ${ }^{1480}$

"Dióse cuenta de un llamamiento para oír el informe de los Señores Diputados de Arcas de Vacantes de Santa Inés, sobre las dudas ocurridas acerca de la provisión de la plaza de Infante de Coro vacante por la promoción de Rafael Vázquez a otra de Acólito; y enterado el Cabildo de su contexto, acordó conformarse, y se conformó con dicho informe, como resulta”. ${ }^{481}$

Don Benito Torrellas, actualmente músico de la Real Cámara y Capilla, solicita al Cabildo que le pague los 14.000 reales que se le dejaron de pagar desde la entrada de los franceses a Córdoba. El Cabildo dio comisión a los Diputados de San Acacio para que informen. ${ }^{1482}$

“A virtud de llamamiento para oír el examen y censura de los pretendientes a la plaza de Infante de Coro de esta Santa Iglesia, y proceder a su provisión, se pasó según costumbre a la entrada del Maestro de Capilla, bajones y pretendientes, y oídos que fueron y puesta la censura se executó la votación, y recayó el nombramiento por pluralidad de votos en Joseph María Pérez dando comisión a los Señores Diputados de Arcas de Santa Inés para que le hagan las pruebas y las traigan a el Cavildo con llamamiento para su aprobación”. ${ }^{1483}$

\footnotetext{
${ }^{1478}$ Ibid. Miércoles 4 de Junio de 1817. T. 104, fol. 153 r.

${ }^{1479}$ Ibid. Martes 17 de Junio de 1817. T. 104, fol. 155 v.

${ }^{1480}$ Ibid. Sábado 28 de Junio de 1817. T. 104. fol. 164 r.

${ }^{1481}$ Ibid. Sábado 5 de Julio de 1817. T. 104, fol. 166 r.

1482 Ibid. Miércoles 6 de Agosto de 1817. T. 104, fol. 205 v.

1483 Ibid. Martes 2 de Septiembre de 1817. T. 104, fol. 222 v.
} 
Sobre la solicitud de Don Antonio Gil, "el Cavildo en su vista y en atención a la antigüedad y méritos del expresado Capellán, acordó concederle cien ducados anuales sobre los nueve mil que disfruta.

A continuación se leyó otro informe de los mismos Señores Diputados de Arcas de San Acacio con la parte sobre la pretensión de Don Rafael López, y en vista del informe y dictámenes de Don Juan Guerra Ortíz y del Maestro de Capilla sobre la suficiencia y estado del expresado pretendiente, el Cavildo acordó conceder y concedió por una vez al Don Rafael, dos mil reales, dejándolo a la prudencia de los Señores Diputados el modo y tiempos de suministrarle esta cantidad, disponiendo que a más, se le hagan unos hábitos completos”. ${ }^{1484}$

Se presenta el memorial de Joseph María Pérez, recién elegido Niño de Coro. ${ }^{1485}$

Se presentan las pruebas de limpieza de sangre del Infante de Coro Joseph María Pérez. El Cabildo las aprueba considerando que estaban bien hechas y se atenían al Estatuto. $^{1486}$

Don Miguel Reynaldi, primer violín de la Capilla pide licencia para ir a Madrid a arreglar diversos asuntos propios. El Cabildo acordó que informen al respecto los Diputados de Santa Inés. ${ }^{1487}$

“El Señor Presidente dio cuenta de la vacante de la Sochantría, por muerte de Don Juan Guerra Ortíz, y el Cavildo acordó; dar y dio comisión a los Señores Diputados de Arcas de San Acacio con la parte de Su Ilustrísima para que informen con llamamiento sobre la provisión de esta plaza con lo demás que les parezca conducente". ${ }^{1488}$

\footnotetext{
${ }^{1484}$ Ibid. Jueves 4 de Septiembre de 1817. T. 104, fol. 225 r.

1485 Ibid. Jueves 4 de Septiembre de 1817. T. 104, fol. 226 r.

${ }^{1486}$ Ibid. Miércoles 17 de Septiembre de 1817. T. 104, fol. 231 v.

${ }^{1487}$ Ibid. Sábado 27 de Septiembre de 1817. T. 104, fol. 234 v.

${ }^{1488}$ Ibid. Jueves 6 de Noviembre de 1817. T. 104, fol. 254 r.
} 
"En virtud de llamamiento se leyó un informe de los Señores Diputados de Infantes de Coro de esta Santa Iglesia, sobre los medios para el restablecimiento del Colegio de éstos, a que acompañan los antecedentes, y diligencias practicadas sobre este asunto, y una nota de las rentas consignadas a este objeto, y enterado el Cavildo de todo, y habiendo conferenciado largamente sobre ello, acordó: vuelva el informe a los mismos Señores Diputados para que formen el Plan, Reglamento y Sistema Gubernativo, Económico e Instructivo para dicho Colegio, informando sobre los medios de llevarlo a efecto, y poniéndose de acuerdo con los respectivos Diputados, a que correspondan las diferentes asignaciones de rentas para este objeto, con lo demás que juzguen oportuno para instrucción del Cavildo, y su deliberación; con el correspondiente llamamiento". ${ }^{1489}$

“Sobre la Real Orden dirigida acerca de la instancia hecha a Su Majestad por Don Benito Torrellas, músico que fue de la Capilla de esta Santa Iglesia, y enterado el Cavildo acordó: se dirija al Excelentísimo Señor Ministro de Estado, y del despacho de Gracia y Justicia, el informe que se pide, en los términos propuestos por la Diputación Comisionada”. ${ }^{1490}$

Don Pascual Redel, violinista segundo de la Capilla, pide una ayuda de costa. Se dio comisión a los Diputados de San Acacio para que informasen. ${ }^{1491}$

El Cabildo concede a Don Pascual Redel una ayuda de costa de veinticinco doblones, en consideración a sus largos servicios. ${ }^{1492}$

Sobre la solicitud de ayuda de costa que pide Don Juan de Borja, músico de la Capilla, el Cabildo acordó que se le den veinticinco doblones en atención a las causas que expone. $^{1493}$

\footnotetext{
${ }^{1489}$ Ibid. Miércoles 12 de Noviembre de 1817. T. 104, fol. 256 r.

${ }^{1490}$ Ibid. Sábado 6 de Diciembre de 1817. T. 104, fol. 269 v.

${ }^{1491}$ Ibid. Sábado 6 de Diciembre de 1817. T. 104, fol. 270 r.

1492 Ibid. Martes 23 de Diciembre de 1817. T. 104, fol. 275 r.

1493 Ibid. Martes 23 de Diciembre de 1817. T. 104, fol. 276 r.
} 


\section{8}

"Se leyó una orden del Excelentísimo Señor Secretario de Estado y del despacho de Gracia y Justicia, de fecha 31 de diciembre del año próximo pasado, por la que recuerda al Cavildo el despacho del informe pedido en la solicitud e instancia de Don Benito Torrellas, sobre que se le paguen los catorce mil reales a que asciende el desfalco que se le hizo de sus salarios, como músico de esta Iglesia, desde la entrada de los franceses; y enterado el Cavildo acordó: pase a los Señores Diputados de Arcas de San Acacio, con la parte de Su Ilustrísima para que se evacue y dirija el informe que se expresa, según lo acordado en seis de diciembre pasado más próximo”. 1494

Una vez terminados los edictos para opositar a una Capellanía vacante de la Capilla de San Pedro, sólo se presenta un opositor, Don Gregorio Muñoz de Villarreal, Capellán de Veintena de esta Santa Iglesia, por lo que se acordó examinar a dicho opositor. $^{1495}$

A pesar de que en su momento sólo se presentó un opositor a la Capellanía vacante de San Pedro, que fue el Señor Villarreal, ahora se reciben dos solicitudes más para entrar en la oposición. Una de Don Joaquín Villatoro, Capellán de la Veintena de esta Santa Iglesia, y otra de Don Rafael López, meritorio. Y el Cabildo acordó aceptarlos para que entren en la oposición.

Se leyó una Real Orden de Su Majestad en la que se dice que “a Don Ángel Arteaga, músico tenor de Su Real Cámara y agraciado por Real Decreto de 9 de junio de 1815 con una media ración de esta Santa Iglesia, se le abonen los frutos y rentas desde el día que tomó posesión en dicha prebenda. El Cabildo en su vista acordó: pase este oficio a los Señores Canónigos de Oficio para que contesten a Su Ilustrísima el recibo e informen con llamamiento". 1496

\footnotetext{
${ }^{1494}$ Ibid. Jueves 8 de Enero de 1818. T. 104, fol. 279 v.

1495 Ibid. Martes 17 de Febrero de 1818. T. 104, fol. 295 r.

1496 Ibid. Jueves 26 de Febrero de 1818. T. 104, fol. 298 v.
} 
"Se leyó un memorial de Don Miguel Reynaldi, primer violín de esta Santa Iglesia en el que pide licencia para pasar a Madrid a hacer oposición a unas plazas de la Capilla Real de Su Majestad y otras dos de la Iglesia Metropolitana de Santiago, cuyas oposiciones deben hacerse a fines del próximo marzo, y el Cavildo en su vista acordó pase esta solicitud a los Señores Diputados de Arcas de Santa Inés para que informen con llamamiento.

Otro memorial de Pedro Abenate, músico trompa y pide se le señale alguna cuota bajo el concepto de asistir como lo ha ejecutado hace algunos meses y poderse perfeccionar más. Y el Cavildo acordó: pase a los Señores Diputados de Arcas de Santa Inés para que informen sobre la petición con llamamiento". ${ }^{1497}$

Sobre la anterior solicitud de Don Ángel Arteaga, el Cabildo acuerda lo siguiente: "que se cumpla y execute la Real Orden de Su Majestad entregando a el Don Ángel de Arteaga todo lo que le corresponda para dicha media ración desde el día 29 de julio de 1816 en que tomó posesión de ella”. ${ }^{1498}$

Se leyó un memorial de Don Lope de Mora, violinista de esta Santa Iglesia en el que manifiesta que hallándose gravemente enfermo, demente, Don Joaquín Bach, organista de la villa de Palma de esta Diócesis, "le ha sido forzoso ausentarse de esta ciudad a la referida villa para atender al cuidado y curación del referido su hermano, como también al cobro de sus bienes y efectos; y pide se le condone la gracia de la licencia que necesita para dicho objeto, por el tiempo que el Cavildo tenga por conveniente: quien acordó: pase a los Señores Diputados de Arcas de San Acacio para informar con llamamiento". 1499

“Sobre la solicitud del músico Don Lope de Mora; el Cavildo acordó por votos secretos, se le conceda la licencia que solicita hasta el día del Corpus del corriente año". 1500

\footnotetext{
${ }^{1497}$ Ibid. Jueves 26 de Febrero de 1818. T. 104, fol. 300 v.

${ }^{1498}$ Ibid. Martes 3 de Marzo de 1818. T. 104, fol. 303 r.

${ }^{1499}$ Ibid. Lunes 6 de Abril de 1818. T. 104, fol. 317 r.

${ }^{1500}$ Ibid. Lunes 20 de Abril de 1818. T. 104, fol. 323 v.
} 
Una vez examinado el trompa Don Pedro Abenate, y oída la censura del Maestro de Capilla Don Jaime Balius, se acuerda no admitir a dicho músico en la Capilla. Asimismo el Cabildo acuerda que se le remuneren los días que ha tocado en la orquesta. Igualmente el Cabildo dio comisión a los Diputados de Santa Inés para que busquen un músico “bajonista, que sepa trompa y chirimía”. ${ }^{1501}$

"Se leyó un memorial de Joseph María Pérez, Infante de Coro de esta Santa Iglesia, por el cual pide se le ayude según lo estime el Cavildo, para buscar buen maestro que lo instruya en la música y poder algún día ser útil a la Iglesia y se acordó: pase esta solicitud a los Señores Diputados de Arcas de Santa Inés para que informen con llamamiento". 1502

Don Juan Nepomuceno Puig, bajonista, solicita una ayuda de costa. El Cabildo da comisión a los Diputados de Excusados de Fábrica para que informen con llamamiento. $^{1503}$

Se leyó un memorial de Don Francisco Ferrer, músico primer trompa de la Capilla, en que pide licencia para cambiar de aires con motivo de una enfermedad que padecía. El Cabildo da comisión a los Diputados de Santa Inés para que informen. ${ }^{1504}$

Don Miguel Reynaldi, pide licencia para no asistir al Coro debido "a la fluxión de ojos que ha tenido”. El Cabildo dio comisión a los Diputados de Santa Inés para que informasen. ${ }^{1505}$

El Cabildo concede a Don Miguel Reynaldi, un mes de licencia para que se recupere de sus dolencias.

Igualmente en este Cabildo, se lee un memorial de Don Julián Gálvez, por el cual pide "un socorro o ayuda en atención a el nuevo gasto que se le ha ocasionado con bajar la

\footnotetext{
${ }^{1501}$ Ibid. Viernes 29 de Mayo de 1818. T. 104, fol. 336 v.

1502 Ibid. Martes 7 de Julio de 1818. T. 104, fol. 356 v.

1503 Ibid. Martes 21 de Julio de 1818. T. 104, fol. 360 v.

${ }^{1504}$ Ibid. Martes 28 de Julio de 1818. T. 104, fol. 366 r.

1505 Ibid. Jueves 13 de Agosto de 1818. T. 105, fol. 4 r.
} 
música a el Coro, y se acordó pase a los Señores Diputados de Arcas de Santa Inés para que con la parte de S.I. informen con llamamiento". ${ }^{1506}$

Sobre la solicitud del trompa Don Francisco Ferrer, el Cabildo acordó concederle la licencia que solicita para cambiar de aires y aguas, "hasta la víspera de Todos los Santos exclusive”.

A continuación se leyó otro llamamiento de los mismos Señores sobre la solicitud de ayuda de costa de Don Julián Gálvez, al que se le concedieron mil quinientos reales. ${ }^{1507}$

"Se leyó un memorial de Don Miguel Reynaldi en el que hace presente que sin embargo de no hallarse totalmente restablecido de su padecer de ojos, por obedecer las órdenes del Cavildo, se pondrá en camino a el instante, más como el día 25 se concluye la última licencia que se le concedió, no sabiendo si podrá llegar para aquél día a causa del carruajero con quien tiene ajustado su viaje, suplica se le dispense los pocos días que le sea forzoso el detenerse, y el Cavildo acordó: pase esta solicitud a los Señores Diputados de Arcas de Santa Inés con la parte para su inteligencia y gobierno". 1508

Se presentó un memorial de Don Francisco de Paula Mora, en que pedía un certificado del tiempo que había servido como Niño de Coro. El Cabildo acordó que pase esta solicitud al notario secretario para que le dé la certificación deseada. ${ }^{1509}$

"Se leyó un memorial de Don Francisco Ferrer, primero trompa de la Capilla de Música de esta Santa Iglesia, en el que pide que se le continúe la licencia para restablecer su salud, y acordó el Cavildo que pase a los Señores Diputados de las Arcas de Santa Inés para que informen con llamamiento”. 1510

\footnotetext{
1506 Ibid. Martes 25 de Agosto de 1818. T. 105, fol. 5 r.

${ }^{1507}$ Ibid. Viernes 4 de Septiembre de 1818. T. 105, fol. 8 v.

${ }^{1508}$ Ibid. Viernes 18 de Septiembre de 1818. T. 105, fol. $10 \mathrm{v}$.

${ }^{1509}$ Ibid. Lunes 19 de Octubre de 1818. T. 105, fol. 14 r.

${ }^{1510}$ Ibid. Martes 3 de Noviembre de 1818. T. 105, fol. 18 v.
} 
Se leyó un memorial de Don José Ruiz, tenor de la Capilla de Música de esta Santa Iglesia, en que pide que se le aumente la dotación de su empleo. El Cabildo acordó que pase a los Diputados de Santa Inés para que informen. ${ }^{1511}$

"Se dio cuenta de un memorial de Don Vicente Marín, músico instrumentista de esta Santa Iglesia, en el que expone sus méritos, y su avanzada edad solicitando de la piedad del Cavildo, se digne socorrerle del modo que lo estime más oportuno, y se acordó que pase a los Señores Diputados de las Arcas de Santa Inés con la parte de Nuestro Ilustrísimo Prelado para que informen con llamamiento”. ${ }^{1512}$

“El Señor Don Pedro Segovia como Diputado de Arcas de Santa Inés dixo: que en virtud de la comisión dada por este Cavildo para buscar un sujeto que llenase la plaza de trompa necesaria, y de bajón si era posible, ponía en noticia del Cavildo haberse presentado un joven que según noticias poseía la facultad de las dos dichas cuerdas, de trompa y bajón, con bastante perfección, lo que ponía en su noticia por si pareciera que se oyese, y el Cavildo acordó; que se oiga en el primer día desocupado que dicho señor le pareciese dando cuenta al Cavildo de las resultas". 1513

\section{9}

"Se oyó la censura del Maestro de Capilla sobre la solicitud de Don Juan de la Cruz y Roxas, y el Cavildo en su vista y del informe de los Señores Diputados acordó señalar y señaló al dicho Don Juan, quinientos ducados de los fondos de Arcas Vacantes de Santa Inés, con la obligación de segundo trompa y la de tocar el bajón y el violín cuando el Maestro de Capilla lo disponga o pareciese conveniente”. ${ }^{1514}$

“Se leyó un memorial de Don Juan de la Cruz y Roxas, segundo trompa y bajón de esta Santa Iglesia por el cual pide una ayuda de costa en atención a sus atrasos con

\footnotetext{
${ }^{1511}$ Ibid. Viernes 6 de Noviembre de 1818. T. 105, fol. $20 \mathrm{v}$.

1512 Ibid. Miércoles 18 de Noviembre de 1818. T. 105, fol. 21 v.

1513 Ibid. Miércoles 23 de Diciembre de 1818. T. 105, fol. 31 v.

1514 Ibid. Sábado 30 de Enero de 1819. T. 105, fol. 40 r.
} 
respecto al tiempo que ha estado tocando antes de darle la plaza que obtiene, y el Cavildo acordó; pase a los señores Diputados de Arcas Vacantes de Santa Inés con la parte de Su Ilustrísima”. 1515

El Cabildo concede a Don Juan de la Cruz y Roxas, músico instrumentista, mil quinientos reales de vellón de ayuda de costa. ${ }^{1516}$

Don Miguel Reynaldi, primer violín de la Capilla, solicita que se le abonen las aspas que se le pusieron durante su viaje del año anterior. El Cabildo dio comisión a los Diputados de Santa Inés para que informasen. ${ }^{1517}$

"En este Cavildo se leyó un memorial de Don Lope de Mora, músico de esta Santa Iglesia, en el que refiere los muchos años que lleva de servir a el Cavildo, su crecida familia, y la escasez en que se haya, y pide al Cavildo una ayuda de costa, y se acordó en su vista; pase a los Señores Diputados de Arcas Vacantes de San Acacio con la parte de Su Ilustrísima para que informen con Ilamamiento". ${ }^{1518}$

"Se presentó y leyó un memorial de Don Nicolás Anguita, en el cual hace presente los años que lleva de servir en la Iglesia, su escasez a causa de la manutención de su padre, cuatro hermanos y dos sobrinas huérfanas, en cuya virtud solicita de la piedad del Cavildo, que los doscientos ducados colativos que tenía, y que se le suspendieron por la gracia de Capellanía con que se le agració, se le devuelvan para desahogarse algún tanto; y el Cavildo acordó; pase a los Señores Diputados de Arcas Vacantes de San Acacio con la parte de Su Ilustrísima, para que informen con llamamiento sobre esta solicitud". 1519

\footnotetext{
1515 Ibid. Miércoles 10 de Febrero de 1819. T. 105, fol. 41 r.

${ }^{1516}$ Ibid. Sábado 20 de Febrero de 1819. T. 105, fol. 45 r.

1517 Ibid. Miércoles 21 de Abril de 1819. T. 105, fol. 54 v.

1518 Ibid. Miércoles 23 de Abril de 1819. T. 105, fol. 55 r.

${ }^{1519}$ Ibid. Martes 8 de Junio de 1819. T. 105, fol. 59 r.
} 
El Cabildo acordó conceder y concedió mil quinientos reales de ayuda de costa a Don Lope de Mora, músico violinista de la Capilla. ${ }^{1520}$

“Sobre la solicitud de Don Nicolás Anguita, Capellán de San Acacio, oído que fue el Cavildo acordó; conceder y concedió los 200 ducados que solicita, bajo el concepto en que se expresa el preámbulo del dicho informe”. ${ }^{1521}$

"Se leyó un memorial del $1^{\circ}$ bajonista Don Juan Nepomuceno Puig, por el que pide una ayuda de costa en atención a la suma indigencia y apuro en que se haya, no sólo por el corto sueldo y mucha familia que tiene, si no por el pago de la casa que habita, y el Cavildo acordó; pase a los Señores Diputados de Santa Inés para que informen con llamamiento". ${ }^{1522}$

"Sobre la solicitud de Don Miguel Reynaldi, el Cavildo oído que fue acordó; conceder y concedió a el dicho doscientos ducados de ayuda de costa por una vez. El Señor Armenta contradixo este acuerdo con arreglo a Estatuto”. ${ }^{1523}$

“Se leyó un memorial de D. Nicolás Anguita, Capellán de San Acacio, dando gracias por el aumento de renta que se le ha concedido y ofreciéndose a enseñar música a los ministros de esta Santa Iglesia que el Cabildo le señale”. ${ }^{1524}$

"Un memorial de Don Francisco Ferrer, en que pide que se le continúe el aumento de sueldo que se le concedió cuando se hallaba de trompa único en esta Santa Iglesia, se mandó pasar a los Señores Diputados de Arcas de Santa Inés para que con la parte de Su Ilustrísima, informen sobre él con llamamiento: y no ocurrió otra cosa, de que certifico". 1525

\footnotetext{
${ }^{1520}$ Ibid. Martes 8 de Junio de 1819. T. 105, fol. 59 r.

${ }^{1521}$ Ibid. Sábado 26 de Junio de 1819. T. 105, fol. 62 r.

1522 Ibid. Miércoles 7 de Julio de 1819. T. 105, fol. 64 v.

1523 Ibid. Sábado 10 de Julio de 1819. T. 105, fol. 65 r.

${ }^{1524}$ Ibid. Sábado 24 de Julio de 1819, T.105.

${ }^{1525}$ Ibid. Jueves 29 de Julio de 1819. T. 1015, fol. 69 v.
} 
“Los Señores Armenta y Venegas, como individuos de la Junta de Alojamientos, presentaron una palabra por escrito, pidiendo en arrendamiento para el objeto de su comisión, el Colegio que fue de Niños de Coro; y se acordó que pase este asunto para su decisión a la Diputación de Cabeza de Rentas”. ${ }^{1526}$

"En virtud de llamamiento y oído el informe de los Señores Diputados de Arcas de Santa Inés con la parte de Su Ilustrísima, se acordó que el aumento de cien ducados concedido a Don Francisco Ferrer en 12 de junio de 1816 sobre los cinco mil cien reales de sueldo que antes gozaba, sea y se entienda sin interrupción desde el día en que se acordó a su favor; y no por vía de ínterin, como entonces se determinó si no perpetuamente.

Siguiendo el mismo llamamiento y oído otro informe de los mismos Señores se concedió a Don Juan Puig, bajonista, una ayuda de costa de ochocientos reales de vellón por una vez.

Y un memorial de Don Juan de Cruz Rojas, pidiendo licencia para pasar por 60 días a Granada, se cometió a informe con llamamiento de los mismos Señores con lo que se concluyó, de que certifico". ${ }^{1527}$

El organista Don Francisco Balius, y el bajonista Don Francisco de Lara, presentan sendos memoriales solicitando aumento de salario. Se da comisión respectivamente a los Diputados de San Acacio y Santa Inés para que informen. ${ }^{1528}$

"Se leyó un memorial de Don Salvador Serrano, Capellán Perpetuo de la de San Pedro, pretendiendo que en atención a su aplicación a la música, trabajo en la Capilla de ella, y a la corta renta que en el día tienen dichas Capellanías, se le dé un salario por este Cavildo; y se acordó que los Señores Diputados de Arcas de San Acacio con la parte de Su Ilustrísima informen sobre esta solicitud con Ilamamiento”. 1529

\footnotetext{
${ }^{1526}$ Ibid. Viernes 13 de Agosto de 1819. T. 105, fol. 71 r.

${ }^{1527}$ Ibid. Viernes 13 de Agosto de 1819. T. 105, fol. 72 r.

${ }^{1528}$ Ibid. Miércoles 29 de Agosto de 1819. T. 105, fol. 74 v.

${ }^{1529}$ Ibid. Lunes 30 de Agosto de 1819. T. 105, fol. 75 v.
} 
“Por el Acólito Mariano Vallejo, se presentó memorial para que se le perdonen las aspas en que ha incurrido por su enfermedad de ojos, que le duró doce días, y se acordó que los Señores Diputados del Punto de Horas, informen con llamamiento sobre esta solicitud". ${ }^{1530}$

El Cabildo acordó que se abone al Acólito Mariano Vallejo, el importe de las aspas en que ha incurrido por su enfermedad de doce días. ${ }^{1531}$

“En virtud de llamamiento y oído el informe de los Señores Diputados del Punto de Horas se acordó que al Niño de Coro Gabriel de Mora, se le dé el importe de las aspas en que ha incurrido por los siete días en que ha estado enfermo". ${ }^{1532}$

Don Julián Gálvez y Don Juan de la Cruz y Rojas, ambos músicos de la Capilla, presentan sendos memoriales en que solicitan una ayuda de costa. El Cabildo da comisión a los Diputados de Santa Inés para que informen con llamamiento. ${ }^{1533}$

El Cabildo acuerda conceder al organista Don Francisco Balius, “aumento de renta personal hasta completar la renta de ocho mil reales anuales”. ${ }^{1534}$

“En virtud de llamamiento y leídos los informes de los Señores Diputados de Arcas de San Acacio con la parte de Su Ilustrísima se concedieron sobre dichos fondos al Sochantre Don Joseph González y Alcaide mil y quinientos reales de ayuda de costa por una vez, y a Don Salvador Serrano trescientos ducados de renta anual con la obligación de ser bajo de la Capilla de Música, y mil reales de ayuda de costa por una vez". 1535

"En virtud de llamamiento y oídos tres informes de los Señores Diputados de Arcas de

\footnotetext{
${ }^{1530}$ Ibid. Lunes 27 de Septiembre de 1819. T. 105, fol. 81 r.

1531 Ibid. Viernes 1 de Octubre de 1819. T. 105, fol. 81 v.

1532 Ibid. Miércoles 27 de Octubre de 1819. T. 105, fol. 87 v.

1533 Ibid. Viernes 19 de Noviembre de 1819. T. 105, fol. 93 r.

${ }^{1534}$ Ibid. Jueves 16 de Diciembre de 1819. T. 105, fol. 97 r.

1535 Ibid. Lunes 20 de Diciembre de 1819. T. 105, fol. 97 r.
} 
Santa Inés con la parte de Nuestro Ilustrísimo Prelado, se concedieron a Don Julián Gálvez mil y quinientos reales de vellón de ayuda de costa por una vez.

Al bajonista Don Francisco Lara cien ducados de aumento de renta anual, con la obligación de tocar el contrabajo y la flauta cuando se lo ordene el Maestro de Capilla. Y al bajonista Don Juan Rojas, seiscientos reales de vellón de ayuda de costa por una vez". 1536

\section{0}

Don Juan Nepomuceno Puig, primer bajonista, solicita patitur abierto por padecer una enfermedad en la vista. El Cabildo dio comisión a los Diputados de Santa Inés para que informasen. ${ }^{1537}$

Se leyó un memorial del Acólito Mariano Vallejo pidiendo que se le levanten las aspas en que ha incurrido por su última enfermedad. El Cabildo dio comisión a los Diputados del Punto de Horas más los de Hacienda y Acólitos para que informasen. ${ }^{1538}$

El Cabildo acuerda que se le abonen el importe de las aspas en que han incurrido por estar enfermos, a los Acólitos Don Mariano Vallejo y Don Rafael Vázquez. ${ }^{1539}$

“Un memorial del Capellán Perpetuo de San Acacio, Don Antonio Gil, tenor de la Capilla de Música, en que exponiendo sus méritos y servicios pide aumento de salario; y otro igual de Don Manuel Valls, oboe de la misma Capilla a que acompañaba una obra del mismo en dos tomos dedicada a este Cavildo sobre la enseñanza de dicho instrumento y de flauta; se mandaron pasar a los Señores Diputados de Arcas de San Acacio para que con la parte de Su Ilustrísima informan con llamamiento". 1540

\footnotetext{
${ }^{1536}$ Ibid. Miércoles 22 de Diciembre de 1819. T. 105, fol. 97 v.

${ }^{1537}$ Ibid. Viernes 14 de Enero de 1820. T. 105, fol. 99 v.

1538 Ibid. Lunes 24 de Enero de 1820. T. 105, fol. 102.

${ }^{1539}$ Ibid. Jueves 27 de Enero de 1820. T. 105, fol. 103 v.

${ }^{1540}$ Ibid. Lunes 7 de Febrero de 1820. T. 105, fol. 105 v.
} 
Don Juan Nepomuceno Puig, primer bajonista, pide una ayuda de costa en atención a su estado de escasez, con motivo de los gastos ocasionados por su enfermedad de los ojos. Se dio comisión a los Diputados de Santa Inés para que informasen. $^{1541}$

Don Nicolás Anguita, se ofrece al Cabildo para dar clase de música a uno o dos Niños de Coro o Acólitos. El Cabildo acepta este ofrecimiento con la condición de que Don Nicolás no falte a su deber por esta causa. ${ }^{1542}$

"Sobre la solicitud de aumento de sueldo hecha por Don José Ruiz, músico tenor de la Capilla de esta Santa Iglesia; se acordó que atendida su puntual asistencia a buenos servicios, y cortedad de su salario, se le aumenten y consignen sobre el que disfruta, cien ducados anuales”. 1543

El Cabildo "acordó admitir la donación de las dos escuelas completas de oboe y flauta que presenta y dedica al Cabildo [D. Manuel Valls], dándole las debidas gracias”. Además le informa que en breve se procurará una recompensa económica por esta labor. ${ }^{1544}$

"Sobre las solicitudes de ayuda de costa y patitur abierto que solicita Don Juan Nepomuceno Puig, el Cabildo acordó; conceder y concedió a dicho Don Juan, cien ducados por vía de socorro en atención a su estado de miseria, y en cuanto a la licencia de patitur abierto, desde el día que lo solicitó hasta su restablecimiento en la vista.

A continuación se leyó un memorial de Joseph Molina, Presbítero secularizado, músico contralto de la Capilla de San Cayetano de Madrid, por el que dice desea servir en la Capilla de Música de esta Santa Iglesia y suplica a este Cavildo se digne admitirlo y se acordó; pase a los Señores Diputados de Arcas de Santa Inés para que informen con Ilamamiento con la parte de Su Ilustrísima”. 1545

\footnotetext{
${ }^{1541}$ Ibid. Jueves 16 de Marzo de 1820. T. 105, fol. 111 v.

1542 Ibid. Martes 21 de Marzo de 1820. T. 105, fol. 113 r.

1543 Ibid. Miércoles 17 de Mayo de 1820. T. 105, fol. 132 r.

${ }^{1544}$ Ibid. Lunes 29 de Mayo de 1820. T. 105, fol. 137 v.

1545 Ibid. Miércoles 14 de Junio de 1820. T. 105, fol. 142 r.
} 
“Sobre la solicitud del Presbítero Don José Molina, y enterado el Cavildo dio nuevamente su comisión a los mismos Señores Diputados para que previo llamamiento informen con la parte de Su Ilustrísima sobre el estado actual y rentas de las expresadas Arcas de Santa Inés y asimismo de la idoneidad y suficiencia del interesado". 1546

Se presentó un memorial de Don Francisco Ferrer, músico trompa, en el que pide una ayuda de costa debido a su prolongada enfermedad que le ocasiona muchos gastos. $^{1547}$

El Cabildo acuerda conceder a Don Francisco Ferrer una ayuda de costa de mil cien reales.

Asimismo acuerda, previo informe positivo del Maestro de Capilla, aceptar a Don Joseph Molina como músico de la Capilla tanto en la cuerda de contralto como en la de tiple, con un sueldo de quinientos ducados anuales. ${ }^{1548}$

El Señor Caballero, Diputado de Ceremonias, previene al Cabildo sobre los excesos en el tiempo que otros años ha durado la música en la Nochebuena, sugiriendo que se reduzca la intervención de la Capilla de Música para que no se alargue excesivamente la ceremonia. El Cabildo acordó que esta solicitud pase a los Diputados de Ceremonias para que informen con llamamiento. ${ }^{1549}$

Don Julián Gálvez, músico contrabajo, pide una ayuda de costa exponiendo su crítica situación económica. El Cabildo dio comisión a los Diputados de Santa Inés para que informasen. ${ }^{1550}$

\footnotetext{
${ }^{1546}$ Ibid. Viernes 28 de Julio de 1820. T. 105, fol. 159 r.

${ }^{1547}$ Ibid. Viernes 25 de Agosto de 1820. T. 105, fol. 170 v.

${ }^{1548}$ Ibid. Sábado 16 de Septiembre de 1820. T. 105, fol. $178 \mathrm{v}$.

${ }^{1549}$ Ibid. Viernes 6 de Octubre de 1820. T. 105, fol. $184 \mathrm{v}$.

1550 Ibid. Martes 17 de Octubre de 1820. T. 105, fol. 187 v.
} 
El Cabildo, atendiendo a los buenos servicios y la situación actual de indigencia que vive Don Julián Gálvez, le concede 1500 reales de vellón, de ayuda de costa. ${ }^{1551}$

“Sobre la palabra del señor Caballero, relativa a la solemnidad de los maitines y misa de la Natividad a Nuestro Señor Jesucristo y enterado el Cavildo y precedida una larga discusión y conferencia sobre la materia, se acordó; que en el presente año quede a la prudencia del Señor Presidente la moderación de los villancicos, música y solemnidad de la Misa del Gallo, y a la de los Señores Capitulares el orden de las misas, después de la Solemne”. ${ }^{1552}$

\section{1}

“El Señor Vivar, encargado interinamente del Punto de Horas Canónicas, dio parte al Cavildo; que el Niño de Coro Francisco López, destinado a la asistencia de la Mesa del Punto, a quien había puesto una aspa, por haber faltado al Coro y su destino, cometió en el día de ayer el exceso, no sólo de preguntarle y aún reconvenirle sobre la expresada aspa, si no que advirtió la había quitado de los cuadernos o cuadrantes, de su autoridad propia”. Igualmente refirió que tanto Francisco López como los demás Niños de Coro y Acólitos cometían continuamente faltas de respeto en el Coro. El Cabildo acordó suspender en su cargo y destino Francisco de Paula López, y dio comisión a los Diputados de Infantes de Coro y Acólitos para que informen sobre la conducta de los Niños y Acólitos”. 1553

Sobre las medidas a tomar para el buen régimen de los Niños de Coro, el Cabildo acordó: “que desde luego, y con la brevedad que sea posible, se restablezca y ponga en estado, el Colegio de Niños de Coro; para cuya execución se dio comisión amplia y bastante a los Señores Diputados de Infantes de Coro y Acólitos, en unión con los de Obras Pías; quienes, atendida la vigente necesidad que estimula a esta medida, procurarán realizarlo sin pérdida de tiempo, tomando las que contemplen necesarias, y

\footnotetext{
${ }^{1551}$ Ibid. Martes 5 de Diciembre de 1820. T. 105, fol. 207 r.

1552 Ibid. Sábado 16 de Diciembre de 1820. T. 105, fol. 210 v.

1553 Ibid. Martes 16 de Enero de 1821. T. 106, fol. 6 r.
} 
oportunas a el efecto: y siempre que encuentren algún embarazo en esta operación informarán al Cavildo". 1554

El Señor Don Francisco Peralbo, Diputado de Acólitos e Infantes de Coro, expone al Cabildo determinadas medidas a fin de que se vuelva a abrir el Colegio de Niños de Coro. Defiende la necesidad de determinar una asignación económica para el restablecimiento de dicho Colegio. El Cabildo dio comisión a los Diputados de Santa Inés para que informen con llamamiento. ${ }^{1555}$

Se leyó un memorial de Mariano Vallejo, Acólito de Santa Iglesia en el que expone haber servido de Niño de Coro y Acólito veinte años, y cinco de ellos desempeñando las obligaciones del Pertiguero. Que teniendo una dilatada familia a su cargo solicita del Cabildo una ayuda o socorro con aquello que fuese de su agrado. El Cabildo dio comisión a los Diputados de San Acacio para que informen con llamamiento. $^{1556}$

Se presentó un memorial de Doña María Rafaela de Gálvez y Fonseca, hija del difunto Don Julián Gálvez, individuo de la Capilla de Música de esta Santa Iglesia. En dicho memorial se hacía referencia a los años de servicio del difunto su padre, de su puntual asistencia y de la escasez de su dotación, por lo que solicita del Cabildo una ayuda para pagar el funeral de su padre. El Cabildo dio comisión a los Diputados de Santa Inés para que informasen. ${ }^{1557}$

Como al morir Don Julián de Gálvez queda vacante su instrumento el contrabajo, el Acólito Francisco de Paula, solicita al Cabildo que le preste dicho instrumento por querer aprenderlo: "Se leió un memorial de Francisco de Paula mozo acólito de esta Santa Iglesia por el que suplica se le entregue por vía de empréstito el instrumento llamado Contravajo, que conserva el Cavildo; pues hallándose

\footnotetext{
1554 Ibid. Martes 30 de Enero de 1821. T. 106, fol. 12 r.

1555 Ibid. Sábado 10 de Febrero de 1821. T. 106, fol. 17 r.

${ }^{1556}$ Ibid. Jueves 15 de Febrero de 1821. T. 106, fol. 19 r.

${ }^{1557}$ Ibid. Martes 27 de Febrero de 1821. T. 106, fol. 23 r.
} 
suficientemente instruido en la música, deberá dedicarse a tocar otro instrumento" Se dio comisión a los Diputados de Santa Inés para que informasen. ${ }^{1558}$

“Se leyó un memorial de Doña María Antonia Ilardui, de fecha 15 del corriente, en que pide se abonen a su hijo Francisco de Paula López, Niño de Coro, los quince días que estuvo suspenso por faltas de poco conocimiento, en atención a carecer de medios, y hallarse enfermo con tercianas; y se acordó informe con llamamiento la Diputación de Infantes de Coro”. 1559

El Acólito Mariano Vallejo, solicita una ayuda de costa por los servicios que ha hecho en ausencias y enfermedades del último Pertiguero Don Pedro Antúñe. El Cabildo acuerda que los Diputados de San Acacio una vez vistos los fondos, intenten satisfacer la petición. ${ }^{1560}$

El Cabildo acuerda "se entregue a Francisco de Mora [Infante de Coro] el instrumento de Contrabajo por vía de empréstito”, a fin de que este pueda aprender a tocarlo. Esto debe hacerse bajo la inspección de los Diputados de Santa Inés. ${ }^{1561}$

Don Rafael del Río presenta un memorial en el que hace presente que padece “flato ardiente", que le impide el desempeño de sus obligaciones, y pide patitur abierto. El Cabildo da comisión a los Diputados de Santa Inés para que informen. ${ }^{1562}$

Don Juan Nepomuceno Puig, expone su necesidad de tomar baños para la enfermedad de la vista que padece, para lo cual solicita una ayuda de costa. El Cabildo da comisión a los Diputados de Santa Inés para que informen. ${ }^{1563}$

El Cabildo concede a Don Juan Nepomuceno Puig una ayuda de costa de cien ducados para atender a sus necesidades.

\footnotetext{
${ }^{1558}$ Ibid. Sábado 10 de Marzo de 1821. T. 106, fol. 25 v.

1559 Ibid. Sábado 17 de Marzo de 1821. T. 106, fol. 33 v.

1560 Ibid. Sábado 17 de Marzo de 1821. T. 106, fol. 34 r.

${ }^{1561}$ Ibid. Sábado 31 de Marzo de 1821. T. 106, fol. 42 r.

1562 Ibid. Lunes 14 de Mayo de 1821. T. 106, fol. 69 r.

1563 Ibid. Viernes 25 de Mayo de 1821. T. 106, fol. 79 v.
} 
Asimismo, le concede a Don Rafael del Río, licencia de patitur abierto durante dos meses. $^{1564}$

“El Señor Presidente manifestó; que el Niño de Coro Francisco López, había cometido una falta grave en el exercicio y funciones de su encargo y obligación, por cuya causa lo había suspendido de toda intervención; lo que hacía presente al Cavildo para su conocimiento y determinación, quien acordó; que al Señor Presidente queda autorizado para disponer que continúe o cese la suspensión del Niño de Coro Francisco López, según su juicio prudente y mérito de la falta cometida”. ${ }^{1565}$

“Últimamente una palabra del Señor Don Joseph Aguilar como Diputado de Infantes de Coro que a la letra dice así: quedando muy poco tiempo para que 2 Infantes de Coro cumplan el prefixado por el Cavildo a la duración de su destino, y restando a su retirada uno sólo, puede decirse, hábil para las funciones y canto correspondientes a esta clase de sirvientes del Coro: para evitar las faltas que en este punto deben necesariamente resultar a la retirada de los dos indicados, si anticipadamente no se preparan e instruyen los que hayan de sucederles en sus plazas; ha ocurrido a la Diputación proponer a V.S. que desde luego se admitan estos a dicho efecto, sujetándolos al Maestro en calidad de educandos y sin percibir salario alguno que V.S. en el día no puede aumentar por la escasez de fondos, y que disfrutarán al verificarse su entrada efectiva en las mencionadas plazas. Es cuanto se ofrece a la Diputación hacer presente a V.S. para su inteligencia y determinación. Córdoba y Octubre 8 de 1821. Francisco Peralbo y Calero: Joseph Aguilar y Martínez. El Cabildo en su vista acordó; informen con llamamiento”. ${ }^{1566}$

"A virtud de llamamiento para oír el informe de los Señores Diputados de Infantes de Coro sobre su arreglo, el Cavildo conformándose con el informe en todas sus partes acordó; que se le haga saber a los padres, parientes o tutores de los niños Francisco López y José Pérez, cumplen el tiempo prefixado últimamente por el Cavildo

\footnotetext{
1564 Ibid. Miércoles 20 de Junio de 1821. T. 106, fol. 96 r.

1565 Ibid. Sábado 25 de Agosto de 1821. T. 106, fol. 120 r.

${ }^{1566}$ Ibid. Lunes 8 de Octubre de 1821. T. 106, fol. 137 r.
} 
para su salida, el 15 de noviembre próximo, dando comisión a los mismos Señores Diputados, para que admitan memoriales para la provisión de las dos plazas, informando a Cavildo para determinar lo conveniente con arreglo a el informe". ${ }^{567}$

Con respecto a la oposición para cubrir plazas vacantes de Niños de Coro, el Cabildo acordó señalar el sábado próximo para el examen de los pretendientes y provisión de la plaza. Igualmente acordó que la edad de los niños no puede bajar de 7 años ni subir de $10 .{ }^{1568}$

Una vez realizado el examen para cubrir una de las plazas de Niño de Coro vacante salió elegido el niño Mariano González. El Cabildo acordó que se advierta a los padres o tutores, tanto de los niños que van a entrar nuevos, como de los que ya están, que a la menor falta grave en el desempeño de las funciones de dichos niños, o insubordinación al Cabildo, se procedería a la expulsión de quien así lo hiciera. ${ }^{1569}$

“A virtud de llamamiento con la parte de Su Ilustrísima Nuestro Prelado para oír a los Señores Diputados de Arcas Vacantes de Santa Inés, y proceder a la elección de una plaza de Niño de Coro correspondiente a este Cavildo, oído que fue, se procedió a la elección y recayó la gracia en Joseph Aguilar, dando comisión a los mismos Señores Diputados para las pruebas”. ${ }^{1570}$

“A virtud de llamamiento para oír el informe de los Señores Diputados de Infantes de Coro, sobre el modo de hacer las pruebas a el niño electo Mariano González, oído que fue después de una larga discusión, se pasó a votar si el Cavildo estaba suficientemente enterado y resultó que no lo estaba en el día para determinar sobre este acuerdo, debiendo volver el informe a los mismos Señores para que lo amplíen con los noticias de acuerdos anteriores". ${ }^{1571}$

\footnotetext{
${ }^{1567}$ Ibid. Martes 16 de Octubre de 1821. T. 106, fol. 138 r.

1568 Ibid. Miércoles 7 de Noviembre de 1821. T. 106, fol. 142 r.

1569 Ibid. Sábado 10 de Noviembre de 1821. T. 106, fol. 143 r.

1570 Ibid. Sábado 10 de Noviembre de 1821. T. 106, fol. 144 v.

${ }^{1571}$ Ibid. Viernes 16 de Noviembre de 1821. T. 106, fol. 147 v.
} 
El Cabildo pide informes a los Diputados de Niños de Coro sobre el aspirante Mariano González, exigiendo que en dichos informes conste que dicho aspirante "no es de raza de moros, antes sí hijo de padres cristianos viejos y limpios, y de lexitimo matrimonio". 1572

En el Cabildo del día de la fecha se aceptan las pruebas realizadas a los dos nuevos Niños de Coro, Mariano González y Joseph Aguilar. ${ }^{1573}$

En el día de la fecha se presentan los memoriales de genealogía de los dos Niños de Coro recién elegidos, Mariano González y Joseph Aguilar. ${ }^{1574}$

“Se leyó memorial firmado por D. José Ruiz, D. Rafael Marín y D. Francisco Balius, individuos de la Capilla de Música de esta Santa Iglesia manifestando en él, el estado de apuro en que se encuentran a causa de haber pasado siete meses sin que hayan recibido cantidad alguna perteneciente a sus respectivos sueldos y concluyen pidiendo que se les socorra si no con el todo con parte para poder subsistir". ${ }^{1575}$

"Se leyó un memorial del Niño de Coro que fue Francisco de Paula López y en su vista, el Cavildo acordó no haber lugar a su solicitud de volver a el Coro con sólo la utilidad de los derechos o provechos y que se estén a lo acordado en Cavildo de 16 de octubre último". 1576

\section{2}

Don Joseph Aguilar, oficial de albañilería de la Catedral, pide al Cabildo una ayuda de costa para sufragar las deudas contraídas a raíz de las pruebas de limpieza de

\footnotetext{
1572 Ibid. Sábado 17 de Noviembre de 1821. T.106.

1573 Ibid. Martes 20 de Noviembre de 1821. T. 106, fol. 150 r.

${ }^{1574}$ Ibid. Sábado 24 de Noviembre de 1821. T. 106, fol. 151 v.

1575 Ibid. Viernes 15 de Diciembre de 1821. T.106.

${ }^{1576}$ Ibid. Sábado 22 de Diciembre de 1821. T. 106, fol. 161 v.
} 
sangre que tuvo que aportar su hijo nombrado Niño de Coro. El Cabildo dio comisión a los Diputados de Santa Inés para que informasen. ${ }^{1577}$

“Sobre la solicitud de Doña Bibiana de Mora y hermanas, relativa a la casa que actualmente viven y que ha firmado el Señor Vivar, el Cavildo en su vista y después de una larga conferencia acordó vuelva el informe a la misma Diputación para que lo amplíe con presencia de los acuerdos que haya sobre arrendamiento de casa por Señores Capitulares, más que la que habiten, y el modo con que está firmada la casa indicada por el difunto hermano Don Lope de Mora". ${ }^{1578}$

"Se presentó una palabra de los Señores Diputados de Infantes de Coro, de fecha 4 del corriente en que hacen presente que Francisco Duarte, Niño de Coro ha cumplido la edad de diez y seis, en la que el Cavildo tiene acordado cesen los de su clase en su destino, lo que exponen para que en su vista acuerde lo que sea de su agrado; y enterado el Cavildo acordó informen con llamamiento los mismos Señores Diputados lo que se les ofrezca". ${ }^{1579}$

Don Juan Puig, bajonista, pide una ayuda de costa que le ayude en los gastos de su enfermedad. El Cabildo da comisión a los Diputados de Santa Inés para que informen. $^{1580}$

"Se leyó un memorial de Josefa Bach, viuda de Don Lope de Mora, que sirvió por espacio de cincuenta años la plaza de violinista, como igualmente, su padre la de organista; y pide por esta consideración alguna ayuda de costa, para alimentar los hijos que le han quedado; y el Cavildo acordó pase a los Señores Diputados de Arcas de San Acacio con la parte de Su Ilustrísima para informar con llamamiento”. ${ }^{1581}$

\footnotetext{
${ }^{1577}$ Ibid. Viernes 15 de Febrero de 1822. T. 106, fol. 183 v.

1578 Ibid. Sábado 23 de Febrero de 1822. T. 106, fol. 184 r.

1579 Ibid. Lunes 4 de Marzo de 1822. T. 106, fol. 186 v.

${ }^{1580}$ Ibid. Sábado 9 de Marzo de 1822. T. 106, fol. 190 r.

${ }^{1581}$ Ibid. Sábado 9 de Marzo de 1822. T. 106, fol. 190 r.
} 
El Cabildo concede a Don Juan Puig, bajonista, cincuenta pesos de ayuda de costa. $^{1582}$

Sobre la solicitud de ayuda de costa que hace Don José Aguilar, Infante de Coro, el Cabildo acuerda que se le den veinte duros por una vez. ${ }^{1583}$

Se presenta un memorial del Acólito Rafael Vázquez en que solicita se le perdonen las aspas que le ha originado la enfermedad que ha padecido. Se dio comisión a los Diputados de Acólitos para que informen. ${ }^{1584}$

Don Rafael del Río, pide patitur abierto y presenta certificación del facultativo que le asiste. El Cabildo acordó que informen con llamamiento los Diputados del Punto de Horas. ${ }^{1585}$

El Cabildo concede a Don Rafael del Río, licencia de patitur abierto hasta fin de diciembre próximo. ${ }^{1586}$

“Un memorial de Acólito Rafael Vázquez, con el que presenta certificación de haber estado enfermo; y pide se le remitan las aspas, que le ha ocasionado su falta de asistencia a el Coro; y se acordó informen con llamamiento los Señores Diputados de Acólitos.

Se leyó otro memorial de José Aguilar, José González y Diego Sáenz, padres de los Infantes de Coro de esta Santa Iglesia, en que haciendo presente su situación, y estado indigente para poder alimentar y vestir a los expresados sus hijos; piden al Cavildo se digne señalarles la dotación que sea de su agrado, para poder continuar en su exercicio con decencia, quien acordó; pase a los Señores Diputados de Obras Pías, para que informen con llamamiento sobre esta solicitud". 1587

\footnotetext{
1582 Ibid. Jueves 21 de Marzo de 1822. T. 106, fol.195 r.

1583 Ibid. Jueves 21 de Marzo de 1822. T. 106, fol. 195 v.

${ }^{1584}$ Ibid. Miércoles 27 de Marzo de 1822. T. 106, fol. 199 r.

1585 Ibid. Miércoles 3 de Abril de 1822. T. 106, fol. 203 r.

${ }^{1586}$ Ibid. Miércoles 22 de Mayo de 1822. T. 106, fol. 212 r.

${ }^{1587}$ Ibid. Martes 18 de Junio de 1822. T. 106, fol. 217 v.
} 
El Cabildo acuerda que a Don Rafael Vázquez, se le levanten las ciento cuarenta y seis aspas que constan en los cuadrantes, en atención a su enfermedad. ${ }^{1588}$

Respecto a la solicitud de los padres de los Niños de Coro, el Cabildo acuerda “que desde el primero del corriente julio se aumente la dotación de los Niños de Coro, a tres reales diarios, según anteriormente les estaba consignado y percibían”. ${ }^{1589}$

Se presentó un informe de los Diputados de Niños de Coro, sobre la solicitud de varios pretendientes para cubrir una plaza vacante de esta clase, y el Cabildo acordó que el día 23 del corriente se celebren los exámenes y la provisión de esta plaza. ${ }^{1590}$

“Doña Antonia Mesa, viuda, hace presente al Cavildo que su hijo Mariano Zurbano a quien V.I. hizo la gracia de nombrarle en la plaza vacante de Infante de Coro, tiene un año más de lo que se requiere para su admisión, y pide no le sirva de obstáculo para la continuación de la gracia ya concedida; el Cavildo acordó que dicha solicitud pase a la Diputación de Infantes de Coro para su conocimiento y para que informen con llamamiento cuanto se les ofrezca". ${ }^{1591}$

“El bajonista Don Juan Nepomuceno Puig pide a V.S. por memorial que ha presentado, acompañado de una certificación del facultativo que le asiste, que le conceda patitur abierto, obligándose sin embargo en los días que le persistan sus achaques a asistir al Coro, y el Cavildo acordó que pase a los Señores Diputados de Arcas de Santa Inés con la parte para que informen con llamamiento sobre esta solicitud". 1592

\footnotetext{
1588 Ibid. Miércoles 10 de Julio de 1822. T. 106, fol. 223 r.

${ }^{1589}$ Ibid. Miércoles 24 de Julio de 1822. T. 106.

${ }^{1590}$ Ibid. Martes 13 de Agosto de 1822. T. 106, fol. 234 v.

1591 Ibid. Martes 27 de Agosto de 1822. T. 106, fol. 237 v.

1592 Ibid. Martes 27 de Agosto de 1822. T. 106, fol. 238 v.
} 
El Cabildo confirma el nombramiento del Infante de Coro Mariano Zurbano, a pesar de tener un año más de lo determinado habitualmente para el ingreso de los niños. $^{1593}$

Se presentan las pruebas de limpieza de sangre del Niño de Coro Mariano Zurbano y Mesa. El Cabildo se conforma con dichas pruebas y acuerda permitirle entrar con sobrepelliz en el Coro a servir su oficio. ${ }^{1594}$

“El Señor Aguilar Diputado de Infantes de Coro, hizo presente si debería salir el niño Duarte mediante la nueva admisión que acababa de hacerse, y después de una ligera discusión acordó el Cavildo, pesando las razones que se habían manifestado por algunos Señores, que saliese inmediatamente”. ${ }^{1595}$

Se leyó un oficio del gobernador de esta diócesis en que se le comunica al Cabildo que el Señor Don Ángel Arteaga, entre otros, ha sido acusado de conspiración y rebelión contra el sistema constitucional, comunicándole la sentencia pronunciada contra él por la audiencia territorial de Castilla La Vieja y León. Dicha sentencia lo condena a ocho años de confinamiento en una de las Islas Baleares, bajo la vigilancia de las autoridades civiles y militares. ${ }^{1596}$

“En virtud de llamamiento se leyó un informe de los Señores Diputados de las Arcas de San Acacio con la parte de Nuestro Ilustrísimo Prelado sobre la licencia que pide la Junta de Beneficencia a favor de su individuo Don José Luis de los Heros, Capellán Perpetuo del Coro de esta Santa Iglesia. Y el Cavildo conformándose con el parecer de dichos Señores acordó que al susodicho se le tenga como presente en todas las horas canónicas, exceptuando los días festivos y solemnes de rigurosa asistencia". ${ }^{1597}$

\footnotetext{
1593 Ibid. Jueves 5 de Septiembre de 1822. T. 106, fol. 240 v.

1594 Ibid. Viernes 20 de Septiembre de 1822. T. 106, fol. 243 v.

${ }^{1595}$ Ibid. Viernes 20 de Septiembre de 1822. T. 106, fol. 243 v.

1596 Ibid. Lunes 14 de Octubre de 1822. T. 106, fol. 246 r.

${ }^{1597}$ Ibid. Martes 22 de Octubre de 1822. T. 106, fol. 249 v.
} 
“El Señor Aguilar, Diputado de Infantes de Coro dio cuenta que Rafael Sáenz había cumplido la edad de dieciséis años, según lo acordado debía de cesar quedando vacante su plaza correspondiente a la provisión del Cavildo de Señores Canónigos”. 1598

"Se leyó un informe de los Señores Diputados de Arcas Vacantes de Santa Inés con la parte de Su Ilustrísima Nuestro Prelado sobre la solicitud del Presbítero Don Rafael del Río, músico instrumentista de la Capilla de esta Santa Iglesia y el Cabildo conformándose con el parecer de dichos Señores: acordó acceder a la solicitud en los términos y modo que se propone.

Se leyó otro informe de mismos Señores sobre los pretendientes a la plaza vacante de Infantes de Coro, y el Cabildo nombró en ella a Francisco del Pino y Ramírez, y en su consecuencia dio comisión a los mismos Señores para que les hagan las pruebas según costumbre para servir dicha plaza”. 1599

Se leyó un memorial de Don Pascual Redel, músico instrumentista, en el que expone que acaba de padecer una grave enfermedad y necesita algún tiempo para restablecerse, por lo que solicita patitur abierto por el tiempo que el Cabildo crea justo. Se acuerda pase este memorial a los Diputados de San Acacio para que informen. ${ }^{1600}$

En el Cabildo de este día se informa en pocas palabras de la muerte del Maestro de Capilla, y de la decisión de interpretar como se hacía habitualmente los villancicos y la Kalenda de Navidad. ${ }^{1601}$

El Cabildo concede a Don Pascual Redel patitur abierto hasta fin de marzo del año próximo, encargando al interesado asista no obstante al Coro en los días más solemnes. $^{1602}$

\footnotetext{
1598 Ibid. Martes 29 de Octubre de 1822. T. 106, fol. 250v.

1599 Ibid. Viernes 22 de Noviembre de 1822. T. 106, fol. 256v.

${ }^{1600}$ Ibid. Martes 3 de Diciembre de 1822. T. 106, fol. 260 v.

${ }^{1601}$ Ibid. Miércoles 4 de Diciembre de 1822. T. 106, fol 261 r.

1602 Ibid. Jueves 5 de Diciembre de 1822. T. 106, fol 262 v.
} 
En este Cabildo se leen las pruebas hechas a Francisco del Pino, recién nombrado Infante de Coro. El Cabildo las aprobó y acordó permitir al agraciado entrar desde el día de la fecha en el Coro con sobrepelliz a servir su plaza.

En el mismo Cabildo se acuerda dar a Don Gregorio Villarreal setecientos cincuenta reales por vía de limosna y por una vez. ${ }^{1603}$

"Se leyó un memorial de los Acólitos de esta Santa Iglesia de fecha del 19, en que suplican al Cavildo se digne decretarles algún socorro para estas Pascuas a buena cuenta hasta que se liquiden las de 1821 y 1822 en vista de las consignaciones que se le hagan por la Junta Diocesana. Y el Cavildo acordó pase a los Señores Diputados de Hacienda y de Acólitos e Infantes de Coro, para que informen con llamamiento". 1604

Respecto a la solicitud de los Acólitos, el Cabildo acordó: “que por los Señores Diputados de Hacienda se les dé un socorro, según su prudencia, teniendo en consideración lo que hayan percibido, y siendo a cuenta y con calidad de reintegro de las consignaciones, que a estos Ministros se hagan por la Junta Diocesana”. ${ }^{605}$

\footnotetext{
${ }^{1603}$ Ibid. Jueves 5 de Diciembre de 1822. T. 106, fol. 262 v.

${ }^{1604}$ Ibid. Jueves 19 de Diciembre de 1822. T. 106, fol., 267 v.

${ }^{1605}$ Ibid. Lunes 23 de Diciembre de 1822. T. 106, fol. 268 r.
} 


\section{CAPÍTULO 6. JAIME BALIUS Y VILA.}

\subsection{NOTICIAS BIOGRÁFICAS. ${ }^{1606}$}

Cuando en 1785 llega Balius a Córdoba, sus funciones como Maestro de Capilla son las anteriormente establecidas en el apartado 5.1., que coinciden con las acostumbradas en la mayoría de las catedrales y que se pueden resumir así: La dirección de la Capilla, la composición de las obras estipuladas, las funciones como juez de oposiciones, el cuidado y archivo de las partituras, etc. Como desde 1771 existe en Córdoba el Colegio de Infantes de Coro, Balius no está obligado a hospedarlos en su casa, ni correr con los gastos de su manutención.

Dicho esto, intentaremos a continuación dibujar un retrato de su vida, valiéndonos de los datos ya conocidos y sobre todo de las noticias que sobre él nos deparan las actas capitulares, las cuentas de Fábrica, etc.

Hemos dividido este apartado en cuatro partes. En la primera nos ocupamos de la trayectoria de Jaime Balius anterior a su llegada a Córdoba. En la segunda se aborda su primera estancia en Córdoba, breve por otra parte. En la tercera, su también breve estancia en Madrid, en el Convento de la Encarnación. Por último, en la cuarta parte abordamos su vuelta definitiva a Córdoba, donde será Maestro de Capilla hasta su muerte. Para ello hemos utilizado amplio material bibliográfico del que se da debida cuenta a pie de página, así como referencias contenidas en actas capitulares o en otros documentos oficiales. ${ }^{1607}$

\footnotetext{
${ }^{1606}$ En la confección de este capítulo hemos tratado de realizar una reconstrucción lo más aproximada posible de la vida pública y privada de Jaime Balius y Vila. Para ello hemos utilizado diversos documentos, desde crónicas de la época, datos procedentes del Padrón Municipal de Córdoba, Actas Capitulares, etc., todos ellos explicitados oportunamente en notas a pié de página. En el caso de las Actas Capitulares, hemos entresacado algunas, las más representativas, procedentes del Vaciado cronológico de noticias musicales.

${ }^{1607}$ Desgraciadamente hasta el momento, no hemos podido encontrar su partida de bautismo ni su expediente de limpieza de sangre. En el primer caso, nos confirman en la parroquia de Santa María del Mar de Barcelona (donde fue bautizado), que durante la guerra civil española se quemaron los archivos de dicha parroquia. En el caso del expediente de limpieza de sangre, no se ha localizado aún en la Catedral de Córdoba ni en la Catedral de Gerona. Sin embargo, tenemos la suerte de que en su día, una parte de dicho expediente, fuera volcado en las actas capitulares de la Catedral cordobesa, como veremos en breve.
} 


\subsubsection{ANTES DE SU LLEGADA A CÓRDOBA. 1750-1785.}

Jaime Balius y Vila nace en Barcelona a finales de 1750 (siendo bautizado el día 15 de Noviembre de ese año en la parroquia de Santa María del Mar), ${ }^{1608}$ y muere en Córdoba el 3 de Noviembre de 1822. Desde muy pronto manifiesta su interés por la música, ingresando en la Escolanía de Montserrat y en 1778, con veinte y ocho años, ya es Maestro de Capilla de Catedral de La Seu d’Urgell. ${ }^{1609}$ En 1780, cuando ya contaba treinta años de edad, es ordenado presbítero por el obispo de Lérida don Joaquín Antonio Sánchez Ferragudo. ${ }^{1610}$ Inmediatamente manifiesta su deseo de cambiar de destino, ya que a partir del verano de 1780 se presenta a oposiciones de Maestro de Capilla en las catedrales de Oviedo, El Burgo de Osma (Soria) y Toledo:

En Oviedo, tras morir el día 6 de Mayo de 1780 Pedro Furrió, hasta entonces Maestro de Capilla, se convocan pruebas para cubrir la vacante. A las mismas se presentan Joaquín Lázaro, Jaime Balius, García de Carrasquedo y Francisco Nájer. ${ }^{1611}$ A finales de Agosto, el Cabildo ya tiene los ejercicios de los opositores. ${ }^{1612}$ Sin embargo no será hasta Enero del año siguiente cuando se resuelva la oposición. Según nos dice Gloria Ballus, el día 15 de Enero de 1781 el Cabildo ovetense trata el tema:

"presentaron la censura de los maestros de capilla de Sevilla (Antonio Ripa) y Málaga (Jaime Torrens) a las obras de los opositores al magisterio de capilla vacante

\footnotetext{
${ }^{1608}$ Así se refleja en su Memorial de Genealogía que está contenido en: A.C.C. Actas Capitulares. Martes 7 de Junio de 1785, T.90, f.130v.

${ }^{1609}$ El 10 de Noviembre de ese año, Jaime Balius eleva la siguiente solicitud al Cabildo de la Seu d’Urgell: “Jaime Balius, Maestro de Capilla de V.S. con la más atenta veneración expone: Como deseando promoverse á los Sagrados Órdenes se ve impossibilitado de lograr sus deseos sin el amparo de su V.S.: por lo que con toda submission suplica a V.S. se digne concederle la gracia de la perpetuidad neccesaria: Favor que espera del proceder de V.S.”. El Cabildo resuelve afirmativamente: “...se concede al suplicante la perpetuidad que solicita...”. Cf. ROIG I CAPDEVILA, Jordi. "Presencia musical en la Catedral de la Seu d’Urgell en la segunda mitad del siglo XVIII a través de sus actas capitulares”. Anuario Musical, 59. Barcelona, Consejo Superior de Investigaciones Científicas, Institución “Milá i Fontanals”, Departamento de Musicología, 2004, pág. 448. A su vez, Roig extrae la información de: Archivo de la Catedral de la Seu d’Urgell. Libro de Resoluciones de 1769 hasta 1792, día 14 de Noviembre de 1778, fol. 151r.

${ }^{1610}$ Cf. NIETO CUMPLIDO, Manuel: “Maestros de Capilla de la Catedral de Córdoba”. Boletín de la Confederación Andaluza de Coros de 1995. Ed. CO.AN.CO. Córdoba, 1995, págs.11 y 12.

1611 Cf. MARTÍN MORENO, Antonio. Historia de la Música Española. Siglo XVIII. Madrid, Alianza Editorial, 1985, pág. 131.

${ }^{1612}$ Cf. BALLUS CASOLIVA, Gloria: La música a la Colegiata Basílica de Santa María de la Seu de Manresa: 1714-1808. Tesis Doctoral. Universidad Autónoma de Barcelona, 2004, vol. II, pág. 6.
} 
en esta iglesia y también el dictamen de los examinadores nombrados por los srs. Comisarios, que fueron don Juan Lombida, don Manuel Saliella, don Manuel Vigil y don José Alvarez y en su vista se acordó que se pongan las censuras para que cualquier señor las pueda ver y que para el primer cabildo ordinario se llame ante diem para la provisión de este magisterio". 1613

El final del proceso es el día 19 de Enero, cuando el Cabildo, tras una votación, decide lo siguiente:

“...se hallaron siete tarjetas en el cajón que decía Mondoñedo [Lázaro], seis en la que decía Lugo [Nájer], siete en la que decía Urgel [Balius] y once en la que decía Santander [García Carrasquedo] y no teniendo ninguno la mayor parte y estando iguales en votos Mondoñedo y Urgel, se volvió a votar cuál de los dos hubiese de entrar en escrutinio con Santander y habiendo tenido Mondoñedo 18 y Urgel 14, se declaró deben entrar en escrutinio Mondoñedo y Santander y vuelto a votar, tuvo Mondoñedo 18 y Santander 12 votos y uno en otro casilla, con lo que quedó electo Mondoñedo, a quien se mandó avisar". ${ }^{1614}$

Joaquín Lázaro aceptó el puesto y “el 10 de Febrero de 1781 tomó posesión de la plaza”. ${ }^{1615}$

Como hemos visto, Balius no pudo ganar la oposición, aunque durante un momento de la votación, mantuvo un empate con el finalmente elegido, Joaquín Lázaro. Allí en Oviedo quedaron sus obras, de las que al menos conocemos tres, que son las siguientes:

1. Do mare cordis impetus, Himno a $8 \mathrm{~V}(\mathrm{~S}, \mathrm{~S}, \mathrm{~A}, \mathrm{~T}, \mathrm{~S}, \mathrm{~A}, \mathrm{~T}, \mathrm{~B})$, bc (para la oposición de 1780). (Legajo 20).

2. Quemdmodum desiderat, Salm a 8 V (S, A, T, B, S, A, T, B), bc. (ejercicio para la oposición de Oviedo de 1780). (Legajo 20).

\footnotetext{
1613 Ibid. pág. 7.

1614 Ibid. pág. 8.

${ }^{1615}$ CASARES, E. y otros: “Joaquín Lázaro”, en: Diccionario de la Música Española e Hispanoamericana. Madrid, Sociedad General de Autores, 1999, Vol. 6, pag. 819.
} 
3. La Fragante azucena. Villancico a 8 V (S, S, A, T, S, A, T, B), violines, flautas, cornos y bc. (para la oposición de 1780). (Legajo 20). ${ }^{1616}$

Antes de conocer oficialmente la decisión del cabildo de Oviedo, que como hemos visto, se produce en Enero de 1781, Balius ya se presenta a otra catedral, en este caso la del Burgo de Osma:

"Siendo MC de La Seo de Urgel pretendió el magisterio de la catedral de El Burgo de Osma, solicitando a su Cabildo (13-IX-1780) que tomase informes de él. Como estos fueron muy favorables se le nombró para el magisterio (25-X-1780). El 22 de Noviembre prometió acudir a su nuevo puesto con la mayor brevedad, pero el 15 de Marzo de 1781 se recibió su carta de renuncia, pues la catedral de Girona le había conferido igual puesto y por ello se había visto precisado $<<$ a ceder al amor de su país de nacimiento, a las instancias de sus parientes y amigos, y especialmente a las de su anciano tío, a quien debe todo su ser >> ". 1617

Según nos dice en conversación personal la doctora Gloria Ballus Casoliva, el “anciano tío” a que se hace referencia es Joan Vila, organista de la Iglesia de Santa María del Pino de Barcelona, hasta su muerte en 1791.

El nombramiento en la catedral de El Burgo de Osma se realiza tras elegir entre Balius y Juan Antonio Juanes. A este respecto sabemos que "son dos los que aspiran a ella: Juan Antonio Juanes, Maestro de Capilla en Alcalá y Jaime Balius, de la Seo de Urgel. El Cabildo decide proveerla según el turno establecido entre él y el Obispo, en Jaime Balius, pero meses más tarde éste escribe comunicando haber obtenido plaza en Gerona”. ${ }^{1618}$ Efectivamente, Balius envía un certificado del Cabildo de Gerona en donde figura su nombramiento:

\footnotetext{
${ }^{1616}$ Cf. BALLUS CASOLIVA, Gloria: La música a la Colegiata Basílica de Santa María de la Seu de Manresa: 1714-1808. Tesis Doctoral. Universidad Autónoma de Barcelona, 2004, vol. II, pág. 35.

1617 GARBAYO, Javier: "Balius Vila, Jaime”, en: CASARES, E. y otros: Diccionario de la Música Española e Hispanoamericana. Madrid, Sociedad General de Autores, 1999, Vol 2, pag. 111.

${ }^{1618}$ PALACIOS SANZ, José Ignacio. Tres siglos de música en la Catedral del Burgo de Osma. Soria, Centro de Estudios Sorianos, 1991, pág. 140.
} 
“[...] Fue presentado por D.n Jayme Balius P.btro Maestro que fue de capilla de nuestra Santa Iglesia el certificado del Canónigo Secretario del Cabildo de la Santa Iglesia de Gerona D.n Felipe de Bojons, que certifica que en los libros de Acuerdos Capitulares que paran en su poder está resuelto que el día nueve del mes pasado el Cabildo de aquella Santa Iglesia admitió por Maestro de Capilla de ella a D.n Jayme Balius, y que el DIA diez y siete de los mismos Mes y Año le perpetuó en el expressado Magisterio señalándole para su congrua sustentación sobre los frutos y productos del magisterio la cantidad que por leyes del Obispado de Gerona se requiere para la congrua sustentación, qual subrogación y señalamiento fue admitido, y aprobado por el provisor de aquel obispado Presidente de dicho Cabildo cuyo certificado dio dicho secretario en Gerona a los 22 de Febrero del corriente Año de 1781 [...]”. 1619

Así pues, a pesar de haber obtenido la plaza en El Burgo de Osma, renuncia a ella por haber obtenido la de Gerona, pero antes aún prueba fortuna en la Catedral de Toledo, a finales de 1780. La oposición estuvo muy reñida pero la plaza la ganó Francisco Juncá, que era Maestro de Capilla de Gerona, aunque ambos sacaron la misma puntuación en los ejercicios. ${ }^{1620}$ El día 16 de Diciembre de 1780 Juncá consigue la importante plaza de Toledo. ${ }^{1621}$

Una de las obras presentadas por Balius para dicha oposición a Toledo fue esta Misa que en su título dice a 4 y a 8 voces, aunque luego también incluye particellas de un Coro $3^{\circ}$, y que se conserva en el archivo de la Catedral de Córdoba:

Missa con Violines, Oboes y Trompas. A 4 y a 8 [a 12] voces. Se cantó por obra voluntaria en la Santa Yglesia de Toledo. Del Maestro D. Jayme Balius Pbro.

Género: Mixto. Plantilla: Coro $1^{\circ}$ : SATB. Coro $2^{\circ}$ : SATB. Coro $3^{\circ}$ : SATB. 1 Violín $1^{\circ}$, 1 Violín $2^{\circ}$, 1 Contrabajo, 2 Oboes, 2 Trompas, 1 Órgano y acompañamiento.

Partitura: Sí. Conservación Partitura: Regular. Particellas: Sí. Conservación Particellas: Buena. Año: 1780.

Observaciones: En el interior otra nota manuscrita dice: "Esta obra se cantó en la Cathedral de Toledo por obra voluntaria de mi oposición. Año 1780. Jayme Balius

1619 BALlUS CASOLIVA, Gloria: La música a la Colegiata Basílica de Santa María de la Seu de Manresa: 1714-1808. Tesis Doctoral. Universidad Autónoma de Barcelona, 2004, vol. II, pág. 10, que a su vez cita el Llibre de Resolucions de la Seu d'Urgell, 1769-1792, num. 1027, fol. 184v.

${ }^{1620}$ Cf. MARTín MORENO, Antonio. Historia de la Música Española. Siglo XVIII. Madrid, Alianza Editorial, 1985, pág. 88.

${ }^{1621}$ Ibid. pág. 96. 
Pbro.". Hay particellas de Coro $3^{\circ}$. La partitura solo tiene Kyrie y Gloria. En las particellas sí está la misa completa. Signatura: 14 / 108 en el A.C.C.
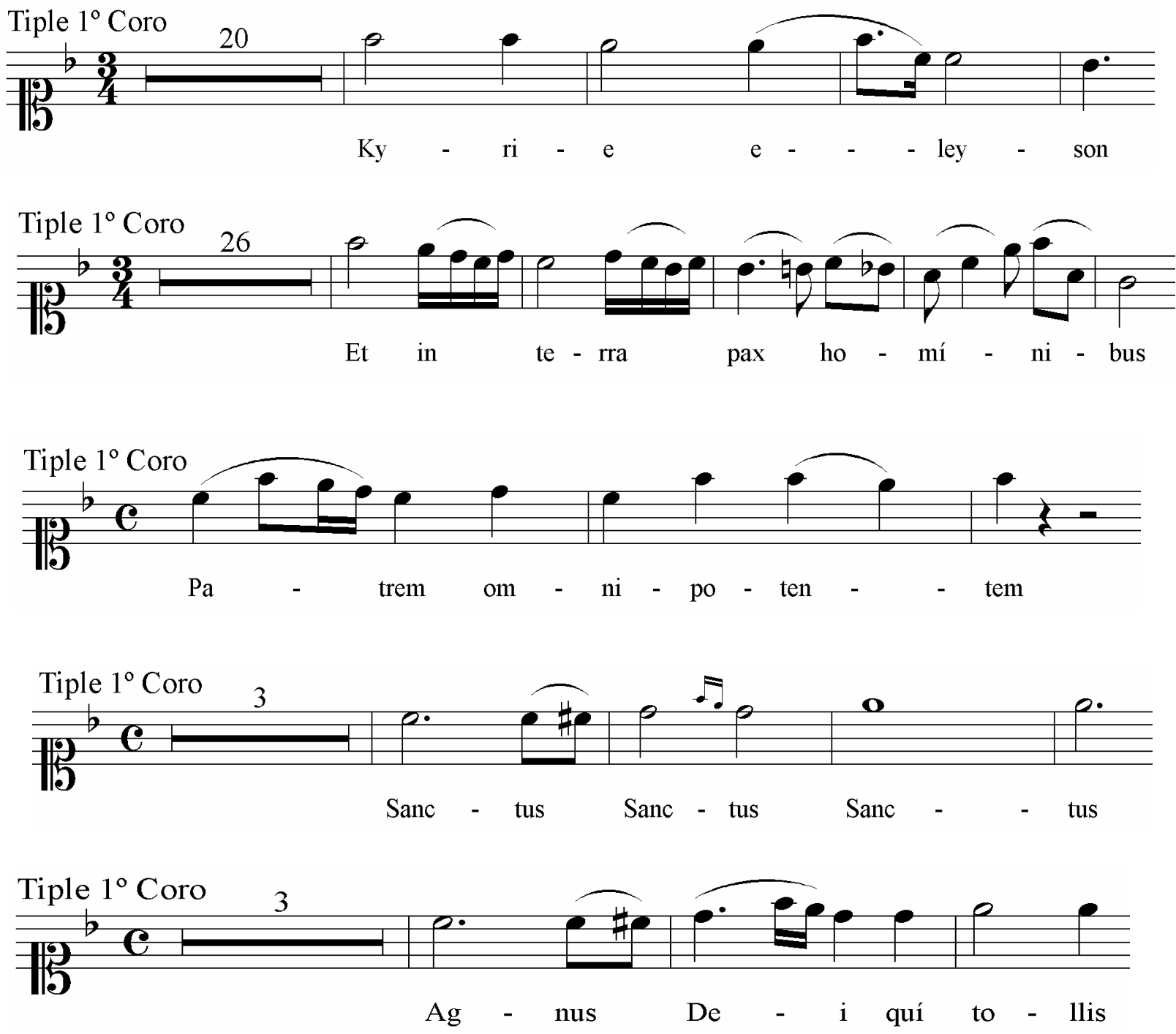

Aquí termina el recorrido de Balius por diversas ciudades, antes de ir a Gerona, sucediendo precisamente a su contrincante en Toledo, el Maestro Juncá. Resumimos sus movimientos en el siguiente organigrama: 


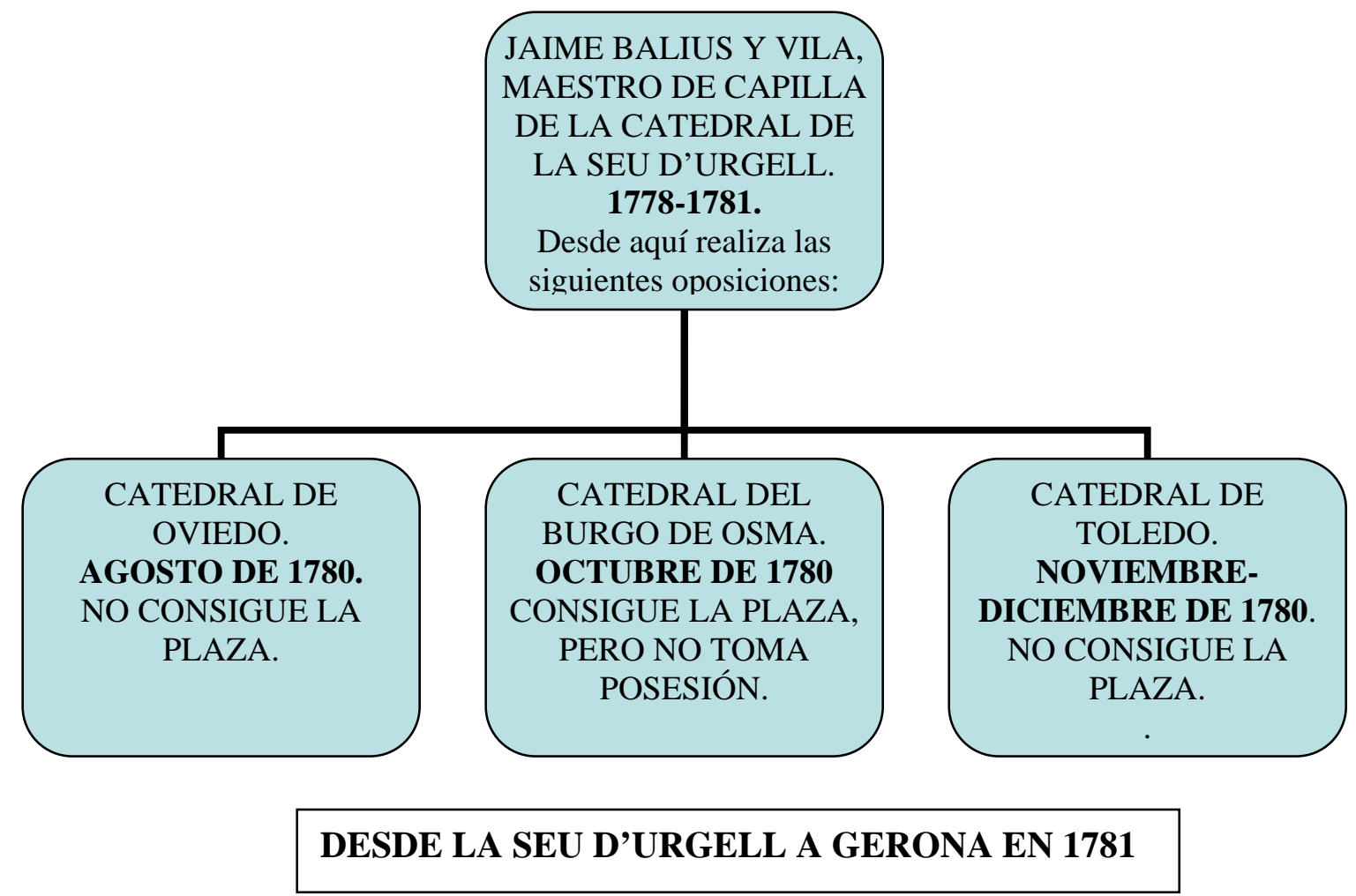

Así pues, pasa de la Seu d’Urgell a Gerona. Allí Jaime Balius y Vila es nombrado Maestro de Capilla el día 9 de Febrero de 1781. “Día 9 de Febrer se mudá lo Mestre per ascenso del R. Fran. Juncá al magisteri de Toledo y entra per Mestre en esta lo R. Jaume Balius y Vila, Mestre de Capella que era de la Cathedral de la Seu de Urgell co-opositor al sobre dit Magisteri de Toledo, en lo cual lográ igual graduació ab lo provist”. ${ }^{1622}$

Durante su estancia en Gerona desarrolla de forma importante su faceta de compositor, dejando alrededor de veinte obras para coro y orquesta, además de participar en tribunales de oposición y de formar a buenos discípulos. ${ }^{1623}$

\footnotetext{
${ }^{1622}$ Llibri dels Noms, y Cognoms dels Escolans del Cor, y / Capella de música de la Santa Isglesia de Gerona. Folio 7.

1623 “La estada d'en Balius a Girona no s'allargá més de quatre anys, i no obstant deixá a l'Arxiu unes vínt obres d'empenta: miserere a 9 veus i orquestra; oratoris, 2 Te Deum, etc, etc., independentment de tot alló seu corresponent a aquesta época i avui, catalogat en la Bibl. Cent. de Barcelona. Conegué d'aprop al gran Mtre. Gonima, llavors jubilat, de qui rebé certament consell i si més no exemple, havent colaborat junts en mants tribunals d'oposicións; així mateix tingué ocasió de formar de molt bons deixebles, entre elles al futur Mtre. Joseph Pons, un seu ecolar de cor. L'any 1785 es mudá Balius de Mtre. a la Catedral de Cordova”. CIVIL CASTELLVÍ, Francesc: El fet musical a les comarques gironines en el lapse de temps 1800-1936. Gerona, Caja de Pensiones, 1970, pág. 12.
} 
Como acabamos de ver (en la última nota a pié de página), uno de sus alumnos en Gerona fue José Pons. Bien merece Pons que le dediquemos unas líneas por las siguientes razones: Entre los alumnos de Balius, éste fue probablemente su preferido. Hasta tal punto, que -como tendremos ocasión de demostrar más adelante-, cuando Balius viaja a Córdoba por primera vez, se lleva a Pons con él, incluso lo aloja en su propia casa. La enseñanza personalizada que recibe, hace que Pons vaya convirtiéndose en un músico de gran calidad. Fue Maestro de Capilla de la Catedral de Gerona (de 1791 a 1793), y también Maestro de Capilla de la Catedral de Valencia (de 1793 a 1818). ${ }^{1624}$ Según Martín Moreno, a Gerona "Ilegó como viceMaestro de la Catedral de Córdoba". ${ }^{1625}$ No hemos podido encontrar hasta ahora el nombramiento de Pons para dicho cargo, sin embargo, es cierto que él mismo se presenta como tal en la correspondencia que mantiene con la Catedral de Tuy. El Cabildo de dicha catedral publica el día 10 de Marzo de 1790 un edicto para cubrir la plaza de Maestro de Capilla. Pons se entera, y les envía la siguiente carta:

"Córdova Abril 9 de 1.790. Illmo. Señor: D. Josef Pons Clérigo tonsurado, de edad de veinte años cumplidos, opositor que a sido a los Magisterios de Capilla, de la Santa Iglesia Magistral de Alcalá de Henares en donde desempeñó los actos de oposición con todo lucimiento; Y en el de Nuestra Señora de la Soledad de Madrid, donde mereció la primera letra, ÿ preeminencia entre siete opositores, como consta del testimonio que tiene en su poder; $\ddot{y}$ últimamente en la Santa Igl ${ }^{a}$ Cathedral de Salamanca, en la qual oposición si V.S.I. tubiere a bien el informarse de los Jueces $\ddot{y}$ sugetos inteligentes (ô mejor pedir las obras que trabajo en dicha oposición) claramente dirán lo que sobresalió de los demás opositores; ÿ actualmente las obras suÿas que se cantan en esta St Igl $^{a}$ Cathedral con motivo de ser vice Maestro, $\ddot{y}$ discípulo de D. Jaÿme Balius Maestro de Capilla de dicha St ${ }^{o}$ Igl $^{a}$. =dice â V.S.I. haver visto un edicto llamando a la oposición del Magisterio de Capilla de esa Santa Igla . A cuÿa oposición no se determina â pasar, por motivo de la dilación del viaje, ÿ por otra parte el gran gasto que no puede soportar. Por tanto= Suppca. a V.S.I. que se digne

\footnotetext{
${ }^{1624}$ Para más información acerca de Josep Pons y de la relación e influencia que tuvo Jaime Balius sobre él, ver: RAMÍREZ Y BENEYTO, Ramón. El compositor Josep Pons i el llenguatge musical per a la liturgia de l' ordinarium: "Misa a 4 y a 8 con oboes, violines y trompas sobre la antífona ecce sacerdos magnus" (1786). Tesis doctoral. Valencia, Universidad de Valencia, Servicio de Publicaciones, 2005.

${ }^{1625}$ MARTÍN MORENO, Antonio. Historia de la música española. Madrid, Alianza Editorial, colección Alianza Música, 1985, volumen IV, pág. 173.
} 
dispensarle el que haga la oposición desde esta Ciudad, en la forma que V.S.I. tubiere por conveniente, ô franquearle el viage, a lo qual estaría eternamente agradecido $\ddot{y}$ rogaría a Dios nuestro Señor leg. M. A. B.L.M. de V.S.I. su mas atento servidor. Josef Pons". 1626

Cabría pensar en la posibilidad (hasta poder encontrar el nombramiento), de que Pons ayudara en la Catedral de Córdoba a Balius en sus labores como Maestro de Capilla de manera extraoficial. En cualquier caso, esta circunstancia no es óbice para que sea considerado como un gran músico. Tal y como dice Martín Moreno, “José Pons es otro de los más importantes compositores de la segunda mitad del siglo XVIII". ${ }^{1627}$

Como hemos dicho, Pons fue quizás el alumno de Balius que obtuvo mayor notoriedad, pero no fue el único. A través de las citas siguientes conocemos algún otro de los que tuvo en Gerona: “Jacint Freixedes escolá del 1784 al 1787 fou contralt i violí de la capella de música fins l'any 1810. Es formá musicalment am el mestre Jaume Balius”. 1628 "Romuald Huguet era músic laic de Girona que començá el seu aprenentatge musical com a escolá del cor de la capella de Música, tenint com a Mestre Jaume Balius i Vila”. 1629

Así transcurren los cuatro años y tres meses que Balius pasa allí. Curiosamente, el mismo año en que Balius es nombrado Maestro de Capilla de la Catedral de Gerona, se produce en la Catedral de Córdoba una circunstancia que llenará muchas líneas de las actas capitulares y que al final acabará por afectarle. La cosa comienza el 6 de Octubre de 1781, cuando el Cabildo cordobés aprueba la convocatoria de oposición para cubrir la plaza de Maestro de Capilla, por jubilación del anterior, Gaitán y Arteaga, al cual sustituye de forma interina Dionisio de la Mata. ${ }^{1630}$

Se produce a partir de entonces una larguísima disputa entre los capitulares sobre competencias en el nombramiento de Maestro de Capilla. Estas profundas

\footnotetext{
${ }^{1626}$ RAMÍREZ Y BENEYTO, Ramón. El compositor Josep Pons i el llenguatge musical per a la liturgia de l' ordinarium: "Misa a 4 y a 8 con oboes, violines y trompas sobre la antífona ecce sacerdos magnus" (1786). Tesis doctoral. Valencia, Universidad de Valencia, Servicio de Publicaciones, 2005, pág. 203. ${ }^{1627}$ Ibid.

${ }^{1628}$ GALDÓN I ARRUE, María Montiel. La música a la Catedral de Girona durant la primera meitat del segle XIX. Tesis Doctoral. Universidad Autónoma de Barcelona. Departamento de Arte, pág. 341. ${ }^{1629}$ Ibid. pág. 660.

${ }^{1630}$ A.C.C. Actas Capitulares. 6 de Febrero de 1781. T.88, fol. 306v.-308v.
} 
divergencias entre canónigos, dignidades, racioneros y medios racioneros acerca de quién tenía capacidad para intervenir en la elección del Maestro de Capilla y de los músicos, hicieron que se paralizara la convocatoria, dilatándose en el tiempo el nombramiento del nuevo Maestro.

Se vuelve a convocar la oposición el 15 de febrero de 1785. Se presentan los siguientes opositores: “Juan Bueno, natural de Palma, Arzobispado de Sevilla, de 42 años, D. Juan Domingo y Vidal, natural de la villa de Reus, Arzobispado de Tarragona, tonsurado, de 47 años, y D. Joseph Feygido y Barceló, natural de la villa de Seros, Obispado de Lérida, de 30 años de edad". ${ }^{1631}$

Juan Bueno era Maestro de Capilla de la parroquia de San Pedro de Sevilla. ${ }^{1632}$ Juan Domingo Vidal, ${ }^{1633}$ era Maestro de Capilla de la Colegiata del Salvador de Sevilla y Joseph Feygido era ViceMaestro de la Real Capilla de S.M. y de su Real Colegio de Música en Madrid.

Sin embargo, antes de elegir entre uno de los tres citados se presenta otro aspirante. El 6 de mayo, el arcediano Medina y Corella comunica la presentación de un opositor que no era otro que el Maestro de Capilla de Gerona, Jaime Balius y Vila. ${ }^{1634}$ Como jueces fueron nombrados don Juan Manuel Gaitán, (Maestro de Capilla jubilado), don Francisco de Ayala (primer organista) y don Mateo Bernia (músico Capellán de Santa Inés).

\subsubsection{SU PRIMERA ETAPA EN CÓRDOBA. 1785-1787.}

Efectivamente, el viernes día 6 de mayo de 1785 se celebra un Cabildo en la Capilla de San Clemente "a la hora sexta", en el cual se informa de lo siguiente: "Por el señor Arcediano de Pedroches, Diputado de Arcas de Santa Inés se dio noticia al

\footnotetext{
1631 A.C.C. Actas Capitulares. 15 de Febrero de 1785. T.90, fol. 93r.

1632 NIETO CUMPLIDO, Manuel: “Maestros de Capilla de la Catedral de Córdoba”. Boletín de la Confederación Andaluza de Coros de 1995. Ed. CO.AN.CO. Córdoba, 1995, pág.11.

1633 Juan Bautista Vidal, según nos dice Garbayo en el mencionado Diccionario de la Música Española e Hispanoamericana. Vol.2., pag. 111.

${ }^{1634}$ A.C.C. Actas Capitulares. 6 de Mayo de 1785. T.90, fol. 119r.
} 
Cavildo de cómo se había presentado opositor al Magisterio de Capilla vacante de esta Santa Iglesia el Maestro que es de la de Gerona”. ${ }^{1635}$

Pocos días después, el Lunes 9 de Mayo de 1785, se celebra otro Cabildo en el que se comunica la firma de la oposición por parte de Balius y el comienzo de las pruebas en la tarde de ese mismo día:

“...en este día ha firmado la oposición D. Jaime Balius y Vila, natural de la ciudad de Barcelona, de edad de 35 años, por haberse bautizado (según la partida que ha presentado) en 15 de Noviembre de 1750, y está ordenado de Presbítero en el año de 1780 por el Ilustrísimo Señor Obispo de Lérida; y en la actualidad es Maestro de Capilla de la Santa Iglesia de Gerona; y en vista de esta relación se acordó por este Cavildo que a dicho D. Jaime Balius y Vila se admita a los exercicios de oposición que se acostumbran hazer para el Magisterio de Capilla vacante en esta Santa Iglesia. Y se nombraron por examinadores para asistir á el exercicio, dar puntos y demás concerniente á D. Juan Gaitán, Maestro de Capilla jubilado, á D. Francisco de Ayala, Organista Primero, y á D. Mateo de Bernia, músico Capellán de Santa Inés; y que concluido dicho exercicio, que ha de comenzar en la tarde de este día después de completas, se cogan las obras y se entreguen á los Señores Diputados para que juntas con las demás de los otros opositores que han exercitado, se remitan al Maestro Ripa de la Santa Iglesia de Sevilla a fin de que ponga su censura, y haga juicio comparativo entre los ejercicios de todos los opositores ". 1636

Aunque no ha llegado hasta nosotros el expediente de oposición, sí sabemos que las obras siguientes las compuso Balius para la prueba:

1. Deus tuorum militum. "Himno a San Lorenzo. A 4 y a 8. Con todo instrumental. Por el Sr. Maestro Don Jayme Balius".

Género: Mixto. Plantilla: Coro $1^{\text {o: }}$ SATB. Coro $2^{\circ}$ : SATB. 1 Violín $1^{\circ}, 1$ Violín 2 2 Oboes, 1 Bajón, 2 Trompas y acompañamiento.

Partitura: Sí. Conservación Partitura: Mala. Particellas: Sí. Conservación

${ }^{1635}$ Ibid.

${ }^{1636}$ A.C.C. Actas Capitulares. 9 de Mayo de 1785. T.90, folio 120r. 
Particellas: Regular. Año: 1785.

Observaciones: En la particella de Bajo vocal (de Bajo 2º), dice: "Bajo y Bajón". Según nos dice Civil y Castellví (en el Diccionario de la Música Española e Hispanoamericana, de Emilio Casares, entrada de Balius Vila, Jaime), este himno, "compuesto para las oposiciones a la magistratura de Córdoba, conserva aún su celebridad”.

Signatura: 80 / 623, del A.C.C.

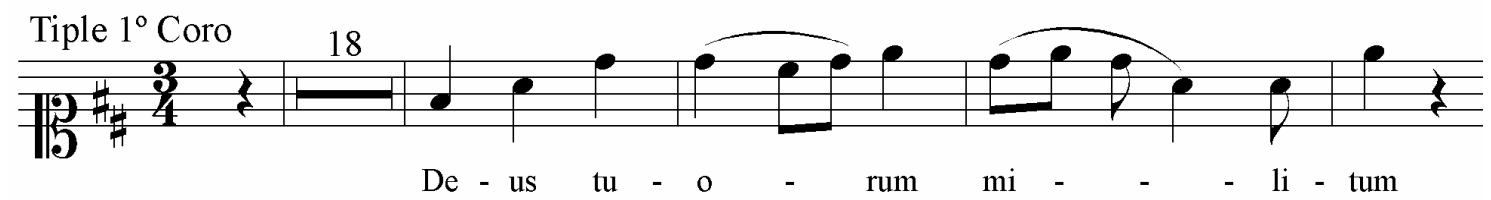

2. Que alegre y complacido. "Aria [y recitado] a Solo. Con Violines, Oboeses y Trompas. De Oposición. Por Don Jayme Balíus. Año de 1785". De Tenor.

Género: Mixto. Plantilla: Tenor. 1 Violín $1^{\circ}, 1$ Violín $2^{\circ}, 2$ Oboes, 2 Trompas y acompañamiento.

Partitura: No. Particellas: Sí. Conservación Particellas: Buena. Observaciones: Obra de oposición al Magisterio de la Catedral de Córdoba. Signatura: 128 / 1248.
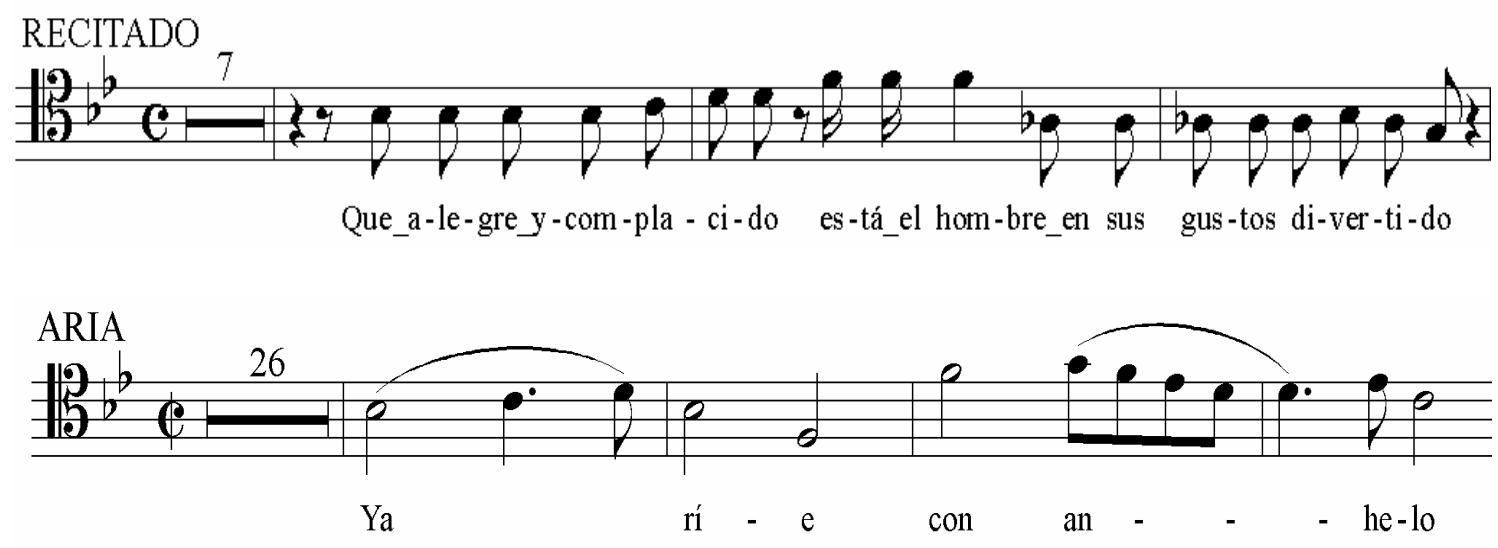

3. Cum vinci tormentis. "Motete a 9 con Instrumentos y sin ellos. De Oposición por D. Jayme Balíus. Año de 1785".

Género: Mixto. Plantilla: Coro $1^{\circ}$ : SSATB. Coro $2^{\circ}$ : SATB. 1 Violín $1^{\circ}, 1$ Violín 2º 1 Contrabajo, 1 Bajón y acompañamiento.

Partitura: Sí. Conservación Partitura: Buena. Particellas: Sí. Conservación 
Particellas: Buena.

Observaciones: Utiliza las siguientes claves: Coro $1^{\circ}$ : Sol en $2^{\mathrm{a}}(\mathrm{S})$, Sol en $2^{\mathrm{a}}(\mathrm{S})$,

Do en $2^{\mathrm{a}}(\mathrm{A})$, Do en $3^{\mathrm{a}}(\mathrm{T})$, Do en $4^{\mathrm{a}}(\mathrm{B})$. Coro $2^{\mathrm{o}}$ : Sol en $2^{\mathrm{a}}(\mathrm{S})$, Do en $2^{\mathrm{a}}(\mathrm{A})$,

Do en $3^{\text {a }}(\mathrm{T})$ y Do en $4^{\text {a }}$ (B). Sirvió como ejercicio de oposición al Magisterio de

Córdoba.

Signatura: 83 / 649.

Tenor de $1^{\circ}$ Coro

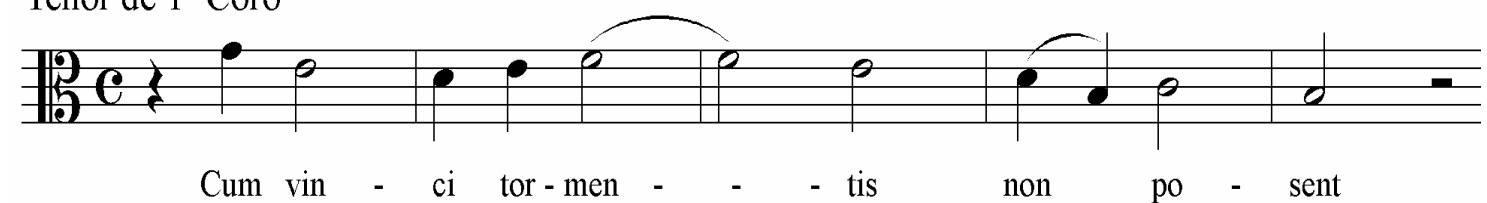

Tiple $1^{\circ}$ de $1^{\circ}$ Coro

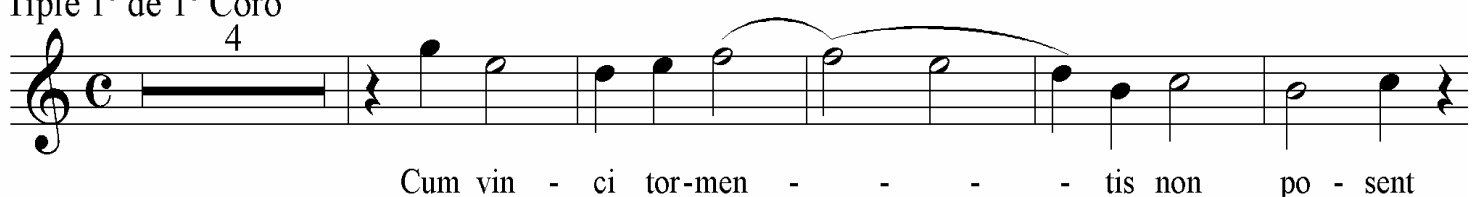

4. Fundamenta ejus. "Salmo a 8 con Violines, $7^{\circ}$ tono punto bajo. Para la oposición del Magisterio de Córdova. Año de 1785. Travajado por Jaume Balius. Maestro de Capilla de la Catedral de Gerona". Género: Mixto. Plantilla: Coro $1^{\circ}$ : SSAT. Coro $2^{\circ}$ : SATB. 1 Violín $1^{\circ}, 1$ Violín $2^{\circ}$, 1 Violón, 1 Contrabajo y acompañamiento.

Partitura: Sí. Conservación Partitura: Buena. Particellas: Sí. Conservación Particellas: Buena.

Observaciones: Falta el papel de acompañamiento. De oposición.

Signatura: 10 / 79.
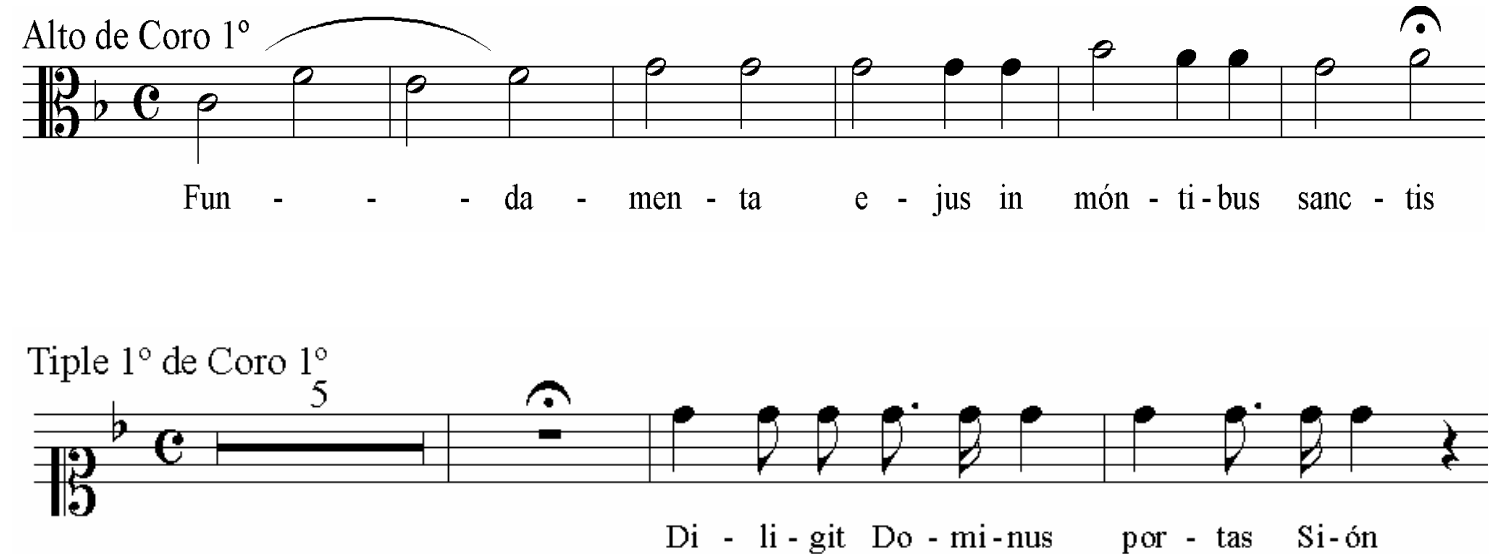
5. La fábrica suprema. "Villancico a 8. Con Violines, Oboeses y Trompas. De Oposición. Por D. Jayme Balíus y Víla. Año de 1785".

Género: Mixto. Plantilla: Coro $1^{\circ}$ : SSAT. Coro $2^{\circ}$ : SATB. 1 Violín $1^{\circ}, 1$ Violín 2º, 1 Viola, 1 Violón, 2 Oboes, 1 Bajón, 2 Trompas y acompañamiento.

Partitura: Sí. Conservación Partitura: Buena. Particellas: Sí. Conservación Particellas: Buena.

Observaciones: En la partitura, dice: "Villancico a 8 con Violines, Oboes y Trompas travajada dentro de las 24 horas por mi, Jaÿme Balius y Vila, Maestro de la Catedral de Gerona. Día 9 de Maio de 1785 para la oposición del Magisterio de la Cathedral de Córdoba". Falta particella de viola. Contiene una larga introducción de 96 compases.

Signatura: 90 / 750.

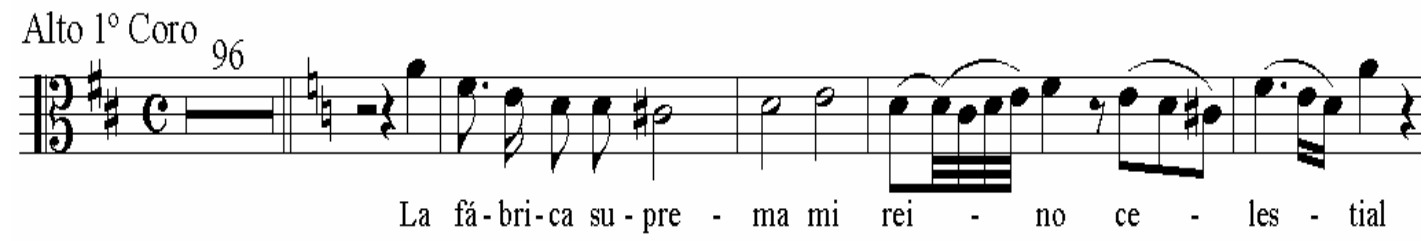

Tiple $1^{\circ}$ de $1^{\circ}$ Coro

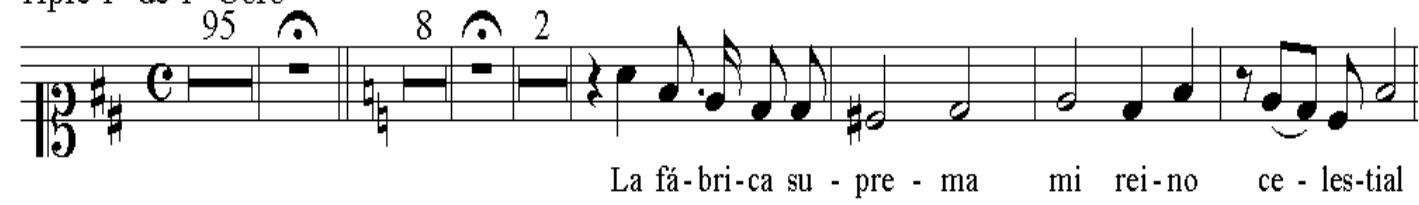

El villancico La fábrica suprema, fue la primera obra que compuso para la oposición, ya que sabemos por las actas capitulares que dicha prueba comenzó el día 9 de mayo por la tarde, y como acabamos de ver por la nota que él mismo pone en la partitura, el mismo día empezó el villancico.

Viendo estas cinco composiciones, podemos comprobar que no se trata de obras menores, ni en extensión ni en la plantilla empleada. Recordemos que cuatro de ellas son para 2 Coros y Orquesta, y sólo una, el Recitado y Aria, es para un solista y orquesta. En el caso del villancico que acabamos de comentar, ha hecho una introducción orquestal de 96 compases, una de las más largas de todas sus obras. 
El día 3 de Junio ya se tienen los resultados de las oposiciones y en el correspondiente Cabildo se comunica que tras las oportunas votaciones...

“...salió nombrado D. Jaime Balius y Vila, Presbítero, Maestro de Capilla de la Santa Iglesia de Gerona, y uno de los cuatro opositores, por todos los votos en el Magisterio de Capilla de esta Santa Iglesia bajo la condición de sugestarse a las reglas prescriptas y que se prescrivan para el exercicio de dicho Magisterio por este Cavildo, y se mandó despachársele el título correspondiente, como se hizo a D. Juan Gaitán, su inmediato antecesor, con los mismos honores y franquicias que disfrutó desde luego, $y$ que se le corra la renta señalada desde el día de hoy inclusive, deviendo asistir a el Coro, y cumplir con todas las obligaciones del Maestro de Capilla, y a este fin también se mandó pasar el correspondiente decreto a la Diputación del Punto de Coro para que se le haga el correspondiente asiento y en las faltas sea aspado lo mismo que se practica con los demás Ministerios asalariados; y que el dicho D. Jaime presente el memorial de su genealogía para las pruevas de limpieza conforme a Estatuto; [...] En atención a los gastos que ha tenido y tiene el dicho D. Jaime Balius Maestro de Capilla se le concedieron de ayuda de costa por una vez cien doblones.

Ittem se dio comisión amplia a los Señores Diputados de Arcas de Santa Inés para que teniendo presente el honor de esta Santa Iglesia gratifiquen á el Maestro Ripa, y hagan los demás gastos que ocurran relativos á el Magisterio de Capilla, y estado último de su provisión". 1637

En sesión capitular de 7 de junio se presentó su genealogía y se dispuso la ejecución del expediente de limpieza de sangre sobre el que se informó en sesión de 22 de diciembre del mismo año, día en que, finalmente, tomó posesión de su oficio. Fruto de dicho expediente que incluye su genealogía, podemos conocer más datos de su biografía.

PRETENDIENTE

D. Jaime Balius pbro natural de Barcelona

bautizado en la Parroquial de Santa María del Mar

en 15 de Noviembre de 1750.

${ }^{1637}$ A.C.C. Actas Capitulares. 3 de Junio de 1785. T.90, folio 126 r. 


\section{PADRES}

D. Francisco Balius y $D^{a}$ Cerafina Vila naturales

de dicha ciudad de Barcelona

ABUELOS PATERNALES

D. Joseph Balius, natural de la ciudad de Cardona

Obispado de Solsona y Victoria Muliet natural de la

Ciudad de Manresa Obispado de Vique.

\section{ABUELOS MATERNALES}

D. Antonio de Vila natural del Lugar de Antes de dicho

Obispado de Vique y $D^{a}$ Serafina Serra natural de

dicha ciudad de Barcelona. ${ }^{1638}$

De su salida de Gerona para venir a Córdoba, también queda constancia en el libro de integrantes de la Capilla Musical de aquella ciudad, donde consta que le sustituyó Domingo Arquimbau. ${ }^{1639}$

El día 6 de Julio, hay oposiciones para cubrir dos vacantes en el Colegio de Infantes de Coro de Córdoba. En este día se presenta un informe de Jaime Balius, en la que es su primera actividad como tal, recogida en las actas capitulares: ${ }^{1640}$ "Se mandó entrar á el Rector de dicho Colegio, el que informó de todas las circunstancias que concurren en los opositores, é hizo su juicio comparativo; y haviéndose retirado, se leyó otro informe del Maestro de Capilla. Y concluído se dio comienzo al examen de

\footnotetext{
1638 A.C.C. Actas Capitulares. Martes 7 de Junio de 1785, T.90, f.130v.

1639 “Día 4 de Juliol de 1785. Se mudá lo Mestre per ascenso del R. Jayme Balius al Magisterio de Córdova y entra per Mestre en esta lo R. Domingo Arquimbau Acolito Mestre que era de la Cathedral de Tortosa y de la Villa de Torroella de Mongri y tingue lo honor de tenir tres Maestrias Plagadas 3 Mesos ÿ se quedá en la Cathedral de Gerona.” Llibri dels Noms, y Cognoms dels Escolans del Cor, y / Capella de música de la Santa Isglesia de Gerona. Folio 7v.

${ }^{1640}$ Nótese que el Maestro empieza a actuar por la urgencia del momento aún antes de haber tomado posesión de su cargo (Diciembre de 1785).
} 
leer, escribir y cantar. ”. Finalmente quedaron nombrados Antonio Díaz y Rafael de León. $^{1641}$

Parece que durante algún período del verano de 1785, Balius abandonó Córdoba para ir a su tierra, estando de vuelta como muy tarde en Octubre. ${ }^{1642}$ De hecho en Octubre es solicitada su presencia para formar parte de un tribunal para cubrir la vacante de la Capilla de San Antonino, por la muerte de D. Joseph de los Ríos, decidiendo el Cabildo, que a los dos examinadores que estaban designados, "se agregue el Maestro de Capilla, respecto de estar ya en la ciudad". ${ }^{1643}$ Ya tenemos por tanto, a Jaime Balius de forma segura establecido en Córdoba, al menos por algún tiempo.

Recién llegado a la ciudad, se instala en la casa $n^{\circ} 23$ del Cabildo, sita en la Plazuela de la Concha. ${ }^{1644}$ Esta plaza se encuentra en la calle Carniceros (hoy en día Martínez Rucker), apenas a 50 metros de la Catedral. Pero no vive solo, sino que junto a él viven "Don Josef Pons, tonsurado, su discípulo, de 16 años. D. Francisco Balius, su sobrino, de 13, y una sirvienta de 30 años". 1645

De inmediato comienzan todos a ocuparse de sus funciones. Balius en calidad de Maestro de Capilla es avisado -como hemos visto anteriormente- para formar parte de un tribunal. Su sobrino Francisco Balius y su discípulo José Pons estudian mientras tanto, y poco a poco se abrirán ambos camino en el mundo de la música. El primero será organista, tanto de alguna iglesia de Córdoba (San Hipólito) como posteriormente de la propia Catedral. Al segundo, Pons, ya lo hemos catalogado anteriormente como uno de los grandes Maestros españoles de finales del siglo XVIII y principios del XIX.

Como hemos dicho, en Diciembre de 1785, previa lectura del expediente de limpieza de sangre de Balius, y siendo éste satisfactorio, se le mandó entrar en la Capilla de San Clemente, donde se celebraba el Cabildo. Entró en dicha estancia Jaime Balius, y en presencia de todos los allí reunidos, juró su cargo:

\footnotetext{
${ }^{1641}$ A.C.C. Actas Capitulares. Miércoles 6 de Julio de 1785, T.90, fol. 144 v.

${ }^{1642}$ Era habitual que cuando un Maestro de Capilla o un músico aprobaba unas oposiciones, se le diera un período de tiempo suficiente para volver a su tierra, recoger sus cosas y traerse a su familia.

1643 A.C.C. Actas Capitulares. Sábado 22 de Octubre de 1785, T.90.

${ }^{1644}$ Archivo de la Parroquia del Sagrario. Censo de habitantes de 1786.

1645 Archivo Municipal de Córdoba. Padrón Municipal del año 1786.
} 
“...y postrándose de rodillas ante el Señor Deán que presidía el Cabildo teniendo en sus manos el libro de los sagrados quatro Evangelios juró por ellos in verbo sacerdotis tener todo respeto, veneración y obediencia a los Señores Capitulares, cumplir con las constituciones echas y/o que se agan para el gobierno de la Capilla de Música y de sus individuos, y defender la Inmaculada Concepción de Nuestra Señora". 1646

Así concluye este episodio del nombramiento de Jaime Balius y Vila como Maestro de Capilla de Córdoba. El proceso completo para cubrir de forma estable la vacante dejada por Gaitán ha durado increíblemente casi cuatro años, desde 1781 a 1785, curiosamente el tiempo que Balius estuvo de Maestro en Gerona. Parece que esta plaza de Córdoba estuvo esperando pacientemente hasta que fue cubierta por la persona que habría de ocuparla largo tiempo.

Si bien nos puede parecer interminable, laborioso y lleno de problemas el proceso que lleva a la elección de Jaime Balius como Maestro de Capilla, no era excesivamente raro que estos problemas tuvieran lugar, ni por supuesto eran exclusivos de Córdoba. Es más, podemos considerarlo casi un camino de rosas si lo comparamos con este otro caso que es muy oportuno citar y que nos adentra en los sucesos acaecidos para la elección de nuevo Maestro de Capilla en la Catedral de Granada a la muerte de D. Manuel Osete en Abril de 1775. En este caso, y gracias al estudio que hace López Calo en su Catálogo del Archivo de Música de la Catedral de Granada sabemos que eran nueve los opositores:
1. Juan Vidal
2. Antonio Caballero
3. Manuel Guifrida
4. Manuel Álvarez
5. Juan de Ortega
6. Francisco Coursell
7. Vicente de Torres
8. Juan Bueno

\footnotetext{
${ }^{1646}$ A.C.C. Actas Capitulares. Jueves 22 de Diciembre de 1785, T.90.
} 


\section{Tomás de Peñalosa}

Sabemos también que recurrieron a los Maestros de Capilla de Toledo, Zaragoza y Córdoba para supervisar los ejercicios. El Maestro de Capilla de Córdoba era todavía Juan Manuel Gaitán y Arteaga, que precedió a Balius.

Del interesante pasaje que nos cuenta López Calo sólo vamos a extractar una mínima parte que ilustre nuestro comentario. En Abril de 1775 comienza el proceso para nombrar nuevo Maestro. Tras múltiples circunstancias, en Febrero de 1777 es elegido Manuel Álvarez y en segundo lugar Juan Bueno.

Pero lejos de concluir el proceso, ahora empiezan las verdaderas complicaciones:

“El 28 de febrero Peñalosa acudió al Rey haciendo presente una irregularidad en que había incurrido el Cabildo: que Manuel Álvarez, nombrado en primer lugar, era inhábil, pues al momento de firmar -y parece que incluso celebrar- la oposición no tenía más que 20 años, cuando el edicto de convocatoria exigía que los opositores tuviesen cumplidos los 21 años al momento de la oposición, por lo que, según él, la elección era irregular $y$, por tanto, nula; por otra parte acompañaba dos certificaciones de algunos músicos de la Catedral acreditando su suficiencia como compositor y para desempeñar las demás actividades inherentes al cargo de Maestro de Capilla. Alude incluso a otras anomalías que, según él, había cometido el Cabildo, como <<la novedad de consultar sucesivamente a varios Maestros de Capilla, remitiendo a su censura las obras de los opositores, en cuyas diligencias se consumió cerca de un año>>; aduce a continuación varios casos similares al actual, como cuando, en 1735, a Matías Riaño, <<con la misma edad de don Manuel Álvarez, el consultado ahora, no se admitió sin renuncia previa del derecho>>; que en 1737 a Juan Roldán <<se negó la admisión hasta que logró tonsurarse $>>$. De sus propios méritos dice que <<últimamente expone a la consideración de V. M. el mérito de haberse cuatro veces presentado a concurso de opositores: la $1^{a}$ en la misma santa iglesia de Granada, en que sacó cinco votos en $2^{\circ}$ lugar; la $2^{a}$ en Antequera, donde hizo renuncia antes de votarla, por instancia de algunos capitulares de su iglesia de Granada; la $3^{a}$ en Málaga, donde tuvo ocho votos en $1^{\circ}$ y $2^{\circ}$ lugar; y la presente, en la 
cual ha tenido siete para el $1^{\circ}$ y uno para el segundo lugar >>. Por todo ello pedía al rey que le nombrase para el cargo de Maestro de Capilla." 1647

Obviando otras muchas circunstancias, nos remitimos al final del proceso, por el cual el día 11 de Noviembre de 1777, y atendiendo a Real Orden de 29 de Octubre, “tomó Peñalosa, con las solemnidades acostumbradas, posesión de la media ración de Maestro de Capilla". ${ }^{1648} \mathrm{Ni}$ que decir tiene que el Cabildo estuvo en contra de este nombramiento, pero evidentemente acató la Real Orden y “a partir de entonces, y no obstante el comprensible resentimiento, obró, en todo momento, con exquisita prudencia y delicadeza con el Maestro". ${ }^{1649}$

Vista esta referencia, volvemos a nuestra ciudad y a nuestro principal protagonista Jaime Balius.

Ya en Enero de 1786 vemos una petición de Balius al Cabildo para que le paguen su salario: "Se leyó memorial de D. Jayme Balius y Vila, solicitando salario, y oydo se acordó dar y dio comisión a los señores Diputados de Arcas de San Acacio para que informen sobre la pretensión del expresado y actual Maestro de Capilla”. 1650

En Agosto de 1786 el Cabildo le da una ayuda para pagar anteriores gastos: "Se procedió a leer el informe de los señores Maestre Escuela y Ferrer sobre la pretensión de D. Jaime Balius, Maestro de Capilla de esta Santa Iglesia. Se propuso por el Señor Deán que se le consignarían cien ducados anuales para el copiante y mil quinientos reales por una vez para subvenir a los crecidos gastos que tuvo en el viage”. Habiéndose votado, se aprobaron dichas cantidades. ${ }^{1651}$

El Cabildo decide examinar a los aspirantes a una plaza de bajón el día 15 de Noviembre de 1786: “Havían firmado 5 opositores, a saber, D. Mateo Tascón, D. Joseph Berner, D. Andrés Muñoz, D. Juan Puig y D. Joseph Cordón”. Una vez

\footnotetext{
${ }^{1647}$ LÓPEZ CALO, José. Catálogo del Archivo de Música de la Catedral de Granada. Granada, Centro de Documentación Musical de Andalucía (Junta de Andalucía), 1991, Tomo I, pág. 117.

${ }^{1648}$ Ibid. Tomo I, pág. 119.

${ }^{1649}$ Ibid.

1650 A.C.C. Actas Capitulares. Martes 24 de Enero de 1786. T. 90.

1651 A.C.C. Actas Capitulares. Martes 8 de Agosto de 1786. T. 91. fol. 45r.
} 
nombrado como juez examinador el Maestro de Capilla, D. Jaime Balius y Vila, se celebran las pruebas, siendo nombrados D. Mateo Tascón y D. Juan Puig. ${ }^{1652}$

Por lo que sabemos, Balius también debió de cobrar prestigio rápidamente fuera de nuestra ciudad, ya que a finales de Octubre de 1786 y por invitación del Cabildo de Jaén ejerció como juez en las oposiciones al Magisterio de Capilla de aquella Catedral. El Cabildo de Jaén queda agradecido al de Córdoba por haber permitido que Balius vaya allí a formar parte del jurado de oposiciones, y así lo manifiesta en carta enviada a Córdoba. El acta capitular correspondiente recoge que en dicha carta el Cabildo de Jaén “da gracias de la licencia concedida por este Cabildo al Maestro de Capilla para que pasase á aquella ciudad en calidad de examinador de los opositores al Magisterio de Capilla de aquella Santa Iglesia, como lo havía solicitado el expresado Cabildo de Jaén". 1653

Aunque solían ser varios los examinadores, en este caso, el Cabildo de Jaén "nombra a Jaime Balius, Maestro de Capilla de la Iglesia de Córdoba, como único juez a la oposición al Magisterio de capilla". [Cabildo de 11-X-1786]. ${ }^{1654}$ Este nombramiento se hace el día 11 de Octubre e inmediatamente se fija el comienzo de las pruebas: "Se señala el día 30 de octubre para comienzo de los actos de la oposición al Magisterio de Capilla y se acuerda que se vaya por el Maestro Jaime Balius y que el deán señale persona que venga en su asistencia”. [Cabildo de 21-X-1786]. ${ }^{1655}$

Y así es como un día de finales de Octubre de 1786, probablemente el día 28, Balius sale de Córdoba en dirección a Jaén. Viaja en las acostumbradas diligencias de la época y probablemente, dadas las fechas y las características pluviométricas de ese año, soporta un clima lluvioso. ${ }^{1656}$

\footnotetext{
1652 Ibid. Martes 14 de Noviembre de 1786. T. 91. fol. 98.

1653 Ibid. Lunes 20 de Noviembre de 1786, T.91.

1654 JIMÉNEZ CAVALLE, Pedro. Documentario Musical de la Catedral de Jaén. Granada, Centro de Documentación Musical de Andalucía, 1978, pág.333.

1655 Ibid. pág. 334.

${ }^{1656}$ PAVÓN, Borja. Anales de la Ciudad de Córdoba, (Manuscrito de la Real Academia de Córdoba). Según Borja Pavón, 1786 fue un año de los más lluviosos de finales del siglo XVIII.
} 
Lo que sí sabemos con seguridad es que el día 29 ya está en Jaén dispuesto a comenzar las oposiciones. ${ }^{1657}$ También sabemos que las pruebas duran aproximadamente una semana, ya que el día 7 de Noviembre se fija la remuneración económica que le corresponde a Balius por el trabajo realizado, y que asciende a 3000 reales. $^{1658}$

Ya está por tanto acabada la oposición y entregada la censura, pero tal y como ha ocurrido en tantos otros procesos para cubrir Magisterios vacantes, aquí también habrá problemas y reclamaciones. En este caso, el que a la postre será Maestro de Capilla de Jaén, Ramón Garay, no se conforma con los resultados y recusa a Balius. ${ }^{1659}$

1657 "El Deán da cuenta de que Jaime Balius, juez a la oposición al Magisterio de Capilla, se encuentra allí y habiéndolo mandado entrar el Deán le expresó «que el Cabdo. atendiendo a su notoria ciencia en la Música, y su mucha conciencia, le había nombrado por único Juez, para los actos, y exercicios, dándoles los puntos que deban cantar» para informar al Cabildo de los opositores más idóneos. Jaime Balius dio las gracias y expuso la conveniencia de que los opositores conozcan el estado de la Capilla: sus voces e instrumentos para poder hacer más arreglada su composición en los puntos que se les diese. Se acordó se haga así y que en vista del papel sobre el examen realizado en 1754, en que se nombró a Juan Martínez, forme el suyo; y que el día 30 empiece a examinar en la teórica y reglas de composición y música a los opositores”. [Cabildo de 29-X-1786]. JIMÉNEZ CAVALLE, Pedro. Documentario Musical de la Catedral de Jaén. Granada, Centro de Documentación Musical de Andalucía, 1978, pág.334.

1658 "Se acuerda que se paguen 3.450 reales de los frutos de la ración del Magisterio de Capilla, por los gastos del juez de la oposición y Maestro de Capilla de Córdoba, Jaime Balius 3.000 reales para Jaime Balius, Maestro de Capilla de Córdoba de gratificación por el tiempo que ha estado en esta ciudad; 300 reales a su criado de gratificación y como copiante de los papeles que se han puesto en música por los opositores a la referida ración; y 150 reales a Vicente Gómez, músico de la Capilla de esta iglesia, copista también de dichos papeles. «Y se encargue al dicho dn. Jayme Balius forme a la mayor brevedad la Censura del juicio que haya hecho, y la presentará. Asimismo mandaron dichos sres. se libren contra dicha obra 600 Rs. en esta forma 30 Rs. a dn. Pedro de Contreras pbro. qe. esta supliendo el cargo de Mro. de Capilla, y costó el Papel de Música, que compró para qe. los opositores pusiesen en Música las obras, que les señaló el Juez, 300 rs. para que los reparta en la Capilla de música por el trabajo, que tubo en la prueba de los opositores a la ración de Mro. de Capilla vacte.; y los 270 rs. restantes al infrascripto secretario por los dros. de los autos del Concurso y costo del Propio, que llebo la Convocatoria a Baeza por si dichos sres. querian hallarse presentes a los actos de concurso».”. [Cabildo de 7-XI-1786] ${ }^{1658}$. JIMENEZ CAVALLE, Pedro. Documentario Musical de la Catedral de Jaén. Granada, Centro de Documentación Musical de Andalucía, 1978, pág.334.

1659 “ «En este día dichos sres. habiendo oído el Llamto. que trata sobre, y en razón de ver la Censura, qe. dejó dada en esta secria. dn. Jayme Balius único Juez en el Concurso a la Ración de Mro. de Capilla vaca en esta sta. Ygla. por muerte del $s^{\circ} r$. dn. Franco Soler, juicio hecho de los opositores a dha racion= Asimismo se vio un memorial de dn. Ramón Garay, opositor a dha Ración, en que da entender no se conforma con el juicio, y censura del citado, dn. Jayme Balius, y le recusa en calidad de único Juez, pidiendo qe. sus obras presentadas, y hechas en este Concurso se remitan a dos o más Mros. de Capilla de la satisfacción del Cabdo. en Toledo, Sevilla, Madrid, u otra parte, y así se ofrece a sufrir nuevo examen, y pruebas a presencia, y vista de tres Mros. de la superior nota, y de lo contrario protesta vsar de su dro. y recursos, que le Convengan. y conferido y tratado por dhos. sres. teniendo en considerazión. qe. el sr. Cano. Penitenrio., que tiene la voz de S.I. como Governor. deste obpdo. y el sr. can ${ }^{\circ}$. Lectoral han faltado a este Cabildo, por estar legitimamte ocupados en los exercicios, y actos de las oposiciones a los Prioratos vacantes; y siendo el ánimo del Cabildo que todos los Sres. concurran. Acordaron suspender el Llamto., y se les preguntará a dhos. Sres. quando podran asistir commodamte. y en vista de su respta. se dara Llamamto. para oir la Censura del Mro. de Caplla de la Sta. Ygla. de Cordova unico Juez para el Concurso a dha racion de Mro. de Capilla vacte. Y el Meml. del dn. Ramon Garay con la censura de dho Juez se pondrán con los autos del Concurso»".[Cabildo de 10-XI-1786]. JIMENEZ 
No volvemos a tener noticias de este proceso hasta el año siguiente, concretamente hasta el 5 de Febrero de 1787. La reclamación hecha por Garay ofendió al Cabildo, que posiblemente así se lo hiciera saber, puesto que el primero escribe una carta de disculpa bajo los argumentos de que en ningún momento quiso ofender al Cabildo, ni poner en duda la fama y categoría de Jaime Balius. ${ }^{1660}$

El Cabildo recibe presiones de personas influyentes cercanas a Garay y al final acaba nombrándolo para el cargo. Curiosamente Ramón Garay pasará largas temporadas fuera de este puesto que ahora tanto reclama, unas veces para trasladarse a Covadonga a ver a sus padres, y otras muchas por enfermedad. En algunas de estas ocasiones llega a estar seis meses de baja. ${ }^{1661}$

Mientras tanto, Balius ya ha vuelto de Jaén, y en la Catedral cordobesa se encuentra interviniendo en diversas oposiciones de músicos, en las que se manifestó riguroso, según testimonio de las actas capitulares. ${ }^{1662}$ Una de estas oposiciones fue la que se hizo en Enero de 1787 para cubrir una vacante en la Capilla de San Acacio. Realizada la prueba, resultó elegido D. José Moyano, cantor tiple, que a la postre se convertiría en una de las personas de confianza de Jaime Balius. ${ }^{1663}$

Todavía tendría tiempo, antes de marchar a Madrid, de examinar a Juan de Borja, aspirante a una plaza de trompa -que fue aceptado- ${ }^{1664}$ y a diversos opositores -

CAVALLE, Pedro. Documentario Musical de la Catedral de Jaén. Granada, Centro de Documentación Musical de Andalucía, 1978, pág.334.

1660 “"En este día se vio un Memorial de dn. Ramón Garay opositor á la Ración de Mro. de Capilla de esta Sta. Yga. expresando bajo de las más solemnes protestas no fue su ánimo ofender al Cabildo, ni tampoco la acreditada fama é inteligencia de dn. Jayme Balius Pbro. Mro. de Capilla de la Sta. Yga. de Cordova, y por lo mismo juraba no lo recusó de malicia en la representación que hizo al Cabildo en el día diez de Noviembre del año próximo pasado de 1786; y presentaba las adjuntas certificaciones en calificación del Conocimto. de su persona, conducta, e instrucción en la facultad de composicion Música, y suplicaba las haya el Cabildo por presentadas, y en su vista perdonarle qualquiera ocasion de sentimto. qe. haya podido ofrecer su anterior representacion, con lo demás qe. expresa dicho Memorial...»". [Cabildo de 5-II-1787]. JIMENEZ CAVALLE, Pedro. Documentario Musical de la Catedral de Jaén. Granada, Centro de Documentación Musical de Andalucía, 1978, pág.335.

${ }^{1661}$ Cf. JIMÉNEZ CAVALLE, Pedro. Documentario Musical de la Catedral de Jaén. Granada, Centro de Documentación Musical de Andalucía, 1978, págs. 335 a 424.

${ }^{1662}$ Cf. NIETO CUMPLIDO, Manuel: “Maestros de Capilla de la Catedral de Córdoba”. Boletín de la Confederación Andaluza de Coros de 1995. Córdoba, Ed. CO.AN.CO., 1995, pág.11.

${ }_{1663}$ Cf. A.C.C. Actas Capitulares. Lunes 29 de Enero de 1787. T.91.

${ }^{1664}$ Ibid. Lunes 27 de Febrero de 1787. T.91. 
cuyos nombres no se citan en las actas- a la plaza de organista $1^{\circ}$, sin que ninguno de ellos lograra el beneplácito del Maestro. ${ }^{1665}$

No obstante, sus relaciones con algunos músicos cordobeses no fueron en principio fáciles, y parece que ello motivó que su primera estancia en Córdoba fuera corta y que se marchara a Madrid. Lo cierto es que después de los problemas que habían existido para cubrir su plaza, con sucesivas demoras por múltiples contratiempos, y ahora que parecía haber encontrado un periodo de estabilidad, Balius abandona Córdoba y marcha a Madrid, quedando de nuevo vacante la plaza, aunque su partida, como veremos a continuación en palabras de Nieto Cumplido, depara algunas consecuencias para los causantes de sus problemas.

"El acta de 31 de julio de 1787 deja constancia de la despedida de Balius y de los motivos que le indujeron a ello: $<<$ Haviéndose dado noticia por algunos señores que don Jaime Balius, presbítero, Maestro de Capilla desta Santa Yglesia, determinaba despedirse, y en efecto estaba nombrado capellán y Maestro de Capilla del Real Convento de la Encarnación de Madrid, y que según se dice la causa de retirarse es por algunas desavenencias con los músicos desta Santa Yglesia y disgustos que le han dado algunos de ellos, cuios motivos le han estimulado a tomar dicha determinación por no exponerse a mayores disgustos>>, se acuerda obtener información para proceder contra los músicos causantes del abandono del Maestro. Estos eran Rafael García, tenor, Mariano Especiali y Juan Busquet, músico instrumentista, a quienes el Cabildo multará por su insubordinación”. 1666

Antes de su partida, entrega en el archivo “los papeles y obras de música que ha compuesto el tiempo que ha estado en esta Santa Yglesia”. ${ }^{1667}$ Mientras está entregando los papeles, el Arcediano de Pedroche entabla conversación con él, y le pregunta si las circunstancias de su despido responden a los problemas aludidos. Balius responde que efectivamente "el despedirse del empleo ha provenido de varias disputas y desazones

\footnotetext{
1665 Ibid. Miércoles 2 de Mayo de 1787. T. 91.

1666 NIETO CUMPLIDO, Manuel: “Maestros de Capilla de la Catedral de Córdoba”. Boletín de la Confederación Andaluza de Coros de 1995. Córdoba, Ed. CO.AN.CO., 1995, págs. 11-12.

1667 A.C.C. Actas Capitulares. Lunes 13 de Agosto de 1787, T.91, fol.256 r.
} 
que le habían dado algunos músicos”. ${ }^{1668}$ Visto lo cual, en ese mismo día se le admite la dimisión del oficio, que interinamente será ejercido por Dionisio de la Mata.

\subsubsection{EL PERÍODO MADRILEÑO. 1787-1789.}

A Madrid llega para ocupar el Magisterio de Capilla del Real Monasterio de la Encarnación, puesto en el que sucedió a Antonio Rodríguez de Hita, y del que tomó posesión el 13 de Agosto de 1787 y en el que permaneció hasta el 10 de Junio de 1789. ${ }^{1669}$

Recién llegado, en el mes de Septiembre, ingresa en la Congregación de María Santísima de la Soledad: “En 12 de septiembre de 1.787 se escribió por hermano de nuestra congregación de la Soledad Don Jayme Balius, maestro de capilla de esta real casa de la Encarnación y lo firmo (Jayme Balius)”. ${ }^{1670}$

Intenta mantenerse informado de la actualidad y se suscribe al periódico El Correo de Madrid. En la lista de suscriptores podemos verlo junto a otros personajes relevantes de la ciudad. "El Correo de los ciegos de Madrid (1786, números 1 a 49), llamado después Correo de Madrid (1787-1791, números 50 a 422), aunque continuó siendo conocido como «el de los ciegos», se presentaba como «Obra periódica en que se publican rasgos de varia literatura, noticias y los escritos de toda especie que se dirigen al Editor», y tomaba forma en la Imprenta de José Herrera. Se publicaba dos veces a la semana (desde el martes 10 de octubre de 1786, número 1), hasta que en octubre de 1790 pasó a semanal, apareciendo su último número, el 422, el 24 de febrero de 1791. "1671

Según nos dice Paulino Capdepón, durante su corta estancia en Madrid, además de cumplir con sus diversas funciones propias de un Maestro de Capilla, compuso cuatro Misas, varias Lamentaciones, Salmos, Responsorios, Villancicos y algún motete,

\footnotetext{
1668 Ibid.

1669 Cf. MARTÍN MORENO, Antonio. Historia de la música española. Madrid, Alianza Editorial, colección Alianza Música, 1985, volumen IV, pág. 88. Según Juan Lucas del Pozo, Balius fue además “Capellán de Su Majestad”. POZO CÁCERES, Juan Lucas del. "Lista de algunos maestros de Capilla de la Catedral de Córdoba”. En Colección de Obras. Córdoba, 1863. Ms., pág. 391.

1670 RAMÍREZ Y BENEYTO, Ramón. El compositor Josep Pons i el llenguatge musical per a la liturgia de l' ordinarium: "Misa a 4 y a 8 con oboes, violines y trompas sobre la antífona ecce sacerdos magnus" (1786). Tesis doctoral. Valencia, Universidad de Valencia, Servicio de Publicaciones, 2005, pág. 172.

${ }^{1671}$ Cf. http://www.filosofia.org/hem/med/m032.htm
} 
conservándose estas obras en el Monasterio de Montserrat ${ }^{1672}$. Las funciones del Maestro anteriormente citadas incluían las siguientes obligaciones:

“El Maestro de Capilla enseña a los acólitos el Canto Llano y de órgano. Y porque deseamos que los muchachos que sirven en el dicho convento se críen de manera que salgan de él aprovechados y puedan ser de servicio para otros ministerios, es nuestra voluntad y mandamos que el Maestro de Capilla que es y fuere del dicho Convento, les enseñe a cantar Canto Llano y de órgano, y mientras no hubiere Maestro de Capilla en propiedad, mandamos que el Capellán que hiciere el dicho oficio de Maestro de Capilla, haga también este ministerio, por lo cual se le dé lo que pareciere competente. Y habiendo mirado bien este capítulo y considerando que también el Maestro de Capilla podrá alguna vez ofrecérsele necesidad de hacer alguna ausencia o estar enfermo, nos ha parecido dejar mano a la Priora y Capellán Mayor para que si les pareciere que haya algún Capellán señalado por teniente de Maestro de Capilla lo que pueda hacer y éste podrá enseñar los niños”. 1673

Es conocida la relación del Monasterio de la Encarnación con la Realeza, ya que fueron Felipe III y Margarita de Austria, a instancia de ésta última, quienes lo proyectaron y por fin lo inauguraron el día 29 de Julio de 1616. Esta especial relación y la cercanía del convento con el hogar de los monarcas propiciaron la construcción de un pasadizo que permitía la comunicación directa con el Palacio Real. ${ }^{1674}$

Sabemos igualmente que se instituyeron varios días al año para realizar celebraciones por aniversarios diversos que tenían que ver con acontecimientos de la familia real y que en dichos días se procuraba que la Capilla de Música estuviera bien reforzada si hiciera falta:

\footnotetext{
${ }^{1672}$ Cf. CAPDEPÓN, Paulino. La música en el Monasterio de la Encarnación. Madrid, Caja Madrid, Ed. Alpuerto, 1997, pág. 45.

${ }^{1673}$ CAPDEPÓN, Paulino. La música en el Monasterio de la Encarnación. Madrid, Caja Madrid, Ed. Alpuerto, 1997, pág. 29. A su vez éste cita: Acta Fundacional del Monasterio de la Encarnación de Madrid, F.IV, nº36.

${ }^{1674}$ La Reina Margarita de Austria utilizaba a menudo este pasadizo para ir al Monasterio a oír misa junto con sus damas de honor. En visita privada al Monasterio de la Encarnación el día 21 de Agosto de 2004, tuvimos ocasión de recibir una interesante explicación sobre éstas y otras cuestiones además de admirar los espacios donde desarrolló su trabajo Jaime Balius.
} 
"Se han de celebrar anualmente cuatro aniversarios: el trece de septiembre por Felipe II; el tres de octubre por la reina Margarita, fundadora del convento y esposa de Felipe III; un tercer aniversario cuya fecha no se cita en el Acta Fundacional, tiene lugar en memoria de los padres de la reina Margarita y el último se establece en el futuro cuando Felipe IV y su mujer fallezcan: concretamente se afirma que todos los capellanes digan misa el Aniversario del fallecimiento del entonces rey. Para dar realce a dichos aniversarios se determina que además de los cantores del propio Monasterio de la Encarnación, puedan participar si fuera necesario, cantores de la Real Capilla". 1675

Según Capdepón, entre las obras que compuso Balius para este Monasterio sobresale su Oh Admirable o Alabado en honor del Santísimo Sacramento. Sepamos la naturaleza de esta obra:

"una composición en castellano y con la forma musical del motete. Desde mediados del siglo XVII se hizo muy popular, siendo bastantes los compositores españoles que desde entonces abordaron esta forma que solía ser cantada durante la octava del Corpus. Según el esquema literario, este Oh Admirable de Balius se compone de dos cuartetas. Es de destacar la figuración virtuosística de flautas y violines, cuya línea melódica difiere en numerosos pasajes de las voces”. 1676

En 1788 muere Carlos III. Para sus honras fúnebres, Jaime Balius escribe una Misa de Difuntos, cuya descripción es la siguiente:

"Misa de Difuntos con Violines, Oboes, Flautas y Trompas. Balius". A 9 voces. Género: Mixto. Plantilla: Coro $1^{\circ}$ : SSATB. Coro $2^{\circ}$ : SATB. 1 Violín $1^{\circ}, 1$ Violín $2^{\circ}, 1$ Contrabajo, 2 Flautas, 2 Oboes, 1 Bajón, 2 Trompas y acompañamiento.

Partitura: Sí. Conservación Partitura: Regular. Particellas: Sí. Conservación Particellas: Buena.

Observaciones: En la página 1 del guión dice: "Se travajó para las Onnras del Sr.

\footnotetext{
${ }^{1675}$ Cf. CAPDEPÓN, Paulino. La música en el Monasterio de la Encarnación. Madrid, Caja Madrid, Ed. Alpuerto, 1997, pág.31.

${ }^{1676}$ Ibid. pág. 45.
} 
Carlos III que seisieron en el Real Convento de la Encarnación de Madrid siendo Maestro de dicha casa el autor de ella". Esta misa se conserva en el archivo de la Catedral de Córdoba con la signatura 61/417, y podemos ver sus íncipits en el volumen II de este trabajo.

Mientras todo esto ocurría en Madrid, en Córdoba se plantea el problema de encontrar un nuevo Maestro de Capilla de prestigio. El 27 de Noviembre de 1788 le recomiendan al Cabildo a D. Manuel Corao. El recomendado es discípulo del Maestro de Capilla de La Seo de Zaragoza, Francisco Javier García Fajer. Pero a pesar de esto, no es admitido. Probablemente la razón es que para entonces, el Cabildo ya había restablecido la relación con Balius, pues aun siendo Maestro del Convento de la Encarnación de Madrid, compone para la Catedral de Córdoba los villancicos de ese mismo año. Así pues, todo indica que el Cabildo no estuvo muy contento en su día con la repentina marcha de Balius a Madrid, y que intentó no romper totalmente los hilos de esa relación, por si en un momento pudieran volver a contar con su presencia en Córdoba, como así sucedió posteriormente.

\subsubsection{SU REGRESO DEFINITIVO A CÓRDOBA. 1789-1822.}

En Marzo de 1789, el Cabildo acuerda reiniciar una vez más la búsqueda de un Maestro de Capilla: “...Siguiendo el llamamiento para oír el informe de los mismos señores Diputados con la parte, sobre hallar Maestro de Capilla, oído que fue dicho informe, se acordó dar comisión a los referidos señores Diputados con la parte para que practiquen las diligencias sobre este asunto en la forma que se les ha comunicado en este Cabildo y de sus resultas informen con llamamiento". ${ }^{677}$

Probablemente la perspectiva de tener que comenzar otro tortuoso camino hasta encontrar nuevo Maestro, hace que el Cabildo vuelva a pensar en Jaime Balius. Dicho y hecho, el 10 de junio de 1789, se produce su readmisión: “Acordó el Cabildo nemine

${ }^{1677}$ A.C.C. Actas Capitulares. Jueves 26 de Marzo de 1789, T.92, fol. 20r. 
discrepante nombrar y nombró Maestro de Capilla de esta Santa Iglesia a D. Jaime Balius, presbítero, que lo es del Real Monasterio de la Encarnación de Madrid, con el salario de quinzemil reales de vellón". ${ }^{1678}$ Además se le conceden los honores de capellán perpetuo y la distinción de entrar en el Coro con las mangas altas en la forma que lo practicaban los demás capellanes.

El 25 de agosto se le autoriza a volver a Madrid durante mes y medio para traer su casa:

"Se leio un Memorial de D. Jayme Balius y Vila, Maestro de la Capilla de Música de esta Sta. Iglesia, en que suplicaba al Cavildo le concediese su permiso y licencia para pasar â la corte y Villa de Madrid para disponer de su casa, poner cobro â algunos intereses y traer su familia. De lo que enterado el Cavildo acordó dar y dio a dicho suplicante su lizencia para dicho viaje por el tiempo de un mes y medio pero con la condición de no salir hasta estar concluida la Bendición del Real Pendón que se hará en esta Iglesia en el próximo mes de septiembre”. 1679

El hecho de que esta acta diga que volvió a Madrid "para traer a su familia” nos hace pensar que, al igual que cuando vino a Córdoba por primera vez se trajo consigo a su sobrino Francisco y a su discípulo José Pons, cuando marchó a Madrid, al Convento de la Encarnación, estos también le acompañaron en el traslado. Apoyan esta hipótesis los comentarios que en su tesis hace Ramón Ramírez Beneyto. Sostiene que Pons va a acompañar a Balius en las diferentes Capillas por las que éste pasa, y que concretamente en la de Madrid, por el hecho de que cuando Pons se presenta a las oposiciones de las iglesias de Alcalá de Henares, la Real Capilla de la Soledad de Madrid y sobre todo la Catedral de Salamanca, se le atribuye un origen madrileño. Por si esto fuera poco, entre el repertorio musical del Convento de la Encarnación que se llevaron al Monasterio de Montserrat, también figura alguna obra suya. ${ }^{1680}$

\footnotetext{
${ }^{1678}$ Ibid. Miércoles 10 de Junio de 1789. T.92, fol. 27v.

1679 Ibid. Martes 25 de Agosto de 1789, T.92, fol.58v.

1680 "Reprenent la qüestió del perquè se li atribueix a Josep Pons en aquelles oposicions a Salamanca l'origen madrileny, en els successius memoràndums que Pons envia -de pròpia mà- als distints llocs en què opta a ocupar les places de mestre de capella vacants, insisteix a repetir que havia opositat a les esglésies d'Alcalà de Henares, i Real Capilla de la Soledad de Madrid. Ja hem plantejat que en el mes de
} 
En todo caso, sabemos que Balius regresa a Madrid a recoger sus cosas, y allí se encuentra todavía el 20 de Octubre. En esa fecha, el Cabildo trata sobre la provisión de la plaza de organista, y decide esperar la vuelta del Maestro para que éste opine sobre el asunto:

"En vista del llamamiento dado ante diem para oír el informe de los Srs. Diputados de Escusados de Música con dicha parte sobre asunto de organista y determinar su provisión en el caso que lo tenga por conveniente el Cavildo; oído que fue, y la lista de organistas que presentaron dichos Srs., aviendo corrido un voto, y hablado cada uno de los Srs. en su lugar lo que tubo por oportuno, acordó el Cavildo que en suposición de estar el Maestro de Capilla en la Corte, y ser su venida a ésta muy pronta, se espere se restituia á esta ciudad y verificado que sea se le manifieste la dicha lista para que se haga cargo de los pretendientes, y además el dicho Maestro informe si ai otros que sean más adecuados para desempeñar el empleo, y actuando de todo con la exactitud que corresponde, de cuenta al Cavildo con toda claridad”. 1681

Ya en 1790, el 26 de enero, se le releva de componer el Miserere acostumbrado para la Semana Santa con el fin de “mejorar algunos himnos y salmos que hay inútiles y servirían en varías funciones”. ${ }^{162}$ Sigue con sus funciones de Maestro de Capilla, entre las que se encuentra examinar a los aspirantes para cubrir diversos puestos de la misma, como vemos el día 2 de Marzo de 1790, en el que da cuenta al Cabildo de las pruebas realizadas a D. José Cabrera, capellán de San Acacio para cubrir la plaza de contralto

juliol de l'any 1.789 el seu mestre Balius estava novament a Madrid, i que ho havia estat pràcticament de forma ininterrompuda des del 12 de setembre de 1.787, data en la qual va ocupar la mestria del Real Monasterio de la Encarnación. Però si fem cas del que el propi Pons ens indica en els seus memoràndums i va ser cert que es va presentar a aquelles dues oposicions, podríem suposar que va romandre algun temps a Madrid, potser fins i tot amb el mestre Balius en el propi Monasterio de la Encarnación. Açò justificaria, almenys en part, que en accedir a l'oposició de Salamanca -des de Madrid- se li atribuïra aquell origen. Vindria a confirmar aquesta hipòtesi el fet que també hem trobat obres seues - com tindrem ocasió de comentar en el seu moment- en l'arxiu de música del monestir de Montserrat a Barcelona. Especialment una d'elles procedent dels fons del Monasterio de la Encarnación de Madrid precisament, els fons del qual, -com és sabut- van ser comprats pel citat monestir de Montserrat $i$ allí es conserven. Es tracta del manuscrit "Missa con Violines, Flautas y Trompas obligadas. A 4 y a 8. Del Mtro. Pons" (AMMM, ms: 4.069)”. En: RAMÍREZ Y BENEYTO, Ramón. El compositor Josep Pons i el llenguatge musical per a la litúrgia de l' ordinarium: "Misa a 4 y a 8 con oboes, violines y trompas sobre la antífona ecce sacerdos magnus" (1786). Tesis doctoral. Valencia, Universidad de Valencia, Servicio de Publicaciones, 2005, págs 200-201.

${ }^{1681}$ A.C.C. Martes 20 de Octubre de 1789, T.92, fol. 76v.

${ }^{1682}$ Ibid. Martes 26 de Enero de 1790, T.92, fol. 113r. 
primero, no siendo en este caso aceptado para esta plaza "pero sí muy al caso para la clase de segundo". ${ }^{1683}$

En Julio, Balius solicita al Cabildo “licencia para salir de este obispado, por padecer continuos dolores cólicos, y nefríticos”. ${ }^{1684} \mathrm{Al}$ final de ese mes de Julio, el día 28, el Cabildo le concede dicha licencia:

"Primeramente en vista del llamamiento para oír el informe de los Srs. Diputados de Arcas de vacantes de la capilla de Sta. Ynés en esta dicha Sta. Iglesia sobre la pretensión de Licencia a favor de D. Jayme Valius y Vila Pbro. Maestro de Capilla en esta, por razón de su quebrantada salud, oído que fue, y lo que dichos Srs. expusieron de palabra, juntamente con lo relacionado de la Certificación jurada de D. Manuel Troncoso Médico Revalidado: acordó el Cavildo conceder y concedió a dicho Balius Licencia para dentro y fuera de este Obispado, por razón de sus accidentes, por tiempo y espacio hasta fin de octubre de este presente año, con tal que si antes se mejorase, este obligado a residir en el Coro, en lo que se le encarga la conciencia, y con tal que se atienda dicha Licencia supera a las Aspas que le correspondan en el tiempo de su ausencia". 1685

Durante esta licencia, viaja a Madrid, y estando allí, el Cabildo se pone en contacto con él "á ver si encuentra en dicha Corte sujeto ó sujetos de más habilidades y mejores voces". 1686

Ya tenemos una referencia de su vuelta a Córdoba, el día 13 de Noviembre de 1790, cuando solicita al Cabildo "se le perdonen las aspas causadas en su ausencia, y en su vista acordó el Cavildo, se le perdonen, respecto a haber estado con la correspondiente licencia”. 1687

En los primeros meses de 1791 vemos al Maestro de Capilla participando en diversas pruebas, sobre todo para cantores, con que se pudiera subsanar la falta de voces que había. De todas ellas (que podemos verlas completas en el Vaciado cronológico de

\footnotetext{
${ }^{1683}$ Ibid. Martes 2 de Marzo de 1790, T.92, fol.121r.

${ }^{1684}$ Ibid. Viernes 23 de Julio de 1790, T.92, fol. 165r.

1685 Ibid. Miércoles 28 de Julio de 1790, T.92, fol.166v.

1686 Ibid. Jueves 12 de Agosto de 1790, T.92, fol. 172r.

${ }^{1687}$ Ibid. Sábado 13 de Noviembre de 1790, T.92, fol.197r.
} 
noticias musicales), citamos una en que informa al Cabildo para la contratación de un tenor venido de Madrid, D. Tadeo Mintegui, el cual fue finalmente admitido “con el salario de quatrocientos ducados anuales". 1688

La escasez de voces antes citada no se soluciona rápidamente. En Julio de 1792, Balius sigue solicitando al Cabildo la contratación de más cantores, sobre todo tenores, por ser "la voz que le hace más falta”. ${ }^{689}$ Afortunadamente, en Octubre, y tras una oposición en la que el Maestro actúa como juez, se contrata un nuevo tenor, D. Antonio Gil. $^{1690}$

1793 no es un año pródigo en oposiciones, por lo que Balius tuvo tiempo de componer una de sus obras cumbre al menos en lo que se refiere a su complejidad. Nos estamos refiriendo a la Kalenda Israelitas Nobles (90/753), hecha nada menos que para 16 voces, violines, flautas, oboes, bajones, trompas, acompañamiento y órgano obligado. Eso sin contar los 10 villancicos, 2 motetes y un miserere que vemos en el catálogo fechados en ese año.

El acta de 23 de Abril de 1794 da fe de que Jaime Balius ha presentado informe al Cabildo sobre la suficiencia de D. Joseph Cheist para ocupar la capellanía de San Acacio. En este caso y como el informe es positivo, se acuerda aceptar la propuesta. ${ }^{1691}$

Pero quizás la principal preocupación de Balius fuera mantener bien dotada su propia Capilla. A este respecto vemos cómo muestra un especial interés por aceptar músicos que tocaran más de un instrumento, (o mejor si tocaban varios instrumentos y también cantaban), ya que podían sustituir a algún otro miembro de la Capilla por motivos de enfermedad y otros. Este es el caso que nos ocupa ahora y que da cuenta de la contratación de D. José Las, tras un magnífico informe emitido por Balius en Octubre de 1795, y en el que recomienda su aceptación como músico instrumentista de la Capilla, ya que "tocaba excelentemente varios instrumentos como la flauta, oboe, fagot

\footnotetext{
${ }^{1688}$ Ibid. Viernes 1 de Abril de 1791, T.92, fol.231v.

${ }^{1689}$ Ibid. Miércoles 4 de Julio de 1792, T.93.

1690 Ibid. Miércoles 3 de Octubre de 1792. T. 93. fol. 150 v.

${ }^{1691}$ Ibid. Miércoles 23 de Abril de 1794. T.94, fol. 64 v.
} 
y violín y que haría mucha necesidad en la Capilla”. ${ }^{1692}$ No era ésta una costumbre solo de la Catedral cordobesa, sino que son muchos los testimonios que nos informan de la existencia en diversas Catedrales españolas de la época, de músicos que tocaban varios instrumentos, e incluso combinaban el canto con la interpretación instrumental.

Como ejemplo, vamos a incluir aquí brevemente uno de los casos más extremos que conocemos de músicos que tocaran varios instrumentos. Se trata de un músico de la Catedral de Almería, coetáneo de todos estos músicos de la Catedral de Córdoba que estamos citando. Su nombre es José Vinuega, y su historia la conocemos gracias al trabajo realizado por Juan López, Cristina Bonillo y Albina Requena sobre noticias de música de la Catedral de Almería, del cual extractamos lo siguiente:

“En Diciembre de 1784, José Vinuega, músico de profesión presenta al Cabildo un memorial en que expresa estar en la ciudad para que se le examine de la destreza de los instrumentos de violín, oboe, flauta, trompa, bajón, violón, fagot, clarín y contrabajo. Se le adjudica día y hora para el examen. En Marzo del siguiente año se nombra a José Vinuega músico de cuerda y viento, con una asignación de 200 ducados anuales y con las obligaciones anejas a su plaza y subordinado al Maestro de Capilla”. 1693

En Abril de 1796, Balius solicita licencia "para ir a su Patria por algún tiempo", ${ }^{1694}$ lo cual se le concede. Ese tiempo debió ser largo, puesto que no volvemos a tener noticias suyas hasta Octubre, en que figura como juez de una oposición para cubrir una vacante existente en la Capilla de San Antonino "respecto a estar ya en esta ciudad". ${ }^{1695} \mathrm{Al}$ mes siguiente, en Noviembre, es requerido para informar acerca de las obras presentadas por Juan López, organista de la Colegiata de Antequera, que aspiraba a ocupar el cargo de Maestro de Capilla de dicha Colegiata. El informe dice lo siguiente:

\footnotetext{
1692 Ibid. Miércoles 14 de Octubre de 1795, T.94.

1693 LÓPEZ MARTíN, Juan y otros. Noticias y Catálogo de Música en el Archivo de la S. Y A.I.C. de Almería. Granada, Centro de Documentación Musical de Andalucía (Junta de Andalucía), 1997, pág.110. 1694 A.C.C. Actas Capitulares. Viernes 13 de Abril de 1796, T.95.

${ }^{1695}$ Ibid. Sábado 22 de Octubre de 1796. T. 95.
} 
"Himno: O gloriosa Virginum, está bien trabajado, todos sus intentos son muy propios, gradúa las voces muy bien como música sin instrumentos, sigue el intento (o paso del Amen) con mucho primor, formándose otro intento para más variación y prosiguiendo con mucha naturalidad: toda esta obra está con mucha pureza del arte.

Villancico con violín y trompas: Está arreglado a la letra y bien proporcionado en su distribución, expresa bien la letra en los recitados y arias. Por tanto coloco a Juan López en primer lugar, dando el segundo a Miguel Jurado. Córdoba 3 de noviembre de 1796”. Jaime Valius". 1696

En Enero de 1797 Balius pide una ayuda de costa al Cabildo, y el día 25 se lee en la sesión capitular un memorial suyo en el que "suplica al Cabildo se digne levantarle las aspas que ha tenido en la temporada que con la correspondiente licencia estuvo ausente en su Patria el año pasado". ${ }^{1697}$ Se le concede esta ayuda en Marzo de 1797, cuando el Cabildo aprueba "una ayuda a costa correspondiente al importe de aspas que ha tenido en ausencia que con licencia de este Cabildo hizo el año pasado a su Patria”. 1698

En Septiembre de 1797 inicia una renovación intensiva de la plantilla orquestal y coral. El día 19 será un día especialmente importante en la vida musical de este periodo, ya que por parte del Maestro de Capilla, Jaime Balius, se presenta al Cabildo un informe completo con la plantilla mínima necesaria tanto de coro como de orquesta para el buen funcionamiento de la Capilla:

"se conceptúan por el Maestro de Capilla por necesarios cuatro tiples con la renta el que más de once mil reales, cuatro contraltos con la de seis mil, cinco tenores con la de seis mil y seiscientos, dos bajos con la de siete mil y setecientos. Seis violines con cinco mil y quinientos, dos trompas con tres mil y trescientos, un acompañamiento con tres mil y trescientos y un bajón con la misma renta”. 1699

\footnotetext{
${ }^{1696}$ Citado por BALLUS CASOLIVA, Gloria: La música a la Colegiata Basílica de Santa María de la Seu de Manresa: 1714-1808. Tesis Doctoral. Universidad Autónoma de Barcelona, 2004, vol. II, pág. 17. ${ }^{1697}$ Ibid. Miércoles 25 de Enero de 1797, T.95.

1698 Ibid. Martes 14 de Marzo de 1797, T.95.

1699 Ibid. Martes 19 de Septiembre de 1797, T.95.
} 
Mientras se realiza la provisión de toda esta plantilla, se aprueba la contratación de manera más urgente de un tiple, un contralto, dos tenores y un bajo, y además un violín, y un acompañamiento. Todo ello para "remediar la falta de voces que en el día se advierte para la correspondiente decencia en el culto divino a que se aspira”. ${ }^{1700}$

En ese momento, parece tan urgente la contratación de músicos, que se faculta al Maestro de Capilla para, en caso de no cubrir las plazas por los cauces reglamentarios, se encargue él personalmente de conseguirlos, y "vaya en persona a buscarlos, concertarlos y traerlos”. ${ }^{1701}$

Así y durante un tiempo, la Capilla goza de cierta estabilidad, aunque no demasiada, ya que el Lunes 18 de Junio de 1798, el Cabildo vuelve a recurrir al Maestro de Capilla para que salga a buscar músicos, facultando igualmente al Maestro de Capilla jubilado D. Juan Manuel Gaitán para que colabore en su búsqueda. ${ }^{1702}$

Parece que la búsqueda concluyó con éxito, a tenor de lo que nos dicen las actas en Noviembre de ese año, cuando el miércoles día 7, el Cabildo acuerda pagarle a Jaime Balius la cantidad de seis mil setecientos ochenta y dos ducados por los gastos causados por el viaje para encontrar a los referidos músicos. Asimismo “...se le concedió en los mismos términos tres mil ducados de ayuda de costa, y se le perdonaron las aspas causadas durante el viaje respecto a lo bien que ha desempeñado la comisión que le confió el Cabildo". 1703

En Abril de 1799, Jaime Balius da su consentimiento para que en la celebración del día de San Pedro, se pueda dividir su Capilla musical en dos partes diferentes con cometidos también distintos, ya que coinciden en el tiempo dos actos en los que era requerida su presencia. Según nos dice el acta capitular, “... con motivo de caer en este año el día de San Pedro Mártir en el primero de Letanías o Rogaciones, en que el Cabildo va en procesión a la parroquia de San Pedro con su Capilla de Música, y desear también el Santo Tribunal de Inquisición que concurra esta a la fiesta que

\footnotetext{
${ }^{1700}$ Ibid.

${ }^{1701}$ Ibid.

1702 Ibid. Lunes 18 de Junio de 1798, T.95.

${ }^{1703}$ Ibid. Miércoles 7 de Noviembre de 1798, T.95.
} 
anualmente celebra en la iglesia de San Pablo de esta ciudad...” ${ }^{1704}$, es por lo que se preguntó al Maestro de Capilla si se podía atender las dos ceremonias, a lo que contestó afirmativamente, ya que “... todo lo que hay que cantar en la función del Cabildo era de facistol solamente y no de música de papeles, y que así se podría repartir la Capilla”. ${ }^{1705}$ En vista de este informe positivo, el Cabildo acuerda “dar su anuencia y permiso para que así se ejecute, distribuyendo el Maestro la Capilla del modo más conveniente a la decencia de ambas funciones". 1706

Sin embargo, no siempre se resuelven los problemas o los imprevistos con tanta facilidad. De nuevo, y como ya había sucedido anteriormente, y era habitual en las catedrales, Balius tiene problemas de disciplina con algunos músicos. Así, en el acta del día 27 de Agosto de 1799 se da cuenta de la “insubordinación de los músicos al Maestro de Capilla y demás superiores” ${ }^{\text {1707, }}$ y especialmente hace referencia a la ausencia “sin decir nada ni pedir permiso alguno”, ${ }^{1708}$ del tenor Antonio Gil.

A principio de 1800 se le pide al Maestro de Capilla que informe sobre dos opositores que se habían presentado a plazas vacantes de la Capilla de San Acacio. Visto el informe el Cabildo acordó: “declarar que Don Manuel Ravé y Don Nicolás Anguita son útiles y necesarios en la Capilla”. ${ }^{1709}$

En Abril de ese mismo año, se comienza a solucionar una cuestión que sin duda preocuparía a Balius como era la falta de un trompa $1^{\circ}$ en su Capilla: “Oído el informe jurado del Maestro de Capilla sobre los opositores que se han presentado y hecho la oposición a la primera plaza de trompa que se haya vacante, pasaron a hacer la votación y habiéndose empatado por dos veces entre Jardín de Málaga y Ferrer de Alicante se dejó pasar otro día su decisión”. ${ }^{1710}$

Para resolver la provisión de esta plaza se vuelve a reunir el Cabildo. Tras volver a votar para deshacer el empate que había entre los dos aspirantes, resulta nombrado Don Francisco Ferrer, “con obligación de asistir a la enseñanza del Colegio de Niños

\footnotetext{
${ }^{1704}$ Ibid. Lunes 22 de Abril de 1799, T.95, fol. 387 r.

1705 Ibid.

1706 Ibid.

${ }^{1707}$ Ibid. Martes 27 de Agosto de 1799, T.95.

1708 Ibid.

${ }^{1709}$ Ibid. Jueves 20 de Febrero de 1800. T. 95, fol. 470 v.

${ }^{1710}$ Ibid. Sábado 26 de Abril de 1800. T. 95, fol. 486 v.
} 
de Coro, siempre que el Cabildo lo tuviese por conveniente, y con el sueldo de 4000 reales anuales". 1711

En Marzo de 1801, vemos de nuevo a Jaime Balius actuando en otra de sus funciones. En este caso se le convoca para que emita informe sobre las aptitudes musicales de los aspirantes para cubrir una beca vacante en el Colegio del Santo Ángel. Reflejamos ahora con más detalle cómo fue el desarrollo de esta prueba:

El Cabildo (reunido en la Capilla de San Clemente), manda llamar al Maestro de Capilla y a los infantes opositores. Se les hace pasar y comienza el examen. A los infantes opositores se les examina “de voz y lectura”, ${ }^{1712}$ y posteriormente se les hace retirar. A continuación, "se mandó al Maestro de Capilla que diese su censura, lo que efectuó por escrito, y se le mandó retirar..."1713 Posteriormente, “resulta nombrado para Colegial del Santo Ángel, el infante de Coro Miguel Colmenero”. ${ }^{1714}$

En Febrero de 1802 encontramos noticias de Jaime Balius, en este caso para examinar de canto a dos aspirantes que pretendían, "la capellanía de San Pedro, vacante en esta Santa Yglesia por fallecimiento de D. Antonio Villalba”. ${ }^{1715}$ Estos aspirantes eran D. Marcos Díaz, de la Catedral de Sevilla y D. Manuel Vázquez, de la Catedral de Córdoba. Se cita al Maestro de Capilla y a los opositores para realizar dicha prueba el viernes día 12 de Febrero.

En el Cabildo celebrado el día 2 de Abril se decide que D. Rafael del Río, (que previamente había solicitado que se le dispensara de cantar por padecer enfermedad que impedía esa labor), “supuesta la imposibilidad que manifiesta para cantar, cumpla su primera obligación de tocar el Biolín en el lugar que le señale el Maestro de Capilla, pero si pudiere cantar y el Maestro lo necesita lo hará del mismo modo, pues de lo contrario el Cavildo tomará las providencias que tenga por conveniente”. ${ }^{1716}$

En ese mismo Cabildo, Jaime Balius presenta un informe sobre el músico contralto D. Fermín Espinosa. Visto el informe, se admite su incorporación y se le

\footnotetext{
1711 Ibid. Martes 29 de Abril de 1800. T. 95, fol. 487 r.

1712 Ibid. Lunes 16 de Marzo de 1801, T.96.

1713 Ibid.

1714 Ibid.

1715 Ibid. Miércoles 10 de Febrero de 1802, T.96.

${ }^{1716}$ Ibid. Viernes 2 de Abril de 1802, T.96.
} 
asignan "quinientos ducados en cada año, advirtiéndole al Maestro que en cumplimiento de su obligación le instruya para el mejor desempeño y arreglo en la Capilla”. ${ }^{1717}$

El día 7 de Abril, miércoles, el Maestro de Capilla presenta informe sobre "los opositores que se han presentado a la Capellanía de San Pedro, vacante en esta Santa Iglesia, por fallecimiento de D. Antonio Villalba". ${ }^{1718}$ A los dos opositores que anteriormente citamos, se le añaden otros dos que se presentaron posteriormente:

"Se mandó entrar al Maestro el cual leió su Ynforme que juró, proponiendo en primer lugar como más apto para el desempeño de las obligaciones de dicha Capellanía a D. Manuel Álvarez, pbro. En segundo lugar a D. Marcos Díaz, pbro y segundo sochantre de la Santa Iglesia de Sevilla. Y en tercer lugar a D. Josef González, pbro. y D. Manuel Vázquez, clérigo de menores, los dos Capellanes de la Veintena de esta Santa Iglesia...”. 1719

En otro orden de cosas y tal como sucedió en el año 1799, ahora en Abril de 1803 también se encarga al Maestro de Capilla que divida ésta para atender tanto la festividad de San Pedro como el requerimiento de la Inquisición para participar en una función al Santísimo. Por tanto, se le pide que “distribuya a los músicos de esta Capilla en disposición de que el próximo día de San Pedro Mártir, cumplan asimismo las honras que hace el Cavildo por nuestro hermano difunto, el señor Aguilar y la función que hacen al Santísimo los señores Inquisidores”. ${ }^{1720}$

Cinco días después se trata en el Cabildo, la provisión de la plaza vacante de la Capellanía de San Acacio, para lo cual es requerido de nuevo Jaime Balius, si bien en esta ocasión surgen algunas dudas sobre si debiera ser él solo o alguien más quien juzgue dichas pruebas. "El Cavildo acordó nombrar y nombró por examinador de los opositores al Maestro de Capilla, y habiéndose suscitado duda sobre si se había de nombrar otro examinador con el Maestro de Capilla, el Cavildo acordó por votos

\footnotetext{
1717 Ibid.

${ }^{1718}$ Ibid. Miércoles 7 de Abril de 1802, T.96.

1719 Ibid.

${ }^{1720}$ Ibid. Viernes 22 de Abril de 1803, T.96.
} 
secretos, que solo el Maestro fuere el examinador". ${ }^{1721}$ Sin embargo la provisión de esta plaza tardaría algo más en producirse, ya que a primeros de Junio vemos cómo tras haber examinado a D. Pedro García, [salmista en la Santa Iglesia de Toledo], Balius no da su aprobación y nos dice que el "opositor a la Capellanía de San Acacio, afecta a la solchantría de nuestra Santa Iglesia, no tenía las qualidades de voz, pericia y demás que se requerían para solchantre de nuestra Santa Yglesia”. ${ }^{1722}$

En Agosto, Balius participa en la elección de D. Fermín Espinosa, para cubrir la Capellanía de Santa Inés. ${ }^{1723}$ Y en Septiembre, concretamente el día 30 (a la hora sexta), el Cabildo acuerda nombrarlo examinador de las oposiciones a las capellanías de San Antonino:

"En virtud del llamamiento para oír la relación de los opositores que han firmado la oposición a las dos capellanías vacantes en la Capilla de San Antonio, se mandó entrar al Notario Secretario quien dio quenta de que havian firmado la oposición por muerte de D.Joseph de los Rios, pbro, D. Manuel Gutierrez Rave, y a la vacante por haver obtenido otra incompatible D. Manuel Álvarez, D. Nicolás Anguita y D. Joseph Luis de Henos, y el Cavildo los admitió por opositores a las respectivas Capellanías. Nombró por examinador de los opositores a D. Jayme Balius Maestro de Capilla...". 1724

En este caso se acordó comenzar con las oposiciones esa misma tarde y seguir las tardes siguientes si fuese necesario.

Sin embargo el acta capitular de este día nos depara alguna que otra sorpresa. Ya en otras ocasiones hemos hablado de los problemas con que ocasionalmente se encontraba Balius debidos al comportamiento de algunos músicos. También sabemos que ésta fue una de las razones que le indujeron a aceptar el cargo de Maestro de Capilla del Real Convento de la Encarnación de Madrid y marcharse de Córdoba durante un período. Podíamos pensar, que el carácter serio del Maestro tuviera alguna responsabilidad en esto, pero la noticia que referimos a continuación demuestra que no

\footnotetext{
${ }^{1721}$ Ibid. Miércoles 27 de Abril de 1803, T.96.

${ }^{1722}$ Ibid. Martes 7 de Junio de 1803, T.96.

${ }^{1723}$ Cf. Ibid. Viernes 26 de Agosto de 1803, T.96.

${ }^{1724}$ Ibid. Viernes 30 de Septiembre de 1803, T.97.
} 
sólo era con el Maestro de Capilla sino que también existían diferencias de los músicos con el Cabildo. Lo comprobamos cuando el Deán nos dice textualmente:

"que para descargo de su conciencia no podía menos de exponer al cavildo que havia algún músico tan olvidado de su obligación y del respeto devido y subordinación a este Cuerpo, que no solo se mantenía fuera y ausente, sino que lo hacía con descaro y habiéndosele negado la licencia que solicitava, lo que podría traer algunos inconvenientes graves, y malas consecuencias, y el Cavildo mandole de llamamiento para tratar y resolver sobre este particular propuesto por el Señor Deán”. ${ }^{1725}$

Hay que destacar en este caso la sensibilidad del Deán, que al menos en acta, no cita el nombre de dicho músico, aunque de los términos que utiliza al hablar del tema en cuestión (“inconvenientes graves”, “malas consecuencias”), se desprende la gravedad de sus acciones.

Viene al caso hacer un pequeño comentario de la complejidad que comportaban normalmente las relaciones entre músicos, Maestro de Capilla y miembros diversos del Cabildo. En palabras de López Calo, y refiriéndose a la situación en la Catedral de Granada (perfectamente extrapolable a la de Córdoba) dice que”el cargo de Maestro de Capilla como la de Granada era particularmente difícil y duro, con grandes responsabilidades y tensiones en el trato diario con los músicos y con los canónigos". 1726

Para ilustrar este comentario vamos a hacer referencia a dos situaciones que reflejan la dificultad de esas relaciones. En ambos casos nos situamos en 1817: ${ }^{1727}$

En el primero, encontramos a D. Vicente Palacios, Maestro de Capilla de la Catedral de Granada, que discute con el Deán, y al parecer le falta el respecto, por lo que el Cabildo propone que se le multe, aunque finalmente queda en un apercibimiento. ${ }^{1728}$

\footnotetext{
1725 Ibid.

${ }^{1726}$ LÓPEZ CALO, José. Catálogo del Archivo de Música de la Catedral de Granada. Granada, Centro de Documentación Musical de Andalucía (Junta de Andalucía), 1991, Tomo I, pág. 150.

1727 Jaime Balius sigue en ese momento ejerciendo su Magisterio en Córdoba.

1728 "El señor deán informó al Cabildo que el Maestro de Capilla de esta santa iglesia había tenido algunas faltas de respeto y sumisión, cuando Su Señoría le había corregido algunos defectos en el templo; y en vista de cuanto expuso, estuvo el Cabildo determinado a que se le impusiese una multa, con
} 
El segundo tiene que ver con la salida de los músicos fuera de la catedral. El repertorio a interpretar y el hacerlo fuera de la Catedral, representaron motivos de conflicto en más de una ocasión. En Córdoba, tenemos múltiples noticias de llamamientos al orden que el Cabildo hace a los músicos por irse a tocar fuera de la Capilla sin el correspondiente permiso. En Granada, este mismo tema da origen al segundo suceso que queríamos comentar: Una vez más el Deán es informado de que músicos de la Capilla con su Maestro al frente, habían actuado fuera de la Catedral y, al parecer, sin permiso del Cabildo. Para más desgracia, los informadores denunciaron que el público había interrumpido con aplausos o correcciones la intervención de la orquesta. Visto lo cual el Cabildo se propuso tratar de inmediato y a fondo estos sucesos. $^{1729}$

Ya de vuelta en Córdoba, y siguiendo los pasos de Balius, vemos cómo a primeros de octubre de 1803, presenta su censura sobre las oposiciones a las que antes aludíamos a la Capilla de San Antonino, quedando finalmente elegido D. Manuel Gutiérrez Ravé. ${ }^{1730}$

No descansó mucho Balius de este tipo de obligaciones, pues tan solo dos días más tarde nos dice el acta capitular que participó en la elección de D. José de los Heros

apercibimiento de determinaciones más severas en el caso de que reincidiese; mas, interponiendo dicho señor su respeto y mediación para que el Cabildo mitigase la pena impuesta, se acordó que el señor juez protector de la música le reprendiese e hiciera los cargos que llevó entendido, apercibiéndolo de que, en lo sucesivo, guarde más moderación y respeto con el señor deán. Y con este motivo se acordó también que el mismo señor protector le notificase que hiciera las composiciones de música que, por su destino, tiene obligación de hacer, previniéndole que, si no lo efectuaba así, se costearían de su haber, como está decretado en diversos acuerdos capitulares”. LÓPEZ CALO, José. Catálogo del Archivo de Música de la Catedral de Granada. Granada, Centro de Documentación Musical de Andalucía (Junta de Andalucía), 1991, Tomo I, pág. 151. Cita el acta capitular de 3 de Septiembre de 1817.

1729 “El señor deán dio cuenta de que se le había informado que el domingo próximo había dado la Capilla de música una función en el convento de Santo Domingo, en que tocaron algunas sinfonías y cantaron motetes y arias, en que no se vio aquella religiosidad, decencia y majestad que se previene por los Padres de la Iglesia y Derecho Canónico en la música de los templos; que algunas personas piadosas e instruidas le habían dado la queja de que la Capilla de música de tan respetable iglesia se hubiese comportado como si hubiera sido una orquesta de teatro; [que] así mismo había advertido al Maestro de Capilla que sin licencia del Cabildo no parecía decoroso saliese a dirigir los músicos fuera de la iglesia, y en su manejo se hacían notables por los fieles ciertas maneras ruidosas de aplauso o de corrección hechas con tanto ruido que distraían la atención de todos; y que, deseando Su Señoría evitar semejantes abusos, lo ponía en noticia del Cabildo para que del modo más prudente y suave se corrijan. Oída semejante propuesta se acordó, por todos votos, dar citación y tratar con detenimiento este importante asunto”. LÓPEZ CALO, José. Catálogo del Archivo de Música de la Catedral de Granada. Granada, Centro de Documentación Musical de Andalucía (Junta de Andalucía), 1991, Tomo I, pág. 151. Cita el acta capitular de 7 de Octubre de 1817.

${ }^{1730}$ Cf. A.C.C. Actas Capitulares. Martes 11 de Octubre de 1803, T97. 
como capellán de San Acacio, por lo que oído el informe bajo juramento del Maestro, “acordó el Cavildo nombrar y nombró a D. Joseph de los Heros en la Capellanía vacante de la Capilla de San Acacio”. ${ }^{1731}$

Ya en 1804, en el mes de Abril vuelve a ser requerido para informar sobre la solicitud de D. Benito Torrellas para formar parte como Bajo de la Capilla de Música. En este caso se acepta dicha solicitud, "señalándole como de salario mil ducados de vellón, con la precisa condición de asistir a la enseñanza de los infantes de coro". ${ }^{1732}$

También en el mes de Abril vemos una solicitud del Maestro pidiendo que se le aumente el presupuesto para gasto de papel: "Se leyó un memorial de Don Jaime Balius, Maestro de Capilla, pidiendo se le aumente el situado para gastos de papel para composiciones, amanuense y poeta, y el Cavildo lo cometió a los Señores Diputados de Arcas Vacantes de Santa Inés, para que con la parte de Su Ilustrísima Nuestro Prelado, informen sobre su contenido con llamamiento". ${ }^{1733}$

Entre las obligaciones de Jaime Balius estaba también la asistencia con su Capilla a funciones paralitúrgicas, como lo demuestra este pasaje que a continuación vamos a detallar y que pone de manifiesto la actividad que desempeñaba dicha Capilla dentro de los tres días de Vela que seguían a la procesión con la imagen del Niño Custodio y de las Santas Reliquias. En las actas capitulares viene perfectamente delimitado el itinerario de la procesión, lo que se tenía que cantar en cada momento, y la participación de la Capilla de Música. Entresacamos este pasaje:

“En estos tres días [...] deberá determinar que haia Vela de Señores en el modo y forma que otras veces se ha practicado, la que deberá principar desde el mismo Viernes al concluirse el Coro por la tarde [...] y mandando a la Capilla de Música y a los Zeladores asistan todas las tardes, los primeros para cantar motetes y arias oportunas y tocar en los intermedios sonatas de instrumentos, y los segundos para

\footnotetext{
${ }^{1731}$ Ibid. Jueves 13 de Octubre de 1803, T.97.

1732 Ibid. Viernes 13 de Abril de 1804, T.97.

1733 Ibid. Miércoles 18 de Abril de 1804. T. 97, fol. 65 r.
} 
evitar los desórdenes que puedan ocurrir en las grandes concurrencias y que ciertamente havrá”. 1734

En Noviembre de ese año (1804), a Balius se le pide opinión sobre el estado de voz que conserva el músico Benito Torrellas: “...habiendo echo entrar al Maestro de Capilla y asegurado que Torrellas no havia perdido cosa alguna de su voz en los cinco meses que ha permanecido en Madrid, se acordó quede incorporado en la Capilla de Música en calidad de Bajo, con la dotación anteriormente señalada de mil ducados anuales...”. ${ }^{1735}$

Al mes siguiente, se presenta al Cabildo por parte del Maestro de Capilla, un dictamen en el que solicita se cubra una plaza de oboe vacante, pero hay dificultades monetarias, "no estando asegurado de que en los fondos de excusados huviese lo suficiente para su dotación”. ${ }^{1736}$

Hay que señalar que en ocasiones, el Cabildo determinaba con especial interés, el repertorio a interpretar por la Capilla Musical. Esto ocurría normalmente con motivo de alguna celebración relevante. Unos párrafos antes hemos visto un ejemplo, a propósito de una procesión. Ahora, y con motivo de una misa especial que se iba a celebrar el día 27 de Enero de 1805, en honor de San Rafael, con el Santísimo expuesto y con la solemnidad acostumbrada en semejantes funciones, se determina que se cante por la Capilla Musical el himno Te Deum, además de fijar otra serie de rituales, por lo que dicta que se “den las órdenes oportunas al Maestro de Ceremonias, Maestro de Capilla, Campanero y demás ministros para el cumplimiento de quanto se ha acordado". ${ }^{1737}$

A principios de Febrero (1805) se presenta un violinista de Sevilla llamado Fructuoso Gomes y "solicita ser admitido en la Capilla, por lo que acuerda oírlo al día siguiente, y se solicita informe posterior del Maestro de Capilla”. ${ }^{1738}$ Este informe llega

\footnotetext{
${ }^{1734}$ Ibid. Miércoles 26 de Septiembre de 1804, T.97.

1735 Ibid. Martes 27 de Noviembre de 1804, T.97.

${ }^{1736}$ Ibid. Sábado 22 de Diciembre de 1804, T.97.

${ }^{1737}$ Ibid. Lunes 22 de Enero de 1805, T.97.

${ }^{1738}$ Ibid. Martes 13 de Febrero de 1805, T.97.
} 
el día 20 de Febrero, cuando, una vez reunido el Cabildo, "se mandó entrar al expresado Maestro de Capilla, y leió la censura que havía dispuesto”. ${ }^{1739}$ Tras posterior deliberación, el Cabildo acuerda admitir al citado músico como miembro de la Capilla.

El 26 de Agosto se determina celebrar oposiciones para cubrir la plaza de primer violín. Se acuerda comenzar el día siguiente, el 27, acordando “nombrar por único examinador a el Maestro de Capilla” ${ }^{1740}$ El resultado nos llega un mes más tarde, el 25 de Septiembre, en que se leyó "la censura del Maestro de Capilla acerca de los opositores a la plaza de primer violín de esta Santa Iglesia”, ${ }^{174}$ después de lo cual se procedió a la votación, resultando admitido D. Miguel Reynaldi.

En el año de 1806, el 29 de Agosto, el Cabildo determina que se celebren las pruebas para cubrir la plaza de oboe $2^{\circ}$ y dice que los opositores "fueran examinados por el Maestro el día siguiente martes por la tarde”. ${ }^{1742}$ De estas pruebas saldrá elegido Cristóbal Bendicho, que al poco tiempo ya solicita al Cabildo una ayuda de costa. ${ }^{1743}$

Comienza 1807 con dos problemas para Balius. El primero hace referencia al ámbito privado de negocios, que también cultivó. Entre las diversas propiedades urbanas que Balius tuvo en Córdoba (y que detallaremos al final de este capítulo), había una casa-huerta en la collación de San Lorenzo. Para su mejora, dispuso aumentar el caudal de agua que por ella discurría, por lo que solicitó al Cabildo que le vendiera parte del agua que éste tenía en una huerta cercana. Pero el Cabildo rechazó dicha venta:

“El Señor Magistral, como Diputado de Hacienda hizo presente al Cavildo que el Maestro de Capilla trata de comprar una cuarta parte de paja de agua de la huerta de Santa María, pretendiendo que el Cavildo le admita en parte de pago el previdario de una casa del Cavildo que tiene en la colación de San Lorenzo y el Cavildo en su

\footnotetext{
1739 Ibid. Miércoles 20 de Febrero de 1805, T.97.

1740 Ibid. Lunes 26 de Agosto de 1805, T.97.

1741 Ibid. Miércoles 25 de Septiembre de 1805, T.98.

1742 Ibid. Lunes 29 de Agosto de 1806, T.98.

${ }^{1743}$ Ibid. Sábado 29 de Octubre de 1806, T.98.
} 
vista acordó dar y dio comisión a los Señores Diputados de Hacienda para que informen con llamamiento". 1744

También tuvo de nuevo problemas disciplinarios con los músicos. En el Cabildo de 15 de Enero, sucedió lo siguiente:

"Se leyó un memorial de Don Jaime Balius, Maestro de Capilla de esta Santa Iglesia en el que expone al Cavildo lo ocurrido el día de la Concepción a la hora de cantar el villancico de la procesión claustral, por falta del respeto debido que experimentó en Don Francisco Ferrer, músico de la Capilla, a quien el Señor Deán le multó en 4 aspas, por defecto y agravio que había cometido: pero considerando que dicha pena sola no es suficiente para borrar el vergonzoso agravio que en el hecho se le hizo a la autoridad del Cavildo y a la que por ley le asiste a él como Juez, Maestro y Cabeza de su cuerpo espera de la notoria justificación del Cavildo se sirva mandar se le dé una completa satisfacción por el dicho Don Francisco Ferrer para que sirva de exemplar a los presentes, y venideros, y el Cavildo en su vista acordó dar y dio comisión a los Señores Espejo y Riera para que informen al Cavildo con llamamiento sobre este memorial”. ${ }^{1745}$ Solicita el Deán asimismo que se le exija a D. Francisco Ferrer una "completa satisfacción [...] para que sirva de exemplar a los presentes y venideros”. 1746

El 12 de Febrero se presenta Gregorio Muñoz y Villareal, salmista de la Catedral de Málaga, para optar a una capellanía de San Pedro, por lo que el Cabildo acuerda que tanto él "como los dos capellanes de veintena de esta Iglesia que tienen firmada

\footnotetext{
${ }^{1744}$ Ibid. Jueves 15 de Enero de 1807. T. 98, fol. 191 v. Las "pajas de agua” eran cantidades determinadas de agua (depende el lugar y la época, pero podían oscilar alrededor de litro y medio por minuto) que se podían adquirir al propietario de una fuente, manantial o venero, normalmente para regar huertos. La titularidad de estas vías de agua podía ser pública (Ayuntamiento) o privada (Cabildo, Condes, Duques, etc.). A veces, los señores adinerados podían dar en concepto de limosna una parte de su agua. Estas costumbres eran habituales ya en épocas anteriores. Como ejemplo pondremos el caso del Convento del Corpus Christi de la localidad de El Viso (Sevilla). Allí, en 1603, la Condesa Doña Beatriz Ramírez de Mendoza funda el convento de Mercedarios Descalzos. Para dotarlo de agua se utiliza la que procede de la fuente situada en la plaza pública, y que era la limosna de "media paja de agua”, que el Conde, Gaspar Juan Arias de Saavedra, concedió al convento. Cf. CAMPILLO, José Ángel. "Religiosidad y Vida Cotidiana en el Convento del Corpus Cristi”, en Revista de Fiestas de la Santa Cruz $n^{\circ}$ XVI. Editorial Asociación Cultural Amigos del Viso. El Viso, 2004.

${ }^{1745}$ Ibid. Jueves 15 de Enero de 1807. T. 98, fol. 192 r.

${ }^{1746} \mathrm{Ibid}$
} 
también la oposición, hagan sus exercicios en la tarde del viernes próximo después de completas, siendo examinadores el Maestro de Capilla, D. Juan Ortiz y D. Manuel Álvarez, Capellanes de San Pedro". ${ }^{1747}$

En Julio de ese año, Balius, junto con D. Alfonso Martín y D. Josef Moyano, músicos de la Capilla, son nombrados como examinadores de D. Nicolás Anguita (contralto de la Capilla), en cuanto a la provisión de la capellanía de San Antonino. ${ }^{1748}$

Como hemos visto en anteriores noticias de este capítulo, la movilidad de músicos entre las Catedrales, Colegiatas y Monasterios era muy frecuente, con el objetivo natural en la mayoría de los casos, de mejorar el estatus económico y profesional. En este caso hacemos referencia al memorial presentado el 27 de Octubre de 1807 por D. Antonio Ordóñez, presbítero músico tiple de la Catedral de Cádiz "solicitando que el Cabildo le señalase día y hora para cantar en el Coro y pudiesen de este modo oírle los señores que no le huviesen oído quando cantó la primera vez, y se acordó que mañana por la tarde miércoles 28 del corriente después de coro cantase, avisando el notario secretario al Maestro de Capilla y al interesado para dicho efecto". 1749

Una circunstancia muy parecida acontece pocos días después, el 31 de Octubre, cuando igualmente es solicitada la presencia del Maestro de Capilla y de D. Juan Ortiz, para que "en la tarde de este día después de completas se le pruebe al expresado Ximenez [Francisco Ximenez Delgado, presbítero, Sochantre de Granada] en Canto Llano y música, para informar al Cabildo de su calidad de voz, pericia $e$ inteligencia". 1750

A partir de 1808, las actas capitulares se ven repletas de noticias referentes a la invasión francesa. A pesar del rechazo general que produce dicha invasión, y que llevó a Balius a escribir un himno de exaltación de la unidad andaluza contra el invasor francés, se le pide a todo el Cabildo que mantenga las formas y las buenas maneras, como vemos en la noticia siguiente:

\footnotetext{
${ }^{1747}$ Ibid. Jueves 12 de Febrero de 1807, T.98.

${ }^{1748}$ Cf. Ibid. Sábado 11 de Julio de 1807, T.98.

1749 Ibid. Martes 27 de Octubre de 1807, T.99.

${ }^{1750}$ Ibid. Sábado 31 de Octubre de 1807, T.99.
} 
"El señor Deán dijo que en la tarde del día anterior havía estado a visitarle una Diputación de la Ciudad, poniendo en su noticia, para que lo trasladase a la del Cabildo, haver recibido una orden del Exmo Sr. Ministro de Hacienda, en que S.E. avisa el tránsito de tropas francesas por esta ciudad en dos divisiones, a fín de que este Ilustre Cuerpo contribuia por su parte a exortar a sus dependientes y ministros a la quietud y tranquilidad, buen trato y acogida de dichas tropas...”. 1751

Sin embargo, llegan noticias del estado en que los invasores dejan el Santuario de la Fuensanta y otros lugares cordobeses, e incluso se llega a cerrar unos días la Catedral de Córdoba "por la irrupción de los franceses". ${ }^{1752}$ Un acta posterior nos confirma que fueron cinco los días que estuvo cerrada la Catedral. ${ }^{1753}$

Habrá que esperar a finales de este año de 1808 para volver a encontrar alguna noticia que afecte al Maestro de Capilla. En este caso, el Cabildo acuerda que los tradicionales villancicos y la kalenda que se interpretan en Navidad, y que tanto trabajo requieren para su puesta a punto, se suspendan debido al ambiente existente por la invasión. ${ }^{1754}$

En 1809, vemos de nuevo a Balius, esta vez requerido para informar de una situación verdaderamente curiosa. En este caso el 5 de Mayo se somete al Cabildo un memorial que dice "que el trompa Borja asiste mucho tiempo y no toca porque parece

\footnotetext{
${ }^{1751}$ A.C.C. Actas Capitulares. Viernes 27 de Mayo de 1808, T.99.

1752 Ibid. Sábado 2 de Julio de 1808, T.99.

${ }^{1753}$ Ibid. Miércoles 6 de Julio de 1808, T.99.

${ }^{1754}$ El Cabildo, "con consideración a las actuales aflictivas calamidades, determinó por uniformidad de votos que se suspenda la música de la calenda y villancicos que de inmemorial tiempo se ha acostumbrado el día víspera del Nacimiento de Nuestro Buen Jesús, extendiéndose este acuerdo a la Nochebuena en la propia forma así como en los días de Pascua, y demás que ha sido estilo cantar villancico; que se cierren todas las Capillas de la Iglesia para que sea la única misa en la citada noche la del Gallo, respecto a deber ser más temprano que en otros años, haciéndose saber a todos los Sacristanes por el notario secretario capitular, cuidando de su execución el infrascrito: que la Prima se cante a las siete en punto, y enseguida la Misa de Aurora, o de Luz, quedando así encargado de cantarla el Señor Tesorero, el Señor Ugalde el Evagenlio, y la Epístola el Señor Magistral: y por último se dio comisión a los mismos Señores Diputados de Ceremonias para que informen los días en que podrán hacerse dos, tres o más sermones, exponiendo su dictamen con respecto al modo y forma en que deberá concurrir en su caso el Cavildo”. A.C.C. Actas Capitulares. Martes 20 de Diciembre de 1808. T. 99, fol. $160 \mathrm{v}$.
} 
que se lo impide la falta de un diente”, ${ }^{1755}$ por lo que se acuerda pedir opinión al Maestro de Capilla y después decidir si se le cambia de instrumento o se le jubila. Posteriormente vemos cómo se le concede la posibilidad de que toque únicamente la viola. $^{1756}$

En Diciembre de este mismo año de 1809, Balius es requerido para examinar a los aspirantes a cubrir tres plazas de niños de coro, "quedando nombrados en ellas Francisco Garrido, Pedro Rivera y Rafael Luque ${ }^{1757}$

1810 es un año decisivo en el funcionamiento de la Capilla de Música. Un año de cambios, de reorganización, de rebajas en los sueldos de los músicos, etc., y la mayoría de estos cambios se dan en los últimos meses del año. No hay, sin embargo, demasiadas noticias del Maestro de Capilla, al menos en su faceta profesional. Por eso resulta gratificante encontrarlo de nuevo en el mes de Octubre al frente de su Capilla, participando en la tradicional procesión que trasladaba a la imagen de San Rafael a su iglesia. En el acta de 11 de Octubre se planifica cuidadosamente el desarrollo de dicho evento, acordando "que se hiciese su traslación en una procesión general, celebrada con toda la pompa y solemnidad que cabe en esta especie de funciones sagradas". ${ }^{1758}$ Para ello lógicamente se cuenta con la parte musical, y se decide lo siguiente: “Al salir la procesión de la Iglesia se entonará el Te Deum, que se cantará alternativamente por la veintena y Capilla de Música”. ${ }^{1759}$

Sin embargo, este año de 1810 nos ha permitido conocer algún detalle más sobre la vida privada de Jaime Balius. Hasta ahora la mayoría de las referencias que venimos haciendo tienen como soporte las Actas Capitulares, pero queremos en este momento incluir una referencia que nos ilustra un aspecto de la vida de Balius fuera de su actividad profesional. Se trata de la compra por su parte de un crucifijo de marfil procedente de los bienes de D. José Roncali, antiguo racionero de la Catedral. Al

\footnotetext{
1755 Ibid. Viernes 5 de Mayo de 1809, T.99.

1756 Ibid. Viernes 12 de Mayo de 1809, T.99.

${ }^{1757}$ Ibid. Miércoles 6 de Diciembre de 1809, T.99.

1758 Ibid. Jueves 11 de Octubre de 1810. T.100.

${ }^{1759}$ Ibid. Jueves 11 de Octubre de 1810. T.100.
} 
parecer este crucifijo tenía gran valor artístico, lo cual era sabido y comentado por diversos personajes de la ciudad, al igual que se supo que había sido adquirido por el Maestro de Capilla de la Catedral. ${ }^{1760}$

A finales de 1810, las preocupaciones de Balius aumentan, ya que su Capilla se va a ver afectada por la escasez económica que se arrastra tras el saqueo de las arcas por los franceses. Esta situación comienza a ser preocupante, con rebajas sustanciales en el sueldo de los músicos e incluso la desaparición del Colegio de Infantes: "el Colegio no puede subsistir por falta de Rentas; el Colegio no sirve ya para la enseñanza música de los niños; el colegio pues debe suprimirse; y una parte de las rentas destinadas a su manutención, debe convertirse para la consignación necesaria de los jóvenes, que hayan de hacer el oficio de niños y acólitos". ${ }^{1761}$

Así comienza 1811, con la desaparición del Colegio de Infantes, aunque se sigue manteniendo la actividad dentro de la Catedral de los Niños de Coro.

Tenemos de nuevo alguna referencia de nuestro Maestro de Capilla, cuando en el acta del día 18 de Mayo de 1811, el Cabildo aprueba que los Capellanes perpetuos y los músicos “asistan á los entierros de los SS. Capitulares, á las casas de estos, y al oficio de sepultura. Y el Cabildo acordó que lo practiquen de este modo, y que se pase la orden competente al Notario Secretario para que lo haga entender a los primeros y al Maestro de Capilla con respecto a los segundos". ${ }^{1762}$

\footnotetext{
1760 "En 21 de Junio de 1810 murió en una de aquellas casas [de la calle Encarnación] el ilustrado Racionero de la Catedral D. José Roncali, tío del general del mismo apellido, quien a fuerza de trabajo y dinero, reunió una magnífica colección de pinturas, esculturas, libros y otra multitud de objetos curiosos, los que en su mayor parte vendieron los albaceas a D. José López Cepero, cura del Sagrario y después Deán de aquella metropolitana iglesia: el distinguido Maestro de Capilla D. Jaime Balius, compró en dicha almoneda un hermoso crucifijo de marfil, que después adquirió D. Salustiano de Trevilla". RAMÍREZ DE ARELLANO, Teodomiro. Paseos por Córdoba. Córdoba, Librería Luque, 1976, tercera edición, pág. 562.

Tenemos más detalles de la venta del mencionado crucifijo: “ $D$. Carlos Ramírez de Arellano tiene de su señora, un lindísimo crucifijo de marfil que heredó de su padre, que fue del señor Roncali, de cuya escultura me habló D. Diego de Monroy ser muy sobresaliente en su mérito artístico y que en la testamentaria del señor Roncali compró D. Jaime Balius, Maestro de Capilla que fue de esta Catedral, y los herederos de éste, vendieron a D. Salustiano Trevilla por el valor de cien ducados". POZO CÁCERES, Juan Lucas del. “D. José Roncali”, en Colección de Obras. Córdoba, 1863. Ms., pág. 234.

${ }_{1761}$ A.C.C. Actas Capitulares. Miércoles 19 de Diciembre de 1810, T.100.

${ }^{1762}$ Ibid. Sábado 18 de Mayo de 1811. T.101.
} 
Pero en 1811 se siguen manteniendo los recortes presupuestarios, lo que afecta a la Capilla y que evidentemente no gustaría a Balius. Así, y siguiendo la trayectoria de los últimos tiempos, el Cabildo acuerda respecto a las plazas de músicos, que “Conforme vaquen estas plazas, quedarán suprimidas y su importe aplicado a los fondos generales de la Fábrica, para que pueda invertirse en todas las necesidades y urgencias de ella. Por ninguna causa se proveerán de nuevo estas plazas...". ${ }^{1763}$

Ya en 1812, en el mes de Marzo, el Cabildo prepara la celebración de la Semana Santa y acuerda “que las Tinieblas del Miércoles Santo se empiecen á las tres y media; y que se prevenga al Maestro de Capilla que las Lamentaciones y el Miserere de dicha tarde, y la del Jueves siguiente, sean de música ligera y abreviada...”. ${ }^{1764}$ Es decir, que los recortes afectan no sólo a las plazas y a los sueldos, sino también a la música. Seguramente todos estos problemas provocaron en el Maestro numerosos malos ratos. No sabemos si fue por esto o por alguna otra necesidad, pero lo cierto es que Balius solicita el día 3 de Octubre permiso para un viaje: "Se leyó otro memorial del Maestro de Capilla en que pide licencia para un viaje». ${ }^{1765}$ Posteriormente, el día 7 del mismo mes, el Cabildo acuerda “conceder y concedió al referido, la licencia que pide para ausentarse de esta ciudad hasta el día último del próximo Noviembre”. ${ }^{1766}$

Ya de vuelta de su viaje, en Febrero de 1813 lo vemos actuando en el examen de varios aspirantes a una plaza vacante de Niño de Coro, quedando finalmente nombrado para ella Francisco de Mora. ${ }^{1767}$

No hemos encontrado más noticias que afecten directamente a Balius durante este año, aunque a juzgar por el resto de noticias musicales, la Capilla siguió su actividad normal con su Maestro al frente.

1814 trae para Jaime Balius nuevas complicaciones en su plantilla de músicos. De entrada, muere el organista $2^{\circ}$, José Benito Bach. Por si fuera poco, un cantor de la

\footnotetext{
1763 Ibid. Jueves 4 de Julio de 1811. T.101.

1764 Ibid. Sábado 21 de Marzo de 1812. T.101.

1765 Ibid. Sábado 3 de Octubre de 1812. T.102.

${ }^{1766}$ Ibid. Miércoles 7 de Octubre de 1812. T.102.

${ }^{1767}$ Ibid. Martes 23 de Febrero de 1813. T.102.
} 
Capilla, el tiple Antonio Ordoñez, es expulsado por sus reiteradas faltas de asistencia. ${ }^{1768}$ Una buena noticia, sin embargo, es la recuperación de la celebración de la Navidad, tal como se hacía antes de la llegada de los franceses, es decir, con los acostumbrados villancicos. ${ }^{1769}$

En Julio de 1815 vemos de nuevo a Balius formando parte de un tribunal para elegir un infante de Coro, del que salió elegido Francisco de Paula López. ${ }^{1770}$

En Agosto, actúa como apoderado representante de Ángel Arteaga, en la toma de posesión de una media ración, que estaba vacante por la muerte (el 29 de Enero de 1811) de Felipe Villaescusa. El Sábado 12 de Agosto se celebra el Cabildo de posesión, en donde “... recibiendo en su compañía a D. Jayme Balius, presbítero podatario de D. Ángel Arteaga, con mi asistencia y la de los testigos que se expresaran, se dirigió al dicho [segundo] coro, y estando en la silla que corresponde le dio S.S. a dicho presbítero á nombre de su Pte. La posesión real”. ${ }^{1771}$

Todavía en 1815, el 27 de Octubre, es convocado como miembro de un tribunal de oposición a una capellanía de veintena. El acta nos dice que se presentaron tres opositores, "y se acordó que se haga el examen de ellos y de qualquiera otro que se presente mañana 28 después de Completas en el Coro, siendo examinadores el Maestro de Capilla, el Sochantre interino, y el segundo". ${ }^{1772}$

Por el acta del día 31, sabemos que "resultó electo por votación canónica para la dicha Capellanía de Veintena D.Antonio de Ayllon, Acólito de esta Santa Iglesia”. ${ }^{1773}$

En Junio de 1816, concretamente el día 10, El señor Deán hizo presente que desde las vísperas de San Rafael el Maestro de Capilla le había dado las quejas por la falta de voces que, según criterio de dicho Maestro, imposibilitaba el correcto

\footnotetext{
${ }^{1768}$ Cf. Ibid. Viernes 7 de Octubre de 1814. T. 102, fol. 276 v.

1769 Cf. Ibid. Viernes 7 de Octubre de 1814. T. 102, fol, 276 r.

${ }^{1770}$ Cf. Ibid. Lunes 10 de Julio de 1815, T.103.

1771 A.C.C. Sección de Capillas y Capellanías. Legajo 5º-3º.

1772 Ibid. Viernes 27 de Octubre de 1815, T.103.

1773 Ibid. Martes 31 de Octubre de 1815, T.103.
} 
funcionamiento de la Capilla, opinión que no es compartida totalmente por el Cabildo. ${ }^{1774}$

No obstante, al poco tiempo la Capilla se refuerza con un nuevo tenor, D. José Ruiz. En ese mismo Cabildo, Jaime Balius recoge la Media Ración de D. Ángel Arteaga, actuando en este caso como apoderado del mismo. ${ }^{1775}$

Todavía estamos en 1816, mes de Septiembre, cuando actúa como examinador de dos nuevos músicos finalmente admitidos: D. Rafael Marín, violoncello y D.Rafael Arroyo, oboe. ${ }^{1776}$ A finales de ese mes hace lo propio como juez de una vacante de Niño de Coro en la que finalmente queda nombrado Francisco Sáez. ${ }^{1777}$

Lo mismo sucede al mes siguiente con Don Gregorio Muñoz Villarreal ${ }^{1778}$ examinado de voz y canto llano, y Don Francisco Lara, como bajón. ${ }^{1779}$ Ambos serán aceptados.

Pero además de atender todas estas obligaciones, Balius encuentra tiempo para ocuparse de sus negocios. Ya vimos que en 1807, había querido comprar (sin éxito) cierta cantidad de agua al Cabildo para regar una huerta de su propiedad. Ahora lo intenta de nuevo, con el mismo resultado. El 3 de Diciembre se lee una solicitud del Maestro de Capilla donde expresa que “quiere comprar una quarta parte de pajas de agua [del Cabildo], cediendo por su importe una casa huerto en San Juan de Letrán”. ${ }^{1780}$ Sin embargo, "sobre la permuta que el Maestro de Capilla propone, dando la casa huerto que tiene en la Calleja de Lagonilla no10 a la calle de la Banda, Parroquia de San Lorenzo, por una $4^{a}$ parte de agua”, ${ }^{1781}$ se negó por parte del Cabildo, tal permuta.

Tras este paréntesis dedicado a sus negocios, Balius vuelve a sus funciones de examinador el Jueves día 19 (acompañado en esta ocasión de D. Miguel Reynaldi y D. Manuel Vals), en que se presenta D. Francisco Navarro, músico bajonista de la Real Capilla de Granada, quien solicita una plaza de bajón. ${ }^{1782}$

\footnotetext{
${ }^{1774}$ Cf. Ibid. Lunes 10 de Junio de 1816, T.103.

${ }^{1775}$ Cf. Ibid. Lunes 29 de Julio de 1816, T.103.

${ }^{1776}$ Cf. Ibid. Miércoles 4 de Septiembre de 1816. T.104.

1777 Cf. Ibid. Sábado 28 de Septiembre de 1816. T. 104, fol. 33 r.

1778 Cf. Ibid. Sábado 9 de Noviembre de 1816. T. 104, fol. 65 r.

${ }^{1779}$ Cf. Ibid. Miércoles 27 de Noviembre de 1816. T.104.

${ }^{1780}$ Ibid. Martes 3 de Diciembre de 1816. T.104.

${ }^{1781}$ Ibid. Viernes 6 de Diciembre de 1816. T.104.

${ }^{1782}$ Cf. Ibid. Jueves 19 de Diciembre de 1816. T.104.
} 
En Enero de 1817 se realizan las pruebas para cubrir la plaza de segundo organista, vacante desde hacía varios años por la muerte de de D. José Bach. Supuestamente debía de estar en el tribunal Jaime Balius, como Maestro de Capilla. Pero en esta ocasión no lo está, sino que fueron los examinadores Don Andrés Lidón, Don Joseph Moyano y Don Miguel Reynaldi. ${ }^{1783}$ Tal vez pudo influir en esta decisión que el único opositor fuese D. Francisco Balius.

En Mayo, se examina de voz y canto llano a D. Rafael López, aspirante a entrar en el Coro, designándose como sus jueces al Sochantre y al Maestro de Capilla. ${ }^{1784}$ Este último examinó en Septiembre a diversos pretendientes a una plaza de Niño de Coro, resultando elegido José María Pérez. ${ }^{1785}$

En 1818, Jaime Balius y Vila comienza a dar síntomas de cierto cansancio, puesto que solicita al Cabildo no asistir diariamente al Coro. El Cabildo lo exonera de la asistencia al Coro, en aquellos días en que hay sólo música de Facistol, debiendo asistir cuando la haya de Papeles, y en todas las festividades importantes. Asimismo el Cabildo encarga a los Diputados de Santa Inés que prevengan al Maestro de Capilla para que “continúe sus trabajos de composiciones que expresa, y de recogerlos y conservarlos para el beneficio de la Iglesia, como lo ofrece”. ${ }^{1786}$

Una pequeña alegría debió ser para él, el anuncio de que el primer violín de la Capilla, D. Miguel Reinaldi, (que llevaba algún tiempo fuera), anunciara su reincorporación en breve. ${ }^{1787}$

Hemos visto hasta ahora, la importancia que tiene para Jaime Balius, que un músico domine varios instrumentos, y la gran influencia que a la hora de su posible contratación tiene esta circunstancia. En 1919, queda de manifiesto este aspecto, cuando se le indica a dos músicos, la obligación que tienen de tocar otros instrumentos siempre que el Maestro de Capilla se lo ordene:

\footnotetext{
${ }^{1783}$ Cf. Ibid. Sábado 25 de Enero de 1817. T. 104, fol. 98 v.

${ }^{1784}$ Ibid. Viernes 23 de Mayo de 1817. T. 104, fol. 147 r.

1785 Ibid. Martes 2 de Septiembre de 1817. T. 104, fol. 222 v.

${ }^{1786}$ Ibid. Viernes 29 de Mayo de 1818. T. 104, fol. 336 v.

${ }^{1787}$ Cf. Ibid. Viernes 18 de Septiembre de 1818. T.105.
} 
En Enero, el día 29, se reúne el Cabildo para oír la censura del Maestro de Capilla sobre la solicitud de D. Juan de la Cruz y Roxas: “y el Cabildo en su vista y del informe de los SS. Diputados acordó señalar y se señaló al dicho D. Juan, quinientos ducados de los fondos de Arcas vacantes de Santa Inés, con la obligación de segundo trompa y con la de tocar el vajón, y violín cuando el Maestro de Capilla lo disponga o pareciese conveniente". ${ }^{1788}$

Lo mismo sucede en Diciembre, cuando el aumento de sueldo de un bajonista lleva implícito tocar otros dos instrumentos: “Al bajonista Don Francisco Lara cien ducados de aumento de renta anual, con la obligación de tocar el contrabajo y la flauta cuando se lo ordene el Maestro de Capilla”. ${ }^{1789}$

Ya en 1820, el sábado 16 de Septiembre, Jaime Balius es requerido para opinar sobre la solicitud de D. José Molina de formar parte de la Capilla de Música:

"Entró el Maestro de Capilla y leyó un informe o certificación que traía por escrito, y recomendaba al Sr. Josef Molina como músico digno tanto en la cuerda de Contraltos como en la de Tiple, y aunque su voz no es del mayor cuerpo, la despide con gana y es agradable al oído; por lo que y teniendo en la voz de tiple cinco o seis puntos altos de falsete superior lo contemplaba el Maestro utilísimo en la Capilla de Música..”. 1790

Tras las pertinentes consultas, es admitido en ella con el sueldo de quinientos ducados. $^{1791}$

Pocos días después, el 6 de Octubre, Balius es objeto de una queja por parte de un Diputado de Ceremonias, el Sr. Caballero. Este, durante el Cabildo, y con motivo de acercarse las fiestas navideñas, solicita que:

\footnotetext{
${ }^{1788}$ Ibid. Viernes 29 de Enero de 1819. T.105.

${ }^{1789}$ Ibid. Miércoles 22 de Diciembre de 1819. T. 105, fol. 97 v.

${ }^{1790}$ Ibid. Sábado 16 de Septiembre de 1820. T105. Como dice Samuel Rubio refiriéndose al Tiple, "no quiere decir necesariamente que se tratara de personas castradas, sino de adultos dotados por la naturaleza de ese timbre; de algunos se sabe incluso que eran casados". RUBIO, Samuel. Historia de la música española desde el "ars nova" hasta 1600. Alianza Editorial, Madrid 1983, pág.29. En otras ocasiones sí eran castrati o bien aunque tuvieran de forma natural una voz aguda se ejercitaban además en la técnica del falsete.

${ }^{1791}$ Ibid.
} 
“...se tomen algunas medidas de remedio en lo que todos ustedes conocen y experimentan en la noche de la Natividad de nuestro Señor Jesucristo, pues dilatando tanto el Maestro de Capilla la música y sonatas instrumentales en los Maitines de dicha noche, resulta que la primera misa que debe principiarse poco después de las doce, se principia por lo regular después de las dos...”. ${ }^{1792}$ Por lo que el Sr. Caballero propone se tomen algunas medidas que "remediaran los abusos e hicieran menos gravosa la residencia en referida noche, mandando al Maestro de Capilla arregle la música que no ecceda de las 12 de la noche...”. ${ }^{1793}$ En acta posterior de 16 de Diciembre se nos dice que "quede a la prudencia del Sr. Presidente la moderación de los villancicos, músicas y solemnidad de la Misa del Gallo y a la de los señores Capitulares el orden de las misas, después de la Solemne". 1794

En 1821, y en lo referente a Jaime Balius, llama la atención que no se le cite expresamente como examinador en diversas pruebas que se realizan en el mes de Noviembre para el acceso de nuevos Niños de Coro. ${ }^{1795}$ No obstante siguió trabajando durante este año en la composición de los villancicos habituales, así como de la Kalenda Cantemos al Encumbrado (96/806).

Sí encontramos su participación en un acto celebrado en Agosto de 1822, relativo al nombramiento de Mariano Zurbano y Mesa como Niño de Coro. Este nombramiento se lleva a cabo una vez que “... habiendo presentado el Maestro de Capilla de ella [de la Capilla] la censura de las voces”, ${ }^{1796}$ se convino en elegir al anteriormente citado.

Ya hemos hablado anteriormente de la posible falta de fuerzas que en los últimos años acompaña a Balius, de su rebaja en la asistencia a Coro, salvo en los días importantes, pero posiblemente hubo un suceso que acabó por desanimarlo, y éste fue la condena a ocho años de confinamiento de una de de sus personas más cercanas, D. Ángel Arteaga (aunque su mejor amigo parece que fue D. José Moyano). Recordemos

\footnotetext{
1792 Ibid. Viernes 6 de Octubre de 1820. T.105.

1793 Ibid.

${ }^{1794}$ Ibid. Sábado 16 de Diciembre de 1820. T.105.

1795 Cf. Ibid. Sábado 10 de Noviembre de 1821. T.106.

${ }^{1796}$ Ibid. Viernes 23 de Agosto de 1822. T106.
} 
que el mismo Balius se desplazó hasta Santo Domingo de la Calzada y se trajo a Arteaga, y que posteriormente fue su apoderado en la recepción de una media ración.

Pues bien, el Lunes 14 de Octubre de 1822, se leyó un oficio del gobernador de esta diócesis (Córdoba), en que se le comunica al Cabildo que el Señor Don Ángel Arteaga, entre otros, ha sido acusado de conspiración y rebelión contra el sistema constitucional, comunicándole la sentencia pronunciada contra él por la audiencia territorial de Castilla La Vieja y León. Dicha sentencia lo condena a ocho años de confinamiento en una de las Islas Baleares, bajo la vigilancia de las autoridades civiles y militares. $^{1797}$

No sabemos hasta qué punto éste nuevo contratiempo influyó en el Maestro de Capilla, lo cierto es que el día 3 de Noviembre, se produce la muerte de Jaime Balius y Vila:

“El Señor Presidente manifestó al Cavildo que habiendo fallecido el Maestro de Capilla Don Jaime Balius, a cuyo cargo corría la impresión y composición de la letra y música de la Calenda y Villancicos de la festividad de la Natividad de Nuestro Señor Jesucristo, lo manifestaba al Cavildo para su resolución en el presente año, en que tan próxima estaba dicha solemnidad. Y el Cavildo después de alguna discusión acordó, que en vista de haberse recogido todos los papeles y composiciones antiguas del difunto Maestro de Capilla se cante este año la Calenda y Villancicos del mismo modo que en los años anteriores, sin hacerse novedad, dando comisión a los Señores Diputados de Ceremonias para todo lo concerniente a ello". 1798

Llama la atención, que no encontremos en las actas capitulares una referencia más extensa y detallada de las circunstancias de su muerte o de los funerales, salvo ésta, interesada y circunstancial, cuando ya había pasado un mes del suceso, sobre todo teniendo en cuenta los muchos años que estuvo de Maestro de Capilla en Córdoba, el que fue "la honra de los Maestros de Capilla de todas las Iglesias de España por el mérito de sus obras". 1799

\footnotetext{
${ }^{1797}$ Cf. Ibid. Lunes 14 de Octubre de 1822. T. 106, fol. 246 r.

${ }^{1798}$ Ibid. Miércoles 4 de Diciembre de 1822. T. 106, fol 261 r.

1799 POZO Y CÁCERES, Juan Lucas del. Rasgos biográficos y fisionómicos [de cordobeses]. [ejemplar mecanografiado]. Córdoba, 1863. Pág.63.
} 
Sabemos que en el momento de su muerte, a los 72 años, Balius tenía su domicilio en la calle Jesús María n³ (nombre que se conserva en la actualidad), en una casa de su propiedad. En dicha casa vivían además Joaquina de Burgos de 21 años, José Reges de 19 (estudiante), Cecilia Tomas de 72 (sirviente) y Ma Ramírez también de 72 años (sirvienta). Asimismo era propietario también de la casa $\mathrm{n}^{\circ} 4$ de la misma calle, que tenía arrendada a D. Manuel Lodeyro, oficial letrado, quien vivía allí con su esposa $D^{a}$ Francisca Castro y sus tres hijos. ${ }^{1800}$ No son las únicas casas que tenía en propiedad, sino que, como veremos en su testamento, también era propietario de otras dos, situadas respectivamente en la calle Siete Rincones (actualmente calle Málaga) y en la calle Pescadería (actualmente calle Luis de la Cerda).

Presentamos ahora su partida de defunción, gracias a la cual conocemos algún detalle más, que tanto escatima la documentación catedralicia:

“En Córdoba á los tres días del mes de Noviembre de mil ochocientos veinte y dos, recibidos los santos sacramentos murió en el distrito de la collación de esta Iglesia Parroquial del Salvador y Santo Domingo de Silos, D. Jaime Vallius Pbro. Maestro de Capilla de la Santa Iglesia Catedral, natural de la ciudad de Barcelona; y al siguiente día fue su cadáver sepultado en el cementerio de la Salud, habiéndosele hecho por esta parroquia el oficio de entierro solemne, de que doy fe $=$ Fábrica 19 reales $=D$. Francisco Pérez Texada”. 1801

En esta iglesia de San Salvador, que está en la Plaza de la Compañía de Córdoba, se celebraron los funerales por la muerte de Jaime Balius y Vila, ya que su último domicilio, la calle Jesús María, muy cercana, pertenecía a la colación de dicha Iglesia.

\footnotetext{
${ }^{1800}$ Archivo Municipal de Córdoba. Padrón Municipal. Año 1822, pág.27.

${ }^{1801}$ Iglesia Parroquial de San Salvador y Santo Domingo de Silos. Libro de difuntos de los años 1806 a 1830, folio 240v.
} 


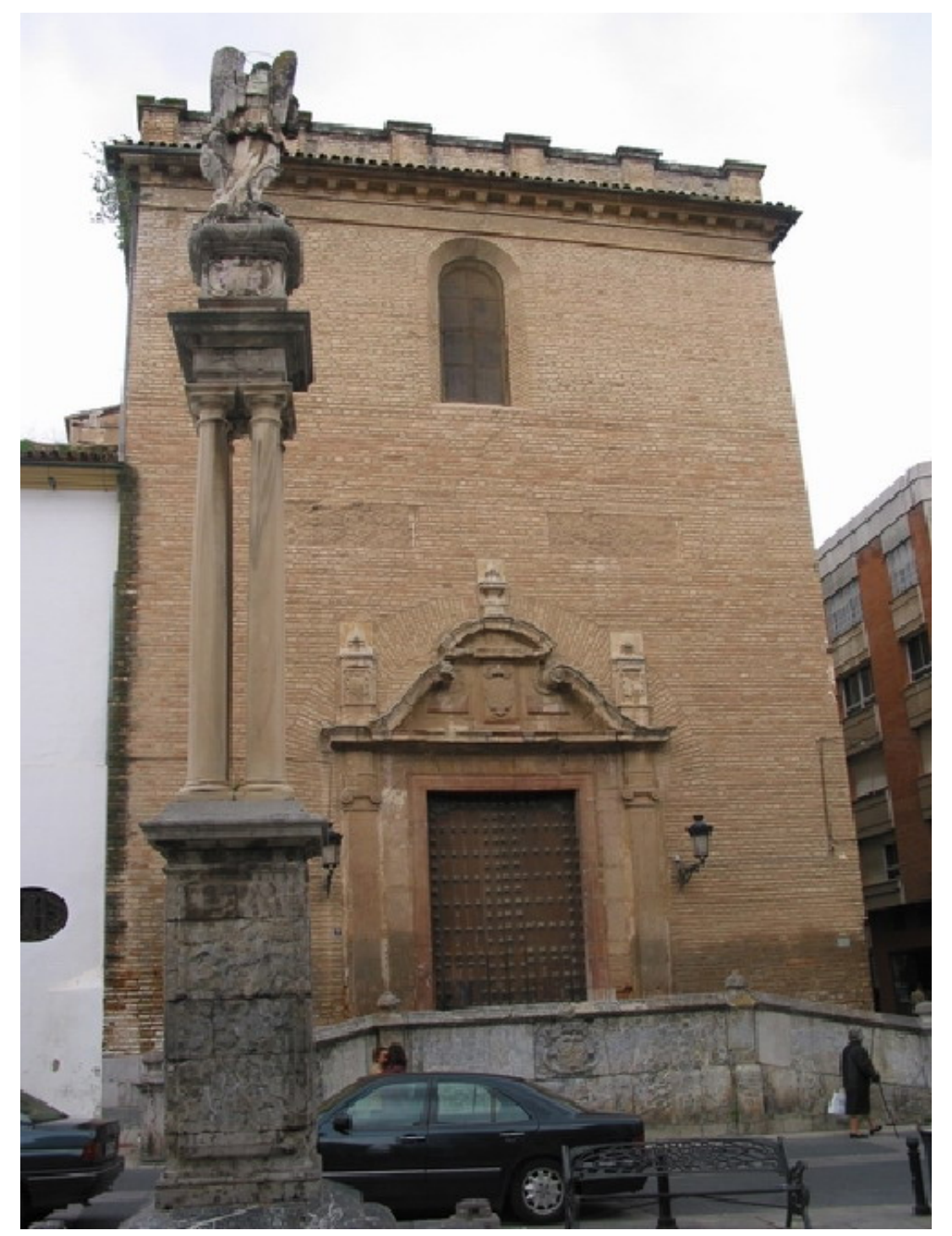

\section{Iglesia del Salvador y Santo Domingo de Silos. Córdoba.}

También consta en dicho libro de defunciones que el año anterior a su muerte, había hecho testamento ante el notario D. Mariano Muñoz y Sanz. ${ }^{1802}$

Gracias a este testamento (que presentamos íntegro en el Apéndice Documental) conocemos algunos datos interesantes: Nombra su heredero fideicomiso a D. José

\footnotetext{
1802 “D. Jayme Valíus, presbítero, Maestro de Capilla de la Santa Iglesia Catedral de esta ciudad, otorgó su testamento al veinte de Febrero de 1821 ante D. Mariano Muñoz y Sanz, por el que dispuso fuese su cadáver revestido con las vestiduras sacerdotales, y que la forma de su entierro fuese en un todo al arbitrio de sus albaceas: Que se digesen cien misas rezadas de las que se hacen [...]. Mandó al Arcángel San Rafael 20 reales de vellón por una vez. Nombró por sus albaceas a D. Juan Baro, D. José Moyano, presbítero y a D. Manuel Vals; y por heredero fideicomiso al dicho D. José Moyano, todo lo cual consta del testamento presentado en esta colectura. Doy fe. Tejada”. Iglesia Parroquial de San Salvador y Santo Domingo de Silos. Libro de difuntos de los años 1806 a 1830, folio 234r.
} 
Moyano, que como vimos en el apartado referido a los músicos de la Capilla, fue un tiple de la Capilla de Música, muy bien valorado por su recto comportamiento y su magnífica voz, y le encarga que reparta sus bienes (fundamentalmente cuatro casas) de la forma acordada. Este reparto de bienes se hace en un documento aparte que después veremos, pero que en aquel momento permaneció secreto por expresa voluntad de Balius, no debiéndose abrir hasta su muerte.

Así se hizo, y una vez muerto se abrió, comprobándose que en este especie de $2^{\circ}$ testamento (también lo podemos encontrar íntegro en el Apéndice Documental) lega sus bienes a diferentes personas. Los beneficiarios principales fueron $\mathrm{D}^{\mathrm{a}}$ Cecilia Tomás, (natural de la Seu d’Urgell, se ha comprobado que fue su sirvienta en Córdoba, aunque probablemente lo fuera desde que el Maestro estuvo en la citada ciudad catalana). $\mathrm{D}^{\mathrm{a}}$ Manuela Ribera (sobrina) y $\mathrm{D}^{\mathrm{a}}$ Ana Joaquina de Burgos. Además, se cita a otros beneficiados subsidiaros en caso de fallecimiento de alguno de los primeros (entre ellos está su sobrino Francisco Balius).

Merece aunque sea un breve comentario el caso de Doña Ana Joaquina de Burgos: Era natural y vecina de Córdoba, hija de D. Francisco Javier Burgos y Da María Josefa Morales, también de esta naturaleza y vecindad. El día 16 de Agosto de 1821 se casó don D. Jaime Dalmau, natural de Calella (Gerona), teniente del Regimiento de Infantería de América (con plaza en Córdoba). Ante el notario D. Mariano Muñoz, se hizo una Carta de Dote, en la que figuran todos aquellos bienes que $\mathrm{D}^{\mathrm{a}}$ Joaquina aporta, haciéndose constar que todos ellos se los ha "dado y comprado D. Jaime Walius, presbítero de este domicilio y Maestro de Capilla de la Santa Iglesia Catedral de esta ciudad, $y$ en cuyas casas se ha criado y educado". ${ }^{1803}$ Estos bienes son muy numerosos, e incluyen joyas, vestidos, muebles y dinero, todo ello con un valor total de 23.000 reales de vellón. Además y por si esto fuera poco, Balius le deja en propiedad, sus dos mejores casas, situadas en los números 3 y 4 de la calle Jesús María.

Así pues, vemos la gran generosidad de Jaime Balius, que entre familiares y personas cercanas, deja repartidos todos sus bienes.

\footnotetext{
${ }^{1803}$ Archivo Histórico Provincial de Córdoba. Sección de Protocolos Notariales. Oficio 33, fol. 226r. El notario era D. Mariano Muñoz y Sanz.
} 
Recapitulando, a través de estas noticias biográficas hemos observado cómo la vida diaria de Jaime Balius y Vila tuvo una gran actividad, y si bien sus obligaciones como Maestro de Capilla le ocupaban la mayor parte de su jornada, también tuvo voluntad e iniciativa para dedicar parte de su actividad a forjarse un patrimonio. Si recordamos ahora el gran número de composiciones que hizo, bien podemos concluir que apenas debía de tener un momento de descanso al día, salvo los momentos en que recorría lo que hoy es el casco antiguo de Córdoba, bien para buscar alguna casa que comprar o bien simplemente para dirigirse a su domicilio a seguir componiendo y a disfrutar de un merecido descanso.

\subsection{SU OBRA.}

Como veremos con detalle en el catálogo, se conservan nada menos que 720 obras de Balius en el Archivo de la Catedral de Córdoba. Además, son muchos los puntos de España donde podemos encontrar sus composiciones, en ocasiones con representación numerosa, como es el caso de la Catedral de Málaga (77 obras de géneros muy diversos). La mayoría de las obras que aparecen en otros lugares también se encuentran en Córdoba, pero no todas, con lo que el número total de su producción sería algo superior.

Sus obras más tempranas conservadas en el A.C.C. datan de 1770, y en ellas vemos a un joven de 19 o 20 años que compuso una colección de Cánticos (Magníficat, Benedictus), a 8 o 10 voces sin instrumentos (en alguno incluye una parte de acompañamiento), en estilo contrapuntístico sobre un cantus firmus. Estos Cánticos (agrupados en un cuaderno) recorren todos los tonos, y aunque presentan ocasionalmente algunos tachones, reflejan ya una mano diestra en la confección de las fugas. Por otra parte no emplea el texto completo de estas piezas, sino tan solo los primeros versos, por lo que son obras necesariamente breves.

Tarda muy poco en añadir instrumentos. Y al año siguiente, en 1771, escribe una obra, Fratres $a$ 8, que además de las 8 voces en dos coros (SATB-SATB), incluye 
violín $1^{\circ}$, violín $2^{\circ}$ y una línea de bajo-acompañamiento. Con esta plantilla e insistiendo en el estilo fugado desarrolla diversas obras en ese mismo año, sobre todo Salmos.

De 1775 es la primera obra que conocemos en la que emplea la que sería su plantilla más utilizada, es decir, 4 u 8 voces con violines, oboes y trompas. Se trata del Responsorio Oh Anima Sanctissima, en el que ya emplea la melodía acompañada, configurada con más libertad de movimientos que en los anteriores ejemplos contrapuntísticos.

A partir de aquí evoluciona rápidamente, construyendo trabajos de amplia factura, en los que incluye cada vez más número de voces e instrumentos, y utiliza variados recursos técnicos, desde el contrapunto, la homofonía o la melodía acompañada, todo ello sobre una rica armonía tonal, y teniendo como guía al bajo contínuo.

Sigue componiendo sobre las formas sacras, pero comienza a destacar su predilección por los villancicos, que al final de su producción sumarán 405 (solo en el A.C.C.), de toda clase, desde los más habituales con copla y estribillo, hasta los de pastorela, de tonadilla, etc., forjando un magnífico repertorio de estas piezas que bien merece dedicarle un trabajo monográfico en el futuro.

Como culminación de estos villancicos y de toda su obra hay que destacar las Kalendas (31), que como veremos posteriormente, representan la máxima expresión tanto en duración, número de voces e instrumentos empleados, recursos estilísticos utilizados, dificultad técnica, etc.

Ahora vamos a ocuparnos de las características principales de su música, intentando primero establecer unos rasgos comunes de su producción y después detallando cada uno de los géneros y formas que emplea. 


\subsubsection{CARACTERÍSTICAS PRINCIPALES.}

\subsubsection{Melódicas.}

La amplia producción musical de Balius y la gran cantidad de formas distintas que trabaja, influyen en su variada proyección melódica. La simetría en el fraseo y las melodías claras, se alternan con otras melodías mucho más elaboradas rítmicamente, como veremos en el punto siguiente. Estas melodías suelen discurrir por grados conjuntos, sobre todo en los pasajes corales, reservando los saltos y los pasajes más virtuosísticos para los solistas. Utiliza con frecuencia recursos para describir musicalmente determinados textos, unas veces dando sensación de ligereza y agilidad, y otras buscando un recurso melódico que respalde un texto que hable de calma, de tranquilidad. Del primer caso ponemos el siguiente ejemplo, perteneciente al villancico Alarma Principados (69/514), ${ }^{1804}$ donde para expresar sensación de velocidad, y dentro de un tempo general “allegro”, enlaza una pequeña progresión ascendente con las palabras “volad” y “venid” de la siguiente forma:

Allegro.

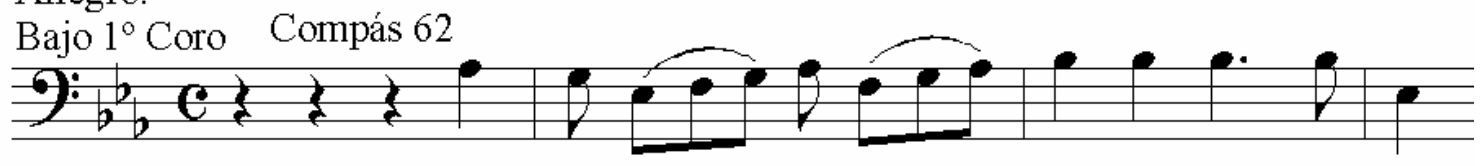

$$
\text { Co - rred vo - lad ve - nid ve - nid lle - gad }
$$

También entraría dentro de este modelo la parte del tenor del oratorio Tiemblo todo (82/645-1), donde imita ese temblor con rápidos floreos superiores en tresillos de semicorcheas mientras pronuncia la palabra tiemblo.

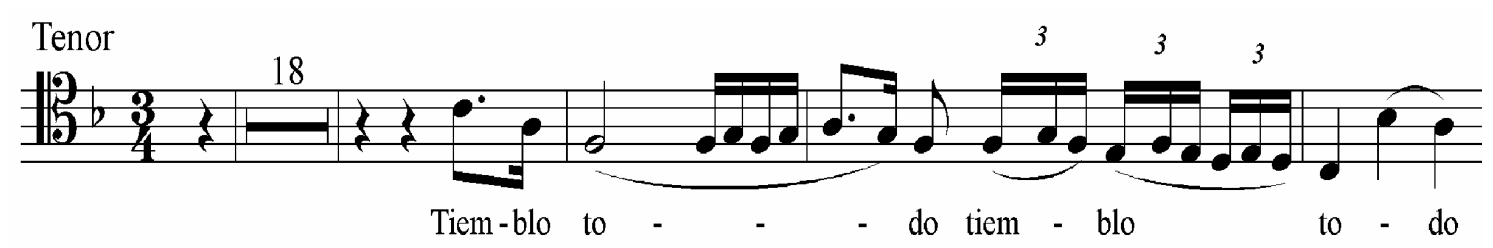

O el Aria El viento se ilumina (67/494), en donde queda patente el ánimo de imitar la ligereza del viento con estas dos escalas ascendentes de fusas, justo al pronunciar la palabra viento.

\footnotetext{
${ }^{1804}$ Esta es la signatura de las piezas en el Archivo de la Catedral de Córdoba. Primero figura la caja donde se encuentra, y tras las barra “/”, la carpeta correspondiente.
} 


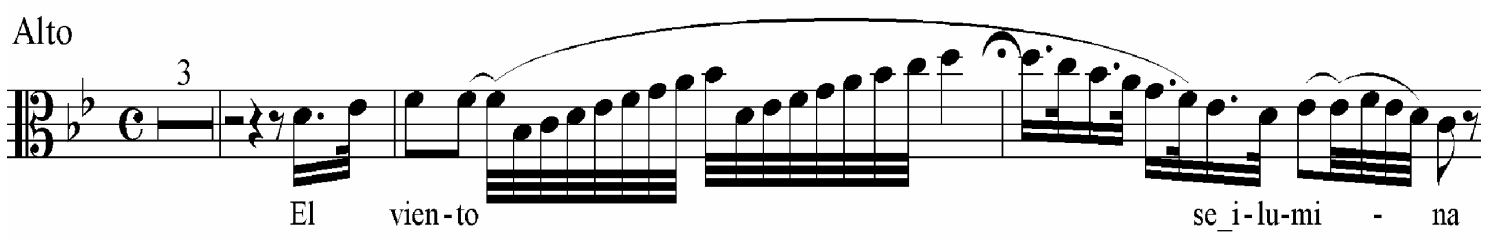

Para ejemplificar el segundo caso, tenemos el villancico Silencio Quedito (64/459), donde (para resaltar el texto, que en ese momento repite la palabra silencio), prácticamente mantiene inalterable la línea melódica, insistiendo sobre una misma nota (re 4), primero en un valor largo como la redonda para detener el movimiento, y después con valores individuales de negra separados por una silencio de ese mismo valor.

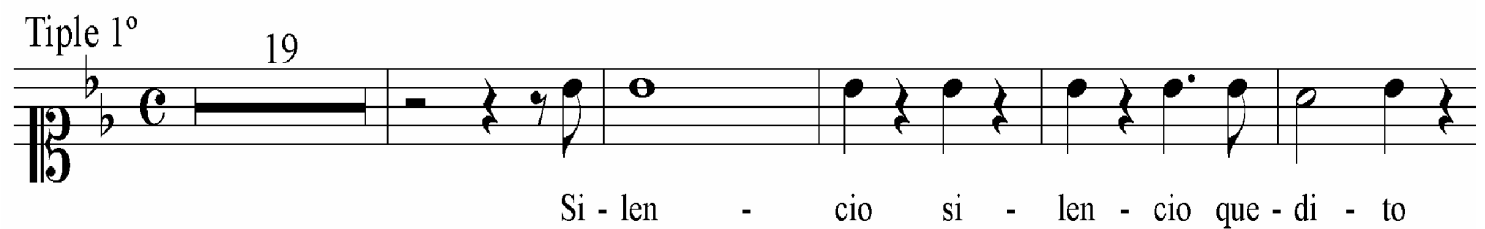

Igualmente utiliza largos melismas que pueden llegar a abarcar varios compases, sobre todo en determinadas formas como son los Recitados y las Lamentaciones. Así sucede en Iod. Manun suam (128/1250-B).

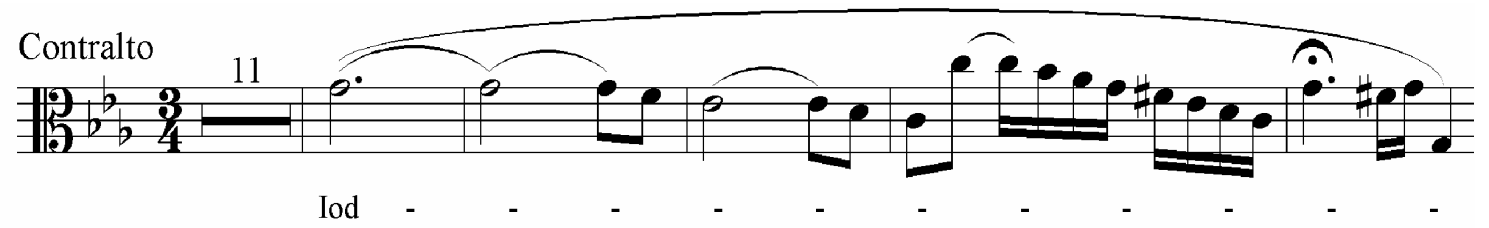

Podemos encontrar mayoritariamente inicios téticos y anacrúsicos, y en menor medida acéfalos. Igualmente la mayoría de los finales son masculinos.

La direccionalidad se ajusta no solo buscando la expresividad general de la frase, sino atendiendo, como hemos visto en los ejemplos anteriores, a criterios figurativos. Hay sin embargo, un giro melódico-rítmico muy característico que vemos con frecuencia en las introducciones, exposiciones o en definitiva, en los inicios de algunas obras, sobre todo los Recitados. Es la típica frase enunciativa, normalmente de dos compases, silábica, de línea estable o ascendente al comienzo, para luego caer en las dos 
notas finales en un intervalo descendente $\left(2^{\mathrm{a}}, 4^{\mathrm{a}}\right.$ o $\left.5^{\mathrm{a}}\right)$, después del cual aparece inevitablemente un silencio. Sirvan los siguientes ejemplos:

Adonde infiel dragón. (2 / 18).

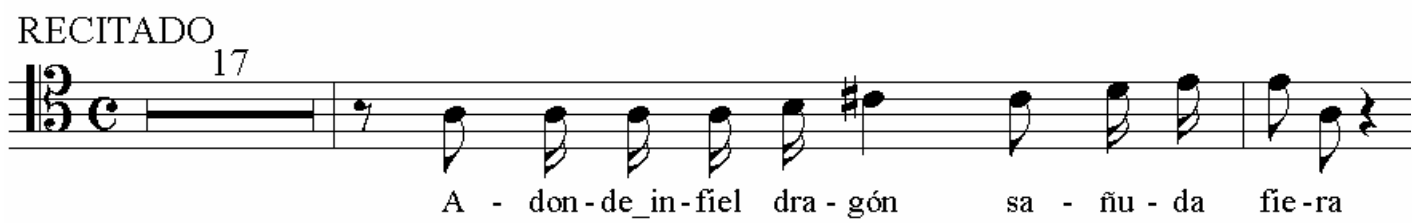

Afligida Sión. (29 / 212-2).

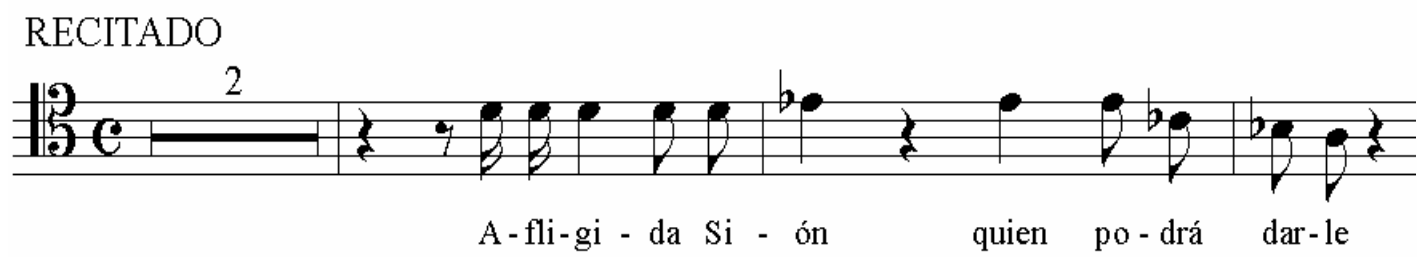

Asómanse los Ángeles. (79 / 606).

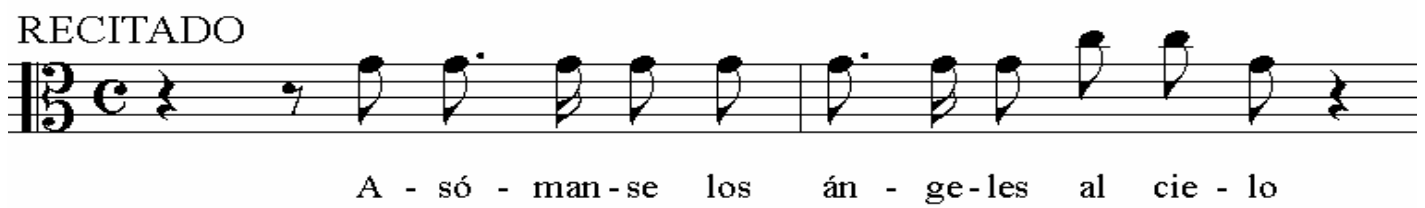

Clara Aurora. (3 / 21-1).

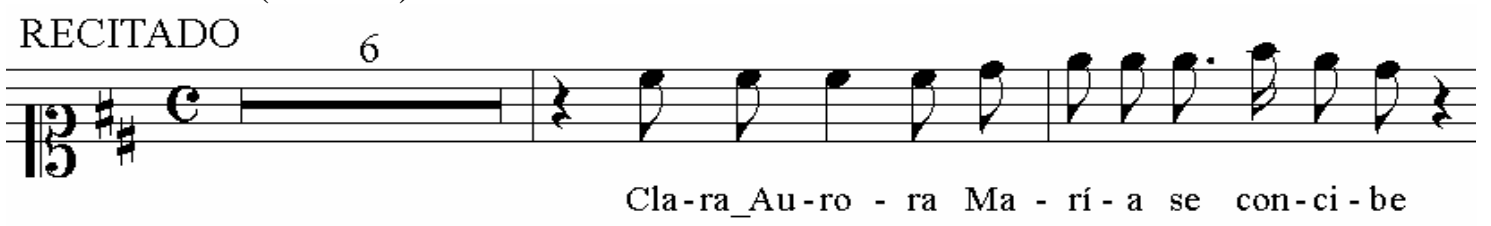

A nuestra bella Patria. Villancico. (84 / 669-1).

Tiple $1^{\circ}$ Coro

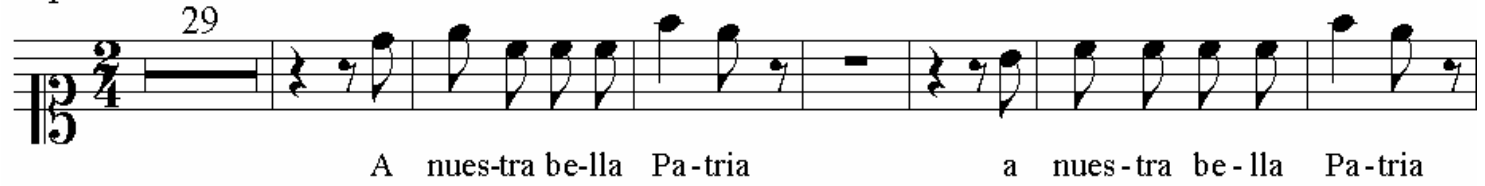

Al instante que los niños. Villancico. (107 / 918). 
Tiple $1^{\circ}$

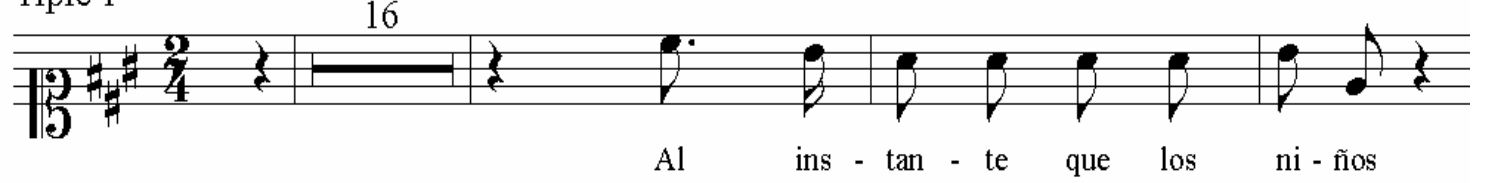

La variedad en la configuración de las melodías, dependiendo del contenido musical que se quiera expresar, o de la forma que en ese momento se esté tratando, podía resumir la amplia representación de melodías con características diferentes que nos podemos encontrar en la música de Balius.

\subsubsection{Armónicas.}

La armonía empleada por Balius entra dentro de lo que conocemos como armonía tonal o armonía clásica. Aunque nos hallamos dentro del clasicismo musical, conserva del barroco la policoralidad y el uso del continuo. Se vale para la confección de sus obras de los principales acordes de este sistema, como son los acordes perfectos mayores y menores, quinta disminuida, quinta aumentada, el acorde de séptima de dominante, séptima disminuida, sexta aumentada, etc.

Una vez establecida la tonalidad principal, modula generalmente a tonos vecinos, sobre todo a través de modulaciones diatónicas y cromáticas. Además utiliza frecuentemente desplazamientos al tono relativo armónico para regresar después al original.

También practica de forma asidua, tras el reposo en la dominante de un modo menor, el ataque directo del acorde tónico del modo mayor relativo. Lo podemos ver en Christus natus. "Ynvitatorio de los Maytines de Navidad" (105/894), de donde hemos extractado las líneas melódicas de Tiple $1^{\circ}$ y Tiple2 ${ }^{\circ}$, junto con el acompañamiento. 


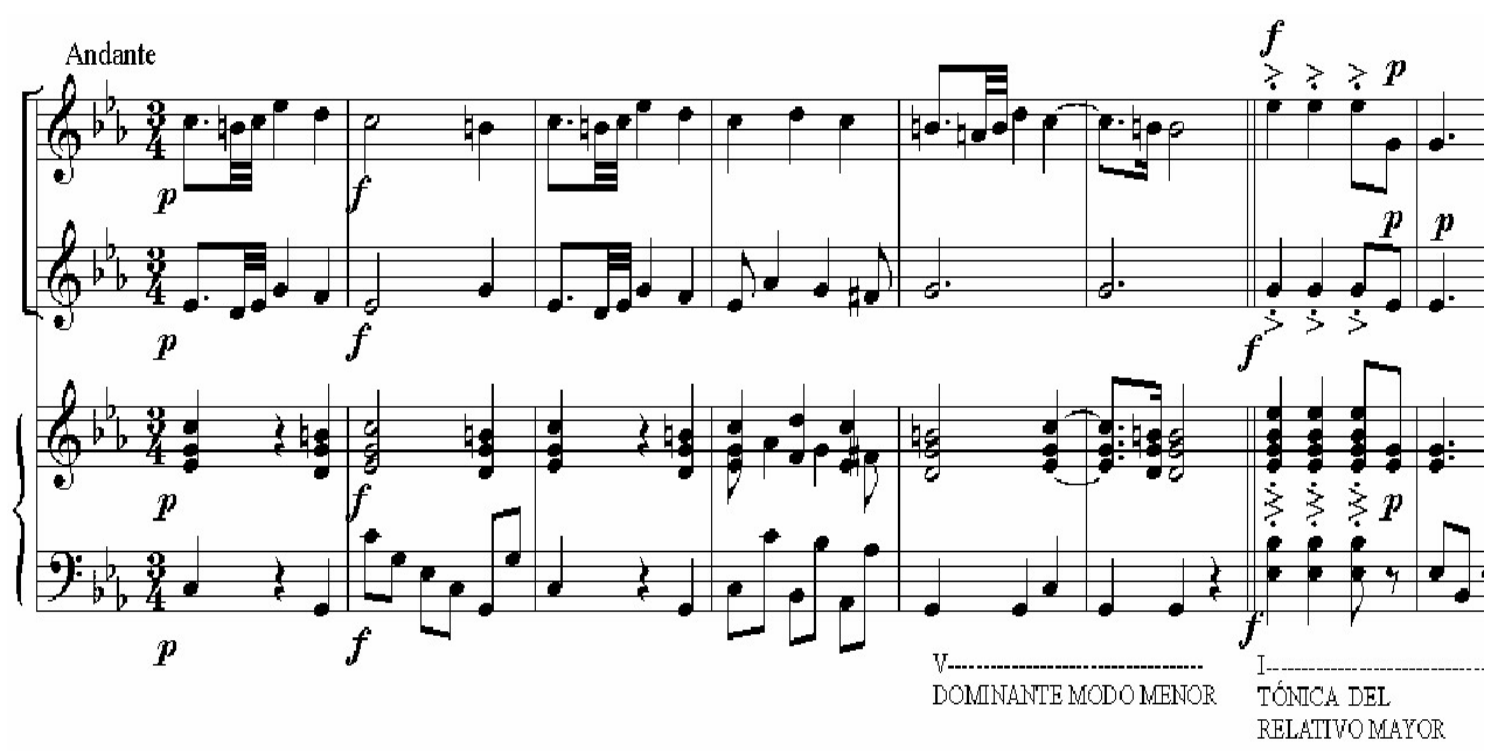

En determinados casos, la llegada a la dominante se efectúa mediante el uso de la interdominante, es decir, la dominante de la dominante. Veamos los compases 106 al 111 del villancico Ahora llegan dos pastores (93/781-7). A pesar de la presencia del sol\# que conduce al acorde de LA, no se puede considerar una modulación definitiva ya que en los compases de resolución aparece el sol natural que integra como séptima el acorde de dominante que prepara la entrada del re menor que le sigue.

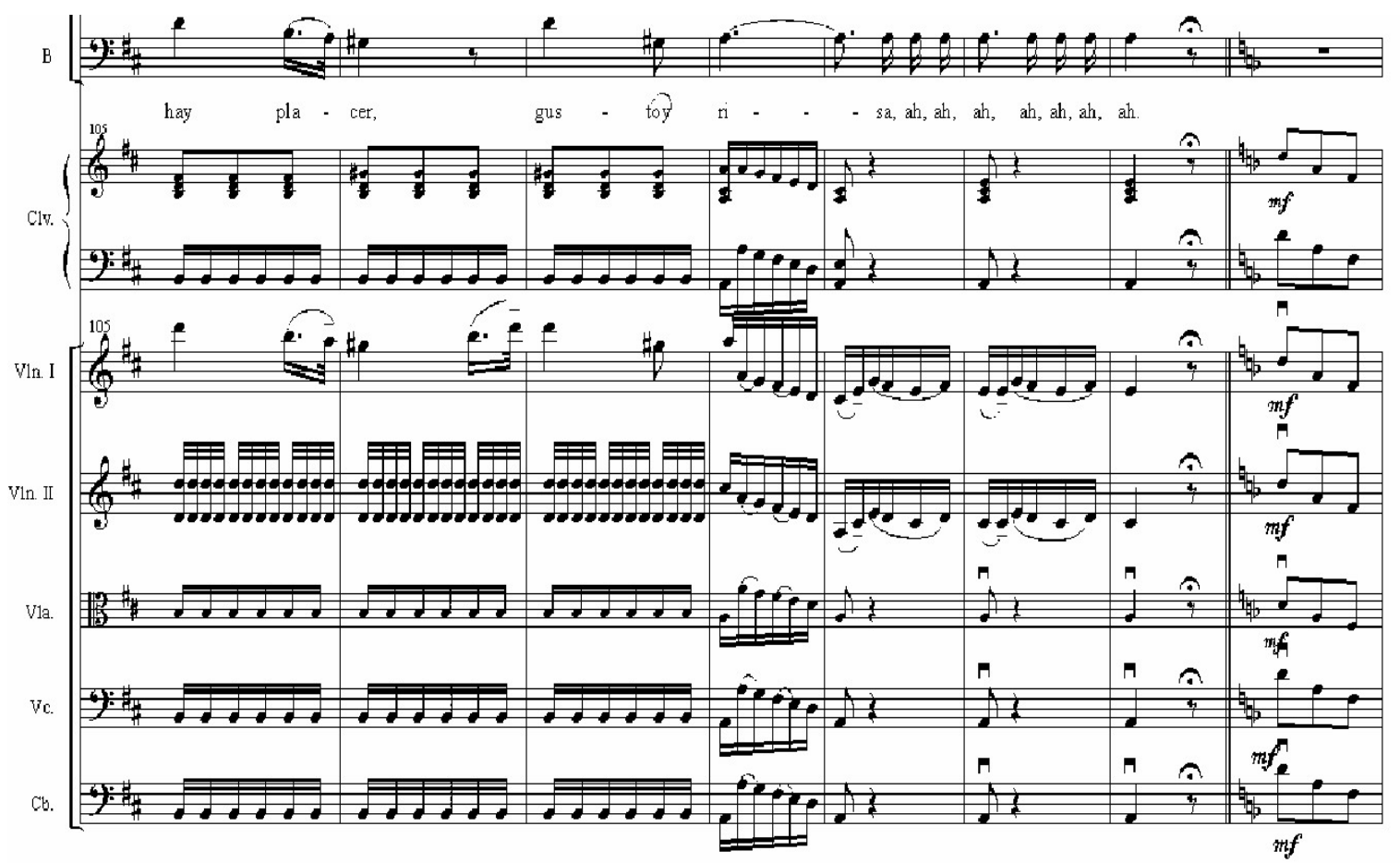


Combina pasajes de ritmo armónico lento con otros en donde cambia más rápidamente de función tonal. Para completar los pilares armónicos se ayuda de los recursos habituales como las notas de paso, apoyaturas, anticipaciones y retardos. Las imitaciones y progresiones son otros recursos expresivos habituales, que se pueden presentar por separado o uniendo ambos elementos, como sucede en la Misa Llana (14/107), de donde procede el siguiente ejemplo extractado del Credo:

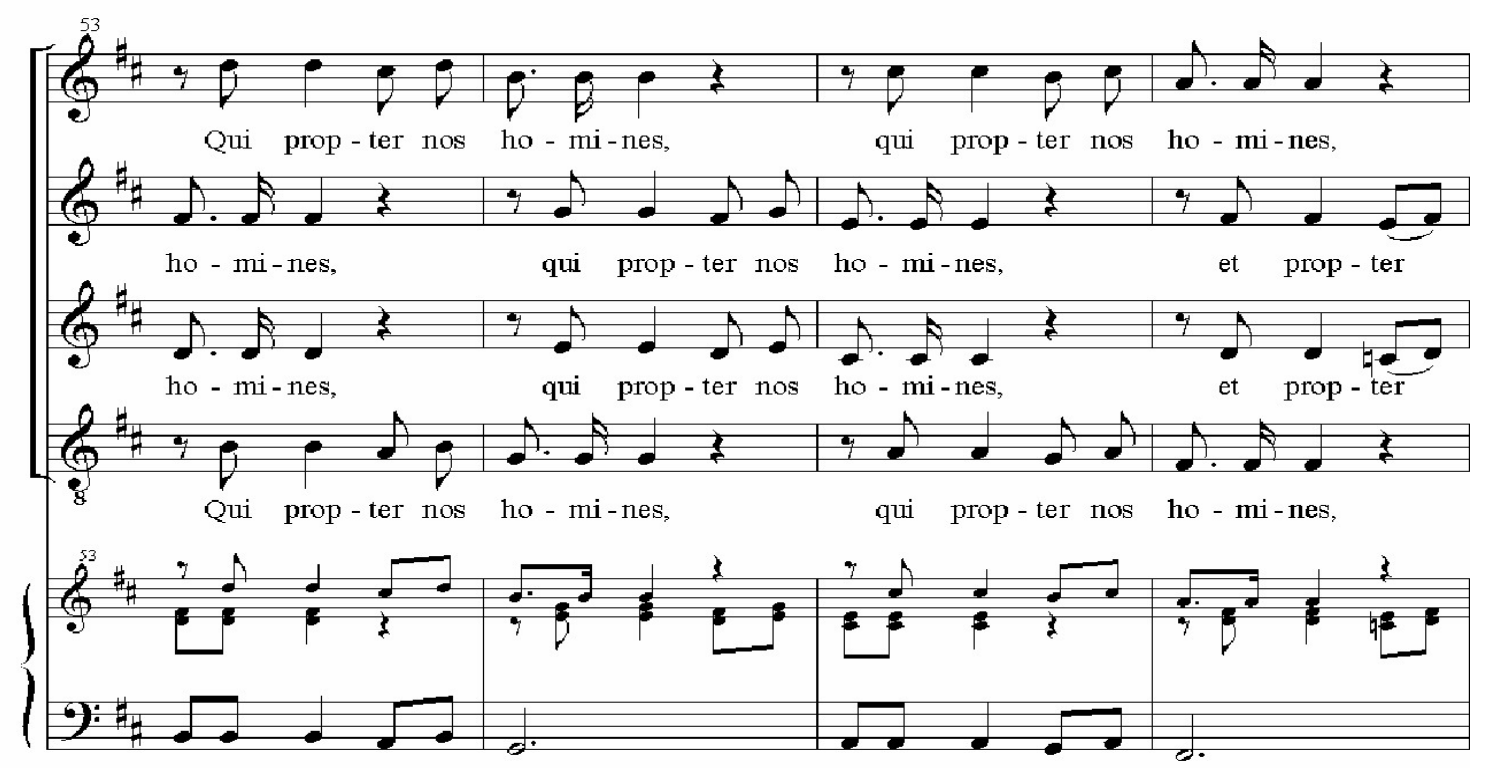

También utiliza indistintamente la homofonía y el contrapunto, tanto en obras diferentes, como en distintos tiempos de una misma obra. Así sucede en la citada Misa Llana. La obra comienza con un Kyrie en contrapunto imitativo: 


\section{Andante}
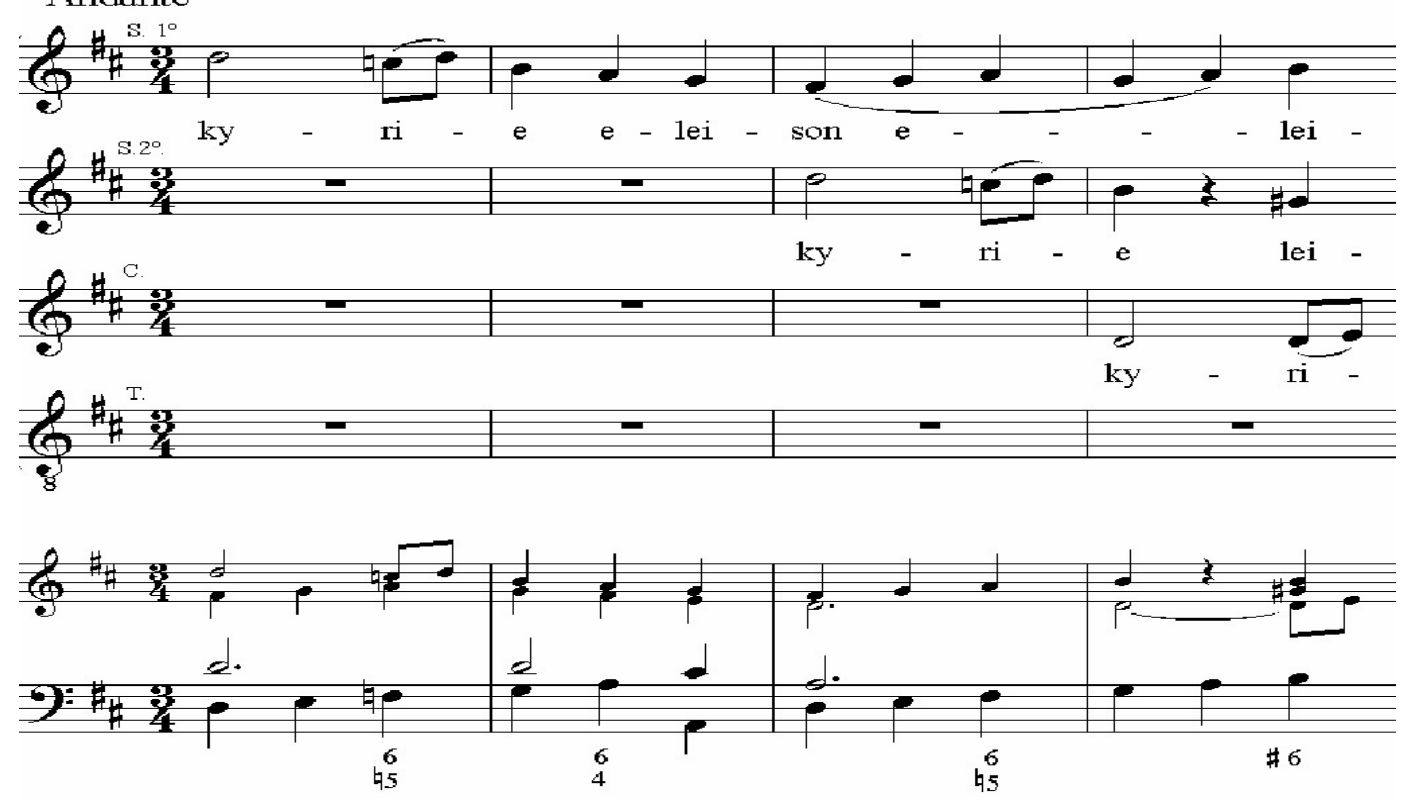

En el comienzo del Credo, sin embargo, utiliza polifonía homofónica:

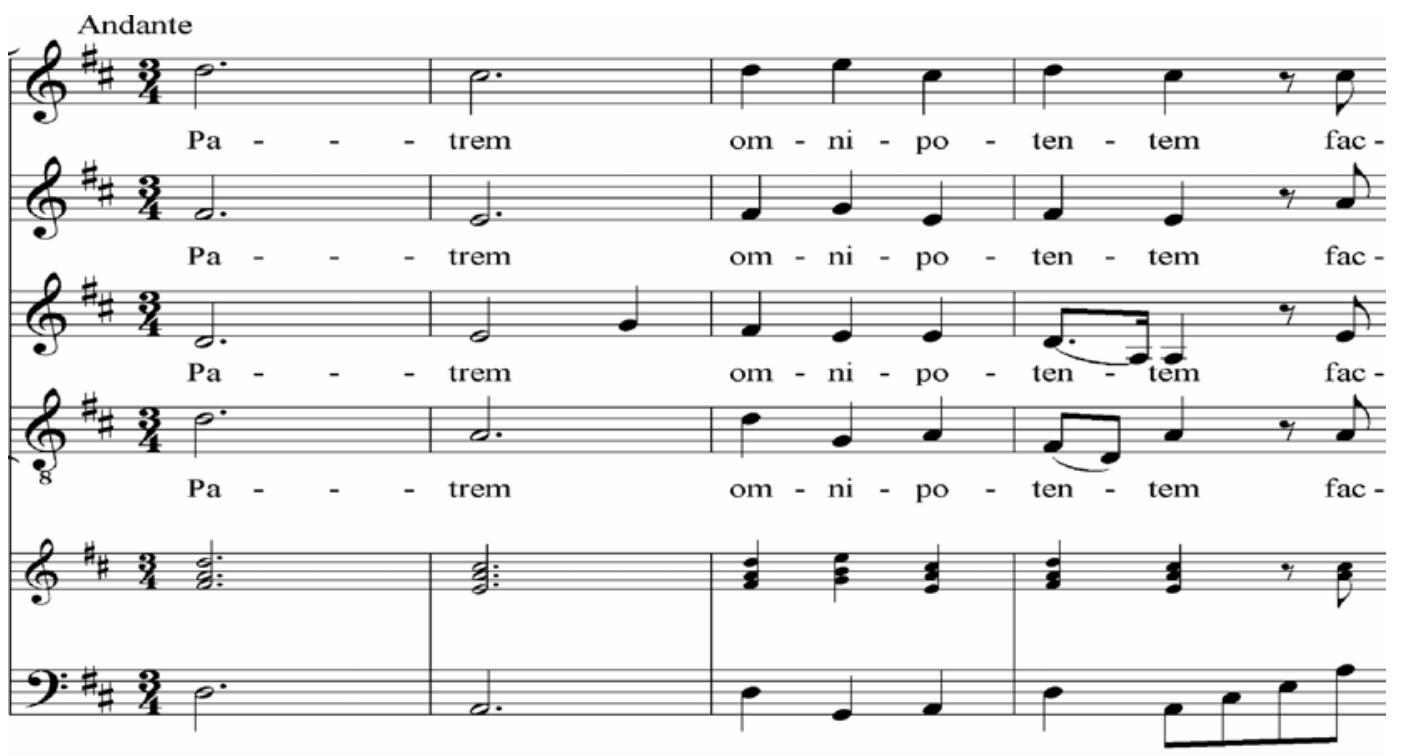

Las cadencias perfectas son la base de sus terminaciones, valiéndose con frecuencia para llevarlas a cabo, del acorde de sexta y cuarta cadencial. Como caso excepcional podemos encontrar alguna obra con final en la Dominante. Esta circunstancia se produce en el Magníficat (2/14), donde comienza la obra en sol menor, pasando luego por varias tonalidades como Sib Mayor, Mib Mayor, do menor, etc., para volver luego a sol menor pero acabando en el quinto grado. Para verificar el ejemplo hemos extractado sólo las partes de la cuerda. 


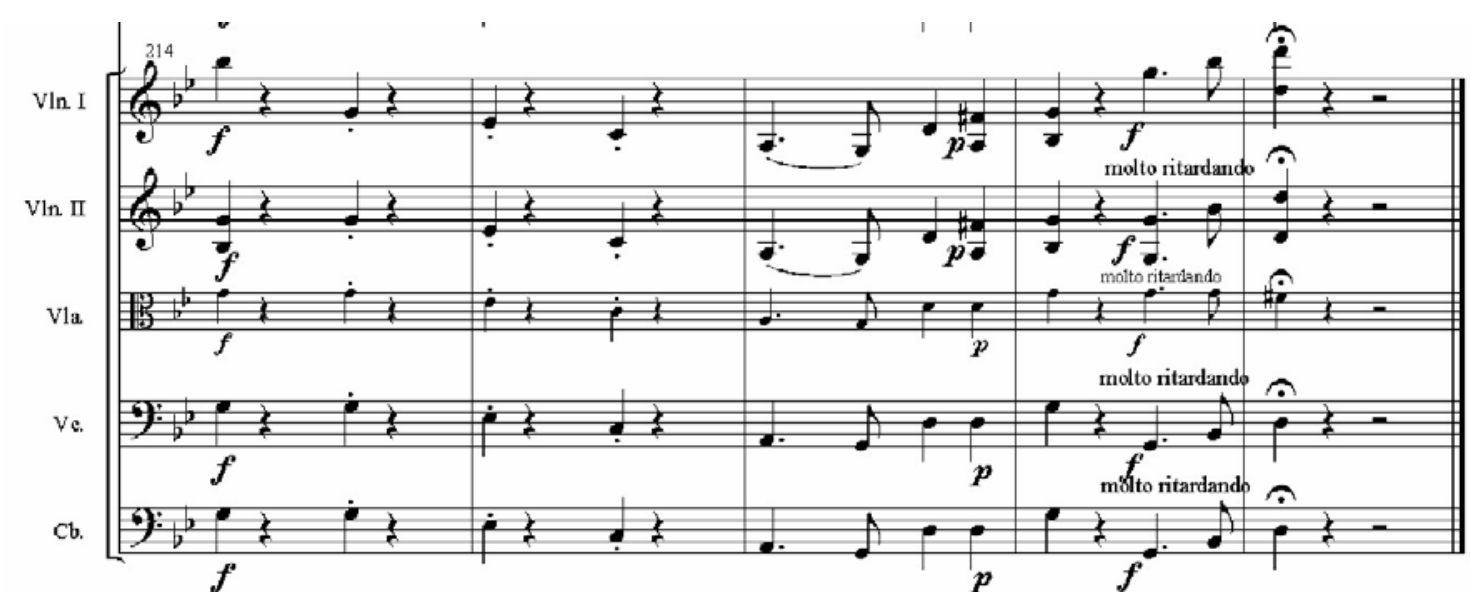

\subsubsection{Rítmicas.}

En la música de Balius, los compases utilizados son ciertamente los más comunes, (4/4, 4/2, 3/4, 2/4, 6/8). Es frecuente sin embargo, que cambie de compás para diferenciar las diversas secciones de una obra.

Si esto no constituye una novedad, sí podría serlo la enorme cantidad de combinaciones rítmicas que utiliza en algunas composiciones, las numerosísimas (y en ocasiones algo rebuscadas) combinaciones de los valores básicos y la alternancia de éstos con grupos de valoración irregular. En alguna ocasión llega a utilizar casi todos ellos, desde la redonda a la semifusa, con puntillos añadidos y síncopas por doquier, con entradas ora téticas, ora anacrúsicas o acéfalas, prefiriendo los finales masculinos. Sirva de ejemplo la Lamentación Heth. Cogitavit Dominus (17/130), donde podemos observar lo siguiente: En los primeros cinco compases de intervención del Tiple $1^{\circ}$ (compases 18 al 22 de la obra), utiliza el compás de $3 \frac{4}{4}$ y como valores rítmicos la fusa, la semicorchea, la corchea, la corchea con puntillo y la negra, pero lo hace de forma que nunca se repite en la misma parte del compás una configuración rítmica similar.

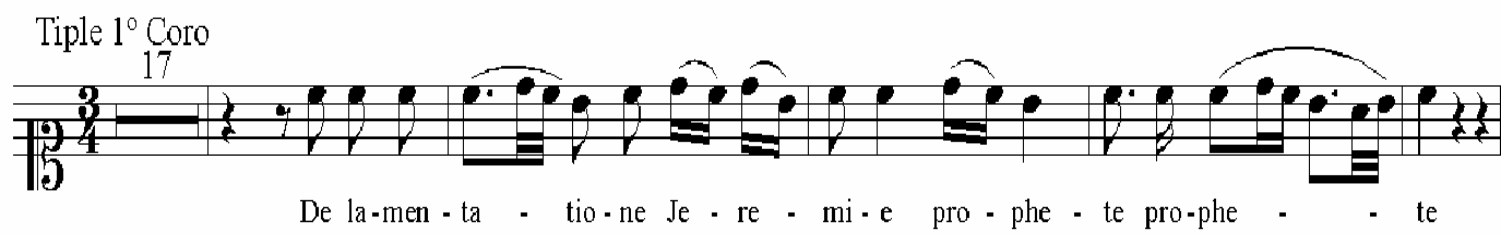




\begin{tabular}{|l|l|l|l|l|l|l|l|l|}
\hline \multicolumn{3}{|c|}{ Compás 18. } & \multicolumn{3}{c|}{ Compás 19. } & \multicolumn{3}{c|}{ Compás 20. } \\
\hline $1^{\text {a }}$ parte & $2^{\text {a }}$ parte & $3^{\text {a }}$ parte. & $1^{\text {a } \text { parte. }}$ & $2^{\text {a }}$ parte. & $3^{\text {a }}$ parte & $1^{\text {a }}$ parte & $2^{\text {a }}$ parte & $3^{\text {a }}$ parte \\
\hline $\begin{array}{l}\text { Un } \\
\text { silencio } \\
\text { de } \\
\text { negra. }\end{array}$ & $\begin{array}{l}\text { Un } \\
\text { silencio } \\
\text { de } \\
\text { corchea } \\
\text { y una } \\
\text { corchea. }\end{array}$ & $\begin{array}{l}\text { Dorcheas. } \\
\text { corchea }\end{array}$ & $\begin{array}{l}\text { Dos } \\
\text { con } \\
\text { puntillo } \\
\text { corcheas. dos } \\
\text { fusas. }\end{array}$ & $\begin{array}{l}\text { Cuatro } \\
\text { semi- } \\
\text { corcheas }\end{array}$ & $\begin{array}{l}\text { Corchea y } \\
\text { mitad de } \\
\text { una negra } \\
\text { sincopada. }\end{array}$ & $\begin{array}{l}\text { Mitad de } \\
\text { una negra } \\
\text { sincopada } \\
\text { y dos semi- } \\
\text { corcheas. }\end{array}$ & $\begin{array}{l}\text { Una } \\
\text { negra. }\end{array}$ \\
\hline
\end{tabular}

\begin{tabular}{|l|l|l|l|l|l|}
\hline \multicolumn{3}{|c|}{ Compás 21. } & \multicolumn{3}{c|}{ Compás 22. } \\
\hline $1^{\text {a }}$ parte & $2^{\text {a }}$ parte & $3^{\text {a }}$ parte. & $1^{\text {a }}$ parte. & $2^{\text {a }}$ parte. & $3^{\text {a }}$ parte \\
\hline $\begin{array}{l}\text { Corchea con } \\
\text { puntillo y y dos } \\
\text { semicorchea. }\end{array}$ & $\begin{array}{l}\text { Corchea y } \\
\text { semicorcheas. }\end{array}$ & $\begin{array}{l}\text { lorchea con } \\
\text { puntillo y dos } \\
\text { semifusas. }\end{array}$ & Una negra. & $\begin{array}{l}\text { Silencio } \\
\text { de negra. }\end{array}$ & $\begin{array}{l}\text { Silencio de } \\
\text { negra. }\end{array}$ \\
\hline
\end{tabular}

En otra Lamentación, Aleph (16/124) utiliza igualmente valores muy diversos, en un larguísimo melisma que ocupa la primera frase:

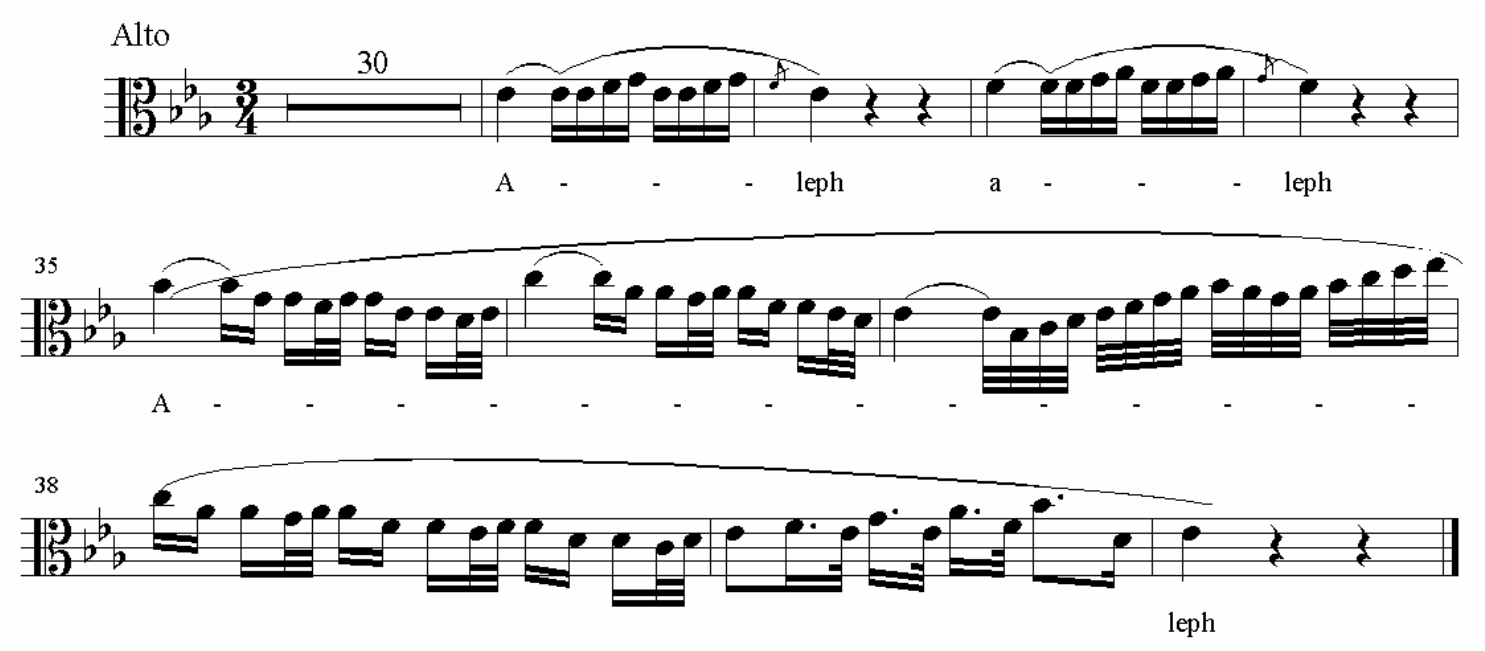

Otro ejemplo que ilustra la variedad rítmica también en las partes instrumentales es el comienzo de la parte de violín $1^{\circ}$ de Frates (7/63). Hemos incluido los compases 1 , 3 y 7 . 

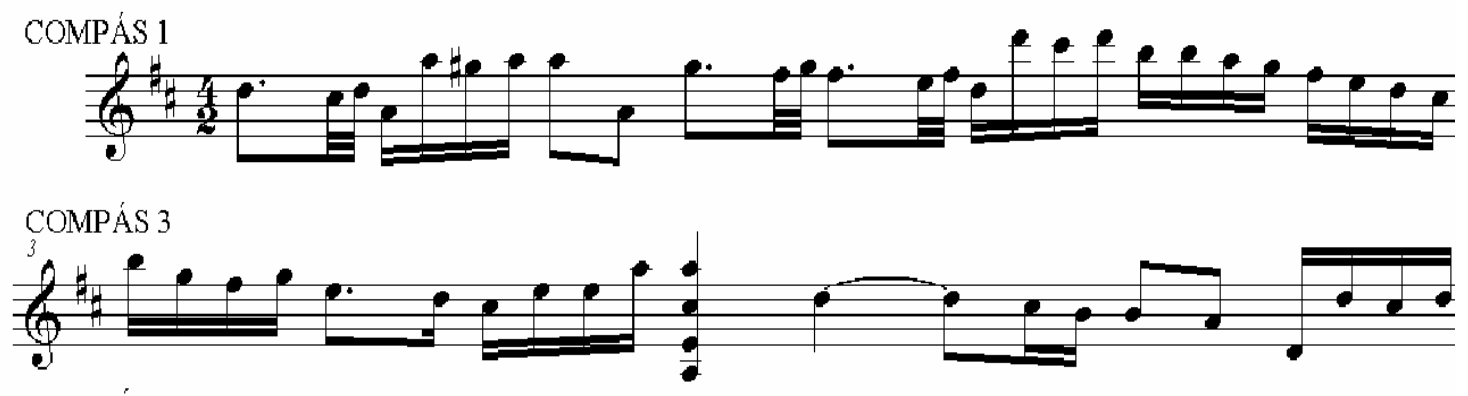

COMPÁS 7

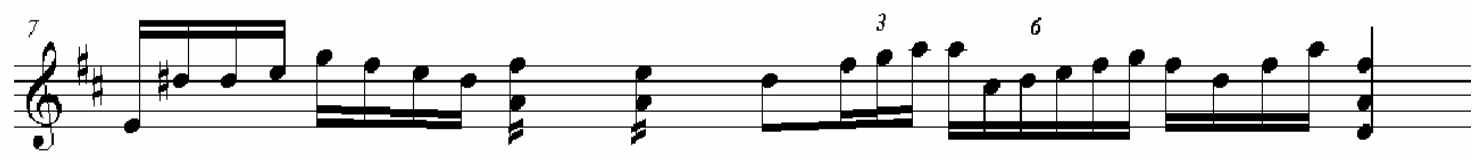

El bajo contínuo sostiene rítmicamente a la partitura, repitiendo la nota más grave del acorde la mayoría de las veces en corcheas o negras. Esto lo combina con pasajes de rítmica contrastante, donde a una serie de valores rápidos, le siguen inmediatamente compases de calma en valores largos, como sucede en el Recitado y Aria De la Antigua Serpiente (2/12), donde a los cuatro primeros compases (2 sobre el I grado y 2 sobre el V), le siguen otros cuatro sobre una pedal de dominante en los que violín $2^{\circ}$, viola y violoncello desarrollan la armonía en redondas:

Compases 1 a 4 (cuerda):

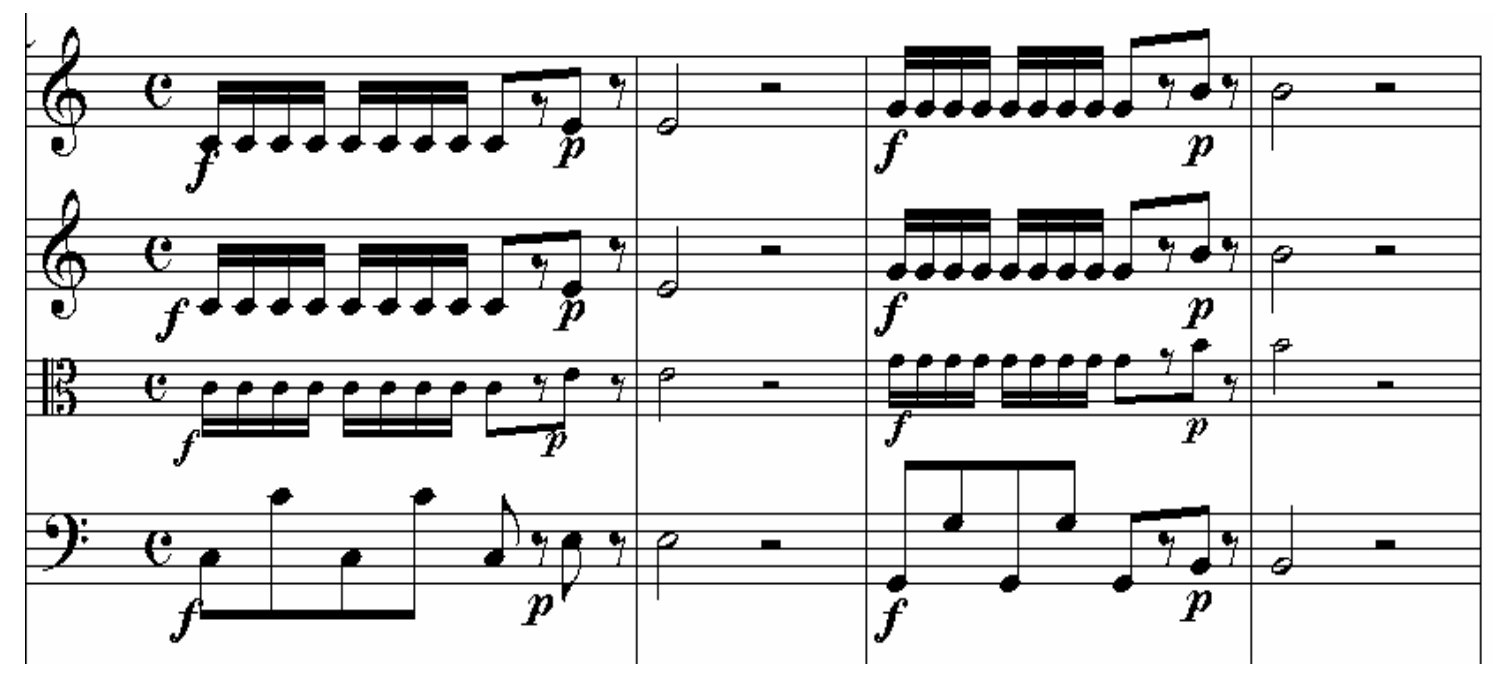


Compàses 5 a 8:

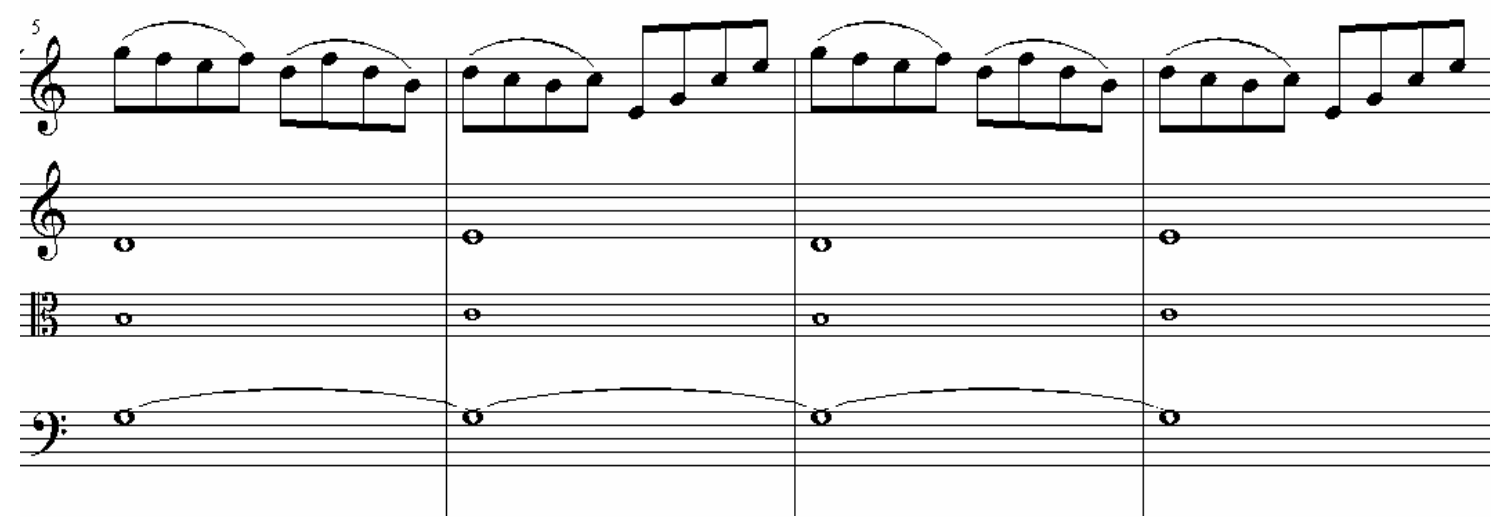

Recurre a figuras rítmicas de igual valor, con unísonos u octavas normalmente descendentes, para resaltar alguna frase del texto. Ponemos como ejemplo dos pasajes. El primero, del villancico De Villaviciosa vienen (62/426), y el segundo de la canción patriótica Nobles Andaluces (113/1009).

De Villaviciosa vienen, compases 123 a 126 (voces):

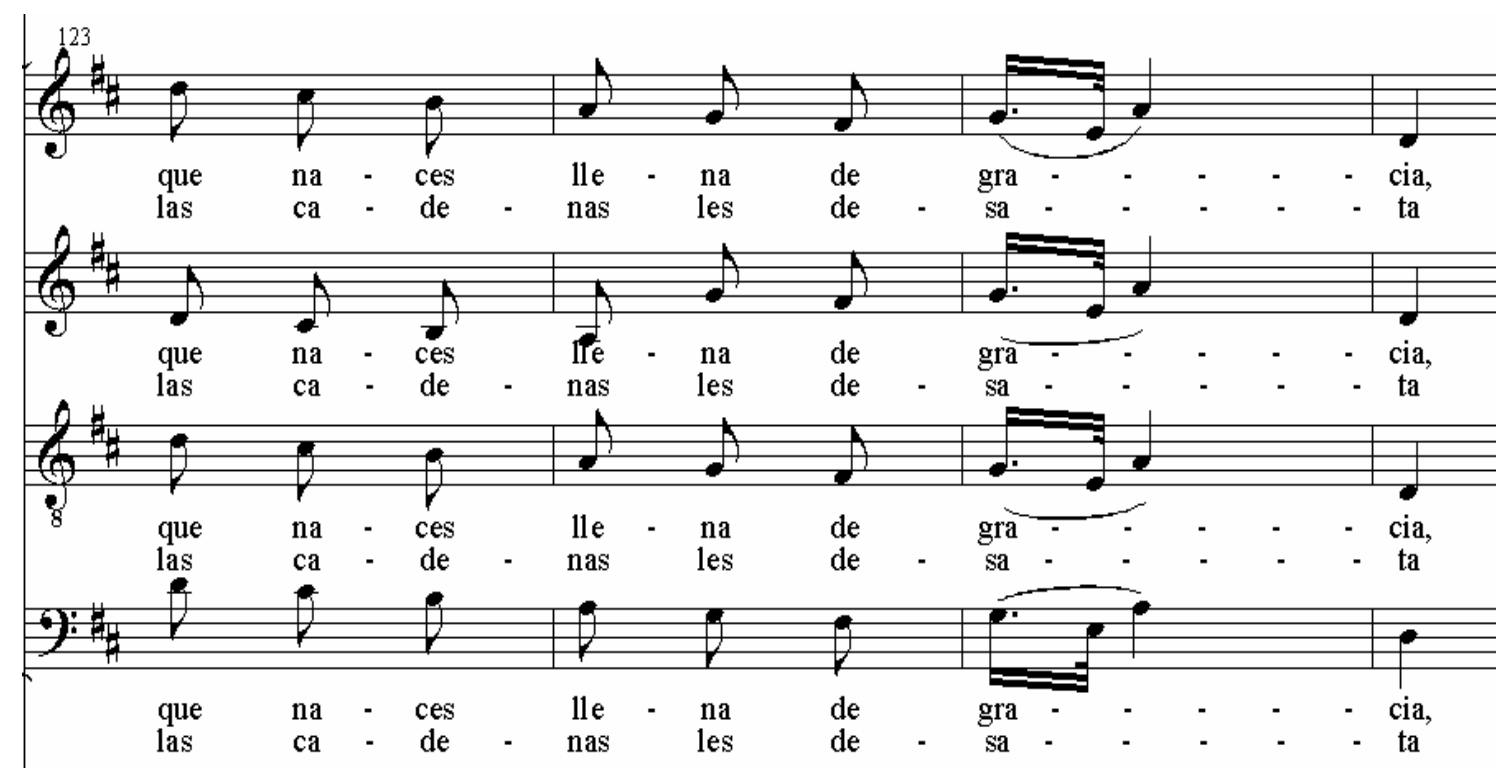


Nobles Andaluces, compases 43 a 46 (voces):

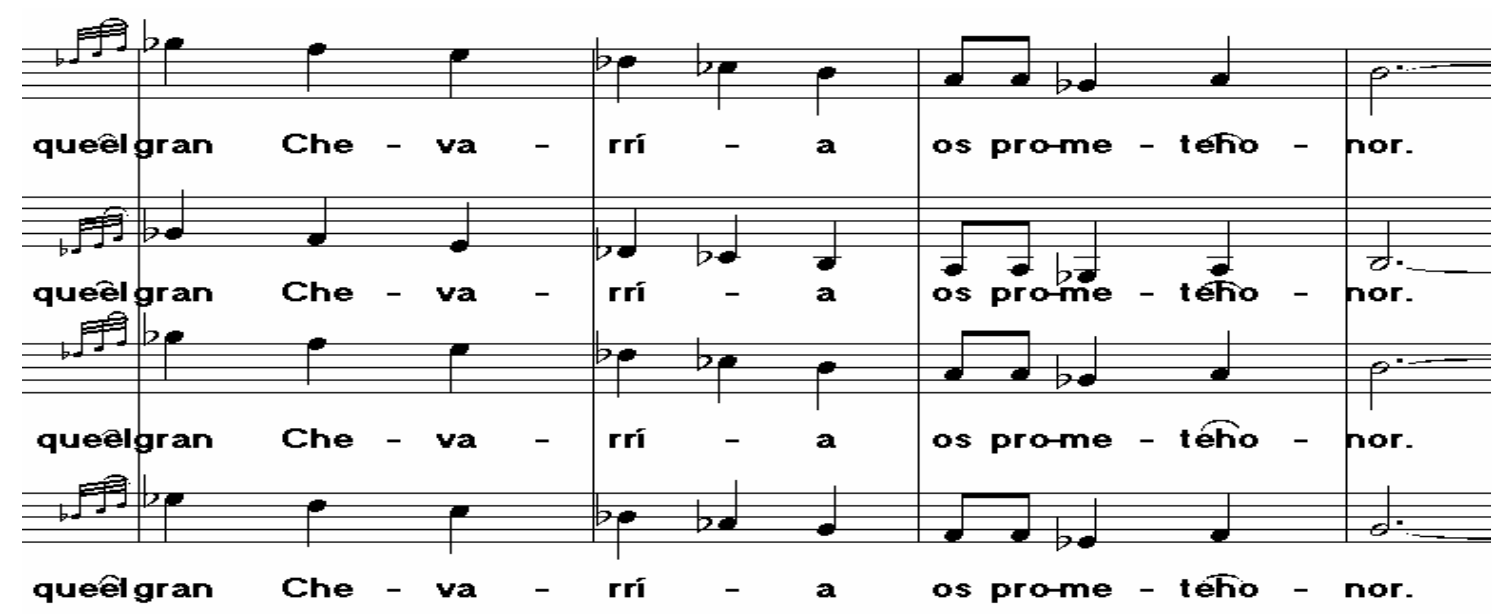

Así pues, y salvo algunos rasgos definitorios arriba comentados, los parámetros rítmicos en Balius, se mantienen dentro de la estética propia del final del Barroco y de parte del Clasicismo, sin duda influidos por la pervivencia de un bajo contínuo que los condiciona y que se conserva durante toda la obra del Maestro.

\subsubsection{Agógicas y Dinámicas.}

No hay en estos campos, especiales características diferenciadoras, pero comentaremos los aspectos principales.

En lo referente a los tempos generales de las obras, encontramos toda la multiplicidad de términos habituales, largo, larghetto, andante, allegretto, allegro, etc., a los que añade otros como, maestoso, más vivo, etc. Estos mismos términos los utiliza no sólo al comienzo de una obra o un movimiento de aquella, sino que son su herramienta habitual para cambiar la agógica dentro de un mismo movimiento.

El fluir de la música de ve detenido con la utilización puntual de calderones sobre las notas o sobre las barras divisorias, o algún tenuto excepcional. Kyrie (3/22). 


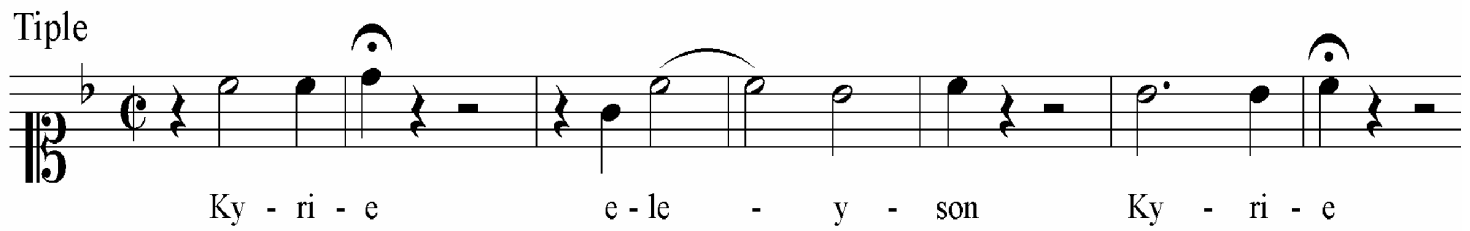

Casi no utiliza los términos acelerando o retardando, aunque lógicamente en los últimos compases de las composiciones, se produciría un descenso del tempo que reforzara las cadencias conclusivas, y ayudara a sentir el final de la obra.

También encontramos los principales grados dinámicos de la época, desde el pianísimo al fortísimo, y en algún momento el sforzando. En muchas ocasiones utiliza el paso de un matiz piano a uno fuerte sin solución de continuidad, de forma inmediata, para acentuar algún contraste brusco que refleje el argumento del texto o para buscar un efecto expresivo. Así sucede en los compases 148 al 151 de Ahora llegan dos pastores (93/781-7), en donde consigue con la alternancia a distancias de solo un compás entre el piano y el fortísimo un efecto muy apropiado que se ve también reforzado por el empleo del acorde de $7^{\text {a }}$ disminuida al pronunciar el coro la sílaba llan de llanto.

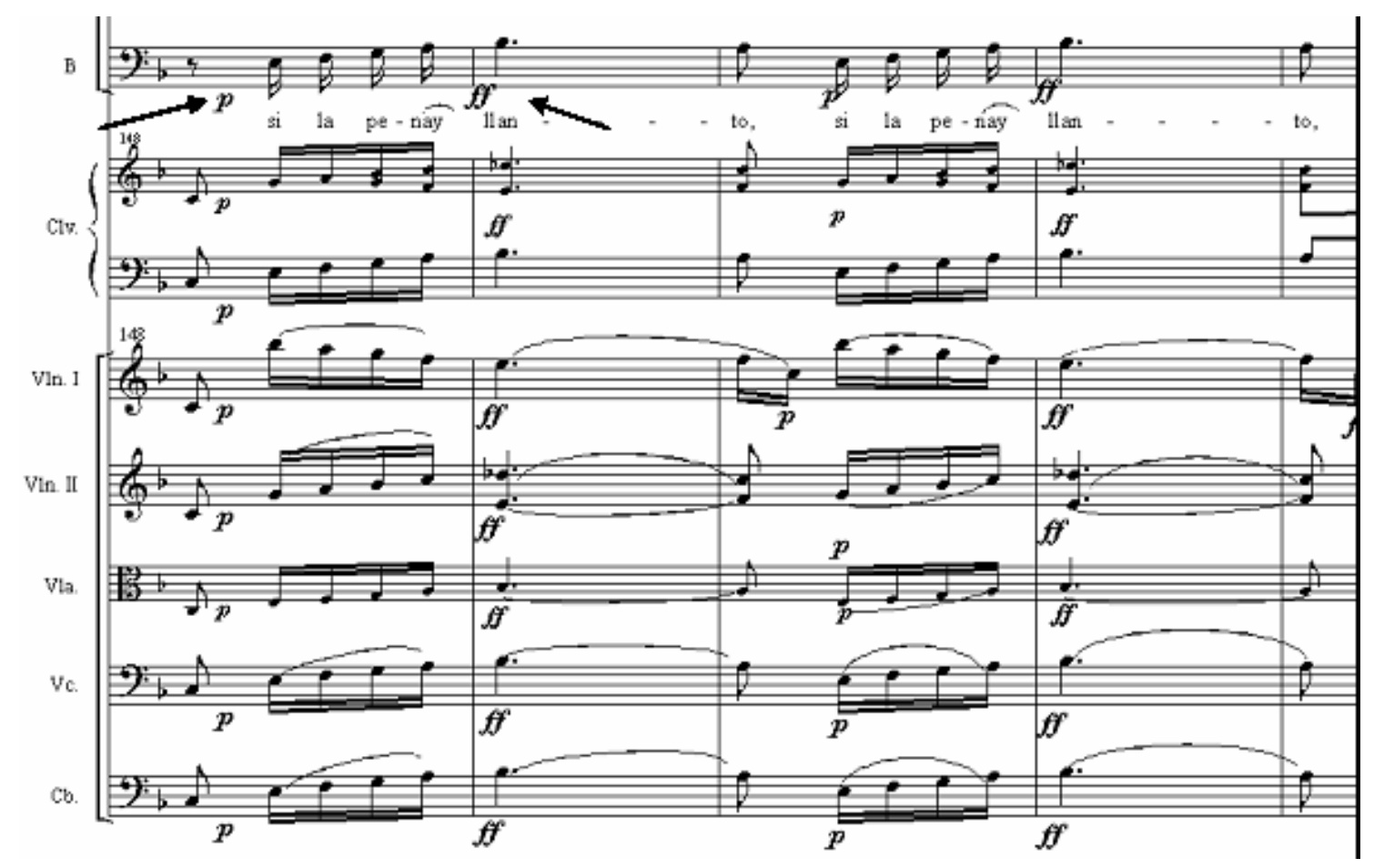


El crescendo es utilizado más frecuentemente que el diminuendo, y en ambos casos con suma prudencia, sin abusar de ellos.

\subsubsection{La Textura.}

Se trata de un término en el que participan de modo multidisciplinar varios conceptos musicales, tales como la línea melódica, el contrapunto, el acorde, el registro, el timbre, etc., considerados de una manera global y sobre todo considerando sus diversos grados de interrelación.

Con todos estos elementos, se puede definir la textura musical como el modo de organizarse y coordinarse las diversas partes integrantes del material sonoro en el discurso musical. Esto va muy asociado a la idea de tejido y a la orografía en la partitura. Es común observar en una misma partitura varias texturas.

Sentados estos principios, podemos decir que la gran variedad de formas musicales que Balius trabaja, hace que utilice igualmente un gran número de texturas diferentes. Desde la textura homofónica, a la contrapuntística, pasando por la melodía acompañada. A su vez, este acompañamiento que se hace a una melodía, puede ser acórdico, imitativo o arpegiado.

Podemos encontrar un acompañamiento muy simple en un recitativo, concediendo en este caso al solista todo el protagonismo y libertad posibles, en una modalidad de melodía acompañada muy esquemática. Así sucede en el Recitado y Aria De la Antigua Serpiente (2/12), donde la orquesta tan solo sostiene la armonía en valores largos mientras la solista quasi recita el texto con mayor libertad. 


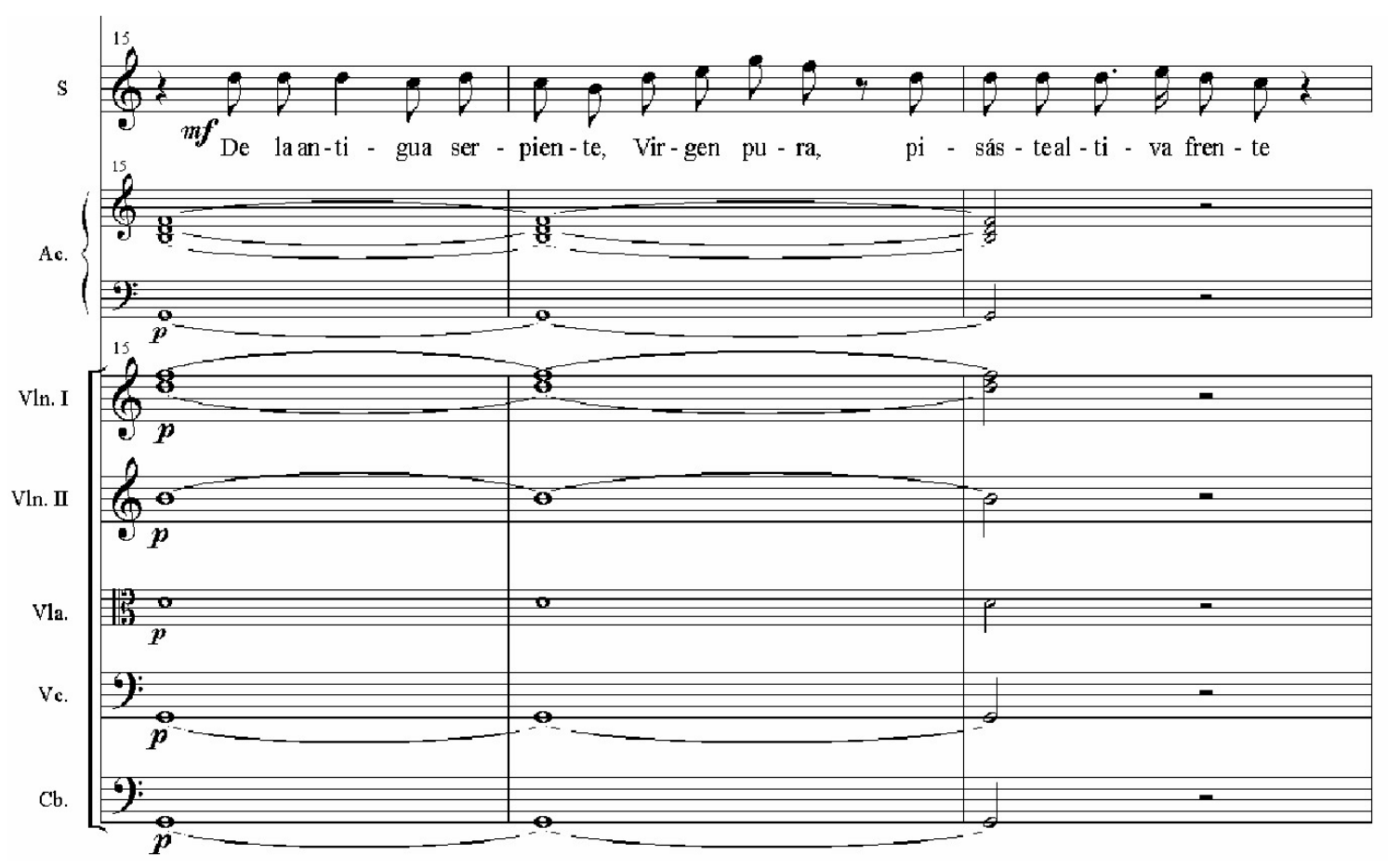

En el extremo opuesto se sitúan las obras a gran orquesta, con coro, solistas, etc., donde vemos gran cantidad de líneas melódicas simultáneas, a veces en homofonía, a veces en contrapunto, como por ejemplo la Kalenda del año 1798, Ay, ay que mi destierro (100/828), a 14 voces, Violines, 2 Flautas, 2 Oboes, 2 Bajones, 2 Trompas, Acompañamiento y Órgano obligado.

Entre estos dos extremos podemos encontrar múltiples configuraciones, desde órgano con voces, orquesta con uno o más solistas, coro “a capella”, etc.

Como ocurre en muchos casos y autores, las diferentes texturas nos ayudan a ver la intención estilística de cada composición. En este caso existe otro remanente barroco que es la policoralidad, pudiendo encontrar obras incluso a 16 voces.

\subsubsection{Los Textos.}

Como cualquier Maestro de Capilla, D. Jaime utiliza los textos en latín propios de la Liturgia. Ellos eran sin duda el plato fuerte de su función en la Catedral. 
En cuanto a los textos en castellano que utiliza para otras composiciones como los villancicos, las canciones patrióticas, etc., raramente tenemos constancia de su autor, aunque lo normal era que esta función se encomendase a un "libretista” externo.

Así lo confirma José María Valdenebro ${ }^{1805}$, que en su libro La Imprenta en Córdoba, cita como autor de la letra de los villancicos de Balius, que se cantaron en la Catedral de Córdoba los años 1785, 1788, 1800 y 1807 a D. Félix de Austria. Y como autor de la letra de los villancicos de 1816 a D. Manuel María de Arjona. ${ }^{1806}$

Aunque de los restantes años no tenemos esa certeza, todo parece indicar que entre 1785 y 1807, el letrista habitual de los villancicos de Jaime Balius pudo ser D. Félix de Austria, ${ }^{1807}$ y que, tras un paréntesis que coincide con la invasión francesa en el que no consta que se hicieran villancicos, siguió realizando esta función D. Manuel María de Arjona. ${ }^{1808}$ Todo ello sin excluir que otros letristas o el mismo Balius realizaran el texto de algún villancico o de otra obra en castellano.

Los temas que abordan estos textos son muy variados, mostrando los autores una gran capacidad inventiva de ideas y de argumentos, y de asuntos, que contienen de manera frecuente rasgos expresivos de espontaneidad y de gracia. Sin duda sería motivo de otro amplio trabajo hacer un análisis temático y métrico de los 416 villancicos de Balius (incluyendo las kalendas).

\footnotetext{
${ }^{1805}$ José María Valdenebro y Cisneros fue Licenciado en Derecho Civil y Canónico, y miembro por oposición del Cuerpo de Archiveros, Bibliotecarios y Anticuarios.

${ }^{1806}$ Cf. VALDENEBRO, José María. La imprenta en Córdoba. Edición Facsimil, Córdoba, Diputación de Córdoba, Delegación de Cultura, 2002, págs. 339, 343, 359, 393 y 404. (1ª Edición, Madrid, Establecimiento Tipográfico "Sucesores de Rivadeneyra", 1900). Este libro fue premiado por la Biblioteca Nacional en 1896. Detalla las diversas imprentas que hubo en Córdoba, y es un catálogo de los libros y folletos impresos en las mismas, pero además incluye amplios fragmentos de algunos de esos libros, que por su especial relevancia, merecieron la consideración del autor.

${ }^{1807}$ El mismo Valdenebro nos aclara en su libro que Félix de Austria era un poeta cordobés, hombre piadoso, que además de poner letra a los villancicos de Balius, ya había publicado anteriormente otro de sus trabajos. Así, los días 9, 10 y 11 de Febrero de 1767, se celebró en Córdoba un Triduo en honor de Simón de Rojas, Capellán Trinitario... "Cuya noticia escribe en apológico estylo Don Félix Joseph de Austria, vecino de dicha ciudad, humilde y rendido esclavo, y cordialísimo afecto de María Santísima y Dulcísimo Nombre, a quien ofrece y consagra [dicha noticia]”. Ibid. pág. 313.

${ }^{1808}$ Manuel María de Arjona nació en el pueblo sevillano de Osuna en el año 1771, y ejerció diversos cargos importantes en su condición de sacerdote. Así fue colegial mayor de Santa María de Jesús, de Sevilla; doctoral de la Real capilla de San Fernando de la misma ciudad y canónigo penitenciario de la Catedral de Córdoba. Fue en esta última ciudad donde, en 1810, impulsó la fundación de la Real Academia de Ciencias, Bellas Artes y Nobles Letras de Córdoba.
} 
Las imprentas cordobesas donde se imprimieron las letras de estos villancicos fueron las siguientes: ${ }^{1809}$

1) Imprenta de Juan Rodríguez de la Torre: En ella se hicieron las letras de los villancicos de los años 1785 a 1803, ambos inclusive.

2) Imprenta de Luis Ramos y Coria: Editó los villancicos de 1804.

3) Imprenta de Rafael García: Editó los villancicos de 1805, 1806 y 1807.

4) Imprenta Real: Editó los villancicos de 1814 a 1819.

5) Imprenta de Rafael García: De nuevo se encarga a esta imprenta la edición de los villancicos de la Catedral de Córdoba, en este caso de los años 1820 y 1821.

\subsubsection{GÉNEROS Y FORMAS.}

Si hacemos un cómputo global de la temática de las obras, es evidente que la mayoría de ellas pertenece al género religioso, como corresponde a un Maestro de Capilla. Dentro de estas obras de carácter religioso podemos distinguir entre las litúrgicas (para la Misa el Oficio) y las paralitúrgicas (para las procesiones, actos de adoración, etc.). Ellas constituyen la mayor parte de su música. Sin embargo, no faltan algunas obras de temática profana de gran contenido social e incluso patriótico. Asimismo utiliza tanto el latín como el castellano, reservando como es natural el primero para los Cánticos (23), Himnos (32), Lamentaciones (14), Misas (42), Motetes (16), Oficio de Difuntos (8), Responsorios y Secuencias (17), Salmos (50), Varia en latín (11). Y el segundo para los Oratorios (7), Recitados y Arias (53), Varia en español (8) y Villancicos (405)-Kalendas (31).

También podemos hacer la distinción entre género instrumental, vocal o mixto. Del primero tenemos tan solo 3 obras. Del segundo 58, y del tercero y más numeroso, 659. En total, suman 720 obras.

${ }^{1809}$ Una pequeña historia de cada una de estas imprentas la podemos encontrar en el citado libro de Valdenebro, La Imprenta en Córdoba. 


\subsubsection{Cánticos.}

Balius pone música a los siguientes cánticos: "Magníficat” (Cántico de la Virgen María, Lucas 1, 46-55), “Benedictus” (Cántico de Zacarias, Lucas 1, 68-79) y “Nunc dimittis” (Cántico de Simeón, Lucas 2, 29-32). Este es el último en la secuencia histórica de los tres grandes Cánticos del Nuevo Testamento. Los tres son llamados, a modo de distinción, los “Cánticos evangélicos”.

Su forma viene determinada por el texto, sirviendo en ocasiones de soporte a toda la obra un cantus firmus gregoriano sobre el que se estructuran el resto de voces. Se alternan versiones corales con otras mixtas. En el primer caso se vale de 2 Coros (SATB-SATB), por ejemplo los cánticos contenidos en 6/53, y en otras ocasiones cuenta con una nutrida orquesta como en el Magníficat (2/14) que está transcrito en el volumen III.

Su escritura es fundamentalmente contrapuntística, intercalando fragmentos homofónicos antifonales en períodos breves. El ámbito de las voces no suele exceder de la octava, siendo los pasajes melismáticos ampliamente utilizados.

\subsubsection{Himnos.}

Los himnos son cantos de alabanza, composiciones poéticas en loor de la Divinidad, de la Virgen o de los Santos. Se reservaban para las fiestas de especial solemnidad, siendo algunos de los más conocidos, el Pange Lingua (Al Santísimo Sacramento), Veni Creator (al Espíritu Santo), o el Te Deum (Acción de Gracias).

En el caso de los himnos nos encontramos con una gran variedad en cuanto a plantillas utilizadas, ya que los podemos tener desde 4 voces a capella, a 7 voces con un esquemático acompañamiento, hasta llegar a himnos que utilizan plantilla mixta coroorquesta. Sin embargo todos ellos son preferentemente silábicos, con una polifonía homofónica salvo pequeñas células de contrapunto imitativo. La estructura estrófica del texto depara una repetición de la misma música para cada una de las estrofas. El ámbito vocal rara vez supera la octava, y es muy característico el desarrollo melódico por grados conjuntos o pequeños saltos interválicos, sobre todo en las voces superiores. Balius dedica frecuentemente los himnos a santos, como San Pelagio, San Rafael, 
Santiago, o bien los compone sobre textos del himnario clásico como el Pange Lingua, Gloria Laus, etc.

\subsubsection{Lamentaciones.}

Con el término "lamentación” se designa una forma bíblica de oración en la que se medita ante Dios sobre un acontecimiento doloroso y trágico. El libro bíblico de las Lamentaciones está compuesto de cinco pequeños poemas redactados después de la caída y conquista de Jerusalén por el ejército babilonio (587 a.C.). Aquel hecho marcó el final del Estado de Judá y el comienzo de una gran diáspora del pueblo judío en el mundo. Sobre él medita el autor de las Lamentaciones. Una antigua tradición los atribuye al profeta Jeremías. Las Lamentaciones se ubicaban en el oficio de Maitines (Tinieblas) del Miércoles, Jueves y Viernes Santo.

La plantilla de Balius para las Lamentaciones es solista y orquesta o coro y orquesta y cuenta con una introducción orquestal. Cuando este coro tiene 4 voces, éstas suelen mantener un diálogo por parejas. En principio soprano y contralto se oponen a tenor y bajo, para después, alternar diversas combinaciones de voces dialogantes pero frecuentemente por parejas. También hay Lamentaciones a 8 voces, como la que nos encontramos en Hegh. Cogitavit Dominus (17/130).

Son obras de una duración considerable, ya que se trata de musicar un texto bíblico considerablemente largo. La orquestación es completa, y en el caso de las versiones para solistas y orquesta, cuentan con grandes pasajes melismáticos, con saltos interválicos, virtuosismos vocales $\mathrm{y}$ todos aquellos recursos tendentes a dar protagonismo al solista. Entre cada uno de estos fragmentos del solista, la orquesta desarrolla unos interludios que sirven para presentar el nuevo motivo.

\subsubsection{Misas.}

La misa constituye el momento crucial de la liturgia y por tanto ha sido atendida por todos los Maestros de Capilla con especial interés. Sus partes fijas son el Kyrie, Gloria, Credo, Sanctus y Agnus. Están en latín, lógicamente, porque era la lengua de la Liturgia. 
Balius compone 42 misas nada menos, además con una gran variedad en la conformación vocal. Tenemos misas a 3, 4, 5, 7, 8, 9 y hasta 12 voces. Su instrumentación va desde un simple acompañamiento de órgano hasta la orquesta completa con cuerda, oboes, fagotes y trompas. En las grandes misas a 8 o más voces, incluye además 2 órganos. En cuanto a su estructura formal, es el texto quien nos conduce en el análisis. Como es natural, el Gloria y el Credo tienen mucha más extensión. Aunque normalmente el Kyrie suele tener un carácter más moderado y el comienzo del Gloria más vivo, en ocasiones es al contrario, como sucede en la misa "Salve Regina" (17/137). A veces no se musicaliza el Credo. Se completa con el Sanctus-Benedictus y Agnus Dei. En el caso de las misas de difuntos se modifica algo la estructura, incluyéndose tiempos propios como el "Réquiem", la secuencia "Dies Irae”, el ofertorio “Domine Jesu Christe”, “Lux Aeterna”, etc.

\subsubsection{Motetes.}

El Motete, es una composición vocal, de larga trayectoria evolutiva desde el siglo XIII hasta nuestros días, por lo general sobre texto sagrado, e históricamente destinado a interpretarse en los oficios religiosos. ${ }^{1810}$ Pueden ser “a capella” o llevar acompañamiento de instrumentos.

Balius utiliza dos tipos de plantillas. Una exclusivamente coral, a 4 o a 8 voces, en todo caso con un acompañamiento opcional, y otra, que integra la gran plantilla orquestal más las voces normalmente a 8, y en dos coros. Aplica aquí en menor medida, la técnica que después veremos muy desarrollada en los salmos, de separar los diferentes conceptos textuales con números musicales independientes. Los dos coros se contestan en ocasiones antifonalmente y en otras cantan juntos redoblando dos o más voces la misma línea melódica. Preferentemente utiliza la homofonía, salvo algunos pasajes en contrapunto imitativo. Cantan en valores moderados o largos, mientras que los violines desarrollan una trama melódico-rítmica mucho más nutrida, en corcheas o semicorcheas. Tal como dijimos refiriéndonos a las partes de la misa, ahora también el texto determina el aspecto estructural. Los textos más comunes del repertorio

\footnotetext{
1810 Sobre la evolución del motete Cf. RUBIO, Samuel. La Polifonía Clásica. Madrid, Biblioteca "La
} Ciudad de Dios”, 1956, págs. 156-173. 
motetístico son: O Sacrum Convivium (51/318), Ave María (62/429), Hoc Corpus (18/1079), etc.

\subsubsection{Música Instrumental. ${ }^{1811}$}

La música instrumental de Balius está representada por el “Cuarteto $n^{o} 3$ ” (29/213), el “Concertino para Trompa y Orquesta en Re Mayor” (127/1225) y la "Sonata para cémbalo con violino obligato" (134/1305). El primero, concebido para el tradicional cuarteto de cuerda, 2 violines, viola y violoncello, se encuadra por su estética y características técnicas dentro del más puro clasicismo musical. Los retardos, apoyaturas y progresiones apoyan una armonía tonal que en sus modulaciones acepta la atracción tradicional de los tonos vecinos. Si bien todos los instrumentos son importantes y trabajan a nivel solista, los violines llevan frecuentemente la melodía por terceras, e incluso el violín $1^{0}$ desarrolla pasajes de especial virtuosismo. Sus cuatro tiempos, allegretto, adagio, minuetto y allegro final (construido en forma de fuga) conforman una pieza de gran vitalidad y dinamismo que bien podría entrar a formar parte del repertorio habitual de los cuartetos clásicos.

Por la numeración de este cuarteto parece evidente que debieron de existir otros, al igual que parece probable que Balius (tanto por su formación musical como por el tipo de orquesta que utilizaba habitualmente) hiciera otras incursiones en el terreno de la Sinfonía.

Del “Concertino para Trompa y Orquesta en Re Mayor", de dimensiones reducidas, sólo se conservan el primero y segundo tiempo. De las dos particellas de trompas, la segunda lleva “obligatto" y hace los pequeños fragmentos solistas. En el primer tiempo, Allegretto 3/8, después de 24 compases de introducción orquestal, donde se exponen un tema A rítmico y uno B melódico, entra la trompa solista, quedándose tan solo el contínuo de acompañamiento. Son apenas cuatro frases las que hace el solista, con los correspondientes interludios instrumentales para acabar todos juntos en

\footnotetext{
${ }^{1811}$ Es patente la escasez de obras puramente instrumentales en los archivos catedralicios; esto es sencillamente porque no formaban parte del repertorio litúrgico necesario para su función. Por eso es un privilegio que se conserven en la Catedral de Córdoba estos tres ejemplares de Balius.
} 
un tutti final. El segundo tiempo Largo, también en 3/8, comienza con una sección A en Re Mayor, tiene una sección central B en re menor, vuelve a repetir A, le sigue una tercera sección C también en Re Mayor, para volver definitivamente a repetir A. Quedando entonces A-B-A-C-A. También es de dimensiones reducidas aunque por su tiempo lento, tiene mayor duración. El papel de las flautas en ambos tiempos es meramente testimonial, redoblando en ocasiones a violines y cubriendo armonías en otras.

En cuanto a la "Sonata para cémbalo con violino obligatto", tiene claramente la disposición de una sonata para violín y clave, siendo el protagonista normalmente el violín. En algunos compases del clave sólo está escrito el bajo con su correspondiente cifrado, como era habitual.

\subsubsection{Oficio de difuntos.}

Solía incluir la Misa (habitual, sin Gloria ni Credo, pero con secuencia “Dies Irae”, ofertorio “Domine Jesu Christe” y conmunio “Lux aeterna”) más el Responsorio "Libera me” y el oficio de Maitines (invitatorio y lecturas).

En el caso de Balius, componen esta sección algún “invitatorio”"1812, y sobre todo algunas “lecciones” como el Parce Mihi. ${ }^{1813}$ Quizás sea ésta una de las piezas con más variedad en cuanto a la instrumentación. Encontramos plantillas de orquesta y solista, orquesta y dúos o tríos, orquesta y coro, etc. A veces el coro es a 4, y otras a 8, como sucede en el Parce Mihi (61/416-1). En cuanto a la orquesta, a veces está completa y otras prescinde de trompas. Cuando utiliza dos coros, el segundo frecuentemente comenta de forma conjunta y breve, el final de la intervención del coro $1^{\circ}$. Cuando aparecen juntos se redoblan diversas voces. No hay excesivos alardes virtuosísticos, los

\footnotetext{
${ }^{1812}$ El invitatorio consiste en una invocación dialogada seguida de un salmo (23, 66, 94 o 99) con una antífona que va cambiando según las fiestas y los tiempos. Se dice como introducción a todo el conjunto de la oración cotidiana; por ello se antepone o bien al oficio de lectura o bien a las Laudes, según se comience el día por una u otra acción litúrgica. El invitatorio no se restringe únicamente a la celebración de la Liturgia de las Horas, ya sea de Laudes o del Oficio de Lecturas, ya que por su propia naturaleza está pensado para preceder e introducir la primera oración del día aunque no sea en el ámbito de la oración litúrgica. Enciclopedia Católica. www.enciclopediacatolica.com.

${ }^{1813}$ Frase tomada del libro de Job 7.16, que ha dado origen a muchas locuciones que todas vienen a significar la idea de la caducidad e insignificancia de las cosas humanas.
} 
tempos larghettos, moderatos, facilitan sensación de estabilidad, el contenido del texto (en latín) invita a la reflexión.

\subsubsection{Oratorios.}

El Oratorio era una composición musical dramática no representada, de tema sagrado, bíblico o no bíblico, para voces solistas, coro y orquesta. Se desarrollaba mediante recitativos, arias, ariosos, coros $\mathrm{y}$ fragmentos instrumentales, todo ello enlazado mediante intervenciones de un narrador. Generalmente su texto se basa en las Sagradas Escrituras y solía cantarse en cuaresma y en festividades especiales. ${ }^{1814}$

De los siete oratorios que encontramos en el catálogo, uno es a 5 voces, 4 a 7 y 2 a 8, incluyendo en esta distribución uno o más solistas, como se puede ver en su ficha correspondiente. Curiosamente, Balius compone cuatro de ellos antes de su llegada a Córdoba, concretamente son Tiemblo todo, (82/645-1) del año 1782, Infeliz hebreo errante, (128/1237) del año 1783, El Tabernáculo y Sacrificio (82/644), también de 1783 y Oratorio a Santo Tomás de Aquino (128/1236) del año 1784. Su estructura coincide con la de los típicos oratorios clásicos, con la presencia de recitativos, arias, duettos y números corales. En algún caso (128/1237), lleva obertura instrumental independiente.

\footnotetext{
${ }^{1814}$ Su nombre "se deriva del oratorio (sala de oraciones) en el que se celebraban lecturas bíblicas y devotas meditaciones con canciones sacras (laudi)". ULRICH, Michael, Atlas de Música. Madrid, Alianza Editorial, 1998. Vol. I, pág. 135. "Representativos fueron los ejercicios de San Felipe Neri, desarrollados desde 1558 en el oratorio del Monasterio de San Girolamo della Caritá y a partir de 1575 en el de Santa Maria in Vallicella. Puesto que eran independientes de la liturgia, el esquema de estos encuentros se podía configurar libremente. Además de oraciones, prédicas y lecturas de la Biblia se entonaban canciones sacras, los laudi a 1 voz o polifónicos”. Ibid. Vol. II, pág.323. Desde 1575 (el 15 de julio una bula pontificia instituía una Congregación de sacerdotes y clérigos seculares bajo el nombre del Oratorio) ya está constituida oficialmente en Roma la Congregación del Oratorio fundada por San Felipe Neri, con las actividades anteriormente expuestas, en donde la música va cobrando progresivamente más importancia. El testimonio musical más temprano que se ha conservado de un oratorio con sus recitativos y coros es la Representación del alma y del cuerpo, de Cavalieri (Roma, 1600), aunque sin duda el compositor de oratorios más célebre del siglo XVII fue Carissimi. En estas piezas, hay un narrador como personaje principal: "La figura central del oratorio es la del narrador, quien, por medio de recitativos (tenor con bajo continuo) expone el texto bíblico o la acción como hilo conductor para los diversos números musicales. Los temas provienen del Antiguo Testamento, a veces también del Nuevo o de las leyendas de los santos. Las partes literarias de composición nueva se adjudicas a los solistas o al coro”. Ibid. pág. 135. Su estructura se desarrolla hasta las grandes producciones de Bach (Pasiones) y Haendel (El Mesías).
} 


\subsubsection{Recitados y Arias.}

Como después veremos, tanto los villancicos como las kalendas incluían ocasionalmente en su estructura recitados y arias. En este apartado nos referimos exclusivamente a aquellas piezas en que éstos se estructuran de forma autónoma y exclusiva.

Podemos definir el Recitativo como el "tipo de discurso declamatorio-musical en que la música sigue con cierta libertad de ritmo, compás y entonación, comparble con la prosa, las inflexiones de la palabra”. ${ }^{1815}$ De carácter narrativo, tiene varias modalidades. $^{1816}$

Aria es el "término empleado originariamente, ya para designar una melodía con variedad de texto sobre la misma estructura poética, ya para referirse a una melodía corta con diferentes estrofas o al aria ostinato. Desde 1650 vino a significar ya una composición para solo o dueto con acompañamiento instrumental, que forma parte sustancial de Oratorio y Cantata de los siglos XVI y XVII y de la ópera hasta el presente". 1817

Por tanto, si hay algunas obras donde los solistas vocales exponen todo su virtuosismo y tienen el papel de protagonistas absolutos, dichas obras son los Recitados y Arias. Aquí utiliza Balius argumentos variados, desde la Asunción de la Virgen, hasta alabanzas al Santísimo Sacramento o a la Concepción de María. Los textos están en

${ }^{1815}$ PÉREZ, Mariano: Diccionario de la Música y los Músicos. Madrid, Ediciones Istmo, 1985, Vol. 3. pág. 92.

${ }_{1816}$ "Recitativo seco: con voz muy libre y cercana al discurso literario, sostenida por unos pocos acordes del clave, en bajo cifrado, que sostenía el tono y ayuda en las modulaciones y cadencias: fue practicado en Italia en los siglos XVII y XVIII. Durante él, solía desarrollarse la acción dramática. Recitativo accompagnato o stromentato: Menos libre que el anterior, de interés más dramático que declamatorio y reservado a los momentos de mayor climax como introductoria al aria; la orquesta comenta e interpreta musicalmente el texto, a cuya expresión se subordina. Se usó además de en la ópera, en la Cantata, el Oratorio y en muchos lieder a una voz. Recitativo airoso: Ha venido a ser el más melódico, breve y transitorio, y se aproxima al aria; se asemeja a un paréntesis melódico pero sin llegar a aria”. Ibid.

1817 "Después de diferentes modificaciones por parte de los compositores italianos de los siglos XVII y XVIII (especialmente de Scarlatti), tomó la forma de la llamada Gran Aria o Aria da Capo, cuya estructura perduró sustancialmente hasta Gluck, constituyendo la base del Estilo Napolitano. El aria napolitana era extensa y de tipo ternario reexpositivo, con una sección central diferente y modulativa haciendo gala de florituras y virtuosismos de toda clase, sobre todo en A y C. Según su grado de expresión y contenido se codificaron muchas clases de arias, siendo las principales di bravura (ágil y brillante), cantábile (lenta y sostenida) y parlante (recitativa y con énfasis en el texto). Los abusos y gorgoritos en los que cayeron algunos cantantes de la Escuela Napolitana las hicieron a veces huecas de contenido expresivo, lo que originó la reforma de Gluck, que tendió más hacia la expresión musical que hacia el lucimiento del cantante”. PÉREZ, Mariano: Diccionario de la Música y los Músicos. Madrid, Ediciones Istmo, 1985, Vol. 1. pág. 76. 
castellano. De las dos partes de las obras, el Recitado es en ocasiones más breve, en estilo silábico, sobre una línea de recitación más continua, como corresponde a su papel de narrador, y con apoyos en notas largas de la orquesta. No obstante, previamente la orquesta ha realizado una introducción de pocos compases para situar la tonalidad. En algunos compases, estos recitativos se desarrollan con acompañamiento de bajo contínuo o incluso sin ningún acompañamiento.

El Aria, por su parte, además de ser más extensa, sirve de vehículo para que la voz exprese todas sus cualidades tímbricas, haciendo un recorrido por toda su tesitura con pasajes más expresivos o más virtuosísticos, más silábicos o más neumáticos o melismáticos. Todo ello alternando interludios orquestales que ayudan a exponer o comentar los temas melódicos, a la vez que permiten el descanso del solista. Balius ha recurrido a las cuatro voces principales para estas piezas. Desde la Soprano hasta el Bajo, todos tienen algún Recitativo y Aria. En ocasiones son dúos o tríos, y en otras ocasiones, aunque las menos, añade al recitado y aria un número de coro final. Así sucede por ejemplo en No temas Bella Esther (6/58).

La orquesta utilizada por Balius en estas composiciones se sustenta sobre la cuerda más oboes, trompas y bajones. En ocasiones los dos oboes son sustituidos por dos flautas.

\subsubsection{Responsorios y Secuencias.}

El Responsorio era en principio una pieza “cuya ejecución tiene lugar después de una lectura con la finalidad de favorecer una breve meditación sobre el contenido de ésta. Los maitines del triduo sacro y los de la liturgia mortuoria, son los temas más utilizados por los polifonistas con relación a esta forma musical sagrada”. ${ }^{1818}$ Algunos responsorios, como los de difuntos, utilizan materiales previos del gregoriano, y otros como los de Semana Santa, no lo hacen.

${ }^{1818}$ RUBIO, Samuel. Historia de la música española desde el ars nova hasta 1600. Madrid, Alianza Editorial, Alianza Música, 1983, pág. 87. Su ubicación preferente era en el “Oficio”, y como hemos visto, concretamente a continuación de la Lectura con que se cerraba cada uno de los tres nocturnos de los Maitines, y con especial relevancia en el Triduo Sacro (Miércoles, Jueves y Viernes Santo). Después se extiende a otras ubicaciones. 
En el caso de Balius, los convierte en verdaderas obras sinfónico-corales con gran número de voces e instrumentos. Es más, casi la mitad de ellos son a 8 voces en dos coros y otros, a 4 y a 5 . El tratamiento que da a las voces es absolutamente variado. Pasajes homofónicos contrastan con otros contrapuntísticos, a veces iniciando una imitación en escalera descendente en el Coro $1^{\circ}$, S-A-T-B, que sigue en escalera ascendente en el Coro 2º como ocurre en Quem Vidistis (101/834). En algún caso como el Responsorio a 8 con violines, oboes y trompas (61/421), hemos encontrado un rasgo diferenciador de la mayoría de las obras de este catálogo, cual es la anotación específica de la palabra "viola” en la partitura general. Bien es sabido que en la mayoría de sus obras, Balius no utiliza violas, siendo muy escasas las ocasiones en que, como ahora hemos visto, cita expresamente a este instrumento. Otras veces como en Hodie Nobis (101/835), realiza imitaciones por grupos completos. Así el Coro $1^{0}$ imita la anterior entrada del Coro $2^{\circ}$ dos partes antes. Enfatiza así lo anteriormente expuesto. Para complementar estas variadas fórmulas, en otras ocasiones hace que una voz a "solo", contraste con un tutti posterior donde entra normalmente la orquesta completa y los dos coros.

Iguales técnicas aplica en las Secuencias ${ }^{1819}$, donde además hace cantar a un coro en forma continuada, sosteniendo una larga melodía, mientras que al segundo lo utiliza como apoyo rítmico en períodos cadenciales o finales de frase. Tal ocurre en Victimae paschali laudes (72/542). En el caso del Stabat Mater (6/52), musicaliza los cuatro primeros versos, y realiza la adaptación de los restantes versos a la misma música que tienen los primeros. Por tanto podemos decir que los Responsorios y Secuencias siguen el mismo esquema de partitura, con grandes orquestaciones, 8 voces de forma

\footnotetext{
${ }^{1819}$ La secuencia fue en principio una especie de himno basado sobre los largos melismas gregorianos vocalizados del Jubilus, sin texto, que seguían al Aleluya de la misa en la liturgia romana, y a los que entre los siglos $I X$ y XV se les aplicó un texto o prosa silábicos a cada nota para su mejor retención. Luego se independizaron como piezas litúrgicas interpoladas. De aquí el nombre de "prosa ad sequentian" o "sequentia cumprosa". Hay confusión sobre sus orígenes, que algunos quieren atribuir al norte de Francia, aunque Notker Balbulus, monje de San Gall, perfeccionase el sistema. Si bien las primeras fueron escritas en prosa, pronto fue verso rimado. Uno de sus principales cultivadores fue Adam de San Víctor (siglo XII). Fueron muchas las compuestas durante tales siglos para casi todos los días del año litúrgico, hasta el punto de que el Conciclio de Trento abolió todas, excepto las cinco que aún se conservan en la actualidad y que son las siguientes: Victimae paschali (Domingo de Resurrección, Wipo, siglo XI), Veni Sancte spiritus (Pentecostés, siglo XII), Lauda Sión (Corpus Christi, Santo Tomás, siglo XIII), Dies Irae (Tomás de Celano, siglo XIII) y Stabat Mater (Jacopone de Todi, Viernes de Dolores, siglos XIII-XIV). Las dos últimas fueron también muy utilizadas desde el siglo XV por los polifonistas y sinfonistas como obras polifónicas y especie de cantatas. PÉREZ, Mariano: Diccionario de la Música y los Músicos. Madrid, Ediciones Istmo, 1985, Vol. 3. pág. 182.
} 
habitual, combinación de redoblamientos con alternancia antifonal de estos dos coros, densas introducciones orquestales, separación ocasionalmente de los distintos versos en distintos números musicales, gran variedad de esquemas rítmicos, etc.

\subsubsection{Salmos.}

Los salmos son la oración de Israel. Son la expresión de la experiencia humana vuelta hacia Dios, expresión de la vida de un pueblo arrastrado por Dios. La tradición hace remontar muchos salmos al Rey David y atribuye algunas colecciones a Córaj y a Asaf. La iglesia los emplea habitualmente en las celebraciones litúrgicas, peregrinaciones, fiestas diversas, etc. ${ }^{1820}$ Algunos son auténticas meditaciones, sobre la vida humana o sobre la historia de Israel y los hay de clasificación más dudosa. Todos ellos están reunidos en el Libro de los Salmos que agrupa 150 de estas piezas. Balius musicaliza algunos de ello frecuentemente, y les aplica una gran riqueza rítmica y melódica además de una gran plantilla sinfónico-coral que incluye normalmente orquesta completa y dos coros. La importancia que le da a estos salmos viene determinada por el tratamiento que otorga a cada una de sus versos, musicalizándolos por separado, en ocasiones con distintas plantillas vocales-instrumentales, distintos diseños melódicos e incluso distinto compás. Así sucede en el Salmo 4 Cum Invocárem (7/63-2). Igualmente sucede con el Salmo 90 Qui hábitat (7/63-3), que en realidad se asemeja a una pequeña cantata donde cada una de las partes del salmo constituye un número musical distinto, incluyendo duettos, solos, coros, etc.

De los 50 salmos que compone, 21 son sobre el Miserere. De estos 21, la mayoría son a 8 voces, pero también los tiene a 9, 12, 13 o 15, alguno de estos últimos compuestos ya en el siglo XIX.

\subsubsection{Varia en castellano.}

Incluimos en este apartado un cántico a la Inmaculada Concepción de la Virgen (para coro a 4 voces SSAT y orquesta), los “gozos” y las canciones patrióticas.

${ }^{1820}$ Forman parte, ante todo, del Oficio (Maitines, Laudes...). 
Los “gozos” son piezas donde se ponderan las cualidades y virtudes de un Santo, ensalzándolas con toda clase de alabanzas. Balius tiene en el archivo de Córdoba 4 obras de este tipo, dedicadas respectivamente a San José, San Rafael, San Francisco de Paula y Santo Tomás de Aquino. En todos los casos utiliza orquesta con oboes y trompas, además de coro a 4 o 8 voces y solistas. La estructura suele incluir una introducción instrumental tras la cual un estribillo es cantado por el coro. A partir de ese momento, diversos solos de soprano, tenor, incluso duettos, van desgranando el texto, para volver posteriormente al estribillo en tutti.

En cuanto a las canciones patrióticas son reflejo del rechazo al invasor napoleónico. Pedrell le atribuye a Balius un “cántico en loor de José Napoleón”. En el archivo de la Catedral de Córdoba se encuentra efectivamente un "Cántico a Napoleón” (84/674). No obstante, aunque el título pueda inducir en esa dirección, este canto es de naturaleza manifiestamente hostil. Así dice un fragmento del texto: "Cantemos la victoria, reúnase la nación, y mueran los franceses con su Napoleón".

Otra obra es Cordobeses Ilustres y Nobles (84/669-3), a la que hicimos referencia anteriormente en el apartado de Fiestas y Celebraciones, cuando hablamos de la visita de Isabel de Braganza a Córdoba, ya que dicha composición fue hecha con motivo de esta visita.

Sin embargo la obra con más difusión de las que componen este apartado, es la canción patriótica Nobles Andaluces (113/1009). Esta obra fue descubierta en 1979 por el canónigo archivero de la Catedral de Córdoba D. Manuel Nieto Cumplido y posteriormente instrumentada y dirigida por D. Luís Bedmar Encinas, estrenándose el día 13 de Enero de 1980 por la Banda Municipal de Córdoba. En esta primera ocasión se hizo solo una versión instrumental. En posteriores ocasiones se repitió añadiendo la parte vocal. Para D. Manuel Nieto, “Es un himno épico” un verdadero "Himno de Andalucía”. 1821

\footnotetext{
${ }^{1821}$ Declaraciones hechas a: Bernier, Juan. “El verdadero himno de Andalucía”, en Tendillas 7, semanario cordobés de bolsillo, número 86, 5 de Enero de 1980, pág. 6 .
} 
NOBLES ANDALUCES. 1808.

Nobles andaluces, volad a mi voz

y romped el fuego al usurpador

y romped el fuego al usurpador.

Corred a las filas,

corred con ardor

que el gran Chevarría

os promete honor.

Ya suena, suena el clarín,

oíd, oíd el tambor,

al arma, guerra, guerra, guerra,

al arma, guerra, guerra, guerra

y muera Napoleón

y muera y muera Napoleón.

El contexto histórico de esta obra coincide con los preparativos para defender la ciudad frente al previsible avance sobre ella del general Dupont, por lo que podemos situarnos hacia el mes de Mayo de $1808 .^{1822}$

La noticia de su descubrimiento, su fase de preparación y su estreno tuvo en su momento una amplia cobertura periodística tanto a nivel regional como nacional. ${ }^{1823}$

\footnotetext{
1822 "El momento histórico en que el compositor escribe y ejecuta esta obra coincide con la disposición de las ciudades andaluzas para defender la región contra los ejércitos franceses dirigidos por el general Dupont. Simultáneamente se cruzan cartas entre Córdoba, Granada, Sevilla, Jaén y Cádiz para estudiar conjuntamente la respuesta andaluza al ejército invasor.

El 7 de Mayo de 1808 las villas de Espiel y Villaviciosa remiten al Ayuntamiento de Córdoba el parte del alcalde de Móstoles dando cuenta de los sucesos del 2 de Mayo en Madrid. Los munícipes cordobeses tratan con D. Pedro Agustín Echavarri, comandante de armas de la plaza (nacido en Sestao el 25 de Junio de 1756), la actitud a tomar y se acuerda ponerse en comunicación con el Capitán General de Andalucía residente en Cádiz. Sevilla responde urgiendo la necesidad de levantarse en armas formando líneas de defensa en Despeñaperros, Córdoba y Sevilla. Imposibilitada de crearse la primera por la premura, se decide fortalecer la segunda, constituyéndose la Ciudad cordobesa en lugar de concentración de los ejércitos andaluces para oponerse al enemigo en el puente de Alcolea. Un ejército en el que se ven unidas las milicias y voluntarios procedentes de Montoro, Écija, Sevilla, Ronda, Córdoba y Cabra junto a los garrochistas de Bailén.

El 29 de Mayo de 1808 el coronel Echevarri, ceñido de la faja de Mariscal de Campo, decreta el alistamiento para la formación de este ejército, iniciándose con la misma fecha predicaciones en los templos invitando al pueblo a tomar las armas.

En este momento y para estos actos es cuando Jaime Balius compone este himno lleno de patriotismo que debió ejecutarse al menos en los actos religiosos celebrados con tal motivo y con tal fin en la Catedral cordobesa”. Extractado del periódico Córdoba del Viernes 4 de Enero de 1980. Firmado por la Redacción.
} 


\subsubsection{Varia en latín.}

Hemos incluido aquí aquellas obras sueltas que por sí mismas no constituyen un gran grupo homogéneo. Podemos encontrar antífonas, letanías, pasillos, piezas de ofertorio, etc. Son piezas todas ellas para coro y orquesta salvo los Pasillos para el Domingo de Ramos (52/328), la antífona Apertum est (83/650) y el invitatorio de los maitines de Navidad Christus Natus (105/894), que son para coro. De la primera obra citada existe en el archivo una reinstrumentación del Maestro de Capilla Gómez Navarro, que pasa de la versión original “a capella” a la inclusión de instrumentos. En el segundo y tercer caso, el coro a ocho voces lleva un bajón y un papel de acompañamiento. Ninguna de las obras incluida en este apartado lleva solistas. Aunque tienen gran variedad temática, en cuanto a su contenido musical no aportan características diferenciadoras de lo dicho hasta aquí.

\subsubsection{Villancicos y Kalendas.}

Como es sabido, el villancico de finales del siglo XVIII en las catedrales españolas tuvo una estructura y una función distinta a lo que hoy conocemos como tal. "Según parece, fue en los albores del siglo XVI cuando se inició una costumbre que tendría gran trascendencia en el desarrollo de la música en España en los siglos siguientes: la de sustituir los responsorios litúrgicos en latín por canciones en lengua castellana". ${ }^{1824}$

López Calo nos dice que esta iniciativa partió de Fray Hernando de Talavera, ex confesor de la Reina Isabel la Católica y primer arzobispo de Granada. ${ }^{1825}$ Esta

\footnotetext{
${ }^{1823}$ Los siguientes periódicos fueron algunos de los que se hicieron eco de la noticia: Diario Córdoba de los días 4, 13 y 15 de Enero de 1980. El Correo de Andalucía (5-Enero-1980), ABC de Sevilla (5-Enero1980), El Alcázar de Madrid (10-Enero-1980), La Voz de España de San Sebastián (12-Enero-1980). ${ }^{1824}$ LÓPEZ CALO, José. Historia de la música española. Siglo XVII. Madrid, Alianza Editorial, 1983, pag. 113.

1825 "En lugar de responsos [ = responsorios] hacía cantar algunas coplas devotísimas, correspondientes a las liciones. Desta manera atraía el santo varón a la gente a los maitines como a la misa. Otras veces hacía hacer algunas devotas representaciones, tan devotas que eran más duros que piedras los que no echaban lágrimas de devoción. Estaba él siempre presente a estos santos oficios (...). En aquesto también, como en otras cosas que adelante se dirá, fue este señor murmurado, que viendo el enemigo cuánto desta manera era Nuestro Señor servido e por consiguiente él desamparado, movió a algunos que dijesen que [no] era bien mudar la universal costumbre de la Iglesia, y que era cosa nueva decirse en la Iglesia cosa en lengua castellana; y murmuraban dello fasta decir que era cosa supersticiosa; pero
} 
costumbre estaba plenamente arraigada a finales del siglo XVI. No obstante, Felipe II los prohibió por decreto de 11 de Junio de 1596, en su Real Capilla, aunque por poco tiempo. $^{1826}$

Así pues, vemos cómo siguen interpretándose estos villancicos, sobre todo en Navidad. Pero no sólo en esa fecha ya que

“...fuera de la Navidad, otra fiesta en que se cantaban muchos villancicos era el Corpus, pero no en los maitines, sino en la procesión, durante la cual se alzaban varios altares, en cada uno de los cuales se hacía «estación» y se cantaba un villancico. Esta costumbre estaba vigente en prácticamente todas las catedrales desde antes de que finalizase el siglo XVI y duró todo el XVII. Una costumbre, en cambio, nació a comienzos de este siglo. Quizá en alguna catedral existiera ya a fines del XVI. Pero cuando realmente cobró fuerza fue en el XVII: las llamadas siestas, reservas, etc. (hubo diversas modalidades según los sitios y las épocas). Se trataba de conciertos sacros, en los que tomaban parte los cantores y ministriles, bien juntos o bien alternándose, durante la octava del Corpus, en que se tenía el Santísimo Sacramento expuesto durante todo el día". 1827

La forma musical de estos villancicos solía ser: introducción-estribillo-coplas, aunque no era la única, sino que podían darse otras combinaciones. ${ }^{1828}$ Una de estas

viendo este varón eminente cuánto de lo dicho Nuestro Señor era servido y cuánto el pueblo animado y consolado, tenía estos ladridos por picaduras de moscas y por saetas echadas por manos de niños". LÓPEZ CALO, José. Historia de la música española. Siglo XVII. Madrid, Alianza Editorial, 1983, pag. 114. A su vez cita: Breve suma de la santa vida del Reverendísimo y Bienaventurado don Fray Hernando de Talavera, ms. de la Academia de la Historia, sign. 9-25-6, e, núm. 114, fol. 149v.

1826 "Felipe II quitó los villancicos de su Real Capilla; ya se han vuelto a introducir, de modo que en las Fiestas, el canto llano del oficio es como de aldea, y no es oído ni visto; y los villancicos se celebran con suma autoridad y solemnidad, y parece que se tiene como principal, y el oficio divino como por accesorio (...). Del día de Navidad y de Corpus Christi no hablo, porque como Dios en este día se humanó tanto, parece se puede tomar un poco más de licencia para el consuelo humano, pero siempre debe hacerse con mucha modestia”. MARTÍN MORENO, Antonio. Historia de la Música Española. Siglo XVIII. Madrid, Alianza Editorial, 1985, pág. 450, que cita a su vez a Fray Martín de la Vera.

${ }^{1827}$ LÓPEZ CALO, José. Historia de la música española. Siglo XVII. Madrid, Alianza Editorial, 1983, pag. 120.

${ }_{1828}$ "La forma musical más común en los villancicos de la segunda mitad del siglo XVII era la de entrada o introducción-estribillo-coplas. Otras varias combinaciones y formas eran usadas con frecuencia, pero la general era ésta. $Y$, de nuevo, como norma general, la introducción solía ser a pocas voces -cuatro-, las coplas a solo, o a solos, mientras que el estribillo era compuesto en el máximo de voces a que estaba compuesto el villancico”. LÓPEZ CALO, José. Historia de la música española. Siglo XVII. Madrid, Alianza Editorial, 1983, pag. 119. 
formas diferentes se daba en el villancico de kalenda, que podía tener una estructura más amplia, además de una mayor plantilla de músicos. ${ }^{1829}$

Durante el siglo XVIII, el villancico evoluciona volviendo a agrandar su forma, con partes procedentes de la influencia de la música teatral y popular. Martín Moreno, nos da un esquema de estos villancicos:

“Estribillo y coplas, reminiscencia del antiguo esquema.

Villancico con tonadilla: Introducción, estribillo, tonadilla, coplas, tonadilla.

Villancico con seguidillas: Introducción, estribillo, coplas, seguidillas, estribillo.

Villancico con aria: Introducción, estribillo, recitado, aria.

Villancico de Kalenda: Introducción, estribillo, aria, minué”. 1830

En cuanto al argumento, suele ser muy variado. Además de los que tratan sobre el nacimiento de Cristo y otros motivos religiosos, abundan también aquellos que están enraizados en la tradición y las costumbres populares. ${ }^{1831}$

La práctica de estos villancicos siguió realizándose “hasta la segunda mitad del siglo XVIII, cuando se inició un movimiento contrario, que culminó hacia fines de ese

\footnotetext{
1829 "En Navidad, a los ocho villancicos de maitines se añadió muy pronto -ciertamente antes de la mitad del siglo XVII- el cantar uno a la «calenda», es decir, en la hora de prima, a la lectura de la «calenda» o martirologio. Más aún, por ser el primero de la fiesta, solía ser el más solemne y de factura más compleja. Y ya queda dicho que, generalmente, el número de 12 voces se reservaba, en exclusiva, para este villancico”. LÓPEZ CALO, José. Historia de la música española. Siglo XVII. Madrid, Alianza Editorial, 1983, pag. 120.

1830 MARTín MORENO, Antonio. Historia de la Música Española. Siglo XVIII. Madrid, Alianza Editorial, 1985, pág. 453.

1831 "En cuanto al argumento, es este de lo más variopinto, siendo muy populares los villancicos con personajes que dialogan sobre los temas relativos al misterio de la encarnación y al nacimiento de Cristo, o cualquier otro tema religioso, pero en el lenguaje popular, y lógicamente también en la música. Así hay villancicos de andaluces, vizcaínos, prusianos, negros, indianos, asturianos, manchegos, portugueses, o los que hacen referencia a la profesión de los personajes (sastre, sacristán, médico, etc.), etc. Cuando se trata de villancicos de personajes no castellanos, el texto suele mezclar frases en castellano con otras del idioma del personaje. Obviamente, la influencia de la música popular ha de ser aquí grande, puesto que se trata de reflejar el lenguaje y las costumbres de la gente llana". MARTíN MORENO, Antonio. Historia de la Música Española. Siglo XVIII. Madrid, Alianza Editorial, 1985, pág. 453.
} 
siglo, o a comienzos del XIX con la abolición de los villancicos y reposición de los responsorios litúrgicos en latín”. ${ }^{1832}$

Los 405 Villancicos y las 31 Kalendas que encontramos en el catálogo de Balius constituyen una inestimable fuente para el conocimiento de su música, ya que en ellos emplea gran variedad de recursos técnicos, una temática muy variada, y lógicamente unas combinaciones instrumentales y vocales muy diversas. En muchos casos, asumen las características anteriormente comentadas.

Las combinaciones corales son plurales, y no siempre concede al coro el formato clásico de SATB, sino que también hace variaciones como SSAT en Silencio Quedito (64/459), AT-SATB en Ö̈ María se Concibe (66/481), ATB en Atended a las voces sonoras (66/486), etc. El texto está en castellano. Se utilizan varios formatos en la construcción de villancicos, desde el que incluye introducción, estribillo y coplas $^{1833}$, pasando por un segundo formato en el que a estas secciones se le suma una nueva, procedente de la música popular, bien sea una tonada o una seguidilla, hasta un tercer formato que se configura sobre un recitado y aria, con o sin coplas. Hay villancicos de Navidad, otros dedicados al Santísimo Sacramento o a la Concepción de Nuestra Señora, de Pastorella, de Tonadilla, etc.

Mención aparte merecen los villancicos de kalenda. Como hemos dicho más arriba, las kalendas eran grandes villancicos que se interpretaban en la víspera de algún día señalado, sobre todo la víspera de Navidad. ${ }^{1834}$ Son las obras de mayor envergadura

\footnotetext{
${ }^{1832}$ LÓPEZ CALO, José. Historia de la música española. Siglo XVII. Madrid, Alianza Editorial, 1983, pag. 119. En la Catedral de Córdoba se interpretaron villancicos al menos hasta 1822, año de la muerte de Balius, en que éste escribió Los pastores llegaron (102/854).

${ }^{1833}$ En esta introducción, se sitúa el tema y se anticipa el contenido de la acción que posteriormente se va a desarrollar. Después aparecen el estribillo y las coplas. Suelen ser muy abundantes las estrofas de estas coplas, lo que unido a que también la primera parte tiene unas dimensiones considerables, hace que al final, el villancico adquiera unas dimensiones considerables.

1834 "La palabra <calenda> hace referencia a la lectura, después de la hora Prima, de los nombres de los santos que se conmemoraban cada día según el Martirologio Romano. Pero se llamó calenda por antonomasia el canto solemne del Martirologio en la víspera de la Navidad, anunciando la conmemoración del nacimiento del Cristo. Por extensión se llamó calenda al primer villancico de Navidad...”. DÍEZ MARTÍNEZ, Marcelino. La Música en Cádiz. La Catedral y su proyección urbana durante el siglo XVIII. Cádiz, Servicio de publicaciones de la Universidad de Cádiz, 2004, pág. 448. En algún caso estas kalendas podían interpretarse en otras fechas solemnes y fiestas importantes, como los patronos de de la catedral o de la ciudad. Así ocurre en Jaén con el Maestro de Capilla Juan Manuel
} 
que tiene Jaime Balius. Tienen su obertura, sus recitativos, arias, dúos y coros, todo ello con una gran orquestación que además de la cuerda, suele incluir dos oboes, dos flautas, dos fagotes, dos trompas y dos órganos. En alguna ocasión, Balius compone una kalenda, basándose en un villancico homónimo. Así sucede con “Con los Reyes ha llegado”, utilizando parte del texto y la melodía del villancico.

La obertura de estas kalendas tiene estructuras variadas. En ocasiones se limita a un número allegro de principio a fin. Pero también encontramos casos donde a este allegro, lo precede una sección lenta, quedando de esta forma:

Obertura: Sección A, lenta. Sección B, rápida.

Después de la obertura, sí es muy común que siga un número de Coro, que es normalmente moderato, majestuoso, y donde el texto establece la temática general de la pieza. A continuación se presentan los recitativos, arias y duetos. Estos contienen una instrumentación mucho más reducida, exponen un mayor virtuosismo vocal y glosan y desarrollan la temática narrativa anteriormente expuesta en el primer número de Coro.

Para concluir, una gran marcha anuncia que estamos cerca del final, y en ella se utilizan todos los recursos orquestales-vocales disponibles. En muchas kalendas, el mismo título nos informa de que además de la instrumentación habitual, se reservan “dos órganos obligados para la marcha final”.

En ocasiones, como sucede en la Kalenda de 1788 (25/180), aunque la portada nos anuncia “Con violines, oboes, bajones, trompas...”, luego, en números interiores, vemos cómo emplea también dos flautas.

Atendiendo a las noticias encontradas en las actas capitulares y a lo reflejado en el archivo de partituras, parece comprobado que a Balius se le pedía que compusiera una de estas obras al año, principalmente para la víspera del día de Navidad. El texto está en castellano y la temática básicamente religiosa, aunque también trata otros temas. Por ejemplo, la Kalenda del año 1791 (51/319), comienza diciendo: “Caudillos al frente, soldados al arma que está el enemigo", o "La victoria es nuestra, seguid la batalla”. Como decimos, suelen ser obras de grandes dimensiones, con alguna excepción como la Kalenda de 1802 (29/212), aunque conservando el formato antes expuesto.

García de la Puente, que lo fue de la Catedral de esa ciudad desde 1711 a 1753 y que compuso 4 kalendas a la Inmaculada. Cf. LÓPEZ ARANDIA, Laura. "Un Maestro de Música del Jaén Barroco. Juan Manuel García de la Puente”. La Revista Palabra. N¹9. Jaén, Instituto Santa Catalina de Alejandría, 2001. 


\subsubsection{PLANTILLA INSTRUMENTAL.}

Debemos tener en cuenta las limitaciones del Maestro de Capilla a la hora de formar su orquesta, y consecuentemente al componer el repertorio para la misma. La Catedral contaba con una plantilla tipo, ampliable “ad casum” con personal contratado. Esta plantilla, y sobre todo su ampliación, podía variar de una época a otra en función de la situación económica del Cabildo. Igualmente debemos tener en cuenta, que tanto la orquesta, como las composiciones para la misma están al servicio de la Liturgia y condicionados por la misma. No podemos pensar, por tanto, en una orquesta y unas composiciones “de concierto", lo que no es óbice para que un público numeroso acudiera a la Catedral para oír a la Capilla interpretar su repertorio, sobre todo los atractivos villancicos, las kalendas o las Canciones Patrióticas que se tocaban con motivo de alguna celebración especial. No obstante y dicho esto, veremos cómo la plantilla instrumental utilizada varía poco de las típicas orquestas de la época, al menos en cuanto a los instrumentos utilizados, no así en cuanto al número de estos instrumentos, que es obviamente menor. ${ }^{1835}$

La orquesta de Jaime Balius está articulada normalmente en torno a lo que sería una orquesta de principios del clasicismo, todavía con la pervivencia del bajo contínuo $^{1836}$ (a veces cifrado y otras sin cifrar) aunque con alguna diferencia como la falta de violas en casi la totalidad de sus obras. Así mismo, no suele distinguir en particellas diferentes los papeles de violoncello y contrabajo, sino que los engloba normalmente con el epígrafe de acompañamiento ${ }^{1837}$ o de contrabajo, si bien es cierto

\footnotetext{
1835 De hecho, Balius pide como mínimo seis violines (ver A.C.C. Actas Capitulares Martes 19 de Septiembre de 1797. T.95, fol. 180v.), aunque siempre que puede aumenta ese número, valiéndose por ejemplo, de los Niños de Coro que estaban estudiando dicho instrumento, y que solicitaban tocar en la orquesta. Él los oía, y si tenían un nivel mínimo, eran aceptados. A esto hay que sumar los dos oboes, los dos bajones y las dos trompas, más uno o dos violoncellos, un contrabajo y el acompañamiento.

1836 "Uno de los [aspectos] que más llama la atención es la pervivencia del continuo [en España] mucho más allá de los límites del tiempo del barroco propiamente dicho, sobre todo en la música religiosa: en España siguió usándose algo muy parecido al bajo continuo hasta entrado el siglo XIX, al menos en algún tipo de composiciones. Esto, [...] fue debido a una inercia conservadora que invadió la música religiosa -aunque esto no le impedía progresar en otros campos- y que duró hasta entrado el siglo XIX". LÓPEZ CALO, José. Historia de la música española. Siglo XVII. Madrid, Alianza Editorial, 1983, pag. 53. En lo que se refiere a música de Balius, la afirmación de López-Calo es absolutamente verificable, ya que aquel incluyó un papel de acompañamiento hasta sus últimas composiciones realizadas en 1822.

1837 "Las primeras manifestaciones del continuo en la música española, [...] aparecen en los dos últimos decenios del siglo XVI. Por supuesto, por entonces no estaba codificado el continuo en España, ni lo estaría en casi (y probablemente sin «casi») un siglo. Ni siquiera estaban claros los conceptos básicos acerca de la naturaleza o razón misma de ser de una tal práctica. Los mismos términos para designarlo -
} 
que acota puntualmente dentro de esa particella los pasajes en que quiere que intervengan de forma diferenciada el violoncello y/o el contrabajo. ${ }^{1838}$ Por tanto, tendríamos como esquema básico: violines primeros, violines segundos, violas excepcionalmente, violoncello y contrabajo. Los violines primeros son los encargados de presentar los temas y llevar la voz cantante, Los violines segundos, además de redoblar en algún momento la melodía, y de hacer contracantos, realizan también una función de acompañamiento, utilizando frecuentemente las dobles cuerdas para realizar partes que corresponderían a la viola, que como hemos dicho está casi siempre ausente. Veamos algunos ejemplos extraídos del villancico De Villaviciosa vienen (62/426):

Violines primeros hacen la melodía y Violines segundos la redoblan (compases 1 al 4):

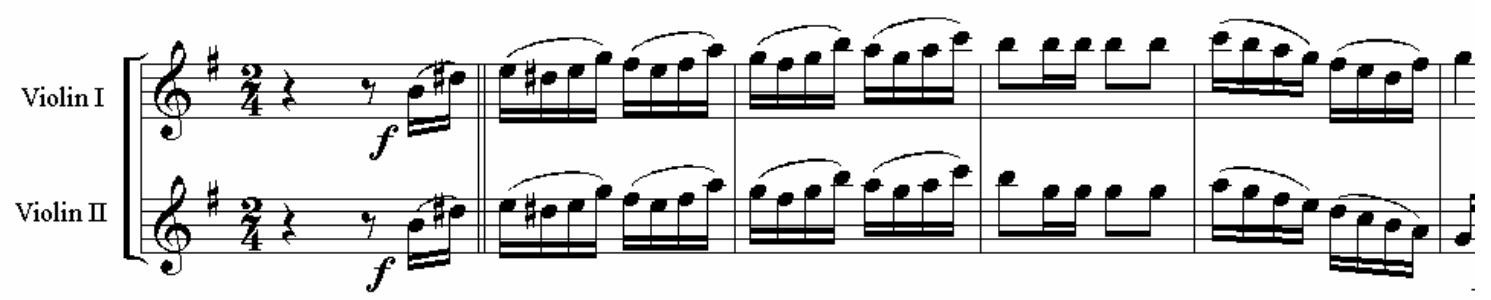

Violines segundos hacen unas pequeñas células de respuesta a la intervención de los primeros (compases 35 y 36):

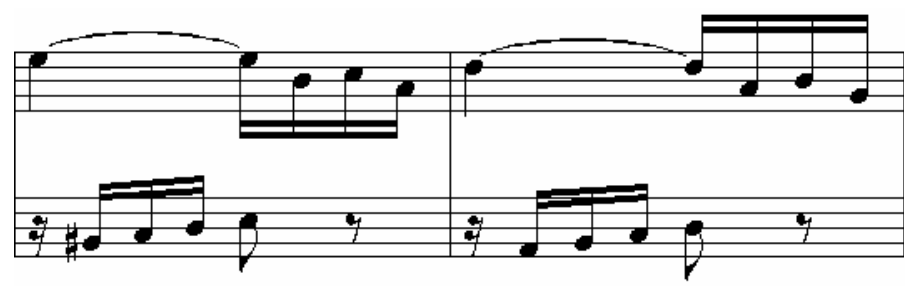

los más usados serían «acompañamiento», «bajo», a quienes frecuentemente se añadía el adjetivo de «general» o «continuo», o, simplemente, suprimido el sustantivo, se usaban los términos «general», «continuo»..., sin más; muy frecuentemente se añadía en los papeles la especificación del instrumento que debía realizarlo («acompaña miento general para el arpa...»)- no aparecerían hasta mucho más tarde. [...] En los últimos años del siglo XVI comienza a hacerse uso de un instrumento polifónico, y precisamente del órgano”. LÓPEZ CALO, José. Historia de la música española. Siglo XVII. Madrid, Alianza Editorial, 1983, pag. 54.

${ }^{1838}$ Como aclaramos en la introducción del volumen II, Catálogo, la interrelación del violoncello y el contrabajo con el acompañamiento es intensa. Mientras que un instrumento polifónico, clave u órgano despliega los acordes del acompañamiento a partir de la línea del bajo, el violoncello y/o contrabajo realizan melódicamente esa misma línea. Igualmente, y tal y como se hacía en otros tiempos, es muy probable que el instrumentista del $\mathrm{Cb}$. se situara junto al que realizara el acompañamiento, leyendo los dos en la misma particella. 
Los violines segundos realizan un acompañamiento en esta sección cadencial utilizando dobles cuerdas (compases 55 y 56).

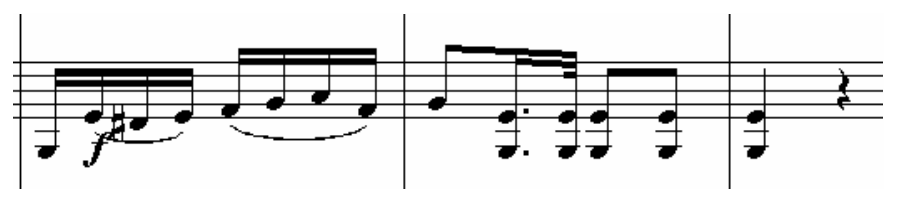

A la cuerda hay que sumar la mayoría de las veces 2 oboes y 2 trompas, y en menos ocasiones 1 o 2 fagotes y 2 flautas. En obras de grandes dimensiones y formato como las kalendas, se utiliza todo el viento citado y se añade 1 o 2 órganos, clarines, o violas.

El papel de las flautas y los oboes cumple tres funciones principales: Una, de reforzamiento ocasional de la cuerda, bien al unísono o bien en octava alta. Otra, la de defender su propio material específico, frecuentemente en pasajes por terceras $\mathrm{u}$ octavas, y por último, y si hubiera coro, para apoyar a las voces sosteniendo las partes agudas. En este último caso, este apoyo puede ser en forma de redoblamiento literal o bien por reducción, es decir apoyando las notas principales del acorde y dejando que las voces desarrollen el pasaje. Vemos a continuación un ejemplo de los oboes apoyando a las voces agudas, tomado del salmo Dixit Dominus (8/68), compases 1 a 5:

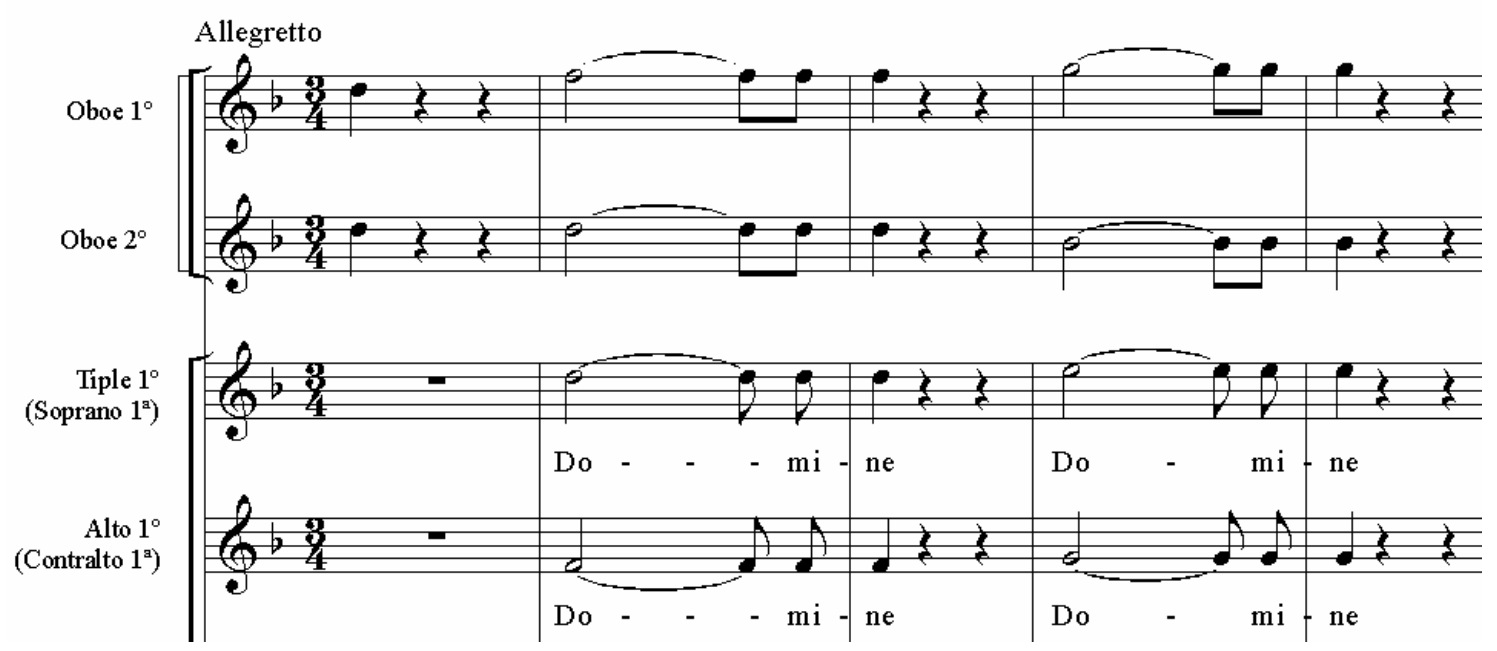

Algo parecido sucede con el fagot. Cuando éste aparece, también puede tener tres funciones. La primera, reforzar el papel de acompañamiento, la segunda interpretar sus propios solos y la tercera sostener el bajo de voces. En este último caso el fagot suele repetir exactamente la línea del bajo. Lo dicho hasta ahora es aplicable a aquellas 
obras donde hay orquesta. Sin embargo, Balius concede una importancia suplementaria al fagot ya que también lo utiliza en obras donde no hay orquesta, sino que son de coro solo. No es extraño ver una obra para coro solo con sus correspondiente particella de bajón (fagot), como sostén armónico. ${ }^{1839}$ En el ejemplo que sigue, procedente del Himno Salutis Humanae (127/1221), el bajón refuerza el acompañamiento:

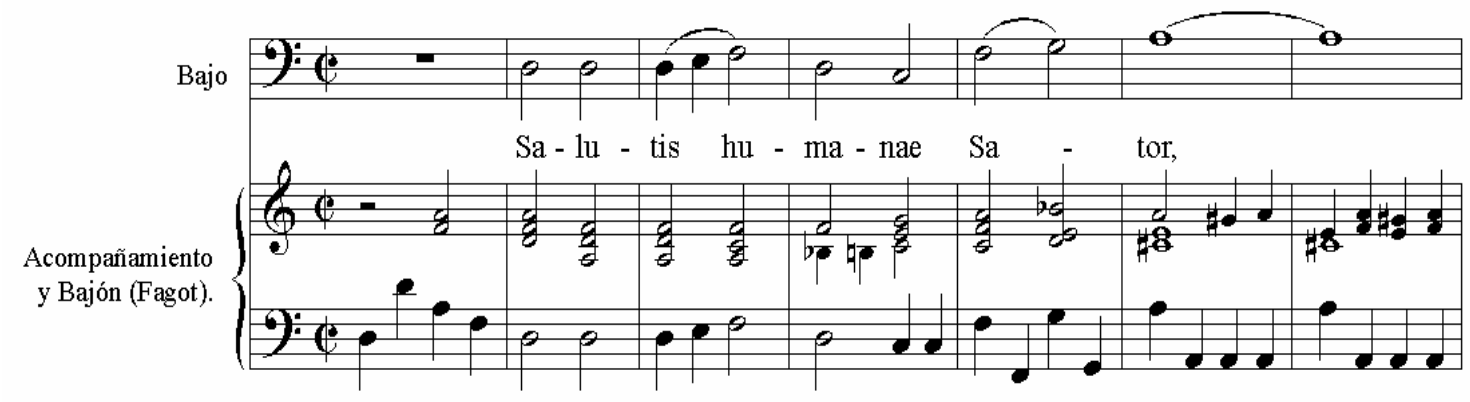

En cuanto a las trompas, siguen ejerciendo la función tradicional de apoyos armónicos en notas largas, o bien apoyos rítmicos coincidiendo con las cadencias finales. ${ }^{1840}$ En este caso hemos entresacado un pasaje del Magnificat (2/14), compases 8 al 13:

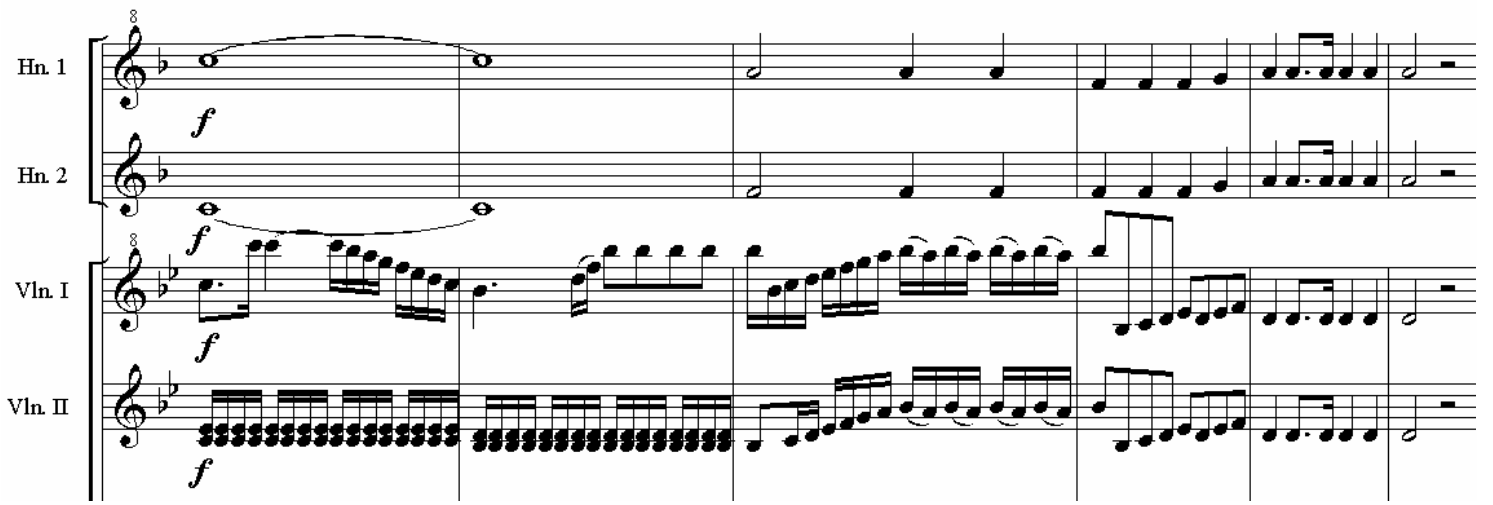

${ }^{1839}$ Esta circunstancia no es nueva, sino que viene desde los primeros tiempos del acompañamiento contínuo en España, que en nota anterior hemos visto que se remonta a los dos últimos decenios del siglo XVI. "Al comienzo el continuo no estaba realizado por un instrumento polifónico, sino por uno monódico, generalmente el bajón o fagot. Este instrumento existía en todas las catedrales, mientras que el otro instrumento bajo más usado, el de cuerda o «violón» (=viola da gamba, violoncelo) tardó más en entrar, al menos en la generalidad de las catedrales, aunque ya existía, como excepción, en algunas. Una posible segunda razón de por qué se sintió en España esta necesidad de introducción de un instrumento acompañante en la polifonía religiosa hacia fines del siglo XVI, fue, probablemente, para sostener a los coros en tono, pues por esa época el número de cantores que formaban la «capilla de música» en nuestras catedrales aumentó considerablemente”. LÓPEZ CALO, José. Historia de la música española. Siglo XVII. Madrid, Alianza Editorial, 1983, pag. 54.

${ }^{1840}$ Hay que tener en cuenta que durante la época de Balius, los pistones no estaban aún implantados. 
Por último, aparecen uno o dos órganos obligados (además del acompañamiento), en las grandes obras sinfónico-corales, y normalmente apoyan las intervenciones de los dos o más Coros de su plantilla.

\subsubsection{PLANTILLA VOCAL.}

La plantilla vocal es muy variada, ya que utiliza numerosas combinaciones de voces tanto en número como en tesituras, variando el tratamiento que da a estas voces en función del género o la forma del momento. Todo esto lo hace dentro de un concepto propio del barroco como es la policoralidad, y que sin embargo se mantiene en Balius hasta su muerte, ya bien entrado el siglo XIX.

Podemos encontrar obras de Balius para una voz solista, en cualquiera de sus tesituras, y acompañamiento, y a partir de aquí, obras desde dos a dieciséis voces pasando por todos y cada uno de los grados intermedios, si bien la mayoría de sus obras a dos coros (ocho voces). ${ }^{1841}$ Todo ello lo detallaremos en el apartado de estadística.

Como hemos dicho anteriormente, el tratamiento de las voces varía dependiendo del tipo de obra, siendo los pasajes corales evidentemente más asequibles que las intervenciones solistas en los recitados, arias o en las lamentaciones a solo, que son de gran dificultad. También los límites de la tesitura se apuran en las obras a solo, aunque como ahora veremos, ello no es óbice para que en algún caso el tratamiento coral de alguna voz sea también extremo en cuanto a tesitura.

De esta forma podemos comprobar que la voz de Tiple, escrita en clave de "do en primera”, suele tener una escritura muy centrada, casi siempre dentro del

\footnotetext{
${ }^{1841}$ Recordemos que la plantilla vocal de la que disponía Balius oscilaba alrededor de los 15 cantantes, es decir, un pequeño Coro que le permitía interpretar obras a 8 o más voces. Esta plantilla se podía ver aumentada con contrataciones puntuales para reforzar el Coro en alguna función importante, o disminuida por la baja temporal o definitiva de alguno de sus componentes. En cualquier caso la necesidad de contar con 15 voces la dejó clara Balius en una petición que hizo al Cabildo y que este aprobó el día 19 de Septiembre de 1797. En ese día el Cabildo acuerda, previo informe del Maestro de Capilla, que la plantilla quede establecida como sigue: "Quatro tiples, con la renta el que más, de once mil reales, quatro contraaltos con la de seis mil, cinco tenores con la de seis mil y seiscientos, dos bajos con la de siete mil y setecientos...”. A.C.C. Actas Capitulares. Martes 19 de Septiembre de 1797. T.95, fol. 180v.
} 
pentagrama, y si sale de él, raramente sobrepasa el "sol 4", salvo alguna excepción, como sucede en el aria de Nace la Aurora (2/17), en donde llega al "la 4":

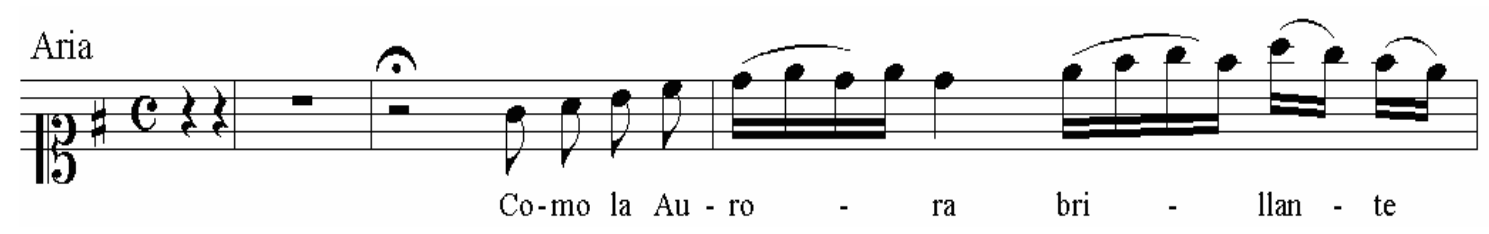

Si esto es una excepción, aún lo es más que la voz que llega a este "la” agudo, no sea solista sino que esté encuadrada dentro de un plantilla coral, como sucede con la parte de tiple de la Kalenda Israelitas Nobles (90/753):

Tiple $1^{\circ}$ Coro. Obertura tacet.

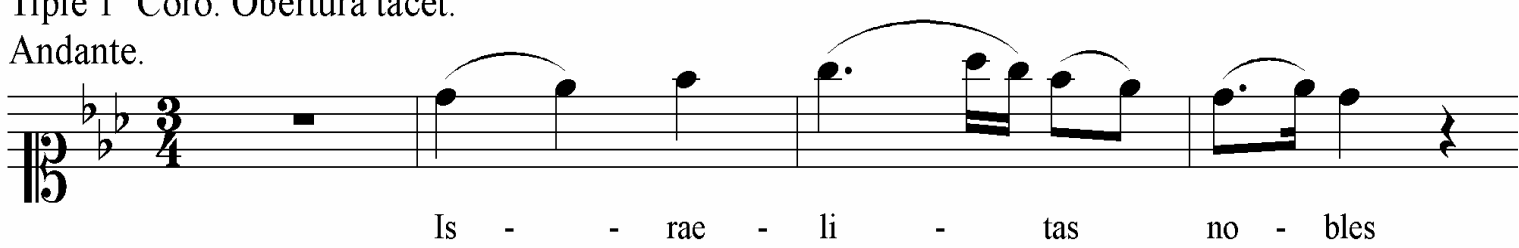

En cuanto a la voz de Alto, vemos como el registro agudo está tratado con cierta contención, no pasando casi nunca del "do 4", ni siquiera en las obras de solista. Sin embargo sí le hace descender casi a los límites de su registro grave. Este caso nos lo encontramos en el gloria de la Misa Llana (14/107), entre los compases 54 al 57, donde se llega al "fa 2":

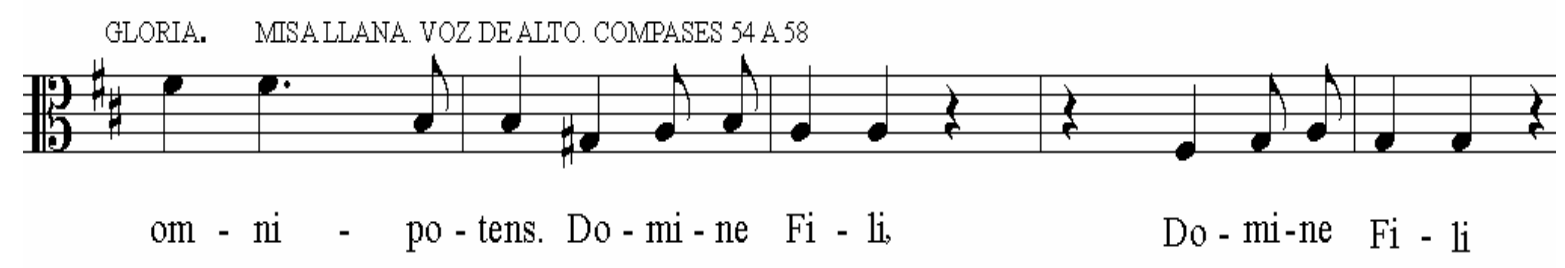

Al igual que el Alto o Contralto busca sacarle partido a su registro medio grave, el Tenor con frecuencia se mueve por la parte media alta de su tesitura, más aun si se trata de obras solistas, llegando entonces al "sol 3", como sucede en el Recitado y Aria Adonde Infiel Dragón (2/18).

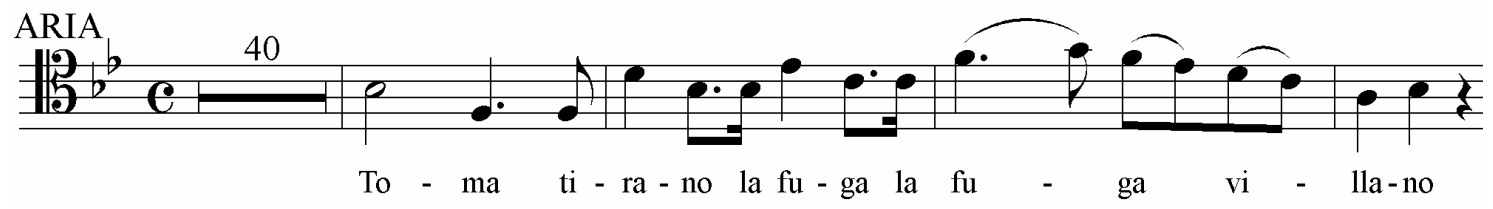


Respecto a la parte de Bajo, nos encontramos con alguna peculiaridad. En principio podríamos decir que en la mayoría de las obras el Bajo está muy centrado, aunque con tendencia a la parte aguda, en lo que actualmente entenderíamos como Barítono, llegando en alguna obra al “mi 3”, como en el villancico Alarma principados (69/514):

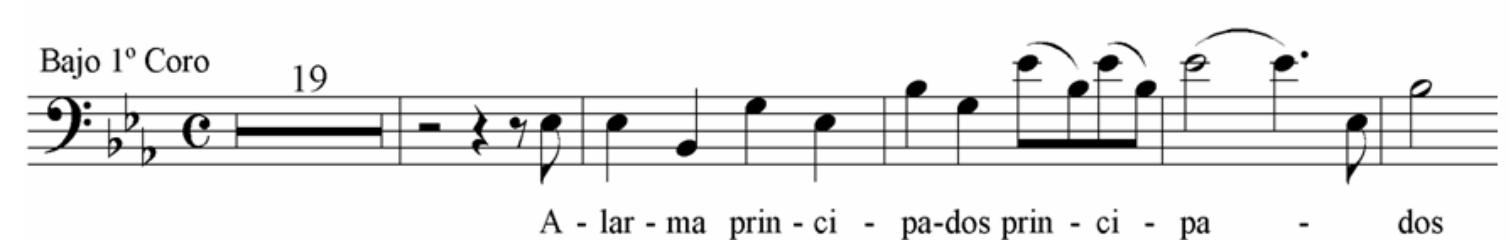

Sin embargo también nos encontramos algún caso en que desciende a terrenos propios de un bajo en toda regla, como sucede en la parte de bajo $2^{\circ}$ de Domine y Dixit Dominus (8/68), en donde se llega a un "re 1":

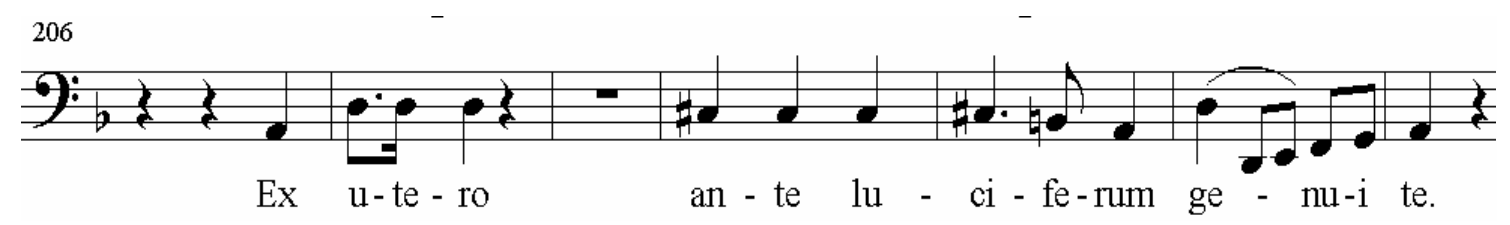

Seguramente estas tesituras estarían condicionadas, por las características concretas del personal a su servicio en cada momento y también por el género elegido y el destino de la composición, más virtuosista evidentemente en el caso de los recitados y arias, villancicos y canciones patrióticas. 


\subsubsection{ESTADÍSTICA.}

Sobre las 720 obras que tiene Balius en el A.C.C., hemos realizado diversas comparaciones estadísticas que nos dan una idea de la distribución de su obra por géneros, formas, plantillas, etc.

A) El primer gráfico hace referencia a la distribución de las obras que tiene Jaime Balius y Vila en el A.C.C., atendiendo al criterio formal.

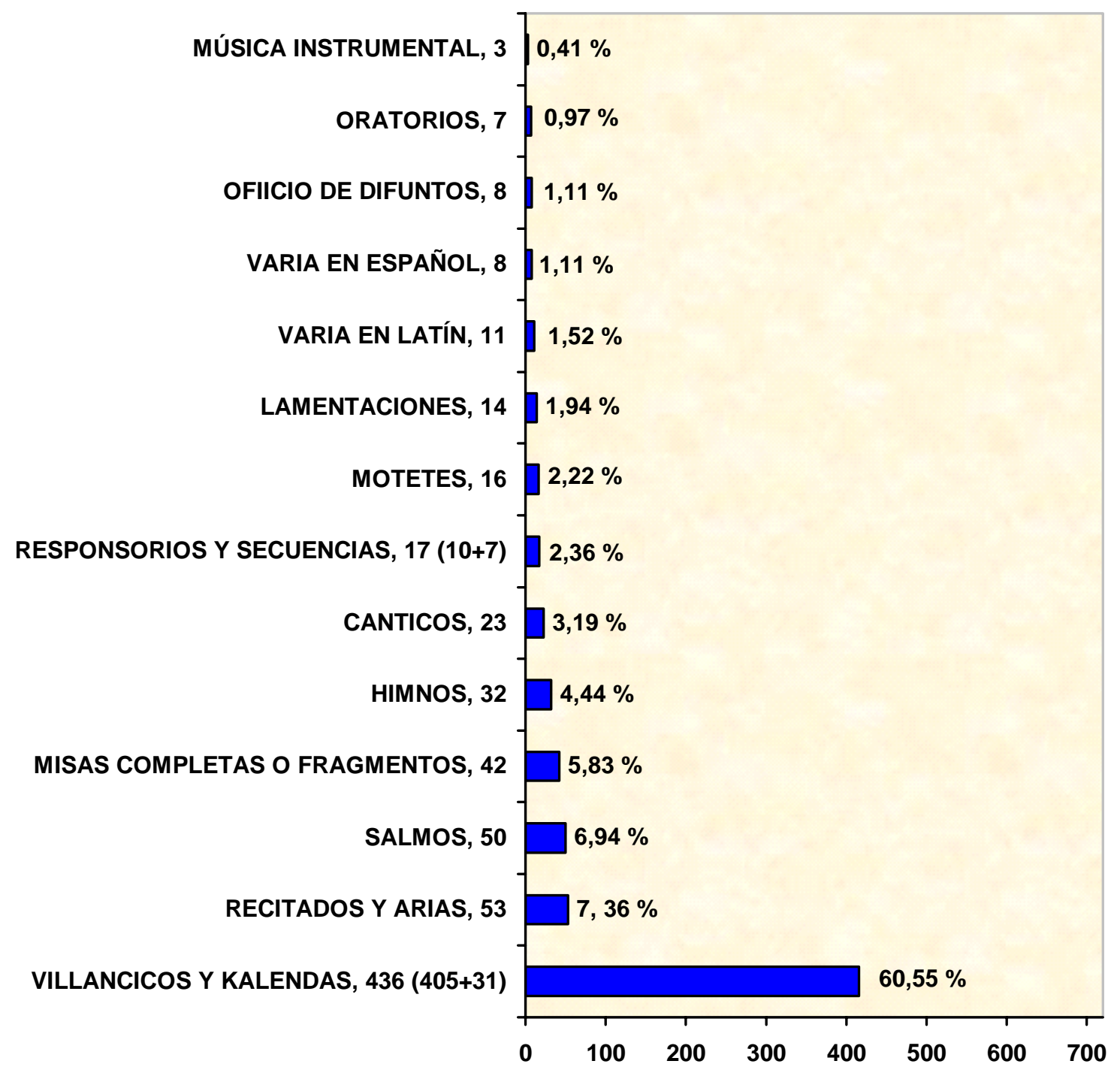


B) Presentamos a continuación un gráfico explicativo de la subdivisión de las obras de Jaime Balius según el criterio de "instrumentales”, “corales” y “mixtas”.

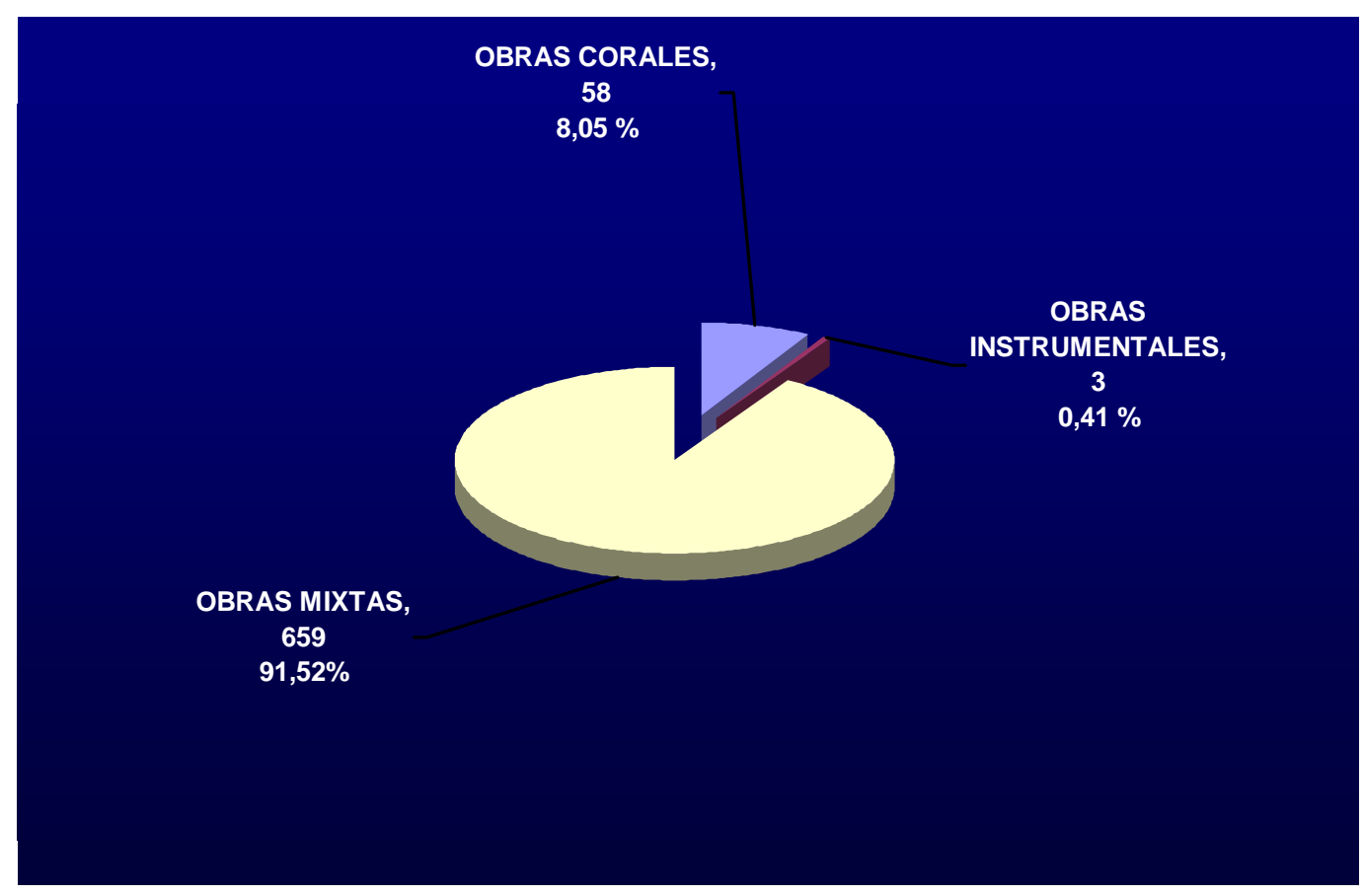

C) Dentro de las 717 obras “corales” y “mixtas”, separamos ahora aquellas que están escritas en castellano y aquellas que están escritas en latín.

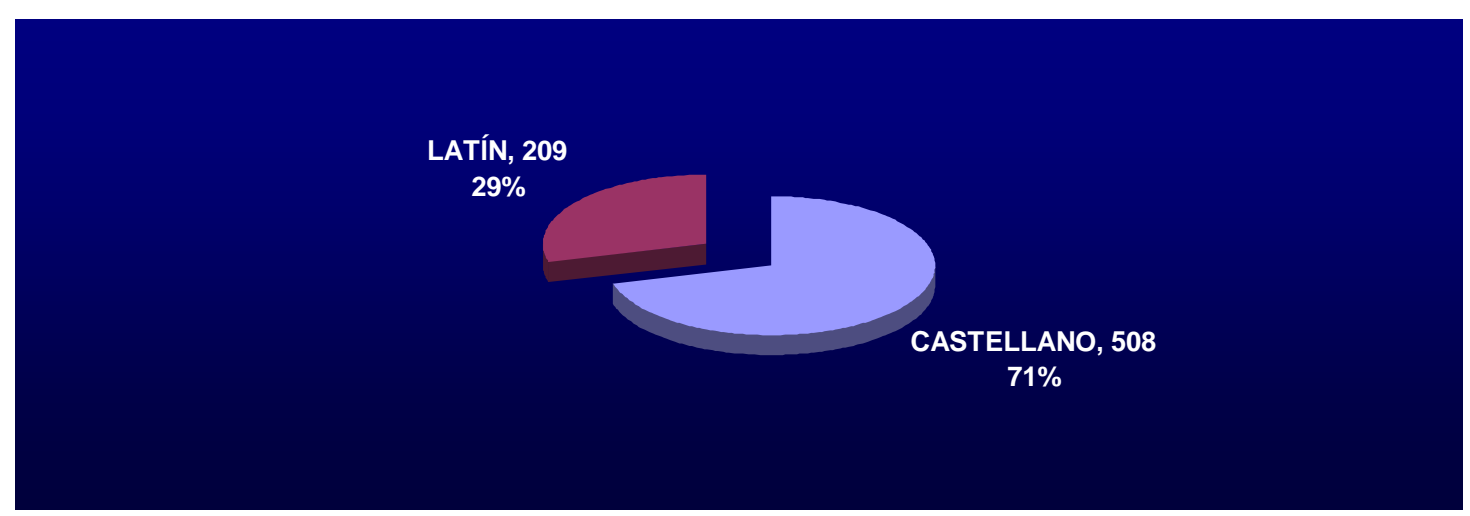

D) En aquellas obras en que se han utilizado voces, hacemos ahora la separación por el número de éstas, desde las que se han compuesto a una sola voz, hasta las que se 
han hecho para dieciséis voces. Suman en total 717 obras, que más las tres obras instrumentales, harían el total de 720.

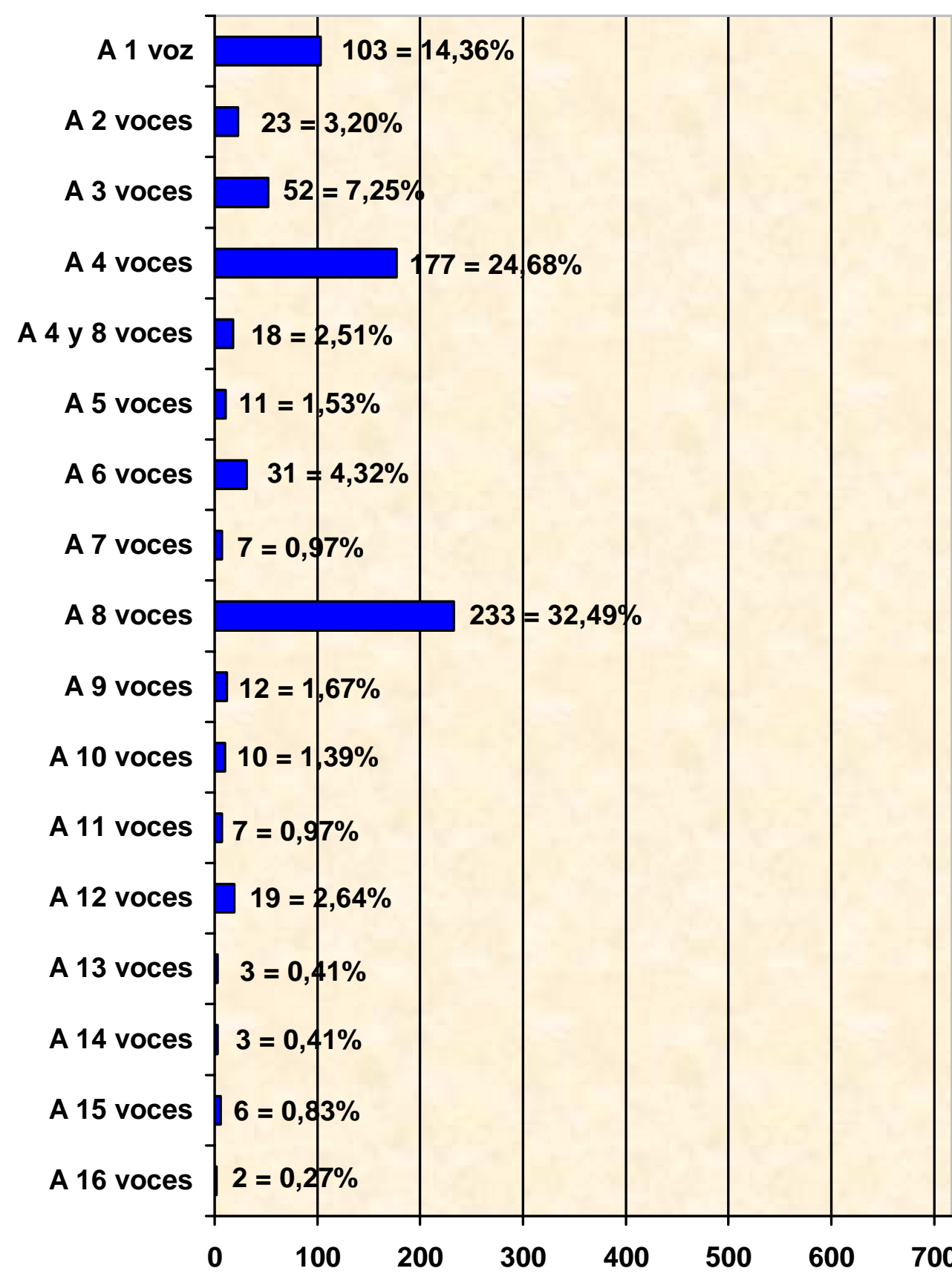

E) También consideramos importante atender a la existencia y estado de conservación de las partituras y particellas, observando su porcentaje con respecto al total de 720 obras. 


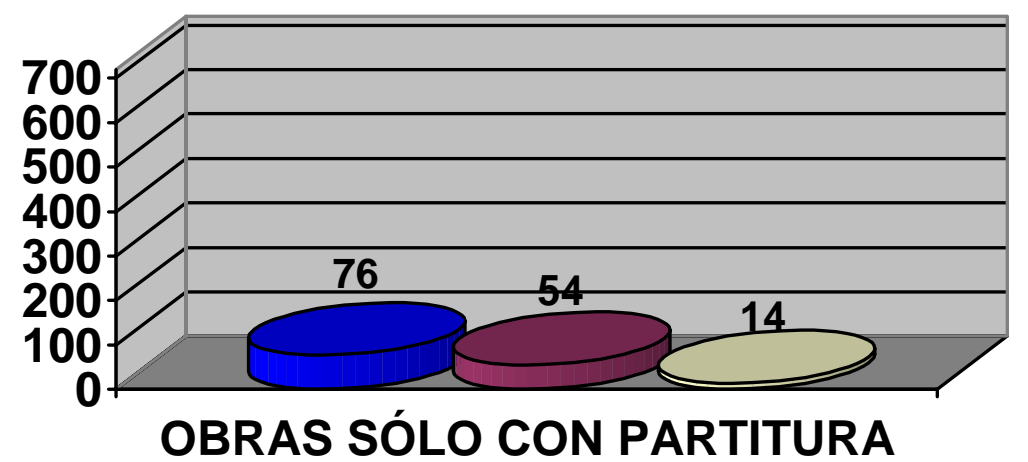

GENERAL, 144 (20 \%)

口CONSERVACIÓN BUENA, 76

$\square$ CONSERVACIÓN REGULAR, 54

$\square$ CONSERVACIÓN MALA, 14

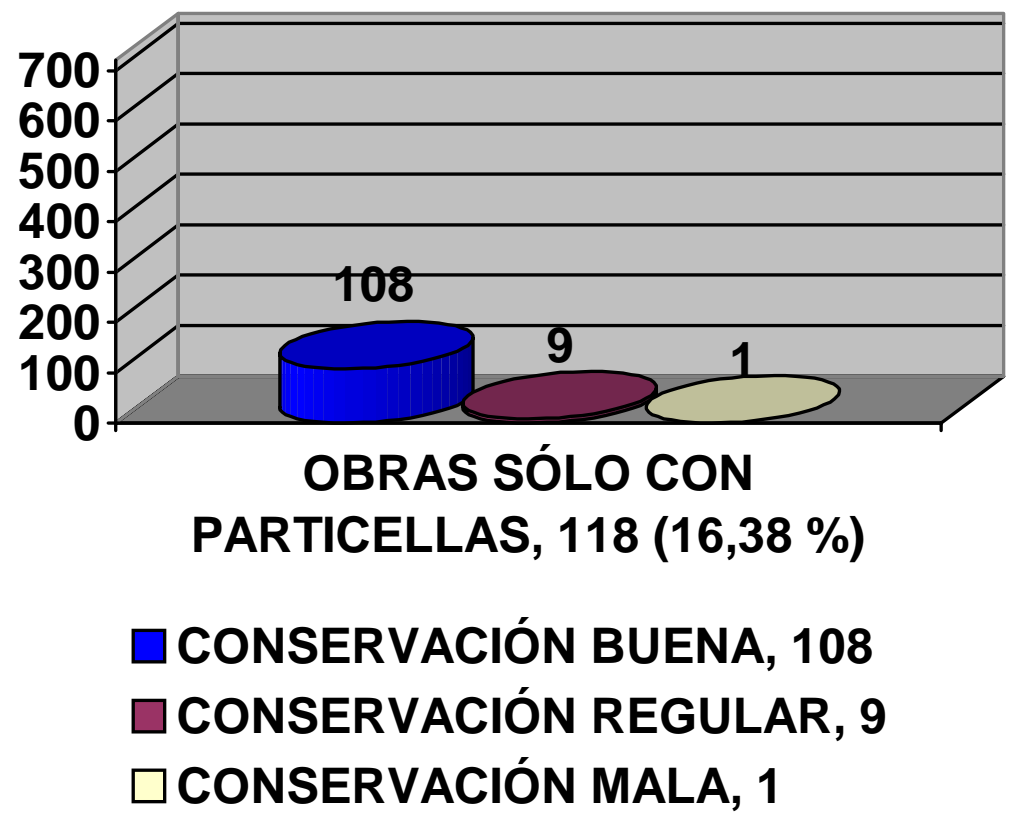

F) Para finalizar el aspecto referente a la conservación, exponemos ahora las obras que tienen partitura general y particellas, con las diversas combinaciones existentes entre partituras en buen, mal o regular estado y sus correspondientes particellas. 
OBRAS CON PARTITURA GENERAL Y PARTICELLAS, 462 (64,16\%). Se presentan desglosadas en tres apartados:

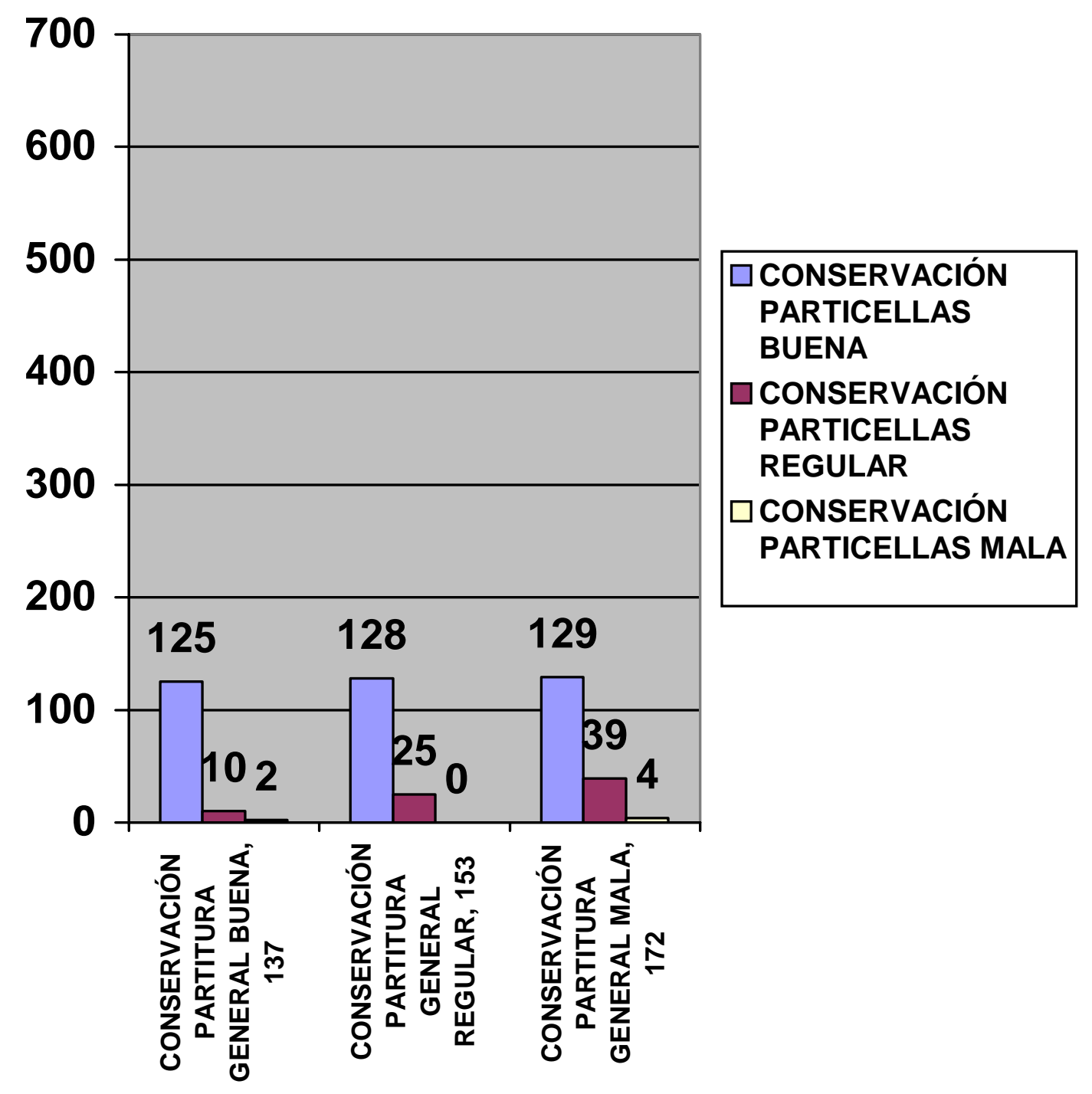

G) En el cómputo global de las 659 obras mixtas (voces e instrumentos), hacemos las siguientes distinciones: ${ }^{1842}$

\footnotetext{
${ }^{1842}$ Hacemos la observación de que todas las obras a las que nos referimos en este punto llevan voces, ya sólo se conservan en el A.C.C. tres obras puramente instrumentales de Jaime Balius: La primera es una Sonata para violín y cémbalo, la segunda es un Concertino para trompa y orquesta y la tercera un Cuarteto de cuerda.
} 


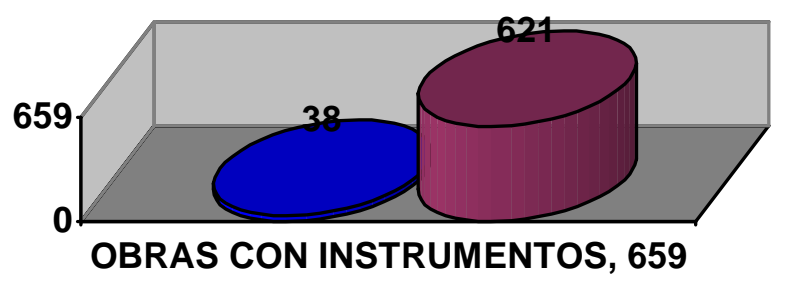

$\square$ OBRAS CON CUERDA + VOCES, 38

$\square$ OBRAS CON CUERDA + VIENTO + VOCES, 621

H) Entre las 659 obras con distinta instrumentación, vemos ahora cuantas utilizan (además de la cuerda), sólo 1 o 2 instrumentos de viento:

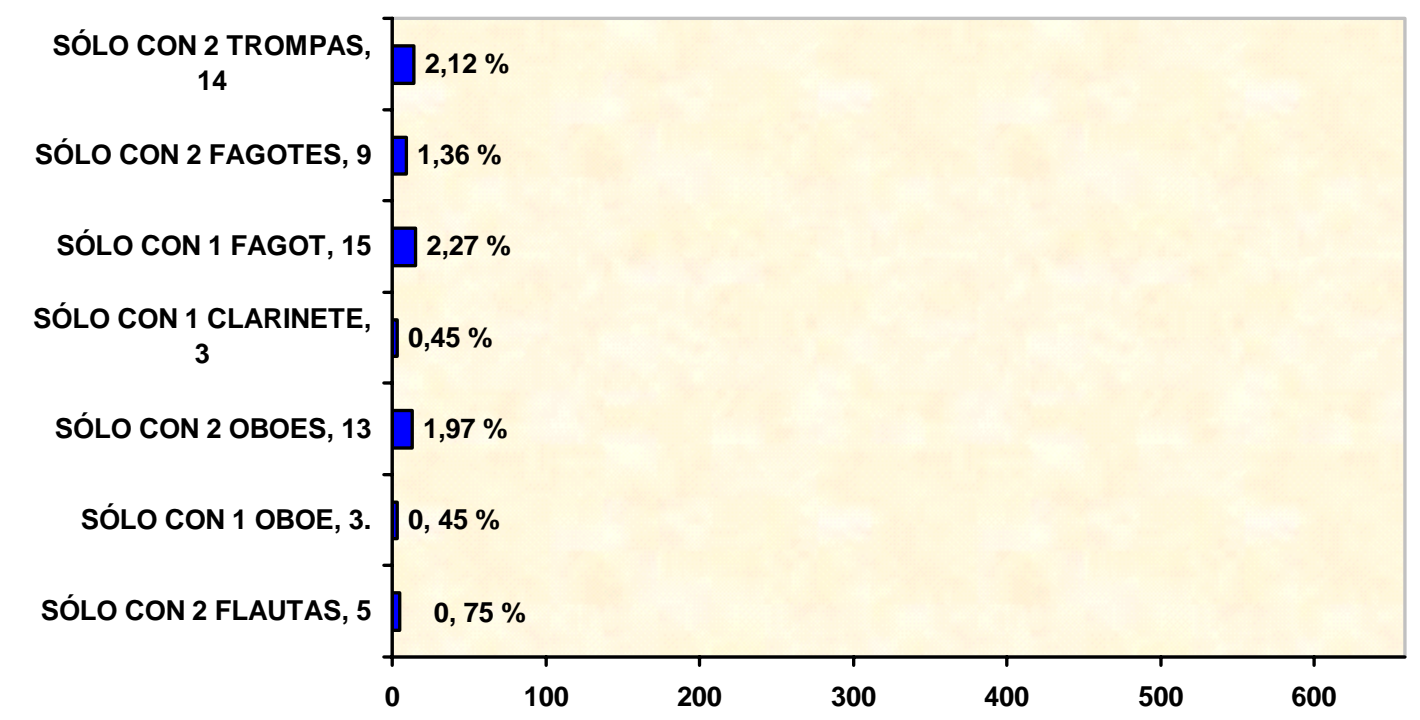

口OBRAS CON SÓLO 102 DOS INSTRUMENTOS DE VIENTO

También es oportuno decir que entre las 659 obras que llevan algún tipo de instrumentación, sólo 19 de ellas incluyen viola, siendo el resto de la cuerda Violín $1^{\circ}$, Violín $2^{\circ}$, Violoncello y Contrabajo. 
I) Obras con diversas combinaciones de instrumentos de viento:

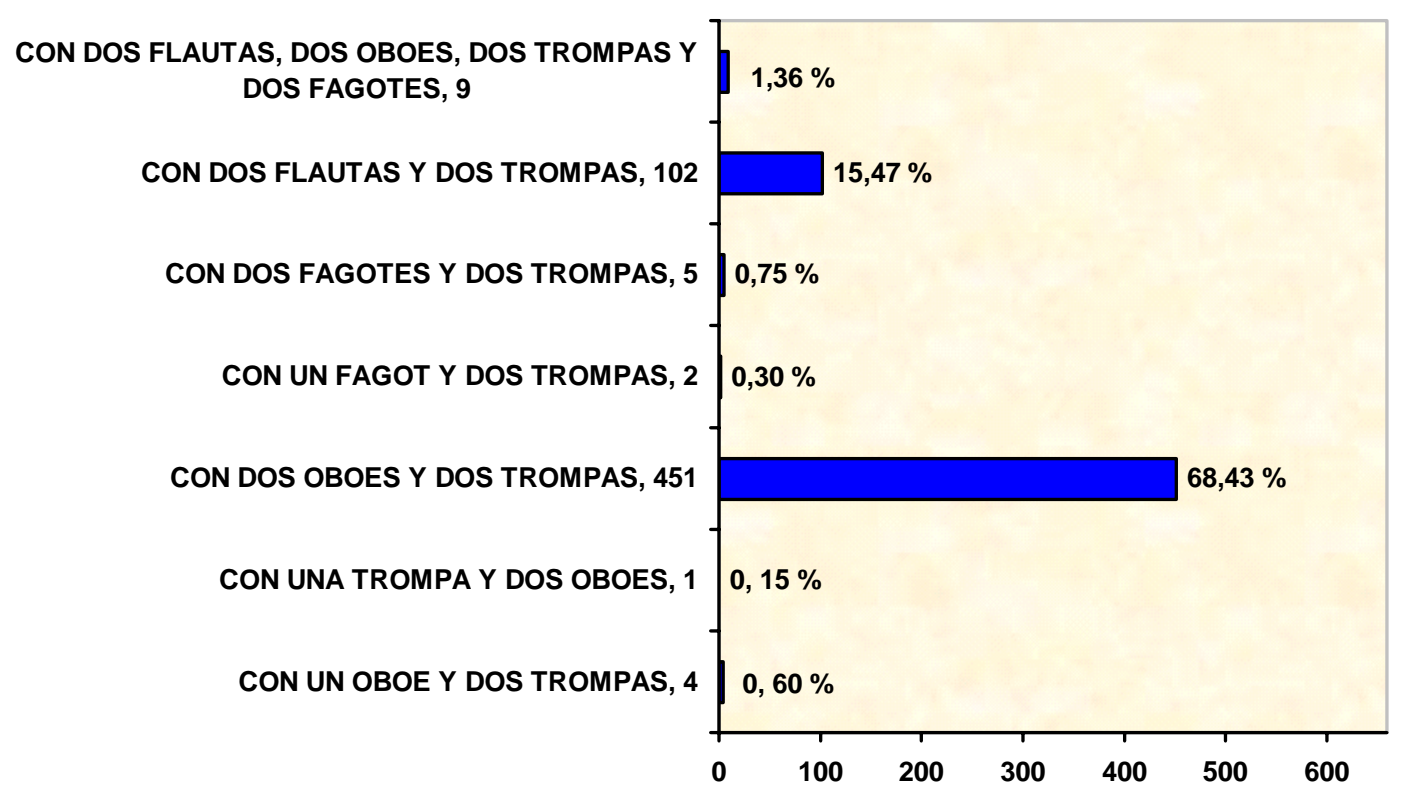

DIVERSAS COMBINACIONES INSTRUMENTALES

J) De las 720 obras totales, aparte del papel de acompañamiento (que evidentemente se hacía con órgano o clave), en algunas obras especifica papeles de uno o dos órganos. Esta es la proporción:

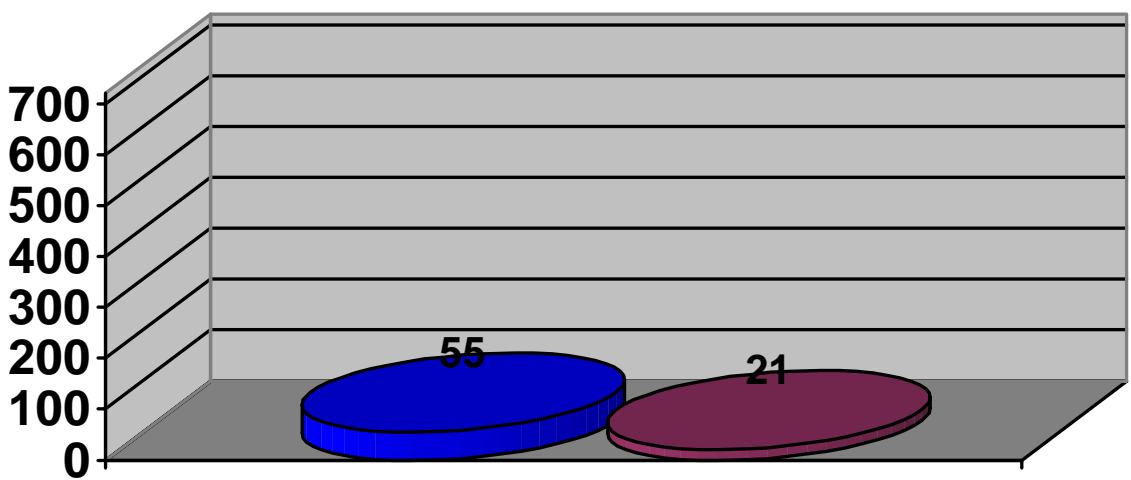

OBRAS CON ÓRGANO

- OBRAS CON UN ÓRGANO OBLIGADO, 55, $\square$ (7,63\%) 21, $(2,91 \%)$ 


\subsection{CONCLUSIONES.}

Al comenzar este trabajo ya teníamos la intuición de que la figura de Jaime Balius y Vila no sólo había sido clave en la vida musical de la Catedral de Córdoba, sino que también tenía una especial relevancia dentro de la Historia de la Música española. Al ir avanzando en la confección del mismo, esa intuición se ha convertido en certeza, sobre todo después de ver el número y la calidad de sus obras, y su proyección a nivel nacional.

Estas y otras circunstancias nos llevan a establecer una serie de conclusiones:

El prestigio de que gozaba en su época era enorme y muy merecido. La consideración que tuvo en todos y cada uno de los destinos en donde estuvo fue muy alta, su presencia y consejo era buscado por todos, y diversas Hermandades en Gerona y Madrid lo hicieron miembro de su comunidad. ${ }^{1843}$

Sin restar importancia a la Catedral de Córdoba, resulta paradójico que un Maestro de su talla, no hubiera finalizado su carrera en otra aun más relevante. A este respecto, era habitual en la vida de un Maestro de Capilla que intentara mejorar su destino, tener mejor sueldo, dirigir una orquesta y un coro con los mejores músicos, o vivir en ciudades donde su proyección artística tuviera mejores perspectivas. En el caso de Jaime Balius, a partir de La Seu d’Urgell, va pasando por Gerona y Córdoba, hasta llegar a Madrid (1787), nada menos que al Real Monasterio de la Encarnación, lugar a priori privilegiado, muy cercano al Palacio Real, y que en principio podría suponer un ascenso, o al menos un punto ideal desde donde aumentar su crédito. También le hubiera permitido estar en contacto directo con los músicos de la Corte, y en definitiva con el ambiente musical de la capital del reino.

Sin embargo, a los dos años de estar allí vuelve a Córdoba, de donde había salido, al parecer, por algunas disputas con los músicos. Probablemente en esta decisión tuviera mucho que ver la buena disposición del Cabildo de la Catedral de Córdoba, que aun después de la marcha de Balius a Madrid, siguió manteniendo muy buenas relaciones con él, hasta el punto de encargarle los villancicos del año 1788. En cualquier

\footnotetext{
${ }^{1843}$ En Gerona, la Congregación de los Dolores y en Madrid la Congregación de María Santísima de la Soledad.
} 
caso, parece lógico pensar que si hubiera seguido en Madrid, su carrera habría tenido una mejor culminación. ${ }^{1844}$

Otra conclusión significativa es que sus obras están muy extendidas por toda España, y aunque en Córdoba están la mayor parte de ellas, hay algunas que no se encuentran en nuestra ciudad. Ciertamente precisar cuántas y cuáles, requeriría la comparación exhaustiva de todas las obras existentes en los distintos lugares donde se conservan, verificando no sólo el título, sino el contenido musical. También sería importante incluir el estudio de las "marcas de agua" del papel, que nos aclararía otros datos importantes como la procedencia del mismo. La dimensión de dicho trabajo de comparación y verificación es grande y compleja, y rebasa los objetivos de este proyecto. En todo caso nos arrojaría un catálogo superior a las 720 obras aquí reseñadas. ${ }^{1845}$

La magnitud de su obra nos depara otra evidencia, y es que Jaime Balius invirtió la mayor parte de sus horas de vida en componer, y que además gozó de una gran rapidez mental y facilidad técnica. Esa agilidad la proyectó sobre muchas formas musicales, pero una de ellas fue sin duda su preferida: el villancico. Los 436 ejemplares que nos ha dejado son prueba de ello. El resto de sus composiciones son las propias de la tradición catedralicia (misas, salmos, lamentaciones, cánticos, etc.).

\footnotetext{
1844 “...Los compositores, instrumentistas y cantores aspiran a los puestos mejor pagados y de mayor prestigio, y estos se encuentran en buena medida en Madrid, al amparo de la Corte. [...] Hay tres importantes capillas musicales en Madrid: la Real Capilla, la del Monasterio de la Encarnación y la de las Descalzas Reales. A ellas se añadirá más tarde la de las Salesas Reales, fundada por la reina doña Bárbara de Braganza. La más importante de todas es la Real Capilla, que se puede considerar como centro de la música <<oficial>> religiosa que marca los gustos y prácticas musicales españolas. La culminación de la carrera musical tiene lugar cuando se llega a alcanzar algún puesto de la Real Capilla”. MARTÍN MORENO, Antonio. Historia de la música española. Madrid, Alianza Editorial, colección Alianza Música, 1985, volumen IV, págs. 27-28.

${ }^{1845}$ Valga el siguiente ejemplo: En la Bilioteca Nacional se conservan las letras de los Villancicos que se cantaron en la Seu d'Urgell el año de 1778, y a los que Balius puso música. Son los siguientes: "Patriarcas y Profetas", "Porque los niños ignoran", "Pastores mirad a Bato", "Un sacristán y un barbero", "Como oyeron los pastores", "Las Vírgenes de Belén”, "Qué podrá hacer mi amor, quando el Divino" y "Arrulla suave”. Ninguno de ellos está en Córdoba. Cf. GUILLÉN BERMEJO, María Cristina; y RUIZ DE ELVIRA SERRA, Isabel, coords.: Catálogo de Villancicos y Oratorios en la Biblioteca Nacional. Siglos XVIII-XIX. Madrid, Dirección General del Libro y Bibliotecas, 1990, pág. 55.
} 
Como vimos en su capítulo correspondiente, el estilo compositivo de Balius se encuadra, en general, dentro de lo que llamamos clasicismo, si bien perduran en él algunos rasgos propios del barroco, como el bajo contínuo o la policoralidad.

Una costumbre de la época era la celebración en la Catedral de Córdoba de numerosas ceremonias religioso-sociales que podían ir desde la bienvenida a un Rey o alta autoridad que visitara la ciudad, hasta un acto de afirmación constitucional, pasando por masivas congregaciones para dar gracias por el término de alguna plaga o calamidad que hubiera afectado a la ciudad. Todas estas ceremonias incluían la interpretación del habitual Te Deum. Como intérpretes estaban los músicos de la Capilla, y al frente de ellos, su Maestro. Para contribuir a la majestuosidad de estas celebraciones, Balius escribió diversas obras, ${ }^{1846}$ por lo tanto, podemos decir que tuvo un papel de cierta relevancia en momentos importantes de la Historia de Córdoba. Como hemos visto, este protagonismo era compartido por los músicos. La Capilla de Música era sin duda el conjunto vocal-instrumental más importante de la ciudad y participaba en aquellos actos que tuvieran cierta importancia, no sólo dentro sino también fuera de la Catedral. ${ }^{1847}$

Las actas capitulares nos han permitido comprobar que la vida diaria de los músicos de entonces era muy difícil. En algunos casos pasaban verdaderas dificultades para sobrevivir, por lo que frecuentemente pedían ayudas extraordinarias al Cabildo. Estas “ayudas de costa” permitían llegar a fin de mes sobre todo a los que tenían los sueldos más bajos. Estos sueldos variaban sustancialmente dependiendo del puesto que ocuparan, siendo los mejores pagados el Maestro de Capilla, el organista, el violín principal y los cantores solistas. ${ }^{1848}$ En el Apéndice Documental hemos incluido una tabla que nos sirve de ejemplo. En ella vemos esta disparidad, que nos ofrece cifras

\footnotetext{
${ }^{1846}$ Recordemos Nobles Andaluces, himno para alentar la resistencia de Andalucía contra la invasión de los franceses en 1808, y Cordobeses Ilustres y Nobles, canción en honor de la visita de Isabel de Braganza a Córdoba en 1816.

${ }^{1847}$ A veces incluso era solicitada su presencia para actuar en dos sitios a la vez, el mismo día y a la misma hora, lo que obligaba a dividir los efectivos, para poder atender ambos compromisos.

1848 Esto era lógico, sobre todo en los casos del Maestro de Capilla y el organista, por las muchas obligaciones que tenían, tanto en el aspecto interpretativo, como en el compositivo y pedagógico.
} 
como los 13.200 reales que cobraba José Moyano (tiple), o los 3.300 que cobraba Francisco Cascante (contrabajo). ${ }^{1849}$

A través del presente estudio hemos podido constatar la importancia del Colegio del Santo Ángel de Niños de Coro. A pesar de su trayectoria intermitente, durante el tiempo que funcionó fue un contínuo vivero de jóvenes músicos que en su mayoría pasaron a formar parte de la Capilla de Música. Las Constituciones del Colegio (que presentamos íntegras en Apéndice Documental), nos muestran un régimen de trabajo duro, y unas normas discipliarias estrictas. A pesar de ello, muchos padres solicitaban al Cabildo la admisión de sus hijos, estableciéndose una verdadera competencia para cubrir las plazas vacantes. ${ }^{1850}$

Volviendo a Jaime Balius, y teniendo en cuenta lo dicho sobre él hasta ahora, debemos afirmar que nos encontramos ante una de las figuras más sobresalientes de la música española de finales del siglo XVIII y principios del XIX, por número de obras, calidad y difusión de las mismas, por el reconocimiento de sus contemporáneos, etc. Y que -aunque algunos insignes musicólogos españoles como Pedrell, López-Calo, Civill Castellví o Martín Moreno alaban su figura- su consideración actual está por debajo de todos los méritos citados, por lo que indudablemente su vida y su obra merecen un mayor reconocimiento y una puesta en valor a la que esperamos haber contribuido con este trabajo.

\footnotetext{
${ }^{1849}$ Sin embargo, estos sueldos se vieron afectados a raíz de la entrada de los franceses en Córdoba. El saqueo que hicieron en las arcas del Cabildo provocó una disminución drástica de las retribuciones. Esta disminución fue mayor en los sueldos más altos y muy pequeña en los más bajos. José Moyano pasó de cobrar 13.200 reales a 7.000. Francisco Cascante, de 3.300 a 3000.

${ }^{1850}$ Este interés venía determinado no sólo por asegurar la educación de sus hijos, sino también para que tuvieran comida y ropa, que el colegio les daba a sus internos.
} 


\section{CAPÍTULO 7. FUENTES Y BIBLIOGRAFÍA.}

\subsection{FUENTES MANUSCRITAS.}

ARCHIVO DE LA CATEDRAL DE CÓRDOBA.

Actas Capitulares: Tomos 85 a 106.

Constituciones y Arreglamento que deben observar el Maestro de Capilla, Músicos y cantores de la Sancta Yglesia de Córdova, echo en 17 de Febrero de 1601. Obras Pías, caja 816, $\mathrm{n}^{\circ} 9$.

Cuentas de fábrica: Tomos 4040 a 4049.

Estatutos de Pérez Contreras. Ms. 166.

Sección de Capillas y Capellanías: Años 1785 a 1822.

Sección de Música: Partituras: Cajas 1 a 134. Carpetas 1 a 1311.

Sección de Obras Pías: Años 1785 a 1822.

ARCHIVO DE LA CATEDRAL DE GERONA.

Llibri dels Noms, y Cognoms dels Escolans del Cor, y / Capella de música de la Santa Isglesia de Gerona.

ARCHIVO DE LA IGLESIA DEL SAGRARIO DE CÓRDOBA.

Padrón de habitantes: Año 1786.

ARCHIVO DE LA IGLESIA DEL SALVADOR DE CÓRDOBA.

Libro de difuntos de los años 1806-1830.

ARCHIVO HISTÓRICO PROVINCIAL DE CÓRDOBA.

Sección de Protocolos Notariales, Oficio 33. Escrituras ante D. Mariano Muñoz y Sanz. Años de 1821 y 1822.

ARCHIVO MUNICIPAL DE CÓRDOBA.

Padrón de habitantes: Años 1785, 1786, 1800, 1821, 1822.

BIBLIOTECA PROVINCIAL DE CÓRDOBA. 
POZO CÁCERES, Juan Lucas del. Colección de Obras. Córdoba, 1863. Ms.

BIBLIOTECA MUNICIPAL DE CÓRDOBA.

POZO Y CÁCERES, Juan Lucas del. Rasgos biográficos y fisonómicos [de cordobeses]. Córdoba, 1863.

\subsection{FUENTES IMPRESAS.}

\section{ARCHIVO DE LA CATEDRAL DE CÓRDOBA.}

Constituciones del Colegio del Ángel de la Guarda, que para la manutención, cristiana educación y útil enseñanza de los Infantes que sirven al Coro de la Santa Iglesia Catedral de Córdoba, ha fundado el Ilmo. Señor Deán y Cabildo de ella. Córdoba, 1771.

Constituciones y Estatutos que su Magestad Cathólica Felipe IV, nuestro Señor, mandó hacer para el buen govierno, y servicio de su Capilla Real, sita en la Santa Iglesia Catedral de Córdova. Córdoba, 1704

FRESNEDA, Fray Bernardo de. Estatutos de la Sancta Iglesia Catedral de Córdoba. Antequera, 1577.

XIMENEZ Y HOYO, Manuel. Ceremonial y manual de las preces, antífonas, himnos, salmos y oraciones que deben decirse en esta Santa Iglesia Catedral de Córdoba. Córdoba, 1805

\section{BIBLIOTECA MUNICIPAL DE CÓRDOBA.}

ANÓNIMO. Noticia Breve de los Obsequios Tributados por la Ciudad de Córdoba a la Reyna Nuestra Señora $D^{a}$ María Isabel de Braganza y a la Serenísima Señora $D^{a}$ María Francisca de Braganza. Córdoba, Imprenta de D. Luis Ramos y Coria, 1816. 
ANÓNIMO. Noticia de las funciones celebradas por el Regimiento de Caballería de Santiago, II ${ }^{\circ}$ de Línea, en el día 21 de Julio de 1820. Córdoba, Imprenta Nacional, 1820.

AYESTARÁN Y LANDA, Agustín. Carta Pastoral de Ilustrísimo Señor D. Agustín de Ayestarán y Landa, Obispo de Córdoba, dirigida á todos sus súbditos y diocesanos, á fin de que se esfuercen á contribuir y suscribir á un Donativo ó Préstamo, ó a ambos, voluntarios, para la defensa de la Nación. Córdoba 1798.

EGUILUZ, Josef. Breve demostración de las principales obligaciones del Magistrado Político y de los individuos que componen el Ayuntamiento. Córdoba, Imprenta de Juan Rodríguez de la Torre, 1796.

LEAL, Rafael. Obsequios de Córdoba a sus Reyes, o descripción de las demostraciones públicas de amor y lealtad que Córdoba tributó a nuestros Católicos Monarcas en los días 11, 12 y 13 de Marzo de 1796, en que la honraron con su augusta presencia. Córdoba, Imprenta de Juan Rodríguez de la Torre, 1796.

Letras de los villancicos que se han de cantar en los Solemnes Maytines del Nacimiento de Nuestro Señor Jesucristo, en esta Santa Iglesia Catedral de Córdoba, en el presente año de 1786/ puestos en música por Don Jayme Balius y Vila. Córdoba, imprenta de D. Juan Rodríguez de la Torre, 1876.

Nuevo Estatuto sobre el modo de cumplir los días de Oficios. Córdoba, 1806.

RAMIREZ Y GÓNGORA, Manuel Antonio. Centuria Histórica donde se expresan los motivos de la confianza de los cordobeses en la protección del Arcángel Señor San Rafael. Córdoba, Imprenta de Juan Rodríguez de la Torre, 179?. 
RAMIREZ Y GÓNGORA, Manuel Antonio. Gozo y lealtad con que orla Córdoba la corona de su triunfo en la Real Proclamación del Rey y Señor D. Carlos Cuarto. Córdoba, Imprenta de Juan Rodríguez de la Torre, 1789.

RAMIREZ Y GÓNGORA, Manuel Antonio. Prospecto o diseño simbólico de la máscara que con motivo de la Real Proclamación de nuestro Rey y Señor D. Carlos Cuarto (que Dios guarde) y que va a executar esta M.N. y M.L. ciudad de Córdoba, tienen dispuesto hacer los individuos de las Artes de Albañilería y Carpintería, con los ramos de Hortelanos, Silleros, y otros asociados a ella. Córdoba, Imprenta de Juan Rodríguez de la Torre, 1789.

SEGOVIA Y VALENZUELA, Francisco José de. Métrica descripción de la Máscara que los honrados gremios de Confitería ó Chocolatería unidos, Especería, Panadería y Zapatería, darán a el público en esta M.N. y M.L. ciudad de Córdoba, como especial signo de amoroso júbilo, por la proclamada exaltación de los reyes nuestros señores $D$. Carlos Cuarto y $D^{a}$ Luisa de Borbón. Córdoba, Imprenta de Juan Rodríguez de la Torre, 1789.

BIBLIOTECA NACIONAL. $^{1851}$

Letras de los Villancicos que se han de cantar en los [...] Maytines del [...] Nacimiento de [...] Jesu-Christo en la [...] Iglesia Cathedral de Urgel [...] año de 1778 / puestos en música por el Licenciado Jaime Balius y Vila su Maestro de Capilla. Seo de Urgel: en la Imprenta de Agustín Ubách, impresor y librero, [1778]. ${ }^{1852}$

1851 Toda esta información está obtenida del magnífico trabajo de la doctora Ballus. Cf. BALLUS CASOLIVA, Gloria: La música a la Colegiata Basílica de Santa María de la Seu de Manresa: 17141808. Tesis Doctoral. Universidad Autónoma de Barcelona, 2004, vol. II, pags. 21-24. Esta a su vez cita a: GUILLÉN BERMEJO, María Cristina; y RUIZ DE ELVIRA SERRA, Isabel, coords.: Catálogo de Villancicos y Oratorios en la Biblioteca Nacional. Siglos XVIII-XIX. Madrid, Dirección General del Libro y Bibliotecas, 1990, pp. 55-60, y 429.

${ }^{1852}$ Contiene las siguientes obras: 1 . Nocturno I villancico Primero: "Patriarcas y Profetas" [Introducción, Recitado, Aria y Remate]. 2. Villancico Segundo: "Porque los niños ignoran” [Introducción, Estribillo, Seguidillas y Coplas]. 3. Villancico Tercero: "Pastores mirad a Bato" [Estribillo y Coplas]; 4. Segundo Nocturno. Villancico Cuarto: "Un sacristán y un barbero" [Introducción, Estribillo y coplas]. 5. Villancico V: "Como oyeron los pastores" [Introducción, Estribillo, tonadilla, Estribillo y Coplas]. 6. Villancico VI: "Las Vírgenes de Belén” [Introducción Estribillo y Pastorela]. 7. Nocturno III. Villancico VII: "Qué podrá hacer mi amor, quando el Divino" [Recitado y Aria]. 8. Villancico VIII: “Arrulla suave" Estribillo y Minué]. 
Letras de los Villancicos, que se han de cantar en lo [...] Maytines del Nacimiento de [...] Jesu-Christo, en esta [...] Catedral de Córdoba, en el [...] año de 1789 / puestos en música por don Jayme Balius y Vila, presbytero, Maestro de Capilla en dicha [...] Iglesia.- Córdoba: en la imprenta de Don Juan Rodríguez de la Torre [1789]. ${ }^{1853}$

Letras de los villancicos que se han de cantar en los [...] Maytines del Nacimiento de [...] Jesu-Christo, en esta [...] Catedral de Córdoba, en el [...] año de 1790 / puestos en música por D. Jayme Balius y Vila, presbytero, Maestro de Capilla en dicha [...] Iglesia. Córdoba: en la Imprenta de Don Juan Rodríguez de la Torre [1790]. ${ }^{1854}$

Letras de los villancicos que se han de cantar en los [...] Maytines del Nacimiento de [...] Jesu-Christo, en esta [...] Catedral de Córdoba, en el [...] año de 1793 / puestos en música por D. Jayme Balius y Vila,[...] Maestro de Capilla en dicha [...] Iglesia. Córdoba: en la Imprenta de Don Juan Rodríguez de la Torre [1793]. ${ }^{1855}$

\footnotetext{
1853 Contiene las siguientes obras: 1. Kalenda. “QQue noche tan clara!” [Introducción, Recitado, Aria, Coro, recitado, Aria, Coro, Recitado a dúo, Aria a dúo, Arrastre y Copla]. 2. Nocturno Primero. Villancico Primero a 8 V: "Pastores, que velais" [Estribillo y Coplas]. 3. Villancico Segundo: "Pasqual, que desvelado" [Recitado y Aria]. 4. Villancico Tercero de Pastorela: "Luego, que entre los pastores" [Introducción, Pastorela (Estribillo) y Coplas (Estribillo)]. 5. Nocturno Segundo. Villancico Cuarto a 4 V: "Vengan, vengan a ver una fiesta" [Estribillo y Coplas (Estribillo)]. 6. Villancico Quinto: "La gloria del Señor se manifiesta" [Recitado y Aria]. 7. Villancico Sexto de Tonadilla: "Después que los pastorcitos" [Introducción, Tonadilla y Coplas (Estribillo)]. 8. Nocturno Tercero. Villancico Séptimo a 3 V; "Bendecid al Señor, Rey supremo" [Estrofa y Coplas (Estribillo)]. 9. Villancico Octavo: "Por un rastro de luz vengo guiado" [Recitado y Aria]. 10. Villancico Nono: Para los niños de coro: "Vino Jesús, Rey eterno" [Introducción, Seguidillas y Coplas (Estribillo)].

${ }^{1854}$ Contiene las siguientes obras: 1. Kalenda. Jesuralén restaurada: "Cruel Babilonia” [Introducción, Recitado, Aria, Coro, Recitado, Aria, Coro, Recitado a dúo, Aria, Arrastre, Copla y Al Arrastre]. 2. Nocturno Primero. Villancico Primero: "Pastores sencillos" [Estribillo y Coplas]. 3. Villancico Segundo: "Desde que al Niño vi, Pasqual, me siento" [Recitado y Aria]. 4. Villancico Tercero de Pastorela: "Como vieron los zagales”. [Introducción, Pastorela y Copla (Estribillo)]. 5. Nocturno Segundo. Villancico Cuarto: "El agua, las fuentes" [Estribillo a 3 V y Coplas (Estribillo)]. 6. Villancico Quinto: "Que hermosa está la Aurora" [Recitado y Aria]. 7. Villancico Sexto de Tonadilla: "Vamos corriendo, vamos" [Introducción (Estribillo), Tonada (Estribillo) y Coplas (Estribillo)]. 8. Nocturno Tercero. Villancico séptimo: "Pasqual con Anton Gilberto” [Introducción y Coplas]. 9. Villancico Octavo: “¿Que es esto gran Josef? Estos pastores" [Recitado y Aria]. 10. Villancico Nono. Para los niños del coro: "Para que de todos modos” [Introducción, Seguidillas y Coplas (Estribillo)].

${ }^{1855}$ Contiene las siguientes obras: 1. Kalenda. El Príncipe de la Paz: “Israelitas nobles” [Introducción, Recitado, Aria, Coro, Recitado, Aria, Coro, Dúo, Aria, Arrastre, Copla y Al Arrastre]. 2. Nocturno Primero. Villancico Primero: "Pastores, pastores" [Introducción y Coplas]. 3. Villancico Segundo: "Llorando el Niño está" [Recitado a dúo y Aria]. 4. Villancico Tercero de Tonadilla: "Para divertir un rato" [Introducción, Tonadilla y Coplas (Estribillo)]. 5. Nocturno Segundo. Villancico Cuarto: "Vamos muchachos" [Introducción (Estribillo) y Coplas (Estribillo)]. 6. Villancico Quinto de un Patán: "Aquí me cuelo, que según he oído" [Recitado y Aria]. 7. Villancico Sexto de Pastorela: "De la cumbre hacia
} 
Letras de los villancicos que se han de cantar en los [...] Maytines del Nacimiento de [...] Jesu-Christo, en esta [...] Catedral de Córdoba, en el [...] año de 1798 / puestos en música por D. Jayme Valius y Vila, [...]

Maestro de Capilla en dicha [...] Iglesia. Córdoba: en la Imprenta de Don Juan Rodríguez de la Torre [1798]. ${ }^{1856}$

Letras de los villancicos que se han de cantar en los [...] Maytines del Nacimiento de [...] Jesu-christo, en esta [...] Catedral de Córdoba, en el [...] año de 1799 / puestos en música por D. Jayme Balius y Vila, [...] Maestro de Capilla en dicha [...] Iglesia. Córdoba: en la Imprenta de Don Juan Rodríguez de la Torre [1799]. ${ }^{1857}$

Letras de los villancicos que se han de cantar en los [...] Maytines del Nacimiento de [...] Jesu-Christo, en esta [...] Catedral de Córdoba, en el [...] año de 1804 / puestos en

Belén” [Introducción, Pastorela y Coplas]. 8. Nocturno Tercero. Villancico Séptimo: “Ahora llegan dos pastores" [Introducción y Coplas (Estribillo)]. 9. Villancico Octavo: "Vos sois Josef el hombre más dichoso" [Recitado y Aria]. 10. Villancico Nono. Para los niños de coro: "Los niños como han oído" [Introducción, Seguidillas y Coplas (Estribillo)].

${ }^{1856}$ Contiene las siguientes obras: 1 . Kalenda. Nuevo aspecto de la tierra y la gloria del Señor: “Ay! Que mi destierro” [Introducción, Recitado, Aria, Coro, Recitado, Aria, Coro y Final]. 2. Nocturno Primero. Villancico Primero. Niño: “A Belén, mortales” [Estribillo y Coplas]. 3. Villancico Segundo. Consuelo: “En Judá es todo alegría” [Estribillo y Coplas]. 4. Villancico Tercero de Pastorela. Redentor: "Así que los pastorcitos” [Estribillo y Coplas (Estribillo)]. 5. Nocturno Segundo. Villancico Cuarto. Alegría: “Alégrate tierra” [Estribillo y Coplas (Estribillo)]. 6. Villancico Quinto. Vencedor: “Quando más arrogante se presenta" [Recitado y Aria] 7. Villancico Sexto de Tonadilla. Misericordioso: "Un Pastor, a quien el Niño” [Introducción, tonada (Estribillo) y Coplas (Estribillo)]. 8. Nocturno Tercero. Villancico Séptimo. Señor: "Dos pastores, que presumen” [Introducción y Coplas]. 9. Villancico Octavo. Pastor: "A Belén llegan” [Estribillo y Coplas (Estribillo)]. 10. Villancico Nono. Para los niños. Verbo: "Los niños, que ya han salido" [Introducción, Seguidillas (Estribillo) y Coplas (Estribillo)].

${ }^{1857}$ Contiene las siguientes obras: 1. Kalenda. La derrota de Amaléc y Josué vencedor: “Aquí donde no hay ríos” [Introducción, Recitado, Aria, Coro, Recitado, Aria, Coro, Final y Copla a dúo]; 2. Nocturno Primero. Villancico Primero. Luz: “Albricias, mortales” [Estribillo y Coplas (Estribillo)]; 3. Villancico Segundo. Gloria: “De los cielos baxa”.[ Estribillo a 3 V y Coplas (Estribillo)]. 4. Villancico Tercero de Pastorela. Fortaleza: "Las zagalas, que en los montes” [Introducción, Pastorela, Estribillo y Coplas (Estribillo)]. 5. Nocturno Segundo. Villancico Cuatro. Vida: "En himnos sonoros" [Estribillo a 4 V y Coplas (Estribillo)]. 6. Villancico Quinto. “¿No eres Dios Niño mío?” [Recitado y Aria]. 7. Villancico Sexto de Tonadilla. Dios: “Avisados los pastores” [Introducción, Tonada (Estribillo) y Coplas (Estribillo)]. 8. Nocturno Tercero. Villancico Séptimo. Alimento: “Acudid mendigos” [Estribillo y Coplas (Estribillo)]. 9. Nocturno Octavo. Principio: “Jesuchristo nace” [Estribillo a 4 V y Coplas (Estribillo)]. 10. Villancico Nono. Para los niños. Hacedor: "Los niños, que en la pasada” [Introducción, Seguidillas (Estribillo) y Coplas (Estribillo)]. 
música por D. Jayme Balius y Vila [...]. Maestro de Capilla en dicha [...] Iglesia. Córdoba: en la Imprenta de D. Luis Ramón y Coria [1804]. ${ }^{1858}$

Letras de los villancicos que se han de cantar en [...]. Maytines del Nacimiento de [...] Jesu-Christo, en esta [...] Catedral de Córdoba, en el [...] año de 1814 / puestos en música por D. Jayme Balius y Vila [...], Maestro de Capilla en dicha [...] IglesiaCórdoba: en la Imprenta Real [1814]. ${ }^{1859}$

Letras de los villancicos que se han de cantar en [...] Maytines del Nacimiento de [...] Jesu-Christo, en esta Catedral de Córdoba, en el año de 1816 / puestos en música por D. Jayme Balius y Vila, presbítero, Maestro de Capilla de dicha [...] Iglesia. Córdoba: Imprenta Real [1816]. ${ }^{1860}$

\footnotetext{
${ }^{1858}$ Contiene las siguientes obras: 1 . Kalenda El remedio de los males: "Infelice tierra” [Introducción, Recitado a dúo, Aria, Coro, Recitado, Aria, Arrastre y Copla]. 2. Nocturno Primero. Villancico Primero: "Baxad de los cielos" [Estribillo y Coplas]. 3. Villancico Segundo: "En un portal hundido y desechado" [Recitado y Aria]. 4. Villancico Tercero de Tonadilla: "Los pastores de Belén” [Introducción, Tonada y Coplas]. 5. Nocturno Segundo. Villancico Cuarto: "A la media noche” [Estribillo a $4 \mathrm{~V}$ y Coplas (Estribillo)]. 6 Villancico Quinto: "Yo os anuncio, decía el rutilante" [Recitado y Aria] 7. Villancico Sexto de Pastorela: "Luego que al cielo volvieron" [Introducción (Estribillo), Pastorela (Estribillo) y coplas (Estribillo)]. 8. Nocturno Tercero. Villancico Séptimo:“Bendecid, hombres” [Estribillo, Coplas]. 9. Villancico Octavo: "O por qué Herodes, te turbas? Qué desvelo" [Recitado y Aria] 10. Villancico Nono para los niños: "Luego que aquellos pastores" [Introducción (Estribillo), Seguidillas (Estribillo) y Coplas (Estribillo)].

${ }^{1859}$ Contiene las siguientes obras: 1. Kalenda. Emmanuel, Dios con nosotros: "Defiéndenos, Señor, oye los ruegos” [Introducción, Recitado, Aria, Coro, Recitado, Aria, Coro, Himno, Copla y Al Himno]. 2. Nocturno Primero. Villancico Primero: "La celeste tropa" [Estribillo y Coplas (Estribillo)]. 3. Villancico Segundo: "La mujer que vio Juan tan adornada" [Recitado y Aria]. 4. Villancico Tercero de Tonadilla: "En las alturas del monte" [Introducción (Estribillo), Tonada (Estribillo) y Coplas (Estribillo)]. 5. Nocturno Segundo. Villancico Cuarto: "Los nuncios ligeros" [Estribillo a $4 \mathrm{~V}$ y Coplas (Estribillo)]. 6. Villancico Quinto: "La paz, oh que alegría” [Recitado y Aria]. 7. Villancico Sexto de Pastorela: "Los pastores que han oído" [Introducción (Estribillo), Pastores (Estribillo) y Coplas (Estribillo)]. 8. Nocturno Tercero. Villancico Séptimo: "Tiritas mi Niño" [Estribillo a $4 \mathrm{~V}$ y Coplas (Estribillo)]. 9. Villancico Octavo: "No hemos de hablar, mi amado, de otra cosa" [Recitado y Aria]. 10. Villancico Nono para los niños: "Quando ven, que hacen los hombres" [Introducción (Estribillo), Seguidillas (Estribillo) y Coplas (Estribillo)].

1860 Contiene las siguientes obras: 1. Kalenda. El desposorio de Esther; "Salid hijas de Sión" [Introducción, Recitado, Aria, Coro, Recitado, Aria a dúo, Sonata final y Copla]. 2. Nocturno Primero. Villancico Primero. Admirable: "Postrados de miedo" [Estribillo y Coplas (Estribillo)]. 3. Villancico Segundo. Consuelo: "Del temor consternados los pastores" [Recitado y Aria]. 4. Villancico Tercero de Tonadilla. Descanso: "Un Pastor, a quien la suerte" [Introducción, Tonada (Estribillo) y Coplas]. 5. Nocturno Segundo. Villancico Cuarto. Alegría: "Lejos de aquí la tristeza” [Estribillo y Coplas (Estribillo)]. 6. Villancico Quinto. Vencedor: "Empresa sublime” [A 3 V Estribillo y Coplas (Estribillo)]. 7. Villancico Sexto de Pastorela. Amor: "El amor es una cosa" [Introducción (Estribillo), Pastorela (Estribillo) y Coplas (Estribillo)]. 8. Nocturno Tercero. Villancico Séptimo. Pan vivo: "Pastores, pastores" [Estribillo y Coplas (Estribillo)] 9. Villancico Octavo. Buen Pastor: "Hasta la media noche" [Recitado y Aria]. 10. Villancico Nono. Palabra: "Luego que dio a los pastores" [Introducción (Estribillo), Seguidillas (Estribillo) y Coplas (Estribillo)].
} 
Letras de los villancicos que se han de cantar en los [...] Maytines del Nacimiento de [...] Jesu-Christo, en esta [...] Catedral de Córdoba, en el [...] año de 1817 / puestos en música por D. Jayme Balius y Vila [...], Maestro de Capilla en dicha [...] Iglesia. Córdoba: Imprenta Real [1817]. ${ }^{1861}$

Letras de los villancicos que se han de cantar en los [...] Maytines del Nacimiento de [...] Jesu-Christo, en esta [...] Catedral de Córdoba, en el [...] año de 1818 / puestos en música por D. Jayme Balius y Vila [...], Maestro de Capilla en dicha [...] Iglesia. Córdoba: Imprenta Real [1818]. ${ }^{1862}$

Letras de los villancicos que se han de cantar en los [...] Maytines del Nacimiento de [...] Jesu-Christo, en esta [...] Catedral de Córdoba, en el [...] año de 1819 / puestos en música por D. Jayme Balius y Vila [...], Maestro de Capilla en dicha [...] Iglesia. Córdoba: Imprenta Real [1819]. ${ }^{1863}$

\footnotetext{
${ }^{1861}$ Contiene las siguientes obras: 1 . Kalenda: "Ya del luciente cóncavo zafiro" [Recitado, Recitado, Aria, Recitado, Arrastre, Coplas y Arrastre] 2. Nocturno Primero. Villancico Primero: "O mortales dichosos" [Introducción y Coplas]. 3. Villancico Segundo. Recitado: "O rey, Dios humanado". 4. Villancico Tercero: "Digo pastores?” [Estribillo, Tonadilla y Coplas]. 5. Nocturno Segundo. Villancico Cuarto: "Miren que libres" [Estribillo y Coplas]. 6. Villancico Quinto de Pastorela: "A Belén caminamos gozosos" [Introducción, Pastorela y Coplas]. 7. Villancico Sexto: "Labrador soy zagales” [Introducción (Estribillo) y Coplas]. 8. Nocturno Tercero. Villancico Séptimo: "Qué es esto Amor!” [Estribillo y Coplas]. 9. Villancico Octavo: "Pastorcita Divina" [Estribillo y Coplas]. 10. Villancico Nono: "Arma contra el mundo arma” [Introducción y Coplas].

${ }^{1862}$ Contiene las siguientes obras: 1. Kalenda. En versos amebeos: "A un Astro nuevo admire la tierra" [Introducción, Recitado, Rondó, Recitado, Rondó, Recitado, Recitado e Himno]. 2. Nocturno Primero. Villancico Primero: "O mortales, tan dormidos" [Introducción y Coplas]. 3. Villancico Segundo: "Pastor de la cabaña: sal afuera” [Recitado y Dúo]. 4. Villancico Tercero: “El Sacristán de Betlem” [Introducción, Estribillo y Coplas]. 5. Nocturno Segundo. Villancico Cuarto: "Bien venido, Señor Soberano" [Estribillo a 4 V y Coplas]. 6. Villancico Quinto de Pastorela: “Celebremos, pastorcillos” [Introducción, Pastorela y Coplas]. 7. Villancico Sexto: "Molinerito de amor" [Introducción, Estribillo y Coplas]. 8. Nocturno Tercero. Villancico Séptimo: "Paco, vamos al instante" [Introducción, Tonadilla y Coplas]. 9. Villancico Octavo: "Si hoy llega a Belén" [Introducción y Coplas]. 10. Villancico Nono: "A ver y admirar" [Estribillo y Coplas].

${ }^{1863}$ Contiene las siguientes obras: 1 . Kalenda. La esperanza de la venida del Salvador. Los ministros de la Iglesia, los fieles: "El Sol hoy apresure"; 2. Nocturno Primero. Villancico Primero: "Con suavidad los Coros" [Estribillo y Coplas]. 3. Villancico Segundo: "Como el Señor lo dijo"; 4. Villancico Tercero: "Ven, grande Rey”; 5. Nocturno Segundo. Villancico Cuarto: "Del Dios que a su gente”; 6. Villancico Quinto de Pastorela: "Cantad, pueblos, cantad; toda la tierra" [Introducción y Coplas]. 7. Villancico Sexto: "A la media noche" [Estribillo y Coplas]. 8. Nocturno Tercero. Villancico Séptimo. Pastorela: "Ya que el Niño hermoso" [Estribillo, Pastorela y Coplas]. 9. Villancico Octavo: "Un organero festivo" [Introducción y Tonadilla]. 10. Villancico Nono: “Que Rey es este, o cielos que ha nacido?” [Introducción y Coplas].
} 
Letras de los villancicos que se han de cantar en los [...] Maytines del Nacimiento de [...] Jesu-Christo, en esta [...] Catedral de Córdoba, en el [...] año de 1820 / puestos en música por D. Jayme Balius y Vila [...], Maestro de Capilla en dicha [...] Iglesia. Córdoba: Imprenta Real, [1820]. ${ }^{1864}$

\section{PRENSA.}

ABC de Sevilla (5-Enero-1980).

Diario Córdoba (4, 13 y 15 de Enero de 1980).

El Alcázar de Madrid (10-Enero-1980).

El Correo de Andalucía (5-Enero-1980).

El Egabrense. Decenario independiente, nº 968. 2000.

La Voz de España de San Sebastián (12-Enero-1980).

Tendillas 7, semanario cordobés de bolsillo, número 86, 5 de Enero de 1980.

\subsection{BIBLIOGRAFÍA.}

- A.A.V.V.: Jornadas Metodológicas de Catalogación de Fondos Musicales de la Iglesia Católica en Andalucía. Granada, Centro de Documentación Musical de Andalucía, 1990.

- AgRamonte, Francisco. Diccionario Biográfico Cronológico. Madrid, Aguilar, 1945.

- $\quad$ AgUiLAR GAVILÁN, Enrique. Historia de Córdoba. Madrid, Silex, 1995.

\footnotetext{
${ }^{1864}$ Contiene las siguientes obras: 1 . Kalenda. La columna de nieve y de fuego figura de Maria Santíssima. Moisés, Aarón, Maria, Coro de israelitas: "Cantemos al encumbrado". [Introducción, Recitado, Recitado, Aria a Coros y Coplas]. 2. Nocturno Primero. Villancico Primero: "Pastores, pastores” [Introducción, (Estribillo) y Coplas a dúo (Estribillo)]. 3. Villancico Segundo. Coro de pastores: "Pastores, pastores" [Introducción, (Estribillo) y Coplas a dúo (Estribillo)]; 4. Villancico Tercero: "Viva el feliz contento" [Coplas (Estribillo)]. 5. Nocturno Segundo. Villancico Cuarto: "A la panaderita" [Estribillo y Coplas]. 6 Villancico Quinto: "Corred pastores"; 7. Villancico Sexto: "Asilo venturoso" [Recitado y Coplas]. 8. Nocturno Tercero. Villancico Séptimo: "Como podré celebrarte” [Estribillo y Coplas]. 9. Villancico Octavo: "Festivos zagalejos” [Estribillo, Pastorela y Coplas]. 10. Villancico Nono: "Volvió la primavera".
} 
- ALCOBER, A. La música religiosa en Mallorca. Palma, 1905.

- ALÉN, Ma Pilar. "Las Capillas Musicales catedralicias desde Carlos III hasta Fernando VII”, España en la Música de Occidente (actas del congreso), vol. II, 1987 págs. 39-49.

- ALÉN, Ma Pilar. "La Capilla de Música de la Real e Insigne Colegiata de Sta. María del Campo de La Coruña. (1750-1825)”, en Revista de Musicología, XXVII, 2. Madrid, Sociedad Española de Musicología, 2004.

- Álvarez PÉREZ, J. M.: Catálogo y estudio del Archivo musical de la catedral de Astorga. Pórtico, 1985.

- ANDERSON, M.S. La Europa del siglo XVIII. Madrid, Ed. Aguilar, 1964.

- ANGLÉS, Higinio. "La música conservada en la Biblioteca Colombina y en la catedral de Sevilla”. Anuario Musical 2 (1947).

- ANGLÉS, Higinio. “El Archivo musical de la catedral de Valladolid”. Anuario Musical, III, 1948.

- $\quad$ ANGULO IÑIGUEZ, Diego. Historia del Arte. Madrid, 1978.

- ANÓNimO. Casos Notables de la Ciudad de Córdoba. Montilla, 1982.

- ARANDA DONCEL, Juan. Historia de Córdoba. III. La época moderna. (15171808). Córdoba, 1984.

- ARANDA DONCEL, Juan. La devoción a la Virgen del Socorro en Córdoba durante los siglos XVII al XX. Córdoba, Cajasur, 1998.

- ARAIZ MARTINEZ, Andrés. Historia de la Música Religiosa en España. Barcelona, Labor, 1942.

- ARIAS DEL VALLE. La orquesta de la S. I. catedral de Oviedo (1572-1933). Discurso de ingreso en el Instituto de Estudios Asturianos (6 de noviembre de 1986). Oviedo, Instituto de Estudios Asturianos, 1990.

- ASENJO BARBIERI, Francisco. Biografías y Documentos sobre Música y Músicos Españoles. (Legado Barbieri, tomo I). Edición de Emilio Casares Rodicio. Madrid, Fundación Banco Exterior, 1986.

- ASENJO BARBIERI, Francisco: Documentos sobre Música y Músicos Españoles (Legado Barbieri, Vol. 2). Edición de Emilio Casares Rodicio. Madrid, Fundación Banco Exterior, 1988.

- AYARRA JARNE, José Enrique. La música en la catedral de Sevilla. Madrid, Caja de Ahorros de San Fernando, 1976. 
- BAENA ALCÁnTARA, Ma D. La Mezquita-Catedral de Córdoba. Córdoba, Fco. Baena, D.L. 1986.

- BAGÜÉS, Jon. Catálogo del Antiguo Archivo Musical del Santuario de Aranzazu. Caja de Ahorros Provincial de Guipúzcoa, 1979.

- BALDELLÓ, Francisco de Paula. "La música en la basílica parroquial de Santa María del Mar de Barcelona”, Anuario Musical, XVIII (1962).

- BALDELLÓ, Francisco de Paula. La música en Barcelona. Noticias históricas. Barcelona, Librería Dalmau, 1943

- BALIUS Y VILA, Jaime: Letras de los villancicos que se han de cantar en los Solemnes Maytines del Nacimiento de Nuestro Señor Jesucristo, en esta Santa Iglesia Catedral de Córdoba, en el presente año de 1786/ puestos en música por Don Jayme Balius y Vila. Córdoba, imprenta de D. Juan Rodríguez de la Torre, 1876.

- BALIUS Y VILA, Jaime: Letras de los villancicos que se han de cantar en los Solemnes Maytines del Nacimiento de Nuestro Señor Jesucristo, en esta Santa Iglesia Catedral de Córdoba, en el presente año de 1789/ puestos en música por Don Jayme Balius y Vila. Córdoba, imprenta de D. Juan Rodríguez de la Torre, 1879.

- BALIUS Y VILA, Jaime: Letras de los villancicos que se han de cantar en los Solemnes Maytines del Nacimiento de Nuestro Señor Jesucristo, en esta Santa Iglesia Catedral de Córdoba, en el presente año de 1816/ puestos en música por Don Jayme Balius y Vila. Córdoba, Imprenta Real, 1816.

- BALlUS CASOLIVA, Gloria: La música a la Colegiata Basílica de Santa María de la Seu de Manresa: 1714-1808. Tesis Doctoral. Universidad Autónoma de Barcelona, 2004.

- BARBAStro EZQUERRO Esteban, Antonio. "Archivo de Música de la Catedral de Barbastro (Huesca)”. Anuario Musical 50 (1995).

- BARRADO, Arcángel. Catálogo del archivo musical del monasterio de Guadalupe. Badajoz, Diputación Provincial, Institución de Servicios Culturales, 1945.

- BARRIOS MANZANO, M.P., "La música en la catedral de Coria (Cáceres) durante el Magisterio de capilla de Francisco Bernal (1814-23)”, Revista de Musicología, XIV (1-2), (1991), Pgs.535-547. 
- BARRIOS MANZANO, M.P., "La transición del siglo XVIII al XIX en la catedral de Coria (Cáceres): Magisterio de Juan José Bueno”, Nassarre: Revistaaragonesa de musicología, IX (2), (1993).

- BEDMAR ENCINAS, Luis. "El archivo musical de la Catedral de córdoba en su conjunto y sus principales protagonistas”, en AA.VV. Actas de las II Jornadas de Patrimonio Histórico-Musical de Córdoba. Córdoba, Ayuntamiento de Córdoba, 2004, pág. 117.

- BERNARDO ARES, José Manuel de. Los Alcaldes Mayores de Córdoba (17501833). Córdoba, Publicaciones del Monte de Piedad y Caja de Ahorros de Córdoba, 1978.

- BERNARDO ARES, José Manuel de. "Hacienda Municipal, Oficios y jurisdicciones enajenadas. El Municipio de Córdoba a mediados del siglo XVIII”. Revista Omeya, Córdoba 1979.

- BERNARDO ARES, José Manuel de. "Municipios cordobeses en 1815: análisis económico-administrativo de los gobiernos locales de 29 pueblos de señorío y realengo”. Boletín de la Real Academia de Córdoba. Córdoba, 1977

- BONASTRE, Francesc., "La Capella musical de la Seu de Tarragona a mitjan segle XVIII”, Boletín Arqueológico, IV, (1976-77).

- BONASTRE, Francesc., "Inventan de manuscrits musicais (Ms.M.) de la Biblioteca de Catalunya”, Builetí de la Biblioteca de Catalunya, 10 (1982-84).

- BONASTRE, Francesc: Catálogo del Archivo de Música de la Catedral de Tarragona. Manuscrito conservado en el Instituto de Recerca Musicológica "Ricart i Matas".

- CAlAhORRA MARTíneZ, Pedro. Catálogo del Archivo de Música de la Catedral de Jaca. Manuscrito conservado en la Institución "Fernando el Católico", Diputación de Zaragoza.

- CALZADA OLIVERAS, Josep. Catedral de Girona. Barcelona: Escudo de Oro, 1995.

- CALle GONZÁlez, B., Catálogo de música y documentos musicales del Archivo Catedral de Lérida. Lleida: Dilagro, 1984.

- CAPDEPÓN, Paulino. La música en el Monasterio de la Encarnación. Madrid, Caja Madrid, Ed. Alpuerto, 1997.

- CAPDEPÓN, Paulino. La música en el Monasterio de las Descalzas Reales (siglo XVIII). Editorial Alpuerto, 1999 
- CÁRDENAS, Inmaculada. "La música en la colegiata de Olivares". Anuario Musical 36 (1981).

- CARRATO MEnA, M.A., Catálogo de impresos musicales del siglo XVIII en la Biblioteca Nacional. Madrid: Ministerio de Cultura, 1989.

- CARRERAS LÓPEZ, Juan José. La música en las catedrales en el siglo XVIII. F. J. García (1730-1809). Z. 1983.

- CASARES RODICIO, Emilio., "La música del siglo XIX español: Conceptos fundamentales" en La música española del siglo XIX, Oviedo: U. de Oviedo, 1995, Ps. 13-122.

- CASARES RODICIO, Emilio y ALONSO GONZÁLEZ, Celsa (eds.), La música española en el siglo XIX, Oviedo, Universidad de Oviedo, 1995.

- CASARES RODICIO, Emilio y otros: Diccionario de la Música Española e Hispanoamericana. Madrid, Sociedad General de Autores, 1999.

- CASARES RODICIO, Emilio. La imagen de nuestros músicos. Del Siglo de Oro a la edad de plata. Pórtico. 1997.

- CASARES RODICIO, Emilio. La música en la catedral de León: Maestros del siglo XVIII y Catálogo Musical. Archivos Leoneses 67 (1980).

- CASINI, C., Historia de la música. IX: El siglo XIX. Madrid: Turner, 1987.

- CASTILLEJO GORRAIZ, Miguel. La religiosidad popular cordobesa. Sevilla, 1984.

- CAVIA NAYA, Victoria., La música en la catedral de Valladolid en el siglo XIX: Antonio García. Tesis doctoral, Valladolid, 1999.

- CAVIA NAYA, Victoria. "El Colegio de niños músicos de la Purísima Concepción de Valladolid en el siglo XIX: trayectoria y alternativas a la institución”, en Campos Interdisciplinares de la Musicología. Madrid, Sociedad Española de Musicología, 2002, volumen 2, p. 949.

- CHAILlEY, J., Compendio de musicología. Madrid: Alianza, 1991.

- CHÍA, J., La música en Gerona. Apuntes históricos sobre lo que estuvo en uso en esta ciudad y su comarca... Girona: Paciano Torres, 1886.

- CIVIL CASTELLVÍ, Francesc. "Compositores y organistas gerundenses en el s.XVII”, Anales del Instituto de Estudios Gerundenses, vol. XXI, (1972).

- CIVIL CASTELLVÍ, Francesc: "La Capilla de música de la Catedral de Gerona, 
siglo XVIII” en Anales del Instituto de estudios Gerundenses. Gerona, Volumen XIX, 1968.

- CIVIL CASTELLVÍ, Francesc: El fet musical a les comarques gironines en el lapse de temps 1800-1936. Gerona, Caja de Pensiones, 1970.

- CLIMENT BARBER, José. Fondos Musicales de la Región Valenciana. I. Catedral Metropolitana de Valencia. Valencia, Diputación Provincial, Institución Alfonso el Magnánimo, 1979.

- CORRAL BÁEZ, F.J. La capilla de música de la catedral de Guadix en el siglo XVIII, Tesis doctoral, Universidad de Granada, 1999.

- COSANO MOYANO, Francisco. Iconografía Cordobesa. Córdoba, Cajasur, 1999.

- CRESPI GONZÁLEZ, J. "Biblioteca de Cataluña: El Departamento de música”, El patrimonio musical español de los siglos XIX y XX. Estado de la cuestión. Madrid: Fundación Xavier Salas, 1995.

- CRESPI, J., "Publicaciones periódicas musicales del S. XIX en Catalunya”, XVIII Congreso de la Asociación Internacional de Bibliotecas Musicales, Archivos y Centros de Documentación. Madrid, Asociación Española de Documentación Musical, 1999.

- CRIADO COSTA, Joaquín y PORRO HERRERA Ma José. Anuario de la Real Academia de Córdoba, de Ciencias, Bellas Letras y Nobles Artes. Córdoba, Real Academia, 2003

- CROCE, Benedetto. Historia de Europa en el Siglo XIX. Barcelona, Ed. Ariel, 1996.

- CUADRADO GARZÓN, A., La música en la catedral de Zamora en la primera mitad del siglo XVIII. Tesis doctoral, Castilla-La Mancha, 1998.

- CUENCA TORIBIO, José Manuel. Andalucía, una introducción histórica. Córdoba, Monte de Piedad y Caja de ahorros de Córdoba, 1980.

- CUENCA TORIBIO, José Manuel. Historia de Córdoba. Córdoba, Librería Luque, 1993.

- DABRIO GONZALEZ, Ma Teresa y RAYA RAYA, Ma Ángeles. "Las obras del setecientos”, en: VILLAR MOVELLÁN, Alberto y otros. Córdoba, Arte. Caja Provincial de Ahorros de Córdoba. Córdoba 1994.

- DE LA GUARDIA, Ernesto. Las Sinfonías de Beethoven. Buenos Aires, Ricordi Americana, 1927. 
- $\quad$ DEL MORAL, Cristina. La Guerra de la Independencia. Madrid, Anaya, 1990.

- DÍAZ MOHEDO, Ma Teresa. "La Iglesia Colegial de Antequera y su Capilla de Música, S.XVIII”. Revista de Musicología Vol. XXVIII. Madrid, Sociedad Española de Musicología, 2005.

- DÍEZ MARTINEZ, Marcelino. La Música en Cádiz. La Catedral y su proyección urbana durante el siglo XVIII. Cádiz, Servicio de publicaciones de la Universidad de Cádiz, 2004.

- DURÁN GUDIOL, Antonio. "La capilla de música de la catedral de Huesca”. Anuario Musical 19 (1964).

- EZQUERRO ESTEBAN, Antonio. “Archivo de Música de la Catedral de Coria”. Anuario Musical 51 (1996).

- EZQUerRo ESTEBAN, Antonio. “Archivo de Música de la Catedral de Murcia”. Anuario Musical 50 (1995).

- EZQUERRO ESTEBAN, Antonio. “Archivo de Música de la Catedral de Tudela (Navarra)”. Anuario Musical 50 (1995).

- FABREgA GRAU, Ángel y otros. Catálogo del Archivo Capitular de la S.I. Catedral Basílica de Barcelona. Barcelona. Archivo Capitular de la Catedral. 1969.

- FERNANDEZ DE LA CUESTA, Ismael. Historia de la Música Española. Desde los orígenes hasta el ars nova. Madrid, Alianza Editorial, 1983.

- FITA, F. Un canónigo judaizante quemado en Córdoba. Córdoba, Boletín de la Real Academia de Córdoba. 5 (1885), 401-405.

- GALDON I ARRUÉ, M., La capella de música de la catedral de Girona, del 1800 al 1850. Treball de recerca. U.A.B. 1998.

- GALLEGO, A., “Aspectos sociológicos de la música en la España del siglo XIX”, Revista de Musicología, XIV (1-2), (1991), Ps. 13-31.

- $\quad$ GAllegO, A. La música en tiempos de Carlos III. Madrid: Alianza, 1988.

- GÁNDARA, Xosé Crisanto. “El acompañamiento con el violón y el contrabajo en la música de los siglos XVII y XVIII”, en LOLO, Begoña (Edición al cuidado de). Campos Interdisciplinares de la Musicología. Sociedad Española de Musicología, Madrid, 2001. 
- garbayo MONTABES, F. Javier. Catálogo del Archivo de Música de la Catedral de Ourense. Santiago de Compostela. Instituto Galego das Artes Escénicas e Musicais, 2004.

- GARBAYO, Javier: "Balius Vila, Jaime”, en: Casares, E. y otros: Diccionario de la Música Española e Hispanoamericana. Madrid, Sociedad General de Autores, 1999.

- GARCÍA FRAILE, Dámaso. Catálogo archivo de música de la catedral de Salamanca. Cuenca. Instituto de Música Religiosa de la Diputación Provincial, D.L. 1981.

- GARCÍA MARCELLÁN, José: Catálogo del Archivo de Música de la Real Capilla de Palacio. Madrid, Editorial del Patrimonio Nacional.

- GARCÍA-CUEVAS VENTURA, José. El Cabildo Catedralicio cordobés desde la Revolución hasta la Restauración (1788-1882). Córdoba, Servicio de Publicaciones de la Universidad, 1996.

- GeMBero UStÁRroz, M. La música en la Catedral de Pamplona durante el siglo XVIII. Pamplona: Gobierno de Navarra, 1995.

- GEMBERO USTARROZ, M., "Relaciones musicales entre franceses y españoles durante la Guerra de la Independencia (1808-14): El caso de Pamplona”. Revista de musicología, 20 (1) (1997), ps. 451-466.

- GEMBERO USTARROZ, M., "La música en los espectáculos públicos pamploneses del siglo XVIII” en De música hispana et aliis: Miscelanea en honor al Prof. Dr. José López-Calo, S.J., en su $65^{\circ}$ cumpleaños. Santiago de Compostela: U. De Santiago de Compostela, 1990, Ps. 605-646.

- GOMEZ AMAT, Carlos. Historia de la música española. Siglo XIX. Madrid, Alianza Editorial, 1984, colección Alianza Música, nº 5.

- GOMEZ BRAVO, J. Catálogo de los Obispos de Córdoba y breve noticia histórica de su Iglesia Catedral y Obispado. Córdoba 1778.

- GOÑI GAZTAMBIDE, José. Catalogo del Archivo Catedral de Pamplona. Pamplona. [s.n.], 1965.

- GRACIA BOIX, Rafael. Colección de Documentos para la Historia de la Inquisición de Córdoba. Córdoba, Publicaciones del Monte de Piedad y Caja de Ahorros de Córdoba, 1982.

- GRACIA BOIX, Rafael. Colección de Autos de Fe y Causas de la Inquisición de Córdoba. Córdoba 1983. 
- GREGORI, J.M., "Mestres de Capella i organistes de la col1egiata de Sant Joan de les Abadesses al segle XVIII: documents per a la seva história”, C.U.G.: Estudi General, (1981).

- GROUT, Donald y PALISCA, Claude. Historia de la Música Occidental, II. Madrid, Alianza Editorial, 2001, colección Alianza Música, nº16.

- HERNÁNDEZ ASCUNCE, Leocadio. "El Archivo Musical de la Catedral de Pamplona”. Tesoro Sacro-Musical (1940).

- HIDALGO NUCHERA, Patricio y PADILlA ÁLVAREZ, Francisco. Las Ordenanzas de Colmeneros del Concejo de Córdoba (siglos XV-XVIII). Córdoba, Ediciones La Posada, Ayuntamiento, 1998.

- JAÉN MORENTE, Antonio. Historia de la ciudad de Córdoba. León, 1917.

- Jimenez CAVAlle, Pedro. Documentario Musical de la Catedral de Jaén. Granada, Centro de Documentación Musical de Andalucía, 1978, pág.334.

- LAGUNA PAÚl, Teresa. "Córdoba. La Mezquita y el Casco Histórico". Ciudades y Monumentos de España Patrimonio de la Humanidad. Madrid, Ferrovial, 2001.

- LARA LARA, Francisco Javier. El canto llano en la Catedral de Córdoba. Los libros corales de la misa. Granada, Universidad de Granada, 2004.

- LEZA CRUZ, José Máximo. Acercamiento al estudio de la capilla musical del Real Monasterio de Guadalupe. El Patrimonio Musical de Extremadura, Fundación Xavier de Salas, Madrid, 1993.

- LOLO, Begoña. La música en la Real Capilla de Madrid. José de Torres y Martínez Bravo (1670-1738). Editorial Alpuerto, 1990

- LÓPEZ CALO, José. Catálogo del Archivo de Música de la Catedral de Granada. Granada. Centro de Documentación Musical de Andalucía (Junta de Andalucía), 1991.

- LÓPez CALO, José. Catálogo del Archivo de Música de la Capilla Real de Granada. Granada, Centro de Documentación Musical de Andalucía (Junta de Andalucía), 1993.

- LÓPEZ CALO, José. Documentario Musical de la Capilla Real de Granada. Granada, Centro de Documentación Musical de Andalucía (Junta de Andalucía), 2005.

- LÓPEZ CALO, José. Historia de la música española. Siglo XVII. Madrid, Alianza Editorial, 1983. 
- LÓPEZ-CALO, José. La música en la Catedral de Zamora. Zamora. Diputación Provincial, 1985.

- LÓPEZ-CALO, José. La música en la Catedral de Burgos. Burgos. Caja de Ahorros del Círculo Católico de Burgos, 1995.

- LÓPEZ-CALO, José. La música en la Catedral de Calahorra. Logroño. Consejería de Cultura, Deportes y Juventud, 1991.

- LÓPEZ-CALO, José. La música en la catedral de Palencia. Palencia. Diputación Provincial, 1980.

- LÓPEZ-CALO, José. La Música en la catedral de Santo Domingo de la Calzada. Logroño. Consejería de Educación, Cultura y Deportes, 1988.

- LÓPEZ-CALO, José. La música en la Catedral de Segovia. Segovia. Diputación Provincial, 1988.

- LÓPEZ-CALO, José. Catálogo del archivo de música de la Catedral de Ávila. Santiago de Compostela. Sociedad Española de Musicología, 1978.

- LÓPEZ-CALO, José. Catálogo musical del Archivo de la Santa Iglesia Catedral de Santiago. Cuenca, Instituto de Música Religiosa, 1972.

- LÓPEZ-CALO, José. "La música en la catedral de Plasencia”, en El patrimonio musical de Extremadura, Fundación Xavier de Salas, Madrid, 1993

- LÓPEZ MARTíN, Juan y otros. Noticias y Catálogo de Música en el Archivo de la S. Y A.I.C. de Almería. Granada, Centro de Documentación Musical de Andalucía (Junta de Andalucía), 1997.

- LOVETT, Gabriel. La Guerra de la Independencia y el Nacimiento de la España Contemporánea. Barcelona, Ed. Península, 1975.

- MACKENZIE, A.S.: A year in Spain by a young American. Boston, Hilliard, Gray, Little and Wilkins, 1829.

- MADURELL, J.M., "Documentos para la historia de los maestros de capilla, infantes de coro, maestros de música y danza y ministriles en Barcelona (s. XIVXVIII)”, Anuario Musical, IV (1949).

- MARFIL, Pedro. "La Catedral”, en AAVV. Córdoba, Patrimonio de la Humanidad. Córdoba, Diario Córdoba, 2002.

- MARQUÉS, S., L'ensenyament a Girona al segle XVIII. Girona, Collegi Universitari, 1985. 
- MARTÍN GONZÁLEZ, J.J. “Oposiciones al Magisterio de la capilla de la Catedral de Valladolid durante el siglo XIX”, Revista de musicología, XIV (1-2), (1991), Ps. 511-534.

- MARTÍN MARTÍN, Teodoro. “Aproximación a los efectos de la desamortización sobre las Capillas Musicales”. Letras de Deusto, vol. 35, $\mathrm{n}^{0}$ 109. OctubreDiciembre 2005.

- MARTín MORENO, Antonio. Historia de la Música Española. Siglo XVIII. Madrid, Alianza Editorial, 1985.

- MARTín MORENO, Antonio. Historia de la Música Andaluza. Sevilla, Editoriales Andaluzas Unidas, 1985.

- MARTÍn MORENO, Antonio. Catálogo del Archivo de Música de la Catedral de Málaga. Granada, Centro de Documentación Musical de Andalucía, 2003.

- MARTÍN QUIÑONES, M.Á. La música en la Catedral de Málaga durante la segunda mitad del siglo XVIII: la vida y la obra de Jaime Torrens. Tesis doctoral. Universidad de Granada, 1997.

- MARTÍN QUIÑONES, M.Á. Joaquín Tadeo de Murguía 1759-1836, Organista de la Catedral de Málaga. Universidad de Málaga, 1987.

- MARTÍNEZ ANGUITA, M.R. La música civil y religiosa en Jaén en el siglo XIX. Jaén: U. De Jaén, 1995.

- MARTÍNEZ ANGUITA, M.R., "Panorama musical en Jaén, ciudad andaluza, en el siglo XIX” en España en la música de occidente, Madrid: Ministerio de Cultura, 1987, Ps. 241-249.

- MARTÍnEZ SOLAESA, Adalberto. Catedral de Málaga. Órganos y Música en su entorno. Málaga, Servicio de Publicaciones de la Universidad, 1996.

- MYERS BROWN, Sandra. "Las Desamortizaciones Eclesiásticas del siglo XIX en España y sus consecuencias sobre la música (Madrid y Toledo)”. Revista de Musicología Vol. XXVIII. Madrid, Sociedad Española de Musicología, 2005.

- $\quad$ MIRÓ BACHS, A., Cien músicos célebres españoles. Barcelona: Ed. Ave, 1955.

- MORALES, Alfredo J. Hernán Ruiz “El Joven”. Madrid, Akal Ediciones, 1996.

- MOREnO CUADRO, Fernando. Arte Efímero Andaluz. Córdoba, Servicio de Publicaciones de la Universidad de Córdoba, 1997. 
- MORENO VALERO, Manuel. "Saqueo de las tropas francesas en Córdoba”, en Boletín de la Real Academia de Córdoba, $n^{\circ} 138$ (Enero-Junio 2000). Córdoba, Real Academia, 2000.

- MOYA ULlDEMOLINS, J. Patrimonio y desamortización eclesiástica en Córdoba. Tesis doctoral. Córdoba 1983. Inédita.

- MUJAL ELÍAS, Juan. Historia de la Música de Lérida. Lérida. Dilagro, 1975.

- MUNETA MARTínEZ DE MORENTÍN, Jesús María. Catálogo del Archivo de Música de la catedral de Albarracín. Teruel. Instituto de Estudios Turolenses de la Exma. Diputación Provincial, 1984.

- MUNETA MARTínEZ DE MORENTÍN, Jesús María. Catálogo de los fondos musicales de la Colegiata de Alquézar. Teruel, 1996.

- MUR BERNAD, Juan José de. Catálogo del Archivo de Música de la Catedral de Huesca. Huesca. J.J. de Mur, D.L. 1993.

- NAVARRO GONZALO, Restituto y otros. Catálogo musical del archivo de la Santa Iglesia Catedral Basílica de Cuenca. Cuenca. Instituto de Música Religiosa, 1973.

- NIETO CUMPLIDO, Manuel. "La música en la Catedral de Córdoba (12361577)”, en AA.VV. El Patrimonio Histórico-Musical de Córdoba. Córdoba, Ayuntamiento de Córdoba, 2004.

- NIETO CUMPLIDO, Manuel: "Maestros de Capilla de la Catedral de Córdoba”. Boletín de la Confederación Andaluza de Coros de 1995. Córdoba, Ed. CO.AN.CO., 1995.

- $\quad$ NIETO CUMPLIDO, Manuel y otros. Historia del Monte de Piedad y Caja de Ahorros de Córdoba. Córdoba, Monte de Piedad, 1979.

- $\quad$ NIETO CUMPLIDO, Manuel. La miniatura en la Catedral de Córdoba. Córdoba, Monte de Piedad y Caja de Ahorros de Córdoba, 1973.

- NIETO CUMPLIDO, Manuel. La Catedral de Córdoba. Córdoba, Publicaciones de la Obra Social y Cultural de Cajasur, 1998.

- $\quad$ NIETO CUMPLIDO, Manuel y RECIO MATEO, Luis. La Mezquita Catedral de Córdoba, Patrimonio de la Humanidad. Córdoba, Edilux, 2006.

- ORTÍ BELMONTE, Miguel Ángel. Córdoba durante la Guerra de la Independencia, 1808-1813. Córdoba, Imprenta "La Comercial”, 1930. 
- ORTIZ MOLINA, M.A. Antonio Caballero, Maestro de Capilla Real de Granada de 1757 a 1822. Universidad de Granada, 1996.

- PAJARES BARÓN, Máximo. Catálogo del Archivo de Música de la Catedral de Cádiz. Granada, 1993, Centro de Documentación Musical de Andalucía.

- PALACIOS BAÑUELOS, Luís. Historia de Córdoba. La etapa contemporánea. Córdoba, Publicaciones del Monte de Piedad y Caja de Ahorros de Córdoba, 1990.

- PALACIOS SANZ, José Ignacio. “Aproximación histórica a la capilla de música en la catedral de Burgo de Osma durante el siglo XIX: De Bernardo Pérez al Motu propio”, Revista de musicología, XIV (1-2), (1991), Ps. 549-559.

- PALACIOS SANZ, José Ignacio. Tres siglos de música en la Catedral del Burgo de Osma. Soria, Centro de Estudios Sorianos, 1991.

- $\quad$ PAlMER, R. y COLTON, J.: Historia Contemporánea. Akal. Madrid, 1980.

- PAUly, R. La música en el período clásico, Buenos Aires: Ed. Víctor-Lerú, 1980.

- PAVIA I SIMÓ, Josép. “Documents per a l'estudi de les capelles de música de Barcelona, 1763-1820”. Anuario Musical, XXXVII, (1982).

- PAVÍA I SIMÓ, Josep. “Archivo de Música de la Catedral de Tortosa”. Anuario Musical 51 (1996).

- PAVÓN, Borja. Anales de la Ciudad de Córdoba, (Manuscrito de la Real Academia de Córdoba).

- PEDRELL, Felipe. Catálech de la Biblioteca Musical de la Diputació de Barcelona, 2 vols., Barcelona: Palau de la Diputació, 1908-1909.

- PEDRELL, Felipe. Diccionario biográfico y bibliográfico de músicos y escritores de música españoles, portugueses e hispanoamericanos, antiguos y modernos. Barcelona: Víctor Berdós, 1987.

- PEDRELL, Felipe. Diccionario técnico de la música. Barcelona: Isidro Torres, s.d.

- PÉREZ, Mariano. Diccionario de la Música y los Músicos. Madrid, Ediciones Istmo, 1985. (3 volúmenes).

- PERIS LACASA, José: Catálogo del Archivo de Música del Palacio Real de Madrid. Madrid, Patrimonio Nacional, 1993.

- $\quad$ PONZ, Antonio. Viage de España, Madrid, 1971. 
- PUJOL, David. Els mestres de l'Escolania de Montserrat. Montserrat. Ediciones del Monasterio de Montserrat, 4 vols.

- QUEROL, Miguel. "El archivo de música de la colegial de Jerez de la Frontera”. Anuario Musical 30 (1975).

- RAMÍREZ DE ARELLANO, Teodomiro: Paseos por Córdoba. (2ª Edición). León, Ed. Everest, 1975.

- RAmíRez DE ARELlanO, R. El Teatro en Córdoba. Ciudad Real, Tip. del Hospicio Provincial, 1912.

- RAMÍREZ DE LAS CASA DEZA, L.M. Colección de los autos generales y particulares de la Fe celebrados por el Tribunal de la Inquisición de Córdoba. Córdoba, 1836.

- RAMÍREZ DE LAS CASAS DEZA, L.M. Indicador Cordobés, León, 1976.

- RAMÍREZ DE LAS CASAS DEZA, L.M. Anales de la Ciudad de Córdoba, Córdoba, Editada por Real Academia. Impresa en Tipografía Artística, 1948.

- RAMIREZ I BENEYTO, Ramón. El compositor Josep Pons i el llenguatge musical per a la litúrgia de l' ordinarium: "Misa a 4 y a 8 con oboes, violines y trompas sobre la antífona ecce sacerdos magnus” (1786). Tesis doctoral. Valencia, Universidad de Valencia, Servicio de Publicaciones, 2005.

- RIFÉ i SANTALÓ, J. “Les obligacions del mestre de capella: Notes per a i’estudi deis mestres de capelia de la Seu d'Urgell a la primeria del segle XVIII”, Recerca musicológica, XIII (1998).

- RIFÉ i SANTALÓ, J. "Notes sobre el fons musical de l'Arxiu de la Catedral de Girona”, Congres de Musica a Catalunya: Llibre de actes del congres organizat pel Consell de la Musica, 1995, ps. 1113-1116.

- ROIG I CAPDEVILA, Jordi. "Presencia musical en la Catedral de la Seu d’Urgell en la segunda mitad del siglo XVIII a través de sus actas capitulares”. Anuario Musical, 59. Barcelona, Consejo Superior de Investigaciones Científicas, Institución “Milá i Fontanals”, Departamento de Musicología, 2004.

- ROSEN, Ch., El estilo clásico. Haydn, Mozart, Beethoven. Madrid: Alianza Editorial, 1986.

- RUBIO PIQUERAS, F. El archivo musical de la Catedral de Toledo. Tesoro Sacro Musical (1927, 1928, 1929). 
- RUBIO, Samuel. Historia de la música española desde el ars nova hasta 1600. Madrid, Alianza Editorial, Alianza Música, 1983.

- RUBIO, Samuel. La Polifonía Clásica. Madrid, Biblioteca La Ciudad de Dios, 1974.

- RUBIO, Samuel. El archivo de música de la catedral de Plasencia. Anuario Musical 5 (1950).

- RUBIO, Samuel. Catálogo del Archivo de Música del Monasterio de San Lorenzo del Escorial. Cuenca, Instituto de Música Religiosa, 1976.

- RUIZ IZQUIERDO, Julián y otros. Catálogo de libros manuscritos, incunables y de música. Zaragoza. Institución "Fernando el Católico", D.L. 1984

- SALAZAR, Adolfo. La música de España (2). Desde el siglo XVI a Manuel de Falla, Madrid: Espasa Calpe, 1972.

- SALDONI, B., Diccionario biográfico-bibliográfico de efemérides de músicos españoles, Madrid: Imprenta Pérez Dubrull. (1868-81).

- SANCHEZ MARMOL, Fernando. Andalucía Monumental. Granada, Biblioteca de la Cultura Andaluza, 1985.

- SANZ, $\mathrm{M}^{\mathrm{a}}$ Jesús. La Custodia Procesional. Enrique de Arfe y su escuela. Córdoba, Publicaciones Obra Social y Cultural Cajasur, 2000.

- SCHOMMER, Alberto Y VILLAR MOVELLÁN, Alberto. La búsqueda: la Mezquita de Córdoba. Córdoba: Caja Provincial de Ahorros de Córdoba, D.L. 1993.

- SEVILlANO, Justo. “Catálogo musical del archivo capitular de Tarazona”. Anuario Musical 16 (1961).

- SIERRA PÉREZ, José: La música del Archivo del Real Monasterio de Guadalupe. El Patrimonio Musical de Extremadura, Fundación Xavier de Salas, Madrid, 1993.

- $\quad$ SIMÓN SEGURA, F. La desamortización española del siglo XIX. Madrid, 1973.

- SISCART Montserrat y GONZALO Jesús. Catálogo del Archivo Musical de la Concatedral de San Pedro de Soria. Soria, Caja de Salamanca y Soria, 1992.

- SOBRINO SÁNCHEZ, R., "La música sinfónica en el siglo XIX”, en La música española en el siglo XIX, Oviedo: U. de Oviedo, 1995, Ps. 279-323. 
- SOBRINO SÁNCHEZ, R., "Un estudio de la prensa musical española en el siglo XIX: Vaciado científico e índices informáticos de la prensa musical española”, Revista de Musicología, XVI (6), (1993), Pgs. 3510-3518.

- SOlís RODRÍGUEZ, Carmelo. El Archivo Musical de la Catedral de Badajoz. Una aportación documental. El Patrimonio Musical de Extremadura, Fundación Xavier de Salas, Madrid, 1993.

- SUBIRÁ, José. "La música en la Real Capilla madrileña y en el Colegio de Cantorcicos: Apuntes históricos”. Anuario Musical 14 (1959).

- SUBIRÁ, José. "La música en la Capilla y Monasterio de las Descalzas Reales”. Anuario Musical 12 (1957).

- STEVENSON, Robert.: La música en las catedrales españolas del Siglo de Oro. Madrid, Alianza Editorial. 1993.

- STEVENSON, Robert: La música en la catedral de Sevilla. Madrid, Sociedad Española de Musicología, 1985.

- TEJERIZO ROBLES, Germán. Villancicos Barrocos en la Capilla Real de Granada. Sevilla, Junta de Andalucía, Consejería de Cultura, 1989.

- TORRE DE TRUJILLO, Lola de la. "El archivo de música de la Catedral de Las Palmas”. El Museo Canario 25/89-92 (1964), 26/93-96 (1965).

- TORRE MOLINA, Ma José de la. "Las constituciones de 1766 de la Capilla de Música de la Catedral de Málaga”. Revista de Musicología Vol. XXVIII. Madrid, Sociedad Española de Musicología, 2005.

- TRILlo, Joán y VILLANUEVA, Carlos. La música en la catedral de Tui. Diputación, 1987.

- TRILlO, Joám y VILLANUEVA, Carlos. "El Archivo de Música de la Catedral de Mondoñedo”. Publicaciones de Estudios Mindonienses 10 (1993).

- $\quad$ ULRICH, Michael, Atlas de Música. Madrid, Alianza Editorial, 1998.

- VALDEnebRO, José María. La imprenta en Córdoba. Edición facsimil. Córdoba, Diputación de Córdoba, Delegación de Cultura, 2002. (1 ${ }^{\text {a }}$ Edición, Madrid, Establecimiento Tipográfico “Sucesores de Rivadeneyra”, 1900).

- VÁZQUEZ LESMES, Rafael. "La Capilla de Música de la Catedral de Córdoba: apuntes para su historia”. Córdoba, Boletín de la Real Academia de Córdoba, 110. (1986). 
- VÁZQUEZ LESMES, Rafael. Córdoba y su Cabildo Catedralicio en la modernidad. Córdoba, Cajasur, 1987.

- VÁZQUEZ LESMES, Rafael. "El Colegio de Niños de Coro de la catedral de Córdoba: antecedentes, fundación y constituciones”. AA.VV. La Iglesia Española y las Instituciones de Caridad. Actas del Simposium organizado por el Instituto Escurialense de Investigaciones Históricas y Artísticas. El Escorial, Ediciones Escurialenses, 2006.

- VENTURA, José Manuel. Historia Ilustrada de Córdoba. Córdoba, Almuzara, 2005.

- VICENTE DELGADO, Alfonso de. La Música en el Monasterio de Santa Ana de Ávila (siglos XVI-XVIII). Sociedad Española de Musicología, 1989.

- VIDAL SALES, José Antonio. Crónica Íntima de las Reinas de España. Barcelona, Ed. Planeta, 2004.

- VILAR, J.M., "Els mestres de capella i els organistes de la Seu de Manresa durant el segle XVIII”, Anuario Musical vol. 42 (1987), ps. 111-129.

- VILAR, J.M., La Música a la Seu de Manresa en el s. XVIII. Monográfics, $n^{\circ} 5$. Manresa: Centre d’Estudis del Bages, 1990.

- VILlar MOVELlan, Alberto. La Catedral de Córdoba. Sevilla, Caja San Fernando, 2002.

- VILLAR MOVELLÁn, Alberto y otros. Córdoba, Arte. Córdoba, Caja Provincial de Ahorros de Córdoba. 1994.

- VIRGILI BLANQUET, M.A., "La música en la Guerra de Independencia: Una nueva fuente documental”, Revista de Musicología, XIV (1-2), (1991), Pgs. 51-61. 


\section{ANEXOS. APÉNDICE DOCUMENTAL. \\ DOCUMENTO №1. Sobre la visita de Carlos IV a Córdoba en 1796. ${ }^{1865}$ (extracto)}

“Con fecha de 18 de Diciembre de 1795 dirigió el Excmo. Señor Gobernador del Consejo al Señor Corregidor de esta Ciudad de Córdoba una orden en que le prevenía; que habiendo resuelto el Rey N. S. emprender su viage á la Ciudad de Sevilla, desde el Real Sitio de San Lorenzo, llevando en su compañía á la Reyna N. Sra. y á los Señores Príncipe de Asturias, Infante Don Antonio, y Príncipe de Parma, con las Señoras Infantas Doña Maria Amalia, y Doña María Luisa sus Esposas; y habiendo de transitar por Córdoba á su vuelta de Sevilla al Real Sitio de Aranjuez, le encargaba la composición de caminos \&c. En el Cabildo del 29 del mismo mes comunicó el Sr. Corregidor á la Ciudad dicha orden, y oída que fue, causó la más extraordinaria alegría no solo al Nobilísimo Ayuntamiento, si no también á todo el Pueblo, en que se esparció muy pronto la noticia.

Sus Magestades salieron del Escorial el día 4 de Enero de 1796. Vinieron por Extremadura, y deteniéndose algunos días en Badajoz, tuvieron el gusto de ver á su Augusta Hija la Sra. Doña Carlota Joaquina, Infanta de España, y Princesa del Brasil.

Era necesario crear una Diputación, compuesta de Señores Veinticuatros y Jurados, que con el Señor Corregidor dispusieran quanto tuvieran por conveniente, fueron nombrados los Señores, que declaran las siguientes notas, y se les dieron amplias facultades. El Sr. D. Josef de Eguiluz, dignísimo Corregidor de esta Ciudad, bien conocido en todo el Reyno por los elogios, que con tanta verdad y justicia da á su zelo, actividad y demás virtudes de un gran Magistrado, el célebre D. Antonio Pons en su Viage de España tomo 17 Cart. 5. num. 53. El Sr. D. Diego de León, Cavallero del Orden de Calatrava, Teniente Coronel de Milicias, Teniente Alguacil mayor del Nobilísimo Ayuntamiento de la Ciudad de Córdoba, con voz y voto de preeminencia y del Sto. Tribunal de la Inquisición de dicha Ciudad. Los Señores Veinticuatros D. Diego de Montesinos Fernandez de Vera, Señor de Villar-alto: D. Josef Muñoz y

\footnotetext{
${ }^{1865}$ LEAL, Fray Rafael. OBSEQUIOS DE CÓRDOBA A SUS REYES, o descripción de las demostraciones públicas de amor y lealtad que Córdoba tributó a nuestros Católicos Monarcas en los días 11, 12 y 13 de Marzo de 1796, en que la honraron con su augusta presencia. Córdoba, Imprenta de Juan Rodríguez de la Torre, 1796.
} 
Velasco, Cavallero del Orden de Calatrava, y Capitán del Regimiento de Milicias Provinciales de Córdoba: D. Rodrigo Fernández de Mesa y Argote, Cavallero Pensionista de la Real y Distinguida Orden de Carlos III; y D. Josef de Va1enzuela y Faxardo, Cavallero Pensionado de dicha Real y Distinguida Orden, Maestrante de la Real de Sevilla, Alguacil mayor perpetuo con voz, voto y asiento de preferencia de la Villa de Hornachuelos, y Capitán de Infanteria y del Regimiento Provincial de Córdoba. D. Francisco de Luna y D. Bernardo Carmona, Jurados.

En el Cabildo del día 2 de Febrero se presentó una proposición hecha por los Señores Diputados, en que se manifestaba quanto debía executarse en orden a adornos de la Ciudad, recibimiento y hospedage de sus Magestades, \&c. Todo fue aprobado por unánime consentimiento, y mandado executar.

La Ciudad pasó los oficios acostumbrados al Excmo. Sr. Arzobispo, Obispo de esta Diócesis; al Venerable Cabildo Eclesiástico, y al Santo Tribunal de la Inquisición, para que por su parte concurrieran á hacer mas solemnes las funciones de recibimiento, obsequios, \&c.

La Ciudad convocó a los Gremios, y les expuso la obligación que tenía todo vasallo de manifestar en esta ocasión su fidelidad y amor al Soberano. Todos se prestaron muy gustosos á tan justas insinuaciones. Se dio orden á varios Pueblos, para que á determinado tiempo acudieran á la Capital con provisiones de boca, y otros efectos, que se tuvo por conveniente encargarles. Se dispuso que se renovara el antepecho del Puente.

A principios de Marzo cayó abundante nieve, cosa muy rara en Córdoba, aún en el rigor del invierno. Las lluvias fueron muy continuas, y muy recias y copiosas las granizadas. Algunos días amanecieron los campos cubiertos de escarcha, y se experimento tal frió, que fue preciso encender lumbre en los aposentos.

El día 18 de Febrero hubo noticia cierta del feliz arribo de SS. MM. á la Ciudad de Sevilla y en conseqüencia acordó la Ciudad escribir á SS. MM. felicitándoles por este motivo. EL día 23 del mismo se leyó en Cabildo con gran satisfacción la contextacion del Excmo. Señor Príncipe de la Paz, en que de orden del Rey Nro. Sr. daba gracias á la Ciudad por tal demostración: y en Cabildo de 1 de Marzo, teniendo la Ciudad noticia deque SS. MM. Llegarían á Córdoba el día 11, determinó nombrar una Diputación, que saliera a cumplimentar á SS. MM. á la Carlota. En efecto a las 10 
de la mañana del día 10 de Marzo salió dicha Diputación de Córdoba, y llegó á la Carlota a las 12 del mismo día, y habiendo sabido que SS. MM. pararían en la Aldea de Quintana para mudar tiros, determinó pasar á dicho punto de apostadero, para tener el honor de cumplimentar á SS. MM., y ofrecerles las llaves de la Ciudad.

Los Diputados que salieron á cumplimentar á SS. MM fueron los Señores Don Diego de León, Don Josef Muñoz de Velasco, el Marques de Lendinez, y Don Rodrigo de Mesa, Veintiquatros: Don Bartolomé Velez, y Don Francisco de Luna, Jurados, presididos del Señor Don Luís de Herrera del Consejo de S. M. y Alcalde mayor primero de esta Ciudad. Estos con el acompañamiento del Escribano de Ayuntamiento Don Antonio Mariano Barroso, uno de sus Oficiales titulares, Portero mayor, y Agente, pasaron en varios Coches á la Aldea de Quintana el día 11. Como á 1as diez y media de la mañana llegaron los coches de SS. MM., AA., y Real Comitiva, y habiendo parado el coche en que venían SS. MM. inmediato á la Diputación, salió el Sr. Don Diego de León de su lugar, y haciendo tres reverentes demostraciones de acatamiento, se acercó al postigo derecho del coche y pronunció un breve discurso. Al mismo tiempo se ofrecieron á las Reales Plantas dos 11aves de plata, primorosamente trabajadas, en un azafate de la misma materia.

El día 11 en que llegaron SS. MM. á Córdoba, cesaron la lluvias, se disiparon las nubes, y abonó el tiempo. Sin embargo de la gran concurrencia de gente, que hubo en Córdoba en los días que permanecieron SS. MM. en ella, los comestibles estuvieron abundantísimos y más baratos que en otras ocasiones.

El Balcón de SS. MM. constaba de dos cuerpos de Arquitectura de orden Corintio. En los tafetanes de los clarines de las dos Famas, que coronaban este edificio, se leían varias inscripciones relativas al asunto.

En la Cruz del Rastro se figuraba un monte en cuya cima había una graciosa cúpula sostenida de varias columnas. En medio se representaba Mercurio sobre mi montón de vanderas, y de otros trofeos.

Las ventanas y balcones se adornaron de ricas y vistosas colgaduras. Los Músicos de los Regimientos de Córdoba, y de Milicias Provinciales formaban dos Orquestas á la entrada del Puente.

Las Milicias Provinciales estaban formadas en dos filas desde la Puerta del Puente, hasta la del Palacio Episcopal. 
A la hora del medio día entraron SS. MM. en Córdoba, entre alegres aclamaciones del Pueblo, y general repique de Campanas. Se apearon en el Pa1acio Episcopal, donde los recibió el Ayuntamiento, presidido por el Sr. Don Josef de Eguiluz, su Corregidor, y formado con sus Mazeros. Acabada la comida admitieron sus SS. MM. á besar sus Reales manos á la Ciudad, al Cabildo Eclesiástico con su Excmo. E Ilmo. Prelado, á todos los Gefes Militares, Títulos, y Caballeros particulares.

Había cinco orquestas de Música: la primera frente del Palacio Episcopal: la segunda en la Plaza Mayor: la tercera en las Casas Capitulares: la quarta en la Plazuela de S. Hypolito; y la quinta en el balcón de la Inquisición.

La Iluminación de la seria y magestuosa fachada de las Casas Capitulares se componía de doce mil luces, gran multitud de vasos de colores, y veinte arañas de crista1. En su distribución presentaban las luces á la vista pilastras, colgantes, y otros adornos arquitectónicos. Los balcones estaban adornados con cortinas carmesíes guarnecidas de flecos de p1ata. En el balcón principal se colocó un rico dosel de terciopelo carmesí, en medio del qual estaban bordadas las Armas de España Con oro, plata y sedas de diversos colores.

En la tarde del mismo día doce pasaron SS. MM. á visitar la Catedral: Templo, cuya grandiosidad y magnificencia prueban, que la Arquitectura Arábiga no era tan mezquina y grosera como comúnmente se piensa. En la Puerta llamada del Perdón recibió á SS. MM. el Excmo. é Ilmo. Señor Obispo con su Cabildo y Clero, según previene el Ceremonial en semejantes casos. La Música cantó el Te Deum Laudamus y debaxo del Palio fueron conducidas SS. MM. procesionalmente hasta el Altar mayor; y hecha oración al Santísimo, examinaron atentamente el Templo, y quanto hay en él digno de verse". [...] 


\section{DOCUMENTO $\mathrm{N}^{\circ} 2$. Ceremonial y manual de las preces, antífonas, himnos, salmos y oraciones que deben decirse en esta Santa Iglesia Catedral de Córdoba. (1805). ${ }^{1866}$ (extracto) (25 PRIMERAS NORMAS).}

\section{“INSTRUCCIÓN PRELIMINAR.}

El Maestro de Ceremonias, avisado que sea de haberse determinado en Cabildo alguna rogativa ó función particular y extraordinaria, tendrá cuidado de prevenir al Campanero, al Sacristán mayor, al Maestro de Capilla, al Sochantre, á los Capellanes y demás Ministros de la Iglesia, para que cada uno cumpla a con su obligación en la parte que le toque según los artículos siguientes.

\section{RÉGIMEN DE CAMPANAS.}

1. En la noche antecedente al día determinado para alguna rogativa se tocará á ella un quarto de hora antes de las Ánimas: al día siguiente se repetirá dicho toque, tanto por la mañana, como por la tarde, mientras se digan las preces y hagan las procesiones de rogativa acostumbradas, y que en este libro se expresarán.

2. Quando haya dos Misas por esta causa siempre deberá hacerse en la Conventual la señal para alzar acostumbrada.

3. En los días de primera y segunda clase no se tocara a rogativa por tarde, ni mañana, ni en la noche antecedente; pero sí en la noche del mismo día clásico.

4. Quando hubiere Misa Solemne con Santísimo manifiesto, se harán los repiques acostumbrados por espacio de media hora en la noche antecedente después de las Aves Marías: del mismo en el día siguiente por la mañana se repetirán al principiarse Nona para exponer á su Magestad, y después de la Misa para reservarlo; pero si en la Misa ya expresada no estuviere el Santísimo expuesto, no se harán estos repiques.

${ }^{1866}$ XIMENEZ Y HOYO, Manuel. Ceremonial y manual de las preces, antífonas, himnos, salmos y oraciones que deben decirse en esta Santa Iglesia Catedral de Córdoba. Córdoba, 1805. 
5. Quando por las tardes haya rogativa, se omitirá el toque correspondiente á la procesión de difuntos, que puede ocurrir por haber al día siguiente oficios ó anniversario.

6. Quando se hiciere fuera de la Iglesia alguna procesión de las que no se suponen en la tabla, se anticipará la Campana una hora si fuere por la mañana, y media solamente si ocurriere por la tarde. Pero si la procesión se dirigiere á alguna Iglesia de las acostumbradas, determinará el Cabildo lo conveniente sobre esto sin embargo de lo que va anotado en algunos capítulos de este libro.

7. En todas las procesiones del número antecedente asistirán las cruces parroquiales y por consiguiente se hará señal para ellas en el tiempo y modo acostumbrado.

8. Sobre los repiques y toques de rogativa, que deberán hacerse en procesiones de acción de gracias y otras, observará el Campanero lo que va prevenido en las notas respectivas de varios capítulos de este Ceremonial.

Nota:

Se suspenderá enteramente el toque de rogativa en los días de Rogaciones o Letanías generales, pues el de estas equivaldrá al de cualquiera otra rogativa con que ellas concurra, como asimismo se suspenderá por la tarde en los casos que expresan los números 28, 31, 32 y 33 de esta instrucción.

\section{ROGATIVA POR LAS MAÑNANAS}

9. Por la mañana, concluida la Misa Conventual, depondrán los Ministros sagrados la casulla y manipulos en el lado de la Epístola, y vistiendo el Preste pluvial del mismo color de la Misa que ha celebrado, se pondrán de rodillas en la primera grada del Altar: entonces se principiarán las preces que van apuntadas en sus lugares respectivos: y terminadas estas cantará de pie el Preste las oraciones que correspondan y con ellas se concluirá el oficio; pero en el día en que se cante la Misa solemne votiva por este objeto, se dirán solamente después de esta las citadas preces y oraciones, con lo demás que en su lugar se expresará. 


\section{ROGATIVA POR LAS TARDES}

10. Quando por la tarde hubiere rogativa, se hará después de completas procesión al Sagrario vestidos con ornamentos morados el Preste, Ministros y Acólitos que conduzcan la Cruz y los Ciriales. Allí estará el Santísimo manifiesto, y se procederá cantando la Veintena el salmo Miserere según costumbre; pero si acaso se anotare ó previniere expresamente en alguno de los capítulos de este libro, se dirán en lugar de este salmo las letanías de los Santos, con arreglo a la doctrina del capítulo 1.

11. Inmediatamente que lleguen los Ministros sagrados a la ínfima grada del altar dentro de las verjas, se arrodillarán, hasta que concluido el salmo ó las letanías, se principien las preces del modo que se anotará. Entonces, el Preste de pie con los Ministros pondrá incienso, sin bendición, ministrándoselo el Diácono, e incensaría Santísimo more sólito: se continuarán y concluirán las preces y oraciones, y después cantará la Capilla de Música con bajones y obúes el motete O vere Deus.

12. En seguida se dirigirá la procesión á la Capilla de Nuestra Señora de Villaviciosa, sin reservar al Santísimo; cuya diligencia queda cargo de los Ministros del Sagrario: y siendo de rubrica terminante, que en las rogativas no se digan himnos, ni cánticos de alegría, sino salmos penitenciales ó graduales, deberá la Capilla de Música, alternando con la Veintena, cantar en tono grave y pausado en el transito desde el Sagrario a Villaviciosa el Salmo Domine, nein furore tuo que en su lugar se anotará. Luego que la procesión haya llegado á la nave de dicha Capilla, el Cabildo y Clero quedarán en el plano de ella, y subirá al altar de Nuestra Señora el Preste con los Ministros: en donde colocada la Cruz y Reliquias que estos acostumbran llevar; pondrá aquel incienso con bendición, e incensará el Altar con asistencia de los Ministros more sólito: entre tanto se cantará abaxo por los Músicos Sub tuum presidium \&c. lo que concluido, y dicho por dos Seises el v. de la Virgen, cantará el Preste la oración Concedere \&c.

13. De allí seguirá la procesión al Altar mayor por los postigos del Coro, cantándose por la Veintena las antífonas de San Rafael, Santiago y Santos Patronos: el 
Preste con los Ministros subirá hasta la ínfima grada de aquel, donde concluidas las antífonas, y dichos por dos Seises los vv. correspondientes, cantará sus tres oraciones con terminación breve, y todo se concluirá. = Durante este acto deberá el Cabildo y Clero estar de rodillas en el Coro, como acaba de practicarlo delante de Villaviciosa.

14. De este modo se continuará la rogativa por espacio de nueve días, con las interrupciones y modificaciones que se expresarán en los números 28 y siguientes de esta Instrucción.

\section{MISAS SOLEMNES DE ROGATIVA.}

15. En uno de estos nueve días, á saber, en el primero que estubiere desocupado, ó no impedido, se cantará una Misa solemne votiva después de Nona con todo el aparato de primera clase, como asimismo con las Imágenes de Nuestra Señora de Villaviciosa y San Rafael en los costados del Altar, estando manifiesto Santísimo, que se expondrá inmediatamente antes de la dicha Misa, del modo que se previene en el Apéndice al cap. 38.

16. Si esta Misa fuere de la Virgen ú otra festiva, se cantará con instrumentos: se dirán en ella Gloria y Credo: se añadirá á la oración principal, que le corresponda, la de la necesidad que se padezca, debaxo de distinta conclusión, incluyendo, en ésta la oración del Santísimo por hallarse expuesto: y se le dará el Prefacio propio, si lo tiene, ó el de la infraoctava, si en alguna ocurriere, ó el del tiempo en que se celebrare, ó el común por último, con los ornamentos correspondientes. Finalmente, si esta Misa, siendo de la Virgen, se cantáre en alguna octava suya, no será la del tiempo, sino la principal de la fiesta la que se celebre.

17. Después de esta Misa vestirá el Preste capa pluvial, \&c. como queda expresado en el número 9: dirá las preces y oraciones, inclusas las del Santísimo por hallarse expuesto, y las de Nuestra Señora y San Rafael, por estar sus Imágenes en el Altar según costumbre: concluidas dichas preces, cantará la Capilla de Música el motete Ó vere Deus. =. En éste día no habrá procesión de rogativa al Sagrario, ni otra cosa perteneciente á ella. 
18. En seguida cantará la dicha Capilla de Música Tantum ergo Sacramentum: el Preste de pie con los Ministros pondrá incienso sin bendición, é incensará arrodillado al Santísimo more sólito: dos Seises dirán de rodillas el v. Panen de coelo: dicho Preste solo de pie cantará el v. y oración correspondientes y se reservará al. Señor, con arreglo en todo á lo que se previene en el Apendix al cap. 38.

19. Pero si la Misa, según Rubricas, Acuerdos del Cabildo, y costumbre mas antigua de esta Iglesia, fuere de aquellas que están al fin del Misal para el tiempo de rogativa, y se expresará en los capítulos respectivos de éste libro, se celebrará con ornamentos morados: se cantará á dos coros sin instrumentos: no tendrá Gloria; ni Credo, sino ocurriere en Domingo: se le dará una oración, uniendo á ella, baxo de una conclusión, la del Santísimo por hallarse expuesto: se dirá el Prefacio que se expresa en el número 16: y después de ella se hará lo que va anotado en el número siguiente.

20. Concluida la Misa deberá pasar el Preste con los Ministros aliado de la Epístola, donde depuesta la casulla y los tres manipulos, vestirá aquel el pluvial morado correspondiente, y se practicará quanto queda anotado en los núm. 17 y 18. = Exceptuanse los casos en que se diga la Misa pro eligendo Summo Pontífice; pues en éstos se observará en un todo lo prevenido en los números 16 y 17.

21. Pero quando el Señor Obispo asista en el Coro, y suba á decir las preces en el Altar mayor, no será necesario que los Ministros sagrados pasen al lado de la Epistola para vestir el pluvial y deponer los manipulos, pues S.I. hará en todos estos casos las veces del Preste en la reservación del Señor.

\section{MISAS SOLEMNES DE ACCIÓN DE GRACIAS.}

22. En aquellos días en que con arreglo á rubrica se hubiere de cantar Misa solemne votiva de acción de gracias, será también con Santísimo manifiesto: se dirá una oración, á la que se añadirá baxo de una conclusión la de acción de gracias, que se halla en el Misal Romano después de la Misa de Sanctissinia Trinitate, y la conmemoración del Santísimo después, baxo de la misma conclusión , con todo lo 
demás que se expresa en los números 15 y 16, solamente con la excepción de no decirse el motete Ó vere Deus.

23. Después de dicha Misa se cantará el Te Deum por costumbre antigua de esta Iglesia, y deberá ser del modo siguiente: pasaran los Ministros sagrados al lado de la Epístola, donde depuesta la casulla y los tres manipulos, vestirá el Preste capa pluvial del mismo color del ornamento con que haya celebrado, y puesto con dichos Ministros de pie en la segunda grada del Altar entonará el citado himno, y continuará sin arrodillarse rezándolo con ellos, mientras se canta por la Capilla de Música: en seguida se dirán las preces que en su lugar van anotadas, y se reservará al Santísimo según se previene en el número 18. Es de advertir que en el Coro deberán todos estar de pie durante dicho himno, así como los Ministros sagrados lo executan en el Altar, según esta declarado por la Sagrada Congregación de Ritos en 27 de Marzo de 1779.

24. Si esta Misa se cantáre en otra Iglesia, donde no estubiere expuesto el Santísimo, siempre que se exponga y reserve, será con arreglo a lo que va dicho en los números 15 y 18: y si asistiese el Señor Obispo se observará en los casos de este número y del antecedente respectivamente lo mismo que va anotado en el número 21.

25. Para celebrar estas Misas solemnes votivas ya expresadas en los dos artículos que anteceden, se convidarán por el Maestro de Ceremonias tres Señores, Dignidad, Canónigo y Racionero entero más antiguo según costumbre”. 


\section{DOCUMENTO $\mathrm{N}^{\circ} 3$. Sobre los abusos que se producen en el canto durante las procesiones. ${ }^{1867}$}

“Cabildo pleno extraordinario sábado $1^{\circ}$ de diciembre de 1.810 después de oficios. En este día los señores Deán y Cabildo, dignidades, canónigos, racioneros enteros y medios, in sacris constituidos juntos y congregados en la Capilla del Exmo. Sr. Salazar, donde por ahora acostumbran celebrar sus Cabildos, citados ante diem por el Sr. Pertiguero, acordamos lo siguiente:

A virtud del llamamiento para oír el informe de los señores Diputados de Ceremonias sobre varios puntos, que se les habían comisionado en el Cabildo último de reformación, se leyó a dicho informe separadamente y por artículos, según venia dispuesto y su tener esa como sigue = En cumplimiento de la comisión que V.S. nos dio para que le informásemos sobre varios puntos en el Cabildo de reformación del martes 6 de noviembre último, hemos creído deberlo hacer con individual separación según aparece de los artículos siguientes, a fin de que pueda V.S. acordar y resolver sobre cada uno de ellos separadamente, y por su respectivo orden, para evitar toda confusión.

Artículo $1^{\circ}=$ sobre los abusos que hay en el canto en las procesiones que salen fuera de la Iglesia $=$

Las grandes pausas ó interrupciones, que se observan, y se han introducido por la desidia de los Cantores entre verso y verso, quando se cantan los himnos y salmos, prescritos para estas procesiones, son seguramente un abuso, que no puede cohonestarse, ni por el cansancio, que es consiguiente a las circunstancias en que se canta, ni por la solemnidad de las procesiones dichas. Las pausas moderadas en la alternación del canto, así como son consiguientes a la solemnidad de éste, conducen también en ánimos y circunstancias devotas a elevar y enfervorizar mas el espíritu; pero si aquellas son excesivas con extremo, y por otra parte la ocasión es muy expuesta a distracciones, sobre ser contrarias a la continuación del rezo, prescrita por las Rúbricas, inducen a la indevoción, y son causa de que la imaginación y la lengua se extravíen, para incurrir en los defectos más notables. Tales son las pausas que notamos

1867 A.C.C. Actas Capitulares. Sábado 1 de Diciembre de 1810. T. 100. 
en el canto de las procesiones que salen a la calle; y tales son las circunstancias, y los efectos que se resultan. Quando se alterna con un verso, apenas queda memoria del anterior; y si todos no van expuestos á equivocar por el olvido el que toca á corresponde, á lo menos los que no oyen la entonación del sochantre por su distancia, apenas aciertan ó no cantan. Entre tanto abundan las conversaciones y corrillos, y entre verso y verso hay una continuada distracción, á que convida la variedad de objetos en las calles. No se guarda ceremonia; no hay la moderación que corresponde, y la falta de silencio cada día es más notable. Para remediar en parte estos excesos, conviene contar aquel abuso, que, como va dicho, no se puede cohonestar. Antiguamente se cantaban las letanías en estas procesiones, y aunque el sochantre llevaba un continuado y principal trabajo, no se observaban semejantes pausas. Las circunstancias y la solemnidad eran las mismas; por la calle se cantaba como ahora, y sin embargo el canto se alternaba continuadamente, y no había tanta conversación. No tiene duda, que el cantar andando, y por un piso desigual, como es la calle, molesta y cansa mucho; pero no por eso las pausas ó descansos han de llegar hasta un extremo reparable, como el que se nota. También es cierto, que es muy opuesto á la majestad y gravedad de una procesión solemne la precipitación o ligereza casi no interrumpida en el canto de sus preces; pero este es un extremo vicioso, en que no es necesario incurrir, así como lo es la pausa inmoderada y excesiva, que lejos de contribuir á la solemnidad dicha, la reforma, ocasionando los defectos ya indicados. Para conciliarlo todo somos de parecer, que V.S. debe acordar, que las dichas pausas deben moderarse, y que no haya más interrupción entre verso y verso, que la que se acostumbra en el caso de los día de $1^{a}$ clase; y que para su execución hagamos saber este acuerdo los Diputados de V.S. al sochantre y al Maestro de Capilla, encargándoles estrechamente su observancia, como de quién depende inmediatamente este abuso y su reforma, y haciéndoles responsables de la omisión o descuido que se note en dicha alternación del canto en los himnos y salmos, que respectivamente toquen á la veintena y á la Capilla.

Otro abuso se ha introducido en el canto del Te Deum, que se dice en las mismas procesiones y es no cantarse nada por la Capilla ni por nadie, quando toca el verso de la música: los instrumentos solos son los que suplen, y el citado himno por consiguiente se dice ó canta a medias. Esto es tan claramente deparable y defectuoso, que no es necesario detenerse á demostrarlo. Es verdad, que quando se canta el Te 
Deum en el coro en el órgano, no se canta el $2^{\circ}$, que tocar éste; pero hay una voz, que lo dice en alto, y suple por el coro. En las Procesiones dichas no hay este arbitrio, ni conviene adoptarlo. Un medio sencillo y fácil es el que debe ponerse en execución; y es, que el Maestro de Capilla componga una música sencilla para los versos del Te Deum que corresponden a la Capilla en su alternación con la veintena, y que ésta música sea proporcionada y respectiva al Canto Llano, en que está apuntado el otro himno en los nuevos libretes, destinados al efecto; repartiendo los competentes papeles a los músicos y llevando el compás en otras ocasiones, como lo lleva, y ha llevado en otras equivalentes o semejantes. Con esto cantarán los músicos; irán unidos al Maestro, como les está prevenido, se observará nuestro ceremonial sobre el canto de este himno en estos casos, y se ahorrarán muchas conversaciones. Igual comisión que la anterior podrá V.S. dar a sus Diputados de Ceremonias, y sobre todo lo otro acordará, lo que mejor parezca. $==$

Oído este primer artículo del informe, se conferenció sobre los dos puntos, que contiene; y no convenidos los pareceres, se procedió a la votación por pelotas, de la cual, executadas separadamente. Sobre ambos puntos, resultó por mayoría de votos el acuerdo del Cabildo, por el cual se conformó éste con el otro informe en todas sus partes; y dio comisión a los mismos S.S. para que hagan saber este acuerdo al sochantre y al Maestro de Capilla, a fin de que cuiden de evitar, y eviten las pausas inmoderadas en el canto de las dichas preces, sin que haya más interrupción entre verso y verso de ellas, que la que se acostumbra en el coro en los días de $1^{a}$ clase; y para que el expresado Maestro componga una música sencilla para los versos del Te Deum, que ahora solamente tocan los instrumentos, en la forma y modo, que se explica en dicho informe; con los demás, que éste previene”. 


\title{
DOCUMENTO Nº4. El Colegio de Infantes de Córdoba.
}

\author{
A) Constituciones del Colegio de Infantes. ${ }^{1868}$
}

\section{NOTICIA DE ESTA FUNDACIÓN}

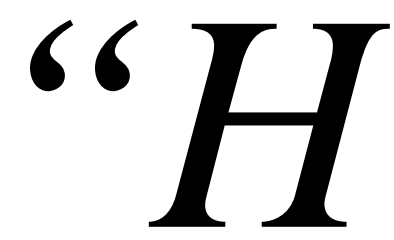

avia muchos años, que subcesivamente reynaba en los individuos de este Ilustrísimo Cabildo, el piadoso deseo, de que se erigiese un Colegio, para la mejor educación, y enseñanza de los Niños, que sirven el Coro de su Santa Iglesia, viendo con summo dolor, que la libertad de vivir en sus Casas, los tenìa expuestos à un lastimoso abandono, à la relaxación de costumbres, è ignorancia de las principales instrucciones, que les son debidas, y útiles. Frustrada (aunque por otro santo fin) la fundación de semejante Colegio, empezada à hacer por el Eminentísimo Señor Cardenal Salazar, Obispo que fue de esta Ciudad, continuò el zeloso ánimo de los Capitulares, promoviendo de tiempo en tiempo esta pia, y decorosa idea. Llegò al fin el día tan deseado de lograrla: este fue el DIA diez y siete de Abril del año pasado de mil setecientos sesenta y nueve, en que junto el Cabildo, à que precedió llamamiento ante diem, y oydo un difuso, y bien fundado informe de diferentes Señores Capitulares, à quienes havia comisionado, para que trabajasen este asunto, acordó votado por votos verbales, y también secretos, nemine discrepante, que se fundase este Colegio, para dicho fin, con el titulo del SANTO ÁNGEL DE LA GUARDA; tan digno, y propio para educación de Niños, y mas de estos, que inmemorialmente han estado baxo su protección, y cuidando de su culto; y con todas las demás circunstancias, y cosas expuestas en dicho informe, y constan puntualmente de el Auto Capitular de aquel DIA; mandando así mismo, que los mismo Señores comisionados, fuesen trayendo al Cabildo, con llamamiento, todos los particulares, que sobre este mismo asunto se fuesen ofreciendo, hasta su conclusión perfecta; y juntamente, que pasasen à verse con el Ilustrisimo Señor Don Martín de Barcia, nuestro Prelado, (que de Dios goze) à darle quenta, de parte del Cabildo, de haverse tratado, y efectuado esta fundación, tan digna de su agrado, y santo zelo; y pedirle (para quando llegase à estado) su licencia, è

${ }^{1868}$ A.C.C. Obras Pías. Caja No534. 
interposición de su jurisdicción ordinaria para la erección. Por el orden, y celebración de Cabildos respectivos, el de Señores Dignidades, y Canónigos, y el de Señores Canónigos con la parte de su Ilustrísima unieron sus acuerdos, y facultades à este pensamiento, teniéndolo por de reciproco interés, con aquella exemplar buena correspondencia, con que siempre tratan los negocios entre sì estos tres Cuerpos, como resulta de los acuerdos correspondientes de quince de Abril de dicho año, y circunstancias de ellos; à cuyos respectivos sufragios echò Dios su bendición, de forma, que los primeros fundamentos de esta obra, aparecieron ya edificio perfecto, con Casa muy grande, y commoda, Capilla muy bella, y rentas suficientes para su manutención anual, con que dotaron perpetuamente este Colegio dichos Cabildos, como mas largamente consta en sus Autos Capitulares yà citados; y para que se lograsen desde luego los efectos útiles de esta pia resolución, muchos Señores Capitulares, con exemplar zelo, hicieron efectivas cantidades de dinero, que formaron un fondo de cinquenta mil reales vellòn, con que se reparò la Casa, se le proveyò de las ropas, menajes, utensilios, y demàs necesario; à que se agregaron algunos Ornamentos Sagrados, pinturas, y varias cosas, dadas por otros Señores Capitulares.

En este estado (è interin que se evacuaban las diligencias judiciales, que de acuerdo con nuestro Ilustrisimo Prelado, empezaban à dirigir à su Tribunal de Justicia dichos Señores Comisionados, al expresado fin, de obtener la licencia para la erección) determinò el Cabildo, en el celebrado el día veinte y uno de Febrero del año pasado de mil setecientos setenta, que se estableciesen en el Colegio de los Infantes en numero de doce, con Maestro, y sirvientes, gobernándose por entonces, como Casa particular de enseñanza; y con efecto se fueron à vivir à ella en el veinte y siete siguiente.

Ya estaban en este tiempo formadas por los Señores Comisionados estas Constituciones para la mejor administración, y régimen del Colegio, teniendo presentes las de los Infantes, fundado en Toledo por el Eminentísimo Señor Cardenal Siliceo, para el servicio del Coro de aquella Santa Iglesia Metropolitana; las de los Colegios de otras Santas Iglesias, y los estatutos de esta, en los lugares que tratan de estos Niños; las que con efecto havian sido aprobadas, y mandadas guardar por el Cabildo en el que se celebrò pleno Lunes veinte y tres de Octubre de mil setecientos sesenta y nueve, à hora de sexta ; ordenando también, que se pusiese un exemplar de ellas en su Archivo, 
y otro en la Oficina de Obras pías de su Patronato, à las que desde luego agregó este Colegio, y su administración.

Una enfermedad summamente prolongada, y grave de nuestro Ilustrisimo Prelado, que al fin le quitò lastimosamente la vida, el Sábado veinte y dos de Junio de este año de setenta y uno, con universal sentimiento, tuvo detenido el curso de los Autos de erección; y siguiéndose la vacante del Obispado, en cuya jurisdicción ordinaria subcediò el Cabildo de Señores Canónigos, fue necesario al pleno, mandar seguir ante el Señor Provisor General, Sede Episcopali Vacante, las dichas diligencias judiciales empezadas, y con efecto continuò su comisión à los dos mismos Señores antes comisionados à este fin. Conclusas con efecto, y con Audiencia del Fiscal, puso el Señor Provisor General su Auto de aprobación, y confirmación de la fundación de este Colegio, con el titulo del SANTO ÁNGEL DE LA GUARDA, y sus Constituciones, declarando à el Ilustrísimo Señor Deán, y Cabildo pleno por Patrono, y Administrador

perpetuo de èl, interponiendo su autoridad, y judicial Decreto con fecha de tres de Septiembre de este mismo año de setenta y uno; y en el Cabildo celebrado en el siguiente día quatro, le dieron quenta dichos Señores de estar evaquadas perfectamente todas las diligencias judiciales. En vista de lo qual, y no estando distante el día dos de Octubre, fiesta del SANTO ÁNGEL DE LA GUARDA, día tan propio, como ser el Titular de la Casa, mandò el Cabildo, que en èl se vistiesen las Becas à los Infantes, y se empezase en toda formalidad el régimen de este Colegio, y observancia de sus Constituciones, que son las siguientes.

\section{CONSTITUCIONES}

\section{(I)Titulo de este Colegio}

Este Colegio se ha de titular del ÁNGEL DE LA GUARDA, baxo cuya alta protección estubieron inmemorialmente los que el Estatuto de esta Santa Iglesia nombra Mozos de Coro, y yà se llamaràn Infantes, y los que inmemorialmente han tenido en ella Altar dedicado à este Santo Ángel, cuidando de su culto, y haciéndole en èl fiesta annual, el día dos de Octubre.

(2) Patronato, y Administración. 
Es Patrono de este Colegio el Ilustrísimo Deán, y Cabildo pleno de esta Santa Iglesia, y su administración ha de correr à cargo de sus Diputados de Obras pìas, como de las demàs de su Patronato; y del mismo modo que las otras, llevando al Cabildo cada dos años las quentas para su aprobación, y dar las providencias convenientes.

\section{(3) Señores Diputados}

Los dos Señores Diputados, que annualmente nombra el Cabildo, à quienes comete qualquiera cosa perteneciente à estos Niños, y à los Acólitos, seràn Diputados de este Colegio, y serà de su cargo, pasar à verlos algunas veces entre año, para saber, si se observan estas Constituciones, y todo aquel orden conveniente à su dirección, respectivas aplicaciones, y puntual asistencia de sus Maestros. También verán, y firmarán el quaderno del gasto mensual ordinario, y extraordinario, que formarà, y les pasarà el Rector, para que con esta precisa formalidad, sea satisfecho de su importe por los Señores Diputados de Obras pìas.

(4) Numero de individuos, y sus nombramientos.

Por ahora, y mientras son mas las rentas de este Colegio, con que pueda el Cabildo estender las facultades, que para este caso dexa reservadas, seràn solamente sus individuos los siguientes: un Rector Sacerdote, de aprobadas costumbres, y conducta prudente, el qual serà nombrado por el Cabildo pleno. Doce Infantes, de los quales ha de nombrar el mismo Cabildo pleno los seis, y los otros seis el Cabildo de Señores Deán, y Canónigos con la parte de su Ilustrísima nuestro Prelado, cada qual con respeto à la que tienen en esta fundación: igualándose por esto en las primeras vacantes, que haya el numero de seis, y seis, correspondiente à cada Cabildo; y si acaeciere la precisa expulsión de algún Infante, la determinarà el Cabildo, que lo nombrò, en el modo que los Estatutos, y Bulas de anexión lo disponen. Y para servir el Colegio, habrà un Portero, un Mandadero, y un Cocinero, los quales seràn recibidos, $y$ despedidos, por noticia que dè el Rector à los Señores Diputados.

(5) Maestros para su instrucción

Hasta que aumentadas las rentas de este Colegio, pueda nombrarse un Maestro de Canto Llano, lo serà el mismo Rector, que por esta razón gozarà el situado de los 
doscientos treinta y cinco reales ocho maravedis vellòn, y veinte y quatro fanegas de trigo, que annualmente paga la Mesa Capitular; y así serà de su cargo (à màs de lo que se expresarà en la Constitución, que habla de èl) dar à los Infantes lección de Canto Llano, y demàs canturìas de Coro. También tendràn por Maestro de Canto de Órgano, al que nombra el Cabildo, y le estàn situados en los excusados de Música doscientos veinte reales vellòn, y doce fanegas de trigo; y el que ahora mas que antes, deberà ser muy diestro en la música, y en el buen estilo de cantar, para que adelanten en uno, y otro à los Infantes, hasta hacerse utiles al Coro, y a sí mismos. Y si también fuese compositor, les darà lección de ella, à los que convenga, que la aprehendan: pero si no lo fuese, los Señores Diputados dispondràn, quien de la Capilla de Música lo haga. De algún tiempo à esta parte, y con esta mira quando se ha recibido algún Instrumentista para la Capilla de Música por qualquiera de los Cabildos, se le ha impuesto la obligación de dar lección de èl à qualquier Niño de Coro, que se inclinase à aprehenderlo: en virtud de la qual, ò imponiéndosela ahora à qualquiera de ellos, en cuyo titulo no conste, el Rector citarà con orden de los Señores Diputados à aquellos que los Infantes necesiten para esta instrucción. Para que los Infantes aprendan la lengua latina, acudiràn à oirà el Catedrático de latinidad: y si se consiguiere de su Ilustrísima, que esta se establezca en este Colegio, lo lograràn mejor; para cuyo caso estàn dispuestas en èl Clases commodas, y con manejo exterior, para que también puedan entrar, y salir libremente los Estudiantes extraños. Finalmente, porque suele suceder, que quando son recibidos estos Niños, estàn à un muy tiernos en leer, y escribir, no obstante que se les examina en uno, y otro según el Estatuto, cuidarà el Rector, que haviendo algunos que lo necesiten, vaya al Colegio algún Maestro, que les dè lección, dándole algún estipendio, que pondrà en el quaderno mensual del gasto, para que tengan los Señores Diputados noticia de esto.

\section{(6) Traxe de los infantes}

Dentro del Colegio usaràn los Infantes de un Balandràn de paño obscuro, que les sirva de decencia, y abrigo; para asistir al Coro vestiràn mantos, y bonetes encarnados, y sobre el manto sobrepelliz, à excepción de las octavas, en que se vestiràn los ocho que elija el Rector, de Baqueros, y sombreros, como hasta aquí. Para salir à la 
calle sobre el manto encarnado usaràn de Becas azules, y de los mismos bonetes encarnados.

\section{(7) Altar del Santo Ángel}

Siempre dedicaron estos Niños sus cultos à su Ángel Protector de la Guarda en el altar que tiene en esta Santa Iglesia, haviendole hecho Retablo dorado, Lámpara de plata, y Ornamentos; y celebrándole en èl muchas Misas Rezadas, y la fiesta annua con Misa Cantada, Sermòn, y Música el DIA dos de Octubre; y del mismo modo continuarà devoción tan laudable, dirigiéndola el Rector.

(8) Rector, y su cargo

El Rector, como cabeza del Colegio lo gobernarà con el zelo, y conducta prudente que pide la buena crianza, y utiles aplicaciones de unos Niños, que haviendo de llegar à Jóvenes en esta Casa, pasan en ella estas dos edades, en que se forma el carácter feliz, ò desgraciado de los hombres. Por tanto su empeño principal ha de ser, engendrar en ellos unos sentimientos, dignos de un cristiano, y de los que han de ser Ministros de la Iglesia. A la economìa de la Casa ha de ser muy aplicado, conservando siempre en su poder las llaves de los Comestibles, y de la Roperìa, y hallándose presente, quando haya que sacar, ò entrar qualquier cosa de estas Oficinas: y asimismo proveyéndose en los tiempos oportunos de los géneros necesarios para el consumo, con noticia de los Señores Diputados, à quienes embiarà el quaderno de la quenta mensual, comprehensivo del gasto ordinario, y extraordinario, para que le firmen, y cobrar su importancia, como se ha dicho en la Constitución tercera. Cuidarà con grande atención de que los sirvientes del Colegio, no solamente no perbiertan en malas costumbres à los Infantes, ni introduzcan en ellos el vicio del tabaco de humo, sino que los traten con mucha cortesìa, sin abusar de las licencias, que crean, darles la desigualdad de edades. $Y$ para sus ausencias, y enfermedades, nombrarà al Infante de mejor juicio, y conducta con el nombre de Vice-Rector.

(9) Distribuciones de tiempo

Cada mes confesaràn, y comulgaràn en la Capilla, precediendo la noche antes examen general de la Doctrina Cristiana, y algunas advertencias devotas sobre los 
Sacramentos, que han de recibir, y como deben recibirlos. Todo el año se lebantaràn por la mañana hora, y media antes de empezar la Campana, excepto los días, por cuyas festividades se adelanta demasiado; siendo llamados rato antes por el mandadero con el toque de una campanilla de mano. Antes de empezarse à vestir, se persignarà cada uno, y dirà el versículo: Dignare Domine die isto sine peccato nos custodire; y la oración: Domine Deus Omnipotens, qui ad principium bujus diei, Vestidos concurriràn todos, à labarse, y peinarse al quarto destinado para esto: desde allí iràn inmediatamente à la Capilla à la Misa, que oiràn de rodillas, y muy devotamente. Acabada, al Refectorio, à desayunarse; y hecho esto empezarà el estudio, que à cada Infante le tenga designado el Rector, principalmente el repaso de la Kalenda, que se ha de cantar aquel día, de los versículos, y demàs cosas del Coro. Al toque de la media de la Campana de la Catedral en punto concurriràn todos al quarto del vestuario, en donde se pondràn los mantos, y sobrepellices, y tomaràn los vonetes, y puestos en orden los llevarà el Rector à la Catedral ante sì de dos en dos, y del mismo modo volveràn. Quando lleguen al Coro, hincados de rodillas rezaràn una Estación al Santísimo, y luego prepararà cada uno las cosas de su ministerio. En estos actos, y los demás que exerzan en la Iglesia, y quando salgan à la calle de Beca, mantendràn una compostura muy modesta, y en el Coro la misma con mucho silencio, y las manos juntas sobre el pecho, cubiertas con el vonete, se pararàn à qualquier Señor Capitular, que pase por delante, ò qualquier Capellan del Coro, especialmente si es Sacerdote. En este, y los días en que asisten en èl los Colegiales de San Pelagio, nada innovaràn de las practicas, y costumbres que ha havido siempre respecto de ellos. Empezada Prima en el Coro destinarà el Rector los Infantes que asistan en la Capilla de la Concepción, y al Punto de las Misas, y esto ultimo, hasta que (como se piensa por el Cabildo) se encomiende à otros, para que quede mas numero en el Coro, y no se distraigan con este motivo. También estarán prontos à vestirse quando no haya el preciso numero de Acólitos, y lo mande el Señor Deán, ò Presidente, como se ha hecho hasta ahora, poniéndose Sotana azul. Bueltos al Colegio con el mismo orden, observaràn las distribución, que para sus estudios respectivos les tenga hecha el Rector, y este velarà sobre su aplicación, y adelantamientos. Tocadas las once, y media en todo tiempo, se les permitirà un quarto de hora de recreación, y à las doce menos quarto al toque de Campana se labaràn las manos, y entraràn à comer al Refectorio: en pie por sus 
antigüedades, y precedidos del Rector, darà este la bendición, y eligiendo alguno que lea algún libro devoto, mientras comen, lo haràn los demás con aseo, y silencio, siendo servida la mesa por el mandadero, y la lección de un día en cada mes serà estas Constituciones. Acabada la comida, daràn gracias, y volveràn à labarse, y permitiéndoseles algún corto rato de recreación, tomaràn siesta por aquel tiempo, que según sea la estación, pareciere al Rector conveniente. Tocada la media de la Campana por la tarde, volveràn à asearse, y vestirse, y por el orden mismo, que por la mañana, iràn à la Catedral, y asistiràn al Coro. Acabado este, volveràn del mismo modo al Colegio, quedándose dos al Rosario de los Señores en nuestra Señora de Villa-Viciosa, que zelarà el Rector no se detengan en la Iglesia luego que se acabe. En el resto de la tarde proseguirà la distribución de estudios respectivos à cada Infante, hasta que empiece la Campana de Maytines, que se les darà de merendar, y pasaràn à la Catedral los dos, que han de asistir à ellos; para su vuelta, por ser de noche, irà con tiempo el Portero à venirlos acompañando con un farol; dada la oración proseguiràn sus estudios, y al toque de las animas en todo tiempo se juntaràn en la Capilla à rezar el Santo Rosario, que acabaràn cantando el Sub tum presidium, la Antífona del SANTO ÁNGEL DE LA GUARDA: Sancti Angeli Custodes nostri, sus versículos Ora pro nobis, in conspectu, y las oraciones por el Rector. Desde allì pasaràn al Refectorio à cenar; lo haràn del mismo modo que comieron, y dadas gracias, se les concederà el tiempo conveniente para recreación, después tocara la campana à silencio, y se retiraràn à dormir. Además de las dichas distribuciones, haràn como siempre se ha practicado la asistencia à las funciones del Sagrario, la de las Capillas de la Catedral, y todas las demás que estos Niños han acostumbrado, aunque aquí no se expresen, excepto el oficio de candela, que por la decencia, aseo, y daño en su salud, cesarà en los Infantes, haciéndolo el Portero del Colegio, como se dirà entre sus obligaciones.

\section{(10) Jabardo}

Siempre que haya numero de Infantes competente, para formar el Ramo de Música, que llaman Jabardo, serà conveniente, que lo formen, porque así se hacen à cantar, y tocar instrumentos en pùblico, y se perfeccionaràn en uno, y otro. Probadas las obras en la Capilla à satisfacción del Rector, y Maestros, iràn en las horas en que no hagan falta en el Coro à las fiestas à que el Rector los embíe, y haya ajustado, 
acompañados del Maestro de Música, ò el de Canto Llano, ò en caso preciso del mismo Rector: pero nunca fuera de Córdoba, porque serìa perbertirse con la libertad del viage, y diversiones de los lugares à que fuesen. El producto de estas fiestas (dada la correspondiente parte al Maestro, que acompañe à los Infantes) lo guardarà el Rector, y lo aplicarà à mantener de havitos negros à los Infantes, que compongan el Jabardo, à los quales se les darà en la mesa el extraordinario de Pasteles, ò Empanadas el día en que hayan tenido alguna fiesta, porque así se les premie, y sirva de estimulo de aplicación à los demás.

(11) Salidas del Colegio, y días de vacaciones

Los Infantes jamàs saldràn del Colegio sin licencia del Rector, y este se las darà muy pocas veces, y por la precisión solamente de vèr à sus Padres, ò Parientes muy inmediatos, y sabiendo que en estas salidas no hay motivo de que se perviertan: saldràn de dos en dos uniendo los de esperimentado juicio con los que parezcan algo inquietos; siempre de Manto, y Beca, y amonestados sobre la buena compostura, paso no apresurado, y urbanidad, con que deben portarse con las personas con quien se encuentren por las calles, no metiéndose à disputar hacera, ni en otras cosas de las que suele haver en los Colegiales. Si alguna vez halla el Rector la precisión de que alguno salga sin compañero, sea de havitos, y bien acompañado. Haviendo oportunidad de que salgan los Infantes alguna vez a divertirse al Campo, lo haràn, sin hacer la menor falta al Coro, y en comunidad, conducidos por el Rector, que ha de determinar estas salidas, ò llevados por disposición suya por alguno de sus Maestros. Las Pasquas, y demás días de fiesta vacaràn à sus aplicaciones, y en ellos, y los ratos de recreación de entre semana, se les permitiràn aquellos juegos propios de sus edades; pero de ningún modo el de Naypes, Dados, ni otro prohivido.

\section{(12) Penas à los delinquentes}

A qualquiera Infante, que delinca en algo, lo penarà el Rector; pero siempre dentro del Colegio. Las penas seràn: que pierda por algunos días la antigüedad en el Refectorio, sentándose à los pies de la Mesa: que sirva esta, quando comen los demás: que tenga poste en los ratos que los demás se divierten, ò juegan: zepo, ò cárcel: pero 
si el delito fuere grave, el Rector darà quenta à los Señores Diputados, para que arbitren lo que tengan por combeniente.

\section{(13) Enfermos}

Si cayere alguno enfermo con necesidad de medicinarse, el Rector llamarà al Medico segundo del Hospital General, y al segundo Cirujano, y Sangrador, si se necesita de este. Para que estos les asistan, lo determinarà el Cabildo, dando su comisión al Señor Diputado de dicho Hospital, para que les anote esta obligación en sus títulos de nombramientos, y en las Constituciones. De la medicina, buena asistencia, y regalo, cuidarà mucho el Rector. Y en esta sola ocasión serà permitido à las Madres de los Infantes, ò la que estè en lugar de ella poder entrar en el Colegio à verlos, y esto con permiso expreso del Rector, que cuidarà de que no se abuse de esta indulgencia. No haviendo este motivo muger ninguna entrarà en el Colegio.

(14) Labado de ropa, y cosido.

Para labar, y coser la ropa de los Infantes, tendrà el Rector cerca de el Colegio alguna buena muger, y de madura edad, à quien se lleve toda su ropa y sobrepellices, $y$ la de las camas del Rector, y sirvientes à este fin, dandole el situado que parezca competente. Y si huviere algún Infante (particularmente de los pequeños) que necesite de que se le limpie la cabeza, lo harà el Rector conducir con el sirviente de mas satisfacción suya, para que esta buena muger lo haga. Cada tres meses vendrà al Colegio un oficial de Sastre, y situado en lugar oportuno, se le irà llevando toda la ropa de color de los Infantes, para que la recosa, ò haga nueva qualquiera cosa que necesiten.

\section{(15) Sirvientes}

Por ahora, y hasta que el Colegio tenga mas rentas habrà en èl tres sirvientes. Un Portero, su cargo serà asistir siempre en la puerta; cuidar de que no salga Infante alguno sin licencia del Rector: ir à la Catedral à la hora de acabarse los Maytines con un farol, para venir en custodia de los dos, que asisten à ellos: y porque enseña la esperiencia, que no conviene à la desencia, y salud de los Infantes, que hagan el oficio de candela, como antes, pasando por la calle, y parte de la Iglesia cargados con la 
paleta del carbón, y cuidando en la Sacristía de tenerlo encendido, para proveer los Incensarios, con que se lastimaban la cabeza, y se enzuciaban los Sobrepellices; serà del cargo del Portero hacer este oficio de candela; para lo que à tarde, y mañana seguirà à los Infantes, quando pasen à la Catedral, y cuidarà de llevarla de San Sebastián, y asistir en la Sacristía, à ministrarla del modo dicho. Un Mandadero, cuyo cargo serà hacer diariamente las camas de los Infantes, y del Rector, barrer la casa, hacer la limpieza, aseàr el Refectorio, poner, y servir las mesas, llamar por las mañanas, y siestas à los Infantes en las horas señaladas con el toque de una campanilla de mano; hacer los recados de la calle, y todo lo que se le mande del servicio del Colegio, y de sus Individuos. $Y$ un Cocinero, cuyo cargo serà diariamente traer la despensa, dando la quenta al Rector, guisar todo lo que se ofrezca en el Colegio, subir la comida, y repartirla para el desayuno, comida, y cena, fregar, prevenir, y encender los faroles de la Casa, y hacer todo lo demás, que le sea mandado. A cada uno de los quales se les darà diariamente un pan de libra, de comer, y cenar su ración ordinaria, y algún desayuno de frutas, y cada mes treinta reales vellòn. El Cabildo reserva sus facultades, para aumentar, ò disminuir el numero, y contexto de estas Constituciones según la oportunidad de los tiempos, y su voluntad.

Las Constituciones preinsertas concuerdan à la letra con las que se hallan en el Quaderno general de Reglas, y Constituciones, que existe en la Notaria mayor de Govierno de la Audiencia Eclesiástica de esta Ciudad, que por ahora corre à mi cargo, à que me remito; que fueron aprobadas en Auto proveído por el Señor Doctor Don Francisco Gutierrez Vigil, Dignidad del Prior, y Canónigo Magistral de la Santa Catedral Iglesia de esta Ciudad, Provisor de ella, y su Obispado Sede Episcopali Vacante, y por mi presencia à los tres del corriente. Y para que conste pongo la presente en Córdoba à catorce de Septiembre de mil setecientos setenta y un años.

Francisco Vicente de Vargas”. 


\section{B) Cabildo sobre la supresión del Colegio de Infantes y la reorganización de los Niños de Coro y Acólitos. ${ }^{1869}$}

“...Cuatro mil quinientos y siete reales y 96 fanegas de trigo cuestan á su mesa Capitular los doce Niños de Coro de constitución, y los seis Acólitos; dotación corta ciertamente é incapaz de mantener a tantos jóbenes, si las obras pías, y otros fondos no contribuyesen para la manutención de los primeros. Apenas pudo haber pensamiento más eclesiástico que el del establecimiento de un colegio, que tubiese el designio de escoger jóvenes aptos, darles educación cristiana, y formarlos bajo buenos principio de moral, y de enseñanza de Coro, y prácticas útiles á su ministerio. No son muchos los años que cuenta este Colegio, pero aún son menos los frutos, que ha podido recoger V.S. de esta juventud, dedicada al servicio del Altar y Coro. Diferentes han podido ver las causas de esta desgracia; unas han sido de la naturaleza del mismo establecimiento, otras de los encargados, y principalmente han influido la indolencia, descuido, y poca aplicación de los Maestros, que por interés, u otras miras, han principiado y concluido casi a un tiempo su enseñanza. Estos defectos, que pudieron haber logrado remedio con el tiempo y la constancia, se han aumentado por la fatalidad, que ha sobrevenido en estos últimos tiempos a todos los establecimientos, en general. Su dotación escasa y mal arreglada desde los principios, se ha menoscabado considerablemente y en esta última época han menguado en términos de que sin embargo de que V.S. tenía acordada la disminución de las plazas, y han estado reducidas a la mitad, se han mantenido en su pobreza con tantas necesidades, que las han tenido, y tienen en la ropa exterior, en su mesa, en el número de luces, en todo; y tiempo hubo, en que aún para su escasísima manutención, faltando fondos propios, la necesidad obligó a buscarlos extraños. Esto ha podido sostenerlos por algunos días ó meses; pero la ruina de la Casa por una parte; por otra la falta de medios para vestirlos con una decencia, que corresponda al ministerio en que se hallan; el abandono, en que los ha dejado el Maestro, que por su enseñanza y mérito podía dar algún aliento y brillo a los jóvenes que estaban bajo su dirección; y la imposibilidad de poder atender con fondos á tantas necesidades juntas, estrechan, sin dar mucho tiempo, a tomar medidas, que sino pueden servir para mejorar el establecimiento, al menos servirán tal vez, para sostener fuera de él, a los

${ }^{1869}$ A.C.C. Actas Capitulares. Miércoles 19 de diciembre de 1810. Tomo 100, s/f. 
que la Yglesia necesite para su preciso servicio. Todos éramos interesados, en que se mejorase y continuase un establecimiento tan propio de la ilustrada caridad de V.S.; pero lloremos los tiempos, que no dejan mas arbitrios, que para ir acabando con todo. Las obras pías de esta Santa Iglesia que han tenido tanta parte en este Colegio; los fondos de Arcas, que han contribuido constantemente, no pueden aumentar sus consignaciones, para reparar el Colegio de tantos atrasos y necesidades, y mucho menos la Mesa Capitular, y en tal situación la necesidad obliga a tomar un partido, desagradable a la verdad, pero indispensable para todas las atenciones de V.S. el Colegio no puede subsistir por falta de Rentas; el Colegio no sirve ya para la enseñanza de música de los niños; el colegio pues debe suprimirse; y una parte de las rentas destinadas a su manutención, debe convertirse para la consignación necesaria de los jóvenes, que hayan de hacer el oficio de Niños y Acólitos. Nosotros no queremos anticipar el juicio de los respetables Cabildos en el manejo de sus intereses; pero si es excusable que los deseos, y las opiniones de economía se anticipen en tiempos tan desgraciados, lo hacemos insinuando en general las ideas, que pueden adoptarse, para que no falten jóbenes en el servicio del Coro, siendo mucho menos dispendioso este arbitrio, que el actual de Comunidad: ideas, que al fin deben sugetarse el examen de una comisión especial, que informe a V.S. de todos los particulares. El colegio debe cerrarse en los primeros días del año próximo, y según vayan vacando las plazas del número actual, bien fuera de Niños ó Acólitos, debe reducirse quanto más sea posible, y aquel que sea capaz de poder ser mantenido por los dos ó tres reales diarios, que se puedan reunir. Los Niños quedarán en la misma clase en que hoy se hallan los Acólitos; esto es, que harán el servicio fuera del colegio ó comunidad; pasarán a sus casas, donde estarán a expensas de sus padres; y estarán obligados a presentarse por mañana y tarde como los acólitos. Su manto u capa en adelante será del mismo del color azul, ó de negro, si fuere más económico; sus oficios y cargas han de quedar reducidas a quanto menos pueda ser, y espere V.S., que así como no faltan monaguillos en las Parroquias para sus respectivos ministerios, tampoco faltarán a V.S. niños para las ocupaciones que hoy desempeñan.

Por este medio V.S. debe recobrar los mil reales, que para el edificio se pagan a Obras Pías, y las consignaciones de trigo y maravedies, que estaban señaladas para uno y otros; y reducido su número de Acólitos y Niños, como sucederá bien pronto, 
lograrán alguna economía los otros fondos, y en ella se logrará tal vez una dotación diaria, que asegure la subsistencia de los Acólitos, sin necesidad de las ayudas de costa, que deben quedar igualmente suprimidas. No es tan dificultosa de poner en execución esta nueva planta de Acólitos y Niños”.

\section{C) Decreto de supresión del Colegio de Infantes. ${ }^{1870}$}

“En este día los S.S. Deán y Cabildo, dignidades, canónigos, racioneros enteros y medios, in sacris constituidos, juntos y congregados en la capilla del Excelentísimo Señor Salazar, donde por aora acostumbran celebrar sus cabildos, citados ante diem por su Pertiguero acordaron lo siguiente $=$

A virtud del llamamiento para oír el informe de los Señores Diputados de Hacienda sobre varios puntos de economía y ahorros indicados en el Cabildo del 19 del corriente, se leyó por partes el dicho informe, que a la letra dice así = V.S. tiene aprobado en su acuerdo de 19 del presente diferentes puntos de economía que para su execución y último arreglo exigen nuevos informes y resoluciones, no habiéndose podido presentar por entonces, sino las ideas y pensamientos en general. V.S. tiene mandado a este fin, que expongamos lo que parezca conveniente, y hemos adoptado tres de aquellos, para que comiencen con el año las nuevas disposiciones. No pudiendo V.S. continuar por la falta absoluta de fondos, y escasez de arbitrios la manutención del Colegio de Infantes o Niños de Coro, acordó su supresión, sin perjuicio de conservar bajo otra planta á los mismos, que han servido y sirven en el Coro, Altar, y demás, ó á los que se consideren necesarios V.S. debe llevar al cabo su resolución, pero en el interin con mayor conocimiento de las rentas aplicadas a aquel establecimiento arregla V.S. su número y dotación, igualmente que de los Acólitos, conviene resolver lo que importa para el servicio, que no puede cesar.

Artículo $1^{o}$ : Desde el día primero del año próximo se cortan las respectivas cuentas de los fondos de la Mesa Capitular y demás, que estaban aplicados a la subsistencia de este establecimiento.

${ }^{1870}$ A.C.C. Actas Capitulares. Lunes 31 de diciembre de 1810 a la hora sexta. Tomo 100, s/f. 
Artículo $2^{\circ}$ : Desde el mismo día podrán los padres, tíos, tutores, o encargados de los Niños, recogerlos á su respectivas casas, para cuidar de su educación, manutención y destino.

Articulo $3^{\circ}$ : No pudiendo executar alguno tal vez ninguna de estas medidas, $y$ conviniendo por otra parte al decoro de V.S. dar algún tiempo a los mismos y Dependientes de la Casa, para buscar sus respectivos destinos, continuará V.S puramente en su manutención sin sueldo por el término de 8 días, al cabo de los quales se cerrará, y dejará expedita, según convenga.

Artículo $4^{\circ}:$ En este intermedio el Rector con acuerdo de los respectivos Diputados formará un Ynventario de todos los enseres propios del Colegio, comprendiendo ropas, comestibles, utensilios, $y$ quanto haya relativo al establecimiento.

Artículo 5: Si las presentes ideas de economía no lo impiden, podrá V.S mandar entregar a favor de cada Niño y Dependiente la cama, que les ha servido, con su colchón, un par de sábanas, mantas y almohadas.

Articulo 60: Bajo la misma condición podrá disponerse de los Ynstrumentos Músicos, propios de la Casa, que usaban los Niños respectivamente según la profesión de violinista, oboe, y demás, á que estaban dedicados, á excepción del fortepiano, de que podrá V.S determinar con separación, como así mismo de los papeles de música.

Artículo $7^{\circ}$ : Sobre la aplicación de todos los demás efectos, enseres, y utensilios. Según resulte de los Ynventarios, podrá V.S. determinar desde luego á favor del hospital, ó dar comisión a los señores Diputados de Obras Pías, para que con el debido conocimiento destinen según entiendan conveniente.

Artículo $8^{\circ}$ : Por último si V.S. considera correspondiente, y en premio del servicio, que han hecho los Dependientes en la Casa, y de la desgracia de que van a ser 
testigos, quiere dar una muestra de su caridad, resolverá que por Obras Pías se les de una ayuda de costa de 60 reales o lo demás que V.S. a bien tenga.

Artículo $9^{\circ}$ : Los Niños harán el servicio de Coro, Altar, y demás obligaciones; en los términos en que lo practican actualmente, por ahora, y en el interin se conserva el mismo número, quedando al cargo y vigilancia del más antiguo celador de este ramo.

Artículo $10^{\circ}$ : En orden a las horas de presentarse en el Coro y de su ganancia, tendrán su puntuación en el coro, y para la hora de su presentación, ganancias, y demás, se seguirán las mismas reglas que con los acólitos; con la diferencia de que aquellos continuarán en Maitines a lo menos 2, por el turno de costumbre.

Artículo 11º: Continuarán vistiendo para las funciones eclesiásticas el mismo trage de sotana o manto encarnado y sobrepelliz que hoy tienen; a cuyo fin se les entregará la mejor, de que usan en actual servicio, uno del primero y dos del segundo género.

Artículo 12: Quando se informe á V.S. prontamente sobre de dotación, asistencia, servicio, número, y demás que conviene arreglar, tanto respecto á los Acólitos, como respecto de los Niños de Coro, se informará a V.S. igualmente sobre color y forma de sus trages.

Artículo $13^{\circ}$ : Cesan desde el día primero de año las consignaciones del Rector del Colegio, Portero, Cocinera, y demás gastos de comunidad, a excepción de los de manutención por los 8 días inmediatos: Cesará igualmente el real diario, que tenían a su favor los mismos.

Artículo $14^{\circ}$ : Esto es quanto por aora consideramos, que conviene tener presente en este artículo de reforma $=$ 
Oída esta primera parte del Ynforme, acordó el Cabildo conformarse y se conformó con él en todas sus partes, y solamente en cuanto a los efectos muebles y utensilios que resulten del Ynventario que se prescribe, y de los que no haya de hacerse entrega a los Niños y Dependientes, según el dicho informe, adoptó el Cabildo la providencia de dar comisión a los S.S, para que hagan reservarlos, e informando sobre su valor quando se trate de la dotación de los Niños y Acólitos se determine por el Cabildo lo que convenga sobre su destino; y en cuanto a las limosnas que se apuntan por vía de despedida para el Portero y Cocinera de la casa, y para los mismo Niños, acordó igualmente el Cabildo fijarlas para los primeros en la cantidad de cien reales, y para los segundos en la de cuarenta reales a cada uno, todas pagaderas por una sola vez y de los fondos de Obras Pías: mandando que se pase el competente decreto a los S.S. Diputados de estos fondos, para su inteligencia y execución. Últimamente acordó el Cabildo dar y dio comisión a aquellos S.S. para que por si solos arreglen los demás puntos, que no estén claramente decididos en el expresado informe, y en este acuerdo”.

\section{D) Valoración del edificio y los muebles del Colegio de Infantes. ${ }^{1871}$}

“Domingo Vázquez y Rafael de Angulo, maestros de albañilería y carpintería del Ilmo. cabildo de esta Santa Iglesia certificamos que habiendo pasado de orden de los señores diputados de hacienda de la misma, a reconocer y apreciar la casa colegio que fue de infantes y previas las medidas del terreno y del grueso y alto de sus paredes y examinando su actual estado, con los desmejoros y perjuicios que se advierten en algunos de sus tejados, puertas y demás; somos de parecer que vale todo dicho edificio incluida la iglesia en cuanto su fábrica la cantidad de 171802 reales, pero agregando el valor de los dos retablos que hay en la iglesia, sus primeras bancas, campanas y demás muebles de su pertenencia, asciende su importe total a la suma de 183012 reales.

Resumen.

Valor del edificio: 171802.

${ }^{1871}$ A.C.C. Obras Pías. Caja no 523. 
Valor de los retablos y muebles de la Yglesia: 11210.

Total: 183012.

Y por ser verdad según nuestro leal saber y entender lo firmamos en Córdoba a 8 de febrero de $1816 "$.

\section{E) Diligencias de venta del Colegio de Infantes. ${ }^{1872}$}

"Razón de las diligencias practicadas para la venta de la casa colegio que fue de infantes. El 26 de Enero de 1816 se acordó por el Cabildo que los señores Diputados de Hacienda tratando con los de Fábrica de Rentas y Obras Pías informasen sobre el destino que se pudiera dar a dicha casa colegio.

El 20 de Febrero de dicho año informaron los señores Diputados de Hacienda que convendría venderlo al Erario de Cabeza de Rentas para ampliación de las tercias; y el Cabildo acordó que informasen sobre este punto las 2 Diputaciones de Hacienda y Cabeza de Rentas con la parte de S.I.

El 23 del mismo mes informaron las 2 Diputaciones previos los justiprecios de la casa colegio, y noticias adquiridas de los administradores de dineros, que convendría comprarse por el Erario dicha casa colegio en cuenta de pago de las deudas que tenía la Mesa a la Oficina de Cabeza de Rentas, quedando aquel responsable a estas en la cantidad de su importe, que era de 185.909 reales, precio medio resultante de las 2 tasaciones o justiprecios hechos. Y el Cabildo acordó que la Diputación de Hacienda informase de nuebo sobre varios puntos relativos a la extinción o suspensión del colegio, derecho que tubiese a su Iglesia la hermandad de la Escuela de Cristo, y obligación al pago de la alcavala por esta venta. Y que la de Cabeza de Rentas con la parte informase también sobre la absoluta necesidad y utilidad de ampliar las tercias con la citada casa colegio, los gastos precisos para darle este destino, su valor en el mercado normal, y el modo de verificar si compra con el menor detrimento del Erario.

\footnotetext{
1872 A.C.C. Obras Pías. Caja n 523.
} 
El 17 de Mayo y 22 de Junio del mismo año ebaquó la Diputación de Hacienda su informe; y lo mismo se executó por la de Cabeza de Rentas con la parte, acompañando una y otra los documentos competentes, y notas de las Diligencias practicadas sobre el asunto; siendo una de ellas la disposición de la Diputación de Obras Pías de no tener esta Oficina que repetir cosa alguna por dicha enajenación.

En vista de todo acordó el Cabildo en otro día conformarse y se conformó con referidos informes en todas sus partes, determinando que se realizase dicha venta por la cantidad que se expresaba, a saver las quatro quintas partes del precio de 185.909 reales que se le asignó a dicho colegio: que esta venta se haga en cuenta de pago de los adeudos que tiene la Mesa Capitular en favor de la Oficina de Cabeza de Rentas, la cual deberá irse reintegrando de la del Erario progresivamente pero que por este abono no se entienda eximida la dicha Mesa de los pagos anuales a que está obligada para el reintegro total de aquellos. Y dio comisión a los señores Diputados de Hacienda para que lleven a efecto lo acordado otorgando la escritura correspondiente e informen con llamamiento sobre el destino que deba darse a los retablos y demás enseres de la Iglesia del Colegio, los quales no han entrado en tasación ni en venta; con lo demás que consta de dicho informe".

\section{F) Destino de los muebles e instrumentos musicales del Colegio de Infantes. ${ }^{1873}$}

“El 22 de Junio último, en que V.S acordó la venta de la casa colegio, que fue de Ynfantes, al Erario de Cabeza de Rentas, nos dio comisión para que le informásemos sobre el destino que deba darse a los retablos y demás enseres de la Yglesia del colegio, por no haber entrado en dicha venta. Estos están comprendidos con su precio en la certificación dada por los Maestros Alonso de Galvez y Miguel Marquez, cuya copia está al folio $1^{\circ}$ de este expediente; por la cual resulta ser el valor de ellos la cantidad de 11.210 reales de vellón. Además se encuentran varios otros muebles

\footnotetext{
${ }^{1873}$ A.C.C. Obras Pías. Caja n ${ }^{\circ} 523$.
} 
pertenecientes al mismo colegio, y que todavía no se han enagenado: tales son una caldera, un marmitón, un salterio y clave, una campanilla y un guardarropa, que se hallan repartidos en varias casas, y de alguno se ignora el paradero. Somos pues de parecer que no pudiendo tener uso ni destino los muebles de la Yglesia en poder de V.S, deben venderse a beneficio de la Mesa luego que haya compradores, confiando V.S para ello a su Diputación de Hacienda. Pero que por la condulcencia o utilidad de que puedan servir los demás muebles o algunos de ellos para los mismos Niños de Coro, vajo el plan que V.S adopte para su reforma según resulte de la comisión dada sobre este punto, deben recogerse todos estos por la Oficina de Hacienda y conservarse hasta que se acuerde el dicho plan en cuyo caso se dará cuenta a V.S para que determine sobre ellos lo conveniente. Es quanto podemos informar a V.S quién sobre todo acordará lo que mejor parezca. Diputación de Hacienda de la Santa Yglesia de Julio de 1816. Firmado Juan Antonio de Castro. Juan Nepomuceno Lucas de Tena. Pedro de Segovia.

En Cabildo pleno de 23 de Agosto de 1816 se aprobó el anterior informe dando comisión a los señores Diputados de Hacienda para que pasaran a la execución de quanto en el se propone. Firmado Ldo. Villavicencio.

Razón de los muebles del colegio de Niños que se hallan depositados en varias personas que se expresaron.

Salterio y Monocordio = Don Francisco Beltrán.

Campanillo de la puerta = Señor Garrido.

Caldera $=$ Señor Tesorero

Marmitón o paila $=$ no se save.

Otros muebles = dirán en obras pías”. 


\section{DOCUMENTO N5. La Santa Escuela de Cristo. ${ }^{1874}$}

“Como Presidente de la Santa Escuela de Cristo, situada de presente en la Yglesia del Colegio que fue de Infantes de Coro de esta Santa Yglesia certifico que por los libros y asientos de esta Hermandad resulta que habiéndose erigido en el año de 1680, se le asignó por el Ilmo.Sr. D. Alonso Salizanes, Obispo de Córdoba, la Yglesia de San Bartolomé el Viejo de esta collación, y no siendo capaz la dicha Yglesia para la multitud de congregados que acudieron fue trasladada por decreto del mismo Sr. Obispo de 4 de Enero del siguiente año a la Iglesia de San Jacinto que hoy es la tercia del vino. Posteriormente se encuentra que fue trasladada al Hospital de Convalecientes de San Francisco de Asís, después Colegio de los Niños de Coro, aunque no consta el tiempo ni el motivo de esta traslación, ni el decreto en cuya virtud se hizo. Y solamente hay en dichos libros una nota sucinta en 27 de Agosto de 1710, en que se expresa que la Santa Escuela se hallaba por entonces en este Hospital.

Últimamente en el año de 1770, en que el dicho Hospital de Convalecientes se destinó para Colegio aparece firmado un inventario por el Presidente de la Santa Escuela, de los muebles que le eran propios, al qual convino el Señor D. Pedro Cabrera, Deán que era de esta Santa Yglesia.

De cuyo relato se infiere que la Santa Escuela sería admitida por favor e interinamente en la dicha Yglesia del Colegio y que por consiguiente no parece que tiene dinero alguno á comisión en ella, y sí únicamente los bienes inmuebles que constan de un Inventario y son entre otros un crucifijo grande con dosel = una lámina de la Purísima Concepción = otra de San Felipe Neri = dos mesas = cuatro banquillos = dos arcones y algunos ornamentos que están en el cajón de la Sacristía, con los quales está pronta la Santa Escuela a retirarse si el Ilustrísimo Cabildo dispone de la Yglesia para otro uso.

Córdoba 6 de Marzo de 1816. José González y Alcalde”.

${ }^{1874}$ A.C.C. Obras Pías. Caja n ${ }^{0} 523$. 


\section{DOCUMENTO №6. Cabildo sobre la dotación de la veintena y los músicos. ${ }^{1875}$}

“...Tiene muchas más dificultades la que propondremos a V.S. de los veinteneros, cuya dotaciones, sueldos ayudar de costa, y toda su subsistencia, depende exclusivamente de los fondos de la Mesa Capitular bastantemente gravada con este ramo de ministros, ministros dignos de mejor suerte entre todos los del Coro de V.S., ministros absolutamente necesarios, ministros lo más inmediatos al servicio y obligaciones de V.S., ministros que verdaderamente sostienen lo más trabajoso de la residencia del culto, y ministros, cuyo número, si es posible deberá aumentarse, y cuya dotación, si hay arbitrios, debe mejorarse. La veintena, compuesta de ordinario de doce individuos cantores, una ó dos más ó menos, sostenida hasta ahora por la Mesa Capitular, le ha costado y cuesta en cada año poco más de mil ducados en maravedies, y quinientas cuarenta fanegas de trigo, que valoradas al precio de 40 reales cada una importan "21.600” reales, y unidos a los maravedies componen un anual de "33.130" reales. Con esto contribuyen en todos V.S.S. y la parte correspondiente cada uno. Estas cantidades se han extraído todos los años para la manutención de estos Ministros de la primera atención. V.S. ha contribuido constantemente para la subsistencia y alivios de ellos. Ningún fondo ha llamado a su socorro, y por una desgracia igual para V.S. y para los veinteneros han observado esta parte de su primera constitución tan sin variación, que V.S. ha preferido este descuento, y ha sacrificado sus intereses con edificación, para mantener estos primeros apoyos del culto. Si la prosperidad y abundancia general de los frutos y rentas de V.S. ha podido sufrir hasta el día sin menoscabo de su decencia estos gastos; pasaron ya aquellos días felices, en que la economía prudente podía mirarse como mezquindad, los ahorros por debilidad de espíritu y la previsión de las desgracias como una mala preparación de los ánimos. Vivimos ya en tiempos más ruinosos, y en proporción de la cortedad de medios, en que nos hallamos, de las desgracias que hemos padecido y de las desventuras que pueden sobrevenir, conviene buscar los remedios oportunos para que ni el culto público y solemne falte, y V.S. por su moderada congrua pueda atender exclusivamente á la celebración de los oficios, á la observancia de los ritos, y al canto de loor de la

1875 A.C.C. Actas Capitulares. Miércoles 19 de Diciembre de 1810, T. 100, s/f. 
Divinidad. V.S. ha oído ya algunos medios practicables para economizar gastos, pero quedan aún otros, debiendo ser uno de los principales el pensamiento de evitar a V.S. los fondos y frutos, que se consumen en la manutención de la Veintena. Pensamiento fundado en los mismos recursos que se hallan en las manos de V.S. en la generosidad y propensión constante de los demás Cabildos a acudir á las urgencias de V.S., y en la muchedumbre de fundaciones, que aún subsisten en parte a pesar de tantas desgracias. Sobre estos medios extenderemos nuestro pensamiento con franqueza esperando siempre de su interés y bondad, que excuse, y aún justifique algunos más o menos de libertad y extensiones de términos y expresiones, y aún señaladamente suplicamos a los S.S. Individuos otros Cabildos, que sigan paso á paso nuestras intenciones, que jamás han sido ni son prevenir sus determinaciones, anticipar dictámenes, ni usurpar facultades, cuyo exercicio depende absolutamente de los indicados Cabildos, a quien rogamos que tomen en consideración todos los motivos y circunstancias del día para la más armoniosa solución en puntos de tanta importancia. Es muy antigua y constante la unión y conformidad de los designios y pasos de todos los Cabildos en cuanto dice relación a los artículos del culto, urgencias públicas y decoró de sus Individuos. Apenas ha podido interrumpirse está buena correspondencia, y si por desgracia todos los cuerpos, comunidades y hombres, sufren vicisitudes y alteraciones en sus confianzas y reciproco trato por miras equivocadas ó interesadas y a los de esta Santa Iglesia alcanzó en algún tiempo este sello de la debilidad y flaqueza de la naturaleza humana, bien pronto se repararon aquellas desuniones y questiones, que debían servir para aumentar la ruina de todos. En nuestros días por fortuna no hemos visto más que unas mismas ideas siempre, unos mismos pensamientos, un mismo sistema seguido sin interrupción, y sin perjuicios de las respectivas facultades, que corresponden a cada uno de los respetables Cabildos, que gobiernan esta Santa Yglesia. No permita la Providencia Divina para nuestra mayor aparición, que sufra la menor quiebra esta feliz armonía, fruto de la moderación y prudencia de todos y cada uno de los Individuos; porque si ella ha sido tan necesaria en los tiempos de prosperidad y tranquilidad, cuanto más interesa en estos de inquietud y borrasca. Hoy más que nunca debe reunirnos más y más el peligro común; las urgencias, las pérdidas, y los atrasos generales, las contribuciones graves, y quanto en fin ofrecen de amargo las presentes circunstancias, obliga a estrechar más íntimamente nuestras relaciones y dependencias. 
Todo debe ser común en nuestros peligros y recursos; común la dicha y común el perjuicio; común el beneficio, y común la carga de los trabajos. Así solamente disminuiremos los males y disfrutaremos de los bienes. Esta reunión será como un centro, en que nos apoyaremos, para resistir a los impulsos de las desgracias y contratiempos, será como un escudo, que nos defenderá de muchos golpes, y nos pondrá a cubierto de mayores males. Para esta común y recíproca conversación el principal y único de los intereses, la razón ilustrada pide, que se hagan sacrificios de privilegios personales; preciso es que ceda el favor y ventaja momentánea de alguno al mas preciosos de los intereses, que es igualmente suyo por la participación común que podrá importar la conversación de un solo derecho o privilegio para dejar perecer todos los demás. Igual puede ser la utilidad de uno sólo en reservar el nombramiento de una Capellanía, servicio o sacristía, si por este derecho pierde los mayores, lo más inmediatos al ser subsistencia y decencia, y deja escapar el más precioso de todos, que es la unión de bienes, peligros y desgracias. Este es el sacrificio, que se pide, y este mismo esperamos puedan que lo hagan los interesados, según lo exijan las circunstancias y los tiempos y sobre este fundamos desde luego, y sin dudar de su espíritu nuestro de dotación de la Veintena. Así logramos una de las mayores economías para la Mesa Capitular; así aumentaremos sus fondos considerablemente, y disfrutaremos en común y en particular de un beneficio de necesidad y de utilidad para todos. Para descargar a los fondos de la mesa Capitular de este gravamen, es menester discurrir y establecer otros que basten para aquellos gastos. No tenemos que salir de la Santa Iglesia para encontrarlo, y solo hay que trabajar para reunirlo, V.S. debe principiar en estas obras por sí mismo. La reunión y agregación de las Capellanías, servicios y sacristías, fundadas en esta ellas, y las demás de esta Santa Iglesia anunciarnos, que se irán habilitando para un objeto tan importante y tan del interés de todos. No pretendemos arruinar los establecimientos de esta Santa Iglesia, que autorizados por su antigüedad, y por su comunes utilidades del culto y del coro, han logrado la general aceptación de los Prelados, de los Cabildos, y de los fieles de esta Capital y Obispado. Los tiempos y las proporciones fáciles sugirieron en los siglos pasados la idea de la reunión de rentas y fondos en las Capillas de S. Acacio y Sta. Ynes, que es la dotación principal de los músicos; y los tiempos, y las desgracias nos ponen en precisión de evitar gastos y consumos, que tal vez han podido ser excusables. 
Pero tiempo es ya que reflexionaremos sobre nosotros mismos, y sobre la naturaleza de las cosas, y establecimientos, que la casualidad unas veces, el capricho en otras, y generalmente el gusto vario de las edades, han consagrado entre los hombres, como partes esenciales del rito, de la magnificencia, y de la pompa de los templos. La música, digna ciertamente de que tribute sus bellezas y sentimientos a la Divinidad en los augustos templos de nuestras Catedrales, se resiente de su corrupción y decadencia, para que la dejemos abandonada, y seguir sus caprichos, quanto tanto nos aleja del recogimiento, compunción e inocencia, que deben acompañar nuestro espíritu al pie de los Altares. Dejemos a los disputadores de un teatro escolástico hablar en teorías impracticables de la oportunidad y ventajas de la música en los templos. Nosotros entraremos en el corazón del hombre, y nos dará reglas más justas de los efectos que produce la música del día, que todos los razonamientos. El espíritu del hombre se distrae por el canto y los instrumentos; su corazón se engríe y todo él se abandona a las sensaciones de alegría, algazara y júbilo descompasado. Son muy raras las composiciones que se han destinado a la solemnidad de las funciones eclesiásticas por los Maestros más celebres de los últimos tiempos, acomodando todos sus pensamientos a la devoción y sentimientos profundos del corazón. Entre nuestros más distinguidos Maestros de Capilla ha sido tan universal el gusto dominante de la música teatral, que confundiendo los modos propios del uno, con los que eran necesarios para el otro, han convertido la orquesta en un entretenimiento teatral, y en lugar de la variedad, devoción y sublimidad de afectos que debía inspirar la música de nuestra Iglesias, han sustituido la brillantez de sus composiciones, afectos exaltados y pensamientos equívocos. Apenas podrá contarse entre todos los Maestros de España, quien reúna cualidades más eminentes, que el de V.S. para haber reformado la música y colocarla en su verdadero estado, pero las contrariedades que ha sufrido entre los mismos Profesores, la decadencia natural de la Capilla, la falta de voces de la primera cuerda, y al fin las circunstancias generales, que influyen en este ramo, como en todos, obligan a tomar medidas muy diferentes. Pasándose los tiempos, en que se ocupaba la vida y residencia entre las Arias y los Villancicos y si todavía no ha llegado el día, en que se acabe la música de las Catedrales, es preciso prever que así va a suceder. Tarde recobrarán aquellos fondos pingües que en esta Santa Yglesia se consumían entre los músicos: se acabaron aquellas dotaciones que eran el premio de una o dos Arias al 
año, faltarán los Profesores, y se concluirá con este entretenimiento, que tantos y tan inmensos caudales ha costado a la Yglesia de Dios. Pero subsistirá en su lugar el canto eclesiástico, se observará la salmodia, y a ella deberán destinarse las reliquias que queden del pasado tiempo de prosperidad y abundancia. V.S. por la generosidad de los demás Cabildos, por la de la Fábrica con sus excusados, y por los demás, reduciendo el estado de los músicos a auxiliar el Canto Llano con algún instrumento que otro, encontrará medios para su subsistencia. Preparémonos para esta época, y con la sola aplicación, que desde luego se vaya haciendo de los fondos de música para los ministros del canto y rito, no pueden faltar a V.S. los fondos necesarios. Este punto propuesto por V.S. a los demás Cabildos, lo arreglarán y dispondrán en términos, que sin perjudicar a sus usos y exclusivos derechos en aquellos fondos establecerán plazas y dotaciones para el salméo, como lo hicieron para la música. V.S. logrará con este establecimiento una economía inmensa en los gastos que hoy hace para su manutención y resultará por otra parte una ventaja, que es digna de considerarse para las miras de V.S.”. 


\section{DOCUMENTO $\mathrm{N}^{07}$. Cabildo para tratar sobre rebajas en los sueldos de los músicos (I). ${ }^{1876}$}

“En este mismo día los S.S. Diputados y Canónicos, in sacris constituidos, juntos y congregados en la Capilla del Exmo. Sr. Salazar, donde por aora acostumbran celebrar sus Cabildos, citados ante diem por su Pertiguero acordaron lo siguiente.

A virtud del llamamiento para tratar los puntos de económia y ahorros, indicados en el Cabildo anterior, se leyó el informe de los S.S. Diputados de Arcas de S. Acacio con la Pte. de S.Y. el qual decía a la letra lo que sigue = En consequencia de lo acordado por V.S. en 22 del presente sobre la necesidad en que se halla de moderar las rentas de los empleados en la Capilla de Música, y pagados por los fondos de las Arcas de San Acacio, y que para llevar a cabo esta moderación, presentamos las correspondientes listas con expresión de sus salarios, lo hacemos en la nota adjunta, formada por el Notario Secretario con presencia de los libros y asientos, V.S. arreglará este punto como le parezca; pero debemos prevenirle, que importará, que VS. acuerde al mismo tiempo, siguiendo los principios establecidos; Que estas moderaciones ó rebajas son puramente interinas, y mientras subsisten las causas, que han disminuido, $y$ disminuyen tan considerablemente el ingreso de sus rentas. Que durante las mismas circunstancias no se provea plaza ninguna de Capellán, Músico, Sacristán, ni Servidero, y que continúen las vacantes, que hayan ocurrido y ocurran para aliviar los fondos y sus obligaciones. Córdoba, 24 de Diciembre de 1810= Juan de Trevilla= Juan Ramón de Ubillos = Oído este informe, acordó el Cabildo conformarse, y se conformó con él en todas sus partes y para proceder al señalamiento de la cuota respectiva, que a cada ministro ha de disminuirse en su consignación, se conferencio separadamente el punto, y el Cabildo acordó, que se hagan las rebajas, que resultan de las siguiente lista, en que van anotados los respectivos Músicos y Ministros con sus dotaciones anteriores, y las que les quedan líquidas, en la forma y modo que se aprobó por acuerdos o votaciones individuales, teniendo presente la nota indicada en el informe.

${ }^{1876}$ A.C.C. Actas Capitulares. Lunes 24 de Diciembre de 1810, T. 100, s/f. 


\begin{tabular}{|c|c|c|}
\hline$\underline{\text { Lista }}$ & Dotaciones $\quad$ anteriores & Les quedan aora \\
\hline D. Josef Moyano & “13.200” reales. & “7.000”reales. \\
\hline D. Josef Heros & “6.600" & “5.000” \\
\hline D. Alfonso Martín & “9.900" & “6.600" \\
\hline D. Antonio Gil & “9.900" & “6.600" \\
\hline D. Antonio Colloto & “2.200" & $" 2.000 "$ \\
\hline D. Mariano Repiso & “2.200” & “2.000” \\
\hline D. Mariano Especiali & “12.000” & "6.000" \\
\hline D. Benito Torrellas & “12.100” & “7.000" \\
\hline D. Francisco Cascante & “3.300” & “3.000” \\
\hline $\begin{array}{l}\text { D.Mariano Ortega.12 } \\
\text { fanegas de trigo }\end{array}$ & “2.200” & “2.000" y 12 fanegas trigo \\
\hline D. Lope de Mora & “3.840” & “3.000” \\
\hline D. Pascual Redel & “5.500” & “4.500" \\
\hline D. Josef González & “2.750” & “2.500” \\
\hline D. Nicolás Anguita & “4.400" & “3.900” \\
\hline D. Juan Guerra Ortíz & “7.700" & “6.000" \\
\hline D. Manuel Valls & “6.050" & “5.000" \\
\hline D. Francisco Beltran & “1.100" & “1.000" \\
\hline
\end{tabular}

Nota: La Nota o lista de músicos y ministros presentada por los S.S. Comisionados consta de otros cuatro individuos, además de los aquí expresados, a saber D. Alfonso Espino, D. Gil Moscoso, Don Juan de Mora, y el administrador de estas rentas, sobre cuyos salarios o consignaciones acordó el Cabildo que no se rebaje cosa alguna. 
También contenía a D. Rafael García con “2200” reales de dotación, pero considerando el Cabildo que este ministro goza además de una Capellanía, cuyas rentas no se tenían presentes; acordó dar y dio comisión a los mismos S.S. para que informen con llamamiento sobre este punto, a fin de que pueda el Cabildo arreglar con acierto la rebaja en esta dotación. Así mismo contenía otra Nota a D. Pedro Marcial la dotación de “3300” reales, sobre el cual acordó el Cabildo dar y dio comisión a los mismos SS. para que informen con llamamiento lo que deberá hacerse.

Últimamente reflexionando el Cabildo sobre la situación o estado del músico D. Mariano Especiali, (que pon su edad y indisposición de voz no puede ya cantar;) y que tal vez proponiéndole su jubilación, se sacaría mejor partido en el ahorro o disminución de salario, que le está hecha, acordó dar y dio comisión a los mismos señores, para que traten él dicho Ministro sobre este punto; en el caso de que puedan adelantar algo para otro ahorro, informen con llamamiento lo que convenga sobre particular de su jubilación. Firmado: Felipe Ventura González y Manuel Ximenez y Ноуо". 


\section{DOCUMENTO No8. Cabildo para tratar sobre rebajas en los sueldo de los músicos. (II). ${ }^{1877}$}

“En este mismo día los S.S. Diputados y Canónigos in sacris constituidos, juntos y congregados en la Capilla del Exmo. Salazar donde por aora acostumbran celebrar sus Cabildos, citados ante diem por su Pertiguero, con la pte. de S. Y. acodaron lo siguiente:

A virtud del llamamiento para tratar sobre los puntos de economías y ahorros, indicados en el Cabildo anterior, y convencido el Cabildo por lo expuesto en los anteriores de la necesidad de disminuir interinamente y por aora, mientras duren las actuales circunstancias, según se acordó en otro Cabildo, los salarios, o consignaciones, que se pagan a varios Músicos y Ministros por los fondos de Arcas de Sta. Ynés; se procedió al señalamiento de la quota respectiva, que a cada uno de estos ha de disminuirse. Y conferenciado el punto, acordó el Cabildo que se hagan las rebajas o disminuciones que resultan de la siguiente lista, en que van anotados los respectivos Músicos y Ministros, con sus dotaciones anteriores, y las que les quedan aora líquidas, en la forma y modo, que se aprobó por acuerdos o votaciones individuales teniendo presente la nota o lista, presentada por los S.S. Diputados de estas Arcas, a quienes se había comisionado con la parte de S. Y. para este efecto=

\begin{tabular}{|l|l|l|}
\hline Lista & Dotaciones anteriores & Les quedan aora. \\
\hline D. Rafael de Río & “7.500” reales & “6.600”reales. \\
\hline Nada se rebaja a D. Juan & “660” & “660” y 12 fanegas trigo \\
Fernández. 12 fanegas de & & \\
trigo. & & \\
\hline Nada se rebaja a D. Rafael & “660” $660 ”$ y 12 fanegas trigo \\
Gallardo. 12 fanegas trigo & & \\
\hline
\end{tabular}

1877 A.C.C. Actas Capitulares. Lunes 24 de Diciembre de 1810, T. 100, s/f. 


\begin{tabular}{|c|c|c|}
\hline $\begin{array}{l}\text { Nada se rebaja a D. Mateo } \\
\text { Palacios. } 20 \text { fanegas trigo }\end{array}$ & “814” & “814” y 20 fanegas trigo \\
\hline $\begin{array}{l}\text { Nada se rebaja a D. Rafael } \\
\text { Pineda. Administrador }\end{array}$ & “2.750” & "2.750" \\
\hline D. Francisco Ferrer & “5.100” & “4.000" \\
\hline D. Josef Las & “4.950” & “3.500" \\
\hline D. Miguel Reinaldi & “8.800” & “6.000" \\
\hline D. Juan de Borja & “4.400” & “3.500" \\
\hline $\begin{array}{l}\text { Nada se rebaja a D. Julián } \\
\text { Gálvez }\end{array}$ & “550” & “550” \\
\hline D. Francisco Beltrán & “1.100” & “1000” \\
\hline D. Jayme Baliús & “20.000" & “11.000" \\
\hline
\end{tabular}

Nota: La lista de músicos y ministros, presentada por los S.S. Comisiones, contenía además de los aquí expresados, a D. Mariano Ferrer con “1500” reales de dotación; pero considerando el Cabildo que este ministro no asiste á la Yglesia y se halla ocupado en otro empleo incompatible, acordó suspenderle por aora toda la dicha dotación; y dio comisión a los mismos S.S. para que informen con llamamiento si deberá despedírsele.

Últimamente en cuanto a la dotación de “3.300” reales con que contribuyen estas Arcas para el Colegio de Ynfantes, acordó el Cabildo quede suspensa, hasta que se trate del modo y forma de contribuir con estos fondos al nuevo establecimiento que se subrogue al dicho Colegio ó Ynfantes, para el servicio del Coro. Firmado: Felipe Ventura González y Mariano Ximenez y Hoyo”. 


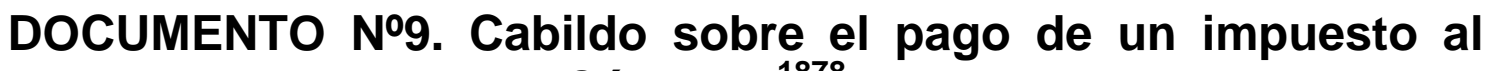 General Gobernador de Córdoba. ${ }^{1878}$}

“En este día los S.S. Deán y Cabildo, Dignidades y Canónigos, Ración enteros y medios, in sacris constituidos, juntos y congregados en la Capilla del Exmo. Sr. Salazar, donde por aora acostumbran celebrar sus Cabildos, acordaron lo siguiente.

El Sr. Deán dijo, había suplicado al Cabildo se juntase, para abrir y leer un oficio del Sr. Prefecto, que venía con la nota de urgente. Efectivamente se leyó, y a la letra decía así = Prefectura de Córdoba = Iltmo.Sr. = El Exmo. Sr. General Governador exige, que V.S.Y. se sirva contestar inmediatamente a las órdenes comunicadas a V.S.Y. con mi carta de ayer para el pago del millón y trescientos mil reales que adeuda ese ilustre cuerpo. En consequencia, sin embargo de que ya dije a V.S.Y ayer, que quedaba esperando dicha contestación, repito ahora nuevamente de la mayor urgencia para satisfacer a dicho Sr. General Governador, por lo que espero, que al recibo de esta se sirva Y.S.Y. dirigirme sin pérdida de momento dicha contestación. Dios que a V.S.Y. muchos años. =Córdoba 24 de diciembre de 1.810= Domingo Badia y Leblich= Iltmo. Sr. Deán y Cabildo = Leído este oficio acordó el Cabildo dar y dio comisión a los S.S. Diputados de Hacienda, para que con la mayor posible brevedad dispongan su contestación con arreglo al Acuerdo celebrado en el Cabildo pleno de esta mañana. Firmado: D. Felipe Ventura González y D. Manuel Ximenez y Hoyo”.

${ }^{1878}$ A.C.C. Actas Capitulares. Lunes 24 de Diciembre de 1810. T. 100, s/f. 


\section{DOCUMENTO $\mathbf{N}^{\circ} \mathbf{1 0}$. Celebración del Regimiento de Caballería de Santiago. ${ }^{1879}$}

"En el instante que este benemérito Regimiento se hizo sabedor de la instalación de las Cortes, y del solemne juramento del Rey se propuso la noble idea de expresar su gratitud ante las aras del Altísimo y de hacer participe á toda Córdoba de su entusiasmo y de la utilidad de una fiesta mucho mas digna que las Anacleterias de los antiguos, cuando estos celebraban la firmeza del trono de sus Reyes. Para ello dispuso que a toda costa en la mañana del corriente se cantara una Misa solemne en la Iglesia de los Padres Franciscos observantes de esta Ciudad; que en el mismo día se diese á la tropa un lucido banquete, y que por la noche hubiese en el campo de la Victoria iluminación, música y un transparente de gran vista. Dar gracias al todo Poderoso por tan felices acontecimientos, implorar la protección de su Santo Patrono de las Españas el Apóstol Santiago, é interesar á los Cordobeses en sus mismos sentimientos de piedad y virtud patriótica, era la materia de sus mas ardientes deseos. Así lo verificó empleándose en la ejecución de estos sus designios desde el Coronel hasta el último soldado.

Era de ver como estos guerreros se disputaban la gloria de tener una parte mas activa en los preparativos á dicha celebridad; y como la fogosidad de sus votos estaba mal avenida con la marcha inalterable del tiempo. Llegado que fue el día señalado, y que ciertamente hará época en la historia particular de este Regimiento, quedó satisfecha la expectación pública, y el gozo, la gloria y el placer se hizo como universal. Esta sola indicación sería suficiente para los que han sido testigos de semejante espectáculo. Pero como la posteridad tiene derecho para exigirnos una narración circunstanciada de quanto puede servirnos de modelo, es preciso referir con brevedad las tres escenas que compusieron el todo de dichas funciones.

A las nueve de la mañana estando ya reunido el numeroso convite de todas las Autoridades, Cabildos, Comunidades Religiosas, Militares, empleados civiles y demás personas, el Sr. Maestre-Scuela Dignidad de esta Catedral acompañado de dos Señores Canónigos de la misma dio principio á la Misa, que le fue oficiada por Capilla de

1879 NOTICIAS DE LAS FUNCIONES CELEBRADAS POR EL REGIMIENTO DE CABALLERÍA DE SANTIAGO, II DE LÍNEA, EN EL DÍA 21 DE JULIO. Córdoba, Imprenta Nacional, 1820. Sólo se conocen las iniciales del autor. J.M. Este artículo se encuentra dentro de un libro que hay en la Biblioteca Municipal de Córdoba, y que tiene la signatura 092-02-03. 
música de dicha Santa Iglesia. Después del Evangelio el Sr. D. José Garrido, Canónigo Magistral, pronunció un elocuente discurso probando, por el origen de las sociedades y de las leyes, el gran beneficio ó favor que Dios ha hecho á España Con la instalación del Soberano Congreso y juramento de nuestro amado Monarca el Sr. D. FERNANDO VII, según y como antiguamente lo prestaban nuestros Reyes de Aragón y Castilla.

Concluida la Misa, el Ilmo. Sr. Obispo entonó el acostumbrado cántico de acción de gracias; y la orquesta desempeñó su parte con la misma perfección y aplausos que los demás.

El Templo preparado para esta oblación, aunque por su estructura es grande y majestuoso, había adquirido para esta ocasión una belleza en sus adornos, que podía servir de geroglífico á la festividad del día. No se puede figurar un aparato religioso más imponente que el de aquella Iglesia enteramente ocupada en todo su pavimento, y lo mismo en su atrio y ángulos que la son contiguos.

La variedad de gentes, en clases, estados, sexos y fortunas y su humilde postración ante el Tabernáculo presentaba en pequeño una imagen de la Iglesia Católica interesada en los respetos que se merecen las instituciones civiles. Allí se veían las armas anudadas con las letras, demostrando que la Religión del Cordero es su más firme apoyo, y que la Constitución de la Monarquía es en ambas la base de su prosperidad. Allí no se echaba de menos persona alguna visible, toda Córdoba parece que se había convocado á dar pruebas autenticas de que una es su voluntad y una su opinión.

Igual enlace y armonía de afectos se hizo sensible cuando á las doce y media el Coronel, Gefes y Oficiales acompañados de la música del Regimiento de America y de un numeroso concurso, pasaron á los dormitorios de las compañías para servir la mesa los soldados. En estas habitaciones ricamente adornadas se presentó uno de los cuadros más vistosos que puede ofrecer la virtud. El simple soldado recibiendo de la mano de su Gefe la fineza, la Copa, los brazos y las señales del mas puro regocijo; las Damas del cuerpo y Oficiales dedicados á Porfía y con emulación generosa á esta clase de servicio; los semblantes de estos bravos defensores de la Patria con la sonrisa de sus labios y centelleo de sus ojos brindando por la Constitución, por el Rey, por su Coronel, Gefes y Oficiales; todo esto hacia recordar las fiestas de este género, que los Griegos y Romanos multiplicaron por las letras del alfabeto para radicar más y más su 
libertad. En seguida de este acto los Gefes y Oficiales tuvieron su comida en el Café de Neptuno, reinando en ella la cordialidad, el orden y los vivas y aplausos de tan augusta celebridad.

A las seis de la tarde se presentó todo el Regimiento en el campo de la Victoria; y el brillo de su vestuario y armamento, su aire noble y serio, y la valentía de sus caballos bastante diestros en guardar y cerrar sus frentes, y en obedecer con presteza toda maniobra, llenó de admiración y de gusto á todos los concurrentes. Habiendo colocado sus estandartes en un gallardo edificio de dos cuerpos de arquitectura que estaba formado al intento en el centro de dicho paseo, permaneció allí dividiendo su fuerza en patrullas y diferentes guardias.

Entrada la noche dejó ver este mismo edificio en todo el lleno su invención. Su primer cuerpo era de orden toscano, y su figura quadrangular. Cuatro estatuas alegóricas sostenían los dichos Estandartes y otros símbolos del Regimiento. Entre las pilastras transparentes se leían varios artículos de la Constitución adornados con graciosos festones y coronas de laurel. Por cuatro arcos bien proporcionados se veía enmedio una fuente Iluminada. El segundo cuerpo era de orden dórico, y entre sus columnas se hallaban espacios elípticos con guirnaldas de flores, en los que estaba pintada la Cruz de Santiago como signo de honor y de aprecio para todos los españoles y especialmente para este Regimiento; un grupo de trofeos militares sobre la cornisa ponía término á este hermoso transparente.

Veianse iluminadas las calles de árboles; ocupados los tres círculos de asientos que había alrededor de dicho cuerpo; y un numeroso concurso embelesado en la lectura de las citadas inscripciones.

El himno del inmortal Riego, y otro compuesto para ese día por un oficial del Regimiento, eran las canciones que entonaban de quando en quando aquellos decididos militares abrazados de varios paisanos que unían á ellos sus voces: los acompañaba la música del Regimiento de América, interpolando diferentes conciertos y piezas del mejor gusto: pero ni la multitud de gentes, ni las innumerables parejas que como por instinto salían bailando valses y contradanzas, ni la impaciente curiosidad con que todos querían acercarse al punto de la reunión, produjo desorden ni queja alguna, antes bien la alegría y el contento era la común divisa de todos los espectadores. 
Siendo yo uno de tantos, me ha parecido justo hacer estos breves apuntes, ya que en esta Capital no hay Periódicos que transmitan á los demás pueblos unas ocurrencias tan dignas de honor y de fama. Llevado de este solo impulso, recibe ó cuerpo de valientes esta pequeñísima ofrenda que en tu obsequio y alabanza coloca en el templo de la memoria uno de tus mas apasionados”.

Córdoba 26 de julio de 1820.

J.M. 


\section{DOCUMENTO $\mathbf{N}^{\circ} 11$. Solemnidad conmemorativadel nacimiento de Nuestro Señor Jesucristo en la Santa Iglesia Catedral de Córdoba. ${ }^{1880}$}

“La vigilia de éste por la mañana se cantaba la prima los tres Salmos con toda solemnidad por las voces de los músicos e instrumentos en el coro y concluidos éstos se cantaba la Antífona y los músicos marchaban a la tribuna, se cantaba por el Sochantre en medio del Coro la Calenda (y mientras se repartían a los Señores Capitulares ministros del Coro y al convite de eclesiásticos seculares y regulares que asistía en unas bancas preparadas para éstos a los lados del coro) las letras de la Calenda y Villancicos por dos Capellanes de la Veintena con los Infantes de Coro que llevaban azafates de plata donde se contenían muchos ejemplares de Villancicos.

Cuando el Sochantre llega a entonar el párrafo de la Calenda en Belén de Judá el nacimiento de Nuestro Señor Jesucristo, todos se ponían de rodillas, hacia el Sochantre pausa, y principiaba la Capilla de música a cantar y tocar la letra de la Calenda que contenía todas las piezas de canto que pueden verse en las impresiones de los Villancicos, concluida la música seguía el Sochantre cantando todo lo que quedaba por cantar en la Calenda hasta su final todo esto duraba por el espacio de hora y cuarto a hora y media; por la tarde se cantaban las vísperas a la hora acostumbrada por la Capilla de música y Salmistas.

En la noche principiaba el repique para los Maitines a las nueve hasta las diez que principiaban los Maitines con el Invitatorio cantado a 4 por Capilla de Música y Salmistas y concluido éste seguían los tres Salmos a canto llano por los Salmistas y concluidos éstos se cantaba la Antífona y versículo y después cantaba en el atril de bronce en punto de solfa un Infante de Coro la Lección primera y concluida se principiaba a cantar por la Capilla de música el primer Villancico y concluido éste se seguía a cantar la segunda Lección por un Señor Capitular y concluida ésta se cantaba el segundo villancico y concluida la Tercera se cantaba el tercer Villancico y lo mismo se practicaba en los dos nocturnos restantes, y concluidos éstos se cantaba el Te Deum por los Salmistas acompañados del órgano y después se principiaba la Misa del Gallo

\footnotetext{
${ }^{1880}$ Cf. LUCAS DEL POZO Y CÁCERES, Juan. "Solemnidad del nacimiento de Nuestro Señor Jesucristo en la Santa Iglesia Catedral de Córdoba”. En Rasgos biográficos y fisonómicos [de cordobeses]. Córdoba, 1863. Biblioteca Municipal.
} 
la que celebraba el Deán siendo de Evangelio un Canónigo y de Epístola un Racionero y la Capilla de Música la oficiaba con música de facistolillo.

Concluida ésta se principiaban los Laudes cantados por los Salmistas acompañados por el órgano todos los maitines duraban hasta las dos y media de la madrugada.

En todo este tiempo se ponía en medio del coro un gran brasero con una carga de picón de retal de encina y una barreta de hierro servía de paleta de las que sostenían las hojas de los libros de pergamino del facistol.

Después media hora antes de las cinco principiaba la esquila de la torre a hacer llamada, hasta el punto de las cinco que cesaba y se daba principio a la hora de prima y después se decía la Misa de luz, todo esto cantado por los Salmistas y la Misa acompañada del órgano y con esto tenía fin la Nochebuena.

Había varias rondas para conservar el orden, compuestas de Canónigos, Capellanes y celadores como también del Provisor con la Audiencia Eclesiástica toda la noche.

En las Festividades de los días de Navidad, Inocentes, Año nuevo y Reyes se cantaban después de la Epístola y al ofertorio de la Misa todos los Villancicos de la Nochebuena y Calenda y de este modo se festejaba estos solemnes días y que en el día no ha quedado más que una sombra y todo esto lo ha causado los trastornos políticos que todo lo ha desquiciado y tiene con el tiempo que concluirlo si Dios no pone remedio a esto. Quiera S.M. que en mis días no vea tal desgracia”. 


\section{DOCUMENTO Nº12. La Tertulia Patriótica de Córdoba. ${ }^{1881}$}

"Desde el año de 1820 al 23 se estableció en esta Ciudad una Tertulia Patriótica pública donde concurrían todos los que gustaban pasar el tiempo entretenidos. Esta tenía por objeto ilustrar al pueblo leyendo los papeles públicos, explicando algunos artículos de la Constitución para probar que esta en nada se oponía a la Religión, se improvisaban discursos y se leían otros.

Esta Tertulia en un principio se estableció en casa de Don Antonio Barroso, siendo esta casa Café Público. Después pasó a establecerse en los claustros del convento de San Pablo, después a las casas del Conde de Gavia junto a Santa Ana, y después al Teatro de las Comedias, y últimamente al taller de Santo Domingo de Silos. Duró hasta que tuvo fin el Gobierno constitucional mediado el año de 23. Fueron los primeros Socios: El Mariscal de Campo y Gobernador Militar Sr. Martínez. Don Manuel María de Arjona y Cubas, Penitenciario de la Catedral. Don Antonio Alcalá Galiano, Intendente de Provincia y el hijo de este Señor. El Sr. Morales Santiesteban. Señor Basconi. Don Mariano de Fuentes y Cruz, vinculista y propietario. Don José Cabezas, padre del Conde actual de Zamora. Don Miguel Cabezas y Barcia. Don José Luis de los Heros y Candil, músico de la Catedral. El Señor Esparza. Don Cayetano Lanuza, médico. El Militar Señor Balmaceda. El Padre Eulogio Rodríguez, Dominico. Don Lorenzo Basabru, vinculista. Linares, oficial de Milicias. El Abogado Naranjo, bien entendido en su facultad. Don Benito Berbejo, Presbítero. Don José López Zapata. González, oficial llamado "siete mil hombres". Don Melchor Pardo, el Lotero. El Padre Sousa. El comisario Señor Nenclari. Don Francisco Golmayo y Caballero. Don Juan Olivares, Beneficiado de la Parroquia de la Magdalena. Don Mariano Esquivel, Catedrático del Colegio de la Asunción. El Señor Alvear, de Montilla. Don José López de Pedrazas, que ha fallecido de Senador y muy acaudalado con los bienes del Estado. El Señor Bernabeu. El Señor Maraver, Padre. Don Cirilo Sánchez, médico. Don Francisco Bastardo de Cisneros, oficial retirado.

Esta Sociedad ofició a las Corporaciones Eclesiásticas y Literarias a fin que concurriesen algunos individuos para que dijesen discursos con el objeto que ilustrasen

\footnotetext{
1881 Cf. LUCAS DEL POZO Y CÁCERES, Juan. "La Tertulia Patriótica de Córdoba”. En Rasgos
} biográficos y fisonómicos [de cordobeses]. Córdoba, 1863. Biblioteca Municipal. 
al pueblo pues algunas veces se juntaban los Socios y no había quien hablase cosa alguna y por el medio de asistir comprometiendo a las Corporaciones se pudo conseguir que no faltase algún orador que dijese algo sobre alguna materia, también asistían algunas Señoras señalándose entre ellas la de Heros, Cirilo y las Muñosas.

Peroraron algunas veces los Señores siguientes:

Don José Garrido, Magistral. Señor Cascallana, Penitenciario. Don Mariano García, doctoral de San Hipólito. Don Juan de Dios Hidalgo, Rector del Seminario de S. Pelagio. Don Gabriel Girón. Don Mariano Esquivel. Los Rectores Pozo, Tejada y Henao. Olivares, Beneficiado. Don Francisco Golmayo y Caballero. Don José Luis de los Heros. El Padre $M^{a}$ Muñóz y Capilla. El Padre Eulogio Rodríguez. El Padre Porras. El Padre Flores. D. Cayetano Lanuza Bernabeu. El Señor Basconi y el Sr. Alvear de Montilla.

Pero los más constantes en la peroración fueron Don Francisco Golmayo, Heros y el Padre Eulogio Rodríguez Maraver, Alcalá Galiano, padre e hijo, El Señor Bernabeu, Esquivel y Don Juan Olivares”. 


\section{DOCUMENTO No13. Testamento de Jaime Balius y Vila (1). ${ }^{1882}$}

"En el nombre de Dios todopoderoso amen. Notorio y manifiesto sea a cuantos este público instrumento vieren como yo D. Jayme Valius Presbítero Maestro de Capilla de la Santa Iglesia Catedral de esta Ciudad de Córdoba y vecino de ella, natural de la de Barcelona, hijo legitimo de D. Francisco Valius y de Doña Serafina Vila difuntos, naturales y vecinos que fueron de dicha ciudad de Barcelona, hallándome por la divina misericordia con buena salud, y en el cabal uso de mis potencias y sentidos creyendo y confesando como firmemente creo y confieso el Altísimo e inefable misterio de la Beatísima Trinidad Padre Hijo y Espíritu Santo, tres personas que aunque realmente distintas tienen unos mismos atributos y son un solo Dios verdadero con una misma esencia; y todos los demás misterios Artículos y Sacramentos que cree y confiesa nuestra Santa Madre Iglesia Católica Apostólica Romana bajo cuya fé he vibido vibo y proiesto vibir y morir como fiel Católico Cristiano tomando por mi intercesora y protectora a la siempre Virgen é Inmaculada Serenísima Reyna de los Ángeles Maria Santísima Madre de Dios y Señora muy nuestra y por medianeros á el Santo Ángel de mi Guarda a los de mi nombre y devoción y demás de la Corte Celestial para que imperen de nuestro Señor Jesucristo que por los infinitos meritos de su preciosísima vida pasión y muerte me perdona todas mis culpas y llebe mi alma a gozar de su Beatífica presencia: Y teniendo la muerte que es tan precisa y natural en toda persona humana como incierta en hora, para estar prebenido con disposición testamentaria, cuando llegue, resolber con maduro acuerdo todo lo concerniente á el descargo de mi conciencia y no tener a la hora de mi fallecimiento algún cuidado temporal que me obste pedir a Dios con todas fuerzas la remisión que espero de mis pecados, otorgo mi testamento de la forma siguiente-

Primeramente encomiendo mi alma a Dios nuestro Señor, que la crió a su imagen y semejanza y la redimió con el infinito precio de su santísima vida pasión y muerte y mandó el cuerpo á la tierra de que fue formado

\footnotetext{
${ }^{1882}$ En este testamento, Balius nombra heredero fideicomiso a D. José Moyano, encargándole que mantenga oculto el destino de sus bienes hasta que él muera. Así lo hace Moyano, y una vez muerto Balius, saca un segundo documento, que presentamos a continuación de éste, en el que se expone con detalle entre quienes se reparten los bienes del Maestro. Archivo Histórico Provincial de Córdoba, Sección de Protocolos Notariales, oficio 33, año de 1821, folio 55r. El notario es D. Mariano Muñoz Sanz.
} 
Mando que mi cadáver sea sepultado en la Iglesia Parroquial de que fuere feligrés á el tiempo de mi muerte y dejo la forma de mi entierro á disposición de los Albaceas que después nombraré-

Mando que en el día de mi entierro siendo ora oportuna y si no en el inmediato siguiente se diga por mi alma una misa de réquiem cantada con vigilia y responso y se paguen por ella y el entierro los dineros de costumbre.

Mando que con la posible inmediación á mi fallecimiento se digan por mi alma la de mis Padres, Abuelos y demás personas por quienes pueda tener algún cargo ú obligación cien misas rezadas de las cuales deducida la cuarta parte correspondiente á la Parroquia, las restantes se celebren en las Iglesias y por los Sacerdotes que elijan mis Albaceas quienes pagaran de mis bienes la limosna de costumbre.

Lego por una vez para ayuda á el costo de la cera con que se alumbra el Santísimo Sacramento en mi Parroquial Iglesia, á la obra y Fábrica de ella y conserbacion de los Santos Lugares de Jerusalén medio real de vellón a cada uno de estos legados píos: Igual cantidad á cada una de las nuebe casas o hermitas de la advocación de Nuestra Señora que existen en esta Ciudad, sus extramuros; y veinte reales de vellón a la iglesia del Señor San Rafael Custodio de Córdoba.

Declaro que me corresponden en toda propiedad cuatro Casas situadas en esta ciudad: la primera que es la de mi habitación señalada con el numero tres en la calle del conbento de Jesús Maria: otra contigua en la misma calle distinguida con el número cuatro: otra sin numero en la calle de los siete rincones: Y la ultima marcada con el numero ventiseis en la calle de la platería conocida con el nombre de la Pescaderia las cuales he adquirido por justos y legítimos títulos que conserbo.

Nombro por mis Albaceas testamentarios a D. Juan de Varo y Cordoba. D. José Moyano presbíteros, y D. Manuel Vals músico de la Santa Iglesia Catedral de esta Ciudad y todos vecinos de ella; a los cuales juntos y a cada uno in solidum confiero amplia facultad para que luego que yo fallezca cumplan y paguen todo lo tocante á la causa pia que llebo dispuesto, a cuyo fin si fuera necesario venderán los bienes mas efectibos y les prorrogo el termino legal por el demás tiempo que fuere menester.

Después de cumplido y pagado todo lo expresado, en el remanente que quedara de todos mis bienes acciones y dineros presentes y futuros instituyo y nombro por mi heredero fideicomiso á el referido D. José Moyano, Presbítero para que distribuya su 
importancia en los términos y para los fines que le tengo comunicados; y mediante á la absoluta confianza y satisfacción que tengo del D. José Moyano, le prohíbo que dé cuentas de las imberciones de mi caudal a los señores Jueces, autoridades Eclesiásticas o Seculares ni a ninguna otra persona sea cual fuere su ministerio o representación. --Reboco y anulo todas las disposiciones testamentarias que ante de ahora haya formalizado por escrito, de palabra ó en otra forma para que no balgan ni hagan fé judicial ni extrajudicialmente, ecepto este mi testamento que mando se tenga por tal y se cumpla en todas sus partes como mi ultima y deliberada boluntad ó en la forma que mas haya lugar por derecho. En testimonio de lo cual así lo otorgo ante el infraescripto escribano de S.M. Público del número y colegio en Cordoba á veinte de Febrero de mil ochocientos veinte y uno. Y el señor otorgante a quien doy fe conozco así lo expresó y firmó en este registro siendo testigos D. Fernando Fernández de Sousa, Mariano Godoy y Francisco Muñoz, vecinos de Córdoba”.

Jayme Walius

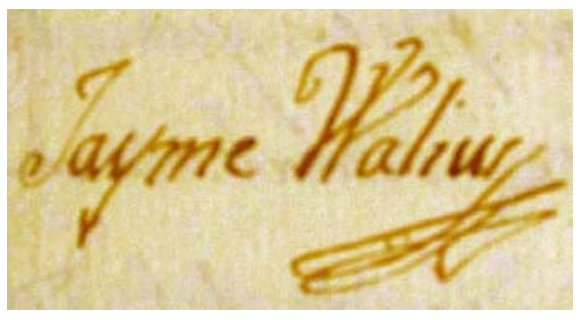

Antemi:

Mariano Muñoz y Sanz.

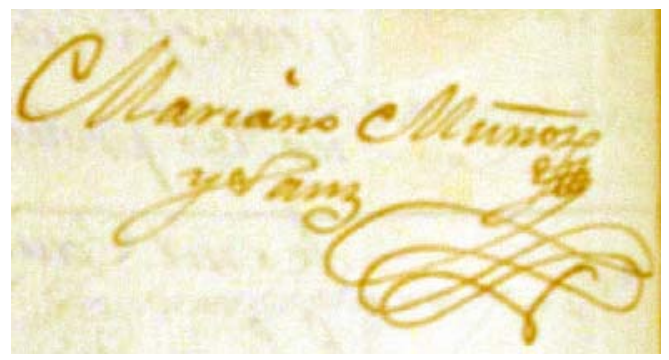




\section{DOCUMENTO N$^{\circ}$ 14. Testamento de Jaime Balius y Vila (2). ${ }^{1883}$}

“Sea notorio por este público documento como yo D. José María Moyano, presbítero, vecino de esta ciudad de Córdoba digo: que D. Jaime Walius, presbítero, Maestro de Capilla que fue de la Santa Iglesia Catedral de ella de igual vecindad, por el testamento que otorgó ante el infrascripto escribano en veinte de febrero de mil ochocientos veintiuno, y vajo cuya disposición falleció en tres de noviembre próximo pasado, me instituyó por su heredero fideicomisario para que distribuyese todos sus bienes en los términos y para los fines que me tenía comunicados, con prohibición de que diese cuentas de su inversión a ninguna autoridad ni persona, cualquiera que fuese su ministerio o representación; y para que los interesados en las cuatro fincas que ha dejado y poseía en esta ciudad, tengan un legítimo título para su adquisición, declaro en la forma que más haya lugar en derecho: que el D. Jaime Walius entre otras cosas me comunicó que era su última voluntad y determinaba dejar la casa principal señalada con el número tres y la inmediata con el número cuatro en la calle de Jesús María a Doña Joaquina de Burgos de esta vecindad, muger lexítima de D. Jaime Dalmau, oficial del regimiento de América, para que ella las disfrutase por los días de su vida, y si moría con sucesión pasaran ambas casas en toda propiedad a sus hijos, quienes podrían disponer de ellas libremente, pero que si moría la Doña Joaquina sin dejar hijo ni descendiente alguno, aunque antes hubiera tenido sucesión, mandaba que se vendiera la casa principal número tres y de su producto se hicieran tres partes: la primera para invertirla en misas en sufragio del alma de D. Jaime Walius y de sus parientes difuntos; la segunda para entregarla al referido D. Jaime Dalmau; y la tercera para distribuirla por partes iguales entre sus cuatro sobrinos, el Padre Maestro Fray José Ribera Religioso Servita en el Convento de Barcelona, Doña Rita y Doña Manuela Ribera, sus hermanas vecinas de aquella ciudad, y D. Francisco Walius, vecino de Córdoba a quien también se le diese en dicho caso la otra casa número cuatro en la calle de Jesús María en toda propiedad y para siempre. Mandó que se diese a la referida Doña Manuela Ribera, su sobrina, perpetuamente y en toda propiedad, la casa número veintiséis en la calle de la pescadería; y finalmente dejó la

\footnotetext{
1883 Archivo Histórico Provincial de Córdoba, Sección de Protocolos Notariales, oficio 33, año de 1823, folio 59r. El notario es D. Mariano Muñoz Sanz.
} 
otra casa sin número en la calle de los siete rincones a su criada Cecilia Tomás de esta vecindad durante los días de su vida: y por su muerte que ocurrió en el día dos del corriente mes, dispuso que heredase esta casa en toda propiedad y para siempre jamás Doña Josefa Amo Fernández de Sousa, muger legítima de D. Mariano López Santiago de esta vecindad. También ordenó el D. Jaime Walius y me manifestó que era su voluntad que la dicha casa en la calleja de los siete rincones fuese perpetuamente socorrida por espacio de dos horas y media en cada día con la media paja de agua que tiene la casa principal número tres en la calle de Jesús María, cuyo gravamen imponía a sus poseedores para siempre jamás, y que con este objeto dejaba construida y corriente la cañería que conduce el agua de una a otra casa. Esta fue por lo respectivo a los bienes raíces la voluntad y determinación final de D. Jaime Walius que como tal me comunicó y para que de ella se habilitara cada interesado las copias o testimonios que pidiere, lo declaro así ante el infrascripto escribano público de ese número y colegio en Córdoba a diecinueve de febrero de mil ochocientos veintitrés. Y el Señor otorgante a quien yo el escribano doy fe que conozco así lo expresó y firmó siendo testigos D. Francisco Redel, D. Julián Díaz y D. Juan de Dios Sánchez, vecinos de Córdoba. Fdo. José Moyano”. 


\section{DOCUMENTO Nº 15. Juán Lucas del Pozo y Cáceres. ${ }^{1884}$}

“Juan Lucas Ramón del Pozo y Cáceres fue natural de la ciudad de Córdoba nacido el 18 de octubre de 1798 y bautizado en la parroquia de San Pedro Apóstol de la misma siendo sus padres Don José y Doña María Rafaela de Cuevas de Berlanga los cuales eran naturales en la misma ciudad. Cuando tuvo edad competente con el deseo que tenía de servir a Dios lo pusieron sus tíos por haber fallecido sus padres antes y haciéndose cargo de él por Octubre de 1806 en el Colegio del Ángel de la Guarda de Infantes de Coro siendo admitido por medio de una solicitud que éstos presentaron al Ilustrísimo Cabildo de la Santa Iglesia Catedral para servir en el coro de la catedral. Y al mismo tiempo instruirse en la música y recibir la educación cristiana que se enseñaba en dicho establecimiento hasta que se cerró el colegio a causa del trastorno que hubo en todas las cosas de iglesia con motivo de la Guerra de la Independencia, cuando los franceses invadieron a la mayor parte de la monarquía española. Continuando asistiendo como infante de coro en la iglesia hasta que fue nombrado acólito en la misma, siguiendo estudiando música y asistiendo a varias academias profesores de la misma facultad como también a las capillas de músicos aficionados ejercitándose en funciones de iglesia. También entró de meritorio en la de la catedral en el año de 1823 y siendo admitido por el Ilustrísimo Cabildo por Junio del año de 26 de músico en referida capilla y al mismo tiempo lo nombró pasante o vicerrector del Colegio del Ángel de la Guarda que un año antes se volvió a abrir donde estuvo cuidando de la educación he instrucción de los infantes hasta que fue separado de éste destino en el año de 1832 por una medida económica que fue necesario hacer por encontrarse este establecimiento atrasado en sus rentas. Igualmente quedando en su destino de músico hasta el año de 1842 que por una orden del gobierno se suprimen todas las capillas de música en todas las catedrales de España quedando por esto sin ningún socorro para poder vivir y no pudiendo ejercitarse en alguna cosa por su edad avanzada, sordo y con otros padecimientos que tiene, llegando por tanto tiempo a la fecha del 22 de Septiembre de 1863 en que escribió estos renglones. En esta conformidad y desgracia, pongo esta nota por ser una cosa no común que me sucedió

\footnotetext{
${ }^{1884}$ Presentamos aquí una breve autobiografía de Juan Lucas del Pozo, músico y cronista que nos ha servido de guía con sus escritos, en muchas partes de este trabajo. POZO CÁCERES, Juan Lucas del. “Apuntes para mi vida”. En Colección de Obras. Córdoba, 1863. Ms., pág. 221.
} 
en el tiempo que estuve de Infante de Coro y es que en ocho meses cuando la Guerra de la Independencia de los franceses por los trastornos que se padecieron, estuve solo haciendo todo cuanto debían de hacer diez o doce niños de coro en el coro: cumpliendo de musiquero, asistiendo al punto de horas canónicas, cantando todo cuánto era necesario en el coro, en fin, todo aquello propio de los Infantes de Coro. Sin pedir por éste servicio, cosa alguna al Ilustrísimo Cabildo; ni el Cabildo se mostró agradecido conmigo, dándome alguna gratificación.

Después que se admitieron algunos infantes cuando tuvieron a bien los canónigos, tuve que instruirles en el canto de ceremonias y demás ejercicios de coro sin mostrarse el Cabildo agradecido conmigo, por supuesto, con ninguna gratificación hasta que estos Señores tuvieron a bien nombrar de director (se supone con su dotación correspondiente), a un capellán de a veintena para su enseñanza.

Pongo esto no por vanidad y alabanza propia si no para que se sepa esta cosa tan rara que tal vez no habrá sucedido en ningún tiempo. Pero todo esto de nada me ha servido para que estos Señores me tengan alguna consideración y memoria.

Después cuando fui recibido en la Capilla de Música estuve de los más comprometidos con el trabajo, porque en todas las festividades grandes y chicas desempeñé los papeles de primer coro siendo éstos los más obligados por tener de antiguo la costumbre los Maestros de Capilla hacer sus composiciones obligando más a la cuerda que yo tenía que cumplir. Mas si esto me sirviera de algún mérito para que se me pagase religiosamente se podría sufrir con paciencia, pero nada de eso. Yo salí con un crédito a mi favor de mucha consideración cuando se extinguió la Capilla por una orden del gobierno de su majestad que no se me ha pagado ni se me pagará nunca por las circunstancias actuales que esto no se remediará en la vida.

En fin, he tenido una suerte muy desgraciada siempre: primeramente cuando estuve en el Colegio de Infantes de Coro, en un tiempo se cerró este establecimiento. Cuando de músico, en mi tiempo se concluyó la Capilla de Música. De consiguiente, la mala suerte, siempre me persigue y creo que está siguiéndome los pasos hasta que ponga término a mis días no parará.

En los años que estuve de pasante o vicerrector en el Colegio del Ángel de la Guarda fue una perpetua esclavitud e incomodidad encerrado de día y noche sin poder salir para nada, como no fuese acompañando a los colegiales al coro, o en la salida los 
días festivos al campo para su recreo: teniendo que sufrir a ellos, a los Diputados, Rector, Maestros, padrinos y criados de la casa, en fin un continuo choque con unos y otros que no se podía aguantar y sin contar por esta cosa más que el escaso alimento diario que con decir comida de comunidad basta. Y sin poder huir de esta cargo por haber sido admitido de músico en la catedral con la obligación de vicerrector de este colegio que tantas incomodidades me hizo sufrir.

Desde el año de 1842 que cesó la capilla de música de funcionar en la Santa Iglesia Catedral continué asistiendo a las funciones solemnes que se celebraron en ella hasta el año de 1852 que concluí mi asistencia. Asistí a varias fiestas particulares en diferentes iglesias de esta ciudad, desde el año de 1842 hasta el año de 1857. Todo esto me valió poca cosa para poder cubrir mis gastos: mi familia me ha dado el alimento diario de comida siete años hasta el presente, también se podrá incluir en esta cuenta la ganancia en la venta de libros, pinturas, regalías y comisiones que he tenido en todo este tiempo, que todo esto podrá ascender a una mitad de ahorros en el gasto de comida en todos estos años. Por consiguiente la otra mitad de la comida, gastos de ropas, lavado de ropa, pago de arrendamiento de la habitación, y todo lo demás, han salido de los fondos de ahorros que tengo; con éstos he podido pasar hasta hoy, día $1^{\circ}$ de Octubre de 1863". 


\section{LÁMINAS.}

\section{CEREMONIAL Y M A NUAL}

DE LAS PRECES, ANTIFONAS, HIMNOS, SALMOS $x$ ORACIONES QUE DEBEN DECISE CORDOBA

EN LAS ROGATIVAS, PROCESIONES Y DEMAS FUNCIONES QUE SE CELEBRAN Y PUEDEN OCURRIR, CON ARREGLO AL RITUAL ROMANO, $X$ LOABLES COSTUMBRES DE DICHA SANTA IGLESIA.

FORMADO DE ORDEN DE LOS ILUSTRISIMOS SEÑORES DON AGUSTIN DE AYESTARAN Y LANDA DIGNISIMO OBISPO, DEAN Y CABILDO DE LA MISMA SANTA IGLESIA.

SIENDO SUS DIPUTADOS EN SAGRADAS CEREMONIAS LOS SEÑORES

DOCTOR DON GREGORIO MARCOS MERLO Y GALAN, CANONIGO MAGISTRAL, Y DON ANDRES XARAMILLO DE LEON, PREBENDADO

EN ELLA.

POR EL DOCTOR DON MANUEL XIMENEZ $Y$ HOYO, MAESTRO DE LAS MISMAS EN DICHA SANTA IGLESIA. AÑO DE 1805 . EN CORDOBA : EN LA IMPRENTA REAL DE DON RAFAEL GARCIA RODRIGUEZ Y CUENCA. 


\section{*}

CONSTITUCIONES DEL COLEGIO

$$
\text { D E } \mathbf{L}
$$

ANGEL DE LA GUARDA, QUE PARA LA MANUTENCION,

CRISTIANA EDUCACION,

Y UTIL ENSEñANZA

DE LOS INFANTES, QUE SIRVEN EL CORO DE LA SANT A IGLESIA

CATEDRAL DE CORDOBA, HA FUNDADO EL ILLMO. SEńOR

DEAN , Y CABILDO DE ELLA.

\section{CON LICENCIA.}

En Cordoba, en la Oficina de Juan Rodriguez, Calle de la Libreria. 


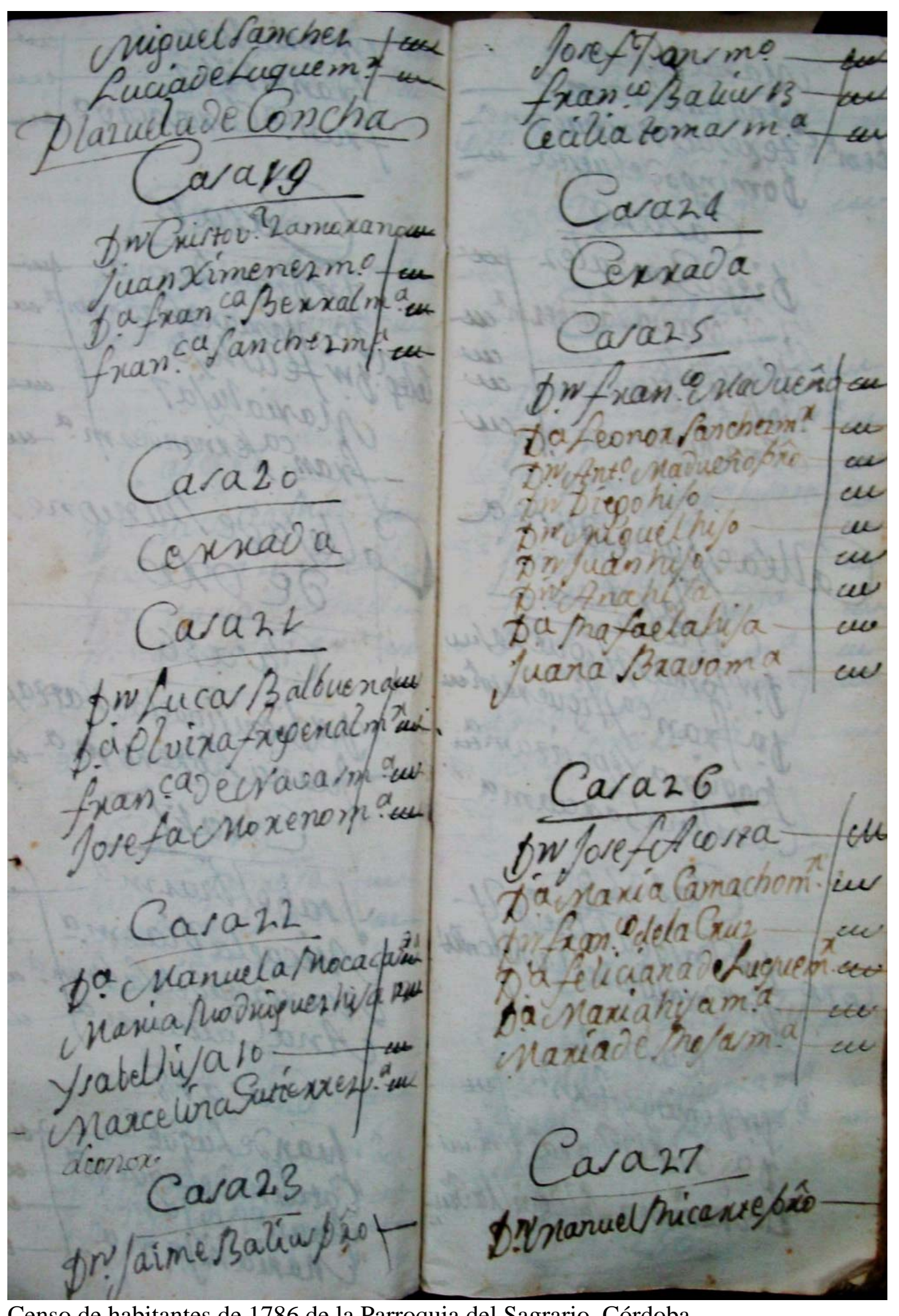

Censo de habitantes de 1786 de la Parroquia del Sagrario. Córdoba.

649 


\section{OBSEQUIOS DE CORDOBA

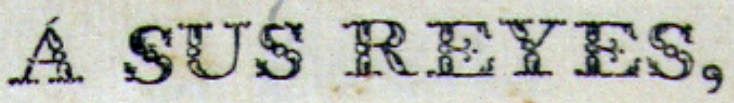
Ó D E S C R I P C I O N

$$
\text { DE LAS }
$$

DEMONSTRACIONES PÚBLICAS

DE A M O Y LEALTA D, QUE CÓRDOBA TRIBUTÓ

\section{Á NUESTROS CATÓLICOS MONARCAS}

EN LOS DIAS I I, I 2 Y I 3 DE MARZO DE I 796, EN QUE LA HONRARON CON SU AUGUSTA PRESENCIA.

$$
\text { ESCRIBIALA R. } 17262
$$

El M. R. P. Fr. Rafaél Leal, Regente de Estudios del Real Convento de N.P.S.Agustin de dicba Ciudad.

\section{EN ELLA.}

En la Imprenta de Don Juan Rodriguez dE LA Torre. 


\section{GOZO Y LEALTAD, CON QUE ORLA

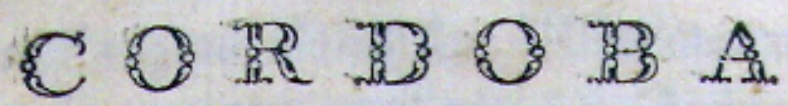

LA CORONA DE SU TRIUNFO

EN LA REAL PROCLAMACION DE EL RET $Y$ SEÑOR

D.CARROS QUARTO, CATOLICO Y SIEMPRE AUGUSTO

NUESTRO SEÑOR

( $Q U E$ DIOS GUARDE MUCHOS AÑOS)

CELEBRADA EN 10. DE SEPTIEMBRE DE 1789 .

$$
\text { ESCRIBIALA }
$$

DON MANUEL ANTONIO RAMIREZ $r$ GONGORA, natural $y$ vecino de esta Ciudad, $y$ dos veces Diputado del Comun de ella:

POR COMISION DE LOS SEÑORES DIPUTADOS de la Junta de Proclamacion.

EN CORDOBA.

EN LA IMPRENTA DE DON JUAN RODRIGUEZ R-1382 DE LATORRE. 


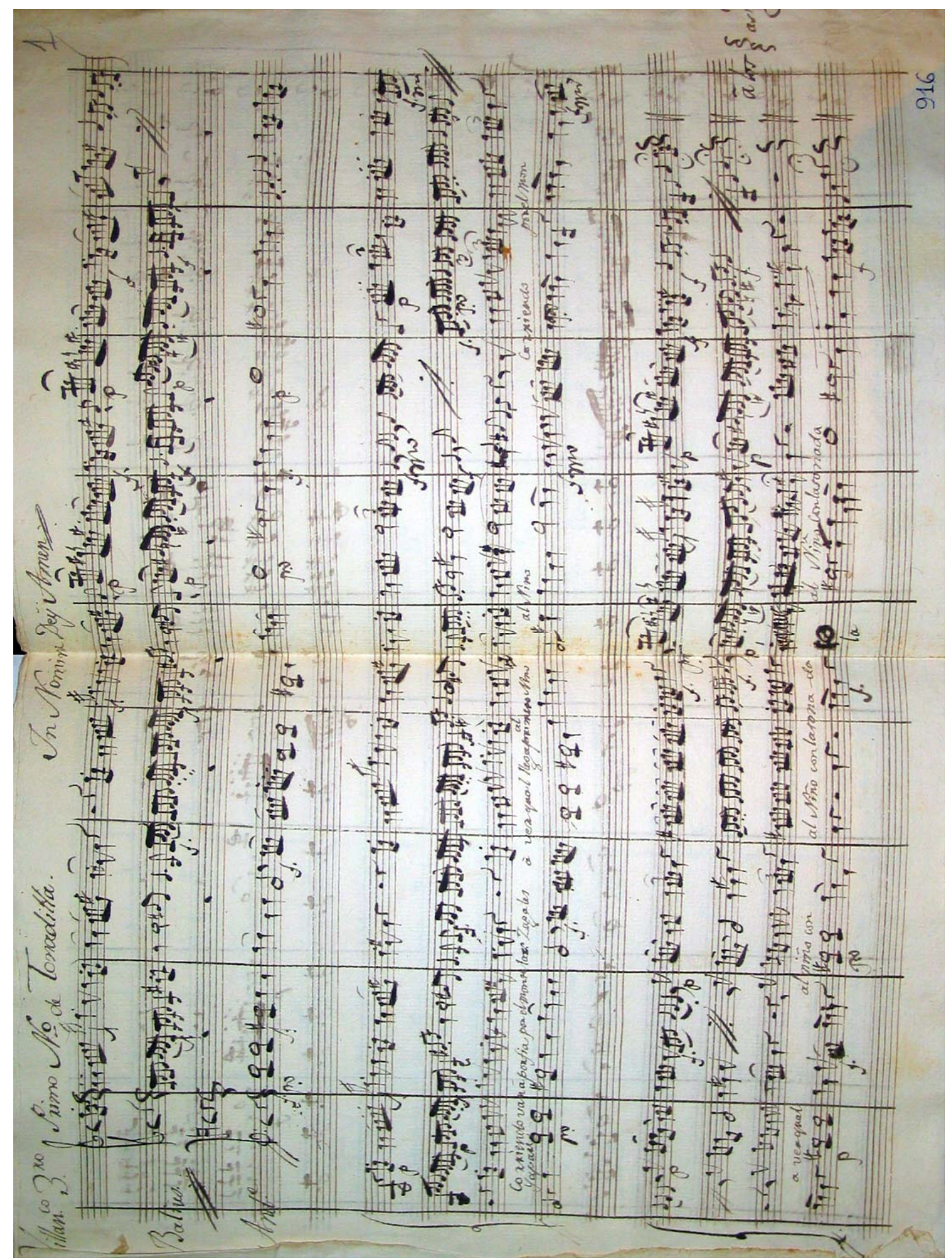

Corriendo van a porfía. Villancico. (106/916) 


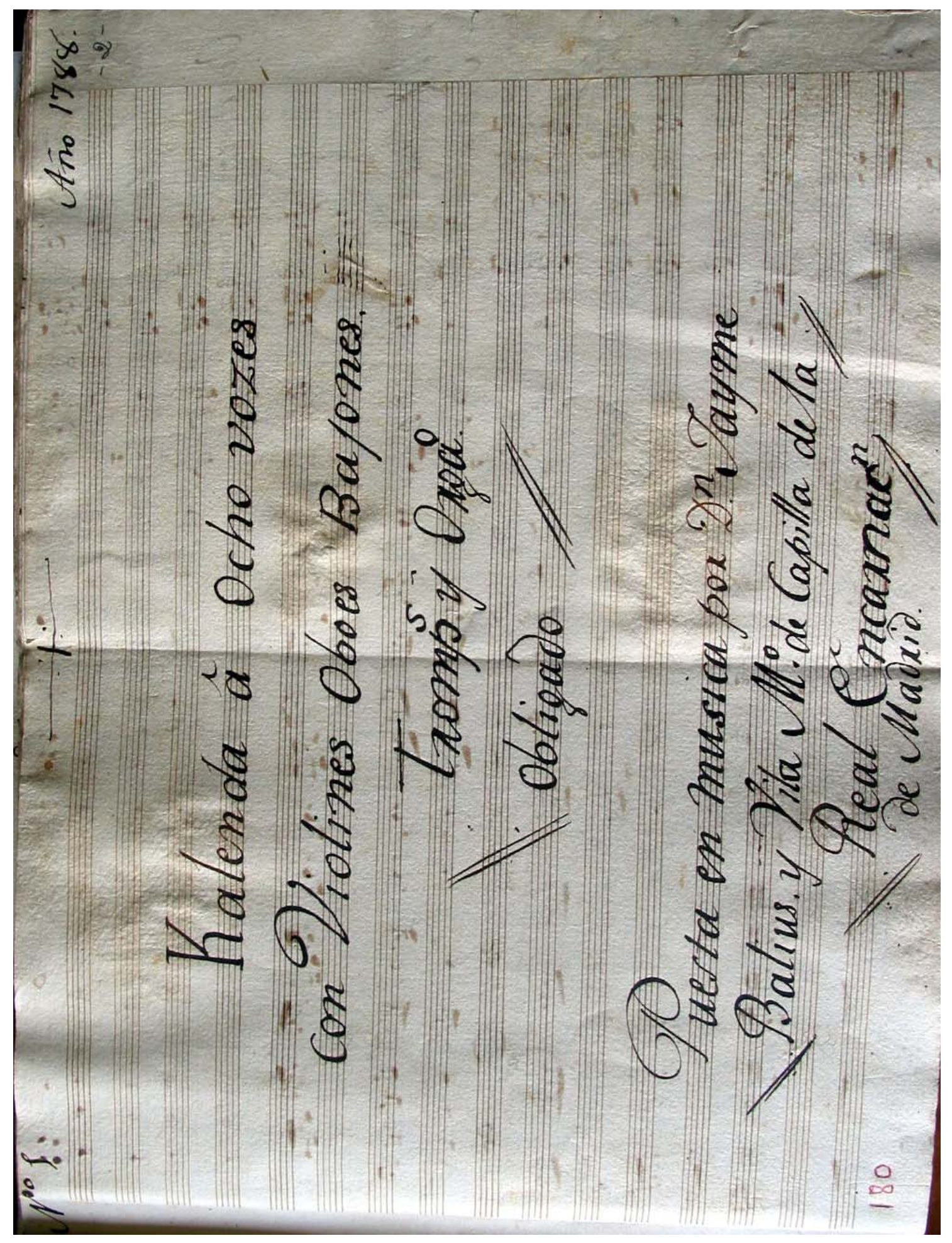




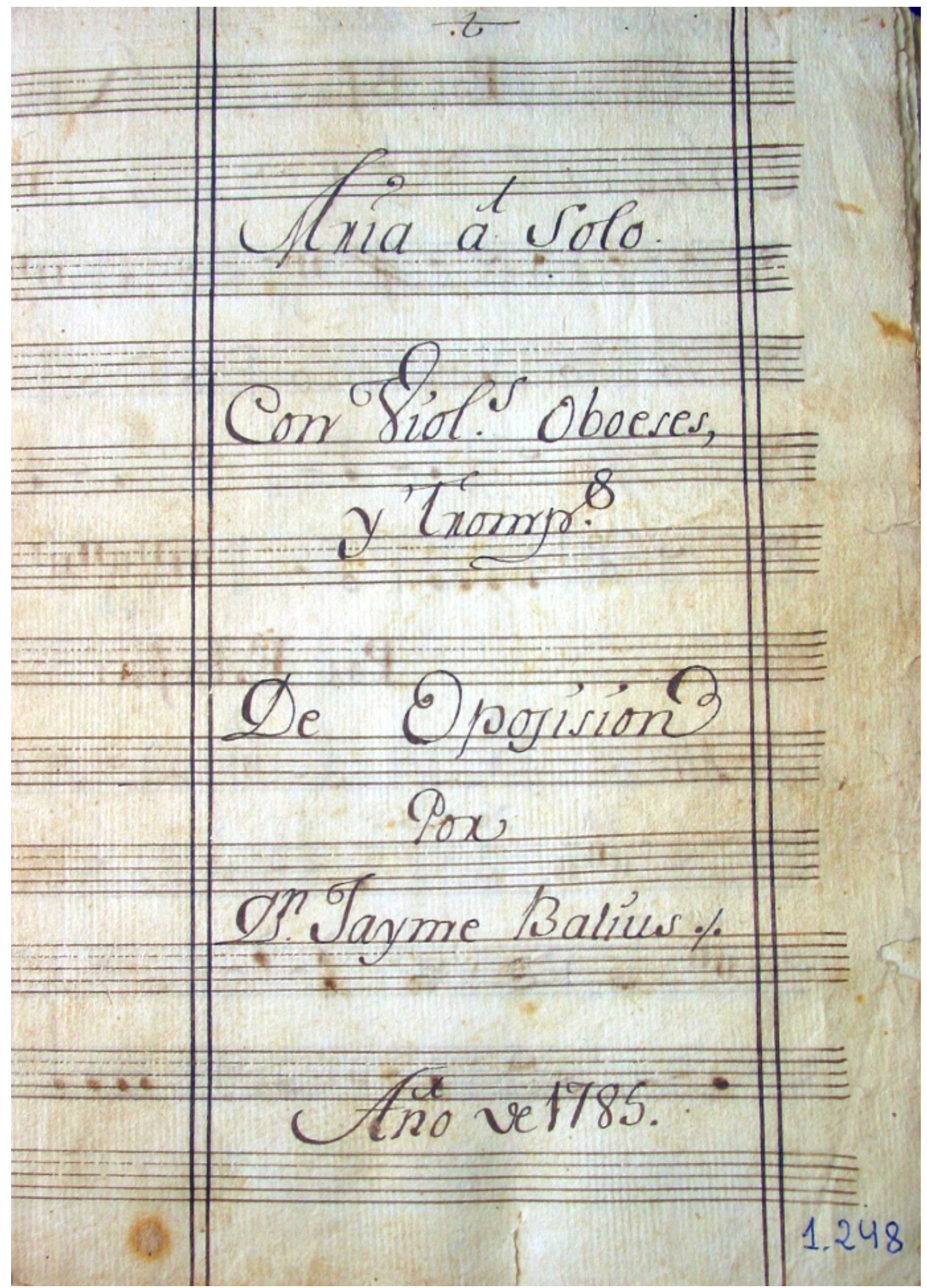

Que alegre y complacido. Recitado y Aria. De oposición. 1785. (128/1248) 


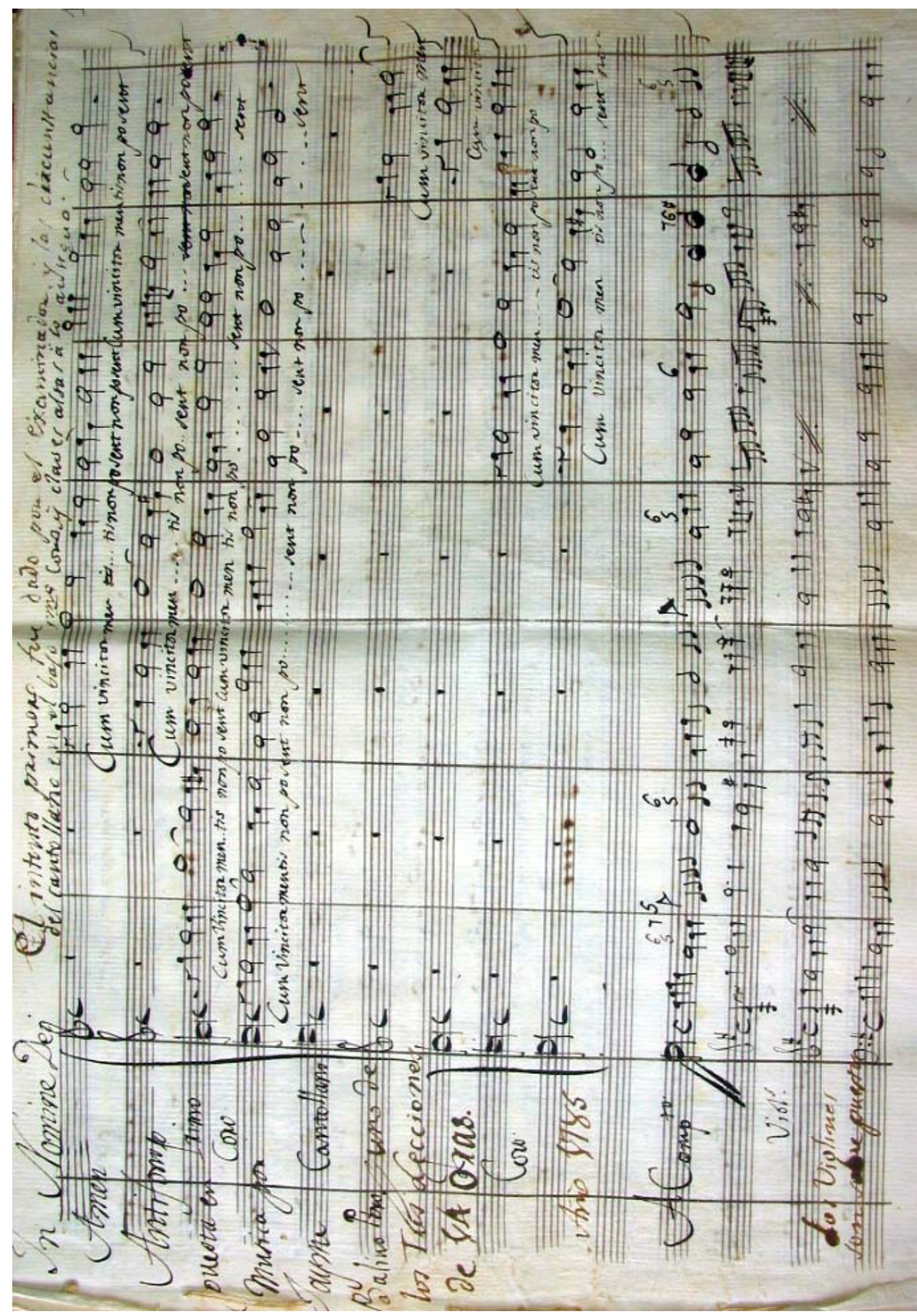

Cum vinci tormentis. Motete de oposición. 1785. (83/649). 


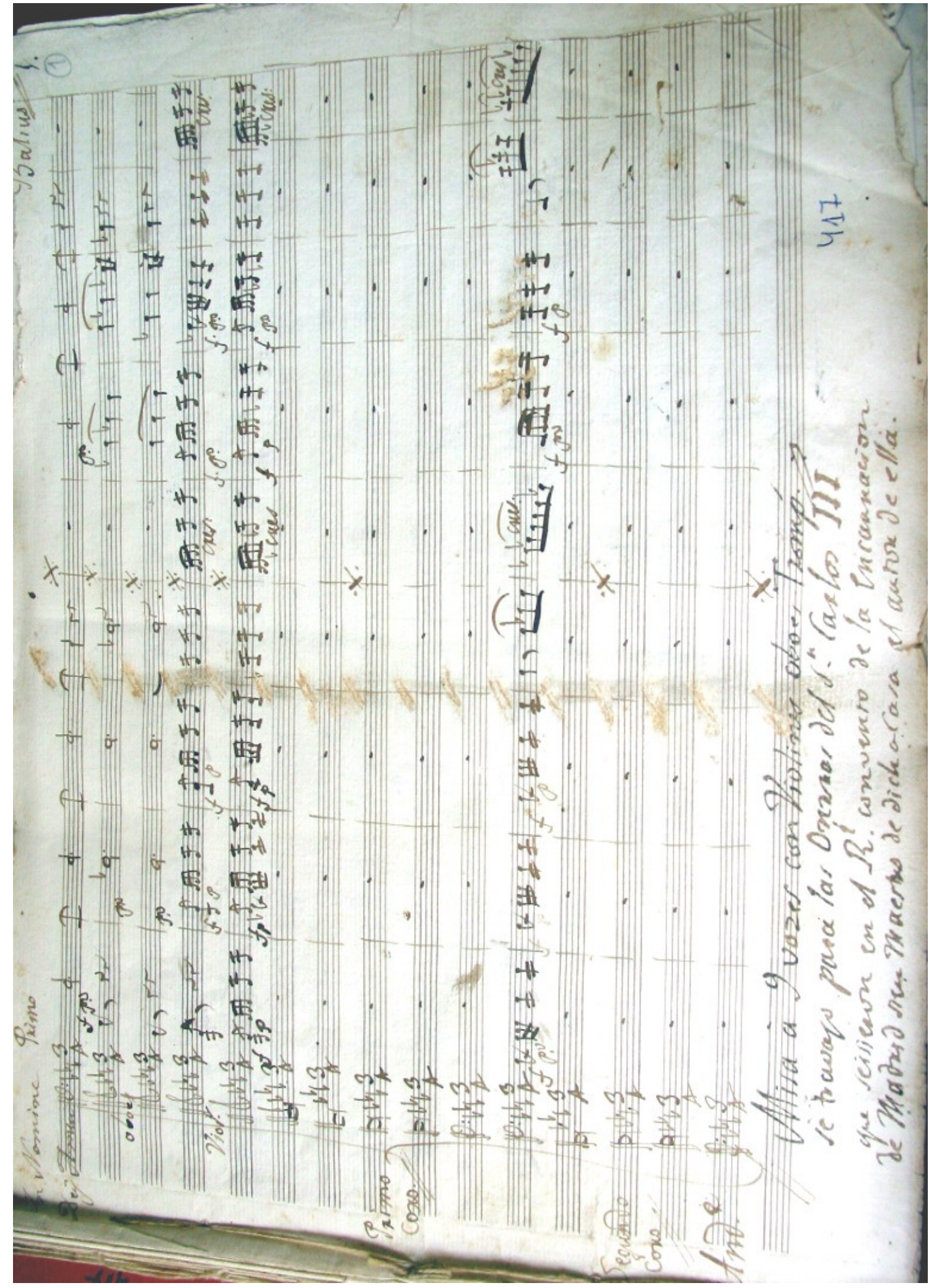

Misa de Difuntos. Por la muerte de Carlos III. (61/417). 


\section{ÍNDICE ONOMÁSTICO}

$\bar{A}$

ABENATE, PEDRO $\cdot 422,423$

AGRAMONTE, FRANCISCO $\cdot$ 41, 567

AGUILAR, JOSÉ · 232, 436, 437, 438

AGUILAR ARRIAZA, LUÍS · 40

AGUILAR GAVILÁN, ENRIQUE · 68, 567

ALAPONT, VICENTE $\cdot 101$

ALBURQUERQUE, JUAN ALFONSO DE · 82

ALÉN, M ${ }^{\mathrm{a}}$ PILAR $\cdot 114$

ALONSO, MATÍAS · 80

ÁLVAREZ, MANUEL · 101,141, 204, 205, 275, 281, 283, 284, 289, 291, 301, 302, 304, 305, 317, 323 , 327, 329, 337, 339, 340, 342, 462, 463, 482, 483, 490

ÁLVAREZ DE TOLEDO, FRAY JUAN · 76

ÁLVAREZ TORRADO $\cdot 41,82$

ANDERSON, $\cdot 28,568$

ANGUITA, GASPAR $\cdot 365$

ANGUITA, NICOLÁS · 101, 138, 164, 254, 259, 261, 262, 263, 265, 275, 276, 277, 289, 293, 294, 301, 302, 304, 312, 313, 320, 323, 354, 362, 392, 426, 427, 431, 480, 483, 490, 625

ANGULO IÑIGUEZ, DIEGO • 69, 568

ARALI, JOAQUÍN · 40

ARANAZ $\cdot 35$

ARANDA, PEDRO DE $\cdot 41$

ARANDA DONCEL, JUAN · 37, 44, 45, 51, 54, 55, 568

ARELLANO $\cdot 101$

ARFE, ENRIQUE DE $\cdot 54,581$

ARJONA, JOSÉ $\cdot 148$

ARJONA Y CUBAS, MANUEL MARÍA· 42, 86, 88, 96, 148, 521, 636

ARQUIMBAU, DOMINGO $\cdot 35$

ARTEAGA, ÁNGEL · 140, 248, 254, 256, 274, 282, 337, 340, 346, 392, 397, 404, 421, 422, 442, 495, 496, 499, 500

ARRIAGA · 36

ARROYO, RAFAEL $\cdot$ 147, 276, 279, 333, 407, 408, 496

AUSTRIA, JUAN DE $\cdot 101$

AYALA, FRANCISCO $\cdot$ 101, 122, 128, 185, 186, 202

AYESTARÁN Y LANDA, AGUSTÍN · 38, 45, 54, 92, 93, 561 
AYLLÓN, RAFAEL · 231, 233

AYMES $\cdot 33$

AZCONA, FRANCISCO $\cdot 101$

$\bar{B}$

BACH, JOSÉ BENITO • 128, 145, 193, 196, 201, 214, 207, 215, 216, 238, 336, 337, 494, 497

BACH J.S. $\cdot 28$

BACH, ISIDRO $\cdot$ 196, 198

BACH, JOAQUÍN · 196, 422

BALIUS Y VILA, JAIME · 3, 5, 12, 13, 19, 20, 21, 22, 25, 27, 28, 29, 30, 32, 34, 35, 37, 41, 44, 59, 64, 69, 82, 83, 98, 101, 103, 116, 117, 118, 120, 121, 122, 126, 128, 129, 130, 132, 133, 134, 135, 136, 138, 139, 140, 143, 144, 145, 146, 147, 148, 150, 158, 171, 173, 176, 179, 187, 199, 202, 203, 227, 232, 233, 240, 246, 275, 276, 331, 336, 386, 397, 403, 404, 408, 411, 412, 413, 414, 415, 416, 423, 428, 429, 438, 445, 446, 447, 448, 449, 450, 451, 452, 453, 454, 455, 457, 458, 459, 460, 461, 462, 463, 464, 465, 466, 467, 468, 469, 470, 471, 472, 473, 474, 475, 476, 477, 478, 479, 480, 481, 482, 483, 484, 485, 486, 487, 488, 489, 490, 491, 492, 493, 494, 495, 496, 497, 498, 499, 500, 501, 503, 504, 506, 509, 513, 517, 519, 521, 523, 524, 525, 526, 527, 528, 529, 530, 531, 532, 533, 534, 538, 539, 540, 543, 544, 547, 548, 551, 554, 555, 556, 557, 561, 562, 563, 564, 565, 566, 567, 569, 574, 638,641

BALIUS, FRANCISCO $\cdot 101,132,415,461$

BALLUS CASOLIVA, GLORIA · 20, 133, 134, 446, 448, 449, 478, 562, 569

BASALLO, FÉLIX · 210

BÁRCENA, PABLO $\cdot$ 147, 192, 255, 261, 287

BARZENAS $\cdot 101$

BAS, GIULIO $\cdot 101$

BEDMAR ENCINAS, LUIS · 22, 100, 533, 570

BEETHOVEN, L. · 27, 28, 29, 30, 31, 32, 35, 36, 572, 580

BENDICHO, CRISTÓBAL · 147, 220, 251, 262, 263, 319, 322, 341, 389, 407, 410, 488

BERLIOZ $\cdot 30$

BERMEJA, JUAN DE LA · 101

BERNARDO ARES, JOSÉ MANUEL DE • 43, 570

BERNIA MATEO $\cdot$ 101, 122, 136, 180, 258, 270, 292, 303, 309, 310, 324, 328, 454

BERNIER $\cdot 533$

BLANCO NAJERA, FRANCISCO $\cdot 98,101$

BOCCHERINI $\cdot 36$

BODUL DE SANTAMANT, PEDRO $\cdot 131,199$

BONAPARTE, JOSÉ · 30, 31, 32, 33

BONAPARTE, NAPOLEÓN · 30, 31, 32, 33, 39, 62, 64, 65, 66, 67, 68, 533, 534 
BONILLA, FRANCISCO · 245, 246, 252, 322, 329, 334, 343, 354 BONILLA, BORDERIA, AGUSTÍN · 101

BORJA, JUAN DE · 149, 185, 194, 195, 228, 259, 272, 274, 311, 312, 353, 420, 467, 628

BRAGANZA, ISABEL DE · 12, 58, 59, 533, 556, 560

BUENO, JUAN · 101, 136, 181, 271, 310, 312, 315, 338, 351, 353, 454, 462, 463

BUSQUETS, JUAN · 144, 181, 182, 200, 251

BUTI, JERÓNIMO $\cdot 40$

$\bar{C}$

CABALLERO Y GÓNGORA, ANTONIO · 45

CABEZÓN, SEBASTIÁN · 139, 202, 272, 341, 342, 378, 383, 393, 400

CABRERA, JOSÉ · 139, 202, 203, 207, 210, 214, 474

CÁDIZ, FRAY DIEGO JOSÉ DE · 55

CAMPILLO, JOSÉ ÁNGEL · 489

CAN DE ROA, LUIS $\cdot 80,98$

CAPDEPÓN VERDÚ, PAULINO · 21, 469

CARNICER $\cdot 36$

CARRASCO, JOSÉ RAPHAEL · 245, 246

CASADO, IGNACIO $\cdot$ 139, 199, 202, 206, 210, 214

CASCAGNI · 137, 144, 226, 227

CASCANTE, FRANCISCO · 146, 242, 258, 262, 271, 278, 279, 296, 299, 308, 310, 324, 325, 335, 337, 339, 340, 346, 348, 354, 355, 396, 407, 413, 414, 415, 416, 557, 625

CAVIA NAYA, VICTORIA · 161, 571

CASARES, EMILIO • 13, 20, 447, 448, 456, 568, 571

CASTRO, DAMIÁN DE $\cdot 41$

CEBALLOS, RODRIGO DE $\cdot$ 80, 98

CERVANTES, ÁLVARO DE · 80, 98

CÍVICO, JUAN ANTONIO • 166, 167

CIVIL CASTELLVÍ, FRANCESC · 13, 20, 21, 451, 456, 571, 572

COLMENERO, FRANCISCO $\cdot 260,261$

COLMENERO, MIGUEL · 260, 325, 334, 343, 344, 481

COMES $\cdot 101,105$

CONTRERAS, AGUSTÍN DE · 98, 101

CORDÓN, JOSÉ · 183, 184, 464

COSANO MOYANO, FRANCISCO • 45, 46, 47, 572

CRIADO COSTA, JOAQUÍN · 42, 572

CROCE $\cdot 33,572$ 
CRUZ Y ROXAS, JUAN DE LA · 150, 425, 426, 429, 498

CUDOIRE, FEDERICO $\cdot$ 149, 222, 228

CUENCA TORIBIO, JOSÉ MANUEL · 39, 42, 572

CUEVAS, JUAN $\cdot 98$

CHAPUY, 50

CHEIST, JOSÉ · 138, 226, 227, 237, 476

D

DABRIO GONZALEZ, Mª TERESA · 41, 75, 572

DAZA, JUAN $\cdot 74$

DEL MORAL $\cdot 33,573$

DELGADO, PEDRO $\cdot 77$

DES PRES, J. $\cdot 101$

DESCARTES $\cdot 25$

DÍAZ, ANTONIO • 159, 180, 213, 461

DÍAZ, GABRIEL · 98

DÍAZ, MARIANO $\cdot$ 196, 248

DÍAZ MOHEDO, M ${ }^{\mathrm{a}}$ TERESA · 126, 573

DÍEZ MARTÍNEZ, MARCELINO · 15, 16, 538

DOYAGÜE $\cdot 35$

DREVETÓN, BALTASAR · 40

DUQUE CORNEJO, PEDRO $\cdot$ 40, 81

DUARTE, FRANCISCO $\cdot$ 405, 406, 413, 439

DURÁN DE LA CUEVA, JERÓNIMO · 80, 97, 98, 100, 101

\section{$\bar{E}$}

ECHAVARRI, PEDRO $\cdot$ 60, 89, 379, 534

EGUILUZ, JOSEF · 43, 561

ENRIQUEZ, ANDRÉS · 101

ESCALONA, FRANCISCO · 231, 232, 243, 245, 247, 317, 326, 329

ESPECIALI, MARIANO · 136, 248, 339, 355, 360, 380, 393, 401, 468, 625, 626

ESPINOSA, FERMÍN · 138, 264, 274, 279, 281, 286, 289, 290, 294, 297, 299, 481, 483

ESPINOSA, FRAY JERÓNIMO $\cdot 41$

ESPINOSA, VICENTE · 89, 148, 182, 183, 190, 196, 197, 205, 206 
ESTRELLA, JOSÉ· 167

$\bar{F}$

FARNESIO, ISABEL DE $\cdot 32$

FERNANDEZ, JOSÉ $\cdot 166$

FERNÁNDEZ DE ENTRE-RÍOS Y LIDÓN, ANDRÉS · 98

FERNÁNDEZ DE LA CUESTA, ISMAEL · 11

FERRER, FRANCISCO · 149, 150, 255, 261, 266, 267, 269, 292, 301, 302, 304, 319, 321, 325, 359, 389, 402, 423, 424, 427, 428, 432, 480, 489, 628

FERRER, MARIANO $\cdot$ 150, 294, 300, 315, 318, 329, 338, 339, 349, 353, 360, 628

FERRER Y BELTRÁN, JOSÉ · 131

FERRERAS $\cdot 101$

FEYGIDO Y BARCELÓ, JOSÉ · 454

FOSCHINI, GAETANO F. 101

FRANCÉS IRIBARREN, JUAN · 101

FRANCO, JUAN · 139, 190, 193, 244, 245, 274, 280

FRESNEDA, FRAY BERNARDO DE · 83, 153, 169, 173, 560

FURRIEL, PATRICIO $\cdot 128,129$

$\boldsymbol{G}$

GAITÁN Y ARTEAGA, JUAN MANUEL · 95, 98, 101, 103, 116, 117, 122, 125, 136, 158, 188, 195, 196, 200, 207, 208, 215, 220, 223, 229, 234, 238, 243, 244, 261, 262, 267, 272, 273, 287, 288, 320, 453, 454, 455, 459, 462, 463, 479

GALÁN · 101

GALDÓN I ARRUE, MARÍA MONTIEL · 21, 453

GALIANO, JOSÉ $\cdot 189$

GALIANO, RAFAEL $\cdot 189$

GALVEZ, JUAN $\cdot 146$

GÁLVEZ, JULIÁN · 184, 212, 221, 243, 257, 293, 295, 304, 305, 317, 318, 327, 328, 350, 351, 362, 423 , 424, 429, 430, 432, 433, 434, 628

GALLARDO, RAFAEL · 137, 328, 627

GARAY, RAMÓN · 466, 467

GARBAYO, JAVIER $\cdot 13,20,448,574$

GARCÍA, ANTONIO $\cdot$ 149, 225, 236, 571 
GARCÍA, FRANCISCO $\cdot$ 231, 232, 233, 257

GARCÍA, JUAN $\cdot$ 138, 204

GARCÍA, PLÁCIDO · 35

GARCÍA, RAFAEL $\cdot 138,181,182,468,522,626$

GARCÍA DE CARRASQUEDO $\cdot 446$

GARCÍA GUERRERO, BARTOLOMÉ · 101

GARCÍA PACHECO, FABIÁN · 101

GARCÍA PALMERANI, DOMINGO $\cdot 40$

GARCÍA-CUEVAS VENTURA, JOSÉ · 87, 90, 93, 96, 97, 121, 163, 574

GIL, ANTONIO - 134, 140, 178, 217, 218, 219, 220, 222, 228, 229, 235, 236, 237, 252, 258, 268, 272, 273, 293, 294, 300, 302, 308, 309, 335, 338, 346, 356, 385, 386, 389, 401, 403, 404, 417, 419, 430, $476,480,625$

GIL, JOSÉ · 101

GIROWEZ $\cdot 101$

GOICOECHEA, V. $\cdot 101$

GÓMEZ, JOSÉ · 128, 235, 243

GOMEZ AMAT, CARLOS $\cdot 20,34,35,574$

GONZÁLEZ DE ACEVEDO, NUÑO · 98

GÓMEZ DE SANDOVAL, ALONSO • 40, 53, 81, 155

GÓMEZ NAVARRO, JUAN ANTONIO • 98, 101

GONZÁLEZ, MARIANO · 178, 437, 438

GONZALEZ, TOMÁS $\cdot 159$

GONZALEZ DURO $\cdot 33$

GRACIA BOIX, RAFAEL · 44

GRANDE AGUSTÍN · 41

GROUT $\cdot 27,575$

GUARDIA, ERNESTO DE LA · 31, 572

GUAXARDO Y FAJARDO, AGUSTÍN · 60

GUENTOS, FRANCISCO $\cdot 179$

GUERRA, JUAN · 290, 301, 411, 419, 625

GUERRERO, VICENTE $\cdot 101$

GUESDÓN · 47

GUILLÉN BERMEJO, MARÍA CRISTINA · 555, 562

GUINER, LUIS · 101

GUTIÉRREZ RAVÉ, MANUEL · 101, 140 
$\bar{H}$

HAËNDEL $\cdot 28$

HALLER, MICH $\cdot 101$

HAYDN, JOSEPH · 27, 28, 29, 30, 31, 36, 101, 580

HERNÁN RUIZ “EL VIEJO” · 73

HERNÁN RUIZ II · 73, 76, 77, 78

HERNÁN RUIZ III · 78

HERNÁNDEZ, FÉLIX · 72, 82

HERNÁNDEZ, PABLO $\cdot 101$

HEROS, JOSÉ LUIS DE LOS · 138, 277, 278, 343, 442, 636, 637

HICIECES, TOMÁS · 102

HIDALGO, ANTONIO • 148, 180, 182

HIDALGO NUCHERA, PATRICIO · 39, 575

HINESTROSA, NICOLÁS · 143

HOEFNAGLE $\cdot 45$

HOFFMANN $\cdot 31$

HUMANES ALDANA, FRANCISCO DE • 98, 102

I

IZQUIERDO, ANTONIO · 166, 167

$\bar{J}$

JAÉN, JOSÉ · 22, 216, 217, 218, 219, 306, 329, 340, 341, 347, 348, 352, 353, 356

JAÉN MORENTE, ANTONIO • 41, 575

JIMÉNEZ CAVALLE, PEDRO • 465, 466, 467

JUANES, JUAN ANTONIO $\cdot 448$

JUKLIR $\cdot 102$

JUNCÁ, FRANCISCO • 35, 102, 449, 450, 451

JURADO, ANTONIO · 329, 362, 364

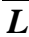

LAGUNA PAÚL, TERESA · 73, 575

LAMBIDA, JUAN ANDRÉS · 131 
LARA, FRANCISCO DE · 148, 412, 413, 415, 416, 428

LARA LARA, FRANCISCO JAVIER · 19, 575

LAS, JOSÉ · 145, 230, 231, 252, 253, 259, 260, 287, 295, 297, 301, 303, 307, 309, 313, 316, 328, 352, 356, 361, 370, 628

LASA MENDIENTE, VICTOR $\cdot 102$

LÁZARO, JOAQUÍN · 446, 447

LEAL, RAFAEL · 57, 92, 561

LEDESMA Y DOBLAS, RAFAEL DE · 266, 267, 384, 385, 394

LEÓN, RAFAEL DE · 159, 180, 217, 219, 461

LIDÓN, ANDRÉS · 130, 132, 134, 216, 221, 224, 225, 268, 270, 273, 274, 332, 334, 335, 385, 386, 415, 416, 497

LONGANINI $\cdot 137,144,273$

LOPE DE MORA · 145, 212, 217, 224, 225, 231, 233, 250, 253, 256, 262, 265, 269, 270, 277, 278, 295, 296, 303, 304, 334, 335, 396, 407, 410, 422, 426, 427, 439, 625

LÓPEZ, FRANCISCO · 196, 197, 198, 396, 397, 433, 436

LÓPEZ, MIGUEL · 178, 231, 232, 233, 235, 236, 256, 263, 264, 396

LÓPEZ, RAFAEL · 412, 413, 417, 419, 421, 497

LÓPEZ AHUMADA, FRANCISCO · 196, 197, 198

LÓPEZ ARANDIA, LAURA · 539

LÓPEZ CALO, JOSÉ · 114, 119, 120, 133, 143, 287, 462, 463, 464, 484, 485, 535, 536, 537, 538, 540, $541,543,574,575$

LÓPEZ MARTÍN, JUAN · 477, 576

LOVETT, GABRIEL · 34, 576

LUCAS DEL POZO Y CÁCERES, JUAN · 40, 118, 130, 136, 500, 634, 636

LUCENA, JOSÉ · 277, 280, 356, 362, 383

LUQUE, RAFAEL DE · 359, 381

$\bar{M}$

MACKENZIE, A.S · 46, 576

MANRIQUE, ALONSO $\cdot 75,76$

MANRIQUE VICENTE, JOSÉ · 98

MARCIAG, PEDRO · 139, 193, 199, 200, 208, 227, 236, 239

MARDONES, DIEGO DE $\cdot 80$

MARFIL, PEDRO $\cdot 80,576$

MARÍN, RAFAEL · 146, 405, 406, 408, 438, 496 
MARÍN, VICENTE · 146, 184, 228, 230, 239, 245, 255, 258, 259, 289, 291, 293, 302, 313, 320, 326,

327, 338, 348, 356, 370, 376, 389, 425

MARRACO, SANCHO $\cdot 102$

MARTÍN, ALFONSO • 136, 225, 299, 302, 332, 353, 490, 625

MARTÍN FERNÁNDEZ DE ANGULO $\cdot 74$

MARTÍN MARTÍN, TEODORO $\cdot 120,151,577$

MARTÍN MORENO, ANTONIO • 20, 114, 446, 449, 452, 469, 536, 537, 555, 577

MARTÍN RODRÍGUEZ DE LA FUENTE · 80, 98, 115, 153, 173

MARTÍN SÁNCHEZ · 80

MARTÍNEZ RÜCKER, CIPRIANO $\cdot 102$

MARTÍNEZ SOLAESA, ADALBERTO • 113, 134, 151, 577

MATA, DIONISIO DE LA · 136, 208, 212, 214, 216, 223, 226, 453, 469

MEDINA Y CORPA, BERNARDO $\cdot 102$

MEGÍA, JOSÉ · 260

MEJIAS, JOSÉ $\cdot 148$

MENCIA, MANUEL $\cdot 102$

MERINO, MATHEO · 196, 197, 240, 241, 244, 245

MESA, JACINTO ANTONIO DE · 98, 100, 102

MINTEGUI, TADEO $\cdot 140,211,213,476$

MIR $\cdot 102$

MITTERER, IGNACIO $\cdot 102$

MOLINA, BRUNO $\cdot 102$

MOLINA, JOSÉ · 137, 431, 432, 498

MONTAGUT, MARIAN ROSA $\cdot 151$

MONTERO, CASIMIRO $\cdot 51$

MONTESA, MANUEL $\cdot 183$

MONTESQUIEU $\cdot 25$

MONTIEL, JUAN DE $\cdot 98$

MORA, FRANCISCO DE · 380, 381, 405, 417, 418, 435, 494

MORA, GABRIEL DE · 405, 429

MORA, JUAN DE · 145, 216, 217, 253, 267, 281, 298, 315, 317, 331, 341, 342, 344, 345, 358, 367, 369, 377,625

MORA, MARIANO DE, $\cdot 166$

MORALES, ALFREDO J $\cdot 77,577$

MORALES, CRISTOBAL DE . 80, 98

MORALES, RAFAEL · 307, 311, 329

MORENO, ÁNGEL · 140, 271, 284

MORENO CUADRO, FERNANDO • 58, 577

MORENO VALERO, MANUEL $\cdot 63,578$ 
MOYANO, JOSÉ · 102, 132, 134, 136, 296, 467, 490, 499, 502, 503, 557, 625, 638, 639, 641, 642

MOZART, W. A. · 27, 28, 36, 580

MUÑOZ VILLAREAL, GREGORIO · 141, 411

MURACHS, JOSÉ · 251

MYERS BROWN, SANDRA $\cdot 120,577$

$\bar{N}$

NÁJER, FRANCISCO $\cdot 446$

NAVARRO, FRANCISCO $\cdot$ 412, 413, 414, 415, 496

NIETO CUMPLIDO, MANUEL · 19, 20, 38, 39, 40, 45, 70, 71, 72, 73, 80, 82, 97, 98, 99, 115, 116, 117 , $125,127,128,129,134,135,142,143,152,155,156,169,171,173,174,446,454,467,468,533$, 578

$\bar{O}$

OCHOA, JUAN DE $\cdot 78,80$

ORDÓÑEZ, ANTONIO · 136, 335, 336, 337, 338, 340, 343, 344, 346, 353, 355, 360, 379, 380, 383, 385, 387, 389, 391, 392, 490, 495

ORTEGA, MARIANO · 148, 180, 182, 184, 263, 290, 297, 303, 332, 356, 390, 407, 408, 409, 410, 625

ORTÍ BELMONTE, MIGUEL ÁNGEL · 37, 38, 64, 68, 578

ORTIZ JUÁREZ, DIONISIO · 38, 41

PACHECO MONTIÓN, JUAN · 98, 102

PADILLA ÁLVAREZ, FRANCISCO · 39, 575

PADILLA, JUAN DE $\cdot 102$

PALACIO RACIONERO, RAMÓN $\cdot 102$

PALACIOS BAÑUELOS, LUIS · 39, 60, 62, 64

PALACIOS SANZ, JOSÉ IGNACIO • 448, 579

PALESTRINA $\cdot 102$

PALISCA $\cdot 27,575$

PALOMINO, ACISCLO ANTONIO, 81

PALOMINO, JUAN FERNANDO $\cdot 45,46$

PAQUERAS $\cdot 102$

PARCERISA $\cdot 47,48,49$

PATIÑO $\cdot 102$

PAULA, FRANCISCO DE · 146, 163, 259, 260, 307, 394, 396, 424, 433, 434, 435, 438, 495, 533, 569 
PAVÓN, BORJA · 465, 579

PAVÓN, JOSÉ $\cdot 189$

PEDRAJAS, FRANCISCO JAVIER $\cdot 40$

PEÑA, JOSÉ DE LA · 218, 219, 220, 224

PEÑA, JUAN DE LA · 144, 179, 191, 209, 216

PÉREZ, JOSÉ MARÍA · 418, 419, 423

PÉREZ, MARIANO · 20, 36, 112, 169, 529, 531, 579

PÉREZ GAYA $\cdot 35$

PÉREZ LINDE, MANUEL · 128, 143

PÉREZ MORAL, LOURDES · 96

PÉREZ RUANO, JOSÉ · 41

PERGOLESI, G. B. $\cdot 102$

PERIS, J. M. $\cdot 102$

PEROSI, L. $\cdot 102$

PICANOL, JOSÉ $\cdot 102$

PLEYEL, IGNACIO $\cdot 102$

PONS, JOSEP · 35, 102, 134, 451, 452, 453, 461, 469 473, 580, 585

PONZ, ANTONIO $\cdot 39,579$

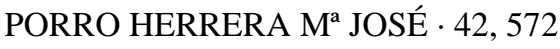

POZO Y CÁCERES, JUAN LUCAS DEL · 118, 164, 321, 322, 357, 398, 469, 560, 643

PRIETO, JUAN · 40

PUGNANI, GAETANO $\cdot 102$

PUIG, JUAN NEPOMUCENO · 148, 184, 188, 201, 206, 207, 209, 236, 259, 267, 270, 287, 294, 296, 311, 316, 318, 323, 325, 332, 333, 335, 337, 351, 354, 362, 369, 376, 389, 414, 418, 423, 427, 428, 430, 431, 435, 439, 440, 441, 464

PULIDO CASTILLO, GONZALO $\cdot 21,22$

$\bar{Q}$

QUERALT, FRANCISCO $\cdot 35,102$

QUESSADA, LOANNES $\cdot 102$

$\bar{R}$

RAMÍREZ DE ARELLANO, R. · 42, 580

RAMIREZ DE ARELLANO, TEODOMIRO • 53, 56, 61, 155, 156, 493, 580

RAMÍREZ DE LAS CASA DEZA, L.M · 37, 43, 580

RAMÍREZ Y BENEYTO, RAMÓN · 452, 453, 469, 474 
RAMIREZ Y GÓNGORA, MANUEL ANTONIO • 53, 56, 57, 561, 562

RAVANELLO, ORESTE $\cdot 102$

RAYA RAYA, M ${ }^{\mathrm{a}}$ ÁNGELES · 41, 75, 572

REBOLLO PUIG, GABRIEL $\cdot 82$

RECIO MATEO, LUIS · 71, 72, 578

REDEL, MATHIAS · 144, 145, 194, 195, 285

REDEL, PASCUAL · 144, 180, 181, 183, 194, 200, 205, 223, 224, 236, 250, 271, 279, 295, 297, 307, $308,358,370,420,443,625$

REYNALDI, MIGUEL · 132, 145, 178, 305, 307, 308, 310, 312, 313, 318, 319, 320, 321, 323, 324, 331,

333, 345, 346, 350, 360, 389, 390, 395, 398, 402, 403, 404, 405, 410, 413, 414, 415, 417, 418, 419,

422, 423, 424, 426, 427, 488, 496, 497, 628

REINOSO DAZA $\cdot 80$

REYES, DIEGO DE LOS · 40

REYES, MANUEL $\cdot 102$

RIEGO · 34, 632

RÍO, RAFAEL DEL · 144, 217, 257, 264, 298, 301, 367, 383, 435, 436, 440, 443, 481

RÍOS, JOSÉ DE LOS · 138, 213

RIPA, ANTONIO $\cdot 122$, 446, 455, 459

RISCOS, JUAN DE $\cdot 98$

RIVERA, PEDRO $\cdot 359,381,492$

ROBERTS, DAVID $\cdot 47$

ROBINEAU $\cdot 102$

RODRÍGUEZ DE HITA · 102

RODRÍGUEZ JUAN, “EL MOZO” · 127

RODRÍGUEZ, JUAN “EL VIEJO” · 127

RODRÍGUEZ LÓPEZ, M. J · 38

ROIG I CAPDEVILA, JORDI · 21, 446, 580

ROJAS Y SANDOVAL, CRISTÓBAL DE • 153, 173, 174

ROLDÁN $\cdot 102$

ROMEO, SEBASTIÁN · 102

ROMERO, MATEO $\cdot 102$

ROSSINI $\cdot 31,35$

ROUSSEAU $\cdot 25$

ROXAS Y MONTES, DIEGO DE $\cdot 102$

RUBIO, SAMUEL · 111, 112, 114, 121, 122, 124, 151, 170, 498, 525, 530, 581

RUIZ,ANTONIO $\cdot 41$

RUIZ, JOSÉ · 140, 403, 417, 425, 431, 438, 496

RUIZ BENDEJO, FRANCISCO · 196, 197, 261, 262

RUIZ CABRERO, GABRIEL · 82 
RUIZ DE ELVIRA SERRA, ISABEL · 555, 562

RUIZ SAMENTEGO, FRANCISCO $\cdot 102$

$S$

SAAVEDRA, ÁNGEL DE · 41

SABORIT, ANTONIO $\cdot 132$

SÁNCHEZ CAÑADAS, TEODOSIO $\cdot 40$

SÁNCHEZ CENTENO $\cdot 99$

SÁNCHEZ MÁRMOL, FERNANDO · 69

SÁNCHEZ SANDOVAL, MANUEL · 40

SÁNCHEZ SOTO, CRISTÓBAL · 41

SANTIAGO, FRANCISCO $\cdot 102$

SANTILLANA, JOSÉ $\cdot 166$

SANZ, DOMINGO $\cdot 102$

SANZ, M ${ }^{\text {a }}$ JESÚS · 54, 581

SCHOMMER, ALBERTO · 72, 76, 581

SCHUBERT $\cdot 27,29$

SEGOVIA Y VALENZUELA, FRANCISCO JOSÉ DE · 57, 562

SERRA, LUIS $\cdot 102$

SERRANO, SALVADOR $\cdot 98,141,142,327,428,429$

SERRACANT Y MAS $\cdot 102$

SIMÓN SEGURA, F·119, 581

SOLER, FRANCISCO $\cdot 102$

$\mathrm{SOR} \cdot 36$

SORIANO FUERTES, INDALECIO $\cdot 102$

STAMITZ, JOAQUÍN · 26

STEVENSON, ROBERT $\cdot 114$

$T$

TALAVERA, JOSÉ · 145, 256, 257, 357, 370, 389, 392, 410, 411

TASCÓN, MATEO · 148, 184, 188, 220, 221, 234, 264, 266, 280, 282, 296, 297, 313, 326, 327, 339,

341, 354, 389, 398, 464

TAYLOR $\cdot 50$

TEIXIDÓ BARCELÓ, JOSÉ · 102

TEJERIZO ROBLES, GERMÁN · 21, 582

THOMAS, IGNACIO DE $\cdot 40$ 
TORRE MOLINA, M ${ }^{\mathrm{a}}$ JOSÉ DE LA · 176, 582

TORRELLAS, BENITO · 141, 283, 284, 285, 286, 290, 291, 294, 295, 305, 306, 314, 334, 354, 392, 395, 396, 401, 402, 406, 412, 418, 420, 421, 486, 487, 625

TORRENS, JAIME $\cdot$ 446, 577

TORRES, EDUARDO $\cdot 102$

TORRES BALBÁS, L. $\cdot 69$

TREVILLA, PEDRO ANTONIO DE • 45, 129, 159

TRIGUILLOS JOSÉ $\cdot 181$

TROMPERI, MANUEL $\cdot 185$

$\bar{U}$

ULRICH, MICHAEL · 528, 582

$\bar{V}$

VALDENEBRO, JOSÉ MARÍA · 521, 582

VALDÉS, JULIO $\cdot 102$

VALVERDE CANDIL, $\mathrm{M} \cdot 38$

VALLEJO, JOSÉ · 257

VALLS, JOSÉ · 215

VALLS, MANUEL · 147, 179, 214, 215, 237, 241, 243, 288, 300, 306, 312, 314, 351, 352, 393, 394, 395, 396, 408, 413, 414, 430, 431, 625

VAN-ACKEN, PHELIPE $\cdot 223$

VASCONCELOS, JOSÉ · 145, 253, 271, 282, 285, 315

VÁZQUEZ, FRANCISCO EULOGIO $\cdot 40$

VÁZQUEZ LESMES, RAFAEL · 19, 83, 91, 97, 116, 117, 152, 157, 173, 175, 176, 381, 411, 418, 430, $440,441,582,583$

VELÁZQUEZ BOSCO, RICARDO $\cdot 82$

VEGA, PEDRO DE $\cdot 80,98,173$

VERDIGUEIR, JUAN MIGUEL $\cdot$ 40, 81

VICH BENNASAR, RAFAEL · 98, 102

VICTORIA, TOMÁS LUIS DE · 100, 102, 109

VIDAL, JUAN DOMINGO $\cdot 102,454$

VIDAL, SEBASTIÁN $\cdot 81$

VIERAS, ALONSO DE $\cdot 80,98$

VILA, JOAN $\cdot 448$

VILLALAR, ANDRES DE · 80, 98 
VILLALBA, JOSÉ · 329, 340

VILLAR MOVELLÁN, ALBERTO • 41, 72, 75, 76, 572, 581, 583

VILLUENDAS, MARIANO $\cdot 210,222,224$

VIÑAS, MARIANO $\cdot 103$

VIVIAN $\cdot 50$

VOLTAIRE $\cdot 25$

W

WEBER $\cdot 27$

WELLINGTON $\cdot 33$

$\boldsymbol{X}$

XIMÉNEZ, DIEGO $\cdot$ 80, 98

XIMENEZ Y HOYO, MANUEL · 89, 176, 560, 589, 626, 629

$\bar{Y}$

YUSTA NAVARRO, BALTASAR · 45, 51

$\bar{Z}$

ZABALA, VICENTE $\cdot 157$

ZAMEZA, JOSÉ $\cdot 103$

ZURBANO, MARIANO $\cdot$ 166, 441, 442, 499 



